\title{
O jovem Pedro Américo entre arte, ciência do belo, e um outro nacional.
}

Fábio D'Almeida Lima Maciel

Tese apresentada ao Programa de Pós-Graduação em Artes Visuais da Escola de Comunicações e Artes da

Universidade de São Paulo para Obtenção do Título de Doutor em Artes

Área de concentração: Teoria, Ensino e Aprendizagem da Arte Linhas de pesquisa: História, Crítica e Teoria da Arte Orientador: Prof. Dr. Domingos Tadeu Chiarelli Julgadora em 01 de agosto de 2016.

São Paulo, setembro de 2016. 
Catalogação na Publicação

Serviço de Biblioteca e Documentação

Escola de Comunicações e Artes da Universidade de São Paulo

Dados fornecidos pelo(a) autor(a)

MACIEL, Fábio D'Almeida Lima

O jovem Pedro Américo entre arte, ciência do belo, e um outro nacional. / Fábio D'Almeida Lima Maciel. -- São Paulo: F. D. L. Maciel, 2016. 602 p.: il.

Tese (Doutorado) - Programa de Pós-Graduação em Artes Visuais - Escola de Comunicações e Artes / Universidade de São Paulo.

Orientador: Domingos Tadeu Chiarelli

Bibliografia

1. Pedro Américo de Figueiredo e Mello 2. Arte brasileira do século XIX 3. Pintura de nu 4. Estética 5. Política das artes I. Chiarelli, Domingos Tadeu II. Título.

CDD 21.ed. -700 
Aos meus pais e irmãos:

"seu Carlinhos", "dona Eliane", Fabrício e Glaucimar.

A minhas sobrinhas e sobrinhos.

A meus amigos. 


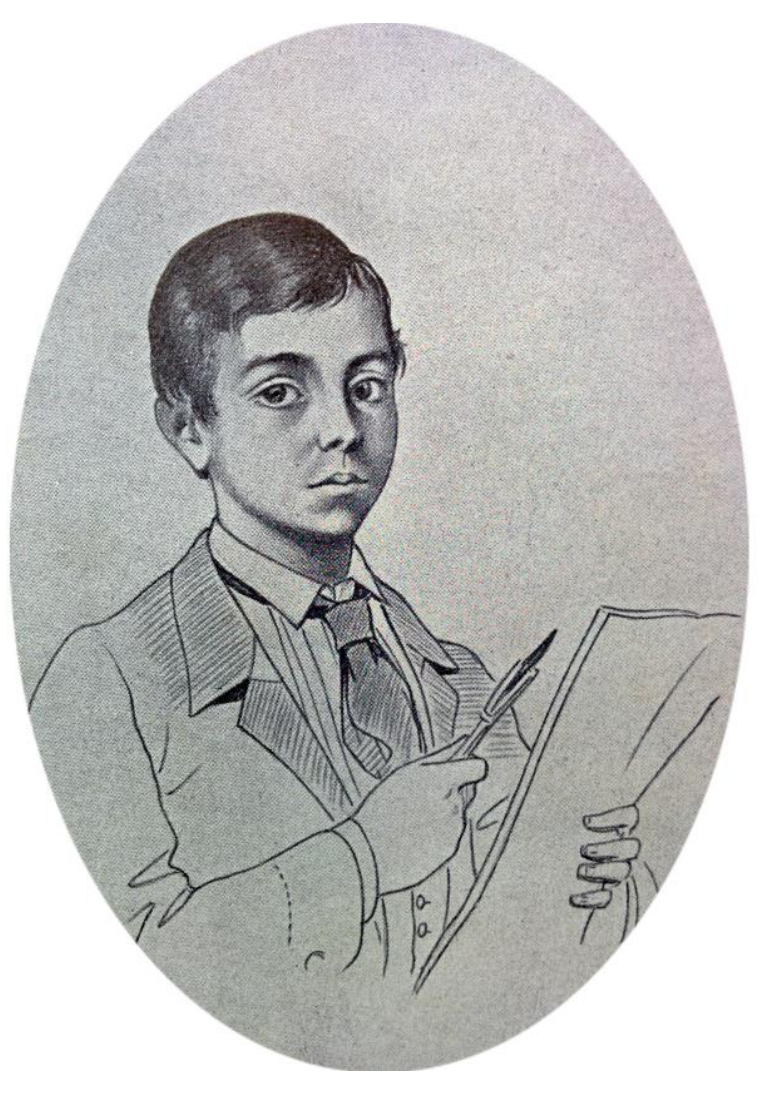




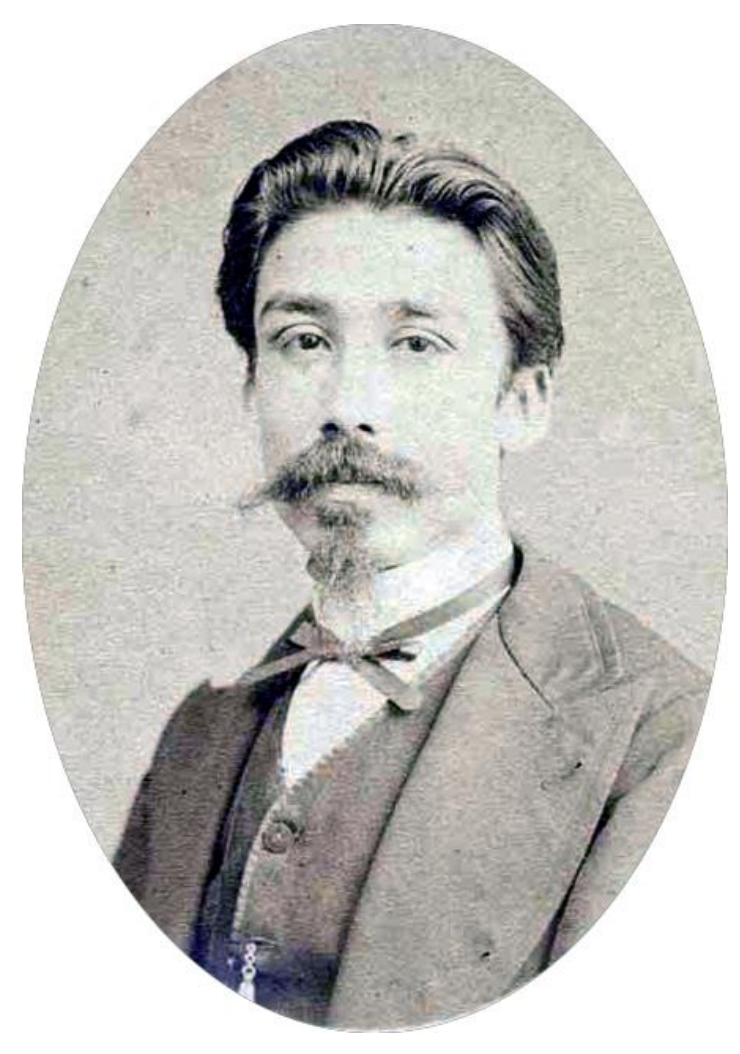




\section{Resumo:}

Esta Tese concentra seu interesse nos anos de formação do pintor e filósofo brasileiro Pedro Américo de Figueiredo e Mello (1843-1905). Toma como objetos principais de reflexão as suas primeiras obras autorais - escritas e pictóricas -, produzidas no fim de sua bolsa de estudos na Europa, especialmente em Paris, concedida diretamente pela Casa Imperial brasileira. São os textos " $L a$ réforme de l'École des Beaux-Arts et l'opposition" (1863), Considerações Filosóficas sobre as Belas Artes entre os Antigos (1864), Cartas de um Plebeu (1865), e a pintura A Carioca (1863-64).

A partir dessas produções, discutem-se retrospectivamente os estudos artísticos e científicos realizados por Américo no Rio de Janeiro, em Paris e em outras cidades européias, suas inclinações artísticas e filosóficas, e suas relações com alguns artistas e políticos, no Brasil e no exterior.

Apresenta-se como hipótese central o esforço do artista em estruturar uma teoria artística e seu primeiro projeto político endereçado às artes no Brasil, que proverão as bases permanente para várias de suas atuações ao longo da carreira.

Defende-se se tratar de uma teoria interessada em revelar o "Belo ideal", mas um "ideal moderno"; e de um projeto centrado na valorização social do artista por meio de uma demanda permanente de instrução teórica e filosófica; na expansão "universal" e obrigatória do ensino do desenho; e na fundação de uma arte nacional que se opusesse - com o aporte das teorias sobre as diferenças entre as "raças" humanas - ao indianismo que, nas artes plásticas, ganhava força no país, a partir dos anos 1860.

Palavras-chave: Pedro Américo de Figueiredo e Mello; arte brasileira do século XIX; arte francesa do século XIX; pintura de nu; estética; ciência do belo; teoria da arte; Ecletismo; filosofia idealista; pintura; arte nacional; política das artes.

\section{Résumé:}

Dans cette thèse, nous nous sommes intéressés à la période de formation du peintre et philosophe brésilien Pedro Américo de Figueiredo e Mello (1843-1905).

Nous y étudions les premières œuvres écrites et picturales de cet artiste, produites à la fin d'une bourse d'études à Paris, offerte directement par la Maison de l'Empereur brésilien. Ces travaux sont La réforme de l'Ecole des Beaux-Arts et l'opposition (1863), Considérations Philosophiques sur les Beaux-Arts des Anciens («Considerações Filosóficas sobre as Belas Artes entre os Antigos») (1864), Lettres d'un plébéien («Cartas de um Plebeu») (1865), et la peinture A Carioca (1863-64).

A partir de ces productions, nous discutons la démarche d'études artistiques et scientifiques poursuivies par Américo à Rio de Janeiro, à Paris et dans d'autres villes européennes. Nous analysons ses intérêts artistiques et philosophiques, et les relations qu'il avait directement ou indirectement établies avec des artistes et des politiciens, au Brésil et à l'étranger. 
L'hypothèse principale de cette thèse concerne l'effort de l'artiste à structurer une théorie artistique et, aussi, un projet politique pour les arts au Brésil. Le premier servira de base permanente à plusieurs d'autres tout au long de sa carrière. Notre postulat de départ est qu'il s'agit d'une théorie adressée à la réalisation du « Beau idéal », mais dans une perspective comprise comme " moderne »; et d'un projet axé sur la valorisation sociale de l'artiste, nourrie par une demande permanente de son apprentissage théorique et philosophique; par l'expansion « universelle » et obligatoire de l'enseignement du dessin; et, finalement, par la fondation d'un art national qui devrait être «blanc », aux yeux d'Américo, en s'opposant de cette manière à la représentation de l'indigène, représentation qui, à partir des années 1860, devenait un symbole important pour les arts plastiques au Brésil.

Mots-clés: Pedro Américo de Figueiredo e Mello; art brésilien au XIXe siècle; art français au XIXe siècle; peinture de nu; esthétique; science du beau; théorie de l'art; Eclecticisme; Philosophie idéaliste; peinture; art national; politique des arts.

\begin{abstract}
:
This thesis is focused on the formative years of the Brazilian painter and philosopher Pedro Américo de Figueiredo e Mello. It takes as its main goals the study of the first original works of this artist, both written and painted, produced at the end of a scholarship in Europe granted by the Brazilian Empire. They are three texts - 'La réforme de l'Ecole des Beaux-Arts et l'opposition' (1863), Considerações Filosóficas sobre as Belas Artes entre os Antigos (1864), Cartas de um Plebeu (1865) - and one painting - A Carioca (1863-64).
\end{abstract}

These productions are discussed here in relation to Américo's both artistic and scientific studies pursued in Rio de Janeiro, Paris and other European cities. They are also discussed considering his artistic and philosophical preferences and the relationships he had established with some artists and politicians in Brazil and abroad.

As a central hypothesis of this Thesis we defend the effort of Américo in order to structure an artistic theory and a first political project addressed to the development of Brazilian arts.

It is argued that this is a theory addressed to the production of the «Ideal beauty» (but, for him, a 'modern ideal'), and a project focused on the artist's social valorization (made through a permanent demand for theoretical and philosophical instruction); on the expansion of 'universal' learning of drawing; and on the foundation of a national 'white' art that should be presented as opposed to the Brazilian 'Indianism'.

Keywords: Pedro Américo de Figueiredo e Mello; Nineteenth century Brazilian art; Nineteenth century French art; Nude painting; Aesthetics; Science of beauty; Theory of art; Eclecticism; Idealist philosophy; Painting; National art; art politics. 


\section{Agradecimentos}

Após 4 anos de dedicação a esta Tese, me dou conta de que deveria ter feito uma lista permanente, na qual adicionasse, a cada semana, os nomes das pessoas que contribuiram com este trabalho. Ao mesmo tempo, imagino que se o fizesse, talvez ao final essa lista teria em extensão o mesmo tamanho desta Tese. Se, fatalmente, esquecerei de citar algumas pessoas que foram importantes a seu modo ao desenvolvimento da pesquisa, ou para mim, espero que se sintam ao menos representadas pela alusão às instituições que representam.

Começando:

Às minhas amigas, orientadoras e colegas permanentes de trabalho, Fernanda Pitta e Elaine Dias. Todos os comentários possíveis sobre a importância que vocês tiveram para o desenvovlimento desta Tese, e de projetos paralelos, não dariam, ainda assim, a ideia da importância que vocês também tiveram para mim, nos últimos anos. Fernanda, já constantemente ao meu lado desde o início do mestrado, é um poço sem fundo de conhecimento e perspicácia. Sua avidez nos estudos e respeito a todos os alunos, amigos e colegas de trabalho é um exemplo que permanece sempre no meu horizonte, mesmo que não seja assim tão fácil seguir. Elaine, que apareceu numa inesquecível viagem de estudos, me inspira e impressiona igualmente por sua inteligência, ética e companheirismo incondicional. Quando as coisas estiveram muitas confusas, na Tese e fora dela, sua permanente disponibilidade, senso crítico afiado e direção de foco me recolocaram no prumo. Sem vocês, é muito provável que esta Tese tivesse escorregado pela culatra.

A Heloisa Espada, a Silvano Gersztel e à pequena Lina, pela amizade, ajuda e ternura de sempre. Heloisa, estudiosa de clareza exemplar, além de uma doce amiga desde os tempos do mestrado, esteve sempre "lá", para o que desse e viesse. Silvano, o mais artístico dos economistas que conheço, esteve sempre presente em conversas e críticas feitas em casa ou em pequenas viagens juntos, ocasiões que foram e são um refresco necessário e desejado desde há anos.

A Tadeu Chiarelli. Ter a sorte de ter há tempo um orientador que saiba ensinare mostrar que uma orientação em pesquisa não precisa excluir a amizade, admiração e orientação pessoais, isso é para poucos. Termino o doutorado sem saber como retribuir a chance que me foi dada desde o meu ingresso no mestrado da ECA-USP. Seu exemplo de ética profissional, de respeito ao trabalho alheio e de sede de conhecimento é outro horizonte que eu espero de ter permanentemente em vista. A Silvia Macedo Chiarelli, sempre amável, alegre e acolhedora.

Aos colegas do Grupo de Estudos Arte \& Fotografia da ECA-USP, verdadeira escola de formação em história, crítica e teoria da arte. Thiago Gil, Mariano Klautau, Eliane Pinheiro, Regina Teixeira de Barros, Fernando Oliva, especialmente, estiveram presentes não apenas nos encontros semanais do grupo, mas fora deles, em conversas e eventos que sempre me estimularam e ainda estimulam.

À Fundação de Amparo à Pesquisa do Estado de São Paulo (FAPESP), e a todos os funcionários que a representam, deixo meus sinceros agradecimentos pelas bolsas conferidas entre 2013 e 2016, que me permitiram desenvolver esta pesquisa, no Brasil e no Exterior.

Às professoras Annateresa Fabris e Maraliz Christo, pela disponibilidade e críticas argutas, que me fizeram, desde a Banca de Qualificação, reavaliar toda esta Tese.

À professora Ana Paula Simioni, pela amizade e amabilidade; e, ainda, pela organização de uma disciplina bastante profícua de discussão de projetos, em 2012, que me ajudou a reorientar o recorte inicial desta Tese.

Ao professor Luciano Migliaccio pelos estimulantes cursos, que sempre abriram círculos de discussão bastante profícuos.

Às professoras Sônia Salzstein, Ana Magalhães e, novamente, Ana Simioni, e ao professor Lorenzo Mammi, pela gentileza e honra de fazerem parte da Banca de defesa, trazendo contribuições importantes para reflexões futuras que sairão deste trabalho. 
À equipe da secretaria do CAP-USP - Estela, Regina e Solange - pela disponibilidade e gentileza de sempre. Um agradecimento especial a Raul Cecílio, sempre atencioso e dedicado aos projetos dos alunos e professores do Departamento.

Ao secretariado da ECA-USP, em especial Miriam e Bruno, sempre dispostos a ajudar, mesmo quando o que eu trazia era, com frequência, problemas.

Aos colegas e amigos do Instituto Itaú Cultural, em especial a Tânia F. Rodrigues, Ivon Piccoli, Laércio Menezes e André Judice, que me mostraram que existem outros lugares além da academia, com um carinho que parece casa de vó.

Aos funcionários da Secretaria de Cultura de Areia e do Museu de Areia, na Paraíba, pela educação e disponibilidade durante uma semana inesquecível de pesquisa. Um agradecimento todo especial a Edilene de Almeida Cardoso Felix, a Sheila e aos estagiários dessas instituições, pela orientação e pela mais que amável recepção, que me fez sentir em casa.

Aos funcionários da Biblioteca Mario de Andrade, em especial a Aline Barbosa Petelin, Beatriz Cristiano Araújo e Natan Tiago B. Serzedello, da Sala de Artes, sempre atenciosos e solicitos.

A Laurène Meulemans, pelo amor, cumplicidade, e pelo esforço desses tempos finais de tese.

À família Meulemans, pela ternura e cordialidade: Christine Meulemans e Yolande Di Gioia, Tarik Boutaleb, Anne Meulemans, Johann Meulemans, Bahar Aybar-Meulemans, "les petites" Amália e Tana e "le petit" Abel.

Aos amigos e colegas que tive a sorte de encontrar em Paris: meus queridos Victor Lairé e Edilson Brito, Pascale Dubois, Élodie Gueneuc, Léonard B. Leygues, Sonia Dias, Alexandra Gonzalez, Alice Renard, Chloé Camonis, Christophe Chaplain, Laurie Hazan, Cyril Gerlain, Elsa kouchnir, Delphine Lebreton, Cyrille R. Gregorio, e Garance Driot.

Aos amigos e colegas do Institut National d'Histoire de l'Art, em especial ao professor Philippe Sénéchal e à professora Chantal Georgel, que aceitou ser minha directrice de recherche, durante o período em que fui acolhido nessa instituição. Agradecimentos especiais ainda a Benjamine Weill, Karima e Margharita.

Aos amigos e colegas pesquisadores e funcionários da biblioteca Jacques Doucet, em especial a Valentine Baillot, Gwenn Riou, Loreline Pelletier, Caroline Vandenberghe, Pierre Mans, Marie Civil, Elodie Baillot, Alice Ensabella, Aline Pighin, Matthieu Leglise, Léonie Marquaille, Reza, Damien, Nicolas, e Xavier Prod'homme.

A Fatima Diniz e a Rogerio Camara, segundos mãe e pai (e meu primeiro e contínuo orientador), a quem admiro e devo muito mais do que algumas linhas de agradecimento neste trabalho. Lá se vão quase 10 anos desde Vitória, e que mais tantos outros venham com o amor de vocês.

A Lorênna Matos Machado, pelo amor e dedicação de muito tempo. Eu, principalmente, e esta Tese devemos muito a você. A Silva de Matos e a Alexandre, pelo acolhimento e alegria com que sempre me recebeu junto à família.

A Catalina Valdes, a Veronica Tell, Carolina Vanegas, Juan Ricardo Rey, Marisa Baldasarre e Lucas Rentero, pela amizade, disponibilidade, e colaboração de sempre.

À minha família, Eliane Márcia, seu "carlinhos" Amaro Maciel, Fabrício, Lorena, Lauren, Jaqueline, "dinda" Angela, minhas tias e tios, primas e primos, sobrinhos e sobrinhas, pela paciência, calma e pelo amor incondicional. Mesmo quando eu estive longe, vocês estiveram perto, o tempo todo. Nada disso seria possível nem teria sentido sem vocês.

A Murilo Gouvea, pela amizade, desde os primeiros períodos da faculdade, que entre encontros, desencontros e avizinhamentos, em São Paulo e em Vitória, continua a compartilhar sua alegria e a me fazer rir, com seu ar de "kasket".

A Carlos Henrique Rodgero Frutoso - "zequinha" - e a Alexandre Carvalho Leite - "floquinho" por uma longa e sincera amizade, que começou com o basquete, no "segundo grau", mas se estendeu para a vida: sorte a minha. 
ÍNDICE

15

INTRODUÇÃO

"O maior dos pintores brasileiros, o menos brasileiro dos pintores"

33

87

SEGUNDO CAPÍTULO

Considerações sobre Considerações Filosóficas sobre as Belas Artes entre os Antigos.

87 Considerações sobre as Considerações

93 Um curso não oficial de história da arte, estética e arqueologia

96 Modelos e referências

104 Áreas de reflexão

$106 O$ método eclético 
111 Método e materiais de Considerações Filosóficas

\section{TERCEIRO CAPÍTULO}

Por um teoria da arte brasileira: questões fundamentais das Considerações Filosóficas sobre as Belas Artes entre os Antigos.

114 Da origem e da separação das artes

122 Do real

130 Do ideal

136 Da beleza

143 Dos princípios e da aparência do Belo

148 Da Imitação

157 Algumas causas e refutações às causas da perfeição da arte grega

163 As principais causas da perfeição da arte grega

168 Por um projeto e por uma teoria das artes no Brasil

\section{QUARTO CAPÍTULO}

O nascimento de uma ninfa brasileira: A (primeira) Carioca.

186 O primeiro grande nu feminino brasileiro

189 O Salão das Vênus, o Salão dos Recusados e a crise da pintura de história

$201 \mathrm{Nu}$ decadente, nu triunfante

205 A encomenda de uma Náiade?

212 Os grandes modelos iconográficos da náiade

215 A ideia da náiade (ou um passeio com as banhistas romanas)

225 Os modelos iconográficos próximos da náiade

228 Uma sintese cronológica sobre a gênese e produção da Carioca 
Um ideal branco e sem tragédia, ou uma beleza anti-indianista para a arte brasileira.

230 A precisão iconográfica

237 A náiade ideal: nua, mas não despida

243 Do modelo (real)

246 Uma regra para a Ninfa

248 - da conveniência

251 - da unidade

254 - da variedade e da simetria

257 - da proporção e da harmonia (um cânone para uma beleza brasileira)

270 - da forma

281 - da forma II: Sócrates afastando Alcebíades do Vício

286 - do claro-escuro

288 - da cor

292 - da graça

298 Um idealismo Eclético

310 A Carioca, Américo, e uma das várias vertentes da "geração de 1863"

313 O significado da Carioca: uma alegoria brasileira para um projeto político das artes.

329 Entre teoria e prática: alguns "desencontros" da Carioca.

\section{$335 \quad$ SEXTO CAPÍTULO}

\section{As Cartas de um Plebeu notório: uma nova reforma para as artes no Brasil.}

334 Um rapport de prospecção

337 Os "obstáculos ao livre desenvolvimento" das Belas Artes no Brasil

338 - Primeiro obstáculo, social.

340 - Segundo obstáculo, cultural 
341 - Terceiro obstáculo, estrutural

342 - Quarto obstáculo, estrutural

344 - Quinto obstáculo, estrutural

344 Um novo projeto para as artes no Brasil

347 A estratégia do jovem Américo

356 O lugar e a extensão do projeto de Américo

356 - "Criação de um curso obrigatório de desenho em todos os estabelecimentos de instrução secundária do Império"

366 - "Criação de pequenas escolas de belas artes nas províncias de primeira ordem" e "Criação de um museu de pintura na corte, independente [...] da academia das belas artes"

367 - "Graves alterações no método de ensino e no regime interno da" Academia Imperial de Belas Artes.

379 - "Equiparação completa" dos professores da AIBA às demais "academias ou faculdades do império"

381 Um projeto arquivado

SÉTIMO CAPÍTULO

A um triz o xilindró, ou Pedro Américo e a "questão de bacharéis".

382 Prólogo dos bacharéis

383 Dados essenciais que antecederam a "questão dos bacharéis"

386 A "Questão de Bacharéis" e os seus alvos

389 Um amigo desconhecido

392 Diplomados ou não diplomados?

397 Artigo 301 do código penal brasileiro: bacharel sem diploma é crime

399 Revelando o principal crítico da "Questão": F. J. Bethencourt da Silva

411 Entre bacharéis, marqueses e barões

416 Um problema entre arquitetos

422 Bethencourt da Silva: arquiteto de uma politica de artistas.

432 Um problema entre artistas

438 Questão de bacharel ou questão de classe? 
441 A "questão de bacharéis" como um sintoma do problema social das artes no Brasil

446 Choque individual entre artistas, propostas similares e estrategias distintas 454 Um choque entre "classes artísticas"

460 Epílogo dos bachareis

471 CONCLUSÃo

485 FONTES CONSULTADAS E BIBLIOGRAFIA

519 CADERNO DE IMAGENS

$593 \quad$ LISTA DE IMAGENS 


\section{Introdução}

O menino [Pedro Américo] aproveitou bem seu tempo durante a sua estada na Europa a expensas de S. M. Imperador.

Nos 3 primeiros anos remeteu para o Rio de Janeiro algumas cópias, e formou-se, diz ele, em 17 ciências, não apresentando diploma, nem por merecimento, nem comprado, porque com 300 francos mensais que percebia do bolsinho do seu protetor não era possível fazê-lo (raridade imprevista!), e aos dois últimos, o que fez ele? Resta-nos ainda saber.

Propagava enfim por esta capital ser grande poeta (pateta!), Literato (estonteado!), podendo já rivalizar com o mais ilustre mestre (?), como orador e que a tribuna lhe pertencia par droit de conquéte. Que petulância!! Três vezes petulância!!!

Sou Poeta! Sou poeta! Dizia ele, até as minhas patrícias me pedem versos.

Bacharel Renato de Guisando [pseudônimo de Francisco Joaquim Bethencourt da

Silva].

"Os imagináveis bacharéis sem diploma". Publicações a Pedido. Jornal do Commércio. Rio de Janeiro, 8 fevereiro de 1866, p.2.

\section{"O maior dos pintores brasileiros, o menos brasileiro dos pintores"}

Caricaturista, ilustrador, bacharel e doutor em ciências naturais, expedicionário, naturalista, músico, romancista, filósofo, professor, político: as atribuições são muitas, e todas foram concomitantes nos discursos e estudos sobre o artista Pedro Américo de Figueiredo e Mello (1843-1905). Foram inauguradas ainda em sua juventude, embora, ao longo do tempo, elas tenham passado a ter valor incerto em si mesmas para se apresentarem quase como adjunto constante à sua mais conhecida $\mathrm{e}$ estudada atividade, a de pintor. Todas as definições, resumidas e direcionadas a essa última atuação, chegaram à sintética atribuição de Pedro Américo como um "pintor universal", cujo modelo, de pronto, deixava lembrar a imagem de identidades artísticas complexas, como as dos pintores do

1 Aparentemente, a primeira vez em que o termo preciso "artista universal" aparece em uma atribuição a Pedro Américo data de 1907, em uma leitura póstuma realizada pouco tempo após sua morte. Ela foi impressa na publicação The Brasil of to-day, em texto em inglês, de Arthur Dias, dedicado às ciências, política e arte brasileiras. O autor afirmou: Let us now write about Brazilian artists — the painters. Not many months ago Brazil lost his most celebrated artist whose renown did not limit itself to Brazil, being universal. He was living in Europe at the time of his death. His name was Pedro Américo". DIAS, Arthur. The Brazil of to-day. Nivelles : Lanneau \& Despret, 1907. p.127.

A última vez que esse termo é usado em uma publicação dedicada ao artista é relativamente recente. Nesse caso, o qualitativo não é inserido somente em corpo de texto, mas estampa de fato o título da publicação de Luís Martins: MARTINS, Lincoln. Pedro Américo: Pintor Universal. Jõao Pessoa: Governo do Estado da Paraíba: 1994. 
renascimento italiano, imagem que ele próprio desde muito cedo assimilou e promoveu, tendo a propósito escolhido viver permanentemente em Florença ${ }^{2}$.

Seria "o maior pintor brasileiro" de todos os tempos, ainda que "o menos brasileiro dos pintores", segundo atribuição póstuma de Monteiro Lobato, que ainda lidava com a leitura eloquente de um pintor que haveria sido mais que pintor, e que, por isso mesmo, teria negado uma parte importante de um projeto que, segundo suas premissas, supunha o engajamento com o país e com uma arte de cor local, então percebida em Almeida Júnior - no seu entender, o mais brasileiro dos pintores brasileiros $^{3}$. Lobato não pôde ver que não encontraria de modo algum em Américo o que reclamava a Almeida Jr., não por incapacidade do artista, mas, justamente, por decorrência de postulados bastante distintos que amparavam cada um deles.

A interpretação original do "pintor universal", transmutada a partir de então em chave de insuficiência e negatividade, se manteve e estendeu por décadas em vários autores; uma imagem que parece de certo modo ser ainda válida a alguns historiadores brasileiros, da arte ou não. Assim, já no centenário do nascimento de Américo, José Lins do Rêgo o encarava como o "grande artista malogrado", que teria "desperdiçado tudo", não tendo "olhos para ver o Brasil": tinha "sangue de indio tapuia" mas "parecia um ático, um europeu da cabeça aos pés." tratou do "drama de Pedro Américo", título curioso de outro discurso comemorativo, no qual retomava a interpretação da suposta falta de "brasilidade" do artista e a conclusão - com uma incômoda e ainda mais acentuada reminiscência imperialista - de que o pintor havia se tornado um "pálido subeuropeu",

A alcunha, mesmo que desacertada, não podia ser mais clara: a Américo, se nem brasileiro (pois, ao empalidecer voluntariamente, teria desnaturado a sua cor brasileira inata e rarefeito seu "sangue de tapuia"), se nem europeu de fato (na qualidade de "sub", estaria evidentemente abaixo disso: apenas "parecia" um), sobraria apenas um limbo pátrio incerto, lugar paradoxalmente incompatível com a

\footnotetext{
${ }^{2}$ Conforme será discutido nesta Tese, será no concurso para a cadeira de Desenho Figurado que realizará em 1865, em disputa com Francisco Antonio Nery e Jules Le Chevrel - em um quase cômico contraste de pseudônimos que Américo apresentará abertamente, pela primeira vez, essa aspiração, ao assinar anonimamente em suas provas a epígrafe leonardesca que dizia: "um pintor sábio na teoria da sua arte pode sem muita dificuldade tornar-se Universal". O pseudônimo adotado por Nery para o concurso era "abril"; e Le Chevrel, "to be or not to be".

3 LOBATO, Monteiro. "Pedro Américo", Revista do Brasil, ano 1, vol.3, n.11, novembo de 1916. pp.256-272; reimpresso em: LOBATO, Monteiro. "Pedro Américo". Idéias de Jeca Tatu. Sào Paulo: Editora brasiliense, 1951, p. 73.

Para uma análise referencial da crítica de arte de Lobato, ver: CHIARELLI, Tadeu. Um jeca nos vernissages. Monteiro Lobato e o desejo de uma arte nacional no Brasil. São Paulo: EDUSP, 1995

${ }^{4}$ REGO, José Lins do. Pedro Américo: conferência lida no Salão de Conferência da sociedade dos Amigos de Alberto Torres. Rio de Janeiro: Casa do Estudante do Brasil, 1943. p.23-24.

5 FREYRE, Gilberto. "o drama de Pedro Américo". In: Pessoas, coisas e animais. 2 ed. Porto Alegre/Rio de Janeiro: Globo, 1981, pp.94-100.
} 
atribuição de "universal" desenvolvida em sua construção biográfica, uma cujo fundamento teórico herdava os estudos em filosofia da história de Vico e Herder, que viam, especialmente a partir da filologia, uma conexão entre todos os povos, no que possuiam de universalmente humano. A defesa desta última imagem parece ter mesmo mantido seu eco sobretudo nos aliados do artista ou em alguns textos posteriores, especialmente nordestinos, de caráter notadamente hagiográfico ${ }^{6}$.

Tais leituras, de um lado ou de outro, complicaram mais do que explicaram. Ali, se encontrará um Américo descomprometido com o seu país, hiperbólico em seus feitos e, menos frequentemente, mas não tão raro, charlatão em algumas de suas afirmações. Lá, um desde sempre prodígios das artes, gênio explosivo voltado a um interesse enciclopédico, dedicado ainda às ciências e à política nacional.

A dúvida permanece quanto à construção de tantas atribuições atreladas ao artista. Afinal, o que queriam dizer todos os qualitativos, e especialmente os positivos, que the foram imputados constantemente, e o que isso contribuiu para que fossem compreendidos a fundo em suas numerosas biografias? Foram inventados para fazê-lo parecer mais do que era? Foram aptidões que teria de fato recebido de uma natureza dadivosa, de um clima quase temperado da cidade de Areia, na Paraíba, que por vezes foi introduzida por seu biógrafos quase como uma nova Grécia, seguindo o fio da perspectiva climática winckelmanniana?

Esta pesquisa lida com algumas das questões que envolvem essa construção complexa desse artista como homem multidotado. Tenta-se compreender, sobretudo a partir do estudo de sua fase de formação (quando essa imagem começa programaticamente a se construir) e de suas primeiras obras autorais, produzidas na Europa, o que significava para o jovem Américo a defesa de uma atuação e formação que não se encerravam em seu mais conhecido e lucrativo mêtier, pelo qual continua, ainda, a mais importar e a ser estudado no Brasil.

Os mesmos valores por muito tempo repetidos, mesmo que em superficialidade, serão convertidos em indagações extraídas de determinadas atuações do artista em sua carreira. Assim, o que teria então significado para Américo cursar em sua juventude um bacharelado em ciências naturais, defender um inédito doutorado na mesma área, diploma em geral ainda muito raro no Brasil do período, e em específico, sem qualquer quaisquer precedentes entre os artistas plásticos do seu tempo? O que significou a mudança que optou fazer desde muito cedo de uma cadeira prática de desenho figurado na Academia Imperial de Belas Artes (para a qual ingressava via concurso), para

${ }^{6}$ Como é o caso do livro de Martins. Ver também: ALMEIDA, Horácio de. Pedro Américo, notícias biográficas. João Pessoa: União Editora, 1943. 
outra teórica, na qual seria o responsável por ofertar o primeiro curso de história da arte, estética e arqueologia numa instituição brasileira? O que significou ocupar, nesse mesmo momento, o posto de conservador da seção de arqueologia do Museu Nacional? O que implicava um pintor dedicar-se a séries contínuas de escritos filosóficos, científicos, artísticos, romances? A se tornar, enfim, a duras penas, após anos de luta para a ocupação de um cargo político, um deputado eleito na República recém-instaurada?

Nem todas essas perguntas não poderão integralmente respondidas nesta Tese, na medida em que algumas se estendem para recortes cronológicos posteriores ao aqui delimitado. Mas, para esta pesquisa, a hipótese que envolve incontornavelmente todas elas é: Pedro Américo estabeleceu, desde muito jovem, linhas gerais de um projeto que seguiria com afinco. Não se trata, naturalmente, de uma destinação pré-determinada imaginada nesta Tese - longe disso -, mas de um conjunto recorrente de intenções que parece ser alimentado continuamente, como ações e reações a determinadas questões que inquietavam o artista. Em todo caso, cabe dizer que esse é um projeto que antes de ser compreendido, precisa mesmo ainda ser descrito. Não se apresentou como um que ele teria propriamente inventado, é verdade. Era antes já existente e almejado por muitos agentes brasileiros da artes, alguns dos quais o haviam influenciado muito desde sua primeira fase oficial de formação, entre 1855 e 1859, no Rio de Janeiro. Era ainda um cuja demanda também encontraria amplo rebatimento em nível internacional, ainda no mesmo período de sua formação européia, realizada em seguida, entre 1859 e 1864.

Neste último contexto, Américo integrou a geração de artistas formados na França durante as décadas de 1850 a 1870, aos quais foi insistentemente requerida uma formação histórica e, sobretudo, filosófica, percebidas como o único meio possível para a saída de mais uma nova crise da "grande arte".

Um primeiro problema era de ordem estética. Naqueles decênios, o grande inimigo "romântico" contra o qual a "arte acadêmica" havia lutado desde a década de 1830 já não assustava mais. Depois da abertura artística que Antoine-Jean Gros (1771-1835), antigo aluno de Jacques-Louis David, havia feito em direção a uma via romântica ainda apegada ao neoclassicismo, muita coisa havia irremediavelmente mudado. Théodore Géricault, morto à flor da idade, no fim da década de 1820, e influenciado por Gros, exacerbara esse sulcro até o rompimento daquela passagem ainda conjunta, deixando entre outras obras a sua monumental Balsa da Medusa (1819), que na metade do século XIX já atraía à sua frente inúmeros artistas e admiradores. Eugène Delacroix, por muito tempo encarado como a antítese irreconcilivável de um artista como Jean-Auguste-Dominique Ingres 
(defensor maior dos princípios clacissistas e também discípulo de David, mesmo que sua produção mostrasse caminhos notavelmente "românticos"), desde a década de 1840 recebia distinções oficiais do governo francês, culminando em sua nomeação à Académie des Beaux-Arts, da qual fazia parte o mesmo Ingres. O relativo apaziguamento e a síntese dificilmente imaginados nos anos 1830 se mostrariam, assim, possíveis aos jovens artistas nos anos 1850, mas a crise da arte continuava, agora pior e com um novo vilão, para muitos ainda mais perigoso: o realismo. Ao passo que românticos e clássicos, a despeito de todas as suas defendidas diferenças antitéticas ${ }^{7}$ (razão $x$ emoção, clareza $x$ imprecisão, belo $x$ sublime, desenho $x$ cor), haviam bem ou mal tido seus desígnios idealistas ${ }^{8}$ conciliados por uma nova geração de artistas aos quais podiam agradar concomitantemente ambos os lados, os realistas sulcavam uma nova frente "sensualista" julgada por muitos demasiadamente perigosa, porque teria deixado de lado o mais importante fim da arte: a realização do famigerado Belo ideal. Mas o realismo era apenas a primeira das várias vertentes artísticas que começavam a pipocar a partir do fim dos anos 1840 - os anos do advento da Segunda República francesa, que garantiam a ascenção da burguesia pelo apoio dado a Charles Louis Napoléon Bonaparte, futuro imperador Napoléon III -, colocando em reavaliação os antigos preceitos "acadêmicos" e ainda "oficiais" que haviam regulado por muito tempo o ensino artístico (esferas que até então marchavam juntas, porém, em pouco tempo, não mais). A reavaliação era ainda imposta aos critérios estabelecidos para apreciação de obras e de artistas nas grandes ou pequenas mostras artísticas, incluindo aquelas nas quais se exibiam os trabalhos dos jovens artistas que desejavam receber o Prix de Rome da École des Beaux-Arts de Paris, instituição modelo para todo mundo. Entre os extensos limites demarcados, de um lado, por um "mercado oficial", suportado pelo governo, e de outro, pelo aparecimento de um promissor mercado de arte privado, bastante heterogêneo em suas demandas - e frequentado por uma classe economicamente ascendente, mas de diferentes níveis culturais -, antigos bolsistas do estado, alunos da École ou de outras escolas, artistas independentes ou auto-didatas, artistas manifestamente contrários à estética acadêmica, pintores de história, de gênero, de retrato, paisagem, natureza-morta, todos, enfim, em suas mais diversas inclinações e interesses, pareciam finalmente encontrar um lugar potencial para suas carreiras. O Salon des Beaux-Arts, por bastante tempo e ainda a mais importante mostra periódica internacional de arte, até então controlado pela Académie, perdia a força hegemônica e outrora: abriam-se cada vez mais mostras independentes e, por vezes, mesmo oficiais, que com ele

\footnotetext{
${ }^{7}$ Para uma leitura já clássica dessas oposições entre clássicos e românticos, ver: FRIEDLANDER, Walter. De David a Delacroix. São Paulo: Cosac \& Naify, 2001.

${ }^{8}$ Sobre o problema da aproximação entre românticos e clássicos enquanto idealistas, e sua contraposição às vertentes realistas, ver a bastante conhecida análise de G. C. Argan: ARGAN, Giulio Carlo. Arte Moderna: do Iluminismo aos movimentos contemporâneos. São Paulo: Companhia das Letras, 2013.
} 
passavam a disputar com sucesso, reivindicando um novo espaço de representatividade e, ainda mais, direitos legais de existência permanente. As antigas teorias artísticas - que proferidas pela Académie e injetadas no seio de suas instituições artísticas haviam dado conta por algum tempo da regulação do que era "bom” ou "mau” gosto e do que poderia ou não ser comprado e asselado como arte - haviam então deitado em boa parte por terra, não sendo mais suficientes para responder todas as expectativas artísticas da "modernidade". O "corpo moribundo" mais célebre desse tombamento, terço de reza ainda frequentado e mantido como estandarte nas instituições acadêmicas, era o legado da arte grega.

Em um tal panorama, a única saída possível para tamanha sinuca de bico, percebida pelo governo imperial francês - que se viu então obrigado e abrir seus horizontes artísticos sem abrir mão dos seus valores morais fundamentais -, era avaliar, na multidão de correntes artísticas, o que era realmente importante, duradouro e característico da "grande arte", independente de sua forma, e o que era passageiro e fruto da moda dos tempos.

Um processo de avaliação como esse parecia não poder vir senão por meio da educação do artista. Não mais uma educação dogmática, mas uma que combinasse prática e teoria, e neste domínio, filosofia e história, disciplinas que alargariam, precisamente, o seu universal estético e intelectual. Essas duas eram, com efeito, então percebidas como irmãs gêmeas especulares, cada uma dedicada, respectivamente, ao permanente e imutável, e ao efêmero e transitório. Seria uma demanda desse tipo - que embora estivesse presente há algumas décadas, nas penas de críticos e relatores franceses oficiais, encarregados de darem seu aval sobre as situações artísticas da França - que culminava na reforma da École des Beaux Arts de Paris e na criação de cursos técnicos e teóricos, incluindo um curso de estética e história da arte aplicada às belas artes; mudanças essas feitas no mesmo momento em que o jovem Américo estudava nessa instituição.

Esse problema de natureza estética ainda se combinava intimamente com outro, de ordem econômica, que corroborava do mesmo modo à identificação da crise da "grande arte" e da perda de uma unidade que se supunha anteriormente existente. Em um processo contínuo de especialização e de defesa da autonomia da experiência estética, a arte - e entenda-se a arte guiada pelos preceitos da Académie des Beaux-Arts - parecia ter deixado de ser útil à sociedade, concentrando-se em um discurso tradicional e autorreferencial, sem qualquer relação com as questões do presente, e sem dúvida a mais urgente: a sua relação com a indústria, defendida a balde como a maior fonte de riqueza do período. O discurso acadêmico havia julgado essa relação bastarda, indigna mesmo ao grande artista. Mas o discurso então oficial do governo francês percebia nessa relação a dupla 
vantagem de restituir o contato e a importância da arte na sociedade - trazendo suas lições aos objetos do quotidiano - e de aumentar significativamente os dividendos da economia nacional. A solução encontrada para resolver esse segundo problema seria, oportunamente, a mesma dada ao problema estético, exigindo uma ampliação das capacidades de reflexão e, especialmente, atuação do "artista moderno". Com efeito,

A revalorização do trabalho [artístico], que vai se operar nos anos que precedem a reforma [da École], responderá à necessidade de promover uma arte aberta ao mundo da indústria contemporânea. Se oporá assim o artista universal, ao mesmo tempo arquiteto, pintor, escultor, mas igualmente organizador de festas e criador de jóias ou de bibelôs, ao artista moderno confinado em um domínio particular, do qual ele não pode sair por falta de estudos gerais. ${ }^{9}$

Do lado de "cá”, no Brasil, estavam presentes os mesmos meios artísticos que, na França, passariam a exigir com insistência aos jovens estudantes dedicação à instrução teórica, ao lado da prática. Mas esses meios eram aqui justificados para fins substancialmente distintos. No país, não se trataria de dar a volta por cima de uma crise que derrubara e confinada em especializações ilhadas algo que já havia sido grande. Tudo estaria ainda a fazer. Sem tradição artística suficientemente estruturada, sem mercado de arte, sem profusão de obras e encomendas, sem indústria potente e, pior, sem consideração social dedicada à classe artística - decorrente do ranço escravocrata, que dominava muitas das atividades manuais -, instruir artistas significaria criar algo que ainda não existia e defender a arte como atividade liberal (como o direito e a engenharia), ainda que o objetivo, oficialmente perseguido, fosse também a realização do Belo ideal.

Não há um só escritor no país que se dedicou às artes no século XIX que não tenha falado em “infância" brasileira nas artes, da inexistência de uma "escola brasileira”, e que não tenha sonhado com um futuro promissor nesse domínio, tão promissor quanto o de uma nação nova, que disporia de tudo para deslanchar e se por ao lado das "grandes" nações européias, e dos nossos "irmãos", também novos mas já potentes, os Estados Unidos.

Nos anos de Américo na AIBA, o compromisso com a educação teórica havia também sido garantido pela retomada e implementação dos antigos planos que vinham desde a época de Joachim Lebreton, integrante da "Missão Artística Francesa", cruzando a “era" em que Félix-Émile Taunay

\footnotetext{
${ }^{9}$ BONNET, Alain. L'enseignement des art au XIXe siècle: la réforme de l'École des beaux-arts de 1863 et la fin du modèle académique. Rennes: Presses Universitaires de Rennes, 2006. p.251.
} 
se encontrava na cabeça da academia. Mas seria Manuel de Araújo Porto Alegre - também ele na fronteira de diversas atuações artísticas e políticas - que iria mostrar pessoalmente o caminho a Américo, como havia feito a propósito com vários dos seus colegas, dentre os quais se incluía Victor Meirelles, então bolsista premiado e residente na Itália e depois na França. Também no Brasil, como na França, Américo foi um fruto "colhido" em tempos de reforma, aqui experienciada pela chamada "Reforma Pedreira", que havia igualmente promovido dois lados operacionais: o da instrução teórica dos artistas plásticos, e técnica, dos artistas industriais.

$\mathrm{Na}$ cruzada de diferentes meios artísticos, nacional e europeu, e no compartilhamento que as suas instituições oficiais faziam do mesmo horizonte, Américo tomava para si essa demanda de intelectualização e alargamento de atuações como profissão de fé, e a levava às suas mais fortes consequências - ao menos em nível pessoal -, jamais atingidas por nenhum outro artista brasileiro no século XIX. Estava fadado a ser o único de sua "espécie".

Desde o início de sua carreira, ele tocou com quase obsessiva assiduidade o problema social das artes no Brasil, com o qual haviam se debatido anos antes, e ainda se entrebuchavam nas décadas de 1850 e 1860, tantos outros agentes importantes no país - Jean-Baptiste Debret, Félix-Émile Taunay, o próprio Porto Alegre, Francisco Joaquim Bethencourt da Silva etc.

Patente em Américo, sem dúvida mais do que em qualquer outro artista no país, estava um descontentamento, para não dizer encabulamento ao se afirmar "apenas" artista. E assim que pôde, ele passou, com efeito, a se subscrever permanentemente "Bacharel Américo" ou "Doutor Américo", pedindo, ademais, que assim se lhe dirigissem. Também evidente nele era a conclusão a respeito da insuficiência que a sua profissão parecia assumir nas diversas relações sociais do Brasil, como se no país o "ser artista" não comportasse, como alhures, o "ser filósofo", o "ser cientista", o "ser empresário", o "ser político", enfim, um agente social importante e, mais que isso, necessário a um país que se construía recentemente independente. Havia, no pintor, um verdadeiro desapontamento em constatar que as artes não participavam em quase nada do "progresso" do país (do qual deveria ser, segundo acreditava, ao lado de outras personalidades, o mais forte braço) e que elas encontravam uma pífia representatividade social, dificilmente ultrapassando o socorro fornecido à vaidade do retrato.

Era precisamente essa situação geral que ele desejava alterar; era esse o horizonte propositivo do seu referido projeto. 
Antes de descobrir os meios de efetuar essas mudanças externas, que envolveriam a política - e ele estava desde muito jovem bastante ciente disso -, ele começou, no entanto, uma interna. Quis ser o antídoto da própria "enfermidade" detectada em sua condição profissional; se tornar a exposição e demonstração em pessoa de que o artista brasileiro poderia mudar sua condição social e intelectual por meio do estudo e do trabalho; e mostrar que a arte, enquanto atividade fundamentalmente liberal, não é só fazer, mas, sobretudo, refletir.

Interessa, pois, demonstrar nesta Tese que, desde o início da sua carreira, não há de fato fronteiras entre o Américo pintor, o Américo filósofo, o Américo teórico. A mesma mão destra pintava, era a que escrevia, e não se pode compreender totalmente a profundidade da arte desse artista sem considerar esse dado fundamental. Suas atuações sempre estiveram imersas em um projeto intelectual (e aqui eu reforço a imagem desse projeto não como algo acabado ou imutável, mas como a de intenções que se lançam ao futuro, respondendo, todavia, a inquietações decorrentes do presente), e sempre exprimiram a íntima relação de concepções filosóficas e artísticas que lhe foram caras durante toda sua vida. Uma das principais contribuições aqui visadas é, portanto, sinalizar os interesses centrais por ele perseguidos desde os seus anos de formação - anos sem dúvida decisivos -, os quais, com o tempo, se perderam nos citados adjetivos.

Na primeira biografia dedicada a Américo, então com 28 anos, Luis Guimarães Júnior, seu amigo próximo, já chamava a atenção do leitor para a importância da dimensão intelectual, ou o que chamou de o "duplo caráter de pintor e escritor" 10 , ao qual se dedicou desde os seus primeiros anos franceses de estudo: "o nosso entusiasta artista, enquanto depositava na oficina de pintura o ousado pincel, brandia a pena desassombrada, e metia-se na turma agitadora dos pensadores e dos filósofos, da pátria de Diderot, e de Lacordaire" ${ }^{\prime 1}$.

Era já na etapa final de realização dessa primeira fase de formação intelectual, que então se compunha de duas formações concomitantes - uma científica, inédita, que perseguia por meio da tentativa de obtenção de um diploma de bacharel, de palestras em sociedades científicas, de leituras de compêndios filosóficos e artísticos; e uma artística, que realizava na École des Beaux-Arts, na École Gratuite de Dessin et Mathématiques, no Museu do Louvre, no Museu Napoléon III, na Biblioteca Nacional de França, nos ateliês de Léon Cogniet e Sébastien Cornu, e em tantas quantas outras cidades européias para onde viajou em estudo e lazer -, que Américo realizava os primeiros

\footnotetext{
${ }^{10}$ GUIMARÃES JÚNIOR, L. Pedro Américo. Rio de Janeiro: Henrique Brown, 1871. p.61.

${ }^{11}$ Idem, ibidem. p.59.
} 
movimentos públicos no sentido de garantir a exequibilidade do projeto teórico e político que então demonstrava concebe rpara as artes brasileiras, conforme será visto.

O que o guiava nesta trincheira - pois para ele, desde que os expunha, era, ao fim e ao cabo, uma guerra que iria encontrar - era uma fieza absoluta no idealismo filosófico, conquistada desde os tempos da AIBA, e que possuía como máximos princípios operativos a razão, a vontade e a liberdade, fornecendo-lhe ainda a certeza da existência de valores espirituais absolutos e incontestáveis, como a ideia mesmo do Belo, ao lado das do Bem e do Verdadeiro. Desenvolveu-se pela primeira vez nesta Tese a interpretação sobre a extensão desse idealismo na primeira fase carreira do artista, e sobre como ele bebia em uma fonte abundante provinda do Ecletismo de Victor Cousin, cuja importância para instituições oficiais tanto dos impérios brasileiro e francês era incontestável. No país, os amigos Porto Alegre, Gonçalves de Malhães, Torres Homem, entre outros pensadores importantes, levaram a bandeira desde os anos 1830 (após a introdução que o frei Montalverne lhes havia feito a essa filosofia), e essa influência já havia se espraiado oficialmente para quase todos os setores administrativos e políticos do poder nos anos 1840, especialmente após o "Golpe da maioridade". A razão era clara: embora ainda profundamente espiritualista, a filosofia eclética havia aberto a defesa do despegamento cabal entre o estado e as instituições eclesiásticas e e a filosofia tomista dominante (no país, especialmente as ordens terceiras, já em gradual desgaste), corroborando a ideia de um estado liberal e, na medida possível no período, laico, que fundaria finalmente todas as expressões elevadas da nova nação.

Conforme será argumentado, as proposições de Américo também concorriam ao mesmo fim e colocavam a arte no centro de um programa educativo para o desenvolvimento do país, em uma frente teórica (por meio do ensino filosófico), econômica (por meio da difusão do desenho, e de sua recepção na indústria) e simbólica (centrada na construção de uma arte de aparência "branca" e, mais do que isso, notadamente anti-indianista). Para o jovem artista, a produção artística era uma luz que guiaria e espelharia a humanidade. E é dessa admissão que provinha a sua compreensão da destinação social do artista, que também não podia admitir que o seu trabalho terminasse em mera contemplação estética desinteressada; isto é, um que não podia jamais se tornar "arte pela arte": expressão que começava então a ser bastante proferida, curiosamente, pelos apóstolos do Ecletismo. Como será visto, a atividade artística deveria ter, ao contrário, para ele, um caráter moral e civilizador.

Aquelas três frentes, que integravam esta destinação, são aqui estudadas a partir de 4 obras, realizadas por Américo entre 1863 e 1865, num período que compreende o fim dos seus estudos na 
Europa e o seu retorno ao Brasil - ainda que respondessem, naturalmente, aos 11 anos de formação artística e intelectual que completava naquele último ano, isso sem considerar os quase dois anos da tão comentada, mas de fato tão pouco conhecida expedição científica, de que participara ainda muito pequeno, ao lado do naturalista Jacques Brunet, no nordeste do país. Tratam-se dos textos $L a$ Réforme de l'École Beaux Arts et l'opposition, escrito e publicado em Paris, em 1863, Considerações Filosóficas sobre as Belas Artes entre os Antigos, escrito em Paris e publicado no Brasil, em 1864, Cartas de um Plebeu, produzido e publicado inteiramente no país, em 1865; e da pintura A Carioca, pintada em Paris entre 1863 e 1864, e apresentada na corte, no início de 1865.

Discute-se aqui como essas obras respondem a fins específicos, lançadas em momentos estratégicos, por ele cuidadosamente ponderados: os dois primeiros textos e a pintura respondiam, cada um, por exemplo, a todos os maiores eventos artísticos ocorridos em Paris entre 1863 e 1864, que se tornaram quase míticos, posteriormente, para toda uma bibliografia sobre a arte moderna: a reforma da École des Beaux-Arts (instituição internacionalmente reconhecida como modelo para muitas outras); a criação do primeiro curso de História da Arte nessa instituição; e a formação dos polêmicos Salons do ano de 1863, com a profusão apresentada de quadros de nus femininos e banhistas.

Considerações Filosóficas sobre as Belas Artes entre os Antigos e A Carioca, os trabalhos de maior envergadura, são especialmente discutidos um relação ao outro, nesta Tese. Até hoje, eles foram dificilmente percebidos como integrantes de um mesmo e coerente conjunto. Trata-se aqui de compreendê-los como obras irmãs, que participam de um mesmo objetivo: o texto é um estudo filosófico com tema e pretensões artísticos; e a pintura, uma produção artística com intenções proporcionalmete filosóficas. Juntos, defende-se, eles abririam o primeiro precedente para uma frequentação assídua que o artista então fazia a produções escritas que antecipassem ou justificassem posteriormente os partidos tomados e as concepções desenvolvidas em suas obras pictóricas. Não será surpresa saber que, em 1882, quando Américo começava a pedir para ser jubilado da AIBA, dedicando-se a campanhas para se eleger deputado, e por em prática, mais uma vez, uma nova leva projetos diretamente devedora daquele de sua juventude, esses dois trabalhos, tivessem sido, um, refeito (A Carioca), e outro, republicado (Considerações Filosóficas). E eles ainda acompanharam um romance, o Holocausto, que narrava poeticamente nada menos do que os anos de formação do artista até a apresentação dessas obras, e o desfecho de suas apresentações, no Brasil. 
Com Américo - repete-se - a teoria nunca se afastou da prática, e é, portanto, nessas duas primeiras obras onde se podem encontrar os fundamentos dessa postura na carreira do artista, sendo mesmo, em certo sentido, uma revitalização das práticas neoclássicas de um J.-L. David, por exemplo.

Os conteúdos e objetivos particulares a cada uma das obras de Américo tratadas nesta pesquisa são estudados em Capítulos específicos, nem sempre proporcionais em tamanho e quantidade. Contudo, em todos eles se tentou contemplar uma leitura internalista das suas produções a outras externalistas, nas quais se consideraram o contexto cultural e social no qual o jovem artista estava imerso (com as limitações ainda existentes, em muitos pontos, da bibliografia sobre o Brasil no século XIX) e, do mesmo modo, as relações diretas ou indiretas estabelecidas com diversas personalidades das artes e das ciências, no Brasil e na Europa.

Para tanto, foi utilizado um material consideravelmente grande e heterogêneo, que incluiu os textos originais do artista-filósofo e a leitura atenta de toda a bibliografia por ele citada, além de uma bibliografia secundária necessária a compreensão de algumas questões por elas levantadas. $\mathrm{O}$ material inclui também cartas de Américo a diversas pessoas, registros de porto, artigos de jornal sobre o artista ou de sua autoria (relativos às suas obras ou a questões e mesmo polêmicas nas quais esteve envolvido), as atas da Congregação da Academia Imperial de Belas Artes, registros e materiais das instituições visitadas nesta pesquisa, no Brasil e no exterior ${ }^{12}$, uma vasta bibliografia sobre a pintura de nu no século XIX, sobre os salões dos anos 1860, sobre a formação dos Salões de arte do período, sobre as discussões sobre arte e indústria, e sobre as reformas do ensino artístico realizadas nesses mesmos anos. Cite-se, ainda, o acesso a coleções em alguns países para os quais Américo viajou.

Esse material proveu um amparo precioso às hipóteses e questões desenvolvidas nesta Tese. Em poucas palavras, o que se encontrará nos Capítulos seguintes é, portanto, a discussão sobre o nascimento, desenvolvimento e desfecho da primeira versão de um projeto do jovem Pedro Américo para as artes brasileiras, dentro do qual se inscreveu ainda uma teoria artística. Com efeito, as duas balizas que delimitam esta pesquisa estão concentradas numa única e mesma ideia de reformas: começa com a instalação de duas reformas efetivas vividas por Américo, no Brasil e na França, em 1855 e 1863, e termina na tentativa de uma por ele próprio estruturada, em 1865-66.

${ }^{12}$ Entre eles: Museu d. João VI, Arquivo Nacional, Museu Imperial de Petrópolis, Palácio do Itamaraty, Biblioteca Nacional do Rio de Janeiro, Museu Regional de Areia, Archives Nationales e Bibliothèque Nationale da França, École des Beaux-Arts Museu d'Orsay, Museu do Louvre, Biblioteca Jacques Doucet. 
Assim, no Primeiro Capítulo, Ao revés da maré: Pedro Américo e La réforme de l'École des

Beaux-Arts et l'opposition, discute-se a participação sui generis do jovem artista nos debates sobre a reforma das Écoles de Paris e de Roma, tendo sido o único aluno da instituição a publicar um texto independente sobre a questão, e sendo além disso um estrangeiro. Argumentam-se as razões que os protagonistas das medidas reformistas apresentaram para alterar as organizações administrativa e curricular dessas instituições, e, sobretudo, os motivos que teriam levado Américo a se manifestar a favor dessas mudanças (e contra quase todos os seus colegas), já na fim da bolsa de estudos concedida pela Casa Imperial. A compreensão desse posicionamento singular é sugerida a partir da leitura crítica do seu primeiro texto publicado, especialmente em relação ao percurso percorrido em seus anos formação, no Brasil e no exterior. São discutidos os legados deixados ao jovem durante o período de seus estudos no colégio d. Pedro II, e na AIBA, sob a égide de Manuel de Araújo Porto Alegre; e são ainda consideradas suas formações artística e científica em Paris, incluindo sua preparação ao bacharelado, suas inclinações estéticas e filosóficas, expressas, entre outras vias, pela escolha das cópias que decide livremente fazer no Museu do Louvre, e pela escolha dos seus professores de pintura particulares, Léon Cogniet e Sébastien Cornu.

O Segundo e Terceiro Capítulos tratam, ambos, do maior e mais importante texto escrito e publicado por Américo em sua juventude, Considerações Filosóficas sobre as Belas Artes entre os Antigos. No primeiro desses capítulos, são sugeridas as circunstâncias favoráveis ao aparecimento desse estudo. Coloca-se-o em relação a um quadro retrospetivo e contemporâneo a Américo, que encontra, de um lado, as demandas teóricas de Porto Alegre aos alunos da AIBA, ingressantes após a reforma de 1855, e, de outro, a abertura do curso de Estética aplicada à História da arte na École des Beaux-Arts de Paris, seguido pelo brasileiro. Defende-se que o texto de Américo se apresentou como o esboço calculado de um primeiro curso de história da arte, estética e arqueologia oferecido no Brasil, sinalizando já a intenção do artista em assumir - como de fato irá fazer - a cadeira homônina criada na instituição brasileira por Porto Alegre.

No Terceiro Capítulo, Por um teoria da arte brasileira, procede-se a uma leitura propriamente internalista das Considerações Filosóficas. Em lugar de realizar a um fichamento linear desse texto, o que se fez foi extrair dele algumas das questões principais que acompanham Américo em sua formação, e em suas produções escritas e pictóricas do período, muitas delas bastante frequentadas ao longo de sua carreira: problemas sobre a gênese e o fim das artes, sobre o belo, o "real", a “imitação" etc. Discute-se com necessária insistência a filiação filosófica do artista ao Ecletismo bem como sua inicial imersão ao Krausismo, absorvido de seu futuro orientador de doutorado em Bruxelas, Guillaume Tiberghien. Nesta parte, defende-se o início de uma adesão permanente que o 
jovem fará ao idealismo filosófico, chamando atenção sobre como esse posicionamento lhe ajudará a desenvolver uma teoria da arte igualmente idealista para o Brasil, e ainda um projeto geral, que definirá, segundo compreendia, as bases gerais para o desenvolvimento das artes no país.

Para ambos os capítulos priorizou-se a primeira versão desse Texto, publicada no segundo semestre de 1864, no Correio Mercantil do Rio de Janeiro, ainda que se tenha também recorrido ao manuscrito desse texto oferecido ao imperador - ligeiramente modificado em algumas partes, e suprimido de outras -, e a uma reedição posterior dessa última versão, simples mas valiosa - tendo em vista a escassez de reedições de fontes primárias no Brasil -, publicada em 2006 por Silvano Alves Bezerra da Silva. Para facilitar ao leitor a comparação entre as interpretações aqui desenvolvidas e as versões do texto de Américo, ambas são sempre indicadas em nota de rodapé, em suas respectivas edições e páginas.

O Quarto e Quinto Capítulos são também dedicados a um único objeto: a pintura $A$ Carioca. De certo modo se aproximando das estratégias dos dois capítulos anteriores, esses estudos também tratam, um, do contexto de produção da pintura; e o outro, da obra propriamente dita. Apresenta-se nesta Tese uma reprodução inédita da primeira versão da pintura, jamais trabalhada em textos anteriores a ela dedicados $^{13}$, o que permitiu estabelecer uma interpretação em boa medida menos problemática, mas sem dúvida ainda não completa, no que concerne às perguntas lançadas a essa obra e ao seu contexto original, sem ter que se recorrer à versão que Américo fazia em 1882 da mesma obra, em diversos níveis de leitura consideravelmente distinta da primeira versão.

No Quarto Capítulo, O nascimento de uma Ninfa brasileira, discutem-se os contextos cultural e artístico parisiense, e pessoal, de Américo, especialmente nos primeiros anos da década de 1860. Apresentam-se uma série de questões que envolvem o surgimento da "ideia" da Carioca, sua condição ou não de "encomenda”, seus modelos iconográficos, contemporâneos e históricos, sua

\footnotetext{
${ }^{13}$ MÁrTIN, Sílvio Santos da Silva. "La Carioca rencontre La Source: Pedro Américo dans l'atelier d'Ingres ?", Loxias, n. 42. Disponível online em : http://revel.unice.fr/loxias/index.html?id=7584 [último acesso: 20 de janeiro de 2016]; OLIVEIRA, Claudia de. “A Carioca' de Pedro Américo: gênero, raça e miscigenação no Segundo Reinado". In: CAIANA. Revista electrónica de Historia del Arte y Cultura Visual del Centro Argentino de Investigadores de Arte (CAIA). N.2 Año 2013.)

Disponível online em: http://caiana.caia.org.ar/template/caiana.php?pag=articles/article_2.php\&obj=98\&vol=2 [último acesso: 10 janeiro de 2016]; OLIVEIRA, Cláudia de; NERY, Laura de. "A Carioca, de Pedro Américo: alegoria e erotismo no imaginário oitocentista brasileiro." In: ANAIS do XXIV Simpósio Nacional de História - ANPUH/ Simpósio temática História Cultural e suas interfaces. São Leopoldo (RS): Unisinos, 2007. Disponível em : ttp://www.ufrgs.br/gthistoriaculturalrs/laura_nery_e_claudia_de_oliveira.html [último acesso: 10 de janeiro de 2016]; PEREIRA, Sônia Gomes. "O percurso e os dilemas de artistas brasileiros em Paris no século XIX: o caso da tela A Carioca de Pedro Américo." In: RIBEIRO, Marilia Andrés; GONÇALVES, Denise da Silva (Orgs.) Anais do XXI Cológio do Comitê Brasileiro de História da Arte. Tiradentes/MG, outubro de 2005. Belo Horizonte: Editora C/ Arte, 2006. [pp.292-301].

Como será visto, ofereço uma leitura bastante distinta das análises desenvolvidas pelos autores acima citados.
} 
aproximação às discussões e exposições artísticas naqueles anos, sobretudo em Paris, e as viagens de formação do artista a coleções artísticas em outras cidades européias, cujas coleções dispunham e várias obras que também estabeleciam próxima relação com a sua pintura. Uma das intenções deste Capítulo foi de se estabelecer um passeio imaginário ao lado do jovem, na visitação que fazia a diversas coleções e exposições, percurso orientado especialmente em direção às obras que certamente haviam despertado seu interesse ao produzir a sua ninfa.

No Quinto Capítulo, Um ideal branco e sem tragédia, entra-se especificamente nos problemas relativos à produção da Carioca. Interessa especialmente argumentar de que maneira essa pintura é uma resposta pictórica à teoria que Américo havia desenvolvido em seu Considerações Filosóficas, embora ela ainda não tenha conseguido responder inteiramente a seus postulados. De todo modo, tenta-se mostrar o esforço do jovem no sentido de entregar a imagem de uma muher ideal, filosófica e racionalmente construída a partir de um mesmo conjunto de "leis estéticas", amparado por uma teoria da imitação, que havia defendido em seu texto. O resultado, defende-se, é uma obra que se quer garantir dentro de um "idealismo eclético", para Américo, procedimento indispensável para transformar sua naiáde em uma imagem ao mesmo tempo verdadeira e brasileira. Quanto a este último aspecto, interpretado à luz do que se sustenta aqui ser o significado da Carioca, se verá de que maneira o jovem procurou criar uma significativa divergência em relação aos programas historiográficos e artísticos empreendidos por membros do Instituto Histórico e Geográfico Brasileiro, dentre os quais se incluía seu mentor Porto Alegre, que privilegiavam a construção de uma série bem conhecida de obras que, especialmente nas décadas de 1860 e 1870, tomam o índio como tema capital. Em lugar de uma pintura indianista, como a Primeira Missa no Brasil ou Moema, produzida por seu colega de estudos na Europa e depois colega de trabalho na AIBA, Victor Meirelles; em lugar de alegorias fluviais também devedoras da mesma iconografia, como as projetadas por João M. Mafra (supostamente com pitacos de Porto Alegre) para a Estátua Equestre de d. Pedro I, executada em Paris por Louis Rochet quase no mesmo período (1862), Américo preferiu entregar uma representante simbólica do Brasil que fosse necessariamente branca, na medida em que percebia e queria acreditar que se tratava de um país "branco". Interessa assim mostrar como é esse um caráter fundamental à Carioca, que se insere como um dos viéses característicos ao projeto artístico e político do jovem Américo.

Originalmente, havia ainda a intenção de se desenvover nesta Tese uma série de questões sobre as circunstâncias que sucedem o aparecimento dessa pintura, especialmente sobre as suas curiosas e contrastante recepções no Brasil: acolhida por parte do público, refutada por outra; premiada pela Academia Imperial de Belas Artes, ao mesmo tempo que rejeitada pela Casa Imperial, a quem era 
destinada. A esse respeito pôde-se coletar um material considerável, mas, infelizmente, não houve tempo suficiente para trabalhá-lo de maneira satisfatória. Trata-se de uma pesquisa que espero realizar futuramente.

No Sexto Capítulo, As Cartas de um Plebeu notório: uma nova reforma para as artes no Brasil, discute-se o projeto do jovem Américo para as artes brasileiras. Nele são apresentadas todas as causas específicas que percebe como obstáculos ao desenvolvimento da arte nacional, a filiação à qual endereçava o seu projeto, e, enfim, as ações que desejava empreender para reverter um tal panorama geral negativo. A mais importante, como será tratado, a intenção de difusão obrigatória do ensino do desenho em todo o Brasil, como maneira de garantir a "universalização" da cultura artística, tornando as artes necessárias e úteis ao país - incluindo aqui a tão discutida utilidade que poderia dar à indústria, no importante período de formação das primeiras Exposições Internacionais e Universais.

O Sétimo e último Capítulo, A um triz do xilindró, trata do desfecho triste e quase trágico desse projeto: as oposições que Américo recebeu desde a sua chegada ao Brasil, que incluiram a desconfortável campanha que o seu futuro colega de trabalho na AIBA, Bethencourt da Silva, empreendeu para que ele fosse realmente preso, por afirmar possuir um título de bacharel sem, no entanto, detê-lo formalmente. Essa rixa, imaginava-se que havia começado apenas no fim da década de 1870, sendo desse modo atualizada e compreendida em sua origem e profundidade nesta Tese. Examina-se o problema das classes artísticas no Brasil, especialmente nos anos 1850 e 1860 - ainda muito pouco trabalhado nos estudos sobre arte brasileira do século XIX - e o cabo de força político que disputavam nesse período; cabo que o jovem Américo, ao lançar seu projeto, parece não ter o menor conhecimento da tensão.

Antes de concluir esta Introdução, cabe talvez apenas comentar sobre dois termos frequentes nesta pesquisa, já introduzidos em seu título.

O primeiro se refere ao qualitativo "jovem", que precede ou mesmo substitui repetidas vezes o nome de Américo. Ele tem, a meu ver, uma função importante. Em estudos de história da arte, não é extamente tão frequente a utilização desse tipo de adjunto. Em contrapartida, em estudos de filosofia e filosofia da arte, essas demarcações são mais correntemente usadas para sinalizar fases específicas da vida de um pensador. Com efeito, a imagem aqui introduzida do "jovem Américo" delimita um período de sua formação dedicado ao ecletismo espiritualista, e um lapso temporal que 
termina com a apresentação de suas primeiras obras escritas e pintadas, cujas recepções, somadas a outras situações importantes, abriram caminho para um nova fase na sua carreira, que se iniciava com a realização do seu Doutorado. Mesmo se nesse novo momento, em 1866, Américo seja ainda um jovem pintor (ele vivia seus 23 anos), se observava uma mudança clara, na verdade um amadurecimento, dos seus pressupostos ecléticos em direção à filosofia krausista praticada na Bélgica. E foi nesse período que Américo tentaria, precisamente, superar algumas das limitações do ecletismo (a insuficiência para o problema da moral, e a defesa da "arte pela arte" como objeto autônomo, que não poderia ter pretensões ao bem e à verdade, mas apenas ao belo). Ainda nesse período, da Carioca "eclética" se verão surgir obras já muito mais próximas às concepções krausistas do seu orientador de doutorado, G. Tiberghien, especialmente aquelas ligadas às noções de virtude, coragem, autossacrifício, desinteresse etc.

O segundo termo é a "ciência do Belo", cuja utilização foi preferida à "estética". Os termos foram por vezes utilizados intercambiadamente, mesmo no século XIX, no Brasil e no exterior. A cadeira de História das Belas Artes, Estética e Arqueologia da AIBA prova-o. Entretanto, a ideia de uma "ciência do Belo" pressupunha como o objetivo da arte, naturalmente, a realização do Belo. Julgando-o uma ideia objetiva, parecia irrefutável a possibilidade de estruturação de uma ciência igualmente objetiva que desse conta de explicar os seus fundamentos. Daí a razão pela qual não pareceu haver problemas aos partidários dessa postura chamarem essa "ciência" de "estética", na medida em que, para eles, a "estética" resumia apenas o estudo do Belo, enquanto fim da arte. Em contrapartida, o termo mais comum utilizado posterior da palavra "estética", ainda no sentido de disciplina filosófica, não pressupunha mais que o fim da arte fosse a realização sensível do Belo, e nem que a imitação fosse o principal meio para produção artística. Para evitar a confusão entre esses termos, optei por utilizar, portanto, no título desta Tese, o termo "ciência do Belo", do qual Américo confessava abertamente acreditar na validade. 


\section{Primeiro Capítulo}

\section{Ao revés da maré: Pedro Américo e La réforme de l'École des Beaux-Arts et l'opposition ${ }^{1}$.}

\section{Contra a maré (acadêmica)}

Em 1863, o ainda jovem pintor Pedro Américo se encontrava em Paris, efervescente capital artística e cultural, aproveitando o final irrevogável de uma bolsa de estudos na Europa. Em 15 de novembro daquele mesmo ano, ele testemunhava a publicação repentina de um decreto imperial que reformava substancialmente o funcionamento administrativo e curricular da École des Beaux-Arts, instituição onde, salvo alguns períodos excepcionais, ele havia estudado desde a sua chegada à cidade. A apresentação desse decreto foi seguida de vários meses de constantes discussões, petições e debates públicos entre alunos, professores e os próprios reformadores. Nestes, se incluíam o superintendente das belas artes do Império, Émilien de Nieuwerkerke, o escritor Prosper Mérimée e o arquiteto e teórico Viollet-le-Duc: personalidades até então externas à instituição, que passavam a impor suas vontades por sobre um colegiado outrora independente. Foi um verdadeiro "chahut", tratando-se, com efeito, da segunda grande polêmica artística do ano. A primeira havia sido resultado de uma decisão do imperador Napoleão III, que havia decidido formar, na primeira metade de 1863, um Salão oficial paralelo (o "Salão dos Recusados”), no qual se expunham as obras provindas das muitas submissões negadas pelo júri do Salon des Beaux-Arts daquele ano - júri formado em sua grande maioria pelos mesmos professores da École.

Das recepções favoráveis e desfavoráveis à reforma, a dos alunos foi quase em uníssono expressa pela negativa. Para eles, as novas medidas (apresentadas a seguir), imediatamente implementadas e sem um plano de adaptação mínimo, alteravam profundamente ou ainda interrompiam o trajeto de muitos, sobretudo o dos mais velhos, que há quase dez anos em formação sonhavam ainda ser lauredos com o Prix de Rome, primeira suposta garantia de um futuro de prosperidade nas artes, depois de tantos esforços. Na sequência de um predecente aberto pela Académie des Beaux-Arts (isto é,

1 Pude realizar este Capítulo graças a uma bolsa de estágio de pesquisa no INHA - Institut National d'Histoire de l'Art, em Paris, realizada entre agosto de 2014 e julho de 2015, obtida junto à Fundação de Amparo à Pesquisa do Estado de São Paulo (FAPESP).

2 "Chahut" ("confusão") foi a expressão original muitas vezes utilizada nos confrontos ocorridos durante os desdobramentos da reforma da École des Beaux-Arts. 
a $4^{\mathrm{a}}$ classe do Institute de France, da qual participavam muitos professores da École $)^{3}$, que nos primeiros dias de janeiro de 1864 publicava sua consternação diante da reforma imposta pelo imperador por meio de seus agentes ditos "déspotas", o corpo discente em sua "quase unanimidade" tomou também por direito "conjurar o que eles consideravam [ser] uma catástrofe destruindo seu futuro, perdendo seus estudos e os das gerações que viriam em seguida."4

Entre essas reclamações destacaram-se duas petições coletivas endereçadas a Napoleão III: a primeira, de fevereiro de 1864, contendo 336 assinaturas; e a segunda, imediatamente posterior, somando mais 149, num total de 485 discentes indignados (por si sós, ou por solidariedade à irritação de seus mestres) com uma mudança repentina no sistema de ensino e recompensa que conheciam. Para reforçar a predominância desse coro de indignação, num dos vários ensaios para o retrocesso do decreto, indicaram o restrito número de 6 únicos alunos da École que seriam abertamente favoráveis às mudanças, cifra catada, mas com equívocos, entre as 109 assinaturas heterogêneas presentes em uma carta pública de felicitações à reforma, impressa no Moniteur Universel, ainda em novembro de $1863^{5}$.

Todos os estudantes que assinaram a carta eram franceses, como também eram os que haviam organizado os protestos contra o decreto. A despeito de suas diferenças de opinião, uma tal predominância sugeria a compreensão geral das novas mudanças na escola como um assunto exclusivamente nacional, afinal, todo o ensino estava voltado até então para o Prix, e apenas nativos poderiam concorrer a ele.

Era talvez por essa razão que a oposição estudantil à reforma de 1863 tivesse lembrado de contar em sua publicação o número diminuto de conterrâneos que simplesmente endossaram aquela carta de felicitações, mas havia esquecido completamente de mencionar a existência de uma brochura de 15 páginas também publicada por um aluno logo após a reforma intitulada “La réforme de l'École

3 "Protestation de l'Académie des Beaux-Arts et mémoire annexé", Moniteur universel, Paris, 6 janvier 1864. Reimpresso em CHESNEAU, Ernest. Le décret du 13 novembre et l'Académie des Beaux-Arts suivi du Rapport de M. de Nieuwerkerke, du Décret du 13 novembre, de la Protestation de l'Académie, et de la Réponse de S. Exc. Le maréchal Vaillant, Ministre de la Maison de l'Empereur et des Beaux-Arts. Paris: Didier et Ce., 1864.

4 S/A. Réclamations des élèves de l'Ecole des Beaux-Arts au sujet de la réorganisation de leur École. Paris: Imprimière de Ad. Lainé et J. Havard, 1864. p.8. Tradução do autor. O trecho original é o seguinte: "la presque uninimité des élèves de l'École des Beaux-Arts avaient spontanément cherché comment ils pourraient conjurer ce qu'ils considéraient comme une catastrophe brisant leur avenir, perdant leurs études et celles des générations qui viendront après eux.

5 A conta, no entanto, não é precisa. Ao todo, subscreveram a carta de felicitações 12 ditos alunos da École. De todo modo, o número é diminuto, e é mais surpreendente constatar que 10 fossem alunos de arquitetura, e apenas dois de pintura (e estes, ambos alunos de artistas bem mais flexíveis em suas proposições e produções: Robert Fleury, sintomaticamente o primeiro diretor empossado após a reforma, e Charles Gleyre). O nome de Américo não consta nessa carta de felicitações, formada unicamente por franceses, o que reforça a compreensão da reforma como um problema que dizia apenas aos pátrios. S/A. Moniteur Universel: Journal officiel de l'Empire Français, Paris, n.333, 29 novembre 1863. p.02. 
des Beaux-Arts et l'opposition. - par un élève"; e havia ainda deixado de comentar que se tratava da única publicação independente feita por um aluno da École, além disso, a favor da reforma ${ }^{6}$.

O autor era ninguém menos do que Pedro Américo ${ }^{7}$, então com 20 anos. Se ainda bastante jovem, ele não era, contudo, um calouro, mas um formando nos últimos meses dos seus 5 primeiros anos na Europa.

É bastante improvável que os demais estudantes desconhecessem a publicação de Américo e também o lado patente que aderia. Ele havia feito o que pôde para fazê-la notar: a brochura estava disponível apenas em língua francesa, vendida em frente à École, na livraria de Auguste-Jean Morel, bastante frequentada por estudantes de $\operatorname{arte}^{8}$. A estratégia de Américo em editar e vender seu texto nessa loja não decorria, certamente, apenas da localização privilegiada da livraria, mas, sobretudo, do aberto apoio político que o editor havia dado às mudanças na instituição. Especializado mormente em publicações de arquitetura, Morel era também proprietário da recém-fundada Gazette des Architectes et $d u$ Bâtiment, dirigida pelo filho do arquiteto e teórico Viollet-Le-Duc: precisamente o mentor intelectual da reforma e também - para a oposição estudantil - seu bode expiatório ${ }^{9}$. Essa relação não era mera coincidência. Por anos Morel mantinha uma amizade muito próxima com o arquiteto, a ponto

6 As demais publicações independentes publicadas sobre a reforma da École des Beaux-Arts eram, todas, feitas por agentes politicamente importantes no cenário artístico francês. Entre eles, o Ministro des Beaux Vaillant, Mérimée, Nieuwerkerke, Viollet-le-Duc, o 'mentor' da reforma, Ingres, Louis Vitet, Beulé (secretário perpétuo da Academia de Belas Artes), Olivier Merson, Philippe de Chennevières, Ernest Chesneau, Charles Giraud.

CHENNEVIÈRES, Philippe de. École Impériale des Beaux-Arts. Examen critique du rapport adressé a S. Exc. Le Marechal de France, ministre de La Maison de l'Empereur et des Beaux-Arts. Paris: E. Dentu, 1864.

CHESNEAU, Ernest. Le décret du 13 novembre et l'Académie des Beaux-Arts suivi du Rapport de M. de Nieuwerkerke, du Décret du 13 novembre, de la Protestation de l'Académie, et de la Réponse de S. Exc. Le maréchal Vaillant, Ministre de la Maison de l'Empereur et des Beaux-Arts. Paris: Didier et Ce., 1864.

GIRAUD, CH. De la réorganisation de l'École des Beaux-Arts. Réponse à la lettre de M. Ingres. Paris: Imprimerie de Ad. Lainé et J. Havard, 1864.

BEULÉ, Charles. "L'École de Rome au dix-neuvième siècle". Extrait de la Revue des Deux Mondes, 15 de décembre de 1863. Paris: Imprimiere de J. Claye, 1863.

VIOLLET-LE-DUC, Eugène E. Intervention de l'État dans l'enseignement des beaux-arts. Paris: A. Morel et Cie, 1864.

INGRES, Jean-Auguste Dominique. Réponse au rapport sur l'École Impériale des Beaux-Arts adressé au Maréchal Vaillant. Paris: Didier et Cie, 1863.

MERSON, Olivier. De la réorganization de l'École Impériale et spéciale des beaux-arts. Extrait de l'Opinion Nationale. Paris: E. Dentu, 1864.

VITET, Louis; VIOLLET-LE-DUC, Eugène. À propos de l'enseignement des arts du dessin. Préface Bruno Foucart. Paris: École Nationale Supérieure des Beaux-Arts, 1984.

7 FIGUEIREDO, Pedro Américo. La réforme de l'École des Beaux-Arts et l'opposition - par un élève. Paris: A. Morel et Cie., 1863.

8 Além disso, tanto a publicação do brasileiro como a Réclamations des élèves eram impressas na mesma tipografia. Tratava-se da tipografia de Ad. Lainé e J. Havard, situada Rua Saint-Pères, 119, rua de trás da École.

9 Morel editava o referencial, impresso cuja propraganda estava a propósito impressa na última capa da brochure do jovem Américo 
de suas revistas se tornarem conhecidas como "fiéis porta-vozes das ideias de Viollet-Le-Duc" ${ }^{10}$.

De uma forma indireta, mas bastante inteligível, o editor havia estendido essa relação a Américo, posto que (para além da posição favorável da brochura à reforma da Ècole), ele havia incluído na última capa da publicação do brasileiro a propaganda de dois estudos referenciais do período, o Dictionnaire raisonné d'Architecture e o Entretiens sur l'Architecture, do mesmo Viollet-Le$\operatorname{Duc}^{11}$.

A decisão consciente feita pelo jovem brasileiro em editar seu texto com Morel trouxe, de fato, alguns efeitos imediatos. Sua brochura havia sido imediatamente incluída na lista bibliográfica da Gazette des Beaux-Arts para o ano de $1864^{12}$, e ainda no catálogo geral de publicações do império francês $^{13}$. Também recebeu algumas menções em revistas especializadas ${ }^{14}$. Entretanto, o mais longo comentário havia sido publicado precisamente pela Gazette des Architectes et du Bâtiment, numa apreciação significativa que introduzia o impresso de Américo em um panorama de publicações feitas sobre a reforma da École:

A discussão continua, cheia de recriminações de uma parte, cheia de ensinamentos de outra, sobre a reorganização da Escola de Belas Artes, da qual o decreto de 13 de novembro de 1863 assentou as bases após ter sido demonstrado tão claramente a urgência. [...]

De nossa parte, nós permaneceremos fiéis à nossa tarefa, tendo cuidado de apresentar consciensiosamente sob os olhos de nossos leitores, à medida que elas se produziram, as peças desse interessante processo.

E de início, não poderíamos passar em silêncio por uma pequena brochura de 15 a 16 páginas, que apareceu baixo o título: A reforma da Escola de Belas Artes e a oposição. O autor, que assina modestamente "um aluno", é um estrangeiro: pensionista do Brasil na Escola da França, ele se ligou, por suas relações, a uma sincera admiração por sua pátria de adoção. Sente-se que ele é orgulhoso do talento dos nossos artistas, da fertilidade e riqueza de suas criações. É este sentimento filial, é esta paixão ardente pela arte e tudo o que se relaciona às artes que o levam a preconizar as novas medidas: ele encontra uma maneira de, em poucas páginas, tocá-las bastante, e tocá-las com justeza: sente-se que o sol dos trópicos aquece essa pluma que corre rápida, colorida e ardente, sem que a imaginação danifique em nada a solidez dos argumentos, a moderação da discussão.

10 Béatrice Bouvier, "L'éditeur de presse architecturale et son équipe rédactionnelle", in Actes du Ve congrès national d'archéologie et d'histoire de l'art, Bordeaux, INHA, 1999, Disponível online em: http://inha.revues.org/2260 [último acesso, maio de 2015]

11 E muito provável que a inclusão dessa propaganda fornecesse algum tipo de "desconto" ao jovem Américo, que publicava às suas próprias expensas, como dito, a sua brochura.

12 Paul Chéron, 'Bibliographie des ouvrages publiés en France et à l'etranger sur les Beaux-Arts pendant le premier semestre de 1864', in Gazette des Beaux-Arts, Paris, 1 juin 1864, sixième année, tome seizième, 1864. p.569.

13 Journal Général de l'Imprimerie et de la Librairie. Deuxième série. Tome VIII. Paris : 1864, p.17 ; Otto Lorenz (ed.), Catalogue Général de la Librairie Française (1840-1865). Tome deuxième. Paris : 1868, p.311.

14 DALY, César. "De la réorganisation de l'École des Beaux-Arts", in DALY, César. Revue Génerale de L'Architecture et des Travaux Publics.Vol. XXII. Paris: 1864. p.29. 
Essa defesa inesperada, na qual um estrangeiro assume tão criteriosamente nossa causa, não pode deixar de ter um efeito feliz no espírito dos alunos da Escola. O Sr. Pedro Américo de Figueiredo não é o único a deplorar os velhos erros; ele fala em seu nome, é verdade: mas o seu protesto não seria ele o eco de um círculo de jovens, fervorosos como ele, apaixonados por grandes idéias de arte e do progresso, envergonhados de ver que, em torno deles, tudo vive, move-se, cresce e prospera, enquanto que as ideias funestas da escola os condenam a ficar estacionários? Não é em nome dessa juventude inteligente que o Sr. Figueiredo falou? Não teria ele compreendido, e com ele os partidários de ideias novas, que seria preciso apenas um deles fazer bem alta sua declaração de princípios para incitar em seguida os temerosos e irresolutos? ${ }^{15}$

Em 28 de dezembro de 1863, imediatamente após a sua publicação, o pequeno impresso do jovem Américo $^{16}$ chamava, assim, a atenção do redator da Gazette por sua dupla excepcionalidade. A primeira, decorrência da tomada de posição precoce de um aluno a favor das reformas, quando quase ninguém em sua condição, e sobretudo falando em próprio nome (não importasse se a favor ou contra), ousava concorrer com as publicações dos reformadores, dos seus aliados e dos seus opositores acadêmicos do Institute de France ${ }^{17}$. A segunda, e ainda mais exemplar, por se tratar de um texto de autoria de um estrangeiro que, embora não pudesse ganhar nada de imediato com a reforma, logo teria compreendido e aderido às promessas de bons resultados inspiradas pelas mudanças - um exemplo raro

15 A passagem original é a seguinte: "La discussion continue, pleine de récriminations d'une part, pleine d'enseignements de l'autre, sur la réorganisation de l'École des Beaux-Arts, dont le décret du 13 novembre 1863 a posé les bases après en avoir si nettement démontré l'urgence.[..] Pour notre part, nous resterons fidèles à notre tâche, en ayant soin de dérouler consciencieusement sous les yeux de nos lecteurs, au fur et à mesure qu'elles se produiront, les pièces de cet intéressant procès. Et d'abord, nous nous en voudrions de passer sous silence une petite brochure de 15 à 16 pages, qui a paru sous le titre de: La réforme de l'École des Beaux-Arts et l'opposition. L'auteur, qui signe modestement "un élève", est étranger: pensionnaire du Brésil à l'École de France, il s'est attaché par se liens d'une sincère admiration à sa patrie d'adoption. On sent qu'il est fier du talent de nos artistes, de la fécondité et de la richesse de leurs créations. C'est ce sentiment filial, c'est cette passion ardent pour l'art et tout ce qui touche aux arts qui le portent à préconiser les nouvelles mesures: il trouve le moyen en quelques pages de toucher souvent et de toucher juste: on sent que le soleil des tropiques échauffe cette plume qui court rapide, imagée et brûlante, sans que l'imagination nuise en rien à la solidité des arguments, à la moderation de la discussion.

Ce plaidoyer imprévu, où un étranger prend en main si judicieusement notre cause, ne peut manquer que d'avoir un heureux effet sur l'esprit des élèves de l'École. M. Pedro Americo de Figueirêdo n'est pas seul à déplorer les anciens errements; il parle en son nome, il est vrai: mais sa protestation ne serait-elle pas l'écho d'un cercle de jeunes gens, ardents comme lui, passionnés pour les grandes idées d'art et de progrès, honteux de voir que tout vit, se meut, grandit et prospère autour d'eux, tandis que de funestes idées d'école les condamnent à rester stationnaires? N'est-ce pas au nom de cette jeunesse intelligente que M. Figueirêdo a parlé? A-t-il compris, et avec lui les partisans des idées nouvelles, qu'il suffisait à l'un d'eux de faire tout haut sa déclaration de principes pour entrâiner à la suite les peureux et les irrésolus?". X.F. "École des Beaux-Arts. Revue de la quinzaine". In: VIOLLET-LE-DUC Fils, M. E.; CORROYER, M. E. Gazette des architectes et du batiment. Paris, Primeiro ano, A. Morel et Cia., 1863. pp.233-235. [Tradução nossa].

16 AMÉRICO, Pedro. La Réforme de l'École des Beaux-Arts et l'opposition - par un éléve. Paris: A. Morel et Cie Editeurs, 1863, 15p.

17 Basta lembrar que a publicação das reclamações dos alunos foi por eles justificada pela publicação prévia do protesto dos professores da École/membros da Académie, o que lhes teria dado o direito de expressarem também suas opiniões. No entanto, essa publicação aparecerá apenas em fevereiro de 1864, quase três meses depois da publicação de Américo. 
que deveria assim cativar a massa de alunos nativos "temerosos" e "irresolutos".

Apesar da vontade do redator de que o opúsculo daquele "jovem dos trópicos" de ideias aquecidas pelo sol atingisse positivamente os demais colegas, ele permaneceu, ao fim e ao cabo, a "falar em nome de uma juventude" "apaixonada pelas grandes ideias da arte e do progresso" de cujo único integrante manifesto foi tão somente ele. E a confirmação disso viria, portanto, pouco mais de dois meses depois, com a publicação compilada daquelas reclamações de fato maciças dos outros alunos, que perceberam na nova conjuntura senão motivos para lamento ${ }^{18}$.

Em fins de 1863, de regresso anunciado ao Brasil, onde era enfim ${ }^{19}$ aguardado por d. Pedro II para assumir, por meio de concurso, a docência na Academia Imperial de Belas Artes do Rio de Janeiro, o jovem Américo se expunha a contrafluxo de quase toda maré "acadêmica" francesa, em uma das maiores e mais importantes disputas do ensino e da política das artes no século XIX ${ }^{20}$.

A atitude, por sua exemplaridade, conduz inevitavelmente ao questionamento sobre as razões que o teriam motivado a essa manifestação e sobre seus significados. Por quê ingressar no fim de sua estadia em um debate sobre o ensino artístico francês se quase todas as medidas impostas pelo novo decreto diziam respeito somente aos professores e alunos pátrios, únicos que podiam concorrer ao grande Prix de Rome, fim maior da existência da École de Paris no sentido de formar artistas de elite? E por quê ainda o fazia, em ação favorável e sui generis em relação à reforma, se a única medida do decreto que iria lhe dizer diretamente respeito (relativa ao acolhimento de estangeiros na instituição) passaria a, justamente, desfavorecê-lo e a todos os outros alunos não franceses ${ }^{21}$, uma vez que não poderiam mais entrar na Escola por meio de concursos semestrais abertos indiscriminadamente, mas apenas e

18 Op. cit.

19 Desde 1862, d. Pedro II requer a volta de Pedro Américo ao Brasil, para assumir a cadeira de desenho figurado, mesmo que sendo necessário para tanto a execução de um concurso público. Américo consegue contudo prorrogar sua estadia para mais dois anos.

20 Philippe de Chennevières, participante da querela em 1863/1864 e futuro diretor de Belas Artes, em sucessão a Charles Blanc, assim qualificava o que para ele havia sido o desdobramento da reforma: "Jamais le monde des arts n'avait été soulevé si violemment; [..] il plut des brochures, et les polémiques les plus violentes remplirent tous les journaux. Jamais, je le répète, on n'avait vu, dans le monde des arts, pareille agitation, insurrection pareille, pugilat semblable, semblable hourvari." CHENNEVIÈRES-POINTEL, Philippe. Souvenirs d'un directeurs des beaux-arts, 1883-1889. Paris. Arthena, 1979. p.96.

$21 \mathrm{Um}$ dos artigos do decreto reformador é bastante explicito quanto aos alunos estrangeiros. Se outrora poderiam concorrer ao ingresso na École, na qualidade de alunos regulares, com a única desvantagem de não poderem concorrer ao prêmio de Roma, por não serem franceses de nascimento, agora, as suas admissões seriam excepcionais, mediadas pela vontade e autorização do Ministro em cargo. "Chapitre III. Admission des élèves. Art.14: [...] Les étrangers pourront, exceptionellement et avec l'autorisation du Ministre, être admis à suivre les cours." VAILLANT, M. "Décret du 13 novembre 1863." In: Giraud. De la reorganisation...p.59. 
excepcionalmente por meio de uma autorização do Ministro das Belas Artes da França ${ }^{22}$ ?

Ainda que essas sejam as primeiras perguntas relacionadas a outras mais gerais colocadas mais à frente nesta Tese, elas poderiam de início ser condensadas numa primeira hipótese: por que a publicação do seu opúsculo, antes de ser uma adesão única a reformas do ensino francês, é uma primeira manifestação pública de uma série de movimentações ora mais, ora menos perceptíveis, que o jovem passa a realizar desde os seus primeiros anos em Paris.

É uma série que culminará, em pouco tempo, na divulgação de um projeto político para as artes no Brasil, no qual Américo propõe ser, ele próprio, em razão de sua sempre defendida busca por erudição e sempre interessada ascenção de status social e econômico, o principal agente de mudanças da classe artística do seu país.

\section{A reforma da Escola de Belas Artes de Paris}

A vontade de reformas artísticas na França não era uma questão recente em 1863. Desde o ínício do século se fazia presente em textos e críticas de diversos autores e, em momentos específicos (sobretudo nas diversas mudanças de regime político do período), conduziram à formação de comissões e Rapports encarregados de definir soluções para o problema do ensino, produção artística e de sua adequação aos novos aparatos políticos e econômicos, tendo quase sempre como alvo das mudanças as três instituições mais importantes para essa atividade no país: a École des Beaux-Arts de Paris, a Escola Francesa em Roma (para onde eram enviados os laureados dos Prix), e a Académie des Beaux-Arts.

Após a queda do regime Napoleônico, uma ordem publicada em 1819 fundava a nova École Royale et spéciale des Beaux-Arts, cujo regulamento constitutivo avalizado apenas em 1838 permaneceria, com poucos acréscimos ou decréscimos, o mesmo até o decreto de $1863^{23}$. Escola gratuita, aberta a todos, onde se ensinava exclusivamente o desenho a partir do modelo vivo e da escultura antiga - numa formação que se complementava íntima, senão obrigatoriamente, com a frequentação em ateliês

22 Américo irá de fato reconhecer o potencial obstáculo que a reforma então impunha aos alunos não franceses: "Quem escreve essas linhas é um estrangeiro que não tem nada a ganhar com essa ou aquela mudança introduzida no sistema de ensino da Escola de Belas Artes; ele perde muito antes do que ganha com a nova reforma." AMÉRICO, Pedro. op.cit. p.14.

No entanto, se essa era única medida que poderia se configurar como um problema para o jovem e seus compatriotas, ela afinal não lhe seria tão mais pertinente, pois, como dito, Américo estava em vias de egresso da instituição.

$23 \mathrm{cf}$. BONNET, Alain. L'enseignement des art au XIXe siècle: la réforme de l'École des beaux-arts de 1863 et la fin du modèle académique. Rennes: Presses Universitaires de Rennes, 2006. p.145 e seguintes. 
privados livremente escolhidos, onde se aprendia, lá de fato, a prática pictórica ${ }^{24}$. As atividades internas da instituição eram desenvolvidas sobretudo a partir da emulação entre os alunos a partir de provas práticas, que competiam uns contra os outros desde a disputa pelos lugares vagos abertos a cada semestre (concours de places), pelos prêmios menores de preparação (concursos de figuras, de composição, perspectiva, anatomia, execução e expressão), até o grande Prix de Rome. Este último era julgado exclusivamente pelo colegiado da École - como dito, integrante quase em sua totalidade também da Académie des Beaux-Arts (uma das cinco classes do Institut de France ${ }^{25}$ ), e que detinha, ainda, o poder exclusivo sobre o aceite das obras enviadas anualmente ao Salon des Beaux-Arts. Em resumo, embora se tratassem de instituições distintas, a École de Paris, de Roma e a Académie, eram comandadas por um grupo restrito de artistas politicamente engajados, cujos membros eram eleitos por eles próprios, em sistema de cooptação, que dominava de maneira quase independente os dispositivos artísticos franceses a partir de premissas estéticas e pedagógicas remanescentes do classicismo davidiano $^{26}$.

A impreteribilidade dessas premissas e o encontro que terão com opiniões divergentes, especialmente quando essas se apresentavam como opiniões oficiais do governo em mando, articula o início de seguidos conflitos culminados na reforma de 1863.

Em 1831, a ascenção de Louis-Philippe, seguida da intenção de uma política artística mais aberta (o próprio rei era grande admirador e comprador de arte flamenga), oferece o pontapé inicial para as oposições à primazia do Institut na regulamentação de todos os assuntos sobre as artes na França. Na ocasião, segundo o estudo exemplar de Alain Bonnet, uma comissão oficial foi "encarregada de fazer um relatório sobre as modificações que poderiam ser levadas aos regulamentos da Escola Real de Belas Artes e da Academia de França em Roma, sobre as relações que deveriam existir entre esses dois estalecimentos e a quarta classe do Instituto, e sobre o modo de julgamento que conviria adotar para os concursos entre os artistas.”, incluíndo-se aí a formação do júri do salão ${ }^{27}$.

24 Para uma visão mais clara da formação dento dos ateliês privados, ver a recente publicação: NERLICH, France; BONNET, Alain (direcs.) Apprendre à peindre: les ateliers privés à Paris - 1780-1863. Tours: Presses Universitaires Fraçois-Rabelais, 2013.

25 São elas: Académie Française, Académie des Inscriptions et Belles-Lettres, Académie des Sciences, Académie des Sciences Morales e Académie des Beaux-Arts.

26 Premissas que dizem sobretudo respeito à manuntenção do desenho (de modelo vivo e escultura antiga) como ferramenta mais importante do aprendizado artístico, e ainda à manutenção que fazia do gênero histórico (inspirado nas narrativas da antiguidade) como a mais alta expressão artística, centrado na ideia da existência de um belo ideal, universal e insuperável.

27 Idem. Ibidem. p.146. 
Conquanto mal sucedida, em função de movimentos internos da própria comissão (que comportava em si boa parte dos membros da mesma Academia que deveria avaliar), uma nova tentativa de mudanças é estruturada em 1848, na esteira das revoluções daquele ano. Nova comissão com o objetivo de produzir um rapport sobre reformas a serem feitas nas Écoles de Paris e Roma, novo entrave causado pela permanência, dentro dela, de membros ligados à antiga organização Nesse intento, no entanto, a presença também forte de membros externos, então opositores ao ensino compreendido como caducado da instituição, abriu campo para formação de dois partidos opostos: "aqueles inclinados a uma evolução controlada pelo respeito às estruturas estabelecidas, [i.e.] os acadêmicos e Charles Blanc [escritor, teórico, e então diretor de Belas Artes]; aqueles inclinados a uma reforma rápida e profunda, [i.e.], [Gustave] Planche, Barye, Jeanron, Labrouste, Delacroix e Garroud.”, e, em seguida, AlfredEmilien de Nieuwerkerke, agente importante para as futuras proposições de $1863 .{ }^{28}$

As duas primeiras tentativas de reformas possuíam, para Bonnet, alguns pontos em comum.

"Elas foram motivadas pela vontade de subtrair a École da tutela acadêmica, ao fazer ingressar artistas independentes nos julgamentos dos concursos. E essa reunião de artistas associados às deliberações do júri acadêmico, que tentava recriar o corpo de associados da antiga academia real, testemunhava o desejo de abrir a quarta classe [do Instituto] ao mundo artístico, de reduzir a autonomia de um cenáculo onipotente, ao diversificar a representação de correntes estéticas. [...] É certo que o julgamento exclusivo dos Salões tinha [até então] pesado mais no descrédito crescente da Academia que o controle que ela exercia sobre o ensino artístico. [...] É impressionante constatar que os reformadores pareciam não ter críticas precisas enderaçadas aos meios de formação de artistas, que a renovação da École parecia assegurar sobretudo sua liberação das amarras acadêmicas. E é nessa indiferença aos procedimentos técnicos do aprendizado que se encontra a diferença principal entre essas duas [primeiras] tentativas e a reforma de 1863, que reafirmará, certamente, a necessidade de se separar a Ecole da Académie, mas que justificará em parte essa necessidade pelas considerações propriamente pedagógicas." 29

Em 1863, retomava-se assim, enfim cabalmente, um problema duraroudo, cuja necessidade de resolução seria ainda mais amplificada com a estruturação recente de mega-eventos que chamavam à sua porta a participação das artes (entre os quais se destacavam as primeiras Exposições Universais na década de 1850). Segundo se compreendeu, a Académie des Beaux-Arts, na permanente orientação dada à École para a manutenção dos seus preceitos “estacionários”, não poderia mais dar conta nesse sentido das demandas do presente, frequentemente afiliadas à ideias de progresso e indústria. E a 
mesma Académie ainda detinha o poder por sobre as duas instituições de ensino que deveriam formar os exemplos vindouros das artes franceses em todos os domínios (arquitetura, escultura e pintura), tornava-se evidente a necessidade de separação política e administrativa entre ela e essas instituições, e, na mesma medida, as reformas nos centros de ensino, no sentido de uma melhor adequação e representação das novas ideias estéticas e maior participação das artes na economia nacional.

Como nos ensaios anteriores, as mudanças propostas em 1863 vieram inicialmente da articulação de uma comissão oficial, formada em 1862, encarregada de dar sua opinião:

" $1^{\mathrm{o}}$, sobre as compras e encomendas feitas aos artistas; $2^{\circ}$, sobre as subscrições às publicações que concerniam às artes; $3^{\circ}$, sobre as recompensas a dar aos artistas ; $4^{\circ}$, sobre os melhoramentos a introduzir nos estabelecimentos de belas artes, tais como a École impériale des Beaux-Arts, a Académie de France, as Escolas gratuitas de desenho de Paris e as Écoles des beaux-arts departamentais; et, $5^{\circ}$, sobre as nominações a fazer no corpo dicente desses diversos estabelecimentos." 30

Ainda que essa comissão incluísse, mais uma vez, membros da Académie $^{31}$, as medidas que levaria a termo (apenas depois de sua dissolução) foram orquestradas para que nelas não interferissem, precisamente, membros concomitantes daquela instituição e da École, daí a razão pela qual a publicação do decreto causara tamanha surpresa aos professores e aos alunos. Pela primeira vez, as intenções para ações reformistas não eram deixadas unicamente nas mãos de artistas (e sobretudo dos participantes de um colegiado insubordinado), mas de ministros, agentes ministeriais, e artistas independentes convidados, numa clara intenção do Estado francês em tomar as rédeas do ensino artístico, diminuindo assim a influência política da quarta classe do Institut ${ }^{32}$.

Foi à incumbência de um pequeno grupo de agentes sombreados diretamente pelo jugo de Napoleão III que a reforma, após o preâmbulo criado pela comissão de 1862, chegou à sua execução; grupo cuja potência de ação se reduzia a não mais do que 5 indivíduos: o Marechal Vaillant, ministro da Maison de l'Empereur et des Beaux-Arts; Nieuwerkerke, diretor geral dos Museus Nacionais (e agente politicamente mais importante para a efetivação das reformas ${ }^{33}$ ); Prosper Merimée (redator de Vaillant, e desde a década de 1850 sempre defensor de reformas progressistas do ensino artístico); Henri

30 BONNET, Alain. op.cit. p.179

31 Eram eles: Ingres, Vernet, Flandrin, Cogniet, Duban, Jouffroy, Gatteaux, Henriquel-Dupont.

32 BONNET, Alain. op. Cit. p.180

33 Perot, Jacques (1945-....). Commissaire d'exposition. Le comte de Nieuwerkerke : art et pouvoir sous Napoléon III: [exposition] Musée national du Château de Compiègne, 6 octobre 2000-8 janvier 2001. 
Courmont, diretor de Belas Artes a partir de 1863, responsável pela adequação jurídica do decreto; e Viollet-le-Duc, de longe o agente mais importante para a implementação da porção pedagógica da reforma - como dito, a sua singularidade em relação aos ensaios de 1831 e 1848.

Viollet-Le-Duc havia feito mesmo aparecer, quase no momento da dissolução da comissão, uma série de artigos intitulada "L'enseignement des beaux-arts: il y a quelque chose à faire",34, na qual diagnosticava uma "doença nas artes francesas", e para a qual o antídoto seria uma mudança completa na estrututura curricular nas Écoles de Paris e Roma. Texto bastante similar em suas proposições a outro publicado em 1848, por Gustave Planche ${ }^{35}$ (também membro extremista da comissão criada naquele ano), ele expunha as preocupações e medidas que o decreto de 1863 (idealizado por ele, redigido e corrigido por seu amigo Merimée, com aval direto de Nieuwerkerke ${ }^{36}$ ) retomaria quase passo a passo.

Preparados e promulgados, os principais pontos do decreto instituíam:

1) a criação de uma cadeira de diretor da École de Paris, sendo este subordinado apenas ao ministro e ao imperador, e não ao colegiado;

2) a reforma no sistema de nomeação de professores, indicados igualmente pelo ministro, e não mais pelo antigo sistema de cooptação, que tendia a, segundo defendeu-se, perpetuar na École os erros de uma confraria que se refazia sempre identicamente, a partir dos mesmos princípios estéticos;

3) a criação de cadeiras novas de pintura, gravura e ateliês preparatórios, num movimento de deslocamento do ensino prático da pintura, escultura e demais ofícios dos ateliês privados em direção à tutela do Estado;

4) a abertura de cursos gratuitos na École, notadamente de história da arte e estética, história e arqueologia, anatomia, perspectiva, matemáticas elementares, geometria descritiva, geologia, física e química elementares (os cursos de história, estética e arqueologia sendo obrigatórios a todos os alunos;

34 VIOLLET-LE-DUC, E. E. I - Gazette des Beaux-Arts, 1862, T.XII, pp.393-402; II - Gazette des Beaux-Arts, 1862, T.XII, pp.525-534; I - Gazette des Beaux-Arts, 1862, T.XIII, juillet, pp.71-82; I - Gazette des Beaux-Arts, 1862, T.XIII, septembre, pp.249-255. Artigos reunidos e reimpressos em: VITET, Louis; VIOLLET-LE-DUC, Eugène. $\grave{A}$ propos de l'enseignement des arts du dessin. Préface Bruno Foucart. Paris: École Nationale Supérieure des Beaux-Arts, 1984.

35 PLANCHE, Gustave. "De l'éducation des artistes en France", Revue des Deux Mondes. 15 novembre 1848, p.608629. Texto republicado posteriormente em coletânea de textos de Planche, intitulada Portraits d'Artistes. Paris: Michel Lévy freres, 1853.

36 MÉRIMÉE, Prosper. La correspondance Mérimée-Viollet-le-Duc / éd. Françoise Bercé. Paris: Ed. Du CTHS, 2001; VIOLLET-LE-DUC. Lettres inédites de Viollet-Le-Duc recueillies et annotées par son fils. Paris: Librairies-Imprimières Réunies, 1902. 
os de anatomia e perspectiva apenas aos escultures, pintores e gravadores; e para os arquitetos, todos, menos anatomia);

5) instituição de um conselho superior de ensino, composto por membros mistos;

6) supressão dos concursos preparatórios;

7) fixação do limite de idade a 25 anos para o concorrentes ao Prix de Rome;

8) supressão dos Segundos Prêmios;

9) redução de 5 para 4 anos no tempo de pensão do Prix, sendo dois anos em Roma e dois em viagens a outros países;

10) supressão do prêmio de paisagem;

11) aumento do valor da bolsa aos pensionistas;

12) introdução de um juri especial, também misto, para o julgamento dos concursos. ${ }^{37}$

Todas essas medidas retomavam as principais preocupações imaginadas para o estabelecimento de uma reforma ao mesmo tempo administrativa e pedagógica das artes francesas. De um lado, retirar da Académie o seu poder sobre o devir artístico, desligando-a da direção da École, anulando seu aval para o envio dos vencedores anuais do Prix de Rome, e ainda suprimindo a sua força na escolha dos artistas que poderiam ingressar, também anualmente, no salões oficiais. Se o "Salão dos Recusados" havia sido uma primeira medida de Napoleão III no sentido de uma conciliação entre o poder vigente e as diversas manifestações artísticas, oficiais (isto é, aquelas produzidas por adjuntos das Ecoles) e não oficiais, a formação de um júri mais sensível às “inovações” (posto que também ele frequentado por artistas diversos) significaria maior abertura das salas de exposição a outras correntes, e ainda uma competição mais honesta que empreenderiam para atrair a atenção do público.

De outro lado, instituir uma grade curricular que permitisse aos alunos alargarem suas possibilidades de reflexão e produção artística, por meio de uma formação mais sólida (dentro da qual o estudo da

37 NIEUWERKERKE. "Rapport à son Excellence le maréchal de France, ministre de la maison de l'Empereur et des Beaux-Arts sur l'Ecole impériale et spéciale des Beaux-Arts”. p.145-153. Publicado originalmente na Gazette des BeauxArts, 1863, T.XV. (Reimpresso em diversos livros e brochuras publicados nas discussões que sucederem a reforma.); VAILLANT, Marechal. Décret du 13 novembre [1863]. Moniteur Universel, Paris, 13 novembre. (Reimpresso em: GIRAUD, CH. De la réorganisation de l'École des Beaux-Arts. Réponse à la lettre de M. Ingres. Paris: Imprimerie de Ad. Lainé et J. Havard, 1864.) 
história da arte, estética e arqueologia seria fundamental), não mais voltada unicamente para a contemplação da arte grega e para a correção do desenho do modelo vivo, mas para outras produções e atividades, dentre as quais se incluíam, segundo desejo de Viollet-Le-Duc e Merimée, a apreciação da arte gótica francesa ${ }^{38}$ e o desenho de memória ${ }^{39}$.

Ponto capital para esse núcleo da reforma fôra expresso inúmeras vezes por Viollet-Le-Duc e seus adeptos por meio da defesa pela originalidade ${ }^{40}$ e liberdade artísticas (ainda que, nesse sentido, delas não pudessem se aproximar, de modo algum, o realismo, "perigo" decorrente da crença no seu suposto e iminente niilismo estético). As "ciências" históricas e filosóficas, em sua ambição de realizar uma síntese das fases e leis da humanidade, haviam muito progredido desde o início do século XIX, e não se poderia aceitar que instituições oficiais de ensino artístíco virassem as costas para as pesquisas de inúmeros estudiosos, que alargavam o conhecimento científico e artístico com o "descobrimento" de outras produções, ocidentais e orientais, antigas e modernas (várias delas incluídas sistematicamente no Museu do Louvre naqueles mesmos $\operatorname{anos}^{41}$ ); ou que se mantivessem fechadas a qualquer contato com a vida prática, isto é, com a indústria ${ }^{42}$. O progresso poderia apenas vir com o conhecimento do passado, mas um passado que incluía idealmente (mesmo que na prática não funcionasse assim) toda a história

38 Sobre esse problema é esclarecedora a defesa que Viollet-Le-Duc faz em seu dicionário de arquitetura. sobre a originalidade do Gótico, e as raízes que ajuda a fincar para o nascimento de uma verdadeira arte nacional, muito anterior à suposta influência de artistas italianos na corte francesa, durante o Renascimento. Ver em especial o artigo Escultura. VIOLLET-LE-DUC, E. E. Dictionnaire raisonnée de l'architecture française du XIe au XVIe siècle. Tome VIII. Paris: Ve. A. Morel \& Cie., 1875. PP.97-289. O dicionário começou a ser publicado em 1854, e concluído em 1868.

Desde o início do século XIX uma série de cadeiras para o estudo medieval são criadas na França, no entanto sempre fora da École des Beaux-Arts. Ver, por exemplo: THERRIEN, Lyne. L'histoire de l'art en France, genèse d'une discipline universitaire. Paris: Éditions du C.T.H.S., 1998.

39 Tanto em seu texto preliminar à reforma (já citado) quanto em texto posterior a ela (Intervention de l'État...), citado em notas seguintes, Viollet-le-Duc defende (e nesse ponto se aproximando de método bastante defendido também por Delacroix nos anos 1840) o método de ensino criado por Lecoq de Boisbaudran, professor francês que instituía a seus alunos um novo método, com exercícios alternados entre o desenho ao ar livre e o desenho de memória.

40 Originalidade e liberdade eram termos já bastante discutidos e defendidos em projetos de reforma anteriores (o da década de 1830, e o de 1848), o que incluía ainda uma exigência não acadêmica do "Romantismo", estudado por Albert Boime: "A preocupação com originalidade na arte Francesa durante o século XIX foi talvez inspirada pela ênfase da revolução sobre a liberdade individual. Certamente, tanto artísticamente quanto filosoficamente, a originalidade tinha sido altamente estimada pelos Acadêmicos desde antes de 1830; mas a novidade da arte Romântica chamava atenção para a noção da originalidade desde os anos 1820 , e, no final desta década, como notou um crítico, a originalidade 'parece ser um vício na França"'. BOIME, Albert. The academy and french painting in the nineteenth century. London: Yale University, 1986. p.09.

41 Como as coleções Egípcias, Gregas, Assírias e Persas, que passam a entrar sistematicamente à coleção do Louvre após a "disputa" arqueológica entre Inglaterra e França, em meados do século XIX.

42 Viollet-Le-Duc e outros autores retomarão essas questões inúmeras vezes. Dele, no entanto, é exemplar a defesa da liberdade artística que continua a fazer mesmo após seu abrupto desligamento da reforma: "Eu acredito e eu continuo a crer que o estudo e a prática das artes só pode progredir com liberdade completa, que, se o regime acadêmico lhes foi funesto, o regime administrativo ou a aliança da ação administrativa e dos erros acadêmicos só podem perpetuar uma situação desfavorável a seu desenvolvimento.", In: VIOLLET-LE-DUC, Eugène E. Intervention de l'État dans l'enseignement des beaux-arts. Paris: A. Morel et Cie, 1864. p.05 
humana conhecida ${ }^{43}$, e não apenas a grega no seu período áureo.

\section{"La réforme" de Américo}

Pedro Américo havia desembarcado em Paris em maio de 1859. Acompanhara, portanto, todo o processo de retomada e reestruturação de um projeto antigo dos reformadores franceses, plano que, anos antes, em vários pontos bastante similar, ele próprio já havia vivido na Academia Imperial de Belas Artes (entre 1855 e 1858), quando também experimentava os efeitos da Reforma Pedreira (18551857), posta em prática por Manuel Araújo Porto Alegre e pelo ministro Luiz Pedreira, e a largos passos alinhada às mesmas ideias discutidas na França desde as tentativas de reformas de 1848 e 1831 (quando o próprio Porto Alegre se encontrava em Paris).

A despeito do seu tamanho relativamente reduzido, não se pode minimizar a importância do seu texto. La réforme de l'École des Beaux-Arts et l'opposition inaugura a carreira de Américo na qualidade de agente também dedicado à reflexão teórica, e prepara os fundamentos de um projeto de longo prazo que nunca abandonará. Trata-se, com efeito, do primeiro texto integralmente publicado ${ }^{44}$ em uma sequência produtiva de dois anos ininterruptos de pinturas e outras publicações apresentadas no Brasil. Essa sequência era precedida e interrompida praticamente no momento em que sabe de sua nova partida à Europa, empreendida em 1866 para obtenção do seu doutorado, esse que inaugurará, por sua vez, numa nova empreitada de produções escritas e pictóricas. Todos esses textos, sem exceção, támbém dedicaram especial atenção ao problema da educação artística e ao da péssima condição social do artista no país.

O posicionamento geral do opúsculo de Américo já está conhecido: nele, ele declarava-se inteiramente a favor da reforma instalada nas Écoles de Paris e Roma. Mas as razões que ele havia estabelecido para essa aprovação eram notadamente distintos das razões estabelecidas pela maioria opositora dos professores-acadêmicos e dos alunos que se apresentavam contra as mudanças: para os docentes, a reforma retirava-lhes a autoridade política e estética sobre as instituições artísticas mais importantes da França (exemplos para o "mundo", segundo defesa do Secretário Perpétuo das Belas Artes, Charles

43 BOIME, Albert. Thomas Couture and the eclectic vision. London: Yale University Press, 1980, p.7

44 É o primeiro texto integralmente publicado mas não o primeiro ensaio de publicação: antes dele, Américo já havia iniciado remotamente, em março de 1863, a impressão das Observações Gerais sobre as Belas Artes entre os Antigos (ver capítulo seguinte.) no Correio Mercantil do Rio de Janeiro, embora logo as interrompesse, retomando-as e levando à conclusão somente um ano depois, entre meados e fins de 1864. 
Beulé, também em texto sobre a reforma ${ }^{45}$ ), e seria contra essa essa medida que eles concentrariam suas oposições; para os alunos, os prejuízos reclamados diziam respeito sobretudo à redução a 25 anos da idade máxima para a disputa do Prix de Rome (agravo para muitos que, vindos de outras províncias, chegavam a Paris já com mais de 20), ao medo de perderam justamente a liberdade defendida pela reforma (já que deveriam estudar num dos 3 ateliês ${ }^{46}$ criados dentro da escola), e ainda ao que julgaram ser a sua submissão a uma “estética oficial”, personificada por Viollet-le-Duc, primeiro professor do curso de estética e história da arte, em $1864^{47}$ - oposição que se mostrou ser apenas direcionada a Viollet-Le-Duc, visto como funesto autor da reforma ${ }^{48}$, e não à disciplina em si, que logo em seguida seria assumida por Hippolytte Taine ${ }^{49}$, e bastante concorrida.

Américo, por sua vez, não fazia qualquer menção aos problemas administrativos da École, ou sobre os problemas políticos que incluíam os estudantes franceses ${ }^{50}$. Como estrangeiro excluído dessas que se tratavam, de fato, das principais e mais debatidas questões da reforma, ele investiu em uma abordagem que colocou seu pequeno texto numa nova posição de excepcionalidade. Se raramente as demais publicações, em função do interesses acima comentados, indagaram os méritos da reforma propriamente concernentes ao ensino artístico, a do brasileiro se concentou quase que exclusivamente nesse tema. E nesse sentido, a parte visível do seu interesse permanecia estreitamente ligado àqueles manifestos pelo mesmo Viollet-le-Duc - conforme citado, o agente da reforma mais engajado com as questões de formação e ensino de artistas - e menos com os seus aspectos políticos e econômicos, como se configuraria para Merimée e Nieuwerkerke ${ }^{51}$.

Os objetivos pedagógicos mais importantes da reforma foram certeiramente compreendidos e

45 BEULÉ, Charles. "L'École de Rome au dix-neuvième siècle". Extrait de La Revue des Deux Mondes de 15 de décembre de 1863. Paris: Imprimiere de J. Claye, 1863. Reimpresso em: BEULÉ, Charles. Causeries sur l'art. Paris: 1867.

46 Seriam empossados os professores dos novos ateliês: Alexandre Cabanel (1823-1889), Isodore Pils (1815-1875) e Léon Gêrome (1824-1904). Para uma lista completa dos professores da École des Beaux-Arts no século XIX, ver: CHAPPEY, Frédéric. "Les professeurs de l'Ecole des Beaux-Arts (1794-1873)". In: Romantisme, 1996, n93. pp. 95-101. Disponível online em: http://www.persee.fr/web/revues/home/prescript/article/roman_0048-8593_1996_num 26 $93 \quad 3129$ (último acesso em outubro de 2014).

47 S/A. Réclamations des élèves...

48 Idem, ibidem. p.37-38.

49 Sobre o curso da École, ver: WAHSH, Philip H. «Viollet-le-Duc and Taine at the École des Beaux-Arts: on the first professorship of art history in France». In: MANSFIELD, Elizabeht (ed.). Art History and Its Institutions. London/New York: Routledge, 2002. pp.85-99.

50 De fato, Américo havia conscientemente ignorado medidas fundamentais do decreto de 1863, tais como a criação da cadeira de director na École, o novo sistema de nomeação de professores, a supressão de prêmios, a diminuição da idade máxima para se concorrer ao Prix de Rome, etc.

51 Para essa questão específica, ver: BONNET, Alain. op. Cit. pp.157-178; ou ainda Idem. "La réforme de l'Ecole des beaux-arts de 1863 : Peinture et sculpture." In: Romantisme, 1996, nº3. Arts et institutions. p.32. 
discutidos por Américo. Pouco mais de um mês após instituição do decreto, demonstrava já perceber que se tratava de um embate de forças que resultava, de um lado, da tentativa de destronar uma doutrina vigente refratária às demais e, de outro, do esforço resistente de um grupo até então autônomo, que já havia experimentado anteriormente ensaios similares, e acreditava ser possível manter ainda suas tradições intactas no seio de suas escolas ${ }^{52}$. No fim, como também havia sido percebido por alguns críticos, como T. Thoré, não seria outra coisa senão a batalha final de uma velha rinha entre "clássicos" e "românticos", entre seus métodos, crenças e aspirações ao ideal artístico

A Académie des Beaux-arts, Américo irá defender, era um "galho velho",53 que não quis, ou não pôde acompanhar, na manutenção de certos princípios demasiadamente rígidos, as mudanças dos novos tempos. Segundo ele, apenas repetia teimosamente seus erros no presentes, os mesmos que a teriam levado a não compreender durante muito tempo a grandeza romântica de um Géricault (artista cuja visão do Naufrágio da Medusa o próprio Américo escolhera copiar no Louvre, em 1860). As justificativas do jovem percutiam o mesmo espírito de destronamento da reforma, na comparação que fazia da École (que irá chamar ironicamente de Académie, se bem que tratassem de duas instituições legalmente distintas) com outras “escolas artísticas” internacionais vigentes:

todo mundo sabe que saindo das fronteiras da França, onde uma república, sob o nome de Académie des Beaux-Arts, escondida num canto da rua Bonaparte, amaldiçoa tudo o que não é produzido pela idolatria da forma, que ela chama de escola clássica ou de tradição, por uma espécie de justificativa de erros que o público não aceita, se encontra na Alemanha uma escola bastante diferente da anterior, pautada em outros princípios, mas tendo também suas belezas, e na Bélgica uma outra cuja originalidade e ousadia ainda fazem lembrar dos mais belos dias da grande pintura flamenga, e cujas produções apresentam um caráter mais harmonioso com o espírito moderno do que a atual escola da França. ${ }^{54}$

A reforma seria "anti-tradicionaliste", Américo ainda defendia. Mas, segundo entendia, assim o seria apenas se com "tradicional" se compreendesse uma única escolha dentre outras possíveis, feita e mantida pelo Instituto há muito. Seus resultados, de todo modo, deveriam trazer novos talentos que não

52 AMÉRICO, Pedro. op. Cit. p.06 e 07, especialmente.

53 Idem, ibidem. p.07.

54 Idem, ibidem. pp.07-08. O trecho original segue assim: "tout le monde sait qu'en sortant des frontières de la France, où une république, sous le nom d'Académie des Beaux-arts, cachée dans un coin de la rue Bonaparte, frappe d'anathème tout ce qui n'est pas produit par l'idolâtrie de la forme, qu'elle appelle école classique ou de tradition, par une espèce de justification des erreurs que le public n'accepte pas, on trouve, en Allemagne, une école en tout différente de celle-ci, basée sur d'autres principes, mais ayant aussi ses beautés, et en Belgique une autre dont l'originalité et la hardiesse font encore rêver aux plus beaux jours de la grande peinture flamande, et dont les productions présentent un caractère plus en harmonie avec l'esprit moderne que l'école actuelle en France." 
podiam se desenvolver com a manutenção exclusiva dos "imitadores dos gregos" 55 ; uma promessa reforçada pela existência de grandes artistas alhures guiados por princípios estéticos distintos dos da Académie - como a "escola romântica" alemã ou a "escola flamenga"

A arte grega antiga, segundo Américo, havia sido de fato exemplar, e ele irá se dedicar (conforme será visto nesta Tese) profundamente a seu estudo. No entanto, o jove compreendia que ela deveria servir antes como estímulo a um artista (partindo-se tão somente do exemplo dos seus princípios geradores) do que como fonte para imitação irrefletida de prodecimentos não mais satisfatórios à modernidade. A “escola" inadequada, escola davidiana ou simplesmente escola clássica, como ele mesmo chamou, se supunha ainda pulsar pelo sulco persistente dos antigos valores que serviram de base para a refundação da École no início do século XIX. Eles se manifestavam por meio da instituição do desenho da estatuária antiga, do modelo vivo e da anatomia, culminando na produção do grande gênero histórico, e ainda por meio do peso e presença ainda latentes de um Ingres, quem, defensor maior do classicismo do seu mestre David, não aceitaria ver tais princípios esconjurados da École, assumindo-a como o "verdadeiro templo de Apolo, consagrado somente às artes da Grécia e Roma". 57

De posse de suas causas, dias após a publicação do decreto de 13 de novembro, Ingres, senador e membro do Instituto (ou, segundo Américo, "o patriarca da Escola de Tradição",58), também saía em protesto à reforma de Vaillant-Nieuwerkerke-Viollet-Le-Duc (com o quais, sobretudo o segundo, já estava em contínuos conflitos desde 1861) e publicava outra Réponse au Rapport. Respostas curtas, rebatidas ponto a ponto em quase todas proposições do relatório e nas seguidas medidas do decreto, o artista defendia que a doutrina pregada na École, em tanto que imutável, pois estruturada sobre princípios universais, não precisaria nem poderia ser modificada, sob pena da destruição da grande arte francesa.

A defesa da liberdade e da originalidade, pregada pelo rapport e decreto - e repetida por Américo - ,

$55 \mathrm{O}$ trecho original é oseguinte: la réforme, "malgré son caractère anti-traditionnel, fera éclore des nouveaux talents, par le brisement d'une chaîne qui les empêchait de se montrer dans l'arène des imitateurs des Grecs." AMÉRICO, P. op. cit. p.9.

56 Em 1862, Américo de fato viajaria à Bruxelas, na Bélgica, para efetuar sua pré-inscrição do no doutorado da Universidade Livre daquela cidade. Deve ter encontrado em contato com a produção de artistas contemporâneos de destaque ligados a uma tradição "realista", entre os quais Alfred Stevens, Antoine Wiertz, Gustaaf Wappers e Charles de Groux.

57 INGRES, Jean-Auguste Dominique. Réponse au rapport sur l'École Impériale des Beaux-Arts adressé au Maréchal Vaillant. Paris: Didier et Cie, 1863. p.04-05.

58 AMÉRICO, P. op.cit.p.10 
seria, para ele, "a linguagem destruidora do romantismo" aprenderia com um método novo (seria tão simplesmente um dom natural, e, claro, raro), e que a liberdade dada a jovens artistas deseducados a saírem pelo mundo a desenhar não os mestres, mas em plein-air ou de memória, poderia ter apenas um triste desfecho ${ }^{60}$. O fim de um tal processo resultaria na retirada da arte de sua sacra autonomia, retirando-lhe sua seiva mais fecunda - a estatuária grega e romana -, e permitindo que se a levasse a caminhos e relações indignas, a pior delas, a sua fusão com a indústria $^{61}$. Ninguém melhor, portanto, que os artistas mais ilustrados, integrantes do Instituto, para avaliar e decidir o porvir da arte francesa, suposição que envolvia, evidentemente, a manutenção do júri do Salon e dos vencedores do grande Prix nas mãos dos acadêmicos. A asserção também excluía, de antemão, qualquer outorga sua à entrada de professores externos para apresentação de cursos livres na École des Beaux-Arts, pois essa, outra fonte "de mil perigos".

Em resumo, tenho a honra de declarar, em minha alma e consciência, que eu me oponho às mudanças projetadas, porque elas destróem a boa organização da Escola, porque eles trazem perigos aos direitos adquiridos e respeitáveis, a um ensino baseado nas grandes tradições clássicas, para colocar em seu lugar um ensino de fantasia e de aventura, jurados incompetentes e uma direção falsa nos estudos. ${ }^{62}$

Américo deve ter lido atentamente a brochura de Ingres. Do contrário, a abertura do seu texto não apresentaria, com a ironia ou pretensão habituais à sua pena, uma repetição precisa do início da réponse do conhecido artista, que entretanto, de súbito, era convertida em antítese do parágrafo original. Se o primeiro parágrafo da réponse abria o texto do seguinte modo : "Il y a toujours dans le monde des esprits inquiets et jaloux de nos gloires contemporaines, mais s'attaquant aussi à celles des anciens qui, tous enfants d'Homère, ont enrichi la terre de leurs chefs-d'oeure classiques. ${ }^{63}$,, o primeiro parágrafo da brochura de Américo assim instalava sua paródia: "Il y a toujours dans le monde des esprits inquiets et jaloux de la renommée qu'ils ont su s'acquérir aux dépens des erreurs de l'époque où ils vivent, et qui semble leur échapper lorsqu'une heureuse innovation vient ouvrir au monde une nouvelle voie ${ }^{64,}$.

59 INGRES. op. Cit. p.6-7.

60 INGRES. op. Cit. p.15-16.

61 Idem, ibidem, p.05

62 Tradução nossa. O original: "En résume, j'ai l'honneur de déclarer, en mon âme et conscience, que je blâme les changements projetés, pars qu'ils détruisent la bonne organisation de l'École, qu'ils portent atteinte à des droits acquis et respectables, à un enseignement basé sur les grandes traditions classiques, pour ne mettre à leur place qu'un enseignement de fantaisie et d'aventure, des juges incompétents et une direction fausse dans les études.” Idem, ibidem. p.20

63 INGRES. Op.Cit. p.03.

64 AMÉRICO, Pedro. op. Cit. p.05. 
Dada a proximidade da publicação dos dois impressos (distantes em pouco mais de 2 semanas), seria difícil aos leitores do jovem não identificarem a paródia ensaiada como mais um reforço em contrariar as opiniões da massa acadêmica, agora representada pela voz imponente do seu mais importante representante. Não fosse suficiente tal citação transmutada, Américo ainda comentava em outro trecho, abertamente, a tomada de posição de Ingres, assegurando que a derrocada da arte viria, ao contrário do que esse defendia, se se deixassem os freios como estavam, e se uma reforma não tivesse sido imediatamente empreendida na École:

Sr. Ingres tem razão de reclamar a seu grande célebre mestre um culto ao qual ele próprio se dedicou; o público, por sua vez, tem razão de lhe recusar obediência, porque ele está cansado de assistir a decadência da Arte, ainda que, por uma ironia da Providência, tudo prospera e progride. Ele está portanto no seu direito ao emancipar a juventude de um jugo tão profícuo à época de David quanto incoveniente hoje, pois ele já desempenhou seu papel e deve deixar o teatro, onde não tem mais o que fazer ${ }^{65}$.

Refutando um dos argumentos de Ingres, especialmente o da dessacralização da arte em sua mistura com a indústria, Américo reafirmava-se, novamente, ao lado do Rapport de Nieuwerkerke ${ }^{66}$, dos textos de Duc, prévios e posteriores à reforma ${ }^{67}$, e de outros aliados dos reformadores ${ }^{68}$. Ele aderia assim à tese de que, naquela combinação, antes de um rebaixamento do gênio artístico, se perceberia uma difusão da cultura artística na indústria, fonte moderna de riquezas, o que significaria dizer, em última instância, uma inserção maior da arte, e de seus princípios elevados, na vida:

65 "M. Ingres a raison de réclamer pour son grand et célèbre maître un culte qu'il lui a voué lui-même; le public, de son côté, a raison de lui refuser obéissance, car il est las d'assister à la décadence de l'Art, alors que, par une ironie de la Providence, tout prospère et tout progresse. Il est donc dans son droit en affranchissant la jeunesse d'un joug aussi heureux à l'époque de David que fâcheux aujourd'hui, car il a joué son rôle et doit quitter le théâtre où il n'a plus que faire.". Idem, ibidem. p.10-11.

66 NIEUWERKERKE. "Rapport à son Excellence le maréchal de France, ministre de la maison de l'Empereur et des Beaux-Arts sur l'Ecole impériale et spéciale des Beaux-Arts, par le Comte de Nieuwerkerke." Reimpresso em: VITET, Louis; VIOLLET-LE-DUC, Eugène. À propos de l'enseignement des arts du dessin. Préface Bruno Foucart. Paris: École Nationale Supérieure des Beaux-Arts, 1984. p.149. (Publicado originalmente na Gazette des Beaux-Arts, 1863, T.XV.)

67 Idem. Op. Cit.; ver ainda a mesma Tese que Viollet-Le-Duc desenvolverá na presença de Américo, no curso de Estética Aplicada à história da Arte, na École des Beaux-Arts, no início de 1864: "Nos gregos, arte e indústria são confundidas como uma só coisa, e prestam apoio mútuo. [..] A arte, com eles, penetra em tudo, e se revela tanto nos utensílios mais comuns, como nos templos que elevam a seus deuses. [..] Essa união estreita da arte grega com a indústria tinha uma enorme vantagem, que era a de vulgarizar as artes.”. VIOLLET-LE-DUC, Eugène-Emmanuel. Esthétique appliquée à l'histoire de l'art. Paris: Énsb-a, 1994. pp.53-54.

68 CHESNEAU, Ernest. Le décret du 13 novembre et l'Académie des Beaux-Arts suivi du Rapport de M. de Nieuwerkerke, du Décret du 13 novembre, de la Protestation de l'Académie, et de la Réponse de S. Exc. Le maréchal Vaillant, Ministre de la Maison de l'Empereur et des Beaux-Arts. Paris: Didier et Ce., 1864. "Como artista, não deveria ele [Ingres] estar, ao contrário, confiante de ver que a indústria reconhece abertametne sua fraqueza quando a arte lhe recusa seu auxílio?” .p.17 
"Sr. Ingres se queixa das palavras do rapport a respeito da indústria na França e da influência das Belas artes sobre essa fonte de riquezas. Entretanto, que nos permitam uma reflexão: a reforma nao tem por fim introduzir a indústria na arte, mas, na verdade, a arte na indústria, e portanto na vida. ${ }^{69,}$

Aqui, apresentava-se um Américo que falava com a lembrança da experiência pessoal, vivida como aluno da primeira classe da AIBA após a Reforma Pedreira, cujos objetivos também envolviam a preocupação do estado brasileiro com a formação artística direcionada à indústria, embora também outras instituições recém-criadas, como o Liceu de Artes de Ofícios, em 1856, se engajassem na resolução do mesmo problema - e que ele, bem jovem, também pôde testemunhar de perto, uma vez que as aulas da instituição recém-aberta eram oferecidas nas salas ao lado do seu quarto, na Igreja São Joaquim $^{70}$. Por certo, havia diferenças notáveis entre as reformas nas escolas francesa e brasileira, mas também contatos notáveis: além da criação das mesmas cadeiras técnicas e teóricas, o mais importante deles parecia ser o interesse de ambos os governos em assumirem, por meio de suas instituições artísticas mais importantes, a direção de formação artística voltada também à indústria, no momento de uma expansão crescente do comércio internacional de produtos, cujas vitrines do desenvolvimento de cada país, conforme citado, se montavam regularmente na realização das Exposições Universais, das quais o Brasil participara seguidas vezes desde 1862 - esta que Américo deve ter visitado durante suas viagens a Londres no mesmo ano.

Mas Ingres não deveria ser recriminado, tampouco seus colegas acadêmicos, porque simplesmente defendiam uma doutrina que julgavam insuperável ${ }^{71}$. O problema, como visto, segundo o jovem, era que essa pretensa insuperabilidade acordara um belo dia descompassada em relação ao "espírito novo". Não formando novos grandes talentos, primeiro o público, depois a crítica, teria dado seu veredicto em favor de mudanças, então apenas ratificadas pelo estado francês.

Ainda que em sua argumentação o jovem não soubesse ou, muito mais provável, fizesse questão de esquecer o autoritarismo do governo imperial de Napoleão III, que tentava a todo tempo dissimular suas vontades em ações de agrado popular, pesava sobre sua escrita a imagem favorável ao liberalismo

69 'M. Ingres se plaint des paroles du rapport à propos de l'industrie en France et de l'influence des Beaux-arts sur cette source de richesses. Cependant qu'on nous permette une réflexion: la réforme n'a pas pour but d'introduire l'industrie dans l'art, mais bien l'art dans l'industrie, et par là dans la vie." AMÉRICO, Pedro. op.cit. p.11

70 OLIVEIRA, J. M. Cardoso de. Pedro Américo: sua vida e suas obras. Paris: Guillard, Aillaud \& Cia, Editores, 1898, p.27. A mesma informação é dada pelo próprio Américo, em cartas da década de 1850, enviadas a Jacques Brunet.

71 Idem, ibidem. p.10; p.13. 
que acreditava existir nas medidas reformistas sobre as Écoles de Paris e Roma ${ }^{72}$.

As mesmas "equidade e moderação" tomadas pelo Estado francês, "sem condenar ao ostracismo os princípios dos homens que ainda ontem excluíam toda originalidade" ${ }^{, 73}$, abririam caminho para uma maior representatividade e diversidade artísticas, dentro e fora das escolas. Um júri formado com diversidade para avaliar e formar anualmente um panorama da arte francesa nos Salons seria, por conseguinte, fruto de uma política supostamente tão liberal ${ }^{74}$ quanto uma escola menos restritiva, que não temeria, mesmo a despeito das opiniões contrárias, a entrada de professores não-acadêmicos. Mas essa entrada, diga-se de passagem, seria feita, segundo o decreto de 1863, exclusivamente a partir do consentimento do ministro, tratando-se, logo, de uma liberdade vacilante, pois moderada pelo Estado.

Segundo Américo, os cursos proferidos por tais professsores, "longe de apresentarem mil perigos em sua aplicação", como temia Ingres, não tenderiam, ao contrário:

a desenvolver nas "jovens mentes" o amor pela instrução e acelerar o movimento das ideias, tão fatalmente desacelerado há alguns anos? Que os alunos escutem as doutrinas as mais opostas, realismo, romantismo, classicismo; cabe ao temperamento de cada um, a seu caráter, enfim a seu gênio, escolher o que lhe convém melhor; porque a natureza deve seguir livremente seu caminho para chegar a um grande resultado, qualquer que seja ${ }^{75}$.

Américo condensa outro dos problemas capitais da reforma, que também se transformarão em questões fundamentais para sua trajetória e projetos pessoais. A partir desse excerto, combinado com vários outros em demais textos escritos posteriormente, ele deixa claramente compreender que o artista do século XIX assumia uma vantagem e uma responsabilidade diante dos seus antecessores: teria do seu lado o conhecimento histórico que, segundo uma perspectiva culturalista do oitocentos, fundada no século anterior pelos estudos de Vico e de $\operatorname{Herder}^{76}$, lhe permitiria compreender os eternos fluxos da humanidade e de suas atividades (infância, progresso, apogeu e decadência), e dessa compreensão o conhecimento das leis que delas derivariam. Em contrapartida, o direito (ou liberdade) de escolha

72 Idem, ibidem. p.11; p.12.

73 Idem, ibidem. p.13. Américo, como argumentarei em seguida, não faz mais do que repetir aqui uma das premissas do Ecletismo filosófico.

74 Idem, ibidem. p.11.

75 No original: “à développer dans «les jeunes têtes» l'amour de l'instruction et à accélérer le mouvement des idées, si fatalement ralenti depuis quelques années? Que les élèves aillent écouter les doctrines les plus opposées, réalisme, romantisme, classicisme; c'est au tempérament de chacun, à son caractère, à son génie enfin, de choisir ce qui lui convient le mieux; car la nature doit suivre librement sa pente pour arriver à quelque grand résultat que ce soit.”. Idem, ibidem. p.12.

76 MAINARDI, Patricia. Art and politics for the Second Empire: The Universal Expositions of 1855 and 1867. New Haven and London: Yale University Press, 1987. p.70. 
exigia dele uma dedicação constante ao estudo teórico, filosófico. Tal lição, Américo havia aprendido, entre vários outros autores tratados ao longo desta Tese, novamente com G. Tiberghien - que utilizava especialmente para produzir o texto Considerações Filosóficas sobre as Belas Artes entre os Antigos (1863-4): “A responsabilidade é proporcional ao grau de liberdade [..] Ela aumenta à medida que nos tornamos mais livres, mais sólidos, mais instruídos." ${ }^{77}$

\section{O artista-filósofo}

Mas para bem eleger (isto é, escolher livremente), cabe ao artista bem conhecer, e esse encargo reatualiza a urgência do reencontro do antigo mito do artista sábio, universal, cujas últimas e maiores expressões, como recorrentemente se defendia, se estavam na Itália em Leonardo da Vinci, em Michelangelo, no círculo francês, um pouco mais próximo, estavam no já bastante respeitado Poussin, outro "artista-filósofo" por excelência, ou, então, no exemplo ainda recente de Paul Delaroche (1797$1856)^{78}$. Essa demanda fundamenta melhor do que qualquer outra explicação a razão pela qual Américo havia escolhido como epígrafe de identificação de suas provas do concurso da AIBA, realizada em meados de 1865, o famoso mote vinciano - "Um pintor sábio na Teoria de sua arte pode, sem muita dificuldade, tornar-se universal. L. S. Vincy"; frase cuja escolha havia sido efetuada na sequência de seu contato com a obra fundadora de Michelet sobre a Renascença, e com a nova interpretação que se fazia então dela como o surgimento de um espírito novo, igualmente universal, como o dos seus maiores $\operatorname{artistas}^{79}$.

Não deve haver dúvidas de que essa requisição à instrução já acompanhava com insistência o jovem desde os tempos da AIBA, com os discursos questionadores de Porto Alegre para a abertura dos anos

77 TIBERGHIEN, Guillaume. Esquisses de Philosophie Morale. Bruxellas: Imprimiérie de Delevingne et Callewaert, 1854. p.28. p.145. O excerto no original é: "De là la responsabilité de l'homme ou l'imputabilité des actes. C'est la conséquence directe de la liberté morale. La responsabilité est donc proportionnée au degré de la liberté. Elle est aggravée ou atténuée selon que la liberté de l'agent est plus ou moins entière. Elle augmente à mesure que nous devenons plus libres, plus fermes et plus instruits."

78 A imagem de Poussin como pintor-filósofo é recorrente no século XIX. Para permanecer na questão da Reforma da École, cabe citar que agentes tão opostos como Ingres e Viollet-le-Duc utilizaram essa referência para desenvolverem seus argumentos a respeito das mudanças. cf. INGRES. Op. Cit. p.16; e VIOLLET-LE-DUC, Intervention de l'État dans l'enseignement des beaux-arts. Paris: A. Morel et Cie, 1864. p.57. Outra análise ainda idêntica, feita a partir de uma referência bibliográfica importante para Américo pode ser encontrada em: SUTTER, DAVID. Philosophie des Beaux-Arts apliquée à la peinture. Paris: Jules Tardieu, 1858. pp.49-52.

79 MICHELET, Jules. Renaissance. Paris: Chamerot, 1855. Especialmente pp.LXXVI-LXXXVI. Será essa interpretação feita por Michelet que fundamentará, também, a Tese de doutorado que Américo defenderá na Bélgica, em 1868, na qual ele pressupõe que o "verdadeiro método científico" teria nascido, precisamente, com o surgimento da "liberdade intelectual" no Renascimento. 
letivos e premiações, ocasições nas quais podia ouvir:

Quando olhamos para os luminares de todas as escolas artísticas, encontramos em cada um deles um homem instruído, uma dualidade. Rafael devia ser cardeal companheiro de Bembo; Vasari é um clássico da língua italiana; Galileu foi pintor, e foi sempre considerado como um árbitro e um gui superior de seus contemporâneos; David era um arqueólogo profundo; Girodet um helenista e um poeta; Delaistre, um fisiologista; Eméric-David, um mestre e um sábio; Mengs, Ziegler, Reynolds, Alberti e outros muitos o que atestam seus trabalhos e escritos. É a estes chefes, a estes mestres idealistas que as artes devem a sua elevação, e não a esses milhares de operários mais ou menos engenhosos, e nem a esses milhões de copistas amaneirados que viverão de reproduções, ou recalcando um terreno perlustrado pela marcha do gênio. ${ }^{80}$

A influência das palavras e conselhos de Porto Alegre sobre Américo não deve ser, portanto, subestimada, nem o significado da criação, também durante a Reforma Pedreira, de uma cadeira de História das Belas Artes, Estética e Arqueologia, que ele não cursou por falta de professor.

Essas circunstâncias forneciam alimento às expectativas pessoais do jovem, e seriam sintomaticamente amplificadas com a criação da mesma cadeira na École des Beaux-Arts, durante reforma de $1863^{81}$, fazendo apenas reafirmar seus interesses alargados de instrução, perseguidos até então em cursos teóricos paralelos ${ }^{82}$, em sua formação concomitante ao Bacharelado em Ciências Naturais na Sorbonne, e em sua frequentação a demais escolas parisienses de desenho e ofícios.

A cadeira da École era, com efeito, inaugurada e conduzida por Viollet-Le-Duc no começo de 1864, na tentativa de resolução de uma premissa pessoal ${ }^{83}$, mas não rara a outros pensadores do periodo, a partir da qual sustentava a importância do alargamento do conhecimento histórico e filosófico dos artistas

80 PORTO ALEGRE, Manuel de Araújo. "Discurso do diretor da Academia das Belas Artes por ocasião da distribuição pública dos prêmios.”. In: Correio Mercantil, Rio de Janeiro, 30 de novembro de 1857, p.1.

$81 \mathrm{Na}$ École o desejo de criação de uma cadeira de história da arte era também antigo, já reclamado pelos reformadores precedentes.

82 Além das leituras e cursos frequentados por Américo, e discutidos no Segundo Capítulo desta Tese, Cardoso de Oliveira, biógrafo e genro de Américo, irá afirmar: "A sede saber, que em outra qualquer natureza estancaria o esforço intelectual aplicada a um único gênero de meditação e de estudo, era indômita em Pedro Américo, e o levava à tarde às conferências públicas do Padre Freppel e de M. De Pressensé, ao curso de arqueologia do célebre Beulé, autor do Processo dos Césares e da Acropóle de Atenas; e, aos domingos ou à noite, às preleções de Faraday, Balard, Jules Janin e outros luminares da ciência experimental, no Colégio de França e no Conservatório das Artes e Ofícios." OLIVEIRA, J. M. Cardoso de. Pedro Américo: sua vida e suas obras. Paris: Guillard, Aillaud \& Cia, Editores, 1898. P.35. Em outro extrato biográfico publicado, publicado em romance de autoria do próprio Pedro Américo, Cardoso adiciona como professores do jovem os cientistas Claude Bernard, César-Mansuète Despretz, e Sainte-Claire Deville. AMÉRICO, Pedro. O foragido. Rio de Janeiro/Paris: H. Garnier, 1899. p.XVI.

$83 \mathrm{O}$ problema já estava colocado por Viollet-Le-Duc em seu Dicionário da arquitetura francesa. $\mathrm{O}$ arquiteto o reatualizava na série de textos que precedem a reforma, após a formação da comissão de 1862. VIOLLET-LE-DUC, E. E. "L'enseignement des beaux-arts: Il y a quelque chose à faire". In: VITET, Ludovic. op. Cit. p.117-18; p.121; p.131 e outras. 
para além das fronteiras da arte grega, ainda que não lhe interessasse de modo algum, como a quase ninguém, refutá-la. O esforço estava evidentemente aparentado à sua defesa da arquitetura e escultura medievais francesas, que, até então relegadas pela Academia de Belas Artes, teriam preparado, para ele e outros autores ${ }^{84}$, o terreno para a Renascença desse país, ao contrário da influência italiana que então se imaginava no período, além do próprio interesse formal que elas manifestavam ${ }^{85}$. Para o arquiteto, mais importante que as formações práticas dos alunos - de resto, bem mais fáceis de alcançar, dada a grande oferta de cursos de desenho na França, sobretudo em Paris - seriam as suas formações teóricas, as quais o Estado deveria prover por meio de suas escolas de artes mais importantes.

Era o que ele implementava na reforma da École e oferecia com um único curso teórico voltado, sem distinção nem fronteiras internas de especialização, para arquitetos, escultores, pintores e gravadores ${ }^{86}$. O objetivo manifesto era o cultivo de suas inteligências, num curso em que se cruzavam arqueologia, filosofia, teoria, crítica e história da arte antigas. A justificava implícita deixava claro o interesse pela contínua valorização da classe artística e, com isso, pela contínua defesa das belas artes como atividade fundamentalmente liberal, em contraste com as artes manuais. Sem educação, afirmava Viollet-Le-Duc, um "artista ignorante não seria nada mais do que um artesão mais ou menos hábil”"87;

"é preciso que ele seja não apenas um obreiro perito com a mão, mas também e sobretudo um filósofo, um observador delicado, um homem sábio ou criado no meio de uma sociedade dotada: em suma, é preciso que ele conheça o que quer representar. [..] Foi esse o caráter eminente do Grego, e, sem precisar ir tão longe, ao estudar a vida dos grandes artistas da renascença, como não admirar o sentido filosófico, a profundidade de pensamentos e de paixões, frequentemente mesmo a erudição de todos esses grandes homens: Leonardo da Vinci, Michelangelo, Ticiano...

O projeto de Viollet-Le-Duc na Ėcole não durou tanto, ao menos com ele à sua frente. Sete aulas após o

84 Para o problema da revalorização dos estudos sobre a arte gótica na primeira metade do século XIX e sua institucionalização na França, ver: THERRIEN, Lyne. L'histoire de l'art en France, genèse d'une discipline universitaire. Paris: Éditions du C.T.H.S., 1998.

85 VIOLLET-LE-DUC, E. E. "Sculpture". In: VIOLLET-LE-DUC, E. E. Dictionnaire raisonnée de l'architecture française du XIe au XVIe siècle. Tome VIII. Paris: Ve. A. Morel \& Cie., 1875. Ver ainda: LENIAUD, Jean-Michel (dir.) Viollet-Le-Duc: les visions d'un architecte. [Exposition, Paris, Cité de l'architecture et du patrimoine, 20 novembre 2014 - 9 mars 2015]. Paris: Norma / Cité de l'architecture et du patrimoine, 2014.

86 IDEM. Esthétique appliquée à l'histoire de l'art. Paris: Énsb-a, 1994. p.11

87 IDEM. Intervention de l'État...p.18-19.

88 Idem. Esthétique appliquée à l'histoire de l'art. Paris: Énsb-a, 1994. p.107. O excerto original: "Pour cela, il faut qu'il ne soit pas seulement un ouvrier habile de la main, mais aussi et avant tout un philosophe, un observateur délicat, un homme savant ou élevé au milieu d'une société choisie: en un mot, il faut qu'il connaisse ce qu'il veut représenter. [..] c'est là ce qui fut le caractère du Grec, et, sans remonter si haut, en étudiant la vie des grands artistes de la renaissance, comment n'être pas frappé du sens philosophique, de la hauteur de pensées et de passions, souvent même de l'érudition de tous ces grands hommes: Léonard de Vinci, Michel-Angel, Titien, et tant d'autres d'un ordre moins élevé sans doute, mais qui eussent pu occuper le premier rang dans un siècle moins favorisé?”. 
início do seu curso, foi levado a pedir demissão em decorrência dos protestos contínuos da maioria do corpo discente, que apenas o percebia como causador do reboliço de suas vidas ${ }^{89}$. No entanto, Américo dispôs por fim de algumas semanas para seguir pessoalmente essas lições, apresentadas no Hémicycle da instituição, e para ser por elas suficientemente influenciado. Afinal, também o jovem decidiria inaugurar em seguida a cadeira de "história das belas artes, estética e arqueologia" da AIBA, apresentando ideias bastante familiares às de Viollet-Le-Duc e, é preciso notar, também às de Porto Alegre. E o texto base no qual se amparará para essas lições, além de sua tese de doutorado - defendida em 1868 - seria o Considerações Filosóficas sobre as Belas Artes entre os Antigos, escrito justamente entre 1863 e 1864 , e publicado imediatamente no Rio de Janeiro ${ }^{90}$.

\section{Do Ecletismo filosófico ${ }^{91}$}

Américo introjetava em si a reivindição de "amor aos estudos". Quando defendia a liberdade para que os alunos entrassem em contato com as correntes estéticas as mais díspares para então encontrarem aquela que melhor lhes coubesse, adotava a universalização de um conceito, mas sobretudo de um projeto, ao q Interesses ecléticos

ual ele próprio passara a se dedicar nas artes e nas ciências, bastante afim ao que convencionalmente se compreendeu ser, na prática artística e na reflexão teórica, uma característica do Romantismo em sua idêntica defesa à liberdade e ao historicismo, herança que provinha sem dúvida da influência primeira que a geração de Porto Alegre - e este especialmente, no Brasil - lhe exerceu.

A defesa ao acesso e reflexão livres de diferentes correntes estéticas era mais um, de uma série contínua de índices que garantia a permanente imersão de Américo nos valores da filosofia eclética de Victor

89 Para uma análise pessoal, desenvolvido por Viollet-Le-Duc, sobre o problema, ver: VIOLLET-LE-DUC, Eugène E. Intervention de l'État dans l'enseignement des beaux-arts. Paris: A. Morel et Cie, 1864; e ainda : MÉRIMÉE, Prosper. La correspondance Mérimée-Viollet-le-Duc. éd. Françoise Bercé. Paris: Ed. Du CTHS, 2001. Para uma análise feita pela maioria dos alunos da École, e o que sentiam em relação a Viollet-Le-Duc: S/A. Réclamations des élèves de l'Ecole des Beaux-Arts au sujet de la réorganisation de leur École. Paris: Imprimière de Ad. Lainé et J. Havard, 1864.

Para uma análise bastante interessante da rápida saída de Viollet-Le-Duc da École, ver: WALSH, Philip H. "Viollet-leDuc and Taine at the École des Beaux-Arts: on the first professorship of art history in France". In: Mansfield, Elizabeth (ed.). Art History and Its Institutions. London/New York: Routledge, 2002. pp.85-99.

90 Conquanto Américo fosse empossado na cadeira de História das Belas Artes, Estética e Arqueologia em 1869, não resta dúvidas que ele o teria feito desde antes, em 1866, não tivesse que sair às pressas do Brasil devido a uma série de conflitos que teve com personalidades importantes das artes do Rio de Janeiro, em especial com Bethencourt da Silva. Sobre essa questão, ver o capítulo: A um triz do xilindró: Pedro Américo e a questão de bacharéis.

91 Nesta Tese, utilizarei sempre maiúsculas para me referir ao Ecletismo, método filosófico desenvolvido por Victor Cousin, e para assim diferenciar o uso deste termo da ideia bastante difundida de ecletismo, provinda originalmente da arquitetura 
Cousin $^{92}$. Tratava-se de um método filosófico pela primeira vez ministrado e discutido na Sorbonne, entre 1817 e 1818, que, em sua última maior expressão, se traduziu em uma obra estética fundamental intitulada Do Verdadeiro, do Belo e do Bem ("Du Vrai, du Beau et du Bien”).

Filosofia bastante absorvida pelo programa político napoleônico de tolerância e valorização de diferentes doutrinas, conquanto estivesse originalmente ligada ao liberalismo da Monarquia de Julho, o Ecletismo também partia, em fundamento, da "vantagem" oferecida pela perspectiva histórica, que se imaginava ser a do século $\mathrm{XIX}^{93}$. Para Cousin, não se deveria nunca negar partis pris anteriores (todos teriam uma semente de "verdade"), nem tomar apenas um como verdadeiro, e nem ainda assumir a tarefa impossível de sintetizar levianamente sistemas irreconciliáveis, mas exercer "um Ecletismo esclarecido que, julgando com equidade e mesmo com benevolência todas as escolas, lhes toma o que têm de verdadeiro, e negligencia o que têm de falso. Já que o espírito de partição não teve bom êxito até hoje, tentemos o espírito da conciliação" ${ }^{94}$. Seus alunos eram encorajados a estudar e traduzir para o francês todas as doutrinas filosóficas e todos os modelos históricos disponíveis, porque, segundo compreendia, apenas a partir desse movimento sintético se poderia atingir um sistema verdadeiramente completo.

Em 1863, Américo continuava a ler a filosofia de Cousin ${ }^{95}$, embora sua introdução retornasse a 1855 , em sua primeira formação no Colégio d. Pedro II - ou mesmo um pouco antes, dado que as primeiras traduções das obras do filósofo francês, no Brasil, datam já do início da década de $1840^{96}$. Após a

92 Para uma melhor análise da relação de Américo com o Ecletismo, ver o segundo Capítulo desta Tese, dedicado às Considerações Filosóficas sobre as Belas Artes entre os Antigos. Ao lado do Ecletismo, nos seus últimos anos de Paris, Américo tentará alinhar o Krausismo (uma corrente de pensamento que seguia a doutrina panenteísta do alemão Karl Christian Friedrich Krause [1781-1832]), aprendido nas interpretações de Guillaume Tiberghien, reitor da Universidade Livre de Bruxelas, onde, a partir de 1866, perseguirá e defenderá seu doutorado.

93 Cousin irá chamar o Ecletismo do "verdadeiro método histórico, e ele tem para nós toda a importância da história da filosofia." COUSIN, Victor. Du vrai, du Beau et du Bien. septième édition. Paris: Didier et Cie, 1858. p.14. Com efeito, Cousin era professor na cadeira de História da Filosofia, e publicava pela primeira vez o seu curso em 1817, um pouco modificado, mas sobretudo acrescentado nas décadas seguintes.

94 Idem, Ibidem. p.10: Exercer un "éclectisme éclairé qui, jugeant avec équité et même avec bienveillance toutes les écoles, leur emprunte ce qu'elles ont de vrai, et néglige ce qu'elles ont de faux. Puisque l'esprit de parti nous a si mal réussi jusqu'à présent, essayons de l'esprit de conciliation." [tradução nossa]

95 Américo citará, e deixará ainda mais clara suas dívidas para com o Ecletismo espiritualista de Cousin no texto das Considerações Filosóficas sobre as Belas Artes entre os Antigos (produzido entre 1863 e 1864; e publicado neste último), especialmente na defesa de uma arte que fosse ideal e exemplar; isto é, uma arte que possuísse uma destinação socialmente e moralmente elevada (no mesmo espírito de Quatremère de Quincy, outra de suas fontes incontornáveis de reflexão). Tratarei melhor desse assunto em Capítulo dedicado às Considerações.

96 A primeira tradução completa de Victor Cousin no Brasil é trabalho de Antonio Pedro de Figueiredo, em Recife, entre 1843 e 1844. A obra escolhida é o "Curso de História da Filosofia Moderna". Em julho de 1844, o concurso de filosofia do Colégio d. Pedro II é vencido por Francisco de Salles Torres Homem, amigo e colaborador de Porto Alegre e Gonçalves de Magalhães desde seus anos, juntos, em Paris. Torres Homem, como Magalhães (professor anteriormente na 
grande reforma do ensino secundário do mesmo ano, que incluía a AIBA, realizada pelo ministro Pedreira (mesmo agente que havia acolhido Américo no Rio de Janeiro), o ensino filosófico no Colégio oficialmente direcionado ao Ecletismo, balizador ainda dos liceus provinciais ${ }^{97}$, era obrigatório ${ }^{98}$ e também um dos sintomas da política imperial, notadamente nos anos 1850 e 1860. Tratava-se de uma política interessada em conciliar ou alternar continuamente o poder entre os "liberais" e os "conservadores"99 como maneira de agradar ambos os lados e diminuir conflitos que também questionassem o alcance do poder moderador, exercido unicamente por d. Pedro $\mathrm{II}^{100}$. Se a monarquia brasileira, constitucional e de base cristã, havia adotado o Ecletismo francês como sistema filosófico oficial, isso era talvez resposta quase lógica à adoção que o Ecletismo, em seus postulados, já havia

mesma cadeira, de 1837 a 1842), consagra oficialmente e dá continuidade ao ensino fundado no Ecletismo. Em 1849, Moraes e Valle traduzirá outra obra de Cousin: "Filosofia Popular". Em 1851, Frei José de Santa Maria Amaral, também um eclético, assuma a cadeira de filosofia do d. Pedro II, e muito provavelmente será o professor de Américo na mesma instituição, posto que tenha permanecido titular da cadeira por décadas. Convém ainda destacar que, na década de 1840, Victor Cousin é mencionado por Félix-Émile Taunay nos discursos proferidos na Academia Imperial de Belas Artes. Agradeço a Elaine Dias por me inteirar dessa informação.

Por fim, o compédio de filosofia que havia se tornado obrigatório no Colégio desde a década de 1840 (o "Curso elemento de Filsofia", de Barbe, traduzido por Joaquim Alves de Souva, em 1846) era também de orientação eclética.

97 Para um panorama importante do Ecletismo oficial no Colégio d. Pedro II, reflexo do interesse que essa formação adquire para o Império até a década de 1880, quando Silvio Romero, Comteano fervoroso, assume a cadeira de filosofia, modificando uma orientação mantida por décadas, ver: PAIM, Antonio. A Escola Eclética.[Estudos complementares à História das idéias filosóficas no Brasil]. $2^{\mathrm{a}}$ edição ampliada. Londrina: Edições CEFIL, 1999. pp.33-39, e p.317-339.

98 CRUZ, André Silveiro da. O pensamento filosófico e o ensino da filosofia na escola secundária brasileira: uma interpretação dos programas de ensino do colégio Pedro II (1837-1951). Dissertação de Mestrado. Uberlândia: UFUB, 2006. Ver ainda Paim: "A corrente eclética representa o primeiro movimento filosófico plenamente estruturado do Brasil. Suas ideias penetram fundo em amplos setores da elite nacional e chegaram a se transformar no suporte último da consciência conservadora em formação". PAIM, Antonio. História das idéias filosóficas no Brasil. São Paulo: Grijalbo, 1967.p.75.

99 Vale lembrar, por exemplo, da manobra realizada em 1853 por Honório Hermeto Carneiro Leão, o poderoso Marquês de Paraná, formando o chamado "Gabinente da Conciliação" (1853-1857), cujo objetivo era justamente o de encontrar uma via do meio para os interesses do partido Conservador e do Liberal. A relação dessa postura com o Ecletismo filosófico não parece ser de modo algum descartável. De início, a obra fundamental de Gonçalves de Magalhães (Fatos do Espírito Humano), publicada poucos meses após a dissolução daquele gabinete, mas escrita ao longo de sua vigência, não deixava dúvidas entre as semelhanças de propósitos nos objetivos daquele gabinete e no método eclético. Para Magalhães, o Ecletismo "é uma filosofia de conciliação e reconstrução que se opõe ao ceticismo", MAGALHÃES, J. G. de. Fatos do Espírito Humano. Paris: Livraria d'Auguste Fontaine, 1858, p.36. Ainda, se se considera, novamente, que os gabinetes dos ministérios mantiveram firme, até a década o fim da década de 1870, a manutenção dos manuais de filosofia de orientação eclética nas escolas, liceus estaduais, e no colégio d. Pedro II. Além disso, as avaliações históricas posteriores, quando se referem aos anos de conciliação, oferecem por vezes leituras e metáforas que não divergem mesmo do "espírito eclético" do Segundo Império. Para Oliveira Lima, por exemplo, o gabinete de 1853 teria tido o objetivo "de fundir elementos de grande valia sob um programa simpático de paz". LIMA, Manuel de Oliveira. O movimento da Independência: O Império Brasileiro (1821-1889).São Paulo: Melhoramentos, 1962. $4^{\mathrm{a}}$ edição. p.354.

100 Para Antonio Paim, "a supremacia dos ecléticos parece haver sido alcançada pelo debate de uma questão central, a do Poder Moderador". PAIM, A. A Escola eclética...p.357. Ver, sobre a questão, do mesmo autor: PAIM, Antônio. "A discussão do Poder Moderador no Segundo Império". Curso de Introdução ao Pensamento Político Brasileiro, unidade III e IV, p. 11-65. Brasília: Ed. UnB, 1982. Ainda sobre o assunto, ver ainda a esclarecedora introdução de Cecilia Helena S. Oliveira para o livro por ela organizado: OLIVEIRA, Cecilia Helena de Salles (org.). Zacarias de Góis e Vasconcelos [coleção: Formadores do Brasil]. São Paulo: Editora 34, 2002. pp.09-55. 
antes feito do espiritualismo e da monarquia constitucional como únicos motores políticos possíveis para a contemporaneidade europeia, da qual, também por escolha de modelo, o Brasil não deseja divergir. A filosofia eclética, segundo Cousin:

auxilia a verdadeira arte, a poesia digna desse nome, a grande literatura; ela é o apoio do direito; ela rejeita a demagogia e a tirania; ela ensina a todos os homens a se respeitare a se amar, e ele conduz pouco a pouco as sociedades humanas à verdadeira república, esse sonho de todas as almas generosas, que apenas a monarquia constitucional pode realizar nos dias de hoje, na Europa. ${ }^{101}$

A influência dessa filosofia era imanente ainda na Academia Imperial de Belas Artes, mas é um fato que suas implicações específicas na instituição ainda devem ser estudadas ${ }^{102}$. Ela estava presente já nos discursos de Félix-Émile Taunay na década de $1840^{103}$ e, posteriormente, nos discursos públicos proferidos sob a égide do então diretor Porto Alegre (1854-57), a quem se ligava desde há muito seus íntimos amigos Gonçalves de Magalhães e Francisco de Sales Torres Homem ${ }^{104}$, todos alunos do frei Montalverne $^{105}$ - um dos primeiros estudiosos a introduzir Cousin no Brasil, na década de 1820 - e alunos ainda do próprio Cousin, na França. Não é impossível imaginar que as palavras do discurso de posse de Porto Alegre na AIBA recém-reformada, o primeiro que Américo verá, em 1855, trouxesse ao jovem, pela primeira vez na instituição, a defesa eclética pela liberdade e transigência; uma defesa que

101 COUSIN, V. op. Cit. p.VIII. O excerto original: "Cette philosophie est l'alliée naturelle de toutes les bonnes causes. Elle soutient le sentiment religieux; elle seconde l'art véritable, la poésie digne de ce nom, la grande littérature; elle est l'appui du droit; elle repousse également la démagogie et la tyrannie; elle apprend à tous les hommes à se respecter et à s'aimer, et elle conduit peu à peu les sociétés humaines à la vraie république, ce rêve de toutes les âmes généreuses, que de nos jours en Europe peut seule réaliser la monarchie constitutionnelle."

102 De fato, a bibliografia sobre o tema é inexistente. Nesta Tese, não pude fazer senão alguns apontamentos necessários à compreensão geral da relações de algumas personalidades da academia com o Ecletismo espiritualista. Acredito que um tal trabalho poderia explicar de outro ponto de vista, por exemplo, as relações e divergências diretas e indiretas que se estabeleceram sobretudo no segundo, terceiro e quarto quartos do século XIX entre o poder executivo, o poder moderador e os membros da congregação da AIBA.

103 No pós-doutorado de Elaine Dias intitulado “A Questão da Arquitetura nos Discursos de Félix-Émile Taunay na Academia Imperial de Belas Artes" (Fau-UsP, Fapesp, Paris IV, 2006-2009), a autora recupera e analisa, entre outras análises, as teorias utilizadas por Taunay na construção de seus discursos proferidos na instituição, entre as quais está aquela de Victor Cousin.

Agradeço a Elaine Dias por me informar das citações que Taunay então já fazia de Cousin, durante sua gestão à frente da AIBA, entre os anos 1830 e 1850.

104 Torres Homem e, sobretudo, Magalhães, logo se tornariam as figuras mais importantes para o desenvolvimento do pensamento eclético brasileiro (eles próprios alunos diretos de Cousin no College de France, em Paris, ao lado de Porto Alegre). Magalhães será também uma personalidade para a qual Américo pagará tributo algumas vezes desde o fim dos anos 1860.

105 Porto Alegre, Francisco de Salles Torres Homem e Gonçalves de Magalhães haviam sido apresentados à filosofia eclética de Cousin por Francisco de Monte Alverne, no Seminário São José, no início da década de 1830, como confessam em cartas a ele enviadas da França (cf., por exemplo, ALEGRE, M. A. de Porto; MAGALHÃES; Gonçalves de. Cartas a Monte Alverne. São Paulo: Comissão Estadual de Cultura, 1962.). Ambos se aproximariam bastante dessa filosofia, e a ativariam em um projeto comum quando da publicação da Revista Nitheroy. Ver. PINASSI, Maria Orlandi. Três devotos, uma fé, nenhum milagre. São Paulo: ed Unesp, 1999. 
seria ainda reforçada outras vezes, ainda durante o período em que o novo diretor ocupava a cadeira. Tratavam-se, sem surpresa, dos mesmos valores que o jovem, ele próprio, futuramente defenderá em seu opúsculo a favor da sequente reforma de Paris:

seja devido à verdade dos tempos, à experiência ou à renovação do pessoal, hoje tenho muito bem fundadas esperanças de realizarmos o seguinte: [..] Estabelecer a liberdade de pensamento e da prática, [..] Banir e combater todas as tendências à tirania do monopólio, porque este é o grande mal das $\operatorname{academias}^{106}$.

Mesmo depois da saída precoce mas voluntária de Porto Alegre, no penúltimo ano de Américo na AIBA, a entrada na direção da instituição de uma nova figura empossada pelo imperador e no entanto fora do ofício e reflexão artísticos, como Thomás Gomes dos Santos (ainda que Porto Alegre o conhecesse bem, pois colegas de trabalho na revista $A$ Reforma ${ }^{107}$ ), manteria, a despeito de tudo, a orientação oficial ao Ecletismo. Gomes dos Santos, anteriormente professor de Higiene e História da Medicina na Escola de Medicina do Rio de Janeiro, combatia havia muito, segundo Antônio Paim, "o reducionismo cientificista e o naturalismo extremado", também filiando-se filosoficamente ao Ecletismo $^{108}$.

Em resumo, a coerência filosófica que se rebatia no plano administrativo - e que justificava portanto a entrada de Gomes dos Santos, em 1857 - parecia apenas manter a mesma relação no plano artístico desde, pelo menos ${ }^{109}$, os anos de direção de Porto Alegre ${ }^{110}$. Nenhuma outra razão explica isso melhor

106 PORTO ALEGRE, M. A. "Discurso de Posse na Academia Imperial das Belas Artes", 1854. In: KOVENSKY, Julia; SQUEFF, Letícia (orgs.). Manuel de Araújo Porto Alegre: Singular \& Plural. São Paulo: IMS, 2014. p.313.

$107 \mathrm{O}$ próprio Porto Alegre assegura esse dado em seus apontamentos biográficos. PORTO ALEGRE, M. A. “Apontamentos Biográficos", 1858. In: KOVENSKY, Julia; SQUEFF, Letícia (orgs.). Manuel de Araújo Porto Alegre: Singular \& Plural. São Paulo: IMS, 2014. p.351.

108 PAIM, Antonio. A Escola Eclética.. Londrina: CEFIL, 1999. p.327.

109 Afirmo que essa postura aparece "pelo menos" desde os anos de Porto Alegre na instituição, porque seria sem dúvida preciso compreender melhor a relação que o direitor que lhe precede, F.E. Taunay, havia (ou não) estabelecido com o método eclético. O período de sua gestão, até a década de 1850, já marcaria a "vitória" dos ecléticos no governos, e a manutenção política e filosófica desse sistema em diversas instituições do império.

110 A única mudança existente, entretanto fundamental ao funcionamento interno da instituição - se eu puder arriscar uma hipótese que me parece bastante provável -, parece vir do interesse do imperador em empossar, a partir de Gomes dos Santos, apenas figuras ligadas unicamente à administração da instituição, não se tratando mais de artistas, com o intuito de diminuir os choques políticos de diferentes representantes classes artísticas no seio da AIBA. Depois da morte de Gomes dos Santos, as diversas discussões e campanhas públicas para lhe encontrar um substituto, mas agora artista, na qual se encontrará o próprio Américo, será encerrada com um balde de água fria quando o imperador empossa o que parecia ser uma nova "zebra", fora do domínio das artes, Nicolau Tolentino. A escolha, me parece, justifica-se novamente pelo embate publicamente conhecido entre professores da AIBA, sem dúvida o mais claro exemplo, aquele travado durante anos entre Américo e Bethencourt da Silva, e seus respectivos aliados, dentro e fora da Academia. Nesse sentido, basta considerar o problema que teria significado o empossamento de um Américo ou de um Betencourt, em 1875 (momento de ingresso de 
do que a escolha reiterada do antigo diretor para que os bolsistas e alunos da AIBA tomassem o “eclético" Delaroche como professor em Paris. também Porto Alegre o considerava "o pintor mais filosófico" e "estético" do período ${ }^{111}$. Os qualitativos imputados ao francês equiparavam-se, de algum modo, à percepção que alguns contemporâneos brasileiros possuíam a respeito da sua própria atuação, isto é, desempenho também filosófico nas artes, já no momento em que tomava as rédeas da academia carioca $^{112}$.

A maior contribuição pictórica de Delaroche para a construção de sua imagem pública enquanto pintor filósofo, certamente a maior contribuição visual até então já produzida para o Ecletismo filosófico nas artes, se situava novamente no mesmo Hémicycle da École des Beaux-Arts que Américo frequentará desde 1859 para as premiações dos laureados do Grand Prix, e especialmente em 1864, quando produz seu Considerações Filosóficas e sua Carioca, para o curso de Viollet-Le-Duc (fig.1.1.).

Tolentino), e a possível relação novo diretor com a oposição política interna na instituição. O resultado desastroso dessa experiência já havia sido testemunhado em 1854, com a saída de F. E. Taunay para entrada de Porto Alegre, em 1854; e com a saída de Porto Alegre, após conflitos políticos dentro e fora da Academia. Em suma, me parece que a escolha reiterada do Imperador em se colocar a partir de então um agente exterior ao trabalho artística vêm de uma reflexão bastante consciente, que deseja instalar uma espécie de "poder moderador" na AIBA.

111 A opinião de Porto Alegre sobre Delaroche é feita em um trecho de conhecida carta enviada a Victor Meirelles, que se dirigiria em pouco tempo a Paris: "Estude o nu, estude anatomia, estude bem o desenho, e veja se toma Mr. Delaroche por mestre, que é hoje o pintor o mais filosófico e o mais estético que eu conheço.". Carta de Porto Alegre a Victor Meirelles. Academia de Belas Artes, 06 de agosto de 1855. In: Revista do Patrimônio Histórico e Artístico Nacional. Rio de Janeiro, n.14, 1959, pp.84-89. Republicada em: http://www.dezenovevinte.net/correspondencias/ [último acesso em Junho de 2015]

112 A. F. Vianna, por exemplo, em um dos exemplares da revista Illustração Brasileira (para a qual colaborava o mesmo Porto Alegre) iniciava desse modo uma série interrompida sobre a Filosofia no Brasil:

"O bem é o fim; a lei, o meio; e a razão, o agente que une o destino que é Deus, com a virtude que é o ato. A filosofia pois é a razão das coisas humanas. Ora, se a filosofia é o princípio que regula o mundo intelectual e moral - é claro que o belo, o justo, que se traduzem pela arte, e o Estado - devem modelar-se por esta ciência que só nos [p.17] explica as causas, e os efeitos, o princípio e o fim, o bem, e o mal [..] O estado sem a filosofia é a negação de toda a justiça, de toda a virtude, e de todos os sacrifícios. [..] [a razão] é um tributo que o espírito honrosamento paga à verdade que é a ciência, a arte, e o estado!

A arte sem filosofia - é a estátua sem espírito, sem harmonia nas formas, e sem a concepção, que eterniza o artefato, e o artista - é o belo em suas expressões individuais, sem o caráter histórico, grande e sublime, que os historiadores tem encontrado nos monumentos antigos. A arte é a expressão mais eloquente do pensamento, se ele não tem a grandeza e magestade...

Há quem pretenda que a arte só se desenvolva larga, magestosa, sob a sombra sinistra do despotismo! A história do belo parece ser a justificação deste pensamento, que é ao mesmo tempo indecoroso para a arte, e para o artista. A liberdade é a fonte de todos os prodígios, e glórias da humanidade, sem ela não compreendemos vida possível, nem entusiasmo patriótico, artístico, ou científico. [...] O verdadeiro gênio artístico ama a liberdade como Sócrates adorou a filosofia - é um amor desinteressado, e puro, porque nasce do entusiasmo que arde e requemia sua alma!

Estado sem filosofia é despotismo.

A arte sem filosofia é importante e vulgar. [...] No número seguinte seguinte trataremos das artes no Brasil, e dos servições que o Sr. Porto-Alegre lhes há prestado. Felizmente graças à bondade do Sr. Cyro, terei a ocasião de Mostrar ao país o quanto venero e respeito esse ilustre brasileira." VIANNA, A. F. "A filosofia no Brasil - I". Illustração Brasileira. vol.II, n.1, Rio de Janeiro, 1855. p.19.

A revista é interrompida em 1855, nesse seu primeiro número, o que impediu Vianna de prosseguir sua publicação. 
Na parede circular da sala, que termina simbolicamente o eixo da Rue de Beaux-Arts (fig.1.2.), sobre o qual ainda repousam os três páteos de entrada, igualmente simbólicos da École -com exemplares historicamente ordenados da arte romana, gótica, renascentista, barroca etc. -, Delaroche havia pintado, entre 1837 e 1841, 75 das consideradas maiores personalidades artísticas de todos os tempos e “escolas", todas colocadas lado a lado, e divididas significativamente em dois grupos: de um lado, o dos coloristas e dos escultores, cuja coerência vem do fato desses artistas desenvolverem uma arte "pictórica"; de outro, o dos arquitetos e artistas da "linha". A despeito dessas diferenças, tão enfatizadas no período, com a assim chamada "querela dos românticos e dos clássicos", o centro simbólico no qual cessariam suas oposições era o mesmo. Ele era traduzido por quatro alegorias das artes, que, juntas, formavam uma espécie de alegoria da história da arte (Arte Grega, Romana, Idade Média e Renascença); era ainda traduzida separadamente pela fonte grega “eterna”, representada pelos maiores artistas da antiguidade: Apeles (pintor), Fídias (escultor) e Ictinus (arquiteto); e por um "gênio das Artes", isto é, uma musa nua, que oferece eternamente os louros aos vencedores do Prix ${ }^{113}$. Acima, na abóboda, a divisão das escolas artísticas, que enunciavam de um lado a outro da parede os artistas representantes daqueles dois grupos. A escola central, todavia, ponto de inflexão das demais e de todo o eixo da Rue des Beaux-Arts (e sintomaticamente alinhada aos gregos), era apresentada como a Escola Francesa, seguindo um discurso igualmente preciso ${ }^{114}$. Lá, ela é escola da "conciliação", que entre o passado e o presente estabelece por meio da história um eixo simbólico direto com a arte da antiguidade, e a única capaz, no presente, de sintetizar todas as verdades estéticas e artísticas de todos os tempos, numa nova fórmula que também almeja seu estatuto de clássica.

O enunciado a um tal programa filosófico eclético não poderia ser mais claro, nem o que a interessava Porto Alegre (leitor e aluno de Alverne e Cousin) na indicação de Delaroche a seus alunos, sugestão que seria, depois da morte desse pintor, coerentemente migrada para Léon Cogniet, outro conhecido de Porto Alegre em seu período parisiense, na década de 1830. Como será visto, também Cogniet, como Delaroche, será frequentemente visto como um écletico por seus contemporâneos.

113113 DELAROCHE, P.; DUPONT, H. L'Hémicycle du Palais des Beaux-Arts: peinture murale exécutée par Paul Delaroche. Paris: Goupil, 1857.

114 A sequência das escolas apresentadas no teto do Hemicírculo, da esquerda para a direita do observador (isto é, dos coloristas aos desenhistas) é: Escola Veneziana, Escola Flamenga, Escola Holandesa, Escola Alemã, Escola Francesa, Escola Lombarda, Escola Bolonhesa, Escola Romana, Escola Florentina. 


\section{Interesses ecléticos}

De sua parte, entre o colégio d. Pedro II e a Academia de Belas Artes do Rio de Janeiro, a dívida de Américo para com a mesma filosofia ${ }^{115}$, repetidamente enunciada nos textos e métodos que serão trabalhados mais à frente, nesta Tese, continuava a ser testemunhada, em 1871, por seu amigo dos tempos do colégio e também seu primeiro biógrafo, Luiz Guimarães Júnior, no justo trecho em que tratará da produção d $A$ Carioca:

O ecletismo, templo engenhoso dos pensamentos humanos, em cuja fachada Victor Cousin gravou o seu venerável nome em caracteres inexpurgáveis, tornou-se fonte perene em que se desalterava o espírito entusiástico do artista paraíbano. A teoria de Cousin é na realidade do livro mais vasto e de mais fácil ingresso às almas cobiçosas, que procuram a origem do sentimento, e o berço das meditações da humaniade pensadora ${ }^{116}$.

Tal método, sintomaticamente, abriria caminho para duas posições tomadas pelo jovem já em seu opúsculo sobre a reforma da École des Beaux-Arts, e revisitadas em outros domínios artísticos, teóricos e práticos. Uma: "relativizando ideias, o ecletismo liberou os intelectuais das regras clássicas, e com isso, assim como com sua ênfase sobre a universalidade, contribuiu para a ascenção do romantismo"117. A outra: os ecléticos "desejaram a imparcialidade de estilos alternativos, a multiformidade de abordagens inclusivas, e a difusão de escolas - o antídoto para a regra autocrática nos domínios político e intelectual." 118

O apego teórico do jovem brasileiro a uma alternativa (e não necessariamente uma simples exclusão) ao sistema acadêmico, no mesmo espírito do Ecletismo de Cousin e das políticas francesas e brasileiras do período, se confirmava de fato em seus gostos pessoais, formação e produção pictórica daquele momento, exógenos à manutenção única do formalismo tradicional da École, sendo sua primeira expressão prátia visível desse período a produção, justamente, de sua Carioca - conforme argumentarei mais à frente, nesta Tese. Sem deixar de respeitar a grandeza de Ingres ou de Jacques-Louis David, a

115Ver o próximo Capítulo, sobre as Considerações Filosóficas sobre as Belas Artes entre os Antigos.

116 GUIMARÃES JÚNIOR, Luiz. Pedro Américo. Rio de Janeiro: Henrique Brown, 1871. pp.49-50.

O interesse renovado de Américo no método de Cousin, ainda em 1871, era expresso por Guimarães em outro trecho, relativo a uma Refutação à Vida de Jesus, que o artista publicará em resposta a um livro de Ernst Renan: "Nutrido das ideias espiritualistas do Ecletismo (bandeira que jamais abandonará) Pedro Américo, consequente com o ensino da história antiga, e tendo assistido a diversas conferências públicas sobre o assunto, escreveu uma judicionsa e eloquente resposta à falsa propaganda de Ernesto Renan, que mereceu ser lida pelos doutos da Igreja, e premiada com a comenda do Santo Sepulcro." Idem, Ibidem, p.58.

117 BOIME, Albert. Thomas Couture and the eclectic vision....p.15.

118 Idem, ibidem. P.22. 
quem mesmo copiava quase um ano após sua chegada à Paris ${ }^{119}$, seus gostos também incluíam a forte atração por mestres "barrocos" e "românticos" e essa última, uma aproximação significativa que o jovem fará ao escolher realizar livremente cópias de Guido Reni e Géricault ${ }^{120}$ (ele também desejava copiar Proudhon ${ }^{121}$ ), posto que desde então suas afinidades eram percebidas como equivalentes às afinidades presentes entre o "oposto" dos "neoclássicos" e "renascentistas". Os interesses de Américo ainda compreendiam a beleza do colorismo e tonalismo (que perceberá em Ticiano, Tintoretto, Veronese, Corregio, Rembrandt e no mesmo Proudhon), em alternativa à exclusividade da doutrina do desenho, pela herança florentina e romana (fig.1.3., fig.1.4., fig.1.7. e fig.1.6.); as várias viagens que realiza não apenas na Itália romana, mas Inglaterra, Bélgica, Holanda, e muito provavelmente Alemanha, algo bastante alinhado à proposição de Viollet-Le-Duc, na realização de excursões fora do cicuito romano; a ação na pintura sem o rigor e método "neoclássicos" tão programáticos, método muito mais caro a seu colega, Victor Meirelles - devoto das séries extensas de estudos e reestudos; e ainda a sua adesão futura e crescente a métodos alternativos de produção pictórica, isto é, esboços limitados, pintura quase direta com poucos desenhos preparatórios, o uso de fotografia ${ }^{122}$ ou projeções ${ }^{123}$ como modelo: esta, outra defesa alternativa ao academismo, que a inscrição que ele fazia na Pétite École, e as lições bastante heterodoxas que deve ter seguido de Lecoq de Boisbaudran, muito

119 Os registros de pedidos de cópias do Louvre revela que Américo copiou o retrato do Papa Pio VII, iniciado em 28 de março de 1860. (Caderno: Registre de Copies, Écoles Italienne et espagnole. 1851-1859, p.165. Cota: *LL26).

120 Ao que tudo indica, a primeira cópia realizada por Américo em Paris é feita a partir de um retrato triplo de Hyacinthe Rigaud, então intitulada Portrait de deux femmes et d'un homme inconnus. Foi iniciada em julho de 1859, poucas semanas após sua chegada à Paris. Trata-se na verdade do retrato triplo de membros da família de Rigaud, pertencente à coleção do Louvre desde o período de Louis XV, e posteriormente identificado (Caderno: Registre de Copies, Écoles Italienne et espagnole. 1851-1859, p.160. Cota: *LL26). O jovem começará a fazer a cópia do Naufrágio da Medusa, de Géricault, em 31 de setembro de 1860, alguns meses após o início da cópia de David. (Caderno: Registre de Copies, Écoles Italienne et espagnole. 1851-1859. Cota: *LL26. Géricault, n.242, Naufrage de la Méduse, p.80.). Ele fará ainda, como se sabe, uma cópia do Rapto de Djanira, de Guido Reni, obra sintética de um "classicismo barroco"; todavia, parte desse caderno e seus respectivos registros foi perdida.

Américo se interessará ainda muitíssimo pela escultura de um Bernini e de um Puget. Em carta a Jacques Brunet de 07 de maio de 1863 Américo manifestava ainda o projeto de copiar a Justiça e a vingança divina perseguindo o crime, de Pierre-Paul Prud'hon, para ofertá-la ao clérigo da Paraíba, se o ajudasse a obter uma bolsa da província, embora essa cópia não pareça ter sido realizada, pois não há registros nos cadernos do Louvre. AMÉRICO, P. "Carta de Pedro Américo a Jacques Brunet, em 07 de maio de 1863”. In: FUNDAÇÃO VINGT-UN ROSADO. Cartas de Pedro Américo de Figueiredo e Melo e Daniel Eduardo de Figueiredo e Melo a Louis Jacques Brunet. Mossoró: Coleção Mossoroense, junho de 2001.

${ }^{121}$ AMÉRICO, P. "Carta a Jacques Brunet em 7 de maio de 1863". In: NEVES, Tancredo. Dossiê Pedro Américo. Mossoró, 2006. Pp.134-36. p.102.

122 Pude trabalhar a inserção da fotografia no trabalho de Américo em minha Dissertação de Mestrado, embora na ocasião me centrasse mais em questões de percepção visual, do que unicamente na fotografia como um método alternativo ao tradicional das academias de arte.

123 Sobre essa questão, ver a tese de Vladimir Machado. A despeito de uma série de questões em relação à produção de Américo sobre as quais estou em desacordo com este historiador, a sua hipótese sobre o uso que o pintor teria feito de projeções luminosas, na Batalha do Avahy, me parece bastante convincente. OLIVEIRA, Vladimir Machado de. Do esboço pictórico à rotunda dos dioramas: a fotografia na pintura de batalhas de Pedro Américo. São Paulo: Tese de doutorado, FAUUSP: 2003. 
provavelmente ajudaram a formar ${ }^{124}$.

\section{Da Liberdade}

Tão claramente presente nessas escolhas, a liberdade reclamada por Américo - de contemplação, de reflexão, de produção -, não deveria consistir, no entanto, em uma escolha necessariamente fortuita, tomada entre um ou outro estilo, entre uma ou outra corrente estética, mas, justamente, na livre propensão outorgada a cada temperamento, isto é, uma liberdade moral que, discernindo sem restrições externas ou internas o que é bom ou ruim, deveria encontrar seu caminho acossando sem rédeas sua própria natureza. A liberdade garantiria ao indivíduo a busca por um ideal elevado, que se expressaria na filosofia pela Moral ou, especificamente - segundo a bibliografia acessada por Américo -, por uma "Biologia Geral", cujos princípios, de acordo com Tiberghien e ainda com Cousin, estariam sugestivamente conectados à Metafísica ${ }^{125}$, pedra angular para toda a filosofia da arte e produção artística francesa até boa parte da segunda da metade do século XIX. A liberdade era o que permitiria a busca pelo absoluto e a realização da natureza humana, "plenamente similar a de Deus",126, em direção ao Bom e ao Belo ${ }^{127}$.

Do ponto de vista artístico, que não excluía de modo algum o filosófico, tratava-se de uma liberdade de método e ação, que dentro do sistema de Cousin, com claras afinidades em Kant ${ }^{128}$ e Hegel $^{129}$ era uma das bases para a definição das três faculdades gerais do homem, ao lado da sensibilidade e da razão (ou da consciência, enquanto sua manifestação pessoal e subjetiva ${ }^{130}$ ), sem as quais nada se faria. Somente "pela liberdade que o homem é verdadeiramente homem, que ele se possui e se governa"131.

A liberdade, exercida por meio da vontade ${ }^{132}$, leva à reflexão, ao exercício profundo e consciente da

${ }^{124}$ Trato do método de desenho de Boisbaudran e da possível influência que ele pode ter tido sobre Américo no Sexto Capítulo desta Tese.

125 TIBERGHIEN, G. op. cit. 105.

126 Idem, ibidem. p.78.

127 Idem, ibidem. p.79; p.83; p.107.

128 Cousin havia sido o responsável por coordenar, com seus alunos, a tradução de uma série de filósofos germânicos. Em 1842, por exemplo, ele lançava o Leçons sur la philosophie, de Kant.

129 Cousin será de fato o primeiro autor a possuir uma transcrição da Estética de Hegel para o francês, cujos cursos em Berlin ele pôde acompanhar durante seu exílio, na década de 1820. cf. Hegel, Georg Wilhelm Friedrich (1770-1831). Esthétique: cahier de notes inédit de Victor Cousin / G. W. F. Hegel ; transcription, présentation et notes, Alain Patrick Olivier. Paris : J. Vrin, 2005.

130 TIBERGHIEN, G. op. cit. p.127.

131 COUSIN, Victor. op.cit. p.32.

132 Também a vontade é ponto importante na filosofia moral de Tiberghien: "Nós chamamos de vontade na instituição 
razão refletida, sendo essa a faculdade primordial que distinguiria o homem dos demais seres, e o colocaria em situação completamente similar à natureza divina, pensante ${ }^{133}$. Esta deve ser necessariamente empregada para conduzir o homem ao caminho das "verdades", pois se trata de uma ponte entre o material e o imaterial, entre o visível e o invisível, entre o particular e contingente e o universal e necessário, entre o "real" e o "ideal""134; em suma, uma faculdade fundamental para se atingir, por meio da consciência, as mesmas "verdades incontestáveis" e "necessárias" - o bem moral que a fruição da arte, por sua vez, permitiria se achegar por meio da razão sensível ${ }^{135}$. O artista edificado e livre, que em sua finitude é infinitamente parecido com Deus, é, ele próprio, um guia importante para esse caminho. É como o barqueiro do Hades, no mundo dos mortos, pois ele que, em seu trabalho, torna sensível a "verdade intuída". Se imerso nesse pensamento e, por consequência, se em sua atividade ele espera encontrar inevitavelmente o bom e o verdadeiro, a demonstração sensível e precisa dessa ideia pode ser provida apenas pela realização do belo ${ }^{136}$.

Mas a beleza, embora seja uma só, não possui apenas uma forma. Não está encerrada em um único sistema ou estilo. Todos possuem seu grau de "verdade", Cousin já dizia, e Américo, como visto, estava de acordo. Ela é uma combinação infinita de novos elementos; é descoberta em cada nova obra verdadeiramente exemplar, convenientemente adequada em suas escolhas formais a seu tempo e a seu lugar. Instruir-se, alargar o conhecimento, vasculhar os anais da história (que fornece a matéria necessária à reflexão), tudo isso é uma maneira de efetuar mais seguramente uma síntese estética propícia a cada obra e, sobretudo, a cada temperamento, no acesso contínuo às leis irrefutáveis presentes em todos os períodos, descobertas pela filosofia. Para Américo, a manutenção de um rigor classicista como único meio possível de desvelar as "verdades" por meio da experiência poética (o que seria, portanto, o contrário da "liberdade"), essa, sim, seria uma escolha artística restritiva e inadequada à contemporaneidade, pois impediria um plano eclético para que "a natureza seguisse livremente sua

analítica da vida, a atividade que dirige e determina as forças e as potencias particulares de um ser, isto é a atividade que tem por objetivo a própria atividade". Tiberghien, op. Cit. p.87.

133 Idem, ibidem, p.90.

134 Idem, Ibidem. p.108-109.

$135 \mathrm{O}$ problema das diferentes razões é desenvolvido dentro a filosofia de Cousin pela polaridade entre a razão espontânea, que sabe sem saber que sabe, e que descobre a verdade a partir de intuições naturais e imediatas (domínio no qual o sentimento e a sensibilidade artísticas tem grande papel); e a razão refletida, que descobre as verdades por meio do esforço e da vontade de conhecer. Ver, por exemplo, na op.cit. p.113, e durante vários momentos da parte que Cousin dedica exclusiva ao problema do Belo em sua filosofia: "Du Beau", op.cit. pp.133-256.

136 Idem, ibidem. p.131. Ver ainda a página 140: "O único meio que nos é dado de nos elevarmos ao ser dos seres sem experimentar deslumbramentos e vertigens, é de fazê-lo com a ajuda do divino intermediário [a razão], isto é, e nos consagrarmos ao estudo e ao amor da verdade e, como veremos oportunamente, à contemplação e à reprodução do belo, sobretudo à prática do bem”. [grifo e tradução nossos]. 
inclinação para chegar a um grande resultado, qualquer que fosse"137. De algum modo, ao lado de Cousin, Tiberghien continuaria a falar aos ouvidos do brasileiro: "A felicidade supõe uma atividade livre. O incômodo e a restrição comprimem o desenvolvimento, interrompem o fluxo fácil e regular da vida e produzem o desconforto ${ }^{138}$ ".

A imagem utilizada por Américo, que sustentaria portanto a força do temperamento individual livremente direcionado ao seu desenvolvimento artístico, partia de uma mesma ideia que, ao final, reencontrava o plano da expressão nacional ${ }^{139}$ : se para cada indivíduo havia uma produção mais adequada à expressão de seu "gênio", e se os "gênios", que eram poucos, se configuravam como expressões individuais, geograficamente inscritas, de uma força antes universal - que se exercia sempre por meio das reclamadas "leis universais da estética": unidade, variedade, equilíbrio, harmonia, ordem, proporção etc. -, então esse seria simplesmente o primeiro movimento de uma série continuada que asseguraria que, para cada povo, haveria também um tipo específico de produção artística, um estilo próprio, derivado do seu temperamento moral. Daí que, se havia uma arte francesa, uma arte alemã, uma arte belga, cada uma com suas próprias e distintas expressões nacionais - suas "originalidades", que não minavam sua universalidade ${ }^{140}-$, implicitamente ao seu discurso deveriam existir princípios próprios para a formação de uma arte brasileira.

Américo não elaboraria completamente essa última tese no seu pequeno opúsculo sobre a reforma da escola francesa, é verdade. Quando muito, a enunciava em algumas frases. Mas o faria paralelamente no texto Considerações Filosóficas, a partir do qual se pode perceber o quão perto ele estava de algumas teses coetâneas e similares a, por exemplo, Hippolyte Taine, sucessor de Viollet-le-Duc no curso de estética e história da arte da École ${ }^{141}$ (ainda que de Taine se valesse de um determinismo cientificista pouco acessado por Américo), especialmente no que dizia respeito a explicações de causa/efeito, a teses racistas tão em voga nos anos 1850, mas, sobretudo, a explicações de produções artísticas segundo a consideração da temperatura moral de cada povo ${ }^{142}$.

137 AMÉRICO, Pedro. op. Cit.p.12.

138 TIBERGHIEN, G. op. Cit. p.191: "La félicité suppose une activité libre. La gêne et la contrainte compriment le développement, arrêtent le cours facile et régulier de la vie et produisent la malaise" [sic].

139 "L'originalité personnelle ne sera désormais sacrifiée à aucune école, à aucune doctrine exclusive, et l'esprit national se développera bien plus à son aise aux rayons d'un nouveau soleil que sous le jour et la bannière d'une antiquité bâtarde et décourageante.” AMÉRICO, Pedro. op. Cit. p.12-13.

140 Idem, ibidem.pp.07-08.

141 TAINE, Hippolyte. Philosophie de l'Art. Paris: Germet Baillières, 1865.

142 Analiserei essas questões em capítulo dedicado a esse texto. 


\section{A reforma de Américo}

Conforme citado, a pequena brochura de Américo se destacava dos demais textos publicados sobre a reforma da École, especialmente em relação à atenção que dedicava às novas medidas endereçadas ao ensino acadêmico francês. Entretanto, seria um erro acreditar que seus propósitos se restringiam unicamente às discussões sobre as mudanças de um sistema de ensino artístico do qual estava prestes a sair, ou apenas porque pensaria desinteressadamente no bem da arte e o no seu desenvolvimento sincrônico ao "progresso moderno" - segundo dirá no final da brochura..

Se não analisados com algumas indagações, os argumentos e leituras oferecidos por Américo podem talvez turvar as principais razões e motivações do seu texto, publicado, deve-se lembrar mais uma vez, no importante momento em que o jovem tomava conhecimento do seu retorno inevitável ao Brasil, reivindicado por d. Pedro II. Em outros termos, se o conteúdo da sua brochura pontuava a todo tempo temas relativos à reformulação curricular da École, a partir da análise de alguns temas da reforma que ele escolhia calculadamente tratar, em detrimento de outros, não se deve descuidar do discernimento de Américo de que as mudanças naquela instituição se tratavam, antes de tudo, de uma ação política e, menos ainda, apagar o próprio interesse político que havia na divulgação do seu opúsculo. E é esse, certamente, o principal motor que o conduziu à sua publicação.

A intenção é irrefutável, e é constatada desde uma série de textos privados, endereçados naquele mesmo momento a amigos e conhecidos poderosos, nos quais assuntos de arte e política com frequência emolduravam o período no qual o jovem publicava La Réforme de l'École des Beaux-arts et l'opposition. Tais interesses foram perfeitamente expostos em duas cartas sequenciais enviadas ao seu antigo tutor e confidente, Louis Jacques Brunet.

Na primeira, escrita uma semana antes da divulgação do decreto de 15 de novembro de 1863, o jovem já lhe expunha:

Tenho tido a lembrança de lançar-me na política de meu país, ao chegar lá, parecendo este o único e incontestável meio de servir ao progresso do nosso desenvolvimento intelectual... É pois convencido que poderia colher alguns frutos mais saborosos do que os que produziriam os esforços encerrados em um ateliê, que me tenho lembrado da carreira política para servir ao país e às Belas Artes; porquanto as palavras pronunciadas no seio do parlamento ${ }^{143}$ são as que

143 A ideia de que parlamento, isto é, na legistaltura, estaria o lugar mais importante para o desenvolvimento das artes de uma nação, é central de defesa de Américo em seu Considerações Filosófica, conforme mostrarei em Capítulo posterior. 
edificam e organizam a sociedade ${ }^{144}$.

Na segunda carta, escrita 9 dias após a reforma, e no momento em que Américo preparava a redação do seu opúsculo, relembrava ao francês os assuntos tratados na correspondência precedente, com um complemento:

Falei-lhe ultimamente de política, e como verá, deixo aparecer na carta que dirijo ao nosso amigo Catonhé algumas ideias a respeito. Tenho um desejo imenso de fundar alguma coisa no Brasil, de não perder lá o que tenho ganho aqui, de completar esta civilização tão imperfeita, reclamando para as Belas Artes e mais ramos de conhecimentos que ilustram a nação, um lugar menos estreito na instrução pública. Mas como poderei dar peso às minhas ideias e palavras, se ficar estranho à política, que tudo dirige? Se me perguntarem a quem incumbe fazer prosperar as artes, eu tão depressa responderia: aos artistas; como dizem e pensam muitos [...]

Entretanto como na [?] dos dogmas os fundadores sempre são mártires, eu só ousaria soprar ideias novas se me vir ao abrigo de altos protetores ${ }^{145}$.

Nos dois pequenos trechos Américo incide em pelo menos quatro questões, para ele estreitamente conectadas, que passarão a ser fatalmente caras em sua trajetória: a de um projeto nacional para as artes, manifestada precocemente por meio do seu desejo de "fundar alguma coisa no Brasil"; a do ensino, decorrente do interesse de encontrar "um lugar menos estreito na instrução pública" para as Belas Artes; colada a essa, a de sua própria formação intelectual, cujo reconhecimento público seria garantido sobretudo por meio do peso de suas "ideias e palavras", e não apenas pelos "esforços encerrados no ateliê"; e a última, a da política, neste caso, uma política das artes, "único e incontestável meio de servir ao progresso do desenvolvimento intelectual” do país.

Era a essa atividade - Américo o sabia das lições de Tiberghien, entre outros autores - "que cabem as reformas praticáveis, como meios de transição do direito atual e o direito ideal." ${ }^{146}$ É especialmente ela, enfaticamente reiterada nos dois excertos, o tema e objeto daquelas cartas. Nelas, como a propósito em muitas outras de suas correspondências conhecidas, Américo coloca em prática uma das

144 MELO, Pedro Américo de Figueiredo e. Carta de Paris a Louis Jacque Brunet em 07 de novembro de 1863. FUNDAÇÃO VINGT-UN ROSADO. Cartas de Pedro Américo de Figueiredo e Melo e Daniel Eduardo de Figueiredo e Melo a Louis Jacques Brunet. Mossoró: Coleção Mossoroense, junho de 2001. s/p.

145 MELO, Pedro Américo de Figueiredo e. Carta de Paris a Louis Jacque Brunet em 24 de novembro de 1863. FUNDAÇÃO VINGT-UN ROSADO. Cartas de Pedro Américo de Figueiredo e Melo e Daniel Eduardo de Figueiredo e Melo a Louis Jacques Brunet. Mossoró: Coleção Mossoroense, junho de 2001. s/p.

146 TIBERGHIEN, G. op. Cit. p.115-116. 
movimentações mais assíduas e bem sucedidas de sua carreira, bem anterior a uma política geral das artes. Trata-se de uma política pessoal, que ele soube ativar a partir de sua sempre contínua afiliação a agentes brasileiros influentes ${ }^{147}$.

São iterados os exemplos de sua precoce frequentação a essa movimentação no Brasil. Eles se encontram nas cartas como as que Américo enviava a Luiz Pedreira na década de 1850, para que, mesmo se já inscrito no colégio D. Pedro II, o ministro agilizasse o quanto antes seu ingresso na AIBA; naquela endereçada ao imperador, na qual, ao lado de um dossiê dos vários prêmios obtidos em seus anos de estudantes, pedia a concessão de uma bolsa ao exterior; naquelas que endereçava nos primeiros anos de 1860 ainda ao monarca, com uma assiduidade que deveria beirar o incômodo, requerendo sempre e com êxito extensões de prazo de sua bolsa européia ou quantias extras de dinheiro; ou ainda naquelas várias que enviava ao próprio Brunet, ao longo de vários anos, para que intercedesse sempre a seu favor ${ }^{148}$.

A apropriada identificação dessa política pessoal é fundamental para a investigação de sua idêntica assiduidade na França; pois é também essa mesma movimentação, nunca desinteressada, que esclarece as razões pelas quais os jovens escolhia seus professores particulares de pintura em Paris, opções essas

147 Isso evidentemente não retira o mérito de sua potência artística ou intelectual, mas, quando muito o contrário, reforça, uma vez que sugere a sua facilidade em se adequar a situações e a efetuar ações que lhe permitissem chegar mais próximo da execução dos seus planos.

148 Jacques Brunet, o antigo naturalista que se julgava fazer parte apenas de sua infância, como seu "descobridor" na pequena cidade de Areia, no início dos anos 1850, teve ao contrário ativo papel de mediador do artista junto à política local do nordeste, sobretudo Paraíba, Pernambuco e Rio Grande do Norte (AMÉRICO, Pedro; MELO, Aurélio Eduardo de Figueiredo e; BRUNET, Louis Jacques. Cartas de Pedro Américo de Figueiredo e Melo e Daniel Eduardo de Figueiredo e Melo a Louis Jacques Brunet .Volume 96 de Coleção Mossoroense. Mossoró: Editora Fundação Vingt-un Rosado, 2001.), até pelo menos o início dos anos 1870 (Brunet morre no início dessa década), dado o prestígio e relações que estabeleceu ao se mudar definitivamente para lá após o convite do então presidente da Província da Paraíba, Antônio Coelho de Sá e Albuquerque, com o intuito de que formasse uma expedição científica para descobrir os recursos da região - qual, bem se sabe, o infante Américo integrou.

O "nosso amigo Catonhé", citado pelo jovem na carta imediatamente posterior ao decreto francês de 1863, era o mesmo Sá e Alburquerque, então presidente da Província da Bahia (havia sido também presidente da Paraíba, das Alagoas, Ministro dos Transportes e da Agricultura, e Ministro as Relações Exteriores) (e em trâmite de se tornar senador, isto é, um conselheiro do Império), que igualmente conhecia Américo desde a infância, tendo, também como se sabe, papel fundamental na sua mudança ao Rio de Janeiro, pelas mãos de Pedreira. Bastante achegado aos mais importantes agentes do Império (o marquês de Olinda, Pedreira, Paes Barreto, Paraná), Sá deveria ser percebido por Américo, a despeito da existência ou não de um laço fraternal entre eles, como mais um veículo catalisador dos seus planos, quando do seu iminente retorno ao Brasil. Ainda que não se saiba do paradeiro da sugerida carta enviada ao presidente da província, ao menos naquela, enviada a Brunet, o artista anuncia também se tratar da política (de vontade de ação), e de provavelmente ser ele aquele político um dos primeiros "abrigos de alta proteção" que deseja conquistar.

Essa é uma movimentação que diz respeito a contatos concomitantes do jovem no Brasil, e mesmo que não não pareça ter ligação imediata com o contexto parisiense ao qual vincula inicialmente seu texto sobre a reforma da École des BeauxArts, não estava de modo algum separada (Em 1861, Sá permanecia, por exemplo, à frente do Ministério das Relações Exteriores, deixando lá algumas relações de influência, retomando a esse gabinente em 1866, quando da nova ida de Américo à Europa.) 
que também justificam, em muitos sentidos, a sua tomada de posição favorável ao decreto imperial e os motivos que o levaram à publicação do seu pequeno opúsculo.

\section{A escolha pessoal para uma formação alternativa (ou Américo e seus professores franceses)}

Ainda restam algumas lacunas do período de formação do jovem na França, sobretudo a artística, e isso em boa parte porque ele, na qualidade de pensionista do imperador, se via desobrigado de muitas exigências regulamentares e burocráticas assacadas aos bolsistas regulares da AIBA. Alguns dos dados verificados nos últimos anos em pesquisas no Brasil ${ }^{149}$, sobretudo os relativos à sua formação complementar em ateliês privados que, como dito, era prática quase obrigatória antes da reforma de 1863, com a formação de ateliês dentro da escola francesa, reposicionam, entretanto, um antigo percurso de formação artística que se julgou que o artista tivesse feito.

Com frequência apresentado com equívocos como aluno e seguidor de Ingres ${ }^{150}$, de Horace Vernet ${ }^{151}$, de Hippolyte Flandrin ${ }^{152}$, foi aluno apenas, respectivamente, segundo registros oficiais e informações

149 Entre eles, está a última biografia atualizada de Américo, feita por Madalena Zaccara, ainda que a autora utilize, em numerosos momentos, dados repetidos diretamente dos primeiros biógrafos de Américo, alguns, no entanto, duvidosos e problemáticos: PEKALA, Madalena Zaccara. Pedro Américo : vie et oeuvre; son rôle dans la peinture du Brésil au XIXe siècle. Tese de doutorado sob a direção de Yves Bruand. Toulouse: Université de Toulouse II, 1995.

Ver ainda o trabalho de Ana Cavalcanti. CAVALCANTI, Ana Maria Tavares. Les Artistes brésiliens et "les prix de voyage en Europe" à la fin du XIXe siècle : vision d'ensemble et étude approfondie sur le peintre Eliseu d'Angelo Vvisconti (1866 - 1944). Tese de Doutorado sob a direção de Éric Darragon. Paris: Université Paris I - Panthéon Sorbonne, 1999.

150 Artigos recentemente publicados ainda buscam estabelecer uma conexão entre o brasileiro e sua suposta frequentação ao ateliê e à estética de Ingres. Ver, por exemplo: MÁRTIN, Sílvio Santos da Silva. "La Carioca rencontre La Source: Pedro Américo dans l'atelier d'Ingres ?", Loxias, n. 42, mis en ligne le 14 octobre 2013 URL : http://revel.unice.fr/loxias/index.html?id=7584 .[Último acesso em em 14 novembro 2014.].

A hipótese de Martin é improvável. A partir do texto de Amaury-Duval, um dos alunos preferidos de Ingres, sobre o cotidiano na oficina desse artista, Martin recupera o dado de um brasileiro de nome "Mello", que dividia o ateliê com outros alunos de Ingres. Entretanto, Duval se refere às décadas 1830 e 1840, o que torna, evidentemente, impossível que Américo tenha frequentado Ingres antes de ter nascido. Mesmo posteriormente, nos anos 1860, não há nenhum registro que faça qualquer menção a essa relação. Além de suas produções serem bastante distintas, não se pode esquecer da crítica do jovem brasileiro à posição para ele dogmática de Ingres como novo chefe da "escola clássica".

Segundo vários autores (Donato de Mello Júnior, Horácio de Almeida, Cardoso de Oliveira, etc.), Américo teria sido simplesmente "aluno de Ingres" (o mesmo valendo para Horace Vernet) e isso decorria sem dúvida mais pelo fato do francês ser ainda arrolado na lista de professores da École de Beaux-Arts (embora não desse lá mais aulas, sempre substituído por Hippolyte Flandrin), do que de fato de fato por sua presença. Com efeito, nem mais em seu ateliê Ingres orientava alunos, o que descarta mais uma vez a possibilidade que tenha sido seu discípulo.

$151 \mathrm{O}$ que também é bastante improvável, uma vez que que Vernet, já bastante debilitado, não estava mais à frente do seu famoso antigo ateliê.

152 Flandrin nunca abriu ateliê privado. Os poucos mais de trinta alunos que teve ao longo de sua vida, a grande maioria vinda de sua cidade natal, Lyon, eram sempre ajudantes já bem formados (muitas vezes enviados por seus irmãos Auguste e Paul), que o ajudavam em suas obras de decoração de igrejas e castelos. Dado também a se considerar é que Flandrin, além de professor e membro do Instituto, também se manifestara abertamente contra o Decreto de 1863 , como sugerem suas cartas a amigos e a Ingres, e como ainda depõe o esboço de uma resposta ao decreto de 1863, que ele acabaria por não publicar, por julgar que a resposta do seu "mestre" havia sido enérgica o suficiente para que precisasse ainda de 
circunstanciais importantes, dos ateliês particulares de dois pintores: Léon Cogniet (1794-1880), e Sébastien Cornu (1804-1870). O primeiro, bem mais conhecido, membro da Académie des Beaux-Arts e professor da École desde a década de 1850 e o segundo não pertencia, de fato, a nenhuma das duas instituições.

Cogniet, segundo documentos na École e dos Archives Nationales da França, foi mesmo o responsável por inscrever Américo em seu primeiro concours de places, em setembro de 1859, seleção que lhe permitiu ingressar na instituição em outubro do mesmo ano. A frequentação aos métodos daquele artista se dava, portanto, logo em seguida à sua chegada a Paris; e essa escolha, efetuada por um jovem recém-chegado e recebido, com recomendações de Porto Alegre, por seu colega Victor Meirelles ${ }^{153}$ (também ele frequentador do mesmo ateliê), deveria parecer de início a mais natural, sobretudo tratando-se do maior e mais disputado espaço privado de ensino artístico de Paris do início da segunda metade do século XIX ${ }^{154}$, depois da morte de Paul Delaroche e do desmantelamento da sua oficina ${ }^{155}$.

Léon Cogniet, mesmo que acadêmico, não fazia parte das alas mais rígidas da École e do Institut, bastante interessado numa aproximação "romântica" dos temas orientalistas, da literatura e história modernas e contemporâneas, sem contudo atingir uma visão tão radical como a de Delacroix, seu coetâneo e antigo colega no ateliê de Pierre Narcisse Guérin. Como Delaroch, seu "Ecletismo amigável", percebido por Charles Baudelaire ${ }^{156}$ e ainda por contemporâneos e reiterado em estudos

outra dele. cf. DELABORDE, Henri. Lettres et pensées d'Hippolyte Flandrin, accompagnées de notes et precedées d'une notice biographique et d'un catalogue des oeuvre de maître. Paris: Henri Plon, 1865. pp.453-492; ver ainda: FLANDRIN, Louis. Un peintre chrétien au XIXe siècle, Hippolyte Flandrin. Paris: Perrin et Cie., 1909. p.171.

$153 \mathrm{Um}$ trecho bem conhecido desta carta, que no entanto possui um paradeiro atual desconhecido, foi reimpresso por Donato Mello Júnior, em pequeno livro sobre Américo: MELLO JÚNIOR, Donato. Pedro Américo de Figueiredo e Melo, 1843-1905. Rio de Janeiro: Pinakotheke, 1983. O trecho apresentado da carta datada de 11 de março de 1859 é o seguinte: "O portador desta é o Sr. Américo, moço de muito talento, pensionista do nosso Imperador. Eu lho recomendo muito e muito, e faço-o discípulo de M. Cogniet, que ele de mim há de ter lembranças pelo Instituto Histórico em 1836." p.18.

154 Sobre os ateliês de Cogniet, ver: NERLICH, France; BONNET, Alain (direcs.) Apprendre à peindre: les ateliers privés à Paris - 1780-1863. Tours: Presses Universitaires Fraçois-Rabelais, 2013; sobretudo os artigos de Michaël Vottero ("Les ateliers de Léon Cogniet", pp.249-262), de Beata Studzizba Kubalska ("Le rôle de l'atelier de Léon Cogniet pour l'histoire de la peinture polonaise", pp.263-274), e Kamila Kludkiewicz ("Henryk Rodakowski dans l'atelier de Léon Cogniet", pp.275-286).

155 Delaroche, por exemplo, como apresentei, o preferido os brasileiros na Europa, também fazia parte, segundo Rosenthal, de um grupo de artistas assim ditos "juste milieu", ligados recorrentemente ao pensamento eclético: "eles eram homens sofisticados que reconheciam as implicações do conflito Clássico-Romântico, mas que não poderiam tomar inteiramente nenhum dos lados. Eles tentaram ao invés efetuar um compromisso entre os dois, tomando emprestado de ambos de diversas maneiras. Delaroche combinou temas Românticos com o desenho e estilo academico, enquanto que Vernet e Scheffer flutuaram entre uma técnica mais livre do pincel e uma aderência à claridade da forma clássica." ROSENTHAL, L. op. cit. p. 10.

156 BAUDELAIRE, Charles. Oeuvres complètes de Charles Baudelaire. II Curiosités Esthétiques. Paris: Michel Lévy Frères, 1868, p.155 : "Que dirai-je de M. L. Cogniet, cet aimable éclectique, ce peintre de tant de bonne volonté et d'une intelligence si inquiète que, pour bien rendre le portrait de M. Granet, il a imaginé d'employer la couleur propre aux 
posteriores $^{157}$, era expresso politicamente ao lado do seu colega Robert-Fleury, o novo diretor da École após a reforma, pela posição que assumiam enquanto "mediadores entre a Académie, defensora da grande tradição, que suas pinturas não desafiavam, e o gosto público, cansado da pompa retórica do classicismo e sensível à renovação dos temas"158 .

Visto com bons olhos pelos reformadores de 1863, que julgaram que ele, ao lado de Fleury, seria também um agente importante para as mudanças instauradas pelo decreto, um conciliador dos "clássicos" e dos "românticos", Cogniet todavia recusava a oferta e tão logo se afastava da École, pedindo oficialmente sua demissão ainda naquele ano.

Sua adesão às recusas dos acadêmicos era notória, e foi mesmo comentada entre cartas de membros do instituto, como as de Flandrin ${ }^{159}$, menos, entretanto, por um recusa à abertura estética que as medidas reformistas propunham, e que ele próprio professava, do que por problemas políticos e pessoais que elas lhe causavam ${ }^{160}$.

Em 1859, Pedro Américo completava seus 16 anos, e o ingresso no ateliê de Cogniet parecia, portanto, provir mesmo da indicação feita por Porto Alegre, seguindo a mesma linha estética de ensino na qual o jovem havia sido inserido em seus anos na AIBA, ainda sob a égide do gaúcho ${ }^{161}$. A certeza de que o

tableaux de M. Granet". Em texto sobre o salão anterior, o de 1845, Baudelaire já havia também desenvolvido análise similar quanto à postura eclética de Cogniet: Salon de 1845. M. Cogniet ignore les caprices hardis de la fantaisie et le parti pris des absolutistes. Fondre, mêler, réunir tout en choisissant, a toujours été son rôle et son but; il l'a parfaitement bien atteint". IDEM, ibidem. p.37.

157 Léon Rosenthal utilizará a sinonímia "juste milieu” para se referir aos ditos pintors ecléticos. ROSENTHAL, Léon. Du romantisme au réalisme. Paris: Éditions Macula, 1987, especialmente capítulo "Juste Milieu": p.202-231. Albert Boime critica a insuficiência do termo utilizado por Rosenthal, chamando atenção para o fato de que o termo "eclético", endereçado a um pintor, envolvia também diversas dimensões políticas e filosóficas, que a ideia de "juste milieu" não poderia dar. Ver: BOIME, A. Thomas Couture and the eclectic vision, em especial a introdução do livro. Ver ainda: BONNET, Alain. L'enseignement des arts au...Op. Cit., sobretudo, o capítulo "Les professeurs", pp.107-122.

158 BONNET, Alain. op.cit. p.p.118.

159 "Carta de Hippolyte Flandrin a Monsieur X...., de Roma, em 02 de janeiro de 1864". FLANDRIN, Hipolyte. op. Cit. p.464.

160 De início, como os demais acadêmicos, Cogniet sabia da redução de força política que a reforma da École causava aos membros do Institute. Em seguida - e essa era a questão pessoal -, sabia ainda melhor que uma das frequentes discussões entre alguns opositores às mudanças se formava em torno do segundo "golpe" que levariam, com a criação de apenas 3 ateliês dentro da escola, que visavam substituir o ensino privado nos ateliês dos mestres por outro regulado pelo Estado. E disso ele, enquanto proprietário de ateliê, como era de se esperar, não poderia sair ileso.

161 Porto Alegre pediria a Vitor Meirelles para receber: "Sr. Américo, moço de muito talento, pensionista do nosso Imperador. Eu lho recomendo muito e muito, e faço-o discípulo de M. Cogniet, que ele de mim há de ter lembranças pelo Instituto Histórico em 1836."Citado por MELLO JÚNIOR, Donato. Pedro Américo de Figueiredo e Melo, 1843-1905: algumas singularidades de sua vida e de sua obra. Rio de Janeiro: Edições Pinakotheke, 1983 p.18.

A escolha de Américo seguia uma linha já indicada pelo então diretor da AIBA, anos antes, a seu colega Vitor Meirelles; isto é, a de tomar Delaroche por mestre, na via de um romantismo histórico menos rígido que o academismo. Se Delaroche morria em 1856, no justo momento que Meirelles chegava a Paris, a escolha mais óbvia parecia Cogniet, enquanto sucessor afamado de mesma linhagem. 
jovem tenha frequentado o ateliê desse artista confirma que, a despeito de se tratar de um (bastante flexível, mas ainda) acadêmico e professor da École, o brasileiro estivesse imerso numa formação privada muito mais aberta e menos dogmática, inserida em um "ecletismo" estético e político que ele próprio irá tomar como ferramenta para suas reflexões artísticas e filosóficas. O ateliê de Cogniet era desse modo o primeiro contato do jovem com um circuito artístico bastante tolerante, que lhe pemitiria adensar, na França, segundo sua vontade, reflexões a respeito de alternativas às doutrinas estéticas oficiais da École.

É esse interesse, em pouco tempo amadurecido ao lado do aprendizado bem sucedido de uma política pessoal, que o levou a buscar em seguida, e por si só, a improvável orientação de Sébastien Cornu (1804-1870), em 1861 ${ }^{162}$. Improvável ao menos do ponto de vista da escolha, até então incomum, de um pintor pouco ou nada conhecido dos artistas brasileiros, nem membro do Institut, nem professor da École.

\section{Sébastien Cornu}

Que Américo tenha seguido por um bom tempo os passos do conhecido Cogniet, ou que tivesse supostamente seguido os passos do afamado Ingres, de Vernet, de Flandrin (o que não foi o caso, como apresentado anteriormente), tudo isso foi muito mais facilmente compreendido e explicado por autores brasileiros - mas sempre e exclusivamente do ponto de visto artístico - do que a escolha pelo “obscuro" Cornu , essa, nunca verdadeiramente comentada. E, no entanto, a escolha por Cornu deve ser compreendida como uma das chaves mais claras de interpretação do projeto nascente de Pedro Américo na França e da sua política, que darão como primeiro fruto o seu opúsculo sobre a reforma.

A despeito do lugar menos evidente que dispunha entre os artistas mais conhecidos do Segundo Império francês, Cornu dispôs, entre as décadas de 1840 a 1870, de ativa carreira nas artes, sendo um dos artistas mais bem pagos e acessados pelo governo napoleônico. Dedicou-se sobretudo à pintura

162 Américo é aluno de Cornu pelo menos desde de 1861. Uma declaração de Cornu datada de outubro daquele ano afirmando que o jovem é seu aluno, e pedindo que d. Pedro II atestando a necessidade de Américo continuar na França para seguir em seus estudos faz parte do acervo do Arquivo da Casa Imperial (sigla: POB), maço 131 - Doc. 6418. Museu Imperial de Petrópolis: "Eu, abaixo assinado, declaro que Mr. Pedro américo de Figueiredo e Mello, meu aluno em pintura, dividiu seu tempo esse ano entre o estudo da arte e das Ciências, que se complementam. Eu penso que os três anos de estudos que ele possuía para seus estudos e para sua viagem na Itália sejam insuficientes para seu bom resultado. Em consequência, eu creio necessário que o s. M. Imperador se digne ainda a ceder a Mr. Américo mais três anos de estudos em Paris". 
religiosa, após se formar inicialmente em pintura histórica na École de Beaux-Arts de Lyon; em seguida em Paris, no ateliê de Ingres durante os anos 1820; e depois em Roma, em mais 6 anos custeados por bolsa obtida de sua cidade natal. Medalhista de Segunda Classe no Salon de 1840, e vencedor da medalha de ouro de Primeira Classe em 1845, as suas encomendas em diversas igrejas em Lyon e em Paris $^{163}$ não o impediram de dirigir, por vários anos, um ateliê liberal que obteve o seu maior reconhecimento, precisamente, nos anos de 1860, 1862 e 1863. Nesse período, Alphonse Monchablon (1835-1907), colega de Américo no ateliê de Cornu e, ao mesmo tempo, aluno do "eclético" Charles Gleyre (1806-1874) ${ }^{164}$ - amigo de juventude de Cornu -, obteve, respectivamente, a Menção Honrosa, o $2^{\circ}$ Segundo Grande Prêmio ${ }^{165}$ e o $1^{\circ}$ Grande Prêmio no Prix de Rome da École, e assim o direito de ser enviado à Villa Medicis para seus 5 anos de bolsa ${ }^{166}$.

O programa de ensino de Cornu - cuja metodologia pode-se ter uma ideia graças a um curso de desenho que publica no ano de sua morte, em $1870^{167}$ - não deve ser, assim, desprezado, nem sua aptidão em preparar, ao lado de C. Gleyre, artistas suficientemente capazes de se adequar aos moldes esperados pela Académie des Beaux-Arts e por uma École ainda não reformada pelo decreto repentino de 1863.

Mas essa é uma primeira conjuntura que justifica potencialmente uma das razões para o ingresso de Américo em seu ateliê, que, ainda assim, não explicaria a sua saída do ateliê de Cogniet, com maior prestígio e numericamente mais cheio de lauredos. Uma segunda conjuntura, amparada por uma razão

163Em Paris, realizou trabalhos, especialmente murais, para a Igreja Saint-Louis-d'Antin, a capela da Bienheureuse Marie na Igreja Saint-Merry, a capela de Saint-Séverin na mesma igreja, a capela da Compassion à Saint-Roch, as fachadas da Igreja de Saint-leu-Taverny, e, em 1865, após a morte de Hippolyte Flandrin, é convidado a terminar as pinturas da igreja de Saint-Germain-des-Prés, especificamente o transcepto. cf. AUDEVAL, Hippolyte. "Salon de 1872, III." La semaine des familles. Paris, n.12, anné 14, Samedi, 22 Juin 1872. pp.177-180.

164 POUILLON, François (éd.). Dictionnaire des orientalistes de langue française. Karthala, 2012.pp.473-474; sobre o ateliêr liberal de Charles Gleyre, e sua atuação for a da Académie e da École, ver também: BOIME, Albert. Op. Cit. Especialmente a seção: Gleyre's Atelier. pp.58-65. E ainda sobre a relação de Gleyre como um artista que resume por excelência o Ecletismo em pintura, ao lado de Thomas Couture, ver também Boime, em: BOIME, A. Thomas Couture and the Eclectic vision. p.20 e p.33.

165 Não há erro ou repetição aqui. Em 1862 não houve $1^{\circ}$ Grande Prêmio. Desse modo, foram dados dois Segundos Grandes Prêmios. GRUNCHEC, Philippe. Les concours des Prix de Rome de 1797 à 1863 . Préface de Jacques Thuillier. Paris : École nationale supérieure des beaux-arts, 1983.

${ }^{166}$ Não pude trabalhar, nesta Tese, as relações estéticas evidentes que existem entre a produção de Cornu e a produção de Américo. Não existe ainda um livro ou pesquisa extensa sobre Cornu. Suas obras estão espalhadas em coleções francesas ou em igrejas do mesmo país. Entretanto, é possível acessar algumas delas em alguns sites de coleções públicas ou de leilões Ver por exemplo: http://www.culture.gouv.fr/public/mistral/joconde fr e http://www.arcadja.com/ [último acesso: 14 de novembro de 2015]. Curiosamente, as imagens disponíveis online das obras de Cornu se aproximam, bastante, das obras produzidas por Américo, especiamelnte a partir de 1880.

167 CORNU, Sébastien. Cours élémentaire et gradué du dessin de la figure humaine./ lithogr. par Jules Laurens ; publ. sous les auspices de S.E.M. le ministre de l'Instruction publique pour servir à l'enseignement dans les écoles primaires de l'Empire sous la dir. de Sébastien Cornu. Paris: A. Morel, 1870. 
política, é bem mais significativa e fornece um quadro mais complexo de intenções que orientam essa escolha. Ela diz respeito à atuação administrativa e política que Cornu excerceu nas artes, atividades que passavam a interessar, precisamente, a Américo, nos últimos anos de suas formação parisiense isto é, seu interesse em ser um artista intelectual envolvido com a política as artes. A escolha por Cornu, bastante refletida como será visto em seguida, se dava, sintomaticamente, no exato momento em que o francês recebia grandes e importantes incumbências políticas e administrativas, ligadas às artes plásticas e industriais, tarefas que estavam notadamente ligadas às mesmas questões expostas no decreto da reforma da École, e no texto de Américo.

Por ligações parentais e por afinidades pessoais, Cornu fazia parte de um íntima rede de relações que possuía como nó a figura de Napoleão III, e como linha mestra a política que esse colocava em prática desde o golpe de estado bem sucedido que praticara em 1852, que o permitiu restaurar o império, lhe devolvendo o poder de uma linhagem real recemte da qual era herdeiro sanguínio ${ }^{168}$.

Em 1834, Cornu se casara com Hortense Lacroix (desde então Hortense Cornu), figura bastante influente do Segundo Império, afilhada da rainha Hortense (mãe de Napoleão) e amiga desde a infância do imperador, a quem, se dizia, ele sempre ouviu com atenção. Após uma primeira tentativa de golpe, na década de 1830, Napoleão havia sido exilado em Ham, onde permanecia até as revoluções de 1848, quando seria primeiro eleito presidente da república françesa, antes de se tornar imperador e, lá, recebia visitas mensais, as mais assíduas, as do casal Cornu, que havia mesmo obtido o direito de estadiarem no forte ${ }^{169}$.

A amizade e fidelidade duraroudas garantiram, após a ascenção de Napoleão, uma retribuição também profissional. A partir desse período, e até o fim de sua vida, sincrônica à queda do império, Cornu receberá ocupações e muitas encomendas do imperador ${ }^{170}$ e de outras personalidades aliadas. Será

168 Era filho de Louis Bonarparte, rei da Holanda, e de Hortense de Beauharnais; sobrinho de Napoleão I.

169 LEDUC, Edouard. Louis-Napoléon Bonaparte, le dernier empereur. Paris: Édition Publibook, 2010. "Mais, les visiteurs les plus assidus seront indeniablement Hortense Cornu et son mari au point que le couple séjournera au fort, régulièrement invité à la table du commandant Demarle." p.28-29.

170 GRANGER, Catherine. L'empereur et les arts: la liste civile de Napoléon III. Paris: École Nationale de Chartes, 2005. p.113.

Em 1849, logo após assumir a presidência da França, Napoleão III requer a Cornu a produção de 4 quadros destinados à decoração da fachada e do portal lateral da igreja Napoléon-Saint-Leu, que seu cunhado, o arquiteto Eugène Lacroix, estava encarregado de restaurar. Idem, ibidem. pp.237-238.

Entre 1856 e 1858, Napoleão requer ao arquiteto Alfred Normand a construção de uma casa em estilo pompeiano. Charle Chauvin é encaregado de ornar o interior com pinturas murais no gosto do terceiro estilo pompeiano, e Cornu ao lado de Gérôme são encarregados de fazerem os quadros decorativos. Idem, Ibidem. p.220.

Em 1864, Napoleão encarrega Cornu da decoração da capela de estilo néo-bizantino, no palácio de Élysée, sua 
ainda convidado a participar, na ala dos não acadêmicos, das comissões de reforma de ensino artístico na França, entre as quais aquela mesma reunida em 1862, liderada por Nieuwerkerke, que preparava com toda segurança, no plano teórico, a publicação do texto sobre das mudanças no ensino artístico francês, de Viollet-Le-Duc ${ }^{171}$; e no político, a realização da reforma da École, no ano seguinte. Tratavase, já de início, do mesmo interesse publicamente demonstrado por Américo em seu texto de 1863, após seus anos no ateliê de Cornu, e não deve ser nenhum um pouco difícil concluir sobre a indubitável influência que as ideias do seu professor exerciam então sobre ele.

A mais importante incumbência de Cornu durante esse anos, que deve também ter interessado bastante a Américo, foi, entretanto, sobrescrita para a avaliação e concorrência da última parte da famosa Coleção Campana ${ }^{172}$, em Roma, sendo enviado para lá expressamente por Napoleão III, em março de 1861, a contragosto do embaixador da França naquela cidade, que sugeria apenas membros do Institut de France e do Louvre ${ }^{173}$.

\section{A coleção Campana e a arte industrial}

Notável conjunto heterogêneo de obras formado ao longo de trinta anos pelo banqueiro Giampietro Campana, reunia pinturas de primitivos italianos - em sua maior parte religiosa -, pinturas do alto Renascimento e uma pequena parte espanhola e flamenga ${ }^{174}$, esculturas ${ }^{175}$, uma coleção exemplar de

residência oficial. Idem, ibidem, p.229.

171 Trata-se do já citado L'enseignement des beaux-arts: il y a quelque chose à faire, publicado ainda em 1862.

172 A primeira parte, bastante significativa, havia sido comprada por E. Guédéonow em nome do Museu do Ermitage, em fevereiro de 1861. Tratavam-se de 3791 peças adquiridas por aquele museus, provindas todas da coleção Campana. cf. NADALINI. Gianpaolo. "De Rome au Louvre, les avatars du Musée Campana entre 1857 et 1862", Histoire de l'art, $\mathrm{n}^{\circ}$ 21/22, 1993, p.51.

173 Idem, ibidem, p.52

174 No catálogo preliminar da coleção as pinturas são apresentadas em ordem cronológica e por escolas. A seguir, uma lista segundo dados originais, não exaustiva, dos artistas mais importantes cujas pinturas estavam representadas na Coleção Campana: Giunta Pisano, Cimabue, Gaddo Gaddi, Giotto, Pietro Cavalinni, Cennino Cennini, Fra Angélico, Paolo Uccello, Pietro della Francesca, Andrea del Castagno, Masaccio, Filippo Lippi, Antonio Pollaiuolo, Andrea Verrocchio, Piero di Cosimo, Sandro Botticelli, Lorenzo di Credi, Luca Signorelli, Ghirlandaio, Mantegna, Vittore Carpaccio, Giovanni Bellini, Zanobi Strozzi, Cosimo Tura, Lorenzo Costa, Dosso Dossi, Bramantino, Gentile da Fabriano, Melozzo da Forli, Giovanni Santi, Pietro Perugino, Pinturicchio, Rafael, Fra Bartolomeo, Giulio Romano, Baldassare Peruzzi, Andrea del Sarto, Bronzino, Michelangelo, Carlo Dolci, Giambellino, Tiziano Vecellio, Paolo Veronese, Giovanni Battista Tieopolo, Giovanni Moroni, Leonardo da Vinci, Correggio, Salvador Rosa, Agostino Caracci, Anibale CAracci, Caravaggio, Guido Reni, Guercino, Domenichino, Francesco Albani, Joseph Ribera, Francesco Zurbaran, Pierre Brueghel, Gerard Seghers, Antoine Van-Dyck, Philippe de Champagne, David Teniers, Rubens. cf. CORNU, Sébastien. Catalogue des Tableaux, des sculptures de la renaissance et des majoliques du Musée Napoléon III. Paris: Librairie de Firmin Didot Frères, fils et cie., 1862.

175 Entre os autores então identificados dessas esculturas: Jacopetto da Spoleto [obra de 1294], Andrea Pisano [1270-1345], Ghiberti, Donatello, Andrea Verocchio, Della Robbia, Michelangelo, Sansovino, Jean de Bologne. Idem, Ibidem. 
cerâmica ocidental e oriental antigas, demais produtos domésticos antigos e modernos ${ }^{176}$, e quantidade enorme de ourivesaria e cristaleria ${ }^{177}$.

Cornu intercedia positivamente na transação, e a compra da coleção (com mais de 6.000 itens) era efetivada em maio de 1861 por valor bastante elevado, e ainda sem qualquer intermédio do diretor geral dos museus nacionais, Nieuwerkerke ${ }^{178}$; ação que, de todo modo similar à futura reforma da École, já confirmava os interesses da política napoleônica no alargamento da representação de outras produções artísticas e períodos na França, que não apenas as gregas.

Cornu tornava-se o administrador da nova coleção, responsável ainda por seus empacotamento e traslado $^{179}$, pela organização de sua catalogação e, em pouco tempo, indicado para ser o formador e novo diretor de um museu em Paris. Ele deveria abrir todas as coleções citadas, ao lado de outras obtidas ao mesmo tempo nas investidas arqueológicas oficiais na Síria, Macedônia e na Ásia Menor, as quais se compunham de sacórfagos, tumbas, cêramicas, jóias, lápides com instrições, esculturas etc. ${ }^{180}$. Hortense Cornu seria de fato a responsável por sugerir diretamente a Napoleão a formação de um museu no qual se poderia ver "tudo o que o Imperador havia feito durante um ano para a ciência e para a arte" ${ }^{181}$. E propunha ainda que deveria se tratar de um espaço "assigné pour le moment au Musée Napoléon III", como foi, afinal, batizado o museu aberto ao público em maio de 1862, mesmo momento da abertura da Exposição Universal de Londres, com grande repercussão da imprensa, devido à natureza particular de suas coleções. (fig.1.7.)

Nem dedicado exclusivamente às artes visuais, nem à história ou à arqueologia, o Museu Napoleão III foi desde logo percebido em sua particularidade por se tratar de uma sorte sem igual de museu de "artes

176 WITTE, J. de. Notices sur les vases peints et a reliefs du Musée Napoléon III. Paris: Librairie de Firmin Didot Frères, fils et cie., 1862.

177 MUSÉE NAPOLÉON III. Catalogue des Bijoux du Musée Napoléon III. Paris: Librairie de Firmin Didot Frères, fils etc cie., p. 1862

178 NADALINI. Gianpaolo. "La collection Campana au musée Napoléon III et sa première dispersion dans les musées français (1862-1863)". In: Journal des savants. 1998, $\mathrm{N}^{\circ}$ pp. 183-225. Ou: http://www.persee.fr/web/revues/home/prescript/article/jds_0021-8103_1998_num_2_1_1618 Último acesso em outubro de 2014.

179 O empacotamento durou de julho a agosto de 1861; no fim do ano, as caixam já haviam chegado em Paris, via porto de Marseille.

180 REINACH, Salomon. Esquisse d'une histoire de la collection Campana. Paris : Leroux, 1905; REISET, M. F. Notice des Tableaux du Musée Napoléon III exposés dans les salles de la colonnade au Louvre. Paris: Charles des Mourgues Frères, 1868; VITET, Ludovic. La Collection Campana. Paris : Impr. de J. Claye, 1862.

181 No original: "tout ce que l'Empereur a fait depuis un an pour la science et l'art."Carta de Hortense Cornu a Napoleão III, de Paris, em 24 de setembro de 1861. Carta integral In: NADALINI. Gianpaolo. "De Rome au Louvre, les avatars du Musée Campana entre 1857 et 1862", Histoire de l'art, n²1/22, 1993, p.58. 
aplicadas" na França ${ }^{182}$, cujo interesse era uma velha exigência dos industriais e artistas ligados a essa atividade $^{183}$, que lá, ao lado das coleções de arte ainda não canonizadas, poderiam então também encontrar séries extensas de objetos e artefatos que uniam com êxito arte e artesania desde a antiguidade: uma amostragem exemplar que lhes poderia servir de modelo, tal com o museu do Louvre, para os pintores e escultores ${ }^{184}$.

Sua permanência, todavia, foi breve ${ }^{185}$, como já era desde o início prevista ${ }^{186}$. Antes dessa dissolução,

182 CHESNEAU, Ernest. La vérité sur le Louvre, le Musée Napoléon III et les artistes industriels. Paris: E. Dentu, 1862; DESJARDINS, Ernest. Notice sur le Musée Napoléon III et promenade dans les galeries. deuxième edition. Paris: Michel Lévy Frères, 1862; DESJARDINS, Ernest. Du patriotisme dans les arts: réponse a M. Vitet sur le Musée Napoléon III. Paris: E. Dentu, 1862; LOUIS, V. Revue des Deux Mondes, Paris, 1er septembre 1862, p.169. ULYSSE,Chevalier. "Notice sur la vie et les travaux de M. Edmond Saglio ; lue dans la séance du 16 mai 1913". In: Comptes rendus des séances de l'Académie des Inscriptions et Belles-Lettres, 57e année, N. 3, 1913. pp. 161-197. http://www.persee.fr/web/revues/home/prescript/article/crai_0065-0536_1913_num_57_3_73202

183 A respeito das intenções durante o governo de Napoleão III de conciliar as artes à indústria, e a criação de instituições com esses fins, ver o texto introdutório, mas bastante instrutivo, de Arnauld Bertinet ao texto de Cornu sobre o Museu Napoleão: CORNU, Sébastien. "Rapport concernant le musée Napoléon III, 1862", in MCWILLIAM, Neil; MÉNEUX Catherine; RAMOS, Julie (dir.), L'Art social de la Révolution à la Grande Guerre. Anthologie de textes sources, INHA (« Sources »), 2014. [En ligne], mis en ligne le 07 juillet 2014, consulté le 17 novembre 2014. URL : http://inha.revues.org/5504

184 O lugar mesmo onde foi inicialmente exposta a coleção era significativo: o Palais d'Industrie, construído para sediar a Exposição Universal de 1855, também ela uma mostra mista de produtos industrais contemporâneos. Segundo Nadalini: "Le Musée Napoléon III aparait donc comme la vitrine de la politique culturelle très active menée par le Seconde Empire dans le domaine de l'art et de l'archéologie antiques. [...] C'est en effet à l'art et à la science réunies qu'était consacré ce Musée, dont le but entièrement neuf' était, au delà de la contemplation du beau, l'encouragement de la création industrielle: le mardi, le Musée était ouvert exclusivement aux professionels de l'art et de l'artisanat." NADALINI, Gianpaolo. op. Cit. p.55.

$185 \mathrm{O}$ museu fechará as portas em outubro de 1862, portanto 5 meses após sua abertura, e sua coleção repartida entre o Louvre e os museus menores das províncias francesas. Por pressão de Nieuwerkerke e alguns acadêmicos - que não concordavam com a extensão da concorrência que a nova coleção fazia ao Louvre - o fechamento havia sido declarado para julho, mas, ao que tudo indica, a prorrogação também veio em função de uma carta que a mesma Hortense Cornu envia ao imperador, em 6 de julho de 1862, pedindo que Napoleão III esperasse mais dois meses antes de fechar o museu; desejo que, segundo afirma, era o mesmo dos industriais franceses, cuja carta conjunta, que ela também teria enviado ao imperador, insistiria no mesmo pedido. A carta integral é publicada em: CORNU, Hortense; ROTHSCHILD, Henri de. "Un document inédit sur l'histoire de la Collection Campana". Revue Archéologique. Quatrième Série, T. 22, (JUILLET-DÉCEMBRE 1913). Paris: Presses Universitaires de France. pp. 115-118. Disponível online em: http://www.jstor.org/stable/41023163

$186 \mathrm{O}$ desmembramento era o destino prometido à coleção Campana, desde o momento de sua compra. O rapport da comissão encarregada de sua partição apresentava seus argumentos e critérios para essa dissolução:

"En acquérant [le cabinet] l'immense galerie du Musée Campana, l'intention du gouvernement, telle qu'elle est exprimée dans l'exposé des motifs de la loi du 1861, était non seulement d'augmenter les collections du Louvre, mais encore de répandre le goût des arts et des études archéologiques par des dons faits à différentes villes. Aucune collection $n$ 'était plus propre à accomplir le but que votre [administration] Excellence s'était proposé. [...] [V.E.] Persuadée que centraliser dans un grand établissement des oeuvres caractéristiques toutes les époques, c'est rendre un [grand] notable service aux études, V. E. n'a négligé aucune occasion d'accroître les collections déjà si considérables du Musée Impérial. Aujourd'hui en [lui] réservant à ce musée les objets les plus remarquables du cabinet Campana, [Elle] V. E. a jugé qu'on pourrait remplir quelques lacunes, et enrichir notablement plusieurs séries. [...] Nous étions persuadés d'ailleurs qu'il valait mieux multiplier dans le principal centre des études [tous] les renseignements utiles, que d'en écarter un seul. Les objets doubles, ou décidément inutiles au Louvre, sont donc les seuls [que] dont nous ayons proposé l'envoi dans les départements." S/A. "Projet élaboré par la Commission spéciale de répartition de la Collection Campana instituée le 21 juillet 1862". In: NADALINI. Gianpaolo. "La collection Campana au musée Napoléon III et sa première dispersion dans les musées français 
Cornu contudo escrevia - sincronicamente à publicação de Viollet-Le-Duc sobre a reforma do ensino artístico francês, e à outra, de Merimée ${ }^{187}$, sobre suas impressões da corrente Exposição Universal de Londres de 1862 - um pequeno rapport ${ }^{188}$, no qual, centrando-se no problema do Museu Napoleão III, abordava questões bastante afins aos estudos dos seus demais colegas de comissão; todos diretamente ligados à política de liberalismo econômico do imperador, sobretudo no que se referia ao fomento das diferentes artes, da arqueologia, e à difusão de conhecimentos para o crescimento da indústria francesa $^{189}$.

É significativo que Cornu tenha assim iniciado o relatório sobre o museu que dirigia - e conhecedor de sua peculiaridade - com uma apreciação dos resultados da Exposição Universal de Londres, tomada a partir do texto de Mérimée ${ }^{190}$. O argumento inaugural era o de que os avanços na indústria inglesa haviam sido consideráveis, e esse resultado teria vindo unicamente pelos esforços daquele país em popularizar "as artes do desenho, das quais o estudo desenvolve o gosto, se não mesmo o cria"191. Américo, como será visto, retomará o mesmo argumento em seu último texto publicado antes do seu ingresso na AIBA. Para Cornu, era chegado o momento de cuidar do mesmo problema na França, sob pena de ser suplantada por sua principal concorrente, na disputa pelo mercado internacional. O remédio: dar "uma séria atenção a nossos estabelecimentos de arte, escolas e museus".

(1862-1863)”. In: Journal des savants. 1998, № pp.213-214.

Ainda sobre o desmantelamento da coleção, a Comissão de Dissolução da Coleção irá afirmar: “ Nous étions persuadés d'ailleurs qu'il valait mieux multiplier dans le principal centre des études [tous] les renseignements utiles, que d'en écarter un seul. Les objets doubles, ou décidément inutiles au Louvre, sont donc les seuls [que] dont nous ayons proposé l'envoi dans les départements." S/A. "Projet élaboré par la Commission spéciale de répartition de la Collection Campana instituée le 21 juillet 1862". In: NADALINI. Gianpaolo. "La collection Campana au musée Napoléon III et sa première dispersion dans les musées français (1862-1863)”. In: Journal des savants. 1998, № pp.213-214.

187 MÉRIMÉE, Prosper. "Considérations sur les applications de l'art à l'industrie à L'Exposition universelle", Exposition de Londres, Rapport du Juri, Classe XXX. "Ameublement et décoration", section I, II, juin 1862. Repris dans P. Mérimée, Etudes anglo-américaines, Champion, 1930, p.203-204.

Disponível online em: http://cnum.cnam.fr/CGI/fpage.cgi?8XAE114_6/251/100/671/0/0 (último acesso em 19 de novembro de 2014)

188 CORNU, Sébastien. "Rapport concernant le musée Napoléon III, 1862", in MCWILLIAM, Neil; MÉNEUX Catherine; RAMOS, Julie (dir.), L'Art social de la Révolution à la Grande Guerre. Anthologie de textes sources. Paris; INHA (“Sources”), 2014. Disponível em. URL : http://inha.revues.org/5504 (ùltimo acesso em 17 novembre 2014).

189 Não seria de se estranhar que essas ideias pudessem ter sido bastante discutidas em alguns jantares que Cornu havia compartilhado com Viollet-Le-Duc, Merimé, e mesmo Victor Cousin, em 1861 e 1862, junto a Napoleão III, na Maison Impériale. Os jantares eram organizados (e comentados em suas memórias) pela princesa Julie Bonaparte, também muito próxima à Hortense Cornu,: ROCCAGIOVINE, Julie Bonaparte; BASSO, Isa Dardano (ed.) La princesse Julie Bonaparte, marquise de Roccagiovine et son Temps, mémoires inédites (1853-1870). Roma: Edizioni di storia e letteratura, 1975. ver especialmente p.148.

190 "L'Exposition universelle de Londres constate un progrès très remarquable dans le goût des Industriels Anglais. Les Industries Anglaises, qui ont pour base les arts du dessin, si elles ne surpassent pas encore nos industries similaires, s'en rapprochent à grands pas au dire des membres de la Commission Impériale et du Juri.". CORNU, Sébastien. Op. Cit. s.p.

191 Idem, Ibidem. 
Em Londres, a Inglaterra, além de centenas de escolas de desenho espalhadas pelo país, havia criado o ainda recente, mas já importante, Museu Kensington ${ }^{192}$ de artes industriais, ao qual caberia "une large part dans le progrès de l'industrie Anglaise." Na França, segundo Cornu,

O Museu Napoleão deveria ser chamado a ocupar o mesmo papel. Ele deveria ser especialmente destinado a popularizar as sãs tradições do belo; a tornar-se não um Museu de Luxo e de escolha reservada a um público [único], mas uma escola de gosto e de ensino prático; um ateliê de estudos para o artista e o industrial. ${ }^{193}$

192 Em seguida rebatizado de Victoria and Albert Museum, como ainda permanece. O Museu foi construção em sequência à Exposição Universal de Londres de 1851, especialmente dedicado à convergência do ensino das artes, da indústria e ciências.

193 [tradução nossa] Idem, ibidem.

Ao contrário do que afirmaria a comissão encarregada da redistribuição da coleção entre os museus franceses (chefiada por Nieuwerkerke), que em seu veredicto defendia o desmantelamento do museu para o enriquecimento do Louvre e dos demais museus departamentais, Cornu defendia a manunteção de sua unidade (nessa questão específica, a da importância da manutenção da coleção tal como originalmente estabelecida, os argumentos de Cornu eram bastante similares aos da Académie des Beaux-Arts, que em relatório requerido por Napoleão a respeito das decisão da Comissão de redistribuição do Museu afirmava, com a assinatura do seu secretário perpétuo, Charles Beulé - também ele um arqueólogo - o interesse de manter o museu inteiro, mesmo que retirado do Palais d'Industrie e levado para dentro das espaçosas paredes do Louvre, servindo de modelo para artistas e artesãos. BEULÉ, Charles. "Rapport de l'Académie des Beaux- Arts sur le Musée Napoléon III. Adressé à S. Exe. M. le Ministre d'État, le 22 novembre 1862". In: NADALINI, Gianpaolo. op.cit. pp.218225.) A exemplaridade do Museu Napoleão diante de todos os outros proviria justamente da constituição de uma "cronologia visível da arte Greco-Italiana aplicada às diversas indústrias desde suas origens, de suas fases sucessivas até à Renascença Italiana. E como a arte Greco-Italiana é aquela de onde procede a arte moderna: estudá-la é imergir novamente na origem primeira e pura." (CORNU, Sébastien. op. Cit. S/p.).

Cornu endossava de certo modo o mesmo argumento no qual (antes de ser informado sobre a dispersão da coleção) identificava que, uma vez pronto, o catálogo completo de pinturas e majólicas do museu recém-formado não "seria menos do que uma história da arte na Itália na época da Renascença." (CORNU, Sébastien. Catalogue des Tableaux, des sculptures de la renaissance et des majoliques du Musée Napoléon III. Paris: Librairie de Firmin Didot Frères, fils et cie., 1862. p.02.) Quanto a essa opinião, houve oposição de outros críticos dos debates sobre a compra da Coleção. Louis Vitet, que também participará ativamente das discussões sobre a reforma de 1863, coloca em dúvida o caráter supostamente sistemático da formação da coleção pelo banqueiro Campana. Em texto dedicado à questão, e publicado originalmente na Revue archeologique, Vitet afirmava que Campana não havia feito um catálogo sequer, tamanha a desorganização de sua coleção (logo, não se trataria de uma coleção composta com método e sobriedade, como se a defendeu). Por isso, "prétendre y avoir découvert, comme on l'a pompeusement déclaré, une grande unité, 'un but entièrement neut, et qui n'a d'analogue nulle part, les élémens complets d'une nouvelle histoire de l'art dans toutes ses transformations,' c'est pure chimère, à notre avis, et, qui plus est, grande imprudence." VITET, Ludovic. La Collection Campana. Paris : Impr. de J. Claye, 1862. p.05. Vitet critica ainda a formação do novo museu, defendendo que, que em lugar de selecionar desde logo da compra da coleção os objetos mais importes, e abrir duas ou três salas incontestáveis no Louvre, fazendo assim com que a crítica baixasse suas armas, "on a voulu faire un grand coup de théâtre, inaugurer un grand musée, le plus grand qu'on eûet encore vu, le décorer du nom du souverain, et démontrer par chiffres aux contribuables qu'ils en avaient pour leur argent; de là cette profusion, ces interminables suites d'objets toujours les mêmes, et cette multitude de pièces équivoques qui jettent sur les morceaux de choix un reflet triste et incertain.” Idem, ibidem, p.6.

Destruir a integridade da coleção do novo Museu seria desse modo arrasar um trajeto visível raro de uma história que importava tanto a artistas quanto a artesãos e industriais. Afinal, a compreensão da história não se faria unicamente com as obras exemplares, colocadas no Louvre, mas com obras também menores, isto é, "obras de transição", que explicariam ainda melhor as obras-primas, bem como as circunstâncias de sua aparição; daí, portanto, a razão para manutenção da nova instituição e para a sua conversão em órgão permanente (com Cornu evidentemente à sua frente). Esse pensamento não deixa de lembrar duas ideias tão inovadoras como a sua, uma anterior e outra posterior. A primeira, que Cornu provavelmente deveria conhecer, vinha das proposições de Quatrèmere de Quincy, que desde o início do século XIX não apenas defendia a manutenção das obras-primas em seus lugares de origens, para que se compreendesse sua "destinação 
O enunciado ao problema da história e do seu ensino, tal como seria importante para Viollet-Le-Duc, na criação de uma cadeira na École pós-reformada - e para Américo, em seu retorno ao Brasil -, aparecia também para Cornu: ele afirmava estar mobilizado, naquele momento - para então popularizar as "sãs tradições do belo" -, na organização "de cursos públicos de história da arte e [sobretudo] de arte aplicada à indústria”, a serem ofertados dentro do Museu ${ }^{194}$.

O acesso fácil a coleções preciosas, somado a uma educação direcionada a esses conjuntos - que em sua totalidade abarcava períodos e produções quase virgens às considerações dos acadêmicos do Institute -, exerceria por fim grande papel na tão reclamada "regeneração do gosto": um mesmo problema que permanecerá, portanto, forte nos debates do ano seguinte, quando da formação dos Salões de $1863^{195}$ e dos desdobramentos publicação do decreto de novembro do mesmo ano. Também as preocupações de Cornu, como aquelas dos reformadores da École, posicionavam a urgência de uma reorganização do ensino artístico; de uma instrução histórica e teórica profunda e menos restrita, especialmente à arte grega, aberta assim aos novos problemas da modernidade e das diferentes trajetórias nacionais que se apresentavam na formação das Exposições Universais ${ }^{196}$. Essa reestruturação era percebida como uma condição sine qua non para o êxito de um novo museu de "artes aplicadas", na medida em que ele viria apenas se ao lado de um novo modelo de ensino direcionado à indústria $^{197}$ - todas essas que seriam as mesmas questões também frequentadas por Américo desde sua chegada ao Brasil.

moral", como defendia a permanência nos Museus não apenas de obras-primas possíveis de serem neles acolhidas, mas de sua alternância com obras de "menor" valor, que dariam não apenas a dimensão a dificuldade das grandes obras, como explicaria mesmo suas aparições. QUINCY, Quatremère de. Considérations morales sur la destinations des ouvrages de l'art, ou de l'influence de leur emploi sur le génie et le gout, et sur le sentiment de ceux qui en jouissnet et en reçevoient les impressions. Paris: L'Imprimière de Crapelet, 1815. P.45.

A segunda ideia, posterior, vem de Alois Riegl, que construirá no final do século XIX uma visão formalista da arte, pautada na produção de ornamentos e de produtos da indústria artística, especialmente após sua entrada no Museum für Kunst und Industrie, em Viena, em 1886.

194 Idem, ibidem. Cornu afirmaria que o professor desses cursos seria Charles Laboulaye, autor que preparava naquele momento um Almanach des progrès de l'industrie et de l'agriculture (1863), com a colaboração de outros estudiosos das artes industriais. Os cursos seriam ofertados aos domingos, para que "os artistas e os artesão pudessem seguilos sem prejuízo dos trabalhos da semana.

195 Sobre o problema da degeneração do gosto no Salão de 1863, ver: SHAW, Jennifer L. "The figure of Venus: Rethoric of the ideal and the Salon of 1863". Art History. Vol. 14, n.4, December 1991. pp.540-570

196 Idem, ibidem. No original: "Il est certain que cette création d'un Musée d'Etudes Spéciales combinée avec une réforme sérieuse de l'école gratuite de dessin de Paris, qui végète sans exercer l'influence qu'elle devrait avoir ; combiné avec la réforme sérieuse des écoles de dessin départementales, produisant des résultats importants, et que ces résultats nous permettraient de conserver notre supériorité dans les œuvres et les industries de goût."

197 Cornu, no entanto, voltava-se mais para a reforma da École Gratuite de Dessin, embora Viollet-Le-Duc e Merimée, por exemplo, embora não a negligenciassem, pensassem mais claramente na École de Beaux-Arts. 
A reforma, que colocava no mesmo plano os novos problemas de um museu sui generis recém-criado, e os velhos problemas pedagógicos de uma instituição como a École, enfim não tardaria, avalizada diretamente por Napoleão III, por meio da ação de alguns de seus aliados mais próximos.

\section{De Cogniet a Cornu, da França ao Brasil, de "élève" a "professeur"}

Américo não está nem um pouco alheio a toda essa movimentação. Além de sua publicação de 1863 tocar em cheio todos esses problemas, seria subestimá-lo se se acreditasse ingênuo ou desinteressado o ingresso que fazia ao ateliê de Cornu, ainda em 1861, poucos dias após o francês assumir suas importantes responsabilidades junto à Coleção Campana e à sua importação a Paris. Não há mesmo hesitações em concluir, como sinalizado anteriormente, que a frequentação a Cornu desde esse período, e a publicação do seu opúsculo em seguida, fariam parte de uma posição estratética do jovem para se tornar parte direta ou indiretamente (e ainda se fazer conhecedor) de um círculo de poder da direção das artes e sua aplicação na indústria na França.

Se, de um lado, a aceitação crescente do seu colega Monchablon (mas não só dele) dentro da École começava a mostrar sinais positivos do ensino junto aos ateliês liberais de Cornu e Gleyre, e portanto um substituto também bem sucedido ao ensino de Cogniet - artista cujos alunos eram alguns dos mais premiados naqueles anos ${ }^{198}$-, de outro, a política Napoleônica na qual estava intimamente envolvido seu novo mestre, bem como Nieuwerkerke, Vaillant, e Viollet-Le-Duc, deveria ser ainda mais cativante para um jovem que já demonstrava a seus amigos o interesse que possuía pela política e pelo desenvolvimento de seus próprios projetos para as artes e a indústria no Brasil; e esses, tanto no seu país quanto nos exemplos daqueles agentes na França, possíveis apenas, como ele afirmou, se se visse sob o "abrigo de altos protetores".

Pesando-se as vantagens, o ingresso na oficina de Cornu, agora mais do que na Cogniet, deve ter parecido o acerto de uma única tacada em dois coelhos. Lá, além de um ensino diário bastante eficiente, é evidente que testemunhasse de perto os trâmites e métodos do seu professor para a formação e organização do novo e inédito museu, o esforço do francês para mantê-lo como instituição permanente e para que lhe deixassem o comando da instituição, e ainda sua participação nas comissões de reforma do ensino artístico no país, notadamente sua relação entre arte e indústria como ferramenta p. 132

198 Os demais ateliês mais premiados entre 1850 e 1863 são os de Picot e de Drolling. cf. BONNET, Alain. op. Cit. 
poderosa para o "progresso" econômico. Cornu parecia ser, com efeito, mais um dos vários exemplos de agentes multi-atuantes e influentes para os quais Américo rendia suas dívidas intelectuais, buscando ainda uma aproximação pessoal.

Se de Viollet-Le-Duc, em 1864, o jovem absorverá rapidamente (conforme discutirei logo em seguida) a lição sobre a urgência de um curso de estética na École, tornando-se o primeiro professor da mesma cadeira criada na AIBA por Porto Alegre, da experiência com Cornu será reforçado "o desejo imenso de fundar [também ele] alguma coisa no Brasil", para enfim "completar esta civilização tão imperfeita". Embora essa intenção na realidade não vingasse, conforme citado, a sua atração pelas reflexões histórica, arqueológica e estética permanecia forte, levando-o a ingressar no Museu Nacional, em 1869 como conservador da seção de Arqueologia, mesmo ano que toma para si curso história da arte. Nesse museu, persistirá outra de suas antigas dívidas para com agentes influentes em sua formação e carreira: passava a ocupar o lugar deixado vago por ninguém menos que Porto Alegre, sem dúvida, como repetirei inúmeras vezes nesta Tese, outra fonte central de inspiração e orientação desde a década de 1850 até o início dos anos 1870, com cuja filha Américo se casara ainda naquele mesmo ano. Mas é antes, como discutido até aqui, mais certamente entre 1861 e 1863, que o jovem começa a movimentar calculadamente as peças de um tabuleiro na intenção de se conchavar na França com agentes responsáveis por uma série de reformas que ele próprio se empenhará em realizar no Brasil, afirmando, em última instância, que bem formado intelectualmente, não apenas em artes, mas sobretudo em ciências, e tendo feito parte dos debates sobre o contexto francês, ele seria o agente mais adequado a uma ação similar no seu país.

A sua Réforme de l'École des Beaux-Arts et l'opposition parece, de início, uma ode às intenções reformistas do governo napoleônico, na qual termina por elogiar abertamente a figura do imperador, do marechal Vaillant, e de Nieuwerkerke. Mas ela é sobretudo o ponto de partida para a mesma defesa no contexto brasileiro, inaugurada dali a poucos meses no texto Considerações Filosóficas sobre as Belas Artes entre os Antigos, datado de 1864. Nesse texto, será visto, é possível perceber seu esforço na reelaboração das ideias divulgadas por Viollet-Le-Duc, Merimée e Cornu, adequando-as ao contexto brasileiro, segundo as ideias imediatas de Porto Alegre, a partir de um método aprendido com a filosofia de Victor Cousin, acrescida da filosofia krausista de Guillaume Tiberghien, e com a utilização dos estudos contrastantes de Quatremère de Quincy e Émeric-David, Ernest Beulé, David Sutter, novamente Viollet-Le-Duc, entre outros. Esse conjunto inicial de proposições se tornará então um 
projeto de mudanças escancarado em uma outra publicação, agora de 1865, Cartas de um Plebeu aos Srs. Deputados, na qual o jovem apresenta um núcleo sugestivo de medidas reformistas para a AIBA e para as artes nacionais. Não sem razão esse texto era publicado quando Américo se prestava ao concurso para professor, isto é, quando ele está prestes a se tornar oficialmente o mais novo funcionário do estado brasileiro.

Em seu Cartas, conforme tratado mais à frente, Américo evidentemente tenciona seguir as ações reformistas já iniciadas por Porto Alegre anos antes, quando à frente da academia carioca, um posto que ele sem dúvida desejaria ocupar ${ }^{199}$. Em 1865, exatos dez anos após o início da Reforma Pedreira do seu mentor brasileiro, o jovem que se afirmará então não apenas artista, mas bacharel da Sorbonne resultado defendido do seu "amor aos estudos", mas também de uma nova distinção social por ele perseguida -, não esconde que deseja ser o continuador daquelas reformas artísticas e industriais. Especialmente por que, segundo defendeu, haviam sido congeladas com a saída repentina de Porto Alegre. Primeira consequência pessoal disso é que a sua desistência da cadeira prática para a qual ingressava, a de Desenho Figurado, fosse justificada pela intenção de assumir uma teórica - como visto, uma das medidas mais significativas da reforma de 1863 da École, e também para a reforma brasileira de 1855, ainda que não realizada.

Dadas as afinidades por muitos percebidas entre um Pedro II e um Napoleão III, ambos imperadores ativos, interessados em seus próprios estudos e nas artes, é de se julgar que Américo desejasse ser proporcionalmente um Viollet-Le-Duc, um Cornu ou um Nieuwerkerke para Napoleão III ou, mais proximamente, um novo Porto Alegre para d. Pedro II, de quem, na qualidade de bolsista da Casa Imperial, já se dizia sentir um abrigado.

199 Rafael Cardoso, em texto dedicado à pintura histórica brasileira, analisa alguns textos dos aliados de Américo que sugeriam que assumisse a direção da Academia, em 1871, após a produção de sua Batalha de campo Grande. Se esse desejo continua lá, num momento bastante produtivo da vida do artista, defendo aqui se ele tenha se iniciado anos antes, logo após a breve permanência de Américo no Brasil, antes de retornar mais uma vez à Europa, em função de uma sequência desastrosa de problemas que teve com outros artistas brasileiros entre 1865 e 1866 . Sobre essa questão, ver o último Capítulo desta Tese. 


\section{Segundo Capítulo}

\section{Considerações sobre Considerações Filosóficas sobre as Belas Artes entre os Antigos.}

\section{Considerações sobre as Considerações}

O texto Considerações Filosóficas sobre as Belas Artes entre os Antigos sucede, em sua versão completa, em poucos meses a impressão do opúsculo sobre La réforme de l'École des Beaux-Arts et l'opposition. Sua publicação integral é iniciada sincronicamente à chegada de Américo ao Brasil, em 1864, para sua admissão ao concurso de professor da cadeira de desenho figurado da AIBA, para o qual havia sido expressamente requerido pelo imperador desde 1862, embora tivesse conseguido uma extensão para mais dois anos na Europa.

Um pouco à contragosto (mesmo em 1864, Américo não queria ainda retornar), o texto surgia como o primeiro aviso público, no Brasil, do projeto intelectual e político que o jovem atribuiu a si, com mais clareza, durante seus anos franceses, mas cuja motivação brotava das intenções instaladas pela reforma e lições de Porto Alegre na AIBA, entre 1855 e 1857, das quais, como sinalizado, o jovem não saía incólume.

Não seria preciso muito para perceber (e de fato não foi difícil para alguns de seus futuros oponentes, que realizavam justamente em 1864 as suas campanhas eleitorais nos jornais) que o texto de Américo se tornava a primeira isca jogada no restrito lago de "alta proteção" no país, esperando que fosse fisgada para pôr assim seus planos em prática. Com seu estudo, ele ansiava atingir os aliados mais fortes, especialmente o maior deles, d. Pedro II, e para tanto produziu duas versões inaugurais completas do texto, levemente distintas em contéudo e forma ${ }^{1}$, mas que não se deixavam alienar da idêntica parte que lhes cabia nas suas esperanças de ação.

\footnotetext{
1 A versão manuscrita enviada ao imperador é suprimida de parte do quarto capítulo da versão apresentada inicialmente no Correio Mercantil. Trata-se de uma parte em que Américo continuava a refutar algumas causas que vários autores, desde o século XVIII, incluindo o mais importante deles, Winckelmann, havia concluído sobre a superioridade da arte grega. As duas causas a que se referem as refutações de Américo, nessa parte, são as ideias de que a religião dos gregos e o caráter sensual dela (cujos deuses se apresentavam em forma de homens e mulheres nus) definiram alguns dos elementos principais para a perfeição das suas artes. Nessa parte, Américo ainda afirmou que em algumas regiões gregas, onde a liberdade política havia sido conquistada, as artes não teriam florescido, contrariando outro dos argumentos winckelmaniannos.

Me parece quase certo que essa parte do seu texto tenha sido suprimida na versão do imperador em função dos desdobramentos desses argumentos, que o levariam a minimizar a importância da forma de um governo para o desenvolvimento específico das artes, opinião no mínimo delicada de ser diretamente enviada, dentro de um textopresente, ao representante do governo do Brasil: "No estudo das teorias artísticas, importa aiinda menos observar a forma dos governos de que, entretanto, se têm com demasia ocupado alguns escritores; porque o que requer todo o qualquer progresso intelectual é constituir-se parte integrante e necessária das funções de uma comunidade política qualquer, sob qualquer regime que seja, mas onde o espírito nacional e cívico possa se desenvolver". cf. AMÉRICO,
} 
A primeira versão completa, divulgada entre 29 de setembro e 28 de dezembro de 1864, era enviada a prelo às páginas do Correio Mercantil do Rio de Janeiro em 28 de setembro, endereçada ao público geral ${ }^{2}$. O jovem artista, autointitulado "Bacharel Américo" - uma denomição não sem peso e sentido, conforme tratarei mais à frente -, procurava logo afirmar, publicamente, a potência de suas ideias com um longo estudo, impresso ao longo de vinte edições intercaladas daquele jornal $^{3}$, e para o qual daria um "grand final", no qual apontava para ele próprio não mais como promessa, mas como agente certo para as artes brasileiras.

Se, nessa versão, tal indicação era ainda mais ou menos implícita, a explicitação tardaria apenas poucos meses, quando uma nova publicação intitulada Cartas de um Plebeu aos Srs. Deputados, abria a sua caixa de projetos. Essa caixa, todavia, se tornaria em outros poucos meses para Américo, com a eclosão do que ficaria conhecida como a fatídica "questão de bacharéis"4, algo talvez similar a uma Caixa de Pandora; ocasião em que se iniciariam as "desilusões" cada vez mais reclamadas por ele nas fases seguintes de sua vida, fossem em textos ou, poeticamente, em obras pictóricas e romances.

A segunda versão de Considerações Filosóficas, esmeradamente manuscrita e um pouco mais sintética que o folhetim, era, por outra via, oferecida diretamente a seu protetor-mór, nos primeiros dias de 1865. Essa versão não estava contudo sozinha. Era cuidadosamente acompanhada da pintura $A$ Carioca e de uma dedicatória:

Desculpai, Senhor, que ao muito alto juízo de V. Majestade eu venha submeter, antes da sua publicação em um livro, esse pequeno trabalho que Vos dedico, insignificante fruto colhido na árvore do bem. Faltar-lhe-á, certamente, o sabor dos que brotam em terreno menos inculto, porém

Pedro. Considerações Filosóficas sobre as Belas Artes entre os Antigos. Edição e estudo introdutório de Silvano Alves Bezerra da Silva. João Pessoa: UFPB, 2006. Estudo Quarto, p.219. Ou ver ainda a edição impressa no: Correio Mercantil. Rio de Janeiro, 10 de outubro de 1864, p.2.

${ }^{2}$ O Correio mercantil era, durante a década de 1860 , um dos maiores jornais da Corte, rivalizando apenas com o Jornal do Commércio, cujas estruturas, seções de artigos, e números de páginas eram, a propósito, muito similares. Em média, possuíam naquela década 4 páginas por edição, todas tipografadas, com sete colunas regulares, salvo em casos de edições comemorativas ou duplas.

3 Cf. as seguintes edições do Correio Mercantil, Rio de Janeiro: 29 de setembro de 1864; 30 de setembro de 1864; 1 de outubro de 1864; 2 de outubro de 1864; 3 de outubro de 1864; 4 de outubro de 1864; 7 de outubro de 1864; 7 de outubro de 1864; 9 de outubro de $1864 ; 10$ de outubro de $1864 ; 12$ de outubro de $1864 ; 14$ de outubro de $1864 ; 30$ outubro de 1864; 02 de novembro de 1864; 15 de novembro de 1864; 16 de novembro de $1864 ; 17$ de novembro de 1864; 19 de novembro de 1864; 21 de novembro de 1864; 25 de dezembro de 1864;26/27 de dezembro de 1864 ;e 28 de dezembro de 1864.

${ }^{4}$ Assim intitulada pela imprensa carioca, a "questão dos bacharéis" foi um episódio ocorrido nos primeiros meses de 1866, envolvendo Pedro Américo e seu amigo e estudos brasileiro e europeu, Daniel Pedro Ferro Cardoso. Foi incitada curiosamente por Bethencourt da Silva, que se esforçou em provar que Américo e seu amigo não eram bacharéis diplomados, conforme defendiam, e a levar essa acusação a termo, um que deveria ser a prisão dos jovens, na medida em que ostentação de títulos falsos era crime previsto no código penal brasileiro. Discuto essa "questão" no último texto desta Tese, apontando para as implicações imediatadas e futuras na carreira de Américo, e também para uma série de relações estabelecidas entre as diversas "classes de artistas" politicamente estabelecidas na corte, nos anos 1850 e 1860. 
não me pareceu isto assaz para que o não dedicasse a Vossa Majestade, pois se nenhuma importância oferece em si próprio, ao menos tem para mim a qualidade de ser um dos dois primeiros que encontrei ao entrar na cultura da minha vida intelectual sendo o outro a minha Carioca, que também vos dedico. Aceitai-o, pois, Senhor, não como uma oferta pretensiosa de mérito, mas como simples e mesquinha prova do meu reconhecimento pelos numerosos e incessantes favores que de Vossa Majestade tenho recebido. ${ }^{5}$

De início, a estratégia de entregar as duas obras juntas era um lúcido intento de fazer o artista cair ainda mais nas graças do imperador, e de se afirmar peremptoriamente como um de seus “protegidos". Mas era, além disso, a confissão da íntima relação entre elas, consideradas os dois primeiros frutos de sua "vida intelectual".

Além do envio interessado, mesclado de agradecimentos de eventos passados e esperanças futuras, a dedicatória não mentia quanto à natureza desses trabalhos e, especificamente, dos seus escritos. Considerações Filosóficas representava o resultado do esforço contínuo do jovem no sentido de uma formação alargada paralela àquela da École de Beaux-Arts e dos ateliês privados, que julgava então imprescindível também para um pintor $^{7}$, sobretudo um com aspirações intelectuais e políticas.

As cartas que enviou a partir de 1861 ao monarca e a encarregados, pedindo que o período de seus estudos fosse estendido para além da data preestabelecida de 1862, assumiam invariavelmente como justificativa não a extensão de sua formação artística, mas o tempo ainda necessário para a conclusão de sua formação científica ${ }^{8}$. E de fato Américo não fabulava, porque era justamente nesse momento que ele deixava pela primeira vez de participar (e por duas vezes consecutivas) do Concours de Places da École des Beaux-Arts ${ }^{9}$ (razão central da concessão do "bolsinho do imperador), permanecendo oficialmente fora da instituição durante todo o ano letivo de 1861 , e retornando apenas no primeiro semestre do ano seguinte.

Também inscrito desde o fim do primeiro semestre de 1860 na École Spéciale de Dessin et de Mathématiques appliqués aux arts industriels - ou também chamada de Pétite École -, ao lado

5 AMÉRICO, Pedro. "Dedicatória a d. Pedro II em 06 de janeiro de 1865.” Arquivo Museu Imperial. Petrópolis, Rio de Janeiro. Maço 135 - Doc. 6622.

${ }^{6}$ Idem, Ibidem.

7 cf. AMÉRICO, Pedro. Considerações Filosóficas sobre as Belas Artes entre os Antigos. Edição e estudo introdutório de Silvano Alves Bezerra da Silva. João Pessoa: UFPB, 2006. [Estudo Quinto], p.142. Ou ver ainda a edição impressa no: Correio Mercantil. Rio de Janeiro, 14 de outubro de 1864. P.2.

8 AMÉRICO, Pedro. "Carta enviada de Paris ao imperador d. Pedro II, em 6 de janeiro de 1862". Arquivo da Casa Imperial do Brasil (Sigla: POB). Maço 131 - Doc. 6418.

9 O primeiro Concours des Places de 1861 é realizado em 01 de abril (semestre de verão); o segundo, em 09 de outubro (semestre de inverno). 
de Victor Meirelles, Américo se afastará por um tempo da École para ingressar no curso preparatório para o Bacharelado em Ciências do bastante conhecido Instituto Ganot; este, um curso também diurno, como o da École. O curso frequentado na Pétite École, sendo, no entanto, noturno, se apresentava como uma alternativa proveitosa, e lhe permitia seguir em seus cursos práticos, sobretudo em desenho, sem disputar com os períodos matutinos e verspertinos dedicados à sua preparação científica ${ }^{10}$.

$\mathrm{Na}$ contramão daqueles que mais tarde, em 1866, concluiriam sobre a inutilidade dessa formação para um pintor $^{11}$, incluindo uma figura de destaque como o arquiteto Francisco Joaquim Bethencourt da Silva - professor da AIBA e fundador do Liceu de Artes e Ofícios do Rio de Janeiro -, Américo reforçava seus pedidos de extensão de prazo com cartas escritas por docentes europeus, que visavam assegurar o benefício dos estudos científicos para a sua futura atuação artística. Elas eram enviadas pelo próprio Adolphe Ganot ${ }^{12}$ (cujas lições d. Pedro II conhecia bem e as estudava com suas filhas), e por Sebastién Cornu ${ }^{13}$, envolvido, como visto, nas recentes reformas do ensino artístico francês e na formação do Museu Napoleão III.

A formação escolhida, o Baccalauréat es Sciences Scindé, constituía duas séries distintas de provas. Américo se submetia à primeira ainda em agosto de $1861^{14}$, tornando-se apto à segunda

10 Américo se inscreve na Petite École em 19 de junho de 1860. Archives Nationales, Registres des Élèves étrangers l'École Impériale Spéciale de Dessin et de Mathématiques, 1855-1946. AJ/53/143.

11 GUISANDO, Bacharel Renato de [Pseudônimo de Bethencourt da Silva]. "bacharéis sem diploma". Publicações a Pedido. Jornal do Commércio. Rio de Janeiro, 27 de janeiro de 1866, P.2.

12 Atestado escrito por M. Ganot em 17 de setembro de 1861, afirmando que, ao frequentar o bacharelado, Américo iria "adquirir uma cultura geral que seria aplicada ao estudo das belas artes, objetivo de sua estadia em Paris.". AMÉRICO, Pedro. Carta enviada de Paris ao imperador d. Pedro II, em 6 de janeiro de 1862. Arquivo da Casa Imperial do Brasil (Sigla: POB). Maço 131 - Doc. 6418.

13 Carta de Sébastien Cornu, de setembro de 1861, pedindo que o imperador custiasse mais dois ou três anos de estudos de Américo na Europa, o que lhe permitiria fazer suas viagens à Itália e assim colher os frutos esperados: "Eu, abaixo assinado, declaro que Mr. Pedro américo de Figueiredo e Mello, meu aluno em pintura, dividiu seu tempo esse ano entre o estudo da arte e das Ciências, que se complementam. Eu penso que os três anos de estudos que ele possuía para seus estudos e para sua viagem na Itália sejam insuficientes para seu bom resultado. Em consequência, eu creio necessário que o S. M. Imperador se digne ainda a ceder a Mr. Américo mais três anos de estudos em Paris". CORNU, M.-Sébastien. "Carta enviada de Paris ao imperador d. Pedro II, em 6 de janeiro de 1862". Arquivo da Casa Imperial do Brasil (Sigla: POB). Maço 131 - Doc. 6418.

Curiosamente, as atividades nas quais Cornu afirmava estar sempre engajado seu novo aluno brasileiro, entre a arte e a ciência, não estavam muito longe das ações que ele próprio, como visto, desempenhava na formação do Museu Napoleão III, the exigindo uma sensibilidade artística, maleabilidade política e interesses científicos diversos (arqueologia, história, história da arte, estética etc.).

14 Para a primeira parte das provas do Baccalauréat es Sciences Scindé, o canditado deveria realizar composições escritas de Física, e provas orais de Física, Química e Ciências Naturais. Os conceitos são B. R. e N. Américo sai com R. em Todas, no entanto com a nota máxima total, que é 3. A questão escrita de Física é a seguinte: "1º Exposer les faits qui concernent les mélanges des gaz et des vapeurs. $2^{\circ}$ ) Une corde tendu par un poids de $15 \mathrm{~kg}$ rend un certain son: quelle devrait être la force de la tension pour que cette corde rendit la tierce majeure du son primitif. On sait que la tierce majeure est représentée par 5/4 quand le son primitif est représenté par 1." ARCHIVES NACIONALES. "Registres des procès-verbaux d'examens et de réceptions au baccalauréat-de-sciences scindé - 1ère Partie", 10 août 1860 - 9 août 1861." Archives Nationales, AJ/16/5470. 
parte, a qual, ainda que se preparando continuamente, não iria realizar ${ }^{15}$. Contudo, na metade de 1862, quando ele retornava à École des Beaux-Arts, depois de passar por novo concurso de ingresso, em que obtém a melhor posição até então ( $3^{\circ}$ lugar), a dedicação constante a seus estudos teóricos - consumados nãos apenas em outros cursos e palestras paralelos ${ }^{16}$, mas também com a primeira série de viagens que fará aos museus e sítios arqueológicos fora da França - já lhe reforçava a crença de ter então se tornado espiritualmente um bacharel, mesmo se ainda não houvesse oficializado essa condição social com um diploma.

Uma carta enviada a uma de suas tias, em junho de 1862, esclarece essa convicção:

Há oito meses que recebi uma cartinha de Vmcê, e há, justamente, oito meses que não tenho escrito para Areias, por ter andado quase sempre viajando; e, algumas vezes que tenho voltado a Paris, tenho tido o que fazer que não me tem sido possível escrever nem mesmo a meu pai.

[..] limito-me a dizer-lhe que fico com excelente saúde e saí aprovado nos meus exames do Bacharelado da Academia de Ciências Físicas e Naturais, passados na Academia de Paris. Observese, porém que não poderei obter o diploma sem fazer exames do Bacharelado em Ciências Matemáticas e Filosóficas, por terem reunido esses três títulos em um só, com a denominação de Bacharelado Completo.

Entretanto sou considerado Bacharel em ciências, e sob esse nome aqui me designam ${ }^{17}$.

A relação que se formará entre esse sentimento bacharelesco e a publicação de Considerações Filosóficas sobre as Belas Artes entre os Antigos não será pequena, nem despremeditada. De fato, quando impressas no Correio Mercantil em 1864, elas eram em grande parte datadas de maio de 1862, momento no qual o jovem passa então a se considerar, segundo confessa à sua tia, um bacharel-artista, e não um artista-bacharel: primeira ascenção social de outras contínuas que galgará em sua carreira, entre as de filósofo-artista, doutor-artista e, por fim, a partir da década de 1870, retomando o transcendente modelo florentino, a de artista universal. Se a subida da categoria de artista-artesão à de bacharel parecia, em sentido único, demasiadamente acentuada

${ }^{15}$ A pesquisa dos registros de Américo nos Archives Nationales de França teve como deimitação de datas o ano de 1859 ao de 1865. Foram olhadas uma vez, e checados uma segunda. Nesse período não há nenhuma entrada de Américo para a realização da segunda prova do bacharelado. Seria preciso ainda olhar o ano de 1866 - ano em que Américo está de volta à Europa - para confirmar cabalmente se ela realiza essa obra. De todo modo, a probabilidade é também mínina, haja vista o início imediato de Américo ao doutorado na Universidade Livre de Bruxelas, que não requeria dos seus estudantes, como na França, um diploma de bacharelado.

${ }^{16}$ Como apresentei em nota, no Capítulo anterior, segundo Cardoso de Oliveira, na primeira edição da biografia dedicada a Américo, o artista teria perseguido, durante seus primeiros anos de Paris, os cursos de personalidades francesas (Michael Farady, Jules Janin, Antoine-Jèrôme Balard, o padre Charles-Émile Freppel, Edmond de Pressensé), no College de France e no Conservatoire des arts et métiers.

17 AMÉRICO, Pedro. Carta à tia, Maria do Rosário Brasileira de Mello, em 29 de junho de 1862. Apud In: TORRES, Francisco Tancredo. Dossiê Pedro Américo. Mossoró: Coleção Mossoró, 2002. p.135. 
no Brasil, o jovem supõe que uma inversão momentânea de fluxo poderia resolver o impasse: a ostenção do título científico ao fim de um estudo sobre artes viria assegurar a conciliação entre aquelas classes, tão constrastantes no país do período, e mostrar a possibilidade de que um só agente pudesse ser um bacharel que pintasse e, por conseguinte, e ainda mais importante, um artista que escrevesse, deixando enfim desobstruída a passagem social para os dois sentidos ${ }^{18}$.

Para realizar essa operação Américo tem que sugerir, entretanto, a existência de um hiato de quase dois anos entre o término da maior parte dos seus escritos filosóficos e a sua primeira apresentação pública completa, em 1864, um lapso que será notado em 1866 por seus adversários ${ }^{19}$. Em síntese, a data de conclusão do texto era adiantada para fazer encaixar o justo período em que ele teria obtido o bacharelado da Sorbonne $e^{20}$.

Entretanto, é certo que, até 1863, Américo não havia ainda terminado seu texto. Uma versão prévia e inacabada desses escritos, publicada no segundo bimestre de 1863, também no Correio Mercantil, sustenta consistentemente essa hipótese. Em 03 e 04 de março daquele ano, dois artigos que compunham os primeiros dois terços da futura introdução para as Considerações Filosóficas (menos de $10 \%$ do texto) ${ }^{21}$ eram impressos com indicação de sequência posterior. Mas a série era abruptamente interrompida, sem quaisquer explicações.

A suspensão decorria, é muitíssimo provável, de uma série de eventos que se desdobravam em Paris em âmbito privado e social do artista. Entre eles, os preparativos de Américo para a participação do primeiro Concours des Places do ano, em abril de 1863; o início da produção da Carioca; e a controvérsia pública gerada pela seleção e exposição de obras para os Salons daquele ano $^{22}$. Em meio a tantos eventos e obrigações, algo deveria ser adiado, e nesse sentido, o que parecia menos urgente para o artista - que já sabia àquela altura que teria ainda quase um ano e meio na Europa - era a continuidade do seu texto.

18 Entretanto, a meu ver, essa estratégia desenvolvida por Américo tratava-se de uma retomada, em sentido formal (isto é, com a ostentação de uma formação oficial), daquilo que Porto Alegre já havia iniciado no Brasil, com seus inúmeros textos históricos e biográficos, e com suas atuações políticas.

19 Justamente essa datação deve ter nutrido a desconfiança de um Bethencourt sobre o que o então estudante teria feito em Paris nos dois anos seguintes, já que não mandaria mais nenhuma cópia. Ver: GUISANDO, Renato de. "Os imagináveis bacharéis sem diploma". Publicações a Pedido. Jornal do Commércio. Rio de Janeiro, 8 de fevereiro de 1866, P.2.

20 Em maio de 1862, data com que é assinada Considerações Filosóficas coincidem, com efeito, com a data na qual Américo pedia à Casa Imperial prorrogação de sua estadia na Europa, precisamente para concluir seus estudos científicos.

21 Segundo Américo deixa entrever em alguns dados em notas e citações nessa introdução, a última parte da introdução será concluída no início de 1864.

22 Como argumentarei mais à frente, não será por acaso a escolha de Américo de produzir a sua Carioca como uma vênus brasileira, justamente no período de vigência do salão informal mas sintomaticamente conhecido como o Salão das Vênus. 
Mesmo que o conteúdo publicado dessa primeira introdução inacabada às Considerações Filosóficas fosse quase idêntico à versão final de 1864, o título que a abria, resumo portanto de suas intenções, era então bem mais modesto, concorde também com uma assinatura igualmente mais modesta do autor. Assim, em março de 1863, o estudo era apresentado como "Observações Gerais sobre as Belas Artes entre os Antigos", de autoria do "Pedro Américo de Figueiredo". Nesse momento, ainda não estão presentes nem o bacharel de um ano e meio depois, nem a aspiração de se entregar ao público carioca um estudo filosófico, dedicado à compreensão do imutável, do permanente e do universal nas artes. A distância na proposição das duas versões perdurava na publicação completa de 1864, uma vez que a introdução do estudo não era apresentada diretamente integrada às Considerações Filosóficas, mas como um estudo que as precedia, um "discurso sobre a importância dos estudos arqueológicos",23.

A conversão para um novo título, além de se adequar à reivindicação de uma recente condição social do jovem, parecia querer então se alinhar a dezenas de "estudos filosóficos" e "reflexões" da mesma natureza que eram publicados nos jornais brasileiros entre as décadas de 1850 e 1860 - sobretudo por bacharéis de direito e medicina -, e aos recentes esforços que o jovem testemunhava, também na França, naquele momento, no sentido da fundação de uma verdadeira disciplina estética francesa, fomentada por ninguém menos que Victor Cousin.

Uma tal manobra, deve-se dizer novamente, garantiria que aquela reclamada extensão de prazo no velho mundo, aceita pelo imperador, não havia sido em vão. O jovem teria voltado um artista-ilustrado, pronto para assumir suas aspirações políticas.

\section{Um curso não oficial de história da arte, estética e arqueologia}

Após sua publicação integral, Considerações Filosóficas não teria a repercussão esperada. Nem publicamente, em resposta à versão do Correio Mercantil $^{24}$, nem pessoalmente, na resposta do

23 CORREIO Mercantil, Rio de Janeiro, 28 de setembro de 1864, p.1. Na publicação inacabada de 1863, Américo parece, todavia, ainda compreender a sua introdução como pertencente ao mesmo conjunto de investigações, posto que o sub-título "importância dos estudos arqueológicos" não precede o estudo, mas integra o título geral de "Observações Gerais sobre as Belas Artes entre os antigos", algo que não se apresentara da mesma maneira na publicação de 1864 .

${ }^{24} \mathrm{Em}$ minhas pesquisas, não pude encontrar nenhum comentário significativo à publicação de Considerações Filosóficas. Na primeira edição da biografia de Pedro Américo publicada por Cardoso de Oliveira, o autor afirmou, entretanto, o seguinte: "Contemporaneamente à Refutação [da Vida de Jesus, de E. Renan], escreveu ainda Pedro Américo os Estudos filosóficas sobre as Belas Artes, que foram publicadas em 1864 no Correio Mercantil, e grangearam ao autor os mais entusiásticos louvores dos principais literatos brasileiros. Entre estes citaremos Frei Camilo de Montserrat, o conselheiro Tomás Gomes dos Santos, e o barão de Pacheco [Manuel Pacheco da Silva], o qual muito insistiu para que Pedro Américo imprimisse em avulso aquele trabalho, prontificando-se ele mesmo a concorrer 
imperador a seu exemplar especial. No entanto, as intenções curriculares e conteúdo desse estudo não deixavam dúvidas: elas preparavam as bases intelectuais para, e eram mesmo pensadas como a versão preliminar de um primeiro curso oficial de história da arte apresentado no Brasil; curso que, como indicado, seriaaberto oficialmente pelo próprio Américo, em 1870, na AIBA.

$\mathrm{O}$ texto era o indício mais evidente, de outros, que sugeria que o jovem tencionava assumir esse curso ainda na década 1860, não fossem os graves problemas que passava a ter, desde o seu retorno, com várias personalidades, entre elas o mesmo Bethencourt da Silva. ${ }^{25}$

Devedor de preocupações similares lançadas por artistas e intelectuais no Brasil de gerações anteriores, o texto de Américo se apresentava como o mais longo estudo então dedicado à estrutução de uma teoria possível para o desenvolvimento da arte nacional, dentro de uma perspectiva em que se cruzavam simultaneamente arqueologia, estética (no seu caso específico, a ciência do belo), e história da arte.

Dez anos após o ingresso do jovem na AIBA, a cadeira sugestivamente batizada de História das Belas Artes, Estética e Arqueologia ${ }^{26}$ não havia sido preenchida, embora prevista na nova grade curricular. As questões levantadas em seu texto lidavam intimamente com essa promessa, e ainda com várias das teses para debate que ele via Porto Alegre apresentar, em 1855, aos professores e a seus colegas da primeira turma da instituição pós-reformada. Das trinta perguntas expostas pelo diretor (e era de se esperar que um número considerável delas fosse pensado em ser discutido naquele curso teórico, logo após sua abertura), ao menos onze se ofereciam à indagação sobre as causas, princípios, e circunstâncias necessários ao desenvolvimento das artes no país ${ }^{27}$, algumas

com uma parte das despesas, o que aliás teve o artista escrúpulos em aceitar.” OLIVEIRA, J. M. Cardoso de. Pedro Américo: sua vida e suas obras. Paris: Guillard, Aillaud \& Cia, Editores, 1898. P.37

$25 \mathrm{O}$ primeiro e o mais grave deles acontecia sintomaticamente entre 1865 e 1866, logo antes da efetivação do jovem como professor na mesma instituição. O conflito, em seus desdobramentos, o levou (ou o ajudou) a sair imediatamente do país com uma licença concedida pelo Marquês de Olinda para continuar seus estudos científicos, agora em Bruxelas: cidade que já conhecia bem, desde que matriculado no bacharelado também em ciências para o ano letivo de 1862-1863, certamente para terminar a segunda parte daqueles exames aos quais, não se sabe ainda exatamente o porquê, não se submetia em Paris. Para uma visão mais detalhada dessa questão, ver o último Capítulo desta Tese.

26 FERRAZ, Luiz Pedreira do Coutto. "Decreto no 1.603, de 14 de Maio de 1855 dá novos Estatutos à Academia das Bellas Artes". Disponível em: http://www2.camara.leg.br/legin/fed/decret/1824-1899/decreto-1603-14-maio-1855558536-norma-pe.html [ùltimo acesso: outubro de 2015]

27 As 11 teses lançadas por Porto Alegre que lidam diretamente com as questões citadas são:

“ $2^{\circ}$ [tese] - Donde procede o mau gosto, e mesmo a indiferença que temos tido até hoje para com a arquitetura, quais as razões por que os exemplares do M. Grandjean não frutificaram, e o que convém fazer em favor desta arte para ter um maior seguro desenvolvimento?

$3^{\circ}$ - O novo sistema de educação artística, ordenado pela reforma, preencherá os seus fins, ou será necessário um novo método? Qual será mais proveitoso; começar pelos processos puramente técnicos para depois passar-se à teoria, ou começar-se pela teoria para depois passar-se à prática, ou o sistema de estudar a teoria envolta com a prática? [..] 
delas tomando como círculo de investigação não apenas o contexto nacional, mas a história conhecida e então em reavaliação dos antigos egípcios e gregos ${ }^{28}$.

O mesmo tema geral concentrava os esforços de Considerações Filosóficas em suas diversas colunas do jornal, e em mais de uma centena de páginas do manuscrito da Casa Imperial. Ele era conhecido antes mesmo de sua publicação. No dia anterior à impressão da primeira parte do texto definitivo, o Correio Mercantil já havia impresso uma chamada, provavelmente soprada pelo jovem, na qual indicava: "Remete-nos de Paris ${ }^{29}$ o Sr. P. Américo de Figueiredo e Mello um interessante trabalho seu a respeito das Belas Artes entre os antigos. Nesse trabalho se estudam as

\footnotetext{
$7^{\circ}$ - Escrever a história da cenografia no Rio de Janeiro e dar as razões por que esta arte não tem progredido entre nós.

$8^{\circ}$ - Para que o Brasil forme uma escola sua, que princípios deverá adotar a Academia como cânones invariáveis para obter esse caráter peculiar que mereça o nome de escola, sem contudo precipitar-se no estilo amaneirado? região?

$9^{\circ}$ - O princípio chamado da imobilidade no Egito foi útil ou fatal ao desenvolvimento das belas-artes naquela
}

$10^{\circ}$ - Se o sistema das recompensas públicas dos atenienses fosse adotado no Brasil, frutificaria ele como na Antiguidade, apesar da nossa diferente organização social, e do nosso caráter individual, ou daria resultado moral e artístico superior ao dos títulos e condecorações? [..]

$13^{\circ}$ - Que meios pode empregar já o governo para enraizar o gosto das belas-artes no Rio de Janeiro, e torná-lo em utilidade pública? [..]

$20^{\circ}$ - O que tem mais concorrido para o atraso da arquitetura, as leis do nosso país e a educação dos nossos homens de Estado, ou a falta de gosto nos particulares?

$21^{\circ}$ - Onde estão as causas da decadência da música no Brasil, onde a música é uma necessidade, e onde se pagam os cantores por preços fabulosos? O que convirá fazer para restaurar a música religiosa profanada escandalosamente pelos próprios músicos [..]? [..]

$25^{\circ}$ - Qual será a razão por que muitas academias se têm tornado infrutíferas e mesmo prejudiciais às belasartes em diferentes épocas e países? [..]

$29^{\circ}$ - A ornamentação e decoração dos edifícios, principalmente a executada pela pintura, deverá substituir os grotescos e arabescos pelos objetos de nossa natureza americana; e qual tem sido a causa porque este caminho novo, apenas encetado por M. Debret e Francisco Pedro do Amaral, nos seus últimos dias, ainda não tomou o seu necessário e útil desenvolvimento?". PORTO ALEGRE, M. A. "Teses para debate [transcrição da Ata da $2^{\mathrm{a}}$ sessão pública da Academia Imperial das Belas Artes, em 27 de setembro de 1855]”. Apud GALVÃO, Alfredo. "Manuel de Araújo PortoAlegre: sua influência na Academia Imperial das Belas Artes e no meio artístico do Rio de Janeiro". Revista do Patrimônio Histórico e Artístico Nacional, Rio de Janeiro, n.14, 1959, pp.42-47. Reimpresso também em: KOVENSKY, Julia; SQUEFF, Letícia (orgs.). Manuel de Araújo Porto Alegre: Singular \& Plural. São Paulo: IMS, 2014. pp.324-25.

28 Porto Alegre, não há dúvidas, fazia com essas indagações incitação similar às questões oficiais francesas abertas como concursos, normalmente respondidas por estudiosos em forma de rapports (relatórios), posteriormente impressos em livros; procedimento que Américo conhecia também muito bem e ao qual fazia mesmo defesa ao final do seu texto. Para algumas das suas questões, o novo diretor já havia esboçado respostas antes mesmo de lançá-las, e em específico no texto - encomendado pelo próprio imperador - intitulado Apontamentos sobre os meios práticos de desenvolver o gosto e a necessidade das belas-artes no Rio de Janeiro, datado do fim de 1853. A propostas encentadas nesse breve texto (algo similar a um breve rapport de especulação), somadas à sua intensa atuação na educação técnica e artística da corte, na qualidade de vereador eleito nos primeiros anos de 1850, o levam portanto a tomar poucas semanas depois a frente da Academia.

Retornarei a esse texto mais à frente, no Sexto Capítulo desta Tese, assim como ao problema dos rapports.

29 A informação de que Américo envia a versão completa de Considerações Filosóficas é duvidosa. Como dito, a publicação é iniciada em 29 de setembro de 1864. Américo já havia chegado ao Rio desde o dia 17 do mêsmo mês, e no Brasil (em específico em Pernambuco), no dia 11. Ver por exemplo: S/A. "Entrada do Porto". Correio Mercantil, 19 de setembro de 1864, p.3. 
causas da sua perfeição entre os gregos"30. Como será tratado, interessava de fato, nesse texto, descobrir as causas daquela defendida supremacia, valendo-se do contra-apoio de outros exemplos históricos destacados, para revertê-las finalmente em favor do circuito brasileiro, preocupação que se enquadrava perfeitamente, portanto, em todos os questionamentos do antigo diretor da academia $^{31}$.

$\mathrm{Na}$ verdade, a questão importaria não apenas ao antigo diretor, mas permanecia inteiramente válida a Thomás Gomes dos Santos, empossado logo após a saída de Porto Alegre. Em um documento preparatório para uma minuta oficial, em 1862, Santos mantinha em seus argumentos as antigas projeções de que cadeira de História das Belas Artes, Estética e Arqueologia deveria ser entregue unicamente a um professor capaz de estudar e mostrar também graficamente "a marcha o desenvolvimento das faculdades do espírito humano, a história dos povos antigos e modernos, [que] poderia então explicar a origem, o progresso, a decadência, o renascimento e todas as vicissitudes da arte, a história dos monumentos, as operações do espírito na criação da beleza ideal". ${ }^{32}$

\section{Modelos e referências}

Os grandes modelos que lidavam com essa questão ainda eram bastante acessíveis a Américo, como eram a Porto Alegre, posto que continuavam a ser creditados como importantes anteparos corretivos de alguns sintomas internacionais, identificados como ciclicamente reincidentes no domínio da arte. Entretanto, as orientações de método que essa correções requeria não eram artísticas, mas filosóficas.

Ainda nos tempos áureos do ecletismo na França - os anos de Porto Alegre, em Paris -, Victor Cousin continuava a carregar na cátedra de filosofia a seguinte indagação: "Vocês poderiam imaginar um fenômeno que comece a aparecer em qualquer tempo ou lugar sem uma causa, física ou moral?"33. Para a pergunta, nenhum pouco nova, diga-se de passagem, pois uma herança do século XVIII, ele próprio trataria de dar resposta atualizada em Do Verdadeiro, do Belo e do Bem,

30 CORREIO MECANTIL, Rio de Janeiro, 28 de setembro de 1864, p.1.

31AMÉRICO, Pedro. Considerações Filosóficas sobre as Belas Artes entre os Antigos. p.117. Ou: Correio Mercantil, Rio de Janeiro, 7 de outubro de 1864, p.2.,entre outras passagens do texto: "depois de termos admitido ser a arte grega de todas a mais bela e a mais completa, aquilo que melhor importa saber é por que meios e circunstâncias chegara ela a tal ponto de perfeição. Neste e nos seguintes capítulos [...] mostraremos a quem devem os antigos habitantes da península helênica aquela excelência de gosto e de doutrinas que produziu".

32 SANTOS, Thomas Gomes dos. "Minuta da Academia, informando requerimento em que Daniel Pedro Ferro Cardoso, intitulando-se bacharel e arquiteto pela Academia de Belas Artes de Paris, pede a cadeira de História das belas arte, estética e arqueologia". Museu d. João VI. Rio de Janeiro. Cota do documento: 4908.

33 COUSIN, Victor. Du vrai, du Beau et du Bien. septième édition. Paris: Didier et Cie, 1858. p.24. 
livro capital cujas reflexões haviam sido sistematizadas desde os anos 1810, precisamente em seu primeiro curso sobre o Belo, na École Normale Supérieure, ainda que sua publicação se efetivasse apenas em 1853: "Todo evento (a queda de uma folha, a morte de alguém) possui uma causa; cada um tem causas particulares e variáveis, mas algo de universal e necessário, que é justamente a necessidade de uma causa" ${ }^{34}$.

A publicação tardia que o filósofo sexagenário então fazia do seu texto reforçava tão somente o interesse geral renovado na década de 1850 na dissolução de uma "nova" crise artística nacional apontada naqueles anos; crise que Cousin pensava poder contribuir, apontando para o verdadeiro caminho que levaria novamente ao Belo ideal nas artes francesas. Tratar-se-ia de um problema que provinha da persistência, para alguns críticos e personalidades, do falso "ideal" presente nas obras de alguns artistas “oficiais", isto é, do rebaixamento dos valores tradicionais da "verdadeira" arte; e, para outros, da advogada ausência de idealização das obras dos artistas das novas gerações, especialmente dos "realistas" 35 .

Cousin havia oferecido como solução inesperada para essa regeneração o resgate do idealismo da "grande" arte francesa do século XVII - período da formação das academias francesas em Paris e em Roma, sob os auspícios de Louis XIV, no qual fizeram seus nomes Nicolas Poussin, Charles Le Brun, Philippe de Champaigne, Eustache Le Sueur, entre outros.

Muitos dos estudiosos e artistas do período concordavam que o resgate de um idealismo sincero seria o caminho para recolocar as artes nos trilhos, entretanto divergiam da proposta de Cousin, acreditando que se deveria sempre retornar ao legado dos gregos para reencontrar os fundamentos e objetivos das artes.

Um desses estudiosos, Quatremère de Quincy - um interlocutor importante para Américo e para o próprio Cousin - era categórico: "Não há dúvidas de que, em nenhuma outra parte e em nenhum outro tempo, a imitação do corpo humano encontrou circunstâncias e causas tão favoráveis a seu estudo como ela encontra nos gregos.",36

Para Quincy, como para os adeptos dessa solução predominante, a referência a J. J. Winckelmann continuava incontornável. Era ele afinal quem havia fornecido, em sua História da

34 Idem, Ibidem, p.45.

35Ver, por exemplo, o Quarto Capítulo desta Tese, especialmente o tópico sobre os Salões de Paris nos primeiros anos da década de 1860 .

${ }^{36}$ [Tradução nossa]. O excerto original segue assim: "Il est indubitable que nulle part et en aucun temps, l'imitation du corps humain n'a trouvé, comme elle en rencontra chez les Grecs de circonstances et de causes aussi favorables à son étude." QUINCY, Quatremère de. Essai sur la nature, le but et les moyens de l'imitation dans les Beaux-Arts. Paris: Treuttel et Würtz, 1823. p.234-235. 
Arte entre os Antigos (1764), o primeiro modelo geral de investigação teórica e filosófica da arte clássica - e também para com ele Cousin confessava honestas dívidas ${ }^{37}$. Sendo os gregos os primeiros visados por Winckelmann em sua investigação, pois aqueles que teriam deixado um número infinito, inequiparável de belos monumentos, sua intenção havia também sido a de se interrogar sobre "as razões e as causas do acolhimento feito à arte grega, e de sua superioridade sobre a de outros povos", para, em seguida, instruir sobre a sua essência, e oferecer lições para a prática dos novos $\operatorname{artistas}^{38}$.

Na medida em que os postulados expostos por Américo em Considerações Filosóficas eram bastante similares aos anteriores, não é de se espantar que também Winckelmann lhe fosse referência irreversível, e base maior do seu modelo especulativo. No entanto, passados exatos 100 anos da primeira publicação da história da arte do alemão, várias de suas concepções já não davam mais conta, ao menos inteiramente, das mesmas questões relançadas no tempo do jovem brasileiro, e isso em função, sobretudo, das expansões de método e dos resultados que as ciências histórica e arqueológica testemunhavam desde o início do século XIX. Com efeito, pouco a pouco no andamento do seu texto Américo se contraporá ou oferecerá leituras alternativas a algumas observações que desde Winckelmann eram tomadas como certas, mesmo no Brasil ${ }^{39}$, para explicar a supremacia grega - hipóteses como clima, religião, forma de governo, a liberdade política, a cultura do corpo e dos esportes etc. Ainda que esses pontos não pudessem ser negligenciados, em sua então suposta insuficiência em explicar a arte grega em seus fundamentos, tornava-se necessário - e o jovem o fará - se inteirar de uma bibliografia posterior, combinando-a com cursos de personalidades eminentes, com visitas regulares aos museus franceses (sobretudo o Louvre, de quem Américo era visitante de carteirinha ${ }^{40}$ ) e com o acesso a coleções estrangeiras, visitadas em seus interlúdios de estudos em Paris.

37 Cousin nutria grande respeito por Winckelmann. Ainda que sua solução proposta para o devir das artes francesas se voltasse para o passado recente da França, ele permanecia em acordo com o alemão, quando se trata da Grécia, em quase todos os pontos fundamentais da História da Arte entre os Antigos, sem dúvida o mais importante deles, a conclusão de que os gregos sempre procediam à idealização de suas figuras. Nesse sentido, Cousin havia assimilado as ideias do alemão de duas maneiras, direta e indiretamente. Direta, a partir da leitura de Winckelmann, cuja exposição aparece na parte dedicada ao belo, em seu Du Vrai, du Beau et du Bien. E indireta, quando absorvia sem restrições as ideias de Quatremère de Quincy, um dos estudiosos mais winckelmannianos da França, no início do século XIX, uma relação que o próprio Cousin não deixava de notar, quando comparar as importâncias de um e outro. .cf. COUSIN, V. op. Cit. p.180.

38 WINCKELMANN, J. Histoire de l'art dans l'antiquité. Paris: Librairie générale française, 2005. p.224-225.

39Ver, por exemplo, a aceitação que Félix-Émile Taunay havia feito dessas causas, em: DIAS, Elaine. P.84 e seguintes.

40 É significativo, por exemplo, que Américo tenha feito carteirinha regular para cópias de obras e acesso ao Museu do Louvre durante todo o período de sua estadia em Paris, renovando-a ininterruptamente. 
O Museu do Louvre e o Museu Britânico foram, de fato, lugares insubstituíveis para o contato direto com o seu objeto de estudo. Num período em que os franceses e os ingleses ainda disputavam e mesmo partilhavam entre si as obras obtidas em excavações - legais ou não - na Grécia, Egito ou no Oriente Médio (sobretudo nos atuais territórios do Irã e do Iraque), seus dois museus capitais eram concebidos como as vitrines mais completas para a compreensão da "evolução" da arte ocidental antiga, que por muito tempo se imaginou ter nascido na "infância" dos Egípcios, encimado no "apogeu" dos Gregos e se extendido à "decadência" dos Romanos. Tratavase de um legado que, durante os anos de Américo na Europa, era precisamente reavaliado, a partir das descobertas das antigas cidades bíblicas de Nínive e Korshabad. Além das incontáveis estátuas (entre elas, algumas célebres, como as das Vênus), bustos e sarcófagos, o jovem sabia que para se ter a ideia mais completa do legado figurativo dos mais importantes templos clássicos existentes, e o maior deles o Parthénon, era justamente no Louvre e mais ainda no Museu Britânico - onde espólios complementares estavam depositados -, que ele deveria ir, e não necessariamente a Atenas.

Essas instituições concentravam, além disso, peças fundamentais para a compreensão da interação e significado das culturas antigas ${ }^{41}$. Por conseguinte, eram lugares que reuníam os principais especialistas em história, arte e arqueologia antigas, muitas vezes os mesmos responsáveis pelas escavações, catalogações e traduções dos artefatos "descobertos", que dava vazão às suas pesquisas em textos, conferências e cursos.

Em Paris, ambas as formas de resultados convergiam à Biblioteca Imperial de França ${ }^{42}$, com a qual o Palais Royal e o Louvre faziam outro dos vários eixos simbólicos importantes da cidade, instituições distantes em poucos minutos a pé umas das outras e, portanto, facilmente acessíveis ao jovem Américo em seus estudos comparativos.

Boa parte da bibliografia que ele escolherá para produzir suas Considerações Filosóficas era resultado desses trabalhos contínuos de especialistas, realizados desde o início do século XIX, que, no entanto, reatualizando ou contrapondo entre si várias das conclusões anteriores a respeito dos antigos, mantinham-se fiéis, ao menos do que dizia respeito às suas investigações artísticas, ao fundamento propositivo de Winckelmann, isto é, às perguntas que indagavam as causas da superioridade das artes entre os gregos.

41 Com efeito, considere-se apenas uma obra-chave para o desvendamento do alfabeto e parte da cultura egípcia, a pedra de Roseta, que havia passado das mãos dos franceses, no início do século XIX, para as dos ingleses, onde Américo pôde ainda ver em 1862, e em 1864, nas duas visitas que faz então ao Museu Britânico, ou ainda os exemplares que permitiram, nos anos 1850 e 1860, a tradução da escrita cuneiforme dos assírios.

42 Uma ordem emitida por Napoleão III instituía a Biblioteca Nacional deveria possuir um exemplar de todos os livros publicados na França, envio que incluía as publicações retroativas em duplicata nas bibliotecas provinciais. A política napoleônica incluía ainda enorme aquisição de livros recentes extrangeiros e obras raras. 
Em extensão a esses resultados, Américo seguirá, em 1863, um já tradicional curso de arqueologia clássica oferecido por Charles Beulé (1826-1874), arqueólogo ${ }^{43}$ e secretário perpétuo da Académie des Beaux-Arts a partir de 1862, curso no qual fazia defesa do legado grego e, como era de se esperar, inteiramente contra a reforma da École des Beaux-Arts, contra a relação da "alta arte" com a indústria, e contra a formação de Salões paralelos oficiais que colocavam em xeque a autonomia da instituição da qual era porta-voz.

A despeito da discordância pessoal de Américo quanto ao aspecto negativo que o arqueólogo percebia naquelas reformas, o curso de Beulé era ainda bastante vantajoso a seus propósitos teóricos, na medida em que lhe trazia reflexões ulteriores de um respeitado estudioso da arte grega às suas leituras, além de um primeiro modelo atualizado de aplicação das circunstâncias do apogeu entre os clássicos em favor do desenvolvimento da "arte moderna", especialmente a brasileira. Também para Beulé, o passado explicava e antecipava o presente, e não poderia ser de forma alguma negligenciado ${ }^{44}$.

Entre os demais cursos que provavelmente o jovem seguiu durante sua primeira formação européia $^{45}$, a partir dos registros e informações por ele apresentadas, seria entretanto aquele

43 Beulé, na qualidade de bolsista da Escola Francesa em Atenas, descobrirá em 1853, a escadaria e o portão principal da Acropóle, refeito durante o século III D.C., então batizada de porta Beulé.

44 No curso de 1858, um dos poucos que pude ter acesso integralmente (além dos de 1857 e 1856), Beulé reitera o interesse do seu curso como uma aplicação das causas antigas em favor a um uso contemporâneo: "Nós tomamos o hábito de nos engajar, no dia de nosso primeiro encontro [em 1856], com coisas do tempo presente, comparando-as com as do passado, comparação instrutiva, que dá à arqueologia um caráter prático e militante". BEULÉ. Cours d'archeologie. Discours d'ouverture à la Bibliothèque Imperiale. Paris: Typhographie de Firmin Didot Frères, Fils et Cie, 1858. p.6-7.

45 Julgo improvável, por exemplo, que Américo também não tenha frequentado, ou ao menos visto, algumas aulas do curso de história e de antiguidades, ofertado a partir do primeiro semestre de 1863 (e durante vinte anos), por Léon Heuzey (1831-1922). O curso deste estudioso "nascido de uma prática organizada em torno das vestimentas [antigas, sobretudo gregas], encontrou seu coroamento na demonstração viva: 'ele cria a lição sobre a vestimenta antiga feita com o modelo vivo. A cada verão, o mestre resumia suas lições do ano fazendo aparecer no palco e vestindo-se ele próprio, com seus dedos hábeis e leves, seja como um egípcio, um caldeu, um assíroi, seja como um soldado grego ou uma tanagréenne, um legionário ou um senador romano."'. INSTITUT NATIONAL D'HISTOIRE DE L'ART. Dictionnaire critique des historiens de l'art. Verbete: Léon Heuzey. Disponível Online:

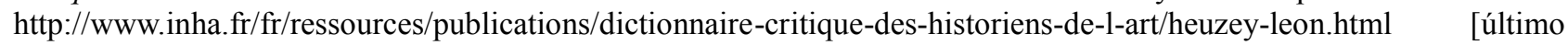
acesso, julho de 2015].

Uma lista de cursos livres oferecidos apenas dentro da École des Beaux-Arts, fornece uma ideia de conhecimentos que estavam disponíveis gratuitamente a qualquer pessoa interessada, sem necessidade de se submeter ao concours des Places. Os cursos da seção de pintura e escultura abertos para o semestre de inverno de 1861 [o qual, como visto, Américo não seguiu como aluno regular, embora pudesse frequentar as lições] eram:

Segunda, 18 de outubro de 1861, abertura do curso de anatomia, professado por M. Robert, membro da Escola de Medicina. Todas as segundas e sextas.

Em 26 de novembro de 1861, abertura do curso de matemáticas, professado por Francoeur [direcionado sobretudo aos alunos de arquitetura]; Todos as terças e sábados, ao meio-dia.

Em 12 de dezembro de 1861, abertura do curso de perspectiva, professado por Constant Dufeux. Todas as segundas e quintas, às $13 \mathrm{~h} 30$.

Em 11 de Janeiro de 1862, bertur do curso de teoria da arquitetura. Todos os sábados, às $13 \mathrm{~h} 30$. 
ofertado justamente pelo reformador Viollet-le-Duc, no começo de 1864, algum tempo após o de Beulé, que lhe oferecia outro modelo imediato sobre a causa da superioridade dos gregos, inteiramente adequado a seus interesses ${ }^{46}$. Viollet-le-Duc era, também ele, defensor de uma tal busca. Pois "do conhecimento dessas causas emerge um aprendizado filosófico necessário a todo artista sério nos tempos em que vivemos." ${ }^{47}$ Era ainda bastante favorável ao estudo da história para o conhecimento e projeção do futuro, tal como pensava Beulé, mesmo se seus postulados e conclusões seguissem caminhos bastante distintos ${ }^{48}$.

Será dialogando especificamente com e respondendo pari passu às lições aprendidas na primeira cadeira de Estética e História das Belas Artes da École des Beaux-Arts que Américo organizará as grandes questões do seu texto ${ }^{49}$. Parece ser de fato a estruturação desse curso, como consequência de um novo contexto institucional na França, uma das circunstâncias responsáveis pela mudança de tom do próprio estudo de Américo, que passava, como visto, de observações gerais sobre a importância dos estudos arqueológicos, bastante próximo assim do curso de Beulé, a um estudo filosófico sobre as belas artes entre os antigos, no qual o comentário à arqueologia não é o centro, mas um de seus vários braços.

O conhecido ineditismo do curso de Viollet-Le-Duc e o que ele significava para a renovação do panorama de ensino oficial das artes francesas era de tal modo encarado analogamente por

Em 16 de janeiro de 1862, abertura do curso de história e de antiguidades, professado por Jarry de Mancy. A partir de 1863 , é substituído, como indicado, por Léon Heuzey. Todas as quintas, às $15 \mathrm{~h}$.

No mesmo dia, abertura do curso de história da arquitetura, professado por Louis-Hippolyte Lebas (titular) ou Albert Lenoir (suplente). Todas as quintas, às $15 \mathrm{~h}$.

LES BEAUX-ARTS. Revue Nouvelle. Trome Troisième. Du 1er juillet au 15 décembre 1861. Paris: Imprimière A.E. Rochette, p.1861. p.318

46 De início, é preciso apenas dizer que, contra a refutação de Beulé sobre reforma da École e sobre a possível relação perniciosa entre arte e indústria, o arquiteto irá defender que os próprios gregos não teriam conhecido distinção entre as duas atividades: a arte neles teria ingressado em todos os domínios da vida e em todos os seus objetos. Ver, por exemplo, VIOLLET-LE-DUC, E. E.; VIOLLET-LE-DUC, Geneviève (org.). Eugène Viollet-le-Duc. Esthétique appliquée à l'histoire de l'art. Paris: École Nationale Supérieure des Beaux-Arts, 1994 p.53-54.

47 Ibidem, Ibidem. p.26-27. O trecho original de Viollet-Le-Duc é o seguinte: "Mais il ne doit pas suffire de constater un fait; nous devons rechercher les causes qui l'ont produit, car de la connaissance de ces causes ressort un enseignement philosophique nécessaire à tout artiste sérieux dans les temps où nous vivons."

48 Um trecho significativo da fala de Viollet-le-Duc no curso da École sobre a importância do passado para a compreensão do presente e projeção do futuro: "Não a alma humana é sempre a mesma, e sempre capaz de produzir novas expresssões de seus sentimentos e dos seus pensamentos. Porém, para possuir essa virtude criativa, é necessário que dela se tenha o conhecimento exato dos trabalhos de nossos antepassados. Não que esse conhecimento deva nos levar a imitá-los servilmente, mas ele coloca à nossa disposição e nos mostra em tudo seus segredos as molas que os outras operaram antes de nós [...] E não tardaremos a reconhecer que esses segregos se reduzem todas a um pequeno número e princípios" [tradução nossa] VIOLLET-LE-DUC, p.27.

49 Os três primeiros estudos apresentados por Américo apresentam forte afinidade de conteúdo com as primeiras classes dadas por Viollet-le-duc, que pôde assistir antes de seu retorno ao Brasil. Entretanto, é visível como, de um momento ao outro do texto, Américo deixa de acompanhar as questões apresentadas nesse curso para dialogar, abertamente (pois ele próprio admite), nos Capítulos 4 e 5, com as ideias expressas em livro de outra personalidade importante do cenários artístico-político francês, Émeric-David. 
Américo em seu texto, a ponto de defender que a sua versão também se tratava de uma contribuição original à língua portuguesa, dado que parece assim reforçar novamente a percepção de Considerações Filosóficas como um primeiro curso impresso de história da arte, estética e arqueologia, isto é, um trabalho que pré-anunciava o preenchimento da lacuna deixada dez anos aberta na AIBA:

Convencidos de que, lembrando este gênero de estudos aos nossos jovens compratiotas, poderíamos prestar-lhes tal qual serviço, empreendemos para isto escrever como nos fosse possível, e sem a pretensão de nos apresentar como arqueólogo ou como escritor diante das ilustrações literárias do Brasil, submetemos estes estudos sobre as belas-artes entre os antigos, fruto de muitas horas passadas no Louvre, na Biblioteca Imperial de Paris, e no Museu Britânico, ao juízo indulgente dos homens de talento, que aplaudem a intenção e a ideia, quando falta o fundo e a forma, em um trabalho semelhante a este, que, talvez sem precedente do mesmo gênero em nossa língua, não deixa de apresentar uma certa dificuldade, sobretudo para mim, que mais conheço o uso das linhas e das cores, que o das palavras e da pena. ${ }^{50}$

Outras aproximações, dificilmente não intencionais, são relevantes. Américo iniciava a publicação do seu estudo quando, já tendo frequentado havia alguns meses o curso de Viollet-LeDuc, o arquiteto também havia lançado o seu à publicação na França e o encaminhava então à impressão das últimas lições ${ }^{51}$. O jovem formatava seu estudo em sete lições (somado de uma introdução, isto é, a parte arqueológica referente às antigas Observações Gerais, e de uma conclusão, que se tratava de sua teoria para as artes no Brasil), mesmo número de aulas preparado pelo francês até o encerramento do seu curso, logo antes de sua saída, devido à pressão exercida pelos alunos que eram contra a reforma da $E^{\prime} c o l e^{52}$. Por fim, seguirá um mesmo roteiro geral (que não deixará no entanto de incorporar roteiros internos específicos) e ainda, precisamente, os mesmos objetivos do curso de Viollet-le-Duc ${ }^{53}$, na raiz winckelmanniana expandida: o francês

50 AMÉRICO, P. op. cit. p.67. Ou: Correio Mercantil, Rio de Janeiro, 29 de setembro de 1864, p.2.

51 Viollet-Le-Duc iniciava seu curso semanal em 29 de Janeiro de 1864, sexta-feira, e o encerra em 18 de março do mesmo ano, numa sequência quase ininterrupta. A publicação dos cursos, sob o título de "Esthétique appliquée à l'Histoire de l'Art. Cours de M. Viollet-Le-Duc. (École des Beaux-Arts), era feita na Revue des cours littéraires de la France et de l'étranger. A primeira lição era impressa na edição e 27 de fevereiro de 1864. Era retomada e seguida pelas demais nas edições de 23 de abril, 11 de junho, 2 de julho, 9 de julho, 30 de julho, 01 de outubro, e 08 de outubro.

52 Alguns autores interpretaram que Viollet-le-Duc havia interrompido seu curso após a sétima aula, em função dos protestos dos alunos. $\mathrm{O}$ arquiteto, no entanto, em carta a amigos, havia confessado que as sete aulas era o número assinado em contrato para o módulo do curso. Ver: VIOLLET-LE-DUC, Geneviève (org.). Eugène Viollet-le-Duc. Esthétique appliquée à l'histoire de l'art. Paris: École Nationale Supérieure des Beaux-Arts, 1994. p.153

53 Resumida, a proposição de Viollet-le-Duc em seu curso era a seguinte: estudo das questões gerais que tocam todas as artes, a análise das obras-primas das melhores épocas, suas relações ou diferenças, e a busca pelas causas que produziram certos resultados importantes. Ver: Idem, ibidem, P.13. Mais à frente, ainda sobre os objetivos do curso, ele 
iniciava seu curso com as recentes teorias filológicas e raciais que levariam ao "descobrimento" da arte arte hindu como berço da arte e civilização ocidentais ${ }^{54}$ (em sua época,Winckelmann nunca poderia ir tão longe), ingressando em seguida no "marco zero" tradicional da arte egípcia (com rápidos comentários sobre a assíria), depois a grega e a romana. Américo, por sua vez, iniciava seu roteiro com as recentes descobertas das artes assírias ${ }^{55}$, encaminhando-se então ao Egito (com breves pinceladas sobre os hindus ${ }^{56}$ ), Grécia e Roma. De um modo ou de outro, em suas vicissitudes, permanecia em ambos a certeza de que a "crítica histórica" repousava na concordância da "autoridade dos livros, das tradições e dos monumentos de arte", elementos que, com método, "dotam a história de uma clareza inextinguível" "57, fazendo aparecer suas leis.

O jovem, todavia, efetuava uma inversão prorporcional de fins em relação a Viollet-Le-Duc; aliás, em relação a quase toda bibiografia francesa dedicada ao assunto: se para esta, a educação teórica, obrigatória e indistinta dos estudantes de arquitetura, escultura e pintura em Paris era uma maneira de formar artistas sábios e assim reencontrar o passado glorioso das artes francesas (era portanto uma retomada ao "caminho sadio"58), para Américo, tratava-se de preparar as bases intelectuais e teóricas ainda inexistentes de uma futura Escola Brasileira, mas com um agravante: no Brasil, educar artistas e artesãos significava, como ele bem sabia, lutar contra o conhecido preconceito estabelecido contra essa classe, em sua tradicional desvalorização diante da classe bacharelesca, o mesmo cujo rastro o levava aos tempos coloniais, instalados com o trabalho manual escravo.

afirmava que não bastaria constatar o fato da perfeição das artes gregas, mas que se deveriam buscar "as causas que o produziram, porque do conhecimento das causas surge um ensino filosófico necessário a todo artista sério no tempo em que vivemos." Idem, ibidem. p.26-27.

54 Sobre a tese a respeito do vínculo arianista com a raíz hindu, ver: JARRASSÉ, Dominique Jarrassé "Trois gouttes d'art nègre. Gobinisme et métissage en histoire de l'art." In: Histoire de l'art et anthropologie. Paris, coédition INHA / musée du quai Branly (« Les actes »), 2009. Disponível online em: http://actesbranly.revues.org/96 [último acesso: 11 de outubro de 2015].

55 Essa única troca, ao que tudo indica, parece vir do desconhecimento (ou do conhecimento superficial) de Américo sobre a arte Hindu, lacuna que tratará de preencher. O programa do seu curso de história da arte, estética e arqueologia na AIBA, aberto em 1870, será iniciado justamente com a arte Hindu. Com relação à bibliografia que utilizará para a produção de seu Considerações Filosóficas, a referência ao livro de De Rouen servirá de complemento a Viollet-Le-Duc, e ao que Americo que compreende serem as características gerais da arte Hindu. Ver: E. LÉVI, DE ROUEN. Étude philosophique sur l'architeture [Étude philosophique sur l'architecture. Mémoire en réponse à la question suivante: Rechercher l'enchainement des diverses architectures de tous les âges, et les rapports qui peuvent exister entre les monuments et les tendances religieuses, politiques et sociales des peuples]. Bruxelles: J.-A. Tircher, 1859.

56 AMÉRICO, P. op. cit. p.100. Ou: Correio Mercantil, Rio de Janeiro, 3 de outubro de 1864, p.2.

57 AMÉRICO, P. op. cit. [“Descobrimentos Arqueológicos...”], p.65-6. Ou: Correio Mercantil, Rio de Janeiro, 29 de setembro, p. 2 .

58 Segundo Viollet-Le-Duc, "nossa missão aqui não é a de formar arqueólogos, nem sábios críticos das coisas do passado; nós devemos buscar antes de tudo produzir e cultivar artistas, artistas práticos, que dêem à artes do nosso século um esplendor digno dele, e dos seus precedentes". [tradução nossa]. VIOLLET-LE-DUC. Op. cit. p.12. 
As Considerações Filosóficas lidavam assim com dois passados, um presente e dois futuros: com o passado glorioso dos gregos e o passado recente da reforma da AIBA; com o presente ligado à atual reforma da École, testemunhado por Américo, e o fato eminente do seu retorno ao Brasil; e com o futuro das artes no Brasil, além do próprio futuro do jovem no país, para o qual projetava a intenção de retomar, ele próprio, as medidas reformistas iniciadas por Porto Alegre nos anos 1850, entre as quais a cadeira de história da arte urgia instalação.

\section{Áreas de reflexão}

Ao estabelecer o seu texto no limite comum da arqueologia, da história e da estética, Américo se ombreava à percepção de diversos estudiosos do período no que dizia respeito às necessárias relações entre essas disciplinas ${ }^{59}$. A arqueologia, em suas novas descobertas, esclarecia e ampliava a história, e a obrigava a se reavaliar ${ }^{60}$. A história, por sua vez, narrando os eventos passados em centenas e mesmo alguns milhares de anos, oferecia um cenário amplo no qual se supunha ser possível deduzir não apenas os percursos, mas fases bem delimitadas da humanidade. Se um ciclo significaria a repetição, em cirscunstâncias temporais distintas, de um mesmo fenômeno universal, então a história tornava-se instrumento indispensável à reflexão filosófica sobre as causas das atividades humanas. Como o que interessava a Américo era justamente desvelar as causas, os princípios ou as "leis imutáveis do belo" entre os gregos, os primeiros que as teriam encontrado completamente, ele sabia que estava também ingressando desse modo no domínio da estética; isto é, a filosofia inteira direcionada ao fenômeno artístico.

59A relação que Américo percebe entre as tres discipinas não se extingue nesse texto de 1864 , mas é levada programaticamente como atuação, na medida em que assume, após seu doutorado em ciências naturais (especificamente voltado à história da filosofia e das artes) e sua formação de pintor de história, o departamento de arqueologia do museu nacional. Sem contar,evidentemente, que ela assumia, precisamente, a cadeira de História das Belas Artes, Estética e Arqueologia, em 1870.

60 Américo de fato inicia e repete em várias páginas do seu texto a questão sobre a recente ampliação do conhecimento histórico das civilizações antigas, até pouco tempo concentrado nos gregos e romanos, e então alargado graças aos "descobrimentos arqueológicos" do fim do século XVIII (ver por exemplo fim da introdução das Considerações). $\mathrm{O}$ argumento é bastante comum, como se sabe, e encontra-se em inúmeros trabalhos que defendem a importância dos trabalhos arqueológicos durante o século XIX para a compreensão da história. Para outra das referências utilizadas por Américo, a do arqueólogo Austin Henry Layard (1817-1894), ver: LAYARD, Austen Henry. Nineveh and its remains: with an account of a visit to the Chaldean christians of Kurdistan, and the yezidis, or devilworshippers; and an enquiry into the manners and arts of the ancient assyrians. London: John Murray, 1849. Ao comentar os descobrimentos sobre os assírios realizados por Emille Botta (outra referência no trabalho do brasileiro) Layard afirmou que: "Uma nova história tinha repentinamente sido aberta para ele - os registros de um povo estavam na sua frente". Idem, ibidem. p.11. 
Américo tem de fato a certeza de que, em 1864, na versão final do seu estudo, ao percorrer a história da arte nas civilizações antigas até os romanos e ao se empenhar em lhes extrair o que têm de causal, está empreendendo fundamentalmente não um estudo em história da arte ou em arqueologia, mas um estudo em filosofia da história (da arte), ciência cuja definição precisa lhe havia sido apresentada pelo trabalho de seu futuro orientador de doutorado, Guillaume Tiberghien, com quem já está em contato desde 1862.

A filosofia, de um lado, "não busca os fatos, mas a causa e a razão dos fatos, [... a essência

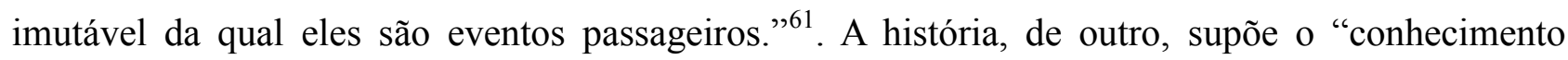
sensível, a noção dos fatos da vida, que nascem e perecem no tempo [..] em suas manifestações individuais e determinadas" $" 62$.

Filosofia e história são distintas, mas sendo ambas diametralmente opostas, e identicamente extensas, elas compartilham entre si todo o saber, formando a totalidade do sistema da ciência, já que possuíam como fim, respectivamente, "o eterno e o temporal, o universal e o particular, o princípio e o fato. Elas são entre elas o que o conhecimento racional é para conhecimento sensível”,63.

A filosofia da história, em vocabulário adequado, é uma conciliadora de ambas as ciências praticadas separadamente. É uma última "ordem de conhecimentos, o conhecimento harmônico ou aplicado que combina os fatos e os princípios". Ela se configuraria, ainda nos anos 1850, como uma:

ciência nova, da qual existem ainda apenas ensaios, ciência intermediária que [..] permite assim apreciar os fatos à luz dos princípios, de julgar os eventos da história, de criticar as instituições, de comparar o que é ou o que foi com o que deve ser, de indicar lacunas que devem ser preenchidas e indicar o caminho à seguir no futuro. Nada de mais importante para a vida individual e para a vida da humanidade em geral." ${ }^{64}$

61 TIBERGHIEN, Guillaume. Esquisses de Philosophie Morale. Bruxellas: Imprimiérie de Delevingne et Callewaert, 1854. p.28.

62 Idem, ibidem. p. 28.

63 Idibem, ibidem. p.28. Sobre a ideia da filosofia da história que une a "filosofia pura" à "história pura" no "ponto de vista dos princípios aos fatos", ver ainda, na mesma obra, a p.42.

64 Idem, ibidem. p.29. O excerto original é o seguinte: “C'est là le fond d'une science nouvelle, dont il n'existe encore que des essais, science intermédiaire qu'on appelle la philosophie de l'histoire, et qui comprend aussi la philosophie de l'histoire de l'humanité. Elle a pour objet d'appliquer, dans tous les domaines de la vie, les principes aux faits, et permet ainsi d'apprécier les faits à la lumière des principes, de juger les événements de l'histoire, de critiquer les institutions, de comparer ce qui est ou a été avec ce qui doit être, d'indiquer les lacunes qu'il faut remplir et de donner la marche à suivre dans l'avenir. Rien de plus important pour la vie individuelle et pour la vie de l'humanité en général". 
Da origem geograficamente inscrita das artes e de sua história a um destino desejosamente localizado no Brasil (fazendo permanecer entre eles o que é necessariamente constante para o porvir das artes), Américo inserirá o roteiro do seu texto, à luz da explicação de Tiberghien, naquele domínio intelectual ${ }^{65}$. Um estudo no qual as possíveis fórmulas que lhe são impostas aceitariam com generosidade as três disciplinas que a ele tanto interessam, na qualidade de pintor que traça a si uma via de erudição. São elas o fundo de reflexão que deve utilizar para estruturar sua teoria e preencher, no futuro, a lacuna que as artes ainda não ocupam devidamente no Brasil.

\section{O método eclético}

Saber o tipo de investigação que se quer empreender não significa no entanto resolver o problema de como fazê-lo, isto é, o problema do método. E é nesse sentido que a sugestiva indicação de Tiberghien, na qual a filosofia da história aparecia como uma perfeita mediadora da filosofia e da história "puras" levaria Américo, quase sem esforço, de volta aos conhecidos procedimentos conciliatórios pregados pelo ecletismo de Victor Cousin.

Cousin, deve-se lembrar, não era um professor de filosofia da história, mas de uma disciplina especular, história da filosofia, e, assim, grande parte de suas reflexões vinham da prática e procedimentos requeridos a essa cadeira. Recusava-se a perceber o ecletismo como uma doutrina filosófica em si: de fato, ele não apresentava nada de novo em substância. Em contrapartida, era precisamente em relação ao método que estava a particularidade e o esforço de sua contribuição, de modo que se apresentava para ele próprio como o "coração do seu trabalho"66.

Se no cerne da sua pesquisa estava o método, no seio do método estava a história ${ }^{67}$, especialmente a história das diferentes doutrinas filosóficas estabelecidas pela humanidade, operação que o ecletismo enuncia sutilmente já em nome. "O ecletismo [afirma Cousin] é, a nosso

${ }^{65}$ Ao fim do seu trabalho, Américo confessava, com efeito, que a compreensão das causas da grande arte só havia sido para ele possível possível por meio do aporte da "história filosófica"AMÉRICO, P. op. cit. Conclusão. p.188. Ou: Correio Mercantil, Rio de Janeiro, 25 de dezembro, p.1.

66 "Esse livro contém portanto a expressão resumida, mas exata, de nossas convicções sobre os pontos fundamentais da ciência filosófica. Nele será descoberto o método que é a alma do nosso empenho, de nossos princípios, de nossos procedimentos, de nossos resltados." [Tradução e grifo nossos] No original: "Ce livre contient donc l'expression abrégée mais exacte de nos convictions sur les points fondamentaux de la science philosophique. On y verra à découvert la méthode qui est l'âme de notre entreprise, nos principes, nos procédés, nos résultats." COUSIN, Victor. Op. cit. p.VI.

67 Sobre a relação de Cousin com a história no período da Monarquia de Julho, e sua relação específica com a produção artística do período, ver: BOIME, Albert. Thomas Couture and the eclectic vision. London: Yale University Press, 1980, Especialmente p. 15 e seguintes. 
ver, o verdadeiro método histórico, e tem para nós toda a importância da história da filosofia; mas há algo que nós colocamos acima da história da filosofia, e por consequência, do ecletismo: é a própria filosofia." $" 68$

Um dos postulados-base é que nenhum dos sistemas estabelecidos desde a antiguidade clássica até a modernidade é, em si, equivocado. Ao contrário, todos são verdadeiros, mesmo que nenhum, em suas limitações e pontos de vistas particulares ${ }^{69}$, o tenha sido completamente. Se, desde Sócrates, mais de dois mil anos de reflexão constante de ilustres não foram capazes de fundar em um único sistema infalível todas as ideias universalmente válidas da filosofia (a ideia do verdadeiro, do belo e do bem), não caberia ao filósofo do século XIX (e por extensão ao artistafilósofo) propor mais uma nova doutrina. De posse do moderno instrumento histórico, ele deveria se voltar em alternativa a todos aqueles já constituídos e realizar uma espécie de filosofia da filosofia, para purificá-los de suas imperfeições. Deveria encontrar a verdade total na junção do quebra-cabeça de verdades fragmentadas, pois toda ciência apenas seria ciência se atingisse as verdades universais.

Da certeza do dever desse novo filósofo surgia a necessidade do ecletismo como aparato de síntese específica, distinta, segundo compreendia Cousin, do sincretismo de base alexandrina. Este sintetizaria "cegamente" opostos que não aceitariam aproximação, ao passo que o ecletismo, pautando-se na razão lúcida, se esforçaria em conciliar apenas sistemas conciliáveis, e assim, sem prejuízos $^{70}$.

O projeto seria sempre possível posto que mesmo as escolas de início bastante distintas guardariam com frequência pontos de união. Todas as "escolas modernas" do século XVIII, por exemplo, a despeito de suas diferenças de resultados e postulados (entenda-se o sensualismo da escola inglesa, e o idealismo da escola alemã) permaneceriam em perfeito acordo no método que

68 [tradução nossa] No original: "L'éclectisme est à nos yeux la vraie méthode historique, et il a pour nous toute l'importance de l'histoire de la philosophie; mais il y a quelque chose que nous mettons encore au-dessus de l'histoire de la philosophie et par conséquent de l'éclectisme : c'est la philosophie elle-même.”. Idem, ibidem. p. 14.

69 Idem, ibidem. p.10. Mais à frente, já na parte sobre o "Bem" do seu estudo, Cousin será ainda mais enfático: "Les systèmes philosophiques ne sont pas la philosophie; ils s'efforcent d'en réaliser l'idée, comme les institutions civiles s'efforcent de réaliser celle de la justice, comme les arts expriment de leur mieux la beauté infinie, comme les sciences poursuivent la science universelle.

Les systèmes philosophiques sont nécessairement imparfaits, sans quoi il n'y en aurait jamais eu deux dans le monde.”. Idem, ibidem. p.274.

70 Idem, Ibidem. p. 10. 
empreendiam, centrado na análise do pensamento $^{71}$ e guiado pela seguinte pergunta: afinal, as ideias são aprendidas pela experiência sensível ou inatas?

A questão era fundamental para Cousin, porque seria precisamente no par oposto sensualismo/idealismo que ele estruturava o devir de uma filosofia que deveria ser sempre espiritualista, isto é, uma que consideraria os sentidos, mas os submeteria ao espirito e à razão ${ }^{72}-$ faculdade que, entre todas as capacidades do homem, seria direta e singularmente herdada de Deus.

A ideia, enquanto revelação da "verdade total", existe, para ele, com ou sem a presença do homem: ela existe a priori como qualidade inerente a Deus, e é para lá que todos deveriam se dirigir, guiados pela mesma razão, por meio da experiência sensível no tempo e espaço (as condições psicológicas da existência humana no mundo). O postulado permitia perceber sem dificuldades o quanto Cousin fundava sua filosofia próxima do idealismo platônico ${ }^{73}$ (e Platão era confessadamente um dos maiores pilares de suas reflexões ${ }^{74}$ ), num lastro que também passava, no que dizia respeito a algumas de suas concepções artísticas, pelos neoplatonismos renascentista ${ }^{75}$ e maneirista $^{76}$.

Se a filosofia deveria se pautar na razão para atingir seu fim, que seria a ideia, era evidente, por conseguinte, seguindo a mesma perspectiva, que a arte deveria seguir o mesmo caminho, enquanto atividade dedicada exclusivamente à produção estética do belo, ao lado do qual, como dito, estão, na tríade platônica, o bem e o verdadeiro.

Novamente, era isso que Cousin desejava propiciar com o ecletismo: os procedimentos filosóficos necessários para se atingir à ideia seja através do bem, do belo e do verdadeiro (isto é, por meio da atividades moral, estética e jurídica). Em outras palavras ainda, o ecletismo era um

71 "Je ne me propose ni d'attaquer ni de défendre aucune des trois grandes écoles qui partagent le XVIII siècle; je ne chercherai point à perpétuer et à envenimer la guerre qui les divise, en signalant complaisamment les différences qui les séparent, sans tenir compte de la communauté de méthode qui les unit. Je viens, au contraire, soldat dévoué de la philosophie, ami commun de toutes les écoles qu'elle a produites, offrir à toutes des paroles de paix. L'unité de la philosophie moderne réside, comme nous l'avons dit, dans sa méthode, c'est-à-dire dans l'analyse de la pensée, méthode supérieure à ses propres résultats, car elle contient en elle le moyen de réparer les erreurs qui lui échappent, et d'ajouter indéfiniment de nouvelles richesses aux richesses acquises." [grifo nosso]. Idem, ibidem. p.9.

72 Ver, entre numerosas passagens de Cousin sobre o assunto, ver: COUSIN, V. op. Cit. p.VII; p.13, p.19, p.25-29, p.42, p.49, p.56, p.71, p.72 etc.

${ }^{73}$ Para um panorama esclarecedor das bases de formação da filosofia de Victor Cousin, ver: WILL, Frederic. Flumen historicum, Victor Cousin's aesthetic and its sources. Chapel Hill: University of North Carolina press, 1965.

74 Idem, ibidem, ,p. 15.

${ }^{75}$ Ver: PANOFSKY, E. Estudos em iconologia. Lisboa: Editorial Estampa, 1995, especialmente os capítulos V e VI: "O movimento neoplatônico em Florença e no norte da Itália" e "O movimento neoplatônico e Michelangelo".

${ }^{76}$ Ver: Idem. Ideia: contribuição à história do conceito da antiga teoria da arte. São Paulo: Martins Fontes, 2000. Em especial, o capítulo "O 'Maneirismo"”. Pp.71-79. 
método (uma aplicação útil, ele também dizia ${ }^{77}$ ) que aspirava permanentemente a um idealismo filtrado num movimento de concilição de opostos parcialmente verdadeiros, contudo sempre conciliáveis.

Com essa ferramenta estruturada por Cousin, Américo acreditava dispor, enfim, de um plano de ação possível para o domínio intelectual esclarecido por Tiberghien.

Mas cabe dizer que as lições mestras (ou, nesse caso, um adequação) sobre a possibilidade desse empreendimento nas artes não se encerrava naqueles dois filósofos: era nova e sugestivamente Viollet-le-Duc quem iria, por fim, em 1864, coroar o problema e sugerir ao jovem que ele continuava na via correta.

Viollet-le-Duc, um liberal criado na Monarquia de Julho - que fez ele próprio acolher e difundir a filosofia de Victor Cousin -, lembrava e reforçava no jovem o que este já tencionava em suas investigações desde sua defesa à reforma da École des Beaux-Arts. Era preciso, também segundo o arquiteto, em conformidade ao filósofo francês, e ainda em acordo com as palavras de Porto-Alegre na posse da AIBA, afastar "todo sistema preconcebido, toda doutrina absoluta, e carregar a coragem paciente do anatomista que busca em um cadáver os segredos da vida."78

Para um bom entendedor do ecletismo isso era suficiente para compreender que Viollet-LeDuc, falando no centro do impressionante Semicírculo da École, "ecleticamente" pintado por Delaroche, tentaria convencer a platéia, e depois os leitores do curso em sua versão impressa, que o método eclético (o verdadeiro "método histórico") era válido não somente para a especulação filosófica, mas para toda atividade que se amparasse na filosofia, enquanto ciência que buscava as verdades universais, nisso se incluindo as produções artísticas. De fato, não se deve esquecer que o arquiteto queria formar "artistas sérios", para os quais o conhecimento filosófico era absolutamente indispensável. Afinal, se um produto é realizado por um método filosoficamente infalível, não importa a sua forma - um texto, uma escultura, uma pintura, um poema -, ele será sempre verdadeiro $^{79}$.

A prova apresentada, presumivelmente irrefutável, retomava justamente o sistema dos clássicos: eles próprios haviam desenhado a sua supremacia artística a partir de um método bastante

77 COUSIN, op.cit. p.VI-VII.

78 "Il faut l'entreprendre sans préventions, em éloignant tout système préconçu, toute doctrine absolue, et y apporter le courage patient de l'anatomiste qui cherche dans un cadavre les secrets de la vie." VIOLLET-LE-DUC, E. E. op. Cit. p.14.

79 Idem, ibidem. p.53. 
similar, senão idêntico ao eclético ${ }^{80}$. Ou, o que seria mais adequado, os ecléticos franceses, na sucessão dos tempos, haviam redescoberto o mesmo e verdadeiro método que os gregos já haviam conhecido e empregado na totalidade de suas atividades, levando-os, assim, à formação da "verdadeira" república, de uma filosofia e arte exemplares e perenes. Antes de qualquer um, eles haviam demonstrado que a arte seria uma só (era a ideia), mas ela (como a ideia), poderia tomar emprestado as mais distintas linguagens e formas para se fazer perceber/entender ${ }^{81}$.

Não apenas essa prova, mas as evidências apresentadas por Viollet-Le-Duc também estavam insistentemente pegadas aos procedimentos cousinianos. Como os modernos ecléticos, os "ecléticos" gregos não teriam inventado nada de novo no que dizia respeito à gramática visual e conteúdo de suas obras. Ao contrário, teriam tomado tudo emprestado dos povos vizinhos, mais antigos que eles $^{82}$, uma herança desse modo também histórica, que eles haviam potencializado por terem ainda sido os primeiros a introduzirem a "arqueologia na arte" ${ }^{, 83}$.

Os gregos teriam, com efeito, ensinado o verdadeiro procedimento de sua grandeza: "procurar nas diferentes formas sucessivamente adotadas pelo espírito humano e meditar sobre essas formas para encontrar uma nova inspiração" ${ }^{\circ 4}$ (esta, uma outra leitura igualmente presente na pena de outros escritores acessados por Américo ${ }^{85}$ ). Eles teriam fundado sua arte sobre uma busca incessante de síntese de elementos que, entretanto, não haverá surpresas, se operaria unicamente a partir de opostos conciliáveis ${ }^{86}$, tendendo sempre à simplicidade, clareza e unidade das partes e do todo, e, por conseguinte, da ideia. Com tal conduta, teriam inagurado, naturalmente, outro procedimento: criaram o verdadeiro racionalismo ${ }^{87}$ na arte, algo que já existiria embrionária mas

80 “O trabalho do espírito grego não é somente uma espécie de ecletismo; é antes de tudo uma análise de materiais diversos com os quais ele se depara, porque, ao lado da inclinação de tomar de todos os lugares o que lhe agrada, há uma impressionante potência de assimilação". [grifo e tradução nossos] Idem, ibidem. p.50.

81 Idem, ibidem. p.26; p.53. A mesma ideia sobre a arte como atividade única que se modifica apenas sensivelmente encontra-se em outros autores lidos por Américo. Ver, por exemplo: SUTTER, J-.D. Esthétique Générale et appliquée contenant les règles de la composition dans les arts plastiques. Paris: Imprimerie Impériale: 1865. P.11; et LAPRADE, Victor de. Questions d'art et de morale. Paris: Libraire académique, 1861. p.21.

82 VIOLLE-LE-DUC. Op cit.. p.52.

83 Ibidem, ibidem. p.59. Nesse ponto, é fácil perceber que na suposição cabal de que arqueologia, história e filosofia andassem juntas desde os gregos, Viollet-le-Duc justificasse a importância renovada dessas disciplinas no período, a mesma presente, conforme citado, na criação da cadeira da AIBA e, conforme citado, no texto de Américo.

84 Idem, ibidem. p.53.

${ }^{85}$ SUTTER, DAVID. Philosophie des Beaux-Arts apliquée à la peinture. Paris: Jules Tardieu, 1858. p.78 : "Le génie ne crée rien, à proprement parler; il s'approprie les faits, il les combine, il saisit les rapports, il choisit, il imite, et ne va point au delà."

86 Idem, ibidem. p.62. Um dos exemplos oferecidos por Viollet-Le-Duc sobre a tendência dos gregos de nunca tentarem conciliar dois elementos antagônicos, irreconciliáveis, está na dedução a partir da qual os gregos teriam percebido ser impossível fundir em uma unidade artística os princípios da Plate-bande que haviam descoberto com os pelasgos com aquele do arco.

87 Uma outra referência bastante importante a Américo, Victor de Laprade (1812-1883), cujas reflexões se assemelham em muitos pontos às de Viollet-Le-Duc, postularia de fato que a criação da filosofia se trataria da grande 
imperfeitamente nos egípcios ${ }^{88}$. Pela mediação da razão, base operatória da filosofia, elevaram e purificaram elementos dispersos e inacabados ${ }^{89}$, num percurso que iria sempre do real ao ideal ${ }^{90}$.

Teria sido com essa capacidade de fundir racional e convenientemente elementos distintos que os gregos conseguiram, enfim, ainda segundo Viollet-Le-Duc, estabelecer suas ordens arquitetônicas $^{91}$ e, em seguida, outra série de leis móveis para as suas produções, como as regras da harmonia e da proporção ${ }^{92}$ (as mais importantes delas, de um lado, o módulo da arquitetura, e de outro, o paragón da escultura).

Durante todo o seu curso, Viollet-Le-Duc repete e retoma essas observações: síntese justa de elementos herdados ou buscados, exercício constante da razão refletida, busca por um ideal: estariam aí, nos gregos, as ações, mas não exatamente as causas, que os teriam levado à verdade por meio de um método também eclético: procedimento necessário à perfeição das artes, e que aguardava ser retomado mais uma vez pelos jovens alunos que o escutavam na instituição recémreformada. Afinal, "o método sintético podia sempre ser empregado"93.

\section{Método e materiais de Considerações Filosóficas}

Após Viollet-le-Duc, Cousin e Porto Alegre, não parecia ser mais preciso a Américo procurar alternativas procedimentais. Era, assim, sobre a linha eclética, que ele estruturava toda a argumentação de suas Considerações Filosóficas.

Primeiro: o jovem ancorava suas reflexões em um terreno artístico no qual a razão e a ideia deveriam imperar. A arte, como será visto, possuía, também para ele, um fim idealista. Enquanto atividade intelectual que necessitaria (da) e se uniria à atividade manual, ela deveria ser amparada por um sistema filosófico que lhe fosse contíguo, tarefa à qual o ecletismo espiritualista se prestava quase perfeitamente ao jovem, sempre reforçado pela escolha cautelosa de uma bibliografia que também assume uma perspectiva permanentemente idealista para o devir das artes.

glória dos gregos, "precisamente porque essa filosofia não é nem o ceticismo, nem o panteísmo", mas um espiritualismo racional. LAPRADE, Victor de. Questions d'art et de morale. Paris: Libraire académique, 1861. P.162.

88 Idem, ibidem. p.51, p.56, p.74, p.78, entre outras. Ainda sobre a herança egípcia que fez os gregos desenvolverem sua arte e filosofia, e a noção de que estes nunca as teriam separado, ver outra referência fundamental a Américo: SUTTER, DAVID. Philosophie des Beaux-Arts apliquée à la peinture. Paris: Jules Tardieu, 1858. p.8.

89 Idem, ibidem. p.50.

90 Idem, ibidem. p.59.

91 Idem, ibidem. p. 63.

92 Idem, ibidem. p. 65.

93 Idem, ibidem. p. 62 
Segundo: Américo também não cria nada de novo: ele o sabia e confessava ${ }^{94}$. E não esperava mesmo que isso lhe fosse imputado, afinal, os seus estudos filosóficos lhe garantiam que os princípios gerativos da grande arte poderiam ser encontrados se se vasculhassem as suas causas, já largamente disponíveis pela história e incessantemente confirmadas com as recentes descobertas arqueológicas. Além disso, essas causas já teriam sido sistematizadas por vasta bibliografia sobre o tema, acessível sem esforço. $\mathrm{O}$ único problema era que também esses trabalhos (do mesmo modo que os sistemas filosóficos, segundo a perspectiva eclética), ainda que perseguissem os mesmos objetivos e questões universais, nem sempre estavam em acordo em seus meios e conclusões, daí a necessidade de sua mediação enquanto um juiz idealmente imparcial.

Terceiro: o que Américo deseja é, assim, efetuar uma síntese dessas pesquisas e, olhando também para a história e para a arqueologia como parte inexorável do método filosófico, assim como para as obras clássicas, descobrir quais causas defendidas por diversos autores lhe pareciam ser verdadeiras, e quais, por contraste, falsas. O horizonte da conciliação era desse modo fundamental, do mesma maneira que lhe imprescindível a premissa da transdisciplinaridade, igualmente presente nas formações das cadeiras teóricas nas academias francesa e brasileira.

O ponto de partida de Américo, deve-se lembrar, era de base setecentista. Começava em Winckelmann (1717-1768), a quem se juntaria quase ao final do trabalho Gothold E. Lessing (17291781) e Montesquieu (mas aqui, não se sabe com que profundidade, pois uma rápida citação).

Se, em Winckelmann, os opostos modernos se corporificavam na luta entre os clássicos e barrocos (num novo ciclo idêntico ao "apogeu" e "decadência" da arte antiga na Grécia e em Roma), para Américo, seguindo Cousin, a oposição reatualizada que pediria todavia não a recusa de um dos lados, mas urgente reconciliação, estava na nova rivalidade que se estabelecia entre os idealistas (estando agora juntos antigos adversários, românticos e neoclássicos) e os realistas, cujas ameaças, que haviam começado na década de 1850, haviam apenas se agravado no decênio seguinte, momento no qual o "Salão dos Recusados” seria o mais novo, mas não último capítulo.

Américo compreende os opostos sensualismo-idealismo como inerentes à história da arte. Esses dois blocos delimitariam não apenas o grau de avanço das artes de um povo (tanto maior ele seria quanto maior fosse sua dedicação ao idealismo), mas, do mesmo modo, o grau de avanço da mesma sociedade. 
A ênfase nessa oposição conduziria o jovem a uma sequência calculadamente escolhida que contemplava trabalhos pós-revolucionários de autores "opostos", como os indíspensáveis Quatremère de Quincy (1755-1849), um “idealista", e Émeric-David" (1755-1839), um "realista" uma oposição que lhe havia sido certamente mostrada pelo próprio Cousin ${ }^{96}-$, e atingia estudiosos ainda vivos e ativos, também opositores entre si política e pessoalmente, como os já citados "clássico" Charles-Ernest Beulé e o "romântico" Viollet-le-Duc.

Apenas os horizontes de questões e conteúdo de todos os autores consultados eram relativamente homogêneos (embora, do ponto de vista da conciliação, isso fosse, como visto, metodologicamente essencial), porque, de resto, o jovem inclui os mais variados formatos de contribuições que se apresentavam em forma de textos filosóficos, históricos, teóricos, romances, diários de expedição, ensaios, anotações etc. Ele procede ora a fichamentos bibliográficos alternados com análises suas, ora a traduções mais ou menos livres dos textos com distintos pontos de vista sobre os mesmos temas, preocupando-se em se contrapor pessoalmente às partes do texto de um autor com as quais estava em franco desacordo, ponto no qual, logo em seguida, por um sutil jogo de manipulação, introduzia novo pensamento de outro que corrobora suas teses. São precisamente nas traduções livres, nas inversões, nas modificações interessadas - enfim, nos momentos tectônicos do seu texto -, que a voz de Américo assim se apresenta. E como todo estudo em filosofia da arte idealista, ele inicia seu percurso do início: da história, da arte e do homem.

95 Com efeito, o trabalho mais conhecido de Émeric-David, Recherches sur l'Estatuaire. Paris: Renouard, 1863 (fonte fundamental para Américo em suas Considerações), era o resultado premiado e publicado de uma questão, um rapport portanto, que no começo do século XIX o Institut de France havia proposto: "Quais foram as causas da perfeição da escultura antiga, e quais seriam os meios de atingi-la? O trabalho de Émeric-David mereceu, por sua vez, resposta diretas de Quatremère de Quincy, que nãoconcordavam com suas respostas àquela questão.

96 cf. COUSIN, V. op. Cit. Huitième Leçon. p.174 e seguintes. 


\section{Terceiro Capítulo}

Por um teoria da arte brasileira: questões fundamentais das Considerações Filosófica sobre as Belas Artes entre os Antigos

\section{Da origem e da separação das Artes}

Um estudo que se dedique à essência e ao devir de um determinado objeto filosófico deverá eventualmente se deparar com as circunstâncias do seu início ${ }^{97}$. A certeza em Américo de que os dois extremos eram, na verdade, perfeitamente idênticos - apesar de suas vicissitudes temporais, ambas partiriam ou retornariam à mesma fonte atemporal - encontrava a mesma convicção de que a humanidade e a arte possuíam percursos e destinos indissociáveis ${ }^{98}$. Tal postulado servia de base para que o jovem iniciasse de fato suas Considerações Filosóficas, logo após concluir, na introdução do seu estudo, o panorama sobre a importância da arqueologia para o alargamento da história.

Américo não inaugurava, no contexto brasileiro, o problema da gênese das artes, mas mantinha um interesse que havia sido e continuava a ser igualmente frequentado por outros escritores nacionais contemporâneos e ainda posteriores. Ele certamente estava familiarizado com algumas dessas deduções (a mais próxima, a de Porto Alegre), e devia compartilhar com elas o conhecimento sobre a duração da questão desde a difusão do modelo winckelmanniano.

$\mathrm{Na}$ busca pela essência da arte grega, Winckelmann dedicara o capítulo inaugural da sua História da Arte à "origem da arte e das causas de sua diversidade por meio dos povos"99. A preocupação manteve-se evidentemente válida em vários trabalhos exemplares em filosofia da arte: os que compartilhavam sua raiz germânica (Herder, Schlegel, Schelling, Hegel, Schiller), e ainda aqueles francófonos (Diderot sendo certamente um dos mais conhecidos, e contemporâneo a Winckelmann).

Especialmente nesta última linhagem de trabalhos que o jovem encontrava o material reflexivo para o estabelecimento de um percurso que o levaria de volta ao nascimento das artes na antiguidade. Manejando um conjunto mais ou menos claro de autores que trataram do mesmo problema (além de Winckelmann, Quatrèmere de Quincy, Émeric-David, Victor de Laprade,

97 TIBERGHIEN, G. op. cit. p.27: "La science de l'origine, de la nature et de la destination de 1 humanité est une partie fondamentale de la philosophie, mais n'est pas la seule".

98 AMÉRICO, P. op. Cit. p.110-11. Ou: Correio Mercantil, Rio de Janeiro, 5 de outubro de 1864, p.2.

99WINCKELMANN, op.cit. p.70-90. 
Viollet-Le-Duc), ele sintetizava as diferentes gêneses e desmembramentos artísticos propostos, articulando-os a partir de suas percepções e, ainda, de seus interesses, para chegar a uma dedução que lhe parecesse justa.

O silogismo inicial era unânime a quase todos eles (à exceção de Émeric-David): o nascimento da arte estaria intimamente ligado ao da religião ${ }^{100}$, porque ambas teriam surgido do culto a uma ideia que escaparia à apreensão sensível, ainda que, nas "sociedades primitivas", fosse ela proveniente precisamente da "síntese confusa dos objetos exteriores"101. Da admiração pelos estímulos sensoriais oferecidos pela natureza, o homem teria concebido a ideia de um ou mais deuses que criavam e regulavam tudo ${ }^{102}$, e passaria a adorá-los por meio de diferentes mas simultâneas manifestações.

Dessa premissa assumida por Américo, resultava outra, também ponto pacífico nas argumentações daqueles autores: a de que todas as artes, nas suas diferentes expressões, estiveram originariamente unidas e voltadas a um mesmo fim. Apenas futuramente elas teriam se separado para atingir graus distintos de desenvolvimento e objetivos específicos a cada uma (e a propósito, o curso oferecido por Viollet-Le-Duc pregava justamente uma volta a esse estado originário, no qual as artes do desenho, tão separadas nos "tempos modernos", poderiam caminhar novamente lado a lado $\left.^{103}\right)$.

Uma tal hipótese conduzia, por sua vez, a uma última indagação, na qual se dissipava por fim a concordância até então estabelecida entre os diferentes pensadores acessados por Américo. Além da causa do nascimento da arte e da condição de existência dos seus diferentes ramos, uma questão fundamental ainda precisava particularmente ser respondida, e dizia respeito, justamente, à gênese temporal das artes e à dedução dos seus desmembramentos. Pois de todas as expressões artísticas existentes desde o aparecimento da humanidade, uma deveria ter sido a primogênita, abrindo caminho para as demais. Mas qual?

Winckelmann e Émeric-David, ambos estudiosos dedicados à escultura clássica - conquanto divergissem em pontos fundamentais quanto às circunstâncias do nascimento da arte - haviam, sem surpresa, conferido às artes do espaço (arquitetura, escultura, pintura) anterioridade em relação às

100 WINCKELMANN, op. Cit. p.235. Viollet-Le-Duc, op.cit. p.11 e p.14-15; LAPRADE, Victor de. Questions d'art et de morale. Paris: Libraire académique, 1861. p.45.

101 AMÉRICO, Pedro. op. Cit. p.69. Ou: Correio Mercantil, Rio de Janeiro, 30 de setembro de 1864, p.1.

102 Idem, ibidem. p.70. VIOLLET-LE-DUC, op. Cit. p.21.

103 VIOLLET-LE-DUC. Op. cit. p.11. 
artes do tempo (música, dança, poesia). Em seguida, estipularam que, entre as artes espaciais, a primeira a ter surgido teria sido a da escultura ${ }^{104}$.

Victor de Laprade e o arquiteto Viollet-Le-Duc, bastante alinhados ideologicamente, propunham por outro lado a antecedência das artes temporais (com prioridade para a poesia ${ }^{105}$ ) sobre as espaciais. Além disso, neste limite, era a arquitetura que assumia primazia e importância genética diante das demais ${ }^{106}$.

Entre esses dois blocos distintos e não exatamente homogêneos internamente (os autores em cada um deles diferiam quanto à dedução nas separações posteriores à primeira atividade artística), a inferência efetuada pelo jovem Américo era curiosa, na medida em que propunha uma leitura que, de alguma forma, entrelaçava as demais.

Para ele, a arte teria nascido de fato como a representação/manifestação sensível de uma ideia, cultuada então em forma de escultura. Entretanto, em seus primeiros passos, como as ideias das "sociedades primitivas" "não se elevam acima dos fenômenos" ${ }^{107}$ percebidos diretamente pelos sentidos $^{108}$, a ideia de Deus ganharia forma sensível na invenção simples mas verdadeira do ídolo, "o embrião de uma obra de arte"109. Esse tipo de escultura "exprime desde o início a imagem de uma ideia, mesmo que em seus meios tenda a imitar rusticamente elementos naturais"110, percebidos como manifestações divinas no politeísmo das religiões mais antigas (como a hindu) ${ }^{111}$.

Em seguida, uma mudança curiosa. Em lugar de deduzir a derivação da escultura, enquanto arte do espaço, em outra de mesma natureza (convencionalmente, a arquitetura), Américo abandonava a percurso winckelmanniano e operava um traslado significativo, dando sequência em seu raciocínio às artes do tempo. Depois de esculpido, o ídolo é posto "à sombra de uma árvore que lhe serve de templo e que o protege" 112 , e em torno dela a tribo adora a imagem que "crê idêntica à divindade".

Aos gritos desordenados, primeira expressão de uma alegria profunda, sucedem palavras cadenciadas e mais brandas, [...] a linguagem singela da família é substituída por frases sonoras e ternas [..] que já não exprimem um fato ordinário; a essas frases se ajuntam sons modulados, ou notas de um valor musical, produzindo um cântico de maviosa melodia; das expressões da alma e

104 WINCKELMANN, op. Cit. p.72; ÉMERIC-DAVID, Toussaint-Bernard. Recherches sur l'art estatuaire. Paris: Renouard, 1863. p.21-22.

105 LAPRADE, op. Cit. pp.30-31.; VIOLLET-LE-DUC, op. Cit. pp.20-21.

106 VIOLLET-LE-DUC, op. Cit. p.29.

107 AMERICO, P. op. Cit. p.70. Ou: Correio Mercantil, Rio de Janeiro, 30 de setembro de 1864, p.1-2.

108 A tese de Américo vem diretamente do cotejamento de Émeric-David. ÉMERIC-DAVID, op. Cit. p.53.

109 Idem, ibidem. p.71. Ou: Correio Mercantil, Rio de Janeiro, 30 de setembro de 1864, p.2.

110 Idem, ibidem. p.73. Ou: Mesma edição apresentada anteriormente.

111 Idem, ibidem. p.70. Ou: Mesma edição anterior.

112 Idem, ibidem. p.71. Ou: Mesma edição anterior. 
da harmonia dos sons se forma o hino. A música e a poesia fazem aliança com a escultura e com a humanidade. ${ }^{113}$

Após a primazia da escultura, que teria criado a imagem sensível da divindade; e após a aparição da música e da poesia como suas sucessoras - manifestações que teriam descoberto em suas adorações a métrica e a harmonia, e desvendado assim as primeiras das "leis fundamentais da estética" -, era necessário dar, enfim, uma casa digna ao ídolo. O sentimento definiria por conseguinte as bases para o aparecimento da "verdadeira" arquitetura (arte que contribuirá com a proporção, outra "lei estética"). "A tenda do guerreiro não é digna de receber uma divindade. Construa-se, pois, para ele um abrigo, como se construíra para o homem, e dêem-se-lhe proporções tais que façam acordo com a majestade divina." 114

Nas cerimônias levadas agora ao interior do templo, aos embalos dos cânticos, nascem as danças ritualísticas. O novo espaço, para se diferenciar das casas, pediria logo materiais duráveis e nobres, e ornamentação: apareceria enfim a pintura "para animar a face da imagem [do ídolo] e o interior" da construção ${ }^{115}$ (curiosamente, a arte na qual Américo havia escolhido se especializar era a última presente no seu percurso dedutivo).

Artes internas (do tempo) e artes externas (do espaço) enfim estariam completas em suas expressões possíveis, todas formando "uma só arte, até que por um trabalho analítico de muitos séculos se desprendam do fundo do santuário." ${ }^{116}$ Estava pronta a sequência da gênese e separação das artes proposta por Américo, que se seguia portanto da seguinte maneira: escultura, música, poesia, arquitetura, dança e pintura.

A insuficiência de dados certeiros sobre a origem precisa da atividade artística, e o esforço de um desmembramento que se pautava em "simples conjecturas", que, portanto, não teria nenhum "valor histórico", eram limitações desde logo proclamadas pelo jovem. Mas a dedução por ele exposta não possuía um valor de simples curiosidade. Não sem motivo a sua apresentação cabal eraseguida por fundamentações críticas encetadas com o intuito de garantir a coerência filosófica do seu desmembramento; afinal, como dito, se sabia muito bem que a ênfase no percurso inicial de um objeto era de importância fundamental para a argumentação filosófica do seu fim. Com efeito, da

113 Idem, ibidem. p.71. Ou: Mesma edição anterior.

114Idem, ibidem. p.71.Quanto ao problema da proporção descomunal dos templos antigos (especialmente dos Egípcios), ela é sem dúvida reflexo da leitura Winckelmann sobre a ideia da divindade nos povos primitivas acompanhar uma forma e tamanho que lhe fosse condizente, ideia bastante difundida posteriormente, embora guardasse, por sua vez, relações com leituras similares em relação à escultura feita por Aristóteles, em sua Poética.

115Idem, ibidem. p.72. Correio Mercantil, Rio de Janeiro, 30 de setembro de 1864, p.2.

116 Idem, ibidem. p.72. 
ramificação esboçada saíam duas implicações significativas para o projeto que o jovem pensava para as artes no Brasil: uma filosófica; a outra, política.

A primeira aparecia ainda no primeiro estudo de Considerações Filosóficas. Sem contradizer o que havia argumentado anteriormente, Américo conferiria à arquitetura a precedência lógica e temporal sobre as demais artes, justificada pela decorrência das necessidades físicas do homem. Mas, contrapondo-se a Laprade e a Viollet-le-Duc ${ }^{117}$, garantia não se tratar de modo algum da "verdadeira" arquitetura, o que justificaria, assim, a impossibilidade dessa atividade figurar no topo da gênese das artes. A "morada primitiva", primeira expressão arquitetônica humana, era fruto de uma reação instintiva (não racional) que mesmo animais como castores e insetos realizam, e além disso com execução infinitamente melhor que a do homem primevo ${ }^{118}$. A arquitetura originária não exprimia nem imprimia nada; ela protegia.

$\mathrm{Na}$ inexistência da razão não poderia haver arte. Ela seria uma atividade superior destinada a concorrer com altos valores humanos, os quais, ao longo do tempo, se aprimoraram idealmente na unidade triádica da filosofia platônica e, ainda mais, na doutrina cristã.

É em decorrência dessa reflexão que se deve compreender a acordância filosófica de Américo em propor a escultura como arte originária, e jamais a arquitetura. Admitir que a arte, enquanto tal, tenha nascido da necesssidade física, e não que seja ela mesmo uma necessidade, seria afirmar que sua gênese era utilitarista, concepção apegada à vida "positiva" (material) que se criticava justamente no período, e da qual Américo mostrava-se repetidamente opositor. Significaria ainda expurgar do seu nascimento qualquer conceito elevado, presente unicamente no homem (e o único capaz de se conduzir às ideias do belo, do bom e do verdadeiro), uma postura que comprometeria todo o devir artístico, naturalmente. Deduzida desse modo, a atividade artística, em seu início, ela nunca seria empregada para nada além da satisfação pessoal; e em seu fim, num extremo proporcional, se transformaria em objeto de luxo ou de interesse ${ }^{119}$; de modo que, em todo seu percurso histórico, nunca ultrapassaria o mero agrado aos sentidos: aqui, se trataria sem dúvida

117 “Alguns autores têm suposto que, por um desenvolvimento natural e espontâneo das obras do espírito humano, à arquitetura cedem em antiguidade todas as artes, porque, como parece justo, o homem teve necessidade de uma habitação, muito antes de ter tido a ideia de adorar um ídolo ou de entoar um hino.”. AMÉRICO, P. op. Cit. p.72. Ou:Correio Mercantil, Rio de Janeiro, 30 de setembro de 1864, p.2.

118 Idem, ibidem. p.73.

119 Nesse ponto, Américo estará em acordo, como repetidamente o esteve em seu texto, com Quatremère de Quincy, que realizará em alguns dos seus trabalhos lidos pelo brasileiro longas digressões sobre a ideia de que "o gosto do luxo se liga ao princípio sensual, o gosto do belo, ao princípio moral. [Le goût du luxe tient au principe sensuel, le goût du beau au principe moral]. QUINCY, Quatremère de. Considérations morales sur la destinations des ouvrages de l'art, ou de l'influence de leur emploi sur le génie et le gout, et sur le sentiment de ceux qui en jouissnet et en reçevoient les impressions. Paris: L'Imprimière de Crapelet, 1815. p.15. 
um retorno fatídico, e inaceitável a Américo, à filosofia do século XVIII, e à sua sugestão de uma arte centrada no gosto pessoal e destinada ao prazer, por meio de categorias estéticas "frívolas" como do agradável $^{120}$. Em resumo, conforme discutirei mais à frente, um semlhante sistema das artes partiria perigosamente e retornaria fatalmente ao puro sensualismo combatido pelos ecléticos e pelos krausistas.

Por outro lado, admitir a escultura como arte originária seria garantir se tratar da "primeira manifestação sensível da atividade humana em que as necessidades positivas da vida natural não tiveram parte". ${ }^{121}$ Arte e religião se tornariam, assim, desde o início, necessárias, nascidas de uma única e mesma demanda inteiramente espiritual e intelectual, no exato momento em que o homem se reconhece como homem, como um ser pensante, diferente dos demais, ciente do passado e curioso do futuro. Mesmo nas limitações dos povos primitivos, a arte, por meio da escultura, nasceria da ideia do impalpável (a ideia de Deus) ${ }^{122}$. E a sua exigência como uma atividade necessária seria desde o seu início aparente e contígua à sua forma, configurada inicialmente com elementos indispensáveis, necessários - uma concepção que Américo sem dúvida comprava de Winckelmann ${ }^{123}$.

Para o jovem, a despeito do seu caráter notacional, o ídolo teria sido "desde os primeiros tempos"124 o "anúncio de uma vida intelectual"125, porque nele sempre esteve presente, necessariamente, como em todo verdadeiro objeto artístico, a "ideia de um objeto destinado a despertar nos outros homens os mesmos pensamentos que teve o autor no momento da

120 Ver, por exemplo, o texto de Montesquieu também citado por Américo: MONTESQUIEU, Charles-Louis de Secondat; STAROBINSKI, Jean. Essai sur le goût. Suivi d'un texte de Jean Starobinski. Paris: Rivages, 1993.

121Idem, ibidem. p.73. Ou:Correio Mercantil, Rio de Janeiro, 30 de setembro de 1864, p.2.

${ }^{122}$ Além de suas dívidas para com as correntes da filosofia idealista contemporâneas, Américo corrobora o ponto de vista de Quatremère de Quincy quanto ao nascimento da arte enquanto imitação ideal: “Obligé de s'exercer, non comme il est arrivé ailleurs à représenter des individus connus, réels, ou ayant réellement existé, selon le goût ou dans le sens du portrait, mais des êtres fantastiques, imaginaires ou poétiques, l'art ne fut tenu qu'à cette sorte d'imitation conventionnelle, qui, philosophiquement parlant, était idéale, puisqu'elle ne devait tendre à donner l'image de personne en particulier". QUINCY, Quatremère. Essai sur la nature, le but et les moyens de l'imitation dans les Beaux-Arts. Paris: Treuttel et Würtz, 1823. p.229.

Tal proposição é precisamente contrária àquela emitida pelo "realista" Émeric-David, e abertamente refutada por Américo. Para E.-David, que centrará suas reflexões artísticas na ideia da imitação, o ídolo primitivo não poderia ser percebido como o início da verdadeira escultura (mesma recusa efetuada por Américo em relação à arquitetura primitiva). A arte começa apenas quando o impulso da imitação estiver presente, e esse impulso surge necessariamente com a imitação dos objetos visíveis. Por isso, para ele, o retrato em escultura teria sido anterior à representação humanizada dos deuses pagãos; isto é, o real antes do ideal. EMERIC-DAVID. op. Cit. p.21.

${ }^{123}$ Para o alemão, a arte teria nascido sensivelmente com o necessário (a forma rudimentar, no início do ciclo artístico), depois passado à beleza (a forma perfeita, no apogeu do ciclo), e atingido a opulência (a forma exagerada, "barroca", marca da decadência). WINCKELMANN, op. Cit. p.71.

124AMÉRICO, P. op. Cit. p.73. Ou:Correio Mercantil, Rio de Janeiro, 30 de setembro de 1864, p.2.

125AMÉRICO, P. op. Cit. p.74. Ou: Ibidem. 
concepção"126. Assim, se o ídolo "imitou, ou exprimiu a semelhança de alguma coisa, foi a um tempo a imagem de uma ideia, e por consequência a fabricação desse ídolo, por muito informe que fosse ele, elevava-se acima de um fato da vida material e instintiva"127.

Apenas um sistema centrado, portanto, na antecedência genética de uma arte figurativa (do espaço ou do tempo) sobre uma não figurativa pode conceber que a arte nasça em torno da ideia humana da unidade da verdade e totalidade divinas, tornando-se desse modo uma atividade desde sempre destinada ao caminho do bem. Apenas as artes figurativas, centradas na ideia verdadeira de Deus e dedicada à imagem primordial do homem (como a mais acabada representação divina na terra), possuiram a capacidade de produzir por conseguinte o Belo moral: a expressão poética das ações virtuosas, as mesmas que todo ser racional deveria perseguir durante sua vida, e em todos os seus domínios.

Essa é certamente a implicação filosófica mais importante de se reter da dedução artística do jovem Américo. Sobretudo por que, dela, também viria o reconhecimento da segunda implicação, política, que trazia a seu projeto artístico.

Se, no contexto internacional, Américo tinha a seu lado várias personalidade bastante respeitadas que posicionavam a escultura no centro dos seus programas filosóficos e históricos, a mesma correspondência não era encontrada no âmbito nacional.

Questão ainda pouco estudada, mas não exatamente nova, o campo da história da arte no Brasil (mesmo antes do seu pontapé “oficial”, em 1870) se forma em estreita relação com pensamentos filosóficos oriundos de debates estéticos do setecentos e do início do oitocentos. Um campo originalmente "puro" dessa disciplina no país não deve ser portanto procurado, na medida em que nunca quisto no período. E não apenas aqui: o caráter multidisciplinar de um curso oficial inédito como o de Viollet-Le-Duc, na França, repleto de indagações filosóficas e arqueológicas, também encontrava, como visto, correspondência direta na prática dos escritos e discursos artísticos apresentados no Brasil do período.

Poucas foram de fato as personalidades eminentes das artes brasileiras que, ao trabalharem em uma perspectiva histórica até o último quarto do século XIX, deixaram de sugerir deduções filosóficas para um possível sistema das artes. O primeiro a abandoná-la parece ter sido o jovem 
Gonzaga Duque, em sua história da arte brasileira $\left(1888^{128}\right)$, o que se explica mais ou menos facilmente por seu engajamento profissional muito mais estreito com a crítica de arte, porém, ainda, por sua clara inclinação, como era então a tônica de sua geração, às vertentes filosóficas positivas, que abandonaram rapidamente o ponto de vista idealista da dedução genética das artes e de sua finalidade $^{129}$. De resto, num lastro de mais de cinquenta anos que vai da publicação de textos ou discursos de Félix-Émile Taunay, Porto Alegre, Bethencourt da Silva, até Félix Ferreira, todos (sintomaticamente adeptos, como Américo, de filosofias idealistas) deixaram suas contribuições para uma gênese filosófica das artes. O mais significativo é que todos, com a única e precisa exceção do jovem pintor, haviam deduzido a arquitetura como arte originária ${ }^{130}$.

Como era de se esperar, as reflexões filosóficas dessas personalidades dificilmente se encerravam como um fim em si mesmo, mas preparavam os alicerces para um plano real de ação, que de contínuo incluiu o desejo de reformas e ampliação da educação artística. Para esses agentes, a arquitetura não era a arte primeira apenas por que, possivelmente, haveria nascido primeiro, como

128 ESTRADA, Luiz Gonzaga-Duque. A arte brasileira. [Introdução Tadeu Chiarelli.] Campinas: Mercado de Letras, 1995.

129 Conforme analisado por Tadeu Chiarelli, é a partir dessa dívida para com o positivismo que Gonzaga Duque estruturará a "moldura" pessimista para as análises desenvolvidas em seu primeiro livro, A Arte Brasileira. Ver: Idem, ibidem.

130 Félix-Émile Taunay, por exemplo, posicionava a arquitetura como a primeira das artes desde os seus primeiros discursos proferidos na AIBA, na década de 1830. A arquitetura seria o fundamento das demais artes, e precisaria estimulada antes das demais (para uma exposição e análise dessa defesa, ver DIAS, Elaine. op. Cit. p.85, p.211, p.216, p.217, e outras seguintes).

Segue o mesmo para Porto Alegre, diretor empossado logo após Taunay, em 1854. Nesse ano, em texto que se propunha a refletir sobre a diferença entre o estatuário e o escultor, Porto Alegre questionava as razões pelas quais o Brasil, até poucos anos antes, não poderia dispor do primeiro do primeiro profissional (isto é, um artista que produzia estátuas monumentos, e não apenas esculturas), questão curiosa sobretudo se se considerasse que no campo geral da cultura brasileira se percebia positivamente uma valorização crescente do teatro, do jornalismo e da literatura. A resposta era a seguinte: "Porque a arquitetura estava morta, porque a arte fundamental do progresso de todas as belas artes era olhada com indiferença e porque os nossos idealistas políticos mais curavam de si do que da pátria." (PORTO ALEGRE, "O Estatuário", In: Ilustração Brasileira, RJ, v.1, n.3, 1854, APUD: KOVENSKY; SQUEFF. Araújo Porto Alegre: Singular \& Plural, p.316).

Poucos meses depois da publicação do texto de Porto Alegre, o jovem Bethencourt da Silva, ascendendo em importância política no contexto artístico brasileiro havia postulato, também como Américo, que as artes originariam da arquitetura, em função da necessidade física do homem de se proteger. Para ele, no entanto, esse estado inicial seria inteiramente aceito como o nascimento da verdadeira arquitetura. A exemplo de Porto Alegre, ele defenderá portanto o mesmo sistema no qual: "sem a arquitetura todas as outras belas artes [..] não podem florescer". (BETHENCOURT DA SILVA. "Duas palavras sobre arquitetura. Ao Ilmo. Sr. Conselheiro Luiz Pedreira do Couto Ferraz, ministro do Império". Belas Artes. In: Brazil Illustrado. Rio de Janeiro, N.5, Vol.1, 31 de julho de 1855. pp.76-77.).

Por fim, Félix Ferreira, bastante amigo de Bethencourt da Silva, será igualmente concorde com o lugar especial da arquitetura na dedução e desenvolvimento das demais artes. Logo no começo do seu livro Belas Artes: estudos e apreciações (1885), Ferreira cita uma obra bastante conhecida de Frédéric Bourgeois de Mercey, Étude sur les beauxarts: depuis leur origine jusqu'à nous jour, livro cuja publicação era feita entre 1855 e 1857 (contemporânea portanto às primeiras ideias sobre o sistema das artes publicadas por sua vez por Bethencourt e Porto Alegre): "Quando construiu o homem a primeira casa? Quando talhou o primeiro adorno? É quase impossível de dizê-lo. O que parece certo, diz Mercey, "é que a arquitetura precedeu a escultura e a esta se seguiu a pintura. Era preciso construir a casa antes de ornála, levantar primeiramente o templo para erigir depois o ídolo". (FERREIRA, Félix. Belas Artes: Estudos e apreciações. Introdução e notas de Tadeu Chiarelli. Porto Alegre, RS: Zouk, 2012. p.49). 
um evento casual. Ela era a primeira a ser deduzida filosoficamente porque deveria ser também a primeira a ser desenvolvida realmente, enquanto fenômeno causal.

A leitura de Américo, conquanto sui generis no plano dedutivo, era idêntica aos demais no plano político. Quando ele promovia pela primeira vez no contexto brasileiro que a escultura deveria ser a arte originária, não afirmava outra coisa senão que ela seria, necessariamente, anterior às demais; que seria para elas uma condição sine qua non; e que, no plano temporal, deveria ser estimulada antes, para que as demais irmãs surgissem naturalmente e, mais do que isso, para que surgissem direcionadas ao caminho da perfeição artística, o mesmo do aperfeiçoamento humano.

Afinal, se a arquitetura, uma arte abstrata e não mimética, se tornasse a primeira no sistema artístico brasileiro, dela viria apenas a ideia da admiração, ou pior, da opulência, valor condizente desde logo a uma sociedade destinada à decadência. Se a escultura, dedicada ao antropomorfismo e presente na forma máxima de monumentos públicos, tomasse a dianteira, forneceria o exemplo moral, excitaria todos os bons pensamentos e sentimentos que uma experiência estética pode fornecer para concorrer com o "progresso" de uma sociedade em particular, e da humanidade em geral. O postulado sugeria claramente os motivos pelos quais o jovem Américo não pôde aceitar que o primeiro grande monumento público brasileiro - a estátua equestre de d. Pedro I - fosse rodeado a seus pés de estátuas índios e animais ${ }^{131}$. Quanto aos primeiros, seres humanos ainda estacionados no "estado primitivo" (no qual a razão ainda não teria alcançado seu pleno desenvolvimento, e no qual o estado incipiente de suas artes provaria essa hipótese, um povo enfim sem "história", sem exemplos cívicos virtuosos), não se poderia esperar muitos exemplos que inspirassem o aperfeiçoamento moral do brasileiro. Quantos aos últimos, a sua ausência de razão e o estado meramente instintivo dispensaria quaisquer comentários.

\section{Do real}

A arte nasceria, portanto, em sua origem histórica, da configuração mais ou menos informe de uma ideia espiritual. Mas essa ideia, por sua vez, também em seu início, seria encetada pela observação da natureza, durante o estado primitivo no qual o homem dificilmente conseguiria ultrapassar os fenômenos naturais. Sensibilidade (matéria) e razão (ideia) estariam assim, desde sempre, ligados no nascimento da arte e da religião e em suas primeiras manifestações sensíveis.

${ }^{131}$ AMÉRICO, Pedro. "Cartas de um plebeu aos Srs. Deputados. Quinta carta". Correio Mercantil. Rio de Janeiro, 29 de junho 1865. P.3. 
Sutilmente, Américo injetava, já na abertura de suas reflexões, o antigo mas ainda extremamente válido problema do real e do ideal na arte, o mesmo que, também como visto, era pauta do dia nas recentes publicações de Victor Cousin sobre o Belo, a partir de 1853.

O ecletismo havia, de fato, reatualizado a validade da questão. Desde 1816, em resposta a seus interlocutores neoclássicos mais próximos, notadamente Quatremère de Quincy e Winckelmann, Cousin havia empreendido uma reavaliação de antigas definições aristotélicas e platônicas ${ }^{132}$ e chegava à concisa proposição de dois tipos de beleza interconectados, a Beleza Real e a Beleza Ideal ${ }^{133}$, assegurando, no plano filosófico, uma doutrina contígua que se iniciava oficialmente também na prática artística, com a refundação da Académie des Beaux-Arts, naquele mesmo ano - instituição da qual o mesmo Quincy será o secretário perpétuo até 1839.

Desejando manter a coerência em suas proposições no que dizia também respeito às partes dedicadas ao Bem e ao Verdadeiro e à intenção reiterada de um balanço conciliatório das teorias sensualistas e idealistas, Cousin havia estipulado ao Belo o que compreendia ser:

duas extremidades igualmente perigosas: um ideal morto, ou a ausência do ideal. Ou se copia unicamente o modelo, e falta a verdadeira beleza ou se trabalha de cabeça e se cai em um idealismo sem caráter. O gênio é uma percepção pronta e certa da justa proporção na qual o ideal e natural, a forma e o pensamento devem se unir. Essa união é a perfeição da arte: as obras-primas estão a esse preço $^{134}$.

Esses dois perigosos extremos, considerados em matéria de arte, seriam proporcionais àqueles em espiritualidade e direito, os quais também deveriam ser evitados para que não se julgasse equivocadamente que o homem fosse, de um lado, um "sublime escravo" do corpo, nem de outro um "angélico habitante de um claustro, pedindo a morte como uma feliz libertação, e a antecipando [..] em uma contínua penitência",135. Seria preciso, de outro modo, contemplar "a natureza com os olhos da alma assim como com os olhos do corpo",136.

132 Sobre essas definições em relação a suas raízes no aristotelismo e no neoplatonismo, ver LEE, Rensselaer W. Ut Pictura Poesis. The humanistic theory of painting. New York: Norton \& Company, 1967; e PANOFSKY, Erwin. Ideia: A evolução do Conceito de Belo. Trad, Paulo Neves. São Paulo: Martins Fontes, 2000.

133 COUSIN, Victor. "Du Beau Réel et du Beau Idéal". In: COUSIN, Victor. Oeuvres de Victor Cousin. Fragments Philosophiques. Tome Deuxième. Cours d'histoire de la philosophie morale. Bruxelles: Société Belge de Librairie, 1841. pp.114-117.

134 "Deux extrémités également dangereuses: un idéal mort, ou l'absence d'idéal. Ou bien on copie le modèle, et on manque la vraie beauté; ou bien on travaille de lète, et on tombe dans une idéalité sans caractère. Le génie est une perception prompte et sûre de la juste proportion dans laquelle l'idéal et le naturel, la forme et la pensée se doivent unir. Cette union est la perfection de l'art : les chefs-d'oeuvre sont à ce prix.". COUSIN, V. Du Vrai, du Beau et du Bien. p.178-179.

135 Idem, ibidem. p. 279 .

136 Idem, ibidem. p.167. 
Também para Américo, continuavam a ser válidos muitos dos autores e bases neoclássicas da filosofia idealista - mesmas bases que ajudaram a fundar a Academia de Belas Artes do Rio de Janeiro $^{137}$, com a chegada a Missão Artística Francesa. Em relação à prática artística, a mais evidente era aquela que se referia à importância dada à correção do desenho (em sua antiga conexão com a razão) por meio da experiência direta do modelo-vivo. $\mathrm{Na}$ arte ou na vida, o contato com o real não poderia nunca ser descartado, e essa é uma ênfase que o jovem reitera em momentos cruciais do seu texto.

As leituras que Américo fazia de Cousin abriam, também para essas questões, novos horizontes de discussão. Mas ele não as encerrava, como de praxe, na referência única àquele filosófo, e, nesse ponto específico, sem dúvida em função de uma insuficiência do ecletismo. A despeito da revalorização que o Cousin havia feito da matéria, a sua defesa insistente de uma metafísica do belo ocupara de tal modo seu trabalho a ponto de não estender, por fim, maiores análises sobre o real, e isso deve ter transformado o problema em algo um tanto sumário, senão ao menos confuso, para o jovem brasileiro.

Uma solução bem mais aprofundada, também ela convenientemente espiritualista, havia sido por ele detidamente estudada novamente a partir das lições krausistas da filosofia moral de G. Tiberghien, que fornecia o suplemento preciso para uma conciliação bem fundamentada da matéria e da ideia, isto é, da sensação e da razão. Para Tiberghien, a partir de Karl C. F. krause, "o homem é espírito e corpo. Ele deve viver como tal, aperfeiçoar sua vida física como sua vida espiritual. O bem do corpo não é estranho ao bem do homem, como pretende um falso espiritualismo."138

A reabilitação da matéria nessa filosofia provinha de sua refutação ao dualismo que seu adeptos percebiam se desprender do deísmo e do panteísmo, em suas formulações de que "Deus é tudo". O krausismo supunha que a separação fundamental da natureza e do espírito, indicada nessas doutrinas, levaria então à negação da vida presente em função da promessa de uma vida eterna,

137 A bibliografia sobre a formação da AIBA e sua relação com o neoclassicismo é enorme. Algumas obras, a título de introdução, são:

MIGLIACCIO, Luciano. "O Século XIX”. In: Mostra do Redescobrimento. São Paulo Fundação Bienal de São Paulo - Associação Brasil 500 anos Artes Visuais, 2000; MORALES DE LOS RIOS FILHO, Adolfo. Grandjean de Montigny e a evolução da arte brasileira. Rio de Janeiro: A Noite, 1941; NAVES, Rodrigo. "Debret, e o Neoclassicismo e a Escravidão". A Forma Difícil. Ensaios sobre arte brasileira. São Paulo: Ática, 1997; ROCHAPEIXOTO, Gustavo. "Introdução ao neoclassicismo na arquitetura do Rio de Janeiro". In: CZAJKOWSKI, Jorge (Org.). Guia da Arquitetura Colonial, neoclássica e romântica no Rio de Janeiro. Rio de Janeiro: Casa da Palavra; Prefeitura da Cidade do Rio de Janeiro, 2000; VALLADARES, Clarival do Prado. Rio Neoclássico. Análise Iconográfica do Barroco e Neoclássico Remanescentes no Rio de Janeiro. Rio de Janeiro: Bloch Editores, 1987. Vol. II.

138 TIBERGHIEN, G. op. Cit. p.217. Ver também: DORTU, Véronique. "Tiberghien, précurseur d'un idéal oublié". In La Pensée et les Hommes. Dossier n²008-018-005. Disponível online em: http://lapenseeetleshommes.be/pdf/2008-018-005\%20-\%20Tiberghien.pdf [último acesso: outubro de 2015]. p.3 
perfeita e sem sofrimentos ${ }^{139}$. Por consequência, delas se desprenderia tão somente a inação, o egoísmo (daí a ideia de ser um falso espiritualismo) e, sobretudo, a impossibilidade de estruturação de uma filosofia moral para a realização do Bem, no presente.

Contra o panteísmo, Krause e depois seus discípulos (sendo Tiberghien o mais conhecido) haviam professado o pananteísmo, e nele a ideia fundamental de que a essência divina não é uma substância puramente metafísica, paralela e fora da realidade, mas que "Deus está em tudo"140 (pan+en+teísmo), e que, além disso, o dever do homem é, mirando a Deus, buscar a realização completa de sua essência, que é sempre boa, em vida. O acréscimo trazia consequências significativas no plano filosófico, especialmente no que se referia à importância do real. Instituíase, assim, uma "metafísica [que] tendia, com efeito, a provar, a despeito de tudo, o princípio de uma dualidade entre o inteligível e o sensível, inerente ao homem como a Deus, mas transcendida pela harmonia de contrários." ${ }^{141}$ A matéria passaria a se apresentar, desse modo, como uma das manifestações da propriedade divina e a se constituir enquanto uma de suas condições de existência real e imediata: diferença importante em relação à argumentação apresentada por Cousin sobre o mesmo assunto, uma vez que, para ele, Deus seria a "substância metafísica do belo, do bem e do verdadeiro" ${ }^{\prime 42}$. Na perspectiva krausista, Deus teria também em si duas propriedades aparentemente opostas, física e metafísica (natureza e espírito), ambas constituindo em harmonia sua essência no "ponto de vista do absoluto" e do "infinito", 143.

Deus não é, contudo, apenas a soma dessas partes. É matéria, espírito e mais que os dois. Em sua completude de ser único e inteiro (“un et entier"), ele se basta; é por si e para si. O homem, em contrapartida, conquanto compartilhando da mesma essência, mas incompletamente realizada, é um dependente. Seu corpo, mesmo que a certo ponto limitando individualmente o "desenvovimento livre e contínuo do ser racional", em razão de suas "pendências, hábitos e impressões", certamente "não é [mais] a prisão da alma. Tem sua dignidade e beleza próprias, como o reflexo da natureza, ao mesmo tempo que é útil a toda vida espiritual." ${ }^{144}$

139 "Le déisme et le panthéisme, doctrines de séparation et de confusion entre Dieu et l'humanité, sont contraires à l'idée de la religion". TIBERGHIEN, G. op. Cit., p..111.

140 Idem, ibidem. p.59.

141 DORTU, V. op. Cit. p.3

142 HELMREICH, Christian. "La réception cousinienne de la philosophie esthétique de Kant. Contribution à une histoire de la philosophie française au XIXe siècle." In: Revue de Métaphysique et de Morale, No. 2, « Esthétique » Histoire d'un transfertfranco-allemand (AVRIL-JUIN 2002), pp. 193-210. Disponível online em: http://www.jstor.org/stable/40903860 [último acesso: outubro de 2015].

143 DORTU, V. op. Cit. p. 65.

144 TIBERGHIEN, G. op. Cit. p.109. 
Dessa constituição binária inexorável, a vida física de todo homem estaria submetida à natureza; e sua vida espiritual se constituiria, por sua vez, em parte da "união do espírito com o corpo e com a natureza, por meio da sensibilidade, em parte da união do espírito com Deus, por meio da razão"145. A dependência não acabaria aí. Ele precisaria, ainda, dos demais homens, aos quais, todos também ilimitados em suas limitações e limitados em suas ilimitações, se uniriam no tempo para formar um novo Ser, proporcionalmente idêntico à "Natureza" e ao "Espírito", e composto nova e precisamente da fusão deles ${ }^{146}$. Esse $\operatorname{Ser}$ se apresentaria pelo nome de "Humanidade". O desenvolvimento desse termo é fundamental para a doutrina krausista e para a estipulação de uma filosofia moral fundada na liberdade e na vontade espontânea de ação (esta, como discutirei mais à frente, outra leitura de suma importância para Américo e para a estruturação de sua teoria para as artes no Brasil).

Esse outro Ser também espelharia, em sua perfeita analogia e interação com os demais, a qualidade constitutiva de Deus como uma unidade harmônica de variedades infinitas "A unidade sem variedade é a uniformidade; a variedade sem unidade é a coleção. A harmonia é a condição que torna possível a variedade na unidade ${ }^{147}$.

Segundo Tiberghien, seria de fato em decorrência da percepção conjunta e necessária da "Natureza", do "Espírito" e da "Humanidade", ou (como ainda os chamaria), desses "objetos do pensamento", que surgiria no homem a ideia mesma de Deus, "ser de toda a realidade, causa e razão da variedade das coisas" ${ }^{148}$ : uma noção, deve-se dizer, que de modo algum contradizia Américo em sua dedução do nascimento da arte como reflexão sobre a natureza e o espírito, para ele, representado pela ideia ${ }^{149}$.

145 Idem, ibidem. p.114.

146 Segundo Tiberghien, "existe no universo um número infinito de espírito finitos, que vivem em união como um só espírito, da mesma maneira que todos os corpos estão unidos na Natureza infinita". O original é o seguinte: "je pense, sauf erreur, qu'il existe dans l'univers un nombre infini d'esprits finis, qui vivent en union comme un seul Esprit, de la même manière que tous les corps sont unis dans la Nature infinie." idem, ibidem. p.19-20.

147 "La unidad sin variedad, es la uniformidad; la variedad sin la unidad, es la colección. La armonía es la condición que hace posible la variedad en la unidad". TOLEDO, Carlos Olivier. "sobre la concepción de 'ciencia del alma' tiberghiana como crítica a la idea positivista de psicología en la segunda mitad del siglo xix mexicano". In: Revista Electrónica de Psicología Iztacala. 15, n.1, marzo de 2012. pp.238.

148 TIBERGHIEN, G. op. Cit. p.21.

149 O excerto original dessa questão em Tiberghien é o seguinte: "L'humanité, l'Esprit et la Nature constituent le monde ou l'univers. Je regarde l'Esprit et la Nature comme les deux moitiés du monde qui se complètent, se pénètrent, s'unissent à divers degrés, et vivent en union intime et parfaite dans l'humanité. Mais ces trois objets de la pensée ne me satisfont pas entièrement. Je distingue l'Esprit de la Nature, je les oppose l'un à l'autre, j'affirme que la Nature n'est pas ce qu'est l'Esprit et réciproquement. Je conçois donc l'Esprit et la Nature comme étant limités l'un par l'autre, comme n'étant chacun qu'une face de la réalité, et non la réalité tout entière, bien qu'ils puissent être illimités ou infinis, chacun dans son genre. Cette pensée m'oblige à m'élever au-dessus du monde, afin de rechercher la cause et la raison supérieure de l'Esprit, de la Nature et de leur union. J'arrive ainsi à une nouvelle notion, à la notion de l'être un et entier, de l'être de toute réalité, cause et raison de la variété des choses, qui contient en soi, sous soi et par soi tous les genres, tous les 
O conhecimento de Deus seria, assim, também resultado da aliança entre o sensível e o racional, real e ideal, eterno e temporal, variável e imutável. Ele seria um conhecimento possível precisamente pela aplicação ou pela harmonia desses dois elementos: matéria e ideia. E ele surgiria, não é preciso fazer muito esforço para perceber, analogamente aos procedimentos da filosofia da história, em seu interesse de fundir equilibradamente história e filosofia: Tiberghien havia chamado, não sem motivo, de conhecimento aplicado ou harmônico, algo um tanto quanto similar em proposição ao método eclético. Na primeira, a matéria forneceria, pela mediação da sensibilidade e a partir do fatos testemunhados no espaço e tempo, a parte analítica e subjetiva do conhecimento. $\mathrm{Na}$ segunda, a ideia se tornaria fundamento para a síntese, esta que seria objetiva e posterior à análise. Com ela viria a compreensão da universalidade, unidade e essência das coisas, que lembram a todo tempo o objeto privilegiado da filosofia, que é Deus.

O que vale como verdade para um domínio filosófico, tem que valer necessariamente para outros. E é por isso que, direcionada a questão para as artes, se deveria chegar cabalmente à noção de que a matéria ou a natureza visível deveria estar para a arte tal como a história estaria para a filosofia: a natureza visível ofereceria os dados analíticos para o artista (os fatos sensíveis e particulares), que deveriam ser transformados em síntese universal ou geral ${ }^{150}$ por meio de sua união com a imaginação (uma faculdade então considerada no período ora como constitutiva ora como paralela à razão ${ }^{151}$, da qual os gênios seriam dotados em seu último grau de expressão). Em qualquer caso, segundo Tiberghien, seria impossível fugir à regra de que "o individual manifesta o universal sob uma forma própria e determinada: cada homem representa a humanidade à sua maneira; uma boa ação reproduz a ideia do bem; uma bela obra [de arte], a ideia do belo sob traços particulares." 152

Se não se considera a introdução que Américo faz da doutrina pananteística desde 1862-63, quando se inscreve no bacharelado de Ciências Naturais em Bruxelas (onde Tiberghien trabalha), e ainda a importância que essa filosofia assumirá para ele nos anos seguintes, a ponto de tomar, no

ordres particuliers de la réalité. L'objet de cette notion, qui se trouve dans toute conscience cultivée, chez tous les peuples, a été désigné sous le nom de Dieu." TIBERGHIEN, G. op. Cit. p20.

${ }^{150}$ Sobre essa concepção dentro da reflexão exclusivamente artística, ver algumas das reflexões que Américo absorve de Quatremère Quincy que se acordavam perfeitamente com as leituras krausistas sobre o real: QUINCY, Quatremère. Essai sur la nature, le but et les moyens de l'imitation dans les Beaux-Arts. Paris: Treuttel et Würtz, 1823. Pp.192-193.

${ }^{151}$ Sobre o problema da imaginação e sua reatualização em relação à razão na filosofia francesa dos séculos XVIII e XIX, ver BECQ, Annie. Genèse de l'esthétique française moderne : de la raison classique à l'imagination créatrice : 1680-1814. Paris: J. Touzot, 1984.

152 TIBERGHIEN, op. Cit. p.23. 
fim da década de 1860, o lugar privilegiado que a filosofia eclética havia ocupado desde os anos 1850 em seu aprendizado filosófico, é bem provável que passem desapercebidas as várias passagens de forte teor krausista que tratam do problema do real em suas Considerações Filosóficas. Mesmo que algumas poucas pistas sejam fornecidas pelo próprio Américo em nota de rodapé, a grande maioria dessas passagens é fruto de transcrições livres e não indicadas do Esboço de Filosofia Moral ("Esquisses de Philosophie Morale”), que Tiberghien havia publicado em 1854 para servir de manual para seus alunos da Universidade Livre de Bruxelas.

A primeira série de reflexões desenvolvida nesse sentido, em Considerações Filosóficas, justificava a postura dos gregos diante da realidade e a contraposição fundamental que a arte clássica teria establecido com, por exemplo, a da Idade Média, tal como Américo a percebia negativamente ${ }^{153}$, a partir do legado de Cousin e, sobretudo, das leituras de Jules Michelet ${ }^{154}$. O apontamento dessas diferenças supunha, não há dúvidas, o horizonte correto a ser perseguido para o desenvolvimento da grande arte.

A Idade Média, em seu "misticismo estéril"155, que tenderia a negar a validade da matéria e da experiência sensível, teria sabido apenas produzir obras nas quais se exprimiam a melancolia e sofrimento constantes, contrários, portanto, ao sentimento e à ideia harmônicos que resultam do belo $^{156}$ :

As doutrinas místicas da escolática tinham por fim humilhar a sociedade, fazendo crer que o esprítio se acha encerrado em uma prisão indigna, de onde é preciso tirá-lo com sofrimentos e preces; criando uma guerra interna, em que a alma sofre como sofre o corpo, e em cuja luta desaparece a unidade da constituição humana. [...] É um erro crer que Deus pôs no mundo a matéria para servir de escárnio ao espírito, com o qual se acha entretanto ligada na mais estreita união. E não é somente erro, mas ingratidão para com a realidade; porque é pela matéria que podem os homens transmitir suas ideias aos outros homens, é por ela que o império do mundo é legado por uma a outra geração [...] Não a adoremos como cegos, mas também não a desprezemos como ingratos ${ }^{157}$.

${ }^{153}$ Quando se manifesta contra a arte da Idade Média, Américo apresenta-se, portanto, pela primeira vez, contra as leituras do medievalista Viollet-Le-Duc.

154Américo sugere ter lido o livro capital de Michelet La Renassaince, inserido em seu longo projeto sobre a história da França. Nesse tomo, Michelet, de início um aluno de Victor Cousin, oficializa uma visão extremamente pessimista da Idade Média como a idade das trevas, que cederá lugar a uma primeira era das luzes, iniciada no Renascimento. Ver: MICHELET, Jules. Renaissance. Paris: Chamerot, 1855.

155 Ambos Cousin e Tiberghien dedicam capítulos dos seus referidos textos à critica e refutação do que intitulam justamente de Misticismo.

156 AMÉRICO, P. Op. Cit. p.147-48. Ou: Correio Mercantil, Rio de Janeiro, 30 de outubro de 1864, p.1. "Se nas sociedades da Idade Média, de cujo misticismo parecemos não ter ainda saído completamente, por uma negação dos princípios que proclamam a infinita sabedoria de Deus, e por consequência, a perfeição das suas obras, a natureza visível é de contínuo ojbeto do mais desdenhoso desprezo..."

157 Idem, ibidem. p.148-9. Ou: mesma edicão da nota anterior 
Os gregos teriam achado, segundo Américo, a via do meio, e em seu processo eclético de síntese, nunca teriam abandonado a observação arguta da natureza, nem a importância desta. A atitude teria definido a naturalidade de suas obras, harmonicamente idealizada ${ }^{158}$. Para o jovem, ainda que o respeito à natureza visível não fosse exatamente uma causa para a supremacia dos gregos, ela seria no entanto uma diretriz fundamental para sua excelência, ao lado da qual se encontraria uma mesma inclinação à representação antropomórfica a que se dedicaram no desenvolvimento do seu sistema artístico.

Entre eles, a "arte ajuntava-se à natureza e a tornava ainda mais bela: por ela todo corpo teve um espírito, e todo o espírito teve um corpo" 159 . Os "antigos" teriam considerado, em sua filosofia, "a natureza debaixo do seu verdadeiro aspecto; como uma criação divina, tirando de Deus sua razão de ser, e unida ao espírito na plenitude de sua essência" ${ }^{" 160}$. Eles teriam provado, antes de qualquer outro povo, que "a dignidade do homem nunca se viu humilhada" na fusão equilibrada da matéria e do espírito; "todas as suas faculdades, intelectuais ou físicas, eram igualmente assuntos da mais profunda contemplação e dos mais generosos cuidados. Admirável unidade de preocupações de estudos, de que não era possível resultar uma civilização menos completa, nem uma estética menos fértil."

A argumentação final sobre o problema do real nas artes, e especialmente nas artes gregas, não poderia encontrar outro desfecho para Américo senão na escultura, como visto, arte de inflexão do sistema artístico por ele proposto e central paras as discussões que desenvolvia. Mais do que qualquer outra manifestação artística, a escultura teriam justamente "por fimm representar a união do espírito e da matéria, sob a sua mais bela aparência, revestida, como em uma solene apoteose, dos mais altos atributos da onipotência" 161 .

É preciso contudo considerar que, conquanto começasse a defender filosoficamente a validade irrefutável da matéria na vida e na arte, Américo não assimilava completamente essa concepção krausista em suas pinturas antes do final da década de 1860, ao menos não em toda a extensão que ela assume para o Krausismo. Nesta doutrina, a ênfase dada à realidade fundamentava não apenas a ideia da Humanidade que existiria enquanto um Ser (como visto, mediando e

158 AMÉRICO, P. op. Cit. p.148. "Um tão belo modo de encarar o mundo e o próprio homem [nos gregos], inteiramente oposto aos princípios do misticismo, devia produzir viçosos frutos na esfera da filosofia, e ainda mais nas belas artes, onde a realização intelectual é inseparável do profundo conhecimento da natureza física.".

159 Idem, ibidem. p.179 [estudo sétimo]. Ou: Correio Mercantil, Rio de Janeiro, 19 de novembro de 1864, p.3, e Correio Mercantil, 21 de novembro de 1864, p.2.

160 Idem, ibidem. p.148 [estudo sexto]. Correio Mercantil, Rio de Janeiro, 30 de outubro de 1864, p.1.

161 Idem, ibidem. p.150 [estudo sexto]. Ou: mesma edição anterior, e ainda: Correio Mercantil, Rio de Janeiro, 2 de novembro de 1864, p.2. 
composto do Espírito e da Natureza), mas ainda à ideia do dever que todos teriam para com uma filosofia moral que se realizava no presente, e que era social, baseada na razão, na liberdade, na vontade e no desinteresse. Nessa filosofia se apresentariam como os seus mais elevados valores de realização o virtuosismo, o heroísmo e o sacrifício ${ }^{162}$.

Seria apenas a partir da apresentação da Batalha do Campo Grande que Américo resolvia, pela primeira vez, ao mesmo tempo teórica e praticamente, essa concepção, levando-a a um epílogo heróico, ainda que dúbio ${ }^{163}$, em sua Batalha do Avahy, sem dúvida a maior contribuição ecléticokrausista jamais exposta no cenário artístico brasileiro.

NA Carioca (como ainda discutirei), o jovem ainda não conseguiria ultrapassar as concepções cousinianas sobre o Belo ideal, fundamentalmente imaterial e alegórico - um belo que se fecha em si mesmo, assumindo uma forma convencional, na qual sua ligação com o Bom e o Verdadeiro parece permanecer em nível apenas discursivo e teórico. O problema do real nessa pintura parece se apresentar sobretudo como uma preocupação de forma, na qual a relação com as questões neoclássicas sobre a expressão e a correção do desenho as mais evidentes.

\section{Do ideal}

Por sua recepção precoce e manutenção do ecletismo desde os tempos do Colégio d. Pedro II, e por sua introdução gradual e voluntária ao krausismo, Américo confessava com insistência as suas dívidas para as correntes filosóficas ainda mais importantes do período, especialmente aquelas reconhecidas por suas orientações espiritualistas. Esta identificação estava desde sempre presente em seus complementos nonimais ou codignomes. Assim, não raro se poderia escutar termos como ecletismo espiritualista quando se referia ao método de Cousin e seus discípulos, e espiritualismo racionalista quando se tratava da doutrina inaugurada por Krause e continuada também por seus seguidores. Nos dois casos, a referência a expressões tão importantes, como "Espírito Absoluto" ou

\footnotetext{
${ }^{162}$ Foi essa reabilitação inicial (mas profunda) da matéria no Krausismo e suas implicações com a filosofia moral, o que permitiu a sua recepção e difusão no Brasil, especialmente em São Paulo. Ali, as lições de Krause proporcionaram desde a década e 1840 uma saída possível para uma lacuna deixada pelo ecletismo em relação a uma filosofia moral que se ligue ao social e não apenas ao método psicológico e individual. No Rio de Janeiro, será preciso esperar até a década de 1870 para que o impasse seja resolvido pela adoção das proposições lançadas por um discípulo de Cousin, Paul Janet, autor do livro La Morale, cuja tradução será oficialmente adotada como manual no Colégio d. Pedro II. Sobre o assunto, ver os breves, mas importantes trabalhos de Antonio Paim. PAIM, Antonio. O Krausismo brasileiro. Londrina: Edições Cefil, 1999; e Idem, A Escola Eclética. Londrina: Edições Cefil, 1999.

${ }^{163}$ Sobre a análise desse heroísmo dúbio na Batalha do Campo Grande, ver CHRISTO, Maraliz C. V. "Quando subordinados roubam a cena: A Batalha de campo Grande de Pedro Américo". In: Sceculum, Revista De História. João Pessoa, jul/ dez. 2008.
} 
"Razão histórica", deixava lembrar, e sem equívocos, a íntima relação que aquelas filosofias estabeleciam com as concepções desenvolvidas por G. W. Friedrich Hegel ${ }^{164}$. E, de fato, não causa surpresas saber que tanto Krause quanto Cousin haviam sido seus alunos na Alemanha antes de desenvolveram suas próprias trajetórias enquanto docentes e pensadores respeitados.

Se nada permite concluir que Américo tenha lido ou acessado diretamente Hegel (ele não apresenta nenhuma referência ou citação ao filósofo alemão), não parece haver motivos para duvidar que uma série de reflexões do alemão atinge por vias indiretas o jovem brasileiro, misturando-se com o legado ainda mais duradouro da filosofia platônica (em suas reinterpretações posteriores), que por sua vez perpassa por todos eles. A despeito todas as diferenças significativas existentes entre métodos ou doutrinas filosóficas estudados pelo brasileiro, permanecia nelas, intocado, o compromisso com uma filosofia que se amparava num conceito central, a ideia.

As explicações oferecidas nas obras de Quatremère de Quincy, Cousin, Tiberghein, Victor de Laprade, Viollet-Le-Duc, Beulé, David Sutter etc., eram essencialmente acordantes e ligavam o termo diretamente à manifestação divina, intuída perfeitamente apenas por meio da faculdade reveladora da razão. Em todas justificava-se por que qualquer atividade idealista era, fundamentalmente, uma atividade espiritualista, e por que a verdadeira arte estava também destinada a este fim, posto que também ela deveria lembrar a universalidade e unidade das coisas e do mundo em Deus.

Conforme sugerido em outros momentos desta Tese, nos anos 1860, Américo demonstrava fazer claramente parte de um círculo comum - e mesmo oficial -, que também sustentava no Brasil a validade e importância das correntes espiritualistas, no mesmo momento da ascensão internacional das correntes positivistas. Essa imersão pessoal mereceria, no final daquela mesma década, o reconhecimento e o agradecimento do próprio Tiberghien, que, rememorando os anos de doutoramento de Américo na ULB, imediatamente seguintes à publicação de Considerações Filosóficas, reforçava a atuação do brasileiro enquanto um jovem baluarte da filosofia idealista diante das "ameaças" positivas:

Era na época em que o positivismo fazia conquistas na Bélgica; eu o havia combatido, como reitor, nos meus discursos de inauguração, mas os discípulos da faculdade de ciências

\footnotetext{
${ }^{164}$ HEGEL, Georg Wilhelm Friedrich. Cursos de Estética. [trad. WERLE, Marco Aurélio]. São Paulo: Edusp, 1999.
} 
pareciam querer consolidar a sua oposição; foi então que V. [Américo] tomou por sua vez a palavra, e, na presença de seus colegas, estupefatos, refutou o empirismo em nome do ideal. ${ }^{165}$.

Seria necessário ainda alguns anos para que Américo e outros agentes brasileiros lutassem oficialmente contra o positivismo no Brasil - muito embora sua Tese de doutorado (impressa inicialmente apenas em francês, em 1869) e seu curso de História das Belas Artes, Estética e Arqueologia se apresentassem desde logo como postos de defesa precoces dentro da AIBA. Entretanto, até a chegada desse momento, a adesão majoritária à filosofia idealista que de certo modo unia personalidades artísticas brasileiras tão distintas da primeira e da segunda metade do século $\mathrm{XIX}^{166}$ sustentava o sentimento geral de que o território intelectual continuava, em relação a esse ponto, relativamente seguro. E a maior garantia parecia ainda ser a identificação compassada que se fazia do primeiro cidadão, d. Pedro II, em matéria filosófica.

É bastante provável que tenha sido a difusão dessa imagem que outorgou Porto Alegre, em um discurso de premiação da AIBA (no qual se encontrava então o pequeno Américo e o próprio d. Pedro II), chamar o imperador de "príncipe idealista", defensor dos princípios do bem, ou da Moral, para todos os brasileiros ${ }^{167}$. E talvez tenha sido essa mesma imagem que incentivou Américo a esperar uma boa recepção da versão manuscrita do seu Considerações Filosóficas, entregue ao imperador. Afinal, um "príncipe idealista” rapidamente compreenderia o caráter e conteúdo igualmente idealistas dos escritos de um de seus súditos, que ademais, depois de 5 anos de financiamento direto, aguardava acolhimento integral para enfim realizar seus projetos.

Ideia é um conceito de fato central à formação, reflexão e atuação artísticas de Américo. Justamente na metade dos anos 1860, ele começava abordá-lo de maneira sistemática, fosse na publicação dos seus primeiros textos, na escolha das cópias de pinturas que realizava, ou em seus primeiros trabalhos artísticos autorais, inaugurados com $A$ Carioca.

165 TIBERGHIEN, G. Cópia impressa de carta enderaçada a Pedro Américo em 30 de setembro de 1870 . $A$ Reforma, 30 de novembro de 1870, p.1

${ }^{166}$ São, se se permite lembrar, Félix-Émile Taunay, Porto Alegre, Bethencourt da Silva, Félix Ferreira.

${ }^{167} \mathrm{O}$ trecho completo no qual Porto Alegre assim designa d. Pedro II é o seguinte: "O principe idealista combate os prejuízos da ignorância, os crimes do egoísmo, as argúcias da ambição e todos os princípios contrários ao bem geral do Brasil [..] A terra move-se, as verdades [...] se manifestam sem que a voz da filosofia seja contrariada, sem que as leis da criação sejam abrogadas pelas tirania ou por essas legiões interessadas na imobilidade do passado e na permanência dos prejuízos." PORTO ALEGRE, M. A. "Discurso do diretor da Academia das Belas Artes por ocasião da distribuição pública dos prêmios aos alunos da AIBA". Correio Mercantil, Rio de Janeiro, 30 de novembro de 1856. p.1. 
Se o peso artístico do termo havia se consolidado em uma longa duração, que passava por suas primeiras formulações socrático-platônicas, no período clássico, e reformulações neoplatônicas, especialmente na teoria artística ${ }^{168}$, a partir do século XVI, ele seria ainda submetido a contínuas e novas leituras no período dos estudos brasileiros e europeus do jovem Américo. Como visto, a sua mais recente atualização (herdeira direta do legado neoclássico e romântico) provinha das proposições eclético-krausistas e suas tentativas em qualquer medida pseudo-aristotélicas ${ }^{169}$ de conciliação da ideia com a matéria; esforço que significava, em última instância, a dissipação final dos preconceitos neoplatônicos sobre o real como uma prisão da alma, fadada a uma luta constante para se libertar e retornar ao seu estado metafísico de origem ${ }^{170}$.

O postulado de que um trabalho artístico, além de deleitar (por meio dos sentidos), deveria sobretudo instruir (por meio da razão), era recuperado também de suas relações mais próximas com o pensamento neoclássico ${ }^{171}$ (sendo novamente Quincy um dos seus maiores teóricos ${ }^{172}$ ), e ele deveria ser garantido abandonando, nesse caso específico, formulações do ecletismo, que, então pressupondo a autonomia completa do fenômeno artístico, passava a instituir a noção de "arte pela arte", além de sua desobrigação para com demais atividades morais ou religiosas ${ }^{173}$. Américo, por certo, não estava pronto para assumir esse ponto de vista especificamente cousiniano, e não parece ser desacertado concluir que a sua aproximação em curso ao krausismo (que se traduzia pela estruturação de uma filosofia moral que não se separava da religião e das artes) lhe permitia manter sua adesão a uma filosofia idealista do seu tempo sem abandonar suas convicções e pretensões artísticas - estas que estavam, afinal, bastante alinhadas às esperanças de outros agentes brasileiros no que dizia respeito à contribuição das artes para o progresso moral e material do Brasil.

${ }^{168}$ E. Panofsky, por exemplo, sustenta que o aparecimento do termo "ideia", embora já presente nos escritos dos Neoplatônicos florentinos, durante o século XV, seria incorporado ao vocabulário da teoria da arte italiana (especialmente em relação ao significado metafísico) apenas a partir da segunda metade do século XVI, mas especialmente no século XVII. Ver, PANOFSKY, E. Ideia.

${ }^{169}$ LEE, Rensselaer W. Ut Pictura Poesis.The humanistic theory of painting. New York: Norton \& Company, 1967. PANOFSKY, E. Op cit. Ver especialmente os capítulos Renascimento, e Classicismo.

${ }^{170}$ Idem, ibidemm; Idem. "O movimento Neoplatônico em Florença e no norte da Itália (Bandinelli e Ticiano)." In PANOFSKY, E. Estudos em iconologia. Lisboa: Editorial Estampa, 1995. p.122.

${ }^{171}$ Sabe-se, no entanto, que a exigência de instrução e deleite presente no neoclassicismo é uma readaptação tardia da doutrina Ut pictura poesis, pregada por escritores renascentistas e barrocos, por sua vez absorvida da fórmula original de Horácio. Para uma discussão sobre a questão, ver: LEE, Rensselaer W. Ut Pictura Poesis.The humanistic theory of painting. New York: Norton \& Company, 1967.p.2.

${ }^{172}$ Quanto a essa questão, também Émeric-David, a despeito de todas de todas as divergências estabelecidas com seu algoz, Quincy, estava de acordo quanto à exigência de uma destinação moral esperada à obra de arte, e quanto à ideia de que a arte apenas pode florescer quando como uma necessidade moral para um povo. Cf. ÉMERIC-DAVID. Op. cit. p.241, p.252-3, entre outras.

${ }^{173}$ A respeito da separação da arte da religião e moral, Cousin vai afirmar: "je ne puis accepter une autre théorie qui, confondant le sentiment du beau avec le sentiment moral et religieux, met l'art au service de la religion et de la morale, et lui donne pour but de nous rendre meilleurs et de nous élever à Dieu." p.185. COUSIN, V. Op. Cit. P.185. 
Para o jovem, exigir da arte um fim moral e espiritualista era garantir sua produção e recepção no domínio intelectual, e por consequência, instituir uma primeira e fundamental cisão teórica entre artes mecânicas, isto é, artes de repetição e dos sentidos, e as artes liberais, fundamentalmente reflexivas. A arte também deveria ser produzida e se guiar pela razão e pela liberdade, na medida que levariam à ideia; e esta, contígua à "verdade".

Evidentemente, a asserção trazia consequências secundárias, mas importantíssimas, entre as quais o mesmo postulado éclético-krausista que previa que a atividade artística deveria considerar mas não se deixar subjulgar pelos sentidos ${ }^{174}$. Se a ideia é impessoal ${ }^{175}$ e anterior ao homem, e se existe independente dele, ela não pode ser, logicamente, fruto exclusivo da experiência, como pregavam os sensualistas (Locke e Condillac). É preciso defender esse ponto de vista para assegurar a manutenção do inatismo (da anterioridade e universalidade das ideias do bem, do belo e do verdadeiro), pois, de outro modo, sendo o homem uma távola rasa, seria impossível deduzir um princípio filosófico que regisse a origem ou o fim de tudo e se voltar ao mundo das ideias absolutas. Do mesmo modo, se tornaria difícil estipular uma teoria "sã", que pudesse guiar tanto o artista quanto o homem, e que os afastasse da decadência ${ }^{176}$, destinada aos povos e às artes entregues unicamente ao prazer e exigências sensoriais.

É em função dessa ideia que Américo aderirá à tese que pressupunha que deixar a arte se guiar pela impressão dos sentidos significaria justamente deturpar os seus objetivos, posto que a sensação, na crítica idealista, poderia levar apenas a uma impressão destituída de qualquer conhecimento duradouro $^{177}$. A sensação, sendo um impressão psicologicamente individual, revelada apenas pela natureza $^{178}$ (a ideia, ao contrário, uma revelação divina), permaneceria numa esfera extremamente restrita e variável, na qual o universal ${ }^{179}$ não conseguiria se manifestar ${ }^{180}$. Em outras palavras, o prazer sensual é efêmero, o prazer intelectual, duradouro.

${ }^{174}$ AMÉRICO, P. op. cit.p.126 [estudo quarto]. Ou: Correio Mercantil, Rio de Janeiro, 9 de outubro de 1864, p.2.

175 Idem, ibidem, p.93 [estudo segundo]. Ou: Correio Mercantil, Rio de Janeiro, 2 de outubro de 1864, p.2.

176 "Mas que triste ideia é preciso fazer da arte, para sustentar que não se pode esta elevar à perfeição sem descer ao sensualismo! Qual é, pois, o seu fim, e que papel representará ela no seio da sociedade? Aplicá-la a satisfazer os sentidos, considerando-a debaixo do ponto de vista da imitação material, não é pô-la a parte desses objetos frívolos, que, tirando sua existência de um princípio inteiramente sensual, não oferecem relação alguma com a cultura do espírito e as necessidades morais do homem? E não foi o sensualismo que em Roma se opôs os últimos progressoas das artes, como nos diz Plínio, que prendeu na Bélgica e na Alemanha o gênio nacional em sua elevação espontânea? Que prostituiu em Veneza e na corte de França o talento de Ticiano, de Le Brun e de tantos artistas da decadência?’. Idem, ibidem. p.217 [estudo quarto]. Correio Mercantil, Rio de Janeiro, 10 de outubro de 1864, p.2.

${ }^{177}$ COUSIN, op. Cit. P.114; TIBERGHIIEN, op. cit. p.138-39.

178 TIBERGHIEN. op.cit. p.139.

${ }^{179}$ COUSIN, op. Cit. P.111-12.

${ }^{180}$ AMÉRICO, P. Op. Cit. p.114 [estudo terceiro]. Ou: Correio Mercantil, Rio de Janeiro, 5 de outubro de 1864, p.2. 
Para Américo, uma arte que se move pelo desejo realista se torna um braço útil ao perigo positivista, em sua convicção cetitista nos fenômenos unicamente observáveis e verificáveis. Num tal processo, Deus some da filosofia como da arte, e a razão, não mais servindo voluntaria e livremente de ponte para um mundo perfeito de verdades eternas, passa a trabalhar em função das necessidades imediatas de um mundo transitório e sem perspectivas. E isso é tudo o que não ser quer, porque assim a filosofia torna-se sociologia, e a arte, pura indústria, o que significaria um retorno, portanto, aos pontos da "infância" ou "decadência" nos quais, por exemplo, uma manifestação como a arquitetura seria determinada pelos extremos identificamente proporcionais da necessidade material ou da opulência.

O ideal para Américo era, portanto, uma doutrina ${ }^{181}$ ainda válida e, mais do que isso, necessária ao presente ${ }^{182}$, que, no entanto, havia sido iniciada no passado glorioso dos gregos: daí outra importância de estudá-los. Mas tratava-se para o jovem, justamente, do desenvolvimento de um ideal moderno ${ }^{183}$, herdado das reivindicações da geração romântica pós-1830 ${ }^{184}$,) que respondesse às demandas da contemporaneidade sem sucumbir ao mesmo tempo a uma imitação vazia do legado clássico ${ }^{185}$. O que ele esperava era a compreensão dos princípios da grande arte e não a imitação dos seus efeitos.

Teria sido a propósito o aparecimento de um tal sistema idealista, em estreita relação com o presente clássico, o que teria definido a supremacia artística deles em toda história da humanidade $^{186}$. Não era apenas o jovem que o afirmaria, nem somente Viollet-Le-Duc ou Beulé, em seus respectivos cursos por ele seguidos, mas a grande maioria dos autores com os quais trabalhava. Como visto, eles atestavam que os gregos teriam inventado o "estilo ideal""187, isto é, o "racionalismo" na arte ${ }^{188}$, ou ainda, precisamente, o "espiritualismo racionalista", 189.

A minoria que não estava de acordo com essa interpretação era também vantajosa de se considerar, na medida em que permitia Américo mostrar as limitações em suas observações. Assim,

${ }^{181}$ Idem, Ibidem. p.125 [Estudo quarto]. Ou: Correio Mercantil, Rio de Janeiro, 9 de outubro de 1864, p.2.

182 BEULÉ. Cours d'archeologie. Discours d'ouverture à la Bibliothèque Imperiale. Paris: Typhographie de Firmin Didot Frères, Fils et Cie, 1858. p.22.

${ }^{183}$ AMÉRICO, P. La Réforme de l'École des Beaux-Arts et l'opposition. p.9.

Cit.

${ }^{184}$ Sobre o problema do "Ideal moderno" entre os românticos da geração de 1830, ver: ROSENTHAL, Léon. Op.

${ }^{185}$ AMÉRICO, P. op. cit. p.9.

${ }^{186}$ AMÉRICO, P. "Considerações Filosóficas sobre as Belas Artes entre os Antigos". p.88 [Estudo segundo]. Ou: Correio Mercantil, Rio de Janeiro, 1 de outubro de 1864, p.2.

${ }^{187}$ WINCKELMANN, op. Cit. P.345; QUINCY, Q. Sur l'idéal.... p.74; IDEM, Essai sur le but et la nature..p.237; SUTTER, D. Op. Cit. P.117.

${ }_{188}$ VIOLLET-LE-DUC, op. cit. p.63-65, entre outras passagens.

${ }^{189}$ LAPRADE, Victor de. op. cit. p.162. 
ele não se esquecia de relembrar o leitor da famosa querela que havia se estabelecido no começo do século XIX entre Quatremère de Quincy e Éméric-David, justamente sobre a ascepção grega do termo ideia, nem de expor a sua concordância ao lado do primeiro que, para ele, teria vencido magistralmente seu "vigoroso adversário"190.

Éméric-David, "nutrido dos princípios positivos do realismo""191, havia suposto que o conceito, derivado de eidos, teria significado entre os gregos apenas "forma visível" "192, e que o que eles haviam buscado em seu sistema artístico teria sido tão somente a representação fiel da natureza, tal como a percebiam ${ }^{193}$. Quincy, por outro lado, "lançando sobre os fatos uma vista mais extensa e profunda" ${ }^{194}$, havia compreendido que a ideia, na doutrina artística dos gregos, teria o papel de designar a presença de um modelo fundamentalmente metafísico ${ }^{195}$, que daria como resultado não formas servilmente tomadas de seres particulares, mas formas universais, sínteses intelectuais de toda espécie de seres ou pensamentos. Para cada um destes objetos haveria de fato um tipo ideal, inacessível à simples experiência direta, mas somente à atividade intelectual ${ }^{196}$.

É claro que cada uma dessas interpretações etmológicas atrelava-se a um programa artístico que, demonstrando racionalmente a perfeição dos gregos, no momento da refundação da Académie des Beaux-Arts, desejava se impor no sentido de reencontrar os princípios específicos que regiam suas produções e recriar todas as circunstâncias possíveis para o desenvolvimento da arte no presente.

Sustentando o posicionamento quincyniano, mais do que deduzir que os gregos jamais teriam imitado por imitar, Américo reforçava, portanto, a ideia difundida de que eles teriam conduzido compassadamente sua arte por uma filosofia racional ${ }^{197}$ de fundo moral e religioso, postura que justificava o porquê de suas mais importantes produções estarem amiúde relacionadas à representação divindades, isto é, a um processo de conversão de formas realmente determinadas (os modelos reais) em outras, idealmente determinadas.

\footnotetext{
${ }^{190}$ AMÉRICO, P. p.125 [Estudo quarto]. Ou: Correio Mercantil, Rio de Janeiro, 9 de outubro de 1864, p.2.

${ }_{191}^{19}$ AMÉRICO, P. p. 125.

192 ÉMERIC-DAVID. Op. cit. p.179: "o belo ideal, considerado nele mesmo, não pode designar outra coisa senão o belo visível, o belo real, o belo da natureza." [tradução nossa]

193 ÉMERIC-DAVID. Recherches sur l'estatuaire. Paris: Renouard, 1863. p.179.

${ }^{194}$ AMÉRICO, P. Op. Cit. p.124 [estudo quarto]. Ou: Correio Mercantil, Rio de Janeiro, 9 de outubro de 1864, p.2.

195 QUINCY, Quatremère. Essai sur la nature, le but et les moyens de l'imitation dans les Beaux-Arts. Paris: Treuttel et Würtz, 1823.pp.-243-245.

${ }^{196}$ Idem, ibidem. p.223.

${ }^{197}$ AMÉRICO, P. p.88 [Estudo segundo]. Ou: Correio Mercantil, Rio de Janeiro, 1 de outubro de 1864, p.2.
} 
Em suma, o que o jovem queria fazer eraa defesa de um ideal filosófico infalível que guiasse a arte. O pintor que desejasse se tornar um filosófo não poderia fugir ao domínio da ideia, pois a filosofia, da maneira como Américo a encarava e a perseguia, em acordo com seus professores, era a "ciência das ideias, a ciência do que é verdadeiro, bom, justo e belo, não aqui ou ali, hoje ou amanhã" 198 , mas sempre.

\section{Da beleza}

O primeiro e incortornável compromisso artístico da doutrina seguida por Américo é a dedicação integral à produção do Belo ${ }^{199}$. Na qualidade de uma das ideias universais da filosofia platônica, permanente em suas atualizações espiritualistas, ele apresenta também, consequentemente, um caráter independente ${ }^{200}$, que se consubstancia perfeitamente sem, no entanto, se confundir com as ideias do Bom e do Verdadeiro ${ }^{201}$. A suposição de que sua existência fosse objetiva implicava a promessa de estabelecimento de uma verdadeira ciência que desse conta de toda sua extensão - isto é, de suas dimensões materiais e espirituais -, orientando com segurança o artista em seu caminho.

Desde as observações desenvolvidas em Considerações Filosóficas, Américo demonstra acreditar cada vez mais na validade de uma "ciência do Belo" (e não exatamente de uma Estética), que se imporia por sobre os danos causados pelos postulados kantianos - especialmente por sobre a noção de que o reconhecimento da beleza em uma obra se ancoraria num julgamento inteiramente individual e psicológico, disso resultando a impossibilidade mesma de um Belo universal. Para ele, o Belo teria uma "realidade estética" que, portanto, transcenderia a "subjetividade estética"202.

${ }^{198}$ TIBERGHIEN, op. Cit. P.27. [tradução nossa]

${ }^{199}$ AMÉRICO, P. op. cit. p.218, [estudo quarto]. Correio Mercantil, Rio de Janeiro, 10 de outubro de 1864, p.2.

${ }^{200}$ Logo nos primeiros capítulos de Considerações Filosóficas, Américo delimitará a leitura do que entende ser o "poder impessoal e divino do belo e da verdade". AMÉRICO, P. op. Cit. p.94 [estudo segundo]. Ou: Correio Mercantil, Rio de Janeiro, 2 de outubro de 1864, p.3. Seu posicionamento teórico em relação a essa noção noção permanerá firme nos anos seguintes, e ainda no fim dos anos 1860 ele continuará a defender a existência de ideias universais e independentes do homem. Sintomaticamente, logo na epígrafe de abertura de sua tese, assinada por ele próprio, pode-se ler: "A verdade é impessoal. Pode-se procurá-la sem encontrar; pode-se encontrar sem reconhecê-la; pode-se reconhecer sem admiti-la; pode-se mesmo se servir dela e negá-la; mas nada pode ser feito para que ela deixe de ser a verdade."O trecho original é : "La vérité est impersonnelle. On peut la chercher sans la trouver; on peut la trouver sans la reconnaître; on peut la reconnaître sans l'avouer; on peut même s'en servir en la niant, mais nul ne peut faire qu'elle ne soit pas la vérité. (L'auteur)". AMÉRICO, Pedro. La science et les sytèmes: questions d'histoire et de philosophie naturelle. Seconde édition. Bruxelles: Gustave Mayolez, 1869.

${ }^{201}$ AMÉRICO, P. Considerações Filosóficas sobre as Belas Artes entre os antigos. p.70 [estudo primeiro]. Ou: Correio Mercantil, Rio de Janeiro, 30 de setembro de 1864, p.1; e: Correio Mercantil, Rio de Janeiro, 30 de setembro de 1864, p.2.

${ }^{202}$ Para a distinção entre "realidade estética " e "subjetividade estética", ver: ZANGWILL, N. The Metaphysics of Beauty. Ithaca: Cornell University Press, 2001. 
O projeto estava de fato bastante em voga na França, exatamente nos seus anos de formação européia, e havia sido oficialmente proposto por Victor Cousin a partir de um concurso aberto no Institut de France, em 1857. A agenda, expressa pelo parecerista do rapport, Barthélemy SaintHilaire, previa encontrar os "princípios de uma ciência de Belo independente" ${ }^{203}$ e, sobretudo, francesa: um intuito tardio que visava desapegar as reflexões estéticas nacionais de suas filiações com a filosofia alemã ${ }^{204}$.

Sendo o fim da arte a percepção sensível e espiritual do Belo, tornava-se evidente, por conseguinte, que semelhante ciência devesse se orientar integralmente à descoberta dos princípios determinantes desse conceito, e logo, do devir artístico. A confluência de objetivos em ambas as atividades colocaria filósofo e artista, teoria e prática, no mesmo plano, a ponto de serem mesmo indispensáveis os seus encontros. Para o mesmo Saint-Hilaire,

as qualidades necessárias para tratar adequadamente uma ciência do Belo são ao mesmo tempo as de um filósofo e as de um artista. [..] se a alma do filósofo não sente vivamente as potentes impressões da beleza, se ele não se emociona ou entusiasma tanto quanto o próprio artista, ele não aprofundará a ciência em todas as suas partes. ${ }^{205}$

Conforme sugerido, era uma demanda de confluência significativamente similar que determinava, no Brasil, as qualidades exigidas desde 1855 ao professor que se ocupasse da cadeira

${ }^{203}$ BARTHÉLEMY SAINT-HILAIRE, Jules. "Rapport fait au nom de la section de philosophie sur le concours relatif à la question du Beau, par M. Barthélemy Saint-Hilaire, lu dans les séances des 16 et 20 avril 1859". In: INSTITUT DE FRANCE. Mémoires de l'Académie des Sciences Morales et Politiques de l'Institut Impérial de France. Tome XI. Paris : impr. de F. Didot, 1862. P.73-74.

204 OLIVIER, Alain Patrick. "Les paradoxes de la science du beau dans la philosophie française". In: LICHTENSTEIN, Jacqueline (org.). Vers la science de l'art : l'esthétique scientifique en France, 1857-1937. Paris : PUPS, DL 2013, cop. 2013. p.22.

O trabalho ganhador do concurso era de autoria de um dos discípulos de Cousin, Charles Lévêque, professor de filosofia do College de France. Transformado em seguida em livro, ele será impresso em 1861, em dois volumes, com o significativo título A Ciência do Belo. Nele, o autor insiste, como era de se eparar, no caráter idealista do Belo. LÉVÊQUE, Charles. La Science du Beau étudiée dans ses principes, dans ses applications et dans son histoire. Paris: Durand, 1861.

${ }^{205} \mathrm{O}$ excerto original: "Nous ajoutons que les qualités nécessaires pour traiter la science du Beau sont à la fois celles d'un philosophe et celles d'un artiste. [...] et si l'âme du philosophe ne sent pas vivement les puissantes impressions de la beauté, s'il n'est pas ému et enthousiasmé autant que l'artiste lui-même, il n'approfondira pas la science dans toutes ses parties.". B. SAINT-HILAIRE. Op. Cit. P.76.

Émeric-David, como visto, referência fundamental a Américo, ao justificar suas qualidades e seus interesses para o descobrimento das causas da perfeição da arte grega, já havia emitido, no início do século XIX, uma união bastante similar àquela defendida por Barthélemy: "Obrigado a ser ao mesmo tempo historiador e artista, nós procuraremos, de início, quais foram os caracteres primitivos do povo grego, suas necessidades, suas instituições, sua situação política, para mostrar como, por um efeito de leis e de costumes, o gosto geral foi conforme à natureza; e como, por outro efeito das mesmas causas, as artes estava submetidas ao gosto geral”. ÉMERIC-DAVID. Op. cit. p.03. 
de História das Belas Artes, Estética e Arqueologia da AIBA ${ }^{206}$, ainda sustentada por um Thomás Gomes dos Santos em $1862^{207}$, e novamente em 1869, quando enfim conferia seu parecer positivo sobre a posse de Américo nessa disciplina ${ }^{208}$.

Simultaneamente artista e filóso, Américo não apenas se via pronto para assumir um curso teórico, mas ele também endossava ${ }^{209}$ a hipótese (trivial a inúmeras personalidades artísticas, no país e no exterior) de que as faculdades filosóficas as quais ele se empenhava pessoalmente em desenvolver haviam determinado, ao longo da história, o destino e glória dos maiores artistas ou obras de arte conhecidas. Era o que ela havia também defendido na carta enviada ao imperador em 1862, em que pedia a extensão de sua estadia em Paris:

Além dos meus trabalhos de pintura, que absorvem a maior parte do tempo, não esqueço um só instante das Ciências, que forma a base de todos os conhecimentos e que brilham nas principais produções dos grandes artistas. Se tal ideia tem parecido estranha a um grande número de pessoas que exercem a arte como profissão, não é menos verdade que os pontos culminantes das belas artes são ocupados por aqueles que reúnem o maior número de conhecimentos; e que, se bastam o gênio e o sentimento para produzirem Rembrandt e Claudio de Lorena, Rafael, Miguel Ângelo e Poussin, são antes de tudo obras do gênio guiadas pelas luzes da ciência e da literatura. ${ }^{210}$

Como indicado, esse requisito havia sido de contínuo reforçado desde os seus primeiros anos na AIBA, sob as demandas de instrução teórica e filosófica instauradas aos artistas pela Reforma Pedreira, e sob a orientação de Porto Alegre; e na sequência, justamente em seus anos Franceses, quando as discussões oficiais levantadas por um Viollet-Le-Duc e por outras personalidades artística e políticas importantes faziam apenas confirmar o desejo atualizado de fornecer uma profunda formação intelectual dos estudantes, sem no entanto abandonar a mesma via

206 "Da [cadeira de] Historia das Bellas Artes - Esthetica e Archeologia

Art.45. Este curso alêm da exposição oral que deve fazer o Professor dos factos e das theorias que lhe são proprios constará tambem de demonstrações graphicas e plasticas já em pedra, já por via de modelos, de sorte que os alumnos comprehendão com a conveniente perfeição o objecto da Cadeira.” FERRAZ, Luiz Pedreira do Coutto. "Decreto $\mathrm{n}^{\mathrm{o}}$ 1.603, de 14 de Maio de 1855 dá novos Estatutos á Academia das Bellas Artes". In: http://www2.camara.leg.br/legin/fed/decret/1824-1899/decreto-1603-14-maio-1855-558536-norma-pe.html [ùltimo acesso: outubro de 2015]

${ }^{207}$ SANTOS, Thomás Gomes. "Minuta da Academia em 1862, informando requerimento em que Daniel PEdro Ferro Cardoso, intitulando-se bacharel e arquiteto pela Academia de Belas Artes de Paris, pede a cadeira de HIstória das belas arte, estética e arqueologia”.Arquivo Museu d. João VI. Rio de Janeiro. Número da cota: 4908.

${ }^{208}$ SANTOS, Thomás Gomes. "Minuta de ofício da Academia ao ministro do Império em 12 de agosto de 1869 , informando sobre o requerimento de Pedro Américo de Figueiredo e Mello, em que pede transferência para a cadeira de História das Belas Artes, estética e arqueologia". Arquivo Museu d. João VI. Rio de Janeiro. Número da cota: 5807.

${ }^{209}$ AMÉRICO, P. Considerações Filosóficas. P.96 [estudo segundo], p.148 [estudo sexto], p.164 [estudo sexto], entre outras. Ou, respectivamente: Correio Mercantil, Rio de Janeiro, 2 de outubro de 1864, p.3; 30 de outubro de 1864 , p.1; e 16 de novembro de 1864, p.2.

${ }^{210}$ AMÉRICO, Pedro. "Carta enviada de Paris ao imperador d. Pedro II, em 6 de janeiro de 1862". Petrópolis, Arquivo da Casa Imperial do Brasil. Maço 131, doc. 6418. 
idealista compartilhada outrora por neoclássicos e por românticos ${ }^{211}$. Não apenas essa via havia sido mantida em ambas as reformas brasileira e francesa, mas a promessa de que a sua travessia, sendo fruto de um genuíno esforço filosófico, também encerraria como recompensa a revelação máxima do Belo ideal ${ }^{212}$.

Em linhas gerais, Américo e seus compatriotas do período não miravam muito longe dos horizontes artísticos que quais Winckelmann, 100 anos antes, afirmara ter sido o dos gregos, sendo ainda os mesmos que o alemão havia pregado aos artistas do seu tempo. De fato, para um como para outro, a tarefa imutável de um verdadeiro artista não era apenas a realização do Belo, mas justamente do Belo ideal ${ }^{213}$. Naturalmente, após tanto tempo - e como consequência de incontáveis trabalhos que, a partir da segunda metade do século XVIII, haviam inaugurado um viés oficial para a reflexão e fundação da Estética como disciplina autônoma, além do advento neoclássico na Académie e na École e de sua reação romântica -, esse conceito havia por certo adquirido para o jovem brasileiro uma nova gama de significados teóricos específicos que Winckelmann teria ignorado. Américo, por exemplo, já não identificava o fundamento da beleza exclusivamente com a estatuária grega (embora ela fosse uma de suas mais verdadeiras expressões), como o teria feito Winckemann, em suas dívidas com a doutrina "belle nature"214. Do mesmo modo, também haviam ganhado novos significados as faculdades que permitiriam a realização mesma do Belo (gênio,

${ }^{211}$ Para um conhecido, mas ainda bastante válido panorama do idealismo nos neoclássicos e nos românticos, ver: ARGAN, Giulio Carlo. Arte Moderna: do Iluminismo aos movimentos contemporâneos. São Paulo: Companhia das Letras, 2013.

${ }^{212}$ A esse respeito, pode-se lembrar a apreciação que Pierre-Jean-Baptiste Chaussard fazia da exposição do Rapto das Sabinas, de Jacques-Louis David: "Se elevando como eles [os gregos] ao belo ideal, descendo pelas mais felizes transições à imitação animada da natureza, à maneira de Rafael, ele imprime [David] à sua composição, a partir dos exemplos deles [dos antigos], o selo de um pensamento profundo, e se propõe a um fim filosófico. O original: "S'élevant comme eux au beau idéal, descendant à la manière de Raphaël, par les plus heureuses transitions, à l'imitation animée de la nature, il imprime, d'après leur exemple, à sa composition, le cachet d'une pensée profonde, et se propose un but philosophique." p.02. CHAUSSARD, P.-J.-B. Sur le tableau des Sabines par David. Paris: Charles Pougens, 1800.

${ }^{213}$ WINCKELMANN, op cit. P.239. Para uma leitura um tanto pessimista, mas esclarecedora do legado Winckelmaninano e de sua exigência de uma arte ideal, ver BAZIN, Germain. História da história da arte : de Vasari a nossos dias. São Paulo: Martins Fontes, 1989. p.83.

${ }^{214}$ Sobre o problema da "belle nature" e a formação de uma teoria artística, especialmente na França, no século XVII, ver: MORTIER, Roland. L'originalité : une nouvelle catégorie esthétique au siècle des lumières. Genève: Droz, 1982: "O classicismo francês do século XVII vai restringir consideravelmente o campo da imitação. Em nome do bom gosto e das boas maneiras ["bienséances"], ele vai excluir do domínio das belas artes um grande número de objetos e reduzir assim o conceito de natureza ao de bela natureza ['belle nature']. Essa limitação se acompanha de outra, que concerne aos modelos nos quais [um artista] deve se inspirar na imitação criadora. A natureza não será vista em estado bruto, mas já decantada através da obra de autores tidos como exemplares. Pode-se falar assim de uma natureza duplamente purificada, posto que afastada de todas suas impurezas, e definir essa mímesis como deliberadamente mediatizada. Sob essa forma ela impregnará toda a estética do tempo e sua ação continuará profunda até o século XIX." P.25-26. [tradução nossa]. Sobre o problema que essa doutrina causará, segundo a percepção de críticos, teóricos e artistas do século XVIII, especialmente na atenção exagerada que dará à imitação das obras dos grandes mestres, disso resultando um afastamento evidente da "verdadeira" natureza, ver ainda : BABBITT, Irving. The New Laokoon: an essay on the confusion of the arts. Boston/New York: Houghton Mifflin Company, 1910. Pp. 12-13; Ver ainda, LEE, R. Op. Cit. Especialmente os capítulos: "Da invenção" e "Da expressão". 
razão, imaginação, liberdade, vontade etc.), assim como as suas relações internas necessárias para essa síntese.

Entretanto, até o período no qual Américo publica as suas Considerações, ao menos uma noção permanecia intacta aos partidários do idealismo artístico: a ideia de que o Belo ideal, embora fosse o último e mais perfeito grau de realização artística, era um entre outros tipos possíveis de Belo.

Duas categorias principais presentes nos escritos do jovem Américo destacam, com efeito, noções tradicionais que pressupõem as existência, de um lado, do Belo real e, de outro, justamente do Belo ideal, tal como Cousin os havia reinterpretado desde as primeiras décadas do século XIX $^{215}$, e sistematizado em 1853, na segunda parte do seu Du Vrai, du Beau et du Bien.

A esta altura, não será preciso estender maiores reflexões para se concluir sobre a insuficiência que o Belo real demonstra ter ao brasileiro. Esse termo então se configura como uma simples impressão decorrente das qualidades aparentes identificadas em um objeto determinado. Trata-se desse modo de uma reação sensorial a um estímulo momentâneo oferecido pela natureza, essa, sim, inteiramente empática e psicológica. A representação artística desse tipo de beleza não exigiria muito de um artista, na medida em que poderia ser obtida a partir de uma tradução apegada à "simples" observação direta ${ }^{216}$. Como consequência, ele construiria um tipo limitado e imperfeito de Belo, típico da maioria dos objetos visíveis, já que a Natureza, embora perfeita em si mesma, dificilmente consegue formar um objeto livre de imperfeições; correção que cabe assim à arte efetuar $^{217}$. Sendo uma atração unicamente corporal, o Belo real obliteraria a razão, pois fazia esquecer que a arte era uma atividade centrada na invenção de uma síntese expressiva, e não na cópia, devendo a todo custo ser evitado ${ }^{218}$.

Os resultados que esse tipo de belo podia oferecer seriam bastante distintos daqueles atingidos pelo Belo ideal, cujos encantos e prazeres não eram os do corpo, mas, precisamente, do

${ }^{215}$ COUSIN, Victor. "Du Beau Réel et du Beau Idéal". In: COUSIN, Victor. Oeuvres de Victor Cousin. Fragments Philosophiques. Tome Deuxième. Cours d'histoire de la philosophie morale. Bruxelles: Société Belge de Librairie, 1841. pp.114-117.

${ }^{216}$ AMÉRICO, P. p.168 [estudo sétimo]. Ou: Correio Mercantil, Rio de Janeiro, 17 de novembro de 1864, p.2.

${ }^{217}$ AMÉRICO, P. p.123-24 [estudo quarto]. Correio Mercantil, Rio de Janeiro, 9 de outubro de 1864, p.2.Américo continua aqui a noção aristotélica de que a arte deve melhorar e generalizar a natureza, já que ela não o pode fazer por ela mesmo. Ver: MATTÉI, Jean-François. "L'émergence de l'idée de beauté en Occident." In: LUMLEY, Henry. Le beau, l'art et l'homme. Paris: CNRS Éditions, 2014. Pp.139-148. A mesma noção, já amplamente estudada, havia sido inicialmente retomada durante do século XV, especialmente a partir do Da pintura, de Alberti, primeiro grande tratado artístico da Renascença: ALBERTI, Leon Battista. Da pintura. [tradução Antonio da Silveira Mendonça]. Campinas: Unicamp, 2014.

${ }^{218}$ AMÉRICO, p.157 [estudo sexto]. Correio Mercantil, Rio de Janeiro, 15 de novembro de 1864, p.2. 
espírito e da razão ${ }^{219}$ (também encarados pelo brasileiro, segundo a concepção absorvida de Quatremère de Quincy, como "prazeres morais"220). O Belo ideal era, para Américo (num encadeamento de citações diretas e indiretas que o levam de Quatremère de Quincy a Cícero), “um certo tipo intelectual de perfeições que nós trazemos no fundo de nossa alma, e que consultaram os grandes artistas" ${ }^{221}$. Em outras palavras ele era, "uma perfeição imaterial que a alma sente através da beleza da matéria"222 ; ou, ainda, a "mais elevada e racional" concepção da "ideia sensível da perfeição",223.

Uma vez antingido, o Belo ideal levaria a uma suspensão - de tempo e de espaço ${ }^{224}$-, qualidade que as estátuas gregas e as obras dos maiores mestres renascentistas não cansariam de lembrar. A verdadeira beleza se tornaria, assim, a expressão de um contentamento pleno, uma purificação $^{225}$ (mas não uma catarse, no sentido aristotélico), onde nenhum outro sentimento, como tristeza, melancolia ou terror - enquanto movimentos anormais do espírito, que obscurecem a razão - podem entrar ${ }^{226}$. Esse é o motivo que impedia Américo de qualificar a arte gótica, em seu suposto misticismo filosófico, de bela ${ }^{227}$, pois a beleza, em suas qualidades visíveis, deveria ser a imagem de "uma eterna paz [que] nasce da perfeição e do repouso". E "não é isto a imagem da divindade?" ${ }^{228}$ Não seria ela a imagem representativa de uma razão plena e perfeita ${ }^{229}$, onde reinam a ordem e a tranquilidade? ${ }^{230}$

Residindo nas duas categorias de Belo duas fontes e dois fins completamente distintos de prazer, torna-se evidente que, dada a centralidade que o homem deve ocupar no devir artístico deduzido por Américo, o Belo real, ancorando-se unicamente nos sentidos, se apresenta como uma

${ }^{219}$ Idem, ibidem. P.114 ; p.115 [estudo terceiro]. Ou: Correio Mercantil, Rio de Janeiro, 5 de outubro de 1864, p.2.

${ }^{220}$ QUINCY, Quatremère. Essai sur la nature, le but et les moyens de l'imitation dans les Beaux-Arts. Paris: Treuttel et Würtz, 1823. P.162, p.176, entre outras.

${ }^{221}$ Idem, ibidem, p.126 [estudo quarto]. Ou: Correio Mercantil, Rio de Janeiro, 9 de outubro de 1864, p.2. O trecho no qual Américo desenvolve essas ideias é, na verdade, uma tradução feito do texto de Quincy, "Essai sur la nature, le but et le moyens de l'imitation dans les Beaux-Arts". O mesmo trecho de Quincy, por sua vez, é uma citação e comentário a uma aludida Oratória, de Cícero. Entretanto, tal obra não existe com esse nome. Talvez trate-se de uma versão moderna da Partitiones Oratoriae que Quincy tinha em mãos, conquanto não pude descobrir mais informações a respeito.

${ }^{222}$ Idem, ibidem, p.157 [estudo sexto]. Ou: Correio Mercantil, Rio de Janeiro, 15 de novembro de 1864, p.2.

${ }^{223}$ Idem, ibidem, p.127 [estudo quarto]. Ou: Correio Mercantil, Rio de Janeiro, 9 de outubro de 1864, p.2.

${ }^{224}$ Idem, ibidem. p.115 [estudo terceiro]. Ou:Correio Mercantil, Rio de Janeiro, 5 de outubro de 1864, p.2.

${ }^{225}$ Idem, ibidem, p.94 [estudo segundo]. Ou: Correio Mercantil, Rio de Janeiro, 2 de outubro de 1864, p.3.

${ }^{226}$ Idem, ibidem, p.114 [estudo terceiro]. Ou: Correio Mercantil, Rio de Janeiro, 5 de outubro de 1864, p.2.

${ }^{227}$ Idem, ibidem. p.110-12 [estudo terceiro]. Ou: mesma edição do Correio, p.2.

${ }^{228}$ Idem, ibidem. p. 114

${ }^{229}$ Idem, ibidem. p.115 [estudo terceiro]. Ou: mesma edição do Correio, p.2.

${ }^{230}$ Idem, ibidem. p.114. [estudo terceiro]. Ou: mesma edição do Correio. 
categoria que corre a todo tempo o perigo de ser concupiscente. Apenas o Belo ideal, na qualidade de abstração racional, se mantém fundamentalmente casto.

Com efeito, a percepção do Belo real e do ideal se assemelhava para Américo, proporcialmente, à imagem de uma mulher tomada “em duas épocas ou períodos diferentes de sua vida": uma, aos 13 anos ou menos; outra, aos 23 anos. ${ }^{231}$ No primeiro momento, a inocência e pureza que existem internamente em sua alma espelham e se fazem mesmo perceber na pureza do seu corpo e gestos, que se acordam perfeitamente na unidade de sua essência: "Eis a época em que a mulher é uma santa imagem da beleza moral" ${ }^{, 32}$. No segundo momento, iniciada aos prazeres e tentações do corpo, ela descobre e manifesta em seus gestos a malícia. Seus movimentos não mais condizem à mesma unidade então existente, mas são calculados e artificiais: sua beleza física "em vez de pureza nos revelam vaidade, porque tudo nela é material, tudo respira desejos [...] nossa atenção, despertada pelo brotar viçoso da natureza física, nela se detém e esquece o resto."233 Aqui, a beleza é incompleta, porque a matéria, em lugar de se unir completamente ao espírito, o deturpa, na atenção dada aos sentidos. Lá, a beleza é incorruptível.

Este último teria sido o tipo idêntico de imagem que inspirava os grandes artistas gregos. Eles teriam mostrado, com o amparo de sua filosofia esclarecida, como seria possível desenvolver um sistema que, conquanto centrado quase sempre na representação de figuras completamente despidas ou semidespidas, não permitiria que fossem percebidas nuas ${ }^{234}$. Ao contrário, passados mais de 2000 anos de suas produções, suas imagens continuavam a ser respeitosamente graves e serenas, porquanto representantes da "religião do amor intelectual"235. Nesse rol de notórios lideraram Fídias (o maior escultor da antiguidade) e Praxíteles (o escultor da graça). E era de fato de um dos dois que Américo, a partir das atribuições dissemelhantes de Quincy e Émeric-David ${ }^{236}$, então presumia ser autoria da "mais bela" (ainda que a "mais simples") estátua conhecida ${ }^{237}$ : a Vênus de Milo.

${ }^{231}$ Idem, ibidem. p.157 [estudo sexto]. Ou: Correio Mercantil, Rio de Janeiro, 15 de novembro de 1864, p.2.

${ }^{232}$ Idem, ibidem. p. 157.

${ }^{233}$ Idem, ibidem. Pp.157-158 [estudo sexto]. Ou: Correio Mercantil, Rio de Janeiro, 15 de novembro de 1864, p.2.

${ }^{234}$ Idem, ibidem. p.159 [estudo sexto]. Ou: mesma edição anterior.

${ }^{235}$ Ibidem, ibidem, p.153 [estudo sexto]. Ou: Correio Mercantil, Rio de Janeiro, 2 de novembro de 1864, p.2.

${ }^{236}$ Idem, ibidem, p.158. Quatremère de Quincy havia proposta a autoria da Vênus de Milo a Praxíteles, em seu texto "Sur la statue antique de Vénus découverte sur l'île de Milo en 1820. Émeric-David, por sua vez, atribuirá a obra à Fídias ou à sua Escola, em seu opúsculo“Observations sur la statue antique de femme trouvée dans l'île de Milo, en 1820, et déposée dans le Musée Royal de France”. A obra, bastante posterior ao período de ambos os escultores sugeridos, é datada do II século A.C., e sua autoria permanece desconhecida.

${ }^{237}$ Idem, ibidem. p. 150 [estudo sexto]. Ou: Correio Mercantil, Rio de Janeiro, 30 de outubro de 1864, p.1; e 2 de novembro de 1864, p.2. 
Mais do que qualquer outra, nessa escultura estavam para o jovem todos os princípios da beleza, todos os atributos que um sistema artístico completo, favorecido ao mesmo tempo por diversas causas, poderia desenvolver na execução de uma obra de arte. Por isso, ela no topo, e suas demais "irmãs" a secundando, deveria continuar no horizonte de um artista que, como Américo, também aspirando ao "ideal moderno", ainda desejasse continuar a "revestir o pensamento com as formas da poesia" e a "conhecer as leis do belo"238.

\section{Dos princípios e da aparência do Belo}

As "Leis" ou os "princípios" do Belo são substantivos sinônimos nos textos filosóficos acessados por Américo, também por ele indistintamente alternados em seus escritos. Enquanto princípios, eles não podem ser muitos, resumindo-se a uma cartilha de conceitos sobre a qual toda obra intitulada bela deve estar integralmente fundada.

Entre todos os autores estudados pelo jovem, um em especial, Jean-David Sutter (18111880), havia dedicado uma série obras consecutivas endereçadas aos estudantes de arte e arquitetura, nas quais expunha metodicamente tais "princípios", esperando suas aplicações práticas nas obras dos futuros artistas.

Também ele um pintor, Sutter havia sido o primeiro professor a oferecer um curso livre e gratuito na École des Beaux-Arts ${ }^{239}$ após a reforma de novembro de $1863^{240}$ - medida, como visto, apoiada pelo brasileiro, na esperança de que as novas cadeiras oferecidas por personalidades competentes e externas à instituição desenvolvessem nos alunos "o amor à instrução", e ampliassem a gama de ideias estéticas lá professadas ${ }^{241}$.

Ainda que Américo, já no Brasil, não tivesse seguido pessoalmente as aulas de Estética geral e aplicada oferecidas na instituição francesa (transformadas em livro ainda no mesmo ano $^{242}$ ), ele havia, entretanto, até aquele momento, estudado ao menos ${ }^{243}$ a primeira grande obra

\footnotetext{
${ }^{238}$ Idem, ibidem, p.87 [estudo segundo]. Ou: Correio Mercantil, Rio de Janeiro, 1 de outubro de 1864, p.2.

${ }^{239}$ S/A. "Cours d'Esthétique Générale et Appliquée par M. David Sutter, peintre". In: Gazette des Architectes et du Batîment. Paris, 1865, 3a. Année, n.10. pp.151-154.

${ }^{240}$ Quando ele abria seu curso de Estética Geral e Aplicada (o qual oferecerá durante anos), no primeiro semestre de 1865, Hippolyte Taine (re)inaugarava quase ao mesmo tempo, também na École, o curso de Estética e História da Arte, substituindo o então egresso Viollet-Le-Duc.

${ }_{241}$ AMÉRICO, P. La réforme de l'École des Beaux-Arts et l'opposition. P.12.

${ }^{242}$ SUTTER, J.-David. Esthétique générale et appliquée. Paris: Imprimerie impériale, 1865.
} 
daquele autor, publicada logo antes de sua chegada a Paris, uma "Filosofia das Belas Artes aplicada à pintura" ${ }^{244}$. Ao que tudo indica, o texto lhe havia causado bastante impacto. Além de consultá-lo e citá-lo ${ }^{245}$ em seus escritos, é ainda possível perceber o esforço que fazia para adequar as lições

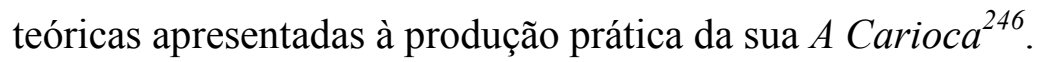

Na medida em que se esforçava para expor metodicamente as "leis" da arte em seus textos, Sutter rogava não tomar nenhum parti-pris estético ${ }^{247}$, salvo aquele que lhe parecia universalmente irrefutável, pois cingindo todos os outros, a saber, o espiritualismo-idealismo artístico. O seu primeiro curso na École havia sido, significativamente, uma extensão precisa de suas discussões anteriores, também sobre o problema contemporâneo do realismo versus idealismo presente na arte francesa $^{248}$. Desse seu conhecido posicionamento estético resultara, com efeito, a recomendação e incorporação de todas suas as publicações à bibliografia sugerida ao aprendizado dos alunos daquela instituição, antes e depois da reforma ${ }^{249}$ - motivo pelo qual o jovem brasileiro tenha provavelmente tomado conhecimento dos textos desse autor.

Segundo o relatório da Académie des Beaux-Arts, emitido precisamente sobre a Filosofia da Arte aplicada à pintura, o autor era elogiado por ter devidamente defendido a "nobreza do pensamento, da poesia e da beleza da forma" na pintura, e por ter da mesma maneira postulado que ela deveria concorrer com as demais artes "para o aperfeiçoamento moral da sociedade" 250 por meio dos "ensinamentos do verdadeiro belo na arte da pintura" 251 . A aproximação com os mesmos pontos de defesa sustentados por Américo em suas Considerações é desde logo notória.

Esquematicamente, sendo o Belo ideal a fusão perfeita e completa da beleza ótica ${ }^{252}$ e da beleza moral - isto é, sendo o resultado da relação de seus meios de aparição com seus fins

${ }^{243}$ Digo "ao menos" porque é bastante provável que tivesse mesmo modo acessado uma segunda publicação, de fins especialmente práticos, também muito conhecida do mesmo autor (pois, como apresento em seguida, oficialmente sugerida aos estudantes da École), uma Teoria simplificada da perspectiva, impressa em 1859. SUTTER, D. Nouvelle théorie simplifiée de la perspective. Paris: Jules Tardieu, 1859.

${ }^{244}$ SUTTER, D. Philosophie des beaux-arts appliquée à la peinture. Paris: J. Tardieu, 1858.

${ }^{245}$ AMÉRICO, P. Considerações Filosóficas. p.122; p.124 [estudo quarto]; p.143 [estudo quinto]; p.158 [estudo sexto], entre outras páginas nas quais as discussões desenvolvidas por Sutter aparecem no trabalho de Américo. Ou, respectivamente: Correio Mercantil, Rio de Janeiro, 9 de outubro de 1864, p.2; 14 de outubro de 1864, p.2; e 15 de novembro de 1864, p.2.

${ }^{246}$ Ver o Quinto Capítulo desta Tese.

${ }^{247}$ SUTTER, D. Esthétique appliquée. p.04.

${ }^{248}$ Ver, por exemplo, BONNET, Alain. Op. Cit. P.189.

${ }^{249}$ A Esthétique générale et appliquée de Sutter era de fato dedicada ao conde Nieuwerkerke.

${ }^{250}$ MERCEY, Frédéric Bourgeois de."Extrait du rapport fait à l'Académie des Beaux-Arts sur l'ouvrage de M. Sutter, intitulé : Traité de la théorie de la peinture, rapport adopté dans la séance du 17 mars 1856." In: SUTTER, D. Philosophie des beaux-arts appliquée à la peinture. Paris: J. Tardieu, 1858. P.01.

${ }^{251}$ Idem, ibidem.

${ }^{252}$ Idem, ibidem. p.101 e seguintes. Chamo aqui atenção para a distinção que Sutter cria entre a beleza ótica frente ao Belo real, anteriormente discutido neste Capítulo. Enquanto este último é uma reação estética limitada e imperfeita, 
metafísicos ${ }^{253}$-, seus princípios deveriam ser, para Sutter, os mesmos que regiam simultaneamente a experiência estética (guiada por princípios técnicos) e a experiência intelectual (guiada por princípios morais) $)^{254}$.

Tornada visível, a beleza ideal seria regida por dois caracteres principais: a grandeza e a ordem; e cada um deles, por sua vez, encerraria uma série de outros valores específicos.

Segundo Sutter, a grandeza compunha-se da forma, do claro-escuro, da cor e da graça ${ }^{255}$, determinando as gradações entre as categorias da ideia do belo até o seu "rompimento" em direção ao sublime - este compreendido como uma categoria estética na qual o "racional" e o "mensurável" cediam lugar ao sentimento de indeterminação, de desmedida e de infinito. As matizações históricas e estéticas já feitas por um Winckelmann, que reconhecia a beleza ideal em seu apogeu grave e severo em Fídias, e a beleza ideal mais "alegre", posto que já temperada pela graça, em Praxíteles e seus seguidores, se somavam também desde o século XVIII às leituras francesas do "pequeno" belo (“le joli”) ou ao agradável (“L'agréable”), ufanado por Montesquieu em seu Ensaio sobre o Gosto - também lido pelo jovem Américo. A passagem de uma categoria à outra se daria pela relação e combinação desses valores entre si. Por exemplo, uma beleza mais grave, como a de uma Atenas Partenos ou de um Zeus Olímpico, ambos de Fídias, exprimiria uma forma mais austera, por meio de conformações quase hieráticas nos gestos das figuras. Em uma Vênus de Médicis, em contrapartida, o gesto de delicado das mãos que cobrem (mas não cobrem realmente ) os seios e o sexo da deusa instalam a graça.

O outro carácter da beleza, a ordem, encerraria, necessariamente, todos os princípios do Belo e, portanto, de sua teoria.

Para Suter, como o Belo é um - diferindo-se sensivelmente apenas em relação a seu grau de aparição -, decorre que o princípio fundamental da arte deve ser a unidade ${ }^{256}$ : da ideia, das linhas,

pautada apenas nos sentidos, para Sutter, a beleza ótica é simplesmente o conceito que lhe permite argumentar determinadas "leis da visão", apreendidas nos objetos ditos belos. Neles, estão acordados visivelmente forma, cor e claro-escuro (p.121). Para Sutter, portanto, um objeto pode ser esteticamente belo em seu último grau, sem ser moral; e ser moral, sem ser esteticamente belo.

${ }^{253}$ Idem, ibidem. p. 116.

${ }^{254}$ Era a partir desse pressuposto que Sutter propunha que o "estudo aprofundado" das leis da arte era "o único meio de adquirir um gosto seguro, um julgamento esclarecido; de reconhecer as causas da beleza ou da feiúra; não somentenas artes, mas ainda na moral.” Idem, Ibidem. P.245-46. Tradução nossa.

${ }^{255}$ SUTTER, J.-David. Esthétique générale et appliquée. Paris: Imprimerie impériale, 1865. p.65.

${ }^{256}$ Segundo Sutter, o "estudo aprofundado das leis da unidade é o único meio de adquirir um gosto seguro, um julgamento esclarecido; de reconhecer as causas da beleza ou da feiúra, não somente nas artes, mas ainda na moral ou na metafísica". [Tradução nossa]. p.246.

MORTIER, Roland. Op. cit, também faz interessantes leituras sobre o problema da unidade entres os "modernos", do século XVII e XVIII. cf. p.26 e 27. Do mesmo modo, BECQ, Annie. Op. cit., em diversas passagens. 
do claro-escuro, do colorido, de ação etc ${ }^{257}$ : não será nenhuma surpresa descobrir que, também para Sutter, teria sido esse o mais importante princípio perseguido pelos gregos, fosse na parte ótica ou na parte metafísica de sua arte ${ }^{258}$.

Assim como a ideia de Deus, o Belo deveria ser, no entanto, uma unidade necessariamente composta de variedades $^{259}$. Sem variedade, a arte torna-se monótona, e, logo, sem vida ${ }^{260}$. Uma tal reunião necessária, ou composição ${ }^{261}$, deveria ser realizada com decoro (ou conveniência ${ }^{262}$ ), que levaria o artista escolher calculadamente o quê e como representar, e regida necessariamente pelos princípios da ordem e da harmonia (que seriam ao mesmo tempo ideias e sentimentos ${ }^{263}$ ), sem os quais, e especialmente sem esta última, "não há beleza"264 . Posto que a "confusão de elementos é o caos" 265 , é precisamente da "harmonia das partes constitutivas" que consiste a unidade de um objeto $^{266}$, e, por conseguinte, a clareza de sua ideia. Por sua vez, o sentimento de harmonia atingiria completamente sua plenitude quando uma unidade estiver determinada com justeza em relação ao todo e às suas partes internas, e isso seria apenas possível na presença da ideia ou (novamente) do sentimento de proporção ${ }^{267}$ : a última mas não menos importante "lei” estética.

Em semelhante urdidura, é fácil concluir que a irrealização ou alteração de quaisquer um dos princípios apresentados por Sutter comprometeria toda a trama, e portanto, a percepção mesma do Belo ideal. Um verdadeiro artista deveria estar atento a todo tempo à necessidade e à relação sistêmica desses valores em seu trabalho, daí o interesse em organizá-los teoricamente de modo a estabelecer um manual filosófico para a prática dos jovens artistas. Ainda a esse respeito, Sutter compreendia que a principal contribuição do seu livro não viria da explanação original das "leis" da

${ }^{257}$ SUTTER, D. Philosophie des beaux-arts appliquée à la peinture. p. 125.

${ }^{258}$ Idem, ibidem. p. 122.

${ }^{259}$ Idem, ibidem. pp.130-132.

${ }^{260}$ Idem, ibidem. p. 130.

${ }^{261}$ Idem, ibidem. p.184-187.

${ }^{262}$ A conveniência, segundo o autor, "prescreve o grau ou a quantidade de variedades que se pode introduzir numa obra de arte". p.123. Sobre o mesmo princípio, ver ainda: p.90; p.92; p.124; p.134, entre outras.

${ }^{263}$ Para a ordem considerada ao mesmo tempo como uma ideia e sentimento em Sutter, ver: idem, ibidem, p.90; Para o mesmo em relação à harmonia, ver: idem, ibidem. p.63 (para sua apresentação como ideia) e p.75 (para sua discussão como sentimento).

A consideração não é particular a Sutter. De fato, outros autores acessados por Américo, e ele próprio, lidavam com os resultados das reavaliações que, desde o século XVIII, se haviam feito das categorias da imaginação (sentimento) e da razão (ideia), acordando-as na noção de uma razão que as conciliaria adequadamente. Essas reavaliações, conforme discuti em Capítulo precedente, já se apresentavam nos trabalhos de Cousin sob a distinção entre razão refletida e razão intuída.

${ }^{264}$ Idem, ibidem. P.75.

265 Idem, ibidem. p. 122.

${ }^{266}$ Idem, ibidem .p. 125.

267 Sobre a importância do princípio da proporção em Sutter, ver: Idem, ibidem. p.113, p.117, p.164, p.169, pp.180-86, p.193, p.278, p.345. 
arte, mas de sua sistematização para fins $\operatorname{práticos}^{268}$, por isso a ideia de uma Estética ou Filosofia aplicada. Ele sabia que os princípios recorrentemente defendidos em seu primeiro grande livro, e mantidos nos seguintes, eram compartilhados por todos os textos filosóficos do período (da arte ou não) ${ }^{269}$ ancorados em mesmo viés idealista ${ }^{270}$ (seriam, com efeito, alguns dos mesmos conceitos tornados teoricamente claros, pela primeira vez, no período romano, a partir da contribuição de Vitruvio $^{271}$, que por sua vez garantia se tratarem novamente dos mesmos princípios seguidos pelos gregos). Quaisquer afinidades que dispunham com as formulações ecléticas ou krausistas, vistas até aqui, não eram portanto de modo algum casuais, nem tão pouco as relações estabelecidas com o Considerações Filosóficas, de Pedro Américo.

Do mesmo modo que a maioria dos textos filosóficos indicada por Sutter, também o texto do jovem brasileiro não expunha sistematicamente os princípios da arte. Américo não parecia encará-lo como necessário, já que argumentava se tratarem leis conhecidas por qualquer adepto ou leitor ocasional de filosofias ou das teorias da $\operatorname{arte}^{272}$, o mesmo que, se suporia, estaria interessado em ler seu texto. Isso não quer dizer que Américo não invocava todos esses conceitos, convenientemente. Assim, se pode ler asserções do seguinte tipo em seu estudo: "a necessidade de clareza, de ordem e de precisão, o sentimento das proporções determinadas", "de completo acordo entre um todo e suas partes", "constituem a ideia do belo" ${ }^{, 273}$. Ou que, diante das esculturas paradigmáticas dos gregos, obras que, "só nos despertam ideias de ordem, de harmonia e de unidade"274, "um espectador esclarecido procuraria em vão tirar ou ajuntar um elemento a esse todo de belezas, sem romper-lhe a harmonia" 275 .

${ }^{268}$ Para Sutter, “os princípios da beleza foram assinalados nos escritos dos filósofos, mas sua aplicação às belas artes tem sido pouco prática; e também a ideia complexa que encerra a palavra beleza foi rejeitada em vantagem a [certo] número de mistérios nos quais apenas o gênio é capaz de penetrar." [Tradução nossa]. Idem, ibidem. p.117.

269 Entre algumas das referências trabalhadas por Américo que também lidam com o problema da unidade, harmonia e variedade como obrigatórios à arte, ver: COUSIN, op.cit., pp.26-27; p.154, p.160, entre outras passagens; ÉMERIC-DAVID, op. cit. p.185; p.234; p.238-39; LAPRADE, op. cit. p.19, p.56; QUATREMÈRE DE QUINCY. Sur l'idéal dans les arts du dessin. Paris: 1805. p.44, p.81; e VIOLLET-LE-DUC, op. cit. p.39, p.51, p.69, p.82.

${ }^{270}$ A similitude entre os trabalhos de Sutter e as demais filosofias idealistas da arte do período já havia sido de fato sinalizada por um editor do Moniteur des Architectes, em 1867, quando da abertura do terceiro do curso de Estética Aplicada daquele pintor: "As ideias que formam o fundo do ensino do Sr. Sutter se encontram em gérmen na maior parte das obras publicadas sobre as interessantes matérias das quais nos ocupamos [isto é, a Estética]." [tradução nossa] MARSAN, Paul de. "Cours d'Esthétique général et appliquée". In: LE MONITEUR des architectes, Paris, 1867, $2^{\circ}$ vol., 2a. série, 1er Juillet 1867. p.124.

${ }^{271}$ VITRUVIOS POLLIO, Marcus. Tratado de arquitetura / Vitrúvio ; tradução do latim, introdução e notas M. Justino Maciel. São Paulo : Martins Fontes, 2007. Ver em especial o Livro I, Capítulo II.

${ }^{272}$ Idem, ibidem. p.157 [estudo sexto]. Ou: Correio Mercantil, Rio de Janeiro, 15 de novembro de 1864, p.2.

${ }^{273}$ AMÉRICO, P. op. Cit. P.113 [estudo terceiro]. Ou: Correio Mercantil, Rio de Janeiro, 5 de outubro de 1864 , p.2.

${ }^{274}$ Idem, ibidem. P.217, [estudo quarto]. Ou: Correio Mercantil, Rio de Janeiro, 10 de outubro de 1864, p.2.

${ }^{275}$ Idem, ibidem. p.115, [estudo terceiro]. A ideia de que a mudança de que uma parte pode quebrar a justa medida, e portanto a beleza e um todo é já claramente exposta por Aristóteles, em sua Arte Poética. 
Como em repetidos momentos do texto do jovem, os gregos continuariam a provar, ainda para essas questões, a universalidade da noção que admitia que:

no mundo moral como no físico, nas obras do Criador, como nas do homem, tudo aquilo que merece o nome de belo" acha-se "em harmonia com todos os seres e com o fim para que fora criado; a beleza do corpo humano, a temperança, a felicidade das sociedades, os movimentos celestes, a ordem, enfim, que liga e mantém debaixo das mesmas leis a criação inteira, não" podem “existir senão pelas relações harmônias do metro e dos números ${ }^{276}$.

Tomando essas noções como máximas universais, Américo supõe que sempre que as artes estiverem perdidas (ou, por relação lógica, se elas ainda não tiverem verdadeiramente florescido, como no Brasil), se um artista instruído se encontrar em dúvidas sobre por onde começar a regenerá-las (engrendrá-las), bastaria apenas retornar aos gregos, o primeiro e infalível gabarito da humanidade para as "leis" da arte e da vida, e assim, como que de imediato, uma bússola infalível a atemporal estaria instalada ${ }^{277}$.

\section{Da Imitação}

Em 1864, ainda não havia dúvidas de que a arte falava por meio da imitação. A formulação de teorias artísticas que propunham uma abstração da forma até seu rompimento total com o código figurativo ainda não era proposta nem mesmo pelos artistas mais radicais do período, como, por exemplo, Courbet e Manet - que, entretanto, executavam sem dúvida procedimentos de simplificação que, de algum modo, começavam a colocar em discussão o problema da abstração em uma nova perspectiva. A antiga perspectiva decorria da mesma exigência idealista e, no entanto, tradicional de que a arte, em seus princípios, deveria unir, ordenar, compor, harmonizar, medir. Essa demanda era amparada, precisamente, pelo postulado de que a atividade artística teria sempre se tratado, e deveria sempre se tratar, de um verdadeiro esforço de abstração do mundo visível.

${ }^{276}$ Idem, ibidem. p.140-41. A sequência quase completa desse excerto é uma tradução que Américo fará dos estudos de Émeric-David (Recheches sur lArt Statuaire), e Louis de Ronchaud (Phídias). Ver a lista da bibliografia citada e/ou utilizada por Américo, em anexo, nesta Tese.

${ }^{277}$ Idem, ibidem. p.87 [estudo segundo]. Ou: Correio Mercantil, Rio de Janeiro, 1 de outubro de 1864, p.2. 
Ainda nos anos de formação de Pedro Américo, no Brasil e no exterior, o termo preciso "abstração" continuava a ser largamente empregado por escritores e filósofos da arte, um uso que também ele não tardava em fazer ${ }^{278}$.

Se, de um lado, esse requerimento resvalava na forte defesa que ainda se fazia do trabalho artístico enquanto uma atividade sobretudo liberal ${ }^{279}$, de outro, continuava a lembrar suas antigas raízes platônicas e a expectativa de uma marcha racional em direção ao mundo metafísico das ideas eternas e completas. Um programa artístico que supunha esse percurso teria como consequência inevitável a problematização da matéria mesma com o qual o artista trabalhava, e ainda dos procedimentos que deveria empregar para tornar sensível a ideia que desejaria expressar. Em outros termos, se arte era uma abstração racional da natureza real, tornava-se fundamental considerar os métodos que regulavam essa tarefa em sua linguagem de base ${ }^{280}$.

Esse era um dos motivos pelos quais, durante os anos 1850 e 1860, importava tanto aos idealistas, continuando um argumento classicista do século XVII ${ }^{281}$, realizarem comparações com os "novos" realistas (afinal, eles sempre teriam existido ao longo da história) no sentido de garantir a insuficiência das investigações destes últimos, supostamente limitados ao método sensualista. A imitação por meio da qual realizavam suas obras, ainda que pudesse demonstrar virtuosamente os meios técnicos (mecânicos) da arte, permaneceria completamente destituída dos seus fins morais (intelectuais).

${ }^{278}$ Sobre a ideia de que a arte deve ser uma atividade de abstração do visível, especialmente no trabalho de Américo, e na bibliografia por ele consultada, ver: AMÉRICO, P. op. Cit. P. 124 [estudo quarto]. Ou: Correio Mercantil, Rio de Janeiro, 9 de outubro de 1864, p.2; BEULÉ, C. op. Cit. P.12; LAPRADE, V. op. cit.p.13-14, p.30, p.139, p.141, entre outras; QUINCY, Q. Essai sur la nature, le but... p.212-213, p.220, p.228-229, p.232, p.233, entre várias outras; Idem, sur l'ideal dans les arts du dessin. p.7, p.27, p.30, p.58, p.60, pp.64-68, p.72, p.100, entre outras; VIOLLET-LE-DUC; op. cit. p.15, p.46.

Sobre o mesmo problema encarado de um ponto de vista mais geral, mas ainda dentro da filosofia: COUSIN, V. op. cit. pp.40-41, pp.43-45, p.120, p.204, entre outras; TIBERGHIEN, G. op. cit. p.27, p.115, p.138-139.

${ }^{279}$ Para uma interessante contribuição em perspectiva histórica sobre a "invenção da arte" como uma atividade liberal, ver: SHINER, Larry. The invention of art: a cultural history. Chicago: University of Chicago Press, 2001.

Sobre a defesa que Américo faz do seu trabalho como uma "carreira liberal", e ainda sobre o preconceito que enfrenta no Brasil, ver AMÉRICO, P. Considerações Filosóficas sobre as Belas Artes entre os Antigos. p.194.

${ }^{280} \mathrm{O}$ problema da estruturação de um método para a imitação, quando o que interessa é a revelação da qualidade imutável do Belo, está presente na crítica e teoria de arte francesas desde o século XVIII. Ver, por exemplo, MORTIER, R. op. cit. p.27: "O século XVIII, especialmente na França, permanece fiel a uma racionalidade do belo, o que implica seu caráter imutável e a necessidade de um aprendizado, isto é, de uma imitação."

281 Para uma leitura sucinta, mas sugestiva do problema, amparada por um amplo terreno histórico, ver: PANOFSKY, E. Ideia, p.106-7: “'Combate contra os naturalistas' e 'combate contra os maneiristas', tal é o programa que define, no sentido em que a entendemos [a ideia] hoje, a 'estética idealista'. Esse combate, que se trava simultaneamente na dupla frente da metafísica e do empirismo, explica o caráter propriamente polêmico e normativo das concepções neoclássicas, que aliás só tomam consciências de si mesmas em razão dessa dupla oposição. Por aí explica-se também uma concepção que a teoria maneirista da arte jamais havia sublinhado, segundo a qual a arte teria necessidade absoluta da natureza como de um substrato ou material que seria preciso purificar, mas, de modo não menos absoluto, se mostraria superior à natureza 'ordinária', ainda não submetida ao processo de purificação, donde resultava que a imitação da natureza teria apenas um valor inferior." 
A distinção dos procedimentos de um artista assim dito manco $^{282}$ e de um verdadeiro artista era expressa pelo próprio Américo por uma outra formulação clássica, de base aristotélica: "para atingir à perfeição da suprema beleza, não basta imitar a natureza nas suas formas sensíveis; é mister ligar ao conhecimento do que é ou existe realmente, o sentimento do que pode e deve ser." ${ }^{283}$

Tendo ainda em mente as reavaliações ecléticas e, especialmente, krausistas sobre o real, Américo era forçado a aceitar que uma obra de arte, "na sua ascepção mais lata" é a "representação sensivel de um fato, de um objeto, ou de um pensamento" ${ }^{284}$; o que não lhe parecia no entanto uma formulação suficiente para "encerrar um pensamento estético" completo, na medida em que isso abriria as portas para um caminho pelo qual o fim da atividade artística poderia também ser percebido como imitação em si mesma, ao lado daquele que levaria à "ideia do belo". Fazendo isso, ele queria deixar claro, desde o início, a sua refutação ao "método acanhado de imitação exclusiva", também chamada de imitação servil ${ }^{285}$, em vantagem de um método que torne sensível, "por meio de formas corporais, a ideia geral e completa de uma beleza cuja perfeição absoluta não se pode encontrar na natureza",286.

Mesmo que os objetivos de um tal método fossem em geral bastante claros ("a ideia geral e completa de uma beleza" só poderia ser uma abstração do indivíduo em direção à sua espécie, de uma ideia particular de beleza à ideia única que represente todas as outras possíveis de seu gênero), ainda durante os anos de formação do jovem Américo, artistas e teóricos continuavam a divergir e a criar novas formulações quanto ao fundamento filosófico da imitação em direção à beleza ideal; e as suas diferenças se concentravam em duas linhagens históricas então já bastante conhecidas.

${ }^{282}$ A expressão original artiste manqué é recorrente nas críticas de arte francesa desde, pelo menos, a geração romântica de 1830. A ideia de uma falta (une manque), sobretudo de imaginação, (qualidade tão cara àquela geração) se referia precisamente aos artistas que, sabendo imitar perfeitamente aquilo que viam, não conseguiam no entanto “imaginar" o que não viam.

${ }^{283}$ AMÉRICO, P. op. Cit. P.126 [estudo quarto]. Ou: Correio Mercantil, Rio de Janeiro, 9 de outubro de 1864 , p.2. Todo o parágrafo no qual Américo inclui essa frase é uma tradução mais ou menos livre do livro Essai sur la Nature, le but et le moyen de l'imitatoin dans les Beaux-Arts, de Quincy. P.243-244. Como se sabe, uma das mais antigas noções conhecidas na quais se considera que a arte representa os homens melhores, piores ou iguais aos demais aparece na Arte Poética de Aristóteles. [Ver ARISTÓTELES, Livro II, 48a]. Também nela se encontra a primeira exigência teórica (embora fundada no pensamento literário, e não pictórico) que esperavada arte a representação de homens não como são, mas como deveriam ser [ARISTÓTELES, IX, 51a e b]. Para uma avaliação crítica sobre como essa formulação encontrará uma teorização posterior, diretamente ligada à pintura, a partir do Renascimento, ver: LEE, Rensselaer W. Ut Pictura Poesis. The humanistic theory of painting. New York: Norton \& Company: 1967. p.6, e pp.09-16.

${ }^{284}$ Idem, ibidem. p.74

${ }^{285}$ SUTTER, D. op. cit p.190; VIOLLET-LE-DUC. op. cit. p.27. A compreensão histórica das artes mecânicas como uma atividade desenvolvida por escravos e servos (portanto supostamente não "racional", e na medida em que o oposto exato da atividade "liberal" ) elucida claramente o que tais autores do período queriam dizer com imitação servil, indigna às belas artes.

${ }^{286}$ AMÉRICO, P. op. Cit. P.128 [estudo quarto]. Ou: Correio Mercantil, Rio de Janeiro, 9 de outubro de 1864 , p.2. Novamente, também nessa sentença, Américo realiza uma citação ao trabalho de Quincy, anteriormente citado em nota. 
De um lado, permaneciam os adeptos da teoria aristotélica da beleza ${ }^{287}$, que, na esteira de Alberti $^{288}$ (1404-1472), seguindo ainda as teorizações cinquecentistas de Ludovico Dolce (1508/101568) e seiscentistas de Giovanni Pietro Bellori (1613-1696), haviam encontrado na anedota do pintor grego Zeuxis o mito fundador dos procedimentos artísticos para a beleza ideal ${ }^{289}$. Na discussão desse método, absolutamente significativa à teoria artística de orientação clássica ${ }^{290}$, a ideia da beleza viria de uma experiência empírica de seleção e combinação das melhores partes oferecidas por diversos modelos acessados por um artista, síntese convencionalmente chamada de "belo de reunião". Nessa discussão também se havia incluído, desde Dolce e Bellori ${ }^{291}$, a ideia de que numa tal seleção, centrada na percepção sensivelmente externa, deveria se incluir o estudo da belle nature - expressão que se transformaria no cartão de visita da doutrina artística central ao século XVII francês, pautada no estudo e imitação das mais belas estátuas gregas ${ }^{292}$. Era numa combinação desses dois procedimentos iniciais que se fundava, ainda no século XVIII, a teoria neoclássica da Beleza ${ }^{293}$, especialmente teorizada por Winckelmann, em sua ênfase incondicional ao legado clássico: como visto, uma teoria que Américo conhecia muito bem, se bem que, conforme discutirei, não estivesse inteiramente de acordo, especialmente em relação à ideia, também

287 Segundo R. W. Lee, “Aristóteles associava a ideia da natureza e a excelência da produção artística ao conhecimento das coisas universais obtido a partir da experiência particular [empírica]; em uma passagem que dialoga com a função idealizadora da arte e que antecipa a história de Zeuxis em escritores posteriores, ele havia notado que a superioridade da arte de um pintor sobre os objetos reais repousava sobre a fusão que fazia de perfeições esparsas em um composto sintético de todas elas " [tradução nossa]. Idem, Ibidem. p. 14-15. A passagem à qual especificamente se refere o autor para chegar a essa conclusão está na Metafísica, na qual o filósofo grego diz: "A arte aparece quando, de uma infinitude de noções experimentais, se descola um único julgamento universal aplicável a todos os casos similares" . Metafísica, Aristóteles, I, 1, 98a.

${ }^{288}$ Ver: ALBERTI, Leon Battista. Da pintura. [tradução Antonio da Silveira Mendonça]. Campinas: Unicamp, 2014. Para uma avaliação da leitura de Alberti sobre a história de Zeuxis, ver: PANOFSKY. Op. Cit. P. 57-58.

${ }^{289}$ A história é bastante conhecida, e repetida até a exaustão até o século XIX: solicitado a pintar a imagem de Helena (a mais bela de todas as mulheres), Zeuxis teria escolhido as 5 mais belas jovens de Crotona e, selecionando diretamente as partes mais belas de cada uma, teria, em seguida, construido um modelo de beleza insuperável. A história de Zeuxis encontra-se no Da invenção, de Cícero (106-43 A.C.). É também contada na História Natural, de Plínio (23-79 D.C.), a qual, segundo R. Lee, havia sido facilmente consultada por artistas e teóricos da Renascença. Ver, Idem, ibidem. p.15, nota 57.

${ }^{290}$ Ver: PANOFSKY, Erwin. Ideia, especialmente o capítulo Renascença.

291 Dolce sugere o estudo conjunto da natureza e da estatuária antiga no seu Dialogo sobre a pintura (1557). O complemento do estudo da estatuária que o autor sugere aos artistas, propondo assim o estabelecimento de um método artístico superior, será reforçado não pela anedota de Zeuxis, em sua imitação seletiva das cinco mais belas mulheres de Crotona, mas pela história do pintor Apeles e do escultor Praxíteles, que, devendo representar Afrodite, dispunham de uma única modelo, a bela Frinéia. Mesmo que um artista moderno dispusesse de uma modelo tão bela quanto a célebre amante dos dois artistas, ela jamais estaria livre de imperfeições, e portanto ele deveria se lembrar da estatuária grega (que já havia mostrado o caminho da beleza ideal), para corrigir em suas obras as imperfeições existentes na natureza.

Quanto à postura de Bellori, R. Lee ainda sugere que "ao dar à teoria da pintura uma orientação aristotélica, Bellori foi o primeiro escritor do século XVII a formular o que se tornou a doutrina central do classicismo francês - a doutrina da 'belle nature' ". [tradução nossa]. Ver LEE, op. Cit. P.11 (para Dolce); e pp.15-16 (para Bellori). Ver ainda PANOFSKY. Op. Cit. P.80 (para Dolce); e pp.101-105 (para Bellori).

${ }^{292}$ LEE, R. Op. Cit. P.17. Sobre o problema da "belle nature”, tal como se reapresentará no começo do século XIX, ver também: BECQ, Annie. Op. Cit. p.839.

${ }^{293}$ Sobre a noção do "belo de reunião", presente nas discussões artísticas do início do século XIX, ver: BECQ, A. Op. Cit. p.811, p.813. 
winckelmanianna, de que o Belo ideal é uma média de diferentes belezas que um indivíduo percebe em vida.

De outro lado, estavam os partidários da teoria neoplatônica da beleza, os quais, continuadores da exegeses "maneiristas" de um Giovanni P. Lomazzo (1538-1592) e de um Federico Zuccari (1542[43]-1609), reverteriam a lógica da teoria artística renascentista, defendendo que a revelação da Beleza ideal seria um processo cujo princípio não poderia ser imputado à experiência sensível direta, mas unicamente à “imagem que se vê refletida no espelho do próprio espírito, [e que] tem sua origem antes em Deus do que na natureza" ${ }^{294}$. Em vão o artista buscaria, portanto, procurar na matéria percebida a ideia do Belo, fosse em um, fosse em vários modelos. E mesmo que o estudo da arte grega, na sua grandeza reconhecida, pudesse ajudar um artista a conhecer plenamente os mais altos valores da arte, ele não poderia se restringir, como se compreendia a partir do século XVIII, a uma imitação da forma clássica, ação que produziria apenas seus efeitos e não suas causas ${ }^{295}$. Uma crítica formada nesse sentido não apenas deveria ruir a hegemonia da doutrina da "belle nature" 296 , mas iria abrir, enfim, a via à reação romântica na França $^{297}$, na sua dupla defesa ao acesso a uma natureza atualizada e, especialmente, a um ideal em muitos pontos similar às fundamentações neoplatônicas sobre a imitação(ainda que muitas vezes ele não se apresentasse enquanto um belo de forma ${ }^{298}$ ): isto é, a recusa à noção teórica de "belo de reunião" em vantagem daquele amparado pela ideia e sentimento existentes a priori no espírito do artista, acessados pela faculdade imaginativa ${ }^{299}$.

Entre as suas referências, Américo irremediavelmente se deparava com esses dois lados da teoria artística (Winckelmann ${ }^{300}$, Émeric-David ${ }^{301}$ e Sutter $^{302}$, por exemplo, adotaram abertamente a

${ }^{294}$ LEE, R. op. cit. P.13. Sobre o novo lugar que os textos de Lomazzo e Zuccari dão ao termo "Ideia", na teoria artística italiana, ver ainda: PANOFSKY, E. Op. Cit. especialmente Pp.85-98.

${ }^{295}$ Pode-se lembrar aqui também da crítica similar que Américo fará aos alunos da "escola davidiana" ou "escola clássica", por ele pejorativamente encarados como "imitadores dos gregos", no sentido aqui em que a "imitação" era então encarada no seu primeiro e insuficiente grau. AMÉRICO, P. La réforme de l'École des Beaux-Arts et l'opposition. P.07-08.

${ }^{296}$ LEE, op. Cit. p.19, p.32.

297 Para uma discussão sobre o movimento romântico como uma reação (embora essa reação seja explicada em categorias demasiadamente antitéticas da arte francesa: racional x irracional, desenho x cor etc.), ver FRIEDLANDER, Walter. De David a Delacroix. São Paulo: Cosac \& Naify, 2001. P.16,e seguintes. Ver ainda: ALLARD, Sébastien. “L'expérimentation romantique”. In: LOYRETTE, Henri. L’art français: Le XIXe siècle (1819-1905). Paris : Éditions Flammarion, 2006. Pp.40-126.

${ }^{298}$ Idem, ibidem. P.56-57.

${ }^{299}$ Cf. BECQ, A. op. cit. p.812.

${ }^{300}$ WINCKELMANN, op. cit. p.252.

${ }^{301}$ ÉMERIC-DAVID. op. cit. p.132.

${ }^{302}$ SUTTER, D. op. cit. p.105 (especialmente) e p.113. 
hipótese da imitação a partir do método do "belo de reunião"; enquanto outros autores como Laprade $^{303}$ e Viollet-Le-Duc ${ }^{304}$ sustentaram suas posições no terreno metafísico).

Mais uma vez o jovem não adotava um ou outro lado integralmente. Sua intenção era a de acordar as teorias aristotélicas e neoplatônicas da imitação, as mesmas cuja oposição ele (mas não somente ele) percebia ainda perdurar na querela dos clássicos e dos românticos. Curioso é que a síntese que ele desenvolvia provinha quase inteiramente de Quatremère de Quincy, nas formulações apresentadas no livro "Sobre o ideal nas artes do desenho"305 (1805) e, sobretudo, no "Ensaio sobre a natureza, o objetivo e os meios da imitação nas Belas Artes" (1823) $)^{306}$. Esse acolhimento foi possível porque o próprio Quincy havia esboçado uma teoria de certo modo precocemente eclética (e, de fato, Américo via o francês como um eclético ${ }^{307}$ ), tentando conciliar, nos procedimentos da imitação, sensação e sentimento, realismo e idealismo, sem, no entanto, também titubear quanto à existência objetiva do Belo ideal numa obra de arte.

Para Quincy, ao se tratar de procedimentos artísticos, era preciso "distinguir duas coisas na obras da imitação: sua concepção e sua execução. ${ }^{308}$ ". A primeira seria evidentemente amparada por um procedimento metafísico ${ }^{309}$. A partir desse também, também para Américo, coerente com o desenvolvimento da sua gênese histórica das artes, o nascimento individual de uma obra decorreria de uma ideia, presente desde o início no espírito do artista.

Isso parecia ser tão verdadeiro a ponto de lhe parecer suficiente relembrar as citações que Quincy havia feito de uma autoridade como Cícero - em seu comentário sobre como o Fídias procedia em suas obras -, para provar que a doutrina do ideal, longe ser "uma especulação dos

\footnotetext{
${ }^{303}$ LAPRADE, V. op. cit. p.23.

${ }^{304}$ VIOLLET-LE-DUC. op. cit. p.40-41; e p.67.

${ }^{305}$ QUINCY, Q. Sur l'idéal dans les arts du dessin. Paris: 1805.

${ }^{306}$ QUINCY, Quatremère. Essai sur la nature, le but et les moyens de l'imitation dans les Beaux-Arts. Paris: Treuttel et Würtz, 1823.

${ }^{307}$ Américo sugere Quincy como um eclético por filiação ao filósofo Pierre Laromiguière (1756-1837), professor de Victor Cousin, e figura extremamente importante para o esboço inicial da filosofia eclética, como visto, empreendida sistematicamente por Cousin durante a primeira metade do século XIX. Cf. AMÉRICO, P. op. cit. p.189 [conclusão]. Ou: Correio Mercantil, Rio de Janeiro, 25 de dezembro de 1864, p.1.

${ }^{308}$ QUINCY, ibidem, p.49.

Em trecho sobre Fídias, bastante próximo à leitura de Quincy, Américo também afirmará: “Duas operações concorriam necessariamente para formar as obras do insígne escultor. Uma consistia, sem dúvida no estudo e no conhecimento individual do modelo que nos cai debaixo dos sentidos, isto é, do ser materialmente considerado; a outra operação reduzia-se ao estudo e ao conhecimento intelectual desse outro modelo que só nos pode ser revelado pela consciência ou senso íntimo, pela razão, e que por isso chama-se ideal.” AMÉRICO, P. op. cit. p.126, [estudo quarto]. Ou: Correio Mercantil, Rio de Janeiro, 9 de outubro de 1864, p.2.

${ }^{309}$ Para Quincy, "O artista concebe de início sua figura ou suas figuras, [...] que ele vê em sua imaginação antes que elas existam em realidade. [...] Essa primeira operação é de tal modo importante, que decide quase tudo" QUINCY, op. cit. p.49. [tradução nossa]
} 
críticos modernos", se expressava, desde os gregos, por um método prático de igual natureza ${ }^{310}$. A escolha do romano, autor que falava de Fídias com uma distância histórica de quase 4 séculos desse artista, e não, por exemplo, de Aristóteles, distante do escultor de poucas dezenas de anos, e na mesma Atenas, se justificava de maneira mais ou menos clara: Cícero, e não Aristóteles ${ }^{311}$, havia pretendido que o maior escultor grego de todos os tempos, ao realizar suas obras, teria sempre buscado em sua mente ${ }^{312}$ um tipo eminente de beleza, que o guiasse em suas execuções: "no fundo de sua alma residia um certo tipo excelso de beleza", decorrente do "sublime arquétipo da infinita autoridade". "Eis [para Américo, para Quincy e, com eles ainda, Cousin ${ }^{313}$ ] o verdadeiro modelo de Fídias, e o único para inspirar essa grandeza altíssona e mais que humana que muitos compreendem, mas que só homens de gênio nô-la fazem conhecer."314.

Participante de um ponto culminante no ciclo artístico, correspondente àquele do alto renascimento, não parecia ser por acaso a similaridade que os procedimentos de Fídias apresentavam aos de Rafael $^{315}$. Deveria soar como outra confirmação o comentário sobre como o "pintor da beleza" 316 teria feito de sua Galatéia (vista por Américo, em Roma), procecimento descrito na tão conhecida quanto citada carta endereçada a Castiglione: "Como há penúria tanto de bons juízes como de belas mulheres, sirvo-me de uma certa ideia que me vem ao espírito." 317

Entretanto, o ponto de partida neoplatônico, dado à concepção de uma obra, especialmente a dos grandes mestres, aguardava ainda sua continuidade em relação ao problema da execução, porque, segundo Américo, além da ideia era indispensável a uma obra de arte uma "excelente expressão das perfeições materiais" ${ }^{318}$.

Para o jovem, essa segunda etapa era expressa como uma exigência aristotélica da experiência real, uma experiência da qual o próprio Fídias não teria de modo algum se abstido ${ }^{319}$.

\footnotetext{
${ }^{310}$ AMÉRICO, P. op. cit. p.125 [estudo quarto]. Ou: mesma edição citada anteriormente.

311 Para uma apreciação bastante conhecida, mas ainda extremamente importante, sobre as particularidades de Cícero e de Aristóteles no que dizia respeito ao Belo ideal, ver: PANOFSKY, E. Op. Cit. pp.15-21.

${ }^{312}$ AMÉRICO, P. op. Cit. pp.-125-128 [estudo quarto]. QUINCY, Q. Op. Cit. p.245.

313 Também Cousin, a partir de Quincy, falará do processo de realização das obras de Fídias pelos mesmo termos de Américo. cf. COUSIN, V. op. cit. p.181.

${ }^{314}$ AMÉRICO, P. 127 [estudo quarto]. Uma análise quase idêntica a essa pode ser encontrada ainda em: QUINCY, Q. Sur l'idéal dans les arts du dessin. Paris: 1805. P.53-54.

${ }^{315}$ Américo verá de fato Fídias e Rafael (à luz das leituras de Winckelmann) como artistas proporcionais no ciclo da história AMÉRICO, P. p.102 e p.105 [estudo terceiro]. Ou, respectivamente: Correio Mercantil, Rio de Janeiro, 3 de outubro de 1864, p.2; e Correio Mercantil, 4 de outubro de 1864, p.1.

${ }^{316}$ AMÉRICO, P. op. cit. p.86 [estudo segundo]. Correio Mercantil, Rio de Janeiro, 1 de outubro de 1864, p.2.

${ }^{317}$ LICHTENSTEIN, Jacqueline. A pintura, textos essenciais. Vol. 4: O belo. São Paulo: Editora 34. 2004. p.13.

${ }^{318}$ AMÉRICO, P. op. cit. p.157 [estudo sexto]. Ou: Correio Mercantil, Rio de Janeiro, 15 de novembro de 1864, p.2.

319 AMÉRICO, P. ibidem. p.126 e 127 [estudo quarto]. Ou: Correio Mercantil, Rio de Janeiro, 9 de outubro de 1864, p.2.
} 
De outro modo, guiado unicamente pela bela figura metafísica que a imaginação lhe revelara - e deve-se pensar aqui, mais uma vez, a beleza humana como cerne do sistema de imitação ao qual Américo se ancora -, o artista faria apenas uma "representação fantástica", repetindo "uma extravagância muitas vezes realizada, e em necessária oposição às ideias humanas do antropomorfismo",320.

Para tornar sensível aquela "beleza cuja perfeição não se pode encontrar na natureza", "é preciso que o esforço de sua imaginação, fecundada sem dúvida por inúmeros paralelos, crie um gênero de norma ou de modelo, no qual se reúnam as perfeições esparsas da realidade"321.

Sem nomeá-la abertamente, o jovem reportava-se à história de Zeuxis, e novamente às conclusões que Quincy (ele, sim, a comentando diretamente) chegava sobre a veracidade ou não dos procedimentos adotados pelo pintor grego para realizar a beleza suprema de Helena ${ }^{322}$, posto que, também para o teórico francês, ainda restava "saber se, na execução, se faz ou pode se fazer uma reunião efetiva de diversos indivíduos, ou de beleza parciais disseminadas na natureza" ${ }^{323}$. $\mathrm{O}$ trecho sobre o assunto, embora extenso, vale a transcrição:

Mas, digamos, que o artista use diferentes modelos - e Zeuxis, para fazer sua Helena, havia escolhido cinco das mais belas mulheres de Agrigento. Sim, responder-se-á, ele consulta as mais belas partes das mais belas figuras, análogas àquela que ele concebeu [mentalmente], para chegar ao complemento da perfeição. [...] Sem dúvida o artista busca onde ele acredita encontrar as formas relacionadas às que pensou em dar à sua figura. Ele busca, no maior número de indivíduos, o princípio regulador do belo que ele quer tornar visível; usa diversos modelos, mas não reúne as partes tal como elas são; ele as modifica em função do tipo interior. [...]

[A partir disso] somos obrigados a reconhecer que a compilação de diferentes modelos não podendo ser possível de uma maneira perceptível, nem na concepção, nem na execução de figuras ideias, a ideia de reunião de partes e de belezas parciais é apenas uma abstração, pela qual se define essa outra abstração da imitação geral, isto é, conduzida à essência do belo e ao princípio universal da natureza. O belo ideal sendo isso, a pesquisa que faz o artista, por meio de diversos modelos, não é outra coisa senão a busca de um princípio que é desenvolvido apenas parcialmente em cada indivíduo, cujo conjunto ninguém pode oferecer, e que apenas o estudo e a observação das leis da natureza podem revelar ${ }^{324}$.

\footnotetext{
${ }^{320}$ Idem, ibidem. p.127 [estudo quarto]. Ou:

${ }^{321}$ Idem, ibidem. p.126-7 [estudo quarto].

${ }^{322}$ QUINCY, Q. Sur l'idéal dans les arts du dessin. Paris: 1805.

${ }^{323}$ Idem, ibidem. p.51. [tradução nossa]

${ }^{324}$ Idem, ibidem. p.52-3 [Tradução nossa]. O paralelo com sutter:
} 
A conclusão evidente da análise oferecida por Quincy sobre a história de Zeuxis é que um artista desprovido de imaginação ${ }^{325}$, a mesma faculdade exigida por Américo aos gênios, não poderia chegar a lugar algum em suas obras, recorrendo ao método do "belo de reunião"326: em vão ele procuraria algo que não conheceria e não saberia como achar. Mesmo para um Fídias, o mesmo método de nada poderia servir se ele não concebesse antes, em sua imaginação, as figuras que iria esculpir, e se não tivesse se deixado guiar em seguida pelo respeito às leis da natureza, no momento em que efetuaria a parte material da sua arte.

Américo estava era, sem dúvida, da mesma opinião. Também para ele, reunir "as perfeições esparsas da realidade", tirando “ de um indivíduo os olhos, de outro a boca, de outro as faces, sem uma regra que presidisse à tal escolha, seria inventar monstros",327.

Outros trechos reforçam a teoria da imitação que Américo absorve de Quincy. Havia apenas uma pequena mas significativa divergência que o jovem fazia em relação às ideias do francês. Ela se referia ao uso que o artista deveria fazer da estatuária grega para o seu trabalho. Enquanto Quincy, seguindo Winckelmann, não contestava a centralidade dada ao estudo dessas produções para a criação da beleza idea ${ }^{328}$, Américo, como visto, sustentava a importância do conhecimento dos princípios e causas que teriam regido a sua excelência, mas julgava absolutamente incontornável o estudo e a preocupação do real, no sentido de se estabelecer um "ideal moderno"329.

${ }^{325} \mathrm{Na}$ medida em que Quincy defende que o belo metafísico, concretizado numa dada obra, é fruto do desenvolvimento ulterior da imagem presente de início no espírito do artista, ele não deixa de demonstrar suas dívidas para com uma sensibilidade romântica que ele próprio tentou oficialmente combater. Para Annie Becq, por exemplo. "Conceber assim o belo ideal mostra como essa noção passa do dogma clássico da natureza escolhida à estética romântica da criação, onde o valor se define pela relação de descontinuidade absoluta que ele mantém com a realidadde." [tradução nossa]. BECQ, A. Op. cit. p.824. Sobre o esforço de Quincy em lutar contra o movimento romântico, ver: SCHNEIDER, R. Quatremère de Quincy et son intervention dans les arts (1788-1850). Paris: Librairie Hachette, 1910. pp.198-202.

${ }^{326}$ Idem, ibidem. p.50.

${ }^{327}$ AMÉRICO, P. op. cit. p.128 [estudo quarto]. Ou: Correio Mercantil, Rio de Janeiro, 9 de outubro de 1864, p.2.

Esse trecho escrito por Américo estabelecia um paralelo sugestivo com um parágrafo escrito por David Sutter: "L'éclectisme, dans les arts, implique le choix; mais il ne suffit pas de prendre et de réunir des objets divers, sans ordre, sans harmonie: il faut trouver le lien qui constitue l'unité du tout; autrement ce tout ne serait pas une création supérieure aux éléments dont il est composé. L'éclectisme, pris dans son vrai sens [que é fillosófico], conduit l'inteligence à la conception du beau idéal et à la découverte des principes qui servent à le réaliser dans la pratique." SUTTER, D. Esthetique apliquée aux Beaux-Arts, p.09.

${ }^{328}$ Sobre o projeto de Quincy de estabelecer um retorno à arte antiga com vistas ao desenvolvimento da arte contemporânea, ver: SCHNEIDER, R. Op. cit. p.203 e seguintes.

${ }^{329}$ Um tipo idêntico de pensamento se encontrava nos textos de um outro autor, Louis Viardot. Um dos textos desse autor que Américo citava abordava claramente a questão da preceptiva artística. No livro "De que modo é preciso encorajar as artes" (“Comment faut-il encourager les arts?”), de 1861, Viardot antecipará alguns argumentos sobre a defesa de um "ideal modeno", o mesmo defendido por Américo desde a publicação do seu opúsculo sobre a reforma da École, ao afirmar: Certamente, "Il faut étudier l'antique, l'étudier sans cesse, ainsi qeu les belles époques de la Renaissance, mais non le copier, ni le refaire. Il faut y prendre des leçons générales e goût et de style, mais non de modèles á décalquer. Les œuvres d'art de l'antiquité et celles e la Renaissance doivent être, comme les livres classiques de ces deux époques, nos maîtres, nos instituteurs; mais à la condition que l'art et la littérature conserveront la 
A teoria da imitação que o jovem desenha pressupunha, assim, um princípio neoplatônico/romântico (a ideia surge na mente do artista, revelada pela imaginação, como uma centelha divina do Belo universal) e se convertia, em seguida, em uma marcha aristotélica/neoclássica (a consulta ao modelo e à natureza). Mas este último direcionamento não sendo, por sua vez, ainda suficiente, era preciso requerer do artista um esforço intelectual consciente (um apelo portanto à razão refletida, especularmente aparentada à imaginação, enquanto razão intuída) no sentido de projetar sobre o modelo percebido os princípios gerais da estética, purificando-o e, portanto, ultrapassando a natureza. Nas palavras do próprio Américo, "não basta ter por modelo a natureza. [...] É preciso, com efeito, interpretá-la, generalizá-la, lançando ideias sensíveis ou que nos desperta o espetáculo da vida e da matéria, no infatigável laboratório da inteligência, onde se devem transformar em um sistema razoável de preceitos que a conduza na prática da execução."330

\section{Algumas causas e refutações às causas da perfeição da arte grega}

Uma arte guiada por uma filosofia idealista, centrada na representação humana ${ }^{331}$, e submetida a princípios estéticos universais (esses, em contrapartida, idênticos aos mesmos princípios filosóficos deduzidos das naturezas divina e humana): todos esses fatores são causas consideráveis da superioridade artística grega defendida por Américo.

Entretanto, ainda que fossem uma porção importante, eles não resumiriam inteiramente a questão.

Outras causas estariam sem dúvida em jogo, e qualquer interessado em compreender as condições da perfeição artística entre os antigos em sua totalidade - o mesmo valendo para outros períodos da arte - se depararia, segundo Américo, com o fato de que a "história das artes [...] apresenta fenômenos que só se podem explicar por considerações multiplicadíssimas"332,

physionomie, l'originalité de leur époque, et seront le fidèle miroir de la société contemporaine."; A nota que segue esse trecho é também interessante: "il est bien entendu qu'en parlant ainsi, je ne veux nullement dire que la peinture doit se borner au sujet contemporain; je veux dire qu'elle doit traiter tous les sujet de son domaine suivant les idées régnantes dans la société. Par exemple, elle a traité, au seizième siècle, les sujets religieux avec la foi; aujourd'hui, elle les traitera avec la philosophie." VIARDOT, Louis. Comment faut-il encourager les arts. Paris: Jules Renouard, 1861. P.62.

${ }^{330}$ Idem, ibidem. p.124, [estudo quarto]. Ou: mesma edição da nota anterior

${ }^{331}$ AMÉRICO, P. op. cit. p.147 [estudo sexto]. Ou: Correio Mercantil, Rio de Janeiro, 30 de outubro de 1864, p.1.

${ }^{332}$ AMÉRICO, P. op. cit. p.118 [estudo quarto]. Ou: Correio Mercantil, Rio de Janeiro, 7 de outubro de 1864, p.2. 
construídas a partir de uma complexa combinação "de acontecimentos e fatos, de doutrinas e de instituições" ${ }^{\prime 33}$.

As causas anteriormente citadas fariam parte de um conjunto ainda maior de mesma natureza, o qual vários dos autores consultados por Américo consideravam ser o das "causas morais". Elas se colocariam ao lado de outras climáticas ou naturais, sociais, políticas, técnicas (físicas ou materiais), e, em última instância, individuais - estas últimas, contudo, geralmente consideradas como menos importantes, já que se tomava certo que o aparecimento de um "gênio" dependeria completamente de causas primeiras e exteriores a ele ${ }^{334}$.

A legitimidade das causas morais parecia irrefutável. Quanto às demais, elas também haviam sido concomitantemente deduzidas por diversas contribuições oferecidas desde o século XVIII (a mais emblemática continuava a ser a de Winckelmann), no sentido de garantir um panorama completo das condições do desenvolvimento artístico na antiguidade. Mas essas dificilmente haviam sido integralmente aceitas, especialmente no século XIX, quando o legado clássico podia já ser confrontado com enorme quantidade de material histórico e arqueológico proveniente das expedições francesas e inglesas realizadas desde o fim do século anterior.

Como visto, a questão ainda importava muitíssimo a personalidades contemporâneas a Américo; e esse interesse, no Brasil ou na Europa, de Porto Alegre a Viollet-Le-Duc, continuava a se amparar em uma justificativa então muito simples: o esclarecimento das causas da grande arte se apresentaria como primeiro e necessário passo para a estruturação de uma teoria infalível das artes. Será de fato após tal elucidação que Américo se sentiria no direito de propor a sua contribuição teórica para o desenvolvimento das artes no país, na última parte do Considerações Filosóficas.

Mas antes, ele a precedia de uma outra conciliação, talvez a última grande do seu texto, na qual eram estreitados, mais uma vez, os algozes do início do século XIX, Quatremère de Quincy e Émeric-David, e suas apreciações sobre a arte grega.

O primeiro, em suas "Considerações morais sobre a destinação das obras de arte", havia deduzido diretamente aquelas causas ${ }^{335}$; o segundo, entretanto, em suas "Pesquisas sobre a arte da estatuária", numa marcha dialética: ele inaugurava suas argumentações por reavaliações que ora refutavam, ora relativizavam as célebres leituras feitas por Winckelmann, em sua História da Arte,

${ }^{333}$ Idem, ibidem. p.167 [estudo sétimo]. Ou: Correio Mercantil, Rio de Janeiro, 17 de novembro de 1864, p.2.

${ }^{334}$ Idem, ibidem. p.195-96, [conclusão]. Ou: Correio Mercantil, Rio de Janeiro, 26-27 de dezembro de 1864, p.2.

335 QUINCY, Q. de. Considérations morales sur la destination des ouvrages de l'art, ou de l'influence de leur emploi sur le génie et le gout, et sur le sentiment de ceux qui en jouissnet et en reçevoient les impressions. Paris: L'Imprimière de Crapelet, 1815. 
porém ainda as causas deduzidas por Jean-Baptiste Du $\operatorname{Bos}^{336}$ (1670-1742) - de quem Winckelmann havia herdado algumas de suas teorias ${ }^{337}$ - e pelo próprio Quincy.

Américo seguiu Émeric-David em sua estratégia. Ele também iniciou suas reflexões sobre a questão com a tradução de um trecho da obra do francês, no qual indagava a posição tomada por alguns "historiadores que, tratando das belas artes" e assinalando "aos gregos a mais alta superioridade na estatuária, atribuem comumente essa aptidão à influência do clima, à religião, à liberdade política, à ‘facilidade dos costumes' e, finalmente, às recompensas dadas aos artistas." 338

O que já parecia bastante certo a Américo era que algumas dessas causas já não se sustentariam da mesma maneira como quando esboçadas nas épocas de Du Bos e Winckelmann, em especial o clima e a religião. Outras (a facilidade do nu, a religião, a liberdade), embora de fato tivessem contribuído para a perfeição da arte grega, eram então encaradas, já por Émeric-David, e ainda pelo jovem brasileiro, como "causas secundárias", o que implicava suas realocações na hierarquia de causas das belas artes ${ }^{339} \mathrm{e}$, por conseguinte, na teoria artística.

O que havia sido para Winckelmann uma das causas mais importantes para sua teoria sobre a arte grega - a importância do clima temperado para o desenvolvimento das aptidões e mesmo sobre as formas de governo daquele povo $^{340}$-, era agora encarada como uma explicação extremamente contestável: os gregos nunca haviam recebido nada de mão beijada da natureza, ora intempestiva, ora impetuosa ${ }^{341}$. Além disso, quando falava-se de arte clássica, se falava sobretudo de arte ateniense, ainda que a pequena extensão territorial que compunha a Grécia modernamente unificada - país cujo clima era praticamente o mesmo em toda sua extensão - não tivesse visto o mesmo desenvolvimento artístico em outras cidades-estados antigos: aqueus, arcádios, espartanos, etólios, fócios, tebanos, tessálios: nenhum desses povos havia, nem de perto, manifestado as aptidões às belas artes dos atenienses ${ }^{342}$.

A distinção mesma do "gênio" desses povos gregos, apresentada como justificativa, por exemplo, para a maneira artística de ser dos atenienses, e bélica, dos espartanos - outro argumento

${ }^{336} \mathrm{Du}$ Bos é autor da importante obra teórica Réflexions critiques sur la poésie et sur la peinture (1712).

${ }^{337}$ Notadamente a teoria climática.

${ }^{338}$ Idem, ibidem. p.118, [estudo quarto]. Ou: Correio Mercantil, Rio de Janeiro, 7 de outubro de 1864, p.2; e ÉMERIC-DAVID, op. cit. p.6.

${ }^{339}$ AMÉRICO, P. op. cit. p.118-19 [estudo quarto]; ÉMERIC-DAVID, op. cit. p.5.

${ }^{340}$ WINCKELMANN. op. cit. pp.89-98.

${ }^{341}$ AMÉRICO, P. op. cit. p.119[estudo quarto]; ÉMERIC-DAVID, op. cit. p.6.

${ }^{342}$ AMÉRICO, P. op. cit. p.120[estudo quarto]; ÉMERIC-DAVID, op. cit. p.6. A contestação do clima como elemento preponderante à formação das belas artes na Grécia é retomada também por SUTTER, D. Op. cit. p.6: “Se a arte moderna não se colocou à altura dos artistas do século XVI, e se ela não seguiu uma marcha ascendente, isso se explica muito mais por causas morais do que por questões de clima, como frequentemente se quis explicar." [tradução nossa] 
fundador do pensamento Winckelmanniano ${ }^{343}$-, também não era mais percebida como suficiente. Para Américo, ainda a partir de Émeric-David, a história política e a organização social de Atenas, caóticas e compostas de confrontos internos permanente entre uma minoria livre e uma maioria de escravos (algo sugestivamente similar à situação brasileira), além das intempéries naturais e dos conflitos com estados vizinhos, traía a ideia de um povo cuja arte, já surpreendentemente existente em meio a tantos obstáculos, fazia apenas lembrar a beleza ideal ${ }^{344}$, ou, em termos propriamente winckelmannianos, a "nobre simplicidade" e a "calma grandeza".

Outra antiga causa, a facilidade dos nus e a suposta beleza dos jovens gregos, cantada pelo alemão, também não poderia mais se sustentar, não ao menos integralmente. De um lado, “os lugares onde as belas artes chegaram ao mais alto grau de perfeição não foram aqueles em que mais belos modelos se encontravam"345; e isso, era novamente Cícero quem teria garantido ${ }^{346}$. Ademais, o desenvolvimento das artes abstratas, como no caso da arquitetura, do mobiliário e da cerâmica, que não dependiam diretamente do modelo-vivo, teria sido, na Grécia, contíguo ao das demais artes figurativas, notadamente a escultura ${ }^{347}$. De outro lado, se havia mesmo uma maior facilidade em observar entre os antigos o "belo" corpo nu - fossem nas cerimônias, ou nos famosos jogos olímpicos -, o que se configuraria de fato como uma das "causas físicas" 348 da perfeição da arte, essa disponibilidade havia sido, de maneira geral, a mesma em toda a Grécia (para Américo, talvez mesmo menos em Atenas), sem que outros estados soubessem tirar dela partido. Apenas os atenienses haviam compreendido como transformar uma "causa física" em um "moral", e essa mudança teria sido possível apenas pela existência de uma teoria e filosofia artísticas particulares, fruto de uma maneira igualmente singular de perceber os corpos nus dos atletas e das virgens para além de sua esfera sensual e individual ${ }^{349}$.

A religião, tão importante na dedução genética das artes para Américo, sucede o problema do nu, e reaparece nas discussões sobre as causas da grande arte. Aqui, todavia, o jovem não utilizou os argumentos de Émeric-David para refutar os de Winckelmann, mas recusou os de ambos, por se tratarem de "dois caracteres incompatíveis" utilizados para defender a religião como

${ }^{343}$ WINCKELMANN. Op. cit. pp.96-97.

${ }^{344}$ AMÉRICO. Op. cit. p.121 [estudo quarto]; ÉMERIC-DAVID. Op. cit. p.7; e também p.83.

${ }^{345}$ AMÉRICO. Op. cit. p.122 [estudo quarto]; ÉMERIC-DAVID. Op. cit. p.7.

${ }^{346}$ ÉMERIC-DAVID. Op. cit. p.8. A citação de Cícero é retirada do seu: Sobre a natureza dos Deuses, Livro Segundo. capítulo 79 .

${ }^{347}$ AMERICO, op. cit. p.122 [estudo quarto]; ÉMERIC-DAVID. Op. cit. p.8.

${ }^{348}$ Referindo-se às "causas físicas", Américo insere nessa parte do seu texto, novamente, um termo do vocabulário quincyano. Cf. QUINCY, Q. De. Op. cit. p.12. Quincy, por sua vez, empresta de Winckelmann a distinção entre causas morais e físicas da arte.

${ }^{349}$ AMÉRICO. op. cit. p.123 [estudo quarto]. Ou: Correio Mercantil, Rio de Janeiro, 9 de outubro de 1864, p.2. 
a "principal causa da estatuária e da pintura". Calculadamente, Américo deslocava o problema, porque não se tratava, nesse ponto, de investigar as causas da arte grega, mas as causas da arte em geral, a partir dos gregos. Winckelmann não havia errado em julgar que as "altas ideias da teogonia grega" ${ }^{, 350}$ teriam sido relativamente importantes para o desenvolvimento da arte clássica em $\mathrm{si}^{351}$, mas teria errado ao supor que a religião pagã daquele povo valia universalmente como causas para a arte. Para Américo, o alemão havia esquecido das "belezas e das poesias das Escrituras e do Evangelho" (mais verdadeiras que as dos gregos, para um jovem cristão como o brasileiro ${ }^{352}$ ), que teriam ajudado a fundar em Florença, durante o Renascimento, outro período da história artística que se igualaria ao clássico. Se os mestres italianos, sob uma doutrina religiosa distinta, haviam conseguido se igualar aos antigos, a especificidade da religião grega não poderia ser, portanto, tomada como causa necessária da grande arte.

Pior que Winckelmann, apenas Émeric-David, quem, interpretando corretamente muitas das causas da arte grega, havia se enganado mais de uma vez quanto à natureza dos seus princípios artísticos, na medida em que se apegava insistentemente a uma leitura "realista" do legado antigo. Para Américo esse novo erro era a leitura que o francês havia feito do "caráter sensual da religião popular, em que o dogma fundamental era que os deuses tinham formas semelhantes às do corpo humano" ${ }^{353}$, cabendo ao artista apenas imitar as belas formas da natureza. A leitura de ÉmericDavid tombava em conclusões ${ }^{354}$ que desagradavam Américo: iriam contra o dado patente de que "apesar de nuas" as figuras dos deuses gregos demonstravam sempre um "castidade serena e grave" 355 ; e tendiam a, justamente, eliminar dos antigos as causas morais de sua arte, que se fundavam num profundo idealismo artístico, esse, sim, universalmente válido à arte.

Não sendo portanto " por consequência do clima, nem à facilidade dos costumes, nem e altas ideias da teogonia, nem ao caráter sensual da religião, que devem os gregos sua proeminência nas belas artes" 356 , restava por fim a Américo, antes de inverter em sentido positivo a sua exposição da causas da perfeição da arte, lidar com um último problema winckelmanniano, sem dúvida o mais

\footnotetext{
${ }^{350}$ AMÉRICO, P. op. cit. p.215 [estudo quarto]. Correio Mercantil, Rio de Janeiro, 10 de outubro de 1864 , p.2.

${ }^{351}$ WINCKELMANN. op. cit. p.252.

${ }^{352}$ Em vários momentos de suas Considerações ,e em vários outros escritos de sua vida, Américo demonstra seu respeito à religião católica, invocando mais, como era de se esperar, o Novo Testamento.

353 AMÉRICO, P. op. cit. p.215 [estudo quarto]; ÉMERIC-DAVID. Op. cit. p.55-6. O trecho em itálico está também presente no livro de Émeric-David; trata-se, por sua vez, de uma citação que ele próprio fará de Heródoto.Histórias de Heródoto, livro I, capítulo 131.

${ }^{354}$ Idem, ibidem. p.217, estudo quarto. Ou: mesma edição anterior.

${ }^{355}$ Idem, ibidem. p.216, estudo quarto.

${ }^{356}$ Idem, ibidem. p.218 [estudo quarto]. Ou: mesma edição anterior; ver ainda: ÉMERIC-DAVID. Op. cit. p.62.
} 
importante de todos: o da liberdade ${ }^{357}$. O conceito, conforme discutido, era também fundamental ao pensamento artístico e filosófico do jovem Américo, desde a publicação de La réforme de l'École des Beaux-Arts et l'opposition. ${ }^{358}$

Para as indagações sobre as causas da arte, tratava-se ao mesmo tempo da liberdade enquanto autodeterminismo individual - de uma autonomia excetuada de todos os tipos de constrangimentos físicos ou morais - e da liberdade caracterizada política e socialmente, essa realizada idealmente por Platão no República ${ }^{359}$, e realmente na antiga Atenas, na constituição de sua República. Se, seguindo mais uma vez Émeric-David, Américo garantia que a primeira dessas liberdades "é evidentemente favorável a todos os exercícios da inteligência"360, ele, contudo, não se esquecia de precaver que ela é uma potência que poderia ser usada para fins exemplares ou pífios. Nesse sentido, ela seria apenas uma entre outras faculdades para que fins idealmente positivos, em qualquer domínio, fossem alcançados.

A segunda, a liberdade política, parecia ser, ao contrário, facilmente questionável. Atenas, ainda que tivesse disposto de uma República, a viu interrompida diversas vezes sem "que deixassem de prosperar a arquitetura e a estatuária" ${ }^{361}$. Florença, durante o Renascimento, não havia gozado de tal organização política, a despeito de sua excelente arte; e a França havia testemunhado o maior desenvolvimento de suas capacidades artísticas sob o estado despótico de Luís XIV. Ou seja, importava "menos observar a forma dos governos de que, entretanto, se têm com demasiado ocupado alguns escritores"362, e se preocupar mais com como eles, não importa qual tipo, encorajam e tornam necessário o material intelectual de que dispõem.

\section{As principais causas da perfeição da arte grega}

${ }^{357}$ WINCKELMANN. Op. cit. p.225; p.227: "Se se considera a constituição e o governo da Grécia, a liberdade é a causa principal do estatuto privilegiado da arte. Foi na Grécia onde a arte teve sempre assento, mesmo ao lado do trono dos reis "; p.229-30: "A liberdade fez elevar o espírto de um povo inteiro como uma nobre ramificação de um tronco sadio. [...] Heródoto mostra que a liberdade foi o primeiro e único fundamento da potência e da grandeza de Atenas".

${ }^{358}$ Ver, por exemplo, o Primeiro Capítulo desta Tese.

${ }^{359}$ AMÉRICO, P. op. cit. p.219 [quarto estudo]. Ou: mesma edição anterior.

${ }^{360}$ AMÉRICO, P. op. cit. p.219 [quarto estudo].

${ }^{361}$ Idem, ibidem. p. 218 [estudo quarto]. ÉMERIC-DAVID. Op. cit. p.62.

${ }^{362}$ Idem, ibidem. p.219 [estudo quarto]. 
Se a "proeminência nas belas artes" entre os gregos não se devia às causas outrora interpretadas como centrais nos trabalhos de uma autoridade como Winckelmann, quais outras poderiam afinal justificar a exemplaridade daquele povo nas artes? ${ }^{363}$

Segundo Américo, como causas gerais e absolutas, "o progresso das belas-artes depende essencialmente", para os antigos ou para qualquer outro povo destacado na história, "do desenvolvimento social e filosófico"364. Precisando-se essas causas: é "na sabedoria dos legisladores, na pureza, e não na facilidade dos costumes, na educação moral da classe livre" onde estão "as causas da perfeição soberana das belas-artes" em todos os tempos ${ }^{365}$. A Grécia teria sido apenas o primeiro lugar onde elas foram combinadas plenamente.

Américo tratava de justificar essa tese decupando cada uma daquelas causas, ainda presentes nas defesas efetuadas por seus contemporâneos franceses, como David Sutter ${ }^{366}$. Sustentava com Émeric-David que, antes mesmo do nascimento das belas artes, os gregos teriam aprendido a nutrir um estado social no qual orbitavam "o sentimento da liberdade, o amor da Glória, o orgulho patriótico, [...] a emulação" sadia entre os habitantes, e todos os "sentimentos nobres" ${ }^{367}$.

A importância desses valores teria sido compreendida pelos legisladores (como há muito o teriam para os primeiros poetas), que trataram de incentivá-las ainda mais em cerimônias, festas e jogos, reforçando o sentido de unidade de seu povo: "Quantas instituições admiráveis de simplicidade foram fundadas com o fim de fortificar a nacionalidade, multiplicando as afeições e cerrandos seus laços! $" 368$. As artes teriam nascido entre os gregos como uma dessas instituições, concorrendo com os mesmos valores para saudar os heróis da pátria, vivos ou mortos; para louvar os deuses; para formar, enfim, um "sistema de moral pública"369.

"Intimamente ligadas ao governo", pelo concurso de encomendas ou de recompensas oficiais, "e sempre consideradas como os principais elementos da vida social", as artes tornaram-se elemento obrigatório na educação pública na Grécia, que previa o ensino oficial das artes do corpo

\footnotetext{
${ }^{363}$ Idem, ibidem. p.218 [estudo quarto]; Ver ainda: ÉMERIC-DAVID. Op. cit. p.62.

${ }^{364}$ Idem, ibidem. p.83, [estudo primeiro]. Ou: Correio Mercantil, Rio de Janeiro, 30 de setembro de 1864, p.2. Ver ainda: SUTTER, D. Philosophie des Beaux-Arts, p.07.

${ }^{365}$ Idem, ibidem. p. 119 [estudo quarto]. Ou: Correio Mercantilc, Rio de Janeiro, 7 de outubro de 1864, p.2.

366 "Existem dois caminhos que a experiência consagrou em todos os tempos para realizar o sentiento do ideal nas artes: a educação filosófica, e o encorajamento do poder." [tradução nossa]. SUTTER, D. Op. cit. p.60.

${ }^{367}$ Idem, ibidem. p.134, [estudo quinto]. Ou: Correio Mercantil, Rio de Janeiro, 12 de outubro de 1864, p.2; ÉMERIC-DAVID. Op. cit. p.16.

${ }^{368}$ AMÉRICO, P. op. cit. p.135 [estudo quinto] Ou: Correio Mercantil, Rio de Janeiro, 12 de outubro de 1864, p.2; ÉMERIC-DAVID. Op. cit. p. 17.

${ }^{369}$ AMÉRICO, P. op. cit. p.137 [estudo quinto] Ou: Correio Mercantil, Rio de Janeiro, 14 de outubro de 1864, p.2.; ÉMERIC-DAVID. Op. cit. p.18-19.
} 
(especialmente a ginástica: com o atletismo e dança) e as artes da mente (música e desenho) ${ }^{370}$. A medida teria instaurado a "excelência e a constância do gosto na Grécia"371, presentes no espírito daquela região até o momento em que permaneceu de pé "o majestoso edifício das leis e da liberdade" ${ }^{372}$. Para Américo, tal educação ensinava, desde a primeira idade, todos os princípios do belo, que também compreenderiam em si um emprego científico, além do artístico: o metro e as proporções descobertos nas artes serviam, por exemplo, como as mesmas bases para o puro pensamento abstrato da ciência matemática, fundamental a qualquer povo ${ }^{373}$.

Melhor instruído, o povo grego exigiria dos seus artistas ainda mais altos estudos, os mesmos que "nós temos deixado de encarar como indispensáveis",374. E o mesmo teria ocorrido com períodos áureos da arte em épocas posteriores, como o da renascença italiana ${ }^{375}$.

A marcha seguida pelo jovem, ainda na esteira de Éméric-David, se aproximava pouco a pouco (de) e chegava enfim, convenientemente, a Quatremère de Quincy, num ponto eclético de possível conciliação. Várias das teses desses autores, aliás, se interseccionavam em questões fundamentais para a leitura que Américo desejava fazer.

Mesmo se o último, ainda bastante próximo do pensamento winckelmanniano, não se opusesse à legitimidade das causas naturais ou políticas sistematizadas pelo alemão, ele confessava se tratarem de causas que estariam fora do alcance de qualquer intenção individual e voluntária: fariam parte das revoluções do espírito e da natureza ${ }^{376}$.

O resultado final desse reconhecimento é o que parece importar, já que, afinal, também Quincy, como Émeric-David, abandonava essa parte do legado teórico de Winckelmann para se concentrar nas causas possíveis de serem tocadas por uma teoria artística, mais uma vez, para ambos, concentradas em "causas morais".

Para Quincy também não era estranha a ideia compartilhada por seu conterrâneo de que, entre os gregos, "as artes da imitação nasceram e se desenvolveram como plantas nativas",

${ }^{370}$ AMÉRICO, P. op. cit. p.138 [estudo quinto] Ou: mesma edição da nota anterior; ÉMERIC-DAVID. Op. cit. p.19.

${ }^{371}$ AMÉRICO, P. op. cit. p.138.

${ }^{372}$ AMÉRICO, P. op. cit. p.137.

${ }^{373}$ AMÉRICO, P. op. cit. pp.140-141; ÉMERIC-DAVID. Op. cit. p.45 e pp.48-49.

${ }^{374}$ AMÉRICO, P. op. cit. p.142 [estudo quinto]. Ou: mesma edição das notas anteriores.; ÉMERIC-DAVID. Op. cit. p.49.

${ }^{375}$ AMÉRICO, P. op. cit. p.142.

${ }^{376}$ Idem, ibidem. pp.2-5. 
suportando "todas as instituições sociais, políticas e religiosas" ${ }^{377}$. E isso, também para ambos, apenas foi possível porque as artes teriam sido "necessárias à glória, à riqueza, à prosperidade gerais." $" 378$

Percebendo no problema da necessidade a causa primeira e unificadora de todas as demais causas secundárias da $\operatorname{arte}^{379}$, cuja perfeita combinação estaria presente na antiguidade clássica e nos períodos exemplares da história artística, era de fato Quincy, mais do que Émeric-David, quem se dedicava ao aprofundamento desse conceito $^{380}$. Ele apresentou três tipos distintos de necessidade.

O primeiro, quando se trataria de um necessidade espontânea; isto é, considerada em relação à geração de obras de artes e à propriedade que elas tem de se produzir sem nenhum auxílio externo $^{381}$.

O segundo, quando ela se referia ao "exercício habitual que uma nação faz das artes", necessidade sendo então expressa pela "ligação natural que elas tem por vezes com as principais necessidades do homem em sociedade" ${ }^{382}$.

O terceiro, quando ela estaria relacionada ao emprego que se faz dessas produções ${ }^{383}$.

Para Quincy, os dois primeiros tipos de necessidade seriam impossíveis de serem causados por uma teoria artística: "Não se pode fazer com que as Artes nasçam delas mesmas, nem que se fundam com as instituições primitivas de uma nação" ${ }^{384}$. O que se pode apenas fazer é fomentar o terceiro tipo; o que significa dizer que a única maneira possível de tornar a atividade artística necessária está na destinação dada à obra. Nesse sentido,

\footnotetext{
${ }^{377}$ QUINCY, Quatremère de. Considérations morales sur la destination des ouvrages de l'art, ou de l'influence de leur emploi sur le génie et le gout, et sur le sentiment de ceux qui en jouissnet et en reçevoient les impressions. Paris: L'Imprimière de Crapelet, 1815. P.03.

${ }^{378}$ ÉMERIC-DAVID. Op. cit. p. 254.

${ }^{379}$ Idem, ibidem. p.01: "Frequentemente se perguntou quais foram as causas morais da grande perfeição das Artes na Grécia. Para isso, há uma resposta que, se não compreende todas as causas, encerra ao menos um grande número. Parece-me que se pode responder rapidamente que a superioridade ou a perfeição que obtiveram os gregos nessa parte, foi devido ao fato de que, para eles, as artes eram necessárias". [tradução nossa]

${ }^{380}$ Além das Considérations morales, o problema é ainda trabalhado por Quincy no livro: QUINCY, Quatremère. Essai sur la nature, le but et les moyens de l'imitation dans les Beaux-Arts. Paris: Treuttel et Würtz, 1823. p.234-235. Neste último ensaio Quincy pressupõe que a necessidade necessidade que os gregos teriam da arte teria como causa principal a sua doutrina religiosa: "A religião dos Gregos foi o princípio, o alimento e o sustento do estilo ideal; e parece que la duração desse estilo dependeu da duração dessa religião". Idem, ibidem. p.102.

${ }^{381}$ QUINCY, Q. Considerations morales. p.01.

${ }^{382}$ Idem, ibidem. p. 02 .

${ }^{383}$ Idem, ibidem. p.02.

${ }^{384}$ Idem, ibidem. p.05. Em outro trecho (Idem, ibidem. p.06), Quincy reforçará a impossibilidade de aplicação dessas duas primeiras causas de necessidade numa teoria artística: "O exame desses tipos de causas podem ser um tema interessante para o filósofo ; mas uma vez que se reconhece que elas estão foram de nosso poder, tudo o que se pode dizer delas é sem aplicação". [tradução nossa]
} 
uma obra é necessária quando ela tem um objetivo fixo e determinado, um emprego de tal modo positivo, que esse emprego impõe ao autor o dever de um caráter especial, compele o espectador a emitir um juízo conforme às razões que fizeram produzir a obra, e o público, a receber dela impressões uniformes e determinadas. ${ }^{385}$

Esse "objetivo fixo e determinado" seria, sem dúvida, o de uma destinação moral: tão mais importante seria uma obra de arte numa sociedade quanto mais "relações de utilidade"386 ela pudesse estabelecer $^{387}$. Isto é, quanto mais útil ela fosse (reclamando o amor à pátria, à religião, à memória dos feitos e das existências das personalidades do passado, etc), mais intimamente ligada à trama social de um povo ela estaria, suportando e sendo ao mesmo tempo suportada por todas as suas instituições ${ }^{388}$.

A mesma ideia de necessidade, já algumas vezes retomada neste Capítulo, atravessava as reflexões que Américo desenvolveu, do início ao fim, em seu Considerações Filosóficas - a saber novamente: as artes teriam nascido como uma necessidade espiritual, e não $d a$ necessidade material , o mesmo conceito que as poderia fazer florescer independente da forma política de um governo.

No que se refere à causa da destinação, a solução dada por Quincy seria inteiramente acolhida por Américo e, a propósito, em completo acordo com a perspectiva krausista (e mesmo com a sua herança neoclássica) da relação entre as artes e a filosofia moral: a arte é necessária a um país e, para ser necessária, ela deve ser moralmente útil.

Entretanto, parecia ao mesmo tempo claro ao jovem que as circunstâncias das três categorias da necessidade artística apresentadas por Quincy eram bastante distintas na França e no Brasil. Se o teórico, por exemplo - avesso à formação de museus com obras deslocadas de suas destinações originais, e pensando ainda um contexto que já lhe parecia abarrotado de obras, produzidas no mais das vezes sem utilidade, em resposta a um mercado anônimo emergente -, iria tratar de se concentrar sobretudo em uma teoria artística pautada na necessidade de arte em relação a seu emprego e à sua aplicação, o jovem brasileiro não poderia se dar ao luxo de desconsiderar a parte de uma teoria artística dedicada ao problema da necessidade em relação ao "exercício habitual que se faz dela em uma nação". E o que justificaria isso era o próprio contexto brasileiro, no qual as grandes encomendas e a cultura artística ainda não haviam se instalado.

\footnotetext{
${ }^{385}$ Idem, ibidem, p.02.

${ }^{386}$ Idem, ibidem. p.06-07.

${ }^{387}$ Idem, ibidem. p.08.

${ }^{388}$ Idem, ibidem. p. 109.
} 
Deveria haver um jeito de estabelecer uma tal ligação "com as principais necessidades do homem em sociedade" ${ }^{389}$. É isso o que Américo desejava, repetidamente, reforçar.

Certamente, essa hipótese não era descoberta por ele na França. Tratava-se antes de outra herança provinda de sua proximidade com as ideias e projetos de Porto Alegre, tornados especialmente claros no rapport "encomendado" por d. Pedro II em 1853, sintomaticamente intitulado "Apontamentos sobre os meios práticos de desenvolver o gosto e a necessidade das belas artes no Rio de Janeiro" ${ }^{\text {390. }}$.

Como será visto, Américo apresentava a partir de outras referências e sobre outros termos a mesma base do projeto que o antigo diretor da Academia havia esboçado para as artes no país ${ }^{391}$. Mas para reforçá-la, lhe parecia agora mais importante recorrer a teóricos e historiadores internacionalmente abalizados, do que às ideias do artista demissionado.

É por isso que para discutir o complemento que faltava à resolução da equação das causas da arte em relação às suas necessidades (a necessidade da atividade artística em um país, especialmente sem esse tipo de tradição, e a necessidade de sua destinação moral), Américo se voltava novamente a Émeric-David, e especificamente aos elementos de sua teoria artística que continuavam em conciliação com a de Quincy.

Ao final do livro "Pesquisas sobre a arte arte da estatuária" (cujo interesse geral na França havia sido renovado devido a uma reedição feita em 1863), Émeric-David reapresentava a pergunta que havia guiado seus interesses de sua investigação ("Quais foram as causas da perfeição da escultura antiga, e quais seriam os meios de atingi-la?"), e a respondia com uma convicção inquebrantável: "Cabe ao legislador operar esse prodígio". Afinal de contas, "as riquezas, as honras, os interesses particulares, e por consequência os costumes, os gostos, as paixões, a vontade dos povos, tudo isso não está nas mãos potentes" dos legisladores? "Árbritos dos nossos destinos, as obras-primas da arte devem ser obra de vocês." ${ }^{392}$

Deve-se novamente reforçar: a convicção teórica sobre o papel dos legisladores em relação à artes, que o jovem Américo demonstrava ter absorvido de Émeric-David, nos primeiros anos de 1860, era, na verdade, a continuação da mesma certeza que ele havia recebido de Porto Alegre, nos

\footnotetext{
${ }^{389}$ Idem, ibidem. p.02.

${ }^{390}$ PORTO ALEGRE, M. A. “Apontamentos sobre os meios práticos de desenvolver o gosto e a necessidade das belas artes no Rio de Janeiro.” IN: KOVENSKY, Julia; SQUEFF, Letícia (orgs.). Manuel de Araújo Porto Alegre: Singular \& Plural. São Paulo: IMS, 2014. pp.307-310.

${ }^{391}$ Conforme discutido, a publicação desse texto precedia em poucas semanas a entrada de Porto Alegre na AIBA para iniciar a reforma de ensino na instituição, após a qual Américo integrava a primeira turma.

392 ÉMERIC-DAVID. Op. cit. p.339.
} 
anos $1850^{393}$. Ela parecia ser, a seus olhos, o meio primordialmente possível de agir numa organização monárquica, cujo sistema operativo se centrava na valorização do bacharelismo e nas relações pessoais que possibilitavam as indicações de altos cargos administrativos ${ }^{394}$. Em outras palavras, para o jovem Américo, como havia sido para Porto Alegre, a causa da necessidade da arte (em Quatremère de Quincy) podia apenas se resolver com a causa dos legisladores (em ÉmericDavid).

\section{Por um projeto e por uma teoria das artes no Brasil}

A conciliação final que Américo fazia dos rivais Quincy e Émeric-David, no sentido de justificar as causas primeiras para o desenvolvimento da arte grega e, por conseguinte, de toda e qualquer $\operatorname{arte}^{395}$, explicava em muitos sentidos as intenções de um projeto político que ele esperava implementar no Brasil.

Se o problema central de Considerações Filosóficas sobre as Belas Artes entre os Antigos era o descobrimento das circunstâncias fundamentais da primazia artística grega, a sua explanação garantiria por fim o primeiro passo para que o jovem (como para todos os autores de textos que lidaram com as mesmas questões) esboçasse " uma rota que possa conduzir ao fim que eles mesmos [os gregos] traçaram" ${ }^{396}$.

Concentrando-se nas causas da necessidade da arte e dos legisladores, Américo endereçava à primeira os seus votos de dissolução de uma antiga queixa das personalidades das artes brasileiras; e à segunda, uma esperança que o perseguia há algum tempo.

De início, estava o preconceito desde há muito estabelecido sobre a atividade artística no Brasil. A sua eliminação se fazia urgente: mantido, de acordo com toda uma bibliografia disponível

393 O antigo diretor da AIBA, no mesmo texto encomendado pelo imperador, afirmava o seguinte sobre a instalação da necessidade das artes no Brasil: "Para que as artes comecem a ter uma vida regular e floresçam pouco a pouco, para que elas espalhem o seu benigno insuflo na moral pública, e na indústria, é necessário que a família artística tenha um ponto de constante apoio no país, e este ponto é o governo". PORTO ALEGRE. "Apontamentos sobre os meios práticos de desenvolver o gosto e a necessidade das belas artes no Rio de Janeiro.” In: KOVENSKY, Julia; SQUEFF, Letícia (orgs.). Op. cit. p.308.

${ }^{394}$ Esse problema é exaustivamente trabalhado no último texto desta Tese: A um triz do xilindró: Pedro Américo e a questão dos bacharéis.

${ }^{395}$ Sobre a ideia de que as causas que teriam definido a excelência da arte grega poderiam recriar a mesma qualidade artística em qualquer tempo ou lugar, ver: AMÉRICO, P. op. cit. p.167, [estudo sétimo]. Ou: Correio Mercantil, Rio de Janeiro, 17 de novembro de 1864, p.2 : os "nomes imortais de Polignoto e Fídias, de Michelangelo e de Rafaello, que nos aparecem no meio do brilho confuso das constelações humanas" são " a conclusão evidente de premissas claramente estabelecidas por um concurso combinado de acontecimentos e de fatos, e doutrinas e de instituições, que não podiam gerar outros frutos, quaisquer que fossem o país e a época onde se tivese encontrado."

${ }^{396}$ ÉMERIC-DAVID. Op. cit. 1863, p.02. 
desde Winckelmann, a sociedade brasileira confessaria sua manutenção não especificamente em um período de "infância" ou "desenvolvimento" de um povo jovem (como muito se ouvia em textos brasileiros da época), mas em um período proporcional ao da decadência e da degenaração; uma contradição que o próprio Porto Alegre havia percebido ${ }^{397}$. Nesse ponto, a situação nacional não pareceria muito diferente da de uma Roma imperial, que, também supostamente avessa ao trabalho artístico - percebido, como no Brasil, enquanto uma atividade manual, não digna -, o relegaria às mãos “despreparadas" e "inferiores" de escravos 398.

Para Américo, como visto, era preciso criar a causa fundamental da necessidade da arte no país, essa deveria ser, não havia dúvida, uma causa moral:

Com efeito, como poderá um objeto ser amado, querido, proclamado com ardor, quando dele não reconhece a sociedade um instrumento com o qual possa satisfazer alguma ou algumas das suas necessidades, ou realizar alguns dos seus transcendentes intentos?"399

Em seguida à exposição do problema, estava a esperança do jovem, que acompanhava a dedução da causa dos legisladores como os únicos capazes de estimular essa necessidade no povo. O auspício de uma tal explicação histórico-filosófica, que continuava a estabelecer uma linha direta com Porto Alegre, amparava convenientemente os mesmos desejos que o jovem declarava a seus interlocutores brasileiros mais próximos, como Jacques Brunet, no período imediatamente anterior à sua chegada ao Brasil, em $1864^{400}$.

Se a filosofia se apresentava como um meio de reconhecer idealmente os limites e a natureza das questões artísticas que lhe interessavam, cabia à política, no entanto, resolvê-los realmente. Mas tratava-se, para o jovem, sempre da alta política; tratava-se de estar ao lado dos agentes que, de fato, comandavam os dispositivos econômicos e culturais do país; persuasão que o levaria a se projetar mentalmente, já em 1863, à "carreira política para servir ao país e às Belas Artes; porquanto as palavras pronunciadas no seio do parlamento são as que edificam e organizam a sociedade. $" 401$

${ }^{397}$ Ver a citação feita do texto de Porto Alegre, algumas poucas notas acima.

398 Cf. WINCKELMANN. Op. cit; VIOLLET-LE-DUC. Op. cit. pp.93-95, entre vários outros trabalhos que trabalham o conceito de apogeu e decadência entre a Grécia clássica e a Roma dos imperadores.

${ }^{399}$ AMÉRICO, P. op. cit. p.190 [conclusão]. Ou: Correio Mercantil, Rio de Janeiro, 25 de dezembro de 1864, p.1.

${ }^{400}$ Ver o Primeiro Capítulo desta Tese.

${ }^{401}$ MELO, Pedro Américo de Figueiredo e. Carta de Paris a Louis Jacque Brunet em 07 de novembro de 1863. FUNDAÇÃO VINGT-UN ROSADO. Cartas de Pedro Américo de Figueiredo e Melo e Daniel Eduardo de Figueiredo e Melo a Louis Jacques Brunet. Mossoró: Coleção Mossoroense, junho de 2001. s/p.

Entre esses agentes legislativos, é certo que Américo incluía, virtualmente, o próprio d. Pedro II, quem, embora representante exclusivo do poder moderador e do executivo - ainda que esse último poder fosse exercido por seus 
Compreendendo a articulação da política no Brasil e a sua estreita relação com a política da artes (tão claramente perceptíveis nas mudanças que o governo imperial por vezes impunha às decisões limitadas e pouco autônomas do corpo acadêmico da AIBA $^{402}$ ), Américo depositava assim sua fé nesse círculo de poder para realizar seus projetos. Essa lhe era, com efeito, a única condição possível; seria "o único e incontestável meio de servir ao progresso do nosso desenvolvimento intelectual" ${ }^{403}$. Além disso, se era verdadeira a ideia de que os incitadores independentes de novos projetos "são sempre mártires"; e se o fim de um mártir seria inevitavelmente o do sofrimento e do sacrifício $^{404}$ (tema que Américo passará a frequentar com assiduidade em suas pinturas e romances, dos anos 1870 em diante ${ }^{405}$ ), ele de fato "só ousaria soprar ideias novas" se se visse "ao abrigo de altos protetores."

Segundo compreendia, não se podia esperar do povo uma demanda suficiente para a criação da causa da necessidade artística no país. Em contrapartida, exemplos contemporâneos, como o caso da criação do Museu Napoleão, feita por seu professor Cornu, e o da reforma da École des Beaux-Arts, ou ainda o caso recente da "revolução artística" da Inglaterra, pareciam confirmar o papel que esse fluxo orientado "de cima para baixo" podia efetivamente desempenhar na mudança ou no desenvolvimento da cultura artística e industrial de um país, especialmente um país sem tradição nessas áreas, como o Brasil ${ }^{407}$. E era essa, diga-se de novo de passagem, outra crença abertamente confessada por Porto Alegre durante os anos de Américo na AIBA ${ }^{408}$.

agentes -, possuia também voz no legislativo, uma vez que indicava os integrantes vitalícios do Senado, além de sancionar as leis aprovadas por este e pela Câmara de Deputados.

${ }^{402}$ As conhecidas nomeações de Félix-Émile Taunay, e M. A. Porto Alegre são algumas das ordens vindas diretamente de d. Pedro II, por meio de seus ministros, que tocavam diretamente o probema da política das artes no Brasil. Sobre o assunto das interferências diretas que essas personalidades repetidas vezes causam à autoridade de decisão da Congregação da AIBA, ver também o último texto desta Tese: A um triz do xilindró: Pedro Américo e a "questão dos bacharéis".

${ }^{403}$ Idem, ibididem.

${ }^{404}$ A ideia de que aqueles que lançam novas ideias, sobretudo no contexto refratário brasileiro, já havia sido ouvido por Américo também da boca de Porto Alegre, no discurso de premiação dos alunos da AIBA, em 1856, cerimônia da qual o jovem participará: "Toda a doutrina nova é contrariada pelos fariseus, e aquele que a personifica levado ao calvário da ignomínia para passar por todas as agonias pela morte, para então ressuscitar e triunfar”. PORTO ALEGRE. "Discurso do diretor da Academia das Belas Artes por ocasião da distribuição pública dos prêmios, em 1856". In: Correio Mercantil, Rio de Janeiro, 30 de novembro de 1856. p.1.

${ }^{405}$ Ver, por exemplo, a Batalha do Avahy, Judith e Holofernes, os vários São Gerônimos, e Cristos Mortos, o Tiradentes esquartejado, entre outras pinuras que Américo realiza durante a sua vida, cujo tema está relacionado ao sofrimento daqueles que lançaram novas ideias ao longa da história.

${ }^{406}$ MELO, Pedro Américo de Figueiredo e. Carta de Paris a Louis Jacque Brunet em 24 de novembro de 1863. FUNDAÇÃO VINGT-UN ROSADO. Cartas de Pedro Américo de Figueiredo e Melo e Daniel Eduardo de Figueiredo e Melo a Louis Jacques Brunet. Mossoró: Coleção Mossoroense, junho de 2001. s/p.

PORTO ALEGRE. "Discurso do diretor da Academia das Belas Artes por ocasião da distribuição pública dos prêmios, em 1856". In: Correio Mercantil, 30 de novembro de 1856. p.1.

${ }^{407}$ AMÉRICO, P. op. cit. p.190-1 [conclusão]: "bastando-nos para prova do que nos abalançamos a afirmar o que já principia a acontecer com a cultura das próprias artes naquele país [Inglaterra], as quais sendo antes de 1855 [data da primeira Exposição Universal] apenas ensinadas convenientemente em três academias, hoje o são em 95; não contano 
Os legisladores que, ao perceberem o aparecimento de uma necessidade social ou econômica, deveriam criar os meios necessários para a sua resolução. Voltando-se sobretudo à extensão das atividades e da esperada largura de instrução desses agentes, Américo pôde resgatar e, mais do que isso, requerer a eles todas as capacidades das faculdades humanas, tão defendidas em seus escritos; pois era no círculo político que a tríade eclética razão-sensibilidade-liberdade, fundida à tríade krausista consciência(razão)-sensibilidade-vontade, mostrava toda a sua potência para execução das "ações constitutivas da lógica, da estética e da moral" "409 (realizando respectivamente as ideias do verdadeiro, do belo e do bom), isto é, ações que levariam ao progressivo e ao completo desenvolvimento de um povo.

De fato, quando Américo, refutando boa parte das antigas causas winckelmannianas da grandeza da arte grega, pedia que se deixassem de lado, de uma vez por todas, "essas opiniões superficiais que pretendem explicar a História pelas aptidões das raças, e as aptidões de cada variedade humana, pelas influências topográficas e climatéricas das regiões que respectivamente habitam" 410 , o que ele fazia era retirar do terreno da arte qualquer causa que lhe parecia indômita ou fortuita, depositando na política- enquanto uma atividade na qual devia prevalecer a ação - todo o devir artístico. Lembrava ainda que o seu oposto, a "inação", era justamente um mal arraigado na sociedade brasileira ${ }^{411}$, mal que se expressava por um apego desmedido à manutenção dos costumes estabelecidos $^{412}$ por uma "vida material"413, "indolente e ociosa" $" 414$, amparada por sua vez pela

como um sem-número de escolas, aliás importantes e muito ricas, que por todo o reino se encontram, e one se têm formado, além de nomes muito dignos de Turner e Reynolds, inumeráveis artistas, sob os auspícios dos quais vive e progride a indústria, há dez anos ameaçada de mortal paralisia, tanto pela falta de cultura artística na Inglaterra, como pela admirável profusão que exibiam a França e a Bélgica na primeira exposição universal."

408 PORTO ALEGRE. "Apontamentos sobre os meios práticos de desenvolver o gosto e a necessidade das belas artes no Rio de Janeiro.” In: KOVENSKY, Julia; SQUEFF, Letícia (orgs.). Op. cit. p.308: " Para contrabalançar este estado de uma sociedade nova e com perigosas crenças das nações decadentes, ou bárbaras, é essencialmente necessária a reação do governo, e que esta seja feita de uma maneira pronta, enérgica e sucessiva; porque toda civilização que parte do alto tem um cunho sagrado, legal, harmônico e progressivo."

${ }^{409}$ DORTU, Véronique. "Unamuno et le krausisme." In: Revue de l'histoire des religions, Paris, PUF, Vol.216, n.4, 1999,p. 445./doc/rhr_0035-1423_1999_num_216_4_1080 [último acesso em 18 de novembro de 2015]

${ }^{410}$ AMÉRICO, P. op. cit. p.167 [estudo sétimo]. Ou: Correio Mercantil, Rio de Janeiro, 17 de novembro de 1864, p.2.

${ }^{411}$ Idem, ibidem. op. cit. p.167: "Lembremo-nos sempre da inação a que condenam o homem todas essas doutrinas que o levam a esperar do solo da Providência os benefícios de um cabedal que só se ajunta com o trabalho, e que só se conserva com os labores de nossa atividade."

412 O seguinte trecho é significativo sobre o problema: "Quando, por entre as fileiras dos antigos adeptos das verdades recebidas, se ouve suspirar por um futuro diverso daquele que nos promete a marcha normal das ieias em curso, toda a sociedade se eleva gritando: - anátema ao utopista que nos quer roubar a tranquilidade e a paz! - e o mais puro amor do bem, a mais ardente paixão do patriotismo sente-se abafada pelas mãos vorazes do egoísmo e do medo, que da sua pusilânime trincheira de imobilidade arroja-lhe o estigma da mais vergonhosa apostasia.” Idem, ibidem. p.193.

${ }^{413}$ Idem. Ibidem. p.192 [conclusão]. Ou: Correio Mercantil, Rio de Janeiro, 25 de dezembro de 1864, p.1. Sobre o mesmo problema, Porto Alegre irá comentar: Ainda "olhamos desdenhosamente para as coisas que estão fora do círculo do posivito-concreto. E enquanto durar este novo círculo de Popílio Lenas, o artista generoso, homem das inspirações, 
escravidão, "essa úlcera aberta no meio da sociedade"415. Ao jovem incomodava a constatação de que, no país, o

equilíbrio das diversas funções sociais, em vez de residir entre as ideias e a sua realização prática, existe justamente entre a ausência da ideia realizável e da fatal realidade; de onde resulta a perpetuidade desse estado de agonizante síncope intelectual, de que todos nós nos queixamos, sem que lhe possamos escapar ${ }^{416}$.

Sem uma mudança verdadeiramente estrutural, pouco importariam os "bem-intencionados exemplos de proteção individual - como o que ele próprio havia recebido da Casa Imperial -, de amor pelos que trabalham, e de homenagem ao talento", porque seriam apenas "flechas muito delicadas lançadas de encontro a uma muralha de ceticismo e de pequenos interesses" ${ }^{\text {417. }}$.

Américo, no entanto, estava seguro de que o panorama deveria e poderia ser revertido. No fim dos seus escritos, ele ensaiava resgatar novamente os princípios da filosofia moral krausista, em especial os presentes nos textos de Tiberghien. Revalidar o real (e a ação) significava finalmente apontar para o presente, e para o difícil equilíbrio entre "as ideias e sua realização prática":

Será porventura o brasileiro fatalmente disposto a tal sonolência, a esse estado semiletárgico a que chega tão frequentes vezes, como se obedecesse a um peso irresistível ou à inércia produzida pela úmida e abrasadora temperatura de intertrópicos? Nada nos autoriza a $\operatorname{crer}^{418}$. Sua viveza no período de adolescência, como sua volubilidade e ardor; seu entusiasmo pelos grandes vultos históricos, pelos seus dotes e feitos; e muitas outras manifestações generosas e espontâneas

não dará um só passo conveniente.” PORTO ALEGRE. “Apontamentos sobre os meios práticos de desenvolver o gosto e a necessidade das Belas Artes no Rio de Janeiro.” In: KOVENSKY, Julia; SQUEFF, Letícia (orgs.). Op. cit. p.307308.

${ }^{414}$ Idem, ibidem. p.194 [conclusão]. Ou: mesma nota anterior.

Outro trecho significativo no qual Américo argumenta sobre caráter ocioso do brasileiro é o seguinte: "Crer que a Divina Providência baixará sobre nós derramando, em uma terra já tão cheia de bens naturais, os benefícios das artes e das ciências, que os outros povos alcançaram com trabalho, e muitas vezes com prolongados sofrimentos, é primeiramente tentar a Deus, como diz o Evangelho, e depois perpetuar o presente estado de defeituosa civilização, recuando indefinidamente o momento de nossa emancipação intelectual, como se fôramos cegos ante a manifesta superioridade da civilização européia, que gratuitamente nos prestaria todos os seus tesouros.” Idem, ibidem. p.201 [conclusão]. Ou: Correio Mercantil, Rio de Janeiro, p.28 de dezembro de 1864, p.2.

${ }^{415}$ Idem, ibidem. p.184 [estudo sétimo]. Ou: Correio Mercantil, Rio de Janeiro, 21 de novembro de 1864, p.2.

${ }^{416}$ Idem, ibidem. p.193 [conclusão].

${ }^{417}$ Idem, ibidem. p.191 [conclusão].

${ }^{418}$ A asserção mesma de que o brasileiro não estava fadado a um "estado letárgico" estabelecia relações diretas com os postulados de Tiberghien, no texto acessado pelo jovem brasileiro. Em um trecho bastante similar à crítica feita por Américo, Tiberghien irá afirmar: "Quem ousaria pretender que o ideal é realizado sob nossos olhos, que a sociedade atual, com todas as suas imperfeições, é o único modo possível de união entre os seres racionais? É preciso por isso colocar a humanidade em desespero, e declara que o que não existe hoje e que não existiu no passado é impossível para todo o sempre? Isso seria certamente um grave erro em lógica, um profundo esquecimento dos ensinamentos da história, e um grande perigo para a sociedade presente, onde tudo protesta contra a imobilidade." [tradução nossa] TIBERGHIEN, G. Op. cit. p.42. Ver ainda, no mesmo autor e obra, a p.106. 
provam, ao contrário, que no coração da raça existem preciosos germens dos mais belos sentimentos, dos maiores talentos e das mais sublimes virtudes ${ }^{419}$.

Ao menos para a arte, o mais importante dos sentimentos, o do Belo, era apresentado nas Considerações Filosóficas - abalizado pela pena respeitada de Quincy - não como um privilégio dos gregos, mas pertencente em mesmo grau ${ }^{420}$ a todos os povos, incluindo, portanto, a "raça brasileira", que, para Américo, sendo branca ${ }^{421}$, não lhe apresenta problemas para refutar as teorias raciais do período, que poderiam justificar a inferioridade do brasileiro em função da "degeneração" derivada de sua miscigenação com as "raças" indígenas e negras ${ }^{422}$. O que estaria em comparação era, desse modo, uma relação caucasiana-caucasiana. A menor ou maior expressão desse sentimento estético e "a diferença a que chegam nas belas artes" seria devido apenas "à necessidade mais ou menos pronunciada de as cultivar, segundo o seu fim e a natureza dos interesses que tiver cada qual de satisfazer" ${ }^{423}$. Estimulá-lo, desenvolvê-lo sobretudo, seria desse modo possível unicamente pela reflexão (consciência/razão) e pela sistemática da vontade e da liberdade ${ }^{424}$ dos dirigentes do país.

Mas, afinal, o que poderiam fazer os legisladores (causa primeira da arte) para tornar necessárias as artes no Brasil (causa segunda), e para contribuir para que elas saíssem da sua "infância"425 e atingissem seu desenvolvimento máximo?

Para Américo, o problema envolvia ao mesmo tempo uma teoria artística e um projeto teórico para as artes; e este, por sua vez, dois alvos: o público e os artistas. Ambos, teoria e projeto, deveriam perseguir os mesmos objetivos, essencialmente morais, e fazer reverter a causa negativa, de mesma natureza, que impedia no Brasil aquele desenvolvimento.

\footnotetext{
${ }^{419}$ Idem, ibidem. Conclusão, p.192. Ou: Correio Mercantil, Rio de Janeiro, 25 de dezembro de 1864, p.1.

${ }^{420}$ Idem, ibidem. Conclusão, p.189. Ou: Correio Mercantil, Rio de Janeiro, 25 de dezembro de 1864, p.1.

${ }^{421}$ A questão do arianismo da "raça" brasileira defendido por Américo será retomada nos três próximos capítulos desta Tese.

${ }^{422}$ Dificilmente, no entanto, ele conseguiu a mesma postura quando se viu obrigado a considerar a "raça brasileira" em sua raízes indígenas e negras.

${ }^{423}$ Idem, ibidem. p.189, conclusão. Ou: Correio Mercantil, Rio de Janeiro, 25 de dezembro de 1864, p.1.

${ }^{424}$ Idem, ibidem. Estudo primeiro, pp.75-76 [Correio Mercantil, Rio de Janeiro, 30 de setembro de 1864, p.2.]; Estudo sétimo, p.167 [Correio Mercantil, Rio de Janeiro, 17 de novembro de 1864, p.2]; e ainda Conclusão, p.193 [Correio Mercantil, Rio de Janeiro, 25 de dezembro de 1864, p.1.]: "Felizmente, ainda nos resta uma consolação: a liberdade, preciosa herança de nossos pais, com a qual podemos reclamar altamente os nossos direitos e os da humanidade inteira".

${ }^{425}$ Idem, ibidem. Conclusão, p.194 [Correio Mercantil, Rio de Janeiro, 26-27 de dezembro de 1864, p.2.] e p.199. [Correio Mercantil, Rio de Janeiro, p.28 de dezembro de 1864, p.2.]
} 
Esta causa, segundo argumentava, já estava identificada: o problema do desprezo que o brasileiro dedicava às artes - condição que caminhava lado a lado com a ideia de que não eram necessárias - era explicado pelo estado propriamente insuficiente de sua educação no país. Faltarlhe-ia a instrução elementar da infância ${ }^{426}$, a instrução artística $^{427}$, e, sobretudo, inexistiria a instrução moral; esta, "certamente a mais importante" ${ }^{28}$, porque só ela poderia reverter a predominância de um estado de pequenos "interesses pessoais" 429.

Da falta de educação artística, inexistente tanto no ensino primário como no superior, provinha a falha no gosto do brasileiro ${ }^{430}$. Da falta de educação moral, surgia o fraco sentimento de amor pátrio, e o pouco interesse nos "prazeres morais"431 - único sentimento capaz de alimentar a "grandeza e insolubilidade moral do Estado" $" 432$.

Ambas, combinadas, resultavam num primeiro prejuízo social para as artes, que as estabelecia como frivolidade; e num segundo, ainda pior, que reforçava a incapacidade de perceber o potencial delas para "disciplinar o espírito", sendo assim nova e repetidamente recomendadas apenas como objeto de "elegância e luxo"433. Sem amparo e prestígio, o ofício artístico caia nas mãos dos pobres ou escravos, fluxo que piorava ainda mais o processo de sua discriminação ${ }^{434}$.

Essa naturalização de preconceitos, que se estenderia até mesmo aos artistas mais ilustres do país, chegava ao ponto de

não se compreender a justa indignação do homem que, tendo recebido no estudo das artes a sua ilustração, nele aumentando a esfera das suas ideias e anteparado a energia de seus nobres sentimentos, balbucia antes de responder a quem lhe pergunta: Qual a tua profissão? ${ }^{435}$

${ }^{426}$ Idem, ibidem. p.192 [conclusão].

${ }^{427}$ Idem, ibidem. p.194 [conclusão].

${ }^{428}$ Idem, ibidem. p.192 [conclusão].

${ }^{429}$ Idem, ibidem. p.193 [conclusão].

${ }^{430}$ Idem, ibidem. p.194, conclusão. Sobre a educação popular em Atenas, e a ideia de terem formado o gosto na Grécia antiga, ver. idem, ibidem. p.176; p.180. estudo sétimo

${ }^{431}$ Idem, ibidem. p.78 [estudo primeiro] Ou: Correio Mercantil, Rio de Janeiro, 30 de setembro de 1864, p.2.; e pp.136-138 [estudo quinto]. Ou: Correio Mercantil, Rio de Janeiro, 14 de outubro de 1864, p.2. Para um sinônimo de "prazer moral", enquanto "prazer do espírito", ver ainda: p.169 [estudo sétimo]. Ou: Correio Mercantil, Rio de Janeiro, 17 de novembro de 1864 , p. 2 ..

Também aqui, o eco da voz de Porto Alegre ressoava nas palavras de Américo: "Não temos [...] na religião do patriotismo um artigo de fé consagrado às artes. PORTO ALEGRE. "Apontamentos sobre os meios práticos de desenvolver o gosto e a necessidade das belas artes no Rio de Janeiro”. Op. cit. p.307.

${ }^{432}$ AMÉRICO, P. op. cit. p.192 [conclusão].

${ }^{433}$ Idem, ibidem. p.194 [conclusão].

${ }^{434}$ A ideia de que apenas pobres e escravos aceitavam aventurar-se no mundo das artes será cuidadosamente desenvolvido por Américo em suas Cartas de um Plebeu, texto fundamental para suas intenções políticas, discutido mais à frente nesta Tese.

${ }^{435}$ Idem, ibidem. p.194, conclusão. 
Américo havia comprado essa indignação, mas não sem antes incorporar, paradoxalmente, o preconceito lançado à classe artística, razão pela qual pode-se compreender por que ele se esforçava tanto para ser apresentado antes como o bacharel do que como o artista Américo ${ }^{436}$.

Certo é que, para ele, o único remédio possível para combater esse prejuízo - a causa negativa da arte no Brasil - era precisamente a educação. Mas havia sem dúvida uma diferenciação imediata de níveis.

Em nível pessoal, posto que o jovem queria mudar o quanto antes a sua situação, tratava-se de uma educação que ainda anexaria à sua formação artística os valores sociais que um diploma de bacharel, bem mais respeitado, carregava no país. Em nível social, a terapia requeria um processo naturalmente mais demorado e extenso, prescrevendo igualmente a educação das massas, uma ao mesmo tempo artística e, outra, moral.

A "temperatura" ou o "estado moral" (expressão bastante difundida pelo determinismo de um H. Taine, mas utilizada concomitantemente por Américo ${ }^{437}$ e inúmeros escritores do período) seria a indicadora das possibilidades de ascenção dos gênios e das artes num determinado país. Eles só surgem suportados por uma estrutura social favorável ${ }^{438}$. Tratar-se-ia, portanto, de uma "lei fenomenal" ${ }^{439}$ :

Com efeito, por toda parte onde a arte chegou a um elevado estado de perfeição foi em uma época de prosperidade pública e de desenvolvimento intelectual, em que o sentimento coletivo da sociedade, impelido para o ideal pelo sopro das ideias patrióticas, produziu essas admiráveis provas da inteligência humana ${ }^{440}$.

${ }^{436}$ Cf., nesta Tese: A um triz do xilindró: Pedro Américo e a questão dos bacharéis.

${ }^{437}$ Idem, ibidem. p.196 [conclusão]. Ou: Correio Mercantil, Rio de Janeiro, 26-27 de dezembro de 1864, p.2.

${ }^{438}$ Idem, ibidem. pp.195-197 [conclusão].

${ }^{439}$ Idem, ibidem. p.197 [conclusão].

${ }^{440}$ Idem, ibidem. p.201 [conclusão]. Ou: Correio Mercantil, Rio de Janeiro, p.28 de dezembro de 1864, p.2.

A ideia desenvolvida nesse excerto está bastante próxima de várias sentenças publicadas por Porto Alegre, durante a década de 1850, pelo menos. Por exemplo: "Interroguem-se todos esses monumentos criados no espaço de oito séculos do seu domínio peninsular, que sempre se encontrará neles, a par da beleza e da perfeição da arte, uma época florescente". PORTO ALEGRE, M. A. "Algumas ideias sobre as Belas-Artes e a indústria no Império do Brasil - $2^{\circ}$ artigo." Guanabara, Rio de Janeiro, tomo I, 1851, pp.135-142. Reimpresso também em: KOVENSKY, Julia; SQUEFF, Letícia (orgs.). Manuel de Araújo Porto Alegre: Singular \& Plural. São Paulo: IMS, 2014. p.299-300. 
Nessa sequência de reflexões, o problema político da educação popular relacionada à recepção artística também encontrava uma base filosófica, de viés hegeliano: educar é estender a razão de um povo e permitir seu desenvolvimento moral em direção ao ideal ${ }^{441}$.

Está sem dúvida na ênfase à educação a parte do projeto geral e teórico do jovem artista voltado ao público brasileiro (um outro projeto, específico e prático, apresentado em suas Cartas de um Plebeu, será comentado em Capitulo posterior ${ }^{442}$ ). A "instrução do povo" seria, assim, a primeira premissa para o desenvolvimento das belas artes, e deveria ser a "função primeira de um Estado, sem a qual não se poderiam elevar as massas ao sentimento do Belo"443 . "Com a instrução popular, o vago sentimento da nacionalidade, apenas conhecido pelo proletário [...] transformar-seia em patriotismo"; e com ela "virá a necessidade de gozar moralmente, e por conseguinte de produzir, como também a impaciência necessária para conquistar os louros de Fídias e de Rafael"444.

Deve-se dizer que a insistência de Américo nesse ponto - a ideia de que a educação geral centralizada no Estado era uma premissa a qualquer desenvolvimento a ser feito no Brasil - nada mais era do que a retomada teórica das discussões e das reformas de ensino primário e secundário instituídas no Império, na década de 1850, por Luiz Pedreira do Couto Ferraz, pelas quais o jovem, conforme apresentado no Primeiro Capítulo desta Tese, havia passado na AIBA e no Colégio d. Pedro $\mathrm{II}^{445}$. As medidas, instituídas por Decreto em fevereiro de $1854^{446}$, instauraram pela primeira

${ }^{441}$ O postulado era quase inteiramente krausista (mesmo se este tivesse, sem dúvida, bases na "razão histórica" hegeliana): Tiberghien, por exemplo, no livro consultado pelo jovem brasileiro, havia definido em seu sistema de filosofia moral a ignorância, ao lado da alienação mental e da emoção (o estado temporário no qual as paixões dominam o indivíduo) como um dos obstáculos para o discernimento e desenvolvimento moral (TIBERGHIEN, G. Op. cit. pp.143-155.). A propósito, a moralidade pediria para sua realização apenas a utilização da razão em sua forma a mais pura (Idem, ibidem. p.153; p.303). Mas os dois últimos estados eram patológicos, muitas vezes incontornáveis e constrangidos por circunstâncias diversas ao sujeito, ao passo que a ignorância era um voluntário, do qual se poderia sempre sair (Idem, ibidem. p.129.), e que deveria ser combatido tanto individualmente quanto socialmente: neste último caso, por meio da política e de projetos para a educação geral (Idem, ibidem. p.302.).

Alguns dos termos utilizados por Américo - um em especial, o entorpecimento ("preguiça", "paralisia"; "indiferença ou inércia moral") - não por acaso se ligavam a essa mesma ideia, sempre relacionada às causas negativas que impediam o desenvolvimento moral e artístico do Brasil: "se o governo chamado a" dirigir seu povo "dele se esquece e o abandona, o entorpecimento o atinge, se não é a anarquia, e a decadência, é o prêmio da sua inércia". (AMÉRICO, P. op. cit. op. cit. p.120 [estudo quarto]. Ou: Correio Mercantil, Rio de Janeiro, 7 de outubro de 1864 , p.2. ${ }^{442}$ Ver o Sexto Capítulo desta Tese.

${ }^{443}$ AMÉRICO, P. op. cit. p.200 [conclusão]. Ou: Correio Mercantil, Rio de Janeiro, p.28 de dezembro de 1864 , p.2.

${ }^{444}$ Idem, ibidem. p.201 [conclusão]. A referência à "Rafael", modificada na citação acima, é feito por Américo como "Raffaelo".

${ }^{445}$ Sob o "Gabinete da Conciliação", coube ao ministro Pedreira, a "própria personificação da conciliação", (e, como visto, amigo próximo de Porto Alegre, e responsável por acolher Américo, tanto na Academia quando naquele Colégio) retomar e implementar os projetos consecutivos que Torres Homem e Gonçalves de Magalhães - os maiores "ecléticos" brasileiros, também amigos íntimos e parceiros de Porto Alegre - haviam proposto na metade da década de 1840, quando exercendo seus mandatos deputados (isto é, de legisladores). Sobre Pedreira como a personificação da conciliação, ver: SAVIANI, Demerval. História das ideias pedagógicas no Brasil. Campinas: Autores associados, 2008. 
vez, no Império, a obrigatoriedade do ensino público primário (excluídos os escravos), e asselavam ainda uma política de centralização, regulamentação e fiscalização dos ensinos primários e secundários pelo aparato governamental, mesmo se, inicialmente, em função das restrições impostas pela promulgação do Ato Adicional de $1834^{447}$, essas medidas tivessem sido implementadas apenas no círculo da corte.

Em vários sentidos, essa reforma estava adequada ao que Américo pensava de um projeto educacional em suas Considerações Filosóficas: o Estado havia tomado as rédeas do ensino, instituindo educação mínima e gratuita a todos, e fornecendo ainda cota fixa de bolsas para aqueles que, sem dispor de meios, mostrassem interesse em seguir em seus estudos ${ }^{448}$.

Mas para um projeto também dedicado ao desenvolvimento das artes, e mesmo das artes industriais (como o comentado caso da "revolução do gosto" na Inglaterra), ainda pareciam faltar alguns elementos fundamentais. Conquanto a "Moral" constituisse o primeiro ponto no currículo da instrução pública primária ${ }^{449}$ pós-decreto, e, ainda, o primeiro ponto (seguido apenas da maioridade legal) para a contratação de professores da rede pública ${ }^{450}$, ela ainda estava intimamente colada ao ensino da religião, com uma duração bastante limitada, e não exatamente ao educação laica ${ }^{451}$. $\mathrm{O}$ ensino da "Filosofia Moral" e o da "História da Filosofia", exercidos de maneira sistemática e inseridos num currículo progressivo, estava oficialmente reservado na corte apenas à escola modelo do país, o Colégio d. Pedro II, e unicamente à segunda classe do ensino secundário ${ }^{452}$ : justamente

P.130. Sobre a retomada de Pedreira dos projetos de Torres Magalhães, ver: PONTES, Vinicius Liorde. A Reforma Couto Ferraz e o estabelecimento de uma direção para a instrução primária e secundária no Império do Brasil. [Dissertação de Mestrado]. Rio de Janeiro: PUC-RJ, 2009. Pp.51-56.

${ }^{446}$ FERRAZ, Luiz Pedreira do Couto. "Decreto No 1.331-A, de 17 de fevereiro de 1854." Disponível online em: http:/www2.camara.leg.br/legin/fed/decret/1824-1899/decreto-1331-a-17-fevereiro-1854-590146-publicacaooriginal115292-pe.html [último acesso: fevereiro de 2016]

${ }^{447} \mathrm{O}$ Ato Adicional de 1834 instituiu mudanças na Constituição de 1824 no sentido de limitar o poder Régio e garantir maior autonomia às políticas locais das Províncias.

${ }^{448}$ LOPES, V. L. op. cit. p.74.

${ }^{449}$ FERRAZ, Luiz P. C. Op. cit. "Art. 47. O ensino primário nas escolas públicas compreende: a instrução moral e religiosa; A leitura e escrita; As noções essenciais da gramática; Os princípios elementares da aritmética; O sistema de pesos e medidas do município."

${ }^{450}$ Idem, ibidem. "TITULO II - Da Instrução pública primária. CAPITULO I - Condições para o magistério público; nomeação, demissão e vantagens dos professores. Art. 12. Só podem exercer o magistério público os cidadãos brasileiros que provarem: $1^{\circ}$ Maioridade legal. $2^{\circ}$ Moralidade. $3^{\circ}$ Capacidade profissional."

${ }^{451}$ Sobre o a urgência de separação o ensino primário e secundário de seu domínio religioso, acordando-os ao ensino laico, no Brasil da segunda metade do século XIX, ver: SAVIANI, D. Op. cit. pp.130-137, em especial os comentários sobre J. Liberato Barroso, cuja obra é citada em nota posterior.

${ }^{452}$ Com relação ao ensino secundário, a Reforma Couto Ferraz instituía no Colégio d. Pedro II duas classes sequenciais de estudos: a primeira classe (4 anos primeiramente, 5, depois de uma outra reforma em 1857), cujo ensino era orientado à formação técnica, para os alunos que, desejando terminar apenas essa parte dos seus estudos, esperavam entrar imediatamente em um ofício; e a segunda classe ( 2 anos), cuja grade curricular era orientada finalmente à formação dos bacharéis em Letras. 
aquela que formaria os bacharéis, a "elite pensante" brasileira saída da capital federal ${ }^{453}$. Mesmo os alunos do secundário que tivessem concluído seus estudos da primeira classe no Colégio (instituição rara e cara para a maioria dos cidadãos livres) se viam preparados especialmente para o ingresso em uma formação técnica ${ }^{454}$ - a do Instituto Comercial, por exemplo -, formação "positiva" e perigosa para Américo ${ }^{455}$.

Quanto às artes, o decreto havia criado o que podia parecer um desserviço ao país, na medida em que, antes - desde a reforma dos estatutos do Colégio, em 1841 -, o ensino do desenho e da música era obrigatório na instituição-modelo, constituindo uma porção significativa do tempo total de aulas ${ }^{456}$. A partir de 1854 , embora se houvesse previsto o aprendizado dessas disciplinas, ambas no ensino primário e secundário em toda a corte, essa frequentação se tornava optativa aos alunos, e a oferta dessas classes não era nem mesmo compulsória às escolas ${ }^{457}$.

Era a esse quadro de "defeituosa e incompleta educação [moral] recebida" desde a infância"458, de "ausência [das artes] na educação intelectual, tanto primária como superior [secundária]"459 que Américo se referia quando também reclamava da causa negativa da arte, e quando chamava, amparado pelas teorias recentes e bastante discutidas na França de um autor e

${ }^{453}$ Para um resumo esclarecedor dessas medidas, e suas relações com o ensino do Colégio d. Pedro II, ver:; VECHIA, Ariclê; LORENZ; Karl M. "O currículo de Couto Ferraz de 1855: compatibilizando o ensino propedeutico com o profissionalizante”. In: IV Seminário de Pesquisa da Região Sul - Anped Sul, 2002, Florianópolis. Florianópolis, 2002. Disponível online em: http://www.portalanpedsul.com.br/admin/uploads/2002/Educacao,_Historia_e_Filosofia/Trabalho/11 57 56 t810.pdf [último acesso em fevereiro de 2016]

${ }^{454}$ A primeira classe do ensino secundário do Colégio d. Pedro II, que durava, portanto, cinco após o decreto de 1857, incluía em sua grade as seguintes disciplinas: primeiro ano: doutrina cristã, português, latim, francês, aritmética, geografia básica; segundo ano: latim, francês, inglês, arimética e geografia; terceiro ano: latim, francês, inglês, aritmética, álgebra, geografia, história da idade média; quarto ano: latim, inglês, geometria elementar, história moderna e contemporânea, história do Brasil, corografia, botânica e zoologia; quinto ano: latim, inglês, trigonometria, corografia, história do brasil, física, botânica, zoologia, grego, alemão básico. cf. LIMA, P. A. op. cit. ver especialmente o artigo 5 do decreto.

${ }_{455}$ AMÉRICO, P. op. cit. p.193.

${ }^{456}$ Segundo K. Lorenz e Vechia, a reforma do Colégio d. Pedro II, em 1841, havia instituído um carga de aulas de desenho e música que compreende aproximadamente $16 \%$ de toda a grade curricular de um aluno inscrito na instituição. LORENZ; VECHIA. Op. cit. p.06.

${ }^{457}$ FERRAZ, L P. C. Op. cit. especialmente o artigo 47, referente às artes no ensino público primário, e o artigo 80, no ensino público secundário.

O decreto posterior de 1857, estritamente ligado ao ensino público secundário da corte, e promulgado por outra figura próxima a Américo (bastante importante para sua ida à Paris, e para seu afastamento da AIBA, em 1866, para a sua segunda ida à Europa), o marquês de Olinda, ainda mantinha as diretrizes gerais do decreto anterior, nas quais o ensino da Filosofia Moral viria no sétimo e último anos dos estudos para os bacharéis, e o desenho, incluído na grade sem especificação de ano, poderia ser ensinado às quintas-feiras (dia de folga, se na semana não houvesse outro feriado), no horário de recreio, ou em qualquer outro feriado. Ver: LIMA, Pedro de Araújo [Marquê de Olinda]. "Decreto $\mathrm{n}^{\mathrm{o}} 2.006$, de 24 de Outubro de 1857 approva o Regulamento para os collegios publicos de instrucção secundaria do Municipio da Côrte." Disponível em: http://www2.camara.leg.br/legin/fed/decret/1824-1899/decreto2006-24-outubro-1857-558097-publicacaooriginal-78997-pe.html [Último acesso em fevereiro de 2016.]. Sobre a parte do decreto relativo às aulas de artes, ver em especial os artigo $4^{\circ}, 10^{\circ}$ e $11^{\circ}$.

${ }_{458}$ AMÉRICO, P. op. cit. P.192 [conclusão]. Ou: Correio Mercantil, Rio de Janeiro, 25 de dezembro de 1864, p.1.

${ }^{459}$ AMÉRICO, P. op. cit. P.194 [conclusão]. 
tradutor bastante conhecido, Louis Viardot ${ }^{460}$, a atenção do Estado e dos legisladores para a implementação do ensino gratuito e generalizado também daquelas cadeiras, como maneira de criar algumas das condições necessárias ao desenvolvimento das artes no Brasil ${ }^{461}$. Se, na corte, existiam esses problemas urgentes, o panorama lhe era logicamente ainda pior, considerada a situação do restante do país, onde os ensinos primário e secundário gratuitos ainda não estavam sistematizados, nem submetidos à chancela estatal, e continuavam a ser dados nas aulas públicas avulsas espalhadas pelo território nacional.

Conforme argumentarei, ao menos com relação à parte artística que Américo julgava caber em suas intenções reais de ação, quando ele propunha um projeto específico para o ensino das artes no Brasil, poucos meses depois da publicação das suas Considerações Filsóficas, era a essa "falha" que dirigia suas preocupações.

Entretanto, até que se chegue a essa questão, deve-se reter sobretudo que a generalização do ensino público e gratuito, mas um que incluísse integralmente o ensino moral e o artístico elementar, é o cenário que Américo julgava ideal para que a ele se coadunasse com perfeição a outra parte do projeto para as artes no Brasil, essa direcionada aos artistas, sempre amparado pelos "legisladores" e pelo Estado.

Ele próprio havia dito: uma população mais instruída moral e artísticamente pediria cada vez mais "prazeres morais" 462 .

Essa parte do projeto, não deve haver dúvidas, cingia em Américo uma teoria artística que já está bastante clara: centrando o devir artístico no Estado e na realização do Belo ideal "moderno", o

${ }^{460}$ Em 1861, Louis Viardot publicava um livro bastante comentado intitulado "Como é preciso encorajar as artes", no qual, discutindo as mesmas questões artísticas que levariam à reforma da École des Beaux-Arts de Paris, pressupunha a importância da generalização do ensino das artes, ao lado da instrução literária e científíca. Américo citará esse texto em momentos precisos do seu texto. Embora seja evidente que não concorde com todos os argumentos do autor (Viardot era contra, por exemplo, o encorajamento dado a artistas, sobretudo aos jovens), alguns trechos do livro do francês se aproximam significativamente dos projetos gerais esboçados pelo jovem no fim de suas Considerações Filosóficas. Um trecho do texto de Viardot em relação à discussão aqui empreendida é o seguinte: “A nossos modernos Péricles, àqueles que tem nas mãos a direção da artes [...] eu gostaria de dar esse conselho: coloque os elementos das artes a disposição de todos, como os elementos da instrução literária e científica. Vocês tem escolas gratuitas de leitura, de escritura e cálculo. Tenham também escolas gratuitas para o desenho linear e para o uso dos artesãos. Se aquelas não fazem poetas, nem historiadores, nem astrônomos, essas também não farão nem pintores, nem escultores, nem arquitetos; mas elas não os impediram de se fazerem." [tradução nossa] VIARDOT, Louis. Comment faut-il encourager les arts. Paris: Jules Renouard, 1861. p.86-87.

${ }^{461}$ Não havia dúvidas de que seus leitores sabiam exatamente do que ele estava falando, afinal de contas, o atual gabinete de 1864 possuía como Ministro do Império José Liberato Barroso: personalidade política que, a exemplo de Pedreira, estava profundamente engajado com o ensino público no Brasil, em sua chancela estatal. Ver: SAVIANI, D. Op. cit. p.135. Segundo Saviani, as "intervenções e reflexões de Liberato Barroso [sobre o ensino foram reunidas no livro A instrução pública no Brasil, publicado em 1867”, considerado “o primeiro estudo de conjunto sobre a educação brasileira". Idem, ibidem. pp.135-136.

${ }^{462}$ Idem, ibidem. p.201 [conclusão]. 
jovem pretendia uma arte de expressão fundamentalmente antropomórfica, orientada por uma teoria da imitação idealista, que produzisse obras públicas tendo em vista suas destinações morais ${ }^{463}$, obras em que se fundiria ainda a verdade da forma (em relação aos sentidos) e a do conteúdo (em relação à razão). Dito de outro modo, isto significa que o compromisso irrevogável de um artista deveria ser com o seu público e com uma temática moral diretamente relacionada a seu tempo (sem dúvida aqui, uma conciliação dos ideários neoclássicos e românticos). Tão logo ele comecasse a trabalhar, reconheceria que, ao lado das instituições públicas de ensino, suas obras também se apresentariam como "historiadores populares e universais de um grande número de fatos, de opiniões, de tradições, que compõem a existência moral das nações ${ }^{464 \%}$. O artista no Brasil deveria endereçar à sua atividade um "fim útil”, e não circunscrevê-la, como visto, em uma autonomia que, seguindo os postulados nesse ponto problemáticos de Victor Cousin, a encaminharia ao círculo fechado da "arte pela arte",465.

Do mesmo modo que o Estado e os legisladores no Brasil possuiriam um compromisso com o povo brasileiro, ele possuiriam outro com os artistas e com as artes. A exemplo dos gregos, eles precisariam empregá-las, como "as letras, as leis e as armas",466, para "nutrir virtudes cívicas [...] ligando-as assim aos destinos da sociedade" 467 .

O sistema artístico de fomento público idealizado por Américo para esse fim retornava novamente a autores como Quincy e, sobretudo, Émeric-David, e se mantinha ainda pertinente para muitos autores do período (ainda que fosse um sistema em parte questionado pela reforma da École des Beaux-Arts, em $1863^{468}$, especialmente por Viollet-Le-Duc). Ele se concentrava em três núcleos de ações oficiais específicos, mas intimamente conectados: o do encorajamento ${ }^{469}$, o da emulação ${ }^{470}$ e o das recompensas ${ }^{471}$.

${ }^{463}$ Idem, ibidem. p.178-79 [estudo sétimo]. Ou: Correio Mercantil, Rio de Janeiro, 19 de novembro de 1864 , p.3.

${ }^{464}$ Idem, ibidem. p.179 [estudo sétimo].

${ }^{465}$ Me parece ser evidente o porquê de Américo defender a arte como um instrumento necessário e com um fim preciso à nação. Relembrando a discussão anterior sobre os preconceitos existentes no Brasil sobre essa atividade, pode-se facilmente concluir que a defesa da autonomia da arte em um país então sem tradição artística, afastando-a dos dispositivos sociais, contribuiria ainda mais para a sua decadência, e para a manutenção de um estado no qual continuaria a ser percebida como não "necessária". Nesse caso, permaneceria a servir ao elogio da vaidade e do luxo, como o caso dos retratos feitos para os espaços privados.

${ }^{466}$ Idem, ibidem. p.173 [estudo sétimo].

${ }^{467}$ Idem, ibidem. p.137 [estudo quinto]. Ou: Correio Mercantil, Rio de Janeiro, 14 de outubro de 1864, p.2.

${ }^{468}$ A emulação, como será visto, constitui uma defesa importante para o sistema artístico imaginado por Américo, e tratava-se justamente do fim dessa prática dentro da École des Beaux-Arts de Paris que proclamava um dos pontos do decreto imperial assinado por Nieuwerkerke, e idealizado por Viollet-Le-Duc e P. Mérimée. Sobre o problema da emulação na reforma da École, ver ainda: BONNET, A. Op cit., em especial, o capítulo "L'émulation".

${ }^{469}$ Sobre o problema do encorajamento nos principais autores estudados por Américo, ver: ÉMERIC-DAVID. Op.cit. p.254; p.303; p.335. QUINCY, Q. Considerations morales. p.19; p.22. SUTTER, D. Op.cit. p.55-56. P.60; p.61. VIARDOT, L. Op.cit. p.17; p.32; p.33; p.71-72; p.83; p.87; p.89. 
Cada uma dessas ações supunha efeitos positivos nas trajetórias dos estudantes, dos artistas e mesmo do público; algumas delas, a propósito, em funcionamento no Império.

O encorajamento que o Estado já dava a seus estudantes havia sido testemunhado, como se sabe, pelo próprio Américo, primeiro na qualidade de bolsista do Império durante seus anos na AIBA, e em seguida na de bolsista do imperador, num interlúdio em que as bolsas da Academia não estavam disponíveis. Aos artistas, por sua vez, o encorajamento oficial (central mesmo para o sistema pensado por Américo, em relação direta com as ideias a Porto Alegre ${ }^{472}$ ) deveria vir da encomenda ou de concursos abertos para a produção de monumentos públicos dos mais variados alcances, utillizando adequadamente esse "homens úteis" à nação - medida que o jovem discutiria ainda mais em suas Cartas de um Plebeu.

A emulação, a próxima ação do sistema artístico oficial, bastante salutar quando bem estimulada, deveria vir, naturalmente, dentro do ensino dos jovens por meio dos concursos internos, nos quais eles se esforçariam para serem sempre melhores, na competição estabelecida com seus iguais. Quando se tratariam de artistas formados, as encomendas ou concursos exigiriam também deles compromisso sério e dedicação, dada a destinação pública de suas obras e o resultado que elas poderiam ter para suas carreiras:

Quando os artistas recebem do governo a nobre missão de contribuir para a manutenção da moral pública, de imortalizar pelas criações do seu talento a história de uma nação inteira; de esmaltar o solo nacional e desenvolver o amor patriótico, pelo espetáculo dos monumentos elevados aos seus pais, à sua genealogia, à religião e às leis, a ideia que concebem da importância das suas produções, o interesse que neles toma o público, o juízo imparcial, que mais depressa obtém-se das massas do que de uma facção, os aplausos de que são cobertos quando a história, as crenças e o patriotismo se vêem dignamente representados, ou o descontentamento popular, quando o monumento não satisfez a expectativa da opinião geral, todos esses motivos de emulação tendem

${ }^{470}$ Sobre o problema da emulação nos principais autores estudados por Américo, ver: BEULÉ, C. Op.cit. p.01. ÉMERIC-DAVID. Op.cit. p.11; p.58; p.97; p.101; p.103; p.108; p.259; p.333. INGRES, J.-D. Op.cit. p.11. MERSON, O. Op.cit. p.13 (Merson também a favor da emulação na École); p.37-38. RÉCLAMATION DES ÉLÈVES; p.13; p.2324. (Os alunos contra a reforma da École eram inteiramente a favor dos concursos e da emulação). ROUEN, E. L. Op.cit. p.31. SUTTER, D. Op.cit. p.49; p.71. VIARDOT, L. Op.cit. p.17, p.18; p.86. VIOLLET-LE-DUC. Intervention de l'État dans l'enseignement... p.40 (O arquiteto era contra os sistema de recompensas público aos jovens; e se tiver, que seja com dinheiro, e não com medalhas); p.48. VITET, L. Op.cit. p.57.

${ }^{471}$ Sobre o problema das recompensas nos principais autores estudados por Américo, ver: BEULÉ, C. Op.cit. p.15. ÉMERIC-DAVID. Op.cit. p.5; pp.264-65; p.268; p.332; p.337. QUINCY, Q. Considerations morales. p.3. ROUEN, E. L. Op.cit. p.265. WINCKELMANN. p.232.

${ }^{472}$ PORTO ALEGRE, M. A. “Apontamentos sobre os meios práticos de desenvolver o gosto e a necessidade das belas artes no Rio de Janeiro.” IN: KOVENSKY, Julia; SQUEFF, Letícia (orgs.). Manuel de Araújo Porto Alegre: Singular \& Plural. São Paulo: IMS, 2014. pp.307-310. 
para comunicar o mais salutar e poderoso impulso ao desenvolvimento das suas faculdades criadoras. ${ }^{473}$

À emulação supunha-se dois caracteres. Um econômico (os artistas disputariam entre si para conseguir os trabalhos) e outro social (se esforçariam para ter o reconhecimento e admiração do público).

Esse dois aspectos também estariam presentes na última e talvez das mais fundamentais ações artísticas ${ }^{474}$ : a das recompensas. O primeiro aspecto deveria ser o da perspectiva pecuniária ou simbólica (aos alunos, pode-se imaginar as medalhas em concursos e exposições; o possível convite para o trabalho conjunto com seus professores, e a obtenção da bolsa de estudos no país ou no exterior: esta, ao mesmo tempo uma recompensa de esforços passados e o encorajamento para dedicações futuros). Mas seria de fato o último aspecto, social, o que, para Américo, se tornaria o mais desejado por um artista:

A maior glória de um verdadeiro artista, e também a única recompensa digna de uma alma generosa quando desempenha a sua sagrada missão, é ser apreciado pelos grandes corações; "Vós destes uma agradável forma aos pensamentos que pela sua elevação nos importunavam, envolto no vago manto do sentimento. Vós fortificastes a nossa confiança no gênero humano, fortalecendo ao mesmo tempo nossa consciência individual. O vosso nome ficará arquivado nas páginas de hoje, e passará cheio de glória à posteridade... Obrigado!",475

Esse tipo de recompensa social se estabeleceria a propósito em caminho de mão dupla: o artista cujo trabalho é merecedor se veria recompensado pelo reconhecimento popular (a glória, o agradecimento público, etc) ou oficial (traduzido em subvenções estatais, em novas obras ou ainda em cadeiras no senado ou ministério ${ }^{476}$ ); ao passo que, por sua vez, um cidadão exemplar, um líder, um herói, enfim, também poderia ter como recompensa dos seus atos e feitos para a comunidade a

${ }^{473}$ AMÉRICO, P. op. cit. p.178 [estudo sétimo].

${ }^{474}$ A grande maioria da bibliografia acessada por Américo trata do problema. Nela, é recorrente a atestação de que, em períodos áureos da arte (Grécia clássica, Renascimento italiano, a era de Luís XIV), que teriam sido também períodos dourados da ilustração dos governantes, se compreendeu a importância de recompensar os artistas convenientemente, de acordo com o mérito e a destinação de suas obras. Um tal sistema aumentaria a emulação sadia, numa círculo continuo de produções exemplares.

${ }^{475}$ Idem, ibidem. pp.197-99 [conclusão]. Ou: Correio Mercantil, Rio de Janeiro, 26-27 de dezembro de 1864, p.2; e Correio Mercantil, Rio de Janeiro, p.28 de dezembro de 1864, p.2.

${ }^{476}$ Idem, ibidem. p.199 [conclusão]. Ou: Correio Mercantil, Rio de Janeiro, p. 28 de dezembro de 1864, p.2. 
homenagem e agradecimento perpetuados em uma obra de arte - como teria sido a prática constante na Grécia antiga (estátuas de personalidades, guerreiros, atletas etc. ${ }^{477}$ ).

O exemplo da comunidade e de seus integrantes inspiraria as ideias dos artistas para suas obras; e as realizações dos artistas realimentariam, em forma de "prazer moral", as ações que unificassem a nação e que estimulassem os exemplos de amor patriótico. Mediada e, especialmente, fomentada pelo Estado, se trataria de uma cadeia contínua na qual a arte serviria e seria útil à moral; e o sentimento moral reconheceria na arte uma de suas mais importantes expressões.

Todo o potencial da teoria quincyana da destinação moral da obra estava, assim, inteiramente absorvido na teoria e no projeto artísticos do jovem Américo, já que lhe parecia ser absolutamente válido para o desenvolvimento da arte na sociedade brasileira contemporânea:

São os grandes assuntos que despertam as grandes ideias, e as que merecem a admiração da posteridade. Se elas faltam ao artista, sua arte reduz-se inevitavelmente a uma ocupação industriosa, agradável, muitas vezes lucrativa, mas não indispensável ao nosso aperfeiçoamento intelectual [...] Destinadas, ao contrário, a excitar grandes ideias, a propagar nobres sentimentos, a imortalizar sublimes ações, a sociedade e a filosofia proclamam a sua utilidade e reclama seu uso. A influência dos monumentos sobre o espírito, sobre a memória, sobre o entendimento, provém muitas vezes menos do seu mérito do que da sua destinação. ${ }^{478}$

O encaminhamento dado por Américo à conclusão de seu texto não poderia reclamar nenhum outro momento que fosse mais propício a uma elevação imediata das "grandes ideias" no país e, com ela, dos "nobres sentimentos", do que o contexto nacional vivido naquele período. Essa orientação, talvez mais sutil hoje, era um dado mais do que evidente a um leitor brasileiro do seu texto, em 1864.

A conclusão da publicação de Considerações Filosóficas sobre as Belas Artes entre os Antigos (em fim de dezembro daquele ano) coincidia com o do irrompimento da Guerra do Paraguai, primeiro grande conflito entre nações do qual o Brasil havia jamais participado.

Não era nenhum pouco fortuita a estratégia de Américo em começar a conclusão do seu texto - parte na qual apresentava, portanto, o seu projeto geral para as artes no Brasil - com um atestado histórico das "causas da civilização helênica no fundo da atividade humana", garantindo

\footnotetext{
${ }^{477}$ Idem, ibidem. p.171, [estudo sétimo]; e novamente: p.198-199.

${ }^{478}$ Idem, ibidem. p.178-79 [estudo sétimo]. Ou: Correio Mercantil, Rio de Janeiro, 19 de novembro de 1864, p.3.
} 
que essas causas continham "dois grandes motores, em aparência opostos, mas na realidade ligados entre si [...]: a arte e a guerra." ${ }^{479}$ Teria sido com essas duas forças que o "espírito helênico" havia fundado e defendido por muito tempo "a comunidade da qual dependia a autonomia nacional." "480

Revoluções civis - como a Revolta do Ronco da Abelha ${ }^{481}$ (sobre a qual Américo comentará também no fím do seu texto ${ }^{482}$ ) ou a Revolta Praieira ${ }^{483}$ (que relembraria no seu Holocausto, romance que tratava, justamente, do trajeto percorrido de sua infância à juventude, entre o nordeste e a Europa ${ }^{484}$ ) - tenderiam a minar o sentimento patriótico e a unidade nacional. Uma guerra entre países, no entanto, alimentaria exatamente o oposto.

Se a arte precisava de "grandes assuntos" que despertassem "grandes ideias", e se os maiores valores morais no sistema krausista aderido por Américo eram, com efeito, o "desinteresse", o "virtuosismo, "o heroísmo" e "o sacrifício" 485 , nenhum outro momento poderia instigar mais sentimentos patrióticos, mais oportunidades para os "legisladores" empregarem seus artistas, "homens úteis" à sociedade, do que aquele no qual o país entrava, um momento de guerra. Todas as expectativas que Américo demonstra ter de um sistema artístico (o sentimento moral que pode e deve despertar a arte figurativa, a destinação da obra, o ideal na arte) convergiam, desse modo, para uma circunstância única na história do país, após sua recente emancipação política. E seria necessário aproveitá-la, como aliás ele o faria programaticamente, em seu ambicioso projeto de representações da Guerra do Paraguai.

A tese parecia ser tão correta que, percorrendo novamente a história do Egito, da Grécia clássica, da Roma dos césares, da Itália do Renascimento e da Contra-Reforma ${ }^{486}$, da Inglaterra de

${ }^{479}$ Idem, ibidem. p.187 [conclusão]. Ou: Correio Mercantil, Rio de Janeiro, 25 de dezembro de 1864, p.1.

${ }^{480}$ Idem, ibidem. p.187-88 [conclusão].

${ }^{481}$ A assim dita "Revolta do Ronco da Abelha" foi o movimento popular contra o governo imperial criado formado entre dezembro de 1851 e fevereiro de 1852, contra a Lei do Censo de 1851. O movimento irrompeu majoritariamente nas províncias da Paraíba (onde o infante Américo ainda se encontrava, em expedição com Jacques Brunet), em Pernambuco, Alagoas, Ceará e Sergipe.

${ }^{482}$ Idem, ibidem. p. 200.

${ }^{483}$ Outra importante revolta irrompida no Nordeste, especialmente em Pernambuco, entre 1848 e 1850, de forte caráter federalista. O estopim, segundo historiadores, teria sido a destituição que d. Pedro faria do então Presidente da Província, Antonio Pinto Chicorro da Gama, um liberal, e a substituição feita com o conservador Pedro de Araújo Lima, o marquês de Olinda (como discutido várias vezes nesta Tese, figura importante para a trajetória inicial de Pedro Américo).

${ }^{484}$ AMÉRICO, P. O holocausto. Florença: Typographia Cenniniana, 1882. P.46 e seguintes.

${ }^{485}$ TIBERGHIEN, G. Op. cit. p.132; p.165; p.169.

${ }^{486} \mathrm{O}$ enorme salto histórico que Américo fará entre a Roma imperial e o Renascimento, deixando de incluindo em sua lista a "Idade Média" é, como visto, concorde à sua visão pessimista em relação a esse período da história européia. Como comentado, para Américo, o período das "trevas" do Moyen Age se caracterizaria por uma falta completa de desenvolvimento artístico, tipo de um período voltado a uma filosofia mística, afastada do "real". 
Elizabeth I, da França de Luís XIV, e da Alemanha de Frederico (o Grande) ${ }^{487}$, Américo havia constatado que todas essas nações haviam vivido o período áureo de suas artes justamente após conflitos bélicos, dos quais elas teriam saído com o espírito patriótico inflamado.

O momento oportuno havia chegado para o desenvolvimento moral e artístico do Brasil, para emparelhá-lo às demais nações européias que lhe serviam de modelo. A conclusão era direta: "Cultivemos, pois, as belas artes, que deixaremos algum dia de parecer inferiores às raças européias, quando considerarmos as nossas produções, quer puramente artísticas quer industriais." "P88 "Propaguemos, pois, a instrução, ilustremos o povo, protejamos e recompensemos o gênio, e será este o único modo de elevar o animal bípede à dignidade de cidadão, e o cidadão ao alto conhecimento do verdadeiro, do bem e do belo" ${ }^{, 49}$.

${ }^{487}$ AMÉRICO, P. op. cit. pp.201-202 [conclusão]. Ou: Correio Mercantil, Rio de Janeiro, p.28 de dezembro de 1864, p.2.

${ }_{488}$ Idem, ibidem. p.200 [conclusão].

${ }^{489}$ Idem, ibidem. p.204 [conclusão]. 


\section{Quarto Capítulo}

\section{O nascimento de uma Ninfa brasileira: a primeira Carioca ${ }^{1}$.}

\section{O primeiro grande nu feminino brasileiro}

Uma ninfa idealizada e de proporções clássicas é a primeira grande composição autoral de Pedro Américo. Por muito tempo esquecida, uma reprodução inédita dessa obra (fig.4.1.) - oferecida aproximadamente em 1881 a Friedrich Wilhelm Viktor Albrecht, futuro imperador Guilherme II, da Prússia, e dada como "perda de guerra” após a Segunda Guerra Mundial ${ }^{2}$ - permite atualizar em um terreno mais concreto uma série de questões até então direcionadas à segunda versão da obra, de 1882 (fig.4.1.). Até então, se imaginou que as "algumas variantes"3 presentes nessa nova versão autorizariam uma leitura regressiva da primeira, e livre de problemas, o que não parece ser o caso ${ }^{4}$.

1 A maior parte deste Capítulo foi realizada graças à concessão de uma Bolsa de Estágio de Pesquisa no Exterior da FAPESP, entre 2014 e 2015. Deixo aqui novamente meus agradecimentos à instituição.

2 A Carioca continua desaparecida. Após a recusa do mordomo da Casa Imperial, Paulo Barbosa, ou de d. Pedro II, em 1865, a pintura permaneceu em posse de Pedro Américo. Era exposta pela última vez numa Exposição Geral de Belas Artes, em 1872. Em agosto de 1875, o quadro era exposto em Florença, "atraindo a atenção geral" da cidade (Gazeta de Notícias. Rio de Janeiro, 04 de agosto de 1875. p.1.). Em 1876, parece integrar as obras enviadas à Exposição Universal da Filadélfia, mas não é certo. O que é certo é que no início dos anos 1880, quase certamente em 1881, a obra é ofertada (ou vendida) a Guilherme II, da Prússia, que se casava precisamente naquele ano, preparando-se para se o herdeiro do império prussiano. A pintura é pela primeira vez mencionada na Coleção do Palácio de Berlim em 1883. Em 1909 estava guardada no Palácio Schönhausen, e em 1926 estava novamente no Palácio de Berlim. Até 1939 havia sido emprestada ao governo em Königsberg. Desde 1945, em decorrência da Segunda Guerra Mundial, era arrolada nos inventários públicos da Alemanha como "perda de guerra". Ver: BARTOSCHEK, Gerd; VOGTHERR, Christoph Martin. Zerstört, Entführt, Verschollen. Die Verluste der preussichen Schlösser im Zweiten Weltkrieg. Gemälde I. Berlin-Brandenburg: Stiftung Preussische Schlösser und Gärten, Potsdam, 2004.

Agradeço a Alexandra Nina Bauer, curadora das pinturas germânicas, flamengas e holandesas das coleções públicas dos Museus Berlinenses, e a Robert Skwirblies, da Technische Universität Berlin, Institut für Kunstwissenschaft und Historische Urbanistik, pela informação precisa de inventário da Carioca nas coleções alemãs.

${ }^{3} \mathrm{O}$ termo "algumas variantes" foi utilizado pelo próprio Américo, quando apresentou a segunda versão da Carioca na Exposição Geral de Belas Artes de 1884. Ver: LEVY, Carlos Roberto Maciel. Exposições Gerais da Academia Imperial e da Escola Nacional de Belas Artes. Rio de Janeiro: Edições Pinakotheke, 1990.

4 Em função da precisão do título que acompanha a segunda versão da Carioca (título que acusa ser essa versão uma "reprodução com variantes”), alguns autores como Cláudia de Oliveira, Laura de Nery, Mártin S. S. da Silva e Sônia G. Pereira normalmente utilizaram este método, projetando leituras na primeira versão a partir dos dados que encontraram na segunda. Embora não eu consiga explorar nesta Tese as diferenças entre as duas obras, deixo indicado que, mesmo não sendo de fato enormes (ao menos em relação à forma), as mudanças inseridas na segunda versão são, no entanto, extremamente significativas, estando sem dúvida em relação à resposta visual que Américo enceta para as críticas que recebeu da primeira obra, resposta na qual o pintor adiciona um claro teor irônico. Espero poder trabalhar essas questões em um texto futuro. Sobre os autores citados, ver: MÁRTIN, Sílvio Santos da Silva. "La Carioca rencontre La Source: Pedro Américo dans l'atelier d'Ingres ?", Loxias, n. 42. Disponível online em : http://revel.unice.fr/loxias/index.html?id=7584 [último acesso: 20 de janeiro de 2016]; OLIVEIRA, Claudia de. "“A Carioca' de Pedro Américo: gênero, raça e miscigenação no Segundo Reinado". In: CAIANA. Revista electrónica de Historia del Arte y Cultura Visual del Centro Argentino de Investigadores de Arte (CAIA). N.2. Año 2013. Disponível online em: $\mathrm{http} / /$ caiana.caia.org.ar/template/caiana.php?pag=articles/article_2.php\&obj=98\&vol=2 [último acesso: 10 janeiro de 
Convencionalmente branca (mas com uma razão precisa que a justifique), e intitulada logo de $A$ Carioca, ela tornava-se o primeiro nu feminino do Brasil. Mas uma adição é necessária. Trata-se não exatamente do primeiro nu, mas do primeiro nu feminino em grandeza natural exposto no país por um artista brasileiro.

A precisão importa porque coloca mais uma vez em evidência as aspirações conscientes e ambiciosas de um jovem de 21 anos, que inicia sua pintura efetivamente em 1863, e a conclui estrategicamente quase um ano depois, quando em regresso ao Brasil para se submeter ao concurso de professor de desenho figurado da AIBA - cadeira dedicada de fato ao estudo da figura humana. Interessa ainda porque não pode diminuir nem fazer esquecer que antes da Carioca, mesmo que em quantidade pouco significativa, o cenário artístico da corte já havia experimentado as primeiras aparições oficiais de nus femininos de artistas estrangeiros e nacionais, alguns dos quais, num período bastante significativo para essa temática, Américo teve a oportunidade de ver, e aos quais daria ulteriormente uma resposta pictórica possível e de fôlego.

Na única Exposição Geral de Belas Artes que o jovem pôde visitar ${ }^{5}$ antes de viajar à Europa ${ }^{6}$, a de 1859, se expuseram, sintomaticamente, mais nus do que durante toda a vigência das EGBAs até aquele momento $^{7}$, no que se configurava um próspero sinal de mudanças para essa temática. A recepção um pouco mais favorável, em contraste com ações de resistência anteriores ${ }^{8}$, provinha também da Casa Imperial, que garantia a exibição de uma Suzana surpreendida pelos velhos, pintura de nu extraída do

2016]; OlIVEIRA, Cláudia de; NERY, Laura de. "A Carioca, de Pedro Américo: alegoria e erotismo no imaginário oitocentista brasileiro." In: ANAIS do XXIV Simpósio Nacional de História - ANPUH/ Simpósio temática História Cultural e suas interfaces. São Leopoldo (RS): Unisinos, 2007. Disponível em : ttp://www.ufrgs.br/gthistoriaculturalrs/laura_nery_e_claudia_de_oliveira.html [último acesso: 10 de janeiro de 2016]; PEREIRA, Sônia Gomes. "O percurso e os dilemas de artistas brasileiros em Paris no século XIX: o caso da tela A Carioca de Pedro Américo." In: RIBEIRO, Marilia Andrés; GONÇALVES, Denise da Silva (Orgs.) Anais do XXI Cológio do Comitê Brasileiro de História da Arte. Tiradentes/MG, outubro de 2005. Belo Horizonte: Editora C/ Arte, 2006. [pp.292-301].

5 A última Exposição realizada na AIBA havia sido em 1852, três anos antes da chegada de Américo à instituição.

6 A exposição de 1859 abre em fevereiro; Américo viaja em março do mesmo ano.

7 Desde a primeira EGBA, em 1841, existiram apenas 2 aparições (a primeira, em 1841, uma Diana surpreendida por Acteon, de Louis Constant Bellisle, representando a conhecida passagem mitológica descrita nas Metamorfoses, de Ovídio, na qual a deusa, junto com ninfas, é flagrada em seu banho pelo jovem caçado Acteon; a segunda, em 1844, uma Andrômeda, exposta por Joaquim Lopes de Barros Cabral). Ver: LEVY, C. R. Maciel. Op. cit.

8 É exemplar que a Congregação da instituição se recusasse a aceitar para sua pinacoteca, no mesmo ano de 1841, dois outros nus femininos, julgados "imorais", embora estivessem devidamente codificados pela mitologia e alegoria, sendo uma as Três graças, e a outra, uma Alegoria à simetria: "Voltando a congregação para a sala das suas sessões, procede-se ao exame de admissão para exposição pública de quadros do Sr. Bellisle, dois são recusados, um dos quais representa as três graças, e o outro uma figura alegórica da Simetria. Esta determinação se funda não na falta de talento, mas no estado de nudez das figuras de mulheres que ali aparecem, devendo a Academia evitar nas suas Exposições qualquer motivo de escândalo que delas possa desviar as famílias", Caderno Atas Sessões Presidência-Diretor, 1841/1856. Rio de Janeiro, Arquivos do Museu d. João VI/UFRJ (M.D.J./UFRJ), Apud: DIAS, Elaine. Paisagem e academia: Félix-Émile Taunay e o Brasil (1824-1851). Campinas: Unicamp, 2009. P.166. 
velho testamento, pertencente à coleção privada ${ }^{9}$ do Imperador ${ }^{10}$. Ela se ombreava ainda a um Rapto de Europa $^{11}$; a uma Vênus e o Amor, atribuída a Giorgione; a uma cópia do Amor Sacro (fig.4.3.), de Ticiano, e a uma de Tarquínio e Lucrécia, de Guido Cagnacci (não exatamente um nu, mas uma pintura contendo o nu feminino como protagonista), enviadas por Victor Meirelles (dali a pouco colega de Américo em Paris); e por fim a uma Bacante, também de autoria de Meirelles ${ }^{12}$. Esta, uma pequena composição do artista (fig.4.4.), mas um índice cabal de transformação dentro da Congregação, que culminaria dali a poucos anos no laureamento institucional da própria Carioca de Américo.

Em 1866, a obra era contemplada com a Medalha de Ouro, em referência à Exposição de 1865, na qual havia sido exposta - logo após uma apresentação inicial na casa Bernasconi \& Moncada -, incitando polêmicas mais ou menos públicas, que envolviam a recusa surda do imperador ou de Paulo Barbosa (mordomo da Casa Imperial, com quem Américo já demonstrava ter problemas em cartas pessoais), e uma recepção igualmente dupla do grande público da corte carioca. Pudica ou licenciosa? Mulher ideal ou mulher real? As questões lançadas em sua recepção desde logo nortearam os juízos sobre a moralidade e o consentimento em se expor no centro do Rio de Janeiro uma inédita mulher despida em ponto grande, cujo pano de fundo, para além de uma simples resistência ao nu por parte da Casa Imperial e da sociedade fluminense frequentadora de exposições, parecia ainda incluir as discussões que há cerca de duas décadas se levantava sobre os problemas da prostituição feminina na mesma região.

Mas a polêmica fazia parte do jogo, especialmente se tratando da exposição do corpo feminino. E Américo sabia o lugar preciso onde inseria a sua Carioca. Uma novidade grandiloquente no contexto brasileiro, cintilada por aqueles signos de mudanças testemunhados na EGBA de 1859, ela era certamente uma reação calculada e ainda mais precisa ao contexto artístico parisiense, fechando a

9 A autoria é atribuída a Dieburg, da "Escola Holandesa". O nome, ao que tudo indica, é uma tradução para o alemão, então bastante comum. Parece ser, na verdade, Ter Borch, no original holandês. Se a suposição estiver correta, pode-se tratar de Gerard Ter Borch: pai de um dos mais conhecidos artistas holandeses do século XVII, seu homônimo, que de fato frequentou o tema da Suzana ao Banho (ver, por exemplo, uma imagem presente na coleção do Rijksmuseum, em: https://www.rijksmuseum.nl/en/collection/RP-T-1887-A-728, ou ainda a base de dados pública da arte holandesa: https://rkd.nl/en/). Se não, pode-se tratar ainda de outros artistas com o mesmo sobrenome, notadamente, Mozes Ter Borch, Herman Ter Borch, ou Hanneke Ter Boch. Ou ainda: Gillis van Tilborch ou Hendrick Ter Brugghen.

Agradeço a David Mandrella, historiador da arte holandesa, pela ajuda na identificação dessa tradução HolandêsAlemão. Agradeço ainda a Leonard Pouy, também historiador da arte holandesa, pela indicação dos nomes dos dois últimos artistas.

${ }^{10}$ Outra pintura de nu também pertencente à coleção do imperador havia sido inserida na Exposição Nacional de 1861. Tratava-se de um nu de Claude-Joseph Barandier, intitulado "Indígenas". Ver fig.4.58.

11 Indicada como pertencendo à "Escola Romana". Quanto a essa obra, não há certeza da nudez, ainda que na iconografia italiana, onde era mais frequente, Europa seja apresentada frequentemente nua ou com o colo descoberto.

12 Ainda hoje exposta no Museu Nacional de Belas Artes. 
tríade de movimentações políticas e artísticas que o jovem projetava com cuidado para cada um dos eventos artísticos mais importantes de 1863 - percebidos então como um ponto de viragem da arte francesa, e momento fundador, para uma grande bibliografia posterior, da "Arte Moderna"

Essa tríade era projetada (como discutido) para expressar objetualmente seus projetos, devedores de seus interesses na filosofia idealista que absorvia a partir das diversas lições de cursos e leituras durantes seus cinco anos de Paris, notadamente àquelas vindas da forte influência de Victor Cousin e de uma bibliografia adjacente. Se para os debates da reforma da École des Beaux-Arts de Paris o jovem havia apresentado como resposta a sua La Réforme de l'École... et l'opposition; se para o controverso curso de estética e história da arte de Le-Duc, as Considerações Filosóficas; para os polêmicos primeiros dois Salons dos anos 1860 (os dois oficiais de 1861 e 1863, e o dos "Recusados" desse último ano), Américo entregava a sua A Carioca - conforme defenderei mais à frente - como uma resposta incarnada ao Belo da tríade eclético-platônica. A sua contribuição para esse "belo" visível seria, não sem justificativa, também a síntese de uma proto-Vênus brasileira e branca, prima de primeiro-grau das demais que afluíam nos salões europeus, e nascida precisamente das mesmas águas do Salão de 1863.

\section{O Salão das Vênus, o Salão dos Recusados e a crise da pintura de história.}

Théophile Gautier, um dos críticos de arte mais influentes até meados do século XIX, havia chegado a uma rápida observação logo após a abertura do Salon de $1863^{14}$. Se existiam nele protagonistas axiomáticos, esses seriam os numerosos nus femininos (entre banhistas, deusas maiores e menores, Ledas, e alegorias) apresentados pelos artistas naquela edição. O número, em sua totalidade, era ainda maior, porque no conjunto total de obras enviadas estavam os artistas que não aceitaram inserir suas obras no segundo salão paralelo, aberto oficialmente por Napoleão III para acolher os copiosos "recusados" pelo jury daquele ano - composto pelos membros da Académie des Beaux-Arts, alguns entre os quais, também professores da École.

$\mathrm{O}$ epíteto que o próprio Gautier fornecia da mostra era terminante: visitava-se naquele ano o "Salão das Vênus"15. A etiqueta não surgia unicamente da profusão de obras inseridas nessa temática,

13 Ver, por exemplo: PICON, Gaëtan. 1863, naissance de la peinture moderne. Paris: Gallimard, 1988; e FRIED, Michael. Le modernisme de Manet ou le visage de la peinture des années 1860. Paris: Gallimard, 2000.

14 O Salão havia sido aberto em 01 de maio.

15 GAUTIER, Théophile. "Salon de 1863". Moniteur Universel. Paris, n.164, 13 e 15 de junho de 1863, p.1 
sem esforço evidente, mas por que se tratavam especialmente de três nus nascentes das águas as maiores sensações do salão: La Naissance de Vénus (O Nascimento de Vênus), de Alexandre Cabanel; uma homônima, de Amaury-Duval (discípulo de Ingres); e La perle et la vague (fable perse) (A pérola e a onda [fábula persa]), de Paul Baudry, interpretada pelos críticos sempre como uma Vênus ${ }^{16}$, a despeito do seu título ${ }^{17}$ (fig.4.5, fig.4.7 e fig.4.6).A ênfase no tema e o sucesso de público do Salão tradicional era relativamente proporcional ao sucesso do "Salão dos recusados". Ainda que menos que a mostra principal, bem mais comentada pela crítica especializada, também lá Édouard Manet convergia atenções quando oferecia com o seu Baigneuses (Banhistas) - posteriormente batizado de Déjeneur sur l'herbe (Almoço na relva) - sua contravisão à alegoria fluvial feminina e aos temas das bacantes idealizadas do período (fig.4.8), sinalizador que antecipava a polêmica Olímpia, exposta em 1865, mas produzida concomitantemente àquela pintura, em 1863 (fig.4.9).

O êxito do tema fluvial (largamente sabido como a melhor licença para a exibição do corpo da mulher ${ }^{18}$ ) era uma continuação do mesmo alvoroço sobre o nu feminino causado no último Salon, de $1861^{19}$, por três outras pinturas de antigos vencedores do Prix: a Nymphe enlevée par un faune (Ninfa raptada por um fauno), também de Cabanel (imediatamente comprada por Napoleão III), Socrate venant chercher Alcibiade chez Aspasie (Sócrates buscando Alcebíades dos braços de Aspasie ${ }^{20}$ ), e a muito discutida Phryné devant l'Aréopage ${ }^{21}$ (Frinéia diante do Areópago), ambas de Jean-Léon Gérôme $^{22}$. (fig.4.10, fig.4.11 e, fig.4.12).

A edição de 1863, em relação à de 1861, abria, entretanto, uma via ainda mais radical para o debate sobre o nu, na sequência de debates artísticos mais amplos que haviam sido sistematicamente iniciados no salão de 1859. Esta edição foi percebida por muitos críticos como um momento importante para a reorientação das artes francesas e para a reavaliação cabal da "hierarquia dos gêneros"

16 Para essa identificação da Pérola de Baudry como uma Vênus, ver: Thoré, Théophile. Salons de W. Bürger (1861 à 1868): Tome premier : 1861-1863. Paris: Renouard, 1870. p.378. Vários outros críticos chegaram à mesma conclusão.

17 Além desses três artistas, Meynier e Briguiboul expuseram também Vênus. Appert, William Bouguereau, Lansac, Raymond Q. Monvoisin, Schutzengerger, Mazerolles, Ehrmann, Blin, entre outros artistas, apresentaram nus banhistas, bíblicos ou mitológicos. cf. MCCAULEY, Anne. Op. cit. p.47.

18 Ver, por exemplo, o verbete baigneuse do Dicionário Larousse do século XIX: LAROUSSE, Pierre. Grand Dictionnaire Universel du Dix-neuvième Siècle, tome.11. Paris: Administration du Grand Dictionnaire Universel, 18661874.

19 Em 1862 não houve o Salon em função da Exposição Universal de Londres.

20 Mesmo tema que a Congregação da AIBA sorteará para Américo e seus adversários no concurso para professor da instituição em 1864.

21 JAGOT, Hélène. Jean-Léon Gérôme Néo-Grec, l'Antiquité dévoyée. Paris: Rumeur des Ages, 2010.

22 Em 1861, Manet também apresentava sua Ninfa Surpreendida. Para uma leitura sugestiva a respeito dessa obra, ver: KRAUSS, Rosalind E. "Manet's Nymph Surprised". The Burlington Magazine, Vol. 109, No. 776 (Nov., 1967), pp. 622-627. Disponível online em: http://www.jstor.org/stable/875434 [último acesso, abril de 2015] 
pictóricos $^{23}$ (mesmo por parte de ex-alunos laureados da École), há muito fixada por André Félibien, desde a fundação da Académie no século XVII, no topo da qual havia se estabelecido a pintura de história.

À medida que a "grande pintura" perdia força, outros gêneros anteriormente "inferiores" naquela escala (pintura de gênero, retrato, paisagem, animais) ganhavam cada vez maior espaço, alimentados simultaneamente pela forte emergência do mercado privado de $\operatorname{arte}^{24}$ (à cuja diversidade da clientela de profissionais liberais e homens de negócios respondia uma também de gosto) e por uma política imperial igualmente favorável à pluralidade de estilos artísticos e de temas, em abordagens preferencialmente moderadas. A partir dos anos 1850, a implementação do "realismo oficial" 25 de Napoleão levava a termo a política "eclética" desenvolvida desde os anos 1830 pelo aparato de LouisPhilippe $^{26}$, mas então não com o intuito de se encontrar também representação para os já sedimentados "românticos" e de definir uma via do meio (juste-milieu) com os "clássicos" (isto é, os "acadêmicos"), mas, sim, de desenvolver um programa de diversidade estética programaticamente desenhada pela nova

23 Gary Tinterow e Henri Loyrette apresentam uma interessante discussão sobre o Salão de 1859 e o problema dos gêneros pictóricos: "O Salão de 1859 marcou o final de uma era sem anunciar o começo de outra; nunca ter habilidades técnicas foi tão comum e grande ambição, tão raro; em todos os lugares a confusão entre os gêneros estava apagando a distinção uma vez já clara e a modificando de cabeça para baixo - a paisagem e a pintura de gênero triunfavam, enquanto que a pintura de história estava declinando, se não morrendo." [tradução nossa]. TINTEROW, Gary; LOYRETTE, Henri. Origins of Impressionism. New York: Metropolitan Museum of Art, 1995. Em específico pp. 07-18; em seguida p.38, para uma precisão sobre o processo da "morte" da pintura de história, naturalmente não como uma morte em si, mas como sua dissolução na pintura de gênero. A mesma discussão, ainda melhor matizada, pode ser encontrada em EISENMAN, Stephen F. Nineteenth Century Art: a critical history. New York: Thames \& Hudson, 2002; ainda mais recentemente nos livros: SÉRIÉ, Pierre. La peinture d'histoire en France 1860-1900. Paris: Arthena, 2014 ; e VOTTERO, Michel. La peinture de genre en France après 1850. Rennes: Presses Universitaires de Rennes, 2012.

24 A bibliografia sobre a emergência do mercado de arte no século XIX na França é enorme, especialmente aquela que trata das vanguardas após o Impressionismo. Para restringir à questão ao contexto do Segundo Império francês, ver: CHAGNON-BURKE, Véronique. "Rue Laffitte: Looking at and Buying Contemporary Art in Mid-Nineteenth- Century Paris". Nineteenth-Century Art Worldwide, vol. 11, $\mathrm{n}^{\circ} 2$ (été 2012). (Disponível em: http://www.19thcartworldwide.org/index.php/summer12/veronique-chagnon-burke-looking-at-and-buying-contemporary-art-in-midnineteenth-century-paris ); GREEN, Nicholas. "Circuits of Production, Circuits of Consumption: The Case of MidNineteenth-Century French Art Dealing". Art Journal, vol. 48, n 1, Nineteenth-Century French Art Institutions (printemps 1989), p. 29-34. (Disponível em : http://www.jstor.org/stable/776917 ); Whiteley, Linda. "Art et commerce d'art en France avant l'époque impressionniste". Romantisme, 1983, vol. 13, n40, p. 65-76. (Disponível em: http://www.persee.fr/web/revues/home/prescript/article/roman_0048-8593 1983 num 13 40 4633); JOYEUX-PRUNEL, Béatrice. Nul n'est prophète en son pays ? l'internationalisation de la peinture des avant-gardes parisiennes, 1855-1914. Paris: N. Chaudun, 2009, em especial o capítulo: "Les marchands d'art et la définition d'une peinture française moderne" (pp. 48-55); MIQUEL, Pierre. Art et argent : 1800-1900. Maurs-la-Jolie: Ed. de la Martinelle, 1987, sobretudo os capítulos: "Les collectionneurs"(pp. 201-302), e "Les marchands"(pp. 303-415); por fim, o livro referencial de Raymonde Moulin: MOULIN, Raymonde. Le Marché de la peinture en France. Paris: Ed. de Minuit, 1989, sobretudo: "Les transformations contemporaines de l'Impressionnisme" (pp. 26-34).

25 Retomo aqui o termo de Albert Boime. cf. BOIME, Albert. "The Second Empire's Official Realism”. In: IDEM. Art in an Age of Civil Struggle, 1848-1871. Chicago/London: The University of Chicago Press, 2007.

26 Sobre a importância do Ecletismo para os anos de Louis-Phillipe, de sua relação com a pintura do Juste-milieu, ver: BOIME, Albert. Thomas Couture and the eclectic vision. New Haven London: Yale University Press, 1980. 
direção de artes, sob o mando influente de Nieuwerkerke - do qual, como visto, a reforma da École seria parte fundamental.

Não se trataria de modo algum de um realismo de causa, como o de Courbet ou Millet, mas antes de um realismo de forma, no qual a sempre exigida "beleza da ideia" deveria se temperar com a "verdade da forma", e no qual ainda se acordariam as intenções cientificistas do período com a influência de novos códigos realistas de representação, sem dúvida o mais potente, a fotografia (que também teve representação oficial no império francês) ${ }^{27}$. Críticos contemporâneos como Gustave Planche - bastante ativo nas defesas e tentativas de reforma da École em 1831 e em 1848 - haviam identificado o interesse geral por esse realismo com a partição da propriedade privada, o que teria levado ao rebaixamento do gosto estético pelo ideal, já que "a burguesia não possuía nem tempo nem tradição suficiente para a sua apreciação" 28 . Ao lado dessa "rasa" demanda formal estaria uma outra de conteúdo, sugerida por Théophile Thoré, cuja parte principal tocava o erotismo, que agradava a massa e fazia fila nos salões: "quem encoraja as ninfas e as cenas galantes de Pompadour? o Jockey-Club e o boulevard italiano. A quem são vendidos esses quadros? Aos cortesãos [o termo também se referia às prostitutas] e aos ricos da Bolsa [de valores], aos dissipadores de uma aristocracia excepcional."29. Tal identificação era quase um complemento de outra de Émile Zola, feita algum tempo após o Salon de 1863, assumindo ainda o Nascimento de Vênus, de Cabanel, como objeto: "Tome uma Vênus antiga, um corpo de mulher qualquer desenhado a partir de regras sagradas, e, ligeiramente, com uma borla, maquie esse corpo com cosméticos e pó de arroz; você terá o ideal do Sr. Cabanel. Esse artista resolveu o difícil problema de permanecer sério e agradar"30.

Como Cabanel na visão de Zola, também o império, na intenção de mostrar uma aparência para esconder sua essência (a de ser um regime autoritário sob a imagem de um popular), devia ampliar os horizontes artísticos, proporcionais aos múltiplos interesses de uma classe média crescente e potencialmente influente para as mudanças políticas do país, pois a mesma classe que havia suportado a

27 Para uma discussão sobre essas questões, indico novamente o estudo exemplar de Boime, “The Second Empire's Official Realism". Sobretudo pp. 577-605.

28 Idem, Ibidem. p.600.

29 A passagem completa é a seguinte: “Qui encourage l'art Mythologique et l'art mystique, les Oedipe et les Vénus, ou les madones et les saints en extase? ceux qui ont intérêt à ce que l'art ne signifie rien et ne touche pas aux aspirations modernes. Qui encourage les nymphes et les galantes scènes Pompadour? le Jockey-Club et le boulevard Italien. A qui vend-on ces tableaux? Aux courtisans et aux enrichis de la Bourse, aux dissipateurs d'une aristocratie exceptionnelle.". THORÉ, Théophile. Salons de W. Bürger (1861 à 1868). Tome second : 1864-1868. Paris: Renouard, 1870. p. 206.

30 Citado em: HILAIRE, Michel; AMIC, Sylvain. Alexandre Cabanel (1823-1889): la tradition du beau. [exposition, Musée Fabre, Montpellier, 10 juillet - 5 décembre 2010, Wallraf-Richartz-Museum \& Fondation Corboud, Cologne, 4 février - 15 mai 2011]. Paris/Montpellier: Somogy éditions d'art-Musée Fabre, 2010. p.214. 
revolução de 1848, na qual Napoleão havia ascendido. Desde sua tomada de poder, notadamente após sua conversão a imperador, os conflitos constantes causados pela dissonância das intenções estéticas e econômicas do seu regime e da maioria dos membros da Académie des Beaux-arts - que desejava manter sua voz operante e seu gosto exclusivo do antigo atualizado em cada salão e em cada premiado de Roma -, levava ao descolamento dos significados de "oficial" e de "acadêmico",31, e suas últimas expressões, como visto, eram articuladas justamente na formação do "Salão dos Recusados", em junho de 1863 (o que contrariava a seleção do jury acadêmico), e na reforma da École, em novembro. Ambas as medidas, com o apoio de alguns acadêmicos interessados em mudanças, questionavam o poder da antiga corporação em vantagem das intenções oficiais do império, no sentido de fornecer um novo direcionamento para linhas gerais das artes francesas. Nessa intenção estava uma das razões mestras pelas quais, no cerne de um projeto que, na acirrada disputa com a indústria inglesa, encorajava o empreendedorismo científico e artístico e sua conexão com a indústria e com o mercado francês, palavras de ordem como "originalidade" e "liberdade" - a primeira introduzida na França no século XVII; a segunda, no contexto revolucionário do início do XVIII ${ }^{32}$ - foram tão repetidas e especialmente acolhidas pelos reformadores. Difundia-se então oficialmente a ideia de que a originalidade não era um traço raro de poucos indivíduos escolhidos ao azar (isto é, um traço do gênio), mas uma característica geral, da qual todos compartilhavam em maior ou menor grau ${ }^{33}$.

Na nova política, não só a Grécia nem o antigo testamento imperavam. Encontram representação vertentes artísticas brandas, mas bastante distintas entre si, conduzidas por artistas que haviam sido ou ainda eram alunos nos mais influentes ateliês do período, todos "ecléticos" ou "liberais", entre eles o de Thomas Couture, Paul Delaroche, Charles Gleyre e Léon Cogniet - grupo no qual se incluía, como sinalizado, aqueles repetidamente indicados aos bolsistas brasileiros pela direção da AIBA. O "realismo" moderado de Rosa Bonheur, Constant Troyon e de Jules Breton (em alternativa ao "realismo de esquerda" de Courbet e de Jean-François Millet), o "realismo fotográfico" de Ernst Meissonier e de seu aluno Edouard Detaille, o "realismo" erótico e historicista de Jean-Léon Gerôme, o “idealismo" sensual e teatral de Alexandre Cabanel (sempre equilibrado pela percepção do modelovivo), o colorismo de Paul Baudry, o formalismo de William Bouguereau, a pintura de fácil fatura e

31 Para uma discussão aprofundada sobre essa separação entre as esferas "oficial" e "acadêmica" na arte francesa do século XIX, ver: BONNET, Alain. Op. cit.; ver ainda: BOIME, Albert. The Academy and the French painting in the Nineteenth Century. New Haven, London: Yale University Press, 1986. Em especial o primeiro capítulo: "The Crystallization of French official Art”.pp.01-21.

32 BONNET, Alain. Op. cit. pp.173-176.

33 Idem, ibidem, p.179-180. 
tema de Alexandre-Gabriel Decamps, etc, todas essas proposições poéticas tiveram lugar e destaque no império, e muitas delas rapidamente se perceberam encorajadas oficialmente.

Nesse grupo notório e diverso de artistas paisagistas, retratistas, pintores de gênero e costumes (vários dos quais haviam sequer passado pela École), estavam alguns daqueles antigos bolsistas romanos da geração de 1850, então estrelas dos salões de 1860, devidamente formados na pintura de história, que também haviam feito sua fama não com grandes máquinas, mas com a pintura de nu de tamanho natural ou ainda de médio/pequeno formato.

A assiduidade com a qual esses laureados frequentaram o nu, alternado (por) ou combinado com a pintura de gênero, pensados e pesados para suas exibições regulares e sucesso nos Salões, confirmava para muitos críticos contemporâneos a crise definitiva pela qual havia entrado o "grande gênero", fossem eles ou não a favor dessa exibição ${ }^{34}$.

$\mathrm{O}$ nu, centro do método acadêmico e ponto de convergência da pintura humanista, de mais a mais se afastava da sua esfera grandiloquente - isto é, verdadeiramente mitológica ou histórica. Tendia a se apresentar também ele como um gênero à parte, destituído de maiores narrativas - mesmo que ainda por vezes vinculado aos símbolos da mitologia ou da tradição cristã -, e já no fim século a sua apresentação puramente formal, já sem qualquer justificativa, era celebrada por periódicos dedicados exclusivamente ao tema ${ }^{35}$. No meio do século e até o fím dos anos 1870 , no entanto, o nu parecia ter então se realinhado a uma prática precedente iniciada na École em meados do século XVIII, na qual se apresentava sob a frequente demanda de "nu historiado"36. Mas a diferença significativa era que, lá, tratavam-se de estudos regulamentares de formação dos alunos da instituição francesa, avaliados pelo colegiado, enquanto que, ali, eram obras acabadas de artistas conhecidos, prontas para serem expostas ao grande público.

O antecedente pictórico mais célebre dessa linhagem, com ou sem ironia, havia sido oferecido pelo

34 Théophile Thoré, por exemplo, concluía que boa parte dessa crise e da decadência da "grande arte" francesa, provinha dos costumes de sua época, e da demanda do público, que não deixava espaço para o artista investir em temas exemplares. THORÉ, Théophile. Op. cit. Salão de 1865. p.206. Para uma maior discussão sobre a adaptação que muitos faziam em suas obras ao gosto variado do público, e sobre a ênfase na anedota e na reconstituição de costumes, ver: HILAIRE, Michel; Amic, Sylvain. Alexandre Cabanel : 1823-1889 : la tradition du beau : [exposition, Musée Fabre, Montpellier, 10 juillet - 5 décembre 2010, Wallraf-Richartz-Museum \& Fondation Corboud, Cologne, 4 février - 15 mai 2011]. Paris/Montpellier : Somogy éditions d'art : Musée Fabre, impr. 2010. p.212.

35 Ver SÉRIÉ, Pierre. La peinture d'histoire en France 1860-1900. Paris: Arthena, 2014, sobretudo o capítulo sobre o nu, que atualiza uma série de questões e bibliografia sobre as discussões sobre o nu no último quarto do século XIX, início do XX. Ver ainda: HADDAD, Michèle. La divine et l'impure : le nu au XIXe. Paris : Jaguar, 1990. p.09.

36 BÉDARD, Sylvain. "Le nu historié: les envois des pensionnaires de l'Académie de France à Rome au XVIIIe siècle", Studiolo, 2006, n.4, p.213-240. 
chefe-de-escola Ingres, que após quase três décadas de tomadas e retomadas, apresentava em 1856, em seu estúdio, a ninfa de La Source ${ }^{37}$ (fig.4.13) - um ano depois da mais recente exibição de sua Banhista de Valpiçon (1808), na Exposição Universal, esta uma obra que, ainda que se tratasse de um dos primeiros envios regulamentares feito pelo então jovem Ingres, na qualidade de bolsista da Villa Médicis, recebia suas primeiras avaliações críticas apenas e justamente a partir da segunda metade dos anos $1850^{38}$ (fig.4.14). O seu destino havia sido bastante distinto do de La Source. A obra era logo vendida por valor exorbitante ${ }^{39}$ e seria reexibida novamente com enorme sucesso de público na galeria Martinet $^{40}$, em 1861 - onde Américo, como o fizera uma legião de artistas, muito provavelmente deve ter ido ${ }^{41}$. Entretanto, mesmo que essa pintura afirmasse todos os seus preceitos idealistas, bem como o apego inquebrável de Ingres à estatuária antiga, no total esvaziamento que havia feito do tema nu a tela foi percebida por alguns de seus contemporâneos como uma simples "academia", virtuosamente construída, mas ainda assim uma "academia", que não justificaria nenhum propósito moralmente

37 Conta-se que Ingres negava que havia representado uma ninfa em sua La Source. Seria para ele pura e simplesmente a representação de uma fonte. No entanto, a identificação iconográfica mais comum dessa obra como uma náiade permaneceu constante. Charles Blanc, mesmo repreendido pelo próprio Ingres, insistia em chamá-la ninfa. BLANC, Charles; BONNASSIEUX, Jean-Marie. Ingres, sa vie et ses ouvrages. Paris : Vve. J. Renouard, 1870. p.192. Curiosamente, ainda hoje, se se acessa o comentário que o Musée d'Orsay exibe da obra, ela continua a ser tratada como uma ninfa: "Ebauchée vers 1820 la toile n'est achevée qu'en 1856. Ingres est alors assisté de deux de ses élèves, pratique courante pour les grands formats. L'influence des moyens d'expression propre à la sculpture sur le traitement de la nymphe est frappante." Para acessar o comentário completo do museu, ver: http://www.musee-orsay.fr/fr/collections/oeuvrescommentees/recherche/commentaire_id/la-source-461.html?no_cache=1 [último acesso em 06 de maio de 2014]

${ }^{38}$ Ver, por exemplo, a referência apresentada pelo próprio Museu do Louvre, detentor da obra. Disponível online em: http://www.louvre.fr/oeuvre-notices/la-baigneuse [último acesso: janeiro de 2016]

39 A obra é comprada em 1857 pelo conde Charles-Marie Tanneguy Duchâtel por 25.000 francos. Em 1878, a obra é doada ao Louvre pela viúva do conde. Em 1986, entra para a coleção do Museu d'Orsay, onde permanece em exibição.

40 A galeria Martinet, deve-se mencionar, tem papel importante para a formação de um circuito artístico alternativo de exposições artísticas em Paris na primeira metade dos anos 1860. O antecedente dado por Ingres com sua La Source, muito criticado de "Acadêmico" nesses anos, era então duplo, o que evidentemente reforça a dificuldade que os críticos e artistas da nova geração, incluindo Américo, tinham para ver que também ele, Ingres, assumia em vários pontos uma postura crítica quanto à exclusividade do cenário artístico francês. Ele próprio havia parado de expor no Salon oficial desde as críticas que havia recebido por seu quadro Le Martyre de Saint Symphorien, exposto em 1834. Para a importância da galeria Martinet nesses circuitos, ver: HUSTON, Lorne. "Le Salon et les expositions d'art: réflexions à partir de l'expérience de Louis Martinet (1861-1865), Gazette des Beaux-Arts, n.116, Paris, Julho-Agosto de 1990. pp.45-50.

41 Outro nus femininos de Ingres ligados ao tema das águas ou banho são célebres. Entretanto, a questão que $L a$ Source colocava para crítica era uma de linhagem do nu feminino que justificava sua aparição sob a desculpa do código mitológico e alegórico, sem no entanto fazê-lo suficientemente. Sua La baigneuse Valpinçon (Museu do Louvre), de 1808, era um apresentado como tal, sem alguma intenção alegórica. Sua Vênus Anadiomena (1808-1848) (Musée Condé, Salle de la Tribune, Chantilly), presente na Exposição Universal de 1855, que fazia uso desse expediente, em sua referência mitológica, e em seu distanciamento formal que retomava, segundo Baudelaire, as lições da arte florentina, romana e medieval, havia sido muito bem recebida; E a famosa sua A Grande Odalisca, de 1814 (Museu do Louvre) - exposta nos salões de 1819, 1846, nas Exposições Universais de 1855 e 1867 - e ainda o seu Banho Turco (1852-1859) (Museu do Louvre), exposto em 1864 no ateliê do artista, em seus orientalismos, que não se justificavam no código mitológico para sua exibição, também não apresentaram maiores problemas para as questões tratadas aqui. Para informações detalhadas dessas obras, ver: POMARÈDE, Vincent; PRAT, Louis-Antoine; GUÉGAN, Stéphane; BERTIN, Eric (orgs.). Ingres, 1780-1867. Paris: Gallimard, Musée du Louvre, 2006. 
elevado de um dos maiores artistas vivos ${ }^{42}$. Em 1864, por exemplo, o pintor Gustave Moreau continuaria a confirmar em seus cadernos escritos essa impressão ${ }^{43}$.

Mas para críticos ligados ao regime, a pintura de Ingres agradava sem reservas porque o artista, com ou sem intenção direta, havia atingido em cheio os interesses do "realismo oficial" napoleônico, quando fundia em sua pintura, com êxito sem precedentes, precisamente, e ao mesmo tempo, um alto grau de idealização e um estupendo realismo formal, que beirava a tactilidade ${ }^{44}$.

O exemplo dado pelo mestre era um convite atrativo para uma subsequente frequentação ao tema por personalidades das mais distintas vertentes, e especialmente os mais jovens, autores dos nus repercutentes dos primeiros Salões dos anos de 1860. Nem mesmo um artista como Courbet, cogitado como a mais nova antítese do antigo pintor (em substituição ao não mais polêmico Delacroix, já aceito na Académie, e cuja morte ocorreria ainda em 1863), ficara imune à visita à galeria. Como consequência, poucos meses da segunda e última exibição de La Source, Courbet oferecia uma obra intencionalmente homônima à de Ingres, na qual uma visão eminentemente naturalista da mulher fazia divergir definitivamente do tema qualquer justificativa mitológica ou iconográfica (trata-se antes de tudo uma mulher que se banha numa fonte, com as curvas, volumes e depressões naturais de um corpo "contemporâneo" - que replicam os mesmos volumes que a circundam -, do que uma alegoria feminina de um corpo idealizado e liso que encarna uma fonte) (fig.4.15). A mesma proposição e título serão igualmente acessados por ele poucos anos depois, em 1868 (fig.4.16), momento no qual os efeitos causados pelas deusas vindas do filão ingresco, notadamente aquelas do Salão de 1863, já começavam a ser avaliados em retrospectiva por alguns críticos:

Os clássicos devem estar contentes: depois do famoso Salão de 1863, onda a Pérola do Sr. Baudry

42 COOKE, Peter. "Gustave Moreau's 'Oedipus and the Sphinx': Archaism, Temptation and the Nude at the Salon of 1864". The Burlington Magazine, Vol. 146, No. 1218 (Sep., 2004), pp. 609-615.

43 A propósito da Source de Ingres, Moreau comentou que se trataria de "uma academia (velho estudo) em uma palavra, executada por um maravilhoso erudito, um profundo conhecedor em matéria plástica". [Gustave Moreau, cahier IV, Musée Gustave Moreau, Paris, p.95-100]. Apud in: HADDAD, Michèle. La divine et l'impure: le nu au XIXe. Paris : Jaguar, 1990. p.19. Além disso, ele também oferecia um balanço crítico moralizador dos nus exibidos nos salões dos anos precedentes, mas esse, um balanço visual, "arcaizante" e mal compreendido pela crítica, com a apresentação do seu Oedipus and the Sphinx. COOKE, Peter. Op. cit. p.615: For "the spuriously mythological motivation behind the female nude, to the hypocritical art pure, the art for art's sake of Ingres and his more naturalistic emulators, Moreau opposed an anti-naturalistic, symbolic, moralising, mythological figure composition, displaying a vigorous, ascetic male nude locked in psychological confrontation with a temptress sphinx, a composition harking back stylistically to the pure aesthetic source of the early Renaissance"

44 Idem, Ibidem. p.614: "The greater naturalism of La Source, compared with Ingres's earlier style, was welcomed by Second Empire critics as a successful synthesis of ideal beauty and nature.50 But it was the more naturalistic aspects of La Source that were to be developed by a younger generation, and it was this naturalism that earned the opprobrium of conservative critics." 
disputa a palma da beleza com a Vênus Anadiomena do Sr. Cabanel, nós temos visto as academias crescerem e se multiplicarem; eu me refiro a essas figuras de homens ou de mulheres nuas - de mulheres sobretudo -, copiadas a partir de um modelo[-vivo] mais ou menos bem construído e que acrescentando pequenos acessórios mitológicos se transformam em divindades do Olimpo ou em personificações alegóricas ${ }^{45}$.

Do nu idealizado como o vórtice da grande pintura de história ao nu que, atingindo passo a passo sua autonomia na prática da "arte pela arte” (já defendida por um crítico como Theóphile Gautier, na metade do século $\mathrm{XIX}^{46}$, pelo amparo filosófico de Cousin), alcançava já no fim dos anos 1860 o simples estatuto crítico de academia, isto é, o da experiência sensível e direta do pintor e seu modelo.

Para uma bibliografia posterior, a marcha em direção a essa independência havia oscilado por muito tempo, dentro da tradição artística ocidental, entre as pretendidas (mas dificilmente mantidas isoladas) chaves opostas do "ideal" e do "real", do universal e do particular, do "nu" e do "despido" "47, da natura naturante e da natura naturata, ou ainda do isolamento e da empatia ${ }^{48}$. Essa oposição como discuti, fundamentalmente filosófica - culminaria, exatamente no contexto dos anos 1860, em novas discussões sobre o estabelecimento dos limites da representação do corpo feminino, por vezes reconhecido com desconforto como representante de determinadas classes sociais existentes ${ }^{49}$; tais

45 [Tradução nossa]. No original: "Les classiques doivent être contents: depuis le fameux Salon de 1863 où la Perle de M. Baudry disputa la palme de beauté à la Vénus Anadyomène de M. Cabanel, nous avons vu les académies croître et multiplier; j'entends que ces figures d'hommes ou de femmes nus - de femmes surtout - copiés d'après un modèle plus ou moins bien construit et que moyennant quelques petits accessoires mythologiques on transforme en divinité de l'Olympe ou en personnifications allégoriques". CHAUMELIN, Marius. "Salon de 1868", La Presse, 27 de maio de 1868, p.3.

46 Sobre a crítica de Gautier, e sua defesa pela autonomia da arte, e por um formalismo idealista que termina na ideia da "arte pela arte", ver a coletânea de suas críticas sobre arte: GAUTIER, Théophile. Critique d'Art: Extraits des Salons (1833-1872). Paris: Seguier, 1994.

O mesmo Courbet, por sua vez, oferece uma oposição a essa noção. A passagem mais conhecida dessa postura pode ser encontrada no seu "Manifesto sobre o Realismo", cuja autoria se acorda convencionalmente ser dele com a colaboração de seu amigo e crítico Champfleury: "Le titre de réaliste m'a été imposé comme on a imposé aux hommes de 1830 le titre de romantiques. Les titres en aucun temps n'ont donné une idée juste de choses [..] J'ai étudié, en dehors de tout esprit de système et sans parti pris, l'art des anciens et des modernes. Je n'ai pas plus voulu imiter les uns que copier les autres : ma pensée n'a pas été davantage d'arriver au but oiseux de "l'art pour l'art". Non! [..] être non seulement un peintre, mais comme un homme, en un mot faire de l'art vivant, tel est mon but". O texto é reproduzido em diversas publicações. Para a versão original, em francês, ver: COURBET, Gustave. Écrits, propos, lettres et témoignages. Paris: Hermann, 2010. Uma versão em inglês do manifesto pode ser também encontrada em: HARRISON, Charles; WOOD, Paul; GAIGER, Jason (eds.). Art in theory, 1815-1900. Oxford: Blackwell, 1998. p.372.

47 Ver, por exemplo, o livro clássico de Kenneth Clark: CLARK, Kenneth. The nude. London: John Murray, 1956. O livro abre uma série de discussões retomadas ou contestadas em estudos posteriores. Por exemplo: CORMACK, Malcolm. The nude in western art. Oxford [Eng.] : Phaidon, 1976; SAUNDERS, Gill. The Nude: a new perspective. London: The Herbert Press, 1989; FOSSI, Gloria. Le nu. Paris, Gründ, 1999. 302 p.; MARNHAC, Anne de. Femmes au bain : les métamorphoses de la beauté. Paris : Berger-Levrault, c1986.; BONNET, Jacques. Femmes au bain : du voyeurisme dans la peinture occidentale. Paris : Hazan, DL 2006, entre outros.

48 Sobre a relação do discurso que liga o julgamento estético racional com o nu ideal, e a sua contraposição com as afinidades entre a empatia (a atração corporal) e o nu "real", ver: DIDI-HUBERMAN, Georges. Ouvrir Vénus. Nudité, rêve, cruauté. Paris: Gallimard, 1999. sobretudo: pp.11-46.

49 T. J. Clark é sem dúvida o representante mais conhecido dessa perspectiva social da arte em relação às discussões 
debates sendo mesmo um sintoma de mudanças nos valores de controle e exibição da mulher, sempre a partir da coerção masculina. A produção artística do período era, em última instância, mais um dos lugares onde se operava a construção dos valores sociais que distinguiam discursivamente os dois sexos (muito mais do que as diferenças fisiológicas ou anatômicas) ${ }^{50}$.

Para diferentes perspectivas historiográficas, as "bordas" que separavam o consentimento e a negação da exposição do corpo feminino, isto é, o limite entre a percepção de uma figura "ideal” e uma "real", do moral e do imoral, bordas que interessaram constantemente a um Manet nesse período, foram desveladas e puídas no mesmo momento em que se teria estabelecido o ponto de partida para uma "história da arte moderna", ambos recorrentemente projetados sobre suas as obras emblemáticas daqueles anos (Baigneuses e Olímpia $)^{51}$. Como analisa Clark, Manet, muito mais do que Courbet nesse sentido (posto que as proposições deste durante os anos 1850 e 1860 eram consideravelmente radicais, afastando-se conscientemente daquelas bordas ${ }^{52}$ ), não oferecia com essas duas pinturas, em seu claro diálogo com a tradição giorgionesca (e a escolha do percebido sensualismo e "realismo" da pintura veneziana não era casual), não um nu idealizado, universal e acabado ao "gosto tradicional". Ao contrário, apresentava uma pintura de fronteira na qual a "estética do esboço", para utilizar agora uma expressão de Albert Boime ${ }^{53}$, estava programaticamente presente no trabalho acabado. A matéria pictural, antes de ser escondida e envernizada em trompe l'oeil, em contribuição às aspirações idealistas que sublimam a importância da matéria no fenômeno estético, apresentava uma concretude e realidade que era proporcional à visão de uma mulher que parecia com incômodos "real": a modelo do artista como indivíduo [Victorine Meurant]; a alusão à prostituta, como classe.

sobre a pintura dos anos 1860, na França, e ao problema de "classe". Ver: CLARK, Timothy James. A pintura da vida moderna : Paris na arte de Manet e seus seguidores. São Paulo: Companhia das Letras, 2004, em especial o capítulo sobre Olímpia.

50 Trata-se aqui de uma perspectiva notadamente feminista. Para dois trabalhos exemplares no campo, ver: NEAD, Lynda. Female Nude: Art, obscenity and sexuality. London/New York: Routledge, 1992; ARSCOTT, Caroline; SCOTT, Katie. Manifestations of Venus: Art and Sexuality, Manchester: Manchester University Press, 2000. Para uma discussão entre os limites das características consideradas masculinas e femininas na representação artística especificamente no Salão de 1863, ver o trabalho exemplar de: SHAW, Jennifer L. "The figure of Venus: Rethoric of the ideal and the Salon of 1863". Art History. Vol. 14, n.4, December 1991. pp.540-570.

51 A tese havia sido já desenvolvida na primeira metade do século XX, ainda em Paris, com a obra de CARCO, F. Le nu dans la peinture moderne 1863-1920. Paris: G. Crès et cie, 1924. Ela é retomada posteriormente por: PICON, Gaëtan. 1863, naissance de la peinture moderne. Paris: Gallimard, 1988, quase ao mesmo tempo do desenvolvimento de uma bibliografia americana, similar desse ponto de vista.

52 Penso em obras polêmicas não pelo limiar de fronteira que apresentam, como as obras de Manet, mas aquelas programaticamente "pornográficas" ou "eróticas" como O sono (1866), A origem do mundo (1866).

$53 \mathrm{O}$ termo é de Boime. A discussão sobre o que ele chama de Aesthetics of the sketch (a qual ele associa diretamente à reforma da École des beaux-arts e às discussões que desenvolvo aqui) pode ser encontrada em capítulo homônimo, no livro: BOIME, Albert. The Academy and French painting in the nineteenth century. New Haven London: Yale University Press, 1986. pp.166-185. 
O resultado desse desvelamento deveria ser a polêmica, conscientemente buscada pelo artista e inserida num projeto de criação de uma arte "antiteatral",54, conforme analisa Fried, herdada do próprio Courbet $^{55}$, no qual valores tradicionais para aceitação do nu feminino (mitologia, história, religião, fábula) eram quebrados ou ainda escancarados em forma de sarcasmo, como o caso novamente de Baigneuses e Olímpia ${ }^{56}$.

Esse traço de "modernidade" na obra de Manet é indiscutível. Mas não é menos verdadeiro considerar que o peso e, sobretudo, a primazia nas polêmicas sobre o nu que ele gerou faz parte da invenção interessada de uma bibliografia (inicialmente francesa, mas especialmente americana) sobre a arte moderna e de vanguarda, que tende a amenizar as diferenças da dita "arte acadêmica",57

A leitura fez quase sempre esquecer que um "recusado" como Manet não inaugurava a polêmica com as suas pinturas de nu, nem que parte dessa "modernidade" pictural e temática - a fatura à mostra e a possibilidade de ver uma mulher real, e não uma ideal, em suas obras -, mesmo se programaticamente escancarada nele ${ }^{58}$, era compartilhada nas obras dos mesmos artistas "oficiais" (confundidos não sem interesse com "acadêmicos") e evidenciada em um percurso considerável de debates que havia produzido uma enorme fortuna crítica desde o início do século XIX ${ }^{59}$. E mais, que os

54 Esta tese de antiteatralidade na obra e Manet é desenvolvida especificamente por Michael Fried. Ver: FRIED, Michael. Le modernisme de Manet ou le visage de la peinture des années 1860. Paris: Gallimard, 2000.

55 Ver, por exemplo, o livro anterior ao de Manet e de sua geração. Nele, Fried insiste na importância de Courbet para o desenvolvimento de uma vertente artística insistentemente "antiteatral" e radical, que no entanto, de mais de mais, se acalma a partir dos anos 1860, justamente os anos de "ascensão" de Manet e de seus amigos (Latour, Legros, etc). FRIED, Michael. Le réalisme de Courbet. Paris: Gallimard, 1993.

56 Segundo John House, "whatever Manet's intention, the effect of his painting was to introduce the blague and the carnivalesque into the Salon" HOUSE, John. "Manet and the De-Moralized viewer". In: TUCKER, Paul H. Manet's Le déjeuner sur l'herbe. Cambridge: Cambridge University Press, 1998. p.87. Para uma ressalva à ironia como o objetivo principal de Manet, ver FRIED, M. Op. cit., em especial a introdução ao livro, onde o autor faz um balanço crítico (também ele não livre de ressalvas) da bibliografia então produzida sobre Manet.

${ }^{57}$ Ver, por exemplo: CARCO, F. Le nu dans la peinture moderne, 1863-1920. Paris: Grès, 1924; PICON, G. 1863 : Naissance de la peinture moderne. Paris: Skira, 1974. FRIED, M. Manet's modernism: Or, the Face of Painting in the 1860 's. Chicago: University of Chicago Press, 1992. Mesmo para um Clement Greenberg, em sua defesa de uma arte óptica, abstrata e autônoma, na qual o recurso às categorias Kantianas - as mesmas de Cousin - define as bases de sua crítica, a obra de Manet é antevista como o sulco para as vanguardas históricas e para o triunfo de Jackson Pollock, menos de 100 anos depois. Para ver a análise que Fried faz da herança de Manet em Pollock, percebida por Greenberg, ver: FRIED, M. Op. cit. p.18, e as notas 50 e 51 , da p.463.

58 Daí também porque a comum aproximação que se faz de Manet com o futuro grupo inicial dos impressionistas, que lhes haviam de fato rendido homenagem, e em especial na pintura de Fantin-Latour, Un atelier aux Batignolles (1870), na qual Manet ocupa lugar de destaque ao lado de Émile Zola, Zacharie Astruc, Otto Scholderer, Auguste Renoir, Edmond Maître, Frédéric Bazille e Claude Monet.

59 Uma recente coletânea de textos críticos sobre os Salões, direcionada especialmente à crítica do nu, pode ser encontrada em: MASSONAUD, Dominique (ed.). Le nu moderne au Salon (1799-1853).Grenoble: ELLUG, Université Stendhal, 2005. Para uma discussão breve, mas profícua desses antecedentes e o posterior legado de Manet, ver a introdução aos textos: "Não se pode esquecer que, antes de Manet, outras recepções escandalizadas haviam anteriormente precedido algumas pinturas ou esculturas, frequentemente consideradas como 'modernas', e que, frequentemente, tratavam do nu.". 
mesmos sintomas mais ou menos fortes em suas obras e em seus êmulos indicavam que as condições finais para a exibição e compreensão contemporâneas dos seus trabalhos haviam sido cabalmente preparadas pela política oficial de Napoleão, em seu interesse por uma diversidade estética e de gênero pictóricos - conquanto Manet e Courbet tenham sido devidamente convidados pelo império a amaneirar um pouco suas posturas ${ }^{60}$.

Gérôme, antigo aluno da École, a despeito de sua creditada erudição, que o levou a ser o líder do pequeno mais influente grupo dos Neogregos no desenvolvimento de uma pintura arqueológica, desde a década de 1850, e especialmente nos Salões de 1859 e 1861, havia também sido repetidamente repreendido por críticos, vários opositores do regime, pelo caráter por vezes pornográfico de suas figuras, cujo "grau zero" para a comparação com um ideal casto poderia ser visto ao mesmo tempo na Source de Ingres, na galeria Martinet. Uma característica que se afirmou ser articulada conscientemente para causar polêmicas, agradar o público e aumentar suas vendas ${ }^{61}$. Em 1861, com a derme também idealizada, perfeitamente branca e lisa de sua Frinéia - a amante "real" do escultor Praxíteles e do pintor Lísipo, e modelo para os dois artistas - , com frequência se identificou a intenção do artista na criação de um jogo sexual que aflorava do contraste dessa figura alva com as demais expressões "realistas", âmbares e concupiscentes dos velhos do Areópago. Para Olivier Merson, para tomar apenas um exemplo de um crítico bastante conhecido, entre outros que comentaram a obra, Gérôme não se guiava nunca por uma ideia filosófica, e "se contentava recorrentemente em seduzir pelos pequenos meios [realistas] de execução. Pouco preocupado em instruir o público e de satisfazer seus nobres sentimentos, ele provoca com frequência seus apetites grosseiros, ele suscita antes desejo que admiração."62 Os neogregos, sintetizados na figura do seu líder, seriam mais hábeis em execução do que sérios, e isso sugeriria seus interesses em desenvolver antes um "estilo" do que fornecer uma arte moralmente educadora ${ }^{63}$.

Entre uma crítica e outra, sobretudo aquelas contra o regime, ora apareciam defesas em direção à

p.9.

60 BOIME, A. Art in an age of civil struggle, 1848-1871. Chicago/London: University of Chicago Press, 2007.p.577.

61 Para o acesso de uma fonte importante de artigos que tratam da recepção contemporânea das obras de Gérôme desde as décadas de 1850 e 1860, ver: JAGOT, Hélène. Op. cit. Entre os críticos que se colocaram publicamente contra a produção e a postura artística de Gérôme estavam: Léon Lagrange, Charles-Olivier Merson, Maxime du Camp, Étienne Delécluze, Claude Vignon, Jean Rousseau. Mesmo Théophile Gautier, antigo colaborador e favorável a Gérôme, via com cautela o caminho que o artista tomava, ingressando numa via da anedota, via pela qual, mais de uma vez, foi comparado a François-Auguste Biard, pintor que havia acabado de chegar de sua estadia de dois anos no Brasil, a partir de 1858.

62 Tradução nossa. Idem, ibidem. p.102.

63 Em 1863, Théophile Thoré ainda refere-se aos quadros de Gérôme de maneira negativa, chamando-os de "bobices históricas" de forma fotográfica. THORÉ, Op. cit. p.377. 
produção de uma arte atualizada, que não se escondesse por de trás de anedotas históricas - sem muito sentido para a modernidade -, ora aqueles críticos mais velhos que, como Merson, revelavam ainda suas dívidas para com o sistema de Victor Cousin, e seus desejos de manutenção de uma arte também antianedótica, mas que permanecesse sempre anexada aos "princípios eternos do bom e do verdadeiro", apartados portanto da "fantasia e da moda",

\section{Nu decadente, nu triunfante}

Gérôme - por sua notoriedade, instrução, e uso controverso que fazia de suas habilidades artísticas era um alvo constante. Ela não era porém o único. A mesma polêmica à qual seus trabalhos conduziram em 1861 havia retornado em 1863, novamente no "Salão acadêmico", com os nus de Baudry e Cabanel, seguidos com menor reverberação pelo de Amaury-Duval - e deve-se insistir a esse propósito que, em relação ao Déjeneur de Manet, os trabalhos desses artistas haviam suscitado uma repercussão contemporânea na crítica e no público bem maior do que aquela do "Salão dos Recusados"65.

Mais uma vez, a recorrência do tema era justificada pela crise irresolvida da pintura de história e sua dissolução em outros gêneros, e em primeira instância, na pintura de gênero ${ }^{66}$. A interpretação sobre essa persistência do nu foi, no entanto, explicada por lados contrastantes, estética e politicamente.

De um, estavam os opositores ao regime e à sua política artística, entre eles antigos conservadores acadêmicos ou suportadores das correntes realistas mais fortes e de tendências revolucionárias, que defendiam que a frequentação ao nu dito idealizado, sobretudo por artistas "oficiais", era apenas uma desculpa que lhes permitia tratar de assuntos libidinosos e imorais, às expensas das fábulas e do código mitológico. Baudry e Cabanel, que eram percebidos como ligados ao Império, nas frequentações controversas a essa iconografia tiveram suas obras lidas como o reflexo de uma mesma decadência artística associada ao regime napoleônico ${ }^{67}$. Dois dos artistas mais importantes do período, antigos bolsistas do estado e representantes da alta cultura, teriam rebaixado a grande pintura, oferecendo no

64 Idem, ibidem. p.104.

65 Para um balanço da recepção dos dois Salões, da Academia e dos "Recusados", ver: MCCAULEY, Anne. "Sex and the Salon: Defining Art and Immorality in 1863". In: TUCKER, Paul. Manet's Le déjeuner sur l'herbe. Cambridge, Cambridge University Press, 1998.

${ }^{66}$ Um crítico, analisando a obra de Cabanel, concluía: "la façon dont elle est posée, les petits amours qui l'entourent ne donnent-il pas l'apparence d'un tableau de genre plutôt que d'une oeuvre sérieuse?" GUEULLETTE, C. Les peintres de genre au Salon de 1863. Paris, 1863. p.6

67 Proudhon, embora não escrevesse uma resenha do Salon de 1863, explicitamente associava o erotismo lá presente com a queda social que ele sentia ser encorajada pelo império. Ele comentaria a mulher da obra de Baudry como se fosse uma prostituta. Ver: MCCAULEY, Anne. Op. cit. p.50. 
grande salão bianual pequenos nus femininos feitos para arrebatar o grande público ${ }^{68}$. Nus que, mesmo com o véu mitológico, ainda que presumidamente vazio em proposição, não teriam escondido um caráter interessadamente polêmico e sexual. Essa relação entre decadência artística e política oficial parecia ainda ser confirmada para esses críticos (republicanos, liberais ou orleanistas) pelo interesse e gosto do próprio imperador por esses nus, comprando-os regularmente nos Salões do período por quantias recordes, e as últimas aquisições, justamente as obras expostas daqueles dois $\operatorname{artistas}^{69}$.

As imagens das Vênus, para opiniões destacadas como a de Maxime Du Camp, passavam assim a significar assim a imagem do declínio da "Escola Francesa", que possuiria mesmo um escala visível. A ascendência erótica no salão de 1863 começava com a obra de Amaury-Duval, mais velada e devedora direta de Ingres - seu professor -, sobretudo da sua Naissance de Vênus (fig.4.17), ainda que numa linhagem maneirista bem mais acentuada. Em seguida Cabanel, a obra mais comentada da edição. Por último, Baudry, cuja torção corporal de sua pérola/Vênus não deixou de ser comparada com a do prazer sexual e com o seu possível resultado, o de uma doença venérea ${ }^{70}$. As duas últimas, especialmente, com seus olhares provocadores, que se projetavam com solicitude em direção ao espectador, ofereciam o que seria a antítese exata da arte: "uma das primeiras qualidades da arte, talvez a principal, é a castidade. A Vênus de Ticiano, a Danae de Corregio, a Galatéia de Rafael, são elas castas. Elas são deusas e não tem nenhuma das provocações femininas ${ }^{71,}$.

Outros críticos seguem uma via paralela àquela de Du Camp (Alfred Stevens, Castagnary, Théophile Thoré), todos condenando essas obras de imorais. De ideais aquelas mulheres não teriam nada: eram feitas de sangue, carne e desejo. Denunciavam ainda, para alguns, a presença indiscreta de suas modelos. Como seria para a recepção das Baigneuses de Manet, e sobretudo para a Olímpia, em 1865 - quando vários comentadores, no entanto conservadores, perceberam em suas obras a imagem

68 Entre outras opiniões contundentes emitidas nesse sentido (como a de Émile Zola), ver, por exemplo: THORÉ, Theóphile. Op. cit. p.378.

69 Para o bem conhecido interesse de Napoleão pelos nus, ver: VITAL, Christophe (ed.). Paul Baudry, 1828-1886. Exposition. Paris: Somogy, 2007. E ainda: HADDAD, Michele. Op. cit. p.93. O imperador já havia comprado a obra de Baudry antes mesmo da abertura da exposição. A imperatriz havia comprado a de Cabanel (Ver nota 35, do texto de Anne Mccauley, citado). Ambos haviam sido identificados com o regime bonapartista (cf. MCCAULEY, Anne, op.cit., p.46.)

70 THORÉ, T. Op. cit. Salon de 1865, p.206.

71 DU CAMP, Maxime. Les Beaux-Arts à l'Exposition Universelle et aux Salons de 1863, 1864, 1865, 1866 et 1867. Paris: Jules Renouard, 1867. P.30. Naturalmente, a defesa que faz Du Camp é interessada. Especialmente as Vênus de Ticiano ou a Galatéia de Rafael são percebidas já no século XIX não como imagem idealizadas e castas, mas justamente como imagens "realistas", no sentido de sua relação com o presente representado. Basta lembrar a esse respeito, para tomar um exemplo pictórico, o caráter programático de Manet, no sentido do resgate de Tíciano e Giorgione, em suas cenas campestres, onde se vêem, como será em seu Déjeneur sur l'herbe, a presença de nus femininos com figuras masculinas vestidas à moda da época. 
das prostitutas parisienses -, foi também possível fazer uma mesma ligação entre o meretrício e as Vênus de Cabanel e Baudry, mas sempre com o agravante de que se tratariam de "pinturas oficiais", compradas pelo imperador para sua coleção particular ${ }^{72}$.

Outra crítica que recaía sobre esses artistas era a de que eles haviam seguido por anos o expediente obrigatório dos grandes mestres italianos em Roma, e da estatuária antiga, mas, por fim, não teriam tirado lição duradoura alguma. E por isso, para um crítico importante como Thoré, também ele defensor do realismo e “descobridor” da pintura holandesa do XVII na França:

A escola francesa, tal como ela aparece no Salão de 1863, não significa nada. Ela não é mais religiosa, nem filosófica; nada de histórica, nem poética; lhe falta ao mesmo tempo a velha tradição e a jovem imaginação; ela não nem franco idealismo, nem naturalismo sincero. Ela não representa nem a humanidade de todos os tempos, nem a sociedade contemporânea, nem os tipos ou os acidentes da existência humana. ${ }^{73}$

As categorias antitéticas oferecidas pelo crítico (velho e novo, tradição e originalidade, verdade e invenção, idealismo e naturalismo, atemporal e contemporâneo) eram empregadas para demonstrar o lugar onde percebia a arte a "arte oficial", isto é, de "Salão", do período. Sem alcançar a universalidade da arte antiga, sem demonstrar um interesse histórico ou poético verdadeiro (a história parecia vir pela noção de anedota), sem aspirar ao puro idealismo (as Vênus eram de "carne e osso"), e sem conseguir se filiar ainda diretamente ao presente (como os realistas), as produções de artistas como Cabanel e Baudry ofereciam não uma alternativa ou uma via do meio à crise artística, mas uma arte a meio caminho de nada. A ela, tudo faltava, e essa "falta", antes de ser uma irrealização, era uma falha.

O descrédito das obras mais comentadas daquela edição do Salon, levantado pelo lado opositor da crítica, não era, como dito, unívoco. Em lado oposto, era devidamente contrabalançado pelos críticos convencionalmente afiliados ao regime (Théophile Gautier ${ }^{74}$, Paul de Saint-Victor ${ }^{75}$, Claude Vignon ${ }^{76}$, entre outros). Publicando em órgãos oficiais ou subvencionados pelo estado francês, o nu feminino era

72 Vários críticos de oposição viram, como Proudhon, uma relação entre as Vênus de Cabanel e Baudry e as prostitutas de Paris. Ver: CAMP, M. op cit. pp.31-34; CASTAGNARY, Jules-Antoine. "Le Salon de 1863". In : IDEM. Salons (1857-1870). Vol. I. Paris: Bibliothèque Charpentier, 1892. STEVENS, Arthur. Le Salon de 1863. Paris: Librairie Centrale, 1866. p.58 ;THORÉ, T. Op. cit., p.382.

73 Tradução nossa. "L'école française, telle qu'elle apparaît au Salon de 1863, ne signifie rien. Elle n'est plus religieuse, ni philosophique ; point historique, ni poétique ; elle manque à la fois de vieille tradition et de jeune imagination ; elle n'a pas plus de franche idéalité que de naturalisme sincère. Elle ne représente ni l'humanité de tous les temps, ni la société contemporaine, ni les types ni les accidents de l'existence universelle". THORÉ, T. Op. cit. Salon de 1863. p.369

74 GAUTIER, Théophile. "Salon de 1863". Moniteur Universel, 164, 13 e 15 de junho de 1863, p.1.

75 SAINT-VICTOR, Paul de. "Salon de 1863". La Presse, Paris, edições de 10, 17 e 24 de maio, e 4, 14, 21, 29 e 29 de junho de 1863 .

76 VIGNON, Claude [pseudônimo da crítica Noémie Cadiot]. "Le Salon de 1863", Le Correspondant, Paris, Junho de 1863. p.363-92. 
para esses escritores não um sinal de declínio artístico, mas, ao contrário, o último campo de resistência da grande arte. Sendo o "dever" principal dos grandes artistas o compromisso com uma arte que se centrasse no homem, o nu era o último invólucro puro e necessariamente válido para o acesso ao Belo ideal $^{77}$; uma última conexão com a antiga doutrina humanista da Ut Pictura Poesis, da qual o aparato artístico francês, retornando à Itália dos séculos XVI e XVII e à Grécia antiga, se via herdeiro. O diálogo mais próximo com essa ideia sem dúvida persistia do legado neoclássico, tanto prático - o método acadêmico que se centrava no nu -, quanto teórico - a presença constante de Winckelmann, mais ou menos fantasmática na crítica de arte do período, mas bem concreta nos estudos de história da arte da metade do século XIX, conforme visto nos dois capítulos anteriores desta Tese. É preciso lembrar apenas uma das diversas passagens, retomadas à exaustão no oitocentos, em que o alemão iria estabelecer "o objeto mais elevado da arte, que é o desenho do nu"78.

Era desse ponto de vista que, um ano após as polêmicas do Salão de 1863, uma vez retornando em 1864, Gautier (a voz sem dúvida ainda mais influente da crítica de arte do período) continuava a afirmar:

o nu é para a pintura o que é o contraponto para a música: a fundação da verdadeira ciência [...] Ele é verdade, beleza e eternidade. A imaginação em busca de um ideal não poderia ir além disso. Assim, é em direção à expressão dessa forma, modelada a partir da imagem do próprio criador, que os esforços e ambições da arte séria devem se empenhar ${ }^{79}$.

Saint-Victor, outro crítico bem conhecido do público, se pronunciou do mesmo modo, e adicionou uma proposição significativa. Ensaiando uma resolução cabal para a crise da "grande arte", defendeu para tanto a soberania do nu histórico e mitológico, o mesmo então condenado pela crítica de oposição:

O gênero [a pintura de gênero] exercido por tantos talentos permanecerá como a pintura da vida privada; a paisagem conquistou um espaço que não lhe será disputado. Mas entre a Paisagem e o Gênero, é necessário que o nu histórico ou mitológico domine, como de um pedestal, as vicissitudes pitorescas da fantasia e do gosto" ${ }^{\text {. }}$.

O nu combinado com a história e a tradição religiosa continuaria a guiar a arte para além da

77 Para uma discussão sobre a defesa do nu como último bastião da grande arte, ver: MCCAULEY, A. op. Cit; SHAW, Jennifer. Op. cit.; e TINTEROW, Gary. Op. cit.

78 WINCKELMANN, J. J. Histoire de l'art dans l'Antiquité. Traduction de Dominique Tassel. Paris: La Pochothèque, 2010. p.158.

79 GAUTIER, Théophile. "Salon de 1864". Moniteur Universel, Paris, 21 mai 1864. p.1.

80 SAINT-VICTOR, Paul de. "Salon de 1864", La presse, Paris, 7 de maio de 1864. 
"fantasia e do gosto". Os lugares dos quais se deveria furtar eram para Saint-Victor o mesmos que para Olivier Merson, em sua crítica à pinturas anedóticas do também "oficial” Gérôme, das quais dizia que eram mera "fantasia e moda". Achar o equilíbrio parecia ser o mais difícil.

Para Merson, Gérôme não havia conseguido. Para Saint-Victor, Gautier, entre outros, Baudry e Cabanel (este sobretudo), sim - mesmo que eles, como a maioria dos críticos a favor desses artistas, afirmassem, sem maiores problemas, "que as assim chamadas Vênus fossem criaturas do amor, que lançavam olhares sedutores" 81 . Sedutores, mas não "indecentes", como os nus de Manet ${ }^{82}$. Nas pinturas daqueles artistas se encontrariam, enfim, fortes exemplos da arte ideal, tornada sensível por meio da exposição de uma beleza feminina julgada também recorrentemente como ideal: branca e lisa (em sua superfície material, mas também na ausência programática de pelos axilares ou pubianos $)^{83}$.

Os dois lados da crítica dos salões dos anos 1860, e exemplarmente o de 1863, definiram portanto, com seus pareceres, seus extremos a partir do antagonismo estético e político. Todavia, eles se acordavam em ao menos um ponto, e esse parece ser o mais sugestivo para as reflexões e decisões que o jovem Américo, testemunha de todos esses debates, iria tomar. Para ambos, o problema não era de modo algum o nu em si mesmo. A sua importância para a arte de todos os tempos, e mesmo para a atual, quase nenhum crítico diminuía ou refutava ${ }^{84}$. A arte grega havia produzido seus mais belos exemplares a partir da figura do nu, e apenas esse exemplo perene era suficiente para ratificar a validade do tema, conquanto nem todos os críticos, incluindo o jovem Américo, pensassem que fosse necessário copiá-los.

A verdadeira questão, a questão sobre a qual os debates se lançaram, era a maneira na qual e, sobretudo, com quais propósitos o nu era apresentado. Francamente naturalizado (para os realistas), francamente idealizado (para os conservadores "acadêmicos"), ou apresentado num idealismo de intenção temperado por um realismo de forma (para os bonapartistas): todas as vias eram possíveis, mas todas traziam consequências.

81 Sobre esse êxito, ver Mccauley, A. Op. cit. pp.46-47.

82 Idem, ibidem. p.47.

83 Para uma discussão sobre essa recepção por parte dos "críticos oficiais", ver: MCCAULEY, Anne. Op. cit. p.47-48.

84 A única exceção, identificada por Anne Mccauley foi a crítica lançada pelos jornais católicos, que afiliavam a representação do nu aos períodos de decadência da arte. cf. MCCAULEY, A. Op. cit. p.52. 
A encomenda de uma Náiade?

“..em abril de ano passado recebi da Imperial Casa de Vossa Majestade a soma de quatro centos francos, destinados aos últimos gastos que devia fazer com os estudos de um quadro representando, sob a figura de uma Náiade, a fonte da Carioca, que havia começado quando na Europa esteve ultimamente o Ilmo. Snr. Dr. Jacobina, Secretário da Mordomia Imperial. Este pequeno quadro há muito está terminado, e só não o tenho remetido ao Paço Imperial, porque todas as economias que tenho procurado fazer na minha pensão, não me tem chegado para comprar uma bela moldura." ${ }^{, 25}$

Ainda faltam alguns elementos para que se compreenda definitivamente a produção da primeira $A$ Carioca $^{86}$. Encomenda ou "oferta" paga pela casa do presenteado? O excerto da carta que o jovem artista envia de Paris a d. Pedro II, em 25 de maio de 1864 esclarece uma série de questões, e matiza, quase ao ponto de contradizer, um dado fornecido por Cardoso de Oliveira. Segundo o biógrafo-genro do artista, se trataria de uma oferta unilateral ao imperador ${ }^{87}$, em agradecimento à concessão da bolsa e favores prestados desde 1855, cuja ideia o jovem teria tido essa ideia em 1862, após uma viagem à Roma: "Oferecendo ao imperador do Brasil, além da Carioca, toda a coleção de quadros mencionada no capítulo antecedendo, patenteou Pedro Américo a nobreza de sua alma e a profunda gratidão de seu coração." Entretanto, uma contraprova fora de uma biografia de tom laudatório é ainda necessária para assegurar essas afirmações. Mesmo Guimarães Júnior, por exemplo, na biografia de Pedro Américo, de 1871, não apresentava algum dado a esse respeito. Outros documentos e registros pesquisados também não ofereceram maiores esclarecimentos ${ }^{88}$.

A gratidão que Américo nutria pelo monarca era sincera, não há dúvidas, mas a data presumida para o surgimento da ideia da Carioca não deixava de se coincidir precisamente a algumas ações ${ }^{89}$ que Américo executava no sentido de prorrogar um pouco mais seus estudos na Europa, cujo fim deveria ser, com visto, também em 1862.

85 AMÉRICO, Pedro. “Carta enviada de Paris ao imperador d. Pedro II, em 24 de maio de 1864”. Petrópolis, Arquivo da Casa Imperial do Brasil. Maço 134 - Doc. 6580.

86 Faço a distinção porque a segunda versão da Carioca havia sido feita pensando que fosse incorporada, como de fato o foi, à coleção da Academia Imperial de Belas Artes, numa leitura retrospectiva do artista, portanto algo cuja destinação é completamente diferente do primeiro contexto da obra.

${ }^{87}$ OLIVEIRA, J. M. Cardoso de. Pedro Américo: sua vida e suas obras. Paris: Guillard, Aillaud \& Cia, Editores, 1898. p.-34-5.

88 Até o momento, pude pesquisar o diário de contas da Casa Imperial, o diário do Imperador, e toda a documentação do Consulado Brasileiro em Paris, durante os anos de Américo na França, mas nada pude encontrar que confirmasse o pagamento, muito provavelmente feito diretamente a Américo por Jacobina. Ainda é necessário, no entanto, pesquisar o diário de Paulo Barbosa, que se encontra no Arquivo Nacional. O diário estava indisponível durante as vezes em que fui ao Rio de Janeiro em pesquisa.

89 Entre essas ações, se incluíam uma outra leva de cartas enviadas a d. Pedro II, entre as quais o jovem pede prorrogação de sua bolsa para além de 1862. Pedro Américo. "Correspondência para D. Pedro II de 6 de janeiro de 1862". Museu Imperial, Petrópolis. Documento M 1316418. 
Por fim, ele obteve a extensão de prazo (já o sabia em junho de $1862^{90}$ ), e a obra aparentava ser assim uma maneira de agradecer ao Imperador por ter prorrogado sua estadia até 1864. Agradecimento, mas também uma justificativa: deveria ser de bom grado mostrar, com uma primeira produção artística original, aproveitamentos práticos obtidos nos anos financiados na Europa que ultrapassassem as cópias que havia enviado e as atestações de professores que colhia desde 1861, com as quais se assegurava a sua assiduidade nos estudos científicos.

Realmente, os esforços dos seus estudos artísticos estavam sendo correspondidos naquele momento. De volta à França, na sequência da importante viagem a Roma, e ao que tudo indica a diversas outras cidades da Itália, realizada quase certamente no segundo semestre de $1862^{91}$ (que precede uma viagem a Bruxelas, e sucede uma a Londres), Américo conquista, em 31 de janeiro de 1863, um segundo lugar no concurso interno da École de figuras inspiradas na antiguidade ${ }^{92}$ - tema, como visto, ao qual se dedica com constância prática e teórica nesse período, e da qual $A$ Carioca, ao lado de Considerações Filosóficas, é evidentemente devedora.

Fosse ou não uma motivação original do artista, fosse um presente ou uma encomenda, a Casa Imperial havia efetivamente pagado a produção da pintura, o que confirma, de início, a participação em sua criação e o interesse pela obra. Seguindo as informações fornecida pelo artista, a Casa expendera no mínimo 400 francos nessa empreitada, relativos aos "últimos gastos" (de outros pressupostos primeiros) para os "estudos do quadro", e não necessariamente para sua execução (outra inferência considerável, que poderia elevar ainda mais o montante citado na carta, sobretudo se ele conseguiu receber mais 6.000 francos que requisitava na mesma correspondência ${ }^{93}$ ).

O acolhimento oficial reforçava indistintamente a manutenção de uma recepção favorável a esse

90 AMÉRICO, P. "Carta de Pedro Américo, de Paris, em 26 de junho de 1862, à tia Maria do Rosário Brasileira de Mello”. In: NEVES, Tancredo. Dossiê Pedro Américo. Mossoró, 2006. Pp.134-36.

91 Estabeleço essa data a partir do cruzamento de diversos documentos, cartas e registros, que permitem pontuar as demais viagens que Américo fez em países como a Inglaterra e Bruxelas, e os meses em que esteve sem sombra de dúvidas em Paris. Para uma melhor visualização do trajeto e do período presumido, ver o mapa apresentado neste Capítulo. Os documentos que utilizei para estabelecer esses cruzamentos incluem os Proccès-verbaux de l'École des Beaux-Arts; as cartas e documentos presentes no Museu Imperial, do periódo em que Américo era bolsista do Imperador; suas biografias; os registros de inscrição e carterinha no Louvre; os registros de cópia, e as cartas enviadas a familiares e amigos. O material está citado ao longo desta Tese, e, especialmente, na bibliografia, ao final deste trabalho.

${ }_{92}$ Procès-verbaux de l'École des Beaux-Arts. AJ/52/491 e 492. Archives Nationales de France.

93 O pedido do montante é feito na mesma carta de Américo a d. Pedro II, em 1862, citada anteriormente em nota, que deveria cobrir os gastos com a moldura (estando a obra supostamente pronta), e com uma outra viagem que desejava realizar à Itália. Não se sabe ainda se o jovem recebeu a quantia requisitada, que era no entanto, extremamente alta para um artista em vias de se formar. À guisa de comparação, basta considerar que duas pinturas de Alexandre Cabanel (um dos artistas mais importantes do se tempo) expostas no Salão de 1861 e 1863 (Ninfa raptada por um fauno, e o Nascimento de Vênus) haviam sido ambas compradas pelo imperador Napoleão III por 15 mil francos cada. 
tipo de representação de alegorias fluviais, pois correspondia, na verdade, a uma antiga herança portuguesa, já bastante acessada na passagem ao Primeiro e Segundo Reinados, ainda que quase sempre ligada à arquitetura comemorativa efêmera ${ }^{94}$. Não sem desencontro, o primeiro grande exemplar duradouro dessa temática provinha da remessa e inauguração ainda recente, no Rio de Janeiro, da estátua equestre de d. Pedro I, em março de 1862, a partir do projeto de J. M. Mafra, e executado em Paris por Louis Rochet ${ }^{95}$. A obra era acompanhada sintomaticamente de quatro grupos escultóricos de indígenas em bronze, encarnando em forma de alegorias nuas os rios mais importantes do império (Amazonas, Madeira, São Francisco e Paraná) ${ }^{96}$. A considerar que entre essas figuras estavam nus masculinos, mas ainda femininos, montados ou cuidadosamente aproximados de animais típicos dos habitats aludidos em cada rio, isso deveria provavelmente justificar a aceitação do corpo nu da mulher exposto permanentemente em praça pública se devidamente acompanhado por um conjunto de demais figuras do sexo oposto e/ou se devidamente "convertido" em imagem da natureza, mais elemento "natural" do que "humano" 97.

Américo havia apreciado esse conjunto de esculturas indígenas antes de quase todos os brasileiros, em uma aparição de destaque e indiscutível contraste de escala com as demais esculturas aceitas no Salon de 1861, em Paris (fig.4.18). Era, vale lembrar, além da mesma edição em que se apresentavam a Ninfa de Cabanel e Frinéia de Gérôme, o Salão em que estava a Primeira Missa no Brasil, de seu colega Vitor Meirelles, primeira obra brasileira aceita na mais importante mostra de arte internacional do período, pintura em que também o nativo nu ganhava papel de destaque, ainda que um acento ornamental.

A recepção de Américo ao conjunto da obra, bastante negativa, provinha de sua repulsa então assumida a esse tipo de programa iconográfico centrado na figura do índio como elemento de

94 Para um panorama sugestivo dessa frequentação à alegoria fluvial no Brasil, ver: Alberto Martin Chillón. "Entre tradição e modernidade: Almeida Reis e o Paraíba”. Revista Caiana. n.5. Segundo semestre de 2014. pp.29-43. Disponível online:

http://www.academia.edu/11333095/Entre_tradiC3\%A7\%C3\%A3o_e_modernidade_Almeida_Reis_e_O_Para\%C3\%ADba [último acesso em março de 2015]

Para uma relação entre as alegorias indígenas e as fluviais no Brasil, ainda na década de 1860, ver MIYOSHI, Alex. Moema é morta. Tese de Doutorado. Campinas: Unicamp, 2010. pp.143-147.

95 KNAUSS, Paulo. "Índios no salão de arte: representação étnica na escultura do século XIX" In: CAVALCANTI, Ana; OLIVEIRA, Emerson D. G.; COUTO, Maria de Fátima M.; MALTA, Marize. Arte e suas Instituições. XXXIII Colóquio Do Comitê Brasileiro De História Da Arte. Rio de Janeiro: UFRJ, 2013.

96 O interesse oficial pela alegoria fluvial seguia após ainda a produção da estátua equestre enviada por Rochet. Mas em 1866/67 era Almeida Reis, bolsista de escultura na Europa, aluno do mesmo Rochet, que enviava a sua própria alegoria indígena representando o rio Paraíba do Sul. Cf. CHILLÓN, A. Op. cit.

${ }_{97}$ Agradeço a Fernanda Pitta por me chamar a atenção para essa questão. 
expressão nacional, também em oposição aos postulados da filosofia idealista aos quais se apegava:

O estudo da arte nunca foi prejudicial à grandeza dos povos; pelo contrário, sempre os elevou acima da barbária e serviu à realização de todos os grandes ideais. Acostumados a considerá-la como frívola ocupação, continuaremos a viver estranhos aos seus encantos, elevando caixões de pedra em vez de palácios, e rodeando de selvagens e répteis a estátua de nossos heróis, como se não descobríssemos no glorioso começo da nossa história um só personagem digno de assentar-se à base do monumento ${ }^{98}$.

Tal postura crítica, impressa em 1865, pouco tempo depois de sua chegada ao Rio de Janeiro, repetia o interesse inicial na produção de sua Carioca, que também era exposta na corte quase no mesmo momento. Além de, evidentemente, o jovem retomar nesse caso específico uma postura que havia aprendido anos antes com Porto Alegre, notadamente a valorização da história do Brasil por meio da escrita biográfica dos seus "grandes homens" em um panteão nacional; atividade desenvolvida pelo antigo diretor da AIBA dentro IHGB, durante seus dez anos como orador na instituição ${ }^{99}$. A Carioca era uma pintura inédita que lhe permitiria entregar, a partir de um outro tipo de construção iconográfica, não apenas uma leitura pessoal para um elemento fluvial importante da corte - em referência a uma prática comum desde o período colonial -, mas, igualmente, a sua combinação com uma outra perspectiva artística, mitológica e ideológica, de representação dos valores nacionais por meio da arte, a partir da imagem de uma mulher branca.

Com essa alternativa ele já se deparava amiúde em Paris, desde 1859, e reagia favoravelmente aos vários monumentos públicos instalados nos lugares que frequentava com frequência para seus estudos e lazer: nas pontes, que cruzava do Rive Gauche (lado da Sorbonne e da École) ao Rive Droite (lado do Louvre e da Biblioteca Nacional) (fig.4.19); no próprio Palácio do Louvre, (fig.4.20), e no adjunto Jardim de Tuileries (fig.4.21, fig.4.22); na praça da entrada principal da Biblioteca Nacional (onde também frequentemente estudava e seguia cursos) (fig.4.23); na histórica Fonte das Ninfas (ou fonte

98 AMÉRICO, Pedro. "Cartas de um plebeu aos Srs. Deputados. Quinta carta". Correio Mercantil. Rio de Janeiro, 29 de junho 1865; Na quarta carta das Cartas de um Plebeu, Américo já havia se referido implicitamente ao trabalho de Rochet de maneira igualmente negativa: "e ainda mesmo que não chegássemos logo a conquistar a perfeição neste ou naquele ramo da cultura artística, deixaríamos de parecer inferiores aos povos de raça europeia, quando se considerassem as nossas produções, quer puramente artísticas, quer industriais; e certamente nos não tornaríamos a ver na contingência de chamar a um estrangeiro que não sente entusiasmo pela nossa história, para executar monumentos da glória nacional.”. AMÉRICO, Pedro. "Cartas de um plebeu aos Srs. Deputados. Quarta carta." Correio Mercantil. Rio de Janeiro, 13 de junho 1865. Uma parte desse trecho é uma apropriação de uma frase escrita na conclusão de suas Considerações Filosóficas sobre as Belas Artes entre os Antigos.

99 Sobre este projeto, ver: ENDERS, Armelle. Les visages de la Nation: Histoire, héros nationaux et imaginaire politique au Brésil (1822-1922). Tese de Doutorado. Paris: Université Paris I, Panthéon Sorbonne, 2004. Especialmente o capítulo: "La 'République de la mort' de Manuel de Araújo Porto-Alegre". Cumpre assinalar que o projeto de Américo, indiretamente aludido nas Cartas (que analisaremos a seguir nesta tese), contrastava no entanto com a postura favorável de Porto Alegre à representação do índio como representante alegórico nacional. 
dos Inocentes), não muito longe da Biblioteca (fig.24); em Versailles, com suas dezenas esculturas representando alegorias fluviais (onde Américo vai logo em sua chegada à Paris ${ }^{100}$ ) (fig.4.25, fig.4.26, fig.4.27, fig.4.28, e fig.4.29); na floresta de Fontainebleau (fig.4.30); e nas grandes estações, recéminauguradas após as recentes reformas de Haussman (fig.4.31, fig.4.32).

Para além da informação sobre o suporte oficial que se deu a Américo, e de um preço mínimo pago ou financiado à pintura, outras três de primeira ordem estão presentes no citado excerto daquela carta ao imperador, escrita maio de $1864^{101}$.

Uma, era que o artista iniciava efetivamente sua obra a partir da mediação de Antônio Araújo Ferreira Jacobina, secretário de Paulo Barbosa. Jacobina esteve em contato direto com o jovem durante todo período de produção da Carioca, e havia viajado à Europa sentido Inglaterra (junho de $1862^{102}$ ) pouquíssimo após a inauguração da estátua de d. Pedro I, onde ficou por algum tempo antes de chegar em Paris, no mínimo em janeiro de $1863^{103}$ (precisamente o momento em que Américo obtém o segundo lugar das figuras inspiradas nos antigos). Ele ainda se encontrava lá quando Américo embarcava de volta ao Brasil, em setembro de $1864^{104}$. É a partir dessa data de chegada do secretário, do concurso de figuras da École e da relação interpessoal com o jovem naquele período, pouco documentada infelizmente - posto que direta -, que devem se encontrar os termos e regulações de criação da obra.

Outro dado: desde as etapas preparatórias para A Carioca, Américo se orientava com uma motivação iconográfica precisa. Ela seria a representação, em forma de náiade, da mina fluvial mais importante do Rio de Janeiro ${ }^{105}$

100 “Je suis arrivé au Havre au milieu de mai, deux jours après j'ai parti pour Paris, et.... me voilà déjà élève de M. Cogniet, attendant le concours des placesour entrer à l'École des beaux-art: Depuis que je suis arrivé, j'ai parcouru le musées de Peinture et d'Esculptures, d'artillerie, marine, jardin des plantes, le grand palais de Versailles, les musées d'antiquités Grecques, Etrusques, Romaines, le Cluny, les bois de (?) de Paris, et enfim, les plus remarquables monuments de Paris." AMÉRICO, P. "Carta de Pedro Américo, em Paris, a Jacques Brunet, em 07 de agosto de 1859." In: AMÉRICO, Pedro; MELO, Aurélio Eduardo de Figueiredo e; BRUNET, Louis Jacques. Cartas de Pedro Américo de Figueiredo e Melo e Daniel Eduardo de Figueiredo e Melo a Louis Jacques Brunet .Volume 96 de Coleção Mossoroense. Mossoró: Editora Fundação Vingt-un Rosado, 2001. S/d.

${ }^{101}$ AMÉRICO, Pedro. "Carta enviada de Paris ao imperador d. Pedro II, em 24 de maio de 1864". Petrópolis, Arquivo da Casa Imperial do Brasil. Maço 134 - Doc. 6580.

102 S/A."Movimentação do Porto". CORREIO MERCANTIL, 08 e junho de 1862. p.01.

103 GUÉRIN-MÉNEVILLE, M. F. E. "Note sommaire sur l'état actuel de la sériciculture dans les cinq parties du Monde". In: Bulletin Mensuel de la Société D'acclimatation, 2e. série, Tome 9.. Paris: 1872.

104 Em carta a Jacques Brunet, enviada de Paris em 29 de setembro de 1864, Américo afirma que continuava a encontrar Jacobina na mesma cidade.

${ }^{105}$ Umas das fontes do rio Carioca nascia (e ainda nasce) na Floresta da Tijuca. Ele havia sido artificialmente canalizada por aquedutos até algumas fontes públicas do centro da Cidade, a mais importante e conhecida delas: a fonte da 
O período que o jovem realizava os estudos para a pintura coincidia, precisamente, com a sequência das aberturas do "Salon des Vênus" e do Salon des Réfusés, em 1863, e das discussões que suscitaram em torno da imagem da mulher, especialmente a da banhista. Américo, é quase certo, não havia terminado a sua pintura ainda em finais daquele ano. Ele confessava a Jacques Brunet, em fins de 1863, quando também certamente escrevia o seu texto sobre recente reforma da École des Beaux-Arts: "Eu vou continuando como posso os meus trabalhos; estou pintando um quadro de bom tamanho para o Imperador, faço além deste um outro que também ofereço a algum figurão da Igreja na Itália." "106 Ele obteve tempo suficiente para ponderar as reações vinculadas às obras de nu expostas pelos mais importantes pintores do período, e para reafirmar os seus próprios posicionamentos estéticos em relação às questões do dia lançadas no contexto parisiense. Se a Exposição Geral de Belas Artes do Rio de Janeiro de 1859 havia confirmado um interesse local crescente na figura do nu, e se os Salons des Beaux-Arts de Paris ainda em $1859^{107}$, 1861, e sobretudo em 1863, haviam reafirmado "oficialmente" a validade do corpo feminino como último grande refúgio da grande arte (após o reclamado declínio da pintura de história), e como elemento privilegiado de representação e discussão artística, continuar a produção de uma ninfa inédita, potencialmente polêmica em sua recepção brasileira, como aquelas na França $^{108}$, era sem equívocos uma dessas afirmações.

Mais do que isso, era uma aposta. E esta está diretamente relacionada a uma terceira informação da carta do jovem. Também desde o início, ele havia concebido sua obra para terminar nas mãos de d. Pedro II, o que lhe desenhava logo um perfil propositivo ${ }^{109}$. Configurava-se como uma pintura que não se prestava a um fim claramente celebrativo (ainda que implicitamente o fosse ${ }^{110}$ ), tampouco histórico,

Carioca (atual Largo da Carioca, antigo Campo de Santo Antônio), inaugurada na década de 1840 a partir do projeto de Grandjean de Montigny (fig.4.33). Ver: SAINT-ADOLPHE, J. C. R. Dicionário Geográfico histórico e descritivo do Império do Brasil. Paris: J. P. Aillaud, 1845. p.246.

106 AMÉRICO, P. "Carta de Pedro Américo, em Paris, a Jacques Brunet, em 24 de novembro de 1863." In: AMÉRICO, Pedro; MELO, Aurélio Eduardo de Figueiredo e; BRUNET, Louis Jacques. Cartas de Pedro Américo de Figueiredo e Melo e Daniel Eduardo de Figueiredo e Melo a Louis Jacques Brunet .Volume 96 de Coleção Mossoroense. Mossoró: Editora Fundação Vingt-un Rosado, 2001. S/d.

107 Américo chega em Paris em maio de 1859. O Salon abria justamente nesse mês, e durava algumas semanas.

108 Conforme enfatizei, mesmo se posteriormente a apresentação do Déjeneur Sur l'herbe, de Manet, tenha sido tomada por uma série de historiadores da arte (especialmente americanos), como um ponto inaugural da "arte moderna", a recepção contemporânea dessa obra produziu pouquíssima reverberação da crítica especializada, salvo as poucas exceções feitas pelos aliados de Manet. Em contrapartida, a resposta crítica dos artistas oficiais acumulou inúmeras publicações. Ver, por exemplo, MCCAULEY, Anne. Op. cit.

109 Guimarães Júnior reitera esse dado na biografia de Américo. Segundo o autor, a obra havia sido exposta ainda em Paris (cujas informações sobre não foram encontradas), e lá recebeu a proposta de um americano para a compra da Carioca. Citando o artista, reafirma que ele a havia destinado "ao Imperador do Brasil, e, custasse o que custasse, havia de levá-la". GUIMARÃES JÚNIOR, L. Op. cit. p. 57.

${ }^{110}$ Retomo esse problema no penúltimo tópico deste Capítulo, dedicado ao Significado da Carioca. 
endereçada a uma coleção privada, e produzida por uma mão masculina para ser contemplada pelo olhar masculino; destinação cuja especificidade é, de início, fundamental para a compreensão de sua produção e de um horizonte de exemplos históricos e iconográficos célebres mirados por Américo, sedimentados numa longa e profusa tradição do tema da banhista.

\section{Os grandes modelos iconográficos da náiade}

Os três primeiros modelos iconográficos da náiade eram incontornáveis a Américo (ele os comentava mesmo em suas Considerações), consentidos já à época como os carros-chefes mais antigos daquela iconografia: a Vênus Accroupie ${ }^{111}$ (séculos III ou II A.C.), e a Vênus de Milo (ca.100 A.C.), e a Vênus de Cnido (IV A.C.). (fig.4.50., fig.4.34. e fig.5.31.).

A primeira havia conhecido numerosas réplicas desde o período romano (algumas presentes em Paris, e também na AIBA), além de várias outras reconstituições modernas que reelaboravam seus braços e cabeça, parcialmente ou totalmente perdidos, a partir da mesma fonte clássica de inspiração. Américo as havia visto em todas as grandes coleções que visitava na França, Itália ou Inglaterra. A Vênus agachada também havia tido suas formas assimiladas, reelaboradas e difundidas, em um número todavia maior, por pintores e gravadores desde fins do século XV (fig.4.35), e ainda no século XIX sua presença se refazia constante em cadernos de desenhos e obras acabadas de inúmeros artistas, independente de suas inclinações estéticas (Delacroix, Ingres, Manet, etc.) (fig.4.36., fig.4.37., fig.4.38., fig.4.39.)

A Vênus de Milo, por sua vez, estava, desde 1821, disponível em lugar de honra à visitação no Louvre (onde permanece), inúmeras vezes frequentado por Américo nos seus 5 anos de Paris ${ }^{112}$. Conforme viso, configurava-se para ele, como para um séquito enorme de artistas, referência obrigatória de estudo, e uma das máximas expressões da arte universal, a despeito também de sua mutilação $^{113}$. Além do elogio incondicional feito a essa estátua em suas Considerações Filosóficas, a

111 Dita ainda Aphrodite Accroupie. Normalmente se atribuiu essa obra a Doidalsès de Bithynie (ativo no III século A.C.), a partir da leitura Plínio, O Velho. No entanto, estudiosos olham com acentuada reticência essa atribuição, sugerindo de fato a renúncia dessa hipótese. cf. PASQUIER, Alain. La Vénus de Milo et les Aphrodites du Louvre. Paris: Éditions de la Réunion des Musées Nationaux, 1985. p.65

112 Desde julho de 1859 Américo possui registro de copistas e de frequentação junto às coleções do Louvre. Ele o renovou anualmente, sem falta, até 1864. Esta última renovação, poucas semanas antes de retornar ao Brasil. Ver: Registres des cartes délivrées aux artistes, aux élèves, permissions délivrées. Musée du Louvre, Paris. Artistes et élèves, 1858-1862, cotas *LL20; e Permission délivrées, classemenet chronologique, 1852-1860, cota *LL15 e *LL16.

113Para se ater apenas às personalidades cujos trabalhos haviam sido lidos por Pedro Américo, a supremacia da Vênus de Milo era citada por Quincy, Émeric-David, Beulé e Viollet-Le-Duc. 
admiração o levaria mesmo a realizar uma cópia pintada da obra ${ }^{114}$ (fig.4.40.), curiosamente afetada pela invenção de um panejamento vermelho que a circunda, inexistente na composição original ${ }^{115}$ (criação talvez resultante de seu conhecimento das recentes descobertas sobre a policromia na estatuária antiga).

Já se concebia entretanto, e Américo o sabia, que a Vênus de Milo pertencia à família das (embora as ultrapassasse) numerosas variações da original Vênus de Cnido, de Praxíteles ${ }^{116}$, artista cuja recepção começava a ser reavaliada justamente naquele momento, diante da influência então inconteste dos estilos mais severos de Fídias e Policleto ${ }^{117}$. A obra era já velha conhecida de Américo, e já havia sido desenhada por ele em 1858, a partir de uma cópia presente na AIBA (fig.4.41.). Também presente no Louvre, onde novamente acessava uma das melhores cópias existentes da original grego, a Vênus de Cnido seria celebrada como o "primeiro nu feminino de tamanho natural" da arte grega ${ }^{118}$. A despeito de algumas interpretações "naturalizantes", Américo (crendo em Quatremère de Quincy) continuava a julgá-las, como a seus pares gregos, sempre ideal, convenientemente de acordo com a defesa da presença de uma arte moralmente elevada naquele período "áureo" da humanidade, e ainda com o apego estético que o alimentará na produção da Carioca $^{119}$.

Essa escultura não havia levantado quaisquer suspeitas quanto à sua identificação iconográfica. Mas o mesmo não se passava com a Vênus de Milo. Havia nela uma particularidade significativa, percebida por Eméric-David, de quem Américo, como visto, absorvia vários dos argumentos do seu

114 Embora não datada, é possível imaginar que essa obra seja do período de formação e Américo.

${ }^{115}$ A motivação para a inclusão desse drapeado no trabalho de Américo é ainda duvidosa. Num contexto imediato, pode ser que ela tivesse alguma relação com as descobertas recentes que se fazia, na metade do século XIX, sobre a policromia nas estátuas antigas. O professor Lorenzo Mammi chamou-me atenção para o fato de que a Vênus de Milo estaria de fato, a partir de 1853, enrolada em um panejamento vermelho. Entrentanto, em investigação posterior, não pude confirmar essa informação específica. O que é certo é que havia mesmo, a partir da metade daquele século, um panejamento posicionado atrás da estátua, na parede dos fundos, encenação feita para chamar ainda mais atenção do mármore branco da estátua. Essa característica é confirmada em diversos textos da época. Ver, por exemplo:

BUNBURY, Frances H.; LYELL, Katharine H. (ed.). Memorials of Sir. C.J.F. Bunbury. Volume 4, part 3. Cambridge: Cambridge University Press, 2011. p.13.

$116 \mathrm{Um}$ dos autores que desenvolvem essa tese é Quatremère Quincy, em texto consultado por Américo, conforme visto nos capítulos anteriores desta Tese. QUINCY, Quatremère de. Sur la statue antique de Vénus découverte dans l'ile de Milo en 1820. Paris: Chez Debure Frères, Libraires du Roi, 1821. p.30-31.

117 PAPET, Édouard. "'L'art a des exigences et de dédains que l'archéologie ne connaît pas.' Praxitèle et la sculpture française de la seconde moitié du XIXe siècle". In: PASQUIER, Alain; MARTINEZ, Jean-Luc. Praxitèle. Catálogo de Exposição. Paris: Louvre, 2007. pp.394-415

118 A informação de que Praxíteles teria sido o primeiro a representar uma deusa completamente nua era recorrente em escritos artísticos desde o século XVII, e se repete também com regularidade na bibliografia consultada por Américo. GREBE, Anja. Vatican: Tous les chefs-d'oeuvre. Paris: Flammarion, 2014, p.424. Por vezes, a obra é também apresentada como o primeiro nu feminino "realista" da antiguidade.

119 Ainda no Louvre se encontrava, e ainda se encontra, a "Cabeça de Kaufmann", creditada como uma réplica exata da cabeça da Afrodite de Cnid.o 
Recherches sur l'art statuaire, salvo a mesma defesa sobre o naturalismo da escultura grega. A partir das interpretações influentes desse autor, que se estenderam para gerações posteriores ${ }^{120}$, acreditava-se que a Vênus de Milo não compunha - como também se inferiu - um grupo escultórico com demais personagens $^{121}$, e sobretudo que, em sua unidade, se trataria não de uma Vênus, mas sintomaticamente de uma ninfa: a ninfa de Milo ${ }^{122}$, protetora da ilha onde havia sido descoberta. Essa interpretação de Émeric-David aprofundava uma outra, defendida ainda pelo mesmo pensador, embora de conhecimento corrente, e aprofundava igualmente outra, argumentada por autores caros a Américo como Quatremère de Quincy, Viollet-Le-Duc, e o próprio Émeric-David. A de que, desde a antiguidade, a arte se projetou a um fim antropomórfico ${ }^{123}$, razão pela qual os gregos haviam aberto caminho para sua superioridade. Nesta compreensão, para que qualquer conceito abstrato, elemento natural (mar, céu, luz, fogo) ou sentimento (amor, ódio, compaixão) fosse representado, ele deveria se encarnar em forma humana, notadamente alegórica ${ }^{124}$. Quincy havia chamado essa orientação de "a língua metafórica da mitologia" ${ }^{25}$. A conclusão reforçava ainda, nesse ponto específico, a influência que exercia sobre o brasileiro uma parte das investigações fundadoras de Winckelmann (reforçadas em seu aprendizado na AIBA e na École ainda não reformada), especialmente aquela em que se definia a figura humana, e em específico o nu, como o objeto mais elevado da arte ${ }^{126}$; como visto, postura ainda defendida pelos críticos e teóricos mais importantes do Segundo Império francês (partidários do regime), com destaque para Charles Blanc, Théophile Gautier e Paul de Saint-Victor, que haviam celebrado o reaparecimento das deusas banhistas nos últimos Salões de 1861 e 1863, como o último ponto de resistência da grande arte, idealista, diante das ameaças "realistas" da contemporaneidade ${ }^{127}$.

120 RAVAISSON, Félix. La Vénus de Milo. Paris: Librairie Hachette, 1871. p.30

121 Essa, por exemplo, era a tese de Quatremère de Quincy, cujo texto sobre a Vênus de Milo, conforme indicado no Capítulo anterior, também havia sido lido por Américo: "eu ouso dizer que essa Vênus era originalmente agrupada com outra figuras, tal como Paris, Adônis ou Marte, com a qual ele era representada, como se diz, em colóquio." QUATREMÈRE DE QUINCY. Sur la statue antique de Vénus découverte dans l'ile de Milo en 1820. Paris: Chez Debure Frères, Libraires du Roi, 1821, P.16

122 ÉMERIC-David, T. B. Mémoire sua la statue antique découverte en 1820 dans l'Île de Milo et déposée au Musée Royal du Louvre". IN: Mémoires de l'Académie des Inscriptions et Belles-Lettres. Paris: Imprimérie Royale, 1821.

123 QUINCY. Sur l'ideal dans les arts...; Para Viollet-le-Duc, o processo de personificação das forças naturais iniciado pelos gregos, cada vez mais aperfeiçoado pela ideia que desenvolvem sobre a imitação, foi o motivo pelo qual haviam sido os iniciadores da verdadeira arte. E, ainda segundo o francês, deveria ser a partir desse exemplo que os contemporâneos deveriam imitá-los. VIOLLET-LE-DUC, E. E. Esthétique appliquée à l'histoire de l'art. P.48

124 ÉMERIC-DAVID. Recherches sur l'art statuaire.

125 QUINCY. Sur la statue antique de... p.24; Viollet-Le-Duc, novamente, sem dúvida conhecedor das lições de Quincy, sugerirá se tratar do "Sistema mítico dos gregos". Idem, Ibidem. p.48.

126 cf. WINCKELMANN. Op. cit. p.158.

${ }^{127}$ Saint-Victor, a respeito do "retorno" do nu nos anos 1860, dirá : "Signalons surtout, comme un symptôme excellent, la réapparition du $\mathrm{Nu}$ qui rentre dans la peinture, après une longue proscription. Les Déesses reparaissent en foule, et se 
A presença da Vênus agachada, a Vênus de Milo e a Cnido como exemplos iconográficos absolutos das banhistas (Vênus ou ninfas) gregas e romanas projetava um rastro durável, que Américo perseguiu em seus estudos artísticos nas academias brasileira e francesa, e especificamente na produção de sua própria náiade. No entanto, ciente de suas existências pelo menos desde 1855, é difícil precisar, somente a partir dessas obras clássicas, o momento em que Américo concebe a "ideia” da Carioca.

\section{A ideia da náiade (ou um passeio com as banhistas romanas)}

Se for atestado crédito a Cardoso de Oliveira, a "ideia" se localiza, como citado, após a viagem de estudos que o jovem cumpre em Roma, em 1862. Segundo o biógrafo, mesmo produzindo várias pinturas (algumas cópias) no seu primeiro período de estudos na Europa, o jovem

não estava, porém, satisfeito; não se sentia ainda na altura da situação que lhe criaram os seus estudos na Europa, nem julgava nenhuma dessas telas, algumas aliás de grandes dimensões, capaz de servir de atestado do seu aproveitamento perante os patrícios, que tanto esperavam do seu pincel. Dominando por essa ideia, empreendeu, em diligência, a sua primeira viagem de instrução ao norte da Itália, da qual encontram-se vivas reminiscências em brilhantes páginas do Holocausto. ${ }^{128}$

Se bem que a informação seja mais ou menos crível (ela é precisa ao menos quanto ao período em que Américo realiza os primeiros estudos da obra), a hipótese é enfraquecida por uma outra, que se esboça a partir de um dado oferecido pelo próprio Américo, esse um paralelo poético, presente precisamente em um trecho de OHolocausto $^{129}$. Nele, o alterego poético do artista, o escultor Agavino (invenção sugestivamente acusativa, em razão do concomitante interesse na estatuária antiga, que encontra expressão paralela nas Considerações Filosóficas), começava a produzir sua primeira obra, $A$ Palmyra, ainda em Paris, interrompendo-a, num período situado, em sua narrativa, algo em torno dos

déshabillent au "Salon, devant le public comme devant Paris, sur le mont Ida. On ne saurait trop applaudir ce retour du Torse exilé. Le nu est l'essence même de l'art [. . .]. L'École du nu, si elle se reforme, peut ramener notre art vers les hauteurs du grand style. Pour que le sens du Beau se perpétue dans un art, il faut que Vénus sorte de l'onde, au moins une fois chaque année;" SAINT-VICTOR, Paul. 'Salon de 1864', La Presse, Paris, 07 de maio de 1864.

${ }_{128}$ OLIVEIRA, J. M. Cardoso de. Pedro Américo: sua vida e suas obras. Paris: Guillard, Aillaud \& Cia, Editores, 1898.p.32.

Em outro extrato biográfico sobre Américo, Cardoso irá repetir a importância de Roma para o surgimento a Carioca: “Apesar dos trabalhos acima indicados, não queria Pedro Américo regressar ao Brasil sem levar uma tela original como atestado do seu aproveitamento, e pintou então, verdadeiramente inspirado depois de uma viagem de instrucção à Itália, o seu esplendido quadro - A Carioca". AMÉRICO, Pedro. O foragido. Rio de Janeiro/Paris: H. Garnier, 1899. p.XVIII-XIX.

129 Como se sabe, $O$ Holocausto é um romance autobiográfico, escrito na década de 1860, e apenas publicado no início dos anos 1880 (o primeiro biógrafo de Américo, Luiz Guimarães, confirma a informação já em 1871), mas calculadamente, ao lado de novas versões das das mesmas obras da juventude; isto é, da nova Carioca, e de uma edição impressa em livro das Considerações Filosóficas. 
anos $1861-1863^{130}$. O personagem “temia” terminá-la:

sem primeiramente ter contemplado os imensos primores com que a piedade, o ouro, a política e a magnificência dos príncipes e dos papas exornaram as cidades italianas, verdadeiros berços da moderna civilização; porque desejava que seu estilo, onde devia transluzir a grandeza do seu amor e da sua saudade, não fosse indigno dos grandes mestres, que seus profundos estudos estéticos habilitavam-no a compreender $^{131}$.

O narrador externo (Américo) descreve com exatidão as cidades italianas pelas quais, saindo de Paris, seu herói percorre nesse período - um caminho bastante verossímil, de fato bastante percorrido por artistas franceses na primeira metade o século XIX, incluindo Viollet-le-Duc ${ }^{132}$; e, se correto, pode ser compreendido como um mapa inédito dos itinerários percorridos pelo próprio artista, na vida real, durante o segundo semestre de 1862, se estendendo também, quem sabe, para os anos seguintes da década de $1860^{133}$ (fig.4.42.).

De volta de Roma, Agavino retomava inspirado - e não começava - a produção da obra, tendo então em mente tudo o que havia visto "nas suas instrutivas viagens". Uma vez concluída (e nesse ponto Américo insere uma curiosa rêverie, que de certo modo denuncia seus desejos), Agavino chama Ingres, "o ilustre chefe da escola francesa" para dar seu juízo sobre a sua produção, que "emudeceu, enlevado era o extasis". O ateliê do jovem se tornaria desde então o ponto de encontro preferido de artistas, amadores e literatos adoradores da escola idealista francesa, "ao passo que ele [Agavino], engolfado em pensamentos estranhos ao orgulho, corrigia os seus escriptos, nos quaes, em noutes não

130 O período não é expressamente referido no trecho. No entanto, os locais e as circunstâncias narradas (Agavino vai a Londres quando da deflagração da Questão Christie, entre Brasil e Inglaterra, em 1863), permitem datar precisamente o período a que se refere esse bloco do seu romance.

131 AMÉRICO, Pedro. O holocausto. Florença: Typographia Cenniniana, 1882. p.294.

132 Viollet-le-Duc, por exemplo, parte para a sua primeira viagem à Itália em 12 de março de 1836, sem trem (que Américo já terá à disposição), viajando durante 18 meses, dos quais, no entanto, permanecerá consideráveis 6 meses em Roma. Com um itinerário pouco comum, ele percorre no entanto quase as mesmas cidades que o jovem sugere no Holocausto ter feito: Nápoles, Sicília inteira (três meses), Roma, passando por Pompéia, Livorno, Roma novamente, Assis, Florença e Veneza. FINANCE, Laurence de . [Directeur de publication. Commissaire d'exposition]. Viollet-le-Duc : les visions d'un architecte : [exposition, Paris, Cité de l'architecture et du patrimoine, 20 novembre 2014-9 mars 2015].Paris : Norma : Cité de l'architecture et du patrimoine, impr. 2014.

133 Segundo uma descrição precisa das viagens, o percurso em ordem cronológica e geográfica é o seguinte: partindo de Paris, de trem, passa por Lyon. De lá, a cavalo e outros meios de transportes chega pelo norte da Itália (e Cardoso de Oliveira, na biografia de Américo, havia garantido que ele havia ido ao norte da Itália) em Turim, passando por Milão, Lombardia, Verona(?), Veneza, Bolonha, Ravena, Rimini, Pesaro, Urbino, Florença, Umbria, Siena, Viterbe, Roma, Nápoles, Tarento, e Parque d'Etna (na Sicília, extremo sul do pais). AMÉRICO, P. O Holocausto, pp.295-301. A única dúvida nessa lista, se essa leitura poética estiver correta, é se Roma seria visitada por Américo logo após Siena, na ida, ou se na volta da viagem, a partir do sul. A descrição não sugere terem sido em ambos os momentos. 
dormidas, derramara larga copia de saber e inspiração."134.

Em relação aos dados históricos essenciais, o trecho não poderia ser mais preciso, mesmo que sua natureza poética o permitiria supor de início - embora de modo algum pareça - uma completa invenção. Evoca os projetos concomitantes, escritos e pictóricos, que Américo desenvolvia realmente entre 1862 e 1863 (deve-se lembrar que o primeiro ensaio de publicação de Considerações Filosóficas data de abril daquele último ano, ainda em elaboração até 1864), bem como seu profundo interesse na filosofia idealista de Cousin e de Krause.

Mas se a interpretação anterior não permite supor Roma como o lugar onde teria nascido a ideia da Carioca (estaria portanto em algum momento entre o Salon de 1861 e a Exposição de Londres de 1862), não parece haver dúvidas entretanto que seria lá, na primeira experiência da "cidade eterna", onde essa ideia tomou uma forma conclusiva, favorecida pelo contato com um outro conjunto específico de obras insignes suficientemente conectadas em suas naturezas propositivas e iconográficas. Uma mesma conexão que, mais ou menos mantida nas obras de 1861 e 1863 dos preferidos de Napoleão III, ele desejava (me parece) provocar em sua pintura. A reverência italiana deve ter apenas aumentado após o resultado tão positivo no concurso da École de figuras inspiradas na antiguidade, sequencial às viagens desse período, como um encorajamento dos seus estudos clássicos.

Em Roma, o circuito percorrido pelo jovem é mais ou menos evidente, na medida em que "obrigatório" aos estudantes de arte, incluindo o seu colega Meirelles, a quem pôde provavelmente pedir conselhos nos quase dois anos em que moraram concomitantemente em Paris: Galeria Borghese, Palácio Farnèse, Villa Farnesina, Palácio Barberini, Capitólio, Vaticano, Panteão, Villa Médicis ${ }^{135}$, e ainda as praças e suas conhecidas fontes com esculturas.

Reiterando um circuito clássico de obras já visitadas em Paris e Londres ${ }^{136}$, as inspirações antigas de que pôde tirar das coleções romanas, em sua maioria abertas aos artistas, continuavam recorrentes nas esculturas gregas de Fídias, Policleto, Praxíteles. Lá podia continuar a visitar uma sequência de outras variações do mesmo tema escultórico antigo da Vênus banhista ou pudica, que estavam insistentemente presentes em lugares de honra do Vaticano (Vênus Félix e um dos exemplares em melhor estado da Vênus Agachada), ao lado dos nus masculinos indiscutíveis do Apolo de Belvedere e

134 AMÉRICO, Pedro. O holocausto. Florença: Typographia Cenniniana, 1882. pp.312-314.

135 Sede da École des Beaux-Arts francesa naquela cidade, destinada aos vencedores do Grand Prix.

136 No mesmo ano de 1862 (antes da viagem italiana) e novamente em 1864, Américo visita Londres, especialmente nas coleções clássicas do British Museum, que incluíam os mármores de Fídias e colaboradores, levados do Parthenon por Lorde Elgin, nos primeiros anos do século XIX. 
do grupo do Laocoonte; estavam ainda no Capitólio (Vênus Capitolina e a Vênus Esquilini); no Palácio Barberini (Vênus Barberini); e na Galeria Borghèse (Vênus Borghèse).

Em um outro circuito, "moderno" - e esse parece ser um núcleo fundamental para uma delimitação mais clara da Carioca - parece vir a lição de uma adequação de tema, programa iconográfico e proposição artística, que Américo encontrará especialmente nas obras pintadas ou desenhadas por Rafael, Michelangelo, Ticiano, Anibale e Agostini Carracci, Guido Reni; e na escultura, por Bernini.

A presença inconteste das banhistas de Tintoretto e Ticiano no Louvre (fig.4.43., fig.4.44.) (tão célebres quanto as Vênus encomendadas a este último por Felipe II, em Madri [fig.5.22.]) havia aberto possivelmente caminho para a percepção desse circuito romano de mais de 300 anos de obras e encomendas célebres, no qual decoração e destinação do nu com motivação pagã estavam intimamente ligadas.

O mesmo Ticiano permanecia muito visitado na Villa Borghèse, por meio do Amor Sacro e Amor Profano, que Américo pôde enfim estudar integral e diretamente, depois de ter visto, em 1859, a cópia parcial de Meirelles na Exposição Geral de Belas Artes. A obra era uma das mais célebres entre as que insistiam na presença alegórica e mitológica do nu feminino ${ }^{137}$ (e em menor quantidade ainda religioso $^{138}$ ). Ela não deve ter todavia sombreado a presença discreta, mas extremamente significativa, de uma bastante conhecida Alegoria da descoberta da América (1585), de Jacopo Zucchi - já presente na coleção original de Scipione Borghèse, no começo do século XVII ${ }^{139}$-, cuja relação com as águas e a contorção do corpo duas figuras sentadas em primeiro plano, muito próximas à da Carioca, talvez fossem ainda menos importantes do que o sugestivo precedente iconográfico oferecido ao jovem (fig.4.45.). As figuras femininas, sorte também de náiades americanas idealizadas, que fitam o espectador com evidente frescor veneziano, encarnavam em mulheres brancas uma concepção alegórica que contrastava com a formação de uma tradição concomitante e bem mais difundida ulteriormente, a partir da qual a América e os seus elementos naturais assumiam as formas também idealizadas de índias nuas e seus atributos acessórios ${ }^{140}$ ( fig.4.x., fig.4.46., fig.4.47., fig.4.48., fig.4.49.,

137 Da coleção original Borghèse, do início do século XVII, estavam presentes as obras com o tema mitológico do nu: uma cópia de Leda e o Cisne de Leonardo da Vinci; Danae, de Correggio; Vênus com dois Amores, de Bresciano;

Vênus e Amor no Mar, Luca Cambiaso, de 1565; O Banho de Vênus, Scarselino, c.1585; A alegoria de Jacopo Zucchi; As Três Graças, de Manetti, c.1610. A caça de Diana, Domenichino, 1617. E, entre outros afrescos do prédio, destacando-se um de Giovanni Lanfranco, Concílio dos Deuses, 1625, presente na della Loggia.

138 Suzana e os velhos, de Rubens, 1606.

139 COLIVA, Anna. Galleria Borghese. Roma: ENEL, 1994.

140 Salvo o caso de rios - tradicionalmente incorporados em formas masculinas. 
fig.4.50., fig.4.51. e fig.4.52.). Tal configuração ganharia sua regulamentação definitiva pouco tempo depois da conclusão da obra de Zucchi, a partir das primeiras edições e traduções da influente Iconologia de Cesare Ripa ${ }^{141}$, nas quais, em todas, a América encontra ilustrações ${ }^{142}$ e era acompanhada pela prescrição ${ }^{143}$ de uma mulher nua, de pele cor castanho escuro, com arco e flecha, véus multicoloridos, coroa de penas, em companhia de animais ${ }^{144}$ (fig.4.53.). O esquema atravessou, como citado, monumentos efêmeros em Portugal, no Brasil colônia e Império, e, no decorrer do processo de reelaboração dessa tradição, notadamente com a fusão de suas características com aquelas do elemento "água", do mesmo manual, culminou mesmo na absorção permanente que se faria nas figuras fluviais do conjunto escultórico de d. Pedro I, entre outros exemplos ${ }^{145}$.

Ainda lá, na Galeria Borghèse, a presença exemplar dos nus de Bernini (Fig.4.54.) - artista para o qual a sensibilidade de Américo pagaria tributo crescente em obras futuras, notadamente na Batalha de Campo Grande -, respondia com equidade a fama de suas fontes, e uma delas em específico, a Fonte dos Quatro Rios, da Piazza Navona, encomendada pelo papa Inocêncio X, na qual o tema alegórico fluvial era igualmente desenvolvido ${ }^{146}$. Se o conjunto do Rio do Prata parece encontrar uma releitura naquela obra posterior do brasileiro ${ }^{147}$, o gesto preciso da figura do Nilo, que deseja desvelar sua face (as fontes desse rio não eram então conhecidas), não deixa de sugerir de todo modo, além de uma mesma posição do corpo sentado que se reclina para trás (fig.5.77.), a mesma graça "praxitelesca" e "rafaelesca" que o braço direito da Carioca, também suspenso e arqueado, deseja exprimir.

Como Bernini, Américo também integrava o grupo dos cultuadores de Rafael. A persistência da imagem do "divino" artista (que Américo equipara mais de uma vez ao intocável Fídias), enterrado não muito longe da Borghèse, no Panteão, devia reatualizar a profunda admiração que o jovem nutria por esse pintor desde os anos 1850, na AIBA - num período em que ele já havia realizado uma cópia mais ou menos livre, provavelmente a partir de gravura, do Arcanjo São Miguel destruindo o demônio,

141 Em 1593, 1602, 1603, 1611, 1613, 1618, 1620, e 1625, as primeiras edições da Iconologia são publicadas em Italiano, esta última, póstuma; em 1644 e 1677, as primeiras em holandês; em 1636, 1643, 1677, 1681 e 1698, em francês. As republicações nos séculos seguintes são inúmeras.

142 Salvo a primeira edição, publicada por Ripa em 1593, sem ainda alguma ilustração.

143 RIPA, Cesare. Iconologia. ed. MAFFEI, Sonia. Torino: Giulio Einaudi, 2012. p.399.

144 OKAYAMA, Yassu. The Ripa Index: Personifications and their Attributes in Five Editions of the Iconologia. Netherlands: Davaco, 1992. p.182.

${ }^{145}$ Para o processo de frequentação das alegorias fluviais com atributos indígenas, ver novamente: CHILLON. Op.cit.

146 A fonte representava então 4 rios mais representativos dos 4 continentes então conhecidos (América, Ásia, Europa, África), a saber respectivamente, Rio da Prata, Ganges, Danúbio e Nilo.

147 CHRISTO, Maraliz C. V. "Quando subordinados roubam a cena: A Batalha de campo Grande de Pedro Américo". In: Sceculum, Revista De História. João Pessoa, jul/ dez. 2008. p.98. 
depositada no Mosteiro de São Bento, no Rio de Janeiro; imagem cujo original pôde visitar em seguida, no Louvre (fig.4.55.). A presença de Rafael em Roma, para se deter apenas nas obras que parecem ter corroborado à ideia da Carioca, era a propósito tripla, todas convenientemente disponíveis ao acesso de artistas e estudantes no circuito artístico correntemente percorrido.

Na Villa Farnesina, por encomenda de Agostini Chigi, estava a célebre sequência de afrescos que Rafael fará com seus alunos, inspirada formalmente em mármores antigos, representando a história de Amor e Psiquê. Dedicada exclusivamente à representação do nu pagão (para a fruição privada de Chigi $^{148}$ e seus amigos), e com ênfase no feminino, se a loggia principal incluía representações multiplicadas de Vênus e Amor, entre outras divindades menos frequentes, elas receberam, ao menos no século XIX, bem menor foco de atenção do que um conjunto de faunos e ninfas centrado numa ninfa maior, a triunfante Galatéia (fig.4.56.), pintado em uma sala adjacente (obra de influência capital para gerações de artistas).

A presença do nu rafaelesco se estendia em outra encomenda anterior visitada por Américo, igualmente famosa, mas esta no Vaticano, notadamente em uma das quatro stanze de recepção que o artista italiano fará para o papa Júlio II, o Salão de Constantino ${ }^{149}$, que começou a ser efetivamente pintada a partir de seus desenhos apenas após sua morte, em 1520, por seu aluno mais conhecido, Giulio Romano, em colaboração com Gianfrancesco Penni e Raffaellino del Colle ${ }^{150}$ (fig.4.57.).

Ainda que os nus pagãos do teto dessa sala disputassem a atenção com os afrescos verticais dedicados à primazia católica de Constantino, em outra pequena sala célebre, também projetada por Rafael e pintada por seus alunos em 1520, eles se centravam nova e exclusivamente em sua aparição mitológica, e lá indiscutivelmente erótica, posto que destinados ao banheiro privado do cardeal Bibbiena. Entre as várias representações de novo significativas de Vênus em sua relação com as águas, presentes nessa obra ${ }^{151}$, estava uma dedicada à ninfa Syrinx e ao fauno Pan, cuja motivação iconográfica (também a de uma banhista sentada em meio à paisagem, que penteia seus cabelos ao sair

148 SAXL, Fritz. "Vila Farnesina". IN: SAXL, Fritz. La vida de las imágenes. Madrid: Alianza Editorial, 1989. p.173181.

149 As demais salas são: a de Heliodoro, a Sala della Segnatura, e a Sala dell'Incendio del Borgo.

150 Coube à Rafael portanto a parte que era considerada muito correntemente no século XIX a mais importante da atividade artística: a do desenho, ação "masculina", em contraposição à pintura (à cor), relacionada sempre à porção "feminina" do métier, suposta secundária. Ver: BATCHELOR, David. La peur de la couleur. Paris: Éditions autrement, 2001.

$151 \mathrm{Na}$ câmara se incluia um Nascimento de Vênus, e Vênus e Amor conduzidos por golfinhos, e ainda muito provavelmente uma Vênus saindo do Banho com Amor. PIETRANGELI, Carlo. Rafaello in Vaticano. Milano: Electa Editrice, 1984. 
da água) parece suficientemente conhecida pelo jovem e absorvida em sua $A$ Carioca (fig.5.60.), como na obra de vários outros artistas, e cujo desenho original, a propósito, já estava presente na coleção do Louvre (fig.5.59.). Conquanto não se saiba se o jovem teve acesso direto a essa câmara em particular, as composições desses afrescos eram amplamente divulgadas desde o século XVI a partir da série gravuras originais de Marcantonio Raimondi, Marco Dente da Ravenna e seguidores ${ }^{152}$ (fig.5.63.), conjunto que, ao lado de outras reproduções-interpretações desses gravadores, bastante conhecidas, como a da Vênus agachada (fig.4.35.), ou a Vênus ferida (fig.5.97.) continuava a ser repetidamente acessado por artistas durante os três primeiros quartos do século XIX, de Ingres a Delacroix, de Cabanel a Manet ${ }^{153}$.

Mantendo-se ainda nas Loggias, outra sugestiva composição representando Betsabéia em seu banho poderia ser estudada pelo jovem (fig.5.61.).

Num dos pisos inferiores do prédio, ainda no Vaticano, Américo havia visitado a obra capital de Michelangelo, a Capela Sistina, que tanto o marcaria - experiência sobre a qual deixava também uma precisa descrição em seu $O$ Holocausto $^{154}$. Já introduzido a alguns aspectos da obra desde os seus

152 Para o catálogo ilustrado de todas as obras conhecidas de Raimondi e discípulos, ver: OBERHUBER, Konrad; STRAUSS, Walter L. (Ed.); BARTSCH, Adam von (1757-1821), compilação. The illustrated Bartsch. The works of Marcantonio Raimondi and of his school. New York : Abaris Books, 1978. 2.vols.

153 A validade dessas imagens para as discussões artísticas dos anos 1860, independemente da postura tomada na batalha artística desses anos, encontrava mesmo uma pertinente confirmação no tão polêmico Le Bain [O Banho] (apenas em 1867 rebatizado de Déjeneur sur l'herbe [Almoço na Relva]), exposto como visto no "Salão dos Recusados" de 1863, cujo modelo, já bastante conhecido, retomava criticamente uma impressão de Raimondi do Julgamento de Paris, de Rafael; ou ainda, para aproximar um mesmo modelo original caro a Américo, em sua Ninfa Surpreendida, de 1861, que não deixava em branco a referência a uma outra interpretação de Raimondi à estátua da Vênus Agachada.

$154 \mathrm{O}$ trecho completo, com ortografia original, sobre a experiência no Vaticano é o seguinte: "Sciente de tudo isto, porém alentado pelo amor do bello, que cada vez ardia mais em sua alma, Agavino desceu da esphera que serve de base á cruz do zimborio, aonde pela primeira vez subira, e foi ver a Capella Sixtina e as Câmaras de Raphael. Ora, quando um homem instruído e sensível entra no Vaticano, como que apodera-se delle um grande espirito, como que soa-lhe aos ouvidos um cântico indefínivel; e elle caminha respeitoso, anhelante, suspenso, como se o espectaculo das maravilhas que o rodeam o desterrasse da realidade, e enchesse-lhe de ether e luz o seio da consciência. É uma deliciosa vertigem, que dura em quanto dura o prodígio da perfeição. Por fim: a alma sente-se abatida, a sensibilidade exhausta, a vaidade anniquilada. Aquella atmosphera vibrante; rarefeita, luminosa, é como a atmosphera das altas montanhas, que só convém ás águias; só essas outras chamadas águias da intelligencia se coraprazem nella, e podem receber sem fadiga os raios das deslumbrantes bellezas em suas retinas de aço.

E era o ambiente que convinha ao nosso artista, o qual demorou-se na Capella Sixtina até que os guardas pediramlhe que sahjsse, á hora em que Pio IX, pela segunda vez no dia, passeava na sua esplendida regia, de cujas galerias illustradas pelo gênio de Raphael abençoava a cidade eterna, já envolta no huraido manto do crepúsculo.

Daquelle paço enorme, cujas câmaras sobem ao fabuloso numero de onze mil, cujos magníficos museus encerram quanto ha mais prodigioso entre os primores das bellas artes, cujas tradições são a um tempo as mais formidáveis e as mais gloriosas, trouxe Agavino bem modificadas as suas idéas a respeito dos papas, e em particular do actual pontífice, cuja protecção ás sciencias, ás lettras e ás artes liberaes se parece tão pouco, em sua generosa munificencia e em sua nobre modéstia, com o que a tal respeito imaginam muitos reputados políticos brasileiros." AMÉRICO, Pedro. Op. cit. pp.304305. 
primeiros anos de École de Paris, por meio da cópia parcial do afresco realizada por Xavier Sigalon (1787-1837), concernente ao Julgamento Final ${ }^{155}$, era apenas lá, em Roma, que o jovem via a obra completa, incluindo a sequência célebres dos Ignudi (fig.5.17). Se, no entanto, eles não estabeleciam vínculo iconográfico direto com sua ninfa (embora se mantivesse um formal), forneciam um modelo potente de imaginação e reelaboração do legado da escultura clássica para o domínio da pintura e da prática do nu, o qual, ainda na metade do século XIX, também não deixava de inspirar inúmeros artistas de sua geração do (incluindo Carpeaux, Bonnat etc.).

Por fim, e para fechar esse circuito descritivo de obras célebres visitadas pelo jovem na cidade, ele deve ter muito provavelmente incluído o ciclo de afrescos da ala oeste do Palácio Farnèse ${ }^{156}$ (propriedade do império francês desde Luís XIV), então conhecida como Galeria Farnèse (15971608), encomendada por Odoardo Farnèse, sobrinho do papa Paulo III, a Annibale Carracci e sua oficina: esse, professor de Guido Reni, como apresentado, muito admirado e mesmo copiado por Américo. Segundo David Sutter, tratava-se do lugar em Roma que, depois da Capela Sistina, era a mais admirada pelos $\operatorname{artistas}^{157}$.

Como a obra de Rafael, o tema era inteiramente pagão, e o expediente, quase completo de nus. Tratava as relações de guerra e paz entre o Amor Celeste (ideal) e o Amor Terrestre (sensualista), e, desde o fim do século XVII (e ainda no século XIX), em decorrência das interpretações vindas de Giovanni Bellori, acreditava-se tratar da superioridade do primeiro sobre o segundo, numa exegese "idealista" desse autor, centrada em chave neoplatônica já bastante discutida em bibliografia sobre o tema $^{158}$. Para Bellori, a obra de Carracci respondia à altura os "agravos" causados pelo naturalismo da obra de Caravaggio, contemporâneo milanês de Annibale, também ativo em Roma. A leitura legada às gerações posteriores não era sem validade para Américo, que deveria sem muito esforço perceber nas obras desses artistas uma sorte de paralelismo com as discussões contemporâneas sobre o idealismo, representado por Cabanel, Baudry e Amaury-Duval ${ }^{159}$, o realismo moderado do regime napoleônico, e

155 A cópia foi feita entre 1834-37 por Xavier Sigalon (1787-1837) para a capela da instituição.

156 Nenhuma documentação ou descrição direta permite garantir a visita de Américo à Galeria, nessas suas primeiras viagens à Roma. A visita é presumível e naturalmente esperada, dada a celebridade do Palácio, desde Luís XIV, sob possessão francesa. $\mathrm{O}$ acesso do jovem à obra é ainda corroborado pelo conhecimento da obra dos Carraccis, que demostra ter; conhecimento melhor expresso talvez no seu discurso de "Distribuição dos prêmios aos artistas na Exposição Geral de Belas Artes de 1872". AMÉRICO, Pedro. Alguns discursos. p.70

${ }^{157}$ SUTTER, DAVID. Philosophie des Beaux-Arts apliquée à la peinture. Paris: Jules Tardieu, 1858. P.48.

158 GINZBURG, Sylvia. Op. cit. p.21; também LEE, Renssealer. Op. cit. e ainda PANOFSKY, E. Ideia ...

159 Se bem que, conforme discutido, sobretudo em Cabanel e Baudry, esse idealismo não parecesse castidade, segundo vários críticos, quando muito uma máscara para a aceitação do nu feminino erótico. 
o realismo extremo representado pelos nus propositadamente carnais e materiais de Courbet e Manet. Passado e presente da arte (como também da filosofia) continuavam a fornecer dois grandes blocos cíclicos de realização poética, a partir dos quais o jovem escolherá aquele fincado numa posição fortemente idealista, conforme argumentado no Capítulo anterior. Retomarei essa questão em seguida, na leitura que se fará de alguns aspectos da produção da Carioca.

Outro legado fundamental e bastante conhecido da grande sala de afrescos Farnèse, também consequência da fortuna crítica que havia começado com seus contemporâneos, estava na empreitada de Annibale, com colaboração do seu irmão Agostino, no sentido de refundar no Palácio, "em uma nova linguagem comum, as grandes tradições regionais da pintura do primeiro Cinquecento [italiano], a saber a escola romana de Michelangelo e Rafael, a escola de Veneza de Ticiano, e a escola Lombarda de Corregio" " $"$. No início do século XIX, Luigi Lanzi, em sua ação também sintetizadora de classificar e organizar as escolas artísticas italianas, oferecia em sua História da Arte uma leitura favorável de que, naquela obra, se combinavam "a elegância dos antigos Gregos e a graça de Rafael, com das imitações de Tibaldi, o favorito [de Annibale], mas também de Buonarroti, e com a vivacidade e força das escolas Venezianas e Lombardas. Essa foi a primeira obra na qual, como uma caixa de Pandora, os vários méritos de todos os grandes artistas italianos foram combinados em um só lugar."

Em sua defesa do legado "barroco" de Annibale, Lanzi contrapunha-se na verdade à recepção que os neoclássicos faziam também contemporaneamente à obra dos Carracci. A opinião destes últimos retomava com prejuízos a tese de equidades cíclicas da história da arte desenvolvida por Winckelmann em sua análise comparativa entre a arte antiga e o Renascimento. Winckelmann postulava, especificamente, que as artes egípcia e grega arcaica equivaliam ao estilo seco da arte italiana antes de Rafael; o alto estilo de Fídias, ao mais alto estilo de Leonardo e do último Rafael; o estilo belo de

160 GINZBURG, Sylvia. Op. cit. p.10-11. Tradução nossa. O excerto original: “C'est précisément dans cette réalisation - les contemporains l'avait bien compris - que le projet des Carracci, et notamment d'Annibale, parvient à son plein accomplissement: refondre dans un nouveau langage commun les grandes traditions régionales de la peinture du premier Cinquecento, à savoir l'école romaine de Michelangelo et de Raffaello, l'école vénitienne de Tiziano et l'école lombarde de Correggio".

161 O trecho inteiro, na tradução inglesa de 1831, é o seguinte: "The work is admirably distributed, and varied with ovals, cornices, and Telamons, the latter sometimes in stucco, sometimes in chiaroscuro; where we recognize his continued studies on the Farnese Hercules, and the Belvedere Torso, of which he could give and accurate drawing merely from memory. In the rest, too, we meet with the elegance of the ancient Greeks and the grace of Raphael, together with imitations not only of his favourite Tibaldi, but of Buonarroti also, as well as the sprightliness and strength to be found in the paintings of the Venetian and Lombard schools. This was the first work, in which, as in a Pandora's box, the various merits of all the great Italian artists were combined together in one view; and in its proper place, I notice the sensation it created at Rome, and the revolution it occasioned in the world of art." LANZI, Luigi. Lanzi's history of painting in upper and lower Italy. Vol. II [in two volumes]. Tradução de Rev. G. W. D. Evans. Londres: J. Hatchard and son, 1831. p.282. 
Praxíteles e Lísipo, ao belo estilo de Correggio e do jovem Rafael; o estilo "imitativo" e "eclético" dos romanos, ao ecletismo dos Carracci e seus seguidores; e por último, o período romano tardio equivalendo ao "decadentismo" percebido em Carlo Maratta (1625-1713) ${ }^{162}$. A paridade, como já se sabe, era explícita: Winckelmann queria definir uma abordagem que demonstrasse a eterna repetição de um percurso que passaria pelo "começo", "continuação", "estabilidade", "declínio", e "fimm" da arte em todos os povos ${ }^{163}$. E, segundo essa perspectiva, a arte precisamente chamada de "eclética" dos Carracci (cujo termo parece, segundo Albert Boime, ser retomado pelo teórico alemão a partir da Encyclopédie de Diderot ${ }^{164}$ ) aproximava-se do fim de um ciclo que deveria ser sempre evitado, ainda que inexorável $^{165}$. A postura era, significativamente, oposta a de Lanzi, que começava então a reavaliar esse modelo cíclico, relativizando a certeza que nele depositava o teórico alemão.

O projeto dos Carracci, revisionista e sintético, manteve-se geralmente mal apreciado até o início do século XX, mas não em unanimidade ${ }^{166}$. A partir precisamente dos anos 1860 (os anos parisienses de Américo), retomando as asserções de Bellori e Lanzi, a identificação do seu ecletismo (termo logo em seguida absorvido criticamente às teorias arquitetônicas ensinadas na École des Beaux-Arts) era já visto favoravelmente por diversos autores, incluindo David Sutter ${ }^{167}$, e se tornava ainda o modelo para uma linhagem de artistas "historicistas" e "filósofos" engajados na doutrina eclética de Vitor Cousin ${ }^{168}$, grupo no qual se incluía com crescente interesse, como tenho discutido, o jovem brasileiro, em suas

162 Sobre a reação do teórico alemão à obra dos Carracci, ver: WINCKELMANN, J. J. Histoire de l'art dans l'Antiquité. Traduction de Dominique Tassel. Paris: La Pochothèque, 2010. p.375; e novamente na página 522: "L'époque de la décadence des arts en Grèce aura sans doute été comme celle qui va de Michel-Ange et Raphaël aux Carrache. Durant cette période, l'art tomba dans une grande barbarie, y compris dans l'école romaine, et même les artistes qui écrivirent sur l'art, comme Vasari et Zuccari, étaient frappés d'aveuglement.".

163 Em inúmeros textos do século XIX, incluindo muitos brasileiros (Taunay, Porto Alegre, Bethencourt da Silva, Félix Ferreira, Gonzaga Duque, etc.), a escala encontra traduções em sínteses equivalentes derivadas daquelas de Winckelmann. A mais comum postura que todo ciclo artístico tem uma "infância, "progresso", "ápice", "declínio" e "decadência".

164 BOIME, Albert. Thomas Couture and the Eclectic Vision. Londres: Yale University Press, 1980. p.11. Sobre a influência de Diderot sobre Winckelmann, Boime faz referência à tese de Rudolf Wittkower. Imitation, eclecticism, and Genius. London: The Johns Hopkins Press, 1965. p.15. O trecho em que Winckelmann discorre sobre os Eclectici está na página 358 da tradução citada na nota anterior.

165 Sobre o preconceito dos neoclássicos contra a obra e Carracci, acusado de excesso formal, ver: BOIME, ibidem. p.11; p.13; p.14; p.21.

166 GINZBURG, Sylvia. Op. Cit.

${ }^{167}$ David Sutter - autor bastante caro a Américo, discutido no Capítulo anterior, e que será também discutido no Capítulo seguinte - havia aderido à vertente de pensadores da metade do século XIX que percebiam os Carraccis não como os representante de um ecletismo decadente (aliás, para Sutter, também o ecletismo era o verdadeiro método, tanto em arte como em filosofia ), mas de fato como um dos três maiores pilares de excelência da arte italiana, ao lado de Giotto e Rafael: "Giotto fut l'exemple de tous les peintres du quatorzième siècle, comme Raphaël fut celui du seizième, et les Carrache celui du siècle suivant. Ils furent les chefs des trois plus grandes écoles suivies par les peintres italiens." SUTTER, D. Op. cit. p.22.

168 SÉRIÉ, Pierre. La peinture d'histoire en France 1860-1900. Paris: Arthena, 2014. p.182-183. E ainda p.178. 
constantes preocupações com a importância da liberdade e com o conhecimento histórico dos diferentes estilos artísticos ${ }^{169}$ como maneira de julgar "com equidade e mesmo com benevolência todas as escolas, [e assim] lhes tomar o que têm de verdadeiro, e negligenciar o que têm de falso" ${ }^{170}$. Curiosamente, a comparação feita 100 anos antes pelo próprio Winckelmann entre os artistas "imitadores" da antiguidade romana e a filosofia eclética e historicista praticada no mesmo tempo por pensadores chamados de "Neo-Alexandrinos" não deixava de lembrar que se tratavam estes últimos, de fato, também uma fonte reflexiva importante para o método de Cousin ${ }^{171}$, embora este negasse naturalmente que o movimento sintético de sua abordagem fosse antes fruto de uma falta de habilidade imaginativa para criação de um sistema com ideias originais (resultado de uma época de decadência da humanidade), como pregava o alemão ${ }^{172}$.

Era essa - e aqui está a hipótese que tentarei desenvolver mais à frente - uma mesma intenção sintética, já expressa favoravelmente por Américo em seu opúsculo e longamente desenvolvida em seu Considerações Filosóficas, que também o guiara na produção de sua ninfa. É sugestivo que ela também encontrará certos paralelos visuais e iconográficos diretos com a obra de Carracci. Em uma das paredes da arcada da Galeria se encontra em afresco uma Vênus conduzida sobre as águas (e novamente a coerência do tema aquático, e dos exemplos que oferece ao jovem). Lá, uma ninfa sentada sobre um golfinho, que empresta, também ela, o modelo geral da clássica Vênus Agachada, reatualizada na síntese das "maneiras" italianas antecedentes (fig.5.70.); o corpo que se projeta em semicírculo; o braço direito em primeiro plano que se dobra em escorço em direção ao ombro oposto, num movimento devidamente contrabalanceado pela cabeça da náiade, que se lança à direita, observando o espectador; a perna direita que se flexiona para baixo, em oposição à esquerda, para cima; o cabelo que se reparte ao meio; enfim, uma série de lições bem apreendidas por Carracci, boa parte delas também presentes n' $A$ Carioca de Américo, a partir de uma fonte clássica em comum.

\section{Os modelos iconográficos próximos da náiade}

Todos esses exemplos romanos maiores eram no mínimo sugestivos para o jovem Américo, e sem dificuldades eles poderiam se multiplicar, a partir de reiterações similares em coleções que o jovem

169 Para uma recapitulação dessas questões em Américo, ver o Primeiro Capítulo da Tese.

170 COUSIN, Victor. Op. Cit. p.10.

171 Ver WILL, Frederic. Flumen historicum, Victor Cousin's aesthetic and its sources. Chapel Hill: University of North Carolina press, 1965.

172 WINCKELMANN, J. J. Op. cit. p.358 
aparentemente visitou em outras regiões italianas (Vêneto, Emília-Romanha [região da Bolonha], Toscana etc.). O que eles ofereciam, no entanto, como discutido anteriormente, não se resumia unicamente a uma relação iconográfica consistentemente conectada ao tema mitológico das águas ou das banhistas - importante, claro, pois a repetição desses motivos confirmava sem dúvida sua influência para a configuração da Carioca. Eles forneciam, além disso, o exemplo de sua adequação dentro de projetos, senão programas visuais complexos (nos quais também se cruzavam perspectivas filosóficas, históricas e políticas), em sua grande maioria com um destinatário preciso e célebre. Já nos anos 1860, eles haviam se convertido em modelos artísticos axiomáticos a partir dos quais a relação entre o encomendador e o artista tornara-se sinônimo de proteção artística, mesmo que as obras mais conhecidas não tivessem originalmente uma destinação pública, mas uma direcionada ao âmbito de fruição particular, com temas pagãos.

Como visto, grande parte dessas relações - a pintura mitológica/alegórica do nu, a destinação e o patronato - serão visadas desde o início por Américo. E elas eram ainda bastante válidas, porque a legitimidade dos modelos retrospectivos cultuados de Rafael para os Chigi e para o Cardeal Bibbiena, de Ticiano para Filipe II, de Carracci para os Farnèse, e de Bernini para os Borghèse, parecia se renovar de maneira mais ou menos evidente nos modelos atualizados e extremamente próximos de Gérôme, Cabanel e Baudry para Napoleão III, especialmente no Salon de 1863. Se bem que nesses últimos exemplos o padrão se modificasse um pouco (os famosos nus alegóricos e mitológicos daqueles três pintores não eram encomendas, mas compras realizadas após, ou mesmo antes de sua exposição oficial, um resultado natural das relações artísticas do período ${ }^{173}$ ), o resultado parecia ser o mesmo para os artistas: celebridade, obras vendidas a valores elevadíssimos e inseridas em coleções particulares para o deleite do olhar masculino (mantendo todas, no entanto, o respeito ao código mitológico, reforçado ainda por meio da idealização e "alisamento" das formas), e um acolhimento oficial aos artistas, que retomava o sucesso outrora experimentado por Ingres, o "pai” moderno do nu feminino.

Gêrome, como visto, desde 1859 na linha de frente das polêmicas sobre nus expostos nos Salons (L'intérieur grec, em 1859; Socrate venant chercher Alcibiade chez Aspasie e Phryné devant l'Aréopage, em 1861) continuava, apesar disso, a ascender em fama. Com ateliê repleto de alunos, recebia ainda em 1861 a importante encomenda do quadro Réception des ambassadeurs siamois par l'Empereur Napoléon III au palais de Fontainebleau para o castelo de Versailles, e antes mesmo de

173 A Perle et a Vague de Baudry, por exemplo, era comprada pela Casa Imperial antes mesmo de sua apresentação no Salon de 1863. 
terminá-lo era indicado, em fins de 1863, como um dos três professores do ateliê de pintura da École des Beaux-Arts recém-reformada.

Cabanel, cuja Nymphe enlevée par un faune havia sido comprada pelo Imperador em 1861, teria sua Naissance de Vénus adquirida em 1863 novamente por ele, logo antes de ser indicado, no mesmo ano, à Académie e também a uma cadeira da École, ao lado de Gérôme. Como o seu colega, tornava-se um dos artistas mais afamados do império, e com um "privilégio": era um dos raros pintores a participar mais de uma vez das recepções organizadas pelo imperador e sua esposa no castelo de Compiège, a partir de 1856 , sempre com grande repercussão na imprensa ${ }^{174}$.

Outra das outras poucas exceções era seu amigo Paul Baudry ${ }^{175}$, que depois de expor dois nus no Salon de $1859^{176}$, uma Madaleine pénitente e uma Toilette de Vénus ${ }^{177}$, e outros dois pequenos no de 1861 , Cybèle e Amphitrite ${ }^{178}$, fazia de sua Perle et la vague (isto é, de sua vênus contorcida), em 1863, a obra mais cara vendida naquela edição ${ }^{179}$, comprada também pela Imperatriz Eugénie ${ }^{180}$ para seu Napoléon. Pouco tempo depois, a proximidade iniciada nos bailes reais com os membros da casa imperial $^{181}$ lhe propiciará o enorme projeto de decoração da Ópera Garnier, começado efetivamente em 1865 (embora os rumores públicos já fossem ouvidos desde 1862) ${ }^{182}$.

Nesses exemplos contemporâneos ao jovem Américo, como naqueles dos séculos XVI e XVII, as semelhanças históricas pareciam evidentes (e não se pode esquecer que Américo acredita nos ciclos da história). Eles sugeriam um caminho para que o jovem entregasse a sua Carioca conjuntamente a Considerações Filosóficas, e afirmasse estar pronto para ser abraçado como um agente importante e oficial das artes do Império brasileiro, ativando assim seus próprios projetos políticos. Como será

174 HILAIRE, Michel; Amic, Sylvain. Alexandre Cabanel : 1823-1889 : la tradition du beau [Exposition, Musée Fabre, Montpellier, 10 juillet - 5 décembre 2010, Wallraf-Richartz-Museum \& Fondation Corboud, Cologne, 4 février - 15 mai 2011]. Paris Montpellier : Somogy éditions d'art : Musée Fabre, impr. 2010.

175 VITAL, Christophe (ed.). Paul Baudry, 1828-1886. [Exposition, Historial de la Vendée, 26 octobre 2007 - 3 février 2008]. Paris: Somogy, 2007. p.77.

176 GUILLAUME, Eugène. Catalogue des oeuvres de Paul Baudry. Paris: École Nationale des Beaux-Arts, 1886. pp.52-54.

177 A Toilette de Vénus foi comprada ainda em 1862 pelo Museu de Bordeaux. VITAL, C. Op. cit. p.286.

178 GUILLAUME, E. Idem, Ibidem. Pp.59-60.

179 MCCAULEY, Anne. Op. cit.

180A imperatriz era frequentadora do ateliê de Baudry desde 1862, e sua cliente em várias obras. Ver: VITAL, C. Op. cit.

181 A partir de 1863 Baudry participa ainda com assiduidade das soirées semanais organizadas pela princesa Mathilde, sobrinha de Napoleão III, concubinada com o poderoso Nieuwerkerke (diretor das Belas-Artes e, como visto, agente maior das reformas de 1863), e personalidade que tem "papel certamente essencial na carreira de pintor oficial de Paul Baudry". cf. VITAL, C. Op. cit. p.79.

182 Idem, Ibidem. p.78. 
discutido no penúltimo Capítulo desta Tese, não era de modo algum casual o fechamento que o texto $A s$ cartas de um plebeu (publicado em tom já um pouco melancólico mas ainda esperançoso) fazia desse círculo de projeções, com o qual Américo desejava afirmar sua capacidade de ação política e intelectual. Com essas obras, e aqui, especialmente, com a sua ninfa, ele almejava uma recepção similar e interessada junto à Casa Imperial. Muito provavelmente, Américo tinha em mente o tipo de relação que o imperador e a imperatriz franceses tinham com os artistas. $\mathrm{O}$ que talvez ele não tivesse em mente, é que a casa imperial brasileira era muito distinta da casa imperial francesa. A recusa brasileira contrastaria fortemente com a política deliberada e contínua de consumo de nus da casa francesa, frustrando as prováveis expectativas do artista.

\section{Uma síntese cronológica sobre a gênese e produção da Carioca}

Em meio à quantidade considerável de informações fornecidas, uma rápida recapitulação sobre a gênese e período de produção da Carioca talvez sejam necessárias. Em resumo, os exemplos das esculturas antigas de ninfas e vênus banhistas como modelos absolutos dessa iconografia já eram bastante conhecidos por Américo há quase 10 anos, desde 1855, ainda na AIBA. Parece ser numa confluência dessas referências primárias, com o acesso regular do tema às inúmeras esculturas e pinturas que rodeavam Américo em seu espaço subsequente de vida em Paris; com o retorno estrondoso dessa iconografia nos primeiros anos de 1860 (Cabanel, Baudry, Amaury-Duval, Gérôme, Bouguereau, Moreau, Courbet, Manet etc); com o "contraexemplo" da escultura de Rochet, em 1861; com as experiências londrinas e, sobretudo, italiana; e com o resultado dos seus estudos teóricos e filosóficos no concurso de figuras inspiradas na antiguidade, que se desenha um horizonte favorável para o nascimento de uma náiade branca e brasileira, segundo Américo a conceberá, e receberá como afirmativo de Jacobina.

Os dados aqui apresentados, se organizados sinteticamente e combinados com outros circunstanciais, permitem esboçar por fim três arcos temporais contínuos, mais ou menos bem delimitados, que esclarecem portanto o percurso de elaboração e aparição da pintura.

O primeiro se estende de maio de 1861 ao fim de 1863, na sequência portanto do Salon de 1861, das viagens e da chegada de Antônio Jacobina a Paris. Nesse arco, parece surgir a "ideia" da obra, e a sua proposição/encomenda/aceitação à/da Casa Imperial, intermediada por seu secretário.

O segundo, do início de 1863 até o fim desse ano, no qual Américo inicia efetivamente os estudos 
e execução da obra em meio aos polêmicos Salons das Vênus, sem contudo terminá-la até o final daquele ano.

E um último lugar, um arco que se estende do começo de 1864 ao começo de 1865 . Esse, relativo à conclusão da obra, à sua primeira exposição, aparentemente em Paris, ao retorno de Américo ao Brasil para inscrição no concurso da AIBA, a alguns retoques feitos na tela ${ }^{183}$, à apresentação da Carioca em uma sala particular no Rio de janeiro, em janeiro de 1865, e sua inclusão logo em seguida na EGBA, em fevereiro; por fim, a oferta ao imperador e a sua recusa ${ }^{184}$.

183 A informação da exposição da pintura ainda em Paris e dos retoques que sofreu é fornecida por Luiz Guimarães, em 1871. cf. GUIMARÃES JÚNIOR, L. Op. cit. Ainda não pude encontrar dados que confirmem essa informação.

184 Segue uma cronologia resumida desse período: Primeiro bimestre de 1862, Londres; De 01 de abril (concours de places) até fim de junho de 1862 (data de carta às tias, enviada de Paris), está em Paris; período da primeira viagem à Itália, em 1862: início: depois do início de Julho; fim: antes do início de novembro. (duração máxima 4 meses). Em 11 novembro de 1862, inscrição na universidade de Bruxelas (em seguida, possivelmente, Londres mais uma vez); 31 de janeiro de 1863, em Paris (segundo lugar no concurso de figuras); entre Abril e o fim do ano de 1863, Paris. 


\section{Quinto Capítulo}

\section{Um ideal branco e sem tragédia: ou uma beleza anti-indianista para a arte brasileira.}

\section{A precisão iconográfica}

Em $A$ Carioca estão todos os elementos tradicionais da alegoria à água, reelaborados continuamente pela pintura desde o Renascimento, a partir das indicações dos escritos e esculturas gregos ${ }^{185}$. Sua

${ }^{185}$ É absolutamente necessário insistir aqui na identificação que faço da Carioca como uma ninfa, colada ao tema das águas e ao filão das Vênus e banhistas tão recorrente no século XIX, já que esta interpretação diverge de maneira significativa de algumas avaliações recentes que encontram na mesma pintura "uma mulher de raça híbrida" (ver, em seguida, OLIVEIRA, Cláudia), ou, ainda, a possibilidade de uma alegoria republicana ou uma alegoria à Liberdade, avaliação vinda sem dúvida da identificação que se faz de Américo como um republicano ou anti-monarquista, sobretudo a partir da interpretação de toda uma bibliografia sobre os trabalhos que ele produz no Brasil a partir da década de 1870 Batalha de Campo Grande, Batalha do Avahy, etc (Para essa interpretação, ver especialmente: PEREIRA, Sônia Gomes. "O percurso e os dilemas de artistas brasileiros em Paris no século XIX: o caso da tela A Carioca de Pedro Américo." In: RIBEIRO, Marilia Andrés; GONÇALVES, Denise da Silva (Orgs.) Anais do XXI Colóquio do Comitê Brasileiro de História da Arte. Tiradentes/MG, outubro de 2005. Belo Horizonte: Editora C/ Arte, 2006. [pp.292-301] p.299.)

De fato, há uma verdadeira insistência (que no mais das vezes não encontra qualquer anteparo documental) em defender Américo desde jovem como um republicano, ora escancarado, ora escondido (um artista-herói-republicano), e de perceber defesas republicanas em suas obras enviadas ou compradas pelo Império, tudo isso apenas porque estabeleceu relações pessoais com republicanos, que não confirmam nada além do fato de ter amigos republicanos. Pouco se discute, por exemplo, sobre os também muitos e verdadeiros amigos monarquistas, "liberais" e "conservadores", que colaboraram com ele durante toda a vida, e com quem manteve íntimo contato (Olinda, Pedreira, Sá e Albuquerque). Américo nunca esteve ligado a um partido direto e é curioso que sempre tenha tentado suas ações políticas a partir primeiro de suas ligações com "conservadores", e somente se na falta disso com "liberais" ou "republicanos". Em termos de política, o artista sempre trabalhou na via do meio, e nisso estava uma de suas armas políticas para permanecer tanto tempo em visibilidade. De todo modo, seus principais contatos com republicanos e abolicionistas (como Joaquim Nabuco) começaram apenas a partir de 1882 , e isso porque não percebia muito mais possibilidades no poder vigente para seus próprios projetos. Não se tratava de uma postura política ideologicamente definida (com efeito, do mesmo modo muitos dos maiores políticos do Segundo Império ora estavam ligados aos chamados liberais, ora aos conservadores).

São, a meu ver, três confusões e uma subestimação ao pintor os motivos que parecem justificar ambas as suposições (da Carioca como uma alegoria à República ou à Liberdade, e de Américo, como um republicano enrustido).

De início, uma confusão objetual: a identificação da Carioca como uma alegoria republicana parece ser fruto do cruzamentos históricos e contextuais recorrentemente feitos entre a primeira e a segunda versão da obra. Refere-se à recepção negativa da primeira partindo sempre do contexto da segunda, que foi logo em seguida incorporada ao acervo da AIBA, e feita quase duas décadas depois, com propósitos e intenções de recepção completamente distintos. Poderia, entretanto, quem sabe, ter sido mesmo incorporada na década de 1860, haja visto a medalha de ouro em 1865 , não fosse um presente para o imperador. Essa é, a meu ver, uma visão bastante problemática que desenvolve Cláudia de Oliveira, em uma série de textos publicados sobre $A$ Carioca desde 2006, o mais recente, de que tenho conhecimento, de 2013. Além de dados básicos bastante equivocados (que incluem erros de informação sobre a formação do jovem, de data da conclusão da pintura, de suas exposições, de suas ofertas etc.), a interpretação que autora faz da segunda Carioca, interrogando sobre o destino e características da primeira, a coloca como uma obra que "aproxima-se das concepções realistas da segunda metade do século XIX, ou seja, das culturas visuais da modernidade: o realismo, o naturalismo e as novas tecnologias da imagem, como a fotografia." A autora ainda propõe que "Em A Carioca [...] predominam as curvas e as ondulações. [...] A curva é livre, sensual e emocional" Trata-se, precisamente, do oposto das leituras desenvolvidas nesta Tese, como será visto em seguida, ainda neste Capítulo. Ver: OLIVEIRA, Claudia de. "A Carioca' de Pedro Américo: gênero, raça e miscigenação no Segundo Reinado". In: CAIANA. Revista electrónica de Historia del Arte y Cultura Visual del Centro Argentino de Investigadores de Arte (CAIA). No $2 \quad$ Año 2013. Disponível online em: http://caiana.caia.org.ar/template/caiana.php?pag=articles/article_2.php\&obj=98\&vol=2 [último acesso: janeiro de 2016]. Ver ainda: OLIVEIRA, Cláudia de; NERY, Laura de. "A Carioca, de Pedro Américo: alegoria e erotismo no imaginário oitocentista brasileiro." In: ANAIS do XXIV Simpósio Nacional de História - ANPUH/ Simpósio temática História Cultural e 
descrição "moderna" precisa era elaborada e difundida por Cesare Ripa, em sua Iconologia" ${ }^{186}$ : uma mulher nua, com longos cabelos em cachos; uma urna de onde brota e jorra a água; a representação de uma paisagem que a contorna (uma invenção veneziana Giorgionesca, ampliada por Ticiano ${ }^{187}$ ). E o significado cultural dessa personificação, combinada com os demais elementos, era bastante conhecido e difundido ainda no século XIX: a identificação das características femininas com a natureza, a "matéria" informe e inconstante, em oposição à interpretação oposta das características masculinas: o homem como agente constante que a molda, que a [en]forma e, por derivação, como cultura ${ }^{188}$.

Num estreitamento iconográfico, Américo declinava a sua imagem alegórica duas vezes para chegar à indicação precisa da fonte da Carioca: de representação do elemento água à sua primeira

suas interfaces. São Leopoldo (RS): Unisinos, 2007.

Disponível em: http://www.ufrgs.br/gthistoriaculturalrs/laura_nery_e_claudia_de_oliveira.html [último acesso: janeiro de 2016].

Desse cruzamento soma-se um outro, que estabelece uma confusão de ordem política: nos anos 1860 não há quaisquer questões ou oposições suficientemente formadas sobre o fim da monarquia no Brasil, nem defesas sobre uma "revolução". Nesse período, ao contrário, como sugerido no Primeiro Capítúlo, os debates políticos giravam em torno dos "liberais", "moderados" e "conservadores" (categorias aliás nenhum pouco fixas, que comportavam câmbios, subcategorias ou agentes difíceis de qualquer categorização), todos monarquistas, que disputavam entre si, e tentavam compreender teórica e legalmente os limites do poder Executivo e Moderador, todos concernentes a d. Pedro II. Américo, se pensasse a sua pintura como uma alegoria à república anteciparia, na França, um cenário de debates políticos que precisaria ainda de vários anos para se amadurecer e chegar a oposições diretas ao governo imperial; algo que me parece, naturalmente, bastante improvável, para não dizer mesmo impensável.

Em terceiro lugar, uma dificuldade iconográfica: o único amparo para essa defesa da Carioca como uma imagem republicana (hipótese de Gomes Pereira) se liga ao fato de ter os seios à mostra, característica que é de todo modo um topos das alegorias femininas. Se a distinção histórica entre primeira e segunda obra fosse ainda assim levada a termo para afirmar que a segunda, feita em 1882, já comportasse uma leitura da República, um pequeno acréscimo pictórico feito nela justifica ainda a sua permanência dentro do domínio das alegorias aquáticas, ligadas à ideia da beleza e da (sub)divindade. Das poucas mas significativas variações presentes nas duas obras (sobretudo no cabeça da ninfa, e isso, em decorrência da recepção crítica da pintura nos anos 1860), há uma adição iconográfica fundamental na segunda versão. Nela, Américo inclui ao pé da ninfa a representação da uma flor de lírio, símbolo bastante conhecido da beleza ideal, segundo as indicações iconográficas clássicas, bastante difundidas também a partir da Iconologia de Cesare Ripa. Estou ciente que tal interpretação iconográfica não pode ser tomada como conclusiva (problematização sugestivamente desenvolvida pelo trabalho de um historiador da arte como Daniel Arrasse: ARRASSE, Daniel. On y voit rien. Paris: Denoël, 2005.), mas estou seguro de que, nesse caso, a pequena adição da flor que Américo fazia na segunda versão da náiade se somava a outros indícios ainda mais claros da relação da sua figura com a alegoria fluvial e com a ideia de uma divindade brasileira; questão que tratarei melhor no fim deste Capítulo.

Por fim, a subestimação: a obra, pela menos a primeira, foi, como visto, desde o início pensada para ser ofertada ao imperador, e é de se rebaixar as intenções pessoais e os projetos de Américo se se supõe que ele ofertava uma leitura republicana, segundo Gomes Pereira, ou uma "provocação", segundo Oliveira, para o representante do poder monárquico, que havia lhe dado ademais 5 anos de bolsas, e que representava o acesso mais imediato à implementação de seus planos profissionais no Brasil.

186 RIPA, Cesare. Iconologia. ed. MAFFEI, Sonia. Torino: Giulio Einaudi, 2012.

187 cf. GENTILI, AUGUSTO, ENTRE OUTROS, que dizem que é de Giorgione a invenção da alegoria em "pleinair".

188cf. SAUNDER, G. p.91, e sobretudo p.93. Para um estudo sobre as características "femininas" na arte, ver ainda: SHAW, Jennifer. Op. cit. 
declinação, a da ninfa; e desta, para uma de suas variações, a da náiade ${ }^{189}$, cujas diferenças nominais e acessórias com outras ninfas (Nereidas, Dríades, Hamadríades, Oreádes etc.) eram bastante conhecidas pelos artistas e popularmente resumidas na década de 1860, por exemplo, pelo Dictionnaire Universel Larousse du XIXe siècle ${ }^{190}$.

Esse "rebaixamento" era consciente, sem dúvida, mas sobretudo necessário para um jovem que desejava antes de tudo não se tornar um "imitador dos gregos", ocupando-se apenas dos princípios artísticos que haviam descoberto. Na falta de uma mitologia brasileira que outorgasse a representação de uma genuína Vênus Carioca (aliás, as Vênus são Vênus, não importante onde), e na recusa em representar uma alegoria provinda de uma recente invenção da mitologia indígena pela literatura brasileira - em função do consentimento de Américo às teorias raciais do período, conforme será tratado em seguida -, ele tem que adequar suas aspirações idealistas aos problemas que aquela iconografia lhe impunha desde o início, para além do problema potencial que já se apresentava a todas as alegorias femininas nuas, fossem mesmo Vênus ou "castas" Dianas: isto é, provar que a representação dessas imagens não era apenas um pretexto do artista para utilizar "o privilégio de mostrar sem véus os charmes da mulher", como sugeria um outro verbete (baigneuse [banhista]) do Larousse ${ }^{191}$.

Em seu valor originalmente mitológico (que se replicava em figuras de linguagem culturalmente

189 O próprio jovem irá se referir algumas vezes em suas cartas, inclusive a d. Pedro II, se tratar A Carioca de uma náiade.

190 O verbete Ninfa, do Larousse, distingue os seguintes tipos: "On appelait naïades les nymphes des fontaines, néréides celles des mers, limmades celles des étangs, dryades et hamadryades celles des bois, oréades celles des montagnes, napées celles des prairies, etc., etc." LAROUSSE, Pierre. Grand Dictionnaire Universel du Dix-neuvième Siècle, tome.11. Paris: Administration du Grand Dictionnaire Universel, 1866-1874. p.1173. Para um verbete ainda mais antigo, mas de todo modo similar ao do Dicionário Larousse, ver: FURETIERE, Antoine. Dictionnaire universel contenant généralement tous le mots françois, tant vieux que modernes, et les termes des sciences et des arts. Volume 2. Paris: Arnoud et Reinier Leers, 1701. p.1067.

191 "Comme on le voit par les descriptions qui précèdent, de tout temps, les peintres et les sculpteurs ont eu le privilège de nous montrer sans voiles les charmes de la femme. Les artistes de l'antiquité n'ont pas manqué de prétextes pour user de ce privilège; lorsqu'ils voulaient représenter une femme vêtue de sa seule beauté, ils n'avaient que l'embarras de choisir parmi les gracieuses divinités proposées au culte de tous. C'est aussi dans la mythologie que les artistes modernes ont puisé le plus souvent leurs inspirations, lorsqu'ils out voulu peindre le nu. Qui pourrait dire combien de Vénus, de Dianes, d'Arianes, de Nymphes, de Naïades, sont écloses sous le pinceau ou le ciseau des maîtres de toutes les écoles! Les occasions de représenter la femme dans toute sa séduisante nudité ne se rencontrent guère dans l'épopée chrétienne; elles sont moins rares dans la Bible. Ils nous suffire de citer Suzanne et Bethsabée, surprises au bain, la première par les vieillard, la seconde par le roi David, deux sujet bibliques qui depuis la Renaissance jusqu'à nos jours, ont été traités presque aussi souvent que celui de Diane au bain. Quel tableau plus gracieux que celui d'une baigneuse, tremblant d'être surprise par quelque indiscret et cherche, par son attitude, à dérober ses charmes qu'elle découvre dans sa précipitation! Une foule d'artistes, peintres et sculpteurs, se sont emparés de ce thème et l'ont traité en dehors de toute préoccupation historique." LAROUSSE, Pierre. Grand Dictionnaire Universel du Dix-neuvième Siècle. Tome 2. Paris: Administration du Grand Dictionnaire Universel, 1867, p.57. 
correntes, fossem no Brasil ou na França, as mesmas ainda hoje existentes), a ninfa estava sem dúvida mais próxima desse perigo ${ }^{192}$. Enquanto divindade subalterna, transitava entre dois mundos e duas atitudes: entre o dos mortais e os dos deuses, entre o "real" e o "ideal", entre a nudez libidinosa e a casta (ora ela acompanha Diana ou Afrodite em seus banhos, ora é requerida, com ou sem seu aval, nas camas masculinas dos dois mundos), e entre a sua dupla natureza dionisíaca-apolínea, herdada ao mesmo tempo da Vênus Pandêmia (associada na cultura cristã à Eva ${ }^{193}$ ) e da Vênus Anadiomena ou Celeste (em sua natureza imaculada, como a Virgem Maria).

Américo escolhe um nu banhista que se mostra sem vergonha, e que devolve o olhar ao espectador, num resgate preciso de uma tipologia da banhista também iniciada no século XVI (Rafael, Julio Romano, Giorgione, Ticiano, Tintoretto, Veronese) e num diálogo ainda direto com as pinturas de nus dos anos 1850 e 1860 (Ingres, A. Cabanel, E. Manet, P. Baudry, J.-E. Delaunay), em contraste com uma iconografia mais “teatral", recorrente no século XVII (na qual aparece a surpresa ou a falsa surpresa da mulher que se percebe observada enquanto nua, em sua intimidade), e ainda mais com aquela do século XVIII, reputada por vezes de sensualista ${ }^{194}$, imoral e escandalosa, a partir dos exemplos mais conhecidos de Watteau, Boucher e Fragonard. Em 1861, ele havia de fato testemunhado todas as críticas recebidas pela Frinéia diante do Areópago, de Gérôme. A pintura havia sido avaliada negativamente por escritores mais conversadores justamente em função do gesto dado à Frinéia, que embora sendo "a beleza incarnada em mulher", em lugar de exibir com orgulho e castidade suas formas perfeitas diante do tribunal que iria lhe julgar, cobre pudicamente seu rosto no momento em que o advogado que a defende repentinamente desvela o seu corpo ${ }^{195}$.

A escolha do jovem Américo, conforme sugerido, havia delimitado positivamente (embora não houvesse esgotado a possibilidade de intercâmbio do) seu campo iconográfico. Não se tratariam de episódios bíblicos ou ainda mitológicos nos quais a exposição do corpo feminino ganharia um sentido moralizante e com um desfecho sempre funesto para o voyeur, com algumas exceções em certos

192 Sobre o problema da ninfa em sua maior proximidade com o "real", ver: HADDAD, Michèle. La divine et l'impure: le nu au XIXe. Paris : Jaguar, 1990 : " La nymphe est beaucoup plus proche de la femme réelle qu'une déesse de l'Olympe qu'il convenait alors de voiler d'idéal; elle n'exige aucune érudition, ni du peintre, ni du spectateur, et permet de peindre le nu, ou tout au moins, de peindre de nudités. Face aux sujets contemporains mis à l'honneur par les réalistes, véhicules subversifs de toutes les idées nouvelles, les nymphes fournissaient aux artistes des sujets de compositions aimables et sans danger pour l'Académie et le Gouvernement." P.24.

193 Ver: PANOFSKY, E. Estudos em iconologia. Lisboa: Editorial Estampa, 1995, especialmente os capítulos V e VI: "O movimento neoplatônico em Florença e no norte da Itália" e "O movimento neoplatônico e Michelangelo".

194 COUSIN, V. Op. cit. p.308-09.

${ }^{195}$ JAGOT, Hélène. Jean-Léon Gérôme Néo-Grec, l'Antiquité dévoyée. Paris: Rumeur des Ages, 2010. p.38. 
$\operatorname{artistas}^{196}$ (Suzana espiada e assediada por velhos, julgados e sentenciados à morte; Betsabéia observada por David; Diana surpreendida em seu banho por Actéon, que é transformado em cervo e devorado em seguida por seus cachorros), mas de um tema derivado da iconografia original das ninfas e deusas no banho, iniciado pela escultura grega, e relacionado ainda mais intimamente à iconografia do nascimento da Vênus Anadiomena em meio às águas, pela pintura.

A exposição da nudez ideal - portanto universal e, em seu sentido neoplatônico, uma beleza “inteligível"197 - não pode ser, nessa perspectiva, uma afronta moral, mas um espetáculo divino, digno de ser apreciado (mesmo que sua origem mitológica, esquecida, fosse o fruto de um episódio trágico $\left.{ }^{198}\right)$. Uma iconografia da qual o exemplo do Nascimento da Vênus de Botticelli, embebida por sua vez novamente em referências à escultura e a textos clássicos, inaugura uma via importante na pintura ocidental - e que Américo, se tendo realmente passado em Florença em 1862, pôde ver de perto, na Galeria dos Uffizi. Com efeito, em suas implicações com o legado da filosofia platônica, a derivação, mas sobretudo o direcionamento dado pelo jovem na escolha daquela iconografia ainda dialogava, com interesse, com a imagem da Vênus em sua estreita relação com os conceitos da Beleza e da Verdade (afinal, é frequente que a deusa seja a expressão visível desses valores na tríade filosófica platônica, ainda bastante defendidas em sua necessária relação pela filosofia de Victor Cousin ${ }^{199}$ ), ambas alegorias também apresentadas em formas femininas e nuas (e o mesmo Botticelli, como se sabe, havia feito uso formal similar dessas representações): a Verdade se apresenta nua e crua ${ }^{200}$, a Beleza, sem véus ${ }^{201}$.

A Carioca é sem dúvida pensada a partir da triangulação desses conceitos filosóficos, todos convergindo, portanto, para o seu denominador alegórico comum: a imagem feminina em seu estado naturalmente ideal. O propósito conceitual, e mesmo a inspiração de alguns detalhes da cena da náiade, parecia ser mesmo reforçado por inspirações também textuais.

${ }^{196}$ É o caso, por exemplo, da Suzanne au bain (1550), de Tintoretto, presente no Louvre [título oficial, que substitui a denominação mais comum de "Suzana e os Velhos"]; obra na qual o artista cria um jogo de cumplicidade entre a Suzana e o espectador, para quem ela olha fixamente, em contraste com a intromissão dos olhares concupiscentes dos velhos, ao fundo.

197 Para algumas questões sobre o conceito de beleza e sua relação com o neoplatonismo renascentista, ver: PANOSKY, E. Essais d'iconologie. Thèmes humanistes dans l'art de la Renaissance. Paris: Gallimard, 1967. p.225.

198 O nascimento da Vênus Celeste ou Anadiomena é contado a partir da castração de Urano por seu próprio filho, Saturno, cujo falo, caído do céu sobre o mar, cria um redemoinho caótico de sangue, esperma e espuma, no qual surge a deusa triunfante.

199 Para uma leitura sintética, mas esclarecedora, sobre a relação do Belo com a Verdade em Cousin, ver: HELMREICH, C. Op. cit. pp.203-204.

200 Para uma discussão sobre o nu e suas variações no Renascimento e Barroco, incluindo a da Nuditas Veritas e Nuditas Pudica, ver: PANOFKSY, E. Essais d'iconologie. Paris: Gallimard, 1967, p.227-233.

201 DIDI-HUBERMAN, Georges. Ouvrir Vénus. Nudité, rêve, cruauté. Paris: Gallimard, 1999. p.18-22. 
No conjunto de textos que Américo maneja no início dos anos 1860 para adensar suas próprias observações e proposições, retorna com insistência aquele de Émeric-David, e aqui um trecho em especial, que lida com sua vez com algumas passagens poéticas clássicas. Tratava-se de um excerto que servia ao mesmo tempo à compreensão das causas e da análise racional da beleza nos gregos, a partir da apropriação que o francês fazia do diálogo de Agatão - contado originalmente por Theocritus, Aristóteles e Terêncio - tendo por tema a reflexão sobre a beleza da jovem Hélice:

E como, com efeito, se recusar a essas verdades, quando busca-se o princípio da beleza do corpo humano? ${ }^{202}[\ldots]$ Eu necessito dos prazeres do homem terrestre e aqueles do ser divino. Ah, se o belo e o bom não fossem, com efeito, a mesma coisa! Beleza perfeita da qual nenhum mortal pode ignorar os charmes; beleza divina para a qual os Gregos elevaram altares, digne-se de mostrar-se aos meus olhos, e assim, o coração ardendo, os braços estendidos em sua direção, eu me prostro e te adoro! [...] O belo Agatão, o discípulo de Sócrates, amava a jovem Hélice, e dizia: [..] ela é alta, entretanto menos do que eu [..] uma pele compacta e lisa, os ossos que se adivinham e que não se percebem, prometem ao tocar uma satisfação recíproca e doce. [...] Os gregos admiram voluptuosamente a elegância dos pés: que vida, que graça, que espírito no seu adorável pé! Tornozelos finos e sólidos portam sem fadiga o peso do corpo; seu calcanhar leve mal toca o solo; os dedos livremente aproximados concorrem todos ao conjunto do movimento. Não, eu não posso expressar a perfeição do seu rosto! Sua cabeça, leve e quase redonda, é um doce fardo para seu pescoço reto, flexível e liso. Os cachos numerosos do seus cabelos se dividem por sobre suas sobrancelhas levemente arqueadas, me deixando ver a pureza de sua face e aquele do seu olhar. Suas sobrancelhas não são muito juntas, e entretanto não são também separadas. Seus olhos, que elas animam, grandes com moderação, e bem destacados, são ainda protegidos por longas e públicas pálpebras. [...] Seu nariz, reto e cerrado, que não é aquilino, mas que se acreditaria dispor a ser; o leve intervalo que o separa da sua boca levemente aberta; um queixo docemente arredondado; dentes frescos e brilhantes como pérolas da manhã; todas essas partes de sua figura foram modeladas seguindo esse feliz princípio.[...] Hélice, Hélice, não me pare! Seus seios, delgados como botões de rosa, mas também delicados, foram separados um do outro com prudência: esse é o travesseiro do amor, quando a cabeça do Deus repousa sobre a penugem. Ser completo! Eu poderia admirar tanta beleza e não te amar ainda! [...] Você fixou em minha alma a ideia da beleza humana e a da perfeição divina. Se Zeuxis tivesse te conhecido, ele não teria procurado várias modelos. Assim falava o belo Agatão. ${ }^{203}$

202 [Tradução nossa]. O original: “[..] Eh! comment, en effet, se refuser à ces vérités, quand on recherche le principe de la beauté du corps humain?" EMERIC-DAVID, T.-B. Recherches sur l'Art Statuaire: considéré chez les anciens et chez les modernes ou mémoire sur cette question proposée par l'Institut National de France: quelles ont été les causes de la perfection de la Sculpture antique et quels seraient les moyens d'y atteindre?. Paris: Mme Ve Renouard, 1863. p.40.

203 [tradução nossa]. O original é o seguinte : “[...] j'ai besoin des plaisirs de l'homme terrestre et de ceux de l'être divin. Oh! si le beau et le bon n'étaient, en effet, qu'une même chose! Beauté parfaite dont nul mortel ne peut méconnaître les charmes; beauté divine à laquelle les Grecs élevaient des autels, daigne donc te montrer à ma vue, et que, le coeur brûlant, les bras tendus vers toi, je me prosterne et je t'adore!...Le bel Agathon, Agathon, le disciple de Socrate, aimait la jeune Hélice, et il disait: [..] Sa taille est haute, moins cependant que la mienne, car la Nature m'a donné la force pour notre bonheur commun. Aimable pudeur, ne me dérobe pas se belles épaules [..] Une chair compacte et polie, des os que l'on devine et qu'on n'aperçoit pas promettent au toucher une jouissance réciproque et moelleuse. [..] Les grecs admirent voluptueusement l'élégance des pieds: que de vie, de grâce, d'esprit, dans son pied charmant! Des malléoles fines et solides portent sans fatigues les poids du corps; son talon léger effleure à peine la terre; des doigts librement rapprochés concourent tous à l'élan de sa course. Non, je ne puis exprimer la perfection de ton visage! Ta tête, légère et presque ronde, est un doux fardeau pour ton cou droit, flexible et poli. Les boucles nombreuses de tes cheveux se partagent au-dessus de tes sourcils faiblement arqués, me laissent voir la pureté de ton front et celle de tes regards. Tes sourcils ne sont pas joints et ne sont 
Essa passagem havia marcado especialmente Américo. De início, na descrição oferecida por Émeric-David - pautada em textos clássicos -, parecem coincidir alguns elementos retrabalhados poeticamente em A Carioca, mas também nas obras de diversos outros artistas, anteriores ou posteriores à sua, que também dedicavam apreço ao legado clássico - e alguns, o jovem havia visto com certo hábito. (P. P. Prud'hon, fig.5.80., Gerôme fig.5.1., Jules Lefebvre, fig.5.47., Gainsborough, fig.5.2., Corot fig.5.83., Manet, fig.5.84.). Talvez o elemento poético mais sugestivo nessa passagem é o da imagem do pé feminino que mal toca o solo, imagem que ao ser absorvida no tema das banhistas, se configura como a imagem do mesmo pé a tocar docemente a superfície da água.

O mesmo trecho trabalhado por Émeric-David continuaria a ser, em seguida, importante para o brasileiro. É absolutamente significativo constatar que o jovem, desconsiderando o ponto fundamental de análise para Émeric-David ${ }^{204}$, iria ler no trecho acima citado o exato oposto do que o autor originalmente queria. Ele retomava aquele excerto em Considerações Filosóficas a partir de um processo bastante hábil de tradução/transcriação, no qual o devaneio de Agatão sobre a beleza e o contentamento que lhe propiciava a "real" Hélice era inteiramente convertido em frases que utilizou para analisar a beleza excelsa e insuperável da "ideal" Vênus de Milo ${ }^{205}$. Mais uma vez, Américo queria submeter ao "Belo ideal" todo o controle sobre o "belo real", para deixá-lo mais próximo da presumida contemplação racional, processualmente anestética, que aquela primeira categoria exigiria, e da qual $A$ Carioca era pensada ser representante.

pourtant séparés. Tes yeux, qu'ils animent, grands avec modération, et bien enchâssés, sont encore protégés par de longues et publiques paupières. [..]. Ton nez droit et ferme, qui n'est point aquilin, mais qu'on croirait disposé à le devenir; le léger intervalle qui sépare de ta bouche à peine ouverte; un menton doucement arrondi; des dents fraîches et brillantes comme des perles de la rosée du matin; tous ces parties de sa figure furent modelées suivant ce principe heureux. [...]Hélice, Hélice, ne m'arrête pas! Tes deux seins, élances comme des boutons de rose, mais aussi délicats, furent écartés l'un de l'autre avec prudence: tel est l'oreiller de l'Amour, quand le duvet fléchit sous la tête du Dieu. Être accompli! J'aurais pu admirer tant de beauté et ne point t'aimer encore! [..] Tu as fixé dans mon âme l'idée de la beauté humaine et cela de la perfection divine. Si Zeuxis eût put te connaître, il n'aurait pas cherché plusieurs modèles!". Ainsi parlait le bel Agaton”. Idem, ibidem. pp.42-44.

${ }^{204}$ Para Émeric-David, o exemplo de Agatão e Hélice - isto é, a apreciação da beleza humana real como se fosse algo acabado e divino -, fazia parte, como visto, de uma estratégia de valorização de um sistema de imitação "real" que ele creditava aos gregos, em oposição ao sistema ideal defendido de Quincy, e sustentado com afinco por Américo.

205 AMÉRICO, Pedro. Op. cit. p.152, estudo sexto (ou: Correio Mercantil, Rio de Janeiro, 2 de novembro de 1864, p.2.). Retomarei o trecho em que Américo analise a Vênus de Milo, mais à frente, ainda neste o Capítulo. 


\section{A náiade ideal: nua, mas não despida}

Conforme sugerido nos três primeiros Capítulos desta Tese, as intenções idealistas de Américo em seus escritos, especialmente em Considerações Filosóficas, não são apenas evidentes, como apresentam um caráter programático. $\mathrm{O}$ mesmo deve ser insistido em relação aos seus interesses artísticos diretamente relacionados à produção da Carioca. Era com ela que a sua oposição permanente ao materialismo e ao positivismo do período (percebidos como um paralelo filosófico das vertentes realistas na arte) encontrava pela primeira vez uma interpretação visual, que estava, ademais, mesmo em suas limitações, perfeitamente de acordo com os seus projetos teóricos para as artes no Brasil, numa pretensão invariavelmente filosófica. Além disso, no contexto em que produz a sua figura, entre a renovação indiscutível do nu como tema inteiramente válido para um quadro, iniciado por Ingres, e um defendido viés idealista, Américo se punha também, como visto, perfeitamente alinhado às supostas intenções gerais e "oficiais" da produção artística do período, nas quais se encontravam o culto ao idealismo, provindo de Rafael, e à claridade, de Ingres: com efeito, o "rafaelismo e [o] ingrismo, perpetuados por Cabanel ou Bouguereau, reúnem o grosso do batalhão de pintores de história formados entre 1860-70"206, grupo no qual o jovem brasileiro fazia parte.

Já em 1871, na biografia sobre o Américo, Guimarães Júnior indicava a fidelidade do pintor a essa vertente estética. Em uma passagem de sua biografia, imediatamente anterior ao início da discussão sobre a náiade, afirmava: após anos de detidos estudos práticos sobre o idealismo exemplar das artes grega e renascentista, e tendo escolhido como "modelo predileto o divino Rafael Sanzio", sem contudo esquecer de dedicar a Michelangelo "incansáveis contemplações estéticas", "o ideal do pintor brasileiro tomou o altar de que jamais se apeou" ${ }^{207}$. Imerso nessa esfera, e antes de voltar ao Brasil de sua primeira formação europeia, Américo:

imaginou conceber e executar uma obra de fôlego, que lhe servisse de credencial ao seu aproveitamento artístico junto do imperador. Foi nessa hora de suprema energia e coragem que o pintor e o poeta, num sublime consórcio de penetração e idealismo, fizeram erguer da tela essa voluptuosa e fresca figura da Carioca $^{208}$.

${ }^{206}$ SÉRIÉ, Pierre. Op. cit. p.156.

${ }^{207}$ GUIMARÃES JR. Op. cit. p.48. Guimarães está repetindo aqui o que Américo havia defendido no seu texto a partir de suas viagens, especialmente em Roma (não por acaso o seu biógrafo tocará nos nomes das estátuas antigas de Rafael e Michelangelo). A experiência das grandes obras da antiguidade e dos séculos XVI e XVII naquela cidade conformam em Américo a certeza de que elas são frutos de grandes gênios, guiados por grandes pensamentos em busca do ideal e da beleza.

${ }^{208}$ Idem, ibidem. p.50-1. 
Em 1898, retomando parte das leituras de Guimarães Jr., e adicionando novas, a partir de um contato também novo com o pintor, Cardoso de Oliveira (genro de Américo) era ainda mais incisivo quanto o idealismo inspirador do jovem Américo:

Imaginou então compor uma obra de arte, à qual desse parcela de sua alma de poeta e de artista, e que pudesse ser considerada uma síntese das idealizações, a filha da espontaneidade, o reflexo do temperamento do autor.

Deixou que o espírito vagueasse no páramos da fantasia, fitando a pátria distante! Aspirou o perfume de vergeis desconhecidos; ouviu harmonias etéreas de vozes celestiais, e pela diafaneidade da inspiração, igual aos Gênios, quase entreviu o céu!

Pediu às Musas sorrisos, mel às flores, frescura às gotas de orvalho, cores ao crepúsculo, candura ao olhar das criancinhas, fogo ao sol, vida à natureza e amor ao coração, e compôs assim a sua palheta!

E quando despertou desse sublime devaneio.... pintou a Carioca!

Essa tela foi composta pelo jovem artista sem intervenção de mestre algum; é uma obra livre ${ }^{209}$.

Em ambos os excertos, todas ações descritas pelos autores para se referirem ao "nascimento" da Carioca permaneciam no mesmo círculo semântico: Américo imaginou, idealizou, concebeu, fantasiou, penetrou em seu próprio espírito, deixando-o vagar livremente. Como resultado dessa promenade espiritual, criou uma "obra livre", nascida da ideia, de um arroubo "espontâneo" da imaginação ${ }^{210}$, por meio do qual teria tocado as "altas esferas" celestiais (lá, onde se situam os "páramos da fantasia"). Depois disso, e apenas depois, quando "desperta do seu sublime devaneio", ele a executou - a exemplo idêntico de Fídias e Rafael.

Se as descrições desse processo inicial parecem exageradas, sobretudo quando programaticamente inseridas em duas biografias laudatórias de próximos do pintor, ela sustentaram, entretanto, e não por acaso, uma postura bastante coerente com as discussões presentes no pequeno opúsculo La réforme de l'École des Beaux Arts et l'opposition, notadamente a defesa pela liberdade artística e pela produção de uma obra que refletisse o "temperamento" do artista. Expressaram ainda coerência em relação ao sistema de imitação ideal que Américo havia defendido com veemência em Considerações Filosóficas, justamente no mesmo momento em que realizava a sua $A$ Carioca $^{211}$. Guimarães Júnior utilizava, aliás,

${ }^{209}$ OLIVEIRA. J. M. C. Op. cit. 1898, p.33.

${ }^{210}$ Trata-se aqui de um recorrente argumento apresentado por escritores brasileiros e estrangeiros da segunda metade do século XIX. A noção de que "a imaginação vive de liberdade, e aquela morre se é subjugada" aparece em quase todos os escritores estudados por Américo. Ver, por exemplo, SUTTER, D. Op. cit. p.59, obra cujo trecho traduzido entre aspas se refere.

${ }^{211}$ Ver novamente, por exemplo, o tópico “Da imitação”, do Capítulo 4 desta Tese. 
os termos precisos sustentados por Quincy (conceber e executar), os mesmos com os quais Américo também havia trabalhado em seu texto.

De fato, os biógrafos do brasileiro defendiam na Carioca nada mais do que ele próprio havia defendido sobre as mais belas esculturas dos gregos e nas obras dos mestres do renascimento: o seu caráter fundamentalmente ideal. O que permitiria a essas obras, tal como à figura de Américo, uma tal identificação proviria de uma série qualidades inerentes (alcançadas por determinados procedimentos) a todos os trabalhos assim rotulados.

A qualidade determinante seria a presença de um modelo necessariamente metafísico. Na definição de Quincy, que bastante agradava Américo, o "estilo ideal” é, em sua acepção gramatical, um criado pela "visão interior" em lugar da "visão exterior"; em sua acepção moral, é um estilo que pretende se elevar sobre o "estilo vulgar" (o da "imitação exclusiva" de um modelo), apresentando-se como uma síntese intelectual de pensamentos e de seres percebidos no que teriam de universal ${ }^{212}$.

Conforme se espera mostrar, não parece haver dúvidas de que o jovem - seguindo um percurso quase obrigatório nos compêndios de filosofia idealista-espiritualista-racionalista, em suas estruturações que iam da psicologia à metafísica - desejava que a sua Carioca fosse ideal e bela em suas três dimensões filosóficas possíveis: o ideal em relação ao sujeito (dimensão na qual estão as esferas da razão e do gosto/gênio, que lhe revelaram a imagem da náiade); em relação ao objeto (e este trata-se de uma alegoria; isto é, de uma ideia apresentada sensivelmente, que se acorda no belo, também em relação a seu objeto, com os valores objetivos da unidade, variedade, ordem, simetria, proporção etc.); e por fim em relação à própria ideia (em sua qualidade imutável e universal).

Perfeitamente unidas, aquelas três dimensões, que conteriam toda a extensão das belezas ótica e moral, formariam precisamente a imagem sensível do Belo ideal. Se se retoma a atribuição de Lessing, que era também tão cara ao jovem brasileiro, percebe-se que Américo quer que a sua náiade seja a expressão da "moral visível"213, da maneira como os antigos, na escultura, e os italianos do Renascimento, na pintura, teriam-na compreendido e representado. Sendo a Moral uma atividade necessariamente ligada à liberdade e à razão, disso decorre - como visto - que as obras inseridas nesse domínio deveriam ser, antes de tudo, um "certo tipo intelectual de perfeições",214. Nesses termos,

${ }^{212}$ QUINCY, Q. Sur l'idéal dans les arts... p.34.

${ }^{213}$ AMÉRICO, P. Op. cit. p.164, estudo sexto. Ou: Correio Mercantil, Rio de Janeiro, 16 de novembro de 1864, p.2.

${ }^{214}$ AMÉRICO, P. Considerações Filosóficas sobre as Belas Artes entre os Antigos. p.126. estudo quarto. Ou: Correio Mercantil, Rio de Janeiro, 9 de outubro de 1864, p.2. 
representar uma mulher nua e alegórica significava estabelecer o compromisso com uma representação que exigisse mais da razão do que dos sentidos (posto que a primeira captaria a ideia $^{215}$ ). Em outras palavras, significava garantir que $A$ Carioca se apresentasse casta: nua, mas não despida; distinção a partir da qual o $n u$ é pensado enquanto uma categoria universal e não dialética; e o despido, ao contrário, pressupondo sempre seu oposto, o vestido.

Américo estava seguro de ter se esforçado em entregar uma imagem que guardasse integralmente essas qualidades em sua primeira grande pintura original. O panegírico similar e paralelo que fará em Considerações sobre as estátuas gregas ${ }^{216}$ - no qual supunha que as belezas excelsas e racionais das Vênus de Milo e de Médicis também permitiriam ver unicamente mulheres nuas, mas jamais sensuais ${ }^{217}$ - emparelhava-se às mesmas argumentações em escritos idealistas de outros autores, como Winckelmann, Quincy, Émeric-David, Cousin, Beulé, Gautier, Charles Blanc, e mesmo Porto Alegre, em especial no já comentado discurso que o jovem assistira em 1856, após o qual recebera mais uma premiação na AIBA: "Os antigos quando fizeram de cada musa uma virgem, sabiam que a arte não pode divinizar a matéria sem o princípio de uma existência imaculada, sem a pureza dos anjos, sem o amor da pátria" 218 .

215 Outras personalidades do período ainda resgatavam, no fim dos anos 1850 e 1860 , termos similares a esse retrabalhado por Américo. Um escritor bastante conhecido como Ernest Chesneau, também por Américo, uma vez que havia se apresentado como um dos protagonistas das discussões da reforma da Escola de Belas Artes de Paris em 1863, havia definido o objetivo da arte naqueles anos como a "celebração da 'realidade moral' sobre e contra a 'realidade material'. A distinção havia sido feita no seu texto "Le Realisme et l'esprit français dans l'art" publicado na Revue des Deux Mondes", citado por : BOIME, Albert. Art in the age of civil struggle, 1848-1871. Chicago: University of Chicago Press, 2007. .p.598.

Sobre a mesma ideia de que a beleza é captada pelos sentidos, mas que é o espírito que a identifica e a compreende, ver: WINCKELMANN. Op. cit. p.244.

${ }^{216}$ Diante da Vênus de Milo, beleza feminina à qual "se ligam os mais altos atributos da inteligência, da bondade e da força; [..] seus atrativos deliciosos encerram tanta nobreza, tanta candura, e ao mesmo tempo tanta majestade, que a nudez ampla e soberba da divindade de Milo só nos traz à mente o gozo intelectual das felicidades eternas.” AMÉRICO, P. Op. cit. p.153, estudo sexto.

${ }^{217}$ Idem, ibidem. Op. cit. p.159 [estudo sexto]; p. 164 [estudo sexto]; p.216 [estudo quarto]. Ou, respectivamente: Correio Mercantil, Rio de Janeiro, 15 de novembro de 1864, p.2; 16 de novembro de 1864, p.2; e 10 de outubro de 1864 , p.2. Na passagem da página 159, embora quisesse manter o mesmo sentido presente nas outras páginas, Américo invertia curiosamente os significados dos termos "nus" e "despido". Ele afirmava: "É pela expressão da beleza dos costumes que apesar de estar inteiramente despida, a Vênus de Medicis não nos parece nua". Nas demais, ele dirá que as estátuas gregas, embora nuas, só despertam "ideias de ordem e de harmonia"; ou então, ainda apesar de estarem nuas, "a humanidade aparece debaixo da sua mais agradável fisionomia, corrigida, enobrecida, divinizada, como se lhe fora dado celebrar na terra as divinas solenidades de sua gloriosa apoteose".

${ }^{218}$ PORTO ALEGRE, M. A. "Discurso do diretor da Academia das Belas Artes por ocasião da distribuição pública dos prêmios, em 1856". Correio Mercantil, 30 de novembro de 1856, p.1.

Sobre os outros autores, Émeric-David, por exemplo, oferecerá ao jovem Américo uma passagem que ele vai justamente retrabalhar em suas Considerações Filosóficas: "É por essa expressão de costumes [expression de moeurs] que, desprovida de toda vestimenta, a Vênus de Médicis não está nua.” ÉMERIC-DAVID. Op. cit. Op. cit. p.243.

Para Quincy, uma assim dita "obra moral" não está unicamente relacionada à representação de heroísmos ou virtuosismo: "O moral de onde essa teria quer dar a ideia significa tão somente o oposto do material e do sensual". p.13. 
Significativamente, a defesa teórica que Américo fazia em seus escritos se transformaria num inesperado presságio que antecipava a resposta que se viria obrigado a dar à primeira personalidade que então publicava, no começo de 1865, comentários à sua pintura.

Em uma apreciação majoritariamente negativa - o que para o jovem havia soado depreciativa -, um crítico anônimo coberto pela assinatura de Gonzalez Coques ${ }^{219}$ havia alegado que $A$ Carioca estava longe de ser ideal (o mesmo defeito que um Bethencourt da Silva imputaria um ano depois à obra, ainda que lhe apontasse para um dado Rafaelesco ${ }^{220}$ ). Ela estaria, ao contrário, repleta de sensualismo e lascívia: esta, uma crítica que, também sugestivamente, preanunciaria a resposta e a recepção negativas da pintura por parte da Casa Imperial ${ }^{221}$.

Concebendo sua náiade como uma representante legítima da beleza ideal - qualidade, deve-se repetir, que deveria ser percebida em termos racionais -, Américo não aceitaria facilmente a ideia de que ela despertasse desejos sexuais ${ }^{22}$. Afinal, se a beleza corporal, pensada enquanto expressão visível do ideal, estava ligada diretamente à pureza da alma, ela transcenderia essas relações carnais.

O crítico, em todas as suas apreciações, ligadas única e exclusivamente à "correção do desenho", pedia à Carioca a sensação de uma "naturalidade" que era justamente o oposto que o jovem buscava em sua obra. E teria sido o próprio articulista que teria se tornado, segundo Américo,: "libidinoso, quando desejais para uma náiade maiores glúteos, mais abundantes nádegas..." ${ }^{223}$.

A pintura possuiria defeitos - o jovem admitia -, sobretudo se tratando do seu primeiro grande trabalho. Mas algumas das falhas indicadas pelo crítico apenas o seriam "para quem, em vez de

QUINCY, Q. Considérations morales.... p.13.

Charles Beulé, nas publicações do seu curso de arqueologia, aberto desde a década de 1850, e seguido por Américo ainda em 1863, havia oferecido leitura similar sobre a castidade das obras gregas: "Eu vos disse anteriormente que a grande escultura era casta, que seus nus, sublimes ou requintados [exquises], passavam por sobre os sentidos para agradar [ravir] as faculdades mais elevadas do espírito." BEULÉ, C. Op. cit. p.16.

${ }^{219}$ O pseudônimo refere-se ao pintor flamengo Gonzalez Coques (1614/18 - 1684), especializado em retratos e pinturas de história.

${ }^{220}$ Após chamar A Carioca de painel rafaelesco, Bethencourt da Silva, sob pseudônimo, ainda perguntará "Onde existe a aplicação do Belo ideal nessa composição?" GUISANDO, Renato de [F. J. Bethencourt da Silva.]. "Os imagináveis bacharéis sem diploma”. Publicações a Pedido. Jornal do Commércio. Rio de Janeiro, 8 de fevereiro de 1866, P.2.

${ }^{221}$ COQUES, Gonzalez [pseudônimo]. “A Carioca. (pintura do Sr. P. Américo - 1864)”. Correio Mercantil. Rio de Janeiro, 30 de janeiro de 1865. P.2.

Ainda que negativa, o crítico havia de fato sugerido que ele havia se encarregado de apontar os "defeitos" da Carioca, posto que a maioria das demais pessoas que a haviam apreciado em sua primeira exibição, na Casa Bernasconi \& Moncada, teriam demonstrado uma reação bastante favorável à pintura, sem lhe apontar os erros.

${ }^{222}$ Para uma leitura crítica "feminista" sobre a pretensão em se representar mulheres nuas que não fossem percebidas sexualmente, ver: NEAD, Linda. Op. cit. p.16.

${ }^{223}$ Idem, ibidem. 
colocar-se na distância conveniente, quiser lamber a tela; o que poderá acontecer com aqueles que acharem atrativo o cheiro das tintas, ou mais frequentemente com os que se deixarem levar pelas sensações que prometem aqueles pomos virginais a um olho indiscreto." ${ }^{224}$ Américo não havia feito "certamente a Carioca para ser devorada."225 Se alguém, como Coques (ou como, futuramente, Bethencourt da Silva), percebia ou queria sensualmente a sua náiade, se trataria não um problema da pintura (na medida que seguiria os princípios objetivos do belo), mas do observador ${ }^{226}$. Tratar-se-ia, enfim, antes de um problema de psicologia que um de metafísica - desculpa que a confortável categoria de um belo objetivo e independente do observador permitiria sempre dar.

$\mathrm{O}$ artista recriminou seu crítico justamente por se recusar "a entrever a minha intenção" 227 . O uso preciso de um tal verbo (ver entre ou através, descortinar, descobrir) acompanhava, justamente, o sentimento pedido à fruição de sua obra, destinada a ultrapassar a percepção dos sentidos (do simples ver), e, nessa travessia, a percepção final da ideia de uma beleza alegórica e - conforme discutirei melhor, mais à frente, neste Capítulo - brasileira.

Esta é a intenção do jovem Américo. Interessava-lhe expressar na forma sensível a profunda admiração que lhe causava a teoria platônica do belo, refiltrada em teorias idealistas oitocentistas, e assumir o compromisso da entrega de uma Natura Naturante (ligada ao princípio e à ideia universal), antes do que uma Natura Naturata (o particular e limitado da experiência concreta).

Aquele mesmo sentimento de segurança que o levava a crer que havia feito adequadamente a sua parte ao produzir A Carioca, parecia por fim se sustentar por haver seguido adequadamente os procedimentos posteriores à concepção da ideia da náiade, notadamente a confrontação e correção da natureza (neste caso, dos seus modelos) a partir de um processo de abstração traçado à luz de uma teoria artística pretendida irrefutável.

${ }^{224}$ Idem, ibidem.

225 AMÉRICO, P. “A Carioca. (Resposta ao Sr. Gonzalez Coques.)” Correio Mercantil, Rio de Janeiro, 31 de janeiro de 1865. p.2. AMÉRICO, P. “A Carioca. (Resposta ao Sr. Gonzalez Coques.)" Correio Mercantil, Rio de Janeiro, 31 de janeiro de 1865 . p.2.

${ }^{226}$ Trata-se de um argumento que o jovem também tomará emprestado de algumas suas referências filosóficas. Ver, por exemplo: COUSIN, V. Op. cit. p.145-146: "Si la Vénus du Capitole ou la Sainte Cécile excitent en vous de désirs sensuels, vous n'êtes pas fait pour sentir le beau".

${ }^{227}$ Idem, ibidem. 


\section{Do modelo (real)}

Em sua primeira biografia impressa sobre Pedro Américo - publicação que servirá de modelo para praticamente todas as outras publicadas até hoje - Cardoso de Oliveira havia abandonado um dado importante sobre a produção Carioca, presente originalmente na biografia escrita por Guimarães Júnior.

O primeiro biógrafo do artista havia afirmado que após ter concebido $A$ Carioca, ele procurou com afinco uma modelo em Paris, e necessariamente uma brasileira, que pudesse ajudá-lo a executar a sua náiade. Bem ou mal - apesar de não se tratar de uma modelo profissional, e que sem dúvida não se despiu para o artista -, ele a encontrou.

Afastado da terra natal, e sem beber os eflúvios da grande natureza americana, sentiu-se o pintor a princípio enleado, traçando o programa de sua concepção. Como procurar uma senhora brasileira no remoinho da Paris alegre e revolucionária, por cujas ruas e praças atravessam durante o dia três quartas partes dos habitantes de toda a Europa!

Pedro Américo, ansioso por copiar um traço, um movimento, um olhar ao natural para o tipo da Carioca, passou mais de uma vez em revista as senhoras que lhe indigitaram no nosso consulado, e ele daria mais do que Ricardo III o seu reino por um braço, uma fronte, uma boca, uma mãozinha feminina e patrícia que se lhe deparasse! My Kingdom for a hand!

A única pessoa encontrada numa dessas incansáveis peregrinações, a Exma. esposa do sr. M. A ., beleza admirada e de vantajosa reputação nos dois mundos, pode descobrir no perfil descrito pelo pintor alguma linha fugitiva de sua fronte bela e pensativa! ${ }^{228}$

A assiduidade do jovem ao Consulado do Brasil em Paris era verdadeira ${ }^{229}$. Lá, numa de suas "incansáveis peregrinações" teria surgido à sua frente a "única pessoa encontrada" para ser potencialmente a modelo real da Carioca, a esposa do Sr. M.A, uma senhora que disporia ao mesmo tempo de qualidades óticas e morais (“beleza admirada e de vantajosa reputação”), necessárias à unidade do Belo.

O dado é sugestivo. Uma perscrutação nos Relatórios do Ministério das Relações Exteriores ${ }^{230}$

${ }^{228}$ GUIMARÃES JR. Luís. Op. cit. p.55-56.

${ }^{229}$ Além dos seus assuntos financeiros e burocráticos mensais que deveriam passar pelo escritório brasileiro na França (recebimento de sua bolsa, envio e respostas de cartas ao imperador, a personalidades políticas no Brasil ou em outros países), durante toda vigência de sua bolsa provida pela Casa Imperial, era infalível sua presença no local todos os dias 2 de dezembro para as comemorações do aniversário do imperador, onde sempre deixou assinado seu nome. Ver: Arquivo do Palácio do Itamaraty, Consulado Geral do Brasil, Rio de Janeiro. Pasta 1808 - 1930 - parte I: embaixadas, consulados, missões especiais no exterior; Poder Legislativo; Tribunal de contas.

${ }^{230}$ VIEIRA, João Pedro Dias. Relatório da Repartição dos Negócios Estrangeiros. Rio de Janeiro: Typographia 
aponta para a presença de um único nome que se encaixa naquela abreviação, o de um belo rapaz da geração de Américo, Egas Moniz Barreto de Aragão (1839-1898), subscritor (e futuro barão) Moniz de Aragão, que já desde 1859 tornava-se Adido do Corpo diplomático Brasileiro na Europa ${ }^{231}$ representante para os assuntos relativos à Prússia entre 1861 e 1863, e depois, à Portugal e Itália, com várias passagens no entanto a Paris (Fig.5.3.). Cedo, casara-se com Maria Francisca Calmon Nogueira da Gama (1842-19??), uma moça que possuía alguns meses ou, no máximo, um ano de idade a mais do que Américo (Fig.5.4.). Tendo ela 21 anos em 1863 (quando o artista então produzia sua $A$ Carioca, após o consentimento financeiro de Jacobina), é possível que a senhora Moniz de Aragão então oferecesse ao artista os traços e aspectos mais próximos da faixa etária que, de Winckelmann a Sutter, se defendia ser a do apogeu da forma feminina, e a mais adequada à representação da beleza em toda a sua completude 232 .

A identificação da moça como a modelo real que havia inspirado Américo, exclusivamente para o rosto da Carioca (conforme sugeriu Guimarães), não é, evidentemente, infalível. Entretanto, a probabilidade não é certamente nula, se consideradas todas as circunstâncias acima apresentadas.

Tratando-se de fato dela ou de outra jovem frequentadora do Consulado nos primeiros anos de 1860, certo é que Guimarães tentava novamente garantir com a sua descrição - e mais uma vez em consonância com as próprias reflexões de Américo sobre a teoria da imitação - o compromisso do artista também com o "real", e aqui, especificamente, o "real vivo", em uma etapa artística posterior à concepção da obra, também indispensável à sua produção.

Como em outras partes do seu texto, a história contada por Guimarães surgia sem dúvida para adequar a narrativa da então breve trajetória de Américo a fórmulas bastante tradicionais em escritos

Universal de Laemmert, 1865; ABRANTES, Marquês de. Relatório da Repartição dos Negócios Estrangeiros de 11 de maio de 1863, apresentado à Assembléia Geral Legislativa. Rio de Janeiro: Typographia Universal de Laemmert, 1864.

${ }^{231}$ SAUER, Arthur. Almanak administrativo, mercantil e industrial do Rio de Janeiro. Rio de Janeiro: Companhia Typographica do Brazil, 1899. p.48.

${ }_{232}$ SUTTER, D. Op. cit. p.173-74: "Os fisiologistas distinguem, na mulher, a idade dos treze aos dezesseis anos, dos dezesseis aos vinte anos, e dos vinte aos vinte e cinco anos.

A jovens moças de treze a dezesseis anos apenas ainda pouco desenvolvimento: o seio apenas começa a nascer, a cabeça é ainda pouco forte, os membros tem uma delicadeza que se assemelha ainda à da magreza, e a natureza faz apenas prometer os charmes que vão dali a pouco despertar. Tudo é casto nessas formas delicadas, nesses contornos vivos e leves, tão bem feitos para inspirar o interesse e o respeito.

No intervalo de dezesseis a vinte anos, os membros se embelezam por um adensamento sólido e delicado; todas as partes são animadas por uma vida e uma consistência novas. A delicadeza e a elasticidade da pele ["des chairs"], a beleza do cabelo, a graça e a expressão dos olhos, vêm pouco a pouco dispor o corpo de atributos da beleza; as extremidades tomam caráter; os contornos da boca são mais determinados, o colo é mais arredondado, os quadris são mais desenvolvidos; o ventre se embeleza sem ganhar muito volume; toda a epiderme é mais diáfana, mais nutrida." [tradução nossa]. 
biográficos ou ficcionais sobre artistas. Das mais recentemente emblemáticas, o procedimento do jovem artista guardaria algo de "balzaquiano", em sua relação em alguns pontos sugestivos com o Chef-d'oeuvre inconnu ${ }^{233}$. Frenhofer, o genial artista da trama de Balzac, após anos preparando uma pintura (também um grande nu feminino ideal), sem jamais terminá-la por falta de uma modelo que lhe fornecesse as pinceladas finais, que a transformariam, a seus olhos, em uma obra-prima, é pego de surpresa pela exuberante beleza da companheira do jovem Nicolas Poussin, a quem pede permissão para que a deixasse posar (neste caso nua). Excetuado da tragicidade que atinge o protagonista da história, morto ao fim (em Américo, aliás, a tragicidade cairá, como visto, em sua obra, ao ser recusada), o jovem brasileiro, ainda solteiro em Paris, também deveria encontrar na mulher de outro a beleza real e necessária à produção da sua figura.

Uma outra aproximação, sem dúvida mais fecunda, já que essa conhecida e comentada pelo próprio Américo ${ }^{234}$, provinha dos mesmos exemplos clássicos interpretados por teóricos desde o Renascimento, sumariamente apresentados no Terceiro Capítulo desta Tese. $\mathrm{Na}$ descrição de Guimarães, é fácil perceber que o jovem brasileiro não teria seguido o método do "Belo de reunião" (um belo que se concebe pela síntese da percepção mesma de diferentes modelos-vivos), mas aquele, como visto, pedido aos artistas primeiro por Ludovico Dolce e, dois séculos depois por Quincy, no sentido de combinarem a percepção da natureza ao estudo das obras dos grandes artistas (eles se referiam especialmente à estatuária antiga), método que deveria ser, todavia, sempre presidido pela premissa neoplatônica da anterioridade da ideia na produção da obra. Era essa a suposição que parecia tornar pouco crível para Américo a história de um Zeuxis, tal como interpretada em seu viés aristotélico/neoclássico, ao passo que, em contrapartida, tornava bastante aceitáveis as histórias de Praxíteles e Apeles, os quais, guiados a priori por uma ideia e teoria esclarecidas, ainda que consultando apenas uma única modelo, Frinéia (beleza memorável, mas não livre de falhas), haviam conseguido esculpir e pintar imagens inigualáveis da Vênus nascida das águas.

Eles imitaram a sua modelo não no que possuía de particular - do contrário teriam feito um retrato, e não uma deusa - mas a utilizaram como um meio para a necessária generalização de suas formas. Era justamente esse procedimento que Guimarães tentava implicitamente garantir quanto ao método empreendido por Américo, quando afirmava que a obra poderia até guardar certos traços longínquos de

${ }^{233}$ BALZAC, Honoré de. "Le Chef-d'oeuvre inconnu". In: DIDI-HUBERMAN, Georges. La peinture incarnée. Paris: les Éditions de Minuit, 1985.

${ }^{234}$ AMÉRICO, P. Op. cit. Estudo sexto, p.160; Idem. Correio Mercantil. Rio de Janeiro, 16 de novembro, p.2. 
sua modelo. Ele dizia: "descobrir no perfil descrito pelo pintor alguma linha fugitiva". O afastamento instalado entre obra e modelo, de certa maneira proporcional ao próprio afastamento pessoal e sexual sugerido haver entre Américo e a senhora M.A. ${ }^{235}$, teria sido, portanto, programaticamente buscado pelo artista e assegurado por um processo racional de abstração, que apenas uma teoria podia, enfim, ensinar.

\section{Uma regra para a Ninfa}

Quanto a essa premissa, o jovem Américo era categórico: “Admitir uma regra é admitir um ideal diverso de todos os indivíduos, um tipo que em vão procurar-se-ia na natureza."236 Com esse procedimento se poderia perceber por quais:

combinações e artifícios da imaginação se produzem as composições ideais, que apesar de serem na pintura e na escultura aplicáveis às imagens dos corpos, não se podem dizer menos metafísicas do que as da poesia escrita. O tipo ideal, uma vez presente à consciência do artista, torna-se o regulador infalível das operações materiais da execução [...] e com ele o homem decide facilmente do grau da perfeição dos objetos naturais, onde, em vez de belezas que exprimam a essência vital da espécie, encontram-se quase sempre mil infrações às leis fundamentais da geração. ${ }^{237}$

Mesmo para os artistas gênios, a admissão de uma regra - isto é, de certas constantes universais descobertas pelo intelecto - seria o traçado mais seguro a seguir, pois "da imaginação inflamada à mão que esculpe guiada por uma teoria, grande distância existe."238

Desde a sua refutação ao primeiro texto publicado sobre $A$ Carioca, estava presente nos argumentos de Américo o problema das leis que haviam amparado a execução da ideia de sua náiade. Inconformado com as leituras do seu exegeta, ele argumentava que, se se percebiam tantos defeitos em sua náiade, "o melhor meio de mostrar o merecimento e a autoridade própria" do crítico em matéria artística, seria "mostrar com provas visíveis os conhecimentos que com tanto heroísmo estampam em uma folha pública":

Sim, faça S. S. com os pincéis, e não com a pena, a demonstração da sua autoridade na matéria;

${ }^{235}$ Américo, por exemplo, ao tratar em suas Considerações a relação dos antigos artistas gregos com suas modelos (dentre os quais estavam os citados Praxíteles e Apeles, amantes de Frinéia), e percebendo um possível problema na aproximação "sensual" que poderia se estabelecer na obra, assegurava que um artista como Praxíteles, quando cego de amor por sua modelo, "a ponto de elevar uma estátua à encantadora cortesã", não se deixou no entanto se levar por essa obsessão quando fazia sua estátua de Vênus. Embora contemplando a Frinéia quando fazia sua obra, e não querendo lhe imprimir "nas faces o sorriso malicioso do original [..] outro fora o sorriso da deusa, e em vez da complacente tebana, a modesta Cratina servira-lhe de modelo". idem, ibidem. p.160; Idem. Correio Mercantil. Rio de Janeiro, 16 de novembro, p.2.

236 AMÉRICO, Pedro. Considerações Filosóficas... Estudo Quarto, p.128. O trecho em questão é mais uma tradução livre que Américo fará de Quincy: QUINCY, Q. Essai sur le but et les moyens de l'imitation dans les beaux-arts. p.245.

${ }^{237}$ Idem, ibidem. p. 128 .

${ }^{238}$ Idem, ibidem. Estudo Quarto, p.124. (Ou: Correio Mercantil, Rio de Janeiro, 9 de outubro de 1864, p.2.) 
exponha depois ao público a grandíloqua expressão dos seus conhecimentos em estética aplicada, que, se corresponder ela à grande ideia que temos de uma divindade alegórica, e ao mesmo tempo da beleza do nosso tipo, então seremos os primeiros a queimar incenso em torno de vossa criação, e a encher de louros o pedestal em que pisar. ${ }^{239}$

Semelhante obra, se afinal realizada, deveria ser, sem dúvida, como o seria a náiade do jovem artista, a expressão visível dos "conhecimentos em estética aplicada". O termo, lembre-se, referia-se diretamente a questões trabalhadas por Viollet-Le-Duc, no curso da École ${ }^{240}$, e principalmente às investigações bastante repercutentes - e incorporadas ao aprendizado da mesma instituição pósreformada - que um David Sutter publicava desde 1858, construindo uma teoria artística também aplicada à pintura, fruto da síntese dos princípios filosóficos presentes em diversos estudos idealistas do século XVIII e XIX.

Conforme indicado no Terceiro Capítulo desta Tese, o jovem havia estudado cuidadosamente ao menos o primeiro grande texto de Sutter, uma sugestiva Filosofia das Belas Artes aplicada à pintura ${ }^{241}$ (que seria seguida, em 1865, justamente por uma Estética Aplicada), livro no qual também tratava das mesmas e principais questões teóricas estudadas por Américo em seus anos de formação; entre elas: o problema da "utilidade das Belas artes", "da necessidade de regras", "do Belo ideal" e "da teoria da arte".

O estudo da reprodução da primeira $A$ Carioca - amparado em alguns pontos, com cautela, pela comparação com a segunda versão da obra - permite realmente perceber o esforço de Américo em adequar a sua pintura a "um sistema razoável de preceitos"242 concentrados em Sutter (mas, repete-se, presentes ainda em textos incontornáveis, como o de Winckelmann), na convicção de que um artista, possuindo "as leis da composição do desenho, do claro-escuro, do colorido, estará em uma situação favorável a grandes sucessos." 243 Mais uma vez, deve-se lembrar que se tratava de um ensaio inicial, de uma primeira obra artística com a qual Américo esperava poder demonstrar seus conhecimentos teóricos e filosóficos; movimento que não excluiu em sua primeira pintura a dificuldade de adequar, em

${ }^{239}$ AMÉRICO, P. “A Carioca. (Resposta ao Sr. Gonzalez Coques.)” Correio Mercantil, Rio de Janeiro, 31 de janeiro de 1865. p.2.

${ }^{240}$ VIOLLET,-LE-DUC, E. E. Esthétique appliquée à l'histoire de l'art. Paris: École Nationale Supérieure des BeauxArts, 1994.

${ }^{241}$ SUTTER, D. Philosophie des beaux-arts appliquée à la peinture. Paris: J. Tardieu, 1858.

${ }^{242}$ AMÉRICO, P. Considerações Filosóficas... Estudo quarto, p.124.

${ }^{243}$ SUTTER, D. Op. cit. p.346. [tradução nossa]. 
alguns pontos, teoria e prática, intenção projetiva e execução prática ${ }^{244}$.

As regras que Américo parecia admitir da teoria sintetizada por Sutter provinham notadamente de sua compreensão dos princípios do Belo ideal em relação a seus dois principais caracteres, já discutidos: a ordem e a grandeza. Cada um deles, por sua vez, encerraria em si um conjunto específico de valores. A ordem abraçaria todos os princípios ou leis do Belo (conveniência, unidade, variedade, diversidade, harmonia, simetria, proporção), e a grandeza, os valores que definiriam a percepção do grau de beleza de um objeto (forma, claro-escuro, cor e graça).

Não será possível tratar detidamente nesta Tese de todas as subdivisões que cada um dos dois caracteres contém. Em parte por falta de espaço e tempo; em parte em função da citada limitação da qualidade da reprodução da obra (que permite que se percebam sobretudo as configurações do desenho e do claro-escuro da Carioca, em detrimento, por exemplo, da cor, e da pouca visibilidade dos demais detalhes que a circundam).

De todo modo, o que se tentará realizar em seguida é uma síntese das regras aparentemente admitidas por Américo em sua pintura a partir do uso e da demanda que fazia, portanto, da "estética aplicada".

\section{- da conveniência}

A conveniência (ou decoro) prescreve a um artista reflexivo a quantidade de figuras e variedades que se pode introduzir em um quadro, a proporção a ser adotada em cada uma delas, o grau de suas belezas, o caráter das expressões, a complexidade da composição etc ${ }^{245}$. Ela aparece a todo o momento, e em cada decisão que um pintor deve tomar em relação a todos os princípios da arte, semelhante ao bom $\operatorname{senso}^{246}$ nas decisões a serem tomadas na vida.

De início, a primeira e geral conveniência deveria ser garantida pelo tema imaginado a uma obra. Ele já adivinha aquilo que convém ou não ao artista adotar. A Carioca, por exemplo, é uma "divindade alegórica", segundo as palavras do próprio Américo. Nessa sua similaridade não fortuita com o objeto

${ }^{244}$ Retomarei esse problema no último tópico deste Capítulo.

${ }^{245}$ Idem, ibidem. p.123; pp.134-136; p.153; p.156; p.169; p.197, entre outras.

${ }^{246}$ Sobre o bom senso como um regulador racional das ações (físicas ou intelectuais) que uma pessoa toma, ver, por exemplo: COUSIN, V. Op. cit. p.152, entre várias outras passagens: "É próprio aos homens de imaginação representarem as coisas e os homens diferentemente de como eles são e de se entusiasmarem por essas imagens fantásticas. [...] O que faz o artista e o poeta é - com um fundo de bom senso e razão, sem os quais tudo resta em vão - um coração sensível, irritável mesmo, e sobretudo uma imaginação viva e potência." [tradução nossa] 
mais elevado da arte grega, o jovem estava ciente de que os gregos haviam adotado como o mais conveniente um princípio invariável e regulador de sua arte: o da economia de figuras ${ }^{247}$. Suas divindades, Américo havia também lido inúmeras vezes em Quincy, eram um composto de ideias abstratas e de propriedades gerais que a arte pôde dar conta apenas por meio de um sistema de síntese, o qual, ao fim e ao cabo, tendia ao mesmo tempo à generalização das formas e à representação unitária desses conceitos ${ }^{248}$. Para Sutter, seguindo Winckelmann, "Acontece mesmo que os antigos se dedicaram no mais das vezes a representar toda a ação por uma única figura"249.

A representação de uma divindade, alegórica ou não, carregava ainda consigo algumas observações filosóficas assim como algumas convenções, as quais, sobretudo numa representação artística, reforçariam a sua condição de existência artística. Do ponto de vista simbólico, uma primeira convenção viria da relação espiritual que se apreendia da linha ou orientação vertical. Para Sutter, esta exprimiria:

em seu caráter moral a potência divina ou humana [...] Sobre o símbolo da vertical, cujo prolongamento se eleva às esferas celestes ou mergulha no abismo, vêm se agrupar as cenas que se ligam à ideia da sabedoria, da justiça e da virtude: a vertical é a linha intelectual.[...] A orientação vertical é a que convém aos temas religiosos, às elevações [“assomptions"], às apoteoses e a todos os temas que demandam nobreza e dignidade ${ }^{250}$.

Essa primeira convenção deveria se harmonizar, na prática artística, com uma outra. Um tema que supõe uma orientação vertical dominante de suas figuras, pede também, por conseguinte, uma tela cuja orientação é, ela própria, vertical (“a forma da tela é uma composição nela mesma, e define a unidade que convém adotar",251).

Às características simbólicas dessa orientação - que expressariam qualidades imaginadas a uma existência madura - os gregos já haviam também compreendido a necessidade de expressar a aparência de uma natureza imutável por meio da sugestão de uma tranquilidade eterna, na qual as ações e paixões bruscamente representadas não poderiam ser convenientes. $\mathrm{Na}$ verdade, eles teriam preferido representar suas divindades, sempre que possível, em repouso, e quando o tema assim não permitia, conseguiram imprimir a suas esculturas a ideia de um tempo não humano, purificado das ações

\footnotetext{
${ }^{247}$ SUTTER, D. Philosophie des beaux-arts appliquée à la peinture. P.137 ; e p.197.

${ }^{248}$ QUINCY, Q. Op. cit. p.232.

${ }^{249}$ SUTTER, D. Op. cit. p.197. Sobre a leitura original de Winckelmann, sobre a "economia de figuras" adotada como princípio nos gregos, ver: WINCKELMANN. Op. cit. Livro IV, capítulo III. "Da expressão e das proporções”.

${ }^{250}$ SUTTER, David. Esthétique générale et appliquée. Paris: Imprimerie impériale, 1865. p.54.

${ }^{251}$ SUTTER, D. Philosophie des beaux-arts appliquée à la peinture. p.136
} 
humanas abruptas ${ }^{252}$.

Mas essa imutabilidade se combinaria, paradoxalmente, com a imagem simbólica de um ser ativo, desenvolvido em todas as suas qualidades físicas e morais. Como resultado, os gregos também haviam definido como outra importante convenção a representação dos seus deuses em estado de eterna juventude, diferenciando-a apenas em relação a uma aparição mais ou menos desenvolvida do ponto de vista da beleza e força corporais ${ }^{253}$.

Essa sequência de qualidades convenientes à natureza de uma divindade está inteiramente presente na Carioca. Sobre o enquadramento e direção verticais, Américo escolhia mesmo desenvolver a ideia de sua alegoria, que, enquanto tal, deveria ser ainda simples, na medida em que a alma preferiria antes as coisas simples e claras, do que profusas e complexas ${ }^{254}$. E como nem sempre simples em arte quer

${ }^{252}$ A ideia da representação do repouso como a mais à natureza de uma divindade retorna, na representação pictórica, às contribuições práticas e teóricas do Renascimento. Para me ater a uma bibliografia original, com a qual tenho trabalhado recorrentemente, lembro que essa é uma demanda que está presente repetidamente em Winckelmann ("A tranquilidade é o estado que convém melhor à beleza", WINCKELMANN. Op. cit. p.273.), em Quatremère de Quincy ("É preciso confessar, como os grandes movimentos são incompatíveis com a dignidade e a nobreza dos personagens, na vida civil, assinala-se também que essa sorte da caráter de imobilidade, se é lícito dizer, corresponde perfeitamente a esse estilo de desenho e de nudez que chamamos de abstrato ou ideal: visivelmente, mais expressão e mais ação não conviriam à nobreza desse estilo." QUINCY, Q. Sur l'ideal dans les arts... p.58 .), em Émeric-David ("Nós já estabelecemos, enfim, esse princípio importante que, na escolha e na expressão das paixões, o estatuário, sem negar a verdade daquela que deseja expressar, deve se manter o mais próximo do repouso possível”. ÉMERIC-DAVID, T. Op. cit. p.239, p.51.), em Sutter (SUTTER. Op. cit. p.149), em Laprade (“A beleza é uma clareza serena, igual, imóvel; o sublime é um relâmpago.” LAPRADE. Op. cit. p.175.), e por fim, também em Américo ("e seu incomparável mérito [das estátuas gregas] reside justamente na grandeza serena e calma que revestem, na tranquilidade cônscia de si próprias, na qual parecem durar eternamente". AMÉRICO, P. Op. cit. p.122. Ou: Correio Mercantil. Rio de Janeiro, 9 de outubro de 1864, p.2.; Ou ainda: "A ordem é a lei suprema de toda criação durável. Para nós, todo movimento ou forma, cuja expressão indica violência ou infração a essa ordem, a essa tranquilidade, na qual a razão, fora das regiões tumultuosas do sentimento, sente-se de posse do seu império, deve ser repudiado pelo artista que quiser imprimir na sua obra o selo da imortalidade.” Idem, ibidem. Op. cit. p.114. Ou: Correio Mercantil, Rio de Janeiro, 5 e outubro de 1864, p.2.)

${ }^{253}$ A leitura de que o estado mais adequado à representação da eternidade é a representação da juventude retorna às leituras de Winckelmann. WINCKELMANN. Op. cit. p.261, e p.252: "E para a ideia que os homens fazem de divindades sensíveis, o que há de mais nobre, de mais estimulante para a imaginação que o estado de eterna juventude e de primavera da vida, cujo simples pensamento pode ainda nos alegrar em uma idade avançada? Essa ideia era conforme àquela da imutabilidade do ser divino e da beleza física juvenil de uma divindade que suscitada a ternura e o amor próprios à transportar a alma a um doce sonho de felicidade." [tradução nossa]

Essas leituras atravessam ainda os trabalhos de vários pensadores e estarão presentes ainda nas publicações de Sutter e do jovem Américo.

Para Sutter, por exemplo, a representação da juventude, apesar de fundamental à natureza divina, era no entanto a mais difícil: "A arte moderna tem mais expressão e patetismo agudo do que a arte antiga, nós admitimos. A cabeça de um homem maduro, com os traços nela denuncia os trabalhos e as paixões, é incontestavelmente mais expressiva, mais patética que a cabeça do adolescente; ele oferece mais detalhes a modelar; sua fisionomia apresenta contrastes, dissonâncias bastante próprias ao efeito, e, digamos, muito mais fáceis de se apresentar que a beleza simples, una, plácida da juventude. Uma figura de uma jovem mulher sempre foi tomada como o que há de mais difícil na pintura [...] Em resumo, a arte moderna, e eu entendo com isso a arte da idade média e a nossa, não fez outra coisa senão juntar algumas rugas à beleza serena e calma, à adorável juventude dos tipos gregos". SUTTER, D. Op. cit. p.176-77. [tradução nossa]

${ }^{254}$ Idem, ibidem. p.197. A noção de que seriam mais belas as ideias que atingem mais rapidamente o espírito está 
dizer pouco ou insuficiente, um único objeto pode, a exemplo do que haviam feito os gregos na escultura, "formar um quadro completo" 255 . O jovem concentrava então o tema do seu quadro em uma única figura (em eterna juventude, e em um estado de confortável tranquilidade) sobre a qual toda a atenção inicialmente se detém, circundada por um conjunto relativamente reduzido de elementos secundários.

Mas quando se tratava justamente de um tema simples, com uma única ou poucas figuras, alguns cuidados deveriam ser tomados. Para que ele se tornasse ainda mais claro e "sedutor", seria ainda conveniente colocar "o ponto de vista no centro da composição, e a linha do horizonte no terço da altura do quadro"256: outro conselho que o jovem seguirá à risca, situando o púbis da Carioca (isto é, o centro imaginário da figura humana em vários sistemas de proporção válidos até aquele momento) no centro preciso da tela, e a linha do horizonte, precisamente, no primeiro terço da pintura (fig.5.5.). O partido aqui não seria apenas simbólico mas, para Sutter, físico, já que também suportado por uma "lei ótica", segundo a qual se concluía que "o raio normal perpendicular à retina é o mais importante do cone visual", diminuindo o interesse dos objetos que se afastariam gradualmente desse raio ${ }^{257}$.

Em uma relação dificilmente casual, essas conveniências iniciais seguidas por Américo para a execução da ideia de sua divindade tenderiam a reforçar o mais importante princípio do Belo, para o qual todos os outros concorriam, inclusive o da conveniência: o princípio da unidade.

\section{- da unidade}

A Carioca é uma. A observação é em si evidente, mas não redundante. Em retrospecto às reflexões filosóficas empreendidas por Américo, a escolha era, na verdade, bastante significativa, a ponto de o caráter unitário de sua existência enquanto a ideia de divindade ter sido duplamente garantido. De um lado, pela centralização do quadro em apenas uma figura; e, de outro, pela precisão unitária do nome da pintura. Essa operação verbal permitia não apenas afirmar a posição da Carioca como única em seu

presente desde Winckelmann (WINCKELMANN. Op. cit. p.246), passando entretanto por argumentos similares no contexto germânico, especialmente nos trabalhos de Franz Hemsterhuis, Johann G. Herder, August Schlegel, entre outros. Ver: HEMSTERHUIS, Franz. "Carta sobre a escultura". In: HEMSTERHUIS, Franz. Sobre o homem e suas relações (tradução, apresentação e notas Pedro Paulo Pimenta). São Paulo: Iluminuras, 2000. Pp.23-42; HERDER, Johann Gottfried von. Sculpture: some observations on shape and form from Pygmalion's creative dream (edited and translated by Jason Gaiger). Chicago: University of Chicago Press, 2002; e SCHLEGEL, August. Doutrina da arte: cursos sobre Literatura Bela e Arte (Tradução e notas de Marco Aurélio Werle). São Paulo: Edusp, 2014.

${ }^{255}$ Idem, ibidem. p.293.

${ }^{256}$ Idem, ibidem. p. 211.

${ }^{257}$ SUTTER, D. Esthétique générale et appliquée. p.34. 
gênero (ou tipo ideal), como evitar precisamente a sua identificação possível com uma Carioca real em particular - posto que o substantivo, já no século XIX, era sinônimo dos habitantes da corte.

A escolha, uma vez tomada, pode parecer lógica, mas não é difícil imaginar que, no seu horizonte de possibilidades - se não imerso nos princípios de uma filosofia idealista -, Américo pudesse ter intitulado sua pintura simplesmente de "A ninfa da Carioca" ou ter quem sabe representado duas ou mais ninfas guardiãs da importante fonte de água da corte; precedentes aliás bastante recorrentes na pintura europeia.

O partido tomado lembrava, ao contrário, com permanência, a necessidade de unidade sistêmica reforçada pelas filosofias idealistas; afinal, a imagem de um deus não era para elas a de um todo indivisível e harmônico que encerraria em si um vasto horizonte de elementos que compartilham da sua natureza?

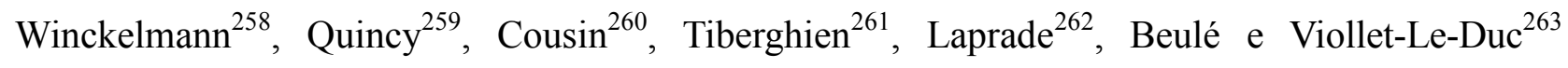
haviam defendido com insistente recorrência o mesmo conceito de unidade que se tornará o norte insubstituível de toda Estética Aplicada de Sutter (a palavra aparece a propósito 206 vezes em sua Filosofia das Belas Artes, e nada menos do que 185 vezes em sua Estética Aplicada.).

A sua primeira e permanente exigência teórica era de fato a de que o quadro, independente do tema ou do gênero, “excite uma única ideia geral, dominante e determinada. Reconhece-se que há unidade

258 Para Winckelmann, a beleza vem da unidade e da simplicidade: "Toda beleza é sublime pela unidade e simplicidade, como o são nossas ações e nossos discursos” WINCKELMANN. Op. cit. p.246. Ver também p.242 e p.247.

${ }^{259}$ Em Quincy, o problema da unidade, ligado diretamente da imitação, se exprime pela ideia de que a imitação generalizada (procedimento incontornável em sua teoria artística) é aquele que tende à unidade do ser, e à unidade das formas." QUINCY. Sur l'ideal dans les arts....p.42. Em outro trecho, afirmará ainda que a ideia de unidade e simplicidade na imitação que conviriam ao estilo ideal (p.81).

${ }^{260}$ Para Cousin, "todas essas teorias que conduzem a beleza à ordem, à harmonia, à proporção, são no fundo uma única e mesma teoria que vê antes de tudo no belo a unidade. E certamente a unidade é bela; ela é uma parte considerável da beleza". COUSIN, V. Op. cit. p.160, entre outras passagens (a outra "parte considerável" que Cousin dirá compor a beleza inteira será, com efeito, a variedade.

${ }^{261}$ Para Tiberghien, como já visto em Capítulo precedente, as condições de existência de um sistema científico, e de um objeto verdadeiro, são a unidade, variedade e harmonia. A ciência inteira, pensada enquanto um único sistema, tem que ter sobretudo unidade. TIBERGHIEN. Op. cit. p.07, entre outras passagens.

${ }^{262}$ A mesma ideia que perpassa tanto o sistema das artes, como a existência unitária de uma obra e arte está também presente em Victor de Laprade: "A unidade exclui a confusão. A justa ideia de uma comunidade geral de objetivos e de princípios entre as artes comporta aquela da diversidade de seus meios". p.19. Para o autor, em muitos pontos próximo de Sutter, a arte deve se manter dentro de sua unidade e limite de ação, movimento que deveria ser proporcional à unidade aparente em uma obra de arte. Idem, ibidem. p.56.

${ }^{263}$ As reflexões que Viollet-Le-Duc desenvolvia em seu curso na École sobre o conceito de unidade na arte grega me parecem sugestivamente próximas das concepções desenvolvidas por Américo na produção da sua $A$ Carioca: "Os gregos, na arte, em lugar de acumular ideias eles tomam uma só, e a fecundam para tirar dela a obra inteira. Por isso suas obras tem esse caráter de unidade que não se encontra em outros povos antes deles.” VIOLLET-LE-DUC. E., Op. cit. p.56. 
em uma composição quando os objetos são convenientes ao tema, e quando eles se acordam para fortalecer a expressão" ${ }^{\text {,64 }}$. Esse acordo deveria ser encontrar em todos os níveis de um quadro. Deveria haver a unidade no desenho, na composição, na expressão e nos gestos, no claro-escuro, na cor. Se um deles aponta para ali, enquanto que outro, acolá, criar-se-ia necessariamente uma divergência, que seria contrária à clareza da ideia que se desejaria representar.

Algumas articulações feitas pelo jovem Américo diretamente em sua $A$ Carioca demonstram com clareza suas dívidas diretas para com o conceito da unidade, e serão aqui reiteradas à medida que se trabalharem os princípios artísticos subsequentes.

Para além do núcleo central que comanda a ideia da unidade na Carioca - isto é, a ideia espiritual e única do belo que se expressa nesse caso também pela representação de uma única figura - pode-se perceber uma acomodação desse conceito em um problema já rapidamente citado no princípio da conveniência, especialmente relacionado à orientação do quadro; questão, como visto, não apenas fundamental ao tema com o qual se relaciona a pintura, mas, do mesmo modo, à composição e ao desenho das figuras que se esperariam dela.

Sendo a representação de uma divindade mais adequada à orientação vertical, um artista deve reforçar esse movimento em seu trabalho a partir de uma conformação clara da unidade de direção de linhas e massas ${ }^{265}$. Se um quadro vertical é dominado por "linhas estéticas" horizontais (termo crítico essencial a Sutter), essa configuração destruirá a unidade que seria portanto imposta previamente por seu formato. Ideia e execução (ou, em outras palavras, a unidade moral e a unidade ótica da obra) se encontrariam desataviadas, e com isso, a Beleza ideal estaria desde logo comprometida.

Seria desse modo absolutamente indispensável que tal quadro fosse composto inteiramente em reforço às linhas estéticas verticais, numa hábil combinação de formas, zonas compositivas e cromáticas. Mas não se trataria necessariamente de uma linha visível presente no quadro, senão ao menos a sensação de uma ou mais linhas imaginárias que se formam na relação interna de uma figura em relação a suas partes, ou externa, entre duas ou mais figuras ${ }^{266}$. Não se trataria tampouco de uma linha perfeitamente vertical, mas, antes, de uma com predominância vertical, de uma que reforçasse a

${ }^{264}$ SUTTER, D. Op. cit. p. 195.

${ }^{265}$ Idem, ibidem. P.136.

${ }^{266}$ Idem. Esthétique appliquée. pp.32-33: "As linhas estéticas não são sempre linhas arquiteturais tiradas à regra; elas são formadas mais frequentemente por uma figura de pé, uma árvore, vários objetos superpostos ou situados na mesma direção. [...] Como dois pontos são suficientes para se fazer uma [linha] reta, disso resulta que dois, três ou mais objetos sobrepostos [num quadro composto] ou situados num mesmo sentido formem uma linha estética. Quanto mais essa linha for uma, mais ele é dominante; quanto mais ela for composto por pequenos objetos, menos ela é afirmada" [tradução nossa] 
direção imperativa de uma obra (uma linha diagonal, por exemplo, em relação a uma orientação vertical, tenderá a reforçar esta direção, ao passo que, combinada com uma orientação horizontal, mudará de natureza).

Também aqui se perceberá o partido tomado por Américo, que tendia a corroborar as lições estéticas de Sutter. Ele escolheu, com efeito, para a sua Carioca, a presença de uma linha estética vertical dominante de natureza oblíqua (fig.5.6.), que se inicia no canto superior esquerdo (na zona onde a porção curva de água que tomba parece certo modo replicar o segmento da linha entre omoplata e o ombro direito da ninfa), se estende por seu tronco (em um movimento reforçado pela linha quase reta de suas costas), passa pela linha de mesma orientação desenhada pelo tecido (supostamente) vermelho, e culmina em seu pé (cujo ângulo da planta segue o mesmo da linha estética traçada).

Essa linha somente pode ser percebida em razão de um outro preceito estético, esse diretamente ligado à expressão do nu: "O nu sendo o meio mais potente para moldar e colocar em evidência as linhas características e correspondentes que determinam a unidade de expressão, os tecidos ou vestimentas não deve esconder as extremidades, nem articulações"267; algo que o jovem fará, apenas escondendo o sexo da Carioca. Como o nu é principal em uma figura "as roupagens são um acessório para cobrir, e não para esconder",268.

\section{- da variedade e da simetria}

A ênfase de que um todo precisa ser organizado em uma unidade dominante pressupõe, naturalmente, que ele seja composto de diferentes partes. Se a unidade é o primeiro e regente princípio estético, ela somente poderia existir na presença da variedade. Um quadro sem variedades é monótono, assim como também será um quadro cheio de diversidades, que disputam desordenadamente a atenção do observador, tornando a ideia confusa.

Diversidade e variedade não são, portanto, princípios idênticos. A diversidade está em relação à quantidade de objetos representados numa obra; e a variedade, ao contraste e movimento internos $\operatorname{criados}^{269}$. Enquanto que a primeira não é necessariamente requerida, a segunda é condição impreterível para a produção da beleza.

\footnotetext{
${ }^{267}$ Idem. Philosophie des Beaux-Arts. p.157.

${ }^{268}$ Idem, ibidem. p.200.

${ }^{269}$ Idem, ibidem. p. 130.
} 
Como a unidade, a variedade resulta no sentimento ou ideia da simetria. E a simetria, para Sutter,

divide, por assim dizer, o tema em três partes: ele situa no meio as partes únicas, dominantes; ao lado, aquelas que são repetidas ou secundárias; a terceira serve para fazê-las valorizar reciprocamente. Essa ordem forma uma espécie de equilíbrio que dá liberdade e graça à composição: é um dos principais meios de seduzir a alma de um espectador. ${ }^{270}$

A Carioca é um quadro sem muitas diversidades: a conveniência havia sugerido a Américo representar a ideia de sua tela em uma única figura dominante. Mas "como a unidade faz com que as coisas estejam entre elas em relações perfeitas de harmonia, e que uma coisa muita simples possa ser muito bela, se essa simplicidade é conveniente ao tema" ${ }^{\text {"271 }}$, ele procedia à conformação da variedade em sua obra a partir de uma relação entre as partes de sua náiade.

Uma primeira adequação da obra ao princípio da variedade aparece no desenho de linhas secundárias e terciárias, igualmente necessárias a uma composição, que deveriam ser, contudo, distintas da primária, em natureza e extensão ${ }^{272}$. Américo desenhava uma secundária que se estende do pé e perna esquerdos da náiade, passando por seu joelho esquerdo, e terminando no evidente prolongamento desenhado pelas linhas diagonais das árvores, ao fundo (Fig.5.6.). Ela constitui, junto com a linha dominante, o vórtice para o movimento vertical ascendente em temas de divindades, explicado por Sutter em uma das figuras esquemáticas do seu livro (Fig.5.7., ilustr. 11). Uma terciária parte também, , do mesmo ponto (mais alto) da linha secundária e é conduzida até o outro lado da tela pela linha que se forma com a paisagem ao fundo, com o alinhamento dos dois punhos da ninfa, e com o pequeno segmento de água, que encontra, por sua vez, o início da linha estética primária.

A junção dessas linhas estéticas fornece a impressão curiosa de um triângulo irregular de base invertida. Ainda que nada autorize se tratar de uma interpretação segura, não seria contudo extremamente absurdo imaginar que um tal desenho triangular, ao envelopar um tipo ideal brasileiro, pudesse quem saber definir para Américo a abstração metafórica do mapa do Brasil: uma configuração possivelmente precoce e sutil, mas tão sugestiva quanto aquela que fará precisamente 30 anos depois com intenção bem mais negativa, e com linhas estéticas bem mais veementes - em seu Tiradentes

${ }^{270}$ Idem, ibidem. p.195.s

${ }^{271}$ Idem, ibidem. p. 136.

${ }^{272}$ Para Sutter, por exemplo, num quadro de orientação vertical: "é preciso uma linha vertical dominante, uma vertical secundária, uma vertical terciária, as linhas estéticas devendo ser de dimensões diferentes e de naturezas diversas para constituir a variedade, elemento essencial da harmonia, da beleza". [tradução nossa] Idem, ibidem. p.32. 


\section{Esquartejado (1893). (fig.5.8.)}

Outra adequação ao princípio da variedade estava relacionada ao problema simetria e ao contraste instalado na postura da náiade. Em escultura, o problema havia encontrado seu cânon original no Doríforo de Policleto, escultura-modelo perdida, que representava uma figura de pé, na qual, por um equilíbrio harmônico entre as partes, cada membro do corpo (braços, pernas, e a linha do tronco) está em contraposto ao membro imediatamente oposto (uma perna em relação a outra), e de semelhança com o membro oposto da outra parte (a perna direita com o braço esquerdo, por exemplo).

Estando sentada, o mesmo princípio não valia exatamente para a figura de Américo, que não deixou, entretanto, de trabalhá-la em oposições calculadas. Ele indicará na náiade um movimento no qual o braço direito, esticado, contrasta com a perna direita, completamente dobrada (embora ambos os membros realizem proporcionalmente os movimentos mais tensionados), e a perna direita, mais solta e aberta, responde ao braço esquerdo, completamente flexionado, estando também ambos mais relaxados em comparação aos dois demais. Além disso, um outro princípio fundamental da simetria, em relação à variedade está presente: a linha dos ombros e a do quadril são (como nas esculturas colocadas de pé) variadas, a primeira orientada de cima para baixo; a segunda, de baixo para cima. O contraste estabelecido afasta sensivelmente a figura do então dito "estilo severo",273 ou "hierático" (dos egípcios, ou da Grécia “pré-clássica”); este que, se ainda possível de impor uma beleza austera à forma, perdia sem dúvida em graça.

Sintomaticamente, aqui está um nova similaridade entre $A$ Carioca e outra leitura sintética estruturada por Sutter. São "as linhas oblíquas que determinam a variedade, a graça, o movimento e a harmonia. As linhas do gênero severo são simples e pouco variadas; nos temas graciosos, elas tem mais movimento e variedade; nas cenas dramáticas, elas são violentamente contrastadas." 274 De fato, além de escolher uma linha oblíqua como dominante em sua pintura, Américo inscrevia em sua figura, seguindo aquela linha, um movimento de rebatimento e de rítmica crescente, sugerido pela conexão das diagonais do pé, perna e coxa direitos, e do tórax. Outras linhas oblíquas, bem mais sutis na figura, aparecem para somar em variedade, estando presentes, por exemplo, na relação de paralelismo entre a coxa direita e o braço direito, e entre a perna esquerda e o antebraço esquerdo.

A passagem de uma linha para outra, que se conectam pelas extremidades do corpo da ninfa ou que

${ }^{273} \mathrm{O}$ termo, como se sabe, é amplamente empregado por Winckelmann, em sua História da arte.

${ }^{274}$ Idem. Esthétique Appliquée. p.58. 
se refletem em paralelismo, parece por fim reforçar o caráter geral da figura, sentada em serenidade; caráter que, conforme visto, conviria melhor à representação de divindades, especialmente as femininas. E, nesse ponto, a Estética Aplicada também não deixaria de assegurar ao jovem Américo que "uma graduação sustentada nas variedades traz a calma, a ordem, o repouso, a suavidade; a interrupção, a oposição ou o choque nessas variedades traz o movimento, o contraste, a desordem, o ruído, qualidades que podem se tornar defeitos se elas não estão em harmonia com o modo determinado pelo tema.",275

\section{- da proporção e da harmonia (um cânone para uma beleza brasileira)}

Ainda conforme os preceitos concatenados de Sutter, para que um objeto seja oticamente belo, é necessário uma combinação precisa de três meios: forma, claro-escuro e $\operatorname{cor}^{276}$. E para que ele seja completamente belo, em suas partes física e moral, é necessário, como visto, que esses meios se acordem perfeitamente à ideia do quadro.

É um outro sentimento ou ideia que avaliza, enquanto julgamento, a realização desse acordo total: o sentimento de harmonia ${ }^{277}$. Se indissociável da ideia do belo, ele emanaria, no entanto, como a simetria, também do princípio da unidade ${ }^{278}$. A harmonia funciona, dentro deste princípio, como uma regra $^{279}$ (ou metro) que pesa o que parece justo ou não. Ela é, com efeito, um sentimento ou ideia que se ativa a partir da reunião e comparação de partes, respondendo às relações estabelecidas entre dois ou mais elementos. Assim, para que haja a necessária unidade nas cores, no claro-escuro, no desenho, na composição, no gesto, deve haver em todas essas esferas uma perfeita e recíproca ideia de harmonia.

Num quadro dominado pela imagem nua e idealizada de uma mulher, o problema se concentrava, mais do que em qualquer outro elemento, naqueles três meios necessários à realização sensível do belo: na forma, pelo desenho; no claro-escuro, pelo modelado; e na cor, pela pintura. Mas, entre os três, não

${ }^{275}$ Idem. Philosophie des Beaux-Arts. p. 135.

${ }^{276}$ Idem, ibidem. p. 121.

277 G. Tiberghien, por exemplo, para citar apenas um filósofo idealista que não estava diretamente ligada ao problema da estética, também expressará opinião similar a Sutter sobre o caráter determinante da beleza: "Le signe éclatant de cette ressemblance des êtres finis avec l'Être infini est la beauté. Le beau, c'est le divin dans le fini, c'est l'unité pleine ou l'harmonie dans les choses déterminées, reproduit sans l'harmonie de l'essence divine et appelant l'harmonie dans notre âme." TIBERGHIEN, Guillaume. Esquisse de la philosophie morale, précédée d'une introduction à la Métaphysique. Bruxelles: Imprimerie de Delevingne et Callewaert, 1854. p.67

${ }^{278}$ Idem, ibidem. p.70.

${ }^{279}$ Idem, ibidem. p.63: "A razão, o sentimento e a regra são três termos necessariamente encadeados, que compõem a fórmula das belas artes. - A regra está no princípio da unidade, de onde emana a ideia de ordem e de harmonia". [tradução nossa] 
parecia haver dúvidas de que era o primeiro (frequentemente considerado como a parte "masculina" e mais importante da arte) que oferecia a maior base "racional" para o julgamento e apreciação estética da figura humana. Porque aqui o sentimento de harmonia em relação à beleza ideal podia se amparar num último princípio ou lei da estética - o da proporção - e num longo campo de contribuições sobre esse conceito, que retornava (entre especulações duvidosas e dados certeiros) ao período áureo dos gregos.

Com efeito, toda uma tradição artística e filosófica (que incluía em última instância as diretrizes da Académie des Beaux-Arts, em sua orientação originalmente neoclássica), tomava as relações estabelecidas entre as diferentes partes de um homem ou de um edifício como um - se não $o$ - fator determinante para a identificação da beleza de uma figura: a beleza ideal era tradicionalmente admitida como resultado de uma matemática sensível. Ou, novamente, nas palavras de um Sutter, a harmonia ou unidade de um quadro era sobretudo um problema de "regra".

Essa noção era então a retomada de um fundamento que havia sido programaticamente expresso e reiterado desde Vitruvio ${ }^{280}$. Era dele, a propósito, o primeiro exemplo diretamente conhecido de um sistema de proporções (ainda que originalmente bebido na invenção grega) que obteve, entre todos os outros sistemas, maior longevidade, a saber, o sistema de fração, a partir do qual uma parte específica de um objeto (ou corpo) se apresenta como o módulo que regula a relação interna entre as demais partes e o todo.

O próprio Winckelmann, enquanto fonte reflexiva tão importante para a nova École des BeauxArts, do início do século XIX, havia retomado positivamente o mesmo sistema (emprestando as reflexões de seu amigo, pintor e teórico Raphael Mengs) e ainda a certeza de que a justa proporção entre as partes era uma condição não possível, mas necessária do belo ${ }^{281}$. Quincy, secretário perpétuo de belas artes na França na primeira metade do mesmo século e, como visto, em muitos pontos caudatário das ideias de Winckelmann, estava inteiramente de acordo. E mesmo um Viollet-le-Duc, crítico de várias posturas da Académie, não deixava de lembrar a Américo e aos demais alunos presentes em seu curso de história da arte a absoluta importância das proporções para a produção de

${ }^{280}$ VITRUVIOS POLLIO, Marcus. Tratado de arquitetura / Vitrúvio ; tradução do latim, introdução e notas M. Justino Maciel. São Paulo : Martins Fontes, 2007. Cf. especialmente o livro IV.

281 Em uma, entre várias passagens em que lida com o problema da beleza e da proporção, Winckelmann afirma: "O desenho do nu se funda sobre o conhecimento de certas ideias da beleza; essas ideias resultam em parte da grandeza e de relações, em parte de formas, das quais a beleza era o objetivo dos primeiros artistas gregos, como o diz Cícero: as formas constituem a figura, as grandezas e suas relações determinam a proporção" [tradução nossa]. WINCKELMANN. Op. cit. p.238. 
obras que aspirassem ao belo ${ }^{282}$. Era certo que os mais célebres artistas gregos possuíam cânones, e os utilizavam como um "guia na prática das dimensões relativas do corpo humano. Mas isso seria uma simples indicação, uma medida destinada a evitar erros" ${ }^{283}$. Esses pensadores mantinham no jovem Américo a certeza que ele já havia escutado de Porto Alegre, republicando-o, ele próprio, em Considerações Filosóficas ${ }^{284}$ : os artistas gregos aprendiam a geometria; tinham seus cânones artísticos, suas regras para a direção e proporção, os quais chamavam de cânones matemáticos. E não havia sido a esmo, estando aqui Porto Alegre novamente de acordo, que a mesma preocupação retomada pelos florentinos durante o Renascimento havia desenhado um novo cenário de excelência artística. ${ }^{285}$

Apesar de também atestar integralmente a fundamental importância das proporções, Sutter, curiosamente, não havia oferecido uma contribuição efetiva sobre o tema em seus textos. Mas a justificativa era dada:

Nós deveríamos dar aqui, para completar este trabalho, a anatomia e as proporções do corpo humano; mas o doutor Genga e Gérard Audran tendo tratado essas matérias [...], nós recomendamos ao leitor as suas obras. O trabalho de Gérard Audran contém as proporções do corpo humano, medidas das mais belas figuras da antiguidade. ${ }^{286}$

Não sem razão que o jovem Américo acolhia, nesse "ponto manco" das lições de Estética Aplicada de Sutter, as observações sobre as proporções dos teóricos e pensadores anteriormente citados. E somava, além disso, como será visto, as suas próprias, para conformar tais contribuições a um procedimento eclético, agora de síntese prática, na medida em que continuava a crer que um sistema de consecução do ideal era impossível sem o aporte de um sistema de determinadas proporções gerais ${ }^{287}$, e

282 Na lição IV do curso da École em 1864, cujo tema versa sobre a formação da arte grega, Viollet-le-Duc afirmava: "O grego estabelece leis, não mais leis hieráticas e imóveis [como as dos egípcios, ele quer dizer], encerrando o espírito humano em um círculo intransponível, mais leis sem cessar perfectíveis, que guiam sua marcha sem interromper seu desenvolvimento. É assim que ele faz intervir essas regras de harmonia e de proporções que subsistem ainda hoje." [tradução nossa]. VIOLLET-LE-DUC. Op. cit. p.65. Na lição V, novamente, ele entrará nos méritos das proporções da arquitetura grega, e postulará a necessidade de "cavar" para encontrar o verdadeiro fundo criativo das artes gregas, que parecem tão simples a princípio. Idem, ibidem. p.86.

283 "Les plus célèbres artistes grecs avaient du reste établie des canons. C'est-à-dire des statues types servant de guide dans la pratique pour les dimensions relatives des parties du corps humain. Mais c'était une simple indication, une mesure destinée à éviter les erreurs, et pas autre chose." VIOLLET-LE-DUC, Eugène-Emmanuel. Esthétique appliquée à l'histoire de l'art. Paris: Énsb-a, 1994. p.85.

284 Para uma apreciação sobre esse problema no Considerações Filosóficas, ver novamente o Terceiro Capítulo desta Tese, especialmente o tópico: Dos princípios e da aparência do Belo.

${ }^{285}$ PORTO ALEGRE, M. A. "Discurso do diretor da Academia das Belas Artes por ocasião da distribuição pública dos prêmios.”. In: Correio Mercantil, Rio de Janeiro, 30 de novembro de 1856, p.1.

${ }^{286}$ SUTTER, D. Esthétique appliquée... p.60.

287 WINCKELMANN, J. Op. cit. p.280. 
que esse sistema, descoberto pelos gregos, ainda se encontraria disponível e infalível a um pintor "moderno".

Sintomática e de fundamental importância era aquisição que o jovem Américo havia de fato feito (e sem dúvida antes mesmo de ler a sugestão de Sutter) do manual de proporções de Audran, logo após sua chegada em Paris. A publicação, produzida na segunda metade do século XVII ${ }^{288}$, continuava a ser um dos textos sobre proporções mais conhecidos e vendidos aos artistas até o século XIX. Adquirido pelo brasileiro em 1859, ele deve tê-lo acompanhado virtualmente em seus estudos consecutivos à coleção do Louvre, durante seus 5 anos de Paris, mas também no Museu Britânico, nos Capitolini, no Vaticano $^{289}$, na Borghèse, nos Capitolini, etc.

Com ele, Américo deveria imaginar dispor um manual preciso e racional da beleza da forma, tal como interpretada ser o dos gregos e, mais ainda, o do Renascimento (período, como visto, que era o par da antiguidade, dentro do modelo cíclico da história $)^{290}$. Alcançar o Belo ideal pela forma seria, como visto, ultrapassar o belo real, distinção fundamental para Sutter, Cousin, Quincy, Winckelmann, na raiz permanentemente atualizada de Platão, e igualmente preconizada pelo mesmo Audran em seu manual - cuja última edição, datada de 1855, era a que estava nas mãos do jovem: “com um pouco de reflexão, se sentirá que raramente se encontram modelos nos quais todas as partes sejam igualmente belas e em justa proporção. Seria preciso, portanto, escolher apenas o que havia de mais belo em cada uma, e apenas tomar o que se nomeia com razão a Belle Nature. "291

Em meio às dificuldades encontradas pelos artistas para alcançarem o belo, Audran os aconselhava

288 Segundo Claire Barbillon: "L'ouvrage d'Audran jouit d'un très grand prestige durant les deux siècles qui suivent sa première parution [1683]. En témoignent de nombreuses rééditions, ainsi que la parenté très étroite qui l'unit aux nombreux cahiers de gravures d'antiques mesurés qui trouvent place ans les méthodes de dessin ou traités de la peinture au XVIIIe siècle." BARBILLON, Claire. Les canons du corps humain au XIXe siècle. Paris: Odile Jacob, 2004. p.49.

289 Américo muito provavelmente já conhecia a tradução parcial do tratado de Audran feito por Félix-Émile Taunay no período em que é diretor da AIBA (1837-1851). Sobre a tradução desse tratado, e dos demais compêndios disponibilizados aos alunos da academia por Taunay, ver: DIAS, Elaine. Paisagem e academia: Félix-Émile Taunay e o Brasil. Campinas: Editora da Unicamp, pp.112-132.

290 Ver sobre a questão das proporções como a base racional para a beleza: PANOFSKY, Erwin. "Teoria das proporções como mudanças dos estilos", In: PANOFKSY, E. Significado nas Artes Visuais. São Paulo: Perspectiva, 2011, p.129. Ver ainda a sequência da p.131, para a questão das proporções do corpo humano com a harmonia e com os diferentes deuses clássicos.

291 Tradução nossa. O trecho original: "Il semblerait donc suffisant, dis-je, de travailler d'après les modèles vivant. Mais, avec un peu de réflexion, on sentira qu'il ne se trouve que rarement des modèles dont toutes les parties soient également belles et dans une juste proportion. Il ne faut donc choisir que ce qu'il y a do beau dans chacun, et ne prendre que ce qu'on nomme avec raison la Belle Nature". AUDRAN, Gérard.. Les proportions du corps humain mesurées sur les plus belles figure de l'antiquité. Paris: Bance Éditeur, 1855. P.03. Não traduzi esse último termo na citação por se tratar de uma expressão que se refere à doutrina de imitação da estatuária grega, cujo apíce alcançará o século XVIII. Para uma bibliografia sobre o assunto, ver: RENSSELAER, Lee. Op. cit.. 
a "consultar o antigo com inteira confiança". Naturalmente, não todos os antigos, mas seus exemplos expoentes ainda existentes em coleções europeias. Ele havia partido de um grupo pequeno de estátuas clássicas e uma egípcia, o mais célebre para o século XVII francês (permanecendo quase o mesmo para o século XIX), para medir e expor suas proporções a partir do mesmo sistema de fração exposto por Vitrúvio (e frequentado por artistas do Renascimento, como Da Vinci, em seu famoso homem vitruviano). A apresentação da mensuração de esculturas em maior parte masculinas (Antinous egípcio, Laocoonte e seus filhos, Hércules Farnèse, Príamo, Antinous grego, A paz dos Gregos, Apolo de Belvedere, uma Cariátide masculina, o Gladiador moribundo, e um pequeno Amor), era posta ao lado de apenas duas estátuas femininas célebres: a Pastora Grega, depois chamada Vênus Calipígia, e a Vênus de Médicis (portanto, a única divindade feminina então indicada no livro, e a mesma que Américo, então já habituado, havia copiado no mínimo uma vez, em 1858, a partir da cópia presente na AIBA, fig.4.41.).

As medições feitas por Audran, sobretudo desta última - exemplo máximo "da delicadeza das formas, e das graças que podem formar uma beleza acabada" ${ }^{292}$, , forneceu a uma legião de artistas, e sem dúvida para o jovem brasileiro, o modelo reflexivo, no que respeitava ao menos as proporções do ideal feminino, tal como compreendido sistematicamente pelos gregos no período do estilo "gracioso" de Praxíteles. Nela (fig.5.9.), como em quase todas as suas variações célebres (que incluíam, como visto, a Vênus de Milo), a cabeça, centro da alma e da inteligência, seria construída a partir de um módulo inicial definido pela altura do nariz, de sua base até o início das sobrancelhas (essa que será a base da fração do método de Audran). Cada módulo (P) se dividia na interpretação do francês em minutas (M), e cada minuta em meio, terço, ou quarto de minuta.

O rosto e a cabeça ideais se construiriam, nos gregos, a partir da replicação vertical desse módulo (retomando a indicação de Vitruvio, especialmente no que se referia ao rosto $^{293}$ ): um módulo do fím do queixo à base do nariz; outro, desse mesmo ponto ao início das sobrancelhas; outro até a raiz dos cabelos; e outro até o topo da cabeça, totalizando ao final 4P. O corpo seria igualmente considerado a partir da contagem posterior de "cabeças" (embora diversos autores divergissem quanto a esse ponto, utilizando também ainda como medida geral a quantidade de pés ${ }^{294}$, ou em menor ocorrência outra

292 Ibidem, p.4.

293 Ver livro III, I, em VITRUVIOS POLLIO, Marcus. Tratado de arquitetura / Vitrúvio ; tradução do latim, introdução e notas M. Justino Maciel. São Paulo : Martins Fontes, 2007.

294 O próprio Audran, quando considerará a Paix des Grecs, afirma mudar de método, medindo-a a partir do módulo de "pés, polegadas e linhas, para maior exatidão e porque ele é muito pequeno; mas a relação com as medidas tomadas da 
parte do corpo).

Supondo a "correção" da postura da escultura em uma configuração ereta (a mesma que se apresentará como a postura "científica" para a medição do corpo humano no século XIX), o que significa dizer, a conversão de uma "medida técnica" em uma "objetiva" - segundo termos de Panofsky ${ }^{295}$-, a altura do corpo da Vênus era apresentada por Audran de dois modos: 31 partes (P) ou, proporcionalmente, 7 cabeças e três partes (aproximando-se do cânone mais comum, que supunha em vários estudos antigos sobre proporção uma altura média de 8 cabeças $)^{296}$. Sua leitura incluía ainda a apresentação das relações internas horizontais, verticais e oblíquas, mas estas, não exatamente dentro de um sistema prescritivo de relações, senão indicativo, incluindo ainda uma consideração pormenorizada das partes isoladas que compunham o rosto (largura e distância dos olhos, largura do nariz e da boca, demais distâncias verticais, etc).(fig.5.10.)

$\mathrm{Na}$ Carioca, a configuração heterogênea de um rosto desenhado em direta frontalidade, seguido por um corpo que se comporta como escultoricamente no espaço pictórico, oferece um dos primeiros indícios da dívida de Américo para com o manual de Audran (que fornecia justamente indicações métricas apenas paras vistas frontais e perfiladas da Vênus, portanto insuficientes para um pintor que deseja obter o gabarito da "beleza ideal" inteiramente em escorço). Há de fato um claro contraste nos esquemas de representação da fronte e do restante do corpo da ninfa (contraste reforçado pelo "corte" que efetua o braço direito, estendido horizontalmente): seu rosto se baseia notadamente num sistema planimétrico de representação, que considera apenas duas dimensões, ao passo que o restante de seu corpo lida com um sistema geométrico, em perspectiva tridimensional, portanto muito mais complexo para que se mantenha a harmonia entre suas partes em seu diálogo com medidas mais próximas da dimensão técnica (ilusionista e ótica) ${ }^{297}$.

Partir de uma das duas indicações precisas de Audran para o rosto creditado ideal da Vênus parecia deixar menos árdua a tarefa de construção de uma face igualmente ideal de uma náiade que se quererá brasileira; rosto no qual se deveria ainda temperar a "verdade" da ideia e do modelado (então tomado da senhora M.A.) e a conveniência expressiva (mesmo que essa escolha traga outros problemas de

cabeça é perfeitamente exata.” AUDRAN, G. Op. cit. p.07.

295 Cf. Panofsky. Op. Cit.

296 Para uma contra-leitura de alguns poucos autores, que pensavam, por exemplo, que oito cabeças deveria ser a proporção adequada para uma figura viril, ver: BARBILLON, Claire. Op. cit. pp.52-54, também as notas.

297 Tal contraste, me parece, sugere que Américo tenha começado pela fronte de sua figura, medindo-a entre suas partes a partir das indicações de Audran e, em seguida, passando ao restante do corpo, numa configuração de perspectiva consideravelmente distinta. 
adequação entre as partes, discutidos em seguida). E sugestivo assim perceber que Américo respeitava em sua figura todas as indicações de Audran relativas à construção interna da face da escultura (fig.5.11.): o mesmo módulo do fim do queixo à base do nariz se repete dali ao início da sobrancelha, e mais uma vez desta à raiz dos cabelos. A distância entre as extremidades dos olhos equivale aproximadamente a $1 \mathrm{P}$ e dois terços, e a distância propriamente entre os dois olhos equivalente a um olho e meio. A largura do nariz é aproximadamente de meio P. A distância estabelecida entre a base do nariz até o centro da boca sendo igual àquela do centro da boca ao início da curvatura do queixo. A distância desse ponto ao fim do queixo sendo equivalente aproximadamente ao dobro das duas anteriores. O pescoço medindo $2 \mathrm{P} 11 \mathrm{~m}$.

Américo parecia considerar ainda, em sua $A$ Carioca, uma série de medidas do corpo da Vênus oferecidas por Audran. Mas para fazê-lo, respeitando a complicada transição de uma configuração planimétrica da parte superior a uma geométrica, da inferior, usou um hábil expediente que se aproximaria da teorização (extrema) futuramente desenvolvida pelo escultor Adolph Hildebrand, uma reflexão que este julgava impreterível à produção da escultura (e não da pintura), tomando como exemplo a técnica de Michelangelo, a partir qual figuras que já estariam contidas a priori dentro dos planos delimitados do mármore, esperando apenas o artista para serem "liberadas" 298.

Com efeito, todas as partes do corpo da Carioca mais "próximas" do quadro são, sem exceção, trazidas ao mesmo plano (o plano de projeção albertiano, e, nesse caso, o plano escultórico michelangesco), o que permitia ao jovem, valendo-se do princípio básico da geometria descritiva (tal como também descrito por Alberti ${ }^{299}$ ), calcular bem mais facilmente as proporções aparentes mais importantes. O lado direito da Carioca, da cabeça aos pés, é desse modo inteiramente adjacente àquele plano, definindo por conseguinte uma linha de intersecção possível para a combinação da face e do corpo em diferentes sistemas. Sobre esse "plano de controle", a relação proporcional das partes que o tocam, sendo portanto a mesma, não é de modo algum comprometida pela necessidade de concessões perspectivas ou compensações óticas (algo que Américo teve que fazer, e o faz muito bem, por exemplo, com a parte em recuo do braço direito, embora não o conseguiria igualmente, segundo seus próprios críticos, com a perna esquerda da ninfa, desproporcionalmente larga).

298 Hildebrand, no final do século XIX, defenderá a produção de uma escultura "ótica", percebida totalmente de um só ponto, na qual nenhuma de suas partes deveria "sair" do primeiro ou último planos, uma escultura que será portanto "contida" em seus planos para a unidade total de um só ponto (uma prescrição que aproxima a estatuária das balizas óticas do baixo-relevo). HILDEBRAND, Adolph von. Il problema della forma. Firenze: Casa Editrice G. D’Anna.

299 ALBERTI, Leon Battista. Da pintura. [Tradução de Antonio da Silveira Mendonça] Campinas: Unicamp, 1989. 
Várias partes do corpo $A$ Carioca projetadas naquele plano, se medidas a partir do mesmo método de Audran, oferecem aproximações bastante sugestivas com as mesmas partes da Vênus de Médicis ${ }^{300}$ (com no entanto algumas diminuições, referentes à natureza de sua semi-divindade, como discutirei em seguida). (fig.5.12.) 1P7m de largura na metade do úmero da Carioca contra 1P9m na mesma região da grande deusa $^{301}$. $8 \mathrm{P}$ para o ponto que vai das axilas até a curvatura final das nádegas, contra $8 \mathrm{p} 11 \mathrm{~m}$ do lado direito da estátua (uma redução esperada, se se considera a postura arqueada da ninfa, em relação àquela ereta da Vênus). 3P para a espessura da perna no início do fêmur, $2 \mathrm{p} 11 \mathrm{~m}$ para a zona medial, e $2 \mathrm{p} 2 \mathrm{~m}$ para sua extremidade inferior, contra $3 \mathrm{P} 7 \mathrm{M}, 3 \mathrm{P} 1 \mathrm{M}^{1 / 2}$ e $2 \mathrm{P} 5 \mathrm{~m} .2 \mathrm{p} 4 \mathrm{~m}$ para a espessura da perna na junção do fêmur e da tíbia, contra a mesma medida na estátua. $2 \mathrm{p} 2 \mathrm{~m}$ para a espessura da zona medial da tíbia, contra $2 \mathrm{P} 3 \mathrm{~m}$. 1p2m para o fim da tíbia, contra $1 \mathrm{P} 4 \mathrm{~m}$. O pé, medindo um pouco menos que uma cabeça contra $4 \mathrm{p} 4 \mathrm{~m}^{1 / 2}$ na Vênus. E por fim, sua Carioca apresenta uma proporção geral de aproximadamente 7 cabeças e três quartos, a mesma apresentada por Audran para a Vênus (e também para a Bergère Grecque).

A adoção que Américo fazia do sistema de proporções ideais deduzido dos gregos não parece vir, contudo, unicamente da interpretação proposta por Audran. Nenhuma delas a propósito havia sido então considerada "infalível", e a despeito de suas concordâncias quase unânimes em alguns pontos (o módulo do rosto como o nariz, por exemplo), outras divergências eram recorrentes (a cabeça ou o pé como módulo de cálculo para a altura do corpo, bem como seu número canônico para cada divindade). Tal discordância era em boa parte devido à dificuldade de uma medição precisa, segundo a configuração variada das estátuas: tentam-se prever medidas objetivas (e é isso que pede um sistema) a partir da mensuração de medidas técnicas, que nem sempre são as mesmas (uma perna ou braço maior do que o outro, etc), no que se interpretava ser no mais das vezes um ajuste ótico para as posições

300 Chamo atenção para o fato de que essa aproximação que desenvolvo, embora me pareça sugestiva, não seja de modo algum unívoca. Naturalmente, trabalhando com uma reprodução reduzida de uma obra de grandeza originalmente natural, algumas variações, para mais ou para menos, sobretudo nas partes menores do corpo da ninfa em relação às indicações de Audran e de outros teóricos, podem ocorrer. Além disso, como sugeri, à exceção da construção do rosto (a única na qual Audran estabelece um prescrição completa, pautada na relações internas do rosto a partir do módulo P), as proporções relativas ao corpo da Vênus são apresentadas como indicações também aproximativas para os artistas retrabalharem suas medidas.

301 Apresento as medidas referentes ao lado direito da Vênus, aquele que mais se aproxima do ponto de vista explorado por Américo em sua Carioca. As mesmas medidas do lado esquerdo da estátuas são: Metade do úmero, não informada. 9P9m para o ponto de vai das axilas até a curvatura final das nádegas. 3P6m para a espessura da perna no início do fêmur, $3 \mathrm{p} 6 \mathrm{~m}$ para a zona medial, e $2 \mathrm{p} 3 \mathrm{~m}$ para sua extremidade inferior. $2 \mathrm{p} 2 \mathrm{~m}$ para a espessura da perna na junção do fêmur e da tíbia. $2 \mathrm{p} 1 \mathrm{~m}$ para a espessura da zona medial da tíbia. $1 \mathrm{P} 4 \mathrm{~m}^{1 / 2}$ para o fím da tíbia. A medida do pé esquerdo também não foi informada. 
escolhidas e para os pontos de vistas para os quais haviam sido projetadas as estátuas e pinturas ${ }^{302}$.

Ao menos outro exemplo de sistema de proporções ideais foi importante para Américo, vindo, não sem surpresas, da mesma História da Arte entre os Antigos de Winckelmann. Mais uma vez, deve-se pesar o caráter consciente do jovem em suas escolhas. Pois também no que trata das proporções ideais na estatuária clássica, ele tentava efetuar uma síntese de "opostos", quando cotejava uma referência "barroca", impressa pouco tempo após a formação da Academia Real de Pintura e Escultura, no século XVII, e um livro chave para a leitura teorização "neoclássica" na França, após a refundação da Académie em École, na virada do século XVIII para o XIX.

Como Audran, Winckelmann endereçava suas indicações a proveito dos artistas. Embora não tão completa como a de seu êmulo predecessor, a construção das relações de proporção no alemão, que se inicia também com a cabeça, retomava o modelo vitruviano do rosto tripartido a partir do mesmo módulo fornecido pela extensão do nariz, e a altura total do corpo da Vênus de Médicis em 7 cabeças e meia (quase a mesma para Audran) $)^{303}$.

Contudo, no mesmo ponto de acordo entre as duas leituras começava também uma série de divergências, sintomaticamente consultadas apenas em parte por Américo. Winckelmann havia de fato oferecido desde a primeira versão alemã de sua História de Arte (1764), também impresso na primeira tradução francesa $\left(1766^{304}\right)$, um sistema completo de construção e divisão do rosto a partir de frações internas, que no entanto, no começo do século XIX, já havia sido criticado por vários estudiosos, incluindo seu grande admirador, Goethe ${ }^{305}$ (fig.5.13.). O motivo era claro: o cânone que fornecia (na verdade, como dito, um que confessava ter sido aprendido por seu amigo Mengs ${ }^{306}$ ), mostrava de tal modo sua inadequação - ele é por demais estreito - ao do próprio Winckelmann, em uma sequência de desenhos de sua autoria, ulteriormente descobertos, propor a alternativas "corrigidas" e melhor

302 Sobre o assunto, ver ainda o comentário que Audran faz no fim de sua exposição escrita em seu manual. AUDRAN, G. Op. Cit. p.07.

303 A última tradução em francês em 2005, feita a partir da versão alemã de 1764, indica seis cabeças e meia para a Vênus de Médicis. No entanto, todas as traduções da História da Arte de Winckelmann, no século XVIII e XIX (1766, 1781, 1789, 1793, 1801-3) indicam sete cabeças a meia. Resta consultar a versão alemã de 1764 para saber se a última tradução se engana, ou se se trata, desde o século XVIII, de uma mudança interessada, tal como se vê em vários cortes e mudanças efetuas nas traduções antigas. "La taille de la Vénus de Médicis est d'un svelte extraordinaire, et quoique sa tête soit trèspetite, la figure ne porte néanmoins que sept têtes et demie", WINCKELMANN, J. Op. cit.. Tome 1, ed.1802.. p.442.

304 WINCKELMANN, J. J. Histoire de l'art chez les anciens. Paris: Saillant, 1766. Tome I. p.299.

305 KRUFT, Hanno-Walter. "Studies in Proportion by J. J. Winckelmann". The Burlington Magazine, Vol. 114, No. 828 (Mar., 1972), pp. 164-170. Disponível online em: http://www.jstor.org/stable/876908. [Último acesso em: 26-2-2014.]

306 Hanno Kruptf questiona, no entanto, a afirmação de Winckelmann, baseando-se no fato de que todas as indicações que Mengs havia deixado sobre proporções do rosto e corpo humano eram pautadas não na altura do nariz, mas na largura, a partir de relações geométricas extremamente abstratas. cf. Idem, Ibidem. p.168. 
proporcionadas (fig.5.14. e fig.5.15.).

Que o alemão não tenha publicado figura alguma desse cânone, isso mostrava sua evidente insegurança (ainda que tivesse mantido sua descrição, um pouco dúbia ${ }^{307}$, e a referência a Mengs). Explicava ainda o motivo pelo qual, como resultado de recepções negativas desse sistema também na França, a parte de seu texto relativa à construção completa do rosto era suprimida desde a sua segunda tradução francesa, de $1781^{308}$, até a sua última no século XIX, de $1801-03^{309}$, a mesma consultada por Américo.

Nessas edições, foi mantida no entanto uma correção fundamental que Winckelmann impunha às indicações de um contemporâneo francês, Claude-Henri Watelet ${ }^{310}$, devedor direto das reflexões de Audran:

O rosto tem também três partes, isto é, três vezes o comprimento do nariz; mas a cabeça não tem quatro narizes de comprimento, assim como alguns escritores quiseram ensinar. A parte superior da cabeça, a saber, a altura tomada perpendicularmente da origem [raiz] dos cabelos, até o topo, tem tão somente três quartos do comprimento do nariz ${ }^{311}$.

Sintomaticamente, a proporção era a mesma que Américo seguiria para desenhar o cocuruto da

307 De fato, se se seguem as instruções de Winckelmann, sobretudo para a largura do rosto, chega-se facilmente confundir, ao menos nas traduções francesas a que tive acesso (a última, de 2005), as indicações entre o rosto e a cabeça. O desenho mais estreito do alemão, exemplo visual do seu cânone descrito, segue a construção da largura a partir da fração vertical da linha do rosto (3p). O desenho mais largo, no entanto, toma a fração total da cabeça $(3.3 / 4 p)$ para definição da mesma largura, o que o torna bem mais proporcional.

308 WINCKELMANN, J. J. Histoire de l'art de l'Antiquité. Traduite de l'Allemand par M. Huber. Tome II. Leipzig: Jean Gotti, 1781. p.117.

309 O método indicado por Winckelmann para a construção completa de um rosto ideal é o seguinte:

Faz-se uma linha vertical que é dividida em 5 seções: a quinta parte é reservada aos cabelos e o resto da linha é novamente dividida em 3 partes. Para a primeira dessas 3 partes, faz-se uma linha horizontal que forma uma cruz com a vertical; essa horizontal deve ter em largura dois terços da largura do rosto. Dos dois pontos extremos dessa linha, tiram-se curvas até o ponto mais elevado da quinta parte citada anteriormente, curvas que foram o topo do rosto [visage] em forma de ovo. Uma das três partes do comprimento do rosto é dividida em doze partes: três dessas partes, isto é, a quarta parte do terço do rosto, devem ser levadas sobre os dois lados do ponto onde as duas linhas se cortam, e essas duas partes determinam o espaço entre os dois olhos. Essa mesma parte será levada sobre as duas extremidades dessa linha horizontal, e restam então duas dessas partes entre a parte à extremidade dessas linhas e a parte do ponto de intersecção das linhas, e essas duas partes dão o comprimento de um olho; e novamente uma parte é para a altura dos olhos. O ponto do nariz até a fenda a boca tema mesma medida dessa fenda até a cruz do queixo, e desta até a ponta do queixo: a largura do nariz de um lóbulo a outro das narinas contém a mesma medida, mais o comprimento da boca tem duas dela e ele é portanto igual ao comprimento dos olhos e à altura do queixo até o orifício da boca. Eu creio que essa maneira de desenho é clara, mesmo sem figura, e aquele que a seguir não faltará com as belas e verdadeiras proporções". WINCKELMANN. Op. cit. [edição de Daniela Gallo, 2005]. p.282-83. [tradução nossa].

310 WATELET, C.-H. L'Art de peindre: Poème. Avec des réflexions sur les différentes parties de la peinture. Paris: Guérin \& Délatour, 1760.

$311 \mathrm{Na}$ tradução de 1802: "La face a aussi trois parties; c'est-à-dire, trois fois la longueur du nez; mais la tête n'a pas quatre nez de longueur, ainsi que quelques écrivains ont voulu l'enseigner. La partie supérieure de la tête, à savoir, la hauteur prise perpendiculairement de l'origine des cheveux, jusqu'au sommet, n'a que trois quarts de la longueur du nez;". WINCKELMANN, J. J. Histoire de l'art chez les anciens. Paris: Bossange, Masson et Besson, 1802. Tome I. p.436. 
Carioca, cuja cabeça mede por fim 3P3/4. Essa, e as outras duas proporções a mais que pôde consultar em sua edição do texto de Winckelmann (as quais, deve-se insistir, eram quase as mesmas para Audran), a saber novamente, o cânone total cabeças e a divisão tripartida do rosto pautada no módulo vitruviano do nariz. Se o jovem pôde de alguma maneira conhecer o método total do alemão para a construção interna da face na primeira edição francesa de 1766 (o que parece pouco possível, na medida em que não falava alemão), a sobreposição desse grid sobre o da náiade assegura suas incompatibilidades, e, nesse sentido, que Américo o teria de todo modo refutado.

A diminuição do modelo para a cabeça da Carioca (3p3/4, em lugar de 4p), ainda que respeitando as mais recorrentes interpretações da proporção clássica de 7 cabeças e meia ou três quartos para a altura feminina, não deixava de produzir um efeito secundário, resultado justamente da manutenção (a despeito de alguns rebaixamentos em minutas) que fazia das medidas de largura da Vênus, indicadas por Audran. Na nova relação que se estabelecia entre a vertical (direção central na teoria das proporções) e a horizontal (bem menos frequente, e aberta à adequação convenientemente imaginada pelo artista), criava-se a sensação de que sua cabeça é consideravelmente pequena em sua relação ao todo, sobretudo em razão das larguras da parte inferior do seu corpo, as quais, segundo Américo, haviam sido imaginadas de fato maiores. A esse respeito, ele afirmou: "à medida que [o olho do observador] se aproxima da linha de terra, vê crescerem em uma certa escala as proporções da figura." 312

Tal proporção parece, contudo, seguir também reflexões filosóficas e teóricas recorrentes, e posteriormente científicas, quando aplicadas à frenologia, que uma bibliografia acessada por Américo, incluindo o próprio Winckelmann, havia sugerido a respeito da beleza e das formas visíveis das divindades. Algumas dessas reflexões postulavam que : “a mais alta beleza, como disse Cícero a Cotta,

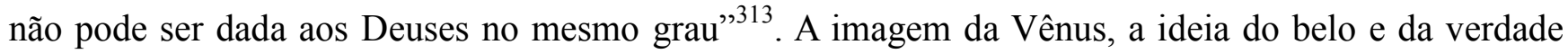
visíveis completamente acabada em si mesma, não poderia ser. portanto, em proporção numérica, idêntica à de uma deusa menor ou à de uma humana, que estaria, uma, a meio caminho, e a outra,

312 Idem, ibidem.

Conforme indicado em tópico anterior sobre as proporções da Carioca, esse aumento gradual, que de fato cria certo desconforto quando se comparam a parte superior da figura com a sua parte inferior, é criado sobretudo por um contraste das larguras da figura (essas que um sistema de proporção, à exceção do rosto, normalmente não prescrevia medidas), e não exatamente das suas alturas.

313 WINCKELMANN. Op. cit. [edição de 1781] p.90 ; ou Idem, ibidem. [edição de 2005] p.273. 
bastante distante da perfeição da primeira. Vênus é uma beleza adulta, em contraste com a beleza de uma semideusa, que foi comparada por alguns teóricos àquela da "flor da idade", de uma mulher jovem ainda não completamente desabrochada.

Audran havia feito a distinção entre a Bergère Grecque e a Vênus de Médicis: 7 cabeças, três partes e seis minutas, e 7 cabeças e três partes, respectivamente. A precisão asseguraria que a cabeça da pastora era menor que a da Vênus. A diferença, embora bastante pequena (sobretudo se se considera que o método de "correção" de postura desenvolvido por Audran não deixava sem dúvida de apresentar aproximações numéricas), era interpretada como teoricamente significativa por Watelet (o mesmo autor criticado por Winckelmann), cujo texto servia de base para o bastante acessado verbete proporções da Encyclopédie de Diderot:

Diferença de proporções ocasionada pela diferença do sexo. As variedades nas proporções são ainda ocasionadas pela diferença do sexo. Independentemente da altura total que é menor nas mulheres, elas têm o pescoço mais alongado, as coxas mais curtas, os ombros e os seios mais fechados, as ancas mais largas, os braços mais gordos, as pernas mais robustas, os pés mais estreitos: seus músculos são menos aparentes, deixam os contornos mais iguais, mais harmoniosos, e os movimentos mais doces. As jovens têm a cabeça pequena, o pescoço alongado, os ombros rebaixados, o corpo menor, as ancas um pouco grossas e os pés pequenos.

Os antigos davam sete cabeças e três de altura à Vênus: essa é a estátua da Vênus de Médicis, e a proporção da deusa [da] Beleza.

A estátua que se conhece sob o nome de Bergère grecque, que é talvez Diana, ou uma de suas ninfas saindo do banho, tem na proporção sete cabeças, três partes e seis módulos, uma característica que ela deve sem dúvida ao exercício da caça e às danças que devem deixar a dimensão das ninfas esbelta e ágil.

É possível que se encontre também nas proporções das Minervas, das Junos, e das Cibeles essas pequenas diferenças, que, uma vez as artes tenham chegado à sua perfeição, estabelecem nuanças mais sensíveis ao sentimento que capta e ao gosto que discerne do que ao olho que calcula. ${ }^{314}$

314 O excerto original é o seguinte: "Différence de proportions ocasionnée par la différence du sexe. Les variétés dans les proportions sont encore occasionnées par la différence du sexe. Indépendamment de la hauteur totale qui est moindre dans les femmes, elles ont le col plus allongé, les cuisses plus courtes, les épaules et les seins plus serrés, les hanches plus larges, les bras plus gros, les jambes plus fortes, les pieds plus étroits: leurs muscles moins apparents rendent les contours plus égaux, plus coulants, et les mouvements plus doux. Les jeunes filles ont la tête petite, le col allongé, les épaules abaissées, le corps menu, les hanches un peu grosses et les pieds petits.

Les anciens donnent sept têtes et trois parties de hauteur à Vénus: telle est la statue de Vénus de Médicis, et la proportion de la déesse Beauté.

La statue qu'on connait sous les nom de la Bergère grecque, qui peut-être est Diane, ou une de ses nymphes sortant du bain, a dans la proportion de sept têtes, trois parties et six modules, un caractère qu'elle doit sans doute à l'exercice de la chasse, et aux danses qui dévoient rendre la taille des nymphes svelte et agile.

Peut-être trouverait-on aussi dans les proportions des Minerves, des Junons, et des Cybeles, ces petite différences, qui, lorsque les arts sont arrivés à leur perfection, établissent des nuances moins sensibles à l'oeil qui calcule, qu'au sentiment qui saisit, et au goût qui discerne.” DIDEROT, Denis; FÉLICE, Fortuné Barthélemy de. Encyclopédie, ou Dictionnaire Universel raisonné des connaissances humaines. Tome XXXV. Yverdon, 1774. p.404. 
Para além do fato de associar iconograficamente a Bergère a uma ninfa saindo do banho, Watelet prenunciava, sobretudo nesse último parágrafo, a conhecida análise de Erwin Panofsky sobre a teoria das proporções no Renascimento e sobre seu legado reivindicado da antiguidade:

As proporções do corpo humano eram celebradas como uma encarnação visível da harmonia musical; elas eram conduzidas aos princípios gerais da aritmética ou da geometria (particularmente à 'seção de ouro': esse período que adorava Platão lhe credita uma importância quase extravagante); elas eram colocadas em relação aos diversos deuses clássicos, de modo que elas eram investidas de uma significação arqueológica e histórica, assim como uma mitológica e astrológica [...]

A coexistência da tradição de Vitruvio e aquela que se imputava a Varron implicava, per se, dois tipos diferentes de proporções: um alto, de nove comprimentos de faces [27P], outro de dez [30P]. E quando se juntou a eles um outro tipo mais curto, os teóricos chegaram à uma tríade a qual podiam colocar em relação, segundo o gosto, com divindades específicas, ou com as três ordens da arquitetura clássica, ou com as categorias estéticas do nobre, do belo, e do gracioso ${ }^{315}$.

Entre Panofsky e Watelet, e investido de uma mesma perspectiva histórica, arqueológica e mitológica identificada por Panofsky, Américo oferecia alguns esclarecimentos verbais sobre os procedimentos práticos que realizava na imagem da ninfa, explicações que eram uma resposta à mesma crítica recebida, em 1865, do desconhecido Gonzalez Coques - justamente em relação ao tamanho aparentemente reduzido da cabeça da Carioca -,:

A diminuição nas proporções naturais da parte superior da figura é o caráter que deve distinguir, segundo os antigos gregos, os romanos e os italianos do renascimento da arte, o aspecto das divindades fluviais e outras da mesma ordem de todas as de superior hierarquia, nas quais ao contrário devem predominar todos os sinais da inteligência ${ }^{316}$.

Se a resposta era feita ou não com o intuito maior de refutar a apreciação de um crítico julgado não especialista, o fato é que alguns dos rebaixamentos comentados são significativos para a expressão teórica e inteligível desses "sinais de inteligência", o primeiro deles, portanto, a relação proporcional da cabeça com o restante do corpo. Esses estavam em relação a um corpus de conhecimento frenológico do qual Américo estava ciente, e mesmo citava em seu Considerações Filosóficas - que estipulava, desde Petrus Camper, uma relação direta entre o tamanho e a forma do crânio e as capacidades intelectuais do indivíduo. Quanto maior a cabeça, mais inteligente uma pessoa seria; o contrário sendo inversamente proporcional.

Há ainda um outro elemento bastante significativo nas indicações de inteligência da Carioca, em

315 WINCKELAMN. Op. cit. p.87.

316 AMÉRICO, P. “A Carioca. (Resposta ao Sr. Gonzalez Coques.)” Correio Mercantil, Rio de Janeiro, 31 de janeiro de 1865. p.2. 
sua relação com o problema da proporção: o pé. Vitruvio, sabe-se muito bem, na demonstração do seu sistema, expunha também a possibilidade de se tomar o pé como base de medida para a altura total do corpo, conselho que foi retomado de fato por teóricos posteriores, incluindo, por exemplo, Alberti ${ }^{317}$. A considerar o dado de que Américo aparentemente leu Vitruvio (ao menos ele também o cita em suas Considerações Filosóficas), ele estaria portanto ciente da corrente interpretação a partir da qual, entre os gregos, a altura total do corpo equivalia em média a 6 pés. Em outras palavras, ele saberia que, segundo essa concepção, na estatuária clássica e sobretudo na estatuária dedicada aos deuses antigos, o comprimento de um pé (em sua relação com a altura total do corpo de 1 para 6) seria maior do que a altura de uma cabeça (como visto, em sua relação de 1 para $71 \frac{1}{2}$ ou 7 3/4 da altura).

Com efeito, de todas as diminuições que o jovem fazia em sua ninfa estava precisamente a do pé; diminuição "objetiva" e não técnica, posto que o pé direito, quase inteiramente de perfil, se encontra sobre o mesmo "plano de controle" das demais proporções laterais da figura. Em lugar de apresentar desse modo um pé que deveria ser maior do que a altura da cabeça de uma mesma fígura (sendo o valor dela igual a aproximadamente três quartos da extensão dele), Américo desenhava em sua figura um pé que é, todavia, um pouco menor do que a cabeça de sua ninfa (valendo aproximadamente $3 \mathrm{p} 4 \mathrm{~m}$ ). Aqui, trata-se de mais uma mudança sutil, mas num sistema de beleza ideal, extremamente importante para a devida avaliação racional da beleza da sua figura. Essas diminuições, evidentemente, não tornariam a Carioca pouco inteligente, dentro de um tal sistema. Ao contrário, filiariam-na à beleza excelsa das Vênus, aquilatando-a, entretanto, à devida escala iconográfica da qual fazia parte.

\section{- da forma}

Ao conformar A Carioca a um sistema de proporções do corpo humano, Américo dava mais um e importante passo em direção à necessária generalização e abstração de formas que pediria o Belo ideal. Até esse ponto, ele havia aplicado perfeitamente os princípios estéticos em sua obra, tendo em mente as observações de Sutter, de Quincy, entre outros pensadores, a partir das quais se sustentava que, desde os antigos, cada divindade, “com suas formas poéticas e atributos mitológicos, tornava-se um composto de ideias abstratas, de propriedades gerais que a arte só pode tornar sensível aos olhos e inteligíveis e ao espírito pela realização de um estilo de imitação ideal ou generalizado". 318

${ }^{317}$ Ver ALBERTI. Op. cit.

${ }^{318}$ QUINCY, Q. Essai sur la nature, le but et les moyens de l'imitation dans les beaux-arts. p.232. Em outro trecho da mesma obra, Quincy ainda dirá sobre princípio de simplificação dos gregos: "Assim, eles baniram da imitação do corpo 
Enquanto primeiro procedimento necessário a essa abstração das formas, a adequação da Carioca às proporções gerais de um sistema de representação idealista, deveria ser seguida por - senão mesmo realizada concomitantemente com - uma outra ação igualmente necessária. Tratava-se do conhecido e mais do que defendido processo de "simplificação" das formas, ao qual também haviam procedido os gregos e todos os grandes artistas desde a antiguidade. Ainda nas palavras de Quincy, uma obra verdadeira era aquela que guardava "um conjunto de relações e proporções marcadas com uma regularidade que apenas o método pode dar", e que ainda suprimisse as "partes acidentais que destroem a forma geral." 319 Se Américo desejava fazer como um dos seus grandes ídolos, Rafael (segundo indicação de Guimarães Júnior), e representar com beleza e clareza as suas ideias, seria realmente preciso que ele, seguindo uma idêntica sugestão presente então em Sutter, aprendesse a simplificar a sua obra em tudo o que pudesse, eliminando detalhes pouco essenciais ${ }^{320}$. E era, com efeito, um exemplo como o de Rafael (mais do que seu outro ídolo, Michelangelo) que parecia ser mais adequado à representação de uma figura feminina em sua relação com as águas; tema que, se pedia necessariamente auxílio à beleza, não podia prescindir de um pouco de graça. Segundo Sutter

não vemos, de fato, que as linhas de Michelangelo são impetuosas, veementes, terríveis, e que as de Rafael têm nobreza, dignidade, graça? As linhas, do mesmo modo que o claro-escuro e o colorido, tem nelas mesmas uma significação que as permite expressar os diferentes modos com força, energia ou suavidade. ${ }^{321}$

Havia sido mais uma vez Winckelmann o primeiro a afirmar categoricamente que a simplicidade, ao lado da unidade, eram a fonte de Belo ${ }^{322}$. Tratar-se-ia de mais uma herança grega de todos o países que se diziam adoradores do Belo ideal.

Se, para o alemão, essas simplicidade e unidade comportavam, de um lado, o citado princípio da “economia de figuras" (importando a variedade, simetria e harmonia interna em uma figura ou em um

humano, precisamente, todos esses pequenos detalhes, dos quais a arte moderna parece ter feito seu principal estudo.." p.33.

${ }^{319}$ Idem, ibidem. p.239. [tradução nossa]

${ }^{320}$ Para Sutter, por exemplo, "Rafael não se contenta em copiar o contorno e os drapeados das estátuas antigas que Roma possuía, mas ainda a expressão, a simplicidade, a nobreza e os princípios sobre os quais estava fixada a arte dos antigos. Por esse estudo assíduo, seu estilo se expande, seu desenho se aperfeiçoa. Eliminando as pequenas formas, os detalhes pouco essenciais que a natureza apresenta, ele demonstra a escolha das composições pela escolha das ideias". SUTTER, D. Philosophie des Beaux-Arts. p.42. [tradução nossa]

${ }^{321}$ Idem, ibidem. p.216.

322 WINCKELMANN. Op. cit. p.242. Em outra passagem, também bastante significativa, das páginas 246 e 247 , Winckelmann dirá sobre o mesmo problema da unidade e da simplicidade: "A beleza extrema está em Deus, e a ideia da beleza humana se aperfeiçoa à medida que ela pode ser pensada em harmonia com o ser supremo, que a ideia da unidade e da indivisibilidade distingue para nós a matéria. [...] As formas de uma tal imagem são simples, contínuas e variadas no seio desta unidade, o que lhes torna harmoniosas [...] Toda beleza é elevada pela unidade e pela simplicidade". [tradução nossa] 
pequeno conjunto delas ${ }^{323}$ ), de outro, envolviam ainda mais o mesmo princípio da simplificação e do embelezamento de formas que mais tarde Quincy e Sutter continuariam a pedir aos jovens artistas. Para ele, assim como para todo um filão de teóricos (incluindo, em última instância, o jovem Pedro Américo, conforme discutirei ao fim deste Capítulo), um procedimento que ao mesmo tempo simplificasse formalmente uma figura (reforçando a sua unidade) e a embelezasse (conformando-a a um cânon regulado por proporções prévias) significava tornar sensível, por fim, o "melhor" e "mais puro" conjunto de formas das "raças brancas", em seu tipo ideal - ainda que para Winckelmann, como visto, esse ideal fosse coletivo, e não metafísico, como para o brasileiro.

O estabelecimento de um conjunto de proporções, mais do que uma adequação, era, portanto, a imposição de um limite: uma barreira de formas (na verdade, era o fundo uma barreira de raça) que não se poderia atravessar, e que encerraria em si um número limitado, ainda que relativamente grande, de variações. Se as relações das bases e alturas do nariz, da boca, do olho, do rosto etc, não se poderiam romper num sistema proporcional, sob risco de "desvirtuar" a beleza de uma figura, aproximando-a à ideia "incorreta" de beleza em outros povos, a liberdade do artista em tal sistema estaria, assim, justamente no movimento e característica dados às suas linhas; na estruturação do claro-escuro; e na escolha e combinação convenientes das cores (esta última, uma qualidade que, todavia, para o teórico alemão e para um filão posterior, "contribui à beleza, mas não é a beleza, ela própria ${ }^{324}$ ).

Para Winckelmann, teriam sido de fato os artistas (mesmo italianos) que se apegaram à "ideia do belo em outros povos distantes" os responsáveis por "colocar em dúvida a justeza das ideias da beleza". Bastaria considerar que, nesses mesmo povos, comparações positivas eram "feitas entre as formas da face [humana] e dos animais, cujas mesmas partes nos parecerão disformes e feias." ${ }^{, 325}$

Mesmo que uma tal "anomalia" fosse possível de ser encontrada em alguns europeus, todos estariam de acordo que "quanto mais forte é essa semelhança em algumas partes, ele se torna tão excessiva e tão exagerada, que a harmonia se encontra interrompida, a unidade e a simplicidade contrariadas" 326 . O argumento de Winckelmann o levava desse ponto a outro, a partir do qual argumentava sobre as diferenças das características e da beleza entre as diferentes "raças" humanas:

Quanto mais os olhos são, por exemplo, oblíquos, como o do gato, mais essa direção se afasta da configuração de base do rosto que é a cruz, sendo esse dividido desde suas extremidades em partes

\footnotetext{
${ }^{323}$ Ver, por exemplo, a citação presente na nota anterior.

${ }^{324}$ Idem, ibidem. p. 244.

${ }^{325}$ Idem, ibidem. p.242. Ver novamente BATCHELOR, D. Op. cit.

${ }^{326}$ Idem, ibidem. p. 242 .
} 
iguais na altura e na largura, a vertical ocupando o nariz e a horizontal, o osso orbital. Se o olho é oblíquo, ele corta uma linha que se deve colocar paralela àquela que passa pelo centro dos olhos. É justamente aí onde se deve procurar a razão dessa desgraça que é uma boca torta; porque se, entre duas linhas, se uma se afasta sem razão da outra, esse desvio machuca os olhos. Assim, os olhos desse tipo, tal como se encontram entre nós e, digamos, entre os chineses e os japoneses, como também se vê em algumas cabeças egípcias de perfil, são um desvio. O nariz esmagado dos calmucos, dos chineses e de outros povos afastados é igualmente um desvio: porque ele rompe a unidade das formas que presidiu a construção do resto do corpo, e não há razão para explicar por que o nariz é assim afundado, posto que ele deveria seguir a linha da testa. Do mesmo modo que, em sentido oposto, uma testa e um nariz formados do mesmo osso reto, como os de alguns animais, seriam uma injúria à variedade de nossa natureza. A boca levantada e inchada que os negros têm, em comum como os macacos dos seus países, é uma excrecência supérflua [...] Os pequenos olhos dos países distantes do Norte e do Leste colocam em evidência a imperfeição nas dimensões [dos povos dessas regiões], que são curtas e pequenas. ${ }^{327}$

Da comparação entre homem e animal à comparação entre diferentes "raças" de homem, a simplicidade defendida por Winckelmann no sentido da produção necessária à unidade e à beleza da arte era, assim, uma síntese entre a ideia de "proporção ariana" (tal como presente nas estátuas gregas) e a da regularidade geral dos traços e das formas corporais, da maneira como imaginava ser mais adequada. Tratava-se de uma interpretação cuja natureza reforçava, justamente, o inverso das observações kantianas, desenvolvidas dali a poucos anos; isto é, de um julgamento estético particular, emitido sobre um conjunto particular de obras, com importância em um contexto igualmente determinado, que se pretendia no entanto universalmente válido para dar conta do problema da beleza ideal - que enquanto ideal, como visto, deveria ser logicamente uma.

O problema relativo à "forma geral da beleza" - ponto que lhe parecia indiscutível, e com o qual todos os "povos civilizados, tanto da Europa, como da Ásia e da África" 328 estariam de acordo oferecia ensejo para que o teórico alemão realizasse uma leitura sobre as qualidades visíveis das obras dos gregos, pensando-as como a mais alta manifestação da síntese artística, e desejando orientar seu leitor, dentre os quais imaginava também artistas, a evitar os "desvios" da forma que desagradam aos olhos.

Sintomaticamente, a descrição dessas simplificações e restrições anunciadas fornecia a base da mesma leitura sobre a estatuária grega da qual também se haviam servido Émeric-David, para fins realistas, Quincy, Sutter, Viollet-Le-Duc e Américo, para fins idealistas. Para o brasileiro, ademais, tal elucidação formal não se limitava à contribuição teórica que ele próprio fazia para a leitura da beleza

${ }^{327}$ Idem, ibidem. p.242-243. [tradução nossa]

${ }^{328}$ Idem. Ibidem. p.244. 
excelsa do legado clássico, mas servia de fonte reflexiva para a conformação de muitas partes da figura da Carioca, num momento em que o que parecia importar nela era então o que se defende aqui ser a execução da simplificação e do embelezamento das formas pelo desenho.

A análise da Vênus de Milo, que ele havia publicado em Considerações Filosóficas, feita a partir do citado trecho de Émeric-David, realmente estabelecia uma leitura paralela das mesmas formas que ele havia acabado de dar à sua ninfa, algumas delas justificadas filosófica e "cientificamente" por estudos eugênicos de fisionomia de J. Kaspar Lavater (1741-1801) ${ }^{329}$, e os estudos de fisiologia de Petrus Camper (1722-89), rapidamente citados, ambos autores que seguiam o mesmo legado bibliográfico ao qual se havia referido Winckelmann sobre a relação das fisionomias dos homens e dos animais $^{330}$. Sobre a estátua, o jovem brasileiro havia publicado:

Sua face, que circunscreve um elegante oval, tem alguma inclinação a comprido [..] os cabelos, que ondeiam em torno da cabeça, dividem-se acima das sobrancelhas, fracamente arqueadas, deixando ver a pureza da sua fronte, onde reina uma tranquilidade digna da deusa das delícias eternas. Sua testa não é alta, mas moderadamente vasta; seus olhos, grandes e pudicos, anunciam, pelo movimento de largas pálpebras, um olhar seguro e fascinador; suas sobrancelhas, levemente largas e separadas uma da outra por um vasto intervalo, aumentam o caráter inteligente e poético desse afável semblante, e como nas virgens de Rafael, e na fisionomia do próprio Sanzio.

O nariz é longo até a boa proporção, e tão largo entre as órbitas como na sua base, e o deve ser entre nós, modernos, onde Lavater e Camper nos mostram as pessoas generosas e capazes de grandes empresas, com as órbitas afastadas pela sua espessura. Sua mimosa boca, que um pequeno intervalo separa do nariz, respira o hálito voluptuoso do seu peito; e seus lábios, floridos e aveludados, se encrespam levemente, disfarçando com uma graça infinita um riso interior, que trai a contração involuntária desse queixo arredondado, em torno do qual brinca com tão feiticeira timidez um sorriso meigo e cheio de atração.

A cabeça, nobremente arredondada, repousa sobre um pescoço flexível e liso, em um movimento airoso que se continua até à base do tronco. Seu colo formoso e virginal, onde se elevam generosos seios, é um tesouro de poesia mais belo que a Odisseia. ${ }^{331}$

Como dito, a análise de Américo se aplica suficientemente à Carioca. São, repete-se, princípios da estatuária grega comentados e recomendados até a exaustão, reavaliados desde o século XVIII por Winckelmann, passados para a geração posterior, do início do século XIX $^{332}$, e ainda mantidos na

${ }^{329}$ LAVATER, Johann Kaspar. L'Art de connaître les hommes par la physionomie (1775-1778).Paris: Depélafoi libraire, 1820.

${ }^{330}$ Winckelmann, por sua vez, se referia aos trabalhos de Le Brun sobre a fisionomia humana, publicados ainda na segunda metade do século XVII, e de Buffon. Ver: WINCKELMANN. Op. cit. p.672, nota 8.

${ }^{331}$ AMÉRICO, Pedro. Op. cit.. p.152 [estudo sexto]. E: Correio Mercantil, 02 de novembro de 1864, p.02.

${ }^{332}$ Ver novamente ÉMERIC-DAVID. Op. cit. pp.42-44. 
metade desse século, por exemplo, por Viollet-Le-Duc, por Beulé, ou por Sutter ${ }^{333}$. O jovem artista havia ensaiado conferir à sua ninfa as formas (segundo sua própria expressão) das "belas raças brancas" 334 que os antigos haviam dado ao rosto e ao corpo de seus deuses em geral, e aqui, especificamente, de suas deusas, em seu eterno estado de juventude.

Partindo do rosto (o "centro da alma") da náiade, é nítida a orientação do jovem no sentido de lhe atribuir de fato uma cabeça arredondada que tende "a comprido"; um nariz fino e retilíneo ${ }^{335}$ (um "nariz grego", que, seria desde o teórico alemão, "a primeira qualidade que caracteriza o mais alto grau de beleza" "336), afastando-se, assim, da "monstruosidade" de um "nariz achatado" (nos gregos, não existiriam esses narizes, segundo a descrição do alemão, também retomada por um Sutter, em seus estudos de estética aplicada ${ }^{337}$ ). As sobrancelhas são, como na Vênus de Milo, longas e moderadamente arqueadas (jamais muito arqueadas), suficientemente separadas uma da outra (então interpretado como outro sinal de inteligência, já em Winckelmann ${ }^{338}$ ). Os olhos têm a "grandeza necessária”, proporcional à da cavidade orbital (“de l'os orbitaire”), cuja expressão é fornecida pelos arcos que desenham as pálpebras $^{339}$, sendo ainda consideravelmente separados um do outro (mais um sinal de inteligência). Eles apresentam ainda algo curioso: Winckelmann declarava ter notado que as mulheres (belas e inteligentes) tendiam a ter mais acuidade no olho esquerdo ${ }^{340}$ : singela curiosidade perceber que precisamente o olho canhoto da náiade é desenhado ligeiramente mais acirrado que o destro, sugerindo possivelmente o movimento de encolhimento das pálpebras que usualmente se faz quando se quer observar com mais atenção alguns detalhes de determinado objeto.

${ }^{333}$ SUTTER. Op cit. pp.224-25: "Par cette raison, le profil d'une tête doit rentrer dans le sentiment de celle verticale : la ligne qui joint le front au nez est presque droite, les sourcils sont légèrement arqués, l'oeil est grand, la bouche petite et rapprochée du nez. Le menton est relevé et les pommettes peu ressenties, etc. [...] Si nous dessinons une tête dont le front sera très-bombé, la racine du nez enfoncée, le nez court et relevé, les sourcils très-arqués, l'oeil petit et couvert, la bouche grande et éloignée du nez, le menton fuyant, les pommettes saillantes, nous aurons fait une figure grotesque. Mais, si nous faisons rentrer ces lignes excentriques dans l'unité verticale, nous ferons le front moins bombé, la naissance du nez moins enfoncée, les sourcils moins arqués, l'oeil plus grand, le nez ,plus droit et un peu plus long, le menton plus relevé, etc., et ce portrait, ainsi modifié par l'application des lois de l'esthétique, sera moins laid, tout en conservant une parfaite ressemblance."

${ }_{334}^{334}$ AMÉRICO, P. Op. cit. p.98 [estudo segundo]. Ou: Correio Mercantil, 02 de outubro de 1864, p.03.

335 WINCKELMANN. Op. cit. p.94.

${ }^{336}$ Idem, ibidem. p.283.

${ }^{337}$ Nesse ponto, a dívida de Sutter com as teorias raciais do seu período eram ainda mais evidentes, e expressas, por exemplo, no seguinte trecho: "Com um lápis branco representar-se-á um negro. O traço não cessará de parecer branco: mas os cabelos crespos, a forma do nariz, das bochechas, da boca, denigrirão ["noirciront"] nossos olhos. SUTTER. Op. cot. p.334.

${ }^{338}$ WINCKELMANN. Op. cit. p.284.

${ }^{339}$ Idem, ibidem. pp.284-86.

${ }^{340}$ Idem, ibidem p. 289. 
A testa, enquanto de uma figura jovem, "na flor da idade",341, é curta e horizontalmente ampla. A boca (que Américo estende horizontalmente para além da linha do nariz, numa "correção" de parte seu configuração sugerido por Winckelmann) distancia-se em muito pouco da base do nariz, possuindo ainda o lábio inferior maior que o superior, reforçando assim a "circularidade côncava do queixo, que é fonte de variedade." 342 , e de onde brota também de um leve sorriso. O queixo, por sua vez, arredondado, não possui "covinhas", porque estas, sendo um acidente, não podem ser consideradas como um caráter da "beleza pura e universal"

Passando ao corpo, o pescoço é largo (então a indicação de outra lição da estatuária clássica, que ainda persistia de fato produção interna dos membros da École ${ }^{344}$ ). Possui uma espessura cujo "afastamento dos contornos laterais" teria sido, segundo o próprio Américo, em resposta a Coques, "sempre considerada pelos grandes artistas como o símbolo da opulência e da energia vital; achando-se nisto de acordo com os mais abalizados e profundos críticos, como [Joseph] Spence, Lessing, E.-David, Quatremère de Quincy, e, nos nosso dias, Guizot e V. Cousin." ${ }^{345}$

"Seu colo formoso e virginal, onde se elevam generosos seios" ou, como o próprio Américo ainda se referia à Carioca, seus "pomos virginais"346 (ou como também se chamava no período, suas "maças da beleza", suas "esferas marmóreas" ${ }^{, 347}$ ), são perfeitamente circulares, e generosamente separados ${ }^{348}$, numa abstração clara que os afastam da percepção do modelo-vivo. Eles são como os seios da Vênus de Médicis, numa descrição também oferecida por Winckelmann: "como uma rosa que desabrocha ao nascer do sol, após uma bela aurora, e sai da idade amarga e verde como os frutos antes de sua plena maturidade, isso que indica seios mais generosos do que os das jovens moças. "349 Como consequência dessa identificação virginal, e a exemplo “dos seios das deusas e das amazonas, o mamilo ${ }^{350}$ não é

${ }^{341}$ Idem, ibidem. p.286.

${ }^{342}$ Idem, ibidem. p. 286 .

${ }^{343}$ Idem, ibidem. p. 287.

${ }^{344}$ Ver, por exemplo : Le derniers jours de Corinthe, de R. robert-Fleury; Júpiter e Thétis de Ingres; o mesmo tema de Barry; L'Amour et Psyché, de G. Gérard; La Source de Ingres.

345 AMÉRICO, P. “A Carioca. (Resposta ao Sr. Gonzalez Coques.)" Correio Mercantil, Rio de Janeiro, 31 de janeiro de 1865 . p.2.

${ }^{346}$ Idem, ibidem.

${ }^{347}$ MARNHAC. Op. cit. p.14.

348 ÉMERIC-DAVID. Op. cit. p.43.

${ }^{349}$ WINCKELMANN. Op. cit. p.268.

${ }^{350}$ Embora utilize o termo mamilo ["mamelon", na edição francesa], Winckelmann se refere claramente ao conjunto do mamilo e da auréola. Quando diz que o mamilo não é visível, parece se referir ao mesmo tempo à diferença de cor da auréola em relação aos seios, e ao tamanho dos mamilos. 
visível sobre os seios"351. São "seios escolhidos", os quais, assemelhando-se a certas figuras de Vênus, são como "uvas verdes", ou como "colinas que terminam por uma ponta, forma que parece ter sido tida como a mais bela"352. São essas características que lhe dão um tal ar virginal, pois, quando em frente a uma suposta Vênus, se se vêem seus mamilos, "isso seria uma razão de não olhá-la como uma Vênus" 353 .

Também o umbigo da Carioca guarda clara relações com as leituras originais de Winckelmann, especialmente em relação à representação grega de divindades femininas: ele é "bem profundo", descrevendo "um arco e às vezes um semicírculo"354. Por fim, como na imagem que Émeric-David havia oferecido do pé que mal toca o solo, Winckelmann também enfatizava a configuração buscada por Américo no pé visível da sua náiade: a natureza espiritual das divindades é representada, quanto à parte inferior do corpo, pela leveza no passo $^{355}$. Também Américo afirmava algo similar quando, defendendo $A$ Carioca, reiterava a natureza filosófica de uma divindade fluvial, essa que, como as demais divindades, também deveria se "sustentar naturalmente e sem esforço." 356

As configurações formais realizadas por Américo, dentro da baliza primeira das proporções, inscreviam sua figura em uma abstração que respondia, portanto, à defesa teórica de uma simplificação quase geométrica. Os traços do rosto da náiade (deveriam e) eram de fato construídos a partir do respeito à regularidade dos eixos vertical e horizontal lidos por Winckelmann na estatuária clássica, e nos renascentistas - especialmente Rafael. Do mesmo modo, partes fundamentais do seu corpo, em sua relação crítica com a "forma ideal", manifestavam a vontade de uma conformação que reforçava a "pureza" e a regularidade geométrica das formas da figura: o elogio à forma oval do rosto da Vênus de Milo, também explorada em sua A Carioca, o queixo arredondado, as sobrancelhas arqueadas, o umbigo também desenhado em arco e semicírculo, as linhas circulares do ventre e do púbis, que replicam em crescendo esse mesmo arco, o pescoço cilíndrico, liso e reto, os seios perfeitamente circulares, resguardados até da presença de mamilos marcantes. A ideia do corpo da Carioca como um conglomerado de formas abstraído de sua percepção sensual e pensado a partir de uma recepção inteligível seria até mesmo justificado pelo jovem por um vocabulário que lembrava a construção de

${ }^{351}$ Idem, ibidem. p.252.

${ }^{352}$ Idem, ibidem. p.289.

${ }^{353}$ Idem, ibidem. p. 253 .

${ }^{354}$ Idem, ibidem. p. 289 .

${ }^{355}$ Idem, ibidem. p. 253.

356 AMÉRICO, P. “A Carioca. (Resposta ao Sr. Gonzalez Coques.)” Correio Mercantil, Rio de Janeiro, 31 de janeiro de 1865. p.2. 
uma figura feita em progressão geométrica. Em apenas duas frases, já citadas, ele havia utilizado nada menos do que 4 expressões ou termos que reforçavam essa imagem: "à medida que se aproxima da linha de terra, vê crescerem em uma certa escala as proporções da figura." ${ }^{357}$ (Essa análise parece realmente não desmentir a impressão que se tem desse crescimento gradual da figura em direção à linha de terra, configuração que, concentrando o peso da figura sobre os quadris e pernas, lhe confere peso plástico, outro atributo geométrico ${ }^{358}$ ).

A essa simplificação ou racionalização de formas se combinava ainda uma outra, notadamente em relação às linhas internas e ao contorno. Com efeito, tão regularmente abstraídos quanto as formais corporais da Carioca serão os seus contornos externos, depressões e saliências internas.

Quanto aos primeiros, não será difícil perceber que num horizonte de referências contemporâneas, setecentistas, seiscentistas e quinhentistas, oferecidas pela tradição pictórica, Américo tentava impor um ritmo particular a seu desenho. Em relação aos contemporâneos ou aos artistas ainda relativamente próximos, lidos na via dos idealistas, sua figura era de uma franca abstração, prescindindo da doçura das linhas de um Prud'hon (fig.5.80.) e das linhas arabescas tão acessadas pelo pai moderno do nu, Ingres (fig.4.13.). Também não seguirá o ritmo serpentino das linhas que um Gautier elogiava em artistas como Cabanel, Baudry e Amaury-Duval ${ }^{359}$ (herdeiras, por sua vez, da lição ingresca), (fig.4.5., fig.4.6. e fig.4.7.), nem a impecável sutileza do desenho de um Bouguereau, as quais, entretanto, denunciavam a todo o tempo o modelo-vivo (fig.5.45). Ainda do lado dos contemporâneos, mas o dos "realistas", a distância da Carioca era ainda maior em relação às linhas "impuras" e lânguidas de Manet (fig.4.16.), ou às linhas descontínuas e repletas de depressões e interrupções de Courbet (fig.4.16).

Confrontadas com suas referências renascentistas, maneiristas ou barrocas, parece ainda claro a diferença que Américo adotava em relação à "impetuosidade" da linha michelangesca (fig.5.17), à irregularidade de um Tintoretto (fig.5.x), ou à “moleza” dos contornos de um Rubens e um Rembrandt,

${ }^{357}$ Idem, ibidem.

Conforme indicado em tópico anterior sobre as proporções da Carioca, esse aumento gradual, que de fato cria certo desconforto quando se comparam a parte superior da figura com a sua parte inferior, é criado sobretudo por um contraste das larguras da figura (essas que um sistema de proporção, à exceção do rosto, normalmente não prescrevia medidas), e não exatamente das suas alturas.

${ }^{358}$ Sobre o problema do "estilo plástico", ver, por exemplo, LONGHI, Roberto. Breve mas verídica história da pintura Italiana. São Paulo: Cosac \& Naify, 2006.

359 GAUTIER, Théophile. "Salon de 1863". Moniteur Universel, Paris, 15 de junho de 1863, p.1. Para Gautier, seriam com efeitos essas linhas serpentinas acessadas por artistas como Cabanel as mais convenientes ao corpo feminino idealizado. 
quando também endereçados ao tema das banhistas (fig.5.18, fig.5.19 e fig.5.20). E se, ao que me parece, o jovem tentava explorar um ritmo mais contínuo e sóbrio de um Rafael da Vila Farnesina (fig.5.21), ou de um Ticiano já idoso (fig.5.22.), ainda assim a abstração efetuada na sua náiade ultrapassava sem dúvida a modulação contida mas ainda presente nas linhas dessas duas últimas pinturas, especialmente na de Rafael.

A regularidade geral do desenho da Carioca se aproximava, por exemplo, da de alguns trabalhos de outro contemporâneo, Jean-Jacques Henner (fig.5.23), com a significativa e importante diferença de que Henner de modo algum abandonava a transição orgânica das extremidades das suas figuras - como no caso da sua "casta Suzana", suficientemente harmonizada pela suavidade das curvas femininas do ombro, das costas, das nádegas, do joelho e dos pés. Américo, por outro lado, ainda que na mesma intenção "casta", enxugara de tal modo a modulação das linhas da sua figura até o ponto de "endurecêlas" e masculinizá-las, criando quebras inorgânicas e angulosas nas mesmas inflexões do calcanhar, joelho, nádegas e ombro.

No jovem, a passagem de ritmo de uma linha de contorno a outra é abrupta: uma lembrança talvez do estilo severo das linhas de um Fídias, que Winckelmann fazia repetidamente questão de lembrar como adequado à beleza mais imponente (que viria pela forma). E parece vir mesmo outra vez da estatuária (especialmente a clássica), mais do que da pintura, a conformação do desenho da Carioca à ideia que interessava a Américo. As suas linhas pouco sensuais parecem de fato pagar tributo especialmente ao contorno sóbrio da Vênus de Milo, uma obra que, mesmo se derivada da iconografia graciosa da Vênus de Cnido, apresentava uma natureza mais pudica (a parte inferior do seu corpo é completamente coberta) e linhas bem mais graves do que essa, daí a razão para, ainda nos anos de estudo de Américo em Paris, se imaginar ser possível a autoria de Fídias.

Em conformidade com a simplificação dos contornos da Carioca estava a citada abstração relacionada especificamente às depressões e saliências internas de sua figura. Ou melhor, a ausência delas. Aqui, também o jovem procedia programaticamente ao apagamento das veias, indicações de músculos, tendões e volumes secundários do corpo da sua divindade. Como visto, no (sobre)tempo divino, as indicações de movimento, das paixões, da força - isto é, da indicação física de uma ação que se dá temporalmente, no mundo dos homens - deveriam ser de outra ordem. Também Winckelmann já havia apresentado a natureza filosófica de uma imagem anatomicamente mais abstrata esperada aos deuses; a mesma que um Sutter continuava a sustentar nas publicações também lidas pelo jovem 
Américo. Enquanto o primeiro havia dito: "como é o caso para todas as figuras divinas", elas não se devem ter "nem nervos nem veias"360; o segundo havia rebatido: "A miologia de um indivíduo será bela apenas se pertencer ao seguinte sistema: se se trata de uma Vênus, ela será unida, plena, doce nas flexões, sem músculos aparentes; a beleza das carnes fará esquecer o mecanismo muscular"361. E também o jovem Américo, na resposta endereçada a Gonzalez Coques, pediria mais uma vez a atenção do seu crítico para que compreendesse as intenções inscritas em sua náiade:

reparai, procurai [nA Carioca] a construção óssea dos artelhos, e sobretudo do metatarso, que nada achareis. Sob uma pele demasiado delgada, e talvez por demais branca, nem se quer uma ligeira proeminência acusa a existência do que deve achar no corpo humano o escalpelo, de alguma veia, de algum apoio interior que justifique a certeza dos seus movimentos. ${ }^{362}$

A comparação da Carioca com uma academia que Américo fazia ainda em 1865, destinada à avaliação para o concurso de professor Desenho Figurado da AIBA (fig.5.24.), permite perceber o quanto a intenção de abstração da miologia da figura que manifestava a Coques era procedente. Nesse nu, ainda que um masculino, está uma série de indicações inexistentes na figura da ninfa. Vêem-se perfeitamente indicados os tendões dos pulsos e dos joelhos. Estão bem descritos os ossos destes (especialmente o encontro da patela e da tíbia, que a pele não "esconde" totalmente), além dos do calcâneo e do perônio; estão também indicados os músculos do reto femoral, bíceps, deltoide e oblíquo direitos; e ainda a saliência produzida por uma veia, também visível no antebraço direito.

O contraste entre as duas figuras é bastante sugestivo, mas é verdade que talvez a natureza e a diferença de propósitos dessas imagens enfraqueça o critério estabelecido para suas comparações. Além daquela academia representar um homem maduro, tratava-se, evidentemente, de um exercício no qual a invenção ou a ideia do artista estava consideravelmente limitada, importando ao contrário uma tradução sensível e bem sucedida daquilo que via, reforçada pelo profundo conhecimento que possuía da miologia e da osteologia humana. Em outras palavras, tal obra, centrada na experiência do modelovivo, era um exercício sensualista, o oposto, portanto, da ideia da Carioca.

\footnotetext{
${ }^{360}$ WINCKELMANN. Op. cit. p.261.

${ }^{361}$ SUTTER. Op. cit. p. 167.

${ }^{362}$ AMÉRICO, P. Op. cit. p. 2.
} 


\section{- da forma II: Sócrates afastando Alcebíades do Vício}

Uma outra imagem feita por Américo pode, entretanto, fornecer a condição para o estabelecimento de um critério mais justo para a avaliação da abstração da forma da beleza ideal que tencionava para a sua Carioca. Trata-se de uma outra prova que o jovem realizava para aquele mesmo concurso da AIBA, mas essa, então, a prova final, na qual o que contava era justamente a expressão e a invenção de um tema previamente fornecido aos candidatos, realizado no período de 2 meses e executado a óleo sobre tela.

O assunto desenvolvido pelos concorrentes era um também ligado à antiguidade grega: "Sócrates afastando Alcebíades do vício"363 (fig.5.25), o mesmo tema que o jovem havia visto J.-L. Gérôme explorar e exibir com êxito e críticas no Salon de 1861 (fig.4.11). Por força ou ironia do destino, o próprio Américo (como o "mais moço") havia sido incumbido de sortear os pontos do concurso, retirando aquele que, sem dúvida, entre todos os demais apresentados ${ }^{364}$, se concentrava em um assunto filosófico por excelência idealista, e, além disso, com um enredo que lhe permitiria direcioná-lo sem muita dificuldade a uma orientação fundamentalmente eclético-krausista.

Uma breve explicação é talvez necessária. O tema sorteado pressupunha um episódio composto obrigatoriamente de ao menos de três personagens principais: Sócrates (o filósofo grego que dispensa maiores introduções), o jovem militar Alcebíades, seu discípulo e amigo, e a cortesã Aspásia (amiga de Fídias, companheira de longa data de Péricles, mas também dita amante de outros atenienses influentes em seu tempo). A cena a ser explorada (que deveria ignorar a relação de amantes que teria existido entre os próprios Sócrates e Alcebíades) era simples: o grave filósofo grego dirige-se à casa de Aspásia, onde o jovem se encontra entregue exclusivamente aos prazeres do corpo. Sócrates tentará dissuadi-lo de uma vida dedicada unicamente ao agrado dos sentidos, e, por outro lado, convencê-lo da importância de sua dedicação ao amor intelectual.

No fundo, o tema sorteado do concurso apresentava, em sua esperada lição, a mesma intenção ${ }^{365}$ que Américo havia dedicado à sua Carioca (embora, conforme discutirei, não havia sido claramente

${ }^{363}$ MAFRA, João Maximiano (redator). Ata da Sessão da Congregação e do Diretor da Academia Imperial de Belas Artes no dia 3 de junho de 1865. Museu d. João VI. p.145 (versão digital). Disponível online em: http://www.docvirt.com/docreader.net/docreader.aspx?bib=MuseuDJoaoVI\&pasta=Encadernados\&pesq= [último acesso, janeiro de 2016]

364 Além de Sócrates afastando Alcebíades do vício, os demais temas disponíveis para sorteio eram: Agamenon de volta ao seu palácio [assassinado] por Egisthe; Achiles entrega Briseis aos arautos de Agamenon; Jacob recebendo o vestido ensanguentado de José; O filho pródigo voltando à casa paterna; e Moisés salvo das águas.

365 Tratavam-se, afinal, de obras incorporadas imediatamente ao acervo a AIBA. 
explorada e, por conseguinte, compreendida), e repetidamente defendido nos seus textos de 1863,1864 e 1865, os quais, como visto, respondiam por sua vez, perfeitamente, aos propósitos teóricos da própria Academia. Tratava-se da leitura apologética de uma transcendência ou, ao menos, de uma ascendência por meio da razão ao belo moral platônico (este que, nO Banquete ${ }^{366}$, é justamente apresentado como uma concepção socrática).

A mensagem é, com efeito, bastante clara na composição efetuada pelo jovem brasileiro: é preciso purificar-se da dominação das paixões do corpo para atingir o ideal, no caminho das verdades eternas. Em Américo, Aspásia e Sócrates encarnam os dois extremos desse caminho, sensação e razão. Alcibíades é o representante simbólico desses dois componentes inevitáveis ao homem, mas a sugestão fornecida é que ele é capaz de dosá-los pela ativação pessoal da razão, representada pela consciência. Seus gestos (a mão direita no queixo) e expressões (o olhar longínquo) reforçam a impressão de uma profunda imersão reflexiva, mesmo que pareçam ainda se sugerir algo próximo à irresolução. Mas a dúvida (elemento clássico cartesiano, muito explorado por Cousin) é, ela mesma, resultado do processo contínuo de contestação e ponderação que deve fazer parte da ascensão às verdades universais.

Essa intenção simbólica de subida é o que Américo quer de fato reforçar ao escolher novamente para a sua composição uma direção vertical, em contraste com aquela escolhida por seu principal oponente, Le Chevrel, que, orientando seu quadro horizontalmente, havia enfatizado sobretudo o viés lascivo do episódio (fig.5.27). Alcebíades ainda nu ao lado de Aspásia, que lhe pendura o ombro (isto é, aqui não é a razão, mas o sentido que está ainda colado ao jovem grego), pondera qual caminho seguir. Estando onde está, sua decisão não é ainda suficientemente clara, e o desfecho imaginativo do episódio permanece ainda incerto. Tão incerto a ponto de a figura de Sócrates - paradoxalmente a maior de toda a tela e também a que deveria conduzir a representação daquele episódio - se apresentar como secundária diante do grupo dominante dos amantes.

Em Américo, ao contrário, a orientação da composição reforça precisamente o aspecto moral do episódio (Alcibíades já havia feito afinal sua escolha, largando um copo de vinho ao solo), fazendo uso da "linha intelectual", que se apresenta pela predominância da direção vertical, mais adequada, como havia postulado Sutter, "aos temas religiosos, às elevações, às apoteoses e a todos os temas que

366 Para uma das diversas traduções em português do diálogo platônico-socrático dO Banquete, ver: PLATÃO. Diálogos. [tradução e notas de José Cavalcante de Souza, Jorge Paleikat e João Cruz Costa]. São Paulo: Abril Cultural, 1979. Pp.07-53. 
demandam nobreza e dignidade ${ }^{\text {367 }}$. Este último parecia ser mesmo o caso. Numa replicação sutil da fórmula utilizada para a realização da sua náiade, Américo também colocará Sócrates no centro da tela (a figura máxima do episódio também personifica o eixo intelectual da composição). $\mathrm{Na}$ obra, Alcebíades, então já vestido com as roupas do seu trabalho (seus deveres morais), segue portanto Sócrates (isto é, caminha de braços dados com a razão) e se afasta dos prazeres dos sentidos, marchando, literalmente, em direção à verdade. A linha estética de sua figura, também vertical, é compassada mas suficientemente variada com a do filósofo: este marcha com seu pé direito na frente; e aquele, com o esquerdo. Tal sugestão de desenvolvimento intelectual em direção à revelação das ideias absolutas, que se faz, no entanto, no "real" e no presente (daí a importância do movimento da marcha, horizontal, orientação simbólica do homem na terra), é ainda reforçado por Américo a partir da representação de uma coluna (representante simbólico da cultura) e de um templo (representante da religião), posicionados exatamente atrás da figura de Alcebíades, figuras de cujos respectivos capitel e frontão triangular arremedam a importância da vertical, na sugestão da subida idealista do militar.

Frente a essas duas figuras dominantes na pintura do jovem Américo, é a imagem de Aspásia (fig.5.26.), no entanto, em seu caráter coadjuvante mas fundamental para a composição, a que ainda mais interessa para o citado estabelecimento de um critério de comparação mais justo com a imagem da Carioca. Ambas são figuras femininas em estado de juventude, ambas são representadas sentadas e nuas, tendo apenas as suas regiões sexuais cobertas. Não obstante, uma personifica conceitos exatamente opostos à outra. Se $A$ Carioca é uma divindade que fazia fundamentalmente referência a um "composto de ideias abstratas", a figura de Aspásia, ainda que uma idêntica invenção da mente do jovem Américo, possuía ligação com uma existência feminina outrora verídica, historicamente comprovada, devendo representar simbolicamente a imagem de uma mulher igualmente real, mas lasciva, repleta de tentações e encantos.

Em contraste com a figura masculina de Sócrates - representante da cultura e do amor intelectual, que torna o espectador cúmplice da cena, observando-o com gravidade, como quem diz: "a lição também é para você" -, Aspásia é o amor carnal em pessoa, ministra dos prazeres passageiros, que não propiciam, portanto, conhecimentos duráveis (seguindo as proposições da filosofia de Cousin e Tiberghien, que Américo parece novamente invocar). Ela é o próprio "Vício" do qual o filósofo tentaria afastar o jovem militar. É, enfim, uma filha de Vênus; mas trata-se da Vênus vulgar, Pandêmia, cuja

${ }^{367}$ SUTTER, David. Esthétique générale et appliquée. Paris: Imprimerie impériale, 1865. p.54. 
natureza sensual havia sido revelada por Pausânias, em $O$ Banquete, do qual também teria participado, segundo Platão, Alcebíades.

Em resposta a essa sua natureza simbólica, Américo representa de fato a sua Aspásia como Gustave Boulanger (amigo de Gérôme no grupo dos Neogregos) havia representado, em 1850, numa pintura bastante conhecida, a "real" Frinéia, amante de Praxíteles e Apeles - e não a Frinéia sendo transformada em Vênus por esses artistas (fig.5.28.). Os resultados das duas figuras femininas são relativamente distintos, mas a configuração geral e os meios formais utilizados são praticamente os mesmos. Como Boulanger, o cuidado que havia aparecido nA Carioca, com a conformação de uma linha pouco sensual, é então deixado de lado por Américo para a exploração de um contorno sinuoso da figura, que põe em relevo o caráter especialmente libidinoso da cintura e quadril feminino. Os ângulos presentes no contorno da náiade estão, tanto em Aspásia quanto em Frinéia, apagados. As formas se arredondam, as "carnes" aparecem, e a distância que separava as formas anteriormente realizadas pelo jovem brasileiro das formas oferecidas por um Rubens ou por um Rembrandt não é agora mais tão grande assim. O ventre e os seios da cortesã - "pomos virginais" e circulares n $A$ Carioca - se molificam e parecem estar sujeitos à gravidade "horizontalizante" das meretrizes; impressão que é consequência do desenho de curvas e contracurvas que os lançam para as laterais do tronco. Os mamilos são, enfim, do mesmo modo mais aparentes.

Todo o resto da figura joga também em favor da imagem carnal que deveria transparecer em Aspásia (como também havia sido a intenção de Boulanger, com sua Frinéia). O corpo se reclina contra o encosto da cadeira, em sinal de espera, reforçado pelo sorriso malicioso e pelo gesto da mão que escora a cabeça, mas, evidentemente, não em melancolia. As pernas estão cruzadas, em sinal de volúpia e de repouso indolente - ação que Winckelmann já havia dito ser inconveniente a uma deusa, na medida em que se trataria de uma postura inadequada à sua natureza ${ }^{368}$. Os acessórios, inexistentes $\mathrm{n} A$ Carioca, tendem também a afirmar a beleza "real", mas igualmente artificial da figura. O rosto é bem

${ }^{368}$ WINCKELMANN. Op. cit. pp.273-75. Outro texto, também de autoria de Winckelmann, e com repetidas reedições na metade do século XVIII e no século XIX, reitera as observações apresentadas na História da Artes entre os Antigos: WINCKELMANN. De l'Allégorie ou Traités sua cette matière. Tome Second. Paris: H. J. Jansen, 1799 : "O artista grego buscava expressar as ideias de dignidade e de grandeza até na atitude do repouso que ele dava às figuras de divindades colocadas de pé. A perna direita, colocada ordinariamente na frente, parecia se mover, e a atitude inteira ganhava em graça sem perder equilíbrio. É conhecido que, seguindo essa conveniência estabelecida em função de suas posições locais, as divindades dos antigos não foram jamais representadas com as pernas cruzadas. Uma tal atitude era ou um desaprumo pessoal e característico, como, por exemplo, aquele dos faunos, ou simplesmente a expressão de uma ideia particular. Com efeito, podia-se expressar por penas cruzadas o repouso, a tristeza, a imprudência da juventude, ou uma voluptuosa preguiça; também Psiquê se encontra quase sempre representada dessa maneira quando ela beija o Amor." p.357 [tradução nossa] 
mais branco do que o resto do corpo, em possível referência ao mesmo pó de arroz que Émile Zola havia dito estar repleta a Vênus carnal, de Cabanel; a falsa pinta no rosto (um conhecido acessório para a beleza artificial feminina); a tiara, os brincos, colares e pulseiras; o leque em sua mão esquerda; o drapejado, completamente ornado em suas bordas; estes são ornatos que, totalmente dispensáveis para a representação da beleza ideal, fazem todo sentido na representação da beleza passageira, expressão da vaidade e da luxúria.

Uma análise algo similar havia sido de fato feita pelo próprio Américo, sempre em resposta a Coques, sobre a relação específica entre a paisagem, mais austera, e a sua Carioca:

Notamos ainda algumas mal cabidas reflexões a respeito dos acessórios do nosso quadro; mas limitar-nos-emos a responder que [...] [isso foi] devido à intenção que tivemos de não distrair com a minuciosa perfeição dos pormenores a atenção do espectador, naturalmente levada para a figura que ocupa o centro da tela. Pois nem sempre onde está o brilho existe o ouro ${ }^{369}$.

Na medida em que o pudor e a conveniência dos gregos, ainda válida aos brasileiros, não permitiria que a uma cortesã fossem elevados monumentos com sua imagem "real" 370 , o jovem deve ter então julgado que as diferenças de fato criadas entre sua Aspásia e a sua Carioca estavam bem demarcadas. A máxima com a qual havia postulado - seguindo Émeric-David - que, entre os antigos, "nunca se vira em um templo a imagem de qualquer divindade que fosse, com os traços voluptuosos das virgens da Escola Flamenga, nem tão pouco brilhar em rosto divino a elegância maligna dos tipos de Mignard $^{371}$ ou [Antonio] Canova"372, servia sem dúvida de fundamento de justificação para as dessemelhanças nas formas "setentrionais" de sua Aspásia, e nas formas "meridionais" de sua Carioca.

Com efeito, na primeira apreciação crítica, e além disso oficial que o seu Sócrates afastando Alcebíades do Vício havia recebido, a Academia Imperial de Belas Artes manifestava pela voz “eclética" do seu diretor, Thomas Gomes dos Santos, ter bem compreendido o recado do jovem:

Aquele que tem por anagrama a judiciosa sentença de Leonardo da Vinci: Um pintor sábio na theoria da sua arte pode sem muita dificuldade tornar-se universal [Américo], representou justamente o momento em que Sócrates afasta Alcebíades do Vício. A graciosa amante, lasciva e descuidosa,

${ }^{369}$ AMÉRICO, P. "A Carioca. (Resposta ao Sr. Gonzalez Coques.)" Correio Mercantil, Rio de Janeiro, 31 de janeiro de 1865. p.2.

370 AMÉRICO, Pedro. Considerações Filosóficas sobre as Belas Artes entre os Antigos. Estudo sexto, p.159. Ou: Correio Mercantil, 16 de novembro de 1864, p.02.

371 Pode-se tratar de Pierre Mignard (1612-1695) ou de seu irmão Nicolas Mignard (1606-1668)..

${ }^{372}$ Idem, ibidem. p.160. Ou ainda a mesma edição: Correio Mercantil, 16 de novembro de 1864, p.02.

Para a citação original no livro do autor francês, ver: ÉMERIC-DAVID. Op. cit. p.91. 
exprime bem o caráter pérfido dessas mulheres, que por muito amarem, a ninguém amam; é uma dessas belas gregas, cujas formas arredondadas e encantadores inspiravam os artistas sublimes, que produzirão essas Venus, que fazem, e farão sempre a admiração dos cultivadores da arte. Alcebíades, pensativo e obediente, deixa-se levar por seu sábio mestre; bela figura de mancêbo, com que sonhara Canova para produzir o seu Páris. Sócrates, severo e enjoado do lugar em que seu zelo o obrigara a penetrar, apressa-se em fugir da atmosfera libidinosa que ali se respira: a magnífica cabeça do herói é o fiel retrato que dele nos legara a antiguidade. É para sentir que todas as partes deste belo quadro não estejam acabadas com as três figuras principais. O colorido é quente, vigoroso, brilhante, e cheio de harmonia. O desenho é correto. Os trajes, as roupagens, os móveis e a situação, tudo foi aconselhado pela verdade histórica, e fielmente representado. ${ }^{373}$

\section{- do claro-escuro}

O claro-escuro é também outro problema fundamental que a Estética Aplicada apresentava ao jovem Américo para a produção de sua Carioca. Trata-se de um problema distinto da cor, quase meio termo entre esta e o desenho, mas ainda assim percebido como parte integrante da "parte masculina" do ofício da pintura. O claro-escuro confere "solidez" ou a impressão de tridimensionalidade a uma figura, estando também, em boa medida, vinculado às exigências da "verdade" da forma.

Para Sutter, o primeiro quesito do claro-escuro seria a definição da luz, especificamente de sua direção e quantidade ${ }^{374}$ (ela poderia ser vertical, horizontal ou oblíqua, sendo uma luz larga, média ou estreita $^{375}$ ) (fig.5.29. ilust. 5, 6 e 7.). Do mesmo modo que a variedade, a simetria, a proporção, esse quesito é significativo para a afirmação da unidade ótica de um quadro e da sua ideia. Deveria sempre existir uma relação íntima entre a harmonia das linhas estéticas de uma composição e a direção da luz, definindo a maneira como os objetos são percebidos espacialmente e a sua importância. De fato, seria necessário dar uma direção clara à luz. De outro modo, se ela "fosse disseminada sobre todos os objetos do quadro, não haveria jogo picante, nem verdade, nem unidade no efeito; a pintura seria monótona e desprovida de charme potente que faz reconhecer as obras dos mestres de longe e à primeira vista." ${ }^{376}$ Em razão dessa recomendação, o raio de luz principal deveria "passar sempre pelos objetos mais

${ }^{373}$ MAFRA, João Maximiano (redator). Ata da Sessão da Congregação e do Diretor da Academia Imperial de Belas Artes no dia 09 de agosto de 1865. Museu d. João VI. p.145 (versão digital). Disponível online em: http://www.docvirt.com/docreader.net/docreader.aspx?bib=MuseuDJoaoVI\&pasta=Encadernados\&pesq= [último acesso, janeiro de 2016]

${ }^{374}$ SUTTER. Op. cit. p.328-29.

${ }^{375}$ SUTTER. Esthétique appliquée à la peinture. p.36.

${ }^{376}$ Idem, ibidem. p.213. 
interessantes da composição, de modo a unir esses objetos entre eles pela unidade da luz"377. E a única maneira de fazê-lo seria orientar o feixe principal de luz paralelamente à linha estética dominante do quadro.

Mais uma vez, quase como se seguindo pari passu as observações de Sutter nos elementos cruciais do seu quadro, Américo escolhia para a sua Carioca uma luz larga em primeiro plano, resolvendo-a paralelamente à linha estética dominante do quadro, definida pela figura da ninfa (fig.5.30.). Ele resolveu a iluminação a partir de um esquema oblíquo, especialmente explicado pelo francês ${ }^{378}:$ um feixe de linhas retas, cujo centro representa a luz principal que passa pela ninfa, e as demais linhas, secundárias e terciárias (em acordo com os “princípios da visão”), definindo uma relação gradualmente menos intensa e subordinada de luz sobre os demais elementos do quadro ${ }^{379}$. Américo seguiu, ainda, uma outra importante regra: numa pintura, a luz que entra, tem que sair.

Desse modo considerada, e seguindo portanto um ritmo contíguo à linha estética dominante, a iluminação do quadro requeria o seu oposto necessário, o jogo de sombras, que instala, portanto, um novo eixo oblíquo (e uma nova variedade de linhas, fundamental à unidade), que desenha um contraste harmônico de movimentos, estabelecido a 90 graus da direção da luz. (fig.5.30.)

A resolução dessa relação contrastante mas, repete-se, necessária a qualquer quadro, segundo as recomendações da Estética Aplicada, não era tão simples e exigia do pintor um partido adequado à ideia representada. Mas para a realização do tipo ideal, ao qual Sutter orientava seus leitores, havia apenas uma solução a realizar, variável apenas em modo: a obra deveria ser realizada por meias$\operatorname{tintas}^{380}$.

A despeito da qualidade limitada da reprodução da primeira Carioca, é possível perceber, em comparação com a segunda versão da pintura, que o jovem já havia então assumido esse expediente e se alinhado nesse ponto específico a demais artistas do seu tempo, que haviam estabelecido uma relação próxima com a Académie e com a École des Beaux-Arts, além disso também preocupados com a representação da figura feminina nua (entre eles os citados Ingres, Cabanel, Baudry, Amaury-Duval, Gérôme e Boulanger). Somados a uma significativa massa de alunos que havia passado pela escola,

\footnotetext{
377 SUTTER. Philosophie des Beaux Arts. p.214.

${ }^{378}$ Idem, ibidem. p.213.

${ }^{379}$ SUTTER. Esthétique appliquée à la peinture. p.46.

${ }^{380}$ Idem, Philosophie des Beaux Arts. p.214; Idem, Esthétique appliquée à la peinture. p.36.
} 
eles haviam garantido que "a meia-tinta era a expressão da forma ideal"381.

Se para uma divindade, a exemplo das Vênus, o que contaria na relação do claro-escuro com a beleza ideal era a firmeza, doçura, flexibilidade, fineza e a unidade da pele ${ }^{382}$ (processo já iniciado por Américo pela abstração dos nervos e músculos, tornando-a mais lisa), a modelação da figura deveria reforçar a homogeneidade pedida à sua natureza visível. De fato, o jovem Américo rendia à sua figura um valor tonal médio, com predominância dos tons claros - característica importante para a manutenção da harmonia do objeto -, e realizava, assim, uma unidade que se faz não por contraste, mas por aproximação ${ }^{383}$, disso resultando o aguçamento da oposição da náiade com o fundo, secundário e predominantemente escuro (fig.5.22, fig.5.67.). Se a comparação das duas versões da Carioca continuar correta, ao menos no que parece se referir ao claro-escuro, aparentemente realizados de maneira bastante similar em ambas, se é levado a crer que Américo preferiu se afastar dos efeitos luminosos modulados dos ignudi de Michelangelo, que tanto the haviam surpreendido na Capela Sistina, e mesmo dos nus rafaelescos ainda no Vaticano, ou na Villa Farnesina, tendendo a afirmar sua figura, ao contrário, ao lado da regularidade tonal do nu de um Correggio, ou ainda, novamente, do nu feminino veneziano (especialmente Ticiano e Tintoretto); uma aproximação que havia sido de fato indicada (conforme tratarei logo em seguida) por algumas personalidades brasileiras do período, aliás, não apenas em relação ao claro-escuro, mas igualmente dos efeitos de cor em sua náiade.

\section{- da cor}

Quanto à cor da Carioca, é muito provável que quase tudo o que se diga a esse respeito permaneça no terreno das especulações, se se toma como base apenas a reprodução em sanguínea da primeira obra, e a suposição de que algumas variantes inseridas na segunda versão diziam respeito apenas a mudanças no desenho da ninfa e alguns elementos secundários. Seria realmente o drapejado sob a figura da ninfa o mesmo feito na segunda, combinando o tecido branco e vermelho? A porção de céu ao fundo com a combinação de cores que então já compunham a bandeira nacional? A paisagem? Se essas permanências fossem de fato confirmadas por escrito, é certo que mesmo a percepção da intensidade dessas cores seria afetada naquela reprodução fotográfica (sabe-se por exemplo que até grande parte da

${ }^{381}$ L'ART DU nu au XIXe siècle [exposition, Paris, 14 octobre 1997-15 février 1998, Bibliothèque nationale de FranceFrançois-Mitterrand]. Paris: Hazan/Bibliothèque Nationale de France, 1997.

382 SUTTER. Philosophie des Beaux Arts. p.168-69 e p.170.

${ }^{383}$ Sobre o mesmo problema das meias-tintas, ver ainda: WATELET, Claude-Henri. Encyclopédie Méthodique: BeauxArts. Tome premier. Paris: Panckoucke, 1788, especialmente o verbete o verbete "Demi-teintes", pp.185-86. 
segunda metade do século XIX a fotografia em preto-e-branco era mais sensível a algumas cores que outras, tendendo a mudar seus valores proporcionais).

Essas são dúvidas que poderiam ser enfim esclarecidas apenas com o repentino aparecimento da primeira versão. Suas características cromáticas poderiam ser, então, mais uma vez confrontadas com as lições teóricas de Sutter, que também havia dedicado uma parte inteira da sua Filosofia das Belas Artes ao estudo da aplicação e interação das cores na pintura ${ }^{384}$, contendo ainda, ao final do livro, uma sugestiva análise sobre a "maneira de pintar dos antigos Venezianos" "385. Este interesse não se tratava de uma idiossincrasia do francês mas, antes, uma justa resposta ao interesse geral que a cor da "Escola Veneziana" (assim como a composição e a potência dramática de Caravaggio) havia despertado aos artistas nascidos após a década de $1830^{386}$, uma geração que incluía vários artistas (e eu não tenho dúvidas de que Américo faz parte desse grupo), de cujos projetos pessoais incluíam a assimilação o desenho e a composição florentinos e romanos sem abandonar as valiosas lições dos venezianos.

A estima estava presente na segunda versão da Carioca, obra na qual pode-se perceber uma frequentação da maneira veneziana, especialmente quando relacionada aos temas de nus e sua inserção na paisagem, inaugurados por Giorgione, mas bastante explorados em seguida por Ticiano e Tintoretto. A exploração do contraste da paisagem escura com a pele alva e com tons róseos das figuras femininas, cuja força frente àquele embate é quase sempre reforçada pela presença do panejamento rubro-branco. Vê-se ainda a presença etérea da cor, especialmente explorada pelo uso aparente de glacis, e pela exploração dos "borrados" nos contornos da figura.

Se a reprodução da primeira versão da Carioca não aceita maiores conclusões quanto à configuração geral da cor, é possível, entretanto, ao menos indicar que algumas das apreciações críticas oficiais e não oficiais feitas desde a primeira aparição da obra, no começo de 1865, haviam não raro ufanado as qualidades cromáticas da obra e o sentimento de colorismo do jovem artista, e ainda identificado as características de alguns poucos elementos no quadro.

O primeiro aspecto, sobre a cor geral no quadro, apareceu desde o primeiro comentário da

${ }^{384}$ SUTTER. Op. cit. pp.255-80. Os temas tratados sobre a cor na publicação de Sutter giram em torno da natureza dos raios luminosos (e de sua relação com os estudos científicos sobre a cor desenvolvimentos naquele momento, na França), da polarização da luz e das oposições harmônicas da cor; da harmonia das cores com o "modo" do quadro e do caráter alegórico das cores.

${ }^{385}$ Idem, ibidem. pp.338-33.

${ }^{386}$ Para esse interesse renovado na pintura caravaggista e veneziana, ver, por exemplo: SÉRIÉ, Pierre. Op. cit. Roberto Longhi também passará muito rapidamente pela questão: LONGHI, Roberto. Breve mas verídica história da pintura italiana. São Paulo: Cosac \& Naify, 2005. 
imprensa, publicado quando a obra ainda se encontrava exposta na Casa Bernasconi \& Moncada - "que harmonia naquelas tintas cálidas!" -, e prosseguia sugestivamente a uma aproximação do quadro de Américo às qualidades do colorista Eugène Delacroix ("O quadro do Sr. Américo faz lembrar as vigorosas criações de Eugênio Delacroix." ${ }^{387}$ ).

O elogio era retomado duas vezes, por vias oficiais: a primeira, na indicação de premiação para a Exposição Geral de Belas Artes, em 1865, quando João Mafra transcrevia a análise da Congregação, que percebia no quadro "um colorido vigoroso e agradável" 388 ; e a segunda em 1866, quando da premiação retroativa (concomitante à EGBA daquele ano), Thomás Gomes dos Santos também bradava em discurso "o colorido cheio de vigor" da Carioca $^{389}$.

O mesmo elogio ainda reaparecia poucos anos depois, em 1871, no comentário de Guimarães Júnior, que apresentava Américo como um "talento analítico [que] derramou as mais delicadas cores" sobre a figura da ninfa, cores "que se combinam e exaltam sobre uma paleta predestinada" 390 .

Em 1888, Gonzaga Duque, em sua astúcia costumeira, (embora não se saiba se ele havia visto a primeira versão da obra da pintura) havia também se referido não apenas às qualidades cromáticas da Carioca, mas à própria índole colorística de Américo, manifestada desde a sua juventude: “O pintor coadjuva espontaneamente o desenhista. A tinta é o seu segredo, é o poder criador de suas obras. É uma prodigiosa boceta de Pandora, essa palheta brilhante e opulenta." 391 Defendia ainda que: "em todos os seus quadros é o contraste da cor uma das notas mais firmes de seu estilo" ${ }^{392}$. E a partir do estabelecimento dessas qualidades que compreendia por fim que:

Como todos os coloristas Américo procura o contraste das cores dos acessórios com o objetivo. $\mathrm{Na}$ 'Carioca', um dos quadros mais antigos do autor de 'Jacobed', esta qualidade, ou melhor, está preocupação está indelevelmente acentuada. O ultramar puro do céu parece, a quem observa o quadro por parte, de um efeito exagerado, mas para o conjunto, esse exagero é um elemento de força e, consintam-me dizer, de quentura. Nesse fundo carregado, caloroso, fora do vulgar, a formosa figura sobressai, imponente, grandiosa, fantástica. Se em lugar desse ultramar, o pintor cobrisse a tela com o

${ }^{387}$ CORREIO mercantil. Rio de Janeiro, 16 de janeiro de 1865. p.1

${ }^{388}$ MAFRA, J. M (red.) “Ata da Sessão da Congregação em 01 de maio de 1865”. In: Ata da Sessão da Congregação e do Diretor da Academia Imperial de Belas Artes no dia 3 de junho de 1865. Museu d. João VI. p.145 (versão digital).

Disponível online em: http://docvirt.com/MuseuDJoaoVI/ [último acesso, janeiro de 2016]

389 SANTOS, Thomás Gomes dos. "Ata da Sessão Pública da Academia Imperial das Belas Artes, em 15 de julho de 1866.” ACADEMIA IMPERIAL DAS BELAS ARTES. Atas das sessões públicas do conselho acadêmico da AIBA, 1865, 1866. Museu d. João VI / EBA-UFRJ. Disponível online em: http://docvirt.com/MuseuDJoaoVI/ [último acesso, março de 2016].

390 GUIMARÃES JR. Op. cit. p.51.

${ }^{391}$ DUQUE-ESTRADA, Luiz Gonzaga. Arte Brasileira. [Introdução e Notas, Tadeu Chiarelli]. Campinas: Mercado de Letras, 1995. P.167.

${ }^{392}$ Idem, ibidem. p. 168 
azul de cobalato ou mesmo com ultramar e branco, a parte da rocha em que senta-se a figura não teria o profundo mistério que a envolve nem ela aparecer-nos-ia tão feiticeira e bela porque o tom róseo de suas carnes esmoreceria com a fraqueza dos tons do fundo. ${ }^{393}$

Em 1889, no ano seguinte à publicação dessa análise realizada por Gonzaga Duque, os elogios sobre as qualidades coloristas de Américo, e especialmente direcionados à Carioca, convergiam então, pela primeira vez, em uma identificação dessa obra com uma "escola", assumindo-a sintomaticamente como uma herdeira presumida da tradição veneziana. A identificação fazia parte do verbete sobre Américo, impresso no Dizionario degli artisti italiani viventi, de Angelo Gubernatis, impresso em Florença - cidade onde o brasileiro já morava há quase 15 anos, e onde ao menos uma vez, em 1875, havia exposto a sua náiade ${ }^{394}$. Por duas vezes, em um pequeno trecho, o verbete evocava um estilo "que se avizinha ao veneziano" de uma obra "tomada por muitos conhecedores como um quadro da escola veneziana"395.

Seria apenas anos depois dessa análise que o próprio Gonzaga Duque - num texto publicado em homenagem a Américo, então recentemente morto - iria também relacionar as aplicações de cores da primeira grandeza composição de Américo à Escola Veneziana: “A Carioca, a sua mais notável das primeiras composições, recorda o Ticiano e o Veronês" ${ }^{\text {396. }}$.

O segundo aspecto anteriomente citado (o que se referia às características de alguns elementos presentes no quadro) também apareceram nos primeiros textos publicados sobre $A$ Carioca. A partir deles confirma-se - e neste caso certamente em acordo com a segunda versão do quadro - que a náiade de Américo já possuía os seus lábios rosados, os olhos e cabelos negros ${ }^{397}$ (esta, uma escolha inusual diante da predominância internacional das divindades loiras e de olhos claros, mas, conforme discutirei à frente, um partido calculado e denunciador da intenção de conformação da figura à realidade brasileira). Mas o mais importante, que a reprodução da primeira reprodução permitia de todo modo ver: ela era predominantemente branca.

\footnotetext{
${ }^{393}$ Idem, ibidem. p. 168.

${ }^{394}$ GAZETA de Notícias. Rio de Janeiro, 04 de agosto de 1875. p.1.

395 GUBERNATIS, Angelo de. Dizionario degli artisti italiani viventi, pittori, scultori, architetti. Florença: Tipi dei successori Le Monnier, 1889. p.16-17. [tradução nossa]

396 Gonzaga Duque. Impressões de um amador. Textos esparsos de crítica (1882-1909). [orgs. Júlio Castañon Guimarães e Vera Lins]. Editora UFMG / Fundação Casa de Rui Barbosa, 2001. p. 242.

${ }^{397}$ CORREIO mercantil. Rio de Janeiro, 16 de janeiro de 1865. p.1; S/A. "Revista do Domingo." Diário de notícias. Rio de Janeiro, 02 de outubro de 1870. p.1: "alva, luminosa, poética, com os olhos negros, cheios de luz e promessas; o lábio rubro [..] a alvura da pele de uma doçura de toque, inexprimível tranças negras [...] o fundo da tela banhando um clarão tropical."
} 
Para o próprio Américo ela era "talvez" branca até demais. Mas seguindo todos os grandes teóricos do século XVIII ao XIX, de Winckelmann a Sutter, essa brancura era certamente percebida como um dos caracteres fundamentais para a afirmação do ideal (e de sua unidade) na sua Carioca.

\section{- da graça}

A graça é a última categoria da grandeza em sua relação com a Beleza. Nem todas as representações femininas necessitariam chegar até esse ponto, porque nem toda a divindade deveria ser graciosa. A natureza severa de Atenas não a permitiria ser assim, o mesmo normalmente se passando com Diana, a caçadora, sempre grave em suas representações - azar de quem, aliás, como Actéon, se deparasse com ela em seus banhos, acompanhadas de suas ninfas: os cornos são apenas o primeiro sinal de que o pior ainda está por vir.

São as Vênus, novamente, seguidas também por suas ninfas, que abririam esse caminho: sua dupla essência, desdobrada nas aparições de Pandêmia e Urânia, permitiu desde os gregos o intercâmbio dos atributos presumidos de uma à outra.

Praxíteles havia inaugurado o tema na estatuária com sua Vênus de Cnido (fig.5.31.), o primeiro nu monumental feminino conhecido ${ }^{398}$. A versão original, perdida - mas cuja imagem permanece nas inúmeras cópias em variações romanas - já somava o pudor de Diana (naquela escultura, o ato de esconder seu sexo após o banho, enquanto toma sua vestimenta ${ }^{399}$ ) ao então novo elemento praxitelesco, a graça ${ }^{400}$ (nascida do movimento suave que resulta desse mesmo cobrimento).

De Winckelmann a Sutter não existiram grandes mudanças na maneira de se interpretar o fundamento teórico da graça: ela se formava e residia nos gestos imputados às figuras; isto é, se trataria de um "je ne sais quoi" que nasce das ações e movimentos do corpo ${ }^{401}$, especialmente de suas extremidades. Conquanto geralmente fosse "empregada como sinônimo de beleza", como havia também dito Sutter, ela "serve a indicar certo charmes particulares à beleza, e, ao mesmo tempo, uma

${ }^{398}$ A história, contada por Plínio, o Velho, era a propósito justamente a da existência de duas Vênus, que formavam um par: uma mais severa, vestida; e a outra nua. Tencionada pelo escultor aos habitantes da ilha de Cos, eles haviam entretanto rejeitado a versão nua, logo em seguida adquirida pelos habitantes de Cnido, onde a estátua então ganharia fama secular. PLÍNIO. Natural History. Vol. X. Cambridge: Harvard University Press, 1989. Livro 36, 20-21.

${ }^{399}$ Essa é a interpretação predominante no século XIX. Outras posteriores, no entanto, havia indicado que o gesto da Deusa, antes de significar o pudor, ao esconder seu sexo, era um símbolo de sua fertilidade.

${ }^{400}$ PASQUIER, Alain; MARTINEZ, Jean-Luc. Praxitèle. Catálogo de Exposição. Paris: Louvre, 2007.

${ }^{401}$ WINCKELMANN. Op. cit. p.354. 
coisa diferente e complementar à beleza" ${ }^{402}$. Enquanto esta última se mostraria predominantemente na forma de uma imagem, a graça se ampararia no seu modo ou maneira: "a graça [é] um movimento da alma que é julgado apenas pela ação do corpo, e essa definição é a que geralmente se adota". ${ }^{403}$

Sendo resultado de uma ação, a graça estaria, assim, em necessária relação com a beleza moral e a beleza física (ótica). E por sua natureza de gesto suave mas espontâneo, ela - como a alegoria, no entender de Cesare Ripa - só poderia ser perfeitamente expressa se associada à imagem da mulher, em decorrência de sua natureza também delicada ${ }^{404}$. Com efeito, na medida em que movimentos de "natureza feminina", as ações que fazem nascer a graça deveriam ser tranquilas, e a atenção não deveria ser disputada com outros movimentos de diferentes naturezas; contraste que resultaria ou na quebra da graça, ou, pior, no rompimento da unidade na figura ${ }^{405}$. Os gregos já teriam percebido (e a partir deles, os demais grandes artistas) que a graça ganhava em efeito quando a figura permanecia em repouso. Ela poderia estar de pé, como o caso da Vênus de Cnido, ou a Vênus de Médicis, mas ganharia ainda mais se estivesse preferencialmente sentada, esta sendo uma configuração na qual os gestos, mesmo que pequenos e sutis, seriam concentrados positivamente na fruição da obra:

Se a posição sentada implica necessariamente uma atividade estática, permanece o fato de que elas estejam frequentemente ocupadas em ações concretas (tocar um instrumento musical, realizar um gesto específico, etc.). Mesmo sentado, o corpo humano é capaz de comunicar uma energia notável: é o caso do torso do Belvedere [fig.5.95.], cuja lembrança está presente em uma multidão de obras de arte. Não é raro que as figuras sentadas estejam mergulhadas em um tipo de imersão psicológica: a comodidade dessa postura favorece a concentração e a intimidade consigo mesmo, e ela é característica do humor melancólico. ${ }^{406}$

Não é preciso ir muito além desse ponto para perceber que são já muitas as afinidades dessa questão com a figura da Carioca. Além de escolher em seu quadro a representação da juventude feminina que se encontra sentada, afastando-a da postura ereta escolhida por alguns contemporâneos às suas mulheres nuas, e, mais ainda, da sensualidade horizontal explorada por outros; e além de escolher a predominância compositiva das diagonais com predominância vertical, Américo deseja confirmar cabalmente a expressão corporal da sua divindade pela adoção de uma combinação dupla e precisa de gestos, conformes à natureza igualmente tranquila da figura. Realmente, também como Sutter havia

\footnotetext{
${ }^{402}$ SUTTER. Op. cit. p. 106.

403 SUTTER. Op. cit. p. 106.

${ }^{404}$ Idem, ibidem. p. 108.

${ }^{405}$ Idem, ibidem. p. 107.

${ }^{406}$ RUSSO, William dello. L'art du nu. Paris: Hazan, 2011. P.143. [tradução nossa]
} 
postulado, "a beleza dos gestos depende da conveniência e da disposição ótica das partes"407.

De início, a imagem do pé que toca levemente a água - já aludida aqui. Trata-se de outro movimento tradicional da graça feminina, sugestivo por sua leveza e delicadeza, profusamente explorado em cenas de banhistas, e especialmente das ninfas:

Pretexto para o desvelamento da nudez feminina, a cena do banho, coletivo ou solitário, suscita inumeráveis variações. [...] O motivo pictórico do banho funda um gesto gracioso: um pé na água; tal ninfa se imobiliza, apreensiva, diante do olhar do pintor Le Moyne; tal náiade se encosta sob um berço de folhagens, o corpo ainda iridescente de gotinhas brilhantes. ${ }^{408}$

Em seguida, o gesto suave das mãos. Este gesto, precisamente, interessa aqui explorar, em decorrência da sua íntima significação com o tema original da banhista, isto é, o do nascimento da Vênus nas águas ou o dos seus banhos; e em decorrência, ainda, da passagem historicamente gradual dos primeiros gestos explorados por esse tema em direção a outros que, embora já fosse distintos (e incluindo então não apenas Vênus, mas ninfas e, futuramente, banhistas "desmitologizadas" e "desalegorizadas"), guardavam um evidente vínculo hereditário com as primeiras configurações estabelecidas pela estatuária grega.

Centrado sobretudo num desdobramento formal, o percurso visual que será em seguida desenvolvido não é exaustivo. Ele não é estruturado por quaisquer interpretações propriamente formalistas, iconográficas, iconológicas, estilísticas, culturais ou sociais. Constitui-se, sobretudo, de obras que Américo viu e estudou regularmente em Paris, pessoalmente ou em reproduções, e aquelas que pôde também visitar em suas viagens a Londres, Roma, Florença (possivelmente), Bruxelas, e alhures. O traçado esboçado parece ser ao menos sugestivo, na medida em que (a meu ver) permite posicionar A Carioca na longa duração de uma tipologia da arte ocidental, ainda bastante acessada no momento em que o jovem realiza a sua figura, e com a qual, não há dúvidas, está dialogando com interesse.

São dois os desdobramentos específicos apresentados, concernentes ao tema da banhista.

O primeiro está em estreita relação com imagens cujos movimentos das mãos respondem às formas estabelecidas em uma figura que deve se portar de pé. Aqui, a graça dos gestos é relativamente reduzida, ou ainda contida, pela verticalidade da figura. Seu ponto de partida está, portanto, na mesma

\footnotetext{
${ }^{407}$ SUTTER. Op. cit. p. 156.

${ }^{408}$ MARNHAC. Op. cit. p.47.
} 
Vênus de Cnido (fig.5.31.), de Praxíteles - com o movimento de uma mão que cobre o púbis; e a outra, que apanha o panejamento. Em seguida, em decorrência das inúmeras interpretações do período helenístico e da Roma dos césares, encontrou variações como a Afrodite de Menofantos (fig.5.32.), que então combinava os gestos da Vênus de Médicis (também ela uma variação da Cnido) (fig.5.33.), todavia tomando em sua mão esquerda - a mesma que tapa o sexo - o panejamento outrora suspendido no modelo original. Encontrava ainda outra variação significativa, também já presente em adaptações romanas, nas quais a deusa, ainda de pé, abandonava o gesto pudico e toma pela primeira vez, em suas mãos suspendidas, os cabelos molhados (fig.5.34.).

Ambas as configurações reapareceriam na Itália desde o século XV, e seriam por vezes fundidas entre si, já então contando com as contribuições não apenas da escultura mas também da pintura. Elas se desdobrariam com profusão a partir das interpretações originais ao tema que darão Botticelli em Florença (fig.5.35.), Antonio Lombardo e Ticiano em Veneza (fig.5.36. e fig.5.39.), Rafael Marcantonio Raimondi em Roma (fig.4.56., fig.5.37. e fig.5.39.), e mesmo um Cornelis de Vos, em Anvers (fig.5.42.) - este, numa interpretação inusual ao tema, com a representação de Vênus não se encontra em repouso dinâmico, mas caminha literalmente para fora das águas com as mãos em seus cabelos, como uma banhista das praias de Ipanema.

Seria apenas uma questão de tempo para que, no século XIX, os alunos premiados da École des Beaux-Arts (isto é, os residentes na Villa Médicis, em Roma), ou os artistas franceses profundamente inspirados pela arte italiana, ignorando por vezes os nus profanos do século precedente (sobretudo os de Boucher, Watteau e Fragonard), retomassem as fontes escultóricas e pictóricas do nascimento nas águas - ou ao menos o do banho feminino -, e com eles reinterpretassem o gesto das mãos das figuras femininas sobre os cabelos molhados. Aqui o filão é enorme e passa, em resumo, por Ingres (fig.5.43.), Théodore Chasseriau, (fig.5.44.), Paul Baudry (fig.5.43.), Amaury-Duval (fig.5.44.), Bouguereau (fig.5.45. e fig.5.46.), Fantin Latour (um artista que havia copiado o Naufrágio da Medusa ao lado de Américo) (fig.5.47.), Jules Lefebvre (fig.5.48.), e mesmo Renoir (fig.5.49.) .

O segundo desdobramento da graça no tema da banhista perpassa as obras cujos gestos das mãos em origem não necessariamente relacionados ao toque dos cabelos - e se desdobra, como o primeiro, em interpretações artísticas que também associariam à imagem das águas (portanto da natureza) a força simbólica dos cabelos femininos, em sua conjunta significação com a fertilidade. Mas nesse caso, a 
figura está completamente acocorada ou sentada: um movimento de contração que, em sua intimidade, potencializa a graça, se comparado aos da postura ereta. É de fato esse viés, com os exemplos célebres que dele fazem parte, que forneceu a imagem pertinente dos gestos das mãos que Américo iria explorar em sua Carioca, somando-os àquela imagem do pé, também leve, que mal toca a água.

Para essa configuração, era do mesmo modo uma fonte helênica já comentada que havia aberto o caminho, fornecendo o modelo original: a Vênus de Doidalsas, mais conhecida como Vênus agachada (fig.5.50., fig.5.51., fig.5.52. e fig.5.53.). A obra, além de inspirar ou de ser copiada à exaustão por artistas durante o século $\mathrm{XIX}^{409}$, era é também reconhecida como uma derivação da Vênus de Cnido: embora suas conformações fossem completamente distintas, permanecia nessa versão do escultor grego Doidalsas de Bitínio o legado praxitelesco da Vênus banhista, a sua postura não hierática e a execução de um gesto pudico. Ele explorou uma atitude em que a deusa permanece colada ao solo, uma maneira que seria facilmente adaptada, futuramente, à conformação na qual a divindade se encontraria, então, sentada. No modelo original de Doidalsas, Vênus curva seu braço direito em direção ao lado oposto do corpo, como se surpreendida pelo observador, escondendo seus seios (a exemplo da configuração presente na Vênus de Médicis). Como a Cnido, as variações romanas e reinterpretações futuras serão numerosas.

Já no final do período helenístico apareceriam variações em mármore ou argila nas quais a Deusa, numa torção corporal, então de intenção planimétrica, também passava a ter em mãos seus cabelos para torcê-los (fig.5.54. e fig.5.55.). Posteriormente, na época imperial, a divindade banhista poderia não mais curvar a cabeça em direção ao seu espectador, agarrando um golfinho com a mão outrora pudica (fig.5.56.); poderia tornar sua cabeça, tronco e braço esquerdo em direção novamente ao mesmo espectador, levantando o braço direito, como se se ensaboasse ciente e confortável do voyeurismo que lhe espreita (fig.5.57.); ou poderia, ainda, num mesmo movimento de torso, no entanto, orientado ao alto, ter uma de suas mãos nos cabelos, e a outra, em seu panejamento.

Alguns séculos separaram novamente essas obras e outras incontáveis variantes - incluindo jogos de falsificações "modernas" (fig.5.58.) - das novas interpretações que se fariam delas durante o

${ }^{409}$ Ver, por exemplo : Jacques-Louis David. Vênus agachada. Segunda metade do século XVIII - primeira do XIX. Desenho. Museu do Louvre; Eugène Delacroix. Estudo a partir da Vênus agachada do Louvre. Primeiro quadro do século XIX. Desenho. Museu do Louvre; Paul Cézanne. Esboços de ninfa Agachada. Desenho. Da segunda metade do século XIX ao primeiro quadro do XX. Museu do Louvre; Jean-Auguste-Dominique Ingres. Vênus agachada. Primeiro quarto do século XIX. Desenho. Museu Ingres, Montauban; HENNER Jean-Jacques. Nymphe qui pleure. 4e quart 19e siècle. Pintura. Musée national Jean-Jacques Henner, Paris. 
renascimento. E foi Rafael (como visto, um dos ídolos máximos do jovem Américo), profundamente inspirado no legado grego, o responsável por inaugurar integralmente a graça praxitelesca na pintura, construindo um modelo supremo das figuras femininas sentadas ou agachadas durante seus banhos, que executam toques airosos sobre os seus longos cabelos úmidos.

Algumas dessas representações já foram citadas rapidamente nesta Tese. Rafael inaugurava essa tipologia da imagem feminina na representação da ninfa Siringa e do deus Pan, em uma encomenda para o banheiro reservado do Cardeal Bibienna (fig.5.59.), no Vaticano (o lugar, aliás, não poderia ser mais apropriado); afresco cujo cartão preparatório original se encontrava no Louvre, acessível aos artistas (fig.5.60.). Recorreria quase à mesma postura em uma das Loggias também decoradas no Vaticano, numa representação do tema bíblico de Betsabéia sendo observada pelo rei Davi enquanto se banha (fig.5.61.). E a frequentou mais uma vez em uma composição de Psiquê no banho, que seria, logo em seguida, como a própria composição Pan e Siringa, gravada por Agostini dei Musi e por Marcantonio Raimondi (fig.5.62. e fig.5.63.).

A pertinência desse modelo para os séculos seguintes é enorme, e também encontrou copiosas citações ou reinterpretações italianas, francesas e flamengas. Ele rapidamente apareceu nos motivos das banhistas representados por Palma Vecchio (fig.5.64.), Jean Cousin (fig.5.65.), Jan Swart van Groningen (fig.5.66.), Tintoretto (fig.5.67.), Veronese (fig.5.68.), Jacopo Zucchi (fig.5.69.) e pelos Carracci (fig.5.70.). Permaneceu e se difundiu nos séculos seguintes nas representações de Cavalier d'Arpino (fig.5..71), Rubens (fig.5.73.) Poussin (fig.5.72. e fig.5.74.), Eustache Le Sueur (fig.5.75. e fig.5.76.), Bernini ${ }^{410}$ (fig.5.77.), Artemísia Gentileschi (fig.5.78.), Giuseppe B. Chiari (fig.5.79.), Prud'hon (fig.5.80), Jean-Baptiste Carpeaux (fig.5.81. e fig.5.82.), Jean-Baptiste C. Corot (fig.5.83.), Manet (fig.5.84.), J.-J. Henner (fig.5.85.), Joseph Félon (fig.5.86.), Fantin Latour (fig.5.87., fig.5.88. e fig.5.89.), chegando novamente a Renoir (fig.5.90.), e até mesmo a Cézanne (fig.5.91.), se se quer parar por aí.

Américo não estava desse modo sozinho em seu interesse na configuração do gesto gracioso da banhista sentada, inaugurado por Rafael na pintura. E suponho se tratar da postura da sua figura, combinada com a imagem de um braço docemente arqueado e o outro completamente dobrado em torção horária, ambos postos sobre os cabelos, o traço característico que levaria Bethencourt da Silva a

${ }^{410}$ Em Bernini, trata-se naturalmente não de uma representação feminina, mas sendo também essa uma obra acessada diretamente por Américo, em Roma, é sintomática a sua pertinência enquanto alegoria a um rio, e, mais especificamente, no que tange o problema do gesto gracioso, à manutenção do gesto suave da mão que tenta desvelar o tecido que cobre a cabeça da escultura. 
chamar sua pintura de "painel rafaelesco""411.

\section{Um idealismo Eclético}

Como resultado de seus estudos filosóficos durante os dez anos que precederam 1864, Américo carregava, como visto, uma convicção inquebrantável: se um método fosse verdadeiramente válido a uma atividade, ele também deveria ser para todas as demais, não importando as suas diferentes naturezas.

No domínio teórico, as hipóteses desenvolvidas nesta Tese tiveram por fim a defesa de uma adesão do jovem artista ao Ecletismo filosófico. Aqui, Américo havia recorrido à história e a seus ciclos intermináveis - no entanto invariavelmente idênticos - para descobrir as causas que haviam determinado a supremacia da arte grega. A busca por essa verdade total envolveu uma série de procedimentos de síntese de verdades percebidas como parciais, contrapostas e aproximadas apenas a partir de elementos considerados conciliáveis, movimento que o levou, por fim, ao esboço de uma teoria da arte brasileira, ela própria de síntese.

No domínio prático, isto é, na produção da Carioca, defendo que interessava ao jovem fazer o mesmo. Sua pintura era a primeira tentativa de aplicação da estética e da teoria por ele defendidas. A sua intenção de realizar também uma representação "ideal" e portanto "verdadeira", resultando numa única figura que aspirava, por sua vez, a uma realidade metafísica - uma que o método de imitação “exclusiva” não seria capaz de atingir -, fazia parte do objetivo último do pensamento eclético orientado às artes. Certo, todavia, que esse não seja um fim exclusivo dessa filosofia artística, senão a herança que ela própria recebia de todos os sistemas artísticos precedentes orientados ao idealismo (incluindo os "românticos", "neoclássicos", "barrocos", "renascentistas" e, no início dessa cadeia, os gregos). O que é propriamente eclético era a vontade de síntese, precisamente - uma que se operava em níveis distintos mas simultâneos -, e a compreensão de que ela era impossível sem a liberdade e sem o aporte da história, ambos permitindo ao artista transitar por diversas fronteiras artísticas.

A consideração desenvolvida pelo jovem Américo sobre a arte grega, a partir da qual a percebia como um sistema artístico ainda necessário aos estudos, mas não o único ao qual deveria se dedicar, era o primeiro efeito duradouro que o ecletismo já havia exercido sobre as suas concepções artísticas da

411 GUISANDO, Renato de [F. J. Bethencourt da Silva.]. "Os imagináveis bacharéis sem diploma". Publicações a Pedido. Jornal do Commércio. Rio de Janeiro, 8 de fevereiro de 1866, P.2. 
juventude. Do ponto de vista dos seus princípios e fins, a arte inteira teria sido de fato realizada entre os gregos; mas do ponto de vista de suas manifestações particulares, com exceção da escultura e da poesia, muito pouco havia sobrado para além das maravilhosas histórias de imagens que enganavam animais, homens "comuns" e até mesmo os mais excelentes artistas, tal modo teriam sido perfeitamente pintadas. Se, lá, a resposta imediata à pintura não poderia ser dada, entre os "modernos", em contrapartida, uma série incontável de contribuições havia sido fornecida desde o século XV, contando já mesmo com um novo ciclo idêntico ao dos gregos - que elevara agora a pintura a um patamar inédito de excelência - e com os seus grandes mestres, que rivalizavam então com o sucesso e capacidade dos antigos estatuários. Como as formações dos diferentes sistemas filosóficos ao longo da história, aqui também se tratariam de sistemas artísticos verdadeiros, conquanto o fossem no mais das vezes parcialmente. Rafael se destacaria pela profundidade de suas ideias e pela facilidade e potência de suas composições; Michelangelo pela força expressiva de suas obras; Corregio pelo claro-escuro; Giorgione, Ticiano, Veronese e Tintoretto, pela maestria da cor; Da Vinci, pela profundidade e universalidade do gênio, que aproximaria tudo quanto ciência aos braços da arte, na descoberta de verdades escondidas na natureza. E os artistas posteriores que o jovem havia copiado (os que se sabe Guido Reni, Rigaud, Louis David, Géricault) haviam, eles também, retomado e reelaborado essas qualidades em um novo momento histórico, e com novas motivações.

Estando inteiramente seguro da importância de todas essas contribuições, sem jamais (lembra-se sempre) deixar os gregos de lado, o jovem desejava proceder, como o fazia em Considerações Filosóficas, a outro síntese eclética, da qual participaria a sua náiade. Ainda que o ecletismo por ele desenvolvido tivesse uma relação direta (como será visto) com o seu interesse por diferentes artistas e vertentes ao longo da história, ele não se caracterizaria por uma simples citação a essa ou aquela referência mais ou menos conhecida. Ele apareceria, ao contrário, pelo estabelecimento de procedimentos e critérios que garantiriam ao fim desse processo uma síntese simultânea de várias.

Conforme discutido anteriormente, o ecletismo absorvido por Américo pretendia ser um método antes conciliador do que uma manifestação do "gosto". Na verdade, em teoria, ele queria ser o contrário do gosto - no sentido dado por Kant ou por Montesquieu. O método de síntese adotado pelo jovem respondia perfeitamente ao programa cousiniano, ao querer "unir observação e razão, e não perder de vista o ideal da ciência que o homem aspira, buscá-lo e encontrá-lo pela via da 
experiência" ${ }^{\text {412. }}$.

No primeiro nível de síntese da Carioca estava a tão defendida fusão da verdade da ideia e a da forma $^{413}$, a mesma oposição fundamental a ser resolvida filosoficamente no ecletismo, mas também no krausismo. Aqui, o procedimento deveria combinar a pertinência da ideia fundamentalmente abstrata de uma alegoria à impressão "realista" que a sua obra deveria causar aos sentidos.

Em segundo nível encontrava-se a síntese dos conceitos opostos a serem lidos na obra. Tratar-se-ia de fundir a natureza universal de uma divindade, mesmo que uma portanto alegórica, à sua identificação local - razão pela qual aparece a exigência da cópia generalizada de um modelo "real" e brasileiro que caracterizasse a nacionalidade da Carioca. Aqui também se encontraria a demanda incontornável de uma divindade que fosse, segundo sua pretendida natureza, bela (característica ligada à impessoalidade e imutabilidade das formas) e graciosa (impressão subjetiva, resultante de gestos e movimentos normalmente simples e precisos, e potencializada pela interiorização da figura representada).

Em terceiro e último nível, este ao mesmo tempo relacionado à execução da figura e à maneira pela qual aqueles valores poderiam ser percebidos, estaria a síntese da própria imagem, efetuada, portanto, a partir dos seus três meios de execução: forma, tonalismo e cor. É nesse domínio que se apresenta mais claramente o problema dos seus procedimentos propriamente ecléticos, indicação que emerge em boa parte do esforço do jovem Américo em conciliar diversas características de imagens díspares, e diferentes mestres e "estilos".

Novamente em decorrência da qualidade limitada da reprodução da Carioca, é preciso passar por alto de qualquer análise direta da cor (ela será novamente feita por uma indireta) e manter a relativa cautela quanto ao problema do tonalismo. Entretanto, ao menos quanto ao desenho, a reprodução permite de novo identificar em pontos específicos, mas fundamentais, o que Américo queria fazer, e de fato fazia, ao aplicar o método eclético às artes.

Nesse domínio, ele tentava de fato efetuar uma conciliação iconográfica e formal das características de alguns célebres nus que mais the agradavam e que se adequavam convenientemente à sua ideia, e as ajustava em uma síntese que se pretendia harmônica. Isso que significa dizer que, também neste caso, a sua ninfa era tratada como uma unidade que envelopava e acordava, dentro de si,

${ }^{412}$ COUSIN, V. Op. cit. p. 20.

${ }^{413}$ AMÉRICO, P. Op. cit. Estudo sexto. p.157. Ou: Correio Mercantil, 15 de novembro de 1864. p.02. 
uma série de variedades provindas de outras unidades, com o fim de produzir a beleza.

São muitos os aspectos de outras obras intencionalmente cruzados $\mathrm{n} A$ Carioca. Conforme sugerido, a inspiração inicial da figura provinha das variações praxitelescas da Vênus de Cnido, e em específico das Vênus (ou Afrodites) agachadas (fig.5.93.6), obras cujo ponto de vista principal é aquele em que seu corpo é visto inteiramente de perfil, do mesmo lado para o qual o seu rosto gira - então o mesmo da Carioca. A forma da figura sentada ou mais próxima ao solo era de fato concebida como a mais conveniente a alegorias aquáticas, e era dessa maneira que Cesare Ripa a recomendava, nas diferentes edições ilustradas de sua Iconografia (fig.5.93.9).

Entretanto, a configuração específica oferecida pela Vênus agachada sugeria inicialmente uma intenção que não interessava então a Américo: a divindade, dobrada ao solo e curvando vertical e horizontalmente seu corpo, se retrai em um reflexo pudico, enquanto o jovem desejava insistir na realização da beleza digna de ser mostrada e vista de sua náiade. Se a curvatura original da estátua grega reforça a surpresa da deusa diante do olhar voyeurístico, o jovem escolhia expandir o ângulo original formado pelo tronco, quadril e pernas. Essa escolha conduzia sua figura a um terreno de motivação fundamentalmente rafaelesca, também representado pelas figuras de banhistas anteriormente citadas, presentes no Vaticano, mas aqui, especificamente, ainda mais pela composição da Psiquê gravada por Raimondi. Na imagem original, a figura, também predominantemente de perfil e com as mãos estendidas sobre os cabelos, não está mais agachada, como no modelo de Doidalsas, mas sentada sobre a borda de uma banheira, e, sem dispor de encosto, leva seu tronco à frente, num movimento de sentido contrário ao da $A$ Carioca, que se reclina para trás, sustentando-se na ânfora onde jorra a água. Mas é surpreendente constatar que girando a composição original de Rafael algo em torno de 15 a 20 graus em sentido anti-horário (fig.5.93.4), o que se passa a ter é uma equivalência bastante sugestiva na posição das duas figuras. Lá estão as mesmas posturas dos corpos; estão os mesmos ângulos que se formam entre o tronco, quadril e coxa direita, e entre essa mesma coxa e a perna; e está ainda a aproximação igualmente sugestiva dos gestos das mãos das figuras (agora ainda mais do que antes). Apenas a mão direita da náiade (a mão esquerda da Carioca permanece, por exemplo, quase idêntica, apenas com uma torção levemente mais acentuada), a frontalidade do seu rosto (a mesma da escultura de Doidalsas) e a abertura do ângulo interno formado entre os seus pé e perna direitos, diferem um pouco em diante das posições das mesmas partes na figura rafaelesca.

Mas também nessas diferenças, a intenção de Américo e os seus procedimentos de conciliação 
continuam perceptíveis. Na náiade, o braço direito se alonga e se eleva para dar visibilidade aos seios, que tanto o interessavam para a demonstração da natureza ideal de sua imagem. A mesma parte é imperceptível na Psiquê de Rafael. Muito pouco esforço é requerido para se perceber que os "pomos virginais" da Carioca, vistos em três quartos, seguem integralmente, em suas formas, os mesmos contornos circulares que tanto o jovem havia estudado e louvado na Vênus de Cnido e na Vênus de Milo, durante seus 5 anos de frequentação ao Museu do Louvre, e mesmo antes, na AIBA (fig.5.93.15 e fig.5.93.12). Quanto ao braço estendido - formado por linhas sutilmente moduladas e convergentes em um belíssimo escorço -, o claro contraste que apresenta com as demais linhas "duras" do contorno da figura, especialmente as do tronco e quadril, sugere ali um outro ponto de síntese. Ainda dentro do universo de referências que Américo parece ter em mente, é notável como o braço da Carioca parece compartilhar do mesmo o ritmo suave de alternâncias do braço também verticalmente esticado da Vênus de Médicis. Quando se toma em mãos não exatamente uma fotografia qualquer dessa estátua, mas a reprodução que o jovem Américo dispunha em seu exemplar do manual de proporções de Gérard Audran, se podem de fato encontrar duas representações lineares da figura, uma de perfil e a outra frontal, que estão espelhadas em relação à escultura da Galeria dos Uffizi. E que nova surpresa se tem quando, girando também esta imagem em torno de $60^{\circ}$ no sentido anti-horário, se encontra no braço da náiade o mesmo desenho perfilado do braço da escultura, em quase todos os seus rebatimentos, contornos, e sutil escorço (fig.5.93.3). Entretanto, ainda nele, Américo parece forçar um pouco o escorço com o claro escuro, e, nessa conformação, o gesto feito sem esforço sugere o braço também confortavelmente estendido da Sibila Délfica, de Michelangelo, na Capela Sistina ${ }^{414}$ (fig.5.17.).

Como sugerido no tópico sobre a proporção da Carioca, esse mesmo braço, desenhado como está, é responsável por criar um "corte" entre o tronco e a cabeça da náiade; impressão que deriva não exatamente de sua posição predominantemente horizontal, mas de sua combinação relativamente infeliz com a frontalidade planimétrica do rosto da figura e, em decorrência desta configuração, um ruído suficiente para se deduzir mais um ponto de síntese. Quando igualmente inspirados na Vênus agachada Rafael, Cavalier d'Arpino, Poussin e os Carracci quiseram que suas banhistas - também inteiramente de perfil - tornassem do mesmo modo o rosto em direção ao observador, tomaram o cuidado necessário para não forçarem demais esse movimento, deixando as cabeças de suas figuras em

${ }^{414}$ Agradeço a Elaine Dias e a Fernanda Pitta por me chamarem novamente a atenção para o braço dessa figura. Inicialmente, ele havia me despertado o interesse, especialmente em sua relação aparente com o braço da Carioca. Entretanto, como eu havia me concentrado em um núcleo de nus femininos banhistas que pareciam regar diretamente as intenções de síntese na náiade do jovem Américo, acabei por deixar a Sibila Délfica de lado. Percebo agora, de fato, que uma tal exclusão poderia em dúvida “empobrecer” a execução "eclética” que Américo deseja efetuar em sua náiade. 
três quartos ou, no máximo, em um uma frontalidade que ainda sorvia algum soslaio (fig.5.61., fig.5.71., fig.5.74., fig.70.). O resultado final é sem dúvida mais natural, ou ao menos mais "cômodo". Para uma figura que deveria inspirar tranquilidade e repouso, a completa frontalidade da cabeça da Carioca, na qual se esboça um sorriso à la Monalisa, de inspiração provavelmente leonardesca (aqui, possivelmente uma outra absorção eclética) é por demais forçada, e entra dificilmente em harmonia com a disposição do restante do corpo. Trata-se de uma torsão que funciona bem para a escultura, mas requer cuidados numa pintura então sintetizada a partir de um único ponto de vista. Suponho, no entanto, que Américo tivesse sido "levado" a tanto. Em sua primeira composição original, o jovem dispunha, em seus livros (especialmente no manual de Audran), apenas de prescrições frontais das proporções dos rostos das deusas gregas ou, no máximo, indicações de perfil. Sendo a cabeça a parte mais importante para o reconhecimento da "raça" da sua divindade alegórica, e considerando que qualquer ensaio em representá-la em escorço envolveria a consideração de compensações óticas que poderiam pôr em risco a objetividade matemática das proporções que tinha em mãos, apenas a posição frontal poderia provavemente lhe permitir conciliar sobre esse grid as características gerais e necessárias da beleza ideal e os traços faciais purificados (mas também necessariamente perceptíveis) da sua modelo brasileira.

Da mão e do rosto finalmente à representação do pé, Américo parece ainda permanecer no círculo da antiguidade, mas retornando então à Vênus agachada. Também aqui se perceberá de que maneira ele estudou cuidadosamente o pé direito da escultura, que toca obliquamente o solo, e como assimilou a mesma posição e desenho à sua Carioca, tendo o cuidado de relaxar os três maiores dedos da figura, na medida em que, na estátua, a flexão do pé deveria ser resultado da pressão que o peso do seu corpo alapado lhe causaria. Na náiade do jovem, a perna livre de contato ao solo desoneraria o pé de qualquer contração obrigatória (5.93.1. e 5.93.2).

Com a imagem toda composta, pensada em suas partes, Américo deve ter sem dúvida, em algum momento, procedido ao "torneamento" das formas, especialmente no tronco e nos membros inferiores, então adotando não exatamente a estrutura corpórea das cópias mais antigas de Doidalsas - nas quais especialmente o ventre sugere o preenchimento da pele com uma camada adiposa e, nesse sentido, mais “carnal”, criando ali um ritmo modulado que não agradava Américo nos seus citados procedimentos de abstração e regularização das linhas do contorno da Carioca. Ele também não adotava a estrutura das figuras rafaelescas, sem dúvida mais gorduchas do que a da sua náiade, e menos ainda a constituição dos nus femininos venezianos e flamengos: esses, como visto, Américo mesmo havia acusado de serem 
demasiadamente "reais" e sensuais ${ }^{415}$. O jovem parece se aproximar, nesse caso, de alguns antigos exemplos romanos, também inspirados em Doidalsas, nos quais Afrodite carece então de untuosidade em seu corpo; mas parece seguir, especialmente, dois exemplos "modernos", então já classicizados, que eram oferecidos pelas representações rafaelescas e michelangescas "masculinizadas". Não parece ser de fato casual a lembrança que $A$ Carioca reenvia à estrutura geral e (como consequência dela) à impressão de vitalidade que Michelangelo havia dado às figuras da sua Leda (cuja cópia já estava presente em Londres, em 1862 ${ }^{416}$ ) e da $A$ noite, da Capela dos Médicis, em Florença (fig.5.94., fig.5.95.), nem do mesmas qualidades que se percebem na Vênus ferida, composição original de Rafael, gravada por Marco Dente da Ravenna ( fig.5.97.).

Se esses são procedimentos que correspondem ao que se defende aqui ser o método eclético realizado por Américo na execução da forma da Carioca, outros parecem acompanhar a mesma vontade de síntese, em especial a fusão dessa forma com o claro-escuro e com a cor, em suas fontes históricas e estilísticas igualmente identificáveis.

Mas a compreensão dessa nova e importante intenção de síntese pode ser somente sugerida, conforme citado, por meio de uma análise de segunda mão. Se anteriormente, neste Capítulo, se enfatizou a recorrência com a qual algumas personalidades comentaram a impressão causada pelos aspectos colorísticos da Carioca, esses comentários foram oportunamente ilhados de um conjunto que envolvia, invariavelmente, elogios concomitantes à execução da forma e do claro-escuro da figura.

Assim, se podia ler na primeira e mesma crítica ao quadro, em 1865, feita em sequência à exposição da obra na Casa Bernasconi: "Que explendidos tons! que harmonia naquelas tintas cálidas!" 117 . Também na Exposição Geral de Belas Artes do mesmo ano se leria que a "figura está bem modelada, e tem um colorido vigoroso e agradável, sendo todo o painel de uma execução firme e

${ }^{415}$ A percepção dos nus flamengos e venezianos como nus mais próximos do modelo-vivo, e portanto sensuais, não era exatamente nova na metade do século XIX. Já no começo do século, uma personalidade como Quatremère de Quincy invocaria os três graus e imitação elaborados por Aristóteles em sua Arte Poética (a representação como melhor do que ele é, como ele é, e pior do que ele é) para traçar um paralelo entre os três estilos que encontrados nas "escolas modernas". O primeiro, representando os homens melhores do que seriam, tratando-se do estilo florentino ou romano; o segundo, como os homens seriam, o da Escola veneziana; e o terceiro, com os homens piores do que são, a Escola flamenga. QUINCY, Q. Sur l'idéal dans les arts du dessin. Paris: 1805. P.08.

${ }^{416}$ Sobre as informações oficiais da cópia anônima da Leda, feita a partir de Michelangelo, ver o site da internet da National Gallery of London: https://www.nationalgallery.org.uk/paintings/after-michelangelo-leda-and-the-swan [último acesso é março de 2016].

${ }^{417}$ CORREIO mercantil. Rio de Janeiro, 16 de janeiro de 1865. p.1 
larga" ${ }^{418}$. E no ano seguinte, a repetição de Gomes dos Santos, ao dizer que a náiade de Américo - "em quem despontam primorosas qualidades de gosto e engenho" - possui uma "execução firme e larga, o colorido cheio de vigor" 419 .

Guimarães Júnior falava em: "primor de naturalidade [...] onde o talento analítico derramou as mais delicadas cores"; defenderia a dupla qualidade do "primeiro quadro que possuímos de mais fogo de poesia e esplendor de natureza" ${ }^{420}$, pintura que Américo teria realizado "na combinação peregrina o tipo da verdade e do sentimento"421; e continuaria a empregar termos opostos presumivelmente conciliáveis (desenho-cor; concepção-execução) quando analisava: "O desenho largo e correto do brilhante quadro da Carioca; a perfeição da cabeça e a tinta com que estão incarnados os deliciosos membros da soberba criatura, valem a mais judiciosa recomendação à concepção e execução da tela." 422

Gonzaga Duque se referira tardiamente à obra - mas com um vocabulário sintomaticamente eclético -, na qual "tudo é grandioso na beleza, tudo se equilibra no ardimento, na audácia, no inesperado." ${ }^{423}$ Nesse equilíbrio, lembrava de um jovem Américo que "vibrado pela suntuosidade dos áureos tempos do renascimento, pretendeu fazê-la nas proporções das obras imortais" ${ }^{\text {"424, }}$, concluindo sobre a impressão da obra em que se consubstanciaram concomitantemente qualidades da forma e da cor: "A beleza da forma que a Carioca possui, a flexibilidade de suas curvas, a segurança de seus contornos, a exuberância de suas massas musculares, ficaram como características de um estilo, a que o colorido veio completar com uma turbulência riqueza de tons crus."

Mas de todas essas análises seria novamente A. Gubernatis quem iria "historicizar" as individualidades das qualidades visíveis e combinadas $\mathrm{n} A$ Carioca. Ele associou conjuntamente à náiade não apenas o colorido veneziano, já indicado, mas o "toque” florentino, vindo de Michelangelo;

${ }^{418}$ MAFRA, J. M (red.) “Ata da Sessão da Congregação em 01 de maio de 1865”. In: Ata da Sessão da Congregação e do Diretor da Academia Imperial de Belas Artes no dia 3 de junho de 1865. Museu d. João VI. p.145 (versão digital).

Disponível online em: http://docvirt.com/MuseuDJoaoVI/ [último acesso, janeiro de 2016]

419 SANTOS, Thomás Gomes dos. "Ata da Sessão Pública da Academia Imperial das Belas Artes, em 15 de julho de 1866.” ACADEMIA IMPERIAL DAS BELAS ARTES. Atas das sessões públicas do conselho acadêmico da AIBA, 1865, 1866. Museu d. João VI / EBA-UFRJ. Disponível online em: http://docvirt.com/MuseuDJoaoVI/ [último acesso, março de 2016].

${ }^{420}$ GUIMARÃES JR. Op. cit. p.51.

${ }^{421}$ Idem, ibidem. p.55.

${ }^{422}$ Idem, ibidem. p.55.

423 Gonzaga Duque. Impressões de um amador. Textos esparsos de crítica (1882-1909). [orgs. Júlio Castañon Guimarães e Vera Lins]. Editora UFMG / Fundação Casa de Rui Barbosa, 2001. p. 242.

${ }^{424}$ Idem, ibidem. p. 242.

${ }^{425}$ Idem, ibidem. p. 142. 
algo ibérico, também presente na obra (traço aliás curioso de se considerar); e, por fim, um dado próprio da “América meridional:

[A] dupla genialidade [de Américo, como artista e cientista] e potente atividade influi notavelmente sobre a natureza da sua escola e do seu estilo particular, que se avizinha ao veneziano, sem perder o caráter espanhol e o particular, quente e apaixonado da América meridional. [...] $\mathrm{O}$ primeiro quadro [do artista,] A Carioca, pintado aos vinte e um anos e pertencente ao imperador da Alemanha, foi tomado por muitos conhecedores como um quadro da escola veneziana, se bem que o seu desenho revele um certo orgulho de toque michelangesco $[\ldots]^{426}$

Da identificação da forma e das referências que certamente inspiraram a figura da Carioca às observações repetidamente emitidas por terceiros sobre essa pintura, desde as suas primeiras exposições públicas, permanecia, portanto, a imagem de uma obra na qual interessaria convergir qualidades advindas de diferentes "escolas" artísticas, todas célebres. O método empregado por Américo era como uma flecha, que mirava para atrás e atravessava a história, perfurando, um atrás do outro, os alvos alinhados em seu trajeto. Esse método parecia fincar, assim, seu pé num idealismo eclético, cujo objetivo era a síntese (ou conciliação justa) de sistemas artísticos verdadeiros, mesmo que parcialmente, uma decorrência de suas esperadas limitações históricas. Fídias, Praxíteles, Rafael, Michelangelo, Ticiano, Veronese, Guido Reni, Rigaud, David, Géricault, permaneciam lado a lado, e emprestariam ao jovem o que teriam de melhor, um privilégio que apenas um artista livre era capaz de gozar.

Mas é necessário novamente dizer que esse não parece se tratar de um ecletismo feito às cegas. Um critério era preponderante na Carioca: todos os artistas que Américo sabidamente copiava durante seus anos de estudo em Paris, e aqueles que parece utilizar diretamente para a produção da sua pintura eram artistas, como o jovem, reconhecidos "idealistas" (a única exceção viria dos venezianos, pintores da "vida como ela é", que, entretanto, poderiam ser incorporados por oferecerem a parte "feminina" e “acessória" da pintura). E um segundo critério ainda existia: entre essas referências, predominavam na execução da obra os artistas que haviam contribuído com obras capitais para o tema das banhistas. Tratava-se, desse modo, de uma síntese idealista e histórica, que havia alinhado coerentemente seus modelos a partir de uma mesma filiação iconográfica.

É quase possível imaginar Américo dobrando, girando, torcendo sua náiade mentalmente, e a

${ }^{426}$ GUBERNATIS, Angelo de. Dizionario degli artisti italiani viventi, pittori, scultori, architetti. Florença: Tipi dei successori Le Monnier, 1889. p.16-17. [tradução nossa] 
compondo, em seguida, a partir de um collage de referências que eram são caras, buscando o melhor e mais adequado de cada um delas em suas qualidades gerais (a severidade de Fídias, a graça de Praxíteles, Rafael e Reni, a vitalidade corporal de Michelangelo, a cor veneziana, o acento ibérico [seguindo Gubernatis]) e em suas qualidades específicas (um pé de Doidalsas, um braço de Praxíteles, uma linha de Fídias, uma pose de Rafael, um sorriso de Leonardo, a estrutura ativa de Michelangelo). Por fim ele as fundiu não numa síntese ideal puramente generalista, mas numa que se pretendia, paradoxalmente, brasileira.

A bem da verdade, mesmo com critérios, trata-se de uma fusão em alguns pontos um pouco incômoda, que às vezes relembra um tipo de sincretismo Frankenstein: o tamanho aparentemente reduzido da cabeça da figura; a estranha relação de sua frontalidade planimétrica com o restante do corpo, em viés; o contraste do belo desenho do braço com a economia de curvas do restante do tronco; o tamanho "exagerado" das pernas, sobretudo o da perna esquerda dobrada. Mas, como visto, algumas dessas relações não eram circunstanciais, senão estruturadas deliberadamente com um propósito específico, resultado da "intenção" que Américo quis dar à sua figura. Se elas puderam (e talvez poderiam ainda) ser percebidas enquanto defeitos, anteparados por julgamentos estéticos da "boa forma" ou da "forma natural" (como seria de fato o critério de julgamento estabelecido para alguns críticos desde Coques), é preciso, todavia, fazer um esforço para não se esquecer do campo no qual Américo - um pintor de orientação filosófica - gostaria que a sua náiade fosse precisamente fruída: o da beleza inteligível, lida por meios racionais. O exercício não é exatamente evidente, sobretudo se não se dispõe de todas as referências que guiavam o jovem para justificar racionalmente sua obra; mas a tentativa reestabelece com a devida justiça uma parte das suas "intenções", e isso, afinal, parece contar bastante.

Em suas operações de ajustes, fusão e síntese para criar uma náiade conceitualmente bela, inteligente, virgem e repleta de vitalidade, o que é certo é que Américo não aceitou a recepção da sua obra como algo "real". A sua Carioca, como já discutido, mostra sem muitas dificuldades o quanto ele era irredutível nesse ponto, e, para tanto, basta novamente comparar o distanciamento do seu nu com os nus de artistas “oficiais” franceses expostos nos Salons de 1859, 1861 e 1863, como os de Bouguereau, Cabanel e Baudry. Se ele é comparado com um Almoço na relva, ou com uma Olímpia, de Manet, como essa distância, já relativamente grande, se torna agora oceânica! Ainda que realizando sua obra em Paris, Américo de fato efetuava uma digressão ao "realismo estético oficial” do Segundo Império napoleônico. O ponto onde aqueles artistas haviam chegado com suas obras, abrindo percepção ao 
modelo-vivo e tentando conciliá-lo à apresentação de uma mulher ainda assim ideal, havia ultrapassado o limite que Américo havia estabelecido para sua obra. O jovem parecia considerar o contexto pudico e moralista brasileiro, ou talvez compartilhasse com ele um número suficiente de valores para não ousar ultrapassar a fronteira onde colocara sua obra, pois, de todo modo, ela seria já uma linha de frente.

Conquanto ainda houvesse realizado o seu tipo ideal de humano $\mathrm{n} A$ Carioca (um tipo que então alcançaria nas obras feitas a partir da década de 1880, entre as quais está a segunda versão da pintura), o procedimento eclético que Américo realizava em 1863-1864 não era um que procurava, assim, encontrar uma conciliação entre o modelo-vivo e a imagem alegórica de uma ninfa. Este era o próprio limite do seu ecletismo naqueles anos, no que se referia a suas composições originais. Mesmo se dispondo parcialmente de uma alegada modelo para a náiade, a sua colaboração não pôde ultrapassar a indicação dos traços faciais (a imagem já evidencia, mas Guimarães também o confirmava verbalmente). O "real" teria vindo, desse modo, do estudo de obras "reais" dos antigos mestres.

No final das contas, esse procedimento parece corroborar a hipótese aludida nesta Tese, a de que Américo, ao produzir sua náiade, não desejava seguir a teoria aristotélica da beleza, em sua postulação do "belo de reunião", atingido pela experiência a partir da síntese das mais belas partes de modelos reais. Para ele, importaria também de um "belo de reunião", mas um que, guiado por uma ideia, em lugar de apurar e conciliar as belezas esparsas de objetos naturais - e, enquanto tais, necessariamente defeituosos -, o fez a partir das belezas esparsas de objetos ideais existentes, eles próprios "correções" da natureza.

Estivesse inteiramente ciente ou não, Américo frequentava, entre a teoria e prática, um neoplatonismo que se recomendava de início à linhagem maneirista de F. Zuccari - uma que defendia a anterioridade imaterial da ideia, manifestada em seguida na matéria, sem no entanto ainda "creditar ao artista a habilidade de ultrapassar a realidade por meio de 'purificação' ou 'intensificação’,427 . Mas se tratava de um neoplatonismo que, desejando na verdade corrigir a natureza e para ultrapassar assim as "limitações" teóricas maneiristas, se combinava e permanecia então essencialmente colado às teorias classicistas da segunda metade do século XVII, em especial aquela desenvolvida por G. Bellori, o responsável por transformar pela primeira vez o conceito ideia em Belo ideal ${ }^{428}$, num momento em que eram combatidos ao mesmo tempo a pintura "de cabeça" e o seu presumido oposto, o extremo

${ }^{427}$ PANOFSKY, Erwin. Ideia: A evolução do Conceito de Belo. Trad., Paulo Neves. São Paulo: Martins Fontes, 2000. P.92.

${ }^{428}$ Idem, ibidem. p. 109. 
naturalismo $^{429}$, bem como se defendia e o papel do artista em ultrapassar e corrigir a natureza - todos partidos defendidos pelo brasileiro.

E se Bellori havia de fato suposto que o "terrível declínio" que a arte teria sofrido desde Rafael havia sido enfim contornado nos setecentos pelos Carracci $^{430}$, na elaboração que fariam de um projeto "eclético", historicista e revisionista das grandes escolas italianas, cabe talvez relembrar que esse dever de restauração e conciliação da "grande arte" (ao qual também se vinculavam alguns de seus alunos, como Guido Reni ${ }^{431}$, como visto, copiado pelo brasileiro) havia fornecido de fato um modelo importante para o séquito de artistas "filósofos" e "historicistas" ${ }^{432}$, no século XIX, frequentadores como Américo - da doutrina eclética, muitos, a propósito, alunos ou ex-alunos da École.

Ao menos na parte prática, havia de fato algo de "oficial" na formação desse cortejo de artistas dentro da instituição, posto que, para Albert Boime,:

A prática de copiar [obras dos artistas do passado] levava frequentemente o copista a assumir uma atitude de superioridade em relação a seu modelo [...] Isso era devido, em parte, às políticas ecléticas da Academia, assim como à sua abordagem didática. A academia ensinava ao pupilo buscar uma combinação das melhores qualidades de diferentes escolas com a intenção de que seu trabalho pudesse ser superior a qualquer obra de cada uma delas ${ }^{433}$.

A análise de Boime corrobora em quase toda a sua extensão uma outra, desenvolvida bem mais recentemente por Pierre Sérié, para quem o termo "historicismo", nas discussões aqui desenvolvidas, se traduz por um

qualitativo emprestado originalmente da arquitetura, e que de agora em diante floresce sob a pluma dos especialistas da pintura e da escultura da segunda metade do século XIX. O ecletismo, segundo a definição dada pelo filósofo e historiador da filosofia Victor Cousin, consiste em fundir em um todo coerente o melhor dos sistemas anteriores - ou ao menos o que assim se estima em um determinado momento da história. Foi isso o que fizeram, por exemplo, os Carracci conciliando os aportes dos Florentinos (o desenho), de Correggio (o claro-escuro) e dos Venezianos (a cor), o todo organizado segundo os princípios da claridade, caros às composições romanas de Rafael. A propósito, não é irrelevante ressaltar que entre 1870 e 1900, na crítica [de arte], o nome dos Carracci e o termo de Bolonhês são compreendidos como o paradigma do ensino da Rua Bonaparte [onde se situa da École]. O "historicismo", assim como nós o compreendemos, reenviaria, também ele, a uma relação com o

${ }^{429}$ Idem, ibidem. p. 104.

${ }^{430}$ Idem, ibidem. Pp.103-5.

${ }^{431}$ É sintomático considerar que, ainda no Louvre, em meio às obras-primas dos mestres italianos, dispostas cronologicamente e por escolas no grande corredor conhecido como Grande Galerie, permanece ainda exposto, e desde a época de estudos do jovem Américo, uma alegoria de Guido Reni representando justamente $A$ união do Desenho e da Cor. ( L'Union du Dessin et de la Couleur, ca.1620-25. Óleo Sobre tela).

432 GINZBURG, Sylvia. Op. Cit.

${ }^{433}$ BOIME, Albert. The Academy and French painting in the nineteenth century. New Haven/Londres: Yale University Press, 1986. p.125. 
passado, e com o passado apenas, mas num espírito bastante diferente, que postularia menos a resolução de clivagens anteriores do que as suas exasperações. Os artistas denominados "historicistas" cultivam a diferença, a "bizarrice", a citação claramente identificável - a cultura deles é imensa - de pinturas não recomendáveis: eles trabalham a partir dos maus exemplos e das margens da história das $\operatorname{artes}^{434}$

O final da sentença não é, evidentemente, o caso de Pedro Américo, que desejou trabalhar com as mais avisadas referências, as mesmas com as quais os próprios Carracci haviam trabalhado, num espírito similar ao aludido por Boime. De todo modo, independentemente das fontes exatas buscadas pelo brasileiro, o que se deve mais reter é o fato de que $A$ Carioca se apresentava como a primeira e talvez única contribuição propriamente eclética que um artista brasileiro fazia à arte nacional. E tratando-se de uma obra sem precedentes no Brasil (um precedente filosófico e um também temático), é fundamental reforçar as íntimas correspondências que ela estabelecia com uma entre as várias vertentes artísticas vigentes durante o período em que Américo realizava e concluía sua formação em Paris.

\section{A Carioca, Américo, e uma das várias vertentes da "geração de 1863"}

Se Michael Fried, em boa medida metonímico, falou de Manet, Fantin Latour, Alphonse Legros e Rodolphe Julian, entre outros, como os representantes da chamada "geração de 1863", que se opuseram (como Courbet, mas de maneira distinta) aos preceitos acadêmicos defendidos pela Académie e professados na École $e^{435}$, vale o protesto de que se tratava de uma entre outras "gerações de 1863" que, do mesmo modo, confrontavam a manutenção de alguns dogmas estéticos que perduravam oficialmente nas duas instituições até o final daquele ano. Como aqueles artistas, Américo era também filho legítimo da mesma geração contestadora (lembre-se do seu texto de 1863 em defesa da liberdade pessoal do artista), e é certo que eles guardavam entre si um número suficientemente claro de interesses, a despeito das inúmeras diferenças que os distinguiam talvez mais fortemente.

Manet, por exemplo, também transitava e estudava com assiduidade exemplar diferentes períodos e escolas da pintura europeia, assimilando-os e reelaborando-os a cada pintura que realizava. Quando produzia um nu, como sua Ninfa Surpreendida, ou como o Almoço na relva, tem um olho em Rafael e o outro na tradição clássica; quando pintura sua "infame” Olímpia, era agora Giorgione que lhe

${ }^{434}$ SÉRIÉ, Pierre. La peinture d'histoire en France 1860-1900. Paris: Arthena, 2014. p.182-83.

${ }^{435}$ FRIED, M. Manet's modernism: Or, the Face of Painting in the 1860's. Chicago: University of Chicago Press, 1992. Ver em especial o capítulo sobre a "geração de 1863". 
interessava. Latour, em um estilo pessoal que se corporificou de mais a mais em uma fatura fantasmagórica - por vezes estabelecida no limiar do desmanche das formas e dos planos pictóricos -, compartilhava desde sempre os mesmos interesses, e não é talvez sem interesse considerar que também ele, em 1863, pouco mais de 2 anos depois de Américo copiar o Naufrágio da Medusa, se colocava em frente à obra para copiar o mestre Géricault ${ }^{436}$, que o brasileiro reverenciava publicamente, naquele exato momento, no seu texto sobre a reforma da École. E ainda Julian, futuro proprietário de uma academia de arte concorrente à École, frequentada como se sabe por muitos brasileiros ${ }^{437}$, secundara algumas vezes o jovem Américo para a renovação da carteirinha que lhe permitia realizar cópias das pinturas e esculturas de diferentes períodos da história, presentes no Louvre ${ }^{438}$.

Tratavam-se, aqui especificamente, de quatro jovens pintores (Américo sendo aliás o mais jovem) preocupados com novos rumos da arte, e sobretudo da arte deles. Estavam, todos, de fato engajados teoricamente com a realidade e com o desenvolvimento da "pintura moderna". Mas, para Américo, sendo a maneira com que lidava e compreendia a realidade cada vez mais alimentada pela filosofia (a ponto disso surgir a sua defesa precisa no desenvolvimento de não somente de uma pintura moderna, mas de uma que expressasse o "ideal moderno"), importava adotar um partido artístico que não fosse certamente o mesmo dos seus colegas de profissão, futuramente defendidos como alguns dos legítimos renovadores da pintura no século XIX. Eram, sem dúvidas, perspectivas distintas sobre o que significava ser "moderno" e sobre qual seria o fim da arte.

Para Américo, a liberdade e a história não eram fins em si mesmos, mas, como visto, aportes necessários e, portanto, indispensáveis ao único meio possível de se realizar o ideal no presente: a síntese artística filosófica: uma tarefa quase paradoxal, na medida em que o ideal que defendia era objetivo e absoluto, e, desse modo, atemporal. O lado opositor ao qual aderia, ainda "oficial”, embora não fosse mais "acadêmico", era o mesmo dos reformadores de 1863, e em especial o de Viollet-LeDuc. Não deve ter sido talvez sem algum contentamento e um leve sorriso no rosto (como o de sua Carioca), que o jovem escutou, em 1864 - quando já havia terminado sua pintura e estava então de

${ }^{436}$ Caderno de "Registre de Copies, Écoles Italienne et espagnole. 1851-1859". Cota: *LL26. Géricault, n.242, Naufrage de la Méduse, p.80. Museu do Louvre, Setor de Documentação, Paris.

${ }^{437}$ Para a questão dos artistas brasileiros frequentadores da Académie Julian, no último quarto do século XIX, e para um valioso arrolamento de seus nomes, ver o artigo referencial de Ana Paula Simioni: SIMIONI, Ana Paula C. "A viagem a Paris de artistas brasileiros no final do século XIX", In: Tempo Social, revista de sociologia da USP, v. 17, n. 1. São Paulo, Julho de 2005. pp. 343-366. Disponível online em: http://www.scielo.br/pdf/ts/v17n1/v17n1a14.pdf [último acesso: março de 2016.]

${ }^{438}$ CADERNO de permissões dadas a artistas para realizações de cópias no Louvre, 1852-1860. Cota: *LL15. P.184. Museu do Louvre, Setor de Documentação, Paris. 
retorno marcado ao Brasil -, as palavras do teórico francês sobre o verdadeiro método artístico empregado pelos gregos, o método eclético, que também deveria, segundo defendia, ser empregado pelos jovens estudantes:

Mas ao pesquisar as origens desse ideal [grego], é surpreendente constatar que ele é formado de elementos emprestados de fontes muito diversas e reunidas para formar um novo conjunto bem diferente dos seus compositores. [...] Em resumo, para relembrar a lenda antiga, é pelo procedimento de Praxíteles, que, se dizia, havia reunido em sua casa as mais belas moças da cidade para fazer a sua estátua de Vênus. Essas observações nos levam a saber como nós devemos proceder para rejuvenescer nossas artes modernas, criar uma nova fonte de inspiração e atingir uma verdadeira originalidade, sem tombar na bizarrice. Nós temos em nossas mãos hoje bem mais elementos do que os Gregos tiveram, e esses elementos são de valor bastante diferente: nossa escolha é portanto mais difícil ${ }^{439}$.

Bem antes de Viollet-Le-Duc proferir essas palavras alentadoras no curso de Estética aplicada à história das artes, e durante todo o processo de produção da sua ninfa, Américo atravessava a leitura da então recentemente publicada Filosofia da arte aplicada à pintura de Sutter, que era, aliás, também defensor dos "ecléticos" Carracci como um dos três pilares da arte italiana, com Giotto e Rafael ${ }^{440}$. O jovem havia lido nesse autor a mesma garantia que, afim às suas próprias crenças artísticas, o reenviavam ao método eclético para a produção de obras "verdadeiras":

A luta entre os clássicos e os românticos, que dividiu a opinião desde os Gregos até os nossos dias, poderá durar muito tempo ainda; porque cada uma dessas doutrinas, se apoiando sobre verdades incontestes, não pode encontrar nela mesma argumentos suficientemente potentes, suficientemente vitoriosos para convencer a parte adversária. O progresso filosófico dependerá portanto da descoberta desse meio termo, cujo trabalho é de costurar esses dois pontos antagonistas de uma mesma série, para formar uma harmonia divina que será a unidade metafísica de princípios, isto é, a identidade final entre o belo contemplativo e o belo ativo. ${ }^{441}$ [...] O movimento filosófico que se produz neste momento recrimina a escola realista por colocar de lado os interesses morais da humanidade e de levar a culto os interesses materiais; e [recrimina] a escola romântica por seu desdenho ao realismo e por suas especulações subjetivas. Ora, como não há verdade moral sem reciprocidade, isto é, sem uma balança tênue justa entre dois interesses, o ecletismo que escolhe e reúne o que há de mais perfeito nas artes e nas ciências para disso formar um todo homogêneo, conduz necessariamente à prática dos estudos próprios a realizar a soma do progresso ao qual o espirito humano pode pretender, e é essa a regra adotada pelos mestres hábeis dos quais nós falamos, que conduziram a Renascença a seu apogeu. [...] Unindo-se a arte aos princípios baseados na filosofia, não será preciso temer a confusão e a incerteza

${ }^{439}$ VIOLLET-LE-DUC, E. E. Op. cit. p.61: "Mais en recherchant les origines de cet idéal, on est tout étonné de constater qu'il est formé d'éléments emprunté [sic] à des sources fort diverses et réunies pour former un nouvel ensemble bien différent de ses composant. [...] En un mot, pour rappeler une légende antique, c'est le procédé de Praxitèle qui, disaiton, avait réuni chez lui les plus belles jeunes filles de la ville, pour faire sa statue de Vénus. Ces observations nous amènent à savoir comment nous devons procéder pour rajeunir nos arts modernes, créer une nouvelle source d'inspiration et atteindre à une originalité véritable, sans tomber dans la bizarrerie. Nos avons aujourd'hui sous la main bien plus d'éléments que n'en avaient les Grecs, et ces éléments sont de valeur for diverses: notre choix est donc plus difficile."

${ }^{440}$ SUTTER, D. Op. cit. p. 22.

${ }^{441}$ SUTTER, D. Op. cit. p.61-62. 
que afligem o espírito dos artistas cuja educação foi incompleta. ${ }^{442}$

Não tendo sido esse o tipo de "educação incompleta" que Américo buscou durante seus anos de formação brasileira e francesa, ele estava pronto para levar a sua obra ao Brasil, e exibir com orgulho as suas qualidades "baseadas na filosofia" eclética, portal convergente para todos os demais sistemas filosóficos da história. Para uma pintura interessada em se colocar como um meio igualmente afunilador das contribuições artísticas do passado, é curioso, para não dizer mesmo irônico (mas para Américo uma ironia infeliz) saber que mesmo quando existiram dúvidas sobre onde posicionar criticamente $A$ Carioca desde as suas primeiras exibições no cenário artístico brasileiro, a imagem da via do meio pôde ser, precisamente, utilizada. Contudo, nesse caso, em lugar dessa via significar positivamente uma "balança justa" e conciliatória entre dois extremos, foi uma que, nem para cá, nem para lá, deve ter significado para o jovem pouco, ou quase nada:

citaremos a Carioca do Sr. P. Américo, que foi ultimamente objeto de uma discussão renhida, em que aos gritos de - sublime! - respondiam os gritos de - detestável! - mas que não é nem detestável, nem sublime. O meio termo não é uma posição cômoda, mas nós a tomamos afoitamente, reconhecendo na Carioca uma bela prova de um talento gracioso e correto, mas não limpa de alguns defeitos que lhe foram apontados. ${ }^{443}$

\section{O significado da Carioca: uma alegoria brasileira para um projeto político das artes}

A elaboração de uma interpretação da Carioca que seja suficientemente condizente com o significado projetado por Pedro Américo parece de início depender da compreensão de umas de suas intenções primeiras, e esta se amparava em uma perspectiva fundamentalmente "quincyana": a ideia de que toda obra deveria ter uma destinação clara e, sobretudo, moral, para que não corresse o risco de ser

${ }^{442}$ Idem, ibidem. p.64-65: "La lutte entre les classiques el les romantiques, qui a divisé l'opinion depuis les Grecs jusqu'à nos jours, pourra durer longtemps encore; car chacune de ces doctrines, s'appuyant sur des vérités incontestées, ne peut trouver en elle-même des arguments assez puissants, assez victorieux pour convaincre la partie adverse. Le progrès philosophique dépendra donc de la découverte de ce moyen terme, dont l'office est de relier ces deux points antagonistes d'une même série, pour former une harmonie divine qui sera l'unité métaphysique de principes, c'est-à-dire l'identité finale entre le beau conlemplalif et le beau actif [...] Le mouvement philosophique qui se produit en ce moment reproche à l'école réaliste de mettre de côté les intérêts moraux de l'humanité et de pousser au culte des intérêts matériels; et, à l'école romantique, son dédain pour le réalisme et ses spéculations subjectives. Or, comme il n'y a pas de vérité morale sans réciprocité, c'est-à-dire sans une balance tenue juste entre deux intérêts, l'éclectisme, qui choisit et rassemble ce qu'il y a de plus parfait dans les arts et les sciences pour en former un tout homogène, conduit nécessairement à la pratique des études propres à réaliser la somme de progrès auquel l'esprit humain peut prétendre, et c'est la règle qui fut adoptée par les maîtres habiles dont nous avons parlé, qui conduisirent la Renaissance à son apogée [...] En rattachant l'art aux principes basés sur la philosophie, on n'aura pas à redouter la confusion, l'incertitude qui affligent l'esprit des artistes dont l'éducation a été incomplète".

${ }^{443}$ S/A. "Folhetim. Ao Acaso". Diário do Rio de Janeiro. 21 de fevereiro e 1865. p.1. 
desnecessária. Tal condição que seria indesculpável a um artista que, no plano teórico, manifestava coetaneamente o interesse no desenvolvimento dos meios que tornariam as artes necessárias ao Brasil.

Realmente, bem antes de chegar ao país, A Carioca possuía, conforme discutido, uma destinação precisa: era endereçada às mãos de d. Pedro II, alvo importante e evidentemente singular, que por sua vez duplicava, por assim dizer, os termos da destinação da obra. Se bem que se tratasse de uma pintura cuja alocação deveria por certo ser a coleção privada de uma pessoa pública, essa mesma pessoa pública fazia de sua coleção objeto recorrente de exposição em ocasiões regulares e populares, como nas Exposições Gerais de Belas Artes. A ambiguidade desse jogo de vai-e-vem e a tênue passagem do acesso público ao privado, no caso específico da coleção imperial, eram conhecidas de longa data por Américo - e basta talvez relembrar que na EGBA de 1859, ele pôde ver exposta uma sugestiva Suzana e os Velhos, pertencente ao imperador, como outras também expostas. Essa alternância interessada do domínio do particular ao geral não lhe era aliás uma característica apenas conhecida, mas havia sido de fato explorada pelo jovem com a sua Carioca, e, de modo significativo, em sentido inverso: ele a havia exposto publicamente antes mesmo de ofertá-la pessoal e cabalmente a d. Pedro II (mesmo se a pintura já fosse abertamente anunciada nos jornais como um presente com dono certo ${ }^{444}$ ).

O acesso geral então dado à pintura, antes mesmo de chegar a seu destino final, permite deduzir o vivo interesse do jovem para que fosse vista, como o faria de fato por duas vezes consecutivas: na Casa Bernasconi \& Moncada, em janeiro de 1865, e no fim de fevereiro do mesmo ano, na EGBA. Durante os quase dois meses que separaram o início daquela primeira exibição inédita e o fim da segunda, é de se julgar que ocorrera o fatídico momento da recusa da pintura pela Casa Imperial, porque será o próprio Américo, e não o imperador, quem a colocará novamente em exibição, na Exposição Geral.

Américo, naturalmente, não sabia que tudo isso iria se passar, e não deve ter sido nada menos do que um banho de água fria escutar o "não" da Casa Imperial para uma de seus dois primeiros trabalhos que marcavam, como ele próprio afirmara, o início da sua "vida intelectual"445. Contudo, para que o interessa aqui desenvolver, isso não é, no momento, exatamente importante. Na verdade, para se compreender o significado projetado sobre a Carioca, esse é o ponto limite até onde seria preciso ir, já que a interpretação da náiade diante do próprio imperador, e de parte do público que aparentemente a

444 "Os leitores sem dúvida foram já admirar em casa do Sr. Bernasconi o belíssimo quadro feito pelo jovem pintor brasileiro, o Sr. Pedro Américo de Figueiredo, e por ele oferecido à Sua Majestade o Imperador." Correio Mercantil. Rio de Janeiro, 16 de janeiro de 1865. p.1.

${ }^{445}$ AMÉRICO, P. Dedicatória enviada a d. Pedro II, acompanhando o manuscrito das Considerações Filosóficas sobre as Belas Artes entre os Antigos. Rio de Janeiro, 06 de janeiro de 1865. Arquivo Museu Imperial. Petrópolis, Rio de Janeiro. 
refutou, diz respeito à recepção ulterior da obra em relação a problemas sociais e culturais do período; estudo que, infelizmente, não se poderá cumprir nesta Tese, ainda que se tenha coletado enorme quantidade de material sobre a questão ${ }^{446}$.

Antes de receber a notícia da rejeição da pintura, Américo esperava portanto que as intenções que o haviam orientado a uma tal realização fossem bem recebidas e compreendidas por seu destinatáriomór, e que pudessem ser ainda lidas pelo público que tivesse acesso a ela. A tarefa, sem dúvida, não era das mais fáceis, tratando-se do primeiro grande nu feminino brasileiro, cercado de alguns problemas potenciais, que serão discutidos em seguida. Todavia, o contexto artístico europeu e especificamente o contexto imediato francês (no qual se inscreviam as recepções positivas que o então mais importante chefe internacional de estado, também ele um imperador, havia feito aos nus produzidos pelos artistas mais comentados do período) haviam mostrado que uma recepção exitosa poderia ser de fato possível. Depois de 5 anos na Europa, deveria ser mesmo o circuito francês que se tornava um ponto de comparação preponderante e, talvez mais do que isso, desejável ao jovem Américo.

O primeiro nível significante da Carioca é indubitável, e o seu reconhecimento (com todos os elementos que o garantiam) parece já ter sido suficientemente trabalhado no início deste Capítulo. Ela é uma ninfa, uma náiade especificamente; identificação que provinha de uma significação cultural ainda bastante presente, esta se amparando num reconhecimento iconográfico, e esta, por sua vez, retornando longinquamente a bases textuais e, originalmente, mitológicas.

No entanto, a condição de existência da Carioca enquanto náiade era tão somente seu significado iconográfico e não exatamente - se assim se pode dizer - seu significado iconológico ${ }^{447}$. Muito provavelmente, o mais importante sobre essa obra seria deixado de lado se se para por aí. Em seu recomendado idealismo, A Carioca se revestia de um véu simbólico com o qual se esperava criar uma barreira que separasse suficientemente uma recepção adequada a seus ulteriores significados de uma representação sexual e injustificada do corpo feminino ${ }^{448}$. Ser uma ninfa era um meio, um dos poucos meios a propósito possíveis para a aceitação "oficial" e, também em grande parte, cultural da representação do nu no período, sobretudo o nu feminino (num momento em que nem na École nem na

${ }^{446}$ Espero portanto dar uma contribuição futuramente à compreensão da recepção da Carioca, em texto específico sobre o assunto.

${ }^{447}$ PANOFSKY, E. Significado nas artes visuais. São Paulo: Editora Perspectiva, 2011. pp.51-54.

${ }^{448}$ Para alguns dos fundamentos renascentistas em relação à codificação do nu e sua exibição, ver: GINZBURG, Carlo. "Ticiano, Ovídio e os códigos da figuração erótica no século XVI". In: IDEM. Mitos, emblemas, sinais. São Paulo: Companhia das Letras, 1991. 
AIBA, com bem se sabe, eram ainda admitidas modelos mulheres).

Para Américo, esse processo possuía uma justificação cultural e, ao mesmo tempo, uma filosófica. Conforme discutido nesta Tese, em Considerações Filosóficas ele havia defendido a importância do princípio da antropomorfização da arte antiga. Tratava-se de um processo interpretado por vários estudiosos do período como fundamental à ascensão da grande arte grega, e, em 1864, no mesmo curso de estética seguido pelo jovem brasileiro, Viollet-Le-Duc de fato afirmava que o processo de personificação das forças naturais iniciado pelos antigos, cada vez mais aperfeiçoado pela ideia da imitação, teria sido motivo que os iniciaria no caminho da grande arte ${ }^{449}$. A interpretação não era apenas histórica, mas projetiva, já que esse mesmo procedimento deveria ser repetido pelos jovens artistas da segunda metade do século XIX, no sentido de renovarem a arte contemporânea ${ }^{450}$. Na perspectiva do jovem brasileiro, corporificar a fonte da Carioca em uma forma humana era introduzir assim sua composição num procedimento de bases moral e artística suficientemente sólidas diante da tradição.

Para além desse procedimento, toda a intenção expressa na obra - o seu significado realmente imaginado - parece se concentrar criticamente em três conceitos intimamente relacionados a esse trâmite (e cada um deles desdobrado em um conceito duplo), cuidadosamente declarados pelo próprio Américo. Em momentos distintos de sua réplica a Gonzalez Coques, ele havia sintomaticamente chamado a sua náiade de "divindade alegórica" (sendo a palavra divindade proferida mais de uma vez ao longo do texto), de "mulher simbólica", e enfim de "mulher tipo" $" 451$. Todas essas três combinações de termos são absolutamente significativas, e parecem levar ao mesmo lugar.

${ }^{449}$ VIOLLET-LE-DUC, E. E. Op. cit. p.48.

${ }^{450}$ Idem, ibidem. p.49: "Mas nós podemos tomar emprestado seu espírito [dos gregos], e também buscar por nossa própria conta e com as nossas ideias modernas uma personificação de todas as forças da natureza, e todos os fenômenos que nos circundam, exatamente como fizeram os primeiros homens. Os gregos também mudavam sua mitologia a cada vinte anos, e nós temos, por exemplo, uma série inteira de Vênus que, se bem que reproduzindo todas, no fundo, a mesma emanação divina, diferem entre si de uma maneira notável nas formas e nos permitem reconstituir a história dessa divindade nas ideias da Grécia.” No original: « Mais nous pouvons emprunter leur esprit, et chercher aussi pour notre propre compte et avec nos idées modernes une personnification de toutes les forces de la nature, de tous es phénomènes qui nous entourent, absolument comme firent les premiers hommes. Les Grecs aussi changeaient leur mythologie tous les vingt ans, et nous avons, par exemple, une série entière de Vénus qui, bien que reproduisant toutes, au fond, la même emanation divine, diffèrent pourtant d'une manière notable dans les formes et nous permettraient de reconstituer l'histoire de cette divinité dans es idées de la Grèce."

Para Viollet-Le-Duc, se os antigos tivessem conhecido a locomotiva, por exemplo, certamente a teriam alegorizado, transformando-a em uma musa.

${ }^{451}$ AMÉRICO, P. “A Carioca. (Resposta ao Sr. Gonzalez Coques.)” Correio Mercantil, Rio de Janeiro, 31 de janeiro de 1865. p.2. 
Se Américo tivesse chamado sua Carioca tão somente de alegoria, essa seria uma denominação bem mais fácil de se compreender e do mesmo modo bem menos problemática, pois se ligaria, conforme discutido, a uma prática tradicional de celebração dos rios, que também havia encontrado sua expressão no Brasil desde o período colonial. Mas saber que o jovem, em momento algum, em texto algum de sua autoria, havia chamado assim a sua náiade, ou mesmo de "alegoria fluvial”, e que tivesse além disso subordinado o significado de alegoria ao de divindade, esse, sim, é um procedimento crítico que parece dizer algo mais.

Considerar A Carioca como uma "divindade alegórica" (e não como uma "alegoria divina" - neste caso, a ordem dos fatores alteraria profundamente o produto) significava "inventar" um deus pagão nu num país oficialmente cristão, mas - até certo ponto de sua nudez - inofensivo. O jovem, não há dúvidas, não profanava o evangelho (ele demonstra ser católico suficiente para não fazê-lo), senão conferia existência a uma deusa de fantasia que possuía uma função notadamente simbólica: sua "mulher simbólica". Mas como todo símbolo deve necessária e convencionalmente representar algo (para assim se distinguir do ícone ou, numa perspectiva pierceana, do índice), e como todo deus, verdadeiro ou fictício, deve ter seus crentes que se identificam com ele, também a aparição da Carioca deveria resumir valores que explicassem sua existência conceitual.

A qualidade metafórica da unidade divina que abraça, mas ainda assim ultrapassa todas as expressões individuais de um séquito era, com efeito, invocada por Américo, e atingia finalmente o significado de sua ninfa como uma "mulher tipo",452. Esse tipo é pensado pelo artista, precisamente, como o representante totalitário do belo brasileiro incarnado. O jovem, em resumo a toda uma justificativa que apresentava - que será discutida em seguida -, havia defendido a sua náiade como a "grande ideia que temos de uma divindade alegórica e ao mesmo tempo da beleza do nosso tipo" "453. E com apenas uma única obra, ele havia de fato apresentado a expressão visível da ideia do belo que tanto o ocupava em seus estudos teóricos e, ao mesmo tempo, não uma ilustração, mas uma co-aparição do seu projeto para as artes no Brasil.

Para Américo, em estreita relação com as ideias do seus contemporâneos europeus (alguns, como Viollet-Le-Duc, mergulhados no pensamento racista do Conde de Gobineau ${ }^{454}$ ), "B" de belo queria

${ }^{452} \mathrm{O}$ problema da "imagem tipo" havia sido bastante discutido por Quatremère de Quincy, em livro já bastante citado nesta Tese, posto que utilizado pelo jovem Américo: QUINCY, Q de. Sur l'idéal dans l'art du dessin... p.17.

${ }^{453}$ AMÉRICO, P. Op. cit. p.2.

${ }^{454}$ Para uma discussão esclarecedora sobre as dívidas de Viollet-Le-Duc para com o Gobinismo, ver: JARRASSÉ, Dominique. "Ethnicisation de l'histoire de l'art en France 1840-1870: le modèle philologique". In: RECHT, Roland; 
dizer, entretanto, "B" de branco. Essa era a cor - pensada enquanto "distinção de origem" - escolhida à Carioca, opção que não era de modo algum casual, mas atravessava aqueles mesmos caracteres projetuais, além de outros filosóficos, culturais e, finalmente, raciais.

Pode ser ou uma tremenda coincidência, ou quem sabe mais uma intenção inscrita à pintura, descobrir que entre as diversas interpretações etimológicas do nome indígena "Carioca", significado que havia interessado algumas personalidades brasileiras já no século XIX, se encontravam com recorrência as de "Mãe d'água" (essa, de fato utilizada por Luiz Guimarães para se referir à obra do seu amigo), "Casa da água corrente", "Casa da fonte”, mas por fim, também, as de "Casa de branco" ${ }^{455}$

SÉNÉCHAL, Philippe; BARBILLON, Claire; MARTIN, François-René. Histoire de l'histoire de l'art en France au XIXe siècle. Paris: La documentation Française, 2004. pp.337-360. Ou ainda: IDEM, "Les arts méconnus. Historicité et ethnicité dans l'histoire de l'art au XIXe siècle ", in Nabila Oulebsir et Mercedes Volait (dir.), L'Orientalisme architectural entre imaginaires et savoirs. Paris: Picard ("Collection D'une rive l'autre"), 2009. Disponível online em: http://inha.revues.org/4921 [Último acesso: 04 de abril de 2016]

Para uma discussão paralela sobre o problema das teorias raciais no Brasil, na qual a presença do Conde de Gobineau no país, durante os anos 1860, também é comentada, ver: SCHWARCZ, Lilia Moritz. O Espetáculo das Raças - cientistas, instituições e questão racial no Brasil, 1870-1930. São Paulo: Companhia das Letras, 1993.

${ }^{455}$ CAETANO, Batista. "Etymologias Brazílicas. II. Carioca. - O que significa?” In: GALVÃO, Benjamin Franklin Ramiz (dir.). Anais da Biblioteca Nacional do Rio de Janeiro. 1876-1877. Volume II. Fasc. n.1. Rio de Janeiro: Typ. G. Leuzinger \& Filhos, 1877. pp.404-06. O verbete em sua forma integral, com todas as interpretações colhidas pelo autor, incluindo a sua própria conclusão sobre a questão, é o seguinte:

"Kariauk. Aldeia cujo nome é derivado do de um ribeiro, por estar assente à sua margem, e que é interpretado a casa dos karios composto dessa palavra karios e de auq que significa casa; tirando-se pois os e ajuntando-se auq formar-se-á kariauk. LERY. - Histoire d'un voyage fait en la terre du Brésil (ed. de 1600). chap. XX, pp.398 e 299.

Cary-O'ca ou - Carióca - que quer dizer Água corrente de pedra - significaram com o mesmo vocábulo ou lugar, de que corriam as águas, denominando-se também Mãe d'água, como apelidaram as sesmarias primeiras das terras circunvizinhas. PIZARRO - Memórias históricas do Rio de Janeiro, tom. VII (1822), p.51.

Carioca. Composta de duas palavras indígenas - Cary e $O^{\prime} c a$ que significam segundo alguns etimologistas - Casa d'água corrente, e segundo outros - Água corrente de pedra - foi pelos portugueses chamada Mãe d'água, como se lê nas antigas escrituras de sesmarias das terras circunvizinhas. CÔNEGO FERNANDES PINHEIRO - A Carioca: memória histórica e documentada. Na Revista trimensal do Instituto Histórico do Brazil. tom. XXI (1862), pp.565.

Carioca, Caryoca (Rio de Janeiro, Fonte da Cidade, Aqueduto) - caryca, corre, oca, casa. Domus fontis. Caryocas nomen habitantiun urbis Rio de Janeiro. MARTIUS - Glossaria linguarum brasiliensium, pp.495.

Carioca (casa do branco). VARNHAGEM. Historia Geral do Brasil, tomo I (ed. de 1876) pp. 86 in-fine.

Carioca - segundo as diversas interpretações significa: $1^{\circ}$. Cada d'água corrente, $2^{\circ}$. Água corrente de pedra, $3^{\circ}$. Mãe d'água, $4^{\circ}$. Casa da fonte (domus fontis), $5^{\circ}$. Casa dos karijós, $6^{\circ}$. Casa do branco.

A $1^{\circ}$. Destas interpretações não procede e a $2^{\circ}$., ainda menos; cari ou cary em caso algum podia significar água corrente, e em toda a expressão Carioca não há nada que se refira a itá - pedra.

Se Carioca pudesse provir de itarioka ainda haveria alguma plausibilidade para se interpretar água corrente ou manante de pedra, e isto mesmo forçando a significação de oka ou og.

A significação de mãe d'água é inteiramente inadmissível; não acha-se em parte alguma vocábulo que exprime literalmente mãe d'água e não ser yburasy em uma lenda muito truncada, muito difícil de traduzir-se, e talvez não muito autêntica. Casa da fonte como dá Martius não serve, porque cary não significa fonte; e expressão usada para dizer fonte é ybúra. A explicação de Lery também não satisfaz, e apenas, como ele é um dos mais antigos que dão notícia desse nome, vê-se que o nome da aldeia provinha do nome da fonte, e há então toda a razão de se supor que Carioca é o nome do rio.

A explicação dada pelo sr. Visconde de Porto Seguro procederia se com efeito fosse bem certo que cary ou cari significa homem branco. Mas em guarani ou abañeenga o homem branco é chamado de karai ou karaib, e não kari ou karib. Por conseguinte casa do branco seria karai-og, donde naturalmente karaioka e depois karioca.

Além disso, cumpre lembrar que em kechua há ccari, varão e que é possível que karai entre guaranis e tupis 
em referência às casas (okas) que o "homem branco" (Kara'iwa, e posteriormente caraíba) teria originalmente construído em torno de alguns dos mananciais que formavam o rio Carioca, e que teriam definido o primeiro núcleo urbano da cidade de São Sebastião do Rio de Janeiro.

Se procedente à intenção do jovem, esse significado, historicamente diluído e naquele momento reinterpretado por estudos filológicos, viria apenas corroborar o aspecto já notadamente programático de uma ninfa branca, de olhos e cabelos morenos (como sinalizado, uma mudança fundamental operada por Américo diante das representações dominantes das Vênus e ninfas loiras, de olhos claros), cujas características aludiam à relação de proximidade genética percebida entre as brasileiras e a mulheres portuguesas e as espanholas - estas, cuja beleza as precedia.

A aparição de uma figura idealmente construída em relação a um legado "racial" específico deveria conectar simbolicamente o Brasil a um percurso histórico que interessava a Américo: um traçado arianista que, cruzando a França e Itália, atingia por fim a Grécia “fundadora". A realização da Carioca era, assim, a tentativa de criação de um cânon brasileiro, medido, purificado, esbranquiçado, e extirpado de todas as qualidades simbólicas que supostamente emperravam um país jovem mas já "preguiçoso" ou, nos termos do próprio Américo, "semiletárgico" 456 - características então avaliadas no contexto geral nacional como uma herança das "raças" camitas e indígenas no país ${ }^{457}$. A imagem da ninfa, para além do esforço de se encontrar uma forma harmônica, era, assim, uma veemente afirmação política que o jovem propunha ao sistema artístico brasileiro.

Mas a Carioca não era exatamente uma tese do jovem artista-filósofo. Era, na verdade, uma antítese que, justamente por assim sê-lo, garantia, no Brasil do período, um lugar distinto e único à sua pintura. Pois em lugar de se posicionar em um campo inexistente de representação dos valores

corresponda a kari em kechua.

Lery porém, faz menção de uma aldeia com esse nome, e diz que o nome da aldeia provinha do nome de uma fonte, e Lery é um dos mais antigos que escreveu sobre coisas do Brasil. É de crer pois que fosse com efeito o nome da fonte ou rio. Analisando-se os sons neste pressuposto, a única solução literal é entender-se kaa-ry-og, corrente saída do mato ou do monte; mas ainda forçar-se a significação do $o g$.

Outra interpretação para kaa-ry-og seria casa da corrente do mato, que não deixa de ter tal o qual plausibilidade.

Consta que o falecida Braz da Costa Rubim dera outra interpretação, mas dela não temos outro conhecimento além da notícia."

Outra interpretação mais tardia, do início do XX, ligaria o número Carioca à ideia de Casa dos Acaris (Acari é um peixe cascudo, que vive em rios pedregosos), mas que, com o tempo, foi relacionado à imagem dos guerreiros brancos "encouraçados" que construíram as primeiras moradias em pedra da região, às margens do rio da Carioca. CORREA, Magalhães. Revista Nacional de Educação Ano I, n 5. Rio de Janeiro: Ministério da Educação e Saúde Publica/ Museu Nacional Rio de Janeiro, 1933.

${ }^{456}$ AMÉRICO, P. Op. cit. Conclusão, p.192. Ou: Correio Mercantil, Rio de Janeiro, 25 de dezembro de 1864, p.1.

${ }^{457}$ Ver SCHWARCZ, Lilia Moritz. Op. cit. 
simbólicos nacionais, ela se colocava em oposição direta a um realmente efetivo e já suficientemente denso, que havia então escolhido a figura do índio como o seu maior emblema.

A escolha de uma iconografia oficial para o império, centrada ou mesmo coadjuvada pela imagem do nativo, irritava Américo - e isso justifica a exoneração que fará da tanga pictórica por toda sua vida $^{458}$. Conforme estudado no Quarto Capítulo desta Tese, ele havia de fato associado a ascensão dessa iconografia à ideia que se fazia, no Brasil, da arte como atividade frívola. O recado endereçado à Estátua equestre de d. Pedro I ("Acostumados a" considerar a arte como "frívola ocupação, continuaremos a" rodear “de selvagens e répteis a estátua de nossos heróis" ${ }^{459}$ ) deveria se estender provável e indiretamente à Primeira Missa do Brasil, do seu colega Victor Meirelles (onde os índios também precingem a cena principal), e a qualquer monumento indianista apresentado como símbolo do país.

Em uma postura singular no cenário artístico do período, Américo iria desse modo se opor a uma parte fundamental do espólio incitado desde o início do século XIX por Ferdinand Denis ${ }^{460}$ e Januário Cunha Barbosa ${ }^{461}$, que incitaram o estabelecimento de uma verdadeira literatura brasileira assentada na paisagem nacional, incluindo todos os seus elementos constitutivos (naturais e humanos nativos). Essa instigação, retomada já como um programa pela geração romântica de 1830 - a geração de Gonçalves de Magalhães, F. S. Torres Homem, e do próprio Araújo Porto Alegre -, criou, como se sabe, uma via de mão dupla para a produção intelectual brasileira. De um lado, abriu uma perspectiva fundamental para os estudos etnográficos, por meio do Instituto Histórico e Geográfico do Brasil, deitando as bases para o desenvolvimento duradouro de uma veia da arqueologia nacional, então pulsante no Museu Nacional (então dirigido pelo amigo de infância de Américo, Ladislau Netto) e centrada no estudo e

${ }^{458}$ Em toda sua carreira, de todas as suas obras conhecidas, Américo fez apenas uma representação do índio brasileiro: uma Moema. Mas trata-se de um pequenino estudo sobre cartão, inspirado formalmente na Moema de Victor Meirelles, ainda que num tom fúnebre bem mais acentuado, e datado muito provavelmente da década de 1880, quando a discussão e a afirmação sobre o indianismo lhe parece não ser mais um motivo de preocupação para a afirmação do caráter nacional. A existência dessa imagem - um estudo, repete-se -, longe de sugerir um mudança de orientação no pensamento de Américo, parece ser tão somente de estudo ilustrativo para o poema "A voz de Moema”, publicado por Luiz Guimarães Júnior, em 1880, no volume Sonetos e rimas.

459 AMÉRICO, Pedro. "Cartas de um plebeu aos Srs. Deputados. Quinta carta". Correio Mercantil. Rio de Janeiro, 29 de junho 1865 .

${ }^{460}$ DENIS, Ferdinand. Scènes de la nature sur les tropiques et de leur influence sur la poésie. Paris: Louis Janet, 1824 ; IDEM. Résumé de l'histoire littéraire du Portugal, suivi du Résumé de l'histoire littéraire du Brésil. Paris: Lecointe et Durey, 1828. pp.513-615.

${ }^{461}$ BARBOSA, Januário da Cunha; MIRANDA, José Américo (org. e ed.). Parnaso Brasileiro de Januário da Cunha Barbosa. Belo Horizonte: UFMG, 1999. 
descrição dos índios e dos seus costumes ${ }^{462}$. De outro, forneceu os meios necessários para a criação de uma mitologia brasileira, deliberadamente homérica e igualmente poética, que também elegia a figura do nativo como a do seu herói trágico. Além da presença constante em alegorias do império, e embora a aparição de certo modo independente, mas contínua, da imagem do índio fosse recorrente em periódicos nacionais também desde o início do século XIX, seria justamente no período do retorno do jovem paraibano ao Brasil que o imaginário criado por aquela mitologia poética, continuamente alargada por novas contribuições e então operando quase como uma nova Ut pictura poesis à brasileira, recebia seus primeiros frutos de fôlego nas artes plásticas; o primeiro deles, sintomaticamente, fornecido pelo próprio Victor Meirelles, com a sua Moema (1866): o segundo grande nu feminino do Brasil $^{463}$ (fig.5.98).

Não parece haver dúvidas de que esta pintura - inspirada livremente num trecho de obra literária portuguesa, de $1781^{464}$ - era uma tréplica. Mesmo compartilhando do mesmo plano ideológico da náiade, na intenção de afirmar simbolicamente determinados valores nacionais, Moema se configurava como uma reação quase imediata à visão projetada por jovem Américo, do mesmo modo que a $A$ Carioca, por sua vez, se apresentava, segundo afirmei, como uma réplica bastante refletida, construída para ser não apenas o primeiro nu absoluto do Brasil, mas para ser a primeira contra-alegoria à mitologia indianista brasileira ${ }^{465}$, e a tudo o que ela passava a significar.

É nesse ponto que se pode compreender a precisa escolha de Américo em utilizar o termo “divindade alegórica" quando se referia à sua ninfa. Tratava-se da vontade de realizar a síntese de um novo tipo mitológico que deveria, portanto, ultrapassar o seu sentido puramente alegórico, fundando um novo panteão de representantes do "tipo" brasileiro (este, um potencial problema, de que tratarei em seguida).

A visão invocada pelo jovem estabelecia uma configuração consideravelmente distinta das conformações poéticas que alguns artistas brasileiros, depois de (e incluindo também) Meirelles, realizariam a partir da literatura e estudos indianistas. Desde os anos 1860, os níveis de contrastes

${ }^{462}$ Sobre o problema da etnografia desde a fundação do IHGB, ver: KODAMA, Kaori. Os filhos das brenhas e o Império do Brasil: A etnografia no Instituto Histórico e Geográfico do Brasil (1840-1860). Tese de Doutorado. Rio de Janeiro: Departamento de História da PUC-Rio, 2005.

${ }^{463}$ Para um importante estudo sobre A Moema, de Victor Meirelles, ver novamente: MIYOSHI, Alex. Moema é morta. Tese de Doutorado. Campinas, Unicamp, 2010.

${ }^{464}$ A história de Moema integra um dos cantos do Caramuru (1781), de frei José de Santa Rita Durão.

${ }^{465}$ Nesse sentido é relevante considerar que essa mitologia poética indianista faziam parte de um sistema simbólico que o próprio Porto Alegre ajudara a fundar; aqui, portanto, uma contraposição clara entre o projeto "exclusivo" do jovem artista e o "inclusivo" do seu mentor e futuro sogro. 
incluíam diferentes postulados "raciais", certamente, mas igualmente temáticos e iconográficos. A índia é sempre cor âmbar-pardo e A Carioca, notadamente branca. Como as Saphos, as Ariannes (figuras míticas e legendárias, cujo final é sempre trágico), a figura da nativa é representada sempre em sua dor, no filão de Chateaubriand; imagem que, em acordo com o cenário internacional, ao perpetuar "a lenda do sofrimento, potência inspiradora romântica, participa da ambivalência entre o neoclassicismo e o romantismo" $" 466$. A mistura com branco ou é a sua prevista sentença de morte ou de desgraça. Se agente dessa mistura (Iracema, Moema), o padecimento é o que lhe aguarda; se fruto dessa miscigenação (Marabá), está fadada a um não lugar social (o dos mamelucos, uma nova espécie tropical de camitas), que mantém o acento trágico sobre sua vida. Moema, por exemplo, é um nu também em íntima e fúnebre relação com o tema das águas: um dado que não pode ser subestimado para se pensá-la, mais uma vez, como resposta à Carioca. Ela é representada por Meirelles no auge de sua vida física, ainda que se trate de uma "pintura póstuma". Segundo Alexander Miyoshi, o artista:

integrou seu quadro à tradição pictórica de nus estendidos sobre paisagens naturais, prolongadas ao horizonte; nus míticos e idealizados, dormindo ou sem vida, inconscientes de sua exposição e, assim, viáveis a olhos moralistas. Acrescente-se que a nudez de Moema, sendo ela uma indígena, era condição natural, inocente e plausível, o que autorizou ainda mais a sua transposição à tela. ${ }^{467}$

A Carioca, por outro lado, encarnação do ideal platônico (da beleza, da bondade, da felicidade, e da realização plena), na sua candura, não podia guardar qualquer traço de tragédia ou melancolia. Ela conhece bem a sua beleza verticalizante, e a mostra arbitrariamente. O convite não era à contemplação da dor daquela que não pode se incluir nem mais em um mundo ou em outro, nem à reflexão atualizada da tragédia grega ou do moralismo cristão (Betsabéias, Suzanas etc), mas à contemplação da parte triunfante de sua herança ariana (a cultura europeia) em sua fusão com a parte apoteótica do legado brasileiro (a natureza). A ninfa desfruta, assim, do seu destino, que se mostra no horizonte revelado pelo único clarão concedido pela paisagem, e que, se se pode acreditar numa comparação com a segunda versão da obra, também poderia guardar integralmente as três cores da bandeira nacional.

A oposição realizada formalmente por Américo ao indianismo brasileiro havia sido de fato compreendida (tivesse ela sido autonomamente ou por meio de suas próprias indicações) por uma das

${ }^{466}$ DOTAL, Christiane. "Femme mythiques et légendaires comme allégories modernes au XIXe siècle", In : DOTAL, Christiane ; DRATWICKI, Alexandre. L'Artiste et sa muse. Mythification du créateur et de son modèle, actes du colloque, mars 2005. Paris: 2006, p.45.

${ }^{467}$ MIYOSHI, Alexander Gaiotto. "Moema, a pintura de uma personagem literária." In: ANAIS do IV Encontro de História da Arte - IFCH / UNICAMP, 2008. Campinas: 20008. p.773. Disponível online em: http://www.unicamp.br/chaa/eha/atas/2008/MIYOSHI,\%20Alexandre\%20Gaiotto\%20-\%20IVEHA.pdf [último acesso: março de 2016.] 
primeiras chamadas públicas à exposição da Carioca, na Casa Bernasconi. Na sequência de um elogio à obra, o articulista havia ainda entusiasticamente celebrado:

e como o artista soube desprender-se do estafado uso de representar a mulher americana no tipo indígena, tipo obrigado de todas as alegorias de assunto nacional! A simplicidade da composição não pode ser maior. Sentada, formosa náiade, cuja cabeça exprime a placidez cismadora das mulheres de Landelle ou de Ary Scheffer, alisa as comas soltas. A tez morena, a pupila negra e ardente dizem-a nascido ao estuar dos dias abrasadores da nossa terra. ${ }^{468}$

A análise da ninfa, em contraste com o "tipo indígena", havia entretanto aberto o precedente para uma outra contra-análise que também faria Gonzalez Coques, opondo-se agora à "ideia" da Carioca como um tipo nacional - que se somava, portanto, à sua já referida oposição à obra enquanto pretendida imagem ideal:

As pessoas que tem falado da Carioca exaltam sobretudo a ideia que teve o autor do quadro de abandonar o sediço (!) tipo indígena, usado até hoje nas nossas alegorias pátrias.

Não sabemos onde esteja a verdade da alegoria a não ser assim, revelando o tipo e a natureza que representa.

Quanto a nós, o grandioso da ideia perdeu-se na adoção do tipo. Pode[-se] representar tudo, mas a Carioca, certamente não.

Apague o Sr. P. Américo a etiqueta que escreveu à beira do seu quadro, e ninguém encontrará ali a nacionalidade da alegoria, ninguém dirá que é uma ficção brasileira. [...] Faltou-lhe o brasileirismo. [...] Quiseramos que o muito que lá [na Europa] se aprende fosse aplicado nas coisas que se fizessem aqui, mas imprimindo-se-lhes um cunho de nacionalidade, a fim de que um dia pudesse haver - a arte brasileira. ${ }^{469}$

Coques havia sido o primeiro, e talvez único a levantar um dos problemas aparentemente centrais para o lado concernente à recepção negativa da Carioca: a coincidência do nome da divindade com o nome dos habitantes da corte ${ }^{470}$. E também foi o primeiro a defender criticamente a natureza não "brasílica" da ninfa. Ele a introduziu, por conseguinte, em um paradoxo que era aparentemente insolúvel, se se segue a lógica que ele construía. De um lado, em função de sua suposta lascívia

${ }^{468}$ Correio Mercantil. Rio de Janeiro, 16 de janeiro de 1865. p.1

${ }^{469}$ COQUES, Gonzalez. Correio Mercantil. Rio de Janeiro, 30 de janeiro de 1865. p.2.

${ }^{470}$ A questão era sem dúvida importante, mas certamente não era a única, e se somava a outras culturais e sociais (a prostituição na cidade, em especial nos arredores do largo da Carioca; os significados também problemáticos do termo "ninfa", etc.) 
determinada, a náiade não poderia ser admitida enquanto imagem ideal (isto é, como uma imagem conceitualmente universal). De outro, em função justamente da imagem generalizada e formalmente indeterminada da figura(trocada a etiqueta, poderia ser uma representante de qualquer lugar), a mesma que na primeira sentença the era negada, ela não poderia reconhecida como uma alegoria nacional. Em ambos os casos, sobraria novamente à Carioca a indesejada riba do meio.

Se soubesse que aproximadamente 130 anos após a apreciação crítica dessa suposta insuficiência da sua ninfa, um historiador como José Murilo de Carvalho repetiria, com outros termos, a mesma análise original publicada por Coques, Américo poderia quem sabe dizer se tratar de mais uma das peripécias previstas nos ciclos especulares da história:

Quando lhe ocorreu representar a mulher brasileira, produziu um nu e the deu o nome das habitantes da Corte. Poderia ter escrito embaixo $A$ francesa. A tela foi, aliás, pintada na França, em sua primeira estada de cinco anos na Europa. Ofertada a Pedro II, este a devolveu por não se ajustar aos padrões morais palacianos. ${ }^{471}$

Mas o curioso é que as mesmas razões utilizadas para defender uma tal ausência de brasilidade $\mathrm{n} A$ Carioca - segundo o viés crítico de Coques, e histórico, de Murilo de Carvalho - foram as mesmas que haviam autorizado um estudioso como Sutter, e o próprio Américo, a defenderem a beleza ideal e ariana de uma figura, sem que isso a desenraizasse de sua especificidade nacional $^{472}$ :

A ideia que nós fazemos da beleza em geral é uma; pois, supondo-se várias, isso daria lugar à livre escolha. Por essa razão que as figuras belas diferem pouco entre elas, e são mais difíceis de reproduzir que aquelas que não o são; porque elas se aproximam mais dessa ideia única que torna pouco sensível

${ }^{471}$ CARVALHO, José Murilo de. "República-mulher: entre Maria e Marianne." In: IDEM. A formação das almas: o imaginário da República no Brasil. São Paulo: Companhia das Letras, 1993. p.95.

${ }^{472}$ A esse respeito, me parece ainda ser significativo considerar duas opiniões emitidas sobre a Carioca. Na primeira, Gomes dos Santos havia percebido curiosamente poucas "qualidades gregas", garantindo, contudo, a sua natureza integralmente brasileira: "Na 'Carioca' do Sr. Américo a figura é modelada com perfeição: falta-lhe na verdade a beleza tradicional da arte antiga; e bem fez o pintor em meu conceito, abstendo-se dessa fácil reprodução: violentaria a ninfa grega, exilando-a dos vales da Arcádia para as florestas e fontes da Guanabara seria ato de pouco critério. o Snr. Américo, em quem despontam primorosas qualidades de gosto e engenho, não podia cometer tal erro. A ninfa da Carioca é brasileira, e sua beleza a das nossas patrícias." SANTOS, Thomás Gomes dos. "Discurso de Thomas Gomes ao Imperador sobre as obras premiadas nos anos 1865 e 1866, pronunciado em 15 e julho de 1866." Ata das sessões públicas do Conselho Acadêmico da AIBA, 1865, 1866. Museu d. João VI. p.145 (versão digital).

Disponível online em: http://docvirt.com/MuseuDJoaoVI/ [último acesso, janeiro de 2016].

Gonzaga Duque, por outro lado, diferentemente de Gomes dos Santos, mas também de Coques e de Murilo de Carvalho, perceberá um acordo perfeita entre idealismo-universalismo e o localismo-brasileirismo da Carioca: "O artista, vibrado pela suntuosidade dos áureos tempos do renascimento, pretendeu fazê-la nas proporções das obras imortais, mas, sem querer, deu-lhe a sua alma brasileira.” DUQUE-ESTRADA. L. G. Impressões de um amador. Textos esparsos de crítica (1882-1909). Júlio Castañon Guimarães e Vera Lins (org.). Editora UFMG, Fundação Casa de Rui Barbosa, 2001. p.242. 
o caráter particular de cada uma delas. ${ }^{473}$

Não é difícil concluir por que as imagens "verdadeiramente" belas se pareceriam umas com as outras: compartilhariam, todas, dos mesmos princípios estéticos. Funcionando quase como uma mutação genética em alguns de seus cromossomos, eles tenderiam, precisamente, a diminuir as idiossincrasias de suas aparições individuais, sobrelevando, nessa unificação, a linhagem da espécie ideal, isto é, do "tipo" filosófico humano. Conforme estudado ao longo deste Capítulo, Américo não estava apenas ciente desse movimento, como aderia àqueles princípios com fé inarredável, e de maneira programática, porquanto era justamente a adoção de um tal procedimento que lhe assegurava a resolução conciliatória do mesmo paradoxo universal-ideal $x$ local-determinado, pardoxo irresolvido, portanto, a Coques e a Carvalho - que partiam criticamente de outros valores de análise.

Não considerar toda essa marcha filosófica da Carioca ao caminho da ideia sensivelmente localizada, seria negar esse sentimento especial de alteridade que o artista quis imprimir (à) e percebia em sua obra, em ambos os contextos artísticos brasileiro e internacional. Por certo, à medida que a náiade deliberadamente se aproximava, em alguns pontos, das demais Vênus e ninfas (embora, como visto, também divergisse cuidadosamente em muitos outros), se afastava bastante, com efeito, das representações indígenas brasileiras, cumprindo assim, e com êxito, o programa esperado.

Se se negligencia esse lugar único da náiade no período - ocupado não a esmo, e não sem lide -, corre-se o risco de repetir, sem querer, o mesmo movimento então conscientemente efetuado pela geração modernista, quando jogou num mesmo e indistinto poço, e durante muito tempo, toda a gama variada de produções artísticas realizadas no Brasil durante o século XIX, julgando-as cópias baratas dos trabalhos europeus, desprovidas de "originalidade". E isso seria sem dúvida um choque para um jovem artista que, ao produzir sua náiade, lidava ao mesmo tempo com essas mesmas ideias de "originalidade" e "liberdade", e colaborava ativamente, em frentes teóricas e práticas, tanto para a causa da reformulação da "grande arte" internacional como, ainda mais incisivamente, para a formação da arte nacional.

A Murilo de Carvalho, Américo talvez diria que faltou material crítico suficiente e, talvez, um pouco de olho. A Gonzalez Coques, sem necessitar de uma sessão mediúnica para se fazer ouvir, ele havia efetivamente rebatido a acusação com um argumento quase de mesma natureza:

${ }^{473}$ SUTTER, D. Op. cit. p.119 [tradução nossa] 
e vinde nos tirar da dúvida sobre os vossos ardentes apetites, quando vos declarais em oposição com à ideia de representar a ninfa brasileira, a bela fluminense de hoje, a mulher tipo, sob o exterior de uma mulher branca, em vez de dar-se-lhe a parva e grosseira fisionomia de uma selvagem!

Até quando continuaremos nós a crer e a demonstrar ao estrangeiro que somos ainda aqueles que há três séculos e meios espantavam aos europeus pela sua exquisitice, pelas rudezas das suas maneiras? Poderíamos nós, que achamos no tipo da mulher branca o mais elevado símbolo da inteligência e doçura feminina, desprezar esse tipo pelo da raça vermelha, em que predomina o grande desenvolvimento da face, o exagerado afastamento dos zigomáticos, a bestial expressão da boca, e ainda muitos outros traços de uma variedade humana de inferior inteligência?

Levai a fluminense à escola das Belas-Artes; mostrai-lhe as indígenas de um quadro que se acha bem perto da estátua da Vênus de Milo, e perguntai-lhe qual dessas figuras se parece mais com a brasileira. A fluminense, depois de rir da extravagância da pergunta, apontará invariavelmente para a Vênus de Milo. E esse movimento é tão simples como natural e sincero, porque ninguém hoje se crê no Brasil mais descendente de sangue de tatu, do que dos nossos grandes ilustres avós, dos nossos imortais libertadores. Declaramos, pois, que, trabalhando no interesse do nosso patriotismo, representaremos, sempre que tivermos ocasião, os nossos rios, nascentes, fontes, etc., por figuras que possam representar a raça brasileira, isto é, a raça americana de hoje: branca, inteligente, e em nada inferior à europeia. parte. $^{474}$

Não nos faltou, pois, o brasileirismo, como se exprime S. S. O que faltou foi reflexão da sua

A resposta do jovem é tão veemente, tão esclarecedora de suas intenções e concepções, que tornase difícil ou até mesmo desnecessário ajuntar mais algum comentário. Em suma, branquear as aparições alegóricas não era uma simples escolha, mas uma atitude patriótica, porque eram elas que deveriam representar a "raça brasileira", raça branca e proporcionada às do Velho Mundo (e quem falava isso era um jovem seguro de si, que, após anos no exterior, se vê na mesma altura intelectual dos seus antigos colegas europeus). O mesmo ponto de vista seria de fato reiterado algumas semanas depois, na ocasião da publicação de mais um trecho do texto Cartas de um Plebeu. Nele, Américo supunha que o estado de preguiça crônica do brasileiro,

seria desculpável se nos reconhecêssemos filhos diretos da população indígena da terra de Santa Cruz; mas a história, em harmonia com os fatos, nos faz originados da Europa, nos dias do seu renascimento. É, pois, daí que procedemos; e conformes com a nobreza da nossa origem, elevemo-nos pelo amor do belo à altura dos povos cultos da Europa... ${ }^{475}$

É essa convicção, levada em forma de programa político para as artes, que deveria orientar os artistas brasileiros à fundação de uma verdadeira "Escola Nacional". Ela certamente guiaria Américo. A

${ }^{474}$ AMÉRICO, P. “A Carioca. (Resposta ao Sr. Gonzalez Coques.)” Correio Mercantil, Rio de Janeiro, 31 de janeiro de 1865. p.2.

${ }^{475}$ AMÉRICO, Pedro. "Cartas de um plebeu aos Srs. Deputados. Continuação da quarta carta”. Correio Mercantil. Rio de Janeiro, 16 de junho de 1865. P.2 
relação da sua primeira composição original com essa aspiração é, de fato, bastante significativa, e também Guimarães Júnior, na biografia escrita sobre seu amigo, continuou a reforçar o projeto lançado pela Carioca, em sua relação com o desejo de fundação de uma escola artística brasileira afastada das inclinações indianistas:

A Carioca, que não é um painel perfeito, é incontestavelmente o primeiro quadro que possuímos, de mais fogo de poesia e esplendor de natureza. Pedro Américo fugiu com a maior discrição das tolas presunções e programa restritamente falso, da escola brasileira* (nota: *Escola Brasileira! Creio que é coisa que não existe entre nós. O Brasil Colônia ainda não se libertou das correntes estrangeiras...Por ora, o caráter nacional ainda está para romper a marcha).

Há por aqui (felizmente poucos exemplos aparecem hoje!) uma extravagante representação da escola nacional na pintura, poesia e romance, que se resume em florestas virgens; bandas de tupinambás a frecharem uns aos outros; redes suspensas de jequitibás e qualquer aventura de branco por meio disso tudo, a título de acessório imprescindível. Os poetas e romancistas modernos, tem felizmente mudado a face à rotina primitiva. Citemos dos romancistas, a nossa primeira pena, conselheiro José de Alencar, e Dr. Joaquim Manoel de Macedo; entre os poetas cumpre dar lugar honroso ao Dr. Bernardo Guimarães.

Pedro Américo afastou-se inteiramente das redes em que era uso circunscrever-se o pensamento poético da escola nacional. A sua Carioca, a mãe d'água, a náiade, a suave filha das águas, do perfume e dos raios de sol americano, é morena como uma Andaluza, de cabelos negros como a asa da tormenta e flanco aveludado, com ondulações da serpente e graciosa virgindade das espáduas da onça indomável. $^{476}$

Para quase concluir as apreciações aqui desenvolvidas sobre o significado da Carioca, e sobre as intenções políticas das quais (defendo nesta Tese) ela faz parte, talvez seja ainda relevante sublinhar que a oposição efetuada pelo jovem ao programa artístico indianista, para Guimarães, um "programa falso", não se fundamentava, como pôde ser visto, apenas em uma antinomia simbólica, mas em um verdadeiro postulado de diferenciação racial. Numa nova evocação indireta, entretanto inequívoca dos estudos físiognômicos e frenológicos desenvolvidos na Europa desde o fim do século XVIII e consideravelmente expandidos na primeira metade do século $\mathrm{XIX}^{477}$, a imagem externa do índio anunciaria, também para o jovem brasileiro, a sua inferioridade intelectual diante do branco (e viceversa). Tratar-se-ia da mais pura confirmação, no campo da ciência comparativa, dos postulados da filosofia eclético-platônica, a partir dos quais aquilo que é belo, é bom e é verdadeiro, e, por conseguinte, aquilo que é feio, é ruim e falso. A sociedade brasileira, conveniada à sua suposta condição européia de existência, deveria assim marchar, também em suas representações artísticas, em direção ao branco-belo-ideal e se afastar do pardo-feio-irracional. Postas de tal modo essas premissas,

${ }^{476}$ GUIMARÃES JR., L. Op. cit. p.52-3.

${ }^{477}$ Ver 
não haveria outra escolha senão a imagem de uma proto-vênus brasileira, alva e placidamente triunfante, como a única representante possível para um sistema simbólico e racional, que se dizia representante da ideia localmente manifestada.

Aparenta ser um dado no mínimo curioso considerar que, ainda em 1865, menos de dois poucos meses após Américo apresentar sua Carioca no Brasil, um cientista como Louis Agassiz - depois de dezenas de cartas trocadas com d. Pedro II, com o intuito de buscar apoio para suas pesquisas desembarcava com sua mulher no Rio de Janeiro para um período de pesquisa de aproximadamente um ano no país. Ele estava munido em sua mente de um método etnográfico bastante similar àquele sugerido por Américo ${ }^{478}$. No intuito de provar a veracidade de suas ideias, o brasileiro apelava ao episódio imaginário de uma jovem fluminense (uma Carioca), convidada à AIBA para comparar as representações artísticas de índios (e é provável que ele se referisse à Primeira Missa) com a obra mais perfeita que ele então imaginava existir - a Vênus de Milo -, para que ela desse seu veredito sobre com qual dessas imagens se identificaria em uma perspectiva empática e aparentemente evolucionista (a imagem da história é citada pela alusão à descendência dos avós e dos antigos libertadores). Agassiz, por sua vez, iniciava a encomenda de uma série de fotografias de diferentes "raças" presentes no Brasil naquele período (índios, negros e mesmo chineses). O conjunto visual desses "tipos" - termo de fato já bastante utilizado nos estudos antropológicos do período, cujo significado era, todavia, diametralmente oposto ao admitido pela filosofia idealista -, também medidos e escalonados, mas com base numa outra escala operativa e apreciativa bastante distinta do jovem Américo ${ }^{479}$, serviria do mesmo modo ao cientista para provar a inferioridade das "raças degeneradas" frente às "belas raças" europeias. E as piores delas seriam, para o cientista, as "raças mistas" (fig.5.99.). A confirmação planejada por Agassiz seria contudo feita não a partir da comparação daquelas fotografias com a imagem também científica de um "tipo" branco. Ao contrário, retomando um modelo geral que retornava à segunda metade do

\footnotetext{
${ }^{478}$ Agassiz explica o estabelecimento do seu método comparativo da seguinte maneira: "eu me limitei em meu estudo das raças ao que eu chamaria de método da história natural; isto é, a comparação de indivíduos de diferentes tipos com outro, assim como naturalistas comparam espécimes de diferentes espécies. Isso foi menos difícil [de se fazer] em um país quente, onde a parte inculta da população anda seminua, e é frequentemente vista inteiramente despida. Durante uma estadia prolongada em Manaus, o Sr. Hunnewell fez muitas fotografias características de Índios e Negros, e de meias raças entre essas raças e os brancos. [...] O que de início mais me impressionou ao ver Índios e Negros juntos foi a diferença marcada nas proporções relativas das diferentes partes do corpo. Como macacos de braço cumprido os negros são geralmente delgados, com pernas longas, braços longos, e um corpo comparativamente pequeno, enquanto que os índios tem penas e braços curtos, e um corpo alongado, o tronco sendo também mais pesado em sua constituição. Para continuar a comparação, eu poderia dizer que se o comportamento do Negro lembra os delgados e ativos Gibãos, o Índio lembra mais o lento, inativo, e robusto orangotango." A descrição comparativa segue quanto aos aspectos particulares do corpo dos negros e dos índios. AGASSIZ, Louis. "Permanence of characteristics in different human species". In: AGASSIZ, Louis; AGASSIZ, Elizabeth Cabot Cary. A Journey in Brazil. Boston: Ticknor and Fields, 1869. p.529-30.

${ }^{479}$ As fotografias encomendadas por Agassiz dispunham e captavam seus modelos de frente, costas e perfil.
} 
século XVIII, ele o fazia a partir de uma série de reproduções em cartão postal do busto de Apolo de Belvedere, e do corpo inteiro da mesma Vênus de Milo ${ }^{480}$.

Refutando-se a veracidade de ambos os postulados de Américo e Agassiz, resta que o método de comparação imaginária daquel era, pelo menos, mais criterioso que o método de comparação real desse: afinal, o jovem opunha representações de mesma natureza, presentes em um mesmo museu. Mas no que eles possuíam de mais essencial (suas premissas filosóficas), e à diferença única dos distintos meios que utilizavam para expor suas sínteses (artísticos e científicos), ambos já tinham a mesma certeza do que queriam provar, e do lugar onde desejavam chegar; que era, no fim, o mesmo.

\section{Entre teoria e prática: alguns "desencontros" da Carioca.}

Mesmo realizando um franco esforço de Américo no sentido de responder com uma primeira grande composição a teoria artística e o programa político que desenvolvia nos seus últimos anos de formação francesa, $A$ Carioca era testemunho da dissensão ainda existente entre essas duas esferas, em seu início de carreira. Com essa pintura, o jovem tentava efetuar o que tanto havia defendido como fundamental a qualquer produção contemporânea: a realização do "ideal moderno"481. Tratava-se, como visto, de uma concepção que rogava por uma arte engajada com o seu tempo, uma que respondesse às demandas do presente, sempre, no entanto, amparada pela moral - então por ele encarada como atividade fundamental ao fomento do patriotismo e à promoção da unidade nacional. Com A Carioca, a exemplo dos gregos, ele havia de fato cumprido, no plano teórico, as três condições sob as quais - segundo vários autores, o mais recente deles, Viollet-Le-Duc - essa realização poderia ser possível. Dispunha de "um cânone ou tipo material, um ideal como objetivo, cuidadosamente meditado, e enfim uma escrupulosa e inteligente observação da natureza como meio"482.

Em Américo, o resultado dessa tripla operação é também o da personificação de valores ideais. A sua náiade era uma alegoria, mas o estatuto desejado é o mitológico, na medida em que não se tratava de uma alegoria qualquer. Mas é, paradoxalmente, em decorrência desse procedimento que se surgia a primeira cisão entre a teoria e prática no programa artístico do jovem, protagonizado pela Carioca. Se

${ }^{480}$ Para uma apreciação crítica das fotografias de Agassiz e dos critérios estabelecidos para as diferenciações que fazia entre as raças humanas, ver: MACHADO, Maria Helena P. T. "Race and visual representation. Louis Agassiz and Hermann Burmeister". In: ARAÚJO, Ana Lúcia (ed.) African Heritage and Memories of Slavery in Brazil and the South Atlantic World. New York, Cambria Press, 2015.

${ }^{481}$ Sobre o problema do "ideal moderno" Em Viollet-Le-Duc, ver: VIOLLET-LE-DUC. Op. cit. p.61.

482 Idem, ibidem. p.85. 
as Moemas, as Iracemas, as Marabás eram invenções anteparadas pela literatura nacional e pela invenção de uma mitologia poética que havia se expandido pelo fomento de instituições oficiais durante, pelo menos, as quatro décadas anteriores aos anos 1860, a náiade de Américo era uma divindade sem quaisquer aparatos literários. Seus únicos abrigos culturais existentes eram o nome do rio que representava e a vulnerável coincidência do seu nome com a alcunha também dada à mulher fluminense - perigo então percebido por Coques.

Sem tais anteparos textuais, a figura feminina se apresentava isenta de qualquer anedota, referência histórica ou poética. Ela se introduzia a si mesma, e o fato de ser concebida como uma ninfa parecia, de fato, ser devido menos à sua condição alegórica de existência do que uma a convenção pictórica. Este protocolo parecia funcionar, sobretudo, como uma motivação iconográfica, que embora mantivesse com vantagem os benefícios oferecidos à exibição do nu codificado, estabelecia já uma distância quilométrica do seu vínculo original com a mitologia grega; pois, se assim o mantivesse, a Carioca deixaria necessariamente de ser brasileira, e se colocaria ao lado da Bacante "correggianesca" de Victor Meirelles, obra sem nenhuma pretensão nacionalista, ainda que fosse uma sutil invenção poética e um belíssimo estudo de cores, tons e composição (fig.4.4.).

Na Carioca, não há "momento fecundo", não há necessidade de pedir ajuda à imaginação para ir "além" - se se pensam nas difundidas demandas lessianas. Tudo o que há, está lá, nos limites estabelecidos por sua moldura (incluindo o seu título). Não obstante, não dispor de um tema inteligivelmente claro - isto é, não ter para "contar", mesmo que tivesse programaticamente algo a dizer - não deveria ser potencialmente um problema para a pintura. Quatremère de Quincy já havia postulado que para uma obra ser moral ela não precisaria necessariamente representar heroísmos ou virtuosismos históricos. Na verdade "o moral de que essa teoria quer fornecer a ideia significa apenas o oposto do material e do sensual"483. Assim, seria também moral uma obra cuja imitação fosse destinada exclusivamente ao espírito. Essa, sim, seria uma condição necessária, pois, "efetivamente, já que a beleza do corpo ou o belo físico é o verdadeiro meio de tornar sensível o belo moral, se se cessa de impor à arte a obrigação de expressar a parte moral, que é a alma de uma obra, desde logo cessa para ela a necessidade de elevar à toda a perfeição a parte física" ${ }^{484}$.

A tese atualizada nos anos 1860 encontrava a mesma justificativa a partir de conceitos similares

${ }^{483}$ QUINCY, Q. Considerations Morales... p.13.

${ }^{484}$ Idem, ibidem. p.18-19: "Effectivement, dès que la beauté du corps où le beau physique est le vrai moyen de rendre sensible le beau moral, si l'on cesse d'imposer à l'Art l'obligation d'exprimer la partie morale, qui est l'âme de l'ouvrage, aussitôt cesse pour lui la nécessité de s'élever à toute la perfection de la partie physique." 
abordados por Sutter, repetidamente invocados nesta Tese: para que uma figura expressasse, em último grau, a Beleza moral, o artista deveria se esforçar em refleti-la sensivelmente como Beleza ótica.

Esta última foi, realmente, a única ferramenta que o jovem Américo então dispôs para transformar sua náiade em representante brasileira do Belo ideal. Nesse domínio, ele continuaria a lidar, sugestivamente, com a concepção neoclássica aprendida na AIBA e mantida na École, que prescrevia a mesma importância da coadunação do belo físico com o belo moral ${ }^{485}$ para a justa expressão da ideia. Entretanto, se nas grandes obras neoclássicas - de um David, por exemplo -, a realização da moral se devia em boa medida à representação de narrativas clássicas, metaforicamente interpretadas nos eventos da história contemporânea francesa, na Carioca, essa relação com a moralidade, já que esvaziada em narrativa, encontrou a sua metáfora exclusivamente na forma. Dito de outro modo, as ideias da moral (do bem) e da verdade que o jovem desejava representar se concentravam em uma aparição estética inteiramente subordinada à ideia do belo que tinha como meios exclusivos a relação conceitual de formas. E, com efeito, na comparação já feita com um modelo-vivo de autoria do próprio Américo, não há nada menos espontâneo e conceitualmente "moral" do que $A$ Carioca.

O problema é que todo conceito tem a potência de uma faca de dois gumes: há o significante (eternamente operante) e há os significados (geográfica, temporal e psicologicamente determinados). $\mathrm{Na}$ náiade, a operação que o jovem realizava devolvia uma obra que estava justamente num limiar simbólico muito tênue e - posto que precisamente um nu - perigoso. A moral nela projetada não era tão evidente quando se a observava; prova disso são as distintas recepções que a obra teve, a pior delas, certamente para os planos do jovem, a do imperador.

Nesse limiar, O Belo ideal perigava de ser uma quimera permanente - mesmo se a figura nua fosse a base do ensino para a academia brasileira, e mesmo se o idealismo eclético no qual se inscrevia a ninfa de Américo fosse curiosamente a mesma base filosófica frequentada por inúmeras personalidades do período, incluindo o imperador. Quimérico por que, embora defendido como objetivamente válido e assim desdenhando da esfera psicológica da fruição, o belo incarnado em nu dependia, logicamente, de uma série de relações específicas para ser cultural e socialmente aceito enquanto Belo ideal. Não se tratava aqui, por certo, de uma especificidade do contexto artístico brasileiro. Na verdade, a história exibição do nu, ao menos no século XIX, é a história das recepções contrastantes entre aqueles que aceitavam a exposição do corpo, percebendo (ou dizendo perceber) nele todas as características do Belo

${ }^{485}$ Sobre a herança neoclássica do ideal moral como um ideal física, ver FRIEDLANDER, W. Op. cit. , p.19. 
ideal - suas qualidades estritamente conceituais -, e aqueles que julgavam sua condição imoral, compreendendo nele apenas uma lascívia potencialmente perigosa à moral pública e à privada ${ }^{486}$.

Conforme sinalizado, o problema desses dois lados, "oficialmente" lidos na Carioca, ainda precisa ser investigado, para que se compreendam de maneira mais clara as questões impostas pelo nu no período áureo do Segundo Império brasileiro. Mas o que já se pode concluir é que, de um ponto de vista histórico, aquele limiar conceitual no qual Américo situava a sua obra garantia que ele ainda não havia conseguido ultrapassar, na prática, as limitações teóricas que já percebia no Ecletismo, com específica ligação ao problema da moral. Esse termo no sistema krausista era, como visto, explicado pela ação e pela atuação social, ao passo que a moral eclética (talvez justamente por se tratar de um método filosófico, e não de um sistema) era apresentada por meios puramente conceituais, que estabeleciam seu limite na explicação e na ligação das três ideias platônicas, ademais circunscritas numa cadeia autárquica, que incluía o projeto de arte autônoma.

Como o Ecletismo cousiniano, Américo também deixava insuficientemente resolvido esse problema em sua Carioca, conquanto se tratasse de uma questão que tanto interessava. Também aqui se atestava, enfim, um fluxo artístico frequente: a teoria viria na frente, e a execução precisaria de um pouco de tempo para se encontrar. A moral reclamada teoricamente, como maneira de insuflar o patriotismo, de tornar as artes necessárias, e, assim, fazê-las concorrer integralmente com o "progresso moral" da nação brasileira seria dirimida seis anos depois, na Batalha do Campo Grande, como resultado da conversão triunfalmente krausista dessa outra pintura; empresa não por acaso realizada logo a chegada de Américo ao Brasil, após a realização do seu doutorado na Bélgica, onde havia estudo com Tiberghien. Com a Batalha, ele pintava, por si só, sem encomenda, uma grande máquina de tema patriótico - empreitada, como se sabe, cara, que incluía tela, tintas, aluguel ou disponibilização de espaço para pintar etc. - e assim frequentava o desinteresse e o sacrifício, dois dos três valores krausistas relativos à filosofia moral. O terceiro estava na tela e era sintomaticamente explorado pela figura de Conde d'eu: o heroísmo: valor que, sem se desvincular aqui também do heroísmo, reforçava a ideia de um representante destemido da Casa Imperial (mesmo que na "vida real" essa fosse uma característica problemática do marido da princesa Isabel), que avança furioso contra o inimigo, contra a barbárie, no intuito de proteger patrioticamente o seu povo e a unidade do seu país.

486 Sobre o problema das distintas recepções do nu, especialmente na França, durante a primeira metade século XIX, sugiro mais uma vez a leitura de MASSONAUD, Dominique (ed.). Le nu moderne au Salon (1799-1853).Grenoble: ELLUG, Université Stendhal, 2005. 
Mas para chegar até aí, para fundir pela primeira vez, com êxito, teoria e prática foi preciso uma Carioca (mesmo se esse êxito dificilmente pôde ser percebido por todos ${ }^{487}$; "mal" que se afligiu bastante e sempre Américo, nunca foi, todavia, sua prerrogativa). Talvez por isso o seu apreço permanente por essa pintura, e o lugar insubstituível que ela ocuparia em um horizonte projetivo alimentado por décadas pelo artista, o qual, não suficientemente marcado por uma, dispôs de duas versões dessa mesma pintura.

${ }^{487}$ Especificamente sobre o problema da recepção da Batalha de Campo Grande, ver: CHRISTO, Maraliz de C. V. "Quando subordinados roubam a cena: A Batalha de Campo Grande de Pedro Américo. in Revista Saeculum , n.19. João Pessoa, Jul./Dez. 2008. 


\section{Sexto Capítulo}

\section{As Cartas de um Plebeu notório: uma nova reforma para as artes no Brasil}

\section{Um rapport de prospecção}

Cartas de um Plebeu é a última produção realizada pelo jovem Américo durante a primeira fase de sua carreira no Brasil, fase bastante curta que durou menos de dois anos, circunscrita, de um lado, pela conclusão formal dos seus primeiros estudos na Europa e regresso ao país, em meados de 1864, e de outro, por seu novo retorno àquele continente, no primeiro trimestre de 1866. Esse intervalo marca, como visto, não a execução dos seus três primeiros trabalhos originais, previamente tratados nesta Tese, mas as suas exposições públicas no Rio de Janeiro e suas primeiras recepções.

O novo escrito era o único que havia sido, com efeito, inteiramente produzido e divulgado pelo jovem quando então se encontrava na corte, tratando-se de cinco artigos seriados, impressos entre 18 de maio e 29 de junho de 1865 , em seis diferentes edições, também do Correio Mercantil ${ }^{1}$.

De modo bastante evidente, este texto é uma continuação precisa do Considerações Filosóficas sobre as Belas Artes entre os Antigos: aquele começa justamente onde este pára. A continuidade de assunto sucede, contudo, a descontinuidade das naturezas de ambos os trabalhos. Cartas de um Plebeu são, na verdade, uma "descida" do mundo das ideias ao "real" - numa sintomática relação com a leitura krausista do "direito ideal” tornado "direito atual. É com essa imagem que o próprio Américo se expressa sobre a nova série de escritos:

Quisera nunca descer das altas regiões da teoria, onde tão comodamente me tenha achado até hoje; porém, como falo em nome de interesses aos quais por nenhum modo se poderia comparar os de um só homem, me não deverei acanhar, pedindo-vos que tomeis sob vossa proteção o objeto da maior glória da Grécia antiga e da Itália moderna: as belas artes. ${ }^{2}$

A indicação sugerida pelo jovem não poderia ser de fato mais precisa: com o Cartas de um Plebeu ele tentará colocar em prática parte daquela teoria que havia deixado há alguns meses nos páramos artísticos. Semelhante "descida" se expressará terminantemente pela apresentação de um

\footnotetext{
${ }^{1}$ A Primeira carta era publicada em 18 de maio 1865; a segunda carta, em 21 de maio 1865; a terceira, em 26 de maio 1865; a quarta, em 13 de junho 1865; a continuação da quarta carta, em 16 de junho 1865; a quinta, em 29 de junho de 1865.

2 AMÉRICO, Pedro. "Cartas de um plebeu aos Srs. Deputados. Continuação da quarta carta." Correio Mercantil. Rio de Janeiro, 16 de junho 1865 .
} 
projeto voltado, em específico, ao ensino das artes do desenho no Brasil, em sua tripla função: a da criação do gosto da população, a da sua educação moral, e da difusão dos conhecimentos indispensáveis ao desenvolvimento não apenas das artes plásticas, mas das artes industriais e aplicadas no país. Mas para realizar um tal projeto, demonstrando sua importância e, sobretudo, necessidade, ele o fará introduzir por um tipo muito específico de construção textual, relativamente frequentado no Brasil, mas muitíssimo na França, durante o século XIX: o do rapport.

A tradução mais próxima desse termo em português, "relatório", não faz inteiramente juz a seu significado corrente em francês - e mesmo no Brasil do século XIX, o termo original era com frequência utilizado para precisar a sua natureza. Um rapport tratava-se normalmente de um estudo proposto autonomamente ou, mais com bem mais frequência, encomendado por alguma instituição pública ou particular - não raro sob forma de concurso aberto a qualquer cidadão -, no sentido de estabelecer um diagnóstico de problemas que urgiriam ser compreendidos e, tão importante quanto, um prognóstico de soluções.

O jovem Américo já havia saudado e encorajado em suas Considerações Filosóficas os benefícios desse tipo de texto e sua utilidade geral para o país, e - coisa curiosa mas dificilmente contingente -, com seu Cartas de um Plebeu, de pronto estabelecia uma sutil relação com um bem conhecido texto, na verdade um rapport oficial, encomendado a Porto Alegre em 1853, intitulado "Apontamentos sobre os meios práticos de desenvolver o gosto e a necessidade das Belas-Artes no Rio de Janeiro" "3. Este, um trabalho cujo desfecho havia garantido imediatamente a ascenção de Porto Alegre à frente da AIBA, para instalar a reforma no ensino da instituição, após a qual, conforme apresentado, Américo integrara a primeira turma.

Os objetivos apresentados pelo jovem no seus novos escritos se alimentavam da mesma essência da publicação do antigo diretor:

O meu fim é, pois, expor-vos Exms. Srs., algumas reflexões a respeito das Belas Artes no Brasil; dos obstáculos que segundo o meu ver se opõem ao seu livre desenvolvimento, e dos meios de as fazer progredir, tanto quanto nos for possível.[...] Sei, Exms. Srs., que sois, muito justamente, mais propensos às questões de positivos interesse do que ao estudo de coisas abstratas, ou de dificultosa aplicação à prática social; porém não creio achar entre vós quem ainda duvide o serem as belas-artes uma fonte muito abundante em riquezas intelectuais capazes de ilustrar épocas e nações inteiras ${ }^{4}$.

${ }^{3}$ PORTO ALEGRE, M. A. "Apontamentos sobre os meios práticos de desenvolver o gosto e a necessidade das belas artes no Rio de Janeiro." IN: KOVENSKY, Julia; SQUEFF, Letícia (orgs.). Manuel de Araújo Porto Alegre: Singular \& Plural. São Paulo: IMS, 2014. pp.307-310.

${ }^{4}$ AMÉRICO, Pedro. "Cartas de um plebeu aos Srs. Deputados". Primeira carta. Correio Mercantil. Rio de Janeiro, 18 
Como Porto Alegre, Américo também se dedicará, portanto, a problemas relativos ao desenvolvimento das belas artes no Brasil, e aos meios práticos necessários a essa realização. Entretanto, duas diferenças eram de início significativas entre os dois textos, e se resumiam aos idealizadores ou encomendadores desses escritos e a seus destinatários.

O de Porto Alegre havia sido destinado ao imperador e também por ele diligenciado. Satisfeito com o resultado, requeria o ingresso do intelectual como diretor da AIBA. Já tendo publicado, desde 1850, uma série de escritos sobre as relações entre arte e indústria no Brasil ${ }^{5}$, Porto Alegre então ocupava os cargos de professor da Escola Militar e de vereador substituto da cidade do Rio de Janeiro, engajado, precisamente naqueles anos, com a criação de escolas locais para educação de artistas industriais. Esse mesmo interesse servirá de esteio para a criação de um segundo curso - um curso técnico - dentro da Academia, com a harmônica concorrência do enorme projeto de reforma das educações primária e secundária no império, começando pela corte pelo seu amigo, o ministro Pedreira, já comentado nesta Tese ${ }^{6}$.

O texto de Américo, por outro lado, não possuía encomendador. Ele era o primeiro e único "plebeu" interessado em sua produção, embora dissesse que a motivação era desinteressada e voltada exclusivamente ao bem comum ${ }^{7}$. A máscara da humildade era, com efeito, apenas fachada, pois era a qualquer um patente a autoria do texto; e a assinatura que fazia ainda em título com essa antonomásia, como se quisesse recolher-se ao anonimato, dissipando-se no povo (algo que de fato não desejava), era feita para contrastar respeitosamente com os destinários dos escritos, também indicados na sequência do título principal do seu texto: a inscrição não introduzia apenas as Cartas de um plebeu, mas as Cartas de um plebeu aos Srs. Deputados. A rejeição da Carioca e a aparente pouca recepção de sua teoria nas Considerações Filosóficas por parte da Casa Imperial mostraram-se, muito provavelmente, como experiências suficientes para o jovem mudar a estratégia, especialmente quando os novos destinatários aos quais apelava em seus escritos coincidiam com o elemento catalisador da teoria da arte esboçada por ele traçada: se caberia sempre aos legisladores transformarem a arte em objeto de

de maio 1865 .

${ }^{5}$ PORTO ALEGRE, M. A. “Algumas ideias sobre as Belas-Artes e a indústria no Império do Brasil”. Guanabara, Rio de Janeiro, tomo I, 1851. Tratam-se de três artigos consecutivos, reimpressos também em: KOVENSKY, Julia; SQUEFF, Letícia (orgs.). Manuel de Araújo Porto Alegre: Singular \& Plural. São Paulo: IMS, 2014. p.293-306.

${ }^{6}$ Cf. o Terceiro Capítulo desta Tese.

${ }^{7}$ AMÉRICO, Pedro. "Cartas de um plebeu aos Srs. Deputados". Primeira carta. Correio Mercantil. Rio de Janeiro, 18 de maio 1865 . 
necessidade social, seria portanto aos deputados - a classe política brasileira eleita por intermédio de votação $^{8}$, cuja responsabilidade pressupunha, entre outras atividades, a proposição e, sobretudo, validação de projetos para o "progresso" do país - que se pediria nesse caso abrigo, mais do que o imperador, representante unicamente dos Poderes Executivo e do Moderador.

A esses "aristocratas da inteligência" incumberia "levar ao alicerce uma das pedras angulares" "9 de um Brasil que, em guerra, e assim repentinamente imerso em um "pesadelo agonizante", deveria aproveitar essa oportunidade para sair, enfim, do seu "longo inverno social" (um anterior à guerra). Em uma nova sentença sugestivamente sequencial ao conteúdo do Considerações Filosóficas, na qual o país estaria destinado a vencer a barbárie dionísiaca paraguaia, o jovem continua a augurar às artes um lugar central nas atividades morais e econômicas da nação:

É, pois, chegado o momento da nossa emancipação intelectual; e cumpre-nos pensar, desde já, nas luzes sobre que se deverá elevar o edifício da paz e da futura prosperidade do Brasil, ante os troféus que devemos erguer aos sucessos das nossas invencíveis falantes, contra os últimos arremessos da barbárie. ${ }^{10}$

\section{Os “obstáculos ao livre desenvolvimento" das Belas Artes no Brasil}

Mas para se inscreverem na resolução de um cenário vindouro, as artes deveriam ter antes seus próprios problemas ou, como diria Américo, “obstáculos" resolvidos. E ainda que estes fossem largamente sabidos e comentados não apenas pelo jovem, mas por várias outras personalidades brasileiras, caberia expô-los mais uma vez, posto ser justamente esse o objetivo de um texto-rapport.

\footnotetext{
${ }^{8}$ Nas eleições primárias, paroquiais, de onde saíam os políticos de cada província, podiam votar:

Os cidadãos brasileiros que estivessem "no gozo dos seus direitos políticos", e os estrangeiros naturalizados. Não podiam votar os menores de vinte e cinco anos (à exceção daqueles que tivessem mais de vinte e um ano e fossem: casados, fossem oficiais militares, bacharéis formados e clérigos de ordens sacras), os filhos-família (salvo aqueles que fossem funcionário públicos), os "criados de servir" (salvo os guarda-livros e primeiros caixeiros, criados da Casa Imperial de galão branco e os adminstradores de fazendas rurais e fábricas), os religiosos, e aqueles que não tiverem renda líquida anual de cem mil réis.

Nas eleições secundárias, as quais se elegiam os deputados, senadores e membros dos conselhos gerais de província e da assembléia geral, feitas indiretamente, podiam votar:

Todos aqueles que podia votar nas eleições paroquiais, à exceção daqueles que não tivessem renda líquida anual de duzentos mil réis; os libertos; os criminosos por briga ou devassa.

cf. CONSTITUIÇÃO Política do Império do Brasil., promulgada pela Carta de lei de 25 de Março de 1824.

${ }^{9}$ AMÉRICO, Pedro. "Cartas de um plebeu aos Srs. Deputados". Primeira carta. Correio Mercantil. Rio de Janeiro, 18 de maio 1865 .

${ }^{10}$ Idem, ibidem.
} 
Já tendo apresentado em seu estudo de 1864 reflexões filosóficas centrais sobre as artes ao longo da história, e especialmente entre gregos, Américo deixará em seu novo texto "de considerar a essência moral das belas artes, sua origem histórica e seus progressos através dos séculos, para [assim] me ocupar com a posição do artista no Brasil, em relação ao público e ao governo." 11

A primeira posição relativa seria compreendida como decorrência de obstáculos sociais e culturais para o desenvolvimento das artes no país; e a segunda, em função de obstáculos estruturais, aos quais o próprio governo colaboraria. $^{12}$

- Primeiro obstáculo, social. Os "estudos artísticos [são] considerados entre nós ocupações intermediárias à ciência e ao ofício"13. Desse modo, a eles só

se dedicam aqueles mancebos cujas famílias não estão em circunstâncias de suportar as despesas que requerem os estudos científicos, como sejam o das leis e da medicina. Ora, esses moços, a quem por exceção se ajuntam alguns dos filhos de famílias abastadas, começam geralmente o estudo das Belas Artes no estado da mais completa ignorância, muitas vezes não sabendo nem ler correntemente, e quase sempre ignorando a importância do papel que terão de representar mais tarde na sociedade, e bem assim quais as dificuldades da carreira que abraçaram. ${ }^{14}$

Se aos estudos artísticos somente se dedicam jovens que não têm, de outro modo, futuro promissor são escolhas circunstanciais e não inteiramente livres -, o resultado é, para Américo, o reduzido ingresso daqueles potencialmente dotados de gênio artístico ${ }^{15}$ e a definição de um primeiro horizonte no qual o futuro das artes continuaria a aser apenas uma replicação desses exemplos individuais malogrados. A grande maioria desses jovens, não percebendo perspectivas promissoras em suas carreiras, não se "sacrificará" para a realização de suas atividades, nem jamais dará conta da importância e potencial delas na tecitura social. Tratar-se-ia, para o jovem, de um ciclo social vicioso no qual o povo não se importa muito com a arte, e os artistas, anestesiados, não se vêem impelidos a mudar essa situação. Em um tal cenário, dois desfechos seriam inevitáveis aos destinos profissionais dos jovens brasileiros aspirantes "às musas”.

De um lado, a desistência da profissão artística, seguida da tomada de rumo para outras atuações

\footnotetext{
${ }^{11}$ AMÉRICO, Pedro. "Cartas de um plebeu aos Srs. Deputados". Segunda Carta. Correio Mercantil. Rio de Janeiro, 21 de maio 1865.

${ }^{12}$ Idem ibidem. Segunda carta.

${ }^{13}$ AMÉRICO, Pedro. "Cartas de um plebeu aos Srs. Deputados". Terceira carta. Correio Mercantil. Rio de Janeiro, 26 de maio 1865.

${ }^{14}$ Idem, ibidem. Terceira carta.

${ }^{15}$ Idem, ibidem. Segunda carta.
} 
profissionais, que no mais das vezes não os prendiam a alguma de suas antigas vocações ${ }^{16}$.

De outro, a insistência em continuar a trabalhar com arte. A teima, embora pudesse conferir a um profissonal alguns louros pessoais em início de carreira, terminaria sempre em frustração e arrependimento: haveria o número reduzido daqueles que, ainda no tempo de estudantes, triados semestralmente, obtinham seus prêmios de encorajamento em concursos internos da AIBA. E haveriam aqueles que, eventualmente, num afunilamento espermatozóico ainda mais improvável, importariam um prêmio de viagem ao exterior ${ }^{17}$. Assim,

Chegam à Europa, e ali se entregam à prática dos seus estudos, regressando para o Brasil no fim de 4 ou 5 anos, ainda cheios de esperança e entusiasmo, e trazendo consigo os elementos necessários para formarem uma honrosa reputação e servirem ao progresso da pátria. Expõem as suas primeiras produções, que pela maior parte excitam a crítica ou simplesmente a censura, e crêem achar nessa prova de atenção pública a necessária garantia à realização das suas vastas e belas esperanças. Porém helas [pobre de mim] -! 3 dias depois leêm nos nossos periódicos o panegírico de alguma cópia de Choupel, que os convence da ignorância geral e os faz descer tristemente os primeiros degraus da realidade. [...] Entretanto possuem a certeza de que o seu mérito individual merece a devida atenção dos nossos estadistas, e essa consoladora ideia os leva até a porta do governo a quem se apresentam, não solicitando um favor, mas pedindo-lhe os meios que subsistirem pelo exercício de sua arte, do mesmo modo que se reclama uma indenização legal. ${ }^{18}$

O exemplo fornecido do percurso de um aluno "vitorioso" da AIBA, embora em boa parte procedente em várias de suas argumentações, nesse caso dificilmente encontrava outra pessoa senão o próprio Américo. De fato, ele havia garantido ao leitor de suas Cartas que a veracidade de suas asserções decorreria do atestado de um elemento endógeno ao sistema, isto é, dele próprio, revelado artista no texto. Mesmo que prevista, não deixa de causar certa comoção tal manifestação, feita em sua Terceira Carta $^{19}$ : o autor se oferece como a prova dos nove da desventura reservada aos artistas no Brasil, tendo

${ }^{16}$ Para Américo, se se procurassem alguns dos seus antigos colegas da AIBA (também eles, como ele próprio, qualificados de "gênios, futuros Rafaéis" no período de seus estudos na instituição), se os encontrariam, "uns desterrados, escrevendo poemas e revendo papéis sem relação alguma com o que aprenderam, por preferirem essa à vida do artista, onde não encontravam uma subsistência conforme com a dignidade do homem que segue uma carreira liberal; outros, esquecidos e como atrofiados no retiro, onde os colocou a necessidade de irem vivendo obscuramente para não sofrerem guerra; outros, enfim, extenuando-se em vãs reclamações, em infrutíferos esforços para verem se rompem com essas tradições caducas e rotineiras, que nos tornam insensíveis aos encantos do belo, e fazem o caráter dos povos madraços e egoístas”. Idem, ibidem. Terceira carta.

${ }^{17}$ Idem, ibidem. Terceira carta.

${ }^{18}$ Idem, ibidem. Terceira carta.

19 “Deveis achar-me, Exms., Srs. demasiado rápido nas minhas conclusões, e talvez por demais áspero; mas a razão é 
passado por quase todas as fases demarcadas em suas exposições críticas (insistência na vida artística; notoriedade interna e repetida obtenção de prêmios; saída ao exterior com bolsa; retorno ao país insuflado de ânimo; exposição das primeiras obras e recepção crítica delas, incluindo as encorajadoras; pedidos ao governo de subsistir em sua profissão). Felizmente, ele ainda não havia chegado à fase do início da "desilusão" 20 , da destruição de suas crenças e desejos, vendo-se

banido de entre os homens úteis à sua pátria, e quase obrigado a abraçar qualquer indústria lucrativa para ganhar o necessário pão, que jamais alcançaria pela nobre aplicação das suas faculdades criadoras. Luta em que morre o artista, e com ele um cidadão útil à sociedade, ao mesmo tempo que nela entra um indivíduo incapaz de servir eficazmente ao progresso do seu país. ${ }^{21}$

- Segundo obstáculo, cultural: é devida à "terrível invasão da industria fotográfica nos países novos, como o nosso" ${ }^{22}$.

Américo acreditava que sem uma herança artística bem sedimentada, que guiasse previamente um cidadão em seus juízos estéticos, a imagem mecânica ajudaria a corromper o gosto da "verdadeira arte" e a imaginação, porquanto ofereceria apenas tomadas unitárias, desprovidas de invenção. Essa não seria a primeira nem última vez que um artista brasileiro se manifestava cauteloso quanto aos efeitos provindos da expensão da cultura fotográfica no Brasil, num momento em que, especialmente a partir dos anos 1860, a recepção direta de novas técnicas "negativo-positivo", substituindo rapidamente o daguerreótipo, amplificava a distribuição de imagens fotográficas em papel, e se somava a uma recepção indireta que também delas faziam os primeiros jornais ilustrados instalados no país. Se Porto Alegre, em suas Teses para Debate, já havia demonstrado preocupação à questão, Américo parece ser, no entanto, o primeiro artista a ler na "invasão" da fotografia uma causa moral para o atraso das artes no país. Suas ideias se acordavam nesse sentido com as opiniões desenvolvidas pouco tempo depois por outras personalidades das artes brasileiras, que eventualmente irão argumentar sobre as diferenças entre o "olho" da câmera e o "olho do artista", ou, ainda, sobre as diferenças entre os "verdadeiros desígnios da arte" (a produção do belo ideal, portanto imaginativo) e as limitações da fotografia, com as suas captações diretas e a sua suposta representação sensual e "crua" da realidade - e não é preciso dizer o que isto implicaria no sistema artístico imaginado por Américo.

simples: eu sei de cór história que vos conto, e acho que em vez de vos servir pálidas verdades em taças de ouro, sou mais fiel oferecendo-as nuas, como as encontro, e sem rebuço que as possa desfigurar." Idem, ibidem. Terceira carta.

${ }^{20}$ Idem, ibidem. Terceira carta.

${ }^{21}$ Idem, ibidem. Terceira carta.

${ }^{22}$ Idem, idem. Terceira Carta. 
Se Victor Meirelles ou Bethencourt da Silva desenvolveram textos nessa direção ${ }^{23}$, demonstrando que, a despeito de todas diferenças que tinham com Américo, várias de suas preocupações eram mútuas, também seus argumentos pareciam, como os do jovem, maquiar em alguns momentos um outro nível de inquietações, despertado pela imagem mecânica. Não tratava-se, pois, de serem unicamente desconfiados com o novo meio em razão das supostas falhas em matéria artística (falhas morais e falhas técnicas), mas de criar igualmente uma estratégia retórica para rebaixá-lo estética e funcionalmente, posto que começava a penetrar rapidamente no território de produção de imagens, antes reservado apenas aos artistas. No fundo, o que se aventava (e isto me parece estar claramente no horizonte do jovem Américo) era que a rápida difusão da fotografia poderia ingressar num terreno que, embora fosse de direito desses artistas brasileiros, ainda não havia sido sequer ocupado por eles, justamente por trabalharem em um "país novo", onde o gosto pelas belas artes não estaria ainda desenvolvido. A fotografia era vista como uma ameaça, e a dimensão ainda incerta - pois em curso de sua inclusão social, cultural e econômica, levaria artistas destacados, incluindo o jovem, a emitirem juízos que reafirmassem sempre a superioridade da arte e do artista, enfatizando a responsabilidade que carregavam para o espraiamento dos valores morais na sociedade, panorama de outro modo impossível em uma sociedade dominada pela imagem da máquina.

- Terceiro obstáculo, estrutural: Se a segunda causa negativa (a difusão da fotografia) não poderia ser facilmente controlada, a primeira, no entanto, expressa pela fraca relação do brasileiro com as artes, poderia. Contudo, para Américo, em lugar de ser oficial e paulatinamente remediada pelo governo, era, ao contrário, por ele próprio reforçada. Com efeito, “que importa ao público que haja na corte uma academia de belas artes, quando os artistas que dela saem com seus diplomas não são reconhecidos pelo governo?"24

O problema dos diplomas dos artistas - cuja assumida insuficiência foi tratada anteriormente nesta Tese a partir da insistência do jovem em se apresentar bacharel-artista - é uma imagem curiosa, que retornará, em poucos meses, já em 1866, pessoal e negativamente a Américo. Mas, aqui, esse problema

\footnotetext{
${ }^{23} \mathrm{O}$ texto de Victor Meirelles sobre o assunto foi republicado em uma das edições deste Boletim. Ver: MEIRELLES, Victor. "Relatório da Exposição Nacional de 1866". In: Boletim do Grupo de Estudos do Centro de Pesquisas em Arte\&Fotografia. No.01. Departamento de Artes Plásticas da ECA-USP, Abril-maio de 2006.

Um texto em que Bethencourt entra também em matéria encontra-se em: BETHENCOURT DA SILVA, Francisco Joaquim. Revista Brazileira. Rio de Janeiro, Tomo I, 1879, pp.285-289.

${ }^{24}$ AMÉRICO, Pedro. "Cartas de um plebeu aos Srs. Deputados". Segunda Carta. Correio Mercantil. Rio de Janeiro, 21 de maio 1865 .
} 
é por ele aludido para atestar que os profissionais dedicados aos estudos artísticos não estariam numa posição intermediária e incômoda apenas em relação ao público: essa posição simplesmente refletia o "descuido [oficial] em [deixar de] empregar com trabalhos para a nação, ou simplesmente para os edifícios públicos, os poucos artistas que entre nós se distinguem pela sua ilustração e talento." ${ }^{25}$ Américo já havia dito no Considerações Filosóficas e repetirá: as artes ou qualquer outra atividade humana pode se desenvolver somente se se tornam necessárias: "não há função social que possa escapar ao rigor da lei da necessidade" ${ }^{26}$.

O governo havia criado uma primeira estrutura artística - alimentava a sua primeira base (a AIBA) -, conquanto, paradoxalmente, esquecia do restante indispensável para erguer o edifício. Propunha-se a formar profissionais, dos quais não fazia bom ou nenhum uso para o benefício geral: problema que também outras personalidades, como Porto Alegre, haveriam de relembrar. Seria ele próprio, Porto Alegre, quem iria afirmar, em 1851, que o Brasil "apresenta o singular evento de nas leis municipais da sua capital não se encontrar a palavra - arquiteto! A Câmara Municipal é a expressão popular da capital: se ela desconhece a palavra arquiteto, como se pode aspirar a outra coisa que não seja além de uma criação infantil!",27

Também para o jovem, era notável "o desdém das nossas ilustrações oficiais, que na sua inalterável gravidade parecem considerar inútil, que digo? perigoso, aquilo que tem sido em todas grandes civilizações objeto dos mais assíduos e generosos cuidados. ${ }^{28}$ Tratar-se-ia de uma

contradição do governo com os seus próprios desígnios, quando recusa utilizar-se do juro moral do capital empregado na educação de um artista [...]: não somente me parece uma generosidade ilegal perante o estado que necessita de artistas hábeis, como um atentado contra a civilização e o progresso, do que são as belas artes o mais brilhante elemento. ${ }^{29}$

- Quarto obstáculo, estrutural: Américo sugerirá na Quarta Carta que o governo não mudaria a situação relativa das artes no Brasil não exatamente por que não queria, mas por que desconhecia a pertinência do problema. Essa situação se mantinha precisamente em decorrência da "ausência de

\footnotetext{
${ }^{25}$ Idem, ibidem. Segunda carta.

${ }^{26}$ Idem, ibidem. Segunda carta.
}

27 PORTO ALEGRE, M. A. "Algumas ideias sobre as Belas-Artes e a indústria no Império do Brasil - $2^{\circ}$ artigo." Guanabara, Rio de Janeiro, tomo I, 1851, pp.135-142. Reimpresso também em: KOVENSKY, Julia; SQUEFF, Letícia (orgs.). Manuel de Araújo Porto Alegre: Singular \& Plural. São Paulo: IMS, 2014. p.305.

${ }^{28}$ Idem, ibidem. Terceira carta.

${ }^{29}$ Idem, ibidem. Terceira carta. 
estados relativos à arte, na educação liberal" ${ }^{30}$. Em outras palavras, Américo reclamava a falta de diagnósticos oficiais, encomendados pelo governo, tais como o que ele fazia sumária e independentemente com o seu Cartas. É certo que ao apresentar esse argumento, tinha em mente que a década de 1860, a exemplo das anteriores, continuava a se mostrar um período muito fecundo para a produção de rapports na França. Alguns desses eram de fato resultado dos trabalhos que o jovem havia lido e trabalhado em suas Considerações Filosóficas; e muitos outros, frutos da reunião de Comissões artísticas que propunham novas medidas ou reformas em instituições nas quais havia também estudado, instituições nas quais, não raro, os relatores dos relatórios se tornariam seus reformadores.

Seria justamente da insuficiência desses "estados" "de onde procede a bárbara aversão dos nossos estadistas por tudo quanto respeite às belas artes"31: ignorando a importância da cultura artística no seio do país, e desconhecendo os meios de tirar delas proveito para a sociedade brasileira, pouca coisa poderia mudar.

Urgia o momento em que um projeto em perspectiva fosse lançado, distinguindo o que era ação efêmera que se pensa no presente, e ação que deveria ser pensada como duradoura no futuro: para o jovem, a política não poderia ser, com efeito, pautada na volatilidade das paixões partidárias, mas em ações que visassem mecanismos duradouros de promoção econômica e social. Américo parecia estar inteirado das discussões travadas na década de 1860, cujas pautas, correlatas à sua, giravam em torno dos já citados limites de ação do poder moderador, delegado unicamente ao monarca (cuja existência visava a preservação de um agente "perpétuo" que, estando acima das disputas políticas, velaria pela nação ${ }^{32}$ ), ou ainda em torno das primeiras propostas encetadas para a criação de carreiras permanentes para cargos administrativos na corte (até então preenchidos quase sempre por indicações, fazendo do cargo uma espécie de dança das cadeiras), com o intuito também de garantir que os interesses do "povo" não fossem preteridos pelos interesses individuais de gestores sazonais ${ }^{33}$.

${ }^{30}$ AMÉRICO, Pedro. "Cartas de um plebeu aos Srs. Deputados. Quarta carta." Correio Mercantil. Rio de Janeiro, 13 de junho 1865.

${ }^{31}$ Idem, ibidem. Quarta carta.

${ }^{32}$ Para uma breve introdução ao problema, aconselho a leitura da introdução da historiadora Cecília Helena Lorenzini de Salles Oliveira ao livro por ela organizado: OLIVEIRA, C. H. L. S. (Org.). Zacarias de Góis e Vasconcelos. São Paulo: Editora 34, 2002.

${ }^{33}$ Torna-se exemplar, nesse sentido, o projeto de criação de carreira de presidência de províncias, proposto pelo então deputado João de Almeida Pereira Filho, em 1860. O intuito, já citado, era o de investir permanentemente um indivíduo de obrigações administrativas e garantir a estabilidade dos serviços nas províncias, mesmo em períodos de eleições ou de tomadas de posse dos políticos, quando os gabinetes mudavam, por vezes, bruscamente. Para uma visão contemporânea ao problema, ver. ANDRADE PINTO, Caetano José. Atribuições dos presidentes de província. Rio de Janeiro/Paris: GarnierDurand, 1865. 
- Quinto obstáculo, estrutural: haveria por fim, para o jovem Américo, "a falta de verdadeiros economistas, de homens que compreendam e demonstrem ao governo o quanto [as artes plásticas] importaria[m] às necessidades positivas da nossa pátria" ${ }^{34}$, reforçando, assim, as mesmas conclusões que seriam esboçadas nos rapports desenvolvidos sobre o estado e importância das artes no Brasil. Esses agentes, nem todos exatamente representantes do governo (empresários, latifundiários etc.), mas com a influência que dispunham junto a ele, poderiam desempenhar papel proeminente no fomento às artes do país.

Pode tratar-se aqui apenas de um palpite, ainda que (parece) um bastante possível, mas com esses "verdadeiros economistas" Américo deveria ter em mente pessoas como os poderosos integrantes da Sociedade Auxiliadora da Indústria Nacional ${ }^{35}$, instituição na qual ele havia ingressado havia pouco tempo, no fim de 1864, na qualidade de "sócio efetivo", por força da mediação do seu amigo de AIBA e de estadia na Europa, Daniel Pedro Ferro Cardoso, então um membro do Conselho Administrativo daquela sociedade ${ }^{36}$.

\section{Um novo projeto para as artes no Brasil}

Américo dizia ser ainda possível identificar outros obstáculos talvez menores que os anteriores, mesmo que significativos para o contexto. Mas os problemas enunciados eram mais do que suficientes para a construção do cenário principal contra o qual se deveria lutar, e para que se tivesse a certeza de que um, entre todos, era o preponderante e o mesmo apontado nas Considerações Filosóficas : "todos os fatos que me fosse possível enumerar, originam-se na permanência do primeiro [entrave] de que vos falei" ${ }^{37}$, o da "posição do artista no Brasil, em relação ao público".

A resolução imaginada, conquanto sabidamente onerosa, era direta: todas as causas "prejudiciais à propagação e aperfeiçoamento das belas artes no Brasil [...] desapareceriam se se formassem instituições cujo fim fosse assegurar a dignidade da arte, e bem assim a prosperidade das pessoas que

\footnotetext{
${ }^{34}$ Idem, ibidem. Quarta carta.

35 Sobre a importância da Sociedade Auxiliadora da Indústria Nacional, e as articulações que ligavam Daniel Pedro Ferro Cardoso e Pedro Américo, ver o último texto desta Tese.

${ }^{36}$ Notícias Diversas". Correio Mercantil. Rio de Janeiro. 18 de novembro de 1864. p.2; ver ainda: DIÁRIO do Rio de Janeiro. 15 de novembro de 1864, p.2.

${ }^{37}$ Idem, ibidem. Quarta carta.
} 
profissionalmente a cultivam."38

Mudando-se o estatuto social relativo ao oficío artístico, acabar-se-iam todos os preconceitos e dificuldades dos artistas no país. E mais, não apenas o desses profissionais, mas isso faria com que o próprio país deixasse de "viver na idade média, quando todas as nações cultas dela saíram, há mais de três séculos"39. Desse modo:

mesmo que não chegássemos logo a conquistar a perfeição neste ou naquele ramo da cultura artística, deixaríamos de parecer inferiores aos povos de raça europeia, quando se considerassem as nossas produções, quer puramente artísticas, quer industriais; e certamente nos não tornaríamos a ver na contingência de chamar a um estrangeiro que não sente entusiasmo pela nossa história, para executar monumentos da glória nacional. ${ }^{40}$

O trecho é bastante claro: em 1865, Américo continuava, assim, a manifestar o "desejo imenso" declarado a Brunet, quando lhe endereçava algumas cartas, no exato período em que também escrevia e publicava o seu opúsculo à reforma da École, em 1863. O jovem mantinha a ideia de "fundar alguma coisa no Brasil, de não perder lá o que tenho ganho aqui, de completar esta civilização tão imperfeita, reclamando para as Belas Artes [...] um lugar menos estreito na instrução pública"41. Seria, aliás, em outra carta anterior, de 1862, endereçada também a Brunet e escrita entre preocupações e dúvidas sobre a sua estadia na Europa, que essa intenção era pela primeira vez declarada, em uma condição de perfeita acordância com o projeto que estava então prestes a apresentar, em 1865:

Reformar, com o concurso de algumas pessoas interessadas pelo progresso, o ensino das Belas Artes no Brasil; concorrer, com a adesão de V. M. Majestade o Imperador, para a sua propagação; inaugurar com as gerações novas, cheias de grandes ideias, os bônus(?) de um novo sistema de educação, no qual figurem as Belas-Artes como elemento e não como acessório: eis o meu programa, eis as minhas aspirações. A realização é difícil, entretanto não é impossível, e se me for dado aqui de terminar os estudos que comecei, não creio que as lutas que me esperam no Rio de Janeiro sejam um obstáculo invencível, diante do qual recue de assombro e coragem vigorosa dos amigos da pátria e do progresso. Ao contrário, se voltar agora nada poderei realizar desso tão belo (?): privado de conhecimentos vastos com os quais possa ser ouvido das ilustrações do meu país, limitar-me-ei em cuidar de alguns detalhes de organizações que estiverem ao meu alcance e derivarei para outro, em outra época, a Glória que me

\footnotetext{
${ }^{38}$ Idem, ibidem. Quarta carta.

${ }^{39}$ AMÉRICO, Pedro. "Cartas de um plebeu aos Srs. Deputados. Continuação da quarta carta." Correio Mercantil. Rio de Janeiro, 16 de junho 1865.

${ }^{40}$ Idem, ibidem. Quarta carta.

${ }^{41}$ AMÉRICO, Pedro. "Carta de Paris a Louis Jacque Brunet em 24 de novembro de 1863". In: FUNDAÇÃO VINGTUN ROSADO. Cartas de Pedro Américo de Figueiredo e Melo e Daniel Eduardo de Figueiredo e Melo a Louis Jacques Brunet. Mossoró: Coleção Mossoroense, junho de 2001. s/p.
} 
poderia caber se minhas esperanças fossem satisfeitas. ${ }^{42}$

O potencial que Américo percebia em si mesmo em 1862 - mesma qualidade que será lida em 1866, por críticos e opositores, como egocentrismo e pedantismo -, era proporcional à pretensão do seu projeto. Depois de sua experiência, a partir de 1861, no ateliê de Sébastien Cornu - no qual testemunhara a formação de um museu industrial para estudos de artistas, a criação de inúmeros cursos gratuitos e abertos de desenho - a mesma ideia fixa ocupa, portanto, a mente do jovem, atravessando 1862, 1863, 1864 e, finalmente, 1865: a necessidade repetidamente advogada de se formarem, com o auxílio dele, "instituições que assegurem aos artistas a consideração pública e a estima dos nossos governos", e que ajudem o país a trilhar a via do progresso $^{43}$.

Não se tratariam mais de ideias que se manteriam encerradas em uma campânula teórica, mas de ideias concretamente aplicadas. E para Américo, mostrando finalmente o seu projeto político para as artes, "bastaria a realização de quatro" delas "para que melhorasse consideravelmente o estado em que se acham as belas artes no Brasil"44:

$1^{\text {a }}$. Criação de um curso obrigatório de desenho em todos os estabelecimentos de instrução secundária do Império;

$2^{\text {a }}$. Criação de pequenas escolas de belas artes nas províncias de primeira ordem;

3 a. Criação de um museu de pintura na corte, independente da pequena coleção da academia das belas artes.

$4{ }^{\text {a }}$. Equiparação completa, em tudo e por tudo, dos professores desta academia aos lentes das mais academias ou faculdades do Império. Graves alterações no método de ensino e no regime interno da mesma.

Com a exposição do seu projeto, tornava-se de pronto evidente que as soluções que Américo propunha para as artes brasileiras buscariam reverter os problemas considerados em sua origem. Se esses eram sobretudo sociais e estruturais, as resoluções também o seriam. O principal pensamento que as organizará é o desejo de descentralização do ensino do artístico, garantido por meio de sua horizontalização e universalização (nos limites do que se pode compreender com isso em uma sociedade escravocrata). Esse pensamento presidirá as intenções do jovem em duas frentes, sempre em

\footnotetext{
${ }^{42}$ AMÉRICO, Pedro. “Carta de Paris a Louis Jacque Brunet em 29 de setembro de 1863”. In: Idem, ibidem. s/p.

${ }^{43}$ AMÉRICO, Pedro. "Cartas de um plebeu aos Srs. Deputados. Continuação da quarta carta." Correio Mercantil. Rio de Janeiro, 16 de junho 1865. P.3

${ }^{44}$ Idem, ibidem.
} 
retrospecto às questões teóricas lançadas em suas Considerações Filosóficas: "se estas [as artes], pela cultura do sentimento, devem fazer parte do ensino secundário, fazem [já] parte da indústria comercial pela criação dos valores que elevam a matéria, aumentando deste modo, e sem absorção de capitais, a riqueza pública, o que não é certamente um fato de pouca importância na economia universal”"45.

Das 4 ideias lançadas (5, na verdade, considerando a bipartição da última), todas estavam em estreita relação com as questões e experiências vividas por Américo desde 1855, na AIBA, e desde 1859, na Europa, e não é possível compreender a extensão do seu projeto e campo específico no qual insere suas ideias se não se retomam algumas questões, já comentadas nesta Tese, e se não se tratam de outras, às quais não se fez suficiente alusão. Mas antes desse realizar essa interpretação final sobre os desígnios do jovem, talvez seja antes válido efetuar uma pequena digressão no sentido de se explicar a lúcidas estratégias que ele realizava nesse momento, ao publicar o seu texto, e, assim, compreender com mais clareza as ideias com as quais estava lidando projetualmente.

\section{A estratégia do jovem Américo}

O movimento efetuado por Américo com sua Cartas de um Plebeu era, mais uma vez, calculado, repetindo a mesma articulação geral de todas as suas primeiras obras executadas nos anos anteriores: o texto sobre a reforma da École des Beaux-Arts foi publicado, se se lembra, no calor da hora do debates sobre essa instituição, e também quando se preparava para retornar ao Brasil e se submeter ao concurso da cadeira de Desenho Figurado, ao qual havia sido requerido pelo imperador; o Considerações Filosóficas e $A$ Carioca foram dados a público após sua chegada ao Brasil (quando Viollet-Le-Duc ainda publicava seu curso na imprensa internacional), momento em que o jovem desejava conquistar seu leitores por meio de suas ideias teóricas também publicadas no jornal, e d. Pedro II, por meio de obras entregues pessoalmente, afirmando seu duplo caráter de artista intelectual.

Pois não será surpresa alguma descobrir que o Cartas de um Plebeu aos Srs. Deputados também era publicado quando Américo realizava as provas para o concurso da AIBA, sem dúvida ciente da enorme probabilidade de vencê-lo, dada não apenas a sua evidente capacidade, mas ainda o pedido contundente feito pelo imperador para que retornasse o quanto antes ao país para realizar o processo seletivo, que teve que aliás esperar duas vezes para ocorrer: a primeira retardação, em 1862, quando Américo

\footnotetext{
${ }^{45}$ AMÉRICO, Pedro. "Cartas de um plebeu aos Srs. Deputados. Quarta carta." Correio Mercantil. Rio de Janeiro, 13 de junho 1865 .
} 
consegue sua extensão para mais dois europeus; e a segunda, quando as inscrições tiveram de ser prorrogaradas por 6 meses $^{46}$, tempo nem sempre comum para um concurso desse tipo, para que houvesse tempo suficiente para chegasse a tempo ao Brasil e se candidatasse pessoalmente, medida obrigatória para a validação de sua participação.

Quase tão longa quanto a espera para o início do concurso era o percurso das provas: 3, no total, realizadas durante quase 3 meses ${ }^{47}$. Após realizar a primeira prova em $1^{\circ}$ de maio de 1865 , e a segunda, no dia 6 do mesmo mês, Américo terá de aguardar, com os demais concorrentes, aproximadamente um mês para o início da última etapa (a composição pictórica do Sócrates afastando Alcibíades do vício), que deveria começar no dia 3 de junho e durar no máximo 50 dias úteis (isto é, até o início de agosto de 1865). Será, com efeito, no intervalo entre a segunda e a terceira prova que Américo enviará a prelo o seu novo texto, iniciando-a no dia 18 de maio, e terminando-a no 29 de junho, quando já estava há quase um mês em atividade de ateliê, lhe restando ainda quase um mês para terminar o concurso e aguardar o esperado resultado, do qua sairá mesmo vencedor ${ }^{48}$.

A primeira estratégia realizada pelo jovem não poderia ser, portanto, mais clara: ele publicava calculadamente o seu texto no momento em que se preparava mentalmente para se tornar um funcionário público, confessando a todos, e rogando aos "legisladores", em particular, que estava pronto para assumir responsabilidades concretas, que iam a propósito muito além da vaga de Desenho Figurado (cadeira que, afinal, não lhe "tentava sobremaneira" "49), ligando-se antes de tudo às questões maiores não apenas da arte, mas da economia do período, cujo cerne era o da expansão da atividade industrial do país.

Entre causos e percausos, os dois blocos que de fato ocuparam os dirigentes da AIBA desde antes de

\footnotetext{
${ }^{46} \mathrm{O}$ concurso público foi divulgado em periódicos cariocas. As inscrições permaneceram abertas de 20 de junho a 20 de dezembro de 1864. "Academia das Belas Artes". Correio Mercantil. Rio de Janeiro, 16 de novembro de 1864.

${ }^{47}$ A primeira, uma academia (modelo-vivo), cuja pose era escolhida pela Comissão julgadora, devendo ser concluída em, no máximo, 12 horas. A segunda, à vista do modelo vivo, pedia que se desenhasse uma figura anatômica na qual se apresentaria de um lado do corpo a miologia e, de outro, a osteologia. Nessa, o tempo máximo de produção deveria ser de 6 horas. A última prova, uma composição histórica pintada a óleo, cujo tema seria sorteado, pedia o tempo máximo de 50 dias úteis de execução. Nas duas primeiras provas, os candidatos permaneceriam na mesma sala. A última, em salas separadas. Idem, ibidem.

${ }^{48}$ Américo receberia a notícia, no entanto, em sessão da Congregação de 9 de agosto de 1865, estando presente na academia esse dia. Havia recebido 9 votos, contra 1 do segundo colocado, Le Chevrel, restando ainda um voto em branco. Uma vez dado o parecer, na mesma sessão a Congregação propunha e aprovava Le Chevrel para professor honorário de pintura. ATAS das sessões da congregação e do diretor da Academia Imperial de Belas Artes. "Sessão em 09 de agosto de 1865”. Rio de Janeiro: Museu d. João VI/ EBA-UFRJ. s/d.

Em 1 de outubro de 1865, Américo recebe nomeação.

${ }^{49}$ GUIMARÃES JÚNIOR, Luís. Op. cit. p.50.
} 
sua criação, arte e indústria, haviam se ampliado de maneira extraordinária nos dez anos que marcaram o período de formação no Brasil e na Europa, de Américo e, como visto, estavam presentes em todos os textos e justificativas também por ele oferecidos. No país, especialmente a partir de 1850, a promulgação da lei Eusébio de Queiroz, que previa a abolição do tráfico negreiro, acelerou a premência da resolução, a médio prazo, da transposição de mão de obra escrava à mão de obra livre e qualificada, como maneira de garantir essa transição sem perda da economia nacional. Esse ato, de significativa importância para as relações políticas, sociais e econômicas do país, se adiantava em alguns meses a uma outra articulação, de natureza batante distinta, mas também de grande significação para os cenários econômicos internacional e nacional, expressa pela formação da Great Exhibition of the Works of Industry of all Nations, aberta em $1^{\circ}$ de maio de 1851 e organizada pelo prince Albert (marido da rainha Vitória), em Londres, tornando-se o evento inaugural e preparatório da Exposição Universal de 1855, de Paris - ambas exposições das quais o Brasil não conseguirá ainda participar, mesmo que, na primeira, a Sociedade Auxiliadora da Indústria Nacional tivesse enviado, com bastante interesse, um representante para relatar o evento e os benefícios que o Brasil poderia tirar dos produtos e inovações $\operatorname{expostos}^{50}$, e, na segunda, o próprio governo havia enviado três representantes para essa tarefa ${ }^{51}$.

Ainda em 1851, Porto Alegre publicava (como visto) um texto contendo, justamente, "algumas ideias sobre as Belas-Artes e a indústria no Império do Brasil" - sem dúvida em resposta àqueles acontecimentos internacionais -, ao mesmo tempo em que trabalhava em prol da difusão do ensino artístico para artesãos e operários, o que lhe garantirá, como visto, a entrada à frente da AIBA, para nela realizar, finalmente, a reforma de duplo caráter artístico e industrial, em cooperação com a reforma de 1854 dos ensinos primário e secundário desenvolvida pelo Ministro Luís Pedreira: uma mudança, também como visto, que visava colocar cabalmente sob a tutela do estado os dispositivos de ensino, estipulando enfim um programa homogêneo, e em acordo com as políticas sociais e econômicas do império, no período.

No ano seguinte às instalações dessas reformas se verá, no Rio de Janeiro, a formação da Sociedade Propagadora das Belas Artes, e menos de dois anos depois, em 1858, Francisco Joaquim Bethencourt da Silva, seu idealizador e incitador, conseguirá criar a primeira grande instituição do império

\footnotetext{
${ }^{50}$ Tratava-se do engenheiro Pedro Alcantara Lisboa. Para um estudo detalhado sobre a viagem de Lisboa para visitar a exposição de 1851, em Londres, e suas obrigações junto à Sociedade Auxiliadora da Indústria Nacional, ver: STRAUCH, Paulo Cesar. Pindorama e o Palácio de Cristal. Um olhar brasileiro sobre a Exposição de Londres e 1851. Rio de Janeiro: Editora E-paper, 2008. P.43; p.52, entre outras.

${ }^{51}$ Integravam essa comissão Antonio Gonçalves Dias, Gustavo Schüch Capanema e Giacomo Raja Gabaglia.
} 
exclusivamente dedicada ao ensino industrial, o Liceu de Artes e Oficios do Rio de Janeiro. Bethencourt formava essa instituição num momento bastante oportuno, marcado pela demissão repentina de Porto Alegre da AIBA, em 1857. Opondo-se às decisões do sucessor de Pedreira, Marquês de Olinda (o principal causador da saída voluntária de Porto Alegre), ele deixava a reforma desta instituição incompleta, e nesse sentido mais uma vez se emparelhando a seu amigo Pedreira, que deixando também em 1857 a pasta do Ministério dos Negócios do Império, não conseguia implementar como queria toda a reforma do ensino que havia planejado, concentrada, por fim, apenas na corte.

Porto Alegre, no período em que era diretor da Academia, havia sido favorável à iniciativa de Bethencourt da Silva, e não apenas ele reconhecerá a importância das ações do ainda jovem e bastante ativo arquiteto: a responsabilidade que este assumia ainda lhe legaria uma espécie de "cargo de conciliação", pois sem dúvida não era casual o fato de ter sido requisitado pelo imperador, no mesmo ano em que inaugurava o Liceu, para integrar o corpo docente da Academia, ocupando a cadeira de Arquitetura Civil, no lugar de Job Justino de Alcantara, à revelia dos demais membros da Congregação $^{52}$. E menos ainda causal era a estruturação que finalmente se fazia, dentro da AIBA, com a presença de Bethencourt da Silva, dos estatutos que também implementavam as aulas noturnas nessa instituição, voltadas, como o Liceu, aos operários e profissionais que não podiam estudar durante o dia.

Essas mudanças - como sintomas do interesse geral que então despertava o desenvolvimento econômico do país por meio da indústria, e com ele importando a intervenção de um ensino especificamente voltado a essa atividade - convergiram cada vez mais para urgência da participação do país nos grandes eventos industriais internacionais. Direta ou indiretamente, elas surtiram efeito, pois, no fim 1861, a Sociedade Auxiliadora da Indústria Nacional (então dirigada pelo Marquês de Abrantes, e da qual faziam já parte o mesmo Pedreira e Bethencourt da Silva) e o Imperial Instituto Fluminense de Agricultura organizavam a I Exposição Nacional de produtos naturais, industriais e artísticos, como maneira estrututar a primeira participação do Brasil em uma Exposição Universal, que se faria efetivamente em 1862, em Londres - à qual, conforme sugerido, o jovem Américo havia quase certamente ido, estando sem dúvida naquela cidade, no período.

A I Exposição Nacional foi somente possível de ser realizada por consequência do interesse do governo. Em primeiro lugar, percebendo a importância dessas novas questões, ele havia criado, em julho de 1860, uma sétima e última pasta ministerial para o império, a Secretaria de Estado dos

\footnotetext{
${ }^{52}$ Trabalho mais detidamente essa questão no último texto desta Tese.
} 
Negócios da Agricultura, Comércio e Obras Públicas ${ }^{53}$ - que deveria aliviar a quantidade de funções acumuladas aos Ministérios e às Secretarias de Estado dos Negócios do Império e da Justiça ${ }^{54}$-, cujas novas atribuições incluiriam, sintomaticamente, entre outras funções, os problemas da indústria e do seu ensino profissional, da concessão de patentes, e as exposições de produtos agrícolas e industriais. Em segundo lugar, o governo, ouvindo as reivindicações anteriores daquelas duas sociedades, havia de fato mandado publicar um ano mais tarde, em agosto de 1861, uma série de "Instruções para as Exposições agrícolas nas Províncias do Império", segundo as quais se formariam obrigatoriamente nas "capitais das Províncias do Pará, Pernambuco, Bahia, Minas Gerais, e São Paulo", no início de dezembro de todos os anos, "uma Exposição dos produtos naturais, e industriais". Os objetos resultantes dessas exposições, que de fato ocorreram pela primeira vez ainda em 1861, seriam então "remetidos para a Exposição da Corte" ${ }^{55}$.

A Exposição de 1861 era de fato justificada por Abrantes, em texto do catálogo, como uma resposta a eventos internacionais e também a última sequência de eventos significativos ocorridos no país. Ela teria sido o resultado do "maravilhos efeitos das Exposições Nacionais, que, em 1844 e depois, tiveram lugar em Paris, Berlim, Viena, Madrid", provocando "entre nós o desejo de seguir-se o exemplo dado por aquelas capitais" $"$. Mas

Opôs-se a este desejo não só a crença de alguns de ser ainda inoportuna a sua realização, como o temor de muitos de que o seu provável insucesso mais desabonasse do que acreditasse o país. Nada se fez portanto.

E porém, como justa compensação, esse mesmo desejo malogrado inspirou então naqueles que o tinham manifestado, e em alguns que o haviam contrariado, a profunda convicção de que, para levá-lo a efeito, eram ineficazes os esforços particulares, e tornava-se indispensável a ação poderosa do Governo. Forçoso foi aguardar mais favorável ensejo para produzi-lo.

A preconizada abertura da Exposição Internacional de Londres em 1862, e a evidente conveniência de concorrermos àquela justa do progresso e da civilização, ofereceu-nos aquele ensejo.

${ }^{53}$ Decreto $n^{\circ} 1.067$, de 28 de julho de 1860, cria uma nova Secretaria de Estado com a denominação de Secretaria de Estado dos Negócios da Agricultura, Commercio e Obras Públicas. Disponível online em: http://www2.camara.leg.br/legin/fed/decret/1824-1899/decreto-1067-28-julho-1860-546420-publicacaooriginal-60429pl.html [último acesso: abril de 2016]

54 GABLER, Louise. A Secretaria de Estado dos Negócios da Agricultura, Comércio e Obras Públicas e a modernização do Império (1860-1891)[recurso eletrônico]. Rio de Janeiro: Arquivo Nacional, 2012. p.10. Disponível em: http://www.portalan.arquivonacional.gov.br/ [último acesso: março de 2016]

55 SOUZA E MELLO, Manoel Felizardo. "Instrucções para as Exposições agrícolas nas Provincias do Império". Jornal Treze de Maio. Ano XVII. Pará, 09 de outubro de 1861, n.71. p.1. Disponível online em: http://memoria.bn.br/DocReader/docreader.aspx?bib=700002\&pasta=ano $\% 20186 \&$ pesq $=$ Instruc $\%$ C3 $\%$ A7 $\%$ C3 $\%$ B5es $\% 20$ para $\% 20$ as\%20Exposi $\% C 3 \%$ A7\%C3\%B5es\%20agricolas\%20nas\%20Provincias\%20do\%20Imperio [último acesso, abril de 2016]

${ }^{56}$ ABRANTES, Miguel Calmon du Pin e Almeida, Marquês de. "Prefácio". In: IMPERIAL INSTITUTO ARTÍSTICO. Recordações da Exposição Nacional de 1861. Rio de Janeiro: Imperial Instituto Artístico, 1862. p.3. 
Tocava quase o seu fim o ano de 1860, e cumpria que antecipadamente, de acordo com a convicção adquirida, fosse invocada aquela ação indispensável.

O Imperial Instituto Fluminense da Agricultura e a Sociedade Auxiliadora da Indústria Nacional, encarregando-se dessa patriótica missão, pediram respeitosamente ao Governo Imperial que houvesse por bem dar o necessário impulsos para que fosse organizadas algumas Exposições Provinciais, e uma Nacional nesta Corte, como eficaz meio de poder-se conhecer o estado da nossa produção agrícula e industrial, e promover o seu desenvolvimento.

A Exposição desde logo infirmou a crença de inoportunidade, e desvaneceu o termo de seu insucesso, oferecendo depois amplo assunto à reflexão dos que ocupam-se de questões econômicas, e dos meios de desenvolver a riqueza nacional. ${ }^{57}$

Além destes frutos, produziu ela outros de maior valia. A concorrência, e comparação dos diversos produtos; expostos ao louvor, ou censura do Público, não deixaram de revelar aos cultores da terra, e das artes liberais e mecânicas os defeitos que devem corrigir, os aperfeiçoamentos a que lhes cumpre atingir, e os meios que lhe convém empregar, para que a sua produção ulterior possa igualar senão exceder a dos expositores agora laureados.

O que havia parecido impossível de ser realizado no Brasil nas décadas de 1840 e 1850, em função da descrença e temor de alguns, tornara-se, portanto, possível no despertar dos anos 1860, segundo Abrantes, oferecendo ainda como termômetro dos meios que seriam necessários ao "aperfeiçoamento" dos produtos nacionais. As suas observações seriam muito similares às de Machado de Assis, que, também satisfeito com os resultados da I Exposição Nacional, publicava algumas críticas a respeito, quando ela ainda estava em curso, e após seu encerramento. Em uma delas, oferecerá uma apreciação individualizada dos atores responsáveis para que a ideia de uma tal mostra fosse enfim realizada, depois de tanto tempo quista ${ }^{58}$. Em outra, saudava o novo cenário favorável à participação do Brasil em eventos internacionais e, mais importante, ao interesse então pujante de alguns para o desenvolvimento industrial do país, mesmo se perbesse que o ministério principal que ainda dominava a maioria dos políticos brasileiros fosse o da indolência e da preguiça ${ }^{59}$ :

${ }^{57}$ Idem, ibidem. p.3-4.

58 “Se o leitor acompanhou as discussões do senado este ano, deve lembrar-se que quase no fim da sessão o Sr. senador Penna, que ali ejaculou alguns discursos 'notáveis', entre eles o dos pesos e medidas do Sr. Manoel Felizardo, levantou-se e pediu a opinião do Sr. ministro do fomento acerca da conveniência de representar o Brasil na próxima exposição de Londres. O Sr. ministro, que por uma coincidência, que não passou despercebida, havia previsto os sentimentos do honrado senador, levantou-se e declarou que já havia pensado nisso, e que dentro de quatro dias tinham de aparecer as instruções regulamentares das exposições parciais no Brasil, para delas extrair-se o melhor, e enviar-se à exposição de Londres.Portanto, os dois heróis da exposição são os Srs. Penna e ministro do fomento, a quem, em minha opinião, devem ser conferidas as primeiras medalhas, a não ser que se olhe como prêmio comemorativo a presidência de Mato-Grosso e as ajudas de custo, que, por eleição do sagrado concílio, couberam ao Sr. Herculano Penna. Em todo o caso há uma dívida contraída com o Sr. ministro do fomento." ASSIS, Machado de. "Comentários da Semana". Diário do Rio de Janeiro, 01 de novembro de 1861. Disponível online em: http://machado.mec.gov.br/ [útimo acesso: abril de 2016]

59 “O que dá razão a este marasmo [político dos Ministério]? Causas gerais e causas especiais. Foi sempre princípio 
Uma coisa ficou patente com esta primeira exposição, é que as ideias mudam de natureza com as pessoas e com os tempos. A mesma idéia que agora se realizou, proposta pelo Sr. Dr. Macedo na assembléia provincial, há anos, foi tida por utopia, e granjeou ao digno deputado o nome de poeta. Com o Sr. Penna mudaram as coisas; a utilidade prática da proposta foi reconhecida, e ninguém se lembrou de castigar aquele senador com chascos afrontosos.

Também o que faltava era admitir a hipótese de um consórcio entre poesia e o Sr. Penna, coisas que, na ordem moral, representam aqueles dois pontos que, na ciência humana, são chamados - eixos do mundo.

Ainda bem que a idéia enunciada por um patriota sincero, e só poeta daquela poesia que não pode ser compreendida pelas mediocridades prosaicas que o cercavam, acaba de ser posta em prática de um modo que mostrou bem a sua realidade. ${ }^{60}$

Todo esse panorama é absolutamente significativo para Américo, e para a segunda estratégia realizada em relação ao Cartas de um Plebeu aos Srs. Deputados. De início, será justamente ao considerar as mudanças pelas quais percebia que o Brasil havia passado nos anos anteriores, e apreciando-as com um conjunto de ideias muitos próximas às de Abrantes e às de Machados de Assis, 3 anos antes, sem deixar de lado o contexto bélico brasileiro, que o jovem irá justificar o momento singular e positivo para implementação de um projeto como o seu:

Naufragaria, de certo, se empreendesse atravessar os gelos polares da indiferença de dez anos passados; hoje, porém, que os acontecimentos se precipitam uns após outros para despertar os ânimos, as consciências e a fé, estou certo de que não encontrarei mais aquela invencível barreira, senão na sombra, no ceticismo crônico e degenerado de alguns apóstolos da indolência, os quais, felizmente, nem poderão fazer sombra às falanges da novas gerações, nem abrandar o fogo de suas ardentes e patrióticas aspirações.

A situação política do Brasil, apesar de incômoda, é hoje preferível à de ontem, de que foi ela uma feliz consequência. Chegamos ao apogeu da descrença em todas as matérias, pusemos a coroa na cabeça do ceticismo, disfarçando em estátua de paz [...]

O que haverá com efeito na vida política de um povo que mais se pareça com uma doença incurável do que o adormecimento da consciência? Do abatimento letárgico em que nos havia lançado a convicção de já termos conquistado toda a segurança de uma paz inalterável, no seio da maravilhosa opulência que nos fadou a natureza, somos de repente atirados em um pesadelo agonizante, no qual

nosso do governo aquele fatalismo que entrega os povos orientais de mãos atadas às eventualidades do destino. O que há de vir, há de vir, dizem os ministros, que, além de acharem o sistema, cômodo, por amor da indolência própria, querem também pôr a culpa dos maus acontecimentos nas costas da entidade invisível e misteriosa, a que atribuem tudo. [...] Mas, seja ou não assim, o que nos importa saber é que os nossos governos são, salvas as devidas exceções, mais fatalistas que um turco de velha raça. Seria este ministério uma exceção? Não; tudo nele indica a filiação que o liga intimamente aos da boa escola. É um ministério-modelo; vive do expediente e do aviso; pouco se lhe dá do conteúdo do ofício, contanto que tenha observado na confecção dele as fórmulas tabelioas; dorme à noite com a paz na consciência, uma vez que de manhã tenha assinado o ponto na secretaria. [...] É sob a gerência deste ministrio que vai efetuar-se em nossa capital uma festa industrial, a exposição de 1 de dezembro." Idem, "Comentários da Semana". Diário do Rio de Janeiro, 26 de janeiro de 1862. Disponível online em: http://machado.mec.gov.br/ [útimo acesso: abril de 2016].

${ }^{60}$ Idem, ibidem. 
parecia extinguir-se até a esperança de encontrarmos no âmago da nação um órgão que batesse pela sua nacionalidade. ${ }^{61}$

$\mathrm{Na}$ nova conjuntura do país, a despeito das dificuldades presentes, Américo encontrava uma possibilidade suficientemente concreta para que o brasileiro saísse enfim do que havia chamado, no Considerações Filosóficas, de "estado semiletárgico", e ali, no Cartas de um Plebeu, de um similar estado de "abatimento letárgico", mas ainda de "indolência", "cetismo", e de "adormecimento da consciência”.

Porém, não se tratava apenas de um momento geral aparentemente promissor para seu projeto, senão também, específico. Ele sabia perfeitamente que, no mesmo período em que publicava seu novo texto, os jornais brasileiros - incluindo o Correio Mercantil, que publicava suas ideias - tratavam quase todos os dias, além da Guerra do Paraguai, também da preparação do Brasil na Exposição Internacional do Porto, que se daria em poucas semanas, em setembro de 1865, da preparação já em pleno curso das Exposições Provinciais e da Segunda Exposição Nacional de 1866, e da preparação, por fim, para a segunda participação do Brasil em uma Exposição Universal, em Paris, já marcada para abril de 1867, cuja comissão brasileira havia sido escolhida e divulgada precisamente um dia antes do jovem publicar a sua quarta carta ${ }^{62}$.

Com um cenário como esses, era mais do que lógica a estratagema de também reforçar a ideia de que as artes são fundamentais para o desenvolvimento da indústria nacional e, especialmente, de afirmar quais eram os meios fundamentais que os "cultores da terra, e das artes liberais e mecânicas" reclamados por Abrantes - deveriam empregar para atingir "os aperfeiçoamentos a que lhes cumpre". Trata-se para o jovem de um profícuo ensejo que terá para colocar seu projeto em linha direta com as medidas reformistas que havia conhecido e vivido de perto no Brasil, durante a reforma Pedreira. Conforme se argumentará melhor em seguida, não há dúvidas de que Américo se apresentava como o continuador das reformas de 1855. Esse legado será assumido em seu Cartas pela frase curta, mas esclarecedora, anteriormente citada ("Naufragaria, de certo, se empreendesse atravessar os gelos

\footnotetext{
${ }^{61}$ AMÉRICO, Pedro. "Cartas de um plebeu aos Srs. Deputados". Primeira carta. Correio Mercantil. Rio de Janeiro, 18 de maio 1865.

${ }^{62}$ São muitas as referências nos jornais do período a esses eventos. Sobre a participação do Brasil na Exposição Internacional do Porto, ver, por exemplo: CORREIO Mercantil. Rio de Janeiro, 30 de junho de 1865. p.1; sobre a escolha da Comissão brasileira para a Exposição Universal de 1867, ver: S/A. "Exterior". Jornal do Commércio. Rio de Janeiro, 12 de junho de 1865. p.1.
} 
polares da indiferença de dez anos passados"), aludindo aos desfechos inacabados dos projetos de Couto Ferraz, nas escolas brasileiras, e de Porto Alegre, na AIBA.

Tratava-se da escolha interessada de uma herança específica, feita em detrimento e, especialmente, à excusão de outras. E aqui, a última estratégia feita pelo jovem - um expediente de omissão -, que se combinaria com uma coincidência providencial, ao menos para ele, ajudando-o a afirmar do caráter singular do seu projeto.

A alusão que fazia às reformas de 1855 e à resistência encontrada para instaurar uma cultura artística em estreita relação com a indústria não havia sido acompanhada em um só momento de seu texto do reconhecimento dos esforços empreendidos por algumas personalidades desse domínio, a mais destacada delas então, Bethencourt da Silva. Se d. Pedro II havia concluído que a integração do arquiteto à academia, em 1858, garantiria não apenas a continuidade do projeto de Porto Alegre - ao qual o imperador era condescendente -, mas somaria a ela as forças do Liceu de Artes e Ofícios, em benefício do país, Américo, em 1865, ignorava essa contribuição para reforçar aos deputados o desejo em se tornar o responsável por continuar a congregação daquelas áreas.

Mesmo que o projeto de Américo fosse bastante distinto do de Bethencourt (o jovem era bem mais ambicioso), essa omissão deve ter sido bastante desconfortável - para dizer o mínimo - se se considera que eles deveriam então, em pouco tempo, se tornar colegas de trabalho. Mas não era apenas isso. Para piorar o descômodo, o jovem lançava os seus "gelos polares da indiferença" aos projetos do arquiteto não num momento qualquer da vida deste último. Contingência ou não, Américo pôde se aproveitar do vácuo deixado momentaneamente pelo Liceu, que desde 1864 (e até 1867) havia fechado suas portas em decorrência da falta de sede própria e do decremento da pequena verba que recebia do governo imperial, acirrado pela Guerra do Paraguai ${ }^{63}$, ocorrências que haviam obrigado Bethencourt a se lançar em campanhas políticas para reabilitar sua instituição de ensino industrial.

O campo de ação parecia estar, portanto, aberto.

${ }^{63}$ Cabe ressaltar que o Liceu era uma instituição de inclinação filantrópica. Salvo alguns poucos períodos (mais tardios) nenhum professor recebia pelas aulas oferecidas, havendo, por esse motivo, um grande contingente de voluntários no corpo docente da instituição. 


\section{O lugar e a extensão do projeto de Américo}

Considerados anterioremente alguns aspectos do contexto brasileiro dos anos 1850 e 1860 e algumas das instituições e eventos que se formaram na virada daqueles decênios, dedicados especialmente à relação da arte e da indústria, pode-se agora melhor avaliar o lugar no qual o jovem Américo posicionava o seu próprio projeto político para as artes no Brasil e, do mesmo modo, a sua extensão.

Como visto, trata-se de um projeto vasto, que se propõe a resolver o problema artístico do Brasil em suas relações estruturais mais básicas, a partir da fundação de algumas instituições, e de um triplo movimento de descentralização, horizontalização, e indispensabilidade do ensino artístico.

A comentada filiação que o jovem fará aos projetos reformistas de 1855 - tomando, entretanto, o sistema de ensino artístico e industrial francês como modelo - se torna patente em todos os pontos divulgados do seu projeto e, sem dúvida, ainda mais sensivelmente no primeiro e mais importante deles.

\section{- "Criação de um curso obrigatório de desenho em todos os estabelecimentos de instrução secundária do Império"}

Já nas Considerações Filosóficas, Américo teorizava ser o quadro de "defeituosa e incompleta educação recebida" desde a infância"64 a principal causa negativa para o atraso do Brasil em várias áreas, incluindo o atraso das artes. A reforma de Pedreira e os esforços de Porto Alegre haviam tentado dar conta desse problema total. Pedreira, idealmente, pensava em colocar o ensino secundário e primário de todo o país sob a tutela do estado, uma empresa por demais extensa, que acabou se concentrando mesmo no círculo da corte. Porto Alegre, desde o início, como vereador, havia concentrado suas ações na estrutura artística da capital do império e, em seguida, na instituição mais importante do país.

Américo, por sua vez, desejava reatar e combinar, de início, o projeto daquelas duas personalidades, aumentando - por assim dizer -, num momento aparentemente promissor, a pretensão de Porto Alegre, e tapando o "buraco" deixado por Pedreira na reforma que instituía um novo currículo homegeneizado assim como a obrigatoriedade dos ensinos de base, mas no qual não se incluía como compromisso permanente o desenho.

\footnotetext{
${ }^{64}$ AMÉRICO, P. op. cit. p.192 [conclusão]. Ou: Correio Mercantil, Rio de Janeiro, 25 de dezembro de 1864, p.1.
} 
A relação, nesse ponto, entre as ideias de Porto Alegre e Américo é de fato significativa. Em seu texto de 1851, o antigo diretor irá afirmava:

Quando a sociedade dos ourives propôs um prêmio para remunerar a memória escrita que melhor demonstrasse quais eram as causas da decadência de uma arte, que entre nós já floresceu, quais os meios de reconduzi-la à sua perfeição, e colocá-la a par dos produtos manufaturados pelas outras nações, tivemos de concorrer, e com uma só palavra satisfazer o programa daquela benemérita associação: - o DESENHO.

Estude-se o desenho convenientemente, que a arte do ourives ressurgirá do seu estado de abatimento entre os nacionais, e alcançará aquele grau de perfeição que se denota nos produtos que nos vêm cotidianamente da Europa; tanto mais que esses artefatos sobem de valor e de estima segundo o talento artístico do povo que o exporta

É o desenho e a escritura ideográfica com que representamos todas as ideias que a arte de escrever não pode consignar; é a ainda o desenho um complemento necessário à educação moral do homem, um toque de perfeição que deve receber todo o idealista, quanto mais o artista e o artífice que ele necessitam para melhor e mais cabalmente representarem seus pensamentos e suas criações, que tanto mais belas serão quanto mais perita for a mão que as debuxar no papel e materializá-las no ouro, ou na prata, ou em qualqeur outra matéria. Sem esta linguagem universal de todas as artes, tradutoras das belezas da naturezas, sem este veículo do sentimento das formas plásticas do belo, não há pureza de estilo, não há representação fiel, não há gosto, nem perfeição: o desenho, em todas as obras de arte, é sempre o espelho que reflete o estado de civilização de um povo, e o que indica a sua infância, os seus progressos e a sua decadência. ${ }^{65}$

Como para Porto Alegre, o desenho era para o jovem Américo pedra angular de qualquer projeto artístico ou industrial. O panorama que vislumbrava era o de que a instituição compulsória do aprendizado dessa disciplina, não apenas na corte, mas no país, se tornasse uma medida fundamental para que as artes se vissem enfim, e em curto prazo, indispensáveis e úteis às diversas atividades do império.

$\mathrm{Na}$ quinta e última carta da série (que deveria ter, mas não teve continuação), o jovem desenvolveria melhor a questão:

A criação de um curso obrigatório de desenho em todos os estabelecimentos de instrução secundária do império, Exms. Srs., pode ser considerada, quer pelo lado dos interesses gerais da nossa pátria, quer simplesmente como instituição artística, servindo a progressos especiais. Debaixo do primeiro aspecto, convém notar-se que, não obstante terem as Belas Artes uma existência independente, seus progressos, seu aperfeiçoamento, não são fatos indiferentes a uma sociedade liberal e bem constituída. Que além de servirem ao desenvolvimento harmônico das nossas faculdades e

${ }^{65}$ PORTO ALEGRE, M. A. "Algumas ideias sobre as Belas-Artes e a indústria no Império do Brasil - $2^{\circ}$ artigo.” Guanabara, Rio de Janeiro, tomo I, 1851, pp.135-142. Reimpresso também em: KOVENSKY, Julia; SQUEFF, Letícia (orgs.). Manuel de Araújo Porto Alegre: Singular \& Plural. São Paulo: IMS, 2014. pp.324-25. p.298. 
educarem o espírito nas suaves melodias da forma, predispõem os corações aos sentimentos generosos e grandes, ao mesmo tempo que, pelo hábito das contemplações intelectuais, nos torna mais e mais afeiçoados às verdades morais, cujos princípios nem sempre superabundam no domínio da educação tal qual a praticamos.

O estabelecimento de um curso de desenho em todos os estabelecimentos de instrução secundária do império teria por fim fundar a cultura e o gosto das Belas Artes pela sua mais sólida base, e por efeito o despertar [na] nossa talentosa mocidade que enche os nossos colégios, liceus, escolas, etc..., o gênio da imitação, cujos prazeres, essencialmente conformes com o fim da civilização, tenderiam sempre a tornar mais brandas as nossas inclinações egoísticas, de que dependem todos os males sociais e políticas que afligem a humanidade e maiormente os Brasileiros ${ }^{66}$.

O primeiro aspecto dessa instituição "universal" do desenho se justificava, desse modo, pelo valioso suporte que daria à formação do sentimento patriótico e da educação moral do brasileiro - ambas tarefas já reclamadas, como visto, em toda a extensão da base teórica do Considerações Filosóficas.

O segundo aspecto enfatizado por Américo, que serviria "a progressos especiais", era notadamente o de sua importância na contribuição à indústria, no mesmo espírito aludido por Porto Alegre:

Convencidos, pelo contrário, da necessidade dos estudos de arte, da sua utilidade na vida intelectual, e das vantagens que dele resultariam para todos os progressos pátrios, como o desenvolvimento da alta indústria, da arte da construção civil, e de muitos outros auxiliares da prosperidade nacional, aumentar-se-ão proporcionalmente nossas luzes em semelhante matéria; e com elas o gosto da civilização, o qual é tão completo quando lhe falta o amor do belo, como é completa a vida do arbusto plantado à sombra de uma caverna ${ }^{67}$.

Para que o desenvolvimento industrial pudesse ganhar ainda mais com o ensino do desenho inicialmente presente na escola secundária, ele deveria se combinar, finalmente, com uma nova série específica de instituições:

À ideia de instituírem-se cursos obrigatórios de desenho nos estabelecimentos de instrução secundária, Exms. Srs., poder-se-ia ligar uma outra igualmente exequível: a de formarem-se escolas gratuitas de desenho elementar em todas as freguesias, sobretudo nas grandes capitais; não para a instrução da bacharéis, que a podem pagar, mas para os artífices e operários, os quais, em todos os momentos da vida poderiam com sucesso aplicar os elementos da arte às suas diversas produções ${ }^{68}$.

Ensino do "desenho elementar" não quer dizer aqui outra coisa senão o ensino do desenho linear e

\footnotetext{
${ }^{66}$ AMÉRICO, Pedro. "Cartas de um plebeu aos Srs. Deputados. Quinta carta". Correio Mercantil. Rio de Janeiro, 29 de junho 1865 .

${ }^{67}$ Idem, ibidem.

${ }^{68}$ Idem, ibidem.
} 
geométrico, compreendido, no período, como uma das mais importantes formações necessárias aos artistas industriais no sentido de auxiliá-los em suas produções, ao lado da qual se poderia também se somar, com vantagem, um ensino do desenho de observação.

Mas essa era, no Brasil, parte da tarefa que o Liceu de Artes e Ofícios do Rio de Janeiro havia assumido para si, desde 1858, ainda que estivesse fechado naquele momento; era também a obrigação do curso técnico criado na AIBA, em 1855, cujas matérias Américo havia seguido durante seus anos na instituição e conquistado várias medalhas.

Em verdade, a ideia do jovem, ainda que em contato com os propósitos dos cursos dessas instituições, é aqui sensivelmente diferente. Em primeiro lugar, liga-se à mesma e coerente defesa à horizontalização e diversificação do ensino do desenho em todas as cidades o império - argumento que se tornará ainda mais contundente quando relacionado a outros pontos do seu projeto, como será visto em seguida. Em seguida, respondendo à teoria artística que havia desenvolvido, o jovem imagina de fato um cenário no qual, criadas e gerenciadas pelo governo, essas instituições não correriam, justamente, o risco de serem interrompidas em seus projetos em função da política do dia, ou fechadas, como a instituição de Bethencourt da Silva, inaugurada e mantida por esforço de particulares - fechamento que deveria confirmar a Américo a sua teoria sobre a importância do acolhimento dos “altos protetores" para que um vasto empreendimento, como o seu, especialmente no Brasil, desse certo. Não se pode esquecer que o projeto do jovem é um que se submete permanentemente à proteção do estado, bastante distinto, portanto, das ações efetuadas pelo arquiteto.

A realização de parte significativa desse primeiro ponto é uma conquista que caberia de fato apenas às políticas educacionais do período republicano brasileiro, estendendo-se à segunda metade do século XX, naturalmente já sem a participação do artista, morto em 1905. Entretanto, quando ele, ainda jovem, imagina possível essa realização, tem em mente, sem dúvida, o contexto europeu, com o qual está por anos em contato direto.

De um lado, ele torna-se atraído pelo exemplo do recente avanço industrial da Inglaterra, país que, por meio da fundação de novos museus e escolas de artes plásticas e aplicadas, havia realizado desde os anos 1850 um importante salto qualitativo e quantitativo em sua produção. Essa mudança de situação se tornava, para o brasileiro, um modelo importante para o contexto emergente brasileiro, aparentemente similar em muitos sentidos. Sobre o assunto, Américo falará desde o final de 1863:

No Brasil, não há elementos para que sob a influência das ideias de uma escola, o estudo das 
Belas Artes se possa espalhar, como se vulgarizaram os estudos das letras. Não há uma localidade, por menor que seja, não há um só recanto habitado, no Brasil, que não tenha uma aula de Latim, onde bem ou mal ensina-se a conhecer a literatura romana. Entretanto, em uma tão rica nação, em um país que reclama a tantos títulos o nome de civilização, não há uma só instituição favorável às Belas Artes e por consequência a uma das fontes mais abundantes de prosperidade pública: a indústria comercial. Os produtos da indústria inglesa sempre foram tidos por grosseiros e sem valor algum como objetos de gosto e sabidos um povo inteligente até que o número das escolas gratuitas de desenho, de cinco, fossem levadas a 98; sem falar em uma infinidade de museus criados depois de 1845. Sem falar dos bem feitos de sua cultura sobre a civilização, apresentaria, se me envolvesse na política, os resultados práticos do ensino das Belas Artes entre nós; o que se compreende mais facilmente no Brasil, onde o reinado dos caminhos de ferro e do desenvolvimento material deve suceder evidentemente a apatia em que temos vivido, apesar de termos tantos homens devotados ao bem público e ao interesse geral. ${ }^{69}$

Uma sequência quase idêntica de interpretação - uma que comparava diretamente os ciclos da Roma decadente e da Inglaterra pré-mudanças ao do então atual Brasil - era retomada em 1864, em suas Considerações Filosóficas. Em Roma, a arte teria sido apenas um

meio de dominação, um auxiliar do poder, e sobretudo um movivo de ostentação, de divertimento e de luxo, cujo exercício, praticado quase sempre pelos estrangeiros vencidos, foi muita vezes considerado como uma ocupação subalterna, que parecia insignificante aos olhos do legislador; do que resultou que as belas-artes não faziam parte dos elementos essenciais da civilização, nem mesmo eram um complemento desta, mas um apêndice, como o foram na Inglaterra até o começo deste século, e como continuam a sê-lo nas sociedades americanas, e mormente entre nós ${ }^{70}$.

A Inglaterra do início do século XIX não era a mesma da do meio do mesmo século: teria mudado rapidamente, tornando as artes necessárias desde a década de 1850; para Américo, na verdade, desde 1855: a precisão da data era de fato relevante para trazer de novo à mente do seu leitor a importância daquele ano não apenas para a formação Exposição Universal de Paris, mas para a formação da tentativa similar à inglesa, na corte - ainda que demasiadamente limitada -, empreendida na AIBA, e a certeza de que uma mudança vultosa no cenário brasileiro também seria possível de ser realizada em pouco tempo:

Para prova do que nos abalançamos a afirmar o que já principia a acontecer com a cultura das próprias artes naquele país [Ingaterra], as quais sendo antes de 1855 apenas ensinadas

${ }^{69}$ AMÉRICO, Pedro. "Carta de Paris a Louis Jacque Brunet em 11 de novembro de 1863”. In: FUNDAÇÃO VINGTUN ROSADO. Cartas de Pedro Américo de Figueiredo e Melo e Daniel Eduardo de Figueiredo e Melo a Louis Jacques Brunet. Mossoró: Coleção Mossoroense, junho de 2001. s/p.

${ }^{70}$ AMÉRICO, P. Considerações Filosóficas...p.95 [estudo segundo]. Ou: Correio Mercantil, Rio de Janeiro, 2 de outubro de 1864, p.3. 
convenientemente em três academias, hoje o são em 95; não contando como um sem-número de escolas, aliás importantes e mui ricas, que por todo o reino se encontram, e hoje se têm formado, além de nome mui dignos de Turner e Reynolds, inumeráveis artistas, sob os auspícios dos quais vive e prodrige a indústria, há dez anos ameaçada de moral paralisia, tanto pela falta de cultura artística na Inglaterra, como pela admirável profusão que exibiam a França e a Bélgica na primeira universal. ${ }^{71}$

É sintomático que o modelo oferecido pela Inglaterra também já estivesse presente nos argumentos de Porto Alegre, e é muito provável que estivesse mesmo em seu horizonte de expectativas ao propor a formação das escolas industriais quando vereador na corte, e, em seguida, o curso técnico da AIBA. No texto publicado naquele mesmo ano da "primeira universal", aludida por Américo, o antigo diretor havia do mesmo modo afirmado com entusiasmo "que a nação inglesa, mormente neste século, marcha em uma via progressiva, e que o espírito artístico, o amor do belo ali se desenvolve com uma espantosa rapidez: a cidade de Londres e as moradas dos lords assim o provam."72

Entretanto, deve-se dizer, é muitíssimo provável que não tenha sido com Porto Alegre que Américo dialogava e a quem respondia quando, por algumas vezes, havia tomado a Inglaterra como um dos modelos nos quais o Brasil deveria se espelhar, tendo então garantias dos resultados positivos à indústria nacional se criasse novas instituições de ensino de desenho. Emitindo essas opiniões em 1863, 1864 e 1865 é impossível deixar de lembrar o importante e contínuo contato que o jovem havia estabelecido, desde, pelo menos o início de 1861, com Sébastien Cornu, em seu ateliê e, certamente, no Musée Napoléon III, ao mesmo tempo que frequentava a chamada "Pétite École", isto é, a Escola Especial de Desenho e Matemáticas Aplicados às Artes Industriais (École spéciale de dessin et de mathématiques appliqués aux arts industriels), especialmente entre 1861 e 1862, quando se afasta por um ano inteiro da École des Beaux-Arts para perseguir seus objetivos de instrução científica e técnica.

Conforme discutido no Primeiro Capítulo desta Tese, em 1862, por meio de um rapport, Cornu sairia em defesa do museu que havia acabado de formar, tentando convertê-lo em instituição permanente, e para tanto comparando-o em importância à escola e Museu de artes industrais South Kensignton. O ponto inicial de análise, tendo sido precisamente o dos resultados da Exposição Universal de Londres daquele mesmo ano - na que estaria presente o jovem Américo -, era estruturado por um conjunto de ideias consideravelmente próximas daquele que o jovem brasileiro confessará então a Brunet, um ano

\footnotetext{
${ }^{71}$ Idem, ibidem. p.191 [conclusão]. Ou: Correio Mercantil, Rio de Janeiro, 25 de dezembro de 1864, p.1.

${ }^{72}$ PORTO ALEGRE, M. A. "Algumas ideias sobre as Belas-Artes e a indústria no Império do Brasil $-2^{\circ}$ artigo." Guanabara, Rio de Janeiro, tomo I, 1851, pp.135-142. Reimpresso também em: KOVENSKY, Julia; SQUEFF, Letícia (orgs.). Manuel de Araújo Porto Alegre: Singular \& Plural. São Paulo: IMS, 2014. p.301.
} 
depois, e publicará em seguinte nas suas Considerações Filosóficas. Cornu afirmaria:

A exposição universal de Londres constata um progresso bastante notável no gosto dos industriais ingleses. Se as indústrias inglesas, que têm por base as artes do desenho, não ultrapassam ainda nossas indústrias similares, elas tem se aproximado a grandes passos, no dizer dos membros da Comissão Imperial e do júri.

Isso porque a Inglaterra tem feito grandes esforços, grandes despesas para popularizar as artes do desenho, cujo estudo desenvolve o gosto, se é que ela não o cria. Ela possui agora mais 700 escolas de desenho onde frequentam a juventude e os industriais.

É hora de se preocupar com esses progressos rápidos, com essa organização escolar que são um perigo potente para os nossos industriais de gosto, porque eles [os ingleses] chegarão, em poucos anos, a nos retirar a supremacia do mercado europeu: é hora de trazer o remédio, dando série atenção a nossos estabelecimentos de arte, escolas e museu. [...]

É certo que essa criação de um Museu de Estudos Especiais combinada com uma reforma série da escola gratuita de desenho de Paris [ou seja, a "Petite École"], que vegeta sem exercer a influência que ela deveria ter; combinado [sic] com a reforma séria das escolas de desenho departamentais, produzirá resultados importantes, e que esses resultados nos permitiriam conservar nossa superioridade nas obras e indústria do gosto.

Ora, essa superioridade entra em grande medida no bem-estar, na existência mesma das classes industriais. $^{73}$

Ao mesmo tempo que se referia ao contexto inglês - alusão, não há dúvidas, testemunhada por Américo -, Cornu chamava atenção do jovem brasileiro para ao modelo francês, ao qual ele já tornava quando pensava a viabilidade do seu projeto das artes, no Brasil. Tratava-se do ambiente que conhecia, naturalmente, muito melhor, depois de 5 anos vivendo em Paris e frequentando suas mais importantes instituições artísticas e industriais.

As análises de Cornu não estavam, com efeito, fora de contexto. Depois das Exposições internacional e universal de 1851 e 1855 (das quais a indústria francesa havia ainda sido considerada a vencedora absoluta), o avanço da indústria inglesa e ainda a de outros países europeus, deu lugar ao medo de diversas personalidades políticas de que a França pudesse ser passada para trás em um mercado internacional que se expandia em acirrada concorrência. Desde os primeiros anos da década de 1850, estendendo aos anos 1860, o país identifica e tenta resolver o que Stéphane Laurent definiu como um paradoxo da indústria francesa, em especial o do seu núcleo mais importante, em Paris: “de um lado uma estagnação, e mesmo regressão da formação profissional; e de outro, uma atividade intensa que

${ }^{73}$ CORNU, Sébastien. "Rapport concernant le musée Napoléon III, 1862", in MCWILLIAM, Neil; MÉNEUX Catherine; RAMOS, Julie (dir.), L'Art social de la Révolution à la Grande Guerre. Anthologie de textes sources. Paris; INHA (“Sources”), 2014. Disponível em. URL : http://inha.revues.org/5504 (ùltimo acesso em 27 de março de 2016). [tradução nossa ] 
dava desenvolvimento à atividade profissional e favorizava as mutações sociais e culturais."74

Para resolver esse problema, nascem, precisamente naqueles anos, "os debates sobre a questão, a partir dos quais a ideia de um ensino de artes aplicadas é definida" ${ }^{\text {75 }}$. Como resultado quase imediato,

um grande número de escolas são fundadas ao passo que outras, moribundas, são reativadas, com a ajuda influente de amadores da arte locais reunidos em sociedade ilustradas, que fazem pressão sobre as autoridades municipais. [...] Entretanto, o desenho permanece a base e a matéria dominante da instrução dispensada. Aplicada à indústria, ele compreende, de um lado, a geometria, que dá o rigor ao traçado necessário à repetição e à fiel repetição dos motivos, e, de outro, compreende a representação de observação a partir do modelo (gesso ou então a gravura, a partir de uma obra-prima), que oferecer a qualidade plástica ao ornamento. Considerado como uma medida vital à França, o ensino das artes aplicadas torna-se uma preocupação sensível, que se manifesta sobretudo através de debates, já que, em sua aplicação, ele se afasta ainda pouco da língua do grafismo para encontrar sua coerência e funcionamento próprios. ${ }^{76}$

Essas ações eram quase invariavelmente tomadas a partir das decições expressas em rapports produzidos por comissões específicas de avaliação, fossem por encomenda do governo imperial ou de poderes municipais, como seria o importante caso da cidade de Paris.

Se se lembra (pois também tratado no Primeiro Capítulo desta Tese), ainda em 1862 Cornu havia sido de fato chamado a fazer parte oficialmente, ao lado de Viollet-Le-Duc, entre outros, de uma nova comissão que deveria dar opinião sobre uma série de assuntos relativos ao estado das artes francesas, dentre os quais se apresentavam "os melhoramentos a se introduzir nos estabelecimentos de belas artes, tais como a Escola de Belas Artes, a Academia da França, as Escolas gratuitas de desenho de Paris e as Escolas de belas artes departamentais", e ainda "as nominações no corpo docente desses diversos estabelecimentos",77.

Ainda que com seu rapport Cornu não tivesse conseguido manter aberto o seu museu, nem a integralidade da coleção que havia comprado para o estado francês, ele veria de fato uma série de reivindicações relativas ao ensino e às reformas das escolas de desenho atendidas, e talvez até mais. Logo em 1863, o poder imperial investia e ampliava os cursos na Pétite École, já bastante variados -

\footnotetext{
${ }^{74}$ LAURENT, Stéphane. L'art utile: les écoles d'arts appliqués sous le Seconde Empire et la Troisième République. Paris: L'Harmattan, 1998. p.23.

${ }^{75}$ Idem, ibidem. p. 13.

${ }^{76}$ Idem, ibidem. pp.13-14. [tradução nossa]

${ }^{77}$ BONNET, Alain. L'enseignement des art au XIXe siècle: la réforme de l'École des beaux-arts de 1863 et la fin du modèle académique. Rennes: Presses Universitaires de Rennes, 2006. P.179.
} 
conforme será visto em seguida. Conforme bastante se discutiu nesta Tese, reformará ainda a École des Beaux-Arts, a partir da ação do Marechal Vaillant, do conde Nieuwerkerke, Prosper Merimée e ViolletLe-Duc, todos agentes que demonstravam as mesmas preocupações de Cornu quanto à importância de reformas dos estabelecimentos artísticos mais importantes da França, à imprescindibilidade de criação e difusão dos cursos de desenho em todos o país, e à necessidade de tornar o artista (especialmente os formados ne École) um agente útil à sociedade ${ }^{78}$.

As reivindicações e ações desses indivíduos repousavam integralmente no fito do projeto do jovem Américo. E se as medidas que fizeram por ordem do governo imperial foram por ele saudadas em sua brochura sobre a reforma da escola francesa, não há dúvidas de que deve ter saudado as deliberações da uma nova comissão que, integrada por alguns deles ${ }^{79}$, havia sido requerida em Paris, também em 1863 , mas em nível regional ${ }^{80}$. A intenção decorria da pressão estabelecida pelo Conselho Municipal, que percebia "a necessidade de dotar municiar Paris de uma estrutura de formação ao "grafismo" para seus numerosos operários da arte" 81 , e era "sem dúvida motivada pelas conclusões dos pareceristas do ensino de desenho sobre a Exposição Universal” de 1862.

Essa nova comissão chegaria à proposição de uma "reforma radical" na instrução do desenho. Depois de um ano de discussão, o projeto apresentado era o seguinte:

$1^{\circ}$ Abertura das sessões anuais para concursos, seguidas da entrega de diplomas, tanto para os professores quanto para professoras. O ensino nas escolas da cidade de Paris devia ser confiado exclusivamente a esses professores que tivessem obtido os diplomas.

$2^{\circ}$ A divisão do ensino em ensino de arte e ensino geométrico, a fim de que cada uma desses ramos, confiados a mestres especiais, fosse ensinado de maneira mais completa.

$3^{\circ}$ Pesquisa e criação de novos modelos.

$4^{\circ}$ Melhoramento das salas de desenho e ciação de instalações que correspondam às necessidades de diferentes tipos de estudos.

$5^{\circ}$ Concurso anual entre todas as classes de desenho, afim e estimular o zelo dos alunos.

$6^{\circ}$ Remuneração mais conveniente aos professores, combinada de tal modo que ao vencimento fixo fosse anexado um vencimento eventual, dependendo do número de alunos presentes nas classes, do número de alunos aceitos em concurso, e do número de recompensas por eles obtidas nos concursos gerais.

$7^{\circ}$ Organização do desenho tornada obrigatória em todas as escolas primárias de meninos e

\footnotetext{
${ }^{78}$ Sobre o problema, ver idem, ibidem. pp.255-258.

${ }^{79}$ Entre os integrantes da reforma da École des Beaux-Arts em 1863, estavam também presentes nessa nova comissão de 1863 sobre o ensino artístico municipal, Nieuwerkerke e Viollet-Le-Duc.

${ }^{80}$ A comissão é formada a pedido do barão Haussmann, prefeito da Sena, responsável por toda a reestruturação urbana de Paris, na segunda metade do século XIX.

${ }^{81}$ LAURENT, Stéphane. Op cit. p.31.
} 
meninas.

$8^{\circ}$ Nominação de 2 inspetores encarregados, cada um de sua circunscrição, velar essa reorganização, de seguir seus efeitos e de reportar à Administração as novas necessidades e os progressos realizados. $^{82}$

Essas medidas relativas à organização no núcleo industrial mais importante da França compunham, em 1864, de maneira muito clara, as mais importantes mudanças estipuladas em 1855, por Pedreira, aos ensinos primário e secundário brasileiro (ele também irá estabelecer concursos obrigatórios aos professores dos ensinos públicos e privados, e instituir a necessidade de inspetores que zelem pelo bom andamento da reforma e do ensino), por Porto Alegre na AIBA (a divisão, dentro da academia, de um curso de arte e um curso técnico), mudanças essas que se complementariam com as medidas apresentadas por Américo em suas Cartas. Como visto, já no Considerações Filosóficas o jovem havia de fato julgado a emulação entre artista uma ação importante, que deveria ser utilizada pelo estado para o desenvolvimento das artes. Em seu projeto irá também defender, já está claro, a obrigatoriedade do ensino artístico (no seu caso, imaginado ao ensino secundário), além de defender as revalorizações profissionais dos professores da AIBA, e, por fim, a mudança no método da mesma academia.

Qualquer proximidade do contexto francês dos anos 1850 e 1860 com a primeira e mais importante medida do seu projeto político tratada até aqui não deve ser aqui, desse modo, pensada de modo algum casual, nem mesmo a "limitação" na ênfase exclusiva que Américo fará sobre o desenho [o que Laurent chama de "grafismo"], como medida suficiente para propulsar a parte do seus intentos relativos às indústria.

De todo modo, deve-se considerar que mesmo na França, será apenas na Terceira República (isto é, a partir dos anos 1870) que a superação desse "grafismo" nas escolas técnicas e industriais ${ }^{83}$ dará lugar um tipo de formação mais adequada a cada tipo de ofício. E, no Brasil, também caberá a Bethencourt da Silva e a seu Liceu essa incumbência, aparentemente resolvida a partir dos anos 1880, quando tabelas precisas para formações de diversas profissões artísticas e industriais (entre eles os de armeiro, armador, arquiteto civil, alfaite, carpinteiro, chapeleiro, compositor de tipografia, construtor naval, dourador, decorador, entalhador, gravador, jardineiro, litógrafo, ourives, pedreiro, fotógrafo etc.) são criadas no sentido de garantir uma formação conveniente e diretamente direcionada às inserções desses

${ }^{82}$ BRONGNIART, Jules. "De l'enseigement du dessin. Rapports du jury international à l'Exposition universelle de 1867 publiés sous la direction de Michel Chevalier, Paris, Imp. E Lib. Administratives de Paul Dupont, 1867. Apud in: LAURENT, S. Op. cit. p.32-33.

${ }^{83}$ Sobre o assunto, ver: Idem, ibidem. Especialmente o capítulo 4, “L'impulsion républicaine”, pp.101-140. 
profissionais no mercado ${ }^{84}$.

\section{- "Criação de pequenas escolas de belas artes nas províncias de primeira ordem" e "Criação de um museu de pintura na corte, independente [...] da academia das belas artes."}

A criação de escolas de arte provinciais no Brasil e de um museu de pintura na capital do império é outro modelo que Américo tomará emprestado do contexto francês. O problema da horizontalização também do ensino das artes plásticas (e, portanto, não apenas do desenho voltado à educação do 'gosto' popular e à indústria) já estava presente nas trocas de cartas pessoais pelo menos desde 1863: "No Brasil, não há elementos para que sob a influência das ideias de uma escola, o estudo das Belas Artes se possa espalhar". Entretanto, será no Cartas de um Plebeu, após criticar tanto a AIBA quanto mais uma vez o governo - que não empregaria os artistas nela formados -, que o jovem irá afirmar pela primeira vez publicamente: "Nunca as artes floresceram pela simples influência de uma escola oficial" ${ }^{85}$.

Trata-se de uma frase com dois objetos. Um que invocava a teoria de que o florescimento das artes não poderia vir de uma instituição específica, mas decorreria necessariamente do "amor do povo", das "considerações dos homens de estado", e da "liberalidade do governo" ${ }^{86}$. O outro, precisamente em relação a esse segundo ponto do seu projeto, que supunha a impossibilidade de uma única academia, especialmente num país tão vasto como o Brasil, abraçar todo o desenvolvimento (e nesse caso especificamente artístico) do Brasil.

Se em todos os estabelecimentos de instrução secundária do império haveriam, segundo o projeto de Américo, cursos obrigatórios de desenho, bem como outros voltados aos operários e artesãos em todas as freguesias, era de se imaginar que, num país então inteiramente educado pelo gosto das belas artes, passariam a existir cada vez mais jovens inclinados e encorajados à profissão artística, surgindo, desse modo, a necessidade de escolas locais especializadas, ao menos nas províncias mais ativas do território nacional, que pudessem assim acolher inicialmente esses jovens e futuros artistas.

Mesmo que a AIBA continuasse a ser a instituição central (tal como a École des Beaux-Arts em Paris, continuava a sê-lo, mesmo após a reforma de 1863), os benefícios de escolas provinciais assegurariam

\footnotetext{
${ }^{84}$ SOCIEDADE Propagadora das Belas Artes. Estatutos da Sociedade Propagadora das Belas Artes do Rio de Janeiro. Rio de Janeiro: Typ. Hildebrandt, 1893.

${ }^{85}$ AMÉRICO, Pedro. "Cartas de um plebeu aos Srs. Deputados". Segunda Carta. Correio Mercantil. Rio de Janeiro, 21 de maio 1865.

${ }^{86}$ Idem, ibidem.
} 
a difusão da cultura da "grande arte" por todo o país. E isso significaria, em última instância, fomentar não uma, mas várias "escolas oficiais" no império.

Produzindo-se mais, infere-se, o Brasil necessitaria, certamente, de um novo Museu, que pudesse receber as melhores produções, e estruturar, por fim, um quadro completo e heterogêneo de uma arte nacional que se compunha de suas diferenças e semelhanças locais.

- "Graves alterações no método de ensino e no regime interno da" Academia Imperial de Belas Artes.

As mudanças que Américo visionava de serem feitas na AIBA não eram apresentadas, como visto, como uma ideia destacada em seu projeto. Incluíam-se, antes, na ideia que propunha alterações estruturais à mesma instituição - tratadas no último tópico deste Capítulo. Entretanto, na medida em que parecem constituir um ponto importante, notadamente afim à ideia de difusão e diversificação do ensino do desenho no Brasil, talvez seja válido comentá-las aqui, separadamente.

É bastante difícil de se concluir ou mesmo deduzir o que Américo quer dizer, especificamente, com "graves alterações" no "regime interno" da Academia. Em termos gerais, refere-se - disso não parece haver dúvidas - aos estatutos então vigentes na instituição, instituídos desde a reforma de 1855. Mas eles são demasiadamente amplos para serem comentados a partir de uma única e breve sentença emitida pelo artista.

O segundo problema, "graves alterações no método de ensino" parece ser mais palpável e, embora também não se possa oferecer uma leitura assertiva final, é ainda possível de se estabelecer uma interpretação aproximativa relativamente segura, especialmente se se tomam as opiniões emitidas por Américo sobre o assunto, desde 1863, e se avaliam novamente alguns aspectos de suas formações, mormente durante seu período europeu de estudos.

De início, a proposição que o jovem então faria em seu projeto - a de uma reforma na AIBA e aqui, especificamente, no ensino por ela oferecido - era, em boa medida, previsível. Estranho seria, na verdade, se não o fizesse: todas as propostas européias de expansão do ensino artístico nos anos 1850 e 1860 - que também haviam invariavelmente determinado como um dos seus mais importantes objetivos o auxílio (ou, por vezes, a submissão) da arte à indústria - estipularam, com efeito, ao mesmo tempo a necessidade de reforma de antigas escolas, de criação novas e da forçosa reavaliação dos métodos correntes de aprendizado artístico, então qualificados de retrógrados, posto que pouco adequados às necessidades do mercado e do ambiente industrial. Para um comentador contemporâneo 
da sintomática Exposição de Belas Artes aplicadas à Indústria, realizada ainda em 1863, em Paris (outra exposição que o jovem Américo deve ter muito provavelmente visitado), "a abertura de mercados e o desenvolvimento da concorrência estrangeira então impunha [aos industriais] a renovação de procedimentos didáticos e a redefinição do sistema geral de aprendizado." ${ }^{87}$ Segundo Alain Bonnet, isso queria dizer, em outras palavras, que "a pedagogia artística se encontrava no centro da competição econômica" $^{88}$ do período.

O "belo clássico" - cuja força era maior na França do que na Inglaterra - não era mais suficiente para responder as demandas crescentes de variedade funcional e formal de produtos em um mercado heterogêneo, o qual, visando também a exportação, deveria estar pronto para criar continuamente novos modelos, e em curto prazo.

$\mathrm{Na}$ França, todos os agentes envolvidos nesses problemas, que se apresentavam ademais a favor de mudanças, haviam pretendido não apenas novas disciplinas técnicas e teóricas, mas ainda métodos de desenho liberados das amarras do classicismo, que formassem os alunos em menor tempo (tratar-seiam normalmente de 7 anos de estudos), e que, sobretudo, em cooperação com a liberdade a eles então outorgada, estimulassem a originalidade e a imaginação (ou o que, futuramente, seria chamado de "criatividade").

Como visto no Primeiro Capítulo desta Tese, foi justamente isso que os reformadores de 1863 haviam tentando empreender na instituição artística mais importante da França:

A destinação que a École assinalava aos estudos, formando alunos apenas no grande gênero, de agora em diante sem utilidade prática no novo contexto social, era contrária às necessidades da indústria. Ela desviava, em primeiro lugar, os iniciantes dos empregos industriais, deixando-os esperar uma carreira artística à qual poucos eram destinados; em seguida, ela separava, segundo o dogma acadêmico, a grande arte da arte aplicada; ela impunha, enfim, um estilo retrógrado rejeitado pelo público. Os próprios modos didáticos eram contestados pelos reformadores em função do problema industrial: o longo aprendizado pedagógico fundado sobre a imitação de modelos impedia, eles diziam, a emergência de um estilo contemporâneo autônomo e a renovação regular de propostas. A limitação dos estudos ao desenho unicamente não permitia o conhecimento aprofundado dos materiais e técnicas, conhecimento extremamente necessário na elaboração de um produto manufaturado. ${ }^{89}$

A reforma de base, almejada em todo o sistema artístico francês deveria, desse modo, atingir igualmente a École, sendo o problema da "arte útil" também fundamental para a compreensão das

${ }^{87}$ DARCEL, Auguste. "Exposition des Beaux-Arts appliqués à l'industrie", Gazette des Beaux-Arts, 1863, tome II, pp.481-86. Apud in : BONNET, Alain. Op. cit. p.259, e p.279 (nota 10). [tradução nossa]

${ }^{88}$ BONNET, Alain. Op. cit. p.259.

${ }^{89}$ Idem, ibidem. p.262. 
pretensões do decreto de 1863 , que a reorganizava completamente.

Américo, já está mais que claro, era inteiramente a favor dessa reforma. Em sua brochura publicada sobre o assunto, ele se pronunciou repetidamente em favor da liberdade, da originalidade e da imaginação, pondo-se assim contra a "imitação dos gregos" (mas não contra a compreensão dos seus princípios gerativos, posto que universais). Saiu ainda, como continua evidente no Cartas de um Plebeu, em favor da defesa "da arte na indústria e, então, na vida." "90 A essas relações e faculdades que exaltava em sua primeira publicação, o jovem havia sido iniciado nos seus anos de estudo justamente na AIBA, período no qual Porto Alegre havia pretendido abrir a instituição a uma via eclética, conforme sugerido no Primeiro Capítulo.

Com isso em mente, nao será surpreendente constatar que, ao defender a reforma da École em 1863, o jovem ovacionasse o fato de que a instituição francesa se aproximava enfim do currículo e da organização administrativa da AIBA - em uma curiosa inversão centro-periferia que deveria dar ainda muito o que pensar a estudos futuros sobre o ensino artístico no Brasil do século XIX.

A partir de 1863 o modus operandi da instituição francesa se tornaria, com efeito, praticamente o mesmo da brasileira pós-1855: ela se submeteria então diretamente ao governo imperial, em específico ao ministro do Império em exercício (na França, o Ministro do Imperador e das Belas Artes; no Brasil, o Ministro dos Negócios do Império). Criava-se uma cadeira de diretor, que deveria ser escolhido (como no Brasil) pelo mesmo governo imperial. A escolha dos professsores não seria mais feita por cooptação, mas por indicação do estado (na AIBA, teoricamente a cooptação deveria funcionar como uma primeira indicação, sempre avalizada pelo governo, embora houvessem, como se sabe, repetidos casos nos quais a escolha da Congregação foi sequer considerada e solapada sem rodeios pelo imperador ou por seus ministros). Criaram-se ainda na École os ateliês práticos de pintura e escultura (medida bastante antiga na AIBA, constitutiva mesmo do seu perfil primeiro enquanto escola de ensino artístico num país sem esse tipo de tradição). E instituiram-se matérias técnicas e teóricas inéditas, como as de história da arte e estética, história e arqueologia, anatomia, perspectiva, matemáticas elementares, geometria, geologia, física e química (algumas dessas cadeiras já presentes na academia brasileira desde a década de 1831, e outras, como visto, instituídas na reforma de 1855). Porém, um pequeno mas importante parêntese: mesmo com as mudanças na École, o currículo da AIBA continuava consideravelmente maior, incluindo, como se sabe, a cadeira de desenho de ornatos, de arquitetura civil, de gravura de medalhas e pedras preciosas, e a de pintura de paisagem, flores e

\footnotetext{
${ }^{90}$ AMÉRICO, P. La réforme de l'École des Beaux-Arts...p.11.
} 
animais.

Em 1865, havia outra característica comum às duas escolas, mas esta, precisamente, uma das quais Américo devia ter em mente com a ideia de mudanças no ensino: o método do aprendizado de desenho, mantido em suas bases clássicas: isto é, um método progressivo que instituía uma marcha que ia do simples ao composto, das construções das partes ao todo; que previa uma subida perceptiva gradual de imagens bidimensionais a objetos tridimensionais; e que, compassadamente a esse mesmo fluxo, fundava um ensino artístico no qual o aluno permanecia durante anos concentrado no estudo da tradição clássica (cópias de gravuras, de pinturas e de esculturas) antes de chegar na última etapa de formação, a do modelo vivos e da natureza.

Em cada um dos contextos, brasileiro e europeu, essa manutenção se justificava, contudo, distintamente. No Brasil, ainda que realizando enfim a criação de uma "dupla escola" de artes e ofícios, imaginada desde o início do século por Lebreton, Porto Alegre ainda mantinha sua fé no método tradicional: ele havia de fato instituído a obrigatoriedade de disciplinas técnicas (matemática, desenho linear e geométrico) como pré-requisito a quase todas as formações; mas uma vez passando por elas, e estando o aluno apto a ingressar ao estudo da figura humana por meio da cadeira de Desenho Figurado (para a qual Américo ingressava), o método mantido era o de um aprendizado clássico escalonado "dividido em duas séries: a de cópias de estampas, e de cópias do natural ou estudo do claro-escuro". ${ }^{91}$ Conquanto a passagem nessa cadeira não fosse requerida obrigatoriamente como pré-requisito à de modelo-vivo, a regulamentação de que "só serão nesta admitidos os alunos que por suas habilitações forem designados pelo Corpo Acadêmico no princípio do ano"92 não deixava dúvidas quanto às habilidades práticas e teóricas e o nível que eles deveriam ter então adquirido antes de serem admitidos ao desenho do natural. Para aqueles interessados em ascenderem em seus respectivos cursos, ingressando (se escultores) no estudo de gravura de medalhas e pedras preciosas, e estatuária, e (se pintores) na pintura de história, não havia para onde correr: a mesma formação na cadeira de desenho figurado era requerida.

Na França, especificamente na École, o problema era, como visto, de outra ordem. Antes de 1863, mesmo tendo diversos dos seus membros (incluindo Ingres), por diversas vezes chamados a opinarem sobre a mudanças nos métodos de ensino artísticos correntes nas escolas de desenho oficialmente

\footnotetext{
${ }^{91}$ FERRAZ, Luiz Pedreira do Coutto. Decreto $n^{\circ} 1.603$, de 14 de Maio de 1855, Dá novos Estatutos á Academia das Bellas Artes. Título V, seção VIII. art. 30. Disponível online em: http:/www2.camara.leg.br/legin/fed/decret/18241899/decreto-1603-14-maio-1855-558536-publicacaooriginal-79876-pe.html [último acesso em 28 de março de 2016].

${ }^{92}$ Idem, ibidem. Título V, seção I, art.17.
} 
subvencionadas na França, mormente em Paris, a Académie havia sempre dado a última palavra a seu favor, considerando perigosas quaisquer mudanças ao método que ela próprio havia definido, especialmente as que previam redução do tempo de estudos, e o abandono das raízes clássicas ${ }^{93}$. Após o início de 1864, quando a reforma na École entrava de fato em vigor, o panorama de mudanças parecia se configurar enfim positivo. As cadeiras anteriormente citadas foram criadas e efetivamente implementadas; entretanto, a parte do programa que previa justamente as mudanças no ensino artístico foram finalmente proscritas. Viollet-Le-Duc, como visto, o mentor intelectual da reforma, deixara a escola ainda no início daquele ano, em decorrência da opressiva oposição dos alunos, e do recuo quase imediato que Nieuwerkerke havia feito de algumas medidas do decreto, também em função da pressão que os membros da Académie haviam feito ao imperador e ao marechal Vaillant, Ministro do Imperador de das Belas Artes. Ao menos em relação ao método de desenho (no qual se concentrava, com efeito, todo o ensino e força da Académie), tudo havia ficado igual.

Não obstante, sabia-se muito bem qual o modelo que Viollet-Le-Duc havia imaginado à École des Beaux-Arts: um "curso aberto pelo estudo direto da natureza em plein-air, pelo desenho de memória, como o ensinava Lecoq de Boisbaudran, na Escola Gratuita de desenho, e pelo conhecimento histórico e arqueológico." 94 Com esse método, ele esperava finalmente "favorecer ao aluno a busca pela verdade, a descoberta de sua própria personalidade e o aprendizado da poesia”, permitindo igualmente "desenvolver nele uma qualidade essencial ao criador, a originalidade" $" 95$ - diga-se novamente, de passagem, as mesmas qualidades perseguidas pelo jovem Américo em suas teorias e posturas estéticas. A alusão recorrente que o arquiteto fazia em seus textos à École spéciale de dessin et de mathématiques appliqués aux arts industriels e ao curso de Horace Lecoq de Boisbaudran era, a propósito, fundamental para as suas ideias de mudanças. O próprio arquiteto havia sido professor de composição e história do ornamento naquela escola entre 1835 e 1850, e colega de Boisbaudran, que também já lecionava na instituição desde a década de 1840. Especialmente em seus textos preparatórios para a reforma da École ${ }^{96}$, publicados em 1862, como resultado em curso da citada comissão da qual havia participado com Cornu, Viollet-Le-Duc propunha a Pétite École ${ }^{97}$ como modelo inequívoco ao qual se

${ }^{93}$ Sobre a Académie e sua recusa em mudar os métodos de ensino artístico, ver: BONNET, A. Op. cit. pp.263-272.

${ }^{94}$ Idem, ibidem. p. 182.

${ }^{95}$ Idem, ibidem. p. 183.

${ }^{96}$ VIOLLET-LE-DUC, E. E. I - Gazette des Beaux-Arts, 1862, T.XII, pp.393-402; II - Gazette des Beaux-Arts, 1862 , T.XII, pp.525-534; I - Gazette des Beaux-Arts, 1862, T.XIII, juillet, pp.71-82; I - Gazette des Beaux-Arts, 1862, T.XIII, septembre, pp.249-255. Artigos reunidos e reimpressos em: VITET, Louis; VIOLLET-LE-DUC, Eugène. $\dot{A}$ propos de l'enseignement des arts du dessin. Préface Bruno Foucart. Paris: École Nationale Supérieure des Beaux-Arts, 1984.

${ }^{97} \mathrm{~A}$ École spéciale de dessin et de mathématiques appliqués aux arts industriels havia recebido o apelido de Pétite 
deveria mirar para reformar o ensino artístico, e afirmava que ela estava, "quanto à instrução da juventude, meio século à frente da École des beaux-arts." 98

A razão não era muito difícil de se imaginar, nem o motivo que o levara de fato a transformar, em 1863, esta instituição em algo como um espelho da sua pétite irmã menos afamada. Já no fim dos anos 1850 e início dos anos 1860, quando se discutiam a crise da "grande arte", o perigo da indústria inglesa, e a necessidade de se ampliar e modificar o sistema artístico francês para fazer frente dupla a essas questões, a Petite École não parava de crescer, formando, por exemplo, a maior parte dos ornamentistas empregados nos enormes trabalhos de expansão e integração do Louvre ${ }^{99}$. Segundo Alain Bonnet, se já nos anos 1850 ela era bastante frequentada, nos anos 1860 as inscrições se elevavam "a uma média de 800 a 1000 alunos por ano", a maioria interessada numa carreira ligada às artes industriais ou aplicadas, enquanto que a École des Beaux-Arts, concentrada no desenho e no seu método tradicional, aceitava pouco menos de 100 estudantes por semestre, estes quase exclusivamente desejosos de fama em uma carreira artística. Esse "sucesso era o fruto de uma reputação bem estabelecida que fazia da [petite] escola um modelo de inovação no aprendizado das artes gráficas e plásticas." "100

O seu programa curricular - deve-se dizer - era, especialmente desde a década de 1850, impressionantemente próximo ao da AIBA reformada na mesma década, com a única exceção do ensino de pintura (inexistente na Pétite École), algo facilmente justificável, posto que uma escola que não pretendia formar necessariamente artistas plásticos. "Sob o Segundo Império", o ensino dessa escola "oferecia o aprendizado do desenho geométrico e o aprendizado do desenho de imitação e, depois de 1863, cursos de escultura e arquitetura."101 No curso de arquitetura eram ensinados conhecimentos sobre a construção (a perspectiva, a quebra de pedra, estruturas [de madeira], estática), além de geometria descritiva e formas de arte decorativas. No curso de escultura se faziam modelos a partir dos antigos, da planta ou da natureza. No primeiro curso de desenho, o geométrico, se estudavam matemática, desenho linear e perspectiva; e no segundo eram oferecidos cursos de desenho de cópia [de imagens], desenho de escultura, modelo-vivo e de plantas. Se ofereciam ainda o curso de história e de composição do ornamento e, desde 1847, o curso de memória.

École por sairem dela numerosos futuros alunos da École des beaux-arts, ou ainda, em contrapartida, por receber tantos outros que, saindo desta última de lá também chegaram "interessados em escapar ao cerco pedagógico da academia ao se benecificiar de um ensinou que havia aumentado consideravelmente desde a época de Bachelier", no século XVIII. BONNET, A. Op cit. p.268.

98 VIOLLET-LE-DUC. Op cit. p111-112.

${ }^{99}$ BONNET, A. op. cit. p.269.

${ }^{100}$ BONNET, A. Op. cit. p.268.

${ }^{101}$ LAURENT, Stéphane. Op. cit. p.28-29. [tradução e grifo nossos] 
Este último se referia, precisamente, ao método de Lecoq Boisbaudran. Em nomenclatura completa, ele visava estimular "A educação da memória pitoresca" ${ }^{102}$. Em relação aos demais cursos vigentes ou recentemente desenvolvidos no período, Boisbaudran havia conseguido criar um método que pretendia não tombar nem no extremo de alguns professores - que propunham soluções rápidas, por meio de recursos geométricos, e julgadas pouco profundas para o problema da formação de jovens -, nem em outro, que assumia criticamente ser o da École des Beaux-Arts, em sua manutenção de um ensino enquadrador e uniformizante, que impedia "de desenvolver e de aperfeiçoar o sentimento individual do artista"103, para ele, ponto capital de qualquer curso artístico. Com efeito, o curso idealizado por Boisbaudran se propunha não dogmático e, mais do que isso, extremamente maleável: "qualquer doutrina de arte, qualquer escola concorrente, qualquer disciplina técnica podia adaptá-lo à sua própria estética e a suas próprias necessidades", na medida em que idealizado enquanto um método que se "limitava a ser uma pura ginástica intelectual.",104

Resumidamente, o cerne desse estava no exercício da memória e, desse modo, da (re)produção mental e prática de imagens, que - na esteira do legado romântico - era compreendida como fundamental ao desenvolvimento da imaginação dos artistas. Aos alunos mais jovens ou inexperientes, Boisbaudran oferecia um modelo para que copiassem atentamente. Depois, no mesmo dia ou no dia seguinte, solicitava que, então sem a imagem que havia servido de modelo, ele refizessem de memória o que haviam feito anteriormente. Para alunos mais avançados - alguns dos quais já mesmo dominando a pintura -, Boisbaudran pedia que fizessem o mesmo, no entanto, com cenas ou composições pictóricas inteiras. Por fim, ele os convidada para saírem da sala em direção a lugares públicos, de dia ou de noite, e para que observassem e memorizassem com atenção as impressões que viam (sem efetuar quaisquer esboços). Depois, eram convidados a desenharem o que haviam observado. Ele poderia ainda pedir que se vestissem algumas pessoas em costumes históricos, e que agissem normalmente (gesticulando, caminhando etc.) para que seus alunos, também memorizando essas cenas, pudessem, em seguida, realizar composições mais naturais, afastadas das poses duras e convencionais do método acadêmico. $^{105}$ (fig.6.1, fig.6.2, fig.6.3, e fig.6.4)

A despeito de sua celebridade crescente desde a sua inauguração, o curso de Boisbaudran, de 1847 até

${ }^{102}$ LECOQ DE BOISBAUDRAN, Horace. L'education de la mémoire pittoresque et la formation de l'artiste. Paris: H. Laurens, 1920. O texto foi editado pela primeira vez no mesmo ano de sua abertura, na Petite École, em 1847. Reeditado, sintomaticamente, durante os debates sobre as reformas do ensino em 1862.

${ }^{103}$ Idem, ibidem. p.82.

${ }^{104}$ BONNET, A. op. cit. p.268.

${ }^{105}$ Para uma apreciação mais detida do método de Boisbaudran, ver: LECOQ DE BOISBAUDRAN, H. Op. cit.; e ainda REGAMEY, Félix. Horace Lecoq de Boisbaudran et ses élèves - notes et souvenirs. Paris : H. Champion, 1903. 
1863 (ano sintomático), não fazia parte, paradoxalmente, do curso oficial da Petite École, mas era oferecido permanentemente como uma disciplina optativa.

Para Viollet-Le-Duc era, pois, a "cereja do bolo" de suas intenções reformistas na École des BeauxArts. Ainda na mesma série de textos preparatórios à reforma desta instituição, o arquiteto não apenas enaltecerá o trabalho de Boisbaudran como requererá que este faça parte da comissão de avaliação do ensino artístico então em curso. Seu método se trataria, para Viollet-Le-Duc, de "uma das mais férteis inovações de nosso tempo" ${ }^{106}$, porquanto destinado a exercitar a inteligência e imaginação dos alunos, e não apenas as suas mãos.

Desde 1858, Viollet-Le-Duc havia saído publicamente em defesa do método e das capacidades de Boisbaudran, opondo-o à metodologia tradicional ensinada na École, e nos demais estabelecimentos que lhe eram subsmissos.

Sobre o método tradicional dessa institução, ele irá afirmar:

Nós todos sabemos como se ensina a arte do desenho: coloca-se frente aos olhos das crianças modelos gravados ou litografados, començando pelas reuniões mais simples de linhas até a representação modelada da figura humana; quando o aluno consegue copiar razoavelmente os modelos gráficos, se o coloca em frente a um relevo moldado, depois em frente à natureza viva. Esse método que não é novo, e que por ser antigo não é o melhor, habitua a mão a reproduzir as formas que os olhos percebem, mas ele exercita muito pouco a inteligência dos alunos. De fato, quantas crianças não existem que são hábeis em copiar maquinalmente os modelos que lhe são apresentados, mas que jamais compreendera os planos, o efeito de sombras e luzes; que jamais se deram conta intelectualmente do modelo, da perspectiva; para quem a arte de copiar apenas um tipo de reflexo mecânico a natureza! Ora, é certo que na arte do desenho, a inteligência, a compreensão da forma é necessária para guiar a mão, que é tão somente uma ferramenta mais ou menos perfeita. ${ }^{107}$

Em contrapartida, quando tratando dos resultados do método de Boisbaudran, não exitará em afirmar que o que distinguiria os desenhos

feitos sobre a natureza impressa na memória de nossos jovens artistas são qualidades que nos faltam (desde há muito tempo) na França: a simplicidade, a gravidade e o colorido sólido que nos dá sempre a natureza, a verdade sem trivialidade. Remarquemos bem que não se tratam aqui de obrasprimas, mas que de esboços feitos por jovens de 18 a 20 anos, que serão, a maior parte, estofadores ou papiers, tapeceiros, decoradores. ${ }^{108}$

Em uma apreciação conclusiva, e não sem importância, Viollet-Le-Duc julgava que o sucesso desse

${ }^{106}$ VIOLLET-LE-DUC, E. E. op. cit. p.112.

${ }^{107}$ VIOLLET-LE-DUC, E. E. "Um cours de dessin". In: L'Artiste, Paris, 05 de novembro de 1858. p.154-55.

${ }^{108}$ Idem, ibidem. p. 155 . 
método - que aliás ele próprio utilizava com seus alunos quando professor da Petite École ${ }^{109}$-, além da inovação apresentada, era fruto do tino de Boisbaudran, que sabia escolher o tema a seus alunos e dirigi-los no sentido de suas próprias faculdades naturais, evitando quasiquer banalidades. E seria justamente por todo esse conjunto raro encontrado na figura de um único docente que o arquiteto considerava "desejável que a École des Beaux-Arts incorporasse ambos professor e método"110.

Especialmente em relação aos procedimentos desenvolvidos por Boisbaudran, a defesa de Viollet-LeDuc estava longe de ser uma voz isolada. Dos novos cursos e métodos de desenho desenvolvidos no período que abrangia os anos 1840 a 1860, tratava-se, na verdade, do único unanimemente ovacionado $^{111}$ : palmeado pelas sociedades industriais, pela Légion d'Honneur, por professores da École des Beaux-Arts e, mais importante, até mesmo pela Académie des Beaux-Arts - com a significativa diferença de que onde Viollet-Le-Duc desejava substituir o método tradicional pelo de Boisbaudran, a Académie parecia demonstrar interesse em incorporá-lo ao seu, já que poderia utilizar suas técnicas para reforçar nos alunos a lições da arte clássica feitas e refeitas nos 7 anos de curso normal.

Em 1851, a convite mesmo desta instituição, Boisbaudran submetia seu método ao exame de uma comissão (formada pelso acadêmicos Horace Vernet, Auguste Coder e Robert Fleury - este último, como visto, o futuro diretor da École pós-reformada). O parecer final era farovável ao exercício do método de Boisbaudran ${ }^{112}$, mas essa deliberação não era apresentada sem antes garantir que o novo método não se tratava de uma ameaça à supremacia das diligências acadêmicas:

Longe de se fazer valer mais do que convêm tão felizes resultados, o Sr. Boisbaudran não pretende, de modo algum, que o seu método seja unicamente empregado como uma novidade que libere os alunos dos estudos ordinários e praticados a todo tempo; não, o Sr. Boisbaudran pretende somente dar o meio de cultivar com método a memória dos jovens alunos ${ }^{113}$.

Em 1852, na sequência dessa primeira apreciação artística, positiva e oficial, Boisbaudran tornara-se então interessado em também "obter uma constatação [oficial] da eficácia [do seu método] para a educação das artes industriais" ${ }^{114}$, requerendo assim à Société d'Encouragement pour l'Industrie

${ }^{109}$ Sobre a utilização que Viollet-Le-Duc faz do método de Boisbaudran em seus cursos da Petite École, ver: LENIAUD, Jean-Michel (dir.) Viollet-Le-Duc: les visions d'un architecte. [Exposition, Paris, Cité de l'architecture et du patrimoine, 20 novembre 2014 - 9 mars 2015]. Paris: Norma / Cité de l'architecture et du patrimoine, 2014.

${ }^{110}$ VIOLLET-LE-DUC. Op. cit. p.156.

${ }^{111}$ Ver, por exemplo: BONNET, A. Op. cit. pp.265-270.

112 ROCHETTE, Raul. "Rapport de la Académie des Beaux-Arts sur la méthode d'enseignement de M. Lecoq de Boisbaudran, professeur à l'École spéciale de Dessin." In : LECOQ DE BOISBAUDRAN, H. op. cit. p.59. O rapport original encontra-se nos Archives Nationales de France, cota AN F ${ }^{21}$ 491, dr. III.

${ }_{113}^{13}$ Idem. Ibidem. p.59.

${ }^{114}$ Idem, ibidem. p.59. 
Nationale que se manifestasse a respeito.

Além de se dirigir à Petite École para assistir os alunos do pedagogo trabalharem, representantes da Société, desejando certificarem-se do impacto real que o método de Boisbaudran exercia sobre memória dos estudantes, propuseram assim um concurso contra, precisamente, os alunos da École des Beaux-Arts.

O primeiro professor convidado a apresentar seus alunos foi, curiosamente, o professor de Victor Meirelles dali a pouco tempo, e também futuro mestre de Pedro Américo, Léon Cogniet, que se recusara, todavia, a entrar na disputa. A razão era oferecida por uma resposta franca:

Eu percebo a prova proposta como supérflua: eu não conheço nenhum de meus alunos capaz de se apresentar com vantagem em um concurso de imitação de memória com os alunos os mais exercitados e hábeis do Sr. Boisbaudran. Eu não posso convidar, portanto, nenhum deles a tomar parte numa luta desigual cujo resultado é certo, luta que eu mesmo, pessoalmente, não aceitaria.

Eu mesmo exercitei bastante minha memória, e talvez com alguns frutos. Tenho frequentemente incentivado meus alunos a fazê-lo; mas nem eles, nem eu, temos feito com tanta frequência e método para pretender, na falta do modelo, os resultados que se aproximem de tamanha exatidão matemática dos resultados apresentados pelo Sr. Boisbaudran e constatados pela Académie des Beaux-Arts.

Eu autorizo ao Sr. Boisbaudran a fazer dessa declaração o uso que julgar mais conveniente. ${ }^{115}$

O segundo professor convidado, François-Édouard Picot, embora também pensasse que seus alunos não estivessem suficientemente preparados para uma tal disputa inesperada, aceitou ingressar na contenda, "achando-a, entretanto, interessante e instrutiva."116 Como resultado, a vitória, já esperada, havia sido dada com folga aos alunos de Boisbaudran.

Ambas as aprovações oficiais, ainda que massageassem sem dúvida o ego de Boisbaudran, eram também apresentadas como apêndice de suas publicações no sentido de garantir o aviso de outros sobre a capacidade de exatidão à qual as suas lições podiam chegar, mas, sobretudo, de mostrar a potência de um método "verdadeiro" que, no entanto, sem nenhuma imposição de amarras estéticas, estimulasse sobretudo a inteligência, individualidade e originalidade dos alunos - capacidades então pensadas como fundamentais à imaginação:

O princípio fundamental do meu método é que a memória e inteligência devem sempre ser cultivadas

\footnotetext{
${ }^{115}$ Idem, ibidem. p.61.

${ }^{116}$ Idem, ibidem. p.61.
} 
simultaneamente, e de tal maneira que o desenvolvimento de uma serve ativamente ao desenvolviento da outra.

De resto, eu proponho ordinariamente meus meios aos alunos sem lhes impor nada, a fim de não incomodar o trabalho intelectual deles, e de deixá-los seguir livremente a marcha que lhes é própria. ${ }^{117}$

Uma tal sequência de frases, em especial a última, não deverá exatamente chocar se lembrar em alguma medida a frase categórica que o jovem Américo havia publicado, em 1863, em sua brochura sobre a reforma da École: "Que os alunos escutem as doutrinas as mais opostas [...] cabe ao temperamento de cada um, a seu caráter, enfim a seu gênio, escolher o que lhe convém melhor; porque a natureza deve seguir livremente seu caminho para chegar a um grande resultado, qualquer que seja." ${ }^{118}$ Não é difícil imaginar que o brasileiro - em meio a todos os debates que tanto lhe interessavam e a todos os textos que lia para preparar suas Considerações Filosóficas - tenha lido a segunda e recente reedição que Boisbaudran fazia, em 1862, do seu L'éducation de la mémoire pittoresque, na sequência dos encômios feitos a ele por Viollet-Le-Duc, que o colocavam, 10 anos depois daquelas aprovações da Académie e da Société d'Encouragement, de volta ao foco dos debates artísticos na França. E talvez seja ainda menos dificil - para não dizer quase certo - imaginar que Américo tivesse visto com seus próprios olhos o método de Boisbaudran e ouvido diretamente as suas próprias palavras condescentes de teor algo eclético. Acontece que o jovem brasileiro, se se lembra, estava de fato matriculado na Petite École desde junho de 1860, quando se preparava para sair da École des Beaux-Arts durante pouco mais de um ano, para "cultivar sua inteligência", alargando seus conhecimentos artísticos e, sobretudo, científicos, que lhe eram ademais bastante favorecidos Pétite École, ao contrário da sua “irmã" ilustre.

Considerando tudo o que o jovem defendeu em seus textos (a saber novamente: a imaginação, a liberdade e a originalidade artística, além da fusão da arte na indústria) é muitíssimo provável, muito mesmo, que ao propor, portanto, aquelas "graves mudanças no método de ensino" da AIBA, ele estivesse com os olhos colados no método de Boisbaudran, método de perfeita adaptação, também do ponto de vista filosófico, à bandeira que hasteava ao ecletismo.

\footnotetext{
${ }^{117}$ Idem, ibidem. p.58.

118 AMÉRICO, P. La réforme de l'École des Beaux-Arts et l'oppositon. Idem, ibidem. p.12.
} 
Para concluir esse tópico, há ainda uma última mudança que o brasileiro deveria querer incluir em seus planos de mudança no currículo da academia brasileira; e essa, possivelmente, se trataria de um complemento a seu projeto que pretendia fomentar a inteligência dos jovens alunos: a expectativa de suas educações frente ao conhecimento histórico, estético e arqueológico.

Como visto, Viollet-Le-Duc havia inaugurado o seu curso de Estética aplicada às belas artes, em 1864, clamando-o aberto a todos, sem distinção de especialidade artística nem graduação: todos eram convidados ao anfiteatro da École para tomarem notas de suas lições.

Porto Alegre, por sua vez, ao criar a cadeira de História das Belas Artes, Estética e Arqueologia, mesmo sem inaugurá-la antes de sua abrupta saída, havia deixado sancionado nos estatutos da reforma que "nenhum aluno poderá ser admittido a este curso, sem que tenha três anos completos de estudos na Academia"119. A medida definia, naturalmente, seu público: as lições dessa cadeira estavam reservadas aos estudantes de arte (não aos artesãos inscritos no curso técnico) e, mais especificamente, àqueles que almejavam obter o Prêmio de Viagem. Elas deveriam antecipar, portanto, aos futuros vencedores, conhecimentos teóricos e históricos em arte, fornecidos por meio de aulas que uniriam "exposições orais" a "demonstrações gráficas e plásticas".

A manutenção de uma separação compulsória entre aqueles poderiam obter lições teóricas e filosóficas e aqueles que não podiam devia parecer absurda a Américo. Afinal, o seu projeto não se tratava de um em que a educação moral e artística era fundamental a todo e qualquer tipo de artista, como maneira de alargar suas razões e de mudar seu indesejado lugar social no Brasil?

É difícil que o jovem concordasse com uma tal medida instaurada na reforma de 1855, e provável que ela também entrasse na sua exigência de aterações do método geral de ensino artístico. $\mathrm{O}$ fato de que ele próprio tenha pedido a transferência para o curso noturno da cadeira de História das Artes, Estética e Arqueologia ${ }^{120}$, logo após a abertura que fará dela para o curso diurno, em março de 1870, parece reforça essa hipótese. Ainda mais se se considera que a motivação para essa mudança se amparava em um problema de ordem numérica: precisamente naquele momento, a AIBA contava com quase 300 alunos inscritos no curso noturno, todos do curso técnico: número quase quatro vezes maior que o

${ }^{119}$ FERRAZ, Luiz Pedreira do Coutto. Decreto $n^{\circ} 1.603$, de 14 de Maio de 1855, Dá novos Estatutos á Academia das Bellas Artes. Título V, seção XIII. arts.45 e 46. Disponível online em: http://www2.camara.leg.br/legin/fed/decret/18241899/decreto-1603-14-maio-1855-558536-publicacaooriginal-79876-pe.html [último acesso em 28 de março de 2016].

${ }^{120}$ SANTOS, Thomás Gomes dos. "Minuta de ofício da Academia ao ministro do Império, apresentando a tabela elaborada pela Congregação de professores para o próximo ano letivo, dias e horários, solicitando a transferência da cadeira de História das Belas Artes, estética e arqueologia para a noite, e informando que foi designado o professor honorário, Domingos de Araújo e Silva, para substituir o professor de Arquitetura que se encontra de licença." Rio de Janeiro, M.D.J./UFRJ, documentos avulsos, cota: 5811. 
número de inscritos no diurno - os quais, a propósito, não raro frequentavam em concomitância ambos os cursos ${ }^{121}$.

Ir atrás de um rebanho em número maior possível deveria ser a única coisa certa a fazer, sobretudo se se tratando de um “pastor” ávido por “catequizar” todos, sem distinção, na religião filosófica da artes.

\section{- "Equiparação completa" dos professores da AIBA às demais "academias ou faculdades do império"}

A revalorização social do artista permanece, como visto, tema constante nas argumentações do jovem Américo, e ainda se encontrará na última proposta do seu projeto político, apresentado no Cartas de um Plebeu. Se todas as demais mudanças visadas lidavam com o problema em uma perspectiva estrutural, na qual as esferas culturais e sociais eram as mais recorrentemente problematizadas, tratava-se agora de uma proposta de mudança precisa, notadamente institucional: igualar o status dos docentes da Academia de Belas Artes ao dos professores de demais instituições de ensino do império. O emparelhamento era bastante preciso: não se faria em relação aos docentes de quaisquer instituições, mas aos de ensino superior, demanda que garantia mais uma vez a já discutida compreensão que Américo possuía da arte enquanto uma atividade liberal, que deveria estar, portanto, alinhada às mesmas considerações dispensadas aos bacharéis do país.

O jovem artista e filósofo, mais uma vez, revisitava reivindicações feitas anteriormente por outros agentes no Brasil. Se o problema já estava presente na época em que Porto Alegre era diretor - ele havia tentado aumentar, sem sucesso, o salário dos professores na reformade $1855^{122}$, num momento em que a receita da academia havia aumentado consideravelmente -, estava presente ainda antes, nos anos de F.-E. Taunay à frente da instituição. Segundo Elaine Dias, os críticos contemporâneos a Taunay (e este próprio) reclamavam, já na primeira metade do século XIX, a verba escassa enviada à AIBA e os baixos salários conferidos a seus professores, o que corroboraria o pouco prestígio de que dispunham e ainda a atuação paralela que vários faziam em outras profíssões, no sentido de complementarem suas rendas $^{123}$.

Em 1865, pouca coisa parecia ter mudado para Américo:

\footnotetext{
${ }^{121}$ Os dados completos são fornecidos por Rafael Cardoso, em triagem de bibliografia e documentos primários do Museu d. João VI, no artigo: CARDOSO, Rafael. “A Academia Imperial de Belas Artes e o Ensino Técnico". 19\&20, Rio de Janeiro, v. III, n. 1, jan. 2008. Disponível em: <http://www.dezenovevinte.net/ensino_artistico/rc_ebatecnico.htm>.

122 SQUEFF, Letícia. "A Reforma Pedreira na Academia de Belas Artes (1854-1857) e a constituição do espaço social do artista." In: Cadernos Cedes, ano XX, n.51, novembro de 2000, p.115.

${ }^{123}$ DIAS, Elaine. Paisagem e academia: Félix-Émile Taunay e o Brasil (1824-1851). Campinas: Unicamp, 2009.
} 
Ora, acresce mais que, empregando raramente o artista, ao mesmo tempo que entretém alguns de entre os mais hábeis com um pequeno salário, desproporcionado às incumbências de que estão sobrecarregados, o governo concorre para acostumar o público a considerá-los homens indiferentes à nação, e por consequência inferiores no préstimo individual aos que seguem outras carreiras igualmente liberais. É o que na realidade acontece; e como dos artistas às belas artes há correlação imediata, são estas consideradas quais subalternas ocupações, sem influência alguma na vida pública, e por esta razão sem dignidade social. ${ }^{124}$

Para o jovem, continuava a ser fundamental reavivar as reivindicações dos antigos diretores da academia, pedindo que o governo reconhecesse na atividade dos seus professores uma mesma importância institucional que dava aos docentes das outras "academias e faculdades do império". Não haveria dúvida de que, no conjunto de homens livres no Brasil, o abismo erigido entre os extremos do bacharelismo/doutoramento e o analfabetismo abraçava, em algum lugar incerto entre suas extremidades, os professores da academia. Para que passassem a receber a devida consideração social, juntamente com a importância das suas funções, deveriam ser transpostos ao primeiro lado, e dessa ação, concorrendo com as demais do seu projeto, deveria se seguir de uma completa mudança no valor social dos artistas no país.

Para Américo, esse se tratava de um problema sério, vivido com intensidade em nível pessoal. Ao longo desta Tese se referiu algumas vezes a importância que ele conferia, já no início de sua carreira, logo que havia chegado ao Brasil, ao título de bacharel, que teria conquistado em sua formação científica em Paris, antecipando esse título a seu nome todas as vezes que assinava publicações ou notas na imprensa brasileira. Até que se chegasse o momento em que os professores da AIBA poderiam se ver nivelados aos demais professores-engenheiros, médicos e advogados, sendo dignamente recebidos no país pela ostentação dos diplomas de suas próprias áreas, a estratégia do jovem, que havia escolhido ser reconhecido como um artista-intelectual, era a de utilizar as mesmas armas que lhe infligiam problemas.

Mas essa insistência terá um preço. À força de aferrar-se em sua condição de bacharel no sentido de elevar a sua consideração social enquanto artista, Américo despertará, justamente, a sanha de outros artistas que, não compartilhando a mesma visão do seu projeto, tomaram a sua postura como pedantismo, principalmente quando descobriram que o título que ele bradava não era formalmente validado. Isso lhe deve ter parecido uma reviravolta inesperada, e os efeitos dessa oposição- sem

${ }^{124}$ AMÉRICO, Pedro. "Cartas de um Plebeu aos Srs. Deputados. Segunda Carta" . Correio Mercantil. Rio de Janeiro, 21 de maio de 1865. p.3. 
dúvida, também contra o seu projeto -, serão recorrentemente lembrados em sua carreira, como será visto no capítulo seguinte, o último desta Tese.

Américo deu a cara a tapa, mas esse parecia ser, de fato, o único meio possível para um jovem ambicioso que sabia o lugar que queria ocupar nas artes brasileiras, e que tinha um objetivo bastante claro, que ultrapassava o seu ofício unicamente artístico.

\section{Um projeto arquivado}

Consideradas em sua totalidade, as propostas que Américo apresentava eram, no mínimo, interessantes, e bastante ousadas, sobretudo se se pensa que apenas durante a República o projeto de horizontalização e universalização do ensino do desenho no Brasil, por ele imaginado, seria posto em prática.

Aparentemente, o projeto do jovem deveria ser ainda melhor detalhado na sequência de outras cartas. Ele afirmou pretender ainda desenvolver individualmente suas ideias, tendo conseguido fazê-lo apenas com a primeira das quatro ações sugeridas, pois assunto da sua Quinta Carta. Com efeito, no fim desse texto, ele indicava que "este e os assuntos que ainda ei de tratar merece a vossa ilustrada atenção" 125 ; mas estranhamente não os continuou, sendo mesmo aquela a sua última investida.

Ainda que suas ideias tivessem sido lançadas publicamente com êxito, a impressão era a de que um rastro havia ficado para trás. Difícil saber o quanto; difícil saber exatamente a razão. O fato é que, na prática, elas não atingiram positivamente ninguém. Ou então, se atingiram, não retornaram qualquer resultado benéfico aos intentos primeiros do artista, logo em seguida empossado professor da AIBA. De todas as suas propostas, o mais próximo que ele conseguiu pôr em prática - contudo não em seguida, em 1865, mas apenas em 1870 - foi a inauguração do curso de História das Belas Artes, Estética e Arqueologia, um curso cuja sua história foi, até pelo menos os anos 1880, de permanente instabilidade, com frequentes licenças de Américo, falta de substitutos, ou mesmo falta de alunos.

Permaneceu, entretanto, o projeto (em seu propósito de projétil, de se lançar para o futuro), do qual Tese se esforçou em expor e clarificar um número considerável de dimensões. Mesmo que as ambições reformistas do jovem artista, da maneira como esperava, não tenham nunca tido qualquer lugar de aplicação positiva no cenário das artes no Brasil, sua defesa da educação como uma importante ferramenta para a mudança social dos artistas no país ofereceu de fato pelo menos um representante concreto de sua potência, encontrando o próprio Américo como exemplo.

${ }^{125}$ Idem. [Quinta carta]. Correio Mercantil. Rio de Janeiro, 29 de junho 1865. p.2. 


\section{Sétimo Capítulo}

\section{O desfecho de um projeto: a um triz do xilindró, ou Pedro Américo e a "Questão de Bacharéis".}

\section{Prólogo dos bacharéis}

Do momento em que concluía todas as etapas do concurso para professor da AIBA e que terminava de publicar, em meados de 1865, suas Cartas de um Plebeu, expondo a todos os seus projetos para a arte brasileira, Pedro Américo estava há poucos meses de retornar, mais uma vez, à Europa. O interesse nesse retorno já havia sido curiosamente manifestado a Jacques Brunet, ainda em 1864, logo após a sua chegada ao Brasil $^{1}$ e antes de assumir quaisquer compromissos no país. Entretanto, seriam ambos o malogro na apresentação do seu projeto e, sobretudo, as consequências das movimentações que havia feito para essa exposição que anteciparam, sem dúvida, a data do novo embarque.

Tais consequências vieram em forma do pior problema da qual Américo haveria de participar em sua carreira, sucedido no início de 1866 - muito rapidamente pincelado em suas primeiras biografias, com um tom no qual o jovem é apresentado simplesmente como vítima gratuita de mofineiros que desde logo invejaram o seu "duplo caráter de pintor e escritor" ${ }^{2}$. O sufoco pelo qual

\footnotetext{
1 "Meu caro amigo, passando por Pernambuco apenas algumas horas, não é me possível ir dar-lhe um aperto de mão; queira, pois, me desculpar esta vez, pois não é ingratidão de minha parte. Daqui uns dois ou três meses estarei em Pernambuco, pois já lhe disse, devo visitar minha família na Paraíba antes de voltar à Europa.” AMÉRICO, Pedro. "Carta a Jacques Brunet, escrita a bordo do navio Guyenne, 11 de setembro de 1864." In: AMÉRICO, Pedro; MELO, Aurélio Eduardo de Figueiredo e; BRUNET, Louis Jacques. Cartas de Pedro Américo de Figueiredo e Melo e Daniel Eduardo de Figueiredo e Melo a Louis Jacques Brunet .Volume 96 de Coleção Mossoroense. Mossoró: Editora Fundação Vingt-un Rosado, 2001. s/p.

2 Com efeito, na biografia escrita por Cardoso de Oliveira, a única menção a críticas feitas a Américo no período que intercala sua chegada ao Brasil e seu rápido retorno à Europa aparece em breves alusões, segundo as quais ele, em algum momento entre 1864 e 1865, teria sido gratuitamente atacado por indivíduos que invejavam seus dotes artísticos e suas capacidades intelectuais. Nada é comentado ou precisado para além do fato de que ele, naquele momento, experimentaria uma fase cujo desfecho é semelhante ao da paixão cristã: "Soara, porém, para o artista, a hora fatídica da glorificação pelo martírio, a inevitável crucificação do Gênio.” OLIVEIRA, J. M. Cardoso de. Op. Cit. p.44. Tais acusações teriam magoado tanto Américo, que, para seus biógrafos, tornariam-se o ponto capital para explicar seu retorno à Europa. Os trechos escritos por Cardoso de Oliveira sobre o assunto são os seguintes: "A esperança de um acolhimento fraternal e lisonjeiro por parte de colegas e amigos, e a firme resolução que tomara de ser útil ao desenvolvimento das artes brasileiras, prometiam ao seu espírito entusiasta suaves compensações! Alma de criança, cérebro de poeta, coração feito de arminho, de uma brancura jamais poluída pelo pó sutil e infectuoso da maldade, não podia contar com a obra, torpe e solapadora, dos sentimentos pequeninos, incapaz, como era de nutri-los. Ingênio artista! Quimero sonhador!". Idem, ibidem. p.42. "Continuando cada vez mais renhida a campanha de descrédito, sentia-se Pedro Américo no Rio de Janeiro falto de ar e de espaço, como dentro da acanhada jaula de um leão atordoado pela gritaria e magoado pelas pedradas de garotada infrene. Assim como o nobre animal, de tal forma encurralado, quereria respirar o ar livre das florestas onde viera, o artista sentia a necessidade de viver em um ambiente não saturado de miasmas tão deletérios para sua alma leal e impressionável. Resolveu, pois, voltar para Paris, onde o seu mérito fora devidamente aquilatado.” Idem, Ibidem. p.45.

Oliveira havia, na verdade, retomado aquilo que havia escrito, primeiro, Guimarães Júnior. Este afirmava sobre o assunto, sem contudo precisar qualquer data: "A guerra surda que desde a chegada de Pedro Américo forjavam os
} 
Américo iria passar dispôs até mesmo de um título, dado já à época: a "questão de bacharéis". Tratou-se esta de uma questão extremamente delicada, na qual ele e um de seus melhores amigos na AIBA e na Europa, Daniel Pedro Ferro Cardoso, foram objetos e alvos. Dela participaram, direta ou indiretamente não apenas bacharéis, mas ministros, marqueses e mesmo professores da Academia de Belas Artes, coroando e encerrando negativamente o primeiro ciclo de formação de Américo. Sem dúvida por isso essa "questão" foi limitada a comentários vagos e desacertados em suas primeiras biografias. De outro modo, se a tivessem contado, seriam obrigadas a se deparar com as dezenas de reclamações e acusações que foram publicamente encetadas contra os dois jovens amigos, e a lidar com resultados que poderiam atrapalhar a "ilusão retórica" do artista "gênio", incorruptível, que Américo e seus aliados construiram em torno de sua figura; poderia também trazer à tona seus rivais (fatalmente descobertos no futuro) e as ações que o próprio Américo, com a ajuda de outrem, empreendeu para revidá-los ou solapá-los.

É disso, portanto, que trata o último Capítulo desta Tese: a infeliz conclusão dos projetos imaginados pelo jovem na primeira fase de sua carreira. Ainda que se apresente como um epílogo infeliz aos planos do artista-filósofo, jamais estudado, os eventos que o compõem elucidam de maneira significativa não apenas a recepção de suas ideias no contexto brasileiro, mas iluminam a complexa tecitura do bastante heterogêneo cenário das artes no Brasil do século XIX, juntamente com suas rixas, seus problemas reincidentes e ainda seus preconceitos.

\section{Dados essenciais que antecederam a "questão dos bacharéis"}

Contudo, antes de ingressar propriamente nesse desfecho é necessário ampliar e "corrigir" os dados relativos ao período que compreende a chegada de Américo ao Brasil, a apresentação de suas primeiras obras originais e o seu retorno à Europa (dados expostos nas primeiras biografias do artista e repetidos na grande maiorias das posteriores), e confrontá-los com uma sorte mais extensa

\footnotetext{
inimigos anônimos ou mascarados, começou a agitar-se e a revelar-se em mofinas nos jornais diários ou artiguetes, em que o fel e a acrimonia faziam a melhor parte do estilo e da ciência. O duplo caráter de pintor e escritor foi suficiente para atiçar o ânimo dos invejosos, e dos que pretendem negar salvação, perdão e respeito a todo aquele que busca elevar-se acima do nível da mediocridade, e ambicionar os louros da glória e do triunfo. Durante dois longos meses, em que a amargura e as santas cóleras encheram a transbordar a alma do artista, os mofineiros e cavalheiros das trevas atassalhavam o nome do autor do Alcibíades em mais de três colunas de impressão tipográfica. O desânimo - quem não sentiu um dia o desânimo penetrar-lhe na alma? - apoderou-se do espírito de Pedro Américo, e à semelhança de Galileu, Copérnico, e entre nós Porto Alegre, o artista teve ímpetos de calcar os pés a tela e o pincel, origem de seus negros desgostos.” GUIMARÃES JÚNIOR, Luiz. Pedro Américo. Rio de Janeiro: Henrique Brown, 1871. Pp.61-62.
} 
de eventos que precederam e, em alguns momentos, parecem ter sido a causa para os desdobramentos da "questão des bacharéis"3.

A cronologia revista, a partir do momento que Américo prepara-se para tornar ao Brasil, em 1864, segue da seguinte maneira:

Ainda na França, após pedidos ao Imperador para que esse estendesse mais uma vez sua estadia européia, se lhe determina que volte ao país para participar do concurso da AIBA. Com o retorno inevitável, o artista enviava ao Correio Mercantil as suas Considerações Filosóficas das Belas Artes entre os Antigos, como visto, entre setembro de dezembro de 1864. Em todos os artigos, se se lembra, assinava em capitulares: BACHAREL AMÉRICO.

Ainda novembro em 1864, alguns jornais cariocas noticiavam que o "Sr. Bacharel" Pedro Américo havia recebido do Papa as insígnias da Ordem de Cristo da Palestina ${ }^{4}$, em função de uma refutação que havia escrito no mesmo ano à Vida de Jesus, de Ernest Renan ${ }^{5}$. Outra informação noticiada nos jornais, no mesmo mês, acusava a nomeação do "comendador Pedro Américo" para a Sociedade Auxiliadora da Indústria Nacional, por indicação do "Sr. Bacharel Daniel Pedro Ferro Cardoso"

Alguns dias depois dessa nomeação, embarcava para a Paraíba, de onde retornava em 14 de Janeiro de 1865, momento a partir do qual expunha, como visto, A Carioca, oferecia essa obra e o manuscrito das Considerações Filosóficas, e respondia energicamente, assinando-se novamente "bacharel”, as apreciações lançadas ao seu quadro pelo crítico Gonzales Coques.

Em fevereiro, com a abertura da Exposição Geral de Belas Artes, a Carioca era novamente exposta, com a autoria atribuída ao "Bacharel Pedro Américo de Figueiredo e Mello".

3 Os dados aqui apresentados foram resultado de extensa pesquisa realizada nos documentos pertencentes ao Museu d. João VI (EBA-UFRJ), e em diversos periódicos publicados entre os anos 1864 e 1867, pertencentes à Biblioteca Nacional e à Biblioteca Mario de Andrade, em São Paulo. Destacam-se, sem dúvida, pela importância no período, o Jornal do Commércio e o Correio Mercantil, ambos jornais publicados no Rio de Janeiro. Contudo, dados complementares foram encontrados em demais jornais da corte (como a Semana Illustrada, o Diário de Rio de Janeiro, Correio da Tarde e Opinião Liberal e), e em periódicos de outros estados do Brasil. Entre eles: O Publicador (Paraíba), $O$ Liberal (Recife) e O Ipyranga (São Paulo).

Devido à grande quantidade de material levantado para a produção deste texto, e julgando inviável trabalhar detidamente todas as fontes, sobretudo no que se refere às dezenas de artigos de periódicos que envolvem a "questão de bacharéis", optei por estudá-los a partir da aproximação de tópicos e blocos de ideias em que recorrentemente coincidem. Essa estratégica, ao lado da organização cronológica de todo o material, permitiu (acredito) que compreender mais claramente os problemas debatidos ao longo dessa "questão".

4 Cardoso de Oliveira a chama de "insígnia da ordem do Santo Sepulcro". OLIVEIRA, J. M. Cardoso de. Op. Cit. p.36.

5 “Atos Oficiais". Correio Mercantil, Rio de Janeiro, 17 de novembro de 1864, p.1.

6 "Notícias Diversas".CORREIO MERCANTIL, Rio de Janeiro. 18 de novembro de 1864. P.2. 
De maio a junho de 1865 realizava o concurso na AIBA, publicando ainda o Cartas de um Plebeu.

Em 01 de outubro de 1865, recebia a nomeação ${ }^{7}$ (contudo ainda não a posse) de professor da Academia e, pouco tempo depois, seguia novamente, por breve período, para a Paraíba.

Em 9 de Janeiro de 1866, estava novamente no Rio $^{8}$. Sua passagem era paga pelo Governo da Paraíba, que imprimia em O Publicador: "no paquete - Paraná - surto no porto desta cidade, faça Vmc. dar uma passagem de estado de ré até o Rio de janeiro ao bacharel Pedro Américo de Figueiredo"9.

Em 10 de janeiro de 1866, o Correio Mercantil, o Diário do Rio de Janeiro e o Jornal do Commércio, periódicos que publicavam diariamente as movimentações de embarcações no Porto da cidade, estampavam: "Entradas no dia 9...[vindo dos] Portos do Norte, Dr. Pedro Américo de Figueiredo".

Em 07 de fevereiro, em sessão da Congregação da academia, Américo finalmente tomava posse do seu cargo em cerimônia. Mas essa era a única sessão da Congregação de que participava e apenas de uma parte, pois a reunião já estava quase no fim quando era chamado para ser empossado - antes que partisse para a sua segunda viagem à Europa. Pouco mais de uma semana após a cerimônia ele entrava com um pedido de licença na Secretaria de Estado dos Negócios do Império, administrada pelo Marquês de Olinda, Pedro Araújo de Lima, com o intuito de continuar seus estudos em pintura em Paris (e não mais em ciências, como haviam pedido até então ao imperador). Requeria dois anos de afastamento, sem remuneração.

Em 19 de fevereiro de 1866, Araújo de Lima, também presidente do Conselho de Ministros, estranhamente defere o pedido do artista, encaminhando o expediente para a AIBA. O documento seria lido sem quaisquer comentários ou objeções na sessão da Congregação de 15 de março, precisamente a reunião seguinte à da presença de Américo ${ }^{10}$. O jovem sequer esteve presente na leitura do expediente que autorizava a sua licença. Já havia deixado a corte uma semana antes, tendo seu nome sido arrolado na lista de passageiros que, em 8 de março, seguiam de navio rumo à

7 Américo receberia a notícia, no entanto, em sessão da Congregação de 9 de agosto de 1865 , estando presente na academia esse dia. Havia recebido 9 votos, contra 1 do segundo colocado, Le Chevrel, restando ainda um voto em branco. Uma vez dado o parecer, na mesma sessão a Congregação propunha e aprovava Le Chevrel para professor honorário de pintura. ATAS das Sessões da Conregação e do diretor da Academia Imperial das Belas Artes. Sessão em 09 de agosto de 1865. Rio de Janeiro: Museu d. João VI/ EBA-UFRJ.

8 Américo acompanhava, nessa viagem, Francisco Aureliano, com o intuito de matriculá-lo na AIBA.

9 IDEM AO MESMO... Despaches. O Publicador, ano V, Paraíba, 8 de janeiro de 1866. P.1.

10 ATAS das sessões da congregação e do diretor da Academia Imperial de Belas Artes. Sessão em 15 de março de 1866. Rio de Janeiro: Museu d. João VI/ EBA-UFRJ. 
Paraíba. Acompanhava "um irmão", sem dúvida Francisco "Aureliano"11, futuro pintor, quem trouxera à corte dois meses antes a fim de matriculá-lo na Academia ${ }^{12}$.

Américo não retornaria mais ao Rio de Janeiro até 1869. Em 1866, de maneira muito discreta, zarpava para a Europa da Paraíba ou, mais provável, do movimentado porto de Pernambuco, todavia em data exata ainda desconhecida ${ }^{13}$. Situação bem diversa, portanto, da sua primeira viagem à França, quando, ainda prometido como novo "gênio" das artes no Brasil, vários periódicos anunciaram entusiasticamente a sua partida.

\section{A “Questão de Bacharéis" e os seus alvos}

A inclusão e o reposicionamento de dados alterados ou omissos nas biografias de Américo, especialmente os que dizem respeito aos três primeiros meses de 1866, não deixa de sugerir um estranho descompasso narrativo que elas, de algum modo, perpetraram: uma semana após tomar posse, depois de quase um ano e meio para a conclusão do processo do concurso (cuja realização havia interessado pessoalmente d. Pedro II) Américo deixa se licencia imediatamente do seu cargo sem quaisquer comentários oficiais ou internos (ao menos nenhum que tenha sido registrado nas atas das sessões da AIBA) com um pedido avalizado pelo ministro de uma da cadeiras mais importantes do império.

No pequeno intervalo de oito semanas, uma série de ações, ordinárias e não ordinárias, incluindo as burocráticas (empossamento, afastamento temporário de cargo, viagens seguidas) corre muito rapidamente, como se os desdobramentos entre um e outro evento fossem conduzidos às pressas. Pois foi justamente nesse curto período que eclodiu e se encerrou (após a viagem de Américo) a chamada "questões de bacharéis", cuja narração coube às colunas não-oficiais dos periódicos cariocas abordar.

Os problemas nela contidos vieram à tona, ao menos publicamente, em 15 de janeiro de 1866, seis dias após a chegada do "bacharel Pedro Américo de Figueiredo" à corte, em nova viagem que havia feito à sua região natal. Nesse dia, um crítico resguardado pelo pseudônimo $O S$. Thomé

11 Posteriormente conhecido também como Francisco Aurélio de Figueiredo e Mello ou, mais correntemente, Aurélio de Figueiredo (1856-1916).

$12 \mathrm{O}$ nome de Francisco Aurélio apareceria dias depois do início da viagem, numa nota dos passageiros que agradeciam todo o cuidado dispensado pelo capitão do navio. Américo também assinava esses agradecimentos. Ver: “AGRADECIMENTO”. Correio Mercantil, Rio de Janeiro, 19 de março de 1866. P.2.

13 Até o fim do ano 1867, o nome de Américo não foi encontrado nas movimentações do porto do Rio de Janeiro, o que leva a crer que ele tenha ido para a Europa de Pernambuco mesmo, após deixar seu irmão em Areia e tratar de alguns negócios na Paraíba do Norte (atual João Pessoa, a $120 \mathrm{~km}$ de Recife). Seria ainda necessário checar o movimento dos portos desses dois estados para confirmar o dia de sua ida ao exterior. 
parece ter se incomodado sobremaneira com a repetida apresentação de títulos atribuídos ao artista (bacharel, comendador, doutor), e assim publicou no Jornal do Commércio:

Atenção

Chegou há dias dos Portos do norte o vapor Paraná, e na relação dos passageiros deparamos com o nome do Sr. Pedro Américo de Figueiredo.

Intitulando-se ele Bacharel, como diversas folhas públicas já o tem qualificado, e não vindo na referida relação semelhante título, alguns curiosos desejam saber da verdade, para não julgarem que seja ele um dos sócios contribuintes da Bélgica.

Rogamos pois ao dito senhor queira ter a bondade de depositar o diploma no escritório desta folha para que fiquemos convencidos da identidade do Título. ${ }^{14}$

O S. Thomé

A resposta de Américo, como costume de sua personalidade, não tardou. No dia seguinte, devolvia à imprensa outra nota:

Ao S. Thomé do Jornal de ontem

Que nos tratem por bacharel ou simplesmente pelo nosso nome de Batismo ou de família, é coisa que nunca daremos o cavaco, principalmente se o indivíduo com quem tratarmos nos conhece pessoalmente. Achamos entretanto conveniente prevenir, esta única vez, ao intrigante anônimo, a quem por nossa felicidade muito bem conhecemos, e cujo nome por desprezo não declinamos aqui, que não só possuímos mais de um documento para prova do que somos, - e quem quiser vê-los venha à nossa casa, na rua Larga de S. Joaquim, n. 148. Mas ainda por honra de nosso título, desafiamos ao S. Thomé do Jornal para tratarmos de qualquer questão de física experimental e matemática, química mineral e orgânica, quantitativa ou qualitativa, botânica e fisiologia animal, astronomia, física, geologia e palenteologia, filosofia natural e história das ciências, perante um conselho de juízes competentes, quais os Srs. Lentes da Academia Imperial de Medicina, e assim provaremos que não somos SÓCIO[s] CONTRIBUINTE[s] DA BÉLGICA, mas por uma universidade francesa que não vende títulos.

O bacharel PEDRO AMÉRICO ${ }^{15}$.

Desse ponto em diante, não havia mais volta. A “questão de bacharéis" estava inaugurada. A seu respeito foram publicados, nos 2 meses seguintes, mais de uma centena de textos em diferentes periódicos, entre notas, artigos médios e longos (seriados e não seriados), alguns dos quais replicados em mais de um jornal ou estampados simultaneamente. Ainda que não seja possível

14 O S. THOMÉ. "Atenção”. Publicações a Pedido. Jornal do Commércio. Rio de Janeiro, 15 de janeiro de 1866.

15 AMÉRICO, Pedro. “Ao S. Thomé do Jornal de ontem” Publicações a Pedido. Jornal do Commércio. Rio de Janeiro, 16 de janeiro de 1866. 
saber o número exato de participantes diretos da contenda (dado que alguns possivelmente valiamse de mais de uma assinatura), apresentaram-se 38 nomes e pseudônimos distintos ${ }^{16}$.

O ponto focal da polêmica parecia ser, a princípio, simples. Américo (inicialmente ele) possuía ou não o direito de apresentar-se bacharel? Isso implicava, naturalmente, em ter um título válido expedido por uma universidade, e, de preferência, uma "respeitável”.

O jovem, segundo defendia, dispunha não de uma formação científica comprada nas “condescendentes" instituições belgas (daí a alusão ao termo "sócio contribuinte"17), mas de uma conquistada em uma "exigente" universidade francesa (a Sorbonne era a referência implícita). Os opositores passaram a, dali em diante, contestar essa afirmação de todas as maneiras possíveis.

Para acreditar em Américo, precisavam ter o título em mãos. Não bastaria ao artista dominar tantas ciências quanto julgava (catorze ao todo, excetuando-se ainda as disciplinas artísticas), sob inquérito de banca julgadora competente. Qualquer um podia, foi dito, "por estudo de Gabinete, saber mais de medicina do que uma escola, mas nem por isso tem o direito de usar o título de Doutor ou Bacharel!"18. Para ser respeitado, tomava-se como necessário que apresentasse a universidade em que se formou bacharel, o dia, e o diploma. Caso contrário, "enquanto o não fizesse, não passaria do pintor Pedro Américo" ${ }^{\text {19. }}$.

Logo de início, a rusga começava a mostrar-se mais grave do que parecia. Com efeito, a “questão de bacharéis" não se referia apenas à ostentação de diplomas, mas sobretudo a uma disputa que problematizava o lugar das artes no campo social brasileiro (sendo o valor conferido aos "diplomas" nesse período um dos seus sintomas, como será visto), e ao novo lugar que Américo manifestava publicamente querer ocupar.

No entanto, antes que o debate mostrasse toda a sua envergadura ainda faltava incluir um segundo nome no alvo das investidas.

16 Além de Pedro Américo e Daniel Pedro Ferro Cardoso, que se apresentam com seus verdadeiros nomes, estão os pseudônimos: O S. Thomé; Ou césar ou João Fernandes; Oh! S. Thomé.; Neu eu; A Opinião Pública; Um que tem título; Se for preciso assinaremos o nome; O charlata; A Justiça Divina; A minha reputação está firma; Gonzales Kocques; Ora Puff; A alma de Gonzales Coques; Gonzales Coques; A Moralidade Pública; Suum Cuique; Bacharel Renato de Guisando; A minha reputação está firmada; O orador de Gondolas; O orador das Gondolas; Francisco Gomes de Freitas; O. M. T. A; Bacharel Unorumquorumqus; Dr. Urso; Castor\&Pollux; Ferro sem ferrugem; Dr. Semana; Um homem de bem; Agora sim, Senhor; Gonzales Coques Júnior; Que Vergonha!; João Fernandes Soladade; Um artista; Sine Qua Nom; Art. 301 do Código; Seus admiradores.

17 Isso por que, em algumas instituições belgas, como a Universidade Livre de Bruxelas, não era necessário qualquer exame para a entrada como aluno.

18 CESÁR; FERNANDES, João. "Questão de ser bacharel. "Publicações a Pedido. Jornal do Commércio. Rio de Janeiro, 17 DE JANEIRO 1866. P.2.

19 Ibidem. 
Dois dias depois do artigo inaugural da "questão", cujo objeto era apenas Américo, o mesmo articulista trazia à tribuna o nome de Daniel Pedro Ferro Cardoso, a quem de igual modo se objetava a validade do bacharelado que, desde 1862, também reclamava para $\mathrm{si}^{20}$.

E ele também não tardaria a responder as provocações. Igualmente instigado a apresentar o seu título, ao contrário de Américo ele utilizou de tom brando para rebater a solicitação, se bem que não se esquivasse em afirmar ao fim do artigo com quem seu interlocutor lidava:

Questão de Pasquins

A nossa reputação está feita, a nossa moralidade social, provada. Achamos por isso, e pela atenção devida ao pequeno número de amigos que nos cerca, indecoroso responder aos anônimos da imprensa.

O bacharel DANIEL PEDRO FERRO CARDOSO ${ }^{21}$.

A resposta também não bastou aos críticos. Não bastaria de qualquer maneira, pois, tornava-se logo evidente, o que lhes interessava antes de tudo era emparelhar Ferro Cardoso e Américo na linha de frente da mesma "questão", tornando-a pública.

\section{Um amigo desconhecido}

A aproximação que se fez dos dois nos debates ulteriormente desenvolvidos, antes de ser casual, repousava sobre um dado bem conhecido à época, ainda que tivesse sido pouco comentado nas biografias do artista (e não é difícil imaginar os motivos, já que a lembrança de Ferro em suas histórias poderia trazer os tão indesejados dados que fizeram questão de esquecer). Ferro e Américo tornaram-se muito amigos desde o período em que ingressaram concomitantemente na Academia Imperial de Belas Artes, em 1855, sob os cuidados do então Ministro do Império, Luís Pedreira do

$20 \mathrm{O}$ pseudônimo desse articulista, Oh! S. Thomé., difere muito pouco do primeiro (O S. Thomé), que incluiu Américo na "Questão". Tratam-se possivelmente da mesma pessoa, conforme se percebe na sequência dos textos. O texto que inclui Ferro Cardoso na "Questão" é o seguinte:

"Já que tratamos de Bacharéis sem Bacharelado, perguntaremos: em que faculdade é formado o Sr. Daniel Pedro Ferro Cardoso, para dizer-se e assinar-se bacharel? Não seria fora de propósito esta declaração, pois há por aí muita gente que esteve em França, no tempo em que a sua mercê por lá passou de carreira, e que jura não ser bacharel o Sr. bacharel Ferro Cardoso, porque de tal não existe prova sem diploma. Se sua mercê é capaz, mostre os seus títulos!!!!....". OH! S. THOMÉ. "Bacharel”. Publicações a Pedido. Jornal do Commércio. Rio de Janeiro, 17 de janeiro 1866.

21 FERro CARDOSO, Daniel Pedro. “Questão de Pasquins”.Publicações a Pedido. Jornal do Commércio. Rio de Janeiro: 18 DE JANEIRO de 1866. 
Couto Ferraz. Com histórias de vida similares ${ }^{22}$, também partiram, em 1859, com intervalo de quase um mês entre um e outro, para Paris, a fim continuar seus estudos ${ }^{23}$. Américo, oficialmente, seguia nas artes plásticas; Ferro, a arquitetura e as artes industriais. Este (parece), bolsista do Ministro ${ }^{24}$, recebia essa graça após receber resposta negativa de um pedido que fez à Congregação da Academia para que se lhe desse uma bolsa de estudos na Europa ${ }^{25}$; Américo, como bem se sabe, bolsista direto do Imperador.

Juntos, além de moradias na França e, ao que parece, algumas viagens, frequentaram o instituto do conhecido físico Adolphe $\operatorname{Ganot}^{26}$ (o preparatório para o bacharelado da Sorbonne), o Conservatoire des Arts e Metiers, e, em seguida, realizaram parte das provas do bacharelado em Ciências da Sorbonne ${ }^{27}$.

Ferro retornou ao Brasil no final de 1861 (Américo, como visto, conseguiu prolongar a sua estadia, que também deveria acabar quase no mesmo momento da do seu amigo), onde logo se inseriu em instituições de fomento mercantil e industrial da Corte, estabelecendo também contato com importantes personalidades políticas e empresários do país. Tornou-se membro efetivo da Sociedade Auxiliadora da Indústria Nacional, onde, a partir de 1862, frequentava quase todas reuniões (e que não se esqueça: como bacharel). Exercia, ainda, cargo de "desenhador" no Departamento de Obras Públicas, além de ser o autor de uma série de projetos arquitetônicos, como os da residência de conde d'Eu e da Princesa Isabel (1864), do Asilo do Carmo $(1865)^{28}$, do Asilo

22 Ferro Cardoso e Américo chegaram ao Rio de Janeiro em junho de 1855 e dezembro de 1854, respectivamente. Ambos, nordestinos (Rio Grande do Norte e Paraíba) foram enviados sob os cuidados do Conselheiro do Imperador, e então Ministro e Secretário de Estado dos Negócios do Império, Luís Pedreira do Couto Ferraz. Ferro Cardoso, ao menos no período que sucede seu desembarque, foi acolhido por algum tempo na casa de Pedreira, de quem tornou-se muito próximo.

23 Américo inicia sua viagem em 17 de março de 1859 e Ferro Cardoso, em 19 de maio do mesmo ano. Cf. REGISTRO DO PORTO. Correio Mercantil, Rio de Janeiro, 18 de março de 1859, p.3; e "SEGUIU ONTEM PARA O HAVRE..". Correio Mercantil, Rio de Janeiro, 20 de maio de 1859. p.1.

24 Alguns articulistas da "questão" afirmaram que Ferro teria sido bolsista de algum familiar distante. Entretanto, vários artigos publicados sobre o jovem sugeriram, em momento de menor tensão, e sem tentar encontrar argumentos contra ele, que teria sido bolsista do Ministro do Império. Essa versão parece, de fato, mais plausível, sobretudo quando se considera que Ferro teria sido mesmo apadrinhado por Pedreira e sua mulher, a marquesa de Bom Retiro, além da Marquesa de Olinda.

25 Ver a Ata da Sessão da Congregação e do diretor em 04 de abril de 1859 da AIBA. Embora fosse comentado na reunião que Ferro dispunha de merecimentos para obter uma resposta favorável a seu pedido, consentiu-se que se fosse possível oferecer uma bolsa a um aluno da instituição, essa deveria ser oferecida, naquele momento ao aluno de gravura de melhada Joaquim José da Silva Guimarães Júnior, "que incontestavelmente é o aluno mais aproveitado da Academia". Em 1860, Guimarães Júnior de fato viaja como bolsista para a Europa.

26 No Brasil, os cursos de fisíca de Ganot eram bastante conhecidos. D. Pedro II escrevia em seu diário em 5 de janeiro de 1862 a respeito da educação de suas filhas: "5as [feiras], explicarei a minhas filhas a física de Ganot das 3 às 4..". PEDRO II, Dom. "Diário de 1862". In MINISTÉRIO DA EDUCAÇÃO E CULTURA. Anuário do Museu Imperial, vol XVII. Petrópolis: 1956.

27 É possível que tenham também frequentado, juntos, o curso noturno da Escola Imperial Especial de Desenho e Matemática, Arquitetura e Escultura de Ornamentos para Belas Artes na Industria. Américo era aluno devidamente matriculado. Ainda não foi possível checar se há inscrição de Ferro Cardoso.

28 NOTÍCIAS DIVERSAS. Correio Mercantil, Rio de Janeiro, 6 de março de 1865. P.2. 
dos Inválidos da Pátria $(1865)^{29}$ e da Ordem Terceira do Carmo (1866) ${ }^{30}$; todos igualmente assinados com seu nome e título. A partir de 1863, passou a notabilizar-se como empreendedor e inventor (atividade encorajada dentro da Sociedade), patenteando e sendo responsável por explorar comercialmente uma série de aparelhos de sua autoria (máquinas para resfriamento interno de ambientes; máquinas para secagem de café, etc). Vários deles, é de se notar, aplicados na "indústria" da agricultura, atividade que provia os meios para a formação e manutenção da maioria das fortunas do Brasil do período ${ }^{31}$.

A despeito do seu retorno precoce ao Brasil, Cardoso, nos anos seguintes, ainda manteve estreito contato com Américo ${ }^{32}$. Ele seria mesmo, em meados de 1864, o responsável por amiudar a d. Pedro II (possivelmente durante as reuniões do beija-mão, nas quais seu nome era também frequentemente citado nos jornais) um pedido do artista para que o monarca concedesse seis mil francos para custear a moldura da Carioca e a sua viagem final à Itália, antes do seu retorno ao país. ${ }^{33}$. E é de se notar que, nessa carta, tanto Américo, quanto Ferro, eram introduzidos ao assunto como Bacharéis.

Quando esse último pedido foi negado, e Américo logo dirigia-se ao Rio, a amizade permanecia firme. Ferro, no fim de 1864, sugeriu (com êxito) a citada admissão do artista para a Sociedade Auxiliadora da Indústria Nacional, sem dúvida uma maneira de tentar introduzi-lo a um contato mais estreito com empresários, políticos e industriais eminentes que participavam da associação, e ajudá-lo a colocar em prática alguns dos projetos artísticos que esboçava nas Considerações Filosóficas e nas Cartas de um Plebeu, alguns dos quais, seus destinatários "legisladores". Américo, em contrapartida, aparecia às vezes comentando na imprensa, sempre positivamente, os trabalhos arquitetônicos do amigo ${ }^{34}$.

29 NOTÍCIAS DIVERSAS. Correio Mercantil, Rio de Janeiro, 2 de abril de 1865. P.1.

30 ATAS das sessões da congregação e do diretor da Academia Imperial De Belas Artes. Rio de Janeiro: Museu d. João VI/ EBA-UFRJ, Sessão em 01 de Dezembro de 1866.

$31 \mathrm{Na}$ década de 1880, Ferro passa também a comercializar café e inceticida em Paris, a essa altura, já proprietário de uma casa nessa cidade.

32 Ambos seriam ainda bastante amigos até, pelo menos, a década de 1880, quando ainda trocavam cartas com evidente apreço.

33 A parte da carta em que Américo designa Ferro para tratar o assunto do dinheiro para sua viagem e moldura da Carioca é o seguinte: "Bem sei, senhor, que tenho sido importuno à Vossa Majestade, mas desde que tive a ventura de ser protegido de um soberano, minha imaginação me o apresenta como um pai, a quem pedir não parece feio, mas belo e digno. Não ouso sobrecarregar o presente memorial de amiudadas circunstâncias, porém, o meu amigo Bel. Daniel Pedro Ferro Cardoso terá a honra de tudo expor à Vossa Majestade, e de implorar dela uma benevolente solução.[...] Paris, 24 de maio de 1864. Bacharel Pedro Américo de Figueiredo e Mello.". AMÉRICO, PEDRO. "Carta enviada de Paris ao imperador d. Pedro II, em 24 de maio de 1864”. In TORRES, Francisco Trancredo. Pedro Américo. Mossoró: Coleção Mossoroense, 2002. Disponível em http://www.colecaomossoroense.org.br/acervo/01pedro americo.pdf. Último acesso: maio de 2013.

34 Um comentário do artista a respeito do projeto do palácio para o conde d'Eu e da princesa Isabel, de autoria de Ferro Cardoso, era publicado quase no mesmo momento que ingressa na Sociedade Auxiliadora da Indústria Nacional: 
Assim, em 1866, quando a "questão de bacharéis" era iniciada, não era sem causa que os dois amigos podiam ser observados por críticos como "duas almas em um só corpo"35, "feitos por Deus, e ajuntados pelo Diabo"36. Com o cerco armado, o problema que surgia para qualquer leigo (e ainda existe, de certa maneira) era o de saber quais eram os caçadores que atacavam, ou os caçados que revidavam.

Com efeito, se as biografias de Américo garantiram que, nos primeiros anos de 1860, ele havia sido gratuitamente depreciado por inimigos invejosos, tendo sequer revidado em virtude de sua postura altiva, os vários artigos publicados no começo de 1866 defendiam o lado oposto dessa história, logo, inserindo uma variável que problematizaria a certeza sempre reiterada do virtuosismo do artista.

\section{Diplomados ou não diplomados?}

Para os autores desses artigos, Américo e seu amigo Ferro seriam os verdadeiros detratores. Afirmou-se que desde o momento que retornaram ao Brasil, orgulhosos de suas experiências, formação e títulos europeus, teriam assumido uma postura extremamente crítica em relação à (in)capacidade dos seus conterrâneos, espalhando de ouvido em ouvido o quanto esses poucos sabiam, e eles, muito ${ }^{37}$ (e, diga-se de passagem, conforme ese viu, Américo de fato sustentou por

\footnotetext{
“A respeito do mencionado projeto deu-nos o srn. Pedro Américo de Figueiredo, artista nacional há pouco chegado da Europa, a seguinte informação, que oferecemos à atenção dos leitores:

'O projeto do palácio para a residência de Sua Alteza Real o snr. Conde d'Eu e de sua Augusta Consorte, cujo plano aparesenta uma regularidade admirável, é concebido com grande singeleza, e oferece, um sua ampla fachada anterior aquele aspecto simples e nobre que deve sempre caracterizar as habitações reais. Tem a qualidade de não apresentar pormenores inúteis, nem acumulação de miudezas esculturais, demasidamente despendiosas na construção; e sem fugir do plano comum dos edifícios do mesmo gênero que se encontram na Europa, o sr. dr. F. Cardoso teve o talento de imprimir-lhe o cunho da originalidade, elevando a concepção do seu trabalho acima de tudo que até hoje possuímos"”. PUBLICAÇÕES DIVERSAS. Correio Mercantil. Rio de Janeiro. 14 de novembro de 1864. p.1.

35 GUISANDO, Bacharel Renato de. Publicações a Pedido. Jornal do Commércio. Rio de Janeiro, 24 DE JANEIRO DE 1866, p.1.

36 GUISANDO, Bacharel Renato de. Op. Cit, p.1. Outras aproximações entre os dois artistas foram ainda feitas, além dessas, que aqui cito.

37 São vários os artigos que acusam Américo e Ferro de culpados por iniciar os problemas que culminaram na polêmica da "questão de bacharéis", introduzindo as ações que os jovens teriam empreendido contra algumas personalidades como, por exemplo, professores da AIBA. São eles: NOME, Se for preciso assinaremos o. "Questão de Pasquins". Publicações a Pedido. Jornal do Commércio. Rio de Janeiro, 18 DE JANEIRO DE 1866; DIVINA, A justiça. "Os pecados bacharéis"Publicações a Pedido. Jornal do Commércio. Rio de Janeiro, 20 DE JANEIRO DE 1866, p.1; PÚBLICA, A onipinão. "É ou não bacharel?". Publicações a Pedido. Jornal do Commércio. Rio de Janeiro, DIA 22 DE JANEIRO de 1866; COQUES, A alma de Gonzalez. "O Sr. Pedro Américo de Figueiredo" Publicações a Pedido. Correio Mercantil, Rio de Janeiro,22 de janeiro de 1866, p.3; FIRMADA, A minha reputação está. "Questão de Pasquins". Publicações a pedido. Correio Mercantil, Rio de Janeiro, 23 de janeiro de 1866, p.3; "Bacharel sem bacharelado". Publicações a Pedido. Jornal do Commércio. Rio de Janeiro, 28 de janeiro de 1866, p.2; FIRMADA, Minha reputação está. Publicações a Pedido. Jornal do Commércio. Rio de Janeiro, 30 DE JANEIRO DE 1866; UM ARTISTA. "Bacharéis sem bacharelado". Publicações a Pedido. Jornal do Commércio. Rio de Janeiro, 22 de fevereiro de 1866.
} 
diversas vezes essa postura nos seus textos, embora nunca tenha explicitado publicamente a quem se referia). Teriam caluniado até mesmo um amigo bolsista (possivelmente Victor Meirelles) ${ }^{38} \mathrm{o}$ qual, estudando com eles na França, os havia tomado como amigos ${ }^{39}$. O que se seguiria, portanto, do ponto de vista dos autores dos artigos, seria apenas uma devolução pública aos insultos inicialmente lançados pelos jovens.

Os críticos logo perceberam que a soberba que Américo e Ferro demonstravam por suas formações científicas, curiosamente mais do que a artística, compreenderia o ponto fraco a ser explorado, pois escondia verdades maquiadas. Não era sem motivo que a grande maioria dos artigos (grandes ou pequenos) estampava, entre outros assuntos abordados, pedidos enfáticos para que os dois apresentassem seus diplomas de bacharéis ${ }^{40}$. Ofereceu-se até mesmo quantidade considerável de dinheiro para a Sociedade Asilo dos Inválidos (a Guerra do Paraguai havia acabado de começar), se os artistas os deixassem expostos por um breve período no Jornal do Commércio ou no Correio

É certo, contudo, que os artigos direcionados a Ferro foram em número consideravelmente maior, e proporcionalmente mais agressivos.

38 Victor Meirelles terminaria seus estudos como bolsista da Academia no período em que Américo e Ferro chegam à Europa. Contudo, devido a dois prêmios que recebeu: uma menção honrosa em perspectiva, e um terceiro lugar no concurso interno de Modelo-Vivo, a Academia propôs que se estendesse por mais dois anos o período de sua bolsa, e que se a aumentasse com mais mil francos anuais. Sabe-se que Américo carregava uma carta de Manuel Araújo Porto Alegre, recomendando a Meirelles que ajudasse a Américo a se acomodar e a se habituar no novo país. Além de Meirelles, outros bolsistas que estão na Europa no período em que se encontram os amigos são: Ladislau Netto, também seu colega de estudos na Academica; Almeida Reis, bolsista na Europa a partir de 1862, futuro amigo de Américo; e Henrique Alves de Mesquita.

39 DIVINA, A justiça. "Os pecados bacharéis"Publicações a Pedido. Jornal do Commércio. Rio de Janeiro, 20 de janeiro de 1866, p.1

40 A listagem de artigos que, em algum momento, pedem a apresentação dos diplomas é a seguinte. Apenas a Américo: O CHARLATA. "Ao Bacharel”. Publicações a Pedido. Jornal do Commércio. Rio de Janeiro, 18 de janeiro de 1866; TíTULO, Um que tem. "Questão de bacharéis". Publicações a Pedido. Jornal do Commércio. Rio de Janeiro, 18 de janeiro de 1866; "Mofina". Publicações a Pedido. Jornal do Commércio. Rio de Janeiro, 22 de janeiro de 1866; O S. THOMÉ. "Ao Sr. Pedro Américo". Publicações a Pedido. Jornal do Commércio. Rio de Janeiro, 23 de fevereiro de 1866. p.1

A Ferro Cardoso, apenas: OH! S. THOMÉ. “Ao Sr. Ferro Cardoso (bacharel). "Publicações a Pedido. Jornal do Commércio. Rio de Janeiro, 18 de janeiro de 1866; FIRMA, A minha reputação está. "Mofina". Publicações a Pedido. Jornal do Commércio. Rio de Janeiro, 20 de janeiro de 1866, p.1; KOCQUES, Gonzales. "questão de bacharéis". Publicações a Pedido. Jornal do Commércio. Rio de Janeiro, 22 de janeiro de 1866; PUFF, ora. Publicações a Pedido. Jornal do Commércio. Rio de Janeiro, 22 de janeiro de 1866; TítUlO, Um que tem. "Questão de bacharéis". Publicações a Pedido. Jornal do Commércio. Rio de Janeiro, 18 de janeiro de 1866; A MORALIDADE PÚBLICA. "Bachareleida". Publicações a pedido. Correio Mercantil, Rio de Janeiro, 24 de janeiro de 1866, p.3; FIRMADA, Minha reputação está. Publicações a Pedido. Jornal do Commércio. Rio de Janeiro, 26 de janeiro de 1866, P.2; GONDOLAS, O orador das. "É ou não é bacharel". Publicações a Pedido. Jornal do Commércio. Rio de Janeiro, 28 de janeiro de 1866, p.2; O.M.T.A . "mofina". Publicações a pedido. Correio Mercantil, Rio de Janeiro, 29 de janeiro de 1866, p.3.

Que pedem a ambos a apresentação dos títulos: TÍTULO, Um que tem. "Questão de bacharéis". Publicações a Pedido. Jornal do Commércio. Rio de Janeiro, 18 de janeiro de1866; GUISANDO, Bacharel Renato de. "É ou não é bacharel". Publicações a Pedido. Jornal do Commércio. Rio de Janeiro, 30 de janeiro de 1866; SOLEDADE, João Fernandes. "Questão de Bacharel". Publicações a Pedido. Jornal do Commércio. Rio de Janeiro, 21 de fevereiro de, p.2; OH! S. THOMÉ. "Bacharelomania". Publicações a Pedido. Jornal do Commércio. Rio de Janeiro, 22 de fevereiro de 1866; "Questão de Bacharel”, Publicações a Pedido. Jornal do Commércio. Rio de Janeiro, 23 de fevereiro de 1866. p.2. 
Mercantil $^{41}$. Uma jogada irônica, mas não destituída de malícia e maldade, que procurava testar publicamente a solidariedade dos jovens (declarados cristãos), aos combatentes mutilados que começavam a retornar das batalhas ${ }^{42}$.

Os diplomas, no entanto, nunca foram expostos. E isso foi explicado por dois motivos. Um, fornecido com bem menor frequência, pendia para o lado dos artistas; o outro, recorrente, para o dos seus opositores.

Do primeiro lado, comentava-se que Américo e Ferro não exibiam seus diplomas porque não queriam "dar o braço a torcer" ${ }^{43}$ a seus inimigos, ou por que possuíam "muito brio" e não eram "sem vergonha como os cariocas" 44 . Apresentar publicamente os títulos - segundo se afirmou ouvir dos dois artistas - significaria abaixar a cabeça para "caluniadores".

Do segundo, havia a certeza de que Américo e Ferro não entregavam seus diplomas porque eles de fato não existiam. Assim, a requisição dos títulos era, desde o início da "questão", meramente retórica. Retórica contudo necessária ao desdobramento dos fatos que conduziriam, por fim, a reivindicações drásticas, apresentadas em seguida. Alguns críticos, afirmando também conhecer bastante Américo e Ferro, e o que haviam feito na França, sutentaram manter provas de que os jovens não possuíam o bacharelado nem do Conservatório de Artes e Ofícios (o qual apenas Ferro reivindicava ter cursado, numa circular que publicava na corte em março de 1862), nem da Sorbonne.

Do Conservatório não poderia existir diploma, porque a instituição não era sequer uma faculdade, mas um curso livre público e, portanto, não formava bacharéis ${ }^{45}$. Da Sorbonne, por sua

41 Alguns dos artigos que oferecem ironicamente dinheiro (ora 200, ora 300 francos) se os diplomas de Américo e Ferro fossem depositados na redação dos jornais são: O.M.T.A . "mofina". Publicações a pedido. Correio Mercantil, Rio de Janeiro, 29 de janeiro de 1866, p.3; SOLEDADE, João Fernandes. "Questão de Bacharel". Publicações a Pedido. Jornal do Commércio. Rio de Janeiro, 21 de fevereiro de 1866, p.2; SOLEDADE, João Fernandes. "Questão de Bacharel". Publicações a Pedido. Jornal do Commércio. Rio de Janeiro, 23 de fevereiro de 1866, p.2.

Para se ter uma ideia, 300 francos era, em média, nesse período, a quantia que um bolsista da Academia ou do Imperador recebia mensalmente para arcar com suas despesas na Europa.

42 A Sociedade Asilo dos Inválidos foi criada em 1865 pela Associação Comercial do Rio de Janeiro. Nesse ano, iniciava-se em vários jornais uma grande campanha para subscrição e doação de capital para construção do Asilo, que foi, por fim, inaugurado em 1868, na Ilha de Bom Jesus.

43 GUISANDO, Bacharel Renato de. "bacharéis sem diploma”. Publicações a Pedido. Jornal do Commércio. Rio de Janeiro, 27 de janeiro de 1866, p.2.

44 "Bacharel sem bacharelado". Publicações a Pedido. Jornal do Commércio. Rio de Janeiro, 28 de janeiro de 1866, p.2.

45 Sobre a impossibilidade de emissão de diplomas pelo Conservatoire des Arts et Métiers, alguns artigos publicaram o seguinte:

"Quanto ao Sr. Ferro, apenas, quando há tempos anunciou a sua faustíssima chegada a esta capital, manifestou ter sido discípulo do Conservatório das Artes e Matérias (foi assim, se bem nos recordamos, que no anúncio vinha traduzido o Conservatoire des Arts e Metiers de Paris); ora, não sabemos se o Conservatório das artes e ofícios dá algum título de bacharel". (TÍTULO, Um que tem. "Questão de bacharéis". Publicações a Pedido. Jornal do Commércio. Rio de Janeiro, 18 de janeiro de 1866). 
vez, não existiriam também quaisquer títulos, porque Américo e Ferro, embora preparando-se para o bacharelado em Ciências Físicas e Naturais, não haviam concluído todas as suas provas. Foi dito que eles teriam perseguido e logrado, em agosto de 1861, apenas a primeira parte, das duas necessárias, para a obtenção do diploma ${ }^{46}$. Américo, assim, poderia ter até "documentos comprobatórios" de que teria completado as disciplinas que defendia saber, mas não possuía o diploma de bacharel, o único e condicionador documento que lhe outorgaria o uso daquela "insígnia social".

De fato, os críticos não estavam enganados - conforme discutido especificamente sobre Américo, no Segundo Capítulo desta Tese ${ }^{47}$. Se bem que matriculados e aprovados na primeira parte do curso, nem Américo, tampouco Ferro, haviam concluído o bacharelado scindé na Sorbonne. O primeiro nem mesmo prestou-se ao exame do segundo novo módulo nessa instituição. Após a conclusão das provas do primeiro módulo, no primeiro semestre de 1861, empreendeu por

"Podem só ficar inteiramente convencidos que o Conservatório de Artes e Ofícios de Paris não dá Título algum de bacharel, e muito fácil será adquirirmos provas muito satisfatórias.". (“Questão de Bacharéis”. Publicações a Pedido. Jornal do Commércio. Rio de Janeiro, 20 de janeiro de 1866, p.1).

46 São os seguintes excertos de artigos que afirmavam ter provas, forneciam dados e datas para que se acreditasse que Américo e Ferro não fossem bacharéis:

"Oferecemos 300 francos ao Sr. Pedro Américo pelo trabalho de depositar o seu diploma quer pela Universidade de Bruxelas, quer pela Faculdade de Ciências de Paris, porque estamos inteiramente convencidos e temos provas suficientes que o não tem, embora o dito senhor, que se diz bacharel, não sabendo por onde, tivesse passado nos exames da primeira parte do bacharelado, segundo uma carta que......[ilegível]....aprovado nas matérias que constituem essa primeira parte não lhe dá o direito de usar título algum....[ilegível].

E o Sr. Ferro..[ilegível]...o seu diploma...[ilegível]..coitado! nem por merecimento, nem comprado, ele o pode.”. UNORUMQUORUMQUS, Bacharel. “Aos formidáveis bacharéis”. Publicações a Pedido. Jornal do Commércio. Rio de Janeiro, 31 de janeiro de 1866, p.1.

"Ora, Sr. Américo, Julgávamos melhor da sua inteligência! pois se o senhor não tem diploma de bacharel, como é que se animou a dizer-se e assinar-se com um título de que não tem carta? E se o senhor é bacharel, por que não publica a íntegra do seu diploma?

Não é com evasivas, nem com o seu simples dizer que se prova o direito de usar de um título que se lhe constesta, porque não há hoje quem não saiba que sua mercê apenas fez o exame da primeira parte do bacharelado em ciências scindé [particionado] em agosto de 1861. Esta é que é a verdade, que desafiamos o Sr. Américo a contestar com documentos! Se é capaz, faça-o.”. OH! S. THOMÉ. "Bacharel sem diploma”. Correio Mercantil, Rio de Janeiro, 21 de fevereiro de 1866. P.3.

"Dizendo-se agora bacahrel, como o Sr. Ferro, esqueceu-se o Sr. Américo que já havia dito a um dos professores da academia (cujo nome publicaremos se o Sr. américo nos contestar), que o Sr. Ferro, tendo só feito os primeiros exames do Bacharelado scindé que não dá nenhum título nem nenhum direito, segundo diz o próprio secretário da faculdade...". UM ARTISTA. "Bacharéis sem bacharelado". Publicações a Pedido. Jornal do Commércio. Rio de Janeiro, 22 de fevereiro de 1866.

"O simples fato de terem os exames da primeira parte do bacharelado não lhes dá título algum nem direto de usálo, como provaremos por uma carta de pessoa fidedigna da Universidade de Paris.

O bacharelado em Ciências Físicas e Naturais não confere senão um diploma, e não muitos documentos comprobatórios." SINE QUA NOM. "Os imaginários bacharéis”. Publicações a Pedido. Jornal do Commércio. Rio de Janeiro, 22 de fevereiro de 1866.

"[Américo,] Poderá sua mercê dizer-nos também, se a sua viagem à Europa tem só por fim acabar seus estudos de pintura, como disse ao governo, para obter licença, ou especialmente acabar os seus estudos de bacharel, pois só fez exame da primeira parte deles em Agosto de 1861?". SEUS ADMIRADORES."Bachareleida”. Publicações a Pedido. Jornal do Commércio. Rio de Janeiro, 8 de março de 1866, P.2.

${ }^{47}$ Ver especialmente o primeiro tópico do Capítulo referido, Considerações sobre as Considerações. 
conta própria, durante meses, várias viagens de instrução a outros países europeus ${ }^{48}$; e, em uma delas, inscreveu-se mesmo, em novembro de 1862, na faculdade de Ciências da Universidade Livre de Bruxelas, cuja admissão, à diferença da faculdade francesa, não exigia quaisquer testes ${ }^{49}$. Cardoso, sim, ainda em 1861, se submetia à segunda parte do curso da Sorbonne. Foi todavia reprovado, retornando logo em seguida ao Brasil, sem possibilidades de aplicar-se novamente às $\operatorname{provas}^{50}$.

Se se lembra, conquanto não prosseguisse no curso belga no qual se inscrevera, Américo, alguns meses antes, quando aprovado na primeira parte do curso, afirmava já ser ou, talvez mais importante do que isso, acreditava já ser possível apresentar-se bacharel. $^{51}$.

Com efeito, desse momento em diante, ele deixava de se introduzir "apenas" como o "pintor Pedro Américo" - como seria anos depois desdenhosamente chamado à sua real condição por um dos primeiros críticos da "questão" - para se considerar com insistência o Bacharel Pedro Américo. E ao mesmo procedia Ferro Cardoso, chegando ao Brasil.

Contudo, entre "ser considerado" bacharel e "ser" bacharel de fato havia uma distância considerável (garantida pela existência do diploma), a qual os opositores do artista, conhecendo-a muito bem, desejaram explorar. Era essa a fresta da armadura que encontraram para fazer com que o orgulho que os jovens manifestavam por suas formações científicas se transformasse em vergonha pública, ao se provar o quão indevido seria o uso dos seus títulos.

48 São as viagens em que Américo preparava o material para a produção das suas Considerações Filosóficas e, posteriormente, da Carioca.

49 Contudo, não há registros de que tenha cursado qualquer curso até 1866, quando inicia não o bacharelado, mas o doutorado em ciências naturais.

50 Cardoso realiza a segunda e última série de provas para a obtenção do grau de bacharel nos dias 6 e 7 de setembro de 1861. Ver o caderno Registres des procès-verbaux d'examens et de réceptions au baccalauréat-de-sciences scindé - lère et 2eme Parties. Paris, Archives Nationales, AJ/16/5474.

51 AMÉRICO, Pedro. "Carta à tia Maria do Rosário Brasileiro de Mello, de Paris, em 29 de junho de 1862". In TORRES, Francisco Trancredo. Op.cit. pp.134-36. Meses antes, em janeiro de 1862, Américo enviava uma carta a d. Pedro II, comentando o seu ingresso no bacharelado, e expondo seu desejo de permanecer mais na Europa pare que o concluísse: "Para prova do meu aproveitamento quanto os estudos científicos, passei com excelentes notas os exames do Bacharelado em Ciências Físicas e Naturais, na Academia de Paris. Comecei a parte literária e matemática do Bacharelado em Ciências completo, e não terei prova dessa segunda parte, se tiver a infelicidade de regressar em maio próximo". AMÉRICO, Pedro. "Carta enviada de Paris ao imperador d. Pedro II, em 6 de janeiro de 1862”. In TORRES, Francisco Trancredo. Op. Cit.p.99. 


\section{Artigo 301 do código penal brasileiro: bacharel sem diploma é crime}

Conhecendo-se previamente a inexistência de diplomas, o pedido para que fossem apresentados serviria apenas para se chegar ao ponto esperado: para alguns críticos, uma vez “desmascarados”, o constrangimento público não era ainda suficiente para Américo e Ferro. Não bastava ir do orgulho à vergonha; era necessário levá-los da vergonha à punição legal.

A partir de 18 de janeiro de 1866, e especialmente entre 21 e 24 daquele mês, a "questão de bacharéis" atingia seu vértice, quando pedidos de ações mais drásticas tomaram repetidas vozes. Constatava-se que Américo e Ferro, considerando-se publicamente diplomados, e no entanto não os sendo, estavam incursos no artigo 301 do Código Penal Brasileiro. O crime, segundo o Código, era o seguinte:

Parte VI. Dos crimes policiais.

[...]

\section{Capítulo VII}

Uso de nomes supostos e títulos indevidos.

Art. 301. Usar de nome suposto ou mudado, ou de algum título, distintivo ou condecoração que não tenha.

Penas:

No grau máximo - sessenta dias de prisão, $e$ multa correspondente à metade do tempo.

No grau médio - um mês e cinco dias, idem, $e$ multa, idem.

No grau mínimo - dez dias, idem, $e$ multa, idem. ${ }^{52}$

Art. 302. Se em virtude do sobredito uso se tiver obtido o que de outro modo não conseguiria.

Penas:

As mesmas em que incorreria o réu se obtivesse por violência. ${ }^{53}$

Quaisquer graus de pena previstos no artigo 301, ao qual eram chamados Américo e Ferro, embora exigissem penas de reclusão relativamente pequenas, colocavam-se como inafiançáveis, além de requererem a perda dos cargos ocupados com o auxílio dos títulos indevidos. Com a reivindicação de crime específico iniciada, sinalizava-se já o mal-estar que os artistas teriam causado a algumas pessoas, a ponto dessas desejarem não apenas que eles se retratassem pelo uso indevido de títulos, ridicularizando-se publicamente, mas que fossem recolhidos temporariamente de algumas de suas

52 CORDEIRO, Carlos Antonio. Código Criminal do Império do Brasil. Rio de Janeiro: Typ. de Quirino e irmão, 1861. pp.215-216.

53 A alusão à infração de violência que mais se aproxima daquela detalhada no fim do art. 302 reporta ao art. 145, do mesmo Código: "Cometer qualquer violência no exercício das funções do emprego ou a pretexto de exercê-las. Penas: No grau máximo - perda do emprego, além das mais em que incorrer; no grau médio - três anos de suspensão, idem; no grau mínimo - um ano idem, idem." CORDEIRO, Carlos Antonio. op. cit. p.93. 
liberdades. Nesses termos, dever-se-ia concluir, o cumprimento da pena acompanharia proporcionalmente o aumento da humilhação pública.

Posto que a infração em que teriam incorrido não era cometida contra alguém específico, era necessário que o próprio governo, por meio de seus representantes, acionasse um processo legal contra os dois amigos. Assim, várias foram as autoridades (físicas, jurídicas ou "genéricas") solicitadas para intervir no caso: o "Governo Imperial",54, "as autoridades competentes",55, o "promotor público"56, o "chefe de polícia"57, o "Ministro da Agricultura"58, o "inspetor de Obras Públicas"59; todas, claro, sempre requisitadas para proceder contra Américo e Ferro e a favor da "moralidade pública".

À diferença da primeira nota lançada nesse sentido, cuja requisição era simplesmente a de que as autoridades investigassem se "havia lugar a processo" ${ }^{60}$, os artigos seguintes, já certos da infração cometida, lançaram uma campanha enérgica para a punição (e, diga-se novamente, prisão obrigatória) de Américo e Ferro.

A execução da pena era, segundo a conclusão de alguns articulistas, o procedimento correto a ser seguido; não apenas por se tratarem de duas personalidades conhecidas que teriam ludibriado a opinião pública, mas, também em decorrência disso, para que o exemplo fosse dado a demais indivíduos que desejassem ostentar, sem esforço, um benefício que seria por outros conquistado a

54 OH! S. THOMÉ. "Ao Sr. Ferro Cardoso (bacharel). "Publicações a Pedido. Jornal do Commércio. Rio de Janeiro, 18 de janeiro de 1866.

55 GUISANDO, Bacharel Renato de. Publicações a Pedido. Jornal do Commércio. Rio de Janeiro, 24 de janeiro de 1866, p.1.

56 DR. CHARLATA. "Bacharel sem diploma". Correio Mercantil, Rio de Janeiro, 21 de fevereiro de 1866. P.3; O S. THOMÉ. "Ao Sr. promotor público". Publicações a Pedido. Jornal do Commércio. Rio de Janeiro, 22 de fevreiro de 1866; PÚBLICA, A onipinão. "É ou não bacharel?". Publicações a Pedido. Jornal do Commércio. Rio de Janeiro, 22 de janeiro de de 1866; A OPINIÃO PÚBLICA. "É ou não é Bacharel". Publicações a pedido. Correio Mercantil, Rio de Janeiro,22 de janeiro de 1866, p.3; "Ao Sr. Promotor público". Publicações a Pedido. Jornal do Commércio. Rio de Janeiro, 22 de fevereiro de 1866.

57 "Questão de Bacharéis." Publicações a Pedido. Jornal do Commércio. Rio de Janeiro, 22 de janeiro de 1866; "Questão de bacharéis". Publicações a pedido. Correio Mercantil, Rio de Janeiro, 23 de janeiro de 1866, p.3.

58 O. M. T. A. "Ao Sr. ministro da agricultura, ao Sr. Inspetor de obras públicas e ao Sr. promotor Sizenando Nabuco". Publicações a Pedido. Correio Mercantil, 29 de janeiro de 1866.

59 Idem, Ibidem.

$60 \mathrm{O}$ artigo que inaugurou os pedidos de averiguação das ações de Américo e Ferro pela justiça argumentava o seguinte: "Agora outra questão. $\mathrm{O}$ uso de títulos indébitos é um crime, e como tal punido. Parece que quando se suscita uma questão dessas, às autoridades competentes incumbe averiguar se há lugar a processo. Se são válidos e só podem ser usados os títulos conferidos pelos estabelecimentos ou poderes cujo direito reconhecem as leis gerais do Brasil. Se as autoridades não cumprirem o seu dever, velando por isso, em breve nenhum valor terão esses títulos, para obter os quais tantos gastam saúde, tempo e dinheiro, ou empregam seus méritos. Referimo-nos também aos títulos de nobreza ou honorífico." TíTULO, Um que tem. "Questão de bacharéis". Publicações a Pedido. Jornal do Commércio. Rio de Janeiro, 18 de janeiro de 1866. 
“duras penas”. E não se referiu apenas ao bacharelado, mas também a títulos honoríficos (comendadores, cavaleiros, dignatários) e de nobreza (condes, viscondes, barões, marqueses, etc.) ${ }^{61}$.

Um único artigo, de todos que tocaram no mérito do crime, se posicionou publicamente contrário à execução de processo contra o artista e o arquiteto, julgando ser suficiente o constrangimento público pelo qual já passavam. O articulista, Ferro sem ferrugem, assim concluía:

Bacharéis

Aprovamos quanto se tem dito da pseudo-bacharelice dos Srs. Ferro e Pedro Américo. O que nos parece demais é invocar a ação da polícia contra este pobres moços. É verdade que as leis fulminam penas sobre a usurpação de títulos, mas esses nossos tempos que não comportam cruezas não admitem senão uma punição para essas pequenas misérias sociais: é a do ridículo ${ }^{62}$.

No mais, foi essa única voz que, à exceção de Américo e Ferro, empreendeu eco contrário às demais.

\section{Revelando o principal crítico da "Questão"}

Em sentido favorável à acusação e execução de processo contra os jovens, houve um articulista que igualmente se destacou. E este era ninguém menos do Francisco Joaquim Bethencourt da Silva, arquiteto e, como Américo, professor da Academia Imperial de Belas Artes. A identidade de Bethencourt permaneceriam relativamente obscura se não tivesse replicado, no Correio Mercantil, a mesma série de artigos do Jornal do Commércio. Se neste, ele subscreveu "Bacharel Renato de Guisando" (um trocadilho de "disfarçando", "déguiser", em francês) ao fim de cada artigo, naquele, assinou apenas o último artigo, datado de 7 de fevereiro de 1866 (o mesmo dia da posse de Américo na AIBA), mas com novo heterônimo, “O. M. T. A", sigla com a qual também subscreveu outro artigo fora da série ${ }^{63}$. Tratava-se da mesma assinatura que Bethencourt da Silva havia utilizado várias vezes ao longa das duas décadas anteriores ${ }^{64}$. A abreviação não indicava, naturalmente, as iniciais do seu nome, mas as últimas letras de cada um dos seus nomes e sobrenomes.

61 OH! S. THOMÉ. "Pergunta inocente". Publicações a Pedido. Jornal do Commércio. Rio de Janeiro, DIA 22 de janeiro de 1866.

62 FERRUGEM, Ferro sem. "Bacharéis". Publicações a Pedido. Jornal do Commércio. Rio de Janeiro, 1 de fevereiro de 1866, P.2.

63 O.M.T.A . "mofina”. Publicações a pedido. Correio Mercantil, Rio de Janeiro, 29 de janeiro de 1866 , p.3. Trata-se de um dos artigos que ofereciam dinheiro para a exibição dos diplomas de Américo e Ferro.

${ }^{64}$ Ver, por exemplo: O.M.T.A. "Academia de Belas Artes. O novo método". Belas Artes. Brazil Illustrado, Rio de Janeiro, n.6, Vol.1, 15 de agosto de 1855. pp.84-85. 
Não há dúvidas de que Bethencourt da Silva foi o contendor que, com grande vantagem de volume escrito sobre os outros, por mais vezes publicou artigos na imprensa a respeito da "questão". Ao todo, assinou não menos do que 20 artigos (podem ser ainda mais, se se consideram outros prováveis pseudônimos que tenha também utilizado ${ }^{65}$ ), publicados entre 24 de janeiro, dez dias após o início da polêmica, e 10 de fevereiro de 1866.

Desde os seus primeiros textos, como não era para menos, ele demonstrou grande conhecimento sobre a vida e os passos (incluindo datas precisas) tomados por Américo e Ferro Cardoso, tanto no período em que eram estudantes na Academia Imperial de Belas Artes, quanto naquele em que estudavam na Europa. Um dos nervos mais exaltados da desavença, e com um estilo de escrita muito contundente, que lhe era próprio, desde logo se posicionou "no firme propósito de continuar com esta questão, até que haja alguma providência em conformidade do art. 301 do código penal" ${ }^{\prime 66}$.

Entre os assuntos tratados ao longo dos seus artigos, Bethencourt da Silva comentou sobre os "acessos de loucura" que Américo teria tido "em sua viagem au tour du monde"67; sobre o que concluía ser a incongruência do jovem artista em desejar estudar "dezesete ciências, inclusive a astronomia e a mineralogia, que são grande importância para o estudo do Belo ideal e inteiramente ligadas às Belas Artes [essa é uma ironia, naturalmente]"; e sobre o seu desejo de retornar à Europa para concluir sua formação científica ${ }^{68}$. Incluiu-se na campanha para que Américo e Ferro apresentassem seus diplomas nos jornais ${ }^{69}$, e mesmo naquela, em que, em última instância, se doaria dinheiro para o Asilo dos Inválidos, se assim o fizessem ${ }^{70}$. Pediu às autoridades (e diretamente ao promotor público) providências sobre o crime que os jovens haviam cometido ${ }^{71}$; e, por fim, viu-se indignado diante da letargia que julgou haver para que se prosseguisse o processo, em que desejava avidamente findar em execução de pena.

65 É bastante possível ainda, pelo estilo de escrita, que Bethencourt da Silva tenha sido ainda utilizado do pseudônimo Oh! S. Thomé, outro que assiduamente publicou textos na "questão de bacharéis."

66 GUISANDO, Bacharel Renato de. Publicações a Pedido. Jornal do Commércio. Rio de Janeiro, 24 de janeiro de 1866, p.1.

67 GUISANDO, Bacharel Renato de. "bacharéis sem diploma". Publicações a Pedido. Jornal do Commércio. Rio de Janeiro, 27 de janeiro de 1866, P.2.

68 Idem, ibidem.

69 GUISANDO, Bacharel Renato de. "É ou não é bacharel”. Publicações a Pedido. Jornal do Commércio. Rio de Janeiro, 30 de janeiro de 1866.

70 O.M.T.A ."mofina". Publicações a pedido. Correio Mercantil, Rio de Janeiro, 29 de janeiro de 1866, p.3.

71 GUISANDO, Bacharel Renato de. "Questão de Bacharéis". Publicações a Pedido. Jornal do Commércio. Rio de Janeiro, 2 de fevereiro de 1866, p.2. 
Em meio a essas frequentes publicações, contudo avulsas, Bethencourt empreendeu o maior esforço no sentido de "esclarecer" à opinião pública quem seriam, "de verdade", Américo e Ferro Cardoso, e publicou a única sequência de artigos seriados da "questão de bacharéis".

Em uma frente de ataque, esboçou um primeiro artigo sobre Américo, que teria continuações, embora não tenha levado a cabo (por motivos que tentarei levantar mais à frente). Nessa publicação, iniciava com apreciações a respeito da (não) posição tomada por Américo e seu amigo quando se vendo acusados de um crime, sequer reagindo, o que reforçaria ainda mais as suas culpas; seguia com a lembrança das acusações que os jovens supostamente teriam lançado a professores da AIBA, essas que teriam sido o estopim para o início da "questão"; em seguida, e finalmente, caminhava para duras críticas contra Américo:

Os imagináveis bacharéis sem diploma

"Il faut toujours dire la verite" 72

Apesar da petulância, astúcia, audácia e grande charlatanismo, que caracterizam os Enciclopédicos Ferro Cardoso, e Pedro Américo, ainda se acham em estado de tal letargia, pois que o remorso os acabrunha, que não se atrevem a deixar os covis e se apresentarem publicamente sem a máscara de vergonhosa proteção: eis os homens que se inculcam, aquilo que não são e que jamais o poderão ser sem aturado estudo e trabalho constante. Nome e glória não se adquirem com tanta facilidade, principalmente não estando os senhores estupendos sábios no país dos estúpidos e ignorantes, como diziam aqui e na Europa. Os sertanejos devem procurar os seus iguais e não se confundirem com os que receberam desde a mais tenra infância, educação e princípios muito diferentes e Vms. poderão passar por aquilo que lhes melhor convier nos desertos da África e, aí, vender gato por lebre, se encontrarem alguém que compre, e que nem assim será fácil. Os professores da academia nada sabem, diziam os 2 amigos inseparáveis em alma e corpo, com suas ideias burlescas (esses professores nada sabem porque não foram à Europa e não entraram no Salão de S. Paulo!), só eles (formidáveis sabichões!) tudo tinham aprendido para transformar a instrução pública no Brasil. (Que barbaridade, que estupendo fenômeno!!!). Só o escandaloso patronato pode vencer os obstáculos!!! Vejamos: isto será ou não estupidez? O ferrugem, só falta imitar certos animais herbívoros. É ou não isto verdade?

O Pedro Américo partiu para a Europa em 17 de março de 1859, e depois de ter feito a viagem au tour du monde, chegou ao Rio de Janeiro, cremos nós, em agosto de 1864, com todo o seu infatuado orgulho e sem bases, não tendo ao menos conhecimento das regras gerais da perspectiva aérea e da teoria da paisagem. Apresentando ele, em 1865, em exposição geral que teve lugar na academia das Belas Artes, o seu suntuoso painel com o rótulo - Carioca - despertou a curiosidade dos visitantes, e um anônimo, o Sr. Gonzales Coques, tendo feito a análise (aliás muito justa e razoável) desse painel rafaelesco, ficou completamente aterrado com os insultos e impropérios desse homem (?) em seu gênero (sabedoria inexplicável!!). Onde existe a aplicação do belo ideal nessa composição?

72 A citação ““iil faut toujours dire la verité” é, talvez, um diálogo com as incursões filosóficas desenvolvidas por Jean-Jacques Rousseu, em Les Rèveries du Promeneur Solitaire, especialmente a Quatrième Promenade. 
O menino aproveitou bem seu tempo durante a sua estada na Europa a expensas de S. M. Imperador.

Nos 3 primeiros anos remeteu ele para o Rio de Janeiro algumas cópias, e formou-se, diz ele, em 17 ciências, não apresentando diploma, nem por merecimento, nem comprado, porque com 300 francos mensais ${ }^{73}$ que percebia do bolsinho do seu protetor não era possível fazê-lo (raridade imprevista!), e aos dois últimos, o que fez ele? Resta-nos ainda saber.

Propagava enfim por esta capital ser grande poeta (pateta!), Literato (estonteado!), podendo já rivalizar com o mais ilustre mestre (?), como orador e que a tribuna lhe pertencia par droit de conquéte. Que petulância!! Três vezes petulância!!!

Sou Poeta! Sou poeta! Dizia ele, até as minhas patrícias me pedem versos.

Em ocasião oportuna tratamento das refutações que diziam por aí ter feito às ideias de M. M. Renan e Eméric David.

Bacharel Renato de Guisando

(continuar-se-á) ${ }^{74}$

Depois desse texto, em outra frente de ataque, mais contundente e assertiva que a primeira, Bethencourt publicou sete longos artigos no Jornal do Commércio ${ }^{75}$ e no Correio Mercantil, com os quais passava a demonstrar que os seus ressentimentos eram mais fortes por Ferro Cardoso do que por Pedro Américo; ou, então, que se tornava menos problemático referir-se sem medidas ao primeiro do que ao segundo, às vésperas de ser definitivamente empossado professor, com o evidente interesse de d. Pedro II.

Nesses artigos Ferro é de fato o único objeto de apreciação, ainda que Américo seja citado poucas, porém estratégicas vezes. A justificativa geral fornecida para a publicação da série era a mesma sutentada por outros textos e críticos: a de provar que Ferro não era bacharel e, assim, devolver em forma de humilhação pública $e$ punição legal os inúmeros insultos que teria encetado a várias personalidades desde quando chegara ao Brasil, em fins de 1861.

Se outros artigos da "questão" enunciaram uma ou outra autoridade competente em suas reivindicações para apuração de crime cometido, a série de Bethencourt, já em título, desejava chamar a atenção simultânea de várias personalidades para o caso. A inscrição permanente em todos os artigos era: “Ao Sr. ministro da agricultura, ao Sr. Inspetor de obras públicas e ao Sr. promotor Sizenando Nabuco". Ele demonstrava saber bem os agentes que deveria chamar - e a razão era clara, conforme tratado mais à frente. Juntos, ele integravam, respectivamente, altos cargos de três

73 A bolsa de Américo era de 400 francos mensais, e não 300, conforme sugeriu o crítico.

74 GUISANDO, Renato de. "Os imagináveis bacharéis sem diploma". Publicações a Pedido. Jornal do Commércio. Rio de Janeiro, 8 de fevereiro de 1866, P.2.

75 Os artigos foram publicados, no Jornal do Commércio, entre 2 de fevereiro e 10 de fevereiro de 1866. 
dos quatro poderes do império (o legislativo, o executivo, e o judiciário ${ }^{76}$ ), que tinham como dever dirigir e/ou garantir o bom funcionamento dos órgãos públicos em que Ferro trabalhava, e o bom comportamento dos seus funcionários, em conformidade com a "moralidade" e "legalidade" 77.

Mas havia ainda uma justificativa específica apresentada por Bethencourt da Silva; e essa era ainda mais significativa do que a primeira. A série era lançada em virtude de ser, ele próprio, um dos maiores prejudicados pelas ações de Ferro. Ele teria se tornado, não em 1861 (quando do retorno de Ferro ao Brasil), mas já muito antes, desde 1858, um dos alvos prediletos das depreciações do jovem. E o mais importante: Bethencourt apresentava-se mesmo como um artista cujo orgulho teria sido gratuitamente atacado:

A pessoa que escreve esta exposição, desmascarando um dos mais audaciosos e insólitos pelotiqueiros de que há notícia nesta terra, não tem, nem teve nunca a pretensão de ofuscar os merecimentos, se porventura existissem, do Sr. Ferro Cardoso, cuja glória e saber e nome a ninguém despertara sequer emulação. Na publicação destas linhas, há apenas o dever que tem todo o homem de brio, que se vê gratuitamente ultrajado e ofendido no que há de mais santo e puro para o seu viver de artista, de repelir o caluniador selvagem, ainda que seja mister feri-lo na face para mostrar aqueles que sorrindo o ouviam no ardor da sua maledicência, e aos incautos que o recebiam na sua casa, qual é o caráter moral desse delapidador [sic] da honra alheia; e prova também que semelhante sicofanta não é coisa alguma do que diz, isto é, nem bacharel, nem arquiteto pela escola de belas artes de Paris.

Sem dignidade nem princípio algum de polidez ou de sociedade, já desde 1858 tem ele atassalhado a reputação artística e o caráter de quem jamais nem de leve o ofendera e nem sequer da existência do Sr. Ferro Cardoso se lembrava! ${ }^{78}$

76 O quarto poder configura-se como o Poder Moderador, exclusivamente exercido pela pessoa do imperador.

77 O Ministro da Agricultura, cuja cadeira havia sido criada em 1860 para assumir algumas atribuições antes dadas ao Ministério do Império, era responsável não apenas pela pasta da agricultura, mas também pela da Secretaria de Comércio e de Obras Públicas, onde Ferro trabalhava. Era ainda o Ministério dos Negócios da Agricultura, Comércio e Obras Públicas o responsável por subvencionar a Sociedade Auxiliadora da Indústria Nacional, à qual o jovem era participante ativo, e fornecer patentes de inventos para melhoramento da indústria útil; outra função em que aquele estava imerso. O inspetor de obras públicas era chefe direto do cargo de Ferro (desenhador), responsável por fiscalizar os trabalhos andamento e o desempenho dos funcionários da secretaria, visto que a maioria dos cargos não era preenchida via concurso público, mas por requisição (ou, também, indicação). E o promotor público, Sezinando Nabuco, era, à época, conhecido profissional, responsável por iniciar e investigar processos contra o interesse público. Para uma melhor compreensão do funcionamento do Ministério dos Negócios da Agricultura, Comércio e Obras Públicas entre 1860 e 1891, ver: GABLER, Louise. A Secretaria de Estado dos Negócios da Agricultura, Comércio e Obras Públicas e a modernização do Império (1860-1891). Rio de Janeiro: Arquivo Nacional, 2012.

78 O. M. T. A. “Ao Sr. ministro da agricultura, ao Sr. Inspetor de obras públicas e ao Sr. promotor Sizenando Nabuco.”. Publicações a Pedido. Correio Mercantil, 1 de fevereiro de 1866.

Outras passagens de artigos da série em que Bethencourt da Silva afirma sua posição de vítima são a seguintes: "Apesar de termos sido vítima da sua gratuita e feroz inimizade, da raiva e ódio velho com que possesso nos agredia pelas costas, lançando mão de falsidades para deprimir-nos em frases desonestas e imundas, temos contudo compaixão da sua pueiril soberba, da cega presunção que o faz julgar-se um novo Salomão e um outro Humboldt!” O. M. T. A. "Ao Sr. ministro da agricultura, ao Sr. Inspetor de obras públicas e ao Sr. promotor Sizenando Nabuco." Publicações a Pedido. Correio Mercantil, 3 de fevereiro de 1866. p.2. 
Bethencourt era portanto, no seu dizer, um artista que havia chegado ao limite dos insultos recebidos. Lançava um castigo a Ferro, um longo castigo de sete artigos, com o qual deveria desmascará-lo. O número de publicações poderia ter sido menor, segundo afirmou em um dos textos, se Ferro, que o conhecia pessoalmente, e também como um dos arautos da "questão", não tivesse continuado a se gabar e, ademais, a provocá-lo quando se cruzavam nas ruas ${ }^{79}$. A questão era, à primeira vista, pessoal. Contudo, apenas a princípio ela assim se dava à mostra.

A estratégia era bastante calculada: construir uma narrativa na qual mostrasse como um menino pobre e sem instrução, vindo do interior do Ceará, em 1855, teria a sorte de ser apadrinhado por uma das figuras políticas mais importantes do período, o Ministro Pedreira, e ver toda a sua vida mudar bruscamente para melhor, conquanto continuasse a ser um jovem desprovido de toda "inteligência". E era assim que Bethencourt, em cada artigo, reiterava a "mediocridade" que observava em Ferro Cardoso.

Este, partindo para a Europa semi-analfabeto ${ }^{80}$ - sem ter conquistado o prêmio de viagem, ou a confiança benevolente do "bolsinho" do imperador -, voltaria da mesma maneira, todavia ainda mais prepotente. $\mathrm{O}$ único dom que teria desenvolvido seriaa soberba e a crença de que, sem esforço, poderia se tornar um novo "gênio" das artes e da arquitetura no Brasil (e não é difícil imaginar que havia um paralelo implícito nessa narrativa, que também deveria encontrar Pedro Américo, em suas aspirações à glória nacional). Construía-se assim a imagem de um indivíduo que empregaria quaisquer meios para subir na vida, mas que, para tanto, lhe faltaria tudo: o conhecimento, a moral e o caráter. Os caminhos tomados teriam sido, então, escusos.

E: "Para aqueles que escaparam às tímidas maledicências do Sr. Ferro Cardoso e que não viram, como nós, o seu nome e a sua reputação torpemente enxovalhadas pela mais gratuita inimizade que é possível conceber-se, talvez pareça exagerado o castigo que ora lhe inflingimos, levantando-lhe a viseira; mas, se esses, que porventura julgam demais o que havemos feito, tivessem, como nós, sofrido em silêncio, desde 1858, as mais indignas injúrias que nos podiam arremessar, negando-se-nos até mesmo esse bocadinho de inteligência, ou antes o censo comum que o céu nos deu estamos certos que não mandariam ao Sr. Ferro nem flores, nem pastéis em recompensa dos seus bons serviços!"”. GUISANDO, Renato de. "Ao Sr. ministro da agricultura, ao Sr. Inspetor de obras públicas e ao Sr. promotor Sizenando Nabuco.”, VI, Publicações a Pedido. Jornal do Commércio. Rio de Janeiro, 9 de fevereiro de 1866.

79 A justificativa de Bethencourt para continuar a série de artigos é essa: "Teríamos já talvez, deixando à margem esta nossa enfadonha tarefa, se depois do que havemos dito acerca desta nova gralha da fábula, não nos tivesse Ferro Cardoso de novo injuriado, ajuntando à leviandade com que se houve, inculcando-se bacharel e arquiteto pela escola de Paris, - a impundência de insistir, reclacitrando com vociferações burlescas que era bacharel e que provocando-nos na rua, havia meter na correção o estúpido (!) que escrevia contra o seu saber e a legitimidade do seu título!". O. M. T. A. "Ao Sr. ministro da agricultura, ao Sr. Inspetor de obras públicas e ao Sr. promotor Sizenando Nabuco.” Publicações a Pedido. Correio Mercantil, Rio de Janeiro. 3 de fevereiro de 1866.

80 De fato, dessa maneira Ferro Cardoso foi apresentado nas primeiras que teve seu nome citado na imprensa carioca, em 1855. 
Para iniciar o processo no qual provaria as qualidades que imputava a Ferro, Bethencourt apresentou em um dos seus artigos um longo trecho de uma circular publicada pelo jovem em março de 1862 (portanto logo após o seu retorno ao Brasil), rebatendo ponto a ponto, dentro da própria citação, os dados que defendia serem naquela falsamente forjados ${ }^{81}$.

Ferro já teria retornado ao Brasil como réu potencial, pois se apresentava precedido de um título (e de experiências) de que não dispunha. Enganaria a todos, e o que seria ainda mais grave, segundo o articulista: enganaria o próprio d. Pedro II, posto que, no afã por notoriedade, o jovem se introduziria como bacharel até mesmo nas cerimônias do beija-mão, em frente ao monarca, no palácio de São Cristóvão. Em uma dessas oportunidades teria mentido duplamente, apresentando-se

81 A citação da circular de Ferro, de março de 1862, e os comentários de Bethencourt são esses: "Ilm. $\quad$ Sr.- $\quad$ O bacharel (vejam só isto!) Daniel Pedro Ferro Cardoso, tendo completado (completado?) os seus estudos na Escola Superior de Belas Artes de Paris (é uma falsidade, pois ali apenas se matriculou em 20 de novembro de 1860), de onde acaba de chegar, em cuja cidade foi aluno de Mr. Questel (Mr. Questel assegura que não há tal!) frequentou as aulas noturnos [sic] des Arts et Métiers (estas aulas, de que fala o Sr. Ferro, são os cursos públicos do Conservatoire des Arts e Métiers!) e praticou metodicamente a construção cívil (em que tempo? se ele só esteve, inclusive viagens, dois anos e meio fora do Rio de Janeiro?!) como empregado (?) no escritório (escritório de arquitetura?!) de Mr. Barthomieux, arquiteto de grandes prédios nas ruas de Rivoli e Faubourge St. Honoré, para cujos edifícios o mesmo Bacharel (!) forneceu planos e foi às construções dirigir os trabalhos (que homem extraordinário! que ubiquidade onipotente!) fazendo os orçamentos dos materiais e aprendendo assim a maneira econômica, (já se viu uma mentira mais descabelada? Então o Sr. Ferro foi quem fez plano e orçamentos e dirigiu as construções dos grandes prédios das ruas de Rivoli e Faubourg St. Honoré?! Foi o Sr. Ferro mesmo quem fez os planos e dirigiu as obras confiadas a MR. Barthomieux?! Que fortuna! Se não é esta viagem do sr. Ferro a Paris o que seria de Mr. Barthomieux?! E é um moço quem assim tão descaradamente falta á verdade!)"

Não obstante o assíduo e aproveitado estudo que fez nessa suntuosa e magnifica cidade - nesse mundo resumido -, estudou ela mesma, isto é, visitou frequentes vezes e com boas descrições os seus "maravilhosos monumentos; quis também compará-los às construções das outras principais potências (!) da Europa, para esse fim visitou em primeiro lugar Londres, aquela importante e grandiosa cidade; não perdeu ali o seu tempo, (é ele quem diz e só ele!) percorrendo as galerias dos museus britânicas, Nacional, das Indias, etc, (quantos dias empregou em cada um?) visitou palácios e igrejas com grande atenção, a segunda Categral cristã do universo (S. Paulo em Londres), onde observou, quando nela subiu para entrar a esfera", sobre a qual repousa a cruz, que coroa a extremidade superior daquele amdmirável balão. (Já se viu um maior parlapatão! verdadeiro mal das vinhas da arquitetura!) Visitou em seguida as principais cidades da França, a Suiça, os Ducados de Baden e de Hesse, a Prússia Renana, a Holanda e a Bélgica, cuja viagem de instrução (o que não se pode fazer a vapor!) percorreu 43 cidades! 38 catedrais! 143 museu de diferentes gêneros!!! (em quantos dias?) 18 palácios de primeira ordem e um considerável número de igrejas; não contando centenas de curiosidades de diferentes espécies. (Há nada mais cômico e pedantescamente ridículo do que está estercadura de sabedoria histórica? E tudo isto e o mais foi feito em dois anos e meio!!)

Depois de outras patranhas diz: "o referido Bacharel foi aceito plenamento em Ciências pela universidade de Paris, (que audácia!) e também em arquitetura pela academia das Belas Artes da mesma cidade! (mentira! três vezes mentira!!!)". O. M. T. A. "Ao Sr. ministro da agricultura, ao Sr. Inspetor de obras públicas e ao Sr. promotor Sizenando Nabuco." Publicações a Pedido. Correio Mercantil, Rio de Janeiro, 4 de fevereiro de 1866.

Para Bethencourt da Silva, Ferro não poderia ter concluído o bacharel na Escola Superior de Belas Artes de Paris, pois havia se matriculado no curso apenas em novembro de 1860, um ano antes de retornar ao Brasil: em artigo anterior, ele apresentava até mesmo o número de inscrição de Ferro na instituitação: 1501 (O. M. T. A. "Ao Sr. ministro da agricultura, ao Sr. Inspetor de obras públicas e ao Sr. Promotor Sizenando Nabuco.”. Publicações a Pedido. Correio Mercantil, Rio de Janeiro, 30 de janeiro de 1866. P.3.). Ao contrário do que se teria afirmado, dificilmente o jovem teria trabalhado em um grande escritório de arquitetura e ainda ter encontrado tempo, em pouco mais de dois anos, para estudar e viajar por várias cidades da França, além de Londres, "Suíça, Ducados de Baden e Hesse, a Prússia Renana, a Holanda e a Bélgica, em cuja viagem de instrução percorreu 43 cidades, 38 catedrais, 143 museus de diferentes gêneros, 18 palácios de primeira ordem, e um considerável número de igrejas; não contando centenas de curiosidades de diferentes espécies." Ibidem. 
ainda como comissionado por um pensionista do império (possivelmente Américo), que todavia não teria requisitado, segundo Bethencourt da Silva, qualquer intermédio. ${ }^{82}$.

A prepotência foi, com efeito, o traço característico mais explorado por Bethencourt para desenvolver os argumentos a respeito de Ferro. Depois de mentir para o "primeiro cidadão", não temendo mais nada, o jovem afirmaria estar apto a desempenhar funções para as quais também não possuía formação, nem capacidade ${ }^{83}$. Quereria assumir a cadeira de estética na academia, em 1862; a de hidrografia na Escola da Marinha e a de matemática na Escola Normal, no mesmo ano, e desempenhar alguma função no Instituto Comercial. Todas essas tentativas foram, no entanto, fracassadas. E mesmo o cargo de "desenhador" de obras públicas que desempenhava, única exceção vitoriosa entre os seus intentos, teria sido a ele ofertado não por intermédio de concurso, mas por indicação da sua madrinha de casamento (cujo nome não foi divulgado pelo articulista). Essa, outra possível prova da "mediocridade" do jovem: a de que apenas pelo patronato (o mesmo patronato de que acusaria a Américo se beneficiar) poderia crescer profissionalmente.

Ferro Cardoso, ainda segundo Bethencourt da Silva, se voltaria contra todos aqueles que contrariassem suas aspirações, ou que o preterissem em processos seletivos para cargos públicos:

Como Pasquim, o Sr. Ferro não fala mal de Cristo porque não o conheceu! - O Sr. conselheiro Thomas Gomes dos Santos, porque não lhe dá (a ele, quase analfabeto) a cadeira de estética, é um infame!

A população do Rio de Janeiro, segundo uma carta sua, é uma gentalha! Os fluminenses são homens sem pudor!...O Sr. Dr. Jacobina, ajudante do Sr. Paulo Barbosa, um estúpido, porque queria provas que garantissem a origem dos painéis do Sr. Américo. Enfim! ele só ele merece a sua admiração, o seu respeito e o seu culto! Narciso de nova espécie, só vê o seu saber e a sua suprema inteligência de que se enamora! ${ }^{84}$

82 Bethencourt da Silva parece se referir ao episódio em que Américo teria pedido a Ferro que intervisse junto a d. Pedro II para obtenção de recursos para a compra da moldura da sua Carioca e para a sua viagem à Itália. Se for a esse episódio que se refere, Bethencourt da Silva de fato se equivocava, pois há a carta de Américo ao monarca, na qual introduz Ferro Cardoso como seu procurador, conforme apresentei anteriormente.

O trecho do artigo que aduz a questão é o seguinte: "O homem que mentia ao Imperador, dizendo-se bacharel, que mentia falando como comissionado de um pensionista de seu imperial bolsinho, que de nada o encarregara, perante quem trepidaria na vaidade, na torpeza, na calunia?!

Quem mente ao primeiro cidadão, cuja presença só infunde respeito, como falará verdade entre os seus pares, ante aqueles a quem falta o prestígio da posição e do nascimento?”. O. M. T. A. Op.cit, 30 de janeiro de 1866. P.3.

83 O. M. T. A. "Ao Sr. ministro da agricultura, ao Sr. Inspetor de obras públicas e ao Sr. promotor Sizenando Nabuco." Publicações a Pedido. Correio Mercantil, Rio de Janeiro. 3 de fevereiro de 1866.

84 O. M. T. A. "Ao Sr. ministro da agricultura, ao Sr. Inspetor de obras públicas e ao Sr. promotor Sizenando Nabuco.”. Publicações a Pedido. Correio Mercantil, Rio de Janeiro, 1 de fevereiro de 1866. 
$\mathrm{O}$ vínculo com a academia parece ter de fato sido o elemento catalizador para que Bethencourt da Silva tivesse acesso e apresentasse provas que considerou documentos cabais dos crimes e mentiras de Ferro Cardoso. Tratar-se-ia de uma série de cartas nas quais o jovem arquiteto pediria que comprassem a ele um diploma de bacharel. O quinto artigo da série era concluído da seguinte maneira:

No próximo artigo publicaremos as cartas que Ferro Cardoso escreveu para Paris em data de 24 de março e 6 de abril de 1862, pedindo para lhe comprarem um diploma de bacharel, ainda que viesse com o nome de outro, e data inconveniente, porque ele cá arranjaria isso! E feita esta publicação, veremos estão o que faz o Sr. Ministro, o Sr. inspetor de obras públicas, o Sr. promotor e sobretudo o Sr. chefe de polícia! $!^{85}$

Um dos destinatários das cartas (duas, no total) não poderia ser outro: Pedro Américo. Bethencourt, de maneira muito engenhosa, desejava não apenas provar o uso indevido de títulos de que Ferro havia feito desde 1862. Tencionava apresentar provas de uma tentativa de falsificação de documentos (que, se consumada, representaria outro crime) envolvendo aquele como autor, e Américo como cúmplice potencial ${ }^{86}$.

85 O. M. T. A. "Ao Sr. ministro da agricultura, ao Sr. Inspetor de obras públicas e ao Sr. promotor Sizenando Nabuco." Publicações a Pedido. Correio Mercantil, Rio de Janeiro, 4 de fevereiro de 1866.

${ }^{86}$ Com efeito, nos dois últimos artigos seguintes Bethencourt da Silva apresentava as ditas cartas, justificando, contudo, o quanto lamentava publicá-las, ainda que tal ação lhe fosse reservada como direito de defesa dos insultos recebidos; e as precedia com o juízo de que os manuscritos constituiriam para Ferro Cardoso, "o seu corpo de delito, a negação de tudo quanto ele há dito e feito, e que são matéria suficiente para ser processado e demitido, se ainda há entre nós um resto de dignidade no governo, brio no funcionarismo público e honra no cumprimeiro dos deveres na polícia!" O. M. T. A.. "Ao Sr. ministro da agricultura, ao Sr. Inspetor de obras públicas e ao Sr. promotor Sizenando Nabuco." Publicações a Pedido. Correio Mercantil, Rio de Janeiro, 6 de fevereiro de 1866.

Na primeira carta, ele abreviava a primeira letra o nome do destinatário - pois esse não deveria lhe representar ameaça -, mantendo, de resto, o conteúdo escrito. A correspondência incluía: a ênfase sobre a "ignorância" do jovem à sua língua por meio de destaques internos e comentários feitos pelo publicador); as novidades do ambiente artístico brasileiro, àquela altura bastante agitado com os debates sobre a inaguração da estátua equestre de d. Pedro I, projetada por Louis Rochet; apresentava os problemas e os inimigos que o jovem teria conquistado na busca por emprego em uma repartição pública; comentava rapidamente que a mudança de ministério ameaçava o retorno do seu amigo Pedro Américo e, apenas no fim, tornava-se ao clímax, quando desenvolvia uma rápida requisição para a compra de um título de bacharel. A alusão à ameaça da perda da bolsa de Américo era feito, sem dúvida, em relação aos trâmites que levaram à troca do Ministério Caxias pelo "Ministério dos três dias", de Zacarias de Góis e Vasconcelos, formado a 24 de maio de 1862, justamente no período em que a bolsa de estudos Américo, concedida pelo imperador, cessava. O artista, como visto, além de enviar cartas ao imperador para que esse permitesse estender por mais dois anos sua estadia na Europa, ainda teve como aliado Porto Alegre, que em carta a seu "compadre" Paulo Barbosa, mordomo da Casa Imperial, reiterava o pedido para que não se deixasse retornar o "gênio" Américo.cf. PORTO ALEGRE, Manuel de Araújo. Carta de Berlim a Paulo Barbosa, em 27 de setembro de 1861. LACOMBE, Américo Jacobina. Araújo Porto Alegre: Correspondência com Paulo Barbosa da Silva. Rio de Janeiro: Academia Brasileira de Letras,1991. Pp.108-10.

A primeira carta aqui comentada é apresentada em seguida. Em sua apresentação, não fiz qualquer correção nem atualização para o português corrente. Respeitei o interesse de Bethencourt da Silva em ressaltar os erros que Ferro teria cometido ao escrever suas cartas. Os termos em itálico presentes na citação são indicações do próprio articulista, feitas com o intuito de sublinhar os erros cometidos pelo jovem, ou para chamar atenção para uma ou outra passagem polêmica, como naquelas em que o Ferro pediria que se comprasse o diploma:

“ 'meu a......ultimamente o nosso triste Rio se acha coberto de parures paro o dia d'amanhã que terá lugar (barbarismo!) a inauguração do Estatua ; folla-se, porém eu não tenho o menor receio, de uma forte revolução política, 
Essa segunda suposta carta, essa endereçada a Américo, era a mais polêmica de todas as publicações feitas por Bethencourt da Silva até então e, não por acaso, era publicada no último artigo da sua série (mesmo que ele afirmasse existirem mais cartas em suas mãos ${ }^{87}$ ). Nela, o nome do destinatário era escancarado, sem censuras:

meu caro americo. Rio, 6 de abril de 1862. (Compare-se esta data com a da circular em que ele já se dizia bacharel!)

não podes imaginar quam grande tem sido minhas amarguras estes derradeiros dias; vou entrar em comcurso ${ }^{88} 3^{\text {a }}$ feira 8 d'este, e ainda não tenho un só empenho (Que desgraça! Desta vez estava o homem sem os seus merecimentos!) pois o miserável do Tomas Gomes tem tecido as coisas de tal sorte que até hoje domingo não se sabe quais examinadores - resta-me, apenas, segunda feira que estou combinado com o João Pedreira ${ }^{89}$ para ele escrever ao presidente do

(o homem estava bem informado!) querem modar de Governo, evoyer se promener o Pedrinho . (!!! E era isto dito a um pensionista do Imperador! E com que fim se mentia deste modo a um moço que na Europa mal podia imaginar a distância que ia desta parvoice à verdadei?!) 'o fallatório sempre há algum eseito [sic], mas tu sabes que he o espirito mesquinho brazileiro, (E que tal o amigo da rabeca! Então o espírito brasileira era grande e nobre, levantando-se contra a autoridade legitimamente constituída?! Ora..) se eu já estivesse na frente de um grup isto se efetuaria, (aqui del-rei contra este novo Cromwell! Acautele-se a monarquia! Esteja alerta a polícia alerta, que se um dia chega a estar á frente de um grupo este outro Robispière (em caricatura), lá se vai a coroa da Brasil e a família imperial!!!) este falatório de barulhos políticos se complicão com barulhos patrióticos, isto é, querem esterminar os, portugas, estes, com efeito andão em grupo e já tem havido diferentes prisões en fim amanhaã se verá o resultado:(Com efeito o homem tem jeito para historiador! Isto é que é falar verdade! e tudo o mais são histórias!)

'ah, meu a..tu me faltas para analisar um povo ignorante (e quem mais no caso de o dizer do que o Sr. Ferro!) se tu assestisses, uma só meia hora, os trabalhos da ereccão (!!! Irra!) da estátua, no meio deste tomulto de povo circulão os trabalhos terias ouvido disere as maiores barbaridas que se poden conceber, uns dizião que nunca tinham visto homens daquele, tamanho, outros desião que eram as cabococolos da quelles rio que eram tão grande, outros que nuca tinham visto cavalo tamanha, outros que se faziam muito entendidos desião que era a obra mais perfeita do mundo enteiro, Oh meu Deus eu nuica queria estar no meio de tantos estupidos: (O homem tem razão! Pois não tem?!) podem-se tirar milhares de anedoctas de tanta ignorância.

Meu a.....julga a minha sorte; fui a Dias ao Imperador pedir-lhe a cadeira de esthtica do academia....Este mandou enformar, eis pois uma pretenção minha nas mãos do meu inimigo (que presunção!) este me pediu os meus documentos para informar, hei de levá-los um destes dias.

Creou-se uma escola normal na Praia grande da qual Escola o Diretor é Thomas Gomes, eis que me inscrevo o concurso de matemáticas que terá lugar muito breve, me voila uma segunda vez nas mãos do meu inemigo o que dises, pois, de minha situação? (isto não se comenta!admira-se!) Um só pedido, um só empenho não procurarei para tal infame (que linguagem e que qualificação para um tal homem!), ao contrário sempre o tratarei com a mesma, minha dignidade, e desprezo que até aqui o tenho tratado.

E boa em meu a..., aminha outra pretenção do Instituto comercial depende do homem que tu, com muita graça o apelidaces polechinelo (o Sr. Dr. Pacheco que agradeça estas ausências!) só terá lugar (!) este concurso em maio ou junho.

mete um evelope (!) a carta junta e vai até a universidade - a...aindo esta massada, vai a universidade e pede por mim interesadamente falando com o secretário et lhe dando a carta inclusa, o certificado que lhe escrevi (ele é quem escreveu o certificado que lhe fazia conta!!!) na carta, vê, se pódes adquerir o diploma nem que custe 4 vezes mais (!!!) dis mesmo ao secretário que para me empregar o diploma seria muito útil e que eu desejava muito obte-lo por qualquer que seja o preço (queria subornar o secretário!). Trabalha meu a.... em meu benefício.!". O. M. T. A.. "Ao Sr. ministro da agricultura, ao Sr. Inspetor de obras públicas e ao Sr. promotor Sizenando Nabuco. VI" Correio Mercantil, 6 de fevereiro de 1866.

87 O. M. T. A. “Ao Sr. ministro da agricultura, ao Sr. Inspetor de obras públicas e ao Sr. promotor Sizenando Nabuco. VII" Correio Mercantil, Rio de Janeiro, 7 de fevereiro de 1866.

88 Ferro parece se referir aqui ao concurso para o Instituto Comercial, no qual estava inscrito já em fevereiro de 1862.

${ }^{89}$ Trata-se de João Pedreira do Couto Ferraz, filho do ministro Luíz Pedreira do Couto Ferraz. 
provincia, e assim vermos se podemos saber ostaes: (o melhor amigo do Sr. conselheiro Thomaz Gomes, não descobriria uma tão bela prova do seu caráter e da sisudez com que rege os atos de sua administração.)

meu caro.... sei que te tenho sempe em comodado e agora vou te fazer o único pedido mais importante (que linguagem!) sei be $n$ como tu te massas com estas coisas: não me quis derigir a tal respeito ao Hermogenes, porque - só nós dois - ... Pesso-te (com dois ss!) incaredicamente, vai vem dá passos contraria-te pede sofre, (finalmente apareceu uma vírgula!) e consegue-me! sou eu quem te pesso: a mais tempo me devia ter lembrado de tal - americo eis ahi o que te rogo, e eis ahi un dos meios pelos quais tu poderá chegar - derigi-te ao Bourdon (Rue Savoie 7 ou 9) falla-lhe de minha parte, pede-lhe desculpa, de, ainda não lhe ter escrito e pede-lhe para te guiar. Eis tudo, QUERO QUE TU COMPRES (!!!) UM DIPLOMA DE BACHAREL EM CIÊNCIAS, (e então?!) é um pouco dificil, mas, voilá o meio, o mouço (mouço!!!) que for Bacharel em ciências pode ceder o seu diploma e ir tirar outro, (!) creio que pagando de novamente le montant e, este moço pode dar a desculpa de o ter perdido, (!) ou queimado (!!) e assim a Sorbona lhe dá outro (E que me dizem a esta ideia? Não é má!) quanto a dinheiro, tu te podes te derigir de minha parte ao Hermogenes dizendo-lhe que é para uma compra qualquer e que é muito urgente não me emporto que gastes até....200 fr. com o tal e mesmo mais - se encontrasses aquele pedante que foi em tua casas querendo passar exame porti (Esta não é má! O indivíduo que ia fazer o exame pelo outro é que era o pedante? Que lógica!) era quem poderia arranjar isto com mais facilidade, americo não me faltas em tal pedido, pois me deixas ficar mal: QUANTO O RESTO EU ARRANJAREI - NOME MUDADO EPOCA, etc. etc. (o tal bacharel é um moço de recursos! Pilhava um diploma com o nome de outro e data inconveniente para ele, raspava uma e outra coisa, e escrevia-lhe o seu nome e a data própria! Ah! Robert Macquaire o teu gênio foi vencido!!...)

Eu disse ao miserável Thomas Gomes que tinha meu diploma e que não o tinha tirado por que se achavam funcionando os exames (!) da Sorbone e que en tal epoca não se destrebuem títulos e sim 3 meses depois: disse-lhe isto na ocasião que levei meus documentos pedindo a cadeira de esthetyca (Esthetica com - y- !! não é má!)

Termino meu caro americo te disendo que eu conseguiria e que não te perdouo (!) não me arranjares tal; (!!!) disendo-te mais que nisto consiste hoje minha felicidade, e assim quais não serão os esforços que tu deves fazer - seria muito bon que o TAL DIPLOMA fosse do mês de abril de [18]61 ou destes 3 anos para cá -' !!!! ${ }^{90}$

O desfecho dado por Bethencourt da Silva à sua série era certeiro, ainda que criasse um ruído indesejado nas acusações voltadas até então a Américo, em outros artigos. O ruído provinha da retratação parcial que a publicação dessa carta faria à imagem do artista. Américo podia até sustentar uma formação que não havia concluído completamente, mas se aborreceria com o assunto da compra de títulos, e não teria concordado que um "pedante" fizesse a prova do bacharelado por ele. Com ou sem título, sua preocupação com uma formação científica era legítima.

90 O. M. T. A. “Ao Sr. ministro da agricultura, ao Sr. Inspetor de obras públicas e ao Sr. promotor Sizenando Nabuco. VII". Correio Mercantil, 7 de fevereiro de 1866. 
Direto no alvo, no entanto, estava a prova contra Ferro, supostamente fornecida por ele próprio, de que não possuía qualquer diploma, de que estava desesperado para comprar um, e de que não mediria esforços para obtê-lo, mesmo que isso significasse cometer outras infrações, além daquela que já incorria no art. 301 do Código Penal.

O segundo delito, o de falsificação de documentos, não se consumou, pois, afinal, toda a “questão de bacharéis", desde muito antes da publicação dos artigos de Bethencourt, cercava-se da conhecida ausência diplomas. Os assuntos apresentados nas cartas deveriam sustentar, contudo, mais motivos para que Ferro, em primeiro lugar, e Américo (como seu amigo), por retaliação, tivessem suas reputações definitivamente manchadas. O que importava na publicação das duas cartas não era provar o segundo crime cometido, mas expor a intenção de cometê-lo, se houvesse uma maneira, e, em decorrência disso, oferecer a suposta prova irrefutável das índoles "duvidosas" dos jovens, especialmente da do arquiteto.

Bethencourt da Silva concluía a sua campanha, assim, quase da mesma maneira que a havia iniciado, isto é, reivindicando das autoridades a execução do processo crime:

E depois destas provas, cujos autógrafos [das cartas] podem ser patentes a quem os quiser examinar, o que fará o Sr. ministro da agricultura, o Sr. inspetor das obras públicas e o Sr. promotor público? Continuará o réu impune? Não será ao menos chamado ao juiz competente para ser processado, vedando-se-lhe o abuso que tem praticado, enganando o Imperador, os seus chefes e o país inteiro? ${ }^{91}$

Após essa requisição, ele fazia entretanto um último e ácido pedido para que outras importantes figuras do império, incluindo ministros e marqueses, se manifestassem sobre o caso. Alguns deles, era bem sabido, eram considerados protetores ou interlocutores diretos de Américo e Ferro desde período em que eram estudantes no Brasil, como é o caso de Pedreira e, também, de José Marques Lisboa, ministro brasileiro em Paris, responsável pela legação brasileira no exterior.

O pedido era ácido porque, novamente, retórico. Dessas autoridades, por motivos não explicitados claramente na série de artigos (além da sugestão de patronato), o autor não esperava manifestação alguma, porquanto sugeria serem coniventes com os jovens:

E agora que diz a isto o honrado Sr. conselheiro Pedreira, o Sr. Chefe de polícia, o Sr. Pedro de Alcantara, o Sr. Andrade Pinto e o Sr. Lisboa?

91 O. M. T. A. op.cit. 
Haverá ainda um homem de bem que o trate de bacharel, e lhe aperte a mão, e o considere como um moço honesto?

É de crer que sim! - O absurdo, o patronato e o escândalo sancionaram toda esta infâmia para gloria do Sr. Ferro, e honra dos que assim praticarem $!^{92}$

Embora desejasse que a formação de processo contra Ferro (e também contra Américo, conforme defendia em outros artigos) terminasse em cumprimento de pena, Bethencourt da Silva já sinalizava que o fim inevitável de sua campanha poderia ser o arquivamento da polêmica. Mesmo que as cartas do jovem fossem a sua "prova de delito", para o crítico parecia não restar mais nenhuma das qualidades que havia requerido das autoridades imperiais: "um resto de dignidade no governo, brio no funcionarismo público e honra no cumprimeiro dos deveres na polícia!" "93. O "patronato" teria permitido que tudo aquilo acontecesse, e seria também ele o agente para que tudo fosse lavado.

O delicado terreno em que o Bethencourt da Silva pisava, em meio a políticos poderosos e outras autoridades, permitiu (mesmo que escondido por pseudônimos) apenas que citasse sutilmente alguns nomes, e que comentasse, vez ou outra, mas sem precisar, o acobertamento que alguns agentes faziam dos jovens. Desse modo, em momento algum explicou as possíveis conexões existentes para que se justificasse o "patronato" - talvez, para muitos, conhecidas à época. A única exceção foi feita quando, muito delicamente, afirmou em um dos artigos da série ${ }^{94}$ que Ferro Cardoso teria conseguido o emprego no departamento de obras públicas por influência da sua madrinha de casamento, a qual, no entanto, conforme citado, não foi nomeada. Todavia, os artigos de imprensa podem novamente ajudar a explicar essas conexões.

\section{Entre bacharéis, marqueses e barões}

Em 23 de junho de 1862, o Correio Mercantil estampava uma pequena nota que introduzia o casamento de Daniel Pedro Ferro Cardoso com Luiza Maria Cardoso Pereira de Barros. Se a nota era ordinária, como tantas outras notificações de casamento presentes em jornais do período, as circunstâncias e participantes do evento, não tanto.

Luiza Pereira de Barros pertencia a uma importante família brasileira. Com o matrimônio, Ferro cardoso tornava-se, de súbito, genro do primeiro Barão da Gamboa, José Manuel Fernandes

\footnotetext{
${ }^{92}$ O. M. T. A. "Ao Sr. ministro da agricultura, ao Sr. Inspetor de obras públicas e ao Sr. promotor Sizenando Nabuco.” Correio mercantil, 7 de fevereiro de 1866. Publicações a Pedido. p.3.

93 O. M. T. A.. "Ao Sr. ministro da agricultura, ao Sr. Inspetor de obras públicas e ao Sr. promotor Sizenando Nabuco." Publicações a Pedido. Correio Mercantil, Rio de Janeiro, 6 de fevereiro de 1866. P.2-3

94 O. M. T. A. "Ao Sr. ministro da agricultura, ao Sr. Inspetor de obras públicas e ao Sr. promotor Sizenando Nabuco.” Publicações a Pedido. Correio Mercantil, Rio de Janeiro. 3 de fevereiro de 1866. P.3
} 
Pereira; cunhado de José Maurício Fernandes Pereira de Barros, o segundo Barão da Gamboa; e também de Francisco Firmo Fernandes Pereira, político, e ex-presidente da província do Espírito Santo, na década de 1850 . As testemunhas não eram menos importantes ${ }^{95}$. Como padrinhos de casamento, Ferro teve o seu dito "protetor", conselheiro Luís Pedreira, além de outro importante político, o ex-ministro da Justiça, senador e membro do Conselho Imperial, Eusébio de Queiroz Coutinho Mattoso Câmara (o "saquarema" autor, na década de 1850, da lei de proibição do tráfico negreiro). Como madrinhas, Anna Henriqueta de Barros Pereira Cruz Lima (irmã de sua mulher, e esposa de José Dias da Cruz Lima, membro do IHGB), e a Marquesa de Olinda, Luiza Bernarda de Figueiredo: a grande madrinha a que certamente se referia Bethencourt da Silva quando citava o emprego que ela "arranjou" para Ferro no departamento de obras públicas.

Coincidência ou não, Pedro Araújo de Lima, o Marquês de Olinda (outro antigo “saquarema"), era de fato Presidente do Conselho de Ministros em $1862^{96}$, quando Ferro conseguia seu emprego ${ }^{97}$; e em 1866, justamente no momento em que o mesmo político deferia, ele próprio, a estranha licença concedida a Américo para que se afastasse do seu recém-empossado cargo de docente da AIBA, exercia novamente o cargo de Presidente do Conselho e, concomitantemente, Ministro e Secretário de Estado dos Negócios do Império. Tudo isso feito num período no qual observava seu gabinete e sua longa vida política serem duramente criticados ${ }^{98}$.

Outro nome citado por Bethencourt da Silva no fim da sua série de artigos parecia ainda ter alguma significância para o círculo social frequentado por Ferro. O "Sr. Pedro de Alcantara" era Pedro de Alcantara Bellegarde, membro fundador do Instituto Histórico e Geográfico Brasileiro, sócio da Sociedade Auxiliadora da Indústria Nacional, membro do Conservatório Dramático, tendo exercido o cargo de ministro da Agricultura, Comércio e Obras Públicas entre fevereiro de 1863 a janeiro de 1864, também em um dos períodos em que o Marquês de Olinda era presidente do Conselho de Ministros ${ }^{99}$.

95 CASAMENTO. Correio Mercantil, Rio de Janeiro, 23 de junho de 1862. P.2.

96 Era uma das atribuições do presidente do conselho de Ministros (cargo criado apenas em 1848), formar o ministério, escolhendo, com o aval do imperador, os políticos que ocupariam as diversas pastas do governo.

97 Esse mandato de presidente do conselho, entre vários outros que teve desde o período regencial, começou em maio de 1862 e terminou em 15 de janeiro de 1864 .

98 Talvez a figura mais conhecida que tenha direcionado duras críticas a Pedro Araújo de Lima tenha sido José de Alencar. Justamente em 1866, após a publicação das polêmicas Cartas de Eramos, texto no qual criticava d. Pedro II em sua atuação que estrapolaria os limites do Poder Moderador, ele publica o impresso Ao Marquês de Olinda, no qual criticava duramente o velho político, chamando atenção para o fato de que o seu "tempo" de vigência já teria passado, e que já estaria mais do que na hora, portanto, do marquês se afastar do cenário público.

99 Do lado de Américo, alguns agentes também ainda poderiam ter sido chamados à situação, se a série desejada por Bethencourt da Silva tivesse passado do primeiro artigo. Além de Pedreira, o mais imediato "padrinho", como foi também identificado a Ferro, e do Marquês de Olinda, não possuía importância menor o nome de Antônio Coelho Sá e Albuquerque, presidente da província da Paraíba durante os anos 1850, e responsável por recomendar ao Pedreira para 
A agrimônia que jorrava das últimas palavras do arquiteto e professor da AIBA, sugerindo a manutenção da "infâmia" dos jovens em decorrência do "patronato", não era, portanto, completamente infundada. Ferro (especialmente, pois retornaria ao Brasil antes de Américo) conhecia e mantinha mesmo relações próximas com muitas personalidades importantes do Segundo Reinado, algumas delas igualmente importantes para períodos precedentes da história recente brasileira recente, como o Marquês de Olinda e Eusébio e Queiroz, que também haviam ajudado a dirigir o país durante o Período Regencial ${ }^{100}$.

Contudo, a resposta para o problema levantado pelo crítico não era tão simples quanto ele concluía $^{101}$. Ao contrário do que fez entender, não se tratava de uma via de mão única, na qual Ferro Cardoso, por afeto ou caridade, seria protegido de quaisquer problemas por figuras importantes, mesmo se fossem problemas que ele próprio criasse.

Para além das relações pessoais, o que permitia supor o simples "patronato", questões mais complexas estavam em jogo. Se é verdade que Ferro entrava por intermédio de relações pessoais, em convivência com importantes personalidades quando chegava ao Rio de Janeiro, era também verdadeira a sua ambição profissional, alimentada através de várias atividades. A que mais interessa aqui: a sua assídua participação e contribuição na Sociedade Auxiliadora da Indústria Nacional, a partir de 1862, quase ao mesmo tempo em que se consorciava com uma Pereira Barros ${ }^{102}$. O

que se levasse o jovem ao Rio de Janeiro, para que fosse formalmente matriculado na AIBA. Albuquerque participa da formação do ministério de 1861, exercendo o posto de Ministro dos Transporte, Ministro da Agricultura, e depois, entre 1866 e 1867, período da segunda de viagem de Américo para a Europa, Ministro das Relações Exteriores. Outro nome importante para Américo é Diogo Velho, político também paraibano, que ajudará o artista a conseguir uma bolsa da sua província, concedida entre 1863 e 1866.

100 Pedro Araújo de Lima havia sido Ministro e Secretário de Estado dos Negócios do Império no reinado de d. Pedro I. A primeira vez, muito rapidamente, entre 14 e 17 de novembro de 1823; a segunda, entre 20 de novembro de 1827 e 15 de junho de 1828 . No período regencial, foi chefe de estado entre 16 de abril e 1 de setembro de 1839 , tendo ocupado, um pouco antes, também muito rapidamente, o cargo de ministro e secretário do império, entre 18 e 19 de setembro de 1837.

101 Alguns autores deteram-se no problema do "patronato" durante período imperial, ligando-o a um duplo motivo que, de um lado, encontra tradução nas relações pessoais e, de outro, nas capacidades do indivíduo em utilizar essas relações para ascender socialmente. Sobre o assunto, Buarque de Holanda sintetizaria a seguinte passagem: "No Brasil, o prestígio pessoal costumava prender-se antes à capacidade de acesso a altos cargos públicos, originada principalmente no grau de relação com os senhores da situação...”. HOLANDA, Sérgio Buarque de. Raízes do Brasil. São Paulo: Cia. das Letras, 1995. Antônio Candido retomaria a mesma questão para sugerir como um indivíduo sem "berço de ouro", contudo com muito esforço e boas relações pessoais conseguia, no império, subir de vida, ocupando altos cargos públicos: "Mas ser funcionário [público] dependia de muita coisa. Dos favores, dos protetores, do parentesco e até da habilitação. Quando não havia família, nem padrinhos, nem dinheiro, nem diplomas, - o que fazer?" CANDIDO, Antonio. Um funcionário da Monarquia. São Paulo: Ouro sobre azul, 2007, p.17.

102 Cabe sem dúvida enfatizar a importância observada por alguns estudiosos das relações pessoais como molas propulsoras para ulteriores relações comerciais ou profissionais durante o Brasil imperial. Além de alguns estudos paradigmáticos, especialmente os de Sérgio Buarque de Holanda, como o seu Raízes do Brasil,adiciono à lista Um funcionário de Monarquia, de Antonio Candido. Nele, embora o autor afirme não haver maiores aspirações em sua pesquisa que as de um breve ensaio, é incontestável que Candido tenha construído uma sólida sugestão de "como, numa sociedade de favor [como a brasileira, durante o império], a competência profissional podia granjear a estima dos líderes, mas também levar a conflitos com a engrenagem do patronato, essencial para a atuação desses líderes". $\mathrm{O}$ estudo é ainda mais significativo por desenvolver uma espécie de biografia profissional de Antônio Nicolau Tolentino - 
ingresso nessa organização, embora facultado a princípio a qualquer pessoa, tornava-se apenas "oficial" se se constatasse o benefício que a sua frequentação, depois de algum tempo, promovia à Sociedade e "ao país". Somente então o aspirante tornava-se "sócio efetivo", por meio de registro em ata de reunião, e entrega de um diploma - esse, a propósito, confeccionado por Jean-Baptiste Debret $^{103}$.

O ingresso e o diploma de Ferro foram concedidos a 15 de abril de $1863^{104}$, quase ao mesmo tempo em que entrava com um pedido para que se lhe concedessem o direito de explorar, por 10 anos, o invento de uma máquina para resfriar a temperatura no interior de edifícios ${ }^{105}$. O pedido foi aceito e lavrado justamente pelo então ministro da agricultura, Pedro Bellegarde, e subscrito, como de praxe, por d. Pedro II $^{106}$. Pouco tempo depois, já era apresentado nas reuniões da associação com o significativo cargo de Secretário da Seção de Artes Liberais e Mecânicas, sendo também aceito como membro do conselho; função que lhe outorgaria, além da participação efetiva nas reuniões, uma voz forte na Sociedade, incluindo o direito de propor a nomeação de novos membros - algo que fará, conforme citado, com Pedro Américo, em fins de $1864{ }^{107}$.

Ainda que aspirasse, em discurso, à "prosperidade pública", a Sociedade não era uma organização filantrópica. Conquanto subvencionada pelo Estado, ela era uma associação comercial e, como tal, com orientação particularista. Luís Pedreira de Couto Ferraz, José Manuel Fernandes Pereira, Pedro Araújo de Lima (antigo presidente da sociedade), Miguel Calmon du Pin e Almeida (o Marquês de Abrantes, presidente da sociedade entre 1848 e 1865, e o responsável, como visto, por formar as primeiras Exposições Nacionais e primeira participação do Brasil numa Exposição Universal), entre outros, poderiam ser políticos poderosos interessados de fato em assuntos de promoção nacional; mas eles eram antes, em âmbito particular, latifundiários e grandes comerciantes (de café e cana, sobretudo) que buscavam, também na política, garantir a prosperidade dos seus negócios e dos seus relativos. Ferro Cardoso, assim, desde as suas primeiras participações,

diretor da Academia Imperial de Belas Artes a partir da década de 1880 -, pondo especial atenção sobre como ele, um "burocrata imperial", "saiu do nada e chegou a posições elevadas, capitalizando o esforço para conquistar apoios e praticamente reivindicando as vantagens com base no mérito.”. CANDIDO, Antonio. Um funcionário da monarquia: ensaio sobre o segundo escalão. Rio de Janeiro: Ouro Sobre Azul, 2007. p.17.

103 Os diplomas da SAIN traziam a seguinte inscrição: "Sendo o constante interesse que (nome do novo sócio) tem mostrado em animar e promover a Prosperidade Pública, coadjuvando eficazmente esta Sociedade para conseguir os fins de sua Instituição, resolvo por comum aplauso que para o ornamento dela o nome do mesmo (novamente o nome do sócio) fosse inscrito no número dos seus sócios efetivos, e que para público testemunho se lhe desse o presente título."

104 SOCIEDADE Auxiliadora da Industria Nacional. "Sociedades Literárias e Industriais". Correio Mercantil. Rio de Janeiro, 23 de abril de 1863. p.1

105 Sociedades literárias e industriais. Correio Mercantil, Rio de Janeiro, 17 de junho de 1863.

106 Decreto N. 3.171, de 29 de Outubro de 1863. Disponível online em: http://www6.senado.gov.br/legislacao/ListaTextoIntegral.action?id=60982\&norma=76860

107 "Sessão de Posse do Conselho Administrativo em 2 de janeiro de 1866". O AUXILIADOR da indústria nacional. Rio de Janeiro, n.1 janeiro de 1866. 
entrava numa associação cujas atividades visavam, por fim (ou de início), dar lucro a seus participantes. E ele as correspondeu ${ }^{108}$.

Em resumo, a aproximação constante com os membros da Sociedade, ou com indivíduos a ela ligados, facilitou de fato ao jovem relações pessoais; contudo seria extremamente difícil definir se os limites dessas relações permaneceriam exclusivamente naquele nível, ou, ao contrário, se seriam estabelecidas visando justamente uma ulterior uma relação comercial. E não se refere apenas à vontade de Ferro em travar contato com outros empresários, mas o oposto fazendo-se também verdadeiro. Não deve causar espanto, portanto, que ele tenha se associado comercialmente a várias pessoas durante os anos 1860, 1870 e 1880, incluindo, entre outros "figurões" da política, o próprio Marquês de Olinda, e Araújo Jacobina - o secretário da mordomia imperial nos anos de 1860, proprietário de terras, também político, e responsável por entregar pessoalmente o pedido de encomenda da Carioca a Pedro Américo ${ }^{109}$.

Assim, se se retomam as conclusões feitas por Bethencourt da Silva nas últimas linhas da sua série de artigos, é custoso corroborar a conclusão de que, se havia uma proteção formada em torno

${ }^{108}$ Desde a primeira invenção de sua autoria - ainda projetada para solucionar problemas de suas recentes atividades no departamento de obras públicas -, seguiram-se outras, rapidamente citadas, já voltadas para o fomento e comercialização da produção agrícola, ramo no qual logo ingressava por evidente contato com as atividades comerciais da família da sua esposa (O Barão da Gamboa também era dono de alguns armazéns no Rio de Janeiro, situados, como era de se esperar, na Gamboa, nas proximidades do porto existente naquela região.)

Ferro Cardoso inventou e explorou economicamente máquinas para secar café, inseticidas (dos quais vários compradores deveriam fazer parte da $S A I N$ ), e máquinas que utilizavam magnetismo como força motriz. (Decreto $\mathrm{N}$. 5956 - DE 23 de junho de 1875, "Concede ao Dr. Daniel Pedro Ferro Cardoso privilegio, por oito annos, para uma preparação que diz ter inventado, destinada a substituir o tijolo na construcção de casas", denominado 'polimonolito'; Decreto N. 6184 - de 26 de abril de 1876, "Concede privilegio ao Dr. Daniel Pedro Ferro Cardoso, para introduzir no Imperio marmore Marezzo"; Decreto N. 6645 - DE 31 de julho de 1877, "Concede privilegio a Daniel Pedro Ferro Cardoso para fabricar e vender o apparelho denominado - Seccador pneumatico pela condensação.destinado a seccar café e outros objectos, segundo a descripção que depositou no Archivo Publico"; Decreto N. 6483 - de 18 de janeiro de 1877, "Concede garantia de juro de $7 \%$ sobre o capital de 700:000\$000 á Companhia que o Dr. Daniel Pedro Ferro Cardoso e Adão Benaion organizarem para o estabelecimento de um engenho central destinado ao fabrico de assucar no municipio de Igarapé-mirim, Provincia do Pará". Ferro, contudo, logo desiste desse negócio, pedindo, em outro documento, o cancelamento da concessão; Decreto N. 7296 - DE 17 de maio de 1879, "Concede privilegio a Daniel Pedro Ferro Cardoso para empregar o magnetismo como força motriz"; Decreto N. 7951 - de 18 de dezembro de 1880, "Concede privilegio a Daniel Pedro Ferro Cardoso e Antonio Pinto Moreira, para o formicida de sua invenção, denominado - Licôr insecticida brazileiro"; Decreto N. 8428 - de 18 de fevereiro de 1882, "Concede privilegio a Daniel Pedro Ferro Cardoso para o apparelho de sua invenção denominado - Refrescador, destinado a modificar a temperatura no interior das casas"; Decreto n. 6603 - de 4 de julho de 1887, "Concede privilegio a Daniel Pedro Ferro Cardoso e John Sherrington para o apparelho de sua invenção destinado a seccar o café". Os documentos podem ser acessados por meio do site do Senado Brasileiro: http://www6.senado.gov.br/sicon/\# [último acesso: março de 2013.]

Não bastassem as evidentes vantagens potenciais desses inventos, eles deveriam ganhar valor ainda mais expressivo frente ao contexto no qual, com o fim do tráfico negreiro (levado à frente por um dos seus padrinhos de casamento), começava a imputar aos grandes latifundiários resoluções a médio prazo para a manutenção da produção em suas propriedades. Com efeito, as máquinas de Ferro visavam não apenas aumentar a produção, mas diminuir a mão-de-obra, àquela altura ainda mormente escrava. O próprio Ferro começou, anos depois, a comercializar café, cacau e outros produtos manufaturados na Europa, onde também passou a ter residência fixa.

109 Na Fundação Casa de Rui Barbosa há um dossiê com cerca de 30 documentos relativos à sociedade que Ferro formou com Antonio d'Araújo Ferreira Jacobina, nos anos 1880. O código de catalogação do documento é: $C F B O$ CFBO SFJ DDPFC. 18-12-1880 a 10-04-1889 dossiê. A chamada do registro encontra-se também disponível online no site: http://basesdedados.casaruibarbosa.gov.br/. [último acesso: março de 2013] 
de Ferro e Américo por personalidades políticas importantes na década de 1860, ela era feita simplesmente em decorrência de um "patronato", ou seja, de uma via unilateral "desinteressada" (ou interessada apenas pelo afeto). No caso específico de Ferro, repete-se, o jovem também retribuiria, direta ou indiretamente, para os interesses e atividades que importavam a burgueses aristocráticos como Pedreira, Olinda, Bellegarde, Jacobina, etc.. (nota-se que a grande maioria composta por conservadores), cujos interesses estavam congregados na Sociedade Auxiliadora da

\section{Indústria Nacional.}

Com esse dado em vista, uma dúvida surge, todavia. Se Bethencourt afirmava conhecer tão bem Américo e Ferro Cardoso - como realmente demonstrou nas diversas vezes que forneceu dados precisos sobres suas vidas - seria muito dificil que ignorasse as relações comerciais, especialmente do último, em vantagem exclusiva daquelas de suposto patronato que sustentava existir entre ele e personalidades políticas do período.

Ou ele forçava a circunstância para que os leitores tomassem como verdadeiras suas alocuções, ou existiam ainda outros motivos para que a longa campanha contra Ferro e aquela contra Américo fossem lançadas. E, se existiam, quais eram eles?

\section{Um problema entre arquitetos}

As razões que amparam em vários pontos as investidas feitas por Bethencourt da Silva contra Américo e Ferro Cardoso são explicadas pelo acesso de vários dados que ofereceu nas dezenas de artigos publicados sobre a contenda, e por uma pesquisa ulterior sobre muitos dos confrontos estabelecidos alhures com os dois jovens ${ }^{110}$, em decorrência de interesses e projetos semelhantes.

110 Os dados sobre Bethencourt da Silva ainda são diminutos, perto da importância que teve para o cenário artístico e para o ensino secundário e técnico no Brasil no século XIX. Sobre o Liceu, vários estudos tem sido publicados nos últimos anos. Ver, por exemplo: BIELINSKI, Alba Carneiro. O Liceu de Artes e Ofícios - sua história de 1856 a 1906. 19\&20, Rio de Janeiro, v. IV, n. 1, jan. 2009. Disponível em: $<$ http://www.dezenovevinte.net/ensino_artistico/liceu_alba.htm> [último acesso: abril de 2013]; MORAES, Julio Lucchesi. A Modernidade Acadêmica: Os primeiros tempos do Liceu de Artes e Ofícios de São Paulo. 19\&20, Rio de Janeiro, v. V, n. 4, out./dez. 2010. Disponível em: <http://www.dezenovevinte.net/ensino_artistico/ea_liceusp.htm> [último acesso: abril de 2013]; MURASSE, Celina Midori. A educação para a ordem e o progresso do Brasil: o Liceu de Artes e Ofícios do Rio de Janeiro (1856-1888). (Tese de doutorado em educação). Campinas: Unicamp, 2001.

O único livro predominantemente dedicado ao arquiteto foi publicado em 1956 por um de seus alunos, Álvaro Paes de Barros: “O Liceu de Artes e Ofícios e seu fundador”. Um perfil artístico sobre Bethencourt da Silva já havia publicado por Félix Ferreira em 1876, e republicado em seu livro "Belas Artes: estudos e apreciações", no qual também há outros artigos em que seu nome é citado. Para complementar dados biográficos e profissionais do arquiteto, procedi a consultas em dicionários (como o "Dicionário das famílias brasileiras" de Barata e Bueno, 1999), a levantamentos de artigos em jornais cariocas a partir da década de 1840, a leituras do caderno de matrículas da AIBA e das atas da academia a partir daquele mesmo decênio (Não tive ainda a oportunidade de buscar, se é que existe, o arquivo pessoal de Bethencourt da Silva, com suas correspondências.) 
Com efeito, Bethencourt da Silva, em virtude de sua formação em arquitetura e atuações profissionais $^{111}$, vagava sobre um limiar muito estreito que o fez pisar com destaque ora em terrenos frequentados pelo também arquiteto Daniel Pedro Ferro Cardoso, ora naqueles que, a partir de 1864, no Brasil, desejava ocupar Pedro Américo. De fato, a múltipla compreensão que Bethencourt sustentava de si próprio era apresentada nos inúmeros discursos que proferiu ao longo de sua carreira. Em algumas oportunidades, e com mais frequência, afirmava-se artista; em outras oportunidades, afirmava-se arquiteto; e em outras ainda, poeta.

Essas reivindicações faziam sentido. Em 1866, Bethencourt era, a um só tempo, professor de arquitetura civil na AIBA, homem-chefe da Sociedade Propagadora de Belas Artes (SPBA), agente central e idealizador do Liceu de Artes e Ofícios, secretário do Conservatório Dramático (onde,

Foram ainda procurados dados correlatos nas publicações da Sociedade Propagadora das Belas Artes e do Liceu de Artes e Ofícios do Rio de Janeiro, instituições de que Bethencourt da Silva é o fundador, bem como teses e dissertações desenvolvidas sobre elas.

Já há algum tempo tenho também efetuado o levantamento do livros e de críticas escritas em jornais pelo arquiteto, desde a década de 1850 e até o início do século XX, essas que têm ajudado bastante a compreender os posicionamentos estéticos e os projetos artísticos por ele desenvolvidos desde a sua juventude.

Os dados levantados ainda não são suficientes para se construir uma compreensão que merece essa personalidade tão necessária, me parece - porém já permitem avançar na investigação dos problemas, agentes e breve período (18631866) que me interessam neste texto.

111 Francisco Joaquim Bethencourt da Silva nasce na Ilha das Flores, Portugal, em 1831. Chega ao Brasil ainda muito jovem (possivelmente ainda recém-nascido). Em 1843, aos 12 anos, ingressa como estudante de Arquitetura Civil na Academia Imperial de Belas Artes, tendo como principal professor Grandjean de Montigny. Ganha uma série de prêmios e menções durante seu longo período escolar. (Alguns dados acusam que teriam obtido uma bolsa de estudos em Roma. Ainda não foi possível verificar se procedem). Frequenta regularmente a Academia até 1850 , mesmo ano em que concursa na Inspeção Geral das Obras Públicas, no setor de Desenhos, na Companhia da Glória (corte), responsável pela arquitetura e topografia. Assume o cargo em 1851, exercendo-o até 1859. Nessa década, também torna-se Arquiteto de Obras Públicas da Câmara Municipal do Rio de Janeiro. Em 1856, funda a Sociedade Propagadora de Belas Artes. Em 1858, o Liceu de Artes e Ofícios. Nesse ano, ingressa na Academia Imperial de Belas Artes, na qualidade de professor de arquitetura civil, no lugar de Job Justino de Alcântara. Também leciona na Escola central (futura Politécnica). A partir dessa década, e até o começo do século XX, torna-se um crítico ativos de belas artes e literatura no Rio de Janeiro. Em 1860, recebe a insígnia de oficial da Ordem da Rosa. Em junho de 1862, é nomeado arquiteto Honorário da Casa Imperial. Em janeiro de 1863, pede expulsão da Sociedade Auxiliadora da Indústria Nacional, "por circunstâncias que lhe eram próprias". No mesmo mês, faz discurso na revista da sociedade de ensaio literários sugerindo o mal destino das artes no Brasil. Em setembro de 1863, discursa no fechamento do Congresso Juvenil Artístico. No meio do ano, lança campanha para ser eleito deputado provincial no Rio de Janeiro, pela freguesia da Glória. Fica em segundo lugar na sua paróquia (Freguesia da Glória), ficando contudo em sexto lugar suplente na contagem final (que envolvia as 18 freguesias da corte). Em 1864, em nova eleição, candidata-se a vereador. Em 27 de agosto de 1864, há vários artigos sobre a polêmica levantada sobre o fato de Bethencourt candidatar-se à eleição, pois não seria brasileiro nato. Uma comissão des artistas pouco conhecidos assina pedindo para que se vote em Bethencourt. Fica em $18^{\circ}$ lugar geral, $7^{\circ}$ lugar na suplência. No começo do ano seguinte, na sessão de posse, Bethencourt é apresentado como sexto suplente. Na metade 1866, na 22a Sessão da Câmara Municipal da Corte, Bethencourt assume o cargo de vereador. Assume mandatos nos anos de 1866 e 1867. Neste ano, é também apresentado com juiz de paz. Recebe o título de cavaheiro da Ordem da Rosa. Ainda em 1867, coincidência ou não, reabrem as aulas do Liceu, quando Bethencourt consegue subvenção então do governo para acabar as obras e comprar os materiais necessários para a instalação da nova sede. Em 1871, comendador da Ordem da Rosa. Em 1871, torna-se Arquiteto da Casa Imperial. Em 1876, Dignatário da Ordem da rosa. Nesse ano ainda, assina a introdução da reedição de Memória de um Sargento de Milícias, do seu amigo recém-falecido, Manoel Antônio de Almeida. Desde (pelo menos) o começo da década de 1860, é secretário do Conservatório Dramático, profundamente interessado em poesia e dramaturgia (pois é também escrito), tendo feito mesmo algumas traduções e dando pareceres sobre peças de teatros originais em português ou traduções. Na década de 1880, viaja recorrentemente a Campos dos Goytacazes, onde funda novo Liceu, esse levando seu nome. 
além de praticar a poesia e a dramaturgia, escrevia pareceres formais sobre peças originais ou traduzidas; Conservatório de que também era membro Pedro Bellegarde), professor de desenho na Escola Central ${ }^{112}$, presidente da Associação Nacional dos Artistas Brasileiros, vereador recémempossado na Câmara Municipal do Rio de Janeiro ${ }^{113}$, e um crítico ativo das artes, prática que desenvolverá por décadas.

Se a expressão "arroz de festa" poderia ser aduzida para sugerir a quase ubuquidade institucional de Bethencourt no cenário das várias artes ("maiores e "menores") nesse período, as colisões que começava a ter de fato com Ferro, a partir de 1858, e com Américo, a partir de 1864, delimitariam, no entanto, pelo menos algumas freguesias que ele desejava não frequentar quando os amigos e alguns de seus aliados estivessem presentes.

Quando, sob o pseudônimo de Guisando (ou O.M.T.A), enunciava na série de textos lançados em repúdio a Ferro que o jovem começara a aviltá-lo em 1858, não era esse um ano casual. Aliás, para ambos.

Ferro, nesse momento, estava no seu quarto e último ano de formação em arquitetura na academia brasileira, preparando-se então para dar um primeiro passo na sua vida profissional. De um lado, aspirava a obter um emprego público imediato; de outro, continuar seus estudos em arquitetura na Europa. Fez uma requisição ao Governo para que (sem prestar-se a concurso) se lhe desse uma bolsa de estudos na França ${ }^{114}$. Depois de quase um ano de trâmite, viu seu pedido ser contestado, com a justificativa de que, se uma bolsa fosse dada a alguém naquele momento, esse seria outro estudante que mais destacava-se na instituição: o gravurista Joaquim José da Silva Guimarães Júnior ${ }^{15}$. Entre aquele pedido e a resposta, Ferro testemunharia Bethencourt, já trabalhando então como arquiteto na inspeção de Obras Públicas (mesmo lugar que o jovem conseguiria emprego, em 1862) e na Câmara Municipal, ser nomeado, sem concurso, professor interino de arquitetura na academia ${ }^{116}$. Pode não ser esse um episódio inequívoco - pois mais dados seriam necessários para garanti-lo -, mas parece ter iniciado aí a rixa entre um jovem recémformado em arquitetura, que dispunha apenas de expectativas, e outro, com diferença não tão

112 A Escola Central era a antiga Escola Militar, onde Porto Alegre também havia lecionado, e futuramente a Escola Politécnica.

113 Eleito pela paróquia da Freguesia da Glória.

114 FERRO CARDOSO, Daniel Pedro. "Carta de Daniel Pedro Ferro Cardoso, aluno de Arquitetura, pedindo para completar seus estudos na Europa, com bolsa do Governo. 11 de fevereiro de 1858". Rio de Janeiro: Arquivos do Museu d. Jõao VI/EBA-UFRJ. cód. 002/004 - s/n.

115 ATAS das sessões da congregação e do diretor da Academia Imperial De Belas Artes. Sessão em 04 de abril de 1859. Rio de Janeiro: Museu d. João VI/ EBA-UFRJ.

116 ATAS das sessões da congregação e do diretor da Academia Imperial De Belas Artes. Sessão em 04 de novembro de 1858. Rio de Janeiro: Museu d. João VI/ EBA-UFRJ. 
grande de idade ${ }^{117}$, porém formado há dez anos na mesma área (e um dos discípulos prediletos do falecido Grandjean de Montigny e de Félix-Émile Taunay), que começava a despontar em sua profissão.

A ida de Ferro Cardoso para Europa, ainda que com bolsa obtida por outros caminhos que não passaram pelos da academia, não seria o suficiente para apagar as faíscas chispadas. O primeiro reencontro com Bethencourt - pelo menos institucional - deu-se quase 3 anos depois, em fevereiro de 1862, quando o jovem Ferro, apresentando-se então bacharel, tornava à academia requisitando entrada na instituição, agora como professor da cadeira de Estética ${ }^{118}$ (disciplina vaga desde a sua criação, durante a implantação da reforma de Porto Alegre, em 1855). Ferro teria tencionado, pouco antes, a cadeira de matemáticas aplicadas. Essa, contudo, estava ocupada há poucos meses, também sem concurso, por José Maria Jacinto Rabelo ${ }^{119}$ (professor anos antes indicado e aceito pela Congregação à cadeira de Arquitetura Civil, mas cuja posse não aconteceu em virtude de uma ordem do imperador para que se provesse essa disciplina justamente a Bethencourt da Silva ${ }^{120}$ ). Ainda entrementes, Victor Meirelles, colega de Ferro na Europa, era igualmente indicado por d. Pedro II à cadeira de pintura histórica, em fevereiro de 1862, sendo empossado em maio, sem necessidade de concurso ${ }^{121}$. Ciente desse fato, Ferro pedia então para ser empossado também sem concurso na cadeira vaga da instituição, posto que, em face às condições de ingresso dos demais professores, julgava-se igualmente meritório de assumi-la.

O diretor Thomas Gomes manifestou-se contrário a seu ingresso ${ }^{122}$ (e, muito provavelmente, com o feliz consentimento de Bethencourt). Desconfiava, entre outros motivos, da incapacidade do

117 Bethencourt nasce em 1831. Ferro Cardoso, entre 1837 e 1840.

118 FERRO CARDOSO, Daniel Pedro. "Carta de Daniel Pedro Cardoso enderaçada à Academia Imperial de Belas Artes de 11 de março de 1862". Arquivo Nacional, Rio de Janeiro. Cod. 036/341-341.

119 ATAS das sessões da congregação e do diretor da Academia Imperial De Belas Artes. Sessão em 18 de dezembro de 1861. Rio de Janeiro: Museu d. João VI/ EBA-UFRJ.

120 A proposta de nomeação de Jacinto Rabello foi apresentada em sessão da congregação da AIBA em 02 de junho de 1858. Ibidem. Sessão em 02 de junho de 1858. Rio de Janeiro: Museu d. João VI/ EBA-UFRJ.

A ordem de nomeação de Bethencourt no lugar daquele aparece na reunião de 04 de novembro de 1858 . Ibidem. Sessão em 04 de novembro de 1858. Rio de Janeiro: Museu d. João VI/ EBA-UFRJ.

Embora não haja qualquer dado que ateste o que será dito, tenho a impressão de que a sugestão da nomeação de Bethencourt possa ter sido reforçada ao monarca pelo pintor François-René Moreaux, a quem o arquiteto sinalizara positivamente para que assumisse o cargo de primeiro diretor do Liceu de Artes e Ofícios, e que ocupava simultaneamente, até aquele momento, a função de professor de desenho das filhas do imperador.

121 Ibidem. Sessão em 08 de maio de 1862. Rio de Janeiro: Museu d. João VI/ EBA-UFRJ.

122 SANTOS, Thomás Gomes dos. "Declaração de Thomás Gomes dos Santos ao Ministro do Império [Marquês de Olinda] de 13 de fevereiro de 1863, declarando ser contra o pedido de Daniel Pedro Ferro Cardoso". Arquivo Nacional, Rio de Janeiro. cod. 042/087-087. É provavél que Ferro Cardoso tenha enviado duas cartas. Uma, em fevereiro de 1862, ao Ministro do Império, Marquês de Olinda, e outra, em março, diretamente à academia. Isso justifica por que a resposta de Gomes, contrária à entrada do jovem na academia, seja datada anteriormente do ofício enviado à academia. Ferro havia feito o mesmo em 1858, quando requeria à secretaria do Império a bolsa de estudos na Europa, tendo seu memorando sido encaminhado apenas depois à Academia. 
rapaz e da validade de sua formação, pedindo que apresentasse seu diploma para aferição ao menos institucional dos seus conhecimentos.

Ferro Cardoso fê-lo, em março de 1862. Apresentou, todavia, não um diploma, mas "documentos" (ou, como Américo chamaria, "documentos comprobatórios") que atestavam estar "habilitado para o cargo de professor de Estética"123. Havia mentido ao diretor, assegurando que não conseguiria retirar ainda o seu título, pois quando deixara a França, 3 meses antes, ainda estariam "funcionando" os exames na Sorbonne, e não se expediria portanto nenhum documento ${ }^{124}$. Deve ter sido essa a urgência que o levaria a enviar aquelas supostas (contudo bastante críveis, pois precisas) cartas de março e abril a um inominado e a Américo, respectivamente. $\mathrm{O}$ tempo protelatório que Ferro conseguiria com a mentira deveria ser o necessário para que seus amigos lhe conseguissem o requerido título, no qual, segundo entendia, "consistia $a$ sua felicidade" naquele momento $^{125}$.

A cadeira de Estética, afinal, também não lhe foi concedida, continuando inoperante. E com o fim daquela requisição, também cessavam quaisquer informações sobre mais motivos de desconforto que teriam cruzado seu caminho e o do professor de arquitetura na jurisdição da AIBA, à exceção, naturalmente, do estranho dado de Bethencourt mostrar-se detentor daquelas e de outras correspondências do rapaz. Como elas teriam parado em suas mãos, senão por intermédio de alguém que o conhecia e também a Ferro e a Américo? A propósito, não era uma, mas várias as pessoas que compartilhavam o mesmo círculo social daqueles três.

Ferro Cardoso nunca mais almejou qualquer cargo na academia. E nem precisaria, visto que dali a poucos meses, em junho de 1862, casava-se com uma Pereira de Barros e ingressava rapidamente nos lucrativos negócios da agricultura e do comércio da nova família.

123 FERRO CARDOSO, Daniel Pedro. "Carta de Daniel Pedro Ferro Cardoso ao Diretor da Academia Imperial das Belas Artes [Thomás Gomes dos Santos] de 29 março de 1862", "comprovando com documentos que está habilitado para o lugar de professor de Estética". Arquivo Nacional, Rio de Janeiro. Cod. 041/012-012.

O mesmo episódio da requisição do diploma de Ferro por Gomes é retomado por outro pseudônimo (quem sabe novamente Bethencourt), durante a questão de bacharéis, em 1866: "Se o Sr. Ferro é bacharel, por que não mostrou o seu diploma ao Sr. Conselheiro Thomas Gomes dos Santos, quando ele lhe exigiu? Dar-se-á o caso de o Sr. Ferro falar mais a verdade (?) do que S. Ex. [Gomes], ou foi também por não querer descer até ele? Se não é isto, é aquilo!". FIRMADA, Minha reputação está. "Publicações a Pedido". Jornal do Commércio. Rio de Janeiro, 26 DE JANEIRO DE 1866, P.2.

$124 \mathrm{O}$ trecho que, na carta a Américo de 6 de abril de 1862, Ferro faz menção à mentira contada a Thomas Gomes é o que segue. Mantenho ainda a formatação e inscrições feitas por Bethencourt nas publicações do Jornal do Commércio e do Correio Mercantil: "Eu disse ao miserável Thomas Gomes que tinha meu diploma e que não o tinha tirado por que se achavam funcionando os exames (!) da Sorbone e que en tal epoca não se destrebuem títulos e sim 3 meses depois: disse-lhe isto na ocasião que levei meus documentos pedindo a cadeira de esthetyca (Esthetica com - y- !! não é má!)". cf. O. M. T. A [Francisco Joaquim Bethencourt da Silva]. "Ao Sr. ministro da agricultura, ao Sr. Inspetor de obras públicas e ao Sr. promotor Sizenando Nabuco. VII" .Correio Mercantil, 7 de fevereiro de 1866.

125 Ibidem. 
Fora daquela instituição, entretanto, uma série de "coincidências" ainda se apresentava nas vidas dos dois êmulos, sempre que, ao desvio de caminho de um, ingressava o outro na via anteriormente ocupada. Nunca, porém, seguiam juntos na mesma. Assim é que, depois de Bethencourt se afastar da inspeção de Obras Públicas (entre 1859 e 1860), o arquiteto Ferro lá ingressava na qualidade de "desenhador", ainda em 1862, e, como visto, supostamente por indicação da sua madrinha de casamento, a Marquesa de Olinda. Era esse o mesmo ano em que Bethencourt recebia (talvez para novo desconforto do seu opositor) o prestigioso título de Arquiteto Honorário da Casa Imperial. Quando, em janeiro de 1863, Bethencourt exonerava-se da Sociedade Auxiliadora da Indústria Nacional, da qual até então fazia parte, alegando que "por circunstâncias que lhe eram próprias, não the convém continuar a fazer parte da sociedade"126, logo em seguida, em abril do mesmo ano, Ferro era anunciado como membro efetivo ${ }^{127}$, ativando, pouco tempo depois, outro tipo de emulação, quando assumia ainda o cargo de Secretário da Seção de Artes Liberais e Mecânicas - cujo interesse na área era incontornável a Bethencourt.

Em meados de 1864, o professor da AIBA era demitido de um de seus empregos, o de arquiteto da câmara municipal, aparentemente em função de uma denúncia de não ser ele brasileiro nato, mas estrangeiro não naturalizado ${ }^{128}$, condição que lhe tiraria o direito de trabalhar em uma repartição pública brasileira ${ }^{129}$ (Bethencourt era, de fato, nascido português). Quem era o autor da denúncia, isso ainda não é possível precisar, mas não seria imensa surpresa se se descobrisse que Ferro, com os conflitos continuados desde 1858, manifestava razões para fazê-lo (algumas delas justificadas, talvez, pela vontade de assumir, ele próprio, enquanto arquiteto brasileiro nato, aquele cargo). Pode-se lembrar que o jovem estava incumbido, também em 1864, de construir a residência de conde d'Eu e da Princesa Isabel; atribuição que, em circunstâncias esperadas, deveria ser dada de bom grado ao Arquiteto da Casa Imperial.

Os problemas de Bethencourt com rivais não paravam aí. O assunto da sua "naturalidade" aparecia com mais força em outro contexto, mais amplo, também em 1864, no qual possivelmente reaparecerá Pedro Américo. E talvez tenha sido mesmo nele que se engendraram os procedimentos que levaram à sua exoneração do cargo de arquiteto da câmara municipal.

126 Correio Mercantil. Rio de Janeiro, 05 de janeiro de 1863. p.2

127 Sociedades Literárias e Industriais. Sociedade Auxiliadora da Industria Nacional. Correio Mercantil. Rio de Janeiro, 23 de abril de 1863. p.1.

128 Sobre o processo que corria na câmara em decorrência da denúncia contra Bethencourt, ver: "Ilma. Camara Municipal. Extrato do expediente do mês de agosto de 1864". Correio Mercantil, 24 de outubro de 1864. p.2

129 Podiam trabalhar em repartições públicas brasileiros natos que desfrutassem de suas funções "normais", ou estrangeiros naturalizados nas mesmas condições. 


\section{Bethencourt da Silva: arquiteto de uma política de artistas}

Em 1863, Bethencourt da Silva lançava-se à campanha para ser eleito deputado provincial pelo Partido Progressista ${ }^{130}$, candidatando-se pela paróquia da Glória, no Rio de Janeiro, onde vivia desde a infância ${ }^{131}$. Suas motivações pareciam se justificar pela crise que o Liceu de Artes e Ofícios passava naquele momento, decorrente de falta de verba e sede própria; situação rapidamente agravada, quando do fechamento da instituição, em 1864.

$\mathrm{Na}$ primeira tentativa, o segundo lugar em sua freguesia pareceu-lhe positivo ${ }^{132}$, provavelmente por terminar atrás apenas do ministro das Relações Exteriores e presidente da Sociedade Auxiliadora da Indústria Nacional, Marquês de Abrantes, e na frente mesmo do ministro da Agricultura, Pedro de Alcântara Bellegarde, entre outros candidatos também importantes daquela circunscrição $^{133}$.

130 Nas eleições primárias, paroquiais - de onde saíam os candidatos e eleitores que participariam da segunda etapa da votação, a eleição secundária -, podiam votar:

Os cidadãos brasileiros que estivessem "no gozo dos seus direitos políticos", e os estrangeiros naturalizados. Não podiam votar os menores de vinte e cinco anos (à exceção daqueles que tivessem mais de vinte e um ano e fossem: casados, fossem oficiais militares, bacharéis formados e clérigos de ordens sacras), os filhos-família (salvo aqueles que fossem funcionário públicos), os "criados de servir" (salvo os guarda-livros e primeiros caixeiros, criados da Casa Imperial de galão branco e os adminstradores de fazendas rurais e fábricas), os religiosos, e aqueles que não tiverem renda líquida anual de cem mil réis.

Dessa primeira votação, aqueles que mais recebesse votos formavam uma nova lista de eleitores e candidatos, e, em seguida, iniciavam-se as eleições secundárias (em geral, trinta votantes escolhiam um eleitor/candidato para as eleições secundários). Nelas elegiam-se de fato os deputados, senadores e membros dos conselhos gerais de província e da assembléia geral. Nelas, contudo, dos eleitores escolhidos pela lista primária só podiam votar e ser eleitos aqueles que dispunham de renda de duzentos mil réis anuais. Porém, ainda que possuíssem essa quantia, não podia participar das eleições secundárias os libertos e os criminosos por briga ou devassa. cf. CONSTITUIÇÃO POLÍTICA DO IMPÉRIO DO BRASIL, promulgado pela Carta de lei de 25 de Março de 1824.

131 É no mínimo bastante estranho considerar que nenhum texto sobre Bethencourt, nem aqueles escritos por Ferreira, em seu perfil artístico sobre o arquiteto, em 1876, nem o texto mais próximo que recebeu de uma biografia, de Álvaro Paes de Barros, da década de 1950, tenham considerado sequer uma vez as candidaturas que Bethencourt fez a eleições para deputado e vereador. Dado curioso sobretudo por elas serem empreendidas num período bastante delicado da vida do arquiteto, que almejava seus mandatos para seguir com seus propósitos no Liceu e na SPBA.

132 Bethencourt da Silva, depois do fim das eleições, publicava um artigo agradacendo aqueles que lhe deram votos: "Penhorado pela honra com que os paroquianos da Freguezia da Glória se dignaram de distinguir-me, colocandome no $2^{\circ}$ lugar, entre os 25 eleitores desta freguezia, agradeço, reconhecido tão generoso favor. Afastado do mundo político, desejando apenas o bem do meu país, por cuja prosperidade tenho envidado, na órbito das limitadas habilitações que possuo, todos os meus esforços, - devo aos amigos que me obsequiaram, apresentando-me à aprovação dos meus concidadãos, muita estima e muito reconhecimento. E se o empenho com que tenho procurado elevar a arte e a classe artística, a quem me ufano de pertencer, é o título que me recomendou ao seu patriotismo, posso assegurar-lhes que não me esquecerei jamais nem da significativa prova do seu apreço, nem do valor que dão às minhas tentativas e aos desejos que nutro de espalhar pelo povo, sem ser pesada ao estado, a educação artística que é necessário a sua emancipação mesteiral. Por tudo isto a minha gratidão será perpétua.

Francisco Joaquim Bethencourt da Silva". BETHENCOURT DA SILVA, Francisco Joaquim. "Eleições". Correio Mercantil, Rio de Janeiro. 19 de agosto de 1863.

133 Resultado da contagem final de votos na Freguesia da Glória: "1. Marques de abrantes..468 votos; 2. Francisco Joaquim Bethencourt da Silva..420 [..];5. Conselheiro Pedro de Alcantara Bellegarde..381 [..]; 7. Conselheiro José Pedro Dias de Carvalho..372;8. Conselheiro Bernardo de Souza Franco..370 [..]; 10.Conselheiro JOão Lins Vieira de Sinimbú..362 [..];12. Conselheiro José Thomas Nabuco de Araújo..358"; "Boletim Eleitoral". Correio Mercantil. Rio de Janeiro, 17 de agosto de 1863. p.1. 
Em meados de 1864, Bethencourt lançava-se novamente à política. Concorrendo então ao cargo de vereador, era dessa vez amplamente amparado e divulgado por outras personalidades subscritas abertamente ou por pseudônimos ${ }^{134}$. Nesse ano, afirmava não ter sido sua a vontade de candidatar-se, mas a desses "amigos e colegas da arte" ${ }^{135}$, que o teriam recomendado às eleições, alguns dos quais eram, significativamente, antigos alunos da AIBA e aspirantes mal-sucedidos a

134 Novamente aqui, devo fazer um breve comentário sobre o método adotado. Também na campanha de Bethencourt da Silva, e os problemas que ela gerou, foram encontrados centenas de artigos em jornais cariocas. A grande maioria, sobretudo aqueles de campanha, repetiam-se diariamente, entre agosto e setembro de 1864 . Julgo que seria um trabalho despropositado reiterar na bibliografia uma nota de campanha publicada e republicada diversas vezes, já que ela não configura, em si, um problema. De outro modo, os mesmos artigos publicados por vezes sequencialmente, mas que não faziam parte da campanha de Bethencourt, e sim de contenda que ela gerou entre o arquiteto, seus aliados e oposicionistas, esses apresentarei integralmente na bibliografia, haja vista que cada publicação parece reafirmar uma posição política e territórios específicos de representação.

Devido, ainda assim, à grande quantidade de material, alerto que a estratégia adotada aqui para trabalhar com esses artigos assemelhou-se ao que procedi durante o desenvolvimento da apresentação da "questão de bacharéis" especificamente. Procurei trabalhar com blocos de ideias e debates, os quais me permitiram agrupar os interesses de cada crítico em relação a outros. No caso da polêmica de Bethencourt, chamo atenção para aqueles críticos que saíram em sua defesa, juntando-os inicialmente em notas que seguem essas minhas indicações; chamo ainda atenção para aqueles que manifestaram-se contra o arquiteto e para os motivos de cada grupo.

$135 \mathrm{O}$ artigo de imprensa em que Bethencourt afirma que a sua candidatura fora lançada por outras pessoas é esse: “AO PÚBLICO. Levados por um sentimento raro, que mal posso compreender, e ao qual terei de prestar minha eterna graditão resolveram entre si alguns amigos e colegas da arte recomendar o meu humilde nome à eleição de um dos lugares de vereador da Ilma. câmara municipal.

Esquecido na obscuridade da minha vida de artista de simples mestre de arquitetura, não ousaria jamais apresentar-me tal empenha, não só pela convicção que nutro da minha pouquidade intelectual, mas porque me tem parecido sempre, talvez sem maior razão, que os encargos de confiança, e como este tão nimiamente honrosos, recebem-se, acatando-se, como se recebem as distinções, se alguém que no-los conceder, mas não se pedem; e muito principalmente quando, como eu, se é pobre e sem prestígio de família ou da própria individualidade.

É verdade que, embora filho de um carpinteiro, mas de um carpinteiro honrado, cujo caráter e bondade santa fazem o meu único orgulho, eu podia apelar para a benignidade deste povo generos, que, despido do prejuízo das posições aristocráticas e dos pergaminhos de nobreza, não pergunta nunca aos mandatários do seu poder pelo nome dos seus antepassados.

Nascido do povo, e amigo das liberdade públicas, não me acusando a consciência de haver feito mal a quem quer que seja, poderia, talvez, em nome do amor que consagro às artes e a esta terra que me serviu de berço, solicitar os sufrágios do público fluminense; hesitaria, porém, sempre, sabendo por experiência própria que aqueles que não vivem como hebreus só para si, mas que dominados pelo amor do bem geral e do progresso do país, preferem realizar ideias que aventam, adquirem indubitavelmente desafeições gratuitas, que, embora inacreditáveis, nem por isso deixam de existir e prejudicar tanto como a perseguição dos inimigos que não conhecem.

De mais, parece-me que, não tendo a municipalidade, como tem a assembléia legislativa, fins políticos, nem deliberando em atos de governamentação nacional, o que exigiria predicados que não possuo, poderia talvez, na qualidade de arquiteto, prestar ao município alguns serviços que a outros, embora muito ilustrados, e mais hábeis do que eu, não seria fácil, desconhecendo, por alheios à sua profissão, os princípios da arte.

Contudo, não me resolvera a impetrar tal honra, podendo com mais jus apresentar-se um outro artista, porque na própria mediocridade do meu viver ia eu prestando ao povo e à nação alguns serviços como o ensino gratuito da artes, no Liceu de Artes e Ofícios, espalhando a instrução artistíca de que carecem os nossos operários para se emanciparem da opressão que sobre os seus artefatos exerce o produto das oficinas estrangeiras.

Mas, instado ainda por esses amigos e colegas que acreditam poder eu prestar ao município, com o auxílio de minhas débeis habilitações artísticas, alguns serviços úteis, próprios de minha profissão, tão necessários na nossa cidade, venho declarar que aceitarei, cheio de profundo reconhecimento, os votos que o povo se dignar de conceder-me, certo de que, ambicioso como sou, não dessa ambição mercenária que desonra o homem, mas de pura ambição da glória por que hei trabalhado sempre, farei quanto em mim couber para corresponder, como cumpre, à subida honra que me conferirem". BETHENCOURT DA SILVA, Francisco Joaquim. "Eleições municipais". Correio Mercantil. Rio de Janeiro, 23 de agosto de 1864. P.2. 
docentes na mesma instituição ${ }^{136}$. Além deles, não há dúvidas de que dezenas de outros apoiadores e aliados nutriam pelo arquiteto especial estima, especialmente por ele ter estruturado o Liceu e a Sociedade Propagadora de Belas Artes, e por quererem que aquela instituição voltasse a abrir as suas portas.

Antes que a contagem definitiva para vereança fosse divulgada pela Câmara Municipal (no seu Boletim de outubro/novembro de 1864), o prestígio de Bethencourt junto à comunidade da Glória era reafirmado já em setembro, quando ela lhe delegava o prestigioso e "moralizador" cargo de Juiz de $\mathrm{Paz}^{137}$ da paróquia; função cujas atribuições ${ }^{138} \mathrm{o}$ impeliam a atentar à Constituição, aos

1360 artigo subcrito por "amigos e colegas" de Bethencourt é o seguinte:

"Aos artistas. A comissão dos artistas abaixo assinados apresenta aos seus colegas do município neutro o nome do Sr. Francisco Joaquim Bethencourt da Silva para vereador à Ilma. Câmara Municipal.

A comissão ousa recomendar o distinto artista, que em reunião do dia 28 do mês próximo passado foi apresentado e aceito por grande número de artistas e seus amigos.

Francisco José Martins Filho.

Quirino Antônio Vieira.

Severo da Silva Quaresma.

José Feliciano de Campos.

João José da Cruz Cotrim.

João Duarte de Moraes.

Sabino Rosa de Oliveira.

Quintino José de Faria.

Apollinário Gomes de Oliveira.” S/A.“Aos artistas”. Correio Mercantil. Rio de Janeiro, 31 de agosto de 1864. p.3

Embora inteiramente desconhecidos da historiografia brasileira, esses subscritos eram, em sua maioria, artesãos ligados à Bethencourt por meio do Liceu ou da SPBA.

Quirino Antônio Vieira foi aluno de escultura da Academia na década de 1840, colega de Bethencourt desde esse período. Em 1852, Vieira pedia à academia para ocupar, como susbtituto, a cadeira de Escultura, vaga. Não assume a cadeira. Em 1862, pede a cadeira de Escultura de Ornatos; também indeferida. Desde os anos de 1850, presta serviços à AIBA, sobretudo de reparação do edifício da instituição e de esculturas em gesso.

Quintino José de Faria foi aluno da AIBA desde a metade da década de 1830. Gravurista de medalhas, membro da Sociedade Propagadora de Belas Artes e professor do Liceu, participa da Exposição Geral de Belas Artes de 1862 e obtém medalha de ouro. Em 1863 pede o lugar de professor de escultura de ornatos (indeferido). Em 1869, pede o lugar para professor de gravura (indeferido). Em 1871, pede novamente o cargo (novamente indeferido). Em 1878 e 1879 , novamente (idem).

João Duarte de Moraes foi também aluno de escultura da AIBA no mesmo período que Bethencourt, especializando-se em gravura de medalhas.

Severo da Silva Quaresma participa da EGBA de 1846, com duas pinturas. Em 1879, com uma estátua em Gesso do Visconde do Rio Branco.

Em 1868, logo após a reabertura do Liceu de Artes e Ofícios, fechado desde 1864, algumas das personalidades que assinaram a lista acima apresentada, e outras que também colaboraram ativamente para a candidatura de Bethencourt, foram agraciadas por $\mathrm{d}$. Pedro II com insígnias condecorativas, em virtude dos serviços que haviam prestado ao Brasil em virtude de sua perseverança no Liceu e na SPBA.

Da lista subscrita em em apoio a Bethencourt constam os nomes condecorados: Quintino José Faria, cavaleiro da Ordem de Cristo; Quirino Antônio Vieira, Cavaleiro da Ordem da Rosa.

Os outros apoiadores das instituições dirigidas pelo arquiteto que receberam as insígnias na mesma ocasião são: Jacy Monteiro, amigo próximo de Bethencourt e também ex-aluno da AIBA, e José da Silva: Cavaleiros da Ordem de Cristo; João Theodoro de Aguiar, Mathias José Teixeira e Poluceno Pereira da Silva Manuel: Cavaleiros da Ordem da Rosa. MINISTÉRIO do Império. Notícias Diversas. Correio Mercantil. Rio de Janeiro, 07 de maio de 1868.

137 A notícia da eleição de Bethencourt para Juiz de Paz da Glória (segundo distrito) foi apresentada, entre outros jornais, em: Correio Mercantil. Rio de Janeiro, 14 de setembro de 1864.p.2.

O primeiro lugar foi ocupado pelo Capitão Antonio José Estácio de Lima, com 281 votos; Dr. Alberto Antonio Soares, com 263; José Alves da Graça Bastos, 233. Francisco Joaquim Bittencourt [sic] da Silva, 229. 
decretos e aos Códigos Brasileiros ${ }^{139}$. Não é preciso refletir muito para chegar à óbvia conclusão de quem teria chamado à “questão de bacharéis", aproximadamente um ano depois, quando exercendo

Cada paróquia elegia 4 Juízes de Paz. O tempo duração do cargo era de um ano, assumido pelos eleitos durante o quatriênio de vigência de sua posse, a começar pelo mais votado, seguido dos outros.

138 O Juiz de Paz foi um cargo criado durante o Primeiro Reinado, em 15 de outubro de 1827. Cada paróquia ou freguesia deveria dispor de um, além de um suplente. Os Juizes de Paz eram eleitos no mesmo momento e da mesma maneira com as quais que se executavam as eleições para vereadores. Suas atribuições assemelhavam-se a de um "tribunal de pequenas causas", contudo com acesso facilitado, posto que se tratava de uma pessoa da própria comunidade, incumbida de ajudar a resolver os problemas imediatos dos seus concidadãos.

Ao Juiz de Paz "competia conciliar as partes antes da demanda, processar e julgar as causas cíveis cujo valor não excedesse a dezesseis mil-réis; manter a ordem nos ajuntamentos (reuniões públicas), dissolvendo-os no caso de desordem; pôr em custódia os bêbados durante a bebedice; corrigi-los por vício e turbulência e as prostitutas escandalosas, obrigando-os a assinar termo de bem viver, com a cominação de penas; fazer destruir os quilombos; fazer autos de corpo de delito; interrogar os delinqüentes, prendê-los e remetê-los ao juiz competente; ter uma relação dos criminosos para fazer prendê-los; fazer observar as posturas policiais das câmaras; informar o juiz de órfãos sobre incapazes desamparados e acautelar suas pessoas e bens, enquanto aquele não providenciasse; vigiar sobre a conservação das matas públicas e obstar nas particulares ao corte de madeiras reservadas por lei; participar ao presidente da província quaisquer descobertas úteis que se fizessem no seu distrito (minas); procurar a composição das contendas e dúvidas sobre caminhos particulares, atravessadouros e passagens de rios ou ribeiros, sobre uso das águas empregadas na agricultura ou na mineração, dos pastos, pescas e caçadas, sobre limites, tapagens e cercados das fazendas e campos, e sobre os danos feitos por familiares ou escravos; dividir o distrito em quarteirões que não contivessem mais de vinte e cinco fogos.

No crime, a sua competência para impor penas ia até o máximo de multa de trinta mil réis ou um mês de prisão ou três de correção, havendo casa para isso ou oficinas públicas." RODYCZ, Wilson Carlos. O Juiz de Paz Imperial: uma experiência de magistratura leiga e eletiva no Brasil. Disponível em: http://www.tjrs.jus.br/export/poder_judiciario/historia/memorial_do_poder_judiciario/memorial_judiciario_gaucho/revi sta_justica_e_historia/issn_1676-5834/v3n5/doc/02-Wilson_Rodycz.pdf. s.p.. Ver também: VIEIRA FERREIRA. "Juízes e Tribunais do Primeiro Império e da Regência”. Boletim do Instituto Histórico e Geográfico Brasileiro. Rio de Janeiro: Imprensa Nacional, 1937. p. 28-29.

A partir de 1841, com a Lei de Interpretação do Ato Adicional, e da lei n. 261, de dezembro de 1841, buscou-se, entre outras medidas, mudar várias das atribuições do Juiz de Paz, haja vista que suas funções, alheias até então ao Governo Central, começavam a permanecer de certa maneira obscuras nas localidades (incluindo crimes não reportados, abuso de poder de juízes, etc), e seu poder, muito grande. A partir daquele período iniciava-se assim um processo de diminuição do poder desses cargos. "O juiz de paz foi [então] despojado da maior parte das suas atribuições, reduzidas a aspectos notariais; perdeu a jurisdição policial (formação da culpa), transferida para os juízes municipais e para os chefes de polícia e seus delegados no interior. Por essa reforma, o Governo atribuiu-se a nomeação direta dos juízes municipais e dos promotores, não mais necessitando escolhê-los de listas tríplices propostas pelas Câmaras Municipais. Da mesma forma, passou à sua competência a nomeação dos chefes de polícia, que deveria recair em desembargadores e juízes de direito. Esses chefes passaram a ser auxiliados, no interior, por delegados, que assumiram as funções que antes eram exercidas pelos juízes de paz, realizando um inquérito e, em certos casos, dando a sentença de pronúncia, exercendo também, portanto, funções jurisdicionais.”. RODYCZ, WILSON CARLOS. Op. Cit. s.p.

Para uma breve discussão sobre como as mudanças de atribuições dos Juízes de Paz estavam em relação não apenas aos contrastes estabelecidos entre governo central e governos regionais, mas também em a uma disputa entre uma esfera pública e os direitos garantidos pela Constituição à esfera privada, ver: ALENCASTRO, Luiz Felipe de. Vida privada e ordem privada no Império. In: ALENCASTRO, Luiz Felipe de (org). História da vida privada no Brasil: Império. São Paulo: Companhia das Letras, 1997.

139 A competência e o conhecimento da lei de um juiz de paz, ainda que esperados, não pareciam ser compulsórios, ou mesmo comuns, ao menos nos primeiros anos após a criação do cargo; talvez daí o motivo pelo qual o governo, em 1841, reduziu as competências a ele delegadas. Interpretação cômica sobre falta de zelo, moral e dedicação de juizes de paz encontra tradução na peça de teatro escrita em 1833 por Martins Pena: "O juiz de paz na Roça". Nela, João Rodrigues encarna o que seria um tipo comum de juiz de paz, reconhecido por ele próprio, e sem lamentar, que não apenas não sabe a Constituição mas, mesmo quando alertado por um subalterno sobre seu abusos, faz questão de agir acima das prescrições da lei; realiza conchavos para obter votos em eleições; efetua supostas conciliações nas quais, no fim, a única parte que se beneficia é a sua própria; precisa consultar "letrados" para despachar requerimentos, pois não o sabe fazer sozinho, etc. Ver: PENA, Martins. O juiz de paz na roça (comédia em um ato). Manaus: Editora Valer, 2010. Pp.9-37. 
aquele cargo, o artigo 301 do Código Penal Brasileiro, instando prisão a Ferro e Américo por uso indevido de títulos; intimando aliás a intervenção do "chefe de polícia" e do "promotor": cargos relativamente recentes ${ }^{140}$, cujas atribuições recairiam, anos antes, sintomaticamente sobre as obrigações dos Juízes de Paz.

Ainda um pouco antes do fim da contagem dos votos das eleições, antes mesmo de Bethencourt descobrir sua nova função de Juiz de Paz, o andamento da sua campanha lhe traria, porém, o mesmo "inferno astral" que lançaria a Ferro Cardoso e a Américo, no início de 1866. Em 23 de agosto de 1864, no mesmo dia que o arquiteto publica um artigo no qual agradecia a seus "amigos e colegas de arte" a recomendação do seu nome às eleições daquele ano - anunciando ademais que seria para ele uma honra, "em nome do amor que consagro às artes e a esta terra que me serviu de berço", receber "os sufrágios do público fluminense"141 -, um crítico fazia uma provocação no Correio Mercantil:

É verdade que o Sr. Bethencourt da Silva é natural das ilhas; ilhéu, como por aí dizem em ar de desprezo: mas S. S. está naturalizado cidadão brasileiro. É verdade que se naturalizou para obter ou conservar um lugar público para que fôra nomeado; mas é evidente que mais cedo ou mais tarde o faria por meio-próprio.

É verdade que foi conservador vermelho; mas isto era tão somente pela amizade que tributava ao Exmo. Sr. Euzébio. Hoje é liberal genuíno. - Já Godinho dizia - mudam as folhas e as árvores, tudo muda neste mundo. Porque não devia mudar o Sr. Bethencourt da Silva. Só os burros não mudam por que são burros.

$$
\text { Veritas }^{142} \text {. }
$$

A nota era uma incitação arguta às relações pessoais e às ações que Bethencourt teria executado para introduzir-se nos lugares que lhe interessavam. Era ainda impressa com o conspícuo intuito de abalar sua imagem e seus propósitos políticos, num momento importante de sua campanha, ainda em andamento. Dias após esse primeiro texto refratário, quando outros artigos também começavam a ser impressos a mesmo respeito, Veritas publicava mais uma nota, reincidindo na questão da naturalização do arquiteto:

Leiam todos.

140 Ver nota anterior.

141 BETHENCOURT DA SILVA, Francisco Joaquim. "Eleições municipais". Correio Mercantil. Rio de Janeiro, 23 de agosto de 1864. P.2. O artigo está publicado integralmente em um das notas imediatamente anteriores a esta.

142 VERITAS. "Respostas aos que guerreiam a candidatura do Ilm. sr. Francisco Joaquim Bethencourt da Silva". Correio Mercantil. Rio de Janeiro, 23 de agosto de 1864. P.3. 
Sr. Bethencourt da Silva deixe-se de palanfrório, e responda franca e categoricamente a estas perguntas: $1^{\circ}$ : É ou não V. S. estrangeiro naturalizado? $2^{\circ}$ : Naturalizou-se ou não depois de que foi demitido do lugar de arquiteto da câmara municipal (por ser estrangeiro, e não poder, portanto, ocupar um lugar que competia a um nacional)? $3^{\circ}$ : Naturalizou-se ou não com o fim de ser reintegrado? Ande, responda e publique sua certidão de batismo, se é capaz. Veritas ${ }^{143}$.

Ao contrário da contenda contra Ferro e Américo, nessa, contra Bethencourt, vários foram os aliados que tomaram suas dores, opondo-se ao opróbrio de Veritas ${ }^{144}$. Além dos pedidos de votos, que continuaram repetidamente e foram mesmo intensificados depois do início da polêmica, publicaram-se vários outros artigos que garantiam que os responsáveis por lançar o nome do arquiteto às eleições eram de fato seus "amigos artistas"145. Defendia-se assim que não haveria qualquer ambição pessoal de Bethencourt em sua candidatura (ambição que, de outro modo, seria dali a poucos meses repetidamente atribuída a Ferro e a Américo). Argumentaram, ainda, que se alguns críticos não observavam nele qualidades destacadas, muitos eram os artistas que contavam com ele para que "lhes servisse de transição para sua legítima soberania" ${ }^{146}$; que se havia alguém burro, estúpido, ou interesseiro na história, esse alguém era o Veritas ${ }^{147}$; e que, por ter sido requisitada tão ardentemente a certidão de batismo de Bethencourt ${ }^{148}$, se ofereciam até as coordenadas das folhas do livro da Freguesia de Nossa Senhora da Glória, onde ela se encontraria, documento que também permaneceria à mostra na Tipografia Paula Brito ${ }^{149}$.

Se há nesse último tópico uma evidente coincidência com a futura "questão de bacharéis" aparente na mesma contumácia com a qual Bethencourt solicitava a Ferro e Américo exibirem seus

143 VERITAS. "Leiam todos". Correio Mercantil. Rio de Janeiro, 31 de agosto de 1864. p.3.

144 Todos os artigos localizados que saíram em defesa a Bethencourt são: EPEMINONDAS. "Ao Veritas". Correio Mercantil. Rio de Janeiro, 24 de agosto de 1864. P.2; O VIB ORA. "Ao veritas". Correio Mercantil. Rio de Janeiro, 24 de agosto de 1864. P.2; O ARTISTA. "Eleições”. Correio Mercantil. Rio de Janeiro, 25 de agosto de 1864. P.2; UM QUE CONHECE A AMBOS. "Veritas Veritatis". Correio Mercantil. Rio de Janeiro, 25 de agosto de 1864. P.2; VIEIRA, Quirino Antonio . "Vereança". Correio Mercantil. Rio de Janeiro, 07 de setembro de 1864. p.2; VIEIRA, Quirino Antonio. "Municipalidade. Correio Mercantil. Rio de Janeiro, 07 de setembro de 1864. p.3; OS MEMBROS DA COMISSÃO CENTRAL. Os membros da comissão central. "Eleições municipais". Correio Mercantil. Rio de Janeiro, 07 de setembro de 1864. p.3; MACEDO ASQU. "Aos Artistas". Correio Mercantil. Rio de Janeiro, 07 de setembro de 1864. p.3.

145 O ARTISTA. “Eleições”. Correio Mercantil. Rio de Janeiro, 25 de agosto de 1864. P.2; Aos artistas. Correio Mercantil. Rio de Janeiro, 31 de agosto de 1864. p.3.

146 MACEDO ASQU. "Aos Artistas". Correio Mercantil. Rio de Janeiro, 07 de setembro de 1864. p.3.

147 EPEMINONDAS. "Ao Veritas". Correio Mercantil. Rio de Janeiro, 24 de agosto de 1864. P.2; O VIB ORA. "Ao veritas". Correio Mercantil. Rio de Janeiro, 24 de agosto de 1864. P.2; UM QUE CONHECE A AMBOS. "Veritas Veritatis". Correio Mercantil. Rio de Janeiro, 25 de agosto de 1864. P.2.

148 Além do artigo de Veritas, no qual o autor pedia uma resposta final quanto à naturalização de Bethencourt e a exposição da sua certidão de batismo, ao menos mais um artigo da contenda tocou no mesmo mérito: "Atenção. O sr. Bethencourt da Silva diz agora, nos seu publicados, que nasceu ao mar, entretanto há que assegure que S. S. desembarcou aqui já taludinho. Para tirar todas as dúvidas pedimos a S. S. que publique a sua certidão de batismo. Mas qual! nessa não cai ele."Atenção”. Correio Mercantil. Rio de Janeiro, 26 de agosto de 1864. P.3.

149 OS MEMBROS DA COMISSÃO CENTRAL. Os membros da comissão central. "Eleições municipais". Correio Mercantil. Rio de Janeiro, 07 de setembro de 1864. p.3 
diplomas e os deixarem por algum tempo nas redações dos jornais cariocas -, ela não seria ainda a única.

Como os jovens, também o arquiteto saiu em sua própria defesa, logo após ver seu nome ironizado nos jornais. Na insistência de Veritas em republicar aquele o seu primeiro artigo ${ }^{150}$, Bethencourt fez publicar e republicar uma "resposta" sempre abaixo do texto do seu algoz, todas as vezes que era impresso ${ }^{151}$ :

\section{Resposta}

Aqueles que não vivem, como hebreus, só para si, mas que, dominados pelo amor do bem geral e do progresso do país, preferem realizar ideias que aventam, adquirem inevitavelmente desafeições gratuitas, que, embora inacreditáveis, nem por isso deixam de existir e prejudicar tanto como a perseguição dos inimigos que se não conhecem. ${ }^{152}$

Se o Veritas, órgão das torpezas levantadas por um meu colega, quer que lhe responda cabalmente ao mimo que me dirigiu, tenha a coragem de assinar o seu nome que, se for o de um homem decente, não trepidarei em mostrar-lhe que graças a Deus não temo nem a análise da minha vida pública ou privada, nem a do puro sentimento de amizade que sempre tributei, tributo e tributarei ao Sr. conselheiro Euzébio. Não receio das intrigas ou graçolas dos sicofantas.

Não discuto com mascarados; tenho muito medo de me encontrar com algum ladrão.

Bethencourt da Silva.

A réplica do professor da Academia, emparelhada ao artigo que o criticava, elucida algumas questões, mesmo que não todas. Sugeria que o Veritas era também um "colega" indesejado seu (possivelmente um "colega das artes", como havia chamado outros aliados), e esperava mesmo ser criticado por aqueles que supostamente viveriam "só para si”, quando manifestasse seu propósito de contribuir para o "bem geral e progresso do país".

150 Além da publicação do dia 23 de agosto de 1864, Veritas publicou o mesmo artigo, no Correio Mercantil, nas edições: VERITAS. "Respostas aos que guerreiam a candidatura do Ilm. sr. Francisco Joaquim Bethencourt da Silva". Correio Mercantil. Rio de Janeiro, 25 de agosto de 1864. P.3; VERITAS. "Respostas aos que guerreiam a candidatura do Ilm. sr. Francisco Joaquim Bethencourt da Silva". Correio Mercantil. Rio de Janeiro, 27 de agosto de 1864; VERITAS. "Respostas aos que guerreiam a candidatura do Ilm. sr. Francisco Joaquim Bethencourt da Silva". Correio Mercantil. Rio de Janeiro, 29 de agosto de 1864.p.3; VERITAS. "Respostas aos que guerreiam a candidatura do Ilm. sr. Francisco Joaquim Bethencourt da Silva". Correio Mercantil. Rio de Janeiro, 31 de agosto de 1864. p.3.

151 A "resposta" de Bethencourt apareceu, também no Correio Mercantil, nas edições: BETHENCOURT DA SILVA. "resposta". Correio Mercantil. Rio de Janeiro, 24 de agosto de 1864. P.2; BETHENCOURT DA SILVA, Francisco Joaquim. "Resposta". Correio Mercantil. Rio de Janeiro, 25 de agosto de 1864. P.3; BETHENCOURT DA SILVA, Francisco Joaquim. "Resposta". Correio Mercantil. Rio de Janeiro, 27 de agosto de 1864. P.3; BETHENCOURT DA SILVA, Francisco Joaquim. "Resposta". Correio Mercantil. Rio de Janeiro, 29 de agosto de 1864. P.3; BETHENCOURT DA SILVA, Francisco Joaquim. "Resposta". Correio Mercantil. Rio de Janeiro, 31 de agosto de 1864. P.3.

152 A epígrafe do artigo "resposta" de Bethencourt era um excerto dos agradecimentos aos seus "amigos e colegas da arte", que publicou em artigo de 23 de agosto. 
Veritas, por sua vez, conquanto não tivesse sua identidade revelada mesmo no fim da campanha, também parecia conhecer os meandros de convívio de Bethencourt. Encetou os possíveis motivos sobre a naturalização do arquiteto, lavrada com a suposta intenção de assumir um cargo público para o qual fora nomeado (tratar-se-ia do cargo de professor da academia ou de arquiteto da câmara municipal, ambos nomeações?). Trouxe à baia a também suposta "antiga" inclinação política de Bethencourt, ao lado dos conservadores vermelhos ${ }^{153}$, do qual fazia parte Eusébio de Queiroz (não se esqueça, também padrinho do casamento de Ferro em 1862), que desde a década de 1850 , em resposta positiva a um convite do arquiteto, exercia o cargo de primeiro Presidente da Sociedade Propagadora de Belas Artes e do Liceu de Artes e Ofícios. Trazia ainda a sua suposta "nova" inclinação, a de liberal, referindo-se, sem dúvida, ao fato de subir naquele momento (1864) o segundo gabinete "liberal" de Zacarias de Góis e Vasconcellos - de quem Bethencourt começava de fato a se aproximar -, e que se tornaria sintomaticamente o novo Presidente da SPBA e do Liceu, a partir de $1867^{154}$.

Ainda que mais de um aliado de Bethencourt saísse em sua defesa - retorquindo a Veritas quais atos do arquiteto poderiam justificar seus posicionamentos políticos -, parecia haver mesmo alguma verdade na provocação do crítico. Além da procedente aproximação que Bethencourt investia com o então "liberal” Zacarias de Góis e Vasconcellos (político que, relembrando os três ministérios que assumiu nos anos 1860, chamou essa década de "o quinquênio liberal"155), seria impossível apagar da lembrança a inclusão do nome de Bethencourt para a candidatura a deputado pelo Partido Progressista, em 1863. O partido recém-formado e o termo "progressista" estavam, entre 1862 e 1864, em estreita relação com a formação da "Liga Progressista", encabeçada também por Góis de Vasconcellos e Nabuco de Araújo, e formada por liberais e conservadores moderados, cujo intuito principal era o de fazer oposição aos chamados "conservadores vermelhos"156, grupo do qual faria parte Eusébio de Queiroz, além de opor-se também também a "antigos" como Duque de

153 Os "vermelhos" eram identificados como os velhos políticos já atuantes desde o período regencial, conhecidos por vezes também como "saquaremas".

154

Para maiores aprofundamentos sobre a política ministerial do Segundo Império durante as décadas de 1860, ver: BARMAN, Roderick. Imperador Cidadão. São Paulo: Editora Unesp, 2012; neste, especialmente os capítulos quarto, quinto, sexto e sétimo.; HOLANDA, Sérgio Buarque de. Capitulos de história do Império. São Paulo: Companhia das Letras, 2010. LIMA, Oliveira. Movimento da Independência: O Império Brasileiro (1821-1889). São Paulo: Edições Melhoramentos, 1962; NABUCO, Joaquim. Um estadista do Império: Nabuco de Araújo, sua vida, suas opiniões, sua época. Rio de Janeiro: H. Garnier, 1897; OLIVEIRA, Cecilia Helena de Salles. "Da natureza e limitos do Poder Moderador e a memória do conselheiro Zacarias de Góis e Vasconcelos". in: VASCONCELOS, Zacarias de Góis e. Zacarias de Góis e Vasconcelos. São Paulo: Ed. 34, 2002; SCHWARCZ, Lilia Moritz. As barbas do imperador: D. Pedro II, um monarca nos trópicos. São Paulo: Companhia das Letras, 1998.

155 OLIVEIRA, Cecilia Helena de Salles. "Da natureza e limites do Poder Moderador e a memória do conselheiro Zacarias de Góis e Vasconcelos". Op. Cit.

156 OLIVEIRA, Cecilia Helena de Salles. "Da natureza e limites do Poder Moderador e a memória do conselheiro Zacarias de Góis e Vasconcelos". Op. Cit.p.12. 
Caxias, Marquês de Olinda (que, por sua idade avançada podia ser também assim chamado em alguns momentos, embora fosse mais volátil em seus posicionamentos ao ponto de ter feito parte da formação inicial da "Liga"), e Luiz Pedreira do Couto Ferraz.

Alguns desses eram, conforme visto, membros importantes da Sociedade Auxiliadora da Indústria Nacional - da qual Bethencourt havia acabado de se afastar "por circunstâncias que lhe eram próprias" - alguns dos quais, segundo o arquiteto, "padrinhos" de Ferro e Américo ${ }^{157}$.

Em 1864, alguns dos frequentes pedidos de votos para Bethencourt podiam fazer novamente alusões às suas filiações políticas, trazendo, por exemplo, a assinatura de um "votante da época progressista" " 158 . Outras propagandas eleitorais podiam ainda incluir o nome do arquiteto na "Chapa de Ferro em oposição à Chapa de Ferro" 159 : título de uma coligação "liberal" estruturada contra um grupo conservador, dito "Chapa de Ferro", acusado de empreender "procedimentos criminosos" durante a campanha, que incluíam invadir as casas dos cidadãos cariocas para obrigá-los a lhes converterem votos ${ }^{160}$.

Talvez seja uma coincidência, contudo curiosa, a existência de um certo ferruge, que seria duramente criticado em algumas notas no mesmo período por fazer campanha de porta em porta, não a favor, mas contra alguns candidatos ${ }^{161}$. Esse mesmo ferruge seria ainda apresentado com qualidades muitos similares àquelas que receberia o ferrugem (Ferro) Cardoso, dali a pouco, na “questão de bacharéis". Também ele era apresentado como um "garoto", "paspalhão", "caguete"162.

157 As motivações que "eram próprias" ao arquiteto dificilmente diziam respeito apenas a Ferro. Deveriam estar mais em relação ao que aquela instituição representava para Bethencourt ante tão difícil situação do Liceu. A Sociedade Auxiliadora da Indústria era uma instituição privada, composta por muitos políticos empresários e latifundiários, visando portanto sobretudo o lucro, mas, ainda assim, era subvencionada pelo estado - nada mais "natural" já que seus integrantes eram os gerentes da monarquia, apenas abaixo de d. Pedro II. A Sociedade Propagadora das Belas Artes e o Liceu eram instituições filantrópicas, que não cobravam nada para que fossem frequentadas, tampouco visavam lucro mas, em 1863, deixava de ser amparada pelo governo.

158 Correio Mercantil. Rio de Janeiro, 19 de agosto de 1864. P.2

159 O ARTISTA."Eleições”. Correio Mercantil. Rio de Janeiro, 25 de agosto de 1864. P.2. Outro artigo, que não era propriamente uma propaganda eleitoral, mas uma justificativa da campanha que artistas lançaram o nome de Bethencourt à vereação, também acusavam a inclinação da sua chapa, liberal, contra a Chapa de Ferro, conservadora: "Tendo partido de alguns artistas a ideia de se apresentar consideração dos artistas votantes do município da corte o nome do benemérito artista Francisco Joaquim Bethencourt da Silva, contamos logo com a guerra torpe que sempre se servem certos entes, inimigos mesquinhos e misérrimos, não por ele, mas pela classe que se lembrou de o apresentar, à qual até hoje nada se tem concedido além da honra de conduzir à urna uma chapa de ferro". O ARTISTA."Eleições". Correio Mercantil. Rio de Janeiro, 25 de agosto de 1864. P.2.

160 Outro nome bastante comum para a pressão exercida durante as votações por conservadores extremos ficou conhecido como "eleições do cacete". Cf. ADORNO, Sérgio. Os aprendizes do poder. Rio de Janeiro: Paz e Terra, 1988. P.68.

$161 \mathrm{O}$ artigo que cita o ferruge durante as eleições à veração de 1864 é o seguinte: "Vereança. que se peça a favor, é razoável, mas contra, só porque o médico está pronto para o serviço público e obras meritórias, é infame o Ferruge." Vereança". Correio Mercantil, Rio de janeiro, 01 de setembro de 1864. p.3.

162 "Esse miserável cantador de modinhas, tocador de viola de 93 pontos, paspalhão ferrugento, alcagate de vasilhas vidradas, que anda de porta em porta a furtar votos a um candidato de vereança, criticando uma ação nobre desse cavalheiro, que não pode ser compreendida por almas de lama como a desse garoto, arrepie carreira; porque se 
Essa, todavia, é uma mera especulação que talvez não deva ser tomada em conta, mormente por que se sugeriu que aquele ferruge estivesse especialmente contra um médico canditado à vereação, e não contra o arquiteto.

É verdade também que, embora bastante sugestivas, as pistas sobre os lados políticos tomados por Bethencourt não podem garantir certeza de um seu partido claramente definido. À despeito da filiação Progressista do arquiteto, em alguns artigos abertamente manifestada, e a despeito, ainda, de não se ter produzido nenhuma chamada eleitoral que o aproximasse dos "vermelhos", várias foram as propagandas de 1864 (aliás em maior quantidade) nas quais seu nome foi simplesmente ofertado à vereação, sem prefixos ou sufixos partidários. Não prescindiram, porém, dos comuns, mas extremamente importantes sufixos de "classe", que precisavam a atuação profissional do candidato e o interesse para que se votasse nele. Bethencourt foi também apresentado "arquiteto". Contudo, sem dúvida foi a sua apresentação enquanto "artista" a mais recorrente (uma designação que visava angariar maior identificação da classe geral artística, mais restrita, portanto, se circunscrita apenas à classe de arquitetos).

A intenção principal do artista-arquiteto não parecia ser de fato a de afirmar um ponto de vista político preciso para suas ações, mas a de assumir um cargo que lhe fornecesse poder ou contato político suficiente (que parecia não estar mais nos “conservadores vermelhos") para ajudá-lo a resolver graves entraves que o Liceu enfrentava.

Com o fim da campanha, provada a naturalização de Bethencourt, e sendo-lhe permitido pleitear a vaga na Câmara Municipal, restou porém a frustração. Mesmo com o apoio de vários artistas, somado ao seu prestígio junto à comunidade da Glória, ele não conseguiu ultrapassar o sexto lugar geral na suplência da vereança. ${ }^{163}$

não, talvez o jogo lhe seja fatal. O campista." O CAMPISTA. "Eleição municipal". Correio Mercantil, Rio de janeiro, 03 de setembro de 1864. p.2.

Outros artigos em que o mesmo ferruge é citado são: O COLLEGA FERRUGE. Camara Municipal. Correio Mercantil. Rio de Janeiro, 03 de setembro de 1864. p.2; CAMPISTA. "Eleição municipal". Correio Mercantil, Rio de janeiro, 03 de setembro de 1864. p.2; O COLEGA FERRUGE. Camara Municipal. Correio Mercantil. Rio de Janeiro, 04 de setembro de 1864. p.3

163 Nas eleições para vereador, eram eleitos 9 efetivos e 9 suplentes. Nas eleições de 1864, segundo computação apresentada nos jornais cariocas, Bethencourt obteve 2460 votos na contagem final, coletados em todas as 18 paróquias da província do Rio de Janeiro, apresetando-se em sétimo lugar. A título de comparação, nessa eleição, o primeiro vereador eleito, Dr. João Baptista dos Santos, contou com 5655 votos; o primeiro suplente, Major João Antonio Leite Júnior, 3490. A relação final era dada em vários jornais, folhetos e impressos da corte. Ver, entre outros: Correio Mercantil. Rio de Janeiro, 18 de setembro de 1864. p.2.

O Boletim da Câmara Municipal da Corte do fim do mesmo ano apresentava uma relação um pouco diferente: $\mathrm{O}$ primeiro lugar geral, Dr. João baptista dos santos, obteve 5065 votos; o segundo, Dr. Bezerra de Menezes, 4095, o terceiro, Dr. Francisco de Menezes Dias da Cruz, 4647; o primeiro suplente, João Antonio Leite Júnior, 3544 votos; Bethencourt da Silva, em sétimo lugar, 2505. Boletim da Illustríssima Câmara Municipal da Corte. Rio de Janeiro, outubro a novembro de 1864 volume X - XI - p.6. 
Os seus problemas continuavam, e a situação do principal deles, o Liceu, não havia mudado em nada. Para a sua indignação, continuava fechado.

\section{Um problema entre artistas}

Além da derrota nas eleições para vereadores, a concomitante discussão sobre o mérito de subvenção estatal do Liceu era outro calo muito sensível conquistado recentemente por Bethencourt. Por que patrocinar uma instituição que ensinava o desenho elementar, matemática, química e física, se existiam uma série de outras instituições que, na corte, já as ofereciam? ${ }^{164}$ perguntava o deputado Souza Dantas em sessão da Câmara, em julho de 1864. Custear o Liceu era um gasto extra inútil; gasto retirado do que seria realmente importante naquele momento, como a construção da Estrada de Ferro D. Pedro II $^{165}$; ou, em poucos meses, a já anunciada Guerra do Paraguai.

Bethencourt não precisava que ninguém lhe recomendasse a lembrança do infortúnio que passava a sua instituição, tampouco o fato de que nem todas as personalidades com poder suficiente para apoiá-la acreditavam em sua validade. Se as objeções ou oposições de deputados, embora indigestas, deveriam rebatidas com movimentos ponderados (devido à importância dos seus emissores, de quem o arquiteto, de todo modo, precisava), o mesmo não procedia com aqueles de indivíduos em posição "igual” ou mesmo "inferior” à do arquiteto.

Bethencourt não deveria contar que, desse segundo conjunto, seria Pedro Américo o responsável por pisar no seu calo mais doído, justamente no momento em que estava em sua campanha à vereação para reavivar o Liceu.

Algumas ações feitas pelo pintor a partir de 1864 (não parece mesmo restar dúvidas) criaram a ponta de lança que faltava para arrebentar o último fio possível de relações amigáveis entre ele e o arquiteto, e deflagrar de vez o desconforto recíproco que compartilharão então por décadas. E o episódio público inaugural será, dali a poucos meses, o da "questão de bacharéis".

Em janeiro de 1865, na Sessão de Posse da Câmara Municipal, os nomes e ordem dos eleitos, e contagem de votos, eram novamente um pouco diferentes. Dr. João Baptista dos Santos manteve-se em primeiro lugar, mas com 4616 votos; o primeiro suplente, dr. José Joaquim Monteiro dos Santos, é diferente do da contagem final, obtendo 3082 votos; Bethencourt aparece agora em sexto lugar, com 2135 votos. Boletim da Illustríssima Câmara Municipal da Corte. Rio de Janeiro, janeiro de 1865, volume I. P.2.

164 A Escola Militar, a AIBA e o colégio d. Pedro II eram instituições que ofereciam uma série de disciplinas de instrução elementar e artística, também propostas pelo Liceu.

165 "Parlamento. Senado. Sessão em 28 e julho de 1864". Correio Mercantil, 06 de agosto de 1864. p.1.

Dantas argumentava com o então ministro do Império, José Bonifácio o moço, que mostrava-se a favor da instituição, bem como o ministro anterior, o Marquês de Olinda. 
Para que se compreenda em que medida as ações de Américo tenham atingido negativamente Bethencourt, é necessário (antes de apresentá-las propriamente) desenvolver um breve apontamento sobre onde elas se colocavam em relação aos planos do arquiteto até o período que envolve o fechamento do Liceu (1864-1867).

Quando propunha (e lograva) a formação de uma Sociedade Propagadora das Belas Artes, em 1856, Bethencourt seguia favoravelmente o embalo promovido pela recente Reforma Pedreira na Academia (1855), empreendida sob a orientação de Porto Alegre, cuja proposta principal, já bastante discutido nesta Tese, era a de também valorizar as "artes menores", voltadas mormente para o fomento da "indústria nacional"166. A sucessão de uma atuação política para as artes entre Porto Alegre e Bethencourt era notória (ainda que não fosse articulada nos mesmos termos), pois também o antigo diretor havia iniciado seus projetos enquanto exercia o cargo de vereador pelo Rio de Janeiro, quando era então chamado por d. Pedro II para integrar seus planos aos escopos da $\operatorname{AIBA}^{167}$.

Não obstante, o intuito de Bethencourt parecia, à diferença dos planos da academia, ser exacerbado por um cunho iminentemente prático e imediatista. Trabalhando desde 1850 na inspeção de Obras Públicas e, depois, na câmara municipal, Bethencourt necessitava com frequência da colaboração de mão de obra especializada, que não apenas soubesse o ofício prático da "indústria", mas que ainda fosse capaz de lidar e interpretar o pensamento projetivo em desenhos e plantas; objetos com os quais ele, enquanto arquiteto crente na detenção dos "bons" e "universais" valores do belo, dava visibilidade às suas intenções formais ${ }^{168}$. Seus principais planos, conforme

166 De fato, no segundo discurso que Bethencourt da Silva fazia para a preparação da Sociedade Propagadora de Belas Artes, ele sugeria que o Liceu, antes de ser uma Associação que disputaria com a Academia, seria mais uma instituição para fomento e desenvolvimento das artes no país, posto que apenas a academia não parecia ser suficiente para mudar a situação das artes no país (essa é, afinal, a mesma conclusão que Américo oferecia em suas Cartas de um Plebeu): "A Academia das Bellas-Artes que, como se sabe, possuía em seu grêmio artistas eminentes e insignes, como o Sr. Grandjean de Montigny, via todos os seus esforços e desejos inutilizados ante as crenças de uma população que não queria receber o menor fructo do trabalho artístico, nem considerar essencialmente digna de respeito a profissão das artes. Sob tais princípios o desânimo lavrou, e a Academia foi levada a um plano inclinado, donde só a educação do povo a poderá fazer sair [...] É verdade que o governo imperial tem cuidado ultimamente em reforma-la, em dar-lhe influência no país; mas o que pode uma vontade única, contra a vontade de uma multidão que não conhece as vantagens que se lhe offerece..- Pouco ou quase nada." BETHENCOURT DA SILVA, Francisco Joaquim. "Discurso pronunciado na segunda sessão preparatória da Sociedade Propagadora das Bellas-Artes do Rio de Janeiro, em 28 de Novembro de 1856." In: SOCIEDADE PROPAGADORA DE BELAS ARTES. O Brazil Artístico: Revista da Sociedade Propagadora das Bellas-Artes do Rio de Janeiro. Rio de Janeiro: Typographia Leuzinger, 1911. p.39.

167 Quanto à atuação política eletiva de Porto Alegre e Bethencourt da Silva, os termos divergentes encontravamse no momento em que cada recorria àquele campo. Para Porto Alegre, as ações que desenvolvia para as artes, já como vereador, chamaram a atenção do monarca, levando-o a integrar o artista à instituição. Para Bethencourt da Silva, o recurso de ingresso na política decorria, ao contrário, de uma luta para manter seus planos de ação para as artes ainda operantes, isso após já ser integrado ao corpo docente da academia.

168 Em 1866, Bethencourt fará um discurso na câmara dos vereadores, reforçando os aspectos das construções arquitetônicas do Rio de Janeiro, que seriam erigidas: "sob os impulsos de práticos contrários a todo o sistema do belo, e executadas pela mão rude do alvanil ou do simples prático, e mais das vezes até analfabeto, despindo-se assim uma 
sugeriu não poucas vezes em seus discursos, eram voltados ao "embelezamento" da cidade, construída até então sob o suposto impulso de uma não-inteligência artística ${ }^{169}$.

O pedido de afastamento de Porto Alegre da direção da AIBA, em 1857 (colocando-se em banho-maria as ações de mudança do ensino artístico-industrial), deve ter fornecido o ensejo para a criação efetiva ${ }^{170}$ do Liceu de Artes e Ofícios, em 1858, e para que essa instituição fosse percebida como a "herdeira natural" e mais do que prestimosa dos desígnios da reforma de 1855.

Deve ter sido tão natural quanto evidente, pois, como visto, dificilmente foi casual que a abertura do Liceu antecedesse poucos meses o convite/intimação de d. Pedro II para que Bethencourt assumisse a cadeira de arquitetura civil no lugar de Job Justino de Alcântara (que se aposentava), solapando a decisão unânime da congregação da Academia (e criando um evidente desconforto entre seus membros), que havia proposto Jacinto Rabello para aquela disciplina.

Com a saída de Porto Alegre, d. Pedro II parecia concluir que a integração do arquiteto à academia (um "queridinho" do falecido Grandjean de Montigny e do antigo diretor da AIBA e rival de Porto Alegre, Féllix-Émile Taunay) garantiria não apenas a continuidade da reforma do primeiro, mas somaria as forças das duas instituições (a antiga e a nova) em benefício dos seus propósitos (naquele tão velho desejo de formação de um estabelecimento de mútuo fomento às artes plásticas, gráficas e industriais, já presentes desde o primeiro projeto elaborado por LeBreton, na década de $1810^{171}$ ). Com efeito, não era também casual o fato de que, logo após a entrada do arquiteto na academia, fossem escritos os estatutos que implementavam as aulas noturnas na instituição, permitindo o ingresso efetivo de artífices e artesãos, os quais podiam estudar apenas naquele período.

Bethencourt obtinha uma espécie de "cargo de conciliação", já que, lembra-se mais uma vez, a ideia de "conciliação" entre membros dissonantes, e alternância no poder de agentes de "lados opostos", era uma das políticas mais bem vistas pelo monarca nos anos 1850-1860; política que,

cidade do século XIX de todo o cunho e regra artística que são inseparáveis das edificações da cidades cultas, muito mais daquelas que se exigirão depois dos belos exemplos dos mestres do renascimento da arte, que unem ao aspecto de morada de um povo ilustre as regras de ciência para a conservação da vida, pela luz, pela ventilação e pelas outras condições determinadas pela higiene." Editais. Boletim da Illustríssima Câmara Municipal da Corte. Rio de Janeiro, julho a setembro de 1866, volume VII, VIII e IX - $1-22^{\text {a }}$ Sessão.

169 Um importante discurso de Bethencourt durante a década de 1860 que trazia o problema do embelezamento da cidade por meio da arquitetura e das artes industriais podem ser encontrado naquele proferido em ocasião da posse que toma do cargo de vereador do Rio de Janeiro: BETHENCOURT DA SILVA, Francisco Joaquim. Editais. Boletim da Illustríssima Câmara Municipal da Corte. Rio de Janeiro, julho a setembro de 1866, volume VII, VIII e IX - 1.

170 Refere-se a "criação efetiva" pois, desde 1856, com a formação da Sociedade Propagadora de Belas Artes, estava previsto nos planos da nova instituição a construção futura do Liceu como uma de suas premissas principais para a difusão do ensino artístico-industrial.

171 Ver: LEBRETON, Joachin. Manuscrito inédito sobre o estabelecimento de dupla Escola de Artes no Rio de Janeiro, em 1816. Arquivo Histórico do Consulado Brasileiro, Palácio do Itamaraty, Rio de Janeiro. 
supostamente, diminuindo os conflitos, poderia beneficiá-lo em sua vontade crescente de comandar os assuntos de administração nacional. ${ }^{172}$

Entretanto, D. Pedro II, com seus poderes, podia até mostrar-se favorável ao Liceu e a seu agente central, em seus desígnios de promoção do ensino artístico-industrial no país, mas não podia escapar das suas limitações, que eram a de reinar (embora também quisesse governar) ainda numa monarquia constitucional, onde também seus agentes - senadores, ministros, deputados - possuíam voz e direito de ação. Anos depois, no desamparo que alguns acreditavam dever ser deixado o Liceu, atitude que coexistia com o desamparo do público carioca, pareceu ao arquiteto que a única maneira de mudar a situação a que se dirigia aquela instituição seria uma candidatura audaz à deputação provincial.

No insucesso dessa candidatura (pois a posse do cargo não dependia exclusivamente de voto de direto, mas de uma segunda escolha, indireta, tomada por meio de lista), a segunda opção possível tornava-se uma aspiração um pouco menor, mas ainda válida: a vereação. Com o derribamento inicial também dessa opção, e a certeza do malogro da sua instituição, sobrou a Bethencourt apenas a crença, já manifestada abertamente desde 1863, que em um país como o Brasil, era impossível seguir em frente com quaisquer planos para as artes ${ }^{173}$.

172 Para uma discussão inicial, mas bastante profícua, sobre a política pessoal do imperador entre o final dos anos 1850 e 1860, ver HOLANDA, Sérgio Buarque de. "Por graças de Deus...". in HOLANDA, Sérgio Buarque de. Capítulos de história do Império. São Paulo: Companhia das Letras, 2010.

173 Alguns trechos dos discursos de Bethencourt de 1863 sugerem bem a maneira negativa com a qual percebia o futuro das artes no Brasil naquele momento, e especialmente o futuro das instituições que criara na década de 1850 . Em janeiro daquele ano, fez um discurso no qual se podiae ouvir excertos como esses:

"No lamaçal de reverências diplomáticas, de cortezanias de respeito e de lisonja, como até aqui havemos feito àquele que nos vem injuriar e menosprezar no nosso país, não é que a poesia e a arte há de achar os elementos criadores das glorificantes e imponentes obras do espírito. [...] Quisera a Sociedade Propagadora das Belas Artes do Rio de Janeiro enviar-vos hoje, com as mais ardentes felicitações de regozijo e profunda estima, uma coroa de louros que simbolizasse o prêmio de vossas fadigas e esforços. Não pode, porém, dar ânimos, glórias, quem de ânimos e glórias necessita. Sucumbindo ao peso das nevascas da indiferência pública, ao abandono de muitos, ao esquecimento de todos, pode apenas dizer, como alguns gregos o disseram ao Visconde de Chateaubriand, vendo-o passar em buscar da pátria da poesia e da arte - boa viagem! O ceticismo lavra em todas as classes como um verbo de morte! Somos um povo estranho, que a posteridade não poderá classificar na história do universo. [...]O que há pois a esperar? A onda negra do extermínio cresce de dia em dia; o oceano rola em caixões de espuma que ameaçam submergir os argonautos do progresso, e não haverá força que lhe resista!” BETHENCOURT DA SILVA, Francisco Joaquim. Discurso por parte da Sociedade Propagadora das Belas Artes. Revista Mensal da Sociedade de Ensaios Literários. Rio de Janeiro, 1863, volume 1, pp.99-100.

Um último discurso do ano, esse no Congresso Juvenil Artístico, em setembro de 1863, Bethencourt centrava sua fala ainda em tema similar, "demonstrando o estado e decadência das artes em nosso país e a maneira por que são considerados os artistas brasileiros". Ver: "Congresso Juvenil Artístico". Correio Mercantil. Rio de Janeiro, 11 de setembro de 1863. p.3

Dois anos depois, em 1865, ainda com o Liceu fechado, as conclusões de Bethencourt em seus discursos não pareciam ter mudado muito:

“Astros sem Zênite; o egoísmo de um, a soberba de outros, a indiferença de todos, como as nuvens da tormenta aos etéreos orbes que cobrem do universo o vasto corpo, cegam-lhes o magestoso clarão do gênio com que deviam abrilhantar o mundo. [...]Nas vigílias laboriosas do espírito, o talento do artista e do poeta, abrindo as asas, desprendendo os vôos em que se eleva às regiões da divindade, procurando o sol da eterna luz, - verdadeiro Ícaro da 
O pessimismo e esquecimento público com os quais percebeu suas instituições em 1863, rapidamente estendidos para 1864, contrastariam com o gritante otimismo e, talvez, com a soberba do jovem Américo, que chegava, portanto, precisamente nesse ano à corte, repleto de confiança, projetos e ostentando não o sufixo de artista, o qual foi atribuído a Bethencourt em suas campanhas, mas o insistente (e logo descoberto pedante) prefixo de bacharel.

Para exacerbar o contraste iniciado, o jovem ainda reafirmaria a sua amizade com o “indesejado" Ferro Cardoso e confirmaria sua adesão a instituições e agentes políticos "conservadoes" que Bethencourt acabava de se afastar, como aqueles ligados à Sociedade Auxiliadora da Indústria Nacional.

Poucos dias depois da divulgação do resultado da eleição para vereadoes, quando a "derrota" dos planos políticos do arquiteto e dos seus vários colaboradores parecia aparente, e quando o futuro do Liceu e da Sociedade Propagadora das Belas Artes parecia incerto, o anúncio da chegada de Américo, "prometido" à cadeira de desenho figurado e até então bem-quisto pelo imperador, havia sido precedido da publicação das suas Considerações Filosóficas.

Se, nesse texto, como visto, o jovem fazia vista grossa a qualquer tentativa de mudança em prol dos artistas e artesãos no Brasil que tivesse sido desenvolvida desde a saída de Porto Alegre da AIBA, reclamando de seus estados "semiletárgicos" e ignorando, assim, todo o esforço que uma classe inteira havia empreendido por quase dez anos - cujo líder era ninguém menos do que Bethencourt -, em poucos meses o mesmo jovem conseguiria ainda desferir a investida terminante contra o orgulho do arquiteto e o dos seus aliados, quando publicava seu Cartas de um Plebeu. Colocando-se como exemplo vivo das amarguras que passavam os artistas brasileiros (embora tivesse passado os últimos 5 anos na Europa) e apresentando-se ainda como herdeiro direto, na AIBA (já que tinha certeza que o cargo de professor seria seu), das investidas da reforma de 1855, ele ignorava novamente, como foi também discutido, quaisquer esforços empreendidos dentro da instituição desde a saída de Porto Alegre, ou mesmo fora dela. E mais, ignorava que havia sido Bethencourt o agente tomado por d. Pedro II como o responsável por aquela continuação reformista: ele que colhia, exatamente naquele momento, apenas folhas secas dos seus investimentos.

fábulo, - os hinos da sua ascenção pomposa são o epidécio do seu aniquilamento. Pujanças da humanidade.... triunfos de um dia.... apenas nascidos morrem, na pocema infesta de um século avarento, que se encharca no lodo de um egoísmo iníquo, alheio a tudo que fala da poesia e da arte.[...] Ai!.... outro devia ser a tua sorte, oh! arte, neste vergel de sol, de luz, de flores.” BETHENCOURT DA SILVA, Francisco Joaquim. Discurso por parte da Sociedade Propagadora das Belas Artes. Revista Mensal da Sociedade de Ensaios Literários. Rio de julho, 1865, ano 3, volume 1, p.22. 
O agravante, ainda mais desconfortável por sinal, deve ter sido a sugestão de destinatário que Américo imprimia às suas Cartas. Não era o público em geral, mas os "Sr. Deputados" a quem o artista tentaria convencer de suas boas intenções e capacidades de líder para o "progresso" da indústria e das artes no Brasil; plano que seria levado à frente por meio de uma "revolução" na instrução pública, e para a qual ele já possuía, portanto, um projeto.

Suas propostas, sobrepujadas pela ignorância consciente que lhe permitiu esquecer de outros projetos para as artes nacionais, deve ter soado provavelmente como uma bomba aos ouvidos do arquiteto recém-aspirante a deputado e a vereador, que ainda há pouco observara a discussão sobre a validade do seu Liceu ${ }^{174}$ tramitar pela mesma Câmara de Deputados que Américo tentava alcançar com seus textos.

Uma justificativa para tal ação indecorosa de Américo estaria na sua petulância, e na do seu amigo, ao julgarem, em seus retornos da Europa, que "tudo tinham aprendido para transformar a instrução pública no Brasil”; era isso o que protestava Bethencourt naquele primeiro e único texto da série que dedicaria a Américo. ${ }^{175}$ Outra resposta, contígua à primeira, estaria ainda na sua citada soberba, que o autorizaria a propagar "enfim por esta capital ser grande poeta (pateta!), Literato (estonteado!), podendo já rivalizar com o mais ilustre mestre (?), como orador e que a tribuna lhe pertencia par droit de conquéte ${ }^{, 176}$.

Antes de entrar na instituição que deveria acolhê-lo, Américo tornava-se, assim, rival declarado de pelo menos um de seus membros (e não há dúvidas de que pode ter sido mais de um), colocando-se em páreo para a disputa dos mesmos objetivos do arquiteto, munindo-se, todavia, de outras ferramentas e outros aliados.

Não seria absurdo supor que durante a sessão da Congregação da Academia que decidiu o vencedor do concurso para professor de desenho figurado, em meados de 1865, Bethencourt fosse o único, dos 10 membros presentes, a votar contra o candidato escondido pela pomposa epígrafe "Um pintor sábio na teoria da sua arte pode sem muita dificuldade tornar-se universal". Mesmo ocultos os nomes dos participantes do processo seletivo, aquela era uma inscrição que de pronto sugeria ser mais afeita aos desejos grandiosos, já declarados, de Américo, do que aos do seu principal rival e

174 O Liceu era uma instituição de inclinação filantrópica, de ensino gratuito. Salvo alguns poucos períodos (mais tardios) nenhum professor recebia pelas aulas oferecidas, havendo, por esse motivo, um grande contingente de voluntários no corpo docente da instituição.

175 GUISANDO, Renato de [Pseudônimo de F. J. Bethencourt da Silva]. "Os imagináveis bacharéis sem diploma". Publicações a Pedido. Jornal do Commércio. Rio de Janeiro, 8 de fevereiro de 1866, P.2.

176 Ibidem. 
bastante conhecido da academia, Le Chevrel, que traria a pequena e cômica epígrafe "to be or not to be"; ou ainda do que ao rival mais fraco, e modesto, Francisco Antônio Nery, subscrito "abril" 177.

De todo modo, ainda que vencesse no concurso uma batalha que ninguém julgaria mesmo que tivesse adversários à altura, Américo já havia preparado o terreno para outra batalha, a ser travada no mesmo lugar em que ingressava profissionalmente, e contra aqueles que poderiam ter sido os seus potenciais aliados. A disputa viria, contudo, com um general de peso e um séquito leal, que efetuariam seu primeiro ataque, portanto, em pouco tempo.

\section{Questão de bacharel ou questão de classe?}

Tornando-se à "questão de bacharéis", se ela se deixaria conculir como uma retaliação de Bethencourt a Américo e a Ferro, em resposta à invasão que esses faziam aos planos pessoais do fundador do Liceu, logo, no entanto, ela desvelava cicatrizes ainda mais profundas, marcadas não apenas nos dois jovens, mas no próprio arquiteto, e todas oriundas do lugar social do qual gozavam as artes no Brasil.

Os motivos pelos quais se fez frente inicial contra dois amigos, supostamente aquecidos pela dúvida sobre o direito de que possuíam intitularem-se bacharéis, caíram também como véus frágeis diante dos reais objetivos da contenda. Dúvidas, não as havia, pois o "fato" conhecido desde antes da polêmica era, como visto, que Américo e Ferro não eram bacharéis, e não poderiam ostentar qualquer título dessa estirpe. Carregavam, no máximo, "documentos comprobatórios", os quais nada eram em termos instituicionais ou sociais.

A intenção base da "questão" era de outra sorte, e isso é importante: interessava deixá-los despidos de todos e quaisquer ornatos de que não eram senhores, para, assim, revelar suas verdadeiras condições: sem orgulho, sem diplomas, sem soberba de suas formações científicas, restariam em suas condições de "meros" artistas.

177 As provas eram inscritas sem o nome do autor, mas apenas com uma epígrafe que escolhiam para sua futura identificação, quando se comparariam as provas com papéis que, neles sim, estava o nome e a epígrafe escolhida por cada candidato

Estavam presentes na sessão de escolha do vencedor: o diretor Thomas Gomes dos Santos, e os professores Luiz Carlos da Fonseca, Ernesto G. M. Maia, José da Silva Santos, Francisco Maria Chaves Pinheiro, Bethencourt da Silva, Agostinho José da Motta, Victor Meirelles, Antônio de Pádua e Castro, e Domingos [de Araújo de Silva?]. Faltaria com justificativa Jacinto Rabello. Ausente, Rabello foi computado voto em branco. Nove votos foram direcionados a favor do detentor da epígrafe "Um pintor sábio na teoria da sua arte..", que depois foi revelado, sem muita surpresa, Américo. Um, para Le Chevrel, detentor da epígrafe "to be or not to be". A epígrafe "abril', de Francisco Antonio Nery (reprovado do concurso) era provavelmente um trocadilho, posto que a data do concurso, divulgada em abril, era $1^{\circ}$ de maio. ATAS DAS SESSÕES DA CONGREGAÇÃO E DO DIRETOR DA ACADEMIA IMPERIAL DE BELAS ARTES. Rio de Janeiro: Museu d. João VI/ EBA-UFRJ, Sessão em 09 de agosto de 1865. 
Os jovens, em suas ações, também exibiram e, mais, reforçaram suas cicatrizes. Não cederam publicamente em nenhum momento quanto às dúvidas sobre suas formações paralelas. Quando se viram quase em flagrante, expostos nas cartas em que se pedia que um título fosse comprado, afirmaram serem as correspondências falsas; e reforçaram suas indignações, garantindo que abririam processo judicial contra seus acusadores ${ }^{178}$ (algo que, evidentemente, não o fizeram).

De um lado ou de outro da "questão", o que se quis foi mantê-la sobretudo no nível de protesto ou de defesa dos fins (in)devidos do uso dos títulos. Dificil interessou investigar os meios que teriam conduzido os jovens a se apresentarem como bacharéis. E ainda que esses meios fossem, ao menos para os artistas brasileiros, especialmente os que trabalhavam na corte, bastante conhecidos, devem ter sido eles os aspectos a serem explorados para uma justificativa a respeito de alguns atos de Américo e Ferro.

O papel de um "advogado do diabo", seria, dessa maneira, não o de justificar os fins devidos ou indevidos da ostentação dos diplomas, mas o de proceder justamente em direção àqueles meios, levantando uma ou duas perguntas que realmente parecem importar em um estudo histórico para quem se observe a "questão de bacharéis" com menor acometimento de paixões, isto é, sem julgar antecipadamente a moralidade dos atos cometidos pelos dois jovens.

Se assim se procede, os seguintes questionamentos parecem legítimos: se os dois jovens não eram bacharéis, por que reiteravam insistentemente um título de que não dispunham? E, sobretudo, por que o faziam se incorriam em um crime previsto no código penal?

Dificilmente (pessoalmente acredito nisso) se trata de falta de caráter ou brio de Américo e Ferro Cardoso, como seus críticos e especialmente Bethencourt da Silva, com os motivos, tentaram fazer parecer. Antes disso, o direito de usar aquela "insígnia social" deve ser pois compreendida apenas como a ponta de uma banquisa bem mais profunda, cujas bases ultrapassavam e muito os conflitos gerados pelos participantes da "questão", embora esta seja, sem dúvida alguma, uma amostra frutífera de alguns problemas enfrentandos por artistas no Brasil.

O primeiro argumento em favor dos rapazes pode ser colocado da seguinte maneira: a despeito do uso que fizeram para si do título de "bacharel", em nenhum momento eles haviam questionado a sua verdadeira profissão: eles eram artistas e - especialmente Américo - retornavam ao Brasil repletos de ambição e projetos sinceros para as artes nacionais. Para eles, a verdadeira

178 AMÉRICO, Pedro; FERRO CARDOSO, Daniel Pedro. “Ao público”. Publicações a Pedido. Jornal do Commércio. Rio de Janeiro, 20 de fevereiro de 1866, p.2. 
"questão" da "questão de bacharéis" estava no fato de não anelarem serem chamados apenas de "artistas", uma vez que estava claro haver algo de insuficiente nessa designação.

O segundo argumento a favor está num dado bem conhecido no Brasil, já no século XIX: o de que o bacharelismo era um fardo ${ }^{179}$. Fardo tanto mais pesado e indigesto para aqueles que não o detinham, ou que não mantinham um título socialmente equivalente, como era, particularmente, o caso dos artistas mais destacados da AIBA.

Os cargos públicos, as câmaras de deputados e o Senado eram ocupados sobretudo por bacharéis $^{180}$, e a impressão que poderiam fornecer era a de que esse diploma seria quase um condicionante para a entrada em qualquer cargo de alta consideração social, assemelhando-se a alguns cargos criados no império desde a década de 1830, os quais, esses sim, podiam ser ocupados somente por bacharéis formados, mormente em direito ${ }^{181}$.

Era esse bem conhecido aspecto do Brasil que o jovem Angelo Agostini, emigrado há pouco da Itália, ironizava, em fins de 1864, em uma das primeiras edições da sua revista Diabo Coxo. Nela, uma charge apresentava duas balizas de comparação da vida de um bacharel, e as respectivas aspirações dos indivíduos que nelas se enquadram (fig.7.1): o calouro preguiçoso, que sonha com uma presidência, e o recém-formado, que se "contenta", não sem um pouco de petulância e com igual preguiça, com um cargo de promotor. Agostini fornecia a dimensão de quão distantes e confortáveis as situações dessa classe se configurariam para outras menos abastadas, e em especial o exemplo imaginário do mais jovem que, de terno, vislumbra seu destino não por meio do trabalho, mas enquanto goza o prazer de um cigarro, fumando-o sentado, e calçando apenas uma aconchegada chinela.

179 Dialogo aqui com o título homônimo de um pequeno artigo do Luiz Felipe de Alencastro, publicado na revista Novos Estudos CEBRAP: ALENCASTRO, L. Felipe. "O fardo dos bacharéis". Novos Estudos CEBRAP (São Paulo), n.19, p.68-72.

180 Sobre a ocupação de bacharéis em cargos públicos e na política, desde a Independência, ver: ALMEIDA FILHO, José Carlos de Araújo. O Ensino Jurídico, a elite dos bacharéis e a maçonaria do século XIX. (Dissertação de Mestrado). Rio de Janeiro: Universidade Gama Filho, 2005; especialmente o Capítulo Terceiro "Fomentar a política dos bacharéis para manter o poder".pp.31-74.

Ver também: SIMÕES, Teotônio. Os Bacharéis na política - A política dos Bacharéis. (Tese de doutorado). São Paulo: Universidade de São Paulo/Departamento Ciências Sociais, 1983.

Torna-se também significativa a seguinte passagem escrita por Sérgio Buarque de Holanda: "Na monarquia eram ainda os fazendeiros escravocratas e eram os filhos de fazendeiros, educados nas profissões liberais, quem monopoliza a política, elegendo-se ou fazendo eleger seus candidatos, dominando os parlamentos, os ministérios, em geral todas as posições de mando, e fundando a estabilidade das instituições nesse incontestado domínio." HOLANDA, Sergio Buarque de. Raízes do Brasil. 26.ed. São Paulo: Cia. das Letras, 1995. P.73.

181 Era o caso, por exemplo, dos cargos de Juízes de Direito e os Juízes Municipais, que, a partir da promulgação do Código do Processo Criminal de Primeira Instância, poderiam ser preenchidos apenas por bacharéis, nomeados diretamente pelo imperador. A única exceção aos Juízes Municipais surgia quando, na falta de bacharel, poder-se-ia empossar temporareamente advogados não graduados, contudo com notório conhecimento na prática forense. Cf. RODYCZ, Wilson Carlos. O Juiz de Paz Imperial: uma experiência de magistratura leiga e eletiva no Brasil. Op.cit.s/p. 
Quando Ferro, posto que já se rotulasse bacharel, requeria naquela suposta carta a Américo, de abril de 1862, que lhe comprassem um diploma, pois nele "consistia sua felicidade", era a essa prometida oportunidade de ingresso em empregos mais prestigiados e à possibilidade de aproximação com interlocutores mais poderosos que fazia alusão.

A mesma crença no título de bacharel, também bastante explícita, pairava, como visto, em Américo, e era manifestada - além das suas insistentes assinaturas com aquela insígnia - em algumas cartas enviadas a seu antigo professor, o naturalista Jacques Brunet, e ao próprio d. Pedro II. Mais de uma vez o jovem concluiu que, no Brasil, sem uma formação científica, isto é, sem um diploma de bacharel, nada podia fazer em prol das artes, porquanto, apenas como artista, nunca poderia adquirir poder político suficiente. Com efeito, as artes estariam condenadas a um campo social específico, indesejado, que poderia ser modificado somente se um agente político verdadeiramente poderoso pudesse realizar ações efetivas. E era essa a ambição precoce de Américo, defendida ao longa esta Tese: tornar-se, ele, esse agente.

\section{A "questão de bacharéis" como um sintoma do problema social das artes no Brasil}

O problema social das artes no país não era novo, e as marcas de sua classe eram herdadas de outros tempos. O lugar incômodo que ocupavam na representação social brasileira era uma recorrência, e, com efeito, difícil era deixar de encontrar um discurso ou texto que tomasse as artes como tema principal durante o século XIX, sem que ora vislumbrasse um seu porvir - esse que um dia mudaria para melhor a condição dos artistas no país -, ou sem que ora tomasse o seu desenvolvimento como uma impossibilidade numa nação "positivista", governada por agentes interessados apenas no plano abstrato das ideias, e que observariam nos problemas de execução material e de estética elementos de segundo ou terceiro escalão.

Era desse ponto, portanto, que o embate rotulado de "questão de bacharéis" começava. Para Américo e Ferro, o respeito almejado passaria primeiro por um caminho que lhes parecia irrefutável, ainda que quisessem, por fim, ser exaltados como "artistas dignos". O modo que encontraram foi tornarem-se ou afirmarem-se, eles próprios, precedidos da famigerada insígnia de bacharel, tão famigerada quanto outras, e tão representativas para as relações pessoais, sociais e econômicas que se firmavam no Brasil imperial ${ }^{182}$. Como outros nas suas, Américo e Ferro

\footnotetext{
${ }^{182}$ A voracidade por essas insígnias não era, portanto, direito exclusivo deles, de modo que muitos, em todos os setores da sociedade, lhes fizeram uso similar. Fê-lo d. Pedro II, que as conferiu aos montes com o evidente intuito de obter aliados, espalhando todos os anos dignatários, cavaleiros, oficiais e comendadores da ordem de Cristo ou da Rosa, além de viscondes, marqueses e barões; fizeram-no os inúmeros indivíduos que as aceitavam de bom grado (pois era
} 
encontraram na insígnia bacharelesca a ferramenta que lhes parecia propriciar, a princípio, condições intelectuais e, sobretudo, respeito social para tornar seus projetos e ambições respeitáveis. Não contaram que fossem descobertos e, com isso, que fossem novamente conduzidos à inconveniente condição de sua "classe".

Um dos críticos - aquele único que manifestou-se publicamente contra a prisão dos jovens havia logo percebido a origem da controvérsia. A ostentação de um título falso era um problema social ou, como afirmou, era uma "pequena miséria social" ${ }^{183}$, cuja punição deveria ser de mesmo quilate: "a do ridículo" 184 .

Dificilmente Américo e Ferro consideraram como uma "pequena miséria social" a possibilidade de manter de um título, a julgar por todo esforço que fizeram para defendê-lo publicamente. O bacharelado era de fato um "fardo" para os artistas; porém, em outros domínios, bem ou mal significava uma distinção socialmente válida num país ainda composto sobretudo por analfabetos: grupo onde se incluía a maioria dos escravos, mas também muitos homens livres, e entre eles, significativamente, vários artistas e artesãos.

O bacharelado erigia uma barreira, que não era necessariamente uma barreira intelectual, mas uma justamente social. No país, ele parecia ser mais o atestado de um capital social do que um intelectual. Não se trataria de ser mais ou menos inteligente, mais ou menos capaz (foi o que se contestou a Américo, em resposta à sua afirmação de deter conhecimento em diversas ciências), mas de possuir um diploma válido, expedido por instituição respeitada ${ }^{185}$. O ingresso numa "instituição respeitada" era para poucos abastados, e isso, sim, separaria o trigo do joio; separaria aqueles que gozariam de altas oportunidades políticas e prestígio social daqueles que ficariam nos últimos degraus da cadeia social.

possível recusar) ou as compravam, ostentando-as para benefício próprio; fizeram-no ainda as instituições comerciais tornadas "imperiais", cujos brasões do império convertiam-se em tatuagem em seus cartões e propagandas.

183 Diga-se de passagem o conhecimento de Américo sobre esse problema apontado pelo crítico, isto é, o da importância dada não apenas à auto-apresentação precedida de um título, se se o dispunha, mas o do cuidado necessário para não se deixar de lembrar os títulos de um outrem quando se dirigia a ele. É desse modo, por exemplo, que em uma das várias cartas que o jovem mandava a Jacques Brunet, afirmava não poder escrever para o Conselheiro Catonhé pois não sabia, naquele momento, os títulos pelos quais chamar o político em uma correspondência: "Disseram-me que o Conselheiro Catonhé era Presidente da Bahia. Não sei se isso é verdade, o que me priva de escrever todos os seus títulos no subscrito, segundo o costume do Brasil." MELO, Pedro Américo de Figueiredo e. Carta de Paris a Louis Jacque Brunet em 24 de novembro de 1863. FUNDAÇÃO VINGT-UN ROSADO. Cartas de Pedro Américo de Figueiredo e Melo e Daniel Eduardo de Figueiredo e Melo a Louis Jacques Brunet. Mossoró: Coleção Mossoroense, junho de 2001. $\mathrm{s} / \mathrm{p}$.

184 FERRUGEM, Ferro sem. "Bacharéis". Publicações a Pedido. Jornal do Commércio. Rio de Janeiro, 01 de fevereiro de 1866, P.2.

185 TÍTULO, Um que tem. "Questão de bacharéis”. Publicações a Pedido. Jornal do Commércio. Rio de Janeiro, 18 de janeiro DE 1866. P.2. 
A maioria dos artistas no Brasil não poderia ser "bacharel"186 - no sentido que a palavra assumia no período - não por que não possuíam diplomas, nem por que os seus eram confeccionados em papel, e os dos outros, em pele de carneiro, mas por que suas funções não colhiam, com ou sem certificação de notório saber da sua instituição, o mesmo prestígio social das de demais agentes ${ }^{187}$. Como profissionais liberais e, além disso, como sujeitos livres, conforme outrossim eram todos os bacharéis, eles poderiam até gozar das prescrições de "liberdade" garantidas desde a conjuração da Constituição de 1824. Contudo, quando se trataria de equidade social eram atingidos pelo ricochete de uma condição social antiga, ainda propalada na mesma Carta. A Constituição brasileira, embora previsse o direito à "liberdade" - compreendido como o direito de livre exploração da propriedade particular, sendo a primeira delas a força de trabalho própria -, pressupunha, já em fundamento, a exclusão do direito de "igualdade" universal. Era, pois, com esta preceptiva que, no Brasil, se garantiriam concomitantes a manutenção $e$ a justificação do trabalho escravo (uma propriedade adquirada por uma elite desde os tempos coloniais, que não aceitaria perdê-la gratuitamente), renovando-o, no império, como propulsor das suas principais fontes econômicas ${ }^{188}$. Perpetravam-se, assim, algumas condições culturais (que, conforme visto, nas décadas de 1850 e 1860 se combinaram com os preconceitos estabelecidos das teorias raciais), entre as quais o ordinário preconceito que delimitava, desde muito, o trabalho manual ao elemento servil e o puramente intelectual aos filhos da elite brasileira.

Aí residia a infeliz maldição da qual eram investidos os artistas brasileiros mais destacados, amiúde concentrados em torno da AIBA. Herdeiros de uma "liberdade" sem "igualdade", estavam sabidamente presos entre as exigências de uma alta instrução, como a dos bacharéis, e a consideração social limitada dos demais artistas e artesãos. Em outras palavras, tinham seus corpos

186 Afirma-se aqui que a "maioria dos artistas não poderia ser bacharel", no sentido socialmente conferido a esse título (e não especificamente institucional) porque, como bem se sabe, alguns poucos artistas destacados de fato conseguiram alcançar uma expressiva consideração social no Brasil, incluindo a atuação em postos burocráticos e políticos bastante expressivos. Talvez o maior exemplo seja mesmo o de Porto Alegre, que além do prestígio que gozou dentro de instituições como o IHGB e da direção a ela dada da AIBA, ocupou, por muitos anos, o cargo de consul brasileiro em Portugal.

187 É significativa a passagem na qual Américo, em suas Cartas de um Plebeu, aborda a questão sobre os diplomas expedidos pela academia e sobre a falta de respeito que a sua profissão teria no cenário público carioca: "O atraso em que entre nós se acham as belas artes é devido a causas muito complexas. A primeira é a falta de um futuro pelo qual nossa mocidade possa sacrificar voluntariamente o presente aos estudos artísticos, ante outras carreiras que pela importância de que gozam, atraem toda a atenção dos pais de família; de onde resulta que apenas uma pequena fração daqueles cuja vocação energicamente os impele ao culto das Musas a ele se dedicam, e, ainda quando assim, muitas vezes contra a vontade dos próprios parentes, que, de ordinário mais experientes e conhecedores do espírito da nação, consideram como um dever o desviarem-os de uma vereda tão espinhosas como ilusória e vã.". Um pouco depois dessa passagem, Américo acrescenta: "Que importa ao público que haja na corte uma academia de belas artes, quando os artistas que dela saem com seus diplomas não são reconhecidos pelo governo?". AMÉRICO, Pedro. Cartas de um plebeu. Segunda Carta. Rio de Janeiro, Correio Mercantil, 21 de maio 1865.

188 Para uma apreciação dessa questão, ver ADORNO, Sérgio. Os aprendizes do poder. Rio de Janeiro: Paz e Terra, 1988. 
de trabalho constituídos, de um lado, por "ideias elevadas" e, de outro, pela técnica manual, tão desprezada na constituição dos valores sociais brasileiros durante a colônia e o império ${ }^{189}$.

O ponto central da "questão de bacharéis", na qual se meteram Américo e Ferro, mostrava-se mesmo, afinal, um problema de classe, já que explicitava os desejos dos jovens de incrementarem positivamente o valor de suas posições sociais com os supostos diplomas, ao mesmo passo que, refutando-se-lhes esse acréscimo, se insistia na condição permanente e negativa de suas categorias profissionals.

Foi esse o movito pelo qual, no confronto da "classe artística" com as demais "classes" naquela "questão", foi lembrado a Américo que sem o título de bacharel ele não passaria do "pintor Pedro Américo"190. Também nela, Ferro Cardoso seria lembrado de sua situação "inferior" de artista, e de maneira ainda mais agressiva, que dispensa maiores comentários:

189 O problema do bacharelismo no Brasil, incluindo-se um problema adendo que as artes, enquanto profissão também liberal, experienciam, é sumária, mas claramente exposto por Sérgio Buarque de Holanda, no seguinte excerto:

"Com o declínio da velha lavoura e a quase concomitante ascenção dos centros urbanos, precipitada grandemente pela vinda, em 1808, da Corte portuguesa e depois pela Independência, os senhorios rurais principiam a perder muito de sua posição privilegiada singular. Outras ocupações reclamam agora igual eminência, ocupações nitidamente citadinas, como a atividade política, a burocracia, as profissões liberais.

É bem compreensível que semelhantes ocupações venham a caber, em primeiro lugar, à gente principal do país, toda ela constituída de lavradores e donos de engenho. E que, transportada de súbito para as cidades, essa gente carregue consigo a mentalidade, os preconceitos e, tanto quanto possível, o teor da vida que tinham sido atributos específicos de sua primitiva condição.

Não parece absurdo relacionar a tal circunstância um traço constante em nossa vida social: a posição suprema que nela detêm, de ordinário, certas qualidades de imaginação e 'inteligência', em prejuízo das manifestações de espírito prático ou positivo. O prestígio universal do 'talento', com o timbre particular que recebe essa palavra nas regiões, sobretudo onde deixou vinco mais forte a lavoura colonial e escravocrata, como o são eminentemente as do Nordeste do Brasil, provém sem dúvida do maior decoro que parece conferir a qualquer indivíduo o simples exercício da inteligência, em contraste com as atividades que requerem algum esforço físico.

O trabalho mental, que não suja as mãos e não fatiga o corpo, pode constituir, com efeito, ocupação em todos os sentidos digna de antigos senhores de escravos e seus herdeiros. [...] É que para bem corresponder ao papel que, mesmo sem o saber, lhe conferimos, a inteligência há de ser ornamento e prenda, não instrumento de conhecimento e ação.

Numa sociedade como a nossa, em que certas virtudes senhoriais ainda merecem largo crédito, as qualidades do espírito substituem, não raro, os títulos honoríficos, e alguns dos seus distintivos materiais, como o anel de grau e a carta de bacharel, podem equivaler a autênticos brasões de nobreza. Aliás, o exercício dessas qualidades que ocupam a inteligência sem ocupar os braços tinha sido expressamente considerado, já em outras épocas, como pertinente aos homens nobres e livres, de onde, segundo parece, o nome de liberais dado a deternimadas artes, e, oposição às mecânicas, que pertencem ás classes servis.” HOLANDA, Sérgio Buarque de. Op. Cit. P.83;

A mesma concepção Holanda desenvolve neste fragmento: "Apenas, no Brasil, se fatores de ordem econômica e social - comuns a todos os países americanos - devem ter contribuído largamente para o prestígio das profissiões liberais, convém não esquecer que o mesmo prestígio já as cercava tradicionalmente na mãe-pátria. Em quase todas as épocas da história portuguesa uma carta de bacharel valeu quase tanto como uma carta de recomendação nas pretensões a altos cargos públicos. [..] no vício do bacharelismo ostenta-se também nossa tendência para exaltar acima de tudo a personalidade individual como valor próprio, superior às contingências. A dignidade e importância que confere o título de doutor permitem ao indivíduo atravessar a existência com discreta compostura e, em alguns casos, podem libertá-lo da necessidade de uma caça incessante aos bens materiais, que subjuga e humilha a personalidade.”. Ibidem. P.157.

190 CESÁR; FERNANDES, João. "Questão de ser bacharel. "Publicações a Pedido. Jornal do Commércio. Rio de Janeiro, 17 DE janeiro 1866. 
O Sr. Ferro Cardoso diz a quem ainda lhe dá trela, que não mostra o seu atestado de ter ouvido lições no conservatório de artes e matérias, e que ele chama de diploma de bacharel! porque não desce até os articulistas que lhe estão arrancando as pena do pavão com que se enfeitava!!![..] Diga-me, Sr. Ferro, quem está no último degrau da escala social, porventura tem que descer?! Descer para onde? ${ }^{191}$

Um pouco antes da "questão de bacharéis", o mesmo Bethencourt da Silva, que entre vários outros a incitava, deve ter sentido de igual modo o problema do descrédito das artes quando era ele o alvo de uma questão. Observara, de um lado, o fechamento da instituição filantrópica que dirigiu com afinco por anos - fechamento que, segundo concluiu, se devia à falta de apoio da sociedade carioca e de subvenção estatal efetiva - e recebera, de outro, represálias por desejar assumir um cargo político para representar uma "classe" socialmente descreditada, segundo retrucaram alguns dos seus aliados:

Se ele fosse um mau filho, mau irmão, mau amigo, velhaco, tratante, desordeiro, especulador e aventureiro, isso sim era digno de ser eleito e de muito mais; mas, sendo artista honesto, isso nunca!

Era o que faltava; um artista na câmara municipal; um homem que entende de obras, que pode prestar serviços à nossa cidade e que ama as artes e os artistas!! ${ }^{192}$

Ambos os episódios (esse, de Bethencourt, aquele, dos jovens) encerravam disputas políticas e, novamente, disputas entre "classes". Neles, este termo é de fato repetidamente estampado por ses próprios participantes. O emprego desse substantivo excedia, porém, as reivindicações de uma melhor representação social da "classe artística" frente às demais classes dos bacharéisengenheiros, bacharéis-advogados, bacharéis-médicos etc, na medida em que também era ativo em disputas que pululavam entre diferentes "classes artísticas" que se opunham no restrito campo de ação da corte.

É assim que, nesse segundo círculo de debates, um pouco mais limitado, surgia à vista o fato de que o problema social das artes parecia ser reforçado não apenas pela resistência de outras classes profissionais ao oferecimento de condições mais favoráveis aos artistas, mas, precisamente, pelo confronto existente entre os diversos projetos e agentes das artes, os quais, conscientes dos seus problemas, desejavam mudanças efetivas. Dificilmente se podia perceber um campo artístico

191 CUIQUE, Suum. "Bachareleida". Publicações a pedido. Correio Mercantil, Rio de Janeiro, 24 de janeiro de 1866, p.3.

192 O ARTISTA."Eleições”. Correio Mercantil. Rio de Janeiro, 25 de agosto de 1864. P.2. 
coeso no Rio de Janeiro, tampouco um politicamente unificado. Havia, ao contrário, uma colcha de retalhos, na qual cada pedaço, ao tocar outro imediato, antes de somar-se a uma causa comum, em diversos momentos a colocava em tectonismo.

\section{Choque individual entre artistas, propostas similares e estrategias distintas}

Nos últimos anos, alguns estudiosos intensificaram a observação de que os projetos artísticos de um Félix-Émile Taunay - diretor da AIBA entre a década de 1830 e o início da década de 1850 não eram, em propósito, muito diferentes dos de um Porto Alegre, enquanto diretor da mesma instituição, entre 1854 e 1857. O fundamento dos seus projetos repousava, em boa medida, sobre um mesmo plano propositivo: insuflar as artes nacionais de fôlego; dar a elas significação social num país ainda pouco afeito a seus "encantos", e, proporcionalmente, dar visibilidade e centralidade à Academia e a seus integrantes. Mesmo assim, Taunay e Porto Alegre foram (e continuam a ser) apreciados como inimigos pertinazes.

Continuam a ser assim percebidos, e com justeza, porque de fato confrontaram-se para que um ou outro fossem agentes centrais responsáveis pela execução das mudanças desejadas para "as" artes no Brasil ${ }^{193}$; e essa oposição não se deu em outro lugar senão no campo político ${ }^{194}$. Para tanto,

193 A bibliografia sobre o assunto é extensa, e as respostas para o conflito entre Taunay e Porto Alegre também não são uníssonas. A historiadora da arte Sonia Gomes Pereira, por exemplo, ainda que situe Porto Alegre e Taunay em relação aos seus "desejos quase similares em relação à Academia", inclinou suas conclusões a respeito do embate entre os dois profissionais ao campo estético: "Mais do que a luta pelo poder, diferenciação de geração ou divergência quanto aos métodos de ensino, a 'sincera e completa divergência' parece ser de ordem ideológica não só em relação à interpretação da nacionalidade, mas também nas concepções estéticas". PEREIRA, Sonia Gomes. "A Academia Imperial de Belas Artes no Rio de Janeiro: revisão historiográfica e estado da questão". In: Revista do Programa de PósGraduação em Artes Visuais EBA/UFRJ. Rio de Janeiro: EBA/UFRJ, 2001. p.74.

Alfredo Galvão mantinha suas conclusões em torno da disputa política entre Porto Alegre e Taunay e, em decorrência dela, em torno dos conflitos pessoais daquelas personalidades - conclusões às que, por minha vez, tendo a inclinar-me mais, posto que a existência de um embate estético inicial parece tornar-se ativo quando da definição de um campo de ação específico, político portanto, o qual foi assumido por aqueles artistas. GALVÃO, Alfredo. "Manuel de Araújo Porto-Alegre: sua influência na Academia Imperial das Belas Artes e no meio artístico do Rio de Janeiro". In: Revista do Patrimônio Histórico e Artístico Nacional, n.14, 1959, p.116.

Outros trabalhos que também efetuam comparações e apontam para divergências e similaridades entre as posturas de Taunay e Porto Alegre são os de: UZEDA, Helena Cunha de. O ensino de arquitetura no contexto da Academia Imperial de Belas Artes do Rio de Janeiro: 1816-1889. (Dissertação de Mestrado) Rio de Janeiro: EBA/UFRJ, 2000; e: FERNANDES, Cybele Vidal Neto. Os caminhos da arte: O ensino artístico na Academia Imperial das Belas Artes 1850/1890. (Tese de Doutorado). Rio de Janeiro: IFCS/UFRJ, 2001.

Nos últimos anos, as publicações da Dissertação de Mestrado sobre Porto Alegre, de Letícia Squeff, e da Tese de Doutorado sobre Taunay, de Elaine Dias, promoveram uma ampliação do campo de apreciação dessas personalidades, embora ainda se faça necessário um cotejamento mais detalhado entre as ideias de um e outro, apreciadas nesses trabalhos. Uma futura publicação dos vários textos que escreveram aqueles artistas, a exemplo da divulgação ultimamente feita de escritos de outros artistas brasileiros, o que inclui os de Pedro Américo, são ações que ajudariam, sem dúvida, para que se empreendesse maior aprofundamento em estudos comparados dessa natureza. Para os trabalhos das estudiosas citadas, ver: DIAS, Elaine. Paisagem e academia: Félix-Émile Taunay e o Brasil (1824-1851). Campinas: Unicamp, 2009; e: SQUEFF, Letícia. O Brasil nas letras de um pintor: Manuel de Araújo Porto Alegre (1806-1879). Campinas: Unicamp, 2004. 
cada um se aproximou de aliados considerados suficientemente influentes e, em determinados momentos, quando concentraram forças necessárias, ascenderam por um tempo ao trono almejado e lá permaneceram até que fossem preteridos por outros, ou que pedissem, eles próprios, suas resignações, em consequência do choque com outros agentes - entre os quais incluía-se, conforme citado d. Pedro II, nas interferências diretas que fazia na academia, sobretudo a partir da década de 1850.

A mesma tensão política que obstaria Porto Alegre a Félix-Émile Taunay, a despeito da similaridade dos seus projetos para as artes, reaparecia em Pedro Américo e Bethencourt da Silva, e em seus planos durante a década de 1860. É sintómático que essa polaridade pareça mesmo ser herdada, uma vez que Bethencourt, um dos discípulos prediletos do falecido Grandjean de Montigny, fora sempre visto com bons olhos por Taunay, desde a década de 1840, enquanto que Américo enveredara-se para o lado oposto da "força": o de Porto Alegre. Como os dois algozes anteriores, Américo e Bethencourt punham-se, assim, também a disputar um campo de atuação similar, dentro de uma mesma instituição, e guarnecidos de objetivos bastante parecidos. Ambos colocavam-se, segundo se sugeriu, num posto que parecia ser tomado como o da continuidade dos projetos últimos de Porto Alegre, interrompidos quando da sua saída da AIBA. Em certa medida, não há dúvidas de que ambos imaginavam-se herdeiros institucionais dos antigos diretores, ${ }^{195}$ além de ambos serem notadamente idealistas - ainda que Américo, nesses anos fosse um eclético, e Bethencourt, de outro modo, demonstrava mais suas dúvidas para com o hegelianismo.

Como Porto Alegre e, nesse ponto, também como Félix-Émile Taunay, os dois mais jovens acreditavam na possibilidade de uma guinada simbólica e social para as artes e artistas no país. Contudo, tomando o exemplo específico de Porto Alegre, desejaram retomar e resolver aquela velha polaridade já presente no projeto de 1816 de Le Breton (o da formação de uma dupla escola de artes), fomentando efetivamente não apenas as belas artes, mas também as artes gráficas e industriais: tema tão caro a vários outros países desde a realização da I Exposição Universal de Londres, em 1851.

194 Não deve-se esquecer que Porto Alegre ingressa como diretor da Academia logo após exercer o cargo de vereador do Rio de Janeiro, com o qual iniciaria suas reformas de ensino em escolas municipais da região.

195 É sugestivo que, em 1856, o próprio Porto Alegre, quando era ainda diretor da AIBA, tivesse visto com bons olhos a criação da Sociedade Propagadora das Belas Artes por Bethencourt da Silva, e o declarasse justamente no discurso de entrega dos prêmios aos alunos daquele ano letivo, entre eles, o próprio Pedro Américo. Sobre o assunto, o diretor diria: "A reforma acadêmica ainda não foi compreendida pelo seu lado utilitário, mas eu espero que o será em breve. A fundação que se acaba de fazer de uma sociedade para propagar o gosto das belas artes [a SPBA], justifica o pensamento da reforma, porque as bases de sua constituição são as mesmas dos nossos novos estatutos, e não poderiam ser outras, porque a experiência e a prática de todos os tempos assim o tem ensinado.". PORTO ALEGRE, Manuel Araújo. "Discurso do diretor da Academia das Belas Artes por ocasião da distribuição pública dos prêmios.". Correio Mercantil, Rio de Janeiro, ano XIII, 30 de novembro de 1856. P.1. 
Uma rápida comparação dos textos e discursos proferidos por Bethencourt e Américo, nas décadas de 1850 e 1860, os coloca num mesmo terreno argumentativo e, mais do que isso, propositivo. Para ambos ainda se mantinha forte a conclusão de que a desconsideração que desfrutavam as artes e os artistas no Brasil era resultado do descaso duplo do povo e do governo ${ }^{196}$. Este, especialmente, daria as condições para que se formassem artistas, mas não para que os empregassem, deixando-os como eternos coringas em sua própria pátria ${ }^{197}$. O problema

196 Sobre o descaso das artes no Brasil, podem ser destacados, à guisa de comparação, os seguintes trechos de textos de Américo e Bethencourt da Silva.

Américo: "Todos esses bem-intencionados exemplos de proteção individual [os exemplos da proteção que gozariam os artistas em alguns países europeus], de amor pelos que trabalham, e de homenagem ao talento permanecerão estéreis, porque são flechas muito delicadas lançadas de encontro a uma muralha de cetismo e de pequenos interesses [no Brasil]". MELLO, Pedro Américo de Figueiredo e. Considerações Filosóficas sobre as belas artes entre os antigos [publicado pela primeira vez em 1864]. Estudo introdutório, conformação textual e notas de Silvano Alves Bezerra da Silva. João Pessoa: Editora Universitária/UFPB, 2006. p.191.

Bethencourt da Silva: "Misserrimos artistas! Pigmaleões modernos, cativos do amor do belo, pedindo ao céu um raio daquele fogo sagrado que dá alento e vida, afogados num oceano de irremeável ceticismo, vendo cair-lhes, uma a uma, como lágrimas dos olhos, as desbotadas ilusões da glória, morrem sem ter sequer com que comprar o pedaço de terra em que devem repousar eternamente. BETHENCOURT DA SILVA, Francisco Joaquim. "Discurso por parte da Sociedade Propagadora das Belas Artes". Revista Mensal da Sociedade de Ensaios Literários. Rio de julho, 1865, ano 3, volume 1. p.23-24.

Bethencourt: "Infelizmente para as artes e para o país, tudo caminha pela rotina inepta, e nem um único passo se há dado em direção à estrada do verdadeiro progresso artístico, A NACIONALIZAÇão DA ARTE [...] Desgraçadamente, por um desleixo inqualificável, não se tem querido compreender o que há de útil, de grandioso e de civilizador nas artes, e tudo tem caminhado à mercê dos especuladores da arte, dos operários analfabetos bisonho nas regras mais comesinhas e insignificantes de edificar, a quem os proprietários incautos e inexperientes, sem a menor reflexão, entregam a fortuna, a saúde e a vida." BETHENCOURT DA SILVA. Ao Sr. ministro do Império. Correio Mercantil. Rio de Janeiro, 15 de dezembro de 1860. p.3.

197 Sobre o problema da contradição do Governo em relação às artes brasileiras, já visto ao menos com relação à Américo, no Capítulo anterior, alguns trechos comparativos são os seguintes:

Américo: Não havendo, porém, um futuro que lhes desperte o amor do trabalho e a vontade de vencerem as dificuldades técnicas do estudo, uns abandonam logo a casa do ensino, espalhando-se pelo povo, cheios de ignorância, e ostentando com vaidosa arrogância o nome de artista, que ninguém lhes disputa, por haverem muito poucos que o prezem; outros, os mais talentosos, confiantes antes na benevolência dos seus mestres do que no valor intrínseco dos seus primeiros ensaios, dispõem-se a continuar na academia das Belas Artes até esgotarem a lista das medalhas.[...] Entretanto possuem a certeza de que o seu mérito individual merece a devida atenção dos nossos estadistas, e essa consoladora ideia os leva até a porta do governo a quem se apresentam, não solicitando um favor, mas pedindo-lhe os meios que subsistirem pelo exercício de sua arte, do mesmo modo que se reclama uma indenização legal. $\mathrm{O}$ governo, porém, que não saber fazer da arte um auxiliar ao cumprimento de sua missão política, não os atende, e até pelo contrário procura convencê-los do próprio desdém pelas belas artes.[...] se quiserdes achar a confirmação deste pequeno sorites, procurai saber onde estão esses moços a quem os nossos diários qualificavam de gênios, futuros Rafaéis, etc., nos tempos dos seus primeiros ensaios artísticos, e o que fazem eles hoje, isto é, depois de haverem realizado parte daqueles pomposas predições. Achá-los-eis, uns desterrados, escrevendo poemas e revendo papéis sem relação alguma com o que aprenderam, por preferirem essa à vida do artista, onde não encontravam uma subsistência conforme com a dignidade do homem que segue uma carreira liberal; outros, esquecidos e como atrofiados no retiro, onde os colocou a necessidade de irem vivendo obscuramente para não sofrerem guerra; outros, enfim, extenuando-se em vãs reclamações, em infrutíferos esforços para verem se rompem com essas tradições caducas e rotineiras, que nos tornam insensíveis aos encantos do belo, e fazem o caráter dos povos madraços e egoístas.” MELO, Pedro Américo Figueiredo e. "Cartas de um Plebeu aos Srs. Deputados. Terceira Carta" . Correio Mercantil. Rio de Janeiro, 26 de maio de 1865.

Bethencourt: "Os indivíduos, que ali [na AIBA] tem ido perder seu tempo e sua mocidade no estudo de qualquer dos diversos ramos de belas artes, que a academia ensina, ali estão hoje, como se fossem ociosos, inutilizados para si, para suas famílias e concidadãos; porque, apesar do talento e das habilitações que possuem, nada encontram que fazer, em que se empregue o seu mister, ainda mesmo com os sacrifícios de interesse e de glória que se lhe exigesse; e hoje, acabrunhados sob o peso das urgentes necessidades do pão cotidiano, verdadeiros párias, aí vão deixando o sacerdócio 
fundamental, também por eles conhecido, estava na falta de consideração das profissões artísticas, que embora liberais não seriam percebidas com bons olhos por indivíduos que desejassem um futuro promissor ${ }^{198}$.

As soluções propostas eram as mesmas: disseminar o gosto pelas artes na sociedade; fazê-la notar que aquelas não eram produto de luxo frívolo, dispensável, mas uma ferramenta do progresso $^{199}$, um objeto importante para a difusão dos valores morais ${ }^{200}$.

do culto a que haviam consagrado o seru e a vida, por profissões menos dignas e decentes." BETHENCOURT DA SILVA. “Ao Sr. ministro do Império." Correio Mercantil. Rio de Janeiro, 18 de dezembro de 1860. p.2.

Em outro texto, Bethencourt complementa seu posicionamento: "Os homens mais eminentes do país, aqueles que podem com um simples aceno transformar o terreno inóspito em amenos passeios, lagoas infectadas em cristalinos lagos bordados de obras de arte, de repuxos e estátuas; que podem volver pardieiros imundos em belas casas, em excelentes hotéis, em habitações aprazíveis e saudáveis; esquecem-se do que devem à pátria e à fortuna, desamparam os artistas de quem deviam ser os Mecenas, e tudo fica entregue ao desamparo, até que venha a especulação e a ganância impingir à sorrelfa o algodão por seda, o ferro por prata, o latão por ouro e o granito por Brilhante.” BETHENCOURT DA SILVA. Ao Sr. ministro do Império. Correio Mercantil. Rio de Janeiro, 17 de dezembro de 1860. p.2.

198 Sobre o problema das artes serem percebidas como uma função relegada aos escravos, ou às pessoas mais humildes:

Américo: "O atraso em que entre nós se acham as belas artes é devido a causas muito complexas. A primeira é a falta de um futuro pelo qual nossa mocidade possa sacrificar voluntariamente o presente aos estudos artísticos, ante outras carreiras que pela importância de que gozam, atraem toda a atenção dos pais de família; de onde resulta que apenas uma pequena fração daqueles cuja vocação energicamente os impele ao culto das Musas a ele se dedicam, e, ainda quando assim, muitas vezes contra a vontade dos próprios parentes, que, de ordinário mais experientes e conhecedores do espírito da nação, consideram como um dever o desviarem-os de uma vereda tão espinhosas como ilusória e vã.[...] Ora, acresce mais, que empregando raramente o artista, ao mesmo tempo que entretém alguns de entre os mais hábeis com um pequeno salário, desproporcionado às incumbências de que estão sobrecarregados, o governo concorre para acostumar o público a considerá-los homens indiferentes à nação, e por consequência inferiores no préstimo individual aos que seguem outras carreiras igualmente liberais. É o que na realidade acontece; e como dos artistas às belas artes há correlação imediata, são estas consideradas quais subalternas ocupações, sem influência alguma na vida pública, e por esta razão sem dignidade social.”. MELO, Pedro Américo Figueiredo e. "Cartas de um Plebeu aos Srs. Deputados. Segunda Carta" . Correio Mercantil. Rio de Janeiro, 21 de maio de 1865.

Bethencourt: "Com isto, que a principio parecia conseqüente com as aspirações dos filhos de uma colônia que preparava a sua independência, nasceu a persuasão ou crença de que os Brasileiros em geral não deviam entregar-se a mister algum que não estivesse inscripto na orbita dessas quatro dignidades. Desta sorte, sem que alguém então o presentisse, o funesto prejuízo, que insensivelmente se foi introduzindo e crescendo, levou a sociedade brazileira a tomar como deshonrosas as profissões de artista e de operário, que não podiam ter acção immediata nos actos do governo. Assim pensando, a mocidade que não conseguia entrar em uma dessas quatro classes, preferia a inacção, que lhe preparava uma pobreza pouco digna, a exercer um ofncio ou uma arte que, praticados unicamente pelos escravos para quem isso fora deixado, não the traziam sinão o desprezo de seus concidadãos. BETHENCOURT DA SILVA, Francisco Joaquim. "Discurso pronunciado na segunda sessão preparatória da Sociedade Propagadora das Bellas-Artes do Rio de Janeiro, em 28 de Novembro de 1856." In: SOCIEDADE PROPAGADORA DE BELAS ARTES. O Brazil Artístico: Revista da Sociedade Propagadora das Bellas-Artes do Rio de Janeiro. Rio de Janeiro: Typographia Leuzinger, 1911. P.38.

199 Sobre a arte como ferramenta do progresso para Américo e Bethencourt:

Américo: "Convencidos, pelo contrário, da necessidade dos estudos de arte, da sua utilidade na vida intelectual, e das vantagens que dele resultariam para todos os progressos pátrios, como o desenvolvimento da alta indústria, da arte da construção civil, e de muitos outros auxiliares da prosperidade nacional, aumentar-se-ão proporcionalmente nossas luzes em semelhante matéria". MELO, Pedro Américo Figueiredo e. "Cartas de um Plebeu aos Srs. Deputados. Quinta Carta". Correio Mercantil. Rio de Janeiro, 29 de junho de 1865.

Bethencourt: O povo que quer elevar-se, já o dissemos em outra ocasião, necessita de acolher a arte, de fazê-la social, imperante e dominadora; porque cada linha é uma sílaba, cada coluna uma palavra, cada pirâmide uma frase que se combinam em completam a narração e o monumento que é o poema poliglota, faculdade a todos os povos e nacionalidades. BETHENCOURT DA SILVA. Ao Sr. ministro do Império. Correio Mercantil. Rio de Janeiro, 15 de dezembro de 1860. p.3. 
Também Bethencourt acredita, a partir de uma visão da história cultural, que o "grau de desenvolvimento" das belas artes seria a expressão identitária de uma nação. O Brasil, enquanto um país ainda novo e imperfeito, teria uma arte igualmente imperfeita. Não poderia dispor, portanto, de uma "Arte Nacional" genuína. E dela continuaria carente até que se descobrisse o quanto seria importante para a sociedade. Novamente, como havia sido para outras personalidades destacadas das artes no Brasil, a arte Grega resistia como parâmetro de comparação e exemplo. Seria um modelo perene, que, todavia, não deveria ser buscado necessariamente por meio da imitação das suas produções poéticas, mas pelo exemplo da proteção que aquele povo "primevo" teria dado naturalmente às artes, injetando-as no corpus social, e resultando dessa ação o reflexo percebido em suas "elevadas" produções e no "avanço" de sua sociedade. O recurso, sem dúvida, era uma metáfora que se acreditava ser suficientemente categórica para servir de baliza ao "povo brasileiro", para que esse fizesse o mesmo em seu país ${ }^{201}$. Uma vez abraçadas as artes pelo povo - e apenas em decorrência desse movimento - resultaria a criação das condições para a emersão dos "gênios" nacionais ${ }^{202}$, esses que seriam os responsáveis por introduzir o Brasil nas "páginas brilhantes" da história mundial, atestando seu avanço junto às nações européias, das quais seria filho dileto.

\footnotetext{
Ainda Bethencourt, sobre o mesmo assunto: "Entretanto, ninguém que por menor que seja sua instrução, ignora que o país no qual os conhecimentos artísticos não occupam o primeiro lugar, não pôde proseguir rapidamente na senda do adiantamento e da riqueza. Ninguém hoje ignora que as bellas-artes são o influxo de todas as industrias, as bases de toda a perfeição manufactureira". BETHENCOURT DA SILVA, Francisco Joaquim. "Discurso pronunciado na segunda sessão preparatória da Sociedade Propagadora das Bellas-Artes do Rio de Janeiro, em 28 de Novembro de 1856." In: SOCIEDADE PROPAGADORA DE BELAS ARTES. O Brazil Artístico: Revista da Sociedade Propagadora das Bellas-Artes do Rio de Janeiro. Rio de Janeiro: Typographia Leuzinger, 1911. P.17-18.

200 Sobre as artes como uma ferramenta para difusão dos valores morais na sociedade:

Américo: Que [as artes] além de servirem ao desenvolvimento harmônico das nossas faculdades e educarem o espírito nas suaves melodias da forma, predispõem os corações aos sentimentos generosos e grandes, ao mesmo tempo que, pelo hábito das contemplações intelectuais, nos torna mais e mais afeiçoados às verdades morais, cujos princípios nem sempre superabundam no domínio da educação tal qual a praticamos. MELO, Pedro Américo Figueiredo e. "Cartas de um Plebeu aos Srs. Deputados. Quinta Carta" . Correio Mercantil. Rio de Janeiro, 29 de junho de 1865.

Bethencourt: A magnificência das artes não é só o enriquecimento material do - belo -, é também o engrandecimento moral e estético da nação em que ela se realiza. BETHENCOURT DA SILVA. "Ao Sr. ministro do Império." Correio Mercantil. Rio de Janeiro, 17 de dezembro de 1860. p.2.
}

201 Sobre os Gregos e o fomento que conferiam às artes:

Américo: As honras deferidas pelos atenienses [a seus artistas] eram por tal modo graduadas, que a emulação nunca podia cessar. - Proclamação no teatro do nome do indivíduo a quem se queria honrar; proclamação nos jogos públicos. - Coroa votada pelo senado; coroa decretada pelo povo; coroa oferecida pelas cidades aliadas, na festa dos Panatênios [...]" A citação é, por sua vez, uma citação que Américo faz de um texto de Eméric-David: "Recherche sur l'art statuaire", referência importante para o trabalho escrito do brasileiro. MELLO, Pedro Américo de Figueiredo e. Considerações Filosóficas sobre as belas artes entre os antigos. João Pessoa: Editora Universitária/UFPB, 2006. p.198

Bethencourt: "Quando os Gregos queriam testemunhar o seu respeito aos Deuses, ofereciam-lhes painéis e estátuas representando as suas mais célebres vitórias, ou os retratos dos homens a quem queriam honrar." BETHENCOURT DA SILVA. Ao Sr. ministro do Império. Correio Mercantil. Rio de Janeiro, 17 de dezembro de 1860. p.2.

202 Sobre as condições necessárias ao "florescimento" dos gênios:

Américo: "O gênio não é mais do que um vigoroso talento, uma enérgica inteligência fecundada pelo entusiasmo popular. Se em certas épocas abundam homens de superior inteligência, como nas repúblicas gregas, como durante todo o período da república romana, que preparou a grandeza do Império, e como finalmente na Itália Renascente, isto não quer dizer que a natureza produza momentaneamente melhores, nem mais bem organizados cérebros: é, ao contrário, ao 
Em suma, os alvos de Américo e Bethencourt e o lugar de onde disparavam seus projetos eram análogos. Divergiam, contudo, nos procedimentos e, principalmente, nas armas e aliados que utilizariam.

Américo parece ter percebido que a melhor maneira seria traçar um caminho de "cima para baixo". Tornar-se bacharel (afirmando enfaticamente o lado intelectual, idealista, da sua profissão) colocá-lo-ia já no topo de uma escada árdua, acessível apenas a poucos, permitindo que, assim, se aproximasse de pronto de aliados poderosos (alguns dos quais, a propósito, eram formadores da elite "liberal" bacharelesca, como o foi por décadas seu "padrinho", Luiz Pedreira, professor na Faculdade de Direito de São Paulo) e assim implementar seus projetos. A estratégia do artista estava alinhada mesmo, como visto nesta Tese, às suas intenções pessoais: desejava ser reconhecido como um "artista universal”, isto é um artista-intelectual, ao qual caberia o proveitoso sinômino, no país, de artista-bacharel.

Bethencourt procedia a outra estratégia. De "baixo para cima", angariou aliados de sua própria "classe" profissional e, além disso, conseguiu até mesmo se colocar no limiar de "classes artísticas", conseguindo articular, no interior da Sociedade Propagadora de Belas Artes e do Liceu de Artes e Ofícios, dezenas de profissionais que integravam desde a elite artística brasileira (professores da AIBA), além de membros destacados que não faziam parte diretamente da academia (ex-alunos e estrangeiros, por exemplo), e artistas gráficos e industriais mais ou menos conhecidos ou pouco conhecidos. Além da companhia deles - e em função das suas atuações em outros campos artísticos, como a poesia e literatura -, o arquiteto ainda colheu o apoio de vários membros da imprensa carioca, interessado portanto na atuação desses profissionais enquanto formadores de opinião. Sem dúvida, os mais destacados deles nos primeiros anos daquelas instituições foram: Manoel Antônio de Almeida (amigo de infância de Bethencourt e autor de Memórias de um

tempo em que apareceram tais homens, que se deve atribuir tamanhas manifestações da nossa força intelectual. Diz-se muitas vezes que o gênio se desenvolve a despeito das circunstâncias, porém são frases banais para uso dos filisteus. Para cada homem que, favorecido pelo estado moral do seu tempo e da sociedade em que vive, pode dar um exemplo de latitude da inteligência humana, quantos gênios, não achando o necessário alimento para desenvolver-se, não definharam miseravelmente? [...]O homem não produz sem a ação coletiva de outros homens. É a cooperação da sociedade, que lhe infiltra nas veias o calor necessário para as grandes criações. É indispensável o entusiasmo da nação para exaltar o engenho". MELLO, Pedro Américo de Figueiredo e. Considerações Filosóficas sobre as belas artes entre os antigos. João Pessoa: Editora Universitária/UFPB, 2006.p.195-196.

Bethencourt: "Na época em que a França era governada por um rei que de braços abertos acolhia os artistas; quando Versalhes escancarava suas portas aos esplendores maravilhosos das artes; quando as obras primas da industria vinham activar o brilho das luzes desses saraus duplamente reaes, em que a realeza do talento se unia á realeza da posição, os gênios surgiam como por encanto e com eles suas obras". BETHENCOURT DA SILVA, F. J. "Discurso Recitado perante os membros fundadores da sociedade propagadora as Beas Artes do Rio de Janeiro, no dia de sua organização em 23 de novembro de 1856, no edifício do Museu Nacional”. In: SOCIEDADE PROPAGADORA DE BELAS ARTES. O Brazil Artístico: Revista da Sociedade Propagadora das Bellas-Artes do Rio de Janeiro. Rio de Janeiro: Typographia Leuzinger, 1911. p.18. 
Sargento de Milícias ${ }^{203}$ ), Machado de Assis (também amigo próximo, tendo sido Bethencourt o responsável pelo parecer favorável à encenação da primeira peça de teatro do literato, em 1862, quando o arquiteto era secretário do Conservatório Dramático), Jacy Monteiro (bastante amigo de Bethencourt, também ex-aluno da AIBA e secretário da SPBA e do Liceu) e Carlos de Laet (um dos futuros críticos protagonistas da polêmica das pinturas de Américo e Victor Meirelles na Exposição Geral das Belas Artes de 1879, da qual Bethencourt participaria nova e ativamente como

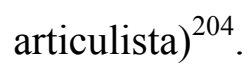

Se, até onde se sabe, nesses primeiros anos ${ }^{205}$, Américo não teria conseguido aproximar qualquer membro da AIBA aos seus projetos - ou não teria desejado recorrer a nenhum desses "iguais" - , Bethencourt, desde formação da SPBA, em 1856, e desde os primeiros anos de funcionamento do Liceu até o seu fechamento temporário, em 1864, havia atraído a colaboração de seus colegas da instituição-mór e de outros artistas igualmente destacados no cenário nacional. Entre eles estavam: François-René Moreaux (além de professor do Liceu, o primeiro diretor do Liceu), Francisco Antônio Nery (êmulo de Américo no concurso para cadeira de desenho figurado e professor do Liceu), Agostinho José da Motta (professor de pintura de paisagem, flores e animais na AIBA; sócio-fundador da SPBA e professor do Liceu), Antonio de Pádua e Castro (professor de escultura de ornatos na AIBA; sócio-fundador da SPBA e professor do Liceu), Joaquim Lopes de Barros Cabral Teive (professor de pintura histórica na AIBA até 1860; sócio-fundador da SPBA e professor do Liceu), Victor Meirelles (também professor de pintura de história da academia; professor por muito tempo no Liceu), Antônio Araújo de Souza Lobo (litógrafo e gravador bastante conhecido na corte; professor do Liceu) etc ${ }^{206}$.

203 Manoel Antônio de Almeida morreu em 1861, num naufrágio, perto dos arredores de Campos dos Goytacazes (RJ). Entretanto, em 1866, durante a "questão de Bacharéis", resquícios de sua amizade com Bethencourt possivelmente ainda reverberavam nas penas do arquiteto. Torna-se curioso notar que uma das qualificações a que Bethencourt, utilizando o pseudônio Renato de Guisando, dirige à amizade entre Ferro e Américo seja bastante similar a uma passagem do Memórias de um Sargento de Milícias, cuja reedição do começo da década de 1870 seria prefaciada pelo próprio arquiteto. Bethencourt diria sobre os dois jovens, no final do artigo publicado no Jornal do Commércio em 24 de janeiro de 1866 (p.1), no ápice da "questão": "Deus os fez, e o diabo os ajuntou". O trecho do romance de Almeida segue da seguinte maneira: “- Ora - replicou Vidinha -, e então, ele não diz 'ora?' Qual! É preciso não ter pingo de vergonha: estas duas criaturas nasceram uma para a outra: Deus os fez e o diabo os ajuntou; uma toma caldo e o outro diz 'ora"” . ALMEIDA, Manoel Antônio de. Memórias de um Sargento de Milícias. Porto Alegre: L\&PM, 2009. P.168.

204 Anos depois, na década de 1870, um nome forte e bastante importante para a defesa do Liceu será, se dúvida, o de Félix Ferreira, que sintomaticamente privilegiará uma leitura da arte brasileira a partir do prisma da arte industrial e do Liceu de Artes e Ofícios do Rio de Janeiro, recebendo especialmente menção do jornalista a atuação de Bethencourt da Silva, um grande amigo seu.

205 No fim da década de 1870 a situação de Américo em relação a demais membros da academia parece se modificar um pouco, quando ele se torna mais próximo de personalidades como Mafra, secretário da AIBA, e Nicolau Tolentino, seu diretor por muitos anos.

206 A lista de professores atuantes quando do primeiro ano após a inauguração do Liceu é a seguinte: Eduardo Julio Janvrot; Eduardo Manoel Francisco Da Silva; Francisco Joaquim Bethencourt Da Silva; Giovani Bruscheti; João Antonio Gonçalves Da Silva; João Da Costa Brito Sanches; João José Alves; João Vieira De Souza Júnior; Dr. Luiz 
O congraçamento de distintos aliados e a definição de estratégias divergentes reforçava, assim, o que talvez fosse o mais importante na proposição dos projetos de Américo e Bethencourt e no vértice conflituoso que se tornaria a "questão de bacharéis": o dado de que, a despeito de suas similaridades, como também haviam sido em boa medida os de Porto Alegre e Taunay, a "questão" construída especialmente entre eles era, portanto, a de um embate político que tencionava definir qual deles seria o agente responsável pelas mudanças de uma ou mais "classes artísticas" que os elegiam representantes.

Bethencourt havia sido, ou havia se imposto como, o eleito de diversas dessas "classes". Em quantidade de aliados, o cabo de força lhe pendia. Américo ainda desejava tornar-se um exemplo, mas suas aspirações, ao contário das do seu êmulo - bem mais propenso à ação do que à elucubração -, permaneciam em notas de papel, direcionadas a membros influentes da política e da economia nacional, para que esses, quando o abraçassem, lhe dessem oportunidade de ação.

Não é preciso insistir novamente que esse embate, cuja órbita era a imprensa, mas o núcleo nervoso e inevitável estava na AIBA, foi tão forte quanto incômodo. Forte a ponto de Bethencourt da Silva se apresentar como o principal agente da campanha para a prisão do seu mais novo colega de instituição, e de Ferro Cardoso. Descreditando-os, se descreditariam seus planos políticos, os quais disputavam, portanto, com os do próprio incitador da "questão de bacharéis". A investida empregada (a de deixá-los aparentes apenas como artistas) expôs, no entanto, a raiz da mesma fraqueza social que Bethencourt e seus aliados da arte possuíam, fossem ou não da academia. Isto é, as "misérias" expostas dos jovens não eram outras senão as mesmas da classe artística geral, as quais eles tentaram esconder sob a abrigada do bacharelado. Incômodo por que a rusga não recebera uma menção sequer nas atas das reuniões dos membros da AIBA, e também por que a licença do recém-empossado Américo não produziu, da mesma maneira, qualquer crítica ou comentário oficial da instituição, que também acolhia, afinal, parte do contingente profissional do Liceu. Fosse como

Pedro Drago; Paluceno Pereira Da Silva Manoel; Quitino José De Faria; Quirino Antonio Vieira; Severa Da Silva Quaresma; Dr. Teofilo Das Neves Leão; Agostinho José Da Mota; Dr. Antonio Paulo De Melo Barreto; Joaquim Lopes De Barros Cabral; Francisco José Martins; João Caetano De Oliveira Aguiar; João Inácio Da Silva Freitas; Luiz Stalone; Dr. Manoel Antonio De Almeida; Dr. Teodoro Antonio De Olivera; Dr. Antonio Ferreira Pinto; João Caetano Ribeiro; Antonio Jacy Monteiro; Antonio Farrel Muniz; Françoix-René Moreaux.

A lista de professores atuantes entre 1860 e 1875 é a seguinte: Alfredo Jorge Eugênio Seelinger; Antonio Araújo De Souza Lobo; Antonio José da Rocha; Antonio de Pinho Carvalho; Dr. Augusto Saturnino da Silva Diniz; Candido Mondaini; Dr. Carlos Maximiano Pimento De Laet; Dr. Emidio Adolfo Vitório da Costa ; Francisco Carlos da Silva Cabrita; Dr. Francisco Xavier Oliveira de Menezes; Heitor Branco de Cordovil; Dr. João Cancio Ferreira da Silva; João Luiz da Costa; Dr. João Neri Ferreira; Dr. João Pedro de Aquino; João Inacio Da Costa Miranda; Joaquim José Marques; Joaquim Rodrigues Antunes Junior; Dr. José Feliciano De Noronha Feital; José Francisco De Souza Bracasense; José Manoel Garcia; Dr. José Rodrigues De Azevedo Pinheiro; José Da Silva Marques; Lourenço Tavares; Manoel Fernandes De Matos Guaiba; Dr. Manoel Luiz De Moura; Manoel Pacheco Da Silva Júnior; Matias José Teixeira; Dr. Miguel Antonio Da Silva; Olimpio Rodrigues Antunes; Victor Meirelles De Lima; Dr. Francisco Portela; Dr. Domingos Jacy Monteiro; Carlos Rumieu; Eduardo Manoel Francisco Da Silva; Dr. Antino Aquiles de Miranda Varejão. BARROS, Álvaro Paes de. Op.cit. pp.103-106. 
fosse, o silêncio significou, em alguma medida, consentimento mútuo ou, no mínimo, um acordo tácito.

\section{Um choque entre "classes artísticas"}

Um breve mas importante interlúdio deve ser feito à "questão de bacharéis", pois pode ajudar a desvelar outros motores que nela jaziam submersos, não obstante operantes.

O confronto entre Américo e Bethencourt certamente não representaria toda a tensão existente entre o que aqui se defende ser um conflito entre "classes artísticas" (tampouco como teria dado conta a rusga entre Taunay e Porto Alegre).

Conquanto desejassem estender seus projetos e ações para outras "classes", como as dos artistas gráficos e industriais, Américo e Bethencourt integravam uma elite artística concentrada na AIBA, que representava ambições especialmente emanadas de uma entre várias outras "classes artísticas" da corte. É desse modo que não se deve surpreender com a similaridade por vezes aparente nos projetos de diversos agentes que atuaram na academia, por mais fortes que fossem suas colisões internas na instituição, e políticas fora dela. Para eles, havia uma recorrente vontade de mudança nos planos social e cultural das artes nacionais, disso resultando uma melhor consideração de suas condições enquanto profissionais destacados e do seu potencial. Mas essa vontade, se for lícito repetir, dizia respeito aos planos de uma "classe artística", os quais poderiam parecer bastante alheios às intenções bem mais modestas de outras "classes".

É verdade que Bethencourt avançou em um terreno que não havia sido satisfatoriamente ocupado por nenhum outro agente antes dele. Por atuação e relações, ele assumiu um lugar de fronteiras, e esse lugar o levou à academia (conforme citado), incitado a exercer uma conciliação. Ele adicionou, com efeito, uma variável aos projetos anteriores da AIBA: a ele coube não apenas levar, de fato, o acesso do ensino artístico voltado para a indústria para dentro da academia, com a implantação de cursos noturnos na instituição, mas, ainda antes, coube criar a primeira instituição dedicada exlcusivamente a esse propósito. No Liceu, consolidou e priorizou uma política efetiva voltada para uma outra "classe artística" que não possuía a mesma visibilidade daquela representada pela academia.

Contudo, Bethencourt da Silva estava longe de ser também uma unanimidade para as "classes" de artistas ainda menos abastados. Transitasse tanto quanto pudesse entre a "classe artística" erudita, a "classe" de artistas melhor instruídos, ou a de artífices mais modestos, havia ainda um não pequeno número de artesãos que não se sentiam representados pelo arquiteto, nem 
por quaisquer outros agentes da AIBA ou do Liceu. Em decorrência desse sentimento, passaram a oferecer-lhes resistência e, na mesma medida, a defender suas próprias causas e interesses, formando, para tanto, seus próprios blocos políticos.

Um sinal dessa resistência: na ocasião da candidatura de Bethencourt à vereação, em 1864, vários outros artistas também se lançaram à campanha para o mesmo cargo, com o intuito de aumentarem os poderes políticos dos seus grupos, logo tencionando ampliar seus campos de ação e representação junto à comunidade carioca. $\mathrm{Na}$ eleição daquele ano, considerando apenas o Rio de Janeiro, e apenas o Partido Progressista, no qual estava inscrito Bethencourt, se apresentaram não menos do que doze artistas abertamente pós-escritos, todos pouco conhecidos, ou mesmo totalmente ignorados pela atual historiografia brasileira. ${ }^{207}$

Seus interesses eram por vezes tão divergentes o ponto de seus sequazes saírem não apenas a favor, mas também contra outros canditados que julgavam não representar satisfatoriamente a “classe artística" em geral, e as suas em particular. Se, por um lado, naquela eleição, Bethencourt da Silva foi ovacionado por alguns como o responsável por levar à frente o cetro que serviria "de transição para a legítima soberania de sua "classe" 208 , por outro, ele também sentiu uma forte oposição; primeiro, do crítico Veritas, alguém de contato aparentemente mais estreito e talvez da mesma "classe", em seguida também de agentes de outras "classes", que defenderam seus próprios projetos em oposição àquele alavancado pelo arquiteto e por seus aliados ${ }^{209}$. Com efeito, durante as campanhas deste último grupo, foi possível ler alguns artigos que tornavam o problema explícito:

207 Listas eleitorais à vereação do Partido Progressita para o ano de 1864:

Freguesia do sacramento: Antonio de Pádua e Silva, artista; Francisco José Mariano da Silva, artista; João Rodrigues Alves, artista; Veríssimo José do Bom-Sucesso, artista.

Freguesia de S. José: nenhum artista candidato.

Freguesia da Candelaria: nenhum artista candidato.

Freguesia de Santa Rita:Antonio Luiz Bastos dos Reis, artista; José de Oliveira, artista; Manoel Esteves de Amorim, artista.

Freguesia de Santana: Florindo Gonçalves Coelho, artista; Ignácio Antunes de Encarnação e Silva, artista.

Freguesia do Engenho Velho: João Antonio dos Santos Cardoso, artista.

Freguesia de Santo Antonio:João Duarte de Moraes, artista.

Freguesia da Glória:Francisco Joaquim Bethencourt da Silva, artista;

Freguesia da Lagoa: Não foram oferecidos dados sobre a ocupação dos candidatos dessa freguesia

Freguesia de S. Cristóvão: nenhum artista candidato.

Freguesia de S. João Batista de Niterói: nenhum artista candidato.

Cf. "Boletim Eleitoral". Correio Mercantil. Rio de Janeiro, 10 de agosto de 1863. p.3.

208 MACEDO ASQU. "Aos Artistas". Correio Mercantil. Rio de Janeiro, 07 de setembro de 1864. p.3.

209 Outros artigos que fizeram oposição a Bethencourt, e não foram assinados por Veritas são:

"Camara Municipal". Correio Mercantil. Rio de Janeiro, 26 de agosto de 1864. P.3; "Atenção". Correio Mercantil. Rio de Janeiro, 26 de agosto de 1864. P.3. 
Aos votantes

O Sr. Bethencourt da Silva, abusando do sentido da palavra artista, quer-nos fazer crer que pertence à nossa classe, e que é para nós ponto de honra elege-lo vereador. Ora, o que há de comum entre nós, honrados artífices, que vivemos do suor do nosso rosto, e S. S. mestre de desenho na escola central, e de não sabemos o que na academia das Belas Artes, vivendo à custa de grossos ordenados acumulados?

Não engolimos bola. O nosso candidato é o Sr. José Antonio dos Santos Cardoso, tipógrafo brasileiro ou outro qualquer que esteja nas suas circunstâncias; há muitos dignos. Não precisamos ir buscar fora do país e em outra classe quem nos represente.

Muitos operários brasileiros ${ }^{210}$.

Como poderia Bethencourt da Silva (estrangeiro naturalizado, arquiteto formado, professor destacado da AIBA, repleto de empregos e vencimentos, e que citava em quase todos os seus discursos as mais altas ideias do "gênio" e do "belo") ser recebido como "o" representante unânime da "classes artísticas", se alguns não observavam nele qualquer identificação com, por exemplo, os propósitos de uma "classe" politicamente quase invisível, como a dos tipógrafos, esta que sse julgava composta igualmente por artistas, mas que possuía outra relação com o trabalho, com o fins de suas produções e, ainda, com a perspectiva profissional?

O recado continha assim pouco de subentendido. Asseverava que somente um representante legítimo de "classe artística operária" - neste caso, o tipógrafo Sr. José Antonio dos Santos ou, em última instância, "outro qualquer" - para compreender os reais problemas pelos quais passavam, e para propor soluções que de fato satisfizessem suas demandas.

De quatro em quatro anos, um dos instrumentos acessíveis para as mudanças que ansiavam as classes tornava-se a política eletiva, que permitiria a entrada dos seus representantes num campo de ação concreto e, por conseguinte, a ativação de um projeto definido por grupos específicos.

Por mais que desejasse servir de representante à "classe operária das artes", Bethencourt talvez parecesse para alguns demasiadamente afastado dela. Não saberia o que era viver do "suor do próprio rosto" (talvez tenha sido essa a única alusão implícita no artigo, expessão que sugeria serem os artífices os responsáveis por "colocar a mão na massa" nas construções e nas oficinas gráficas, enquanto que o arquiteto, como um "bacharel, colocava-se como o mandante das obras a serem construídas e dos textos a serem tipografados). É por essa razão que o projeto que Bethencourt encabeçava podia ser percebido como inapto a satisfazer os planos de mudanças que emanavam internamente da própria “classe operária” das artes.

210 "Aos votantes". Correio Mercantil. Rio de Janeiro, 26 de agosto de 1864. P.3. 
A asseveração torna-se mais clara se pautada em um exemplo concreto. Em 1856, quando Bethencourt lograva a formação da Sociedade Propagadora de Belas Artes, divulgava seus estatutos, que seguiam, em resumo, da seguinte maneira:

- Formação de um Liceu de Artes e Ofícios, para o ensino artístico voltados para os trabalhadores livres;

- Instalação de uma biblioteca de artes;

- Edição de uma revista (cujo primeiro exemplar ganhou edição logo após a formação da Sociedade);

- Realização de exposições com os trabalhos dos alunos.

No mesmo ano, uma Associação Nacional de Artistas Brasileiros era formada em oposição à SPBA, e construída integralmente pela congregação e direção de artesãos completamente desconhecidos. Nos atos de sua fundação, a Associação divulgava seus objetivos e estatutos, os quais, de início, já denunciavam seu contraste com os propósitos da Sociedade guiada por Bethencourt:

Sendo incontestavelmente certo que a classe artística é a mais numerosa do país, e também que é a que mais sofre a todos os respeitos, convém que, formando uma grande associação, promova o seu bem-estar pela maneira seguinte:

\section{PARTE BENEFICENTE}

- Socorros mútuos aos sócios e suas famílias em estado de necessidade;

- Proporcionamento de meios de poderem eles apresentarem-se decentemente na sociedade;

- Livramento das prisões públicas e de toda e qualquer perseguição da autoridade.

\section{PARTE POLÍTICA}

- Obtenção dos direitos a fim de afastar a concorrência estrangeira das obras dos naturais do país;

- Redução daqueles a respeito do material estrangeiro, que for empregado nas fábricas nacionais;

- Combinação de chapas dos artistas para toda e qualquer eleição popular, na órbita da constituição do império;

- União entre sim, a fim de que não nulifiquem a importância da classe, e consigam por este modo o bem-estar e melhoramentos de que necessitam ${ }^{211}$.

Contrapostos, os programas dessas diferentes Sociedades apontavam para direções bastante diferentes, ainda que ambas tivessem repetido, em ocasiões ulteriores, que o maior dos seus propósitos estava no "progresso" das artes no Brasil.

211 "Associação Nacional dos Artistas Brasileiros". Correio Mercantil. Rio de Janeiro, 26 de abril de 1856. p.3. 
Para a primeira, a SPBA, o "progresso" significava artistas melhor instruídos e preparados, que mudassem a imagem da "classe artística" atuando diretamente na comunidade - algo, como visto, também muito próximo dos planos do jovem Américo. O projeto dessa sociedade era o de ascensão social da classe; e era ainda um de fundo cultural: característica percebida por meio da ênfase que, em todas as suas diretrizes, lançava à formação de bibliotecas, exposições, revistas e ensino voltados para uma "classe artística" que, embora humilde, seria letrada e supostamente interessada em seu desenvolvimento intelectual (classe que não deveria ser muito numerosa, haja vista que a revista da Sociedade, a Brazil Artístico, durou apenas o ano de 1856, sendo retomada muito brevemente apenas 55 anos depois, em 1911).

Para a outra, a Associação Nacional dos Artistas Brasileiros, o "progresso" parecia, no entanto, rondar longe de qualquer ação centrada na mudança do status simbólico ou cultural do artesão, ou de uma melhor imagem social. Na proposta dessa congregação, o primeiro problema a ser resolvido era de uma modéstia desconcertante: tratava-se de melhorar as limitadas condições de vida desses profissionais. Era essa a importância dada à "parte beneficente" do programa da instituição, formulada a partir dos principais obstáculos enfrentados pelos artífices fluminenses: como trabalhadores autônomos, cujo ganha-pão era diário e conquistado em cada trabalho efetuado, se viam em apuros junto com suas famílias quando ficavam doentes ou presos (por quaisquer que fossem os motivos). Não por outra razão, uma das principais promessas da nova associação era a de criar uma "previdência social" que pudesse auxiliar os artesãos, sempre que necessitassem.

Em seus estatutos, estava previsto aos associados o auxílio da limitada quantia de um mil-réis por dia que não trabalhassem, por motivo de doença, ou 12 mil-réis mensais, entregues às suas famílas, se se tornassem inválidos ${ }^{212}$. Também uma diária de mil-réis seria liberada se o artesão fosse preso, ou uma igual pensão de 12 mil-réis mensais à sua família se continuasse encarcerado. Por fim, aqueles estatutos ainda previam o auxílio para o que o artífice pudesse se "apresentar decentemente à sociedade" (isto é, um auxílio ou desconto para a compra de roupas), e o mais notável: que dispusessem de um funeral e sepultamento dignos, se morressem sem condições para

212 Na moeda corrente do império, considerando os Mil-Réis (vigentes ainda durante a República, até o ano de 1942), um conto de réis correspondia a um milhão de réis. Isto é, um conto de réis correspondia a mil vezes o valor de 1 mil-réis. Dez tostões equivaliam a 1 mil-réis. Cada tostão equivalia, portanto, a 100 réis.

Em média, nos anos 1860, com 1 mil-réis (o valor médio de uma diária de um artesão) era possível comprar 8 litros de farinha. Com dez mil-réis, era possível se fazer uma feira completa.

Para uma breve comparação, vale talvez considerar que, em 1872, o ainda jovem Pedro Américo dispunha de 17 contos de réis no banco, segundo seu sogro, Manuel de Araújo Porto Alegre. Isso significaria pouco mais de 54 anos de trabalho de um artesão fluminense que, trabalhando todos os dias de sua vida, respeitando apenas algumas tradições religiosas que pregavam o descanso aos domingos, e sem se considerar os feriados. 
custeá-los; requerimento que, se presente nos estatutos da nova instituição, permite crer aquela situação como uma recorrência ${ }^{213}$.

Compreende-se, portanto, por que aquele articulista que apoiava um tipógrafo obscuro como o José Antonio dos Santos Cardoso - provavelmente ele mesmo um profissional da "classe operária" - não se sentia identificado, em 1864, com as propostas talvez para ele abstratas que precediam a ascensão política de um Bethencourt da Silva, de sua Sociedade e do Liceu.

Curiosamente, a formação da ANAB havia sido lançada também por um tipógrafo bastante engajado politicamente, Manoel Affonso da Silva Lima - à época já integrante-chefe da Associação Tipográfica Fluminense e também Juiz de Paz eleito -, profissonal que após derrota de sua candidatura à deputação provincial, em 1856, preparava-se para uma nova à vereança, na mesma região, propondo antes a formação da associação.

A segunda parte fundadora da instituição, a "Parte Política", não era assim nenhum pouco ingênua. Se se acreditava ser "incontestavelmente certo que a classe artística fosse a mais numerosa do país", e isso foi repetido mais de uma vez ${ }^{214}$, tornava-se também certo concluir e explorar que se tratava da classe trabalhadora livre que possuía o maior número de votos disponíveis. Essa identificação era premente em uma daquelas diretrizes centrais dos atos fundadores da Associação, que imputava a "combinação de chapas de artistas para toda e qualquer eleição popular". As chapas de fato existiram e, já em 1856, quando Bethencourt, na SPBA, talvez nem pensasse em candidatura política, a ANAB divulgava sua primeira lista de candidatos a serem votados pelos $\operatorname{artesãos}^{215}$, na qual se incluiu, naturalmente, o nome de Silva Lima.

213 Para o artigo completo sobre os estatutos da Associação Nacional dos Artistas Brasileiros, ver: ASSOCIAÇÃO Nacional dos Artistas Brasileiros. Correio Mercantil. Rio de Janeiro, 12 de fevereiro de 1857. p.2.

214 Outra ocasião próxima em que essa conclusão foi proferida aconteceu, por exemplo, em uma cerimônia que a Associação Nacional dos Artistas Brasileiros mandou celebrar na Igreja da Cruz dos Militares pouco antes da fundação oficial da fundação (em 01 de setembro), da qual participou d. Pedro II. No evento, Manoel Affonso da Silva Lima pronunciou um discurso, o qual apresento apenas uma parte:

"Senhor! - Uma associação nacional fundada sob os melhores aspúcios, porque, congregando os artistas brasileiros, assegurou-lhes um futuro animador e lisongeiro, foi instalada na capital do Império no meio do mais ardente entusiasmo, pois que seus fins são patrióticos, beneficentes e políticos tanto quanto permite a lei fundamental do Estado, que garanta a todas as classes sociais direitos que não podem ser disputados nem interditos sem a mais flagrante violação da mesma lei e abusos de suas terminantes disposições. Essa associação, senhor, é a Associação Nacional dos Artistas Brasileiros, da qual V. M. I. terá pleno conhecimento, e que, escudada nas instituições livres que imperam no país, acudiu ao reclamo das mais imperiosas necessidades dos artistas nacionais que, isolados e sem proteção, viviam longe de esperanças de melhor futuro.

O laço de união que hoje reúne a classe mais numerosa do país [grifo nosso], a classe que alicerça o augusto trono de Vossa Magestada, e presta à nação importantes serviços, é o símbolo da sua regeneração, da regeneração do primeiro dia nacional, é garantidor do bem-estar de tantos Brasileiros que viviam cheios de privações e onerados de deveres, quando a par destes não usufruiam igual soma de direitos, o direito transcendental de intervirem com as outras classes sociais nos negócios públicos." SILVA E LIMA, Manoel Affonso. " Festejos para o dia 7 de setembro". Correio Mercantil. Rio de Janeiro, 08 de agosto de 1856. p.2.

215 OS ARTISTAS. "Lista". Correio Mercantil. Rio de Janeiro, 02 de junho de 1856. p.3. 
De todo modo, Silva Lima não conseguiu permanecer por muito tempo na nova Associação, pois logo descobriram-se irregularidades em sua gestão ${ }^{216}$, passando-a, por meio de escolha eletiva, ao encargo de outros membros. Esse dado poderia ter pouca importância se um dos presidentes futuros eleitos da instituição, especialmente o presidente para o período de 1864 a 1866 , não fosse o próprio Bethencourt da Silva, assumindo-a no mesmo momento em que fazia correr sua campanha à vereança, durante o fechamento do Liceu de Artes e Ofícios. Seria desse modo coincidência que, no momento que a instituição que lhe era mais cara passava por uma crise, Bethencourt anuisse à posse da presidência de outra que, embora em estatuto divergisse dos propósitos do Liceu, possuía número elevado de associados e de potenciais votantes?

Alguns dos concorrentes de Bethencourt ao cargo de vereador em 1864 eram antigos integrantes da Associação ${ }^{217}$, e é bem provável que tenham sidos eles próprios os responsáveis por fazer frente à candidatura do arquiteto, quando ele assumia a gestão da ANAB, pois percebiam o quanto ele poderia se beneficiar do estatuto que aconselhava os associados a votarem nos membros eleitos por chapa escolhida pela instituição, e o quanto isso poderia enfraquecer as possibilidades de implementação dos seus próprios projetos, por intermédio da política.

É bastante difícil tomar como casual, assim, todas essas confluências políticas nas quais Bethencourt centra-se, especialmente entre 1864 e 1866. Do mesmo modo parece irreversível o assentimento de que a nova "classe" da qual ele estava à frente, como um dos representantes e responsável, também bafejasse, mesmo que indiretamente, a tempestade que o arquiteto armava em oposição aos desígnios do seu mais novo, e potencialmente forte, concorrente político das artes, Pedro Américo.

\section{Epílogo dos bachareis}

Tomada enquanto episódio único, a "questão de bacharéis", na sua limitação cronológica, não deixava, conforme proposto aqui, de se configurar enquanto uma mostra caudalosa de relações importantes do ambiente cultural e artístico da corte, no início da segunda metade do século XIX. Atravessada por diversas esferas - pessoais, institucionais, sociais -, ela evidenciava o litígio

O pedido de voto a esses indivíduos foi bastante replicado em edições de jornais cariocas durante a campanha à vereação.

216 Para uma melhor explicação sobre as irregularidades cometidas por Silva Lima na ANAB, ver: "Associação Nacional dos Artistas Brasileiros." Correio Mercantil. Rio de Janeiro, 12 de fevereiro de 1857. p.2.

217 Florindo Gonçalves Coelho, por exemplo, era candidato a vereador pela freguesia de Santana e também subscrito no Partido Progressista na mesma eleição de 1864, da qual participava Bethencourt. Coelho, primeiro tesoureiro da Associação Nacional de Artistas Brasileiros, esteve envolvido (não se pôde apurar se lucrando ou não) nos problemas de desvio de verbas que levariam ao afastamento de Silva Lima do cargo de presidente da instituição. Cf. Correio Mercantil. Rio de Janeiro, 12 de fevereiro de 1857. p.2. 
constante de agentes que entre as transitavam. O resultado foi aqui proposto como a problematização de núcleos muitas vezes lidos como homogêneos pela historiografia brasileira.

A AIBA, como tantas outras instituições artísticas no país (no seu sentido lato), era regida por fortes tensões e colisões ora de agentes internos, ora externos, as quais (parece) deveriam ser, para todos os efeitos, sombreadas, em função de um "decoro institucional”, tensões que excediam muitíssimo qualquer desacordo puramente estético. É devido a esse decoro que se compreende por que Bethencourt publicou apenas o primeiro artigo da série que desejava divulgar sobre Américo. Impresso em 07 de fevereiro de 1866, a data coincidia com o dia do empossamento do jovem na academia $^{218}$, tornando-se portanto desaconselhável a continuação de uma polêmica aberta entre seus membros, o que consequentemente poderia abalar a imagem de uma instituição que, ainda nesse momento, recebia algumas críticas e oposições a respeito de sua validade.

Em cada uma daquelas colisões, algumas faíscas não se acusaram momentâneas, mas duraram anos a fio, fosse na forma de emulação ou na de indiferença alheia. Esse é o panorama traçado entre Bethencourt da Silva e Pedro Américo a partir da "questão de bacharéis", que embora terminasse oficialmente em 1866, se prolongaria tacitamente por décadas, pois ambos nunca conseguiram chegar a um acordo. Basta lembrar que 13 anos depois desse primeiro episódio será novamente Bethencourt da Silva, em 1879, na imprensa, um dos responsáveis por acusar Américo de plágio, quando esse expunha sua grande Batalha do Avahy ao lado da Batalha dos Guararapes, de Victor Meirelles, também professor do Liceu e amigo do arquiteto, endossando-se assim o coro de uma outra questão, essa então conhecida como a "Questão Artística de 1879”.

Até lá, todavia, muitas águas correram por debaixo da ponte, a primeira delas conduzindo ao dito desfecho oficial da "questão de bacharéis"; encerramento que, afinal, mostrou-se em certa medida satisfatório para os dois lados.

Bethencourt da Silva, depois do fracasso inicial de suas campanhas à deputação e à vereança, conseguiu, ainda em meados 1866, em virtude da suplência conquistada naquela última candidatura, assumir o cargo de vereador, no lugar de uma cadeira que vagava ${ }^{219}$. Em pouco tempo

218 Conforme citado, no dia da publicação desse primeiro e único artigo, Bethencourt, como professor da academia, vai assistir a posse de Américo na instituição. A situação deve ter sido embaraçosa para todos. Talvez ainda mais para Américo, um membro ainda estranho num ninho ocupado já por alguns aliados (Victor Meirelles, Bethencourt, Agostinho José da Motta e Antônio de Pádua e Castro).

219 Bethencourt, na posse ao cargo de verador, afirmou que o seu principal objetivo enquanto vereador seria o de executar "todas as medidas que cumpre por um prático para alcançar-se o embelezamento desta capital até hoje construída sob os impulsos de práticos contrários a todo o sistema do belo, e executadas pela mão rude do alvanil ou do simples prático, e mais das vezes até analfabeto, despindo-se assim uma cidade do século XIX de todo o cunho e regra artística que são inseparáveis das edificações da cidades cultas, muito mais daquelas que se exigirão depios dos belos exemplos dos mestres do renascimento da arte, que unem ao aspecto de morada de um povo ilustre as regras de ciência 
concretizava seus planos e curava todos os seus calos. Poucos meses depois, em 1867, para sua felicidade, o novo cargo político e a aproximação com líderes governamentais "liberais", como Zacarias de Góis e Vasconcellos ${ }^{220}$, ajudaram o arquiteto a reabrir as portas do Liceu, para nunca mais fechá-las.

Américo e Ferro Cardoso, por sorte ou influência, não foram presos. O primeiro, não há novidade, conseguiu o tão desejado afastamento para retornar à Europa, curiosamente sucedido pelo segundo, que também logrou licença da seção de Obras Públicas. Mas antes de viajarem, não se contentaram em deixar que fosse de Bethencourt - com aquela sua longa série de artigos - as últimas palavras da contenda. Prepararam, com efeito, um último ato, para a possível consternação do arquiteto.

Se ambos, por meio da imprensa, não responderam a quaisquer provocações e acusações durante toda vigência da "questão" (atitude que foi por seus acusadores tomada como mais uma prova de que eram culpados), em 20 de fevereiro de 1866 (quando Américo já estava afastado sem remuneração da academia, e se encontrava então na Paraíba), eles mandaram publicar conjuntamente uma nota assinada, na qual se lia, tanto no Correio Mercantil quanto no Jornal do Commércio:

Ao público

Os abaixo assinados tendo sido de certo tempo a esta parte atrozmente insultados em artigos incertos no Jornal do Commércio e Correio Mercantil, os quais, além das injúrias que irrogam, os arguem de usar falsamente o título de bacharéis, e atribuem uma correspondência altamente ofensa a caracteres respeitáveis; tratam de, pelos meios judiciais, punir o responsável, ou os responsáveis de tais publicações, protestam contra a falsidade das cartas, de que os seus anônimos detratores simulam fazer extratos, e declaram ao público que são bacharéis como os que a melhor título o sejam, visto que têm os exames e documentos comprobatórios de suas respectivas aprovações, documentos pela fé dos quais acham-se autorizados a usar daquele título.

BACHAREL PEDRO AMÉRICO

BACHAREL D. P. FERRO CARDOSO 221

para a conservação da vida, pela luz, pela ventilação e pelas outras condições determinadas pela higiene.". "Editais". Boletim da Illustríssima Câmara Municipal da Corte. Rio de Janeiro, julho a setembro de 1866, volume VII, VIII e IX 1. 22 a sessão.

220 Será Zacarias Góis e Vasconcellos quem, em uma de suas gestões como ministro do Império, conseguirá o dinheiro necessário para reabrir as portas do Liceu. Ver: PAES. Op. cit., em diversas passagens sobre o político.

221 AMÉRICO, Pedro; FERRO CARDOSO, Daniel Pedro. "Ao Público". Correio Mercantil, Rio de Janeiro, 20 de fevereiro de 1866. P.3; AMÉRICO, Pedro; FERRO CARDOSO, Daniel Pedro. “Ao Público”. Jornal do Commércio, Rio de Janeiro, 20 de fevereiro de 1866. P.2. 
A resposta, ao menos do lado de Américo, era similar a um míssel teleguiado, uma vez que o artista, já bastante longe da corte, sabia que se tornaria despropositada a continuação da "questão" por seus adversários, já que não estava mais lá para receber qualquer punição ou humilhação imediata.

A permanência temporária na Paraíba, além de servir como uma moderadora dos ânimos e como oportunidade de visitar mais uma vez a sua família, ainda guardava uma última intenção, que seria igualmente eclipsada por seus biógrafos poucos anos depois. Se esses, com a intenção de apagar a memória dos episódios conturbados que Américo viveu nos primeiros meses de 1866, garantiram que ele teria retornado à Europa em 1865, isso foi feito para construir a imagem de um jovem que, vendo-se abalado por calúnias gratuitas, empreenderia essa nova viagem desvalido, sem padrinhos, e por puro amor ao conhecimento e ao engrandecimento de sua pátria ${ }^{222}$.

Não se deve duvidar dos objetivos intelectuais de Américo com essa nova excursão, nem que a polêmica de 1866 o tenha de fato abalado: tratava-se de fato de uma personalidade bastante sensível, especialmente desaprumada quando em contato com as críticas dos seus opositores e zoilos, segundo já percebia com perspicácia Gonzaga Duque, em seu A Arte Brasileira, na década de 1880. O episódio será de fato tão marcante na vida do artista, que ele escreverá mesmo um romance sobre a saga dessa fase: o Holocausto ${ }^{223}$. Já apontado por alguns autores como um romance autobiográfico, o que ainda não se precisou é que não se trata exatamente de uma invenção poética da vida do artista, mas, precisamente, de uma em que reinventa os eventos de sua vida até o momento em que se encerra a "questão de bacharéis". Na biografia de 1871, Guimarães já afirmava fato que Américo teria começado a escrever o Holocausto em decorrência de, e logo depois da eclosão da polêmica da qual ele se viu alvo. Segundo seu biógrafo, logo em seguida à sua nova viagem à Europa:

A sua pena não ficou ociosa nessa época dentro da magra bagagem. Desabafar lágrimas e gemidos é o melhor remédio para quem a dor acabrunha e a desventura martiriza impiedosa.

Pedro Américo escreveu, palpitante de desgosto e de desespero, um romance alusivo à sua tormentosa vida, em cujas páginas a lira da doce inspiração cedeu o lugar à lutuosa harpa das cem dores e dos insondáveis martírios. ${ }^{224}$

222 Ver: GUIMARÃES Jr. Op. cit. p.66-67. Sobre o assunto, Cardoso de Oliveira ainda afirma, a partir de Guimarães: "Não dispondo naquela ocasião de outros meios pecuniários, além do pequeno ordenado de professor de desenho, achava-se Pedro Américo deveras embaraçado para realizar a projetada viagem [...] Em semelhante conjuntura, vendo-se Pedro Américo entregue aos próprios recursos, apelou para as energias do seu caráter, pintou diversos retratos e quadros pequenos, e partiu para a Europa, contando - exclusivamente - com os poucos vinténs que lhe estavam dos gastos diários, entre os passageiros de proa do primeiro vapor que saiu do porto". OLIVEIRA, J. M. Cardoso de. op. cit. p.53. O Texto é idêntico à primeira versão da biografia de Cardoso, publicada em 1898.

${ }^{223}$ AMÉRICO, Pedro. Holocausto, Florença: Typ. Genniniana, 1882.

${ }^{224}$ GUIMARÃES JR. Op cit. p.65-66. 
Basta uma leitura em diagonal do Holocausto para perceber a posição de herói e vítima que Américo coloca seu altergo na narrativa: lá, ele incarna, como em outras obras produzidas ao longo de sua vida, a precisa imagem de Cristo, em seu sacrifício individual, feito em prol de um bem maior, que deveria atingir a todos. O desfecho poético desse romance é, aliás, o mesmo e trágico desfecho da narrativa cristã. Só que, no romance de Américo, em lugar do seu protagonista morrer crucificado, ele terá a cabeça decepada (como um Tiradentes) ${ }^{225}$ : uma imagem sugestiva, oferecida por um artista cujo projeto era o de, precisamente, estimular mais o cérebro do que a mão; dele e dos seus congêneres. Construir a visão de um herói, um escultor intelecualmente cultivado, que termina sua vida com a cabeça cortada, era oferecer não apenas a imagem da derrota de um projeto de quem pensava a importância das artes, mas sobretudo a imagem de uma derrota infligida no ponto nevrálgico de suas investidas.

Essa ideia de artista exemplar, engajado com a arte e o desenvolvimento do seu país, embora apresentado como vítima frequente, se estendeu para todos os textos e publicados sobre Américo por seus aliados ou simpatizantes. Como dito logo acima, especialmente nos trechos que tratam da sequência à "questão de bacharéis" - isto é, do desfecho da primeira fase de sua formação e apresentação das primeiras obras originais - suas biografias insistiram na imagem de um artista que, se embora tivesse sua cabeça simbolicamente cortada logo após apresentar no Brasil seu primeiro projeto, não desistiria, passando todas as amarguras possíveis, a primeira delas, a falta ininterrupta de dinheiro, para realizar seus projetos. Não obstante, não deve deixar de ser no mínimo curioso descobrir que, desde o final de 1863, quando quase encerrava o período da extensão da sua bolsa de estudos européia concedida por d. Pedro II, Pedro Américo também havia requisitado e obtido uma subvenção estatal da Paraíba ${ }^{226}$; benefício cuja última parcela (acumulada por atraso) ele requeria lá mesmo, em pessoa, em março de $1866^{227}$.

${ }^{225}$ AMÉRICO, P. op. cit. p.400.

226 A nova bolsa de Américo foi concedida pelo governo paraibano por meio da Lei Provincial N.86, de 03 de outubro de 1863. Entregaria-se-lha em três prestrações, um conto de réis ao ano. A primeira Américo recebeu em 1864; A segunda, atrasando, foi acumulada e entregue junto à última, em finais de 1866. Abaixo, as informações sobre a concessão da bolsa e requerimentos.

[Despache] "N.1157 - Idem do bacharel Pedro Américo de Figuerêdo, pedindo que se mande pagar a quantia de um conto de réis, consignada por lei provincial n.86 03 de outubro de 1863 para a continuação de seus estudos na Europa. - Informe o Sr. inspetor do tesouro provincial.”. DESPACHES. O Publicador, ano III, Paraíba, 28 de novembro de 1864. P.2

[Despache] "N.1854 - Idem de Pedro Américo de Figuerêdo e Mello, bacharel em ciências, pedindo que se lhe mande pagar 1:000\$000 réis por conta da subvenção concedida ao suplicante pela assembléia provincial. - informe o Sr. inspetor do tesouro provincial." DESPACHES. O Publicador, ano IV, Paraíba, 24 de novembro de 1865. P.1

[Despache] "N.333 - O bacharel Pedro Américo de Figueredo e Mello, professor da academia das belas artes do rio de janeiro, pedindo que se manda pagar a quantia de 2:000\$000rs. que lhe forão consignados por lei provincial. - Ao Sr. inspector do tesouro provincial para mandar pagar nos termos da lei."“DESPACHES". O Publicador, ano V, Paraíba, 23 de março de 1866. P.1 
Essa outra omissão dos seus biógrafos contemporâneos, endossada pelo artista e empreendida para fazer encaixar nele a imagem do "gênio" que se fez sozinho, às custas de muito sofrimento, deixou de lado, portanto, o valor adicional, bastante significativo, de 3 contos de réis que recebera da sua província, ou o equivalente a, na mais complacente das hipóteses, 9 anos e meio de salário médio de um artesão vinculado à Associação Nacional de Artistas Brasileiros ${ }^{228}$, profissional para o qual o adjetivo "desvalido" talvez fosse mais apropriado, se se retomam os choques entre as classes artísticas cariocas do mesmo período ${ }^{229}$.

Emparelhada ainda aos 300 francos mensais ${ }^{230}$ que um bolsista brasileiro no exterior recolhia, em média, dos cofres nacionais, aquela subvenção lhe garantiria mais 8.021 francos ${ }^{231}$, valor equivalente a outros 27 meses e meio de bolsa regular de estudos (ou quase 2 anos), quantia e tempo precisos para que empreendesse sua nova viagem de instrução e formação científica na Bélgica.

É provável que justifique-se assim por que Américo não se importou em anuir a uma licença não remunerada da AIBA e supõe-se ainda que, em decorrência dessa outra subvenção, anunciada

[Despache] "n.1108. O bacharel Pedro Américo de Figueiredo e Mello, pedindo que se lhe mande dar a última prestação que lhe foi concedida por lei provincial. - informe o Sr. inspector do tesouro nacional." O BACHAREL PEDRO AMERICO. O Publicador, ano V, Paraíba, 5 de outubro de 1866. P.2

[Despache]"n.1108. O bacharel Pedro Américo de Figueiredo e Mello, pedindo que se lhe mande dar a última prestação que lhe foi concedida por lei provincial. - Volte aoSr. inspector do tesouro nacional para mandar fazer o pagamento requerido." O BACHAREL PEDRO AMERICO. O Publicador, ano V, Paraíba, 5 de outubro de 1866. P.1.

227 Ver nota anterior.

228 Digo "na mais complacente das hipóteses" (para Américo, claro) pois o cálculo equivalente a 9 anos de meio de trabalho de um artesão é feito considerando que um profissional como esse trabalhasse todos os dias durante esses nove anos e meio, sem direito a quaisquer férias, feriados, festividades ou faltas por motivos de doença, com a única exceção do descanso outorgado aos domingos. Logo, essa é uma condição ideal que acrescentaria, em condições reais, mais alguns anos à conta de quanto tempo de trabalho um artesão necessitaria para receber 3 contos de réis.

229 Refiro-me aqui ao contexto carioca, naturalmente, por se tratar do lugar onde se passam os episódios centrais de parte da trama que me interessou compreender. A situação dos artesãos e artifíces fluminenses não parece, no entanto, se distanciar muito da de demais artistas que trabalham em outras regiões economica e politicamente importantes para o Brasil. Do século XVII até as primeiras décadas do século XIX, o valor da diária de um artesão ativo em Salvador (Bahia), capital do Brasil colônia até 1763 era, por exemplo, regulado em média em 640 réis. Apenas a partir da terceira década abrem-se as primeiras concessões que aumentam o valor para 1000 réis, equiparando-se ao benefício requerido, na década de 1850, aos artesãos vinculados, no Rio de Janeiro, à Associação Nacional de Artistas Brasileiros. Para uma recente apresentação de questões concernentes ao trabalhos de artesãos atuantes em salvador do período colonial até metade do século XIX, ver : CAMPOS, Maria de Fátima Hanaque de. A pintura religiosa na Bahia, 1790-1850 (Tese de doutoramento). Universidade do Porto, Faculdade de Letras, 2003.

230 Em média, o valor de uma bolsa de estudos no exterior era de 300 francos mensais. Américo, no entanto, recebia da Casa Imperial uma quantia um pouco acima do esperado: 400 francos. Além desse valor mensal, que recolheu entre 1859 e 1864, ainda obteve valores extras para compra de enxoval, materiais de pintura e desenho e para a conclusão da Carioca, encomendada ao jovem entre 1862-63.

231 Em 06 janeiro de 1866, a cotação do câmbio acusava a conversão de 374 réis para cada franco. Trezentos francos (valor médio de uma bolsa mensal de um estudante do governo) equivaleriam, portanto, a aproximadamente 149.333 réis. Para ver a cotação do câmbio do dia, ver: CORREIO Mercantil. Rio de Janeiro, 06 de janeiro de 1866. p.3.

No ano de 1865, o câmbio entre as mesmas moedas havia variado entre 296 réis (valor mínimo) e 391 réis (valor máximo de conversão) para cada franco. A tabela completa desses valores pode ser encontrada em: ALMANAK Administrativo, Mercantil e Industrial da Corte e Província do Rio De Janeiro. Ano XXII. Rio de Janeiro: Eduardo \& Henrique Laemmert, 1865. p.214. 
quando ainda se encontrava na Europa, já tivesse a aludida certeza de seu breve retorno, tão logo atravessasse o processo do concurso para a academia, para o qual foi, como visto, compulsoriamente requisitado pelo monarca, e para com quem o jovem possuía um "dívida moral", em decorrência de todas as benesses que até então havia obtido ${ }^{232}$.

Em 1869, em fogo baixo por pouco mais de dois anos, Américo e seu amigo Ferro retornavam, ambos, de Bruxelas, laureados publicamente. Agora com diplomas válidos, porém não mais o de bacharel. Tornavam Doutor Ferro Cardoso, e Doutor Pedro Américo:

Com prazer informamos aos nossos leitores da torna viagem de dois moços, patrícios nossos, que deram exuberantes provas públicas, na França e na Bélgica, de seus invejáveis talentos.

O governo acaba de fazer um grande favor à academia das belas artes aproveitando os serviços do primeiro chegado, o sr. dr. Pedro Américo de Figueiredo e Mello, para a cadeira de história das artes, estética e arqueologia.

Indubitavelmente o sr. dr. Pedro Américo é um gênio, que se deleita em reproduzir na tela a beleza ideal.

Como literato, já tem exibido muitas provas de grande merecimento.

O segundo, chegado há poucos dias, o sr. dr. Daniel Pedro Ferro Cardoso, obteve em Paris e Bruxelas o que lhe foi tão obstinadamente aqui negado, o público reconhecimento de seus grandes talentos.

Os jornais, os capitalistas e arquitetos de Bruxelas discutiram e coadjuvaram os vários projetos, esboçados pelo nosso patrício, para o embelezamento da capital.

O Sr. Ernest Laitat publicou um folheto com o seguinte título: '..Recueil de publication qui ont paru en Belgique au sujet de travaux de Daniel Pedro Ferro Cardoso, docteur en sciences de l'université de Bruxelles, etc., etc.'

Continuará ainda o paiz, como o governo, a menosprezar e preterir talentos nacionais? ${ }^{233}$

Se Américo, especificamente, retornava ao Brasil ambicionando consolidar, enfim, publicamente, o direcionamento intelectualista a que se atribuiu desde o fim da década de 1850 não apenas com a formação parcial do bacharelado e com a conclusão do seu doutorado, mas com a rápida mudança que fez da docência de uma cadeira prática para outra mormente teórica, e com a atuação na seção de Arqueologia do Museu Nacional, ocupada anteriormente por seu futuro sogro, Porto-Alegre -, não abriria mão, todavia, de gozar da atribuição concomitante de "gênio" das artes nacionais.

Essa rotulação, esparsamente invocada por seu aliados na imprensa nos seus primeiros anos na corte, logo se tornaria, a partir de 1871, metódica, com o uso de fórmulas discursivas, inauguradas na sua citada biografia: aquela que seu amigo, Luís Guimarães Júnior, escrevia e

232 Deve-se lembrar novamente que Américo, em fins de 1862, já havia se matriculado no doutorado na Universidade Livre de Bruxelas, para onde iria de fato em 1866.

233 S/A."BRASILEIROS DISTINCTOS". Opinião Liberal. Rio de Janeiro, 18 de setembro de 1869. P.4. 
publicava. E será esse um novo momento de atividade e concentração de Américo e de seus aliados para que seus projetos políticos e artísticos, malogrados entre 1864 e 1866, fossem outra vez retomados. Mas agora, a campanha, talvez um pouco mais modesta, será para que ele fosse ao menos empossado como diretor da $\mathrm{AIBA}^{234}$, algo que, mais uma vez, não ocorrerá.

Para sustentar essa imagem biográfica, é evidente que seus aliados tiveram que fazer dobras discursivas para colocar Américo no lugar de destaque que queriam, e, para tanto, a memória dos contemporâneos sobre a "questão de bacharéis" teve de ser, senão apagada, ao menos reorientada, bem como o dado de que Américo havia, de fato, ostentado um título sem poder prová-lo legalmente (mas não intelectualmente) A propósito, a despeito de tudo, certo é que Américo, desde 1862, mais do que afirma-se indevidamente bacharel: ele se sente de fato um, não apenas por que dispunha de "documentos comprobatórios" (os quais, no ano anterior, antes da reforma curricular na Sorbonne, lhe dariam de fato um diploma), mas por que supunha que o esforço dos seus verídicos intentos científicos - cujo atestado social acreditava ser aquele título, e cuja finalidade seria a execução do seu projeto para as artes no Brasil - constratava com os vícios de uma sociedade escravocrata e "preguiçosa" ainda vigente no país, da qual não era nenhum pouco simpático, mas cuja manutenção era sustentada, curiosamente, pela mesma elite intelectual da qual ele se percebia integrante e pela qual sonhava ser abraçado.

Uma vez combinados o sentimento de superioridade que demonstrou manter diante de uma sociedade como essas (mesmo que desejasse mudá-la), com outro sentimento, o de frustração, decorrente da impossibilidade de realizar essas mudanças, se deve ter alertado ao artista e a seus aliados o quão perto ele estaria da noção romântica do "gênio", da imagem do indivíduo que se destacaria sobre todos outros, mas que, por isso mesmo, não conseguiria espaço entre eles e em seu tempo. Para construir a imagem exemplar de um homem "real" que desejava fazer diferença em seu entorno, não se prescindiam alterações e omissões desses episódios infelizes de sua vida, no sentido de torná-lo, assim, um exemplo; no sentido de parecer incontornável a impressão de que deveria ser, ele, o agente central para as mudanças da "classe" geral artística, em sua desejada continuidade aos

\footnotetext{
${ }^{234}$ Ver, por exemplo: ARSEOS. Analyse esthetigraphica do quadro de um episodio da Batalha de Campo Grande planejado e executado pelo Dr. Pedro Americo de Figueiredo e Mello, lente da cadeira de esthetica da Academia das bellas artes do Rio de Janeiro. Rio de Janeiro: Typographia Nacional, 1871.

Trata-se de um, entre vários outros textos de aliados de Pedro Américo que, em 1871 - logo após ele inaugurar o curso de História das Belas Artes, Estética e Arqueologia da AIBA, assumir o cargo de conservador do Museu Nacional, e e apresentar a Batalha do Campo Grande (feita às próprias custas, já aludindo ao espírito notadamente krausista de suas empreitadas) - foram publicados e enaltecimento ao artistas, atestando as suas excelsas capacidades para assumir um lugar importantes para o desenvolvimento das artes no Brasil. Sobre um panorama, a meu ver, muito acertado sobre as discussões que se desenvolvem em torno de Américo nesse periodo, ver: CARDOSO, Rafael. "Ressuscitando um Velho Cavalo de Batalha: Novas Dimensões da Pintura Histórica do Segundo Reinado". 19\&20, Rio de Janeiro, v. II, n. 3, jul. 2007. Disponível em: <http://www.dezenovevinte.net/criticas/rc_batalha.htm>. [último acesso: outubro de 2014].
} 
projetos de Porto Alegre, especialmente quando outros, como Bethencourt da Silva, almejavam o mesmo.

Esse parece ser um dos pontos mais significativos nas possíveis interpretações sobre a exclusão da “questão de bacharéis" nas biografias de Américo. É certo que essa como outras omissões nessas narrativas foram, em uma perspectiva de médio ou longo prazo, ora benéficas ora maléficas à sua imagem.

Para o lado dos prejuízos futuramente colhidos - alguns contra os quais esta Tese se colocou -, que são os que interessam mais comentar ${ }^{235}$, resta ainda em torno da imagem de Américo a resistente ideia de que ele se tornaria, como dito na introdução desta Tese, o "maior pintor brasileiro e o menos brasileiro dos pintores", em referência à sintética mas carregada máxima Lobatiana ${ }^{236}$. Segundo essa interpretação, as inúmeras licenças que Américo pediu, desde a sua posse, atestariam que ele teria tornado a face para o lado oposto ao do Brasil, desejando se manter afastado do seu país e, encantado com as luzes européias, permanecer na França e na Itália, sobretudo.

No propósito de esconder os percausos de 1866, provavelmente perniciosos à construção positiva da imagem do artista, as suas primeiras biografias tiveram que esconder não apenas o dado de que Américo não era tão paciente ou complacente quanto afirmavam, mas também se resignar da omissão de outro que, dentro da mesma "questão", poderia ser proveitoso ao jovem. Esse dado parece apontar para a conclusão de que o artista, em função das estratégias que havia escolhido para apresentar seus projetos e ainda dos embates desde logo efetuados com outros professores da AIBA, e especialmente com Bethencourt e seu aliados, encontrou de pronto um ambiente politicamente hostil a qualquer ação futura dentro da instituição. Se essa incompatibilidade fosse anexada ao delicado quadro de saúde do artista que se agrava nos anos seguintes (quase ignorado, quando não

\footnotetext{
${ }^{235}$ Sobre os frutos positivos colhidos pelas biografias sobre Américo, talvez maior que os negativos, os lapsos propositadamente tencionados por elas atestam, em última instância, a consciência do artista (cuja colaboração com seus biógrafos é enorme) sobre a construção de uma imagem histórica, atravessada por uma narrativa pessoal exemplar. Américo parece saber bem que a biografia (como o autorretrato ou o romance auto-biográfico) não era uma evidência do que alguém havia sido, mas uma sugestão daquilo que interessava fazê-lo parecer; ou, mais acertadamente, de que se trataria de uma memória ativa e seletiva do passado, lançada à posteridade. Essa sua consciência se intensificará muitíssimo da década de 1860 em diante, quando também passará a se auto-representar direta ou indiretamente em todas as suas obras pictóricas mais significativas, isto é, as pinturas históricas, e a tomar seus próprios traços psicológicos e episódios de vida (sempre da maneira como os via) para compor narrativas romanceiras (e ainda publicando nelas, em prefácio ou posfácio, suas biografias "reais").
}

As produções que fará retomarão então, com cada vez maior constância, seus valores pessoais como maneira enfática de afirmar ora a importância da sua imagem (apresentada às positivamente, às vezes, mais para o fim da vida, negativamente) $n a$ história nacional, ora a importância da sua imagem para a construção de uma concepção da história nacional.

Contestando-se ou não as versões biográficas endossadas pelo próprio artista e por seus diversos aliados, o fato é que elas lograram mais do que falharam, posto que até hoje mantêm-se referências irreversíveis.

236 LOBATO, Monteiro. “Pedro Américo”, Revista do Brasil, ano 1, vol.3, n.11, pp.256-272, nov.1916. 
ironizado em vários estudos a seu respeito) e se ainda se considera a conhecida dificuldade de se realizarem projetos para as artes no Brasil durante o século XIX, talvez fossem mesmo poucos os campos de atuação que ainda restassem a Américo no país.

Essa não é, naturalmente, uma justificafiva ulteriormente "descoberta" que o absolveria do seu contínuo afastamento físico do Brasil, mas se apresenta, no mínimo, como um dado novo a ser considerado quando se abordam alguns episódios da vida desse artista, já há muito cristalizados em juízos curtos; dado para o qual esta Tese, resgatando as bases de sua formação artística e filosófica, tentou chamar atenção. 


\section{Conclusão}

Esta Tese esteve integralmente concentrada nos anos de formação e de início de carreira do pintor e filósofo Pedro Américo de Figueiredo e Mello. Prestou-se especial atenção ao período que se estende de 1859, momento de sua primeira ida à Europa, a 1866, ano em que retorna novamente a esse continente para realização uma segunda fase de formação, exclusivamente científica.

Problema de fundo fundamental para esta pesquisa se traduziu pelo questionamento inicial dos diversos rótulos e habilidades que foram imputados ao artista, atribuições estas que acabaram por condensar, de um lado, a partir de determinado momento de sua carreira, a ideia positiva de um artista universal; e, de outro, na negativa que identificava se tratar isso de um triste "desbrasileiramento", como se Américo, desejando ser muitas coisas, tivesse esquecido o que deveria ser seu compromisso primeiro, enquanto artista, com a realidade brasileira e com a formação da tão esperada arte nacional. Muitas das leituras aqui desenvolvidas lidaram ora tacitamente ora mais claramente, com o oposto desta última ideia.

No cerne desta Tese esteve a problematização e, pode-se afirmar, a primeira contribuição realizada no sentido de se lançarem algumas primeiras respostas sobre o significado da imagem de um Pedro Américo que não era apenas pintor. Precisamente, o significado de tudo o que está para além desse "ser pintor" permanece estampado em adjuntos turvos ou, no mínimo, superficiais, não apenas nos primeiros textos escritos sobre o artista, no século XIX, mas em estudos atuais, os quais, em boa medida, repetem esses qualitativos (ora para o bem, ora para o mal) sem de fato compreendê-los.

Problema já não mais de fundo, mas de linha de frente nesta Tese, tornou-se, portanto, a indagação sobre os motivos que transformaram as diversas atuações e faculdades convergidas a Américo sobretudo as atuações intelectuais e científicas - em algo tão importante de ser reforçado em sua carreira. Em outras palavras, tornou-se relevante descobrir por que interessou tanto e permanentemente a esse pintor se fazer conhecido como um artista bacharel-doutor-cientista-filósofo-romancista-político, entre várias outras adjetivações.

Para melhor compreender tal questão, esta pesquisa deteve seu escopo no período em que essa imagem aureolar começou a se construir de maneira programática e, inicialmente, por esforço próprio 
de Américo. Esse processo se iniciou justamente nos anos de formação do artista, mormente no período conclusivo de sua formação européia, quando as suas primeiras produções originais permitiram perceber de maneira mais evidente suas intenções políticas, artísticas e filosóficas, na apresentação de cada uma delas.

O que se tornou desde logo claro nesta investigação, e aqui sustentado repetidamente como hipótese central, foi a estruturação que o então jovem pintor começava a fazer de um projeto complexo para as artes brasileiras, no qual ele era, ao mesmo tempo, causador (na qualidade de autor) e causa (na qualidade de artista também tocado pelos problemas concernentes a tal projeto). Os objetivos principais desse plano visavam uma mudança completa do cenário artístico brasileiro, reconfigurando todas as suas relações com o contexto social, cultural e econômico. Tratar-se-ia de fazer revalorizar as artes num país ainda escravocrata em que ambas as raízes ars e techne, em seus significados relacionados ao "fazer", amparavam o preconceito do trabalho artístico como atividade mecânica e, portanto, subalterna, em contraste com a raíz episteme, em sua ascepção de "saber" abstrato, que tão recorrentemente alimentava a estima pela cultura bacharelesca no país do período. A formação em bacharelado, especialmente em Direito, considerada mesmo em sua origem etmológica (bacca + laureatus, isto é, laureado com ramos de oliveira, ou ovacionado), explica de fato muitas relações sociais e culturais ainda presentes no século XIX, no país, como já demonstrado por vasta bibliografia.

Américo desejava elevar a consideração social da sua profissão ao grau de atividade liberal e, além disso, necessária ao país, e para isso passou a emprender a defesa da importância inadiável da educação: de um lado, a educação intelectual do artista; de outro, a educação artística obrigatória do povo brasileiro, centrada sobretudo do ensino do desenho. Tal resolução, se implementada, prosseguiria em um duplo e positivo fluxo, cujos primeiros efeitos seriam espraiados pelas bases da "pirâmide social", estratificando-se em seguida verticalmente, até os dirigentes do país, que então perceberiam, enfim, o papel considerável que as artes deveriam desempenhar em qualquer país ou período da história. Mas essa transformação deveria ser, paradoxalmente, ativada por uma direção inversa, de cima para baixo: isto é, deveria ser tarefa dos "legisladores" do país instituirem um tal programa; eles eram, com efeito, uma constante dominante e insubstituível na resolução da equação das artes brasileiras, que Américo desejava então resolver.

Bem entendido nesta Tese, este foi um projeto que o jovem não havia inventado, mas havia herdado diretamente do contexto brasileiro da década de 1850, a partir do seu contato com Manuel de 
Araújo Porto Alegre (também por certo indiretamente, a partir do legado da "era" F.-E. Taunay), e se deparado novamente na Europa, em específico na França, na década de 1860 - embora, ali, alguns dos postulados iniciais desse mesmo projeto se apresentassem sensivelmente diferentes. No Brasil, a luta iniciada por Félix-Émile Taunay desde os anos 1830 e 1840 é para desenvolver a cultura artística num país pouco inclinado a seus dotes, exigindo dos artistas formados na Academia uma educação mais alargada, e se ocupando, ele próprio, de traduzir manuais e oferecer material inédito aos alunos, além de iniciar campanha ininterrupta para a criação da mesma cadeira de história da arte. Nos anos 1850, Porto Alegre retoma esse projeto com bastante vigor - beneficiando-se de um momento político propício bem como de relações pessoais providenciais -, e adiciona uma variável antes já existente dentro da instituição ${ }^{1}$, mas muitíssimo pouco explorada prática e curricularmente: a da relação entre arte e indústria, tornando-se esse problema capital para as diretrizes da nova reforma que implementará em 1854-1855.

$\mathrm{Na}$ França dos anos 1860, por sua vez, as cobranças oficiais também passam a exigir dos jovens artistas um compromisso teórico e crítico crescente, e não era de fato raro escutar personalidades artísticas e políticas importantes do periodo clamarem aos alunos que se espelhassem nos modelos do "artista universal" ou do artista filósofo de outrora. No ambiente europeu, o problema que se apresentava era o combate à crise da "arte moderna" e à especialização das atividades artísticas, estas que, respondendo a novas teorias artísticas e filosóficas, pareciam marchar em direção a um isolamento epistemológico, caminho que culminaria de fato, em sua expressão crítica, no discurso sobre a autonomia e confinamentos artísticos nas linhagens formalistas do fim do século XIX e primeira metade do século XX. A sustenção das autoridades francesas de não-especialização e de nãoautonomização da arte esperava garanti-la (aliás, ela e seu autor) como elemento direta e "positivamente" útil à sociedade, já que possuiria um papel importante a cumprir. Esse era um discurso garboso, sem dúvida, mas que recorrentemente incobria os interesses econômicos que o amparavam, decorrência da pressão da indústria e das exigências postas sobre mercados nacionais que passavam então a competir entre si num cenário de trocas internacionais de bens e serviços, que se alargava rapidamente.

No âmago e na fronteira dessas questões nacionais e internacionais, foram situadas, nesta pesquisa,

\footnotetext{
${ }^{1}$ Digo isso porque alguma das disciplinas fundadas na AIBA após a reforma de 1855, embora não fossem oferdas na academia, eram obrigatórias de serem seguidas pelos alunos, na Escola Militar.
} 
as atividades que Américo desenvolveu naqueles anos. Argumentou-se como ele havia levado todas as premissas que pressupunham a exequibilidade dos projetos brasileiro e francês a seu último grau, especificamente quando aplicadas a seus objetos-alvo: os estudantes de arte e de ofícios, a própria condição pessoal do brasileiro no período.

Capítulo após capítulo, o plano de trabalho delimitado nesta Tese, convencional mas estrategicamente organizado em ordem cronológica $^{2}$, seguiu o jovem artista nas primeiras manifestações públicas do seu projeto, sempre que possível confrontando-as com apreciações privadas sobre as mesmas intenções que apresentava em cartas a seus interlocutores do período.

A partir de um estudo detido de quatro obras inéditas de juventude - ainda bem pouco estudadas e jamais analisadas nas relações programáticas existentes entre si, aqui defendidas - se interpretou pela primeira vez os passos realizados por Américo durante os seus anos de formação, bem como os seus significados. Essas análises foram suportadas por uma pesquisa de base consideravelmente grande abraçando fontes primárias e secundárias, no Brasil e no exterior, muitas das quais inéditas -, o que permitiu compreender com relativa segurança não apenas as suas intenções de início de carreira, mas, do mesmo modo, suas preferências artísticas, estéticas e a profundidade de sua dedicação intelectual, características que atravessaram toda a sua trajetória.

Pela análise dos textos escritos publicados por Américo em 1863, 1864 e 1865 (respectivamente La réforme de l'École des Beaux-Arts et l'opposition, Considerações Filosóficas sobre as Belas Artes entre os Antigos, e as Cartas de um Plebeu aos Srs. Deputados), se compreendeu essas produções como respostas bastante calculadas a questões maiores que envolviam a arte em sua relação com a cultura e a economia, na segunda metade do século XIX. Essas produções não foram analisadas apenas internamente, em relação a seus significados projetados, nem como maneira de saber apenas o que Américo queria dizer e fazer. Tão importante foi o esforço de se colocar justamente essas intenções em relação aos contextos que as teriam estimulado.

As investigações aqui empreendidas chegaram - assim se espera - a novas compreensões sobre questões maiores que orientaram Pedro Américo em sua carreira, e ainda sobre o contexto artístico brasileiro dos anos 1850 e 1860, elucidando uma série de pontos ainda muito pouco tratados. Esses

\footnotetext{
${ }^{2}$ Mais uma vez, agradeço a Fernanda Pitta e a Elaine Dias pelas várias conversas que tivemos sobre o problema da organização da data, que me levaram a adotar à Tese esta forma final.
} 
resultados parecem ainda indicar caminhos para a reavaliação futura de algumas interpretações realizadas sobre o mesmo artista e obra em fases posteriores de sua vida.

Uma primeira e nova compreensão já abre, com efeito, esta Tese. No Primeiro Capítulo, investiuse desde o início em uma perspectiva que pudesse esclarecer que não apenas em sua fase mais madura Américo procederia a ações específicas e a aproximações calculadas para realizar os seus planos fosse para produzir pinturas, ou para se introduzir como alguém capaz de assumir cargos políticos e administrativos de importância. Percebeu-se que essa movimentação política já era bastante frequentada pelo artista desde o início de carreira. O resultado mais evidente dessa observação foi apresentado por meio da apreciação do lugar singular que lhe coube nos debates sobre a reforma da École des Beaux Arts de Paris, em 1863. Está claro que ao se tornar o único aluno - além disso um estrangeiro - a publicar um texto independente e a favor das grandes e polêmicas mudanças empreendidas naquela instituição, Américo afirmava publicamente, em contexto internacional, não exatamente sua solidariedade isolada aos reformadores franceses, mas as medidas que ele próprio imaginava serem necessárias de serem retomadas no Brasil. Ele elogiava a reforma da École por ver nela uma qualidade similar de esforços que havia testemunhado no Brasil 9 anos antes, em 1855, quando integrava a primeira turma da AIBA pós-reformada por Porto Alegre.

O que interessou a Américo nessa reforma foi, portanto, a confirmação, na França, dos postulados que o haviam guiado desde a sua formação brasileira. Nesse Primeiro Capítulo foi estruturado pela primeira vez um panamora suficientemente grande das bases de formação do jovem artista, a primeira delas a ser discutida, filosófica. Tratava-se de uma imersão também iniciada no Brasil, e conjuntamente estimulada na AIBA e no Colégio D. Pedro II, que propunha o Ecletismo de Victor Cousin como método filosófico fundamentalmente "moderno", tornando-se naquele momento o mais adequado para um artista que desejava que deseja se tornar um intelectual, e que sua arte fosse ainda recebida moral e inteligivelmente. Esse mesmo ecletismo informou também à base artística de Américo um dos valores fundamentais e incontornáveis que passaria então a defender em sua carreira: o da liberdade. A fé inquebrantável nos modelos gregos que F.-E. Taunay pedia aos alunos da AIBA, nos anos 1830 até 1850, já não valia mais para Américo, a partir de 1855, embora ele continuasse a respeitar e a estudar com afinco os clássicos. Essa reavaliação era inicialmente fruto, como visto, das orientações de Porto Alegre, que pedia de fato em seus discursos que os alunos analisassem e estudassem todas as correntes artísticas possíveis. Era, com efeito, tal demanda de alargamento, já inscrita no método eclético, que apresentava ao jovem artista toda a potência da história: importância dupla para um artista que desejava 
conhecer o belo nas mais variadas manifestações feitas pelo homem, e que caminhava rumo ao final de sua formação, justamente, em pintura de história.

Ainda no Primeiro Capítulo da Tese se discutiu, também pela primeira vez, algumas das razões que levaram a Américo a escolher seus professores particulares franceses. Dissipada a confusão sobre quais teriam sido de fato os seus mestres diretos, foi possível indagar, por fim, a importância do seu primeiro professor no cenário artístico francês, o 'liberal' Léon Cogniet, e compreender o papel ainda mais fundamental que terá o até então desconhecido Cornu para a trajetória de formação de Américo e para a estruturação dos seus primeiros projetos: também Cornu era um pintor de história, estudioso, participante de comissões de reforma do ensino artístico, e responsável pela montagem de um significativo primeiro museu de artes plásticas e industriais na França - tudo o que o jovem brasileiro se propunha a ser e a fazer no Brasil.

Mapeados portanto, inicialmente, a formação e o esboço do projeto que Américo então desenvolvia para si e para a arte brasileira, os capítulos seguintes trataram de segui-lo em suas primeiras aparições concretas, a saber: uma teórico-filosófica, uma prático-artística e uma política.

Como a primeira dessas aparições, o texto Considerações Filosóficas sobre as Belas Artes entre os Antigos foi estudado a partir de sua contribuição mais patente: ele se apresenta como o fundamento intelectual do projeto do jovem Américo. Atravessando-o pela arqueologia, pela filosofia, pela teoria e pela história da arte, o brasileiro circunscrevia seu estudo em uma questão frequente desde o século XVIII (quais foram as causas da perfeição da arte grega?), encontrando na resolução desse problema a oportunidade para elaborar os meios necessários para o desenvolvimento das artes no Brasil. Argumentou-se que a resposta a essas questões se configurou, por fim, como uma teoria artística de fundo moral e idealista, mas que deveria estar necessariamente engajada com o presente, cujo maior objetivo era o da realização do Belo ideal. Essa teoria - fruto da aplicação que o jovem fazia, desse modo, do método eclético, ainda que já atravessada em alguns pontos pela doutrina krausista propunha como ação incontornável o compromisso com a educação do povo brasileiro em geral, e dos artistas, em específico, sempre com a necessária participação do governo.

A importância dada à educação não se traduzia apenas no conteúdo do texto, mas em sua forma. Sustentou-se nesta Tese que Américo de fato concebia seu Considerações Filosóficas como o primeiro curso de história da arte publicamente apresentado no Brasil, amparado ao mesmo tempo pelo desejo de reativar as demandas brasileiras apresentadas por Taunay e Porto Alegre, e pelo diálogo direto com 
o primeiro curso de estética e história da arte inaugurado na École des Beaux-Arts, que ele próprio havia seguido em Paris. Essa intenção, combinada com a proposições da teoria por ele esboçada explica, e muito, a transferência que, em 1869, pedirá da cadeira de Desenho Figurado - isto é, uma cadeira prática - para a cadeira teórica de História das Belas Artes, Estética e Arqueologia, jamais ocupada na AIBA. Esse apossamento nada mais era do que o compromisso pessoal que ele demonstrava ter para com o seu projeto artístico, tratando de se dedicar à formação intelectual dos estudantes da academia, a seu próprio exemplo, num momento em que ele ainda não havia conseguido galar uma posição política no Brasil.

Após discutir sobre a natureza e extensão da parte filosófica e teórica do projeto do brasileiro, se argumentou nos dois seguintes capítulos sobre $A$ Carioca de que maneira esta pintura se apresentava como a expressão prática da sua teoria artistíca. Com efeito, identificou-se pela primeira vez, nesta Tese, o caráter inseparável e mesmo programático de Considerações Filosóficas com a primeira pintura original de Pedro Américo. A Carioca era concebida como a "encarnação" do Belo ideal, tão defendido pelo artista, e isso pôde ser argumentado mais concretamente nesta Tese com a descoberta de uma reprodução inédita da primeira versão de obra, sem dúvida um achado valioso que já permite estabelecer uma série de contraposições e leituras dos distintos contextos das duas versões, e das proposições que Américo havia pensado para cada uma delas. No cruzamento de referências contemporâneas e antigas, extremamente importantes ao artista - aqui enfatizado a partir de uma "reconstrução" do percurso das obras que ele havia visto em diversas cidades, e das discussões artísticas que havia presenciado durante seus anos de formação européia -, foi possível concluir o seu esforço em entregar uma figura que se pretendia universal, posto que programaticamente "ideal". A confirmação desse pretendido caráter em sua Carioca veio, nesta pesquisa, por meio do estudo que Américo fazia, na prática, dos princípios que havia aprendido em sua leituras estéticas. Demonstrou-se como ele construiu sua naiáde notadamente a partir de um conjunto tradicional de valores que pressupunham o Belo ideal, buscando como resultado uma figura unitária, devidamente variada em seus elementos compositivos, conformada em proporções clássicas, e atravessada também ecleticamente por diversas referências de artistas antigos e "modernos".

Contudo, esteve presente a argumentação de que a conformação de uma imagem ideal de modo algum excluía, para Américo, o principal objetivo de sua pintura: tornar-se um ideal brasileiro. Trata-se de uma interpretação inédita, realizada nesta Tese, que identificou $A$ Carioca como uma tentativa do jovem artista em entregar um novo tipo mitológico e alegórico para o Brasil, um tipo branco, 
intimamente filiado aos postulados das teorias raciais dos anos 1850 e 1860. Além disso, foi visto que Américo aderia não apenas à ideia de um "tipo" brasileiro branco, mas a um "tipo" que não fosse, sobretudo, pardo (e, por extensão, negro), opondo-se desse modo, publicamente e de maneira inédita para um artista de sua visibilidade, ao projeto indianista fomentado por seu mentor, Porto Alegre, no IHBG (entre outros), e frequentado artisticamente por colegas de profissão e trabalho, como Victor Meirelles.

Mesmo se correspondendo em boa medida ao projeto teórico esboçado por Américo em suas Considerações Filosóficas, se defendeu que A Carioca ainda havia deixado lacunas entre a sua realização definitiva enquanto obra de arte e as premissas do Belo ideal e moderno que a amparavam. Não há dúvidas de que o jovem tivesse se empenhado em circunscrevê-la no domínio do ideal e da modernidade: sua pintura estava em estreita relação com toda a discussão artística internacional do período, que ainda colocava o nu (e, nesse momento, especialmente o nu feminino) como objeto central da conformação poética na grande arte. Entretanto, o "ideal moderno" que Américo rogava teoricamente era um ideal que se ancorava cada vez mais em uma visão da filosofia krausista: uma arte politicamente engajada, que respondesse diretamente às questões do seu tempo, mas sempre filiada à moral, equilibrada entre a razão e a imaginação. Tratando-se de um nu que se queria mitológico, mas sem se amparar em quaisquer fontes textuais (realização que foi possível ao indianismo brasileiro, a partir de sua conexão com a literatura nacional e internacional), essa moralidade e modernidade na ninfa do jovem artista haviam permanecido apenas em nível formal e, desse modo, se apresentaram de maneira bastante tênue. No fim, a primeira obra de Américo se aproximava mais da visão eclética da autonomia da arte (que o jovem manifestava abertamente não aceitar) do que da ideia de uma poética comprometida com um presente de algum modo identificável. Destacou-se que seria preciso esperar até 1869 para ver o artista iniciar sua primeira contribuição krausista com a Batalha do Campo Grande, que respondia então, de perto, a seu projeto teórico em todas as suas demandas.

Concluídas as exposições teóricas e práticas do que se defendeu ser o projeto de Américo, o Sexto Capítulo tratou de desenvolver a sua última expressão, quando o jovem, prestes a se tornar professor da AIBA, lançava uma campanha política para fazer com que as suas ideias pudessem ser, enfim, concretamente aplicadas no país. As Cartas de um Plebeu aos Srs. Deputados, tratadas no referido capítulo, foram, com efeito, apontadas como a manifestação política do projeto teórico de Américo. Estudou-se como ele se dirigiu ao elemento ativo mais importante de sua teoria (os legisladores), no sentido de chamar a atenção para o principal objetivo dela: a educação artística, em todas as suas 
relações econômicas e culturais.

Nessa parte final sobre o projeto de Américo, ficou patente a natureza do seu texto enquanto um rapport, isto é, um texto em que explicitava os problemas das artes no país, propondo-lhe ainda soluções. Essa proposição se configurou como a ideia de formação de um conjunto de instituições de ensino artístico (algumas delas que continuariam a ser relembradas por Américo décadas depois), e incluiu, também, a intenção de se realizar uma nova reforma na AIBA. Conclui-se o interesse do jovem artista em ser o continuador e o ampliador da reforma de ensino artístico iniciada por Porto Alegre, em 1855; reforma cujos efeitos, segundo deixava entender, não teriam sido ainda inteiramente percebidos, além de se restringirem ao circuito da corte. De um lado, sua ideia era a do fomento de uma estrutura de ensino que promovesse ao mesmo tempo o desenvolvimento das artes plásticas e industriais em todo o território nacional, a partir da horizontalização e obrigatoriedade do ensino artístico nas escolas secundárias, além da criação de cursos de desenho linear, escolas de belas artes provinciais e novos museus. De outro, num nível mais restrito, seu interesse se voltava para a renovação da Academia das Belas Artes, no Rio de Janeiro, especialmente no que dizia respeito a seus métodos de ensino. Sobre esta questão, Américo parecia defender a instalação de um novo método artístico, já afastado das orientações clássicas, que se aproximava, em acordo com todas as suas ideias teóricas desenvolvidas em outros textos (liberdade, imaginação, originalidade), das famosas experimentações desenvolvidas por Lecocq de Boisbaudran, quase certamente seu professor na École Gratuite de Dessin, em Paris. Tratava-se de um método de "educação da memória pitoresca" que visava estimular antes a potência imaginativa do aluno, do que obrigá-lo a copiar, durante anos, os modelos clássicos em gravuras e esculturas, e apenas depois acessar a natureza.

As propostas de Américo, contidas em seu extenso plano de ampliação institucional e de reformas das artes no Brasil, nunca puderam sair do papel. Entretanto, as estratégias que empreendeu e a aproximação que fez de alguns aliados lhe trouxeram, na sequência da exposição de seus intentos, alguns resultados dolorosos. O enredo que sucedeu essa apresentação foi o objeto do último capítulo desta Tese, também inédito em seus materiais e resultados. Nele, tratou-se especificamente da conclusão dos projetos imaginados pelo jovem na primeira fase de sua carreira, que viria em forma de uma obstinada campanha para que ele e seu amigo Daniel Pedro Ferro Cardoso fossem presos, a partir do momento em que se descobriu que eles não possuíam, formalmente, o título de bacharel em ciências naturais de que tanto se orgulhavam. Demonstrou-se que o principal protagonista dessa campanha havia sido outro professor da AIBA, Francisco Joaquim Bethencourt da Silva - arquiteto e também 
fundador do Liceu de Artes e Ofícios do Rio de Janeiro. O que ficou claro era que o engajamento de Bethencourt na realização de ações contra Américo e seu amigo decorria, em grande medida, da concorrência que então percebia ter sido estabelecida com aqueles dois jovens. Mais do que se opor a uma apresentação indevida de diplomas - se conclui -, a Bethencourt interessava enxovalhá-los publicamente, para que ambos, bastante próximos dos políticos mais poderosos do Império, em sua grande maioria "conservadores", não pudessem atrapalhar os seus próprios projetos, os quais, em muitas de suas proposições, se alinhavam bastante ao dos jovens.

Com esse Capítulo, foi antecipada cronologicamente em quase 15 anos uma briga intensa que se imaginou ter formado (e sem saber a razão exata) entre Bethencourt e Pedro Américo a partir de 1879. Essa reavaliação passa mesmo a questionar algumas das conclusões encetadas sobre Américo, em especial a que pressupõe sua falta de engajamento com o contexto artístico brasileiro. Esse capítulo expôs, portanto, de maneira significativa, que a apresentação do projeto de Américo teve um impacto grande, especialmente entre seus adversários, entre os quais estava Bethencourt, que revidaram o jovem de todas as maneiras possíveis, ensaiando minar seus campos de ação. Disso se concluiu que Américo, inicialmente, não se afastou do cenário artístico brasileiro por pura indiferença. Isso teria sido o resultado de um processo gradual (que, no entanto, começou precisamente entre 1864 e 1866) na trajetória de um jovem artista que, tendo planos maiores do que ser unicamente pintor, e grande parte deles estando ligada à política, se viu desde cedo, em decorrência de suas estratégias e alianças, limado, justamente, de um dos campos de ação política mais importantes para as artes nacionais, representado especificamente pela AIBA. Em outras palavras, desde o seu primeiro dia como professor na academia, assumido no início de 1866, o processo já de quase um ano e meio de embates que havia estabelecido com agentes desta instituição não permitiu que encontrasse um lugar de atuação que então esperava ter. Esses problemas, não parece haver dúvidas, também explicam bastante algumas das razões que teriam levado Américo a retornar imediatamente à Europa, e a iniciar, portanto, seu doutorado em ciências naturais na Bélgica. Além de fugir de uma possível prisão, se lhe era negado o diploma e, sobretudo, a consideração social de bacharel - de cuja importância na tecitura social ele bastante ciente e desejava explorar - se consegue perceber todo o seu esforço para ser reconhecido, a partir de 1869, como um doutor. E ele jamais assinaria de outra maneira senão como Doutor Américo.

Além de ter se apresentado como um epílogo infeliz dos primeiros planos do jovem artista-filósofo e o estopim para outros, os materiais e interpretações que compõem o último capítulo desta Tese elucidaram, de maneira também significativa, não apenas parte da recepção das primeiras ideias de 
Américo apresentadas no contexto brasileiro, mas a complexa tecitura do bastante heterogêneo cenário das artes no Brasil do século XIX, juntamente com suas rixas, seus problemas reincidentes e, ainda, seus preconceitos. Insistiu-se na disparidade de programas esboçados pelas diferentes "classes artísticas", tendo, de um lado, a AIBA como a representante dos desígnios mais "elevados" e, de outro, os artesãos e "operários", pobres e completamente desconhecidos da história das artes, que também dispunham de projetos, estes sendo, no entanto, de intenção bem mais modesta. Incluíam, sobretudo, o desejo de uma vida menos difícil e a conquista de direitos civis básicos.

Todos os resultados e discussões aqui apresentados confirmaram, assim, a validade de um objeto bastante atual da historiografia da arte internacional, isto é, a importância dos anos de formação de um artista. Trata-se de um viés ainda pouquíssimo explorado em estudos brasileiros. Ele elucida, em muitos pontos, bases permanentes de reflexão e de proposição que um profissional faz ao longo de sua carreira.

Com Américo não foi diferente. Além de seus anos de formação informarem todas as vertentes intelectuais, artísticas e filosóficas que ele frequentaria até a sua morte, eles ainda anunciaram réplicas futuros do seu primeiro projeto político, reatualizado em momentos distintos porém, de certo modo, especularmente similares em sua carreira, com um desfecho também sempre malogrado às suas intenções. Devo frisar que me refiro ao malogro do Américo político, e não do artista, notavalmente bem sucedido. A essa dupla conclusão ele próprio havia chegado, sem alguma modéstia: quase ao completar os seus 60 anos de idade, ele afirmou em uma carta então enviada ao Barão do Rio Branco:

além de ter emancipado a pintura brasileira [..] sou autor de uns 12 ou 14 trabalhos literários de História, Filosofia Natural, Belas Artes, Romances, Discursos etc; [..] Não representei em política papel saliente; porém a coleção dos meus discursos prova que muito trabalhei nessa nova e alta atmosfera, embora sem entrar em lutas partidárias e todo preocupado da ciência da literatura, do teatro Nacional e das Belas Artes ${ }^{3}$.

Para se ater apenas a um exemplo notável da citada replicação de projetos da juventude que, por sua importância Américo, retornaram em sua maturidade - um problema que deveria, a meu ver, chamar atenção para pesquisas futuras -, pode-se considerar a curiosa revalidação ele fez, em 1882, das mesmas obras estudadas nesta Tese. Aquele era um ano de mudanças e retomadas, no qual iniciava um longo processo de pedidos para ser afastado permanentemente da Academia, e começava a fazer novas alianças e campanhas para se eleger, pela primeira vez, deputado no Brasil - alusão feita na supracitada

3 AMÉRICO, Pedro. "Carta de Pedro Américo enviada de Florença ao Barão do Rio Branco em 25 de Novembro de 1902”. Rio de Janeiro, Arquivo do Itamaraty, cota: L.-812, M-4. P-14. 
carta a Rio Branco. É de se apostar que não seja coincidência que, precisamente nesse momento, Américo (já sem a primeira Carioca) produzia uma segunda versão da obra (com variações pequenas no rosto, mas importantes), republicava ainda a sua tese de doutorado e o Considerações Filosóficas sobre as Belas Artes entre os Antigos (isto é, sua teria e seu projeto geral para as artes no Brasil), e publicava, também, o seu primeiro romance, O Holocausto: como argumentado nesta pesquisa, não apenas um romance autobiográfico, mas uma narrativa que retomava, justamente, os episódios que haviam conduzido o artista à sua "crucificação" pela "questão de bacharéis", em 1866. As novas versões dessas obras de juventude garantiam mais uma vez, a meu ver, a relação sistêmica que Américo percebia entre elas (relação defendida nesta Tese) e, ao mesmo tempo, o caráter notadamente político do qual suas aparições haviam feito e ainda faziam parte nos desígnios do artista.

Essa nova apresentação conectava, assim, diretamente, o jovem Pedro Américo ao Américo maduro, e não há dúvidas de que muitos desses contatos podem ser explorados em pesquisas futuras. Na conclusão desta Tese percebo que algumas relações já são bastante evidentes, como, por exemplo, o que parece ser um vínculo que as reflexões aqui desenvolvidas estabelecem com a Tese de Maraliz Christo, dedicada especialmente, mas não somente, ao Tiradentes Esquartejado (1893), de Américo. Entre os numerosos materiais estudados e análises feitas por Christo, estão, por exemplo, os discursos políticos e cartas enviadas pelo artista-filósofo a colegas e amigos no início da década de 1890. Em alguns desses objetos, Américo propunha a seus interlocutores a criação de uma Galeria Nacional e de Universidades artísticas ${ }^{4}$. Isso nada mais era do que outra retomada e amadurecimento das mesmas propostas que ele havia publicado em Cartas de um Plebeu aos Srs. Deputados, em 1865, especificamente as ideias de "Criação de pequenas escolas de belas artes nas províncias de primeira ordem" e de "Criação de um museu de pintura na corte, independente [...] da academia das belas artes".

Outras perspectivas futuras sobre o trabalho de Américo ainda podem ser indicadas, a partir das questões desenvolvidas nesta Tese. Sem exauri-las, é preciso ainda compreender, de início, a postura “arianista" abertamente defendida por Américo e a importância que ela teve para definição de algumas perspectivas práticas, ligadas diretamente à produção de pinturas em sua carreira, e às matrizes artísticas que havia escolhido estudar nos domínios da estética e da história. Não me parece nenhum pouco improvável concluir que a sua postura em qualquer medida racista, e abertamente anti-indianista

\footnotetext{
${ }^{4}$ CHRISTO, Maraliz de C. V. Pintura, história e heróis: Pedro Américo e "Tiradentes esquartejado". Campinas, 2005 (Tese de doutoramento em História, UNICAMP). p.149, corpo de texto e notas, e p.151.
} 
(do ponto de vista simbólico), tivesse definido a sua sempre frequente recusa na representação de uma arte nacional que não se caracterizasse pela aparência "branca". Para Américo, o brasileiro não tinha "sangue de tatu": era filho direto do europeu e, portanto, branco. Torno mais explicito: não parece fortuito que pudesse ter vindo dessa postura a recusa que ele havia feito, por exemplo, à Batalha dos Guararapes, pintura cuja produção the havia sido inicialmente encomendada, antes de passá-la adiante (sintomaticamente para Victor Meireles) e a propor a sua própria série de quadros sobre a Guerra do Paraguai, bem mais de acordo com a sua teoria do "ideal moderno" e patriótico. Deve lhe ter parecido inconcebível a ideia de representar um episódio que celebraria, precisamente, o momento fundador da nacionalidade brasileira pela fusão simbólica das três "raças" (brancos portugueses, negros e índios) em uma batalha contra o branco holandês. A partir dessa mesma postura pode-se entender por que ele nunca inclui em seus interesses sobre a arqueologia, qualquer questão sobre o início da arqueologia indígena no Brasil, começada precisamente por personalidades que lhe eram próximas (Gonçalves Dias, Gonçalves de Magalhães, Porto Alegre e Ladislau Netto: este, seu colega nos tempos da AIBA, e diretor do Museu Nacional a partir dos anos 1860).

Além desse questionamento a ser feito futuramente, outro parece ser em seguida válido. Ao se reposicionar o interesse e imersão de Américo na Filosofia Eclética de Cousin e no krausismo belga (que, como visto, servia quase como complemento àquele), duas vias são também abertas, me parece. Uma se liga, mais uma vez, diretamente ou indiretamente ao trabalho realizado por Maraliz Christo, e aqui, em especial, à identificação que fez de diversas fontes iconográfias aparentemente utililizadas por Américo em sua Batalha do Avahy (mas também em sua Batalha do Campo Grande e mesmo se estendendo para outras pinturas do artista). Parece ser válido investigar até que ponto essas "citações" de trabalhos que Américo admirava bastante não se tratavam apenas de citações, mas da continuidade na aplicação do método eclético, um de seleção e combinação de "verdades parciais", que inaugurara 10 anos antes, com sua Carioca. Se procedente, é possível esse novo procedimento realizado na Batalha do Avahy lhe fosse o de novo sincretismo visual que ofereceria, ao final, uma extremamente potente unidade pictórica aspirante à verdade filosófica, mas uma que, sem dúvidas, era sensivelmente distinta das unidades estéticas apresentadas na Carioca e na Batalha do Campo Grande, bem mais convencionais (do ponto de vista dos “princípios da estética”).

A segunda via citada continua a problematizar a importância que o Ecletismo, então já combinado com a doutrina krausista, ainda teve para a elaboração dos métodos e objetos da Tese de Doutorado defendida por Américo, uma que defendia a importância da arte para o progresso científico. Juntos, o 
texto das Considerações Filosóficas e o estudo dessa Tese fornecem, disso eu estou bastante seguro, uma perspectiva muito sugestiva de como foi a primeira cadeira de História das belas artes, estética e arqueologia oficialmente ofertado no Brasil.

Encerrando por aqui algumas sugestões de perspectivas futuras que esta pesquisa pode, quem sabe, ajudar a abrir, e me encaminhando, finalmente, ao fechamento desta Conclusão, talvez seja lícito apenas reforçar o que, a meu ver, parece ser a contribuição original aqui oferecida. Até hoje, todos os trabalhos desenvolvidos sobre Américo levaram em conta, de um lado, quase que exclusivamente, a sua atuação como pintor (deixando de lado aquilo que escreveu e pensou), essa sendo a maioria absoluta de textos dedicados a esse artista. De outro lado, uma série de trabalhos tentaram lidar com ou comentar sobre o Américo escritor. Porém, a bem da verdade, as leituras desenvolvidas nesse domínio também não consideraram o Américo pintor e, salvo raras exceções (como as introduções às reedições dos textos desse artista, publicadas por Silvano Alves Bezerra da Silva, ou o estudo de Cláudia Valladão de Mattos), também não conseguiram ultrapassar um simples fichamento do que ele teria dito em suas publicações. Nesta pesquisa, não interessou ver um ou outro Américo, mas os dois, os quais - talvez se tenha esquecido com o tempo, em função justamente do seu "fracasso" como político e escritor - são um. Com efeito, não apenas se perde muito se se continua a lidar separadamente com essas diferentes conquanto intimamente estabelecidas atuações desse artista, como não se consegue chegar ao âmago de suas produções, imbuídas invariavelmente de concepções filosóficas e históricas. Afinal de contas, Não existiram, no Brasil, outros artistas como Pedro Américo. É um caso único. Dito de outro modo, se se quer realmente entender a produção artística de Américo e sua singular postura crítica diante delas, é preciso se deparar com o que ele escreveu sobre arte, ciência e política e com o fato de que, precisamente, a produção artística não foi a sua mais dedicada atuação.

Se desde as suas primeiras obras, o próprio Américo lidou com esse problema que o perseguiu por toda a sua vida - antecipar teoricamente ou explicar as suas pinturas e partidos estéticos, para que não se criassem, ainda mais, os inevitáveis mal-entendidos da crítica nacional -, parece não fazer sentido continuar a se esquecer, deliberadamente, o que foi para ele tão importante: as duas faces de uma moeda difícil de se fundir no Brasil do século XIX, a do intelecual e a do artista, mas que, pela primeira vez, e talvez única no período, ela havia finalmente conseguido cunhar. 


\section{Fontes Consultadas e Bibliografia}

\section{Arquivos, bibliotecas e Museus consultados ou visitados}

\section{No Brasil}

arquivos:

Arquivo Nacional, Rio de Janeiro.

Instituto Histórico e Geográfico Brasileiro, Rio de Janeiro

Museu Histórico e Diplomático do Itamaraty, Rio de Janeiro

Museu Histórico Nacional, Rio de Janeiro

Museu Imperial de Petrópolis

Museu Nacional de Belas Artes, Rio de Janeiro

Museu Regional de Areia, Paraíba.

Paróquia de Areia.

Academia Brasileira de Letras, Rio de Janeiro.

Gabinete Português de Leitura.

\section{Bibliotecas:}

Biblioteca da Escola de Comunicações e Artes da Universidade de São Paulo.

Biblioteca da Faculdade de Arquitetura e Urbanismo da Universidade de São Paulo.

Biblioteca da Faculdade de Filosofia, Letras e Ciências Humanas da Universidade de São Paulo.

Instituto de Estudos Brasileiros da Universidade de São Paulo.

Biblioteca Nacional, Rio de Janeiro.

Museu Nacional de Belas Artes, Rio de Janeiro.

Museu d. João VI, Rio de Janeiro.

Museus:

Museu Histórico e Diplomático do Itamaraty, Rio de Janeiro.

Museu Histórico Nacional, Rio de Janeiro.

Museu Imperial de Petrópolis.

Museu Nacional de Belas Artes, Rio de Janeiro.

Museu Pierre Chalita, Maceió.

Museu de Arte de São Paulo.

Pinacoteca do Estado de São Paulo.

\section{França}

\section{Paris e cidades vizinhas}

\section{Arquivos:}

Musée du Louvre.

Musée d'Orsay.

École Nationale des Beaux-Arts, Paris.

Musée et Jardin du Château de Versailles.

Archives Nationales de France. 
Bibliotecas:

Bibliothèque d'Art et d'Archéologie Jacques Doucet, Paris.

Bibliotèque Nationale de France, Paris

Centre Allemand d'Histoire de l'Art, Paris

Museus:

Musée des Beaux-Arts de Lyon.

Musée du Château de Versailles.

Grand Palais.

Petit Palais.

Musée de l'Orangerie.

Musée du Luxembourg.

Musée du Louvre, Paris.

Musée d'Orsay, Paris.

Musée de l'Armée.

Jardin des Plantes.

\section{Itália}

Roma

Museus e igrejas:

Basilica di San Pietro.

Galeria Corsini.

Galleria Nazionale d'Arte Moderna.

Museu Capitolino.

Museus do Vaticano.

Palazzo Barberini.

Villa Farnesina.

Villa Borghèse.

\section{Veneza}

Museus e Igrejas:

Basilica S. Maria Gloriosa dei Frari.

Ca' Pesaro.

Ca' Rezzonico.

Galeria dell'Academia.

Musei di Piazza San Marco.

Museo di Storia Naturale.

Pallazzo dei Dogges.

\section{Florença}

Museus e Igrejas:

Santa Maria dei Fiori. 
Galleria degli Uffizi.

Museo Bargello.

Pallazo Piti.

Santa Maria Novella.

Galeria Palatina.

Museo di Palazzo Vecchio.

\section{Bélgica}

\section{Bruxelas}

Arquivos e bibliotecas:

Université Libre de Bruxelles.

Museus:

Musée Wiertz.

Musée royal d'art ancien.

Musée Fin de siècle.

\section{Inglaterra}

\section{Londres}

Museus e igrejas:

British Museum.

Victoria and Albert Museum (Antigo Museu South Kensington de Artes Industriais).

National Gallery.

Abadia de Westminster.

\section{Alemanha}

\section{Berlim}

Museus:

Alte NationalGalerie.

Altes Museum.

Gemäldegalerie.

Neue NationalGalerie.

Neues Museum.

Pergamon Museum.

\section{Documentos}

\section{Cartas}

AMÉRICO, Pedro. “Carta a D. Pedro II de 6 de janeiro de 1862”. Museu Imperial, Petrópolis. Documento M 1316418.

AMÉRICO, P. "Carta de Pedro Américo, de Paris, em 26 de junho de 1862, à tia Maria do Rosário Brasileira de Mello”. In: NEVES, Tancredo. Dossiê Pedro Américo. Mossoró, 2006. Pp.13436. 
AMÉRICO, P. "Carta de Pedro Américo, em Paris, a Jacques Brunet, em 07 de agosto de 1859." In: AMÉRICO, Pedro; MELO, Aurélio Eduardo de Figueiredo e; BRUNET, Louis Jacques. Cartas de Pedro Américo de Figueiredo e Melo e Daniel Eduardo de Figueiredo e Melo a Louis Jacques Brunet .Volume 96 de Coleção Mossoroense. Mossoró: Editora Fundação Vingt-un Rosado, 2001. S/d.

AMÉRICO, P. "Carta de Pedro Américo a Jacques Brunet, em 07 de maio de 1863". In: FUNDAÇÃO VINGT-UN ROSADO. Cartas de Pedro Américo de Figueiredo e Melo e Daniel Eduardo de Figueiredo e Melo a Louis Jacques Brunet. Mossoró: Coleção Mossoroense, junho de 2001.

AMÉRICO, Pedro. "Carta de Paris a Louis Jacques Brunet em 24 de novembro de 1863". In: FUNDAÇÃO VINGT-UN ROSADO. Cartas de Pedro Américo de Figueiredo e Melo e Daniel Eduardo de Figueiredo e Melo a Louis Jacques Brunet. Mossoró: Coleção Mossoroense, junho de 2001. s/p.

AMÉRICO, Pedro. "Carta de Paris a Louis Jacques Brunet em 07 de novembro de 1863". In: FUNDAÇÃO VINGT-UN ROSADO. Cartas de Pedro Américo de Figueiredo e Melo e Daniel Eduardo de Figueiredo e Melo a Louis Jacques Brunet. Mossoró: Coleção Mossoroense, junho de 2001. s/p.

AMÉRICO, Pedro. "Carta de Paris a d. Pedro II em 24 de maio de 1864”. Petrópolis, Arquivo da Casa Imperial do Brasil. Maço 134 - Doc. 6580. Reimpressa em TORRES, Francisco Tancredo. Dossiê Pedro Américo. Mossoró: Coleção Mossoró, 2002. Pp.114-116.

AMÉRICO, Pedro. "Carta de Paris a d. Pedro II em 07 de julho de 1864". Petrópolis, Arquivo da Casa Imperial do Brasil. Maço 134 - Doc. 6580.

FERRO CARDOSO, Daniel Pedro. "Carta de Daniel Pedro Ferro Cardoso, aluno de Arquitetura, pedindo para completar seus estudos na Europa, com bolsa do Governo. 11 de fevereiro de 1858". Rio de Janeiro: Arquivos do Museu d. Jõao VI/EBA-UFRJ. cód. 002/004 - s/n.

FERRO CARDOSO, Daniel Pedro. "Carta de Daniel Pedro Cardoso enderaçada à Academia Imperial de Belas Artes de 11 de março de 1862". Arquivo Nacional, Rio de Janeiro. Cod. 036/341341.

FERRO CARDOSO, Daniel Pedro. "Carta de Daniel Pedro Ferro Cardoso ao Diretor da Academia Imperial das Belas Artes [Thomás Gomes dos Santos] de 29 março de 1862". Arquivo Nacional, Rio de Janeiro. Cod. 041/012-012.

\section{Bibliografia}

\subsection{Periódicos}

\subsubsection{Artigos escritos por Pedro Américo sobre a "questão de Bacharéis":}

AMÉRICO, Pedro. "Ao S. Thomé do Jornal de ontem" Publicações a Pedido. Jornal do Commércio. Rio de Janeiro, 16 DE JANEIRO DE 1866.

AMÉRICO, Pedro; FERRO CARDOSO, Daniel Pedro. "Ao Público". Correio Mercantil, Rio de Janeiro, 20 de fevereiro de 1866. P.3

AMÉRICO, Pedro; FERRO CARDOSO, Daniel Pedro. "Ao público". Publicações a Pedido. Jornal do Commércio. Rio de Janeiro, 20 de fevereiro de 1866, p.2

AMÉRICO, Bacharel Pedro. O Publicador, ano V, Paraíba, 5 de outubro de 1866. p.1.

\subsubsection{Artigos sobre Pedro Américo, Ferro Cardoso e sobre a "questão de Bacharéis":}

"Expediente do Governo". O PUBLICADOR. Paraíba, Ano V, 28 de marco de 1866. 
A MINHA REPUTAÇÃO ESTÁ FIRMADA. "Bacharel sem diploma". Correio Mercantil, Rio de Janeiro, 21 de fevereiro de 1866. P.3

A MORALIDADE PÚBLICA. "Bachareleida". Publicações a pedido. Correio Mercantil, Rio de Janeiro, 24 de janeiro de 1866, p.3

A OPINIÃO PÚBLICA. "É ou não é Bacharel”. Publicações a pedido. Correio Mercantil, Rio de Janeiro,22 de janeiro de 1866, p.3

AGRADECIMENTO. Correio Mercantil, Rio de Janeiro, 19 de março de 1866. P.2

ALMANAK Administrativo, Mercantil E Industrial Da Corte E Província Do Rio De Janeiro.

Ano XXII. Rio de Janeiro: Eduardo \& Henrique Laemmert, 1865. p.214.

AMERICO, Bacharel Pedro. CORREIO MERCANTIL, Rio de Janeiro. 31 de Janeiro de 1865.

ART. 301 DO CÓDIGO. Publicações a Pedido. Jornal do Commércio. Rio de Janeiro, 22 de

FEVEREIRO DE 1866.

BEM, Um homem de. "Bachareleida". Publicações a Pedido. Jornal do Commércio. Rio de

Janeiro,12 DE FEVEREIRO DE 1866.

BRASILEIROS DISTINCTOS. Opinião Liberal, Rio de Janeiro, 18 de setembro de 1869. P.4

BRAZILEIRO DISTINTO. O Ypiranga, São Paulo, 2 de março de 1869. P.2

CASTOR\&POLLUX. "Pseudo Bacharéis". Publicações a Pedido. Jornal do Commércio. Rio de

Janeiro, 1 DE FEVEREIRO DE 1866, P.2

CESÁR; FERNANDES, João. "Questão de ser bacharel. "Publicações a Pedido. Jornal do

Commércio. Rio de Janeiro, 17 DE JANEIRO 1866.

COQUES JÚNIOR, Gonzales. "O Sr. Pedro Américo". Correio Mercantil, Rio de Janeiro, 18 de

fevereiro de 1866.

COQUES, A alma de Gonzalez. "O Sr. Pedro Américo de Figueiredo" Publicações a Pedido.

Correio Mercantil, Rio de Janeiro,22 de janeiro de 1866, p.3

COQUES, Gonzales. "A nomeação de um professor de desenho na academia das Belas Artes".

Publicações a Pedido. Correio Mercantil, Rio de Janeiro, 26 de agosto de 1865. P.3

COQUES, Gonzales. "Belas Artes (*)". Publicações a pedido. Correio Mercantil, Rio de Janeiro,

28 de agosto de 1865 . p.3.

COQUES, Gonzales. "Questão de bacharéis". Publicações a pedido. Correio Mercantil, Rio de Janeiro, 23 de janeiro de 1866, p.2

COQUES, Gonzales. CORREIO MERCANTIL, Rio de Janeiro. 01 de fevereiro de 1865.

COQUES, Gonzales. CORREIO MERCANTIL, Rio de Janeiro. 30 de janeiro de 1865.

CORREIO Mercantil, Rio de Janeiro 19 de junho de 1855. P.1

CORREIO Mercantil, Rio de Janeiro 28 de junho de 1855. P.1

CORREIO Mercantil, Rio de Janeiro, 29 de novembro de 1856. P.1

CORREIO Mercantil, Rio de Janeiro, 30 de janeiro 1863. P.3

CORREIO Mercantil, Rio de Janeiro, 4 de janeiro de 1859. Bellas-Artes

CORREIO Mercantil, Rio de Janeiro. 19 de novembro de 1856.

CORREIO MERCANTIL, Rio de Janeiro. 20 de fevereiro de 1865.

CORREIO Mercantil, Rio de Janeiro. 25 de dezembro de 1857.

CORREIO Mercantil. Rio de Janeiro, 05 de janeiro de 1863. p.2

CORREIO MERCANTIL. Rio de Janeiro, 12 de fevereiro de 1857. p.2.

CORREIO MERCANTIL. Rio de Janeiro, 12 de fevereiro de 1857. p.2.

Correio Mercantil. Rio de Janeiro,7 de dezembro de 1855. P.1

CORREIO Paulistano, São Paulo, 24 de novembro de 1864. p.2

CUIQUE, Suum. "Bachareleida". Publicações a pedido. Correio Mercantil, Rio de Janeiro, 24 de janeiro de 1866, p.3 
CUIQUE, Suum. Pseudo Bachareis. Correio Mercantil, Rio de Janeiro, 13 de fevereiro de 1866.

DIVINA, A justiça. "Os pecados bacharéis"Publicações a Pedido. Jornal do Commércio. Rio de Janeiro, 20 DE JANEIRO DE 1866, p.1

DR. CHARLATA. "Bacharel sem diploma". Correio Mercantil, Rio de Janeiro, 21 de fevereiro de 1866. P.3

DR. SEMANA. "Declaração formal. Urbi et Orbi." Semana Illustrada, Rio de Janeiro, 11 de fevereiro de 1866. P.7

DR. URSO. "Ao Bacharel (sem diploma)" Publicações a Pedido. Jornal do Commércio. Rio de Janeiro, 1 DE FEVEREIRO DE 1866, P.2

FERRO CARDOSO, Daniel Pedro. “Questão de Pasquins”.Publicações a Pedido. Jornal do Commércio. Rio de Janeiro, 18 DE JANEIRO de 1866.

FERRUGEM, Ferro sem. "Bacharéis". Publicações a Pedido. Jornal do Commércio. Rio de Janeiro, 1 DE FEVEREIRO DE 1866, P.2

FIRMA, A minha reputação está. "Mofina". Publicações a Pedido. Jornal do Commércio. Rio de Janeiro, 20 DE JANEIRO DE 1866, p.1

FIRMADA, A minha reputação está. "Questão de Pasquins". Publicações a pedido. Correio Mercantil, Rio de Janeiro, 23 de janeiro de 1866, p.3

FIRMADA, Minha reputação está. Publicações a Pedido. Jornal do Commércio. Rio de Janeiro, 26 de janeiro de 1866, P.2

FIRMADA, Minha reputação está. Publicações a Pedido. Jornal do Commércio. Rio de Janeiro, 30 de janeiro de 1866

FREITAS, F. G. De . "O sulfato de ferro, o bacharel de ferro ou carta de ferro , a enferrujada bola de ferro e mais ferrugens universais a isto me excitam!!!”. Publicações a pedido. Correio Mercantil, Rio de Janeiro, 29 de janeiro de 1866, p.3

FREITAS, Francisco Gomes. "Attenção". Publicações a pedido. Correio Mercantil, Rio de Janeiro, 29 de janeiro de 1866, p.3

GONDOLAS, O orador das. "É ou não é bacharel". Publicações a Pedido. Jornal do Commércio. Rio de Janeiro, 28 de janeiro de 1866, p.2

GONDOLAS, O orador das. "Questão de Bacharel”. Publicações a Pedido. Jornal do Commércio. Rio de Janeiro, 26 de janeiro de 1866, P.2

GUISANDO, Bacharel Renato de [Francisco Joaquim Bethencourt da Silva]. "bacharéis sem diploma”. Publicações a Pedido. Jornal do Commércio. Rio de Janeiro, 27 DE JANEIRO DE 1866, P.2

GUISANDO, Bacharel Renato de [Francisco Joaquim Bethencourt da Silva]. "É ou não é bacharel". Publicações a Pedido. Jornal do Commércio. Rio de Janeiro, 30 de janeiro de 1866.

GUISANDO, Bacharel Renato de [F. J. Bethencourt da Silva]. "Questão de Bacharéis". Publicações a Pedido. Jornal do Commércio. Rio de Janeiro, 2 de fevereiro de 1866, p.2

GUISANDO, Bacharel Renato de [F. J. Bethencourt da Silva] "Publicações a Pedido." Jornal do Commércio. Rio de Janeiro, 24 de janeiro de 1866, p.1

GUISANDO, Renato de [F. J. Bethencourt da Silva]. "Ao Sr. ministro da agricultura, ao Sr. Inspetor de obras públicas e ao Sr. promotor Sizenando Nabuco.”, VI, Publicações a Pedido. Jornal do Commércio. Rio de Janeiro, 9 de fevereiro de 1866.

GUISANDO, Renato de [F. J. Bethencourt da Silva]. "Ao Sr. ministro da agricultura, ao Sr. Inspetor de obras públicas e ao Sr. promotor Sizenando Nabuco.”, VII, Publicações a Pedido. Jornal do Commércio. Rio de Janeiro, 10 de fevereiro de 1866, P.1

GUISANDO, Renato de [F. J. Bethencourt da Silva]. "Os imagináveis bacharéis sem diploma". Publicações a Pedido. Jornal do Commércio. Rio de Janeiro, 8 de fevereiro de 1866, P.2 
KOCQUES, Gonzales. "questão de bacharéis". Publicações a Pedido. Jornal do Commércio. Rio de Janeiro, DIA 22 DE JANEIRO de 1866.

M.A."Ao Acaso". Folhetim. Diário do Rio de Janeiro. Rio de Janeiro, 21 de fevereiro de 1865. p.01

NEM EU. O Sr. Pedro Américo. Correio Mercantil, Rio de Janeiro, 17 de janeiro de 1866, p.1

NOME, Se for preciso assinaremos o. "Questão de Pasquins". Publicações a Pedido. Jornal do Commércio. Rio de Janeiro, 18 DE JANEIRO DE 1866.

NOTÍCIAS DIVERSAS. Correio Mercantil. Rio de Janeiro,7 de dezembro de 1855.

O CHARLATA. "Ao Bacharel”. Publicações a Pedido. Jornal do Commércio. Rio de Janeiro, 18 DE JANEIRO DE 1866.

O CORREIO da tarde. Rio de Janeiro, 16 de março de 1859.

O FERRO. "Protesto-bachareleida". Publicações a Pedido. Jornal do Commércio. Rio de Janeiro, 8 de março de 1866, P.2

O S. THOMÉ. “Ao Sr. Pedro Américo”. Publicações a Pedido. Jornal do Commércio. Rio de Janeiro, 23 de FEVEREIRO DE 1866. p.1

O S. THOMÉ. “Ao Sr. promotor público”. Publicações a Pedido. Jornal do Commércio. Rio de Janeiro, 22 de FEVEREIRO DE 1866.

O S. THOMÉ. “Atenção”. Publicações a Pedido. Jornal do Commércio. Rio de Janeiro, 15 DE JANEIRO DE 1866.

O. M. T. A [Bethencourt da Silva]. Publicações a Pedido. "Ao Sr. ministro da agricultura, ao Sr. Inspetor de obras públicas e ao Sr. promotor Sizenando Nabuco." Correio Mercantil, 29 de janeiro de 1866.

O. M. T. A. [Bethencourt da Silva]. "Ao Sr. ministro da agricultura, ao Sr. Inspetor de obras públicas e ao Sr. promotor Sizenando Nabuco." Publicações a Pedido. Correio Mercantil, Rio de Janeiro. 3 de fevereiro de 1866.

O. M. T. A. [Bethencourt da Silva]. "Ao Sr. ministro da agricultura, ao Sr. Inspetor de obras públicas e ao Sr. promotor Sizenando Nabuco.” Publicações a Pedido. Correio Mercantil, 4 de fevereiro de 1866.

O. M. T. A. [Bethencourt da Silva]. "Ao Sr. ministro da agricultura, ao Sr. Inspetor de obras públicas e ao Sr. promotor Sizenando Nabuco.” Correio Mercantil, 6 de fevereiro de 1866. Publicações a Pedido.

O. M. T. A. [Bethencourt da Silva]. "Ao Sr. ministro da agricultura, ao Sr. Inspetor de obras públicas e ao Sr. promotor Sizenando Nabuco.” Correio Mercantil, 7 de fevereiro de 1866. Publicações a Pedido.

O. M. T. A. [Bethencourt da Silva]. Publicações a Pedido. "Ao Sr. ministro da agricultura, ao Sr. Inspetor de obras públicas e ao Sr. promotor Sizenando Nabuco." Correio Mercantil, 30 de janeiro de 1866. P.3.

O. M. T. A. "Ao Sr. ministro da agricultura, ao Sr. Inspetor de obras públicas e ao Sr. promotor Sizenando Nabuco.”. Publicações a Pedido. Correio Mercantil, Rio de Janeiro, 1 de fevereiro de 1866.

O.M.T.A [Bethencourt da Silva]. "mofina". Publicações a pedido. Correio Mercantil, Rio de Janeiro, 29 de janeiro de 1866, p.3

OH! S. THOMÉ. "Bacharel”. Publicações a Pedido. Jornal do Commércio. Rio de Janeiro, 17 DE JANEIRO 1866.

OH! S. THOMÉ. “Ao Sr. Ferro Cardoso (bacharel). ”Publicações a Pedido. Jornal do Commércio. Rio de Janeiro, 18 DE JANEIRO DE 1866. 
OH! S. THOMÉ. "Bacharel sem diploma". Correio Mercantil, Rio de Janeiro, 21 de fevereiro de 1866. P.3

OH! S. THOMÉ. "Bacharelomania". Publicações a Pedido. Jornal do Commércio. Rio de Janeiro, 22 de FEVEREIRO DE 1866.

OH! S. THOMÉ. "Pergunta inocente". Publicações a Pedido. Jornal do Commércio. Rio de Janeiro, DIA 22 DE JANEIRO de 1866.

OH! S. THOMÉ. Publicações a Pedido. Jornal do Commércio. Rio de Janeiro, 18 DE JANEIRO

DE 1866.

OS ARTISTAS. "Lista". Correio Mercantil. Rio de Janeiro, 02 de junho de 1856. p.3.

PÚBLICA, A onipinão. "É ou não bacharel?". Publicações a Pedido. Jornal do Commércio. Rio de Janeiro, DIA 22 DE JANEIRO de 1866.

PUFF, ora. Publicações a Pedido. Jornal do Commércio. Rio de Janeiro, DIA 22 DE JANEIRO de 1866

Questão de Bacharel”, Publicações a Pedido. Jornal do Commércio. Rio de Janeiro, 23 de FEVEREIRO DE 1866. p.2

S/A. "Associação Nacional dos Artistas Brasileiros". Correio Mercantil. Rio de Janeiro, 26 de abril de 1856. p.3

S/A. "Boletim Eleitoral". Correio Mercantil. Rio de Janeiro, 17 de agosto de 1863.

S/A. "Ao Sr. Promotor público". Publicações a Pedido. Jornal do Commércio. Rio de Janeiro, 22 de fevereiro de 1866

S/A. "Aos votantes". Correio Mercantil. Rio de Janeiro, 26 de agosto de 1864. P.3.

S/A. "Associação Nacional dos Artistas Brasileiros." Correio Mercantil. Rio de Janeiro, 12 de fevereiro de 1857. p.2.

S/A. "Atenção". Correio Mercantil. Rio de Janeiro, 26 de agosto de 1864. P.3.

S/A. "Bacharel sem bacharelado". Publicações a Pedido. Jornal do Commércio. Rio de Janeiro, 28 de janeiro de 1866, p. 2

S/A. "Bachareleida". Publicações a Pedido. Jornal do Commércio. Rio de Janeiro, 28 de FEVEREIRO de 1866, p.2

S/A. "Bachareleidas". Publicações a Pedido. Jornal do Commércio. Rio de Janeiro, 27 DE JANEIRO DE 1866, P.2

S/A. "Brasileiros distinctos". Opinião Liberal. Rio de Janeiro, 18 de setembro de 1869. P.4.

S/A. "Camara Municipal”. Correio Mercantil. Rio de Janeiro, 26 de agosto de 1864. P.3.

S/A. "Casamento". Correio Mercantil, Rio de Janeiro, 23 de junho de 1862. P.2

S/A. "Editais". Boletim da Illustríssima Câmara Municipal da Corte. Rio de Janeiro, julho a setembro de 1866, volume VII, VIII e IX - 1. 22a sessão.

S/A. "Mofina". Publicações a Pedido. Jornal do Commércio. Rio de Janeiro, 22 de janeiro de 1866

S/A. "Não é bacharel". Publicações a Pedido. Jornal do Commércio. Rio de Janeiro, 23 DE JANEIRO DE 1866.

S/A. "Notícias diversas". Correio Mercantil, Rio de Janeiro, 23 de dezembro de 1861. P.1

S/A. "Notícias Diversas".CORREIO MERCANTIL, Rio de Janeiro. 18 de novembro de 1864. P.2

S/A. "O BACHAREL PEDRO AMERICO". O Publicador, ano V, Paraíba, 5 de outubro de 1866. P.2

S/A. "Os imaginários bacharéis". Publicações a Pedido. Jornal do Commércio. Rio de Janeiro, 22 de fevereiro de 1866.

S/A. "Questão de Bacharéis." Publicações a Pedido. Jornal do Commércio. Rio de Janeiro, 22 de janeiro de 1866 
S/A. "Questão de bacharéis". Publicações a pedido. Correio Mercantil, Rio de Janeiro, 23 de janeiro de 1866, p.3

S/A. "Questão de Bacharéis". Publicações a Pedido. Jornal do Commércio. Rio de Janeiro, 20 DE JANEIRO DE 1866, p.1

S/A. "REGISTRO do Porto". Correio Mercantil, Rio de Janeiro, 18 de março de 1859.

S/A. "Seguiu ontem para o Havre...". Correio Mercantil, Rio de Janeiro, 20 de maio de 1859. P.1

S/A. "Sessão de Posse do Conselho Administrativo em 2 de janeiro de 1866". O AUXILIADOR DA INDÚSTRIA NACIONAL. Rio de Janeiro, n.1 janeiro de 1866.

S/A. "Sociedade Auxiliadora da Industria Nacional". Correio Mercantil. Rio de Janeiro, 4 de março de 1863. p.1

S/A. "Sociedade Auxiliadora da Industria Nacional". Correio Mercantil, Rio de Janeiro, 13 de março de 1863.

S/A. "Sociedade Auxiliadora da Industria Nacional". Correio Mercantil, Rio de Janeiro, 18 de março de 1863.

S/A. "Sociedade Auxiliadora da Industria Nacional". Correio Mercantil, Rio de Janeiro, 7 de agosto de 1864.

S/A. "Sociedades Literárias e Industriais. Sociedade Auxiliadora da Industria Nacional." Correio Mercantil. Rio de Janeiro, 5 de fevereiro de 1863. p.1

S/A. "Sociedades Literárias e Industriais. Sociedade Auxiliadora da Industria Nacional". Correio Mercantil. Rio de Janeiro, 23 de abril de 1863. p.1

S/A. "Sociedades Literárias e Industriais. Sociedade Auxiliadora da Industria Nacional". Correio Mercantil. Rio de Janeiro, 13 de maio de 1863, p.1

S/A. "Sociedades Literárias e Industriais. Sociedade Auxiliadora da Industria Nacional." Correio Mercantil. Rio de Janeiro, 23 de abril de 1863. p.1

S/A. "Sociedades literárias e industriais". Correio Mercantil, Rio de Janeiro, 17 de junho de 1863. P.1

S/A. Atos Oficiais. Correio Mercantil, Rio de Janeiro, 17 de novembro de 1864, p.1.

S/A. Coisas que o Povo Espera . Correio Mercantil, Rio de Janeiro, 5 de março de 1866.

S/A. Coisas que o povo espera. Correio Mercantil, Rio de Janeiro, 27 de fevereiro de 1866. P.3

S/A. Correio Mercantil, Rio de Janeiro, 24 de fevereiro de 1865. P.2

S/A. CORREIO MERCANTIL. Rio de Janeiro, 06 de janeiro de 1866. p.3.

S/A. Despaches. O Publicador, ano III, Paraíba, 28 de novembro de 1864. P.2

S/A. DESPACHES. O Publicador, ano IV, Paraíba, 24 de novembro de 1865. P.1

S/A. DESPACHES. O Publicador, ano IV, Paraíba, 28 de novembro de 1865. P.1

S/A. IDEM AO MESMO... O Publicador, ano V, Paraíba, 8 de janeiro de 1866. P.1

S/A. Lê-se no Correio Mercantil de 14. Correio Paulistano, São Paulo, 19 de novembro de 1864. p.2

S/A. Movimento do porto. Correio Mercantil, Rio de Janeiro, 15 de janeiro de 1865. P.4

S/A. Movimento do Porto. Correio Mercantil. Rio de Janeiro, 10 de janeiro de 1866. P.3

S/A. Movimento do Porto. Diário do Rio de janeiro. Rio de Janeiro, 10 de janeiro de 1866. P.3

S/A. NOTÍCIAS DIVERSAS. Correio Mercantil, Rio de Janeiro, 05 de novembro de 1865 . P.2

S/A. NOTÍCIAS DIVERSAS. Correio Mercantil, Rio de Janeiro, 6 de março de 1865. P.2

S/A. Notícias Diversas. Correio Mercantil, Rio de Janeiro, 8 de março de 1866. P.1

S/A. Notícias Diversas. Correio Mercantil, Rio de Janeiro, 16 de janeiro de 1865. P.1

S/A. Publicações a Pedido. Jornal do Commércio. Rio de Janeiro, 5 de março de 1866, p.2

S/A. Semana Ilustrada. Rio de Janeiro. 8-15? De março de 1865. 
S/A. Sessão de Posse do Conselho Administrativo em 15 de maio de 1866. O AUXILIADOR da indústria nacional. Rio de Janeiro, maio de 1866. p.242-43.

S/A. Sessão do Conselho Administrativo. O AUXILIADOR DA INSDÚSTRIA NACIONAL. Rio de Janeiro, ano 1868. p.342.

S/A."DESPACHES". O Publicador, ano V, Paraíba, 23 de março de 1866. P.1

S/A."PESSOAS Legimitadas para obterem passaporte". Correio Mercantil, Rio de Janeiro, 11 de maio de 1859.

SENHOR, Agora sim,. "Não é bacharel". Publicações a Pedido. Jornal do Commércio. Rio de Janeiro,17 DE FEVEREIRO DE 1866.

Sessão de Posse do Conselho Administrativo em 2 de janeiro de 1866. O AUXILIADOR DA INDÚSTRIA NACIONAL. Rio de Janeiro, n.1 janeiro de 1866.

SEUS ADMIRADORES. “Bachareleida”. Publicações a Pedido. Jornal do Commércio. Rio de Janeiro, 8 de março de 1866, P.2

SILVA E LIMA, Manoel Affonso. " Festejos para o dia 7 de setembro". Correio Mercantil. Rio de Janeiro, 08 de agosto de 1856. p.2

SINE QUA NOM. “Os imaginários bacharéis”. Publicações a Pedido. Jornal do Commércio. Rio de Janeiro, 22 de FEVEREIRO DE 1866.

SOLEDADE, João Fernandes. "Questão de Bacharel”. Publicações a Pedido. Jornal do Commércio. Rio de Janeiro, 21 de FEVEREIRO DE 1866, p.2

TÍTULO, Um que tem. "Questão de bacharéis". Publicações a Pedido. Jornal do Commércio. Rio de Janeiro, 18 DE JANEIRO DE 1866

UM ARTISTA. "Bacharéis sem bacharelado". Publicações a Pedido. Jornal do Commércio. Rio de Janeiro, 22 de FEVEREIRO DE 1866.

UNORUMQUORUMQUS, Bacharel. “Ao Bacharel sem diploma”. Publicações a Pedido. Jornal do Commércio. Rio de Janeiro, 2 de fevereiro de 1866, p.2

UNORUMQUORUMQUS, Bacharel. “Aos formidáveis bacharéis". Publicações a Pedido. Jornal do Commércio. Rio de Janeiro, 31 de janeiro de 1866, p.1

VERGONHA!, Que. "Bacharelomania". Publicações a Pedido. Jornal do Commércio. Rio de Janeiro, 21 de FEVEREIRO DE 1866, p.2

\subsubsection{Artigos sobre Bethencourt da Silva, sobre as eleições de 1863 e 1864, e sobre a questão da sua naturalidade:}

BETHENCOURT DA SILVA, Francisco Joaquim. "Resposta". Correio Mercantil. Riode Janeiro, 25 de agosto de 1864. P.3

BETHENCOURT DA SILVA, Francisco Joaquim. "Resposta". Correio Mercantil. Rio de Janeiro, 27 de agosto de 1864. P.3

BETHENCOURT DA SILVA, Francisco Joaquim. "Resposta". Correio Mercantil. Rio de Janeiro, 29 de agosto de 1864. P.3

BETHENCOURT DA SILVA, Francisco Joaquim. "Resposta". Correio Mercantil. Rio de Janeiro, 31 de agosto de 1864. P.3

BETHENCOURT DA SILVA, Francisco Joaquim. "Discurso por parte da Sociedade Propagadora das Belas Artes". Revista Mensal da Sociedade de Ensaios Literários. Rio de julho, 1865, ano 3, volume 1, pp.19-

BETHENCOURT DA SILVA, Francisco Joaquim. Discurso por parte da Sociedade Propagadora das Belas Artes. Revista Mensal da Sociedade de Ensaios Literários. Rio de Janeiro, 1863, volume 1, pp.97- 
BETHENCOURT DA SILVA. "Eleições municipais". Correio Mercantil. Rio de Janeiro, 23 de agosto de 1864. P.2

BETHENCOURT DA SILVA. "resposta". Correio Mercantil. Rio de Janeiro, 24 de agosto de 1864. P.2

BETHENCOURT DA SILVA. A arte e os artistas. Correio Mercantil. Rio de Janeiro, 16 de janeiro de 1864. p.2

BETHENCOURT DA SILVA. A arte e os artistas. Correio Mercantil. Rio de Janeiro, 29 de janeiro de 1864. p.2

BETHENCOURT DA SILVA. Ao Sr. ministro do Império. Correio Mercantil. Rio de Janeiro, 15 de dezembro de 1860 . p.3

BETHENCOURT DA SILVA. Ao Sr. ministro do Império. Correio Mercantil. Rio de Janeiro, 17 de dezembro de 1860 . p.2

BETHENCOURT DA SILVA. Ao Sr. ministro do Império. Correio Mercantil. Rio de Janeiro, 18 de dezembro de 1860. p.2

BOLETIM da Illustríssima Câmara Municipal da Corte. Rio de Janeiro, outubro a novembro de 1864 volume X - XI - p.6

BOLETIM da Illustríssima Câmara Municipal da Corte. Rio de Janeiro, janeiro de 1865, volume I. P.2

CAMPISTA. "Eleição municipal". Correio Mercantil, Rio de janeiro, 03 de setembro de 1864. p. 2

EPEMINONDAS. "Ao Veritas". Correio Mercantil. Rio de Janeiro, 24 de agosto de 1864. P.2

MACEDO ASQU. "Aos Artistas". Correio Mercantil. Rio de Janeiro, 07 de setembro de 1864. p.3

O ARTISTA."Eleições". Correio Mercantil. Rio de Janeiro, 25 de agosto de 1864. P.2

O CAMPISTA. "Eleição municipal". Correio Mercantil, Rio de janeiro, 03 de setembro de 1864. p.2

O COLEGA FERRUGE. Camara Municipal. Correio Mercantil. Rio de Janeiro, 04 de setembro de 1864. p.3

O COLLEGA FERRUGE. Camara Municipal. Correio Mercantil. Rio de Janeiro, 03 de setembro de 1864. p.2

O INDIGNADO CONTRA OS REGULOS DE ALDEIA. "Santana do Macacú." Correio Mercantil, 02 de setembro de 1864. p.3

O VIB ORA. "Ao veritas". Correio Mercantil. Rio de Janeiro, 24 de agosto de 1864. P.2

OS ARTISTAS FIRMES. "Atenção". Correio Mercantil. Rio de Janeiro, 07 de setembro de 1864. p.2

OS ARTISTAS. "Lista". Correio Mercantil. Rio de Janeiro, 02 de junho de 1856. p.3

OS MEMBROS DA COMISSÃO CENTRAL. "Eleições municipais". Correio Mercantil. Rio de Janeiro, 07 de setembro de 1864. p.3

S/A. "Associação Nacional dos Artistas Brasileiros Trabalho, União e Moralidade.". Correio Mercantil, 23 de setembro de 1864. p.3

S/A. "Associação Nacional dos Artistas Brasileiros". CORREIO MERCANTIL. Rio de Janeiro, 26 de abril de 1856. p.3

S/A. "Associação Nacional dos Artistas Brasileiros." CORREIO MERCANTIL. Rio de Janeiro, 12 de fevereiro de 1857. p.2

S/A. "Boletim Eleitoral". Correio Mercantil. Rio de Janeiro, 17 de agosto de 1863. p.1

S/A. "Ilma. Camara Municipal. Extrato do expediente do mês de agosto de 1864". Correio Mercantil, 24 de outubro de 1864. p.2 
S/A. "Ministério do Império". Notícias Diversas. Correio Mercantil. Rio de Janeiro, 07 de maio de 1868.

S/A. "Vereança". Correio Mercantil, Rio de janeiro, 01 de setembro de 1864. p.3

S/A. "Aos votantes". Correio Mercantil. Rio de Janeiro, 26 de agosto de 1864. P.3

S/A. "Atenção". Correio Mercantil. Rio de Janeiro, 26 de agosto de 1864. P.3

S/A. "Boletim Eleitoral". CORREIO MERCANTIL, Rio de Janeiro, 10 de agosto de 1863. p.3

S/A. "Camara Municipal". Correio Mercantil. Rio de Janeiro, 26 de agosto de 1864. P.3

S/A."Chapa de Ferro em oposição à chapa de ferro". Correio Mercantil. Rio de Janeiro, 07 de setembro de 1864. p.2

S/A. "Editais". Boletim da Illustríssima Câmara Municipal da Corte. Rio de Janeiro, julho a setembro de 1866, volume VII, VIII e IX - 1

S/A. "Notícias Diversas". CORREIO MERCANTIL. Rio de Janeiro, 11 de dezembro de 1854. p.1.

S/A. Aos artistas. Correio Mercantil. Rio de Janeiro, 31 de agosto de 1864. p.3

S/A. Congresso Juvenil Artístico. Correio Mercantil. Rio de Janeiro, 11 de setembro de 1863. p.3

S/A. Correio Mercantil, Rio de Janeiro. 19 de agosto de 1863

S/A. Correio Mercantil. Rio de Janeiro, 11 de agosto de 1863. p.3

S/A. Correio Mercantil. Rio de Janeiro, 06 de setembro de 1864, p.2

S/A. Correio Mercantil. Rio de Janeiro, 19 de agosto de 1864. P.2

S/A. Foi ao Sr. Barros... Correio Mercantil. Rio de Janeiro, 04 de abril de 1867. p.1

S/A. Ilma. Câmara Municipal. Correio Mercantil. Rio de Janeiro, 08 de maio de 1867. p.2

S/A. Juiz de Paz. Correio Mercantil. Rio de Janeiro, 14 de setembro de 1864.p.2

S/A. Noticias diversas Correio Mercantil, 23 de setembro de 1862. p.1

S/A. Os escandalos do Conservatório dramático Correio Mercantil, 15 de junho de 1862. p.2

S/A. Parlamento. Senado. Sessão em 28 e julho de 1864. Correio Mercantil, 06 de agosto de 1864. p. 1

S/A. Resultado da eleição. Correio Mercantil. Rio de Janeiro, 11 de setembro de 1864. p.2

S/A. Resultado da eleição. Correio Mercantil. Rio de Janeiro, 13 de setembro de 1864. P.1

S/A. Resultado das eleições. Correio Mercantil. Rio de Janeiro, 18 de setembro de 1863. p.2

S/A. Sarau da Arcádia Fluminense. Correio Mercantil, 02 de janeiro de 1866

SCIENCIA COMMERCIO E ARTES. "Para Vereadores". Correio Mercantil. Rio de Janeiro, 07 de setembro de 1864. p. 2

SILVA E LIMA, Manoel Affonso. " Festejos para o dia 7 de setembro". Correio Mercantil. Rio de Janeiro, 08 de agosto de 1856. p.2

UM ARTISTA. "Para vereador". Correio Mercantil. Rio de Janeiro, 24 de agosto de 1864. P.2

UM ARTISTA. "Para Vereador". Correio Mercantil. Rio de Janeiro, 19 de agosto de 1864. P.2

UM ARTISTA. "Para Vereador". Correio Mercantil. Rio de Janeiro, 20 de agosto de 1864. P.3

UM ARTISTA. "Para Vereador". Correio Mercantil. Rio de Janeiro, 22 de agosto de 1864. P.3

UM QUE CONHECE A AMBOS. "Veritas Veritatis". Correio Mercantil. Rio de Janeiro, 25 de agosto de 1864. P.2

UM VOTANTE DE S. JOSÉ. Para vereadores. Correio Mercantil. Rio de Janeiro, 23 de agosto de 1864.

VERITAS. "Leiam todos". Correio Mercantil. Rio de Janeiro, 31 de agosto de 1864. p.3

VERITAS. Respostas aos que guerreiam a candidatura do Ilm. sr. Francisco Joaquim

Bethencourt da Silva. Correio Mercantil. Rio de Janeiro, 23 de agosto de 1864. P.3 
VERITAS. Respostas aos que guerreiam a candidatura do Ilm. sr. Francisco Joaquim Bethencourt da Silva. Correio Mercantil. Rio de Janeiro, 25 de agosto de 1864. P.3

VERITAS. Respostas aos que guerreiam a candidatura do Ilm. sr. Francisco Joaquim Bethencourt da Silva. Correio Mercantil. Rio de Janeiro, 27 de agosto de 1864.

VERITAS. Respostas aos que guerreiam a candidatura do Ilm. sr. Francisco Joaquim Bethencourt da Silva. Correio Mercantil. Rio de Janeiro, 29 de agosto de 1864. p.3

VERITAS. Respostas aos que guerreiam a candidatura do Ilm. sr. Francisco Joaquim Bethencourt da Silva. Correio Mercantil. Rio de Janeiro, 31 de agosto de 1864. p.3

VIEIRA, Quirino Antonio . "Vereança". Correio Mercantil. Rio de Janeiro, 07 de setembro de 1864. p.2

VIEIRA, Quirino Antonio. "Municipalidade. Correio Mercantil. Rio de Janeiro, 07 de setembro de 1864. p.3

\subsection{4 diversos}

ACADEMIA IMPERIAL DAS BELLAS ARTES. “Academia Imperial das Belas Artes”. Correio Mercantil. Rio de Janeiro, 16 de novembro de 1864.

ASSIS, Joaquim Maria Machado de. "Folhetim. Ao Acaso". Diário do Rio de Janeiro. 21 de fevereiro e 1865. p.1.

ASSIS, Machado de. "Comentários da Semana". Diário do Rio de Janeiro, 26 de janeiro de 1862. Disponível online em: http://machado.mec.gov.br/ [útimo acesso: abril de 2016].

ASSIS, Machado de. "Comentários da Semana". Diário do Rio de Janeiro, 01 de novembro de 1861. Disponível online em: http://machado.mec.gov.br/ [útimo acesso: abril de 2016]

BETHENCOURT DA SILVA. "Duas palavras sobre arquitetura. Ao Ilmo. Sr. Conselheiro Luiz Pedreira do Couto Ferraz, ministro do Império". Belas Artes. In: Brazil Illustrado. Rio de Janeiro, N.5, Vol.1, 31 de julho de 1855. pp.76-77.

COQUES, Gonzalez. Correio Mercantil. Rio de Janeiro, 30 de janeiro de 1865. p.2.

CORREIO Mercantil, Rio de Janeiro, 28 de setembro de 1864, p.1.

CORREIO mercantil. Rio de Janeiro, 16 de janeiro de 1865. p.1.

CORREIO Mercantil. Rio de Janeiro, 16 de janeiro de 1865. p.1.

GAUTIER, Théophile. "Salon de 1863". Moniteur Universel. Paris, n.164, 13 e 15 de junho de $1863, \mathrm{p} .1$

GAZETA de Notícias. Rio de Janeiro, 04 de agosto de 1875. p.1.

MARSAN, Paul de. "Cours d'Esthétique général et appliquée". In: LE MONITEUR des architectes, Paris, 1867, $2^{\circ}$ vol., 2a. série, 1er Juillet 1867. p.124.

O AUXILIADOR da Indústria Nacional. 1862-1867. Rio de Janeiro.

PORTO ALEGRE, Manuel Araújo. "Discurso do diretor da Academia das Belas Artes por ocasião da distribuição pública dos prêmios.". Correio Mercantil, Rio de Janeiro, ano XIII, 30 de novembro de 1856. P.1.

PORTO ALEGRE, Manuel de Araújo. "Discurso do diretor da Academia das Belas Artes por ocasião da distribuição pública dos prêmios.”. In: Correio Mercantil, Rio de Janeiro, 30 de novembro de 1857, p. 1

S/A. "Revista do Domingo." Diário de notícias. Rio de Janeiro, 02 de outubro de 1870. p.1. S/A. Moniteur Universel: Journal officiel de l'Empire Français, Paris, n.333, 29 novembre 1863. 
S/A."Cópia impressa de carta enderaçada a Pedro Américo em 30 de setembro de 1870". A Reforma, 30 de novembro de 1870, p. 1

SOUZA E MELLO, Manoel Felizardo. "Instrucções para as Exposições agrícolas nas Provincias do Império". Jornal Treze de Maio. Ano XVII. Pará, 09 de outubro de 1861, n.71. p.1. Disponível online em:

http://memoria.bn.br/DocReader/docreader.aspx?bib=700002\&pasta=ano\%20186\&pesq=Instruc\%C3

$\% \mathrm{~A} 7 \% \mathrm{C} 3 \% \mathrm{~B} 5$ es $\% 20$ para $\% 20$ as $\% 20$ Exposi $\% \mathrm{C} 3 \% \mathrm{~A} 7 \% \mathrm{C} 3 \% \mathrm{~B} 5$ es\%20agricolas\%20nas\%20Provincia s\%20do\%20Imperio [último acesso, abril de 2016]

\section{Bibliografia}

\subsection{Escritos de Pedro Americo (em ordem cronológica)}

AMÉRICO, Pedro. La réforme de l'École des Beaux-Arts et l'opposition-par un élève. Paris: A. Morel et Cie., 1863.

AMÉRICO, Bacharel Pedro. "Considerações filosóficas sobre as belas artes entre os antigos.

Estudo primeiro". Correio Mercantil. Rio de Janeiro, 30 de setembro de 1864. Pp.1-2.

AMÉRICO, Bacharel Pedro. "Considerações filosóficas sobre as belas artes entre os antigos.

Estudo segundo, continuação". Belas Artes. Correio Mercantil. Rio de Janeiro, 2 de outubro de 1864. Pp.2-3.

AMÉRICO, Bacharel Pedro. "Considerações filosóficas sobre as belas artes entre os antigos. estudo terceiro".Belas Artes. Correio Mercantil. Rio de Janeiro, 3 de outubro de 1864. p.2.

AMÉRICO, Bacharel Pedro. "Considerações filosóficas sobre as belas artes entre os antigos. Estudo terceiro, continuação". Belas Artes. Correio Mercantil. Rio de Janeiro, 4 de outubro de 1864. Pp.1-2.

AMÉRICO, Bacharel Pedro. "Considerações filosóficas sobre as belas artes entre os antigos. Estudo terceiro, continuação". Belas Artes. Correio Mercantil. Rio de Janeiro, 5 de outubro de 1864. p.2.

AMÉRICO, Bacharel Pedro. "Considerações filosóficas sobre as belas artes entre os antigos. Estudo quarto". Belas Artes. Correio Mercantil. Rio de Janeiro, 7 de outubro de 1864. p.2

AMÉRICO, Bacharel Pedro. "Considerações filosóficas sobre as belas artes entre os antigos. Estudo quarto (continuação)." Belas Artes. Correio Mercantil. Rio de Janeiro, 9 de outubro de 1864. p.2.

AMÉRICO, Bacharel Pedro. "Considerações filosóficas sobre as belas artes entre os antigos. Estudo quarto (continuação)". Belas Artes. Correio Mercantil. Rio de Janeiro, 10 de outubro de 1864. p.2.

AMÉRICO, Bacharel Pedro. "Considerações filosóficas sobre as belas artes entre os antigos. Estudo quinto". Belas Artes. Correio Mercantil. Rio de Janeiro, 12 de outubro de 1864. p.2.

AMÉRICO, Bacharel Pedro. "Considerações filosóficas sobre as belas artes entre os antigos. Estudo quinto (continuação)". Belas Artes. Correio Mercantil. Rio de Janeiro, 14 de outubro de 1864. p.2.

AMÉRICO, Bacharel Pedro. "Considerações filosóficas sobre as belas artes entre os antigos. Estudo sexto". Belas Artes. Correio Mercantil. Rio de Janeiro, 30 de outubro de 1864. p.1.

AMÉRICO, Bacharel Pedro. "Considerações filosóficas sobre as belas artes entre os antigos. Estudo sexto(continuação)". Belas Artes. Correio Mercantil. Rio de Janeiro, 2 de novembro de 1864. p.2. 
AMÉRICO, Bacharel Pedro. "Considerações filosóficas sobre as belas artes entre os antigos. Estudo sexto (continuação)". Belas Artes. Correio Mercantil. Rio de Janeiro, 15 de novembro de 1864. p.2.

AMÉRICO, Bacharel Pedro. "Considerações filosóficas sobre as belas artes entre os antigos. Estudo sexto (continuação)." Belas Artes. Correio Mercantil. Rio de Janeiro, 16 de novembro de 1864. p.2.

AMÉRICO, Bacharel Pedro. "Considerações filosóficas sobre as belas artes entre os antigos.Estudo sétimo". Belas Artes. Correio Mercantil. Rio de Janeiro, 17 de novembro de 1864. p.2.

AMÉRICO, Bacharel Pedro. "Considerações filosóficas sobre as belas artes entre os antigos. Estudo sétimo (continuação)". Belas Artes. Correio Mercantil. Rio de Janeiro, 19 de novembro de 1864. Pp.2-3.

AMÉRICO, Bacharel Pedro. "Considerações filosóficas sobre as belas artes entre os antigos. Estudo sétimo (continuação)". Belas Artes. Correio Mercantil. Rio de Janeiro, 21 de novembro de 1864. p.2.

AMÉRICO, Bacharel Pedro. "Considerações filosóficas sobre as belas artes entre os antigos. Conclusão". Belas Artes. Correio Mercantil. Rio de Janeiro, 25 de dezembro de 1864. p.1.

AMÉRICO, Bacharel Pedro. "Considerações filosóficas sobre as belas artes entre os antigos. Conclusão". Belas Artes. Correio Mercantil. Rio de Janeiro, 26-27 de dezembro de 1864. p.2.

AMÉRICO, Bacharel Pedro. "Descobertas Arqueológicas do nosso século seu alcance histórico importância da ciência que as estuda.". Belas Artes. Correio Mercantil. Rio de Janeiro, 29 de setembro de 1864. Pp.1-2.

AMÉRICO, Bacharel Pedro."Considerações filosóficas sobre as belas artes entre os antigos.Estudo segundo". Correio Mercantil. Rio de Janeiro, 1 de outubro de 1864. P.2

AMÉRICO, Pedro. Considerações Filosóficas sobre as Belas Artes entre os Antigos. Edição e estudo introdutório de Silvano Alves Bezerra da Silva. João Pessoa: UFPB, 2006.

AMÉRICO, P. "A Carioca. (Resposta ao Sr. Gonzalez Coques.)" Correio Mercantil, Rio de Janeiro, 31 de janeiro de 1865. p.2.

AMÉRICO, Pedro. "Cartas de um plebeu aos Srs. Deputados". Primeira carta. Correio Mercantil. Rio de Janeiro, 18 de maio 1865.

AMÉRICO, Pedro. "Cartas de um plebeu aos Srs. Deputados". Segunda Carta. Correio Mercantil. Rio de Janeiro, 21 de maio 1865.

AMÉRICO, PEdro. "Cartas de um plebeu aos Srs. Deputados". Terceira carta. Correio Mercantil. Rio de Janeiro, 26 de maio 1865.

AMÉRICO, Pedro. "Cartas de um plebeu aos Srs. Deputados. Continuação da quarta carta." Correio Mercantil. Rio de Janeiro, 16 de junho 1865.

AMÉRICO, Pedro. "Cartas de um plebeu aos Srs. Deputados. Quarta carta." Correio Mercantil. Rio de Janeiro, 13 de junho 1865.

AMÉRICO, Pedro. "Cartas de um plebeu aos Srs. Deputados. Quinta carta". Correio Mercantil. Rio de Janeiro, 29 de junho 1865.

AMÉRICO, Pedro. "Considerações filosóficas sobre as belas artes entre os antigos. Conclusão". Belas Artes. Correio Mercantil. Rio de Janeiro, 28 de dezembro de 1864. p.2.

AMÉRICO, Pedro. La science et les sytèmes: questions d'histoire et de philosophie naturelle. Seconde édition. Bruxelles: Gustave Mayolez, 1869.

AMÉRICO, Pedro. A ciência e os sistemas: questões de história e de filosofia natural. Edição e estudo introdutório de Silvano Alves Bezerra da Silva. João Pessoa: Ed. Universitária/UFPB, 2001.

AMÉRICO, Pedro. Holocausto, Florença: Typ. Genniniana, 1882. 
AMÉRICO, Pedro. "Cartas de um pintor", Rio de Janeiro, Gazeta de Noticias, n. 236, ano X, sábado, 23 de agosto de 1884, p. 1. Disponível online em: bndigital.bn.br/hemeroteca-digital/; ou em: http://www.dezenovevinte.net/txt_artistas/cartas_pedroamerico.htm [último acesso, 13 de maio de 2016]

AMÉRICO, Pedro. "Cartas de um pintor". Rio de Janeiro, Gazeta de Noticias, n. 241, ano X, quinta-feira, 28 de agosto de 1884, p. 1. Disponível online em: bndigital.bn.br/hemeroteca-digital/; ou em: http://www.dezenovevinte.net/txt_artistas/cartas_pedroamerico.htm [último acesso, 13 de maio de 2016]

AMÉRICO, Pedro. "Cartas de um pintor". Rio de Janeiro, Gazeta de Noticias, n.260, ano X, terça-feira, 16 de setembro de 1884, p.1. Disponível online em: bndigital.bn.br/hemeroteca-digital/; ou em: http://www.dezenovevinte.net/txt_artistas/cartas_pedroamerico.htm [último acesso, 13 de maio de 2016]

AMÉRICO, Pedro. Amor d'esposo: narrativa histórica. Florença: Imprensa de l'arte della stampa. 1886.

AMÉRICO, Pedro. Alguns discursos. Florença: Imprensa de l'Arte Della Stampa, 1888.

AMÉRICO, Pedro; OLIVEIRA, Cecília H. de S. e MATTOS, Cláudia V. de (orgs.). O brado do Ipiranga. São Paulo: EDUSP, 1999. (Florença, 1888).

AMÉRICO, Pedro. Relatório apresentado ao governo imperial sobre o congresso internacoinal de preservação de monumentos de arte. [Manuscrito]. Paris, 1889. Disponível online em https://bndigital.bn.br/acervodigital/ [último acesso: dezembro de 2015.]

AMÉRICO, Pedro. Discursos. Rio de Janeiro: Imprensa Nacional, 1892.

AMÉRICO, Pedro. O foragido. Rio de Janeiro/Paris: H. Garnier, 1899. p.XVI.

AMÉRICO, Pedro. Na cidade eterna. Florença: 1901.

\subsection{Escritos sobre Pedro Americo}

ALMEIDA, Horácio de. Pedro Américo, notícias biográficas. João Pessoa: União Editora, 1943.

ARSEOS. Analyse esthetigraphica do quadro de um episodio da Batalha de Campo Grande planejado e executado pelo Dr. Pedro Americo de Figueiredo e Mello, lente da cadeira de esthetica da Academia das bellas artes do Rio de Janeiro. Rio de Janeiro: Typographia Nacional, 1871.

BARROS, Francisca Argentina Gois. A arte como princípio educativo: uma nova leitura biográfica de Pedro Américo de Figueiredo de Mello. Fortaleza, 2006. (Tese de Doutoramento em Educação, UFCE].

BOCAIÚVA, Quintino. “A Batalha de Campo Grande (Quadro Histórico) - Carta de Quintino Bocaiúva a Pedro Américo - publicada na gráfica". Rio de Janeiro, A República, 10 de Outubro de 1871.

CARDOSO, Rafael. "Ressuscitando um Velho Cavalo de Batalha: Novas Dimensões da Pintura Histórica do Segundo Reinado". 19\&20, Rio de Janeiro, v. II, n. 3, jul. 2007. Disponível em: $<$ http://www.dezenovevinte.net/criticas/rc_batalha.htm>. [último acesso: outubro de 2014]

CHRISTO, Maraliz C. V. "Quando subordinados roubam a cena: A Batalha de campo Grande de Pedro Américo". In: Sceculum, Revista De História. João Pessoa, jul/ dez. 2008.

CHRISTO, Maraliz de C. V. “A pintura histórica na América Latina.” In: BESSA, Pedro (org.). Integração Latino-Americana. Juiz de Fora: UFJF, Belo Horizonte: FAPEMIG, 1993, p. 331-332.

CHRISTO, Maraliz de C. V. "O esquartejamento de uma obra: a rejeição ao Tiradentes de Pedro Américo". LOCUS: revista de história. Juiz de Fora: Núcleo de História Regional e EDUFJF, v.4 n², dez.1998, p.143-167.

CHRISTO, Maraliz de C. V. Pintura, história e heróis: Pedro Américo e "Tiradentes 
esquartejado”. Campinas, 2005 (Tese de doutoramento em História, UNICAMP).

COLI, Jorge. "O sentido da batalha : Avahy, de Pedro Americo ", Projeto História (artes da história \& outras linguagens), São Paulo: PUC-São Paulo, n. 24, junho, 2002, p.113-127.

COTRIM, Álvaro. Pedro Américo e a Caricatura. RJ, Edições Pinakotheke, 1983.

DESENHOS de Pedro Américo, pintor neoclássico brasileiro do século XIX. Secretaria de Estado da Informação e Turismo, s/d.

DIAS, Elaine. Pedro Américo. [coleção Folha Grandes Pintores]. São Paulo: Folha de São Paulo, 2014.

DUQUE-ESTRADA, Luiz G. Impressões de um amador. Textos esparsos de crítica (18821909). [orgs. Júlio Castañon Guimarães e Vera Lins]. Editora UFMG / Fundação Casa de Rui Barbosa, 2001.

DUQUE-ESTRADA, Luiz Gonzaga. Arte Brasileira. [Introdução e Notas, Tadeu Chiarelli]. Campinas: Mercado de Letras, 1995.

GUBERNATIS, Angelo de. Dizionario degli artisti italiani viventi, pittori, scultori, architetti. Firenzi: Tipi dei successori Le Monnier, 1889.

GUIMARÃES JÚNIOR., Luiz. C. Pereira. "Perfil de Pedro Américo". In: Sonetos e Rimas. Rio de Janeiro: H. Brown e João de Almeida, 1871.

GUIMARÃES JÚNIOR, L. Pedro Américo. Rio de Janeiro: Henrique Brown, 1871.

GUIMARÃES, Argeu. "Paixão e Glória de Pedro Américo". Conferência no IHGB, 29 de setembro de1942, reproduzida no mensário do Jornal do Commércio.

HUDSON, Octaviano. Pedro Américo, pintor de batalhas. Descrição do quadro histórico da Batalha de Campo Grande. Rio de Janeiro, Henrique Brown e João Almeida Editores. Tipografia da República, 1871.

MÁRTIN, Sílvio Santos da Silva. "La Carioca rencontre La Source: Pedro Américo dans l'atelier d'Ingres ?", Loxias, n. 42, mis en ligne le 14 octobre 2013 URL :

http://revel.unice.fr/loxias/index.html?id=7584

MARTINS, Lincoln Mello. Pedro Américo: Pintor Universal. S/l. Fundação Banco do Brasil Governo do Estado da Paraíba, 1994.

MELLO JÚNIOR., Donato. Pedro Américo de Figueiredo e Melo, 1843-1905. Rio de Janeiro, Pinakotheke, 1983.

OLIVEIRA, Claudia de. “'A Carioca' de Pedro Américo: gênero, raça e miscigenação no Segundo Reinado". In: CAIANA. Revista electrónica de Historia del Arte y Cultura Visual del Centro Argentino de Investigadores de Arte (CAIA). No $2 \mid$ Año 2013.) Disponível online em:

http://caiana.caia.org.ar/template/caiana.php?pag=articles/article_2.php\&obj=98\&vol=2 [último acesso: janeiro de 2016].

OLIVEIRA, Cláudia de; NERY, Laura de. "A Carioca, de Pedro Américo: alegoria e erotismo no imaginário oitocentista brasileiro." In: ANAIS do XXIV Simpósio Nacional de História - ANPUH/ Simpósio temática História Cultural e suas interfaces. São Leopoldo (RS): Unisinos, 2007.

Disponível em : ttp://www.ufrgs.br/gthistoriaculturalrs/laura_nery_e_claudia_de_oliveira.html [último acesso: janeiro de 2016]

OLIVEIRA, J. M. Cardoso de. Pedro Américo: sua vida e suas obras. Paris: Guillard, Aillaud \& Cia, Editores, 1898.

OLIVEIRA, J.M. Cardoso de. Pedro Américo sua vida e suas obras. Rio de Janeiro: Imprensa Nacional, 1943.

OLIVEIRA, J.M. Cardoso de. Pintura brasileira, Pedro Américo, Catalogo das obras do grande mestre brasileiro anotado e acompanhado de apontamentos biographicos. Paris-Lisboa: Livrarias Aillaud e Bertrand, 1924. 
OLIVEIRA, Vladimir Machado de. "Do esboço pictórico à rotunda dos dioramas: a fotografia na pintura das batalhas de Pedro Américo”. São Paulo: 2002 (Tese de doutoramento, Departamento de História da USP).

PEKALA, Madalena de Fátima Zacara. Pedro Américo, vie et oeuvre: son rôle dans la peinture du Brésil au XIXe siècle. Toulouse: 1995. (Tese de doutorado, Université de Toulouse - Le Mirail).

PEKALA, Madalena de Fátima Zacara. Pedro Américo: um artista brsileiro do século XIX. Recife: Editora UFPE, 2011.

PEREIRA, Sônia Gomes. "O percurso e os dilemas de artistas brasileiros em Paris no século XIX: o caso da tela A Carioca de Pedro Américo." In: RIBEIRO, Marilia Andrés; GONÇALVES, Denise da Silva (Orgs.) Anais do XXI Cológio do Comitê Brasileiro de História da Arte. Tiradentes/MG, outubro de 2005. Belo Horizonte: Editora C/ Arte, 2006. [pp.292-301].

ROSEMBERG, Liana R. B. Pedro Américo e o olhar oitocentista. Rio de Janeiro: Produções Barroco Editoriais, 2002.

SÁ, Ivan Coelho de. A academização da pintura romântica no Brasil e sua ligação com o pompierismo francês: o caso de Pedro Américo. Rio de Janeiro:1995 (Dissertação de mestrado, EBAUFRJ).

TORRES, Francisco Tancredo. Dossiê Pedro Américo. Mossoró: Coleção Mossoró, 2002.

VASARI, Giorgio. Analyse critica da Batalha de Campo Grande e do Combate de Riachuelo dos distinctos mestres Dr. Pedro Americo e Commendador Victor Meirelles. Rio de Janeiro.

Typographia Universal de Laemmert, 1872.

\subsection{Sobre arte brasileira}

ABRANTES, Miguel Calmon du Pin e Almeida, Marquês de. "Prefácio". In: IMPERIAL INSTITUTO ARTÍSTICO. Recordações da Exposição Nacional de 1861. Rio de Janeiro: Imperial Instituto Artístico, 1862.

AMARAL, Cláudio Silveira. John Ruskin e o desenho no Brasil. Tese de Doutorado. São Paulo: Faculdade de Arquitetura e Urbanismo da Universidade de São Paulo, 2005.

BARROS, Álvaro Paes de. O Liceu de Artes e Ofícios e seu fundador: depoimento histórico do primeiro centenário da grande instituição. Rio de Janeiro: 1956.

BIELINSKI, Alba Carneiro. "O Liceu de Artes e Ofícios - sua história de 1856 a 1906”. 19\&20, Rio de Janeiro, v. IV, n. 1, jan. 2009. Disponível em: http://www.dezenovevinte.net/ensino artistico/liceu_alba.htm>.

BIELINSKI, Alba Carneiro. Liceu de Artes e Ofícios do Rio de Janeiro - dos pressupostos aos reflexos de sua criação - de 1856 a 1900. (Dissertação de Mestrado) Rio de Janeiro: EBA-UFRJ, 2003.

CARDOSO, Rafael. "A Academia Imperial de Belas Artes e o Ensino Técnico". 19\&20, Rio de Janeiro, v. III, $\quad$ n. $1, \quad$ jan. 2008. Disponível em: $<\mathrm{http}: / /$ www.dezenovevinte.net/ensino_artistico/rc_ebatecnico.htm $>$.

CAVALCANTI, Ana Maria Tavares. Les Artistes brésiliens et "les prix de voyage en Europe" à la fin du XIXe siècle : vision d'ensemble et étude approfondie sur le peintre Eliseu d'Angelo Vvisconti (1866 - 1944). Tese de Doutorado sob a direção de Éric Darragon. Paris: Université Paris I - Panthéon Sorbonne, 1999.

CAVALCANTI, Ana; OLIVEIRA, Emerson D. G.; COUTO, Maria de Fátima M.; MALTA, Marize. Arte e suas Instituições. XXXIII Colóquio Do Comitê Brasileiro De História Da Arte. Rio de Janeiro: UFRJ, 2013.

CHIARELLI, Tadeu. Um Jeca nos vernissages. São Paulo: Edusp, 1995. 
CHILLÓN, Alberto Martin. "Entre tradição e modernidade: Almeida Reis e o Paraíba". Revista Caiana. n.5. Segundo semestre de 2014. pp.29-43. Disponível online:

http://www.academia.edu/11333095/Entre tradiC3\%A7\%C3\%A3o_e modernidade_Almeida_Reis_e _O_Para\%C3\%ADba [último acesso em março de 2015]

CHILLÓN, Alberto Martín. "O Gênio do Brasil e as Musas: Um manifesto ideológico numa nação em construção". 19\&20, Rio de Janeiro, v. IX, n. 1, jan./jun. 2014. Disponível em:

$<\mathrm{http}$ //www.dezenovevinte.net/obras/obras_amc.htm>

DIAS, Elaine. Paisagem e academia: Félix-Émile Taunay e o Brasil (1824-1851). Campinas: Unicamp, 2009.

FERNANDES, Cybele Vidal Neto. Os caminhos da arte: $O$ ensino artístico na Academia Imperial das Belas Artes - 1850/1890. (Tese de Doutorado). Rio de Janeiro: IFCS/UFRJ, 2001.

FERRAZ, Luiz Pedreira do Coutto. "Decreto no 1.603, de 14 de Maio de 1855 dá novos Estatutos à Academia das Bellas Artes". Disponível em: http://www2.camara.leg.br/legin/fed/decret/1824-1899/decreto-1603-14-maio-1855-558536-normape.html

FERREIRA, Félix. Belas Artes: Estudos e apreciações. Introdução e notas de Tadeu Chiarelli. Porto Alegre, RS: Zouk, 2012.

FERREIRA, Félix. Bethencourt da Silva. Perfil artistico. Rio de Janeiro: Imprensa Industrial, 1876.

FERREIRA, Félix. Do ensino profissional. Rio de Janeiro: Imprensa Industrial, 1876.

GALVÃO, Alfredo. "Manuel de Araújo Porto-Alegre: sua influência na Academia Imperial das Belas Artes e no meio artístico do Rio de Janeiro". In: Revista do Patrimônio Histórico e Artístico Nacional, n.14, Rio de Janeiro, 1959.

GALVÃO, Alfredo. Subsídios para a História da Academia Imperial e da Escola Nacional de Belas Artes. Rio de Janeiro: Escola Nacional de Belas Artes, 1954, pp.85-147.

KOVENSKY, Julia; SQUEFF, Letícia (orgs.). Manuel de Araújo Porto Alegre: Singular \& Plural. São Paulo: IMS, 2014.

LEVY, Carlos Roberto Maciel. Exposições Gerais da Academia Imperial e da Escola Nacional de Belas Artes. Rio de Janeiro: Edições Pinakotheke, 1990.

LICEU DE ARTES E OFÍCIOS DO RIO DE JANEIRO. Relatórios do Lycêo de Artes e Officios. Diretorias de 1882 a 1884. Rio de Janeiro: Typographia de J. P. Hildebrandt, 1884.

MEIRELLES, Victor. "Relatório da Exposição Nacional de 1866". In: Boletim do Grupo de Estudos do Centro de Pesquisas em Arte\&Fotografia. No.01. Departamento de Artes Plásticas da ECA-USP, Abril-maio de 2006.

MELLO JÚNIOR, Donato. "Manuel de Araújo Porto-alegre e a Reforma da Academia Imperial das Belas Artes em 1855: a Reforma Pedreira", Revista Crítica de Arte, n.4 (1981), pp.27-53.

MIGLIACCIO, Luciano. "O Século XIX”. In: Mostra do Redescobrimento. São Paulo Fundação Bienal de São Paulo - Associação Brasil 500 anos Artes Visuais, 2000.

MIYOSHI, Alexander Gaiotto. "Moema, a pintura de uma personagem literária." In: ANAIS do IV Encontro de História da Arte - IFCH / UNICAMP, 2008. Campinas: 20008. p.773. Disponível online em: http://www.unicamp.br/chaa/eha/atas/2008/MIYOSHI,\%20Alexandre\%20Gaiotto\%20\%20IVEHA.pdf [último acesso: março de 2016.]

MIYOSHI, Alexander Gaiotto. Moema é morta. Tese de Doutorado. Campinas: Unicamp, 2010.

MORAES, Julio Lucchesi. "A Modernidade Acadêmica: Os primeiros tempos do Liceu de Artes e Ofícios de São Paulo". 19\&20, Rio de Janeiro, v. V, n. 4, out./dez. 2010. Disponível em: $<$ http://www.dezenovevinte.net/ensino_artistico/ea_liceusp.htm> [último acesso: abril de 2013].

MORALES DE LOS RIOS FILHO, Adolfo. Grandjean de Montigny e a evolução da arte 
brasileira. Rio de Janeiro: A Noite, 1941.

MURASSE, Celina Midori. A educação para a ordem e o progresso do Brasil: o Liceu de Artes e Ofícios do Rio de Janeiro (1856-1888). (Tese de doutorado em educação). Campinas: Unicamp, 2001.

NAVES, Rodrigo. "Debret, e o Neoclassicismo e a Escravidão". A Forma Dificil. Ensaios sobre arte brasileira. São Paulo: Ática, 1997.

O BRAZIL ARTÍSTICO: Revista da Sociedade Propagadora das Bellas-Artes do Rio de Janeiro, Nova Phase. Rio de Janeiro: Typogrpahia Leuzinger, 1911.

PEREIRA, Sonia Gomes. "A Academia Imperial de Belas Artes no Rio de Janeiro: revisão historiográfica e estado da questão". In: Revista do Programa de Pós-Graduação em Artes Visuais EBA/UFRJ. Rio de Janeiro: EBA/UFRJ, 2001. p.74.

REVISTA do Patrimônio Histórico e Artístico Nacional. Rio de Janeiro, n.14, 1959.

RIOS FILHO, Adolfo Morales de los. "O Ensino Artístico: Subsídio para a Sua História" in IHGB, Anais do Terceiro Congresso de História Nacional, v.8. Rio de Janeiro, 1942.

ROCHA-PEIXOTO, Gustavo. "Introdução ao neoclassicismo na arquitetura do Rio de Janeiro". In: CZAJKOWSKI, Jorge (Org.). Guia da Arquitetura Colonial, neoclássica e romântica no Rio de Janeiro. Rio de Janeiro: Casa da Palavra; Prefeitura da Cidade do Rio de Janeiro, 2000.

SIMIONI, Ana Paula C. "A viagem a Paris de artistas brasileiros no final do século XIX", In: Tempo Social, revista de sociologia da USP, v. 17, n. 1. São Paulo, Julho de 2005. pp. 343-366. Disponível online em: http://www.scielo.br/pdf/ts/v17n1/v17n1a14.pdf [último acesso: março de 2016.]

SOCIEDADE PROPAGADORA DAS BELAS ARTES. Estatutos da Sociedade Propagadora das Belas Artes do Rio de Janeiro. Rio de Janeiro: Typ. Hildebrandt, 1893.

SOCIEDADE PROPAGADORA DAS BELLAS-ARTES. Estatutos. Rio de Janeiro: Indústria Nacional de J. J. C. Cotrim, 1871. p.5-6

SOCIEDADE PROPAGADORA DE BELAS ARTES. O Brazil Artístico: Revista da Sociedade Propagadora das Bellas-Artes do Rio de Janeiro. Rio de Janeiro: Typographia Leuzinger, 1911.

SOUZA FILHO, Tarquinio. O Ensino Technico no Brasil. Rio de Janeiro: Imprensa Nacional, 1887.

SQUEFF, Letícia. "A Reforma Pedreira na Academia de Belas Artes (1854-1857) e a constituição do espaço social do artista." In: Cadernos Cedes, ano XX, n.51, novembro de 2000. Pp.103-118.

SQUEFF, Letícia. O Brasil nas letras de um pintor: Manuel de Araújo Porto Alegre (18061879). Campinas: Unicamp, 2004.

STRAUCH, Paulo Cesar. Pindorama e o Palácio de Cristal. Um olhar brasileiro sobre a Exposição de Londres de 1851. Rio de Janeiro: Editora E-paper, 2008.

UZEDA, Helena Cunha de. O ensino de arquitetura no contexto da Academia Imperial de Belas Artes do Rio de Janeiro: 1816-1889. (Dissertação de Mestrado) Rio de Janeiro: EBA/UFRJ, 2000.

VALLADARES, Clarival do Prado. Rio Neoclássico. Análise Iconográfica do Barroco e Neoclássico Remanescentes no Rio de Janeiro. Rio de Janeiro: Bloch Editores, 1987. Vol. II.

\subsection{Arte Européia}

\subsubsection{Sobre a reforma da École des Beaux-Arts de Paris (ou relacionados a)}

AUDEVAL, Hippolyte. "Salon de 1872, III." La semaine des familles. Paris, n.12, anné 14, Samedi, 22 Juin 1872. pp.177-180. 
BAUDELAIRE, Charles. Oeuvres complètes de Charles Baudelaire. II Curiosités Esthétiques. Paris: Michel Lévy Frères, 1868.

BEULÉ, Charles. "L'École de Rome au dix-neuvième siècle". Extrait de la Revue des Deux Mondes, 15 de décembre de 1863. Paris: Imprimiere de J. Claye, 1863.

BEULÉ, Charles. Causeries sur l'art. Paris: 1867.

BOIME, A. Art in an age of civil struggle, 1848-1871. Chicago/London: University of Chicago Press, 2007.

BOIME, Albert. The Academy and the French painting in the Nineteenth Century. New Haven, London: Yale University Press, 1986.

BOIME, Albert. Thomas Couture and the eclectic vision. New Haven London : Yale University Press, 1980.

BONNET, Alain (direcs.) Apprendre à peindre: les ateliers privés à Paris - 1780-1863. Tours: Presses Universitaires Fraçois-Rabelais, 2013.

BOUVIER, Béatrice. "L'éditeur de presse architecturale et son équipe rédactionnelle", in Actes du Ve congrès national d'archéologie et d'histoire de l'art, Bordeaux, INHA, 1999, Disponível online em: http://inha.revues.org/2260 [último acesso, maio de 2015]

BONNET, Alain. L'enseignement des art au XIXe siècle: la réforme de l'École des beaux-arts de 1863 et la fin du modèle académique. Rennes: Presses Universitaires de Rennes, 2006.

CHAPPEY, Frédéric. "Les professeurs de l'Ecole des Beaux-Arts (1794-1873)". In: Romantisme, 1996, n93. pp. 95-101. Disponível online em:

http://www.persee.fr/web/revues/home/prescript/article/roman_0048-8593_1996_num_26_93_3129

(último acesso em outubro de 2014).

CHENNEVIÈRES, Philippe de. École Impériale des Beaux-Arts. Examen critique du rapport adressé a S. Exc. Le Marechal de France, ministre de La Maison de l'Empereur et des Beaux-Arts. Paris: E. Dentu, 1864.

CHENNEVIÈRES-POINTEL, Philippe. Souvenirs d'un directeurs des beaux-arts, 1883-1889. Paris. Arthena, 1979.

CHÉRON, Paul. "Bibliographie des ouvrages publiés en France et à l'étranger sur les Beaux-Arts pendant le premier semestre de 1864", in Gazette des Beaux-Arts, Paris, 1 juin 1864, sixième année, tome seizième, 1864.

CHESNEAU, Ernest. La vérité sur le Louvre, le Musée Napoléon III et les artistes industriels. Paris: E. Dentu, 1862.

CHESNEAU, Ernest. Le décret du 13 novembre et l'Académie des Beaux-Arts suivi du Rapport de M. de Nieuwerkerke, du Décret du 13 novembre, de la Protestation de l'Académie, et de la Réponse de S. Exc. Le maréchal Vaillant, Ministre de la Maison de l'Empereur et des Beaux-Arts. Paris: Didier et Ce., 1864.

CORNU, Hortense; ROTHSCHILD, Henri de. "Un document inédit sur l'histoire de la Collection Campana". Revue Archéologique. Quatrième Série, T. 22, (juillet-decembre 1913). Paris: Presses Universitaires de France. pp. 115-118. Disponível online em: http://www.jstor.org/stable/41023163

CORNU, Sébastien. Catalogue des Tableaux, des sculptures de la renaissance et des majoliques du Musée Napoléon III. Paris: Librairie de Firmin Didot Frères, fils et cie., 1862.

CORNU, Sébastien. Cours élémentaire et gradué du dessin de la figure humaine./ lithogr. par Jules Laurens ; publ. sous les auspices de S.E.M. le ministre de l'Instruction publique pour servir à l'enseignement dans les écoles primaires de l'Empire sous la dir. de Sébastien Cornu. Paris: A. Morel, 1870 .

COUSIN, Victor. Du vrai, du Beau et du Bien. septième édition. Paris: Didier et Cie, 1858. 
DALY, César. "De la réorganisation de l'École des Beaux-Arts", in DALY, César. Revue Génerale de L'Architecture et des Travaux Publics.Vol. XXII. Paris: 1864.

DELABORDE, Henri. Lettres et pensées d'Hippolyte Flandrin, accompagnées de notes et precedées d'une notice biographique et d'un catalogue des oeuvre de maître. Paris: Henri Plon, 1865. pp.453-492; ver ainda: FLANDRIN, Louis. Un peintre chrétien au XIXe siècle, Hippolyte Flandrin. Paris: Perrin et Cie., 1909.

DESJARDINS, Ernest. Du patriotisme dans les arts: réponse à M. Vitet sur le Musée Napoléon III. Paris: E. Dentu, 1862.

DESJARDINS, Ernest. Notice sur le Musée Napoléon III et promenade dans les galeries. deuxième edition. Paris: Michel Lévy Frères, 1862.

GIRAUD, CH. De la réorganisation de l'École des Beaux-Arts. Réponse à la lettre de M. Ingres. Paris: Imprimerie de Ad. Lainé et J. Havard, 1864.

GRANGER, Catherine. L'empereur et les arts: la liste civile de Napoléon III. Paris: École Nationale de Chartes, 2005.

GRUNCHEC, Philippe. Les concours des Prix de Rome de 1797 à 1863. Préface de Jacques Thuillier. Paris : École nationale supérieure des beaux-arts, 1983.

INGRES, Jean-Auguste Dominique. Réponse au rapport sur l'École Impériale des Beaux-Arts adressé au Maréchal Vaillant. Paris: Didier et Cie, 1863.

INGRES, Jean-Auguste Dominique. Réponse au rapport sur l'École Impériale des Beaux-Arts adressé au Maréchal Vaillant. Paris: Didier et Cie, 1863.

JOURNAL Général de l'Imprimerie et de la Librairie. Deuxième série. Tome VIII. Paris: 1864.

LEDUC, Edouard. Louis-Napoléon Bonaparte, le dernier empereur. Paris: Édition Publibook, 2010.

LENIAUD, Jean-Michel (dir.) Viollet-Le-Duc: les visions d'un architecte. [Exposition, Paris, Cité de l'architecture et du patrimoine, 20 novembre 2014 - 9 mars 2015]. Paris: Norma / Cité de l'archtecture et du patrimoine, 2014.

LORENZ, Otto (ed.), Catalogue Général de la Librairie Française (1840-1865). Tome deuxième. Paris : 1868.

LOUIS, V. Revue des Deux Mondes, Paris, 1er septembre 1862, p.169. ULYSSE,Chevalier. "Notice sur la vie et les travaux de M. Edmond Saglio ; lue dans la séance du 16 mai 1913". In: COMPTES rendus des séances de l'Académie des Inscriptions et Belles-Lettres, 57e année, N. 3, 1913. pp. 161-197. Disponível em :

http://www.persee.fr/web/revues/home/prescript/article/crai_0065-0536_1913_num_57_3_73202

MCWILLIAM, Neil; MÉNEUX Catherine; RAMOS, Julie (dir.). L'Art social de la Révolution à la Grande Guerre. Anthologie de textes sources, INHA (« Sources »), 2014. Disponível em : http://inha.revues.org/5504

MÉRIMÉE, Prosper. "Considérations sur les applications de l'art à l'industrie à L'Exposition universelle", Exposition de Londres, Rapport du Juri, Classe XXX. "Ameublement et décoration", section I, II, juin 1862. Repris dans P. Mérimée, Etudes anglo-américaines, Champion, 1930.

Disponível online em: http://cnum.cnam.fr/CGI/fpage.cgi?8XAE114 6/251/100/671/0/0

MÉRIMÉE, Prosper. La correspondance Mérimée-Viollet-le-Duc / éd. Françoise Bercé. Paris: Ed. Du CTHS, 2001.

MERSON, Olivier. De la réorganization de l'École Impériale et spéciale des beaux-arts. Extrait de l'Opinion Nationale. Paris: E. Dentu, 1864.

MICHELET, Jules. Renaissance. Paris: Chamerot, 1855.

MORTIER, Roland. L'originalité : une nouvelle catégorie esthétique au siècle des lumières. Genève: Droz, 1982. 
MUSÉE NAPOLÉON III. Catalogue des Bijoux du Musée Napoléon III. Paris: Librairie de Firmin Didot Frères, fils etc cie., p.1862.

NADALINI. Gianpaolo. "De Rome au Louvre, les avatars du Musée Campana entre 1857 et 1862", Histoire de l'art, n 21/22, 1993.

NADALINI. Gianpaolo. "De Rome au Louvre, les avatars du Musée Campana entre 1857 et 1862", Histoire de l'art, n’ 21/22, 1993.

NADALINI. Gianpaolo. "La collection Campana au musée Napoléon III et sa première dispersion dans les musées français (1862-1863)”. In: Journal des savants. 1998, N pp. 183-225. Ou: http://www.persee.fr/web/revues/home/prescript/article/jds_0021-8103_1998_num_2_1_1618

NADALINI. Gianpaolo. "La collection Campana au musée Napoléon III et sa première dispersion dans les musées français (1862-1863)”. In: Journal des savants. 1998, º pp.213-214.

PEKALA, Madalena Zaccara. Pedro Américo : vie et oeuvre ; son rôle dans la peinture du Brésil au XIXe siècle. Tese de doutorado sob a direção de Yves Bruand. Toulouse: Université de Toulouse II, 1995.

PEROT, Jacques. Commissaire d'exposition. Le comte de Nieuwerkerke : art et pouvoir sous Napoléon III: [exposition] Musée national du Château de Compiègne, 6 octobre 2000-8 janvier 2001.

PLANCHE, Gustave. Portraits d'Artistes. Paris: Michel Lévy freres, 1853.

POUILLON, François (éd.). Dictionnaire des orientalistes de langue française. Karthala, 2012.

QUINCY, Quatremère de. Considérations morales sur la destinations des ouvrages de l'art, ou de l'influence de leur emploi sur le génie et le gout, et sur le sentiment de ceux qui en jouissnet et en reçevoient les impressions. Paris: L'Imprimière de Crapelet, 1815.

REINACH, Salomon. Esquisse d'une histoire de la collection Campana. Paris : Leroux, 1905.

REISET, M. F. Notice des Tableaux du Musée Napoléon III exposés dans les salles de la colonnade au Louvre. Paris: Charles des Mourgues Frères, 1868.

ROCCAGIOVINE, Julie Bonaparte; BASSO, Isa Dardano (ed.) La princesse Julie Bonaparte, marquise de Roccagiovine et son Temps, mémoires inédites (1853-1870). Roma: Edizioni di storia e letteratura, 1975.

ROSENTHAL, Léon. Du romantisme au réalisme. Paris: Éditions Macula, 1987.

S/A. Réclamations des élèves de l'Ecole des Beaux-Arts au sujet de la réorganisation de leur École. Paris: Imprimière de Ad. Lainé et J. Havard, 1864.

SHAW, Jennifer L. "The figure of Venus: Rethoric of the ideal and the Salon of 1863". Art History. Vol. 14, n.4, December 1991. pp.540-570.

SUTTER, DAVID. Philosophie des Beaux-Arts apliquée à la peinture. Paris: Jules Tardieu, 1858.

TAINE, Hippolyte. Philosophie de l'Art. Paris: Germet Baillières, 1865.

TIBERGHIEN, Guillaume. Esquisses de Philosophie Morale. Bruxellas: Imprimiérie de Delevingne et Callewaert, 1854.

VIOLLET-LE-DUC, E. E. Dictionnaire raisonnée de l'architecture française du XIe au XVIe siècle. Tome VIII. Paris: Ve. A. Morel \& Cie., 1875.

VIOLLET-LE-DUC, Eugène-Emmanuel. Esthétique appliquée à l'histoire de l'art. Paris: Énsb-a, 1994.

VIOLLET-LE-DUC, E. E. Intervention de l'État dans l'enseignement des beaux-arts. Paris: A. Morel et Cie, 1864.

VIOLLET-LE-DUC. Lettres inédites de Viollet-Le-Duc recueillies et annotées par son fils. Paris: Librairies-Imprimières Réunies, 1902.

VITET, Louis; VIOLLET-LE-DUC, Eugène. À propos de l'enseignement des arts du dessin. 
Préface Bruno Foucart. Paris: École Nationale Supérieure des Beaux-Arts, 1984.

VITET, Ludovic. La Collection Campana. Paris : Impr. de J. Claye, 1862.

WINCKELMANN, J. J. Histoire de l'art dans l'Antiquité. Traduction de Dominique Tassel;

Introduction et notes de Daniela Gallo. Paris : La pochothéque, 2005.

WITTE, J. de. Notices sur les vases peints et a reliefs du Musée Napoléon III. Paris: Librairie de Firmin Didot Frères, fils et cie., 1862.

X.F. "École des Beaux-Arts. Revue de la quinzaine". In: VIOLLET-LE-DUC Fils, M. E.; CORROYER, M. E. Gazette des architectes et du batiment. Paris, Primeiro ano, A. Morel et Cia., 1863.

\subsubsection{Teoria e filosofia da arte, especialmente na França, no século XIX}

ALBERTI, Leon Battista. Da pintura. [tradução Antonio da Silveira Mendonça]. Campinas: Unicamp, 2014.

ALLARD, Sébastien. "L'expérimentation romantique”. In: LOYRETTE, Henri. L'art français: Le XIXe siècle (1819-1905).

ARGAN, Giulio Carlo. Arte Moderna: do Iluminismo aos movimentos contemporâneos. São Paulo: Companhia das Letras, 2013.

BABBITT, Irving. The New Laokoon: an essay on the confusion of the arts. Boston/New York: Houghton Mifflin Company, 1910.

BARTHÉLEMY SAINT-HILAIRE, Jules. "Rapport fait au nom de la section de philosophie sur le concours relatif à la question du Beau, par M. Barthélemy Saint-Hilaire, lu dans les séances des 16 et 20 avril 1859". In: INSTITUT DE FRANCE. Mémoires de l'Académie des Sciences Morales et Politiques de l'Institut Impérial de France. Tome XI. Paris : impr. de F. Didot, 1862.

BATCHELOR, David. La peur de la couleur. Paris: Éditions autrement, 2001.

BECQ, Annie. Genèse de l'esthétique française moderne : de la raison classique à l'imagination créatrice : 1680-1814. Paris: J. Touzot, 1984.

BEULÉ. Cours d'archeologie. Discours d'ouverture à la Bibliothèque Imperiale. Paris: Typhographie de Firmin Didot Frères, Fils et Cie, 1858.

BOTTA, Émile. Lettres de M. Botta sur ses découvertes à Khrsabad, près de Ninive. [Publiées par M. J. Mohl]. Paris: Imprimière Royale, 1845.

CHAUSSARD, P.-J.-B. Sur le tableau des Sabines par David. Paris: Charles Pougens, 1800.

COUSIN, Victor. Du vrai, du Beau et du Bien. septième édition. Paris: Didier et Cie, 1858.

COUSIN, Victor. Oeuvres de Victor Cousin. Fragments Philosophiques. Tome Deuxième. Cours d'histoire de la philosophie morale. Bruxelles: Société Belge de Librairie, 1841.

DORTU, Véronique. "Tiberghien, précurseur d'un idéal oublié". In La Pensée et les Hommes. Dossier n²008-018-005. Disponível online em: http://lapenseeetleshommes.be/pdf/2008-018005\%20-\%20Tiberghien.pdf [último acesso em 15 de novembro de 2015]

DORTU, Véronique. "Unamuno et le krausisme." In: Revue de l'histoire des religions, Paris, PUF, Vol.216, n.4, 1999, p. 445. Disponível online em: http://www.persee.fr/doc/rhr_00351423_1999_num_216_4_1080 [último acesso em 18 de novembro de 2015]

E. LÉVI, DE ROUEN. Étude philosophique sur l'architeture [Étude philosophique sur l'architecture. Mémoire en réponse à la question suivante: Rechercher l'enchainement des diverses architectures de tous les âges, et les rapports qui peuvent exister entre les monuments et les tendances religieuses, politiques et sociales des peuples]. Bruxelles: J.-A. Tircher, 1859.

ÉMERIC-DAVID, Toussaint-Bernard. Recherches sur l'art estatuaire. Paris: Renouard, 1863. 
FRIEDLANDER, Walter. De David a Delacroix. São Paulo: Cosac \& Naify, 2001.

GOLDSTEIN, Carl. Teaching Art: Academies and Schoos from vasari to Albers. Cambridge: Cambridge University Press, 1996.

HEGEL, Georg Wilhelm Friedrich. Cursos de Estética. [trad. WERLE, Marco Aurélio]. São Paulo: Edusp, 1999.

HELMREICH, Christian. "La réception cousinienne de la philosophie esthétique de Kant.

Contribution à une histoire de la philosophie française au XIXe siècle." In: Revue de Métaphysique et de Morale, No. 2, «Esthétique » Histoire d'un transfertfranco-allemand (AVRIL-JUIN 2002), pp. 193-210. Disponível online em: http://www.jstor.org/stable/40903860

LAPRADE, Victor de. Questions d'art et de morale. Paris: Libraire académique, 1861.

LAYARD, Austen Henry. Nineveh and its remains: with an account of a visit to the Chaldean christians of Kurdistan, and the yezidis, or devil-worshippers; and an enquiry into the manners and arts of the ancient assyrians. London: John Murray, 1849. 2 vols.

LEE, Rensselaer W. Ut Pictura Poesis.The humanistic theory of painting. New York: Norton \& Company, 1967.

LES BEAUX-ARTS. Revue Nouvelle. Trome Troisième. Du 1er juillet au 15 décembre 1861. Paris: Imprimière A.-E. Rochette, p.1861.

LÉVÊQUE, Charles. La Science du Beau étudiée dans ses principes, dans ses applications et dans son histoire . Paris: Durand, 1861.

LICHTENSTEIN, Jacqueline (org.). Vers la science de l'art : l'esthétique scientifique en France, 1857-1937. Paris : PUPS, DL 2013.

LICHTENSTEIN, Jacqueline. A pintura, textos essenciais. Vol. 4: O belo. São Paulo: Editora 34. 2004.

MATTÉI, Jean-François. "L'émergence de l'idée de beauté en Occident." In: LUMLEY, Henry. Le beau, l'art et l'homme. Paris: CNRS Éditions, 2014. Pp.139-148.

MEROT, Alain. "La notion de 'Beau idéal'. In: LUMLEY, Henry. Le beau, l'art et l'homme. Paris: CNRS Éditions, 2014.

MONTESQUIEU, Charles-Louis de Secondat; STAROBINSKI, Jean. Essai sur le goût. Suivi d'un texte de Jean Starobinski. Paris: Rivages, 1993.

PAIM, Antonio. O Krausismo brasileiro. Londrina: Edições Cefil, 1999; e Idem, A Escola Eclética. Londrina: Edições Cefil, 1999.

PANOFSKY, E. Estudos em iconologia. Lisboa: Editorial Estampa, 1995.

PANOFSKY, E. Ideia: contribuição à história do conceito da antiga teoria da arte. São Paulo: Martins Fontes, 2000.

QUINCY, Q. de. Considérations morales sur la destination des ouvrages de l'art, ou de l'influence de leur emploi sur le génie et le gout, et sur le sentiment de ceux qui en jouissnet et en reçevoient les impressions. Paris: L'Imprimière de Crapelet, 1815.

QUINCY, Q. Sur l'idéal dans les arts du dessin. Paris: 1805.

QUINCY, Quatremère. Essai sur la nature, le but et les moyens de l'imitation dans les BeauxArts. Paris: Treuttel et Würtz, 1823.

S/A. "Cours d'Esthétique Générale et Appliquée par M. David Sutter, peintre". In: Gazette des Architectes et du Batîment. Paris, 1865, 3a. Année, n.10. pp.151-154.

SCHNEIDER, R. Quatremère de Quincy et son intervention dans les arts (1788-1850). Paris: Librairie Hachette, 1910.

SHINER, Larry. The invention of art: a cultural history. Chicago: University of Chicago Press, 2001.

SUTTER, Jean-David. Nouvelle théorie simplifiée de la perspective. Paris: Jules Tardieu, 1859. 
SUTTER, J.-David. Philosophie des Beaux-Arts apliquée à la peinture. Paris: Jules Tardieu, 1858.

SUTTER, J.-David. Esthétique Générale et appliquée contenant les règles de la composition dans les arts plastiques. Paris: Imprimerie Impériale: 1865.

TIBERGHIEN, Guillaume. Esquisses de Philosophie Morale. Bruxellas: Imprimiérie de Delevingne et Callewaert, 1854.

VIARDOT, Louis. Comment faut-il encourager les arts. Paris: Jules Renouard, 1861.

VIOLLET-LE-DUC, Geneviève (org.). Eugène Viollet-le-Duc. Esthétique appliquée à l'histoire de l'art. Paris: École Nationale Supérieure des Beaux-Arts, 1994.

WILL, Frederic. Flumen historicum, Victor Cousin's aesthetic and its sources. Chapel Hill: University of North Carolina press, 1965.

WINCKELMANN, J. Histoire de l'art dans l'antiquité. Paris: Librairie générale française, 2005.

ZANGWILL, N. The Metaphysics of Beauty. Ithaca: Cornell University Press, 2001.

\subsubsection{Sobre o problema do nu e assuntos correlatos à Carioca}

AGASSIZ, Louis; AGASSIZ, Elizabeth Cabot Cary. A Journey in Brazil. Boston: Ticknor and Fields, 1869.

ARRASSE, Daniel. On y voit rien. Paris: Denoël, 2005.

ARSCOTT, Caroline; SCOTT, Katie. Manifestations of Venus: Art and Sexuality, Manchester: Manchester University Press, 2000.

BARBILLON, Claire. Les canons du corps humain au XIXe siècle. Paris: Odile Jacob, 2004.

BARTOSCHEK, Gerd; VOGTHERR, Christoph Martin. Zerstört, Entführt, Verschollen. Die Verluste der preussichen Schlösser im Zweiten Weltkrieg. Gemälde I. Berlin-Brandenburg: Stiftung Preussische Schlösser und Gärten, potsdam, 2004.

BÉDARD, Sylvain. "Le nu historié: les envois des pensonnaires de l'Académie de France à Rome au XVIIIe siècle", Studiolo, 2006, n.4, p.213-240.

BLANC, Charles; BONNASSIEUX, Jean-Marie. Ingres, sa vie et ses ouvrages. Paris : Vve. J. Renouard, 1870.

CADIOT, Noémie. "Le Salon de 1863", Le Correspondant, Paris, June 1863. p.363-92.

CARCO, F. Le nu dans la peinture moderne 1863-1920. Paris: G. Crès et cie, 1924.

CHAGNON-BURKE, Véronique. "Rue Laffitte: Looking at and Buying Contemporary Art in Mid-Nineteenth- Century Paris". Nineteenth-Century Art Worldwide, vol. 11, n² 2 (été 2012).

(Disponível em: http://www.19thc-artworldwide.org/index.php/summer12/veronique-chagnon-burkelooking-at-and-buying-contemporary-art-in-mid-nineteenth-century-paris

CHAUMELIN, Marius. "Salon de 1868”, La Presse, 27 de maio de 1868, p.3.

CLARK, Kenneth. The nude. London: John Murray, 1956. O livro abre uma série de discussões retomadas ou contestadas em estudos posteriores. Por exemplo: CORMACK, Malcolm. The nude in western art. Oxford [Eng.] : Phaidon, 1976; SAUNDERS, Gill. The Nude: a new perspective. London: The Herbert Press, 1989.

FOSSI, Gloria. Le nu. Paris, Gründ, 1999. 302 p.; MARNHAC, Anne de. Femmes au bain : les métamorphoses de la beauté. Paris : Berger-Levrault, c1986.

BONNET, Jacques. Femmes au bain : du voyeurisme dans la peinture occidentale. Paris : Hazan, DL 2006.

CLARK, Timothy James. A pintura da vida moderna : Paris na arte de Manet e seus seguidores. São Paulo: Companhia das Letras, 2004. 
COLIVA, Anna. Galleria Borghese. Roma: ENEL, 1994.

COOKE, Peter. "Gustave Moreau's 'oedipus and the Sphinx': Archaism, Temptation and the Nude at the Salon of 1864". The Burlington Magazine, Vol. 146, No. 1218 (Sep., 2004), pp. 609-615.

COURBET, Gustave. Écrits, propos, lettres et témoignages. Paris: Hermann, 2010.

DELAROCHE, P.; DUPONT, H. L'Hémicycle du Palais des Beaux-Arts: peinture murale exécutée par Paul Delaroche. Paris: Goupil, 1857.

DIDEROT, Denis; FÉLICE, Fortuné Barthélemy de. Encyclopédie, ou Dictionnaire Universel raisonné des connaissances humaines. Tome XXXV. Yverdon, 1774.

DIDI-HUBERMAN, Georges. Ouvrir Vénus. Nudité, rêve, cruauté. Paris: Gallimard, 1999.

DOTAL, Christiane. "Femme mythiques et légendaires comme allégories modernes au XIXe siècle", In : DOTAL, Christiane; DRATWICKI, Alexandre. L'Artiste et sa muse. Mythification du créateur et de son modèle, actes du colloque, mars 2005. Paris: 2006.

DU CAMP, Maxime. Les Beaux-Arts à l'Exposition Universelle et aux Salons de 1863, 1864 , 1865, 1866 et 1867. Paris: Jules Renouard, 1867.

EISENMAN, Stephen F. Nineteenth Century Art: a critical history. New York: Thames \& Hudson, 2002.

ÉMERIC-David, T. B. Mémoire sua la statue antique découverte en 1820 dans l'Île de Milo et déposée au Musée Royal du Louvre".In: Mémoires de l'Académie des Inscriptions et Belles-Lettres. Paris: ImprimiÈre Royale, 1821.

EMERIC-DAVID, T.-B. Recherches sur l'Art Statuaire: considéré chez les anciens et chez les modernes ou mémoire sur cette question proposée par l'Instituto National de France: quelles ont été les causes de la perfection de la Sculpture antique et quels seraient les moyens d'y atteindre?. Paris: Mme Ve Renouard, 1863.

FINANCE, Laurence de. [Directeur de publication. Commissaire d'exposition]. Viollet-le-Duc: les visions d'un architecte : [exposition, Paris, Cité de l'architecture et du patrimoine, 20 novembre 2014-9 mars 2015]. Paris: Norma : Cité de l'architecture et du patrimoine, impr. 2014.

FRIED, M. Manet's modernism: Or, the Face of Painting in the 1860's. Chicago: University of Chicago Press, 1992.

FRIED, Michael. Le modernisme de Manet ou le visage de la peinture des années 1860. Paris: Gallimard, 2000.

FURETIERE, Antoine. Dictionaire universel contenant generalement tous le mots françois, tant vieux que modernes, et les termes des sciences et des arts. Volume 2. Paris: Arnoud et Reinier Leers, 1701.

GAUTIER, Théophile. "Salon de 1864". Moniteur Universel, Paris, 21 de maio de 1864. p.1.

GAUTIER, Théophile. "Salon de 1863". Moniteur Universel, 164, 13 e 15 de junho de 1863, p.1.

GAUTIER, Théophile. Critique d'Art: Extraits des Salons (1833-1872). Paris: Seguier, 1994.

GINZBURG, Carlo. "Ticiano, Ovídio e os códigos da figuração erótica no século XVI". In:

Idem. Mitos, emblemas, sinais. São Paulo: Companhia das Letras, 1991.

GINZBURG, Sylvia. La galerie Farnèse : les fresques des Carrache à l'ambassade de France à Rome. Paris : Gallimard, 2010.

GREEN, Nicholas. "Circuits of Production, Circuits of Consumption: The Case of Mid-

Nineteenth-Century French Art Dealing". Art Journal, vol. 48, $\mathrm{n}^{\circ}$ 1, Nineteenth-Century French Art Institutions (printemps 1989), p. 29-34. Disponível em : http://www.jstor.org/stable/776917

GUEULLETTE, C. Les peintres de genre au Salon de 1863. Paris, 1863.

GUILLAUME, Eugène. Catalogue des oeuvres de Paul Baudry. Paris: École Nationale des Beaux-Arts, 1886.

HADDAD, Michèle. La divine et l'impure : le nu au XIXe. Paris : Jaguar, 1990. 
HARRISON, Charles; WOOD, Paul; GAIGER, Jason (eds.). Art in theory, 1815-1900. Oxford: Blackwell, 1998.

HEMSTERHUIS, Franz. "Carta sobre a escultura". In: HEMSTERHUIS, Franz. Sobre o homem e suas relações (tradução, apresentação e notas Pedro Paulo Pimenta). São Paulo: Iluminuras, 2000. Pp.23-42.

HERDER, Johann Gottfried von. Sculpture: some observations on shape and form from Pygmalion's creative dream (edited and translated by Jason Gaiger). Chicago: University of Chicago Press, 2002.

HILAIRE, Michel; Amic, Sylvain. Alexandre Cabanel : 1823-1889 : la tradition du beau : [exposition, Musée Fabre, Montpellier, 10 juillet - 5 décembre 2010, Wallraf-Richartz-Museum \& Fondation Corboud, Cologne, 4 février - 15 mai 2011]. Paris/Montpellier : Somogy éditions d'art : Musée Fabre, impr. 2010.

HILDEBRAND, Adolph von. Il problema della forma. Firenze: Casa Editrice G. D’Anna, 1949.

HOUSE, John. "Manet and the De-Moralized viewer". In: TUCKER, Paul H. Manet's Le déjeuner sur l'herbe. Cambridge: Cambridge University Ppress, 1998.

HUSTON, Lorne. "Le Salon et les expositions d'art: réflexions à partir de l'expérience de Louis Martinet (1861-1865), Gazette des Beaux-Arts, n.116, Paris, Julho-Agosto de 1990.

JAGOT, Hélène. Jean-Léon Gérôme Néo-Grec, l'Antiquité dévoyeé. Paris: Rumeur des Ages, 2010.

JARRASSÉ, Dominique. "Trois gouttes d'art nègre. Gobinisme et métissage en histoire de l'art." In: Histoire de l'art et anthropologie. Paris, coédition INHA / musée du quai Branly ( « Les actes »), 2009. Disponível online em: http://actesbranly.revues.org/96 [último acesso: 11 de outubro de 2015].

JARRASSÉ, Dominique. "Les arts méconnus. Historicité et ethnicité dans l'histoire de l'art au xixe siècle ", in Nabila Oulebsir et Mercedes Volait (dir.), L'Orientalisme architectural entre imaginaires et savoirs. Paris : Picard ("Collection D'une rive l'autre"), 2009. Disponível online em: http://inha.revues.org/4921 [Último acesso: 04 de abril de 2016]

JARRASSÉ, Dominique. "Ethnicisation de l'histoire de l'art en France 1840-1870: le modèle philologique”. In: RECHT, Roland; SÉNÉCHAL, Philippe; BARBILLON, Claire; MARTIN, François-René. Histoire de l'histoire de l'art en France au XIXe siècle. Paris: La documentation Française, 2004. pp.337-360.

JOYEUX-PRUNEL, Béatrice. Nul n'est prophète en son pays? l'internationalisation de la peinture des avant-gardes parisiennes, 1855-1914. Paris: N. Chaudun, 2009.

KRAUSS, Rosalind E. "Manet's Nymph Surprised". The Burlington Magazine,Vol. 109, No. 776 (Nov., 1967), pp. 622-627. Disponível online em: http://www.jstor.org/stable/875434

KRUFT, Hanno-Walter. "Studies in Proportion by J. J. Winckelmann". The Burlington Magazine, Vol. 114, No. 828 (Mar., 1972), pp. 164-170. Disponível online em: http://www.jstor.org/stable/876908 [Último acesso em: 26-2-2014.]

LANZI, Luigi. Lanzi's history of painting in upper and lower Italy. Vol. II [in two volumes]. Traduction by Rev. G. W. D. Evans. London: J. Hatchard and son, 1831.

LAROUSSE, Pierre. Grand Dictionnaire Universel du Dix-neuvième Siècle, tome.11. Paris: Administration du Grand Dictionnaire Universel, 1866-1874.

L'ART DU nu au XIXe siècle [exposition, Paris, 14 octobre 1997-15 février 1998, Bibliothèque nationale de France-François-Mitterrand]. Paris: Hazan/Bibliothèque Nationale de France, 1997.

LAURENT, Stéphane. L'art utile: les écoles d'arts appliqués sous le Seconde Empire et la Troisième République. Paris: L'Harmattan, 1998.

LECOQ DE BOISBAUDRAN, Horace. L'education de la mémoire pittoresque et la formation de l'artiste. Paris: H. Laurens, 1920. 
LONGHI, Roberto. Breve mas verídica história da pintura Italiana. São Paulo: Cosac \& Naify, 2006.

MASSONAUD, Dominique (ed.). Le nu moderne au Salon (1799-1853). Grenoble: ELLUG, Université Stendhal, 2005.

MIQUEL, Pierre.Art et argent : 1800-1900. Maurs-la-Jolie: Ed. de la Martinelle, 1987.

MONREAL, Susana. "Les krausistes 'belges'. Contribution à l'étude de leur influence en Amérique Latine. BTNG-RBHC, XXIII, 1992, 3-4, pp.477-491.

MOULIN, Raymonde. Le Marché de la peinture en France. Paris: Ed. de Minuit, 1989.

NEAD, Lynda. Female Nude: Art, obscenity and sexuality. London/New York: Routledge, 1992.

OBERHUBER, Konrad; STRAUSS, Walter L. (Ed.); BARTSCH, Adam von (1757-1821), compilação. The illustrated Bartsch. The works of Marcantonio Raimondi and of his school. New York : Abaris Books, 1978. 2.vols.

OKAYAMA, Yassu. The Ripa Index: Personifications and their Attributes in Five Editions of the Iconologia. Netherlands: Davaco, 1992.

PANOFKSY, E. Significado nas Artes Visuais. São Paulo: Perspectiva, 2011.

PANOFSKY, Erwin. Ideia: A evolução do Conceito de Belo. Trad, Paulo Neves. São Paulo: Martins Fontes, 2000.

PANOSKY, E. Essais d'iconologie. Thèmes humanistes dans l'art de la Renaissance. Paris: Gallimard, 1967.

PASQUIER, Alain. La Vénus de Milo et les Aphrodites du Louvre. Paris: Editios de la Réunion des Musées Nationaux, 1985.

PASQUIER, Alain; MARTINEZ, Jean-Luc. Praxitèle. Catálogo de Exposição. Paris: Louvre, 2007.

PEVSNER, Nikolaus. Academias de arte: passado e presente. São Paulo: Companhia das Letras, 2005.

PICON, Gaëtan. 1863, naissance de la peinture moderne. Paris: Gallimard, 1988.

PIETRANGELI, Carlo. Rafaello in Vaticano. Milano: Electa Editrice, 1984.

PLATÃO. Diálogos. [tradução e notas de José Cavalcante de Souza, Jorge Paleikat e João Cruz Costa]. São Paulo: Abril Cultural, 1979.

PLÍNIO. Natural History. Vol X. Cambdridge: Harvard University Press, 1989.

POMARÈDE, Vincent; PRAT, Louis-Antoine; GUÉGAN, Stéphane; BERTIN, Eric (orgs.). Ingres, 1780-1867. Paris: Gallimard, Musée du Louvre, 2006.

QUATREMĖRE DE QUINCY. Sur la statue antique de Vénus découverte dans l'ile de Milo en 1820. Paris: Chez Debure Frères, Libraires du Roi, 1821.

RAMOS, Julie (dir.), L'Art social de la Révolution à la Grande Guerre. Anthologie de textes sources. Paris; INHA (“Sources”), 2014. Disponível em. URL : http://inha.revues.org/5504 (ùltimo acesso em 27 de março de 2016).

RAVAISSON, Félix. La Vénus de Milo. Paris: Librairi Hachette, 1871.

REGAMEY, Félix. Horace Lecoq de Boisbaudran et ses élèves - notes et souvenirs. Paris : H. Champion, 1903.

RIPA, Cesare. Iconologia. ed. MAFFEI, Sonia. Torino: Guilio Einaudi, 2012. p.399.

RIPA, Cesare. Iconologia. ed. MAFFEI, Sonia. Torino: Guilio Einaudi, 2012.

RUSSO, William dello. L'art du nu. Paris: Hazan, 2011.

SAINT-VICTOR, Paul de. "Salon de 1863". La Presse, Paris, edições de 10, 17 e 24 de maio, e 4, 14, 21, 29 e 29 de junho de 1863.

SAINT-VICTOR, Paul de. "Salon de 1864", La presse, Paris, 7 de maio de 1864.

SAUER, Arthur. Almanak administrativo, mercantil e industrial do Rio de Janeiro. Rio de Janeiro: Compahia Typographica do Brazil, 1899. 
SAXL, Fritz. "Vila Farnesina". IN: SAXL, Fritz. La vida de las imágenes. Madrid: Alianza Editorial, 1989.

SCHLEGEL, August. Doutrina da arte: cursos sobre Literatura Bela e Arte (Tradução e notas de Marco Aurélio Werle). São Paulo: Edusp, 2014.

SÉRIÉ, Pierre. La peinture d'histoire en France 1860-1900. Paris: Arthena, 2014.

STEVENS, Arthur. Le Salon de 1863. Paris: Librairie Centrale, 1866.

SUTTER, David. Esthétique générale et appliquée. Paris: Imprimerie impériale, 1865.

THERRIEN, Lyne. L'histoire de l'art en France, genèse d'une discipline universitaire. Paris:

Éditions du C.T.H.S., 1998.

THORÉ, Théophile. Salons de W. Bürger (1861 à 1868). Tome second : 1864-1868. Paris: Renouard, 1870.

TINTEROW, Gary; LOYRETTE, Henri. Origins of Impressionism. New York: Metropolitan Museum of Art, 1995.

TUCKER, Paul. Manet's Le déjeuner sur l'herbe. Cambridge, Cambridge university press, 1998.

VIOLLET,-LE-DUC, E. E. Esthétique appliquée à l'histoire de l'art. Paris: École Nationale Supérieure des Beaux-Arts, 1994.

VIOLLET-LE-DUC, E. E. "Um cours de dessin". In: L'Artiste, Paris, 05 de novembro de 1858. pp.154-156.

VITAL, Christophe (ed.). Paul Baudry, 1828-1886. [Exposition, Historial de la Vendée, 26 octobre 2007 - 3 février 2008]. Paris: Somogy, 2007.

VITRUVIOS POLLIO, Marcus. Tratado de arquitetura / Vitrúvio ; tradução do latim, introdução e notas M. Justino Maciel. São Paulo : Martins Fontes, 2007.

VOTTERO, Michel. La peinture de genre en France après 1850. Rennes: Presses Universitaires de Rennes, 2012.

WATELET, Claude-Henri. Encyclopédie Méthodique: Beaux-Arts. Tome premier. Paris: Panckoucke, 1788.

WHITELEY, Linda. "Art et commerce d'art en France avant l'époque impressionniste".

Romantisme, 1983, vol. 13, n40, p. 65-76. (Disponível em:

http://www.persee.fr/web/revues/home/prescript/article/roman 0048-8593 1983 num $13 \quad 40 \quad 4633$ ).

WINCKELMANN, J. J. Histoire de l'art chez les anciens. Paris: Saillant, 1766. Tome I.

WINCKELMANN, J. J. Histoire de l'art de l'Antiquité. Traduite de l'Allemand par M. Huber. Tome II. Leipzig: Jean Gotti, 1781.

WINCKELMANN, J. J. Histoire de l'art chez les anciens. Paris: Bossange, Masson et Besson, 1802.

WINCKELMANN, J. J. Histoire de l'art dans l'Antiquité. Traduction de Dominique Tassel. Paris: La Pochothèque, 2010.

\section{Bibliografia}

\subsection{História, filosofia e cultura no Brasil do século XIX}

ADORNO, Sérgio. Os aprendizes do poder. Rio de Janeiro: Paz e Terra, 1988.

ALEGRE, M. A. de Porto; MAGALHÃES; Gonçalves de. Cartas a Monte Alverne. São Paulo: Comissão Estadual de Cultura, 1962.

ALENCAR, José de. Ao Marques de Olinda. Rio de Janeiro: typ. de Pinheiro e Comp, 1866.

ALENCASTRO, Luiz Felipe de (org). História da vida privada no Brasil: Império. São Paulo:

Companhia das Letras, 1997. 
ALMEIDA FILHO, José Carlos de Araújo. O Ensino Jurídico, a elite dos bacharéis e a maçonaria do século XIX. (Dissertação de Mestrado). Rio de Janeiro: Universidade Gama Filho, 2005

ALMEIDA, Manoel Antônio de. Memórias de um Sargento de Milicias. Porto Alegre: L\&PM, 2009.

ANDRADE PINTO, Caetano José. Atribuições dos presidentes de província. Rio de Janeiro/Paris: Garnier-Durand, 1865.

ANDRADE, Andre Luiz Alipio de. Variações sobre um tema : a sociedade auxiliadora da industria nacional e o debate sobre o fim do trafico de escravos (1845-1850). (Dissertação de Mestrado). Campinas:UNICAMP, Instituto de Economia, 2002.

BARBOSA, Januário da Cunha; MIRANDA, José Américo (org. e ed.). Parnaso Brasileiro de Januário da Cunha Barbosa. Belo Horizonte: UFMG, 1999.

BARMAN, Roderick. Imperador Cidadão. São Paulo: Editora Unesp, 2012; neste, especialmente os capítulos quarto, quinto, sexto e sétimo.;

CAETANO, Batista. "Etymologias Brazílicas. II. Carioca. - O que significa? ” In: GALVÃO, Benjamin Franklin Ramiz (dir.). Anais da Biblioteca Nacional do Rio de Janeiro. 1876-1877. Volume II. Fasc. n.1. Rio de Janeiro: Typ. G. Leuzinger \& Filhos, 1877. pp.404-06.

CANDIDO, Antonio. Um funcionário da monarquia: ensaio sobre o segundo escalão. Rio de Janeiro: Ouro Sobre Azul, 2007.

CARVALHO, José Murilo de. "O Juiz de Paz da Cidade.". O Globo. Rio de Janeiro, 18 de fevereiro de 2011.

CARVALHO, José Murilo de. “República-mulher: entre Maria e Marianne.” In: IDEM. $A$ formação das almas: o imaginário da República no Brasil. São Paulo: Companhia das Letras, 1993.

CONSTITUIÇÃO Política do Império do Brasil., promulgada pela Carta de lei de 25 de Março de 1824.

CORDEIRO, Carlos Antonio. Código Criminal do Império do Brasil. Rio de Janeiro: Typ. de Quirino e irmão, 1861. pp.215-216.

CRUZ, André Silveiro da. O pensamento filosófico e o ensino da filosofia na escola secundária brasileira: uma interpretação dos programas de ensino do colégio Pedro II (1837-1951). Dissertação de Mestrado. Uberlândia: UFUB, 2006.

DENIS, Ferdinand. Résumé de l'histoire littéraire du Portugal, suivi du Résumé de l'histoire littéraire du Brésil. Paris: Lecointe et Durey, 1828.

DENIS, Ferdinand. Scènes de la nature sour les tropiques et de leur influence sur la poésie. Paris: Louis Janet, 1824.

ENDERS, Armelle. Les visages de la Nation: Histoire, héros nationaux et imaginaire politique au Brésil (1822-1922). Tese de Doutorado. Paris: Université Paris I, Panthéon Sorbonne, 2004.

FREYRE, G. Sobrados e mucambos: decadência do patriarcado rural e desenvolvimento do urbano. Rio de Janeiro: Livraria José Olympio Editora, 1961.

GABLER, Louise. A Secretaria de Estado dos Negócios da Agricultura, Comércio e Obras Públicas e a modernização do Império (1860-1891)[recurso eletrônico]. Rio de Janeiro: Arquivo Nacional, 2012. p.10. Disponível em: http://www.portalan.arquivonacional.gov.br/ [último acesso: março de 2016]

HOLANDA, Sérgio Buarque de. Capítulos da história do Império. São Paulo: Companhia das Letras, 2010.

HOLANDA, Sergio Buarque de. Raízes do Brasil. 26.ed. São Paulo: Cia. das Letras, 1995.

KODAMA, Kaori. Os filhos das brenhas e o Império do Brasil: A etnografia no Instituto Histórico e Geográfico do Brasil (1840-1860). Tese de Doutorado. Rio de Janeiro: Departamento de História da PUC-Rio, 2005. 
LIMA, Manuel de Oliveira. O movimento da Independência: O Império Brasileiro (18211889).São Paulo: Melhoramentos, 1962.

LIMA, Pedro de Araújo [Marquê de Olinda]. "Decreto nº 2.006, de 24 de Outubro de 1857 approva o Regulamento para os collegios publicos de instrucção secundaria do Municipio da Côrte." Disponível em: http://www2.camara.leg.br/legin/fed/decret/1824-1899/decreto-2006-24-outubro1857-558097-publicacaooriginal-78997-pe.html

MACHADO, Maria Helena P. T. "Race and visual representation. Louis Agassiz and Hermann Burmeister". In: ARAÚJO, Ana Lúcia (ed.) African Heritage and Memories of Slavery in Brazil and the South Atlantic World. New York, Cambria Press, 2015.

MAGALHÃES, J. G. de. Fatos do Espírito Humano. Paris: Livraria d'Auguste Fontaine, 1858.

MARCONDES, Renato Leite e MOTTA, José Flávio. "Duas fontes documentais para o estudo de preços de escravos no Vale do Paraíba paulista". Revista Brasileira de História. Vol 21, n.42, 2001. pp. 486-514.

MINISTÉRIO DA EDUCAÇÃO E CULTURA. Anuário do Museu Imperial, vol XVII. Petrópolis: 1956.

NABUCO, Joaquim. Um estadista do Império: Nabuco de Araújo, sua vida, suas opiniões, sua época. Rio de Janeiro: H. Garnier, 1897;

OLIVEIRA, Cecilia Helena de Salles (org.). Zacarias de Góis e Vasconcelos [coleção: Formadores do Brasil]. São Paulo: Editora 34, 2002.

PAIM, Antonio. A Escola Eclética.[Estudos complementares à História das idéias filosóficas no Brasil]. 2a edição ampliada. Londrina: Edições CEFIL, 1999.

PAIM, Antonio. História das idéias filosóficas no Brasil. São Paulo: Grijalbo, 1967.p.75.

PEDRO II, Dom. "Diário de 1862”. In MINISTÉRIO DA EDUCAÇÃO E CULTURA. Anuário do Museu Imperial, vol XVII. Petrópolis: 1956.

PENA, Martins. O juiz de paz na roça; O noviço; Quem casa quer casa. Manaus: Editora Valer, 2010.

PINASSI, Maria Orlandi. Três devotos, uma fé, nenhum milagre. São Paulo: ed Unesp, 1999.

PIRES DE ALMEIDA, J. R. Officina na Escola, o Ensino Profissional Posto em Pratica nas Escolas Particulares de Sua Magestade o Imperador. Rio de Janeiro: Lombaerts \& Cia., 1886.

RODYCZ, Wilson Carlos. O Juiz de Paz Imperial: uma experiência de magistratura leiga e eletiva no Brasil. Disponível em:

http://www.tjrs.jus.br/export/poder_judiciario/historia/memorial_do_poder_judiciario/memorial_judic iario_gaucho/revista_justica_e_historia/issn_1676-5834/v3n5/doc/02-Wilson_Rodycz.pdf. (Acessado em março de 2013).

SAINT-ADOLPHE, J. C. R. Dicionário Geográfico histórico e descritivo do Império do Brasil. Paris: J. P. Aillaud, 1845. p.246.

SAVIANI, Demerval. História das ideias pedagógicas no Brasil. [2.ed.] Campinas: Autores Associados, 2008.

SCHWARCZ, Lilia Moritz. As barbas do imperador: D. Pedro II, um monarca nos trópicos. São Paulo: Companhia das Letras, 1998.

SCHWARCZ, Lilia Moritz. O Espetáculo das Raças - cientistas, instituições e questão racial no Brasil, 1870-1930. São Paulo: Companhia das Letras, 1993.

SIMÕES, Teotônio. Os Bacharéis na politica - A política dos Bacharéis. (Tese de doutorado).

São Paulo: Universidade de São Paulo/Departamento Ciências Sociais, 1983.

VASCONCELOS, Zacarias de Góis e. Zacarias de Góis e Vasconcelos. Introdução e notas:

Cecília Helena Salles de Oliveira. São Paulo: Ed. 34, 2002;

VECHIA, Ariclê; LORENZ; Karl M. "O currículo de Couto Ferraz de 1855: compatibilizando o 
ensino propedeutico com o profissionalizante". In: IV Seminário de Pesquisa da Região Sul - Anped Sul, 2002, Florianópolis. Florianópolis, 2002. Disponível online em:

http://www.portalanpedsul.com.br/admin/uploads/2002/Educacao,_Historia_e_Filosofia/Trabalho/11_ 57 56 t810.pdf

VIANNA, A. F. “A filosofia no Brasil - I”. Illustração Brasileira. vol.II, n.1, Rio de Janeiro, 1855. p.19.

VIEIRA FERREIRA. “Juízes e Tribunais do Primeiro Império e da Regência”. In: Boletim do Instituto Histórico e Geográfico Brasileiro. Rio de Janeiro: Imprensa Nacional, 1937.

VIEIRA, João Pedro Dias. Relatório da Repartição dos Negócios Estrangeiros. Rio de Janeiro: Typographia Universal de Laemmert, 1865; ABRANTES, Marquês de. Relatório da Repartição dos Negócios Estrangeiros de 11 de maio de 1863, apresentado à Assembléia Geral Legislativa. Rio de Janeiro: Typographia Universal de Laemmert, 1864.

\section{Arquivos Consultados para a produção deste Capítulo:}

Instituto de Estudos Brasileiros da Universidade de São Paulo, São Paulo.

Arquivo Nacional, Rio de Janeiro.

Museu Imperial, Petrópolis.

Biblioteca Nacional, Rio de Janeiro.

\section{Sites da internet consultados:}

Site do Senado Brasileiro

http://www6.senado.gov.br/sicon/\#

Site do Arquivo Nacional

www.an.gov.br/sian/

Site da Casa de Rui Barbosa

http://basesdedados.casaruibarbosa.gov.br/

Hemeroteca da Biblioteca Nacional.

http://hemerotecadigital.bn.br/

Museu D. João VI.

docvirt.com/MuseuDJoaoVI/

Câmara dos Deputados

http://www2.camara.leg.br/atividade-legislativa/legislacao/pesquisa/avancada

Bibliothèque Nationale de France

gallica.bnf.fr

Archives Nationales de France

www.archivesnationales.culture.gouv.fr

Musée du Louvre

www.louvre.fr

British Museum

www.britishmuseum.org 
Caderno de imagens Primeiro Capítulo 



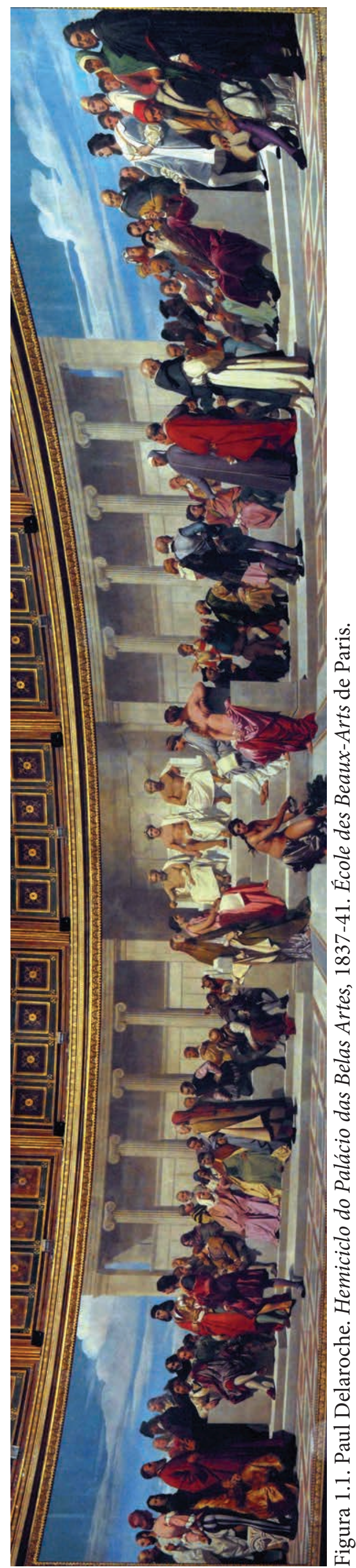




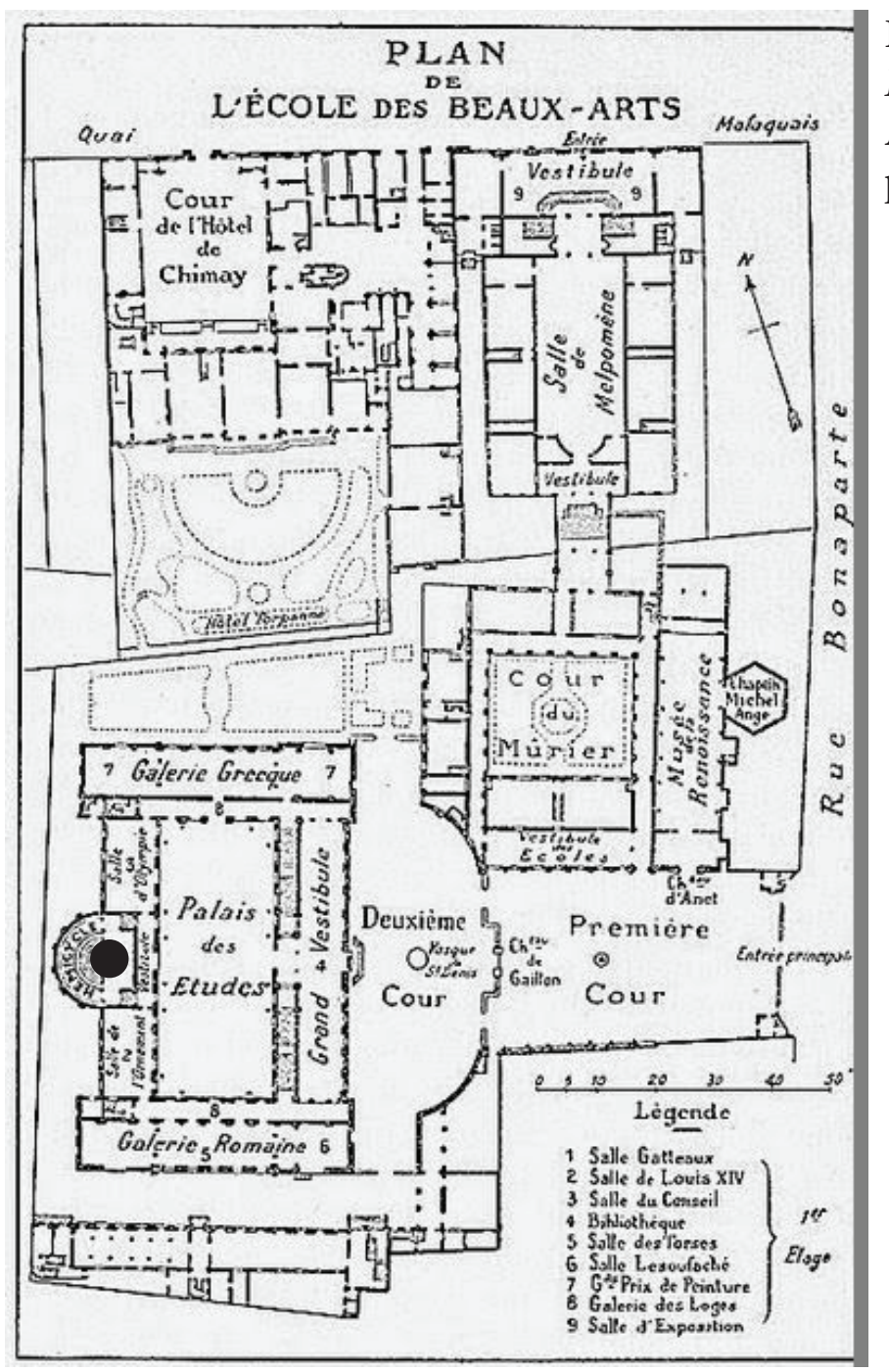

Figura 1.2. Plano do terreno da École des Beaux-Arts de Paris.

A posição do Hemiciclo no complexo de prédios está indicado pelo círculo negro.

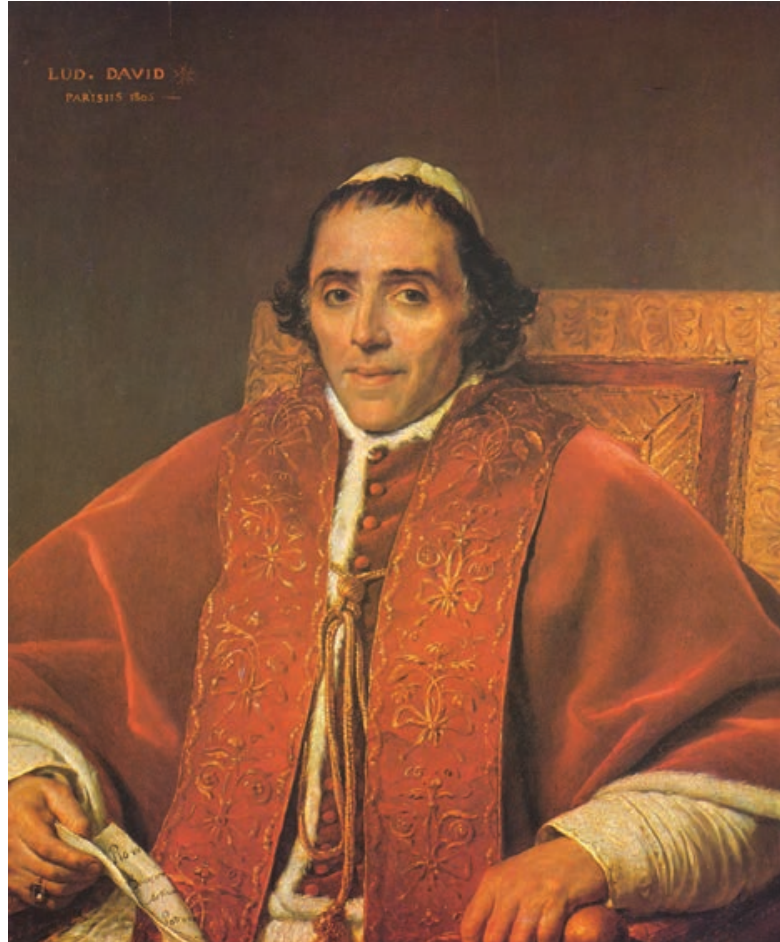

Fig.1.3. Jacques-Louis David. Retrato do Papa Pio VII. 1805, óleo sobre madeira, $86 \times 71 \mathrm{~cm}$. Musée du Louvre.

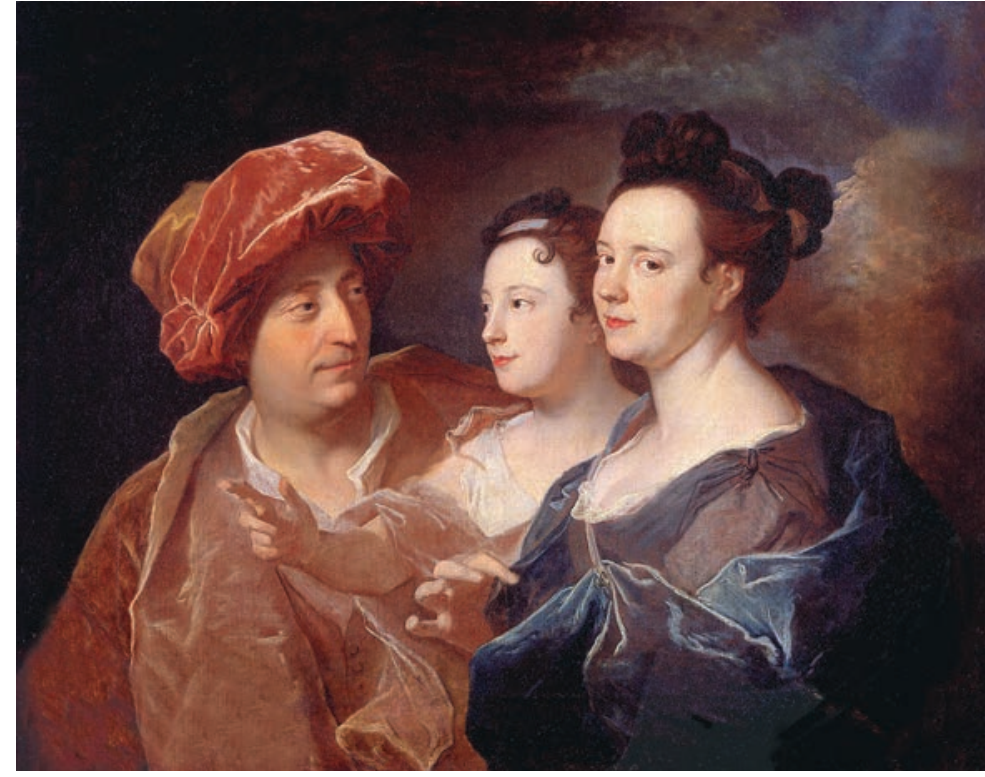

Fig.1.4. Hyacinthe Rigaud. Portrait d'Honorat Joan Lafita, Clara Rigaud, Soeur de Hyacinthe Rigaud et de leur fille aînée Maria. Também intitulado: La famille Laffite. 1695-1696, óleo sobre tela. $83 \times 103 \mathrm{~cm}$. Paris, Musée du Louvre. 


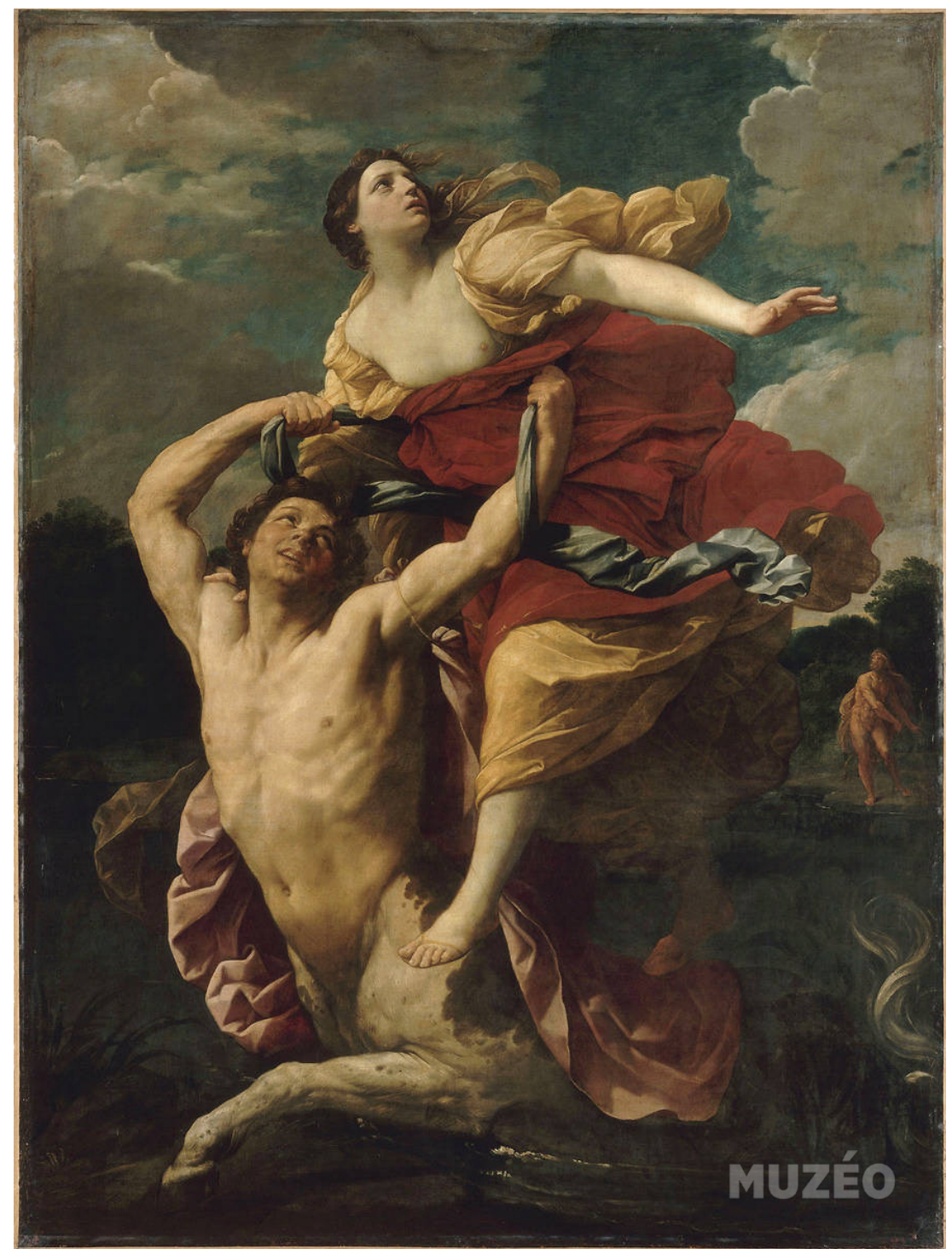

fig.1.5.Guido Reni. Déjanire enlevée par le centaure Nessus. ca.1617-21. óleo sobre tela. 239 x $193 \mathrm{~cm}$. Musée du Louvre.

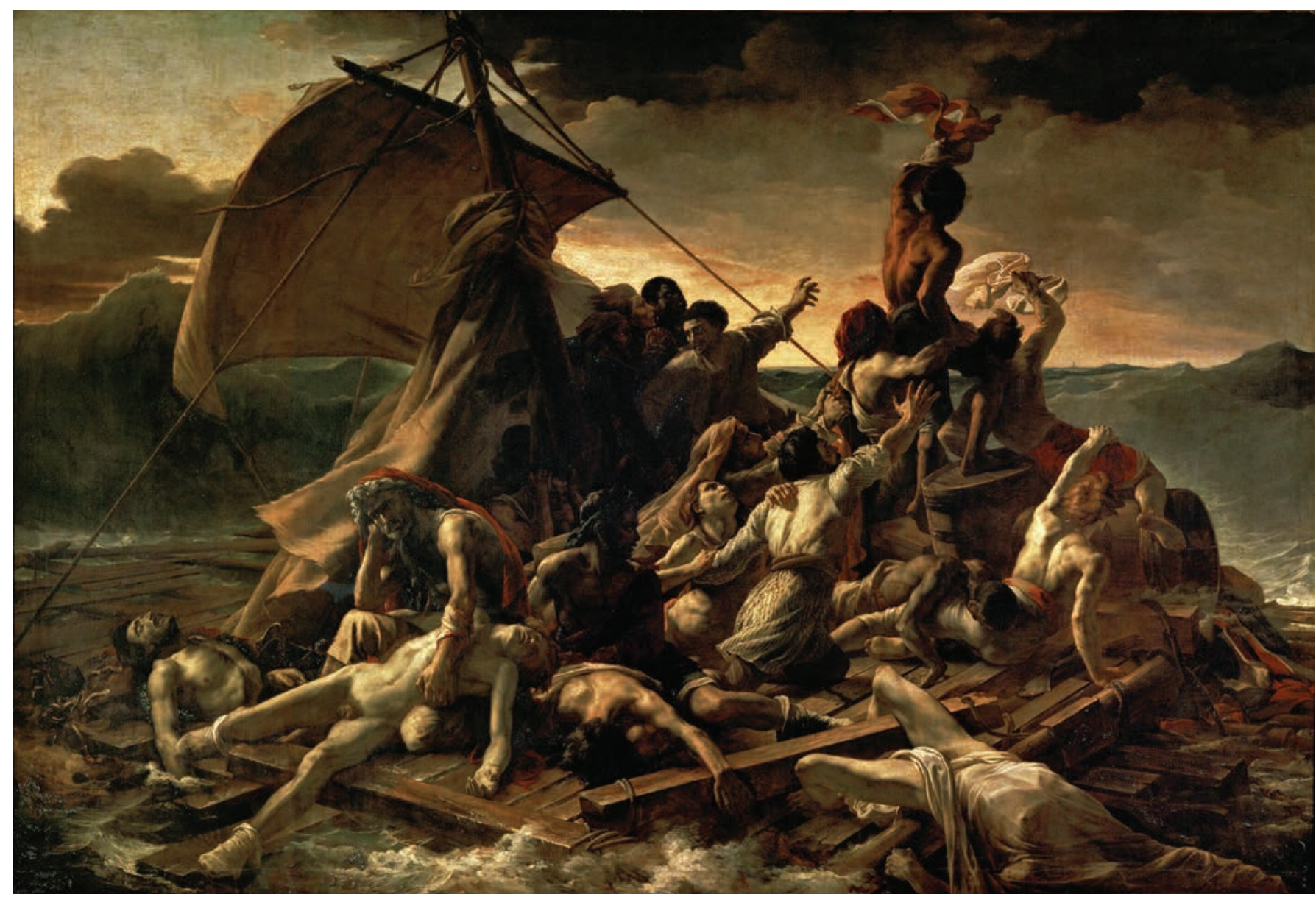

fig. 1.6.Théodore Géricault. Le Radeau de la Méduse. 1818-19, óleo sobre tela, 491 x 716 cm. Musée du Louvre. 


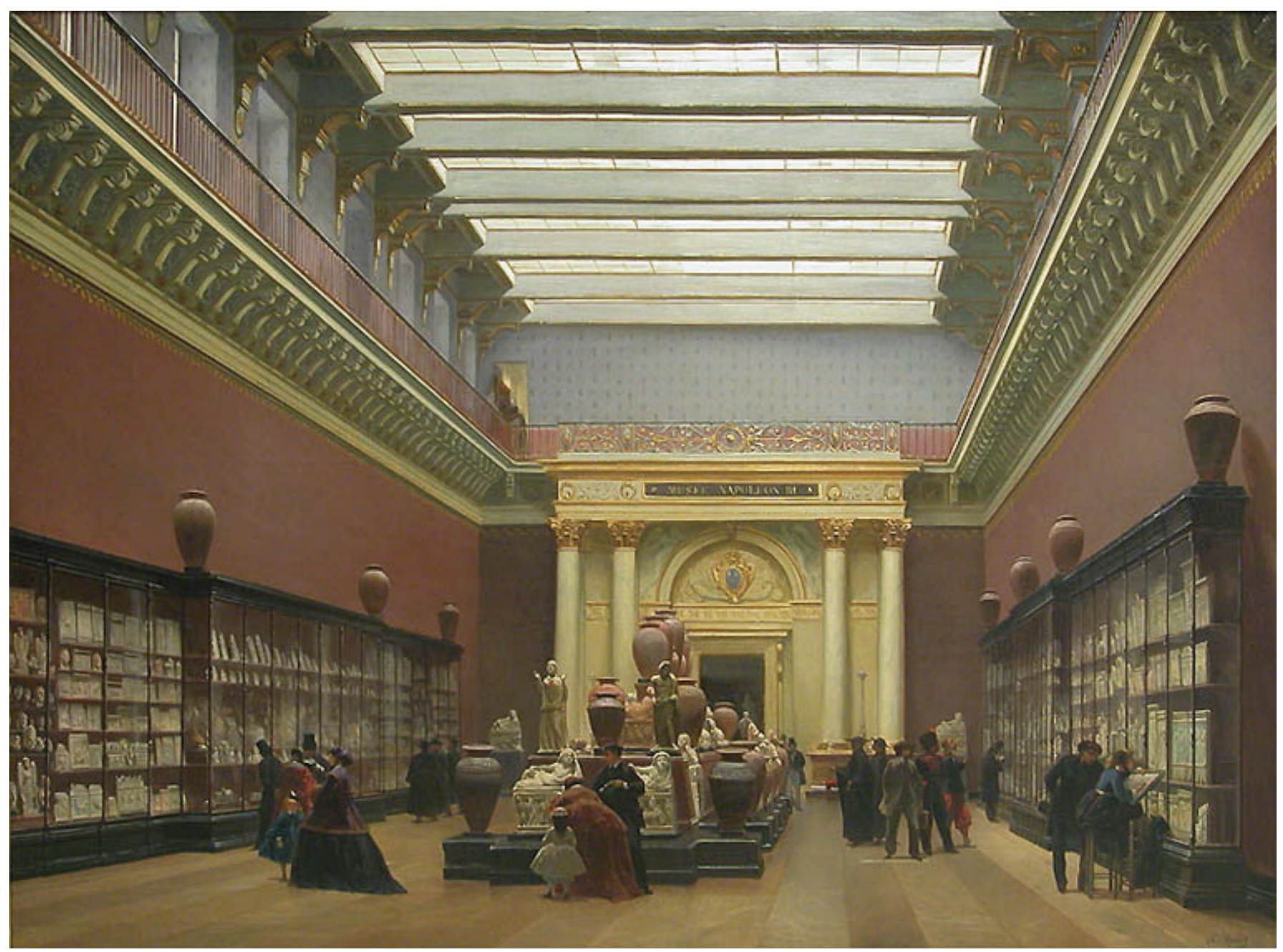

fig.1.3. Charles Giraud, Musée Napoléon III, sala de terracotas no Louvre, também conhecida como A Galeria Campana. 1866, óleo sobre tela. Museu do Louvre, Paris. 
Caderno de imagens Quarto Capítulo 


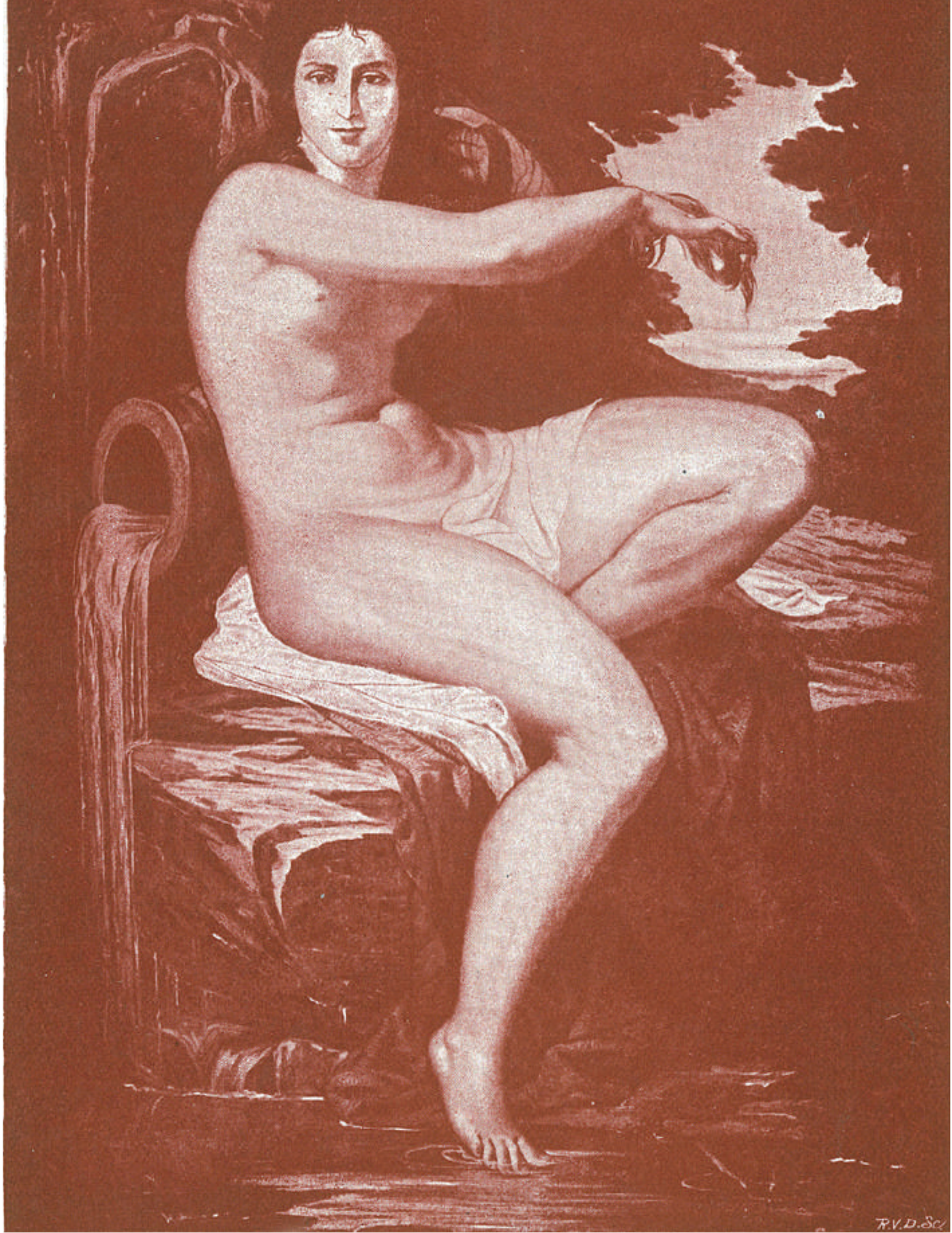

Figura 4.1. Pedro Américo. A Carioca, 1863-4, óleo sobre tela, 203 x 134 cm. Localização atual e estado desconhecidos. 


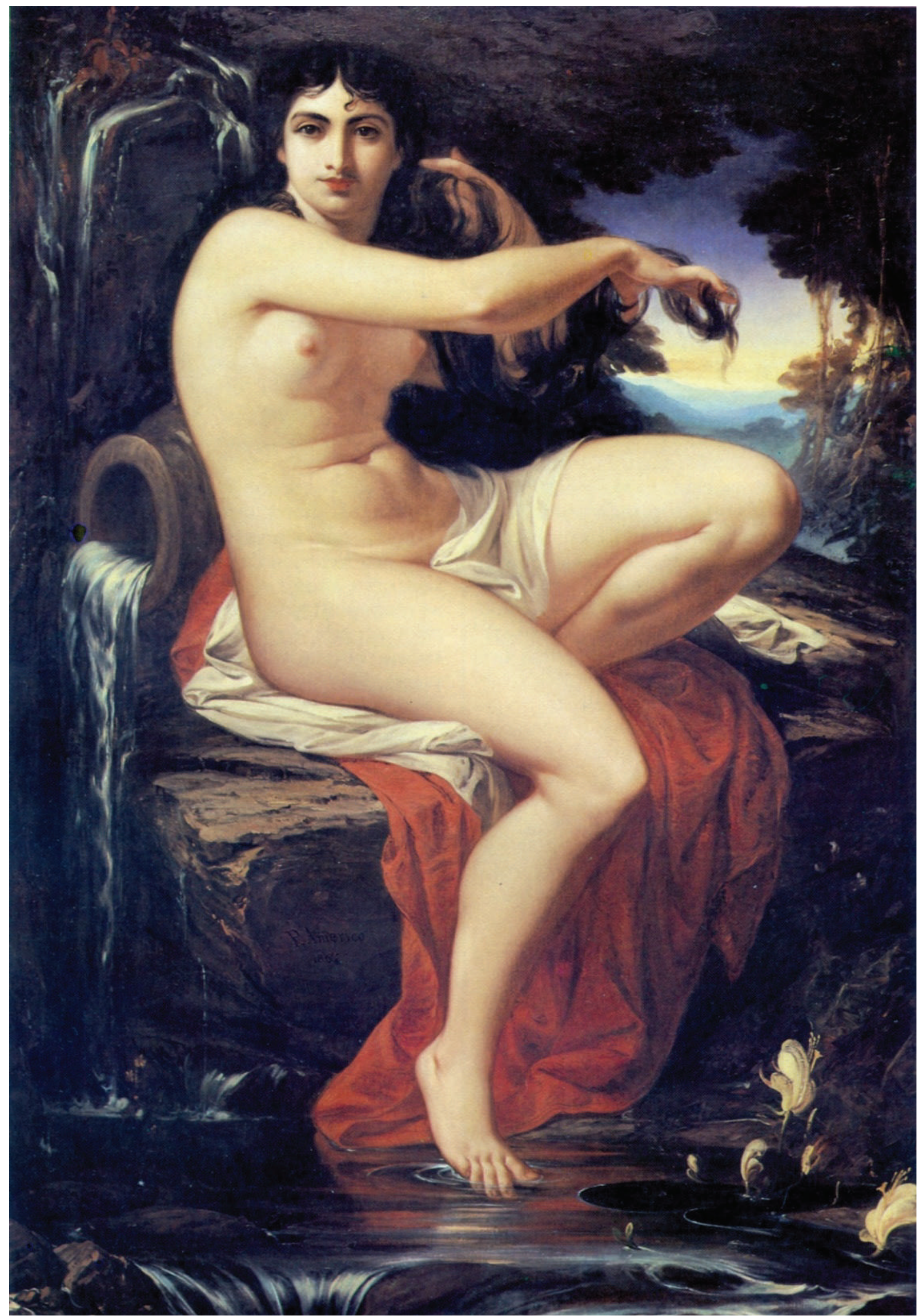

Figura 4.2. Pedro Américo. A Carioca, 1882, óleo sobre tela, 205 x 135 cm. Museu Nacional de Belas Artes, Rio de Janeiro. 


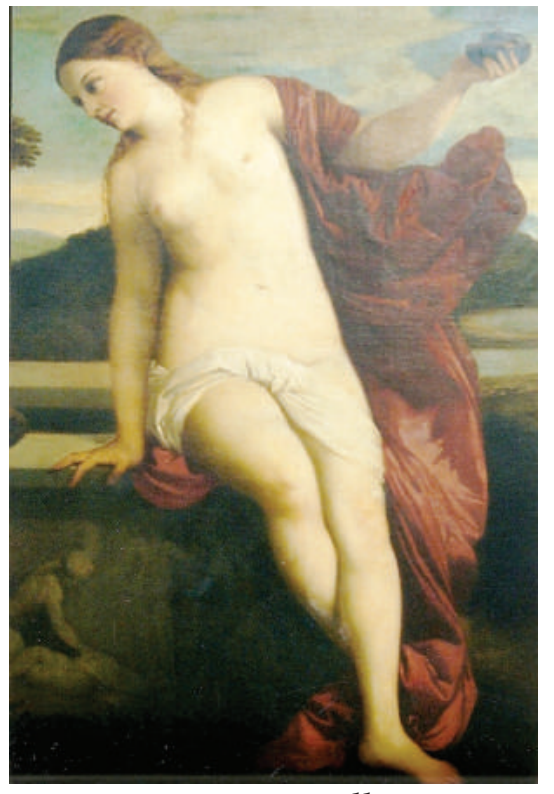

Fig.4.3. Victor Meirelles. Amor sacro, cópia de Ticiano, óleo sobre tela, $107 \mathrm{x}$ $88,5 \mathrm{~cm}$. Museu Dom João VI.

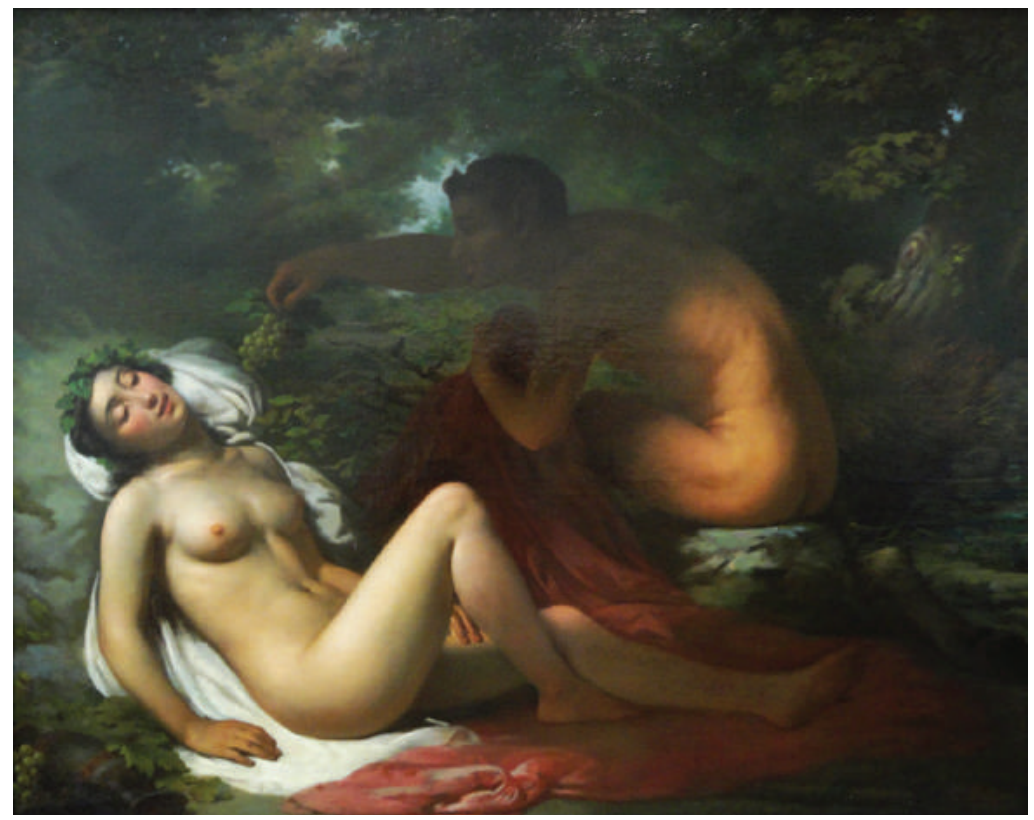

Figura 4.4. Victor Meirelles. Bacante, 1857-58, óleo sobre tela, 77.9 x $87.5 \mathrm{~cm}$. MNBA.

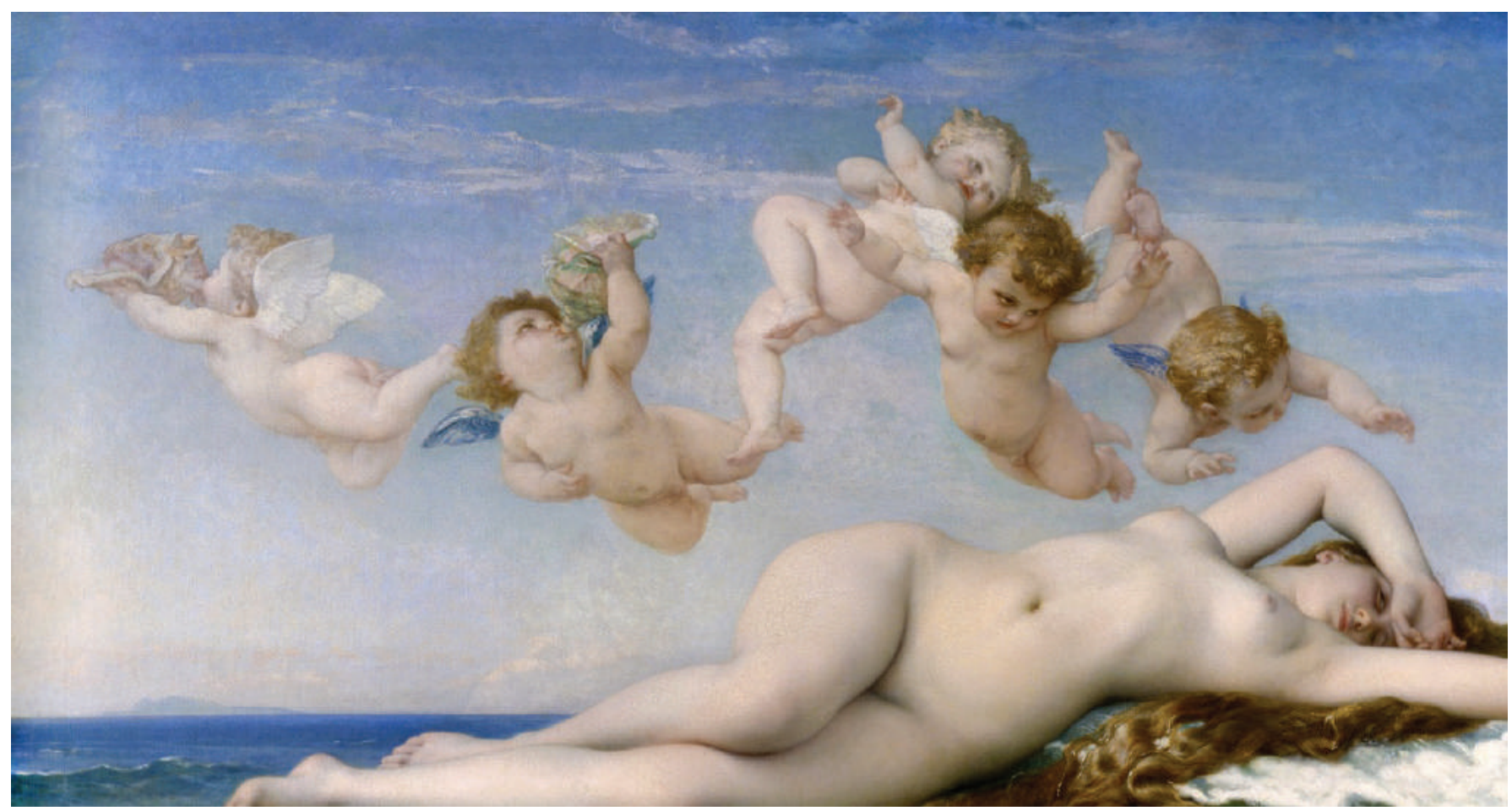

Figura 4.5 . Alexandre Cabanel. Naissance de Vénus. 1863, óleo sobre tela, 130 x 225 cm. Musée d’Orsay.

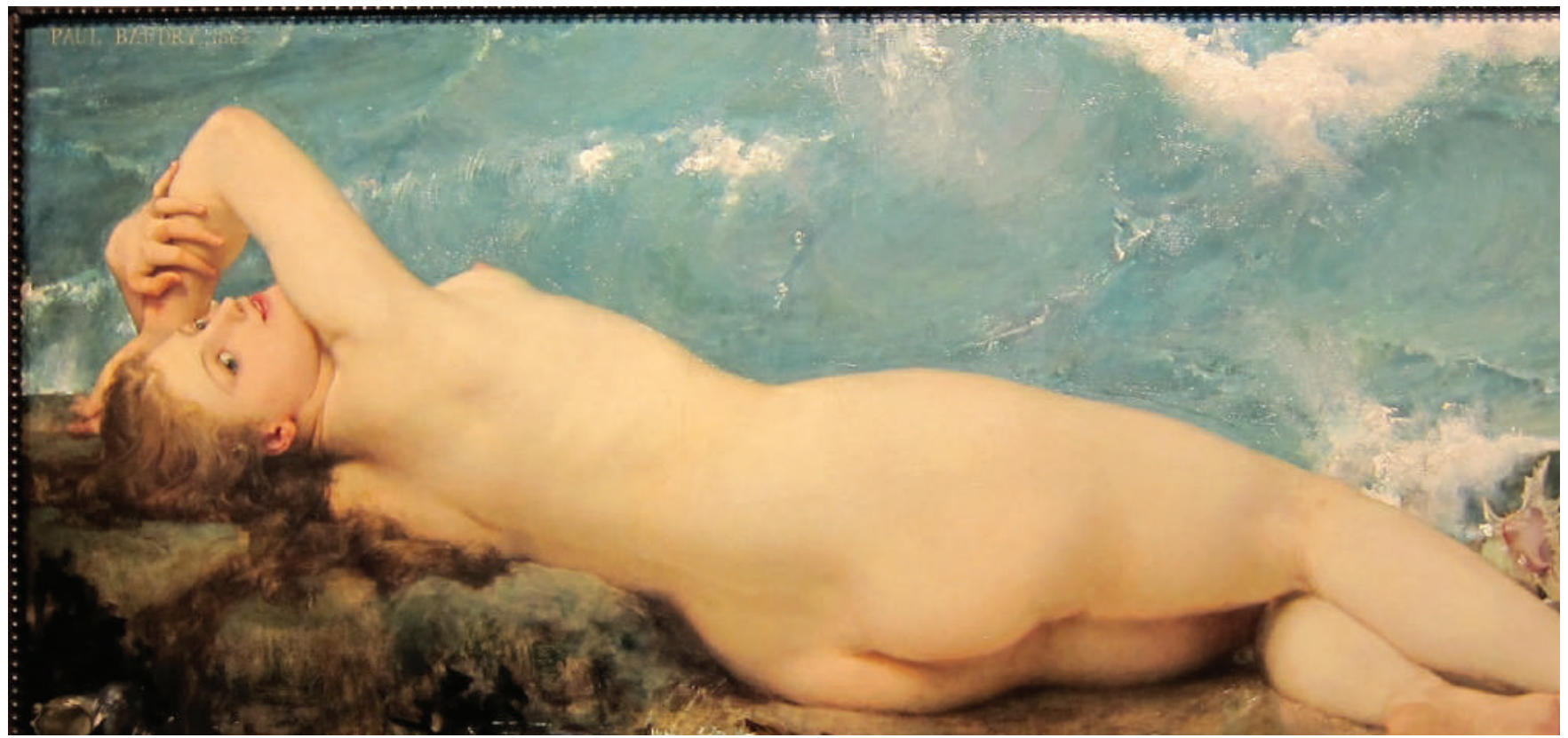

Fig.4.6.Paul Baudry. La Perle et la vague, 1862, óleo sobre tela, $83.5 \mathrm{~cm} \times 178$ c. Museo del Prado, Madrid. 


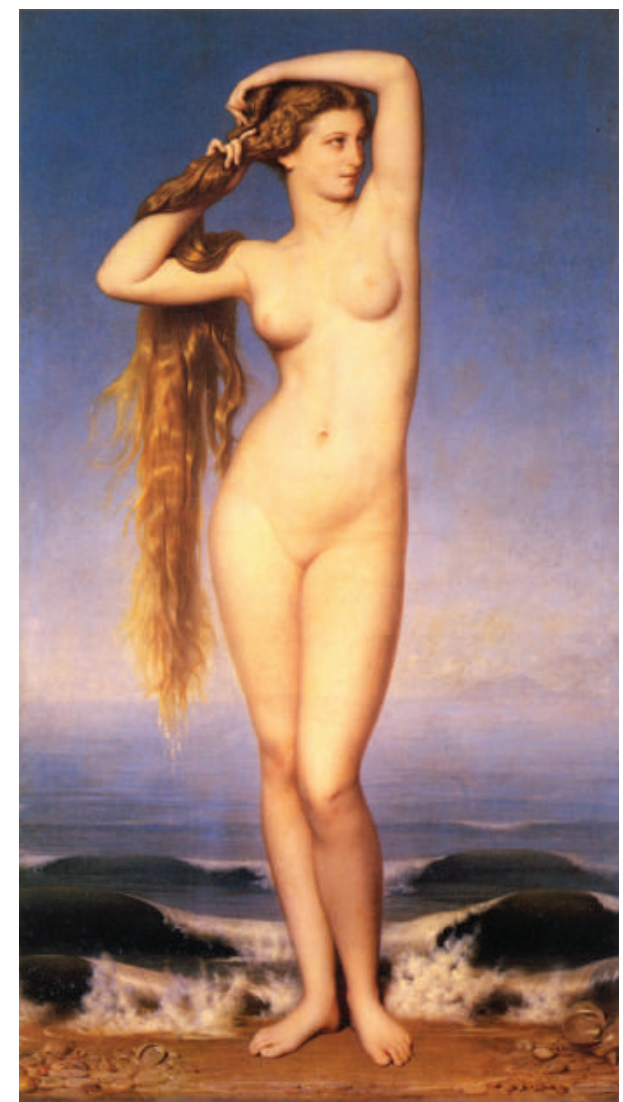

Fig.4.7. Amaury-Duval. La Naissance de Vénus. 1862, óleo sobre tela, $196.85 \times 108.90 \mathrm{~cm}$. Palais des beaux-arts de Lille.

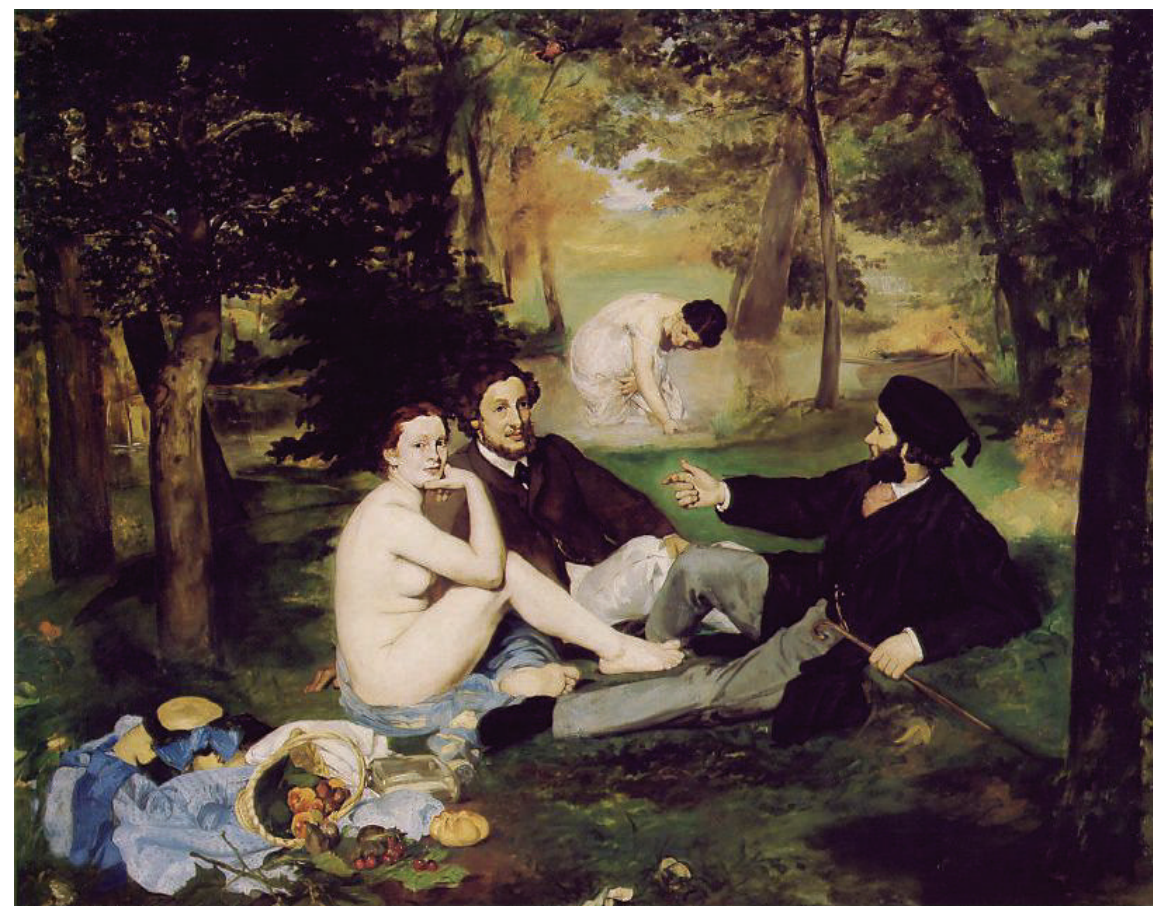

Fig.4.8.Édouard Manet. Déjeuneur sur l'herbe. 1862-3, óleo sobre tela, 208 x $264 \mathrm{~cm}$. Musée d'Orsay.

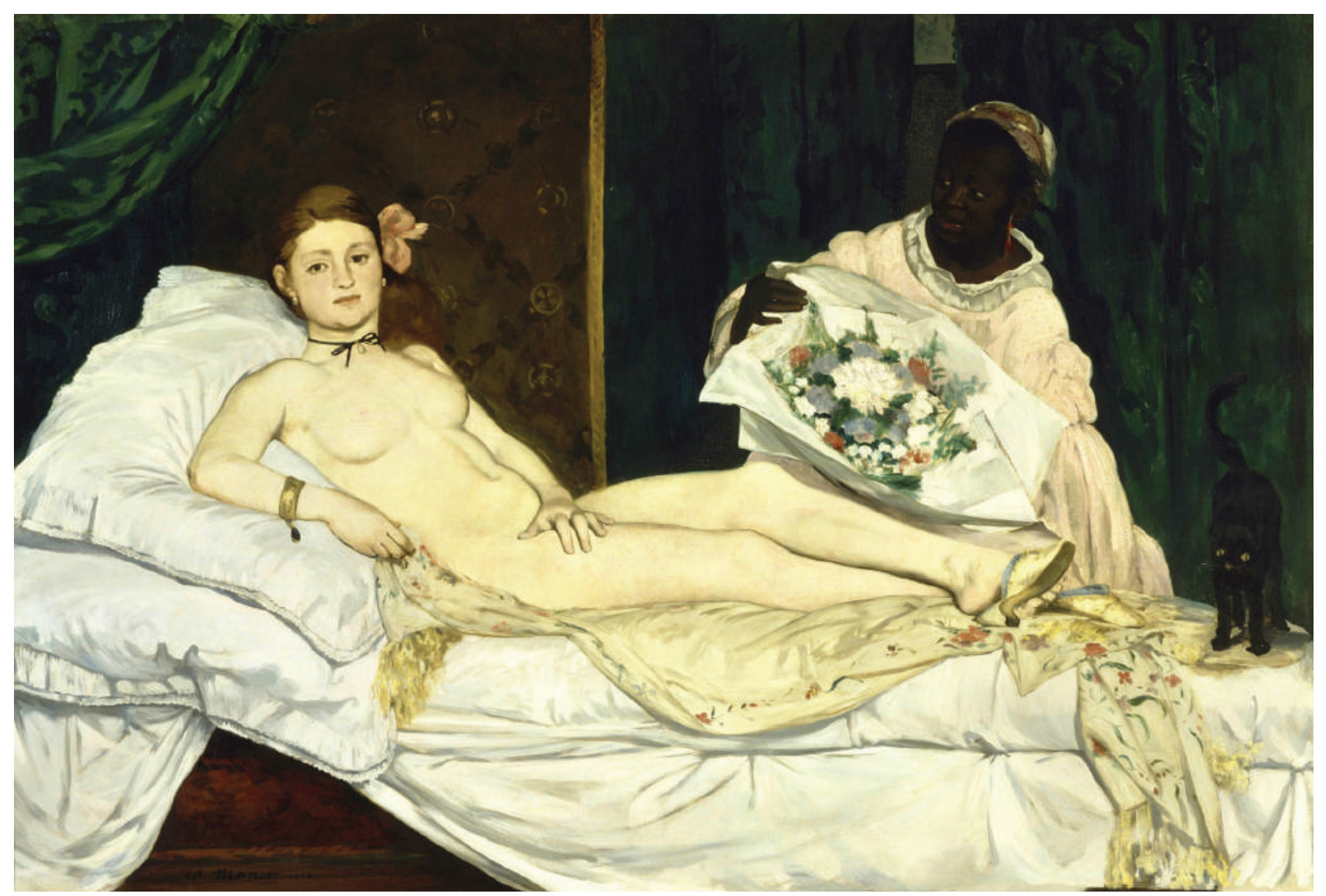

Fig.4.9.Édouard Manet. Olympia. 1863, óleo sobre tela, 130.5 x 190 cm. Musée d'Orsay. 


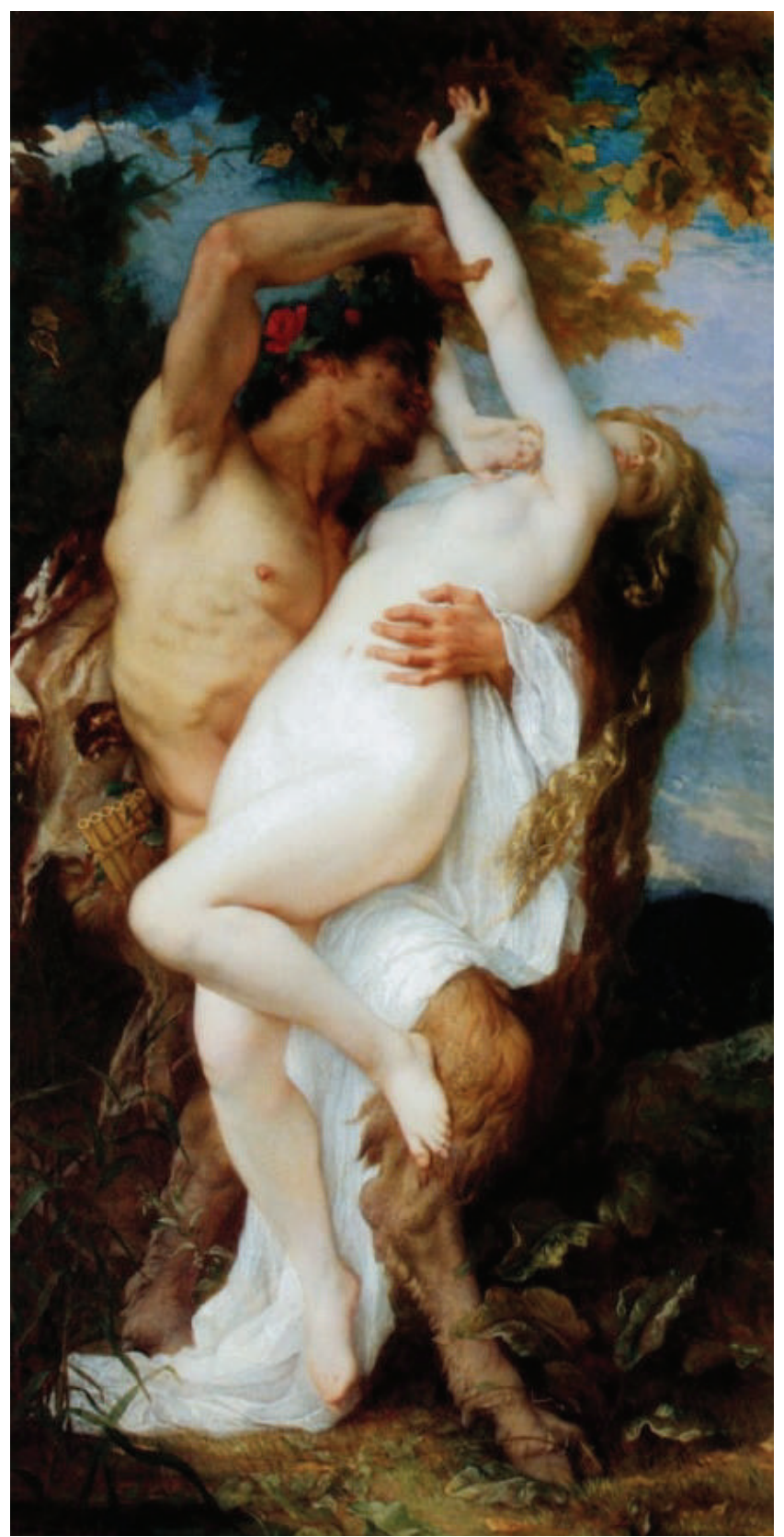

Fig.4.10. A. Cabanel. Ninfa

abduzida por um fauno. 1861,

óleo sobre tela, 130.5 x 190

$\mathrm{cm}$. Musée d'Orsay.

Fig.4.11. Jean-Léon Gérôme. Socrates buscando Alcibiades na casa de Aspásia, 1861, óleo sobre tela, Terence Garnett collection.

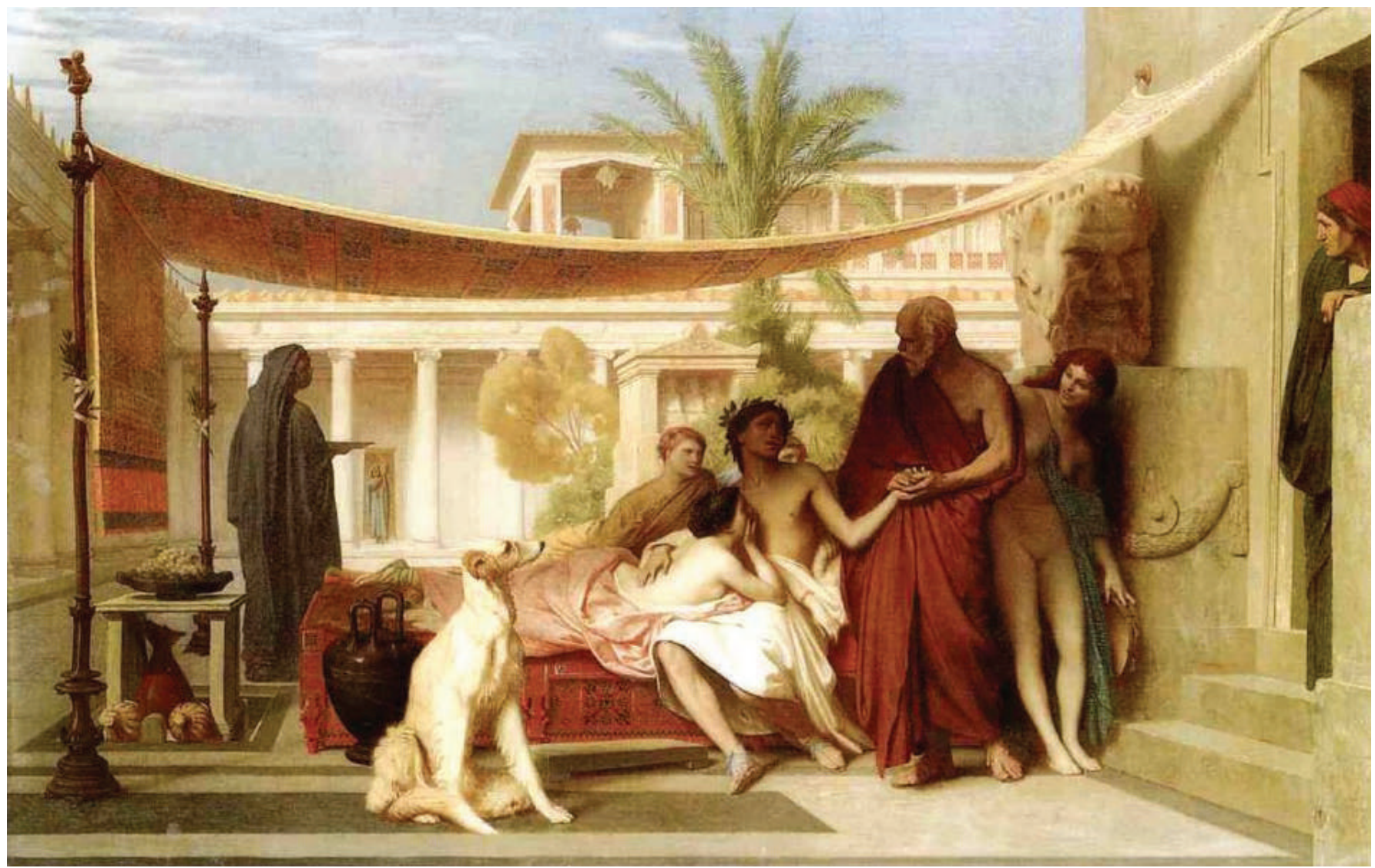




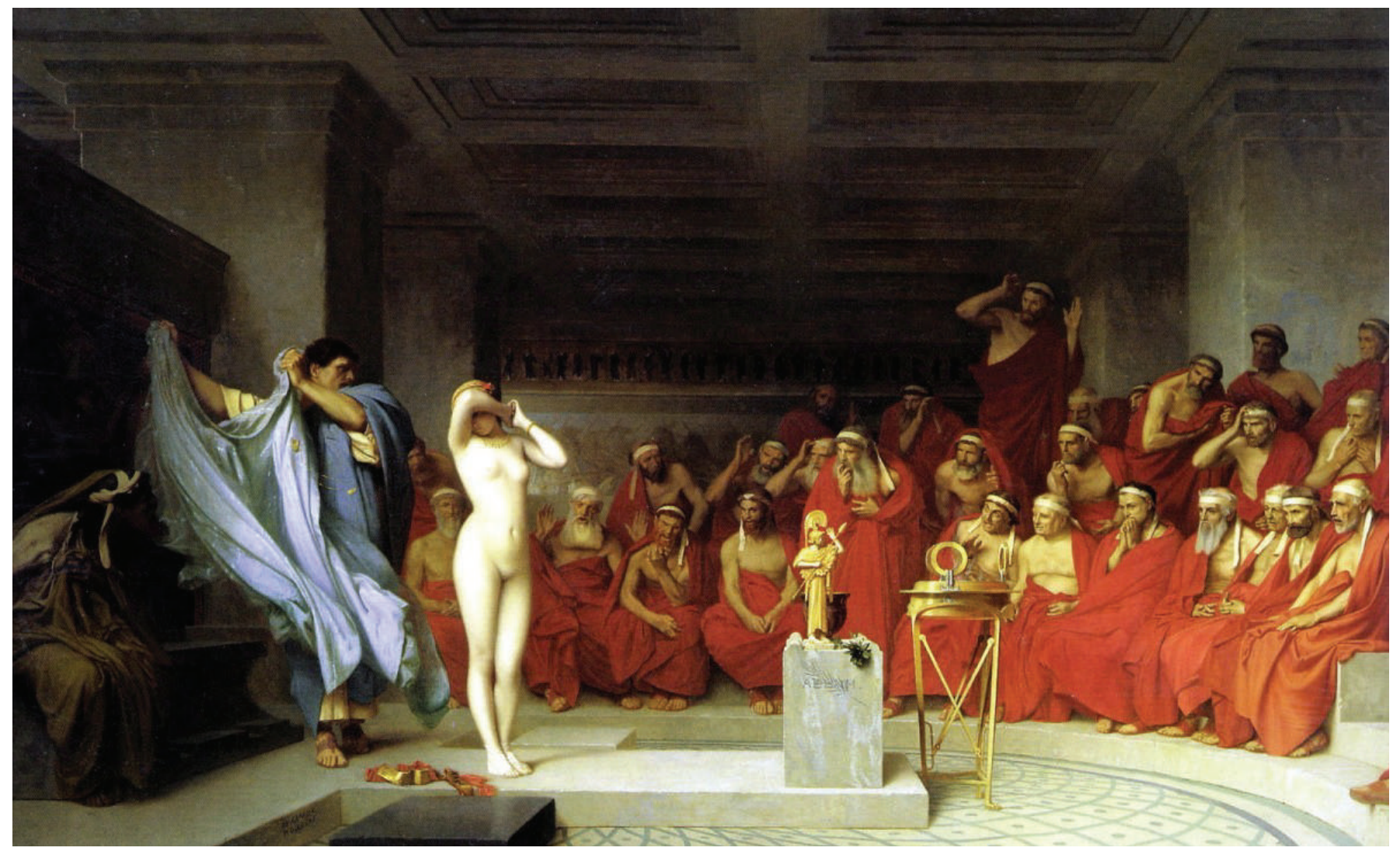

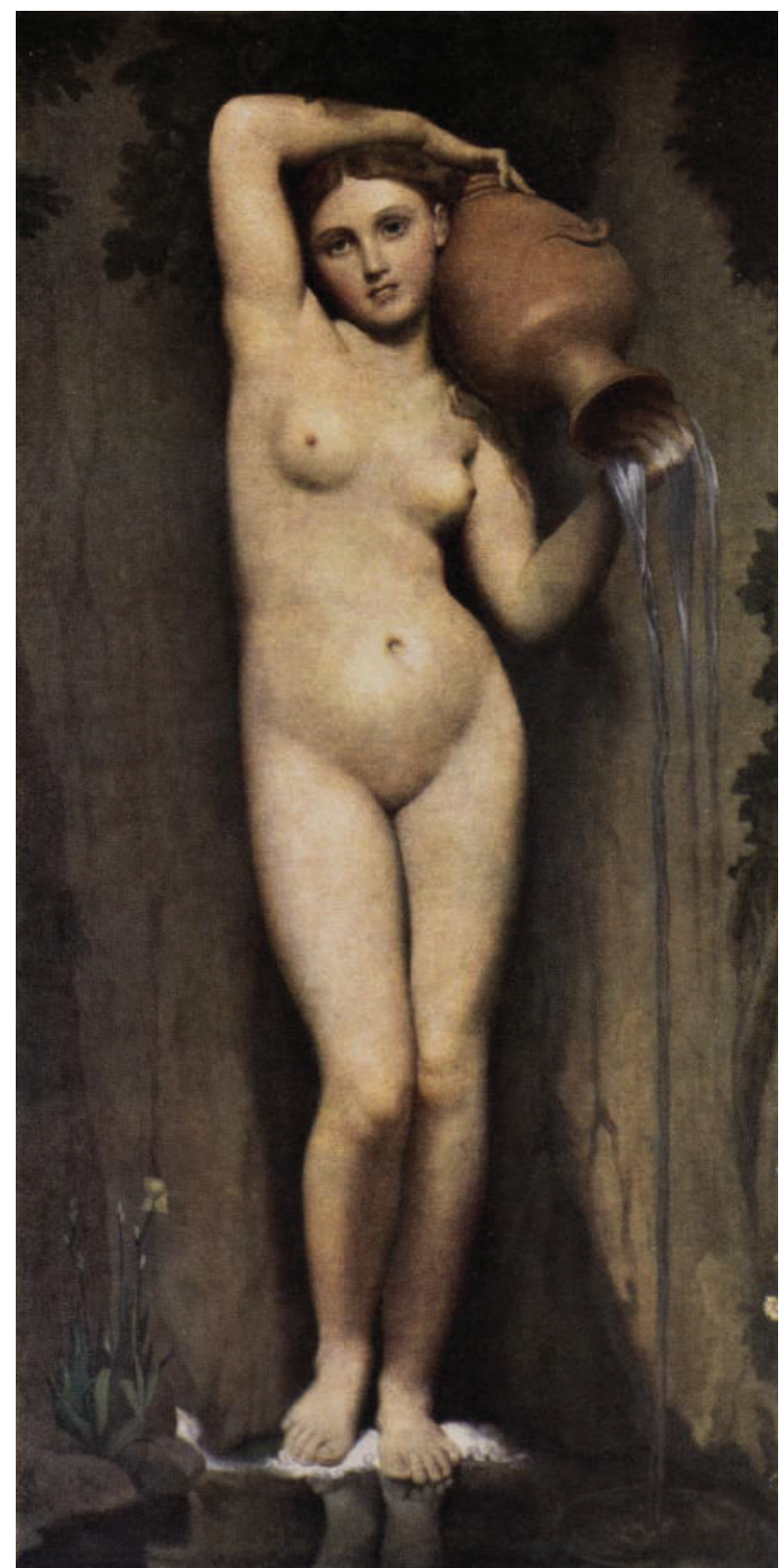

Fig.4.13. Jean-Auguste-Dominique Ingres. $\mathrm{La}$ Source. 1820-1856, óleo sobre tela, 163 x 80cm. Musée d'Orsay.
Fig.4.12. Jean-Léon Gérôme. Frineia diante do areópago, 1861, óleo sobre tela, 80,5 × $128 \mathrm{~cm}$, Hamburg Kunsthalle, Hamburgo, Allemanha.

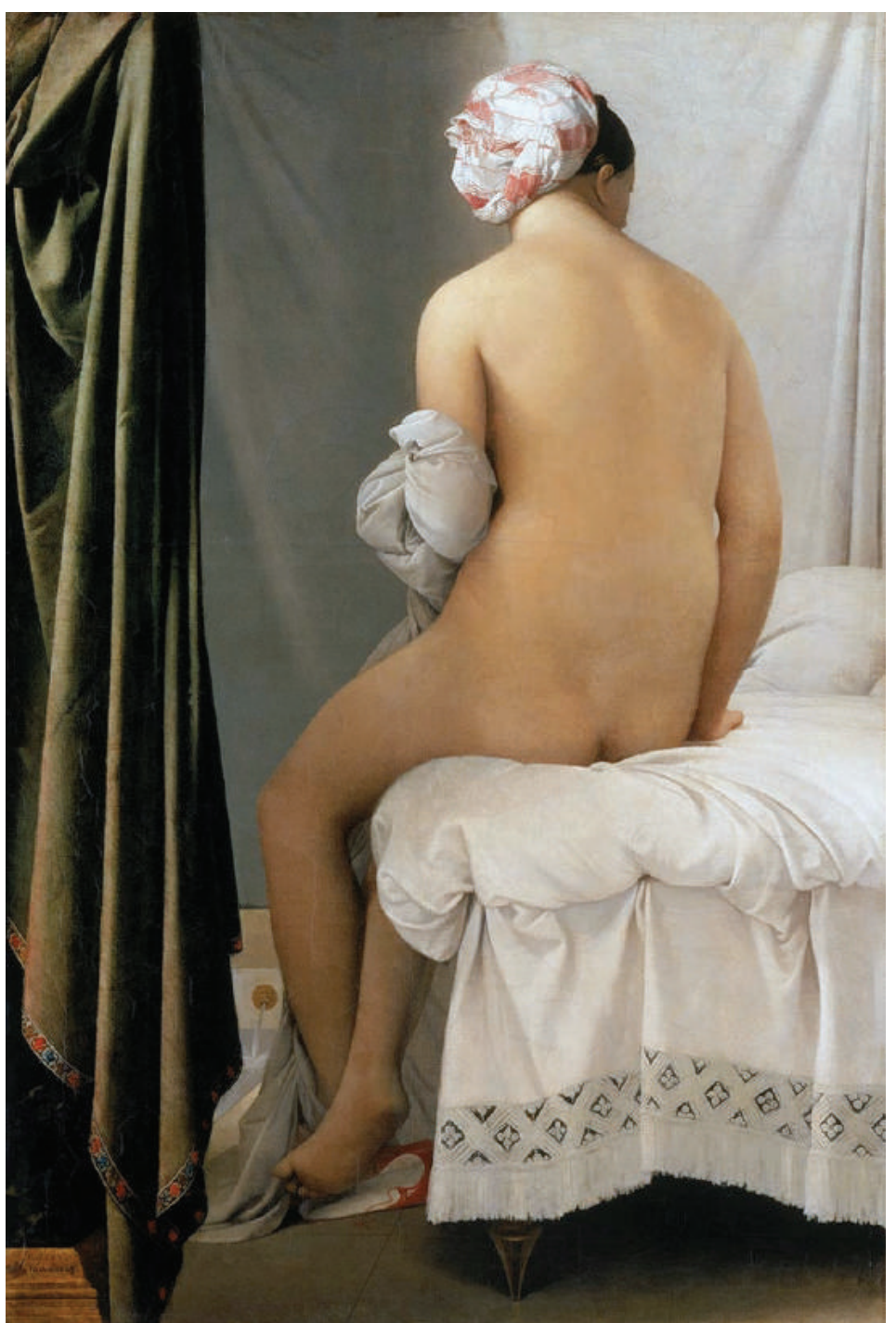

Fig.4.14. Ingres. A Banhista de Valpincon, 1808, óleo sobre tela, Museu do Louvre. 



Fig.4.16. Gustave Courbet. La Source. 1868, óleo sobre tela, Musée d'Orsay

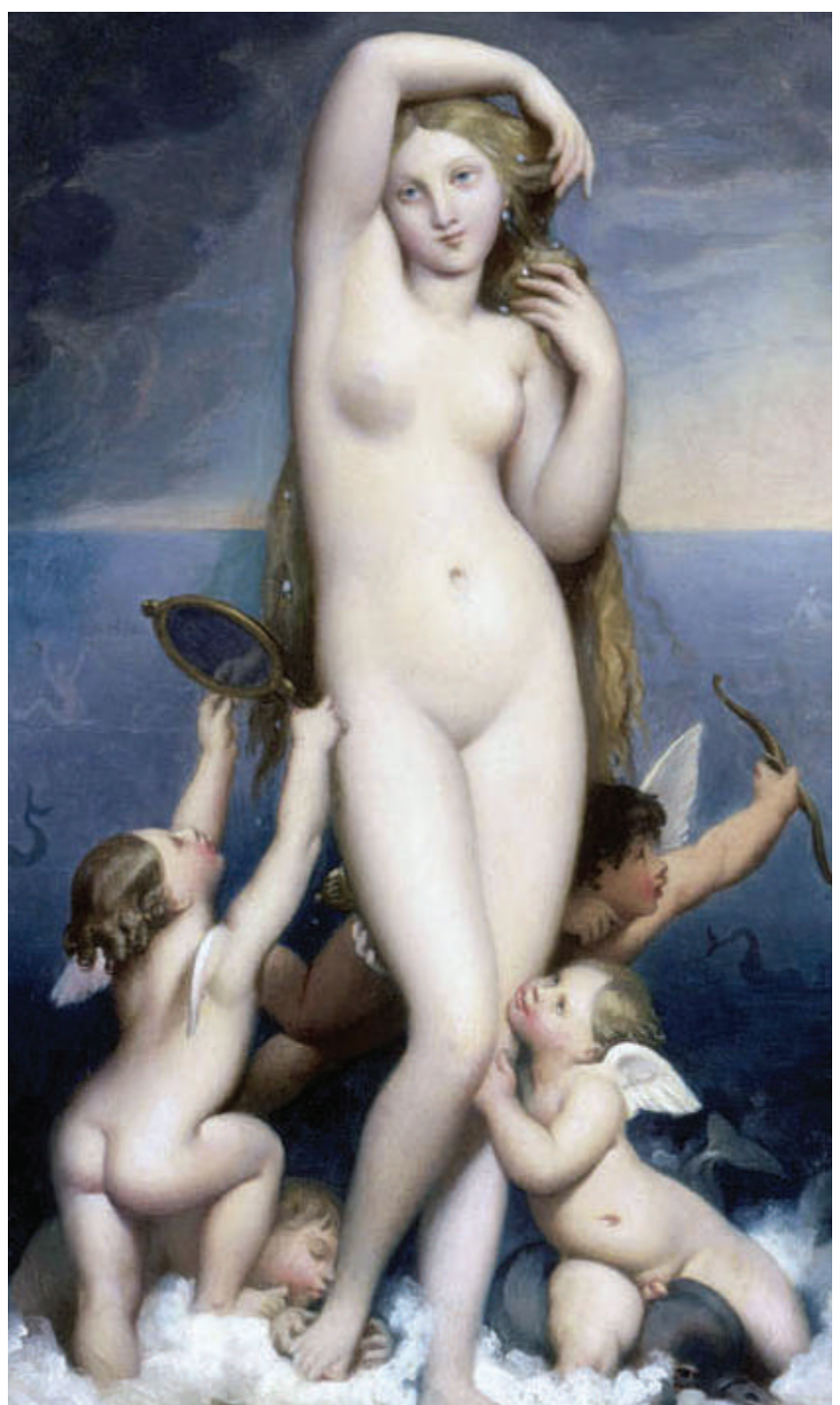

À extrema esquerda, no alto: fig.4.15. Gustave Courbet. La Source. 1862, óleo sobre tela, 120 x $74.3 \mathrm{~cm}$. Metropolitan Museum of Art.

Fig.4.17. Jean-Auguste-Dominique Ingres, Venus Andyomène, 1858, óleo sobre tela, $64,18 \times 36,14 \mathrm{~cm}$. Musée Condé, Chantilly 


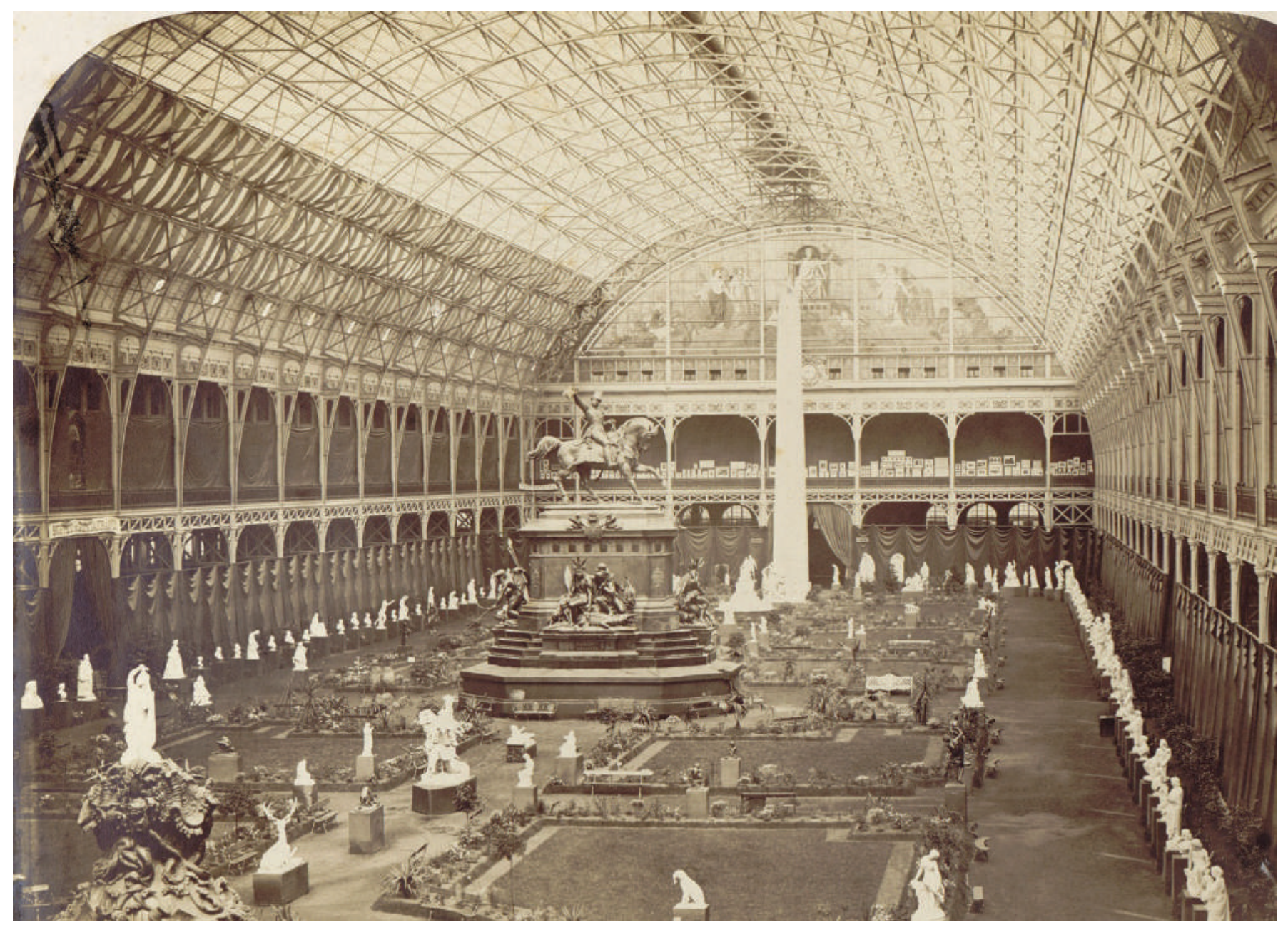

Fig.4.18. Pierre-Ambroise Richebourg (1810-1875). Salon des Beaux-Arts. Nef du Palais de l'Industrie. Paris VIIIe. 1861, fotografia, tiragem em papel albuminado, 38.5 x $27.5 \mathrm{~cm}$. BNF, Paris.
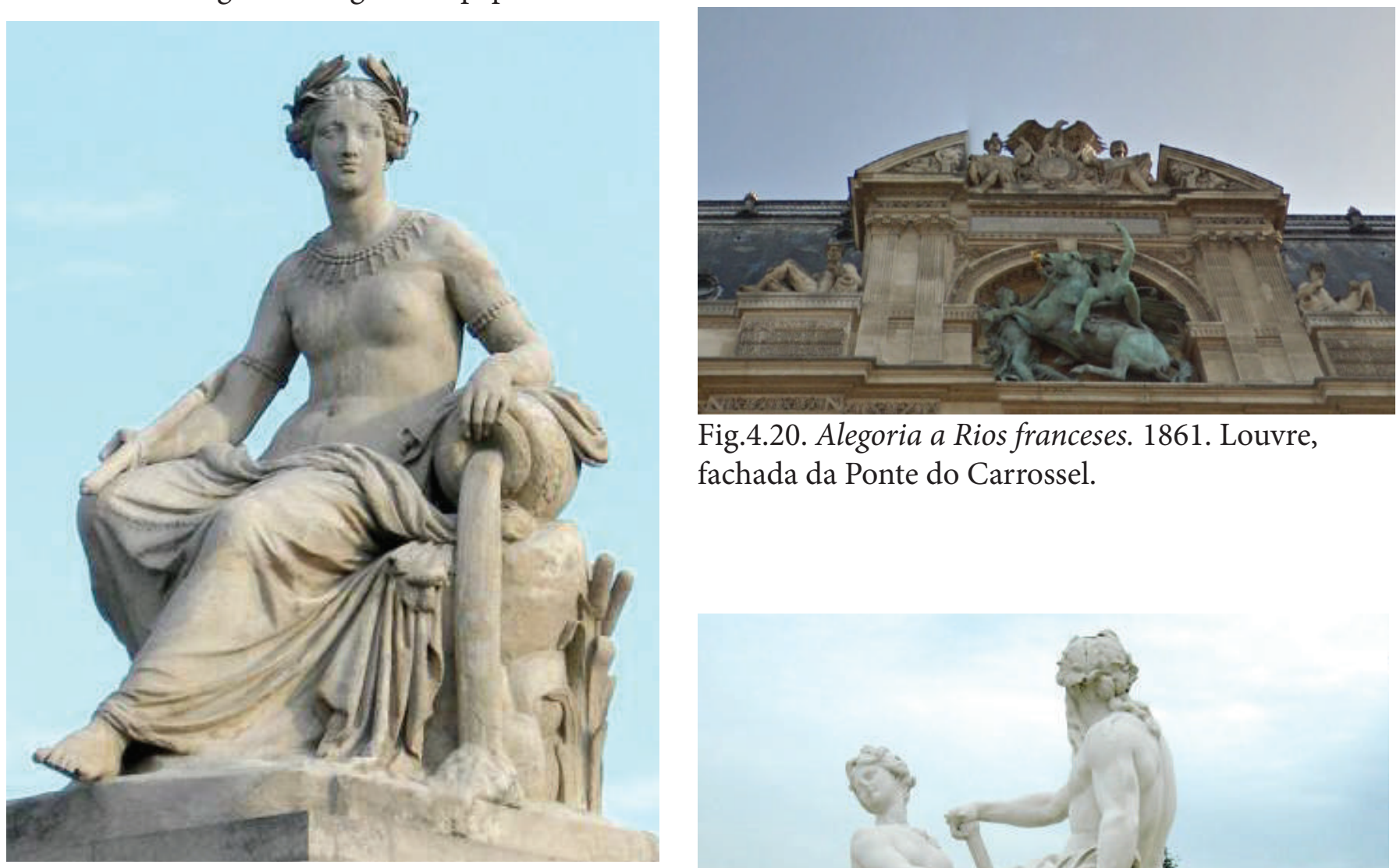

Fig.4.20. Alegoria a Rios franceses. 1861. Louvre, fachada da Ponte do Carrossel.

Fig.4.19. Louis Petitot. La Seine, 1846. Rive gauche, Ponte do Carrousel. Paris.

Fig.4.21. Nicolas Coustou, 1658-1733. La Seine et la Marne, 1704-1712. Jardin des Tuileries, Paris.

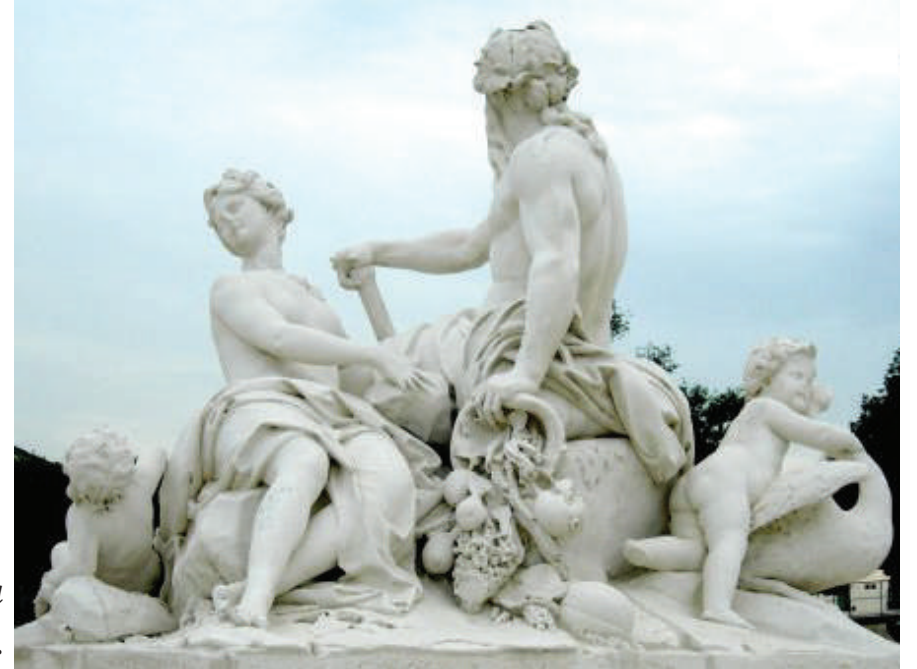




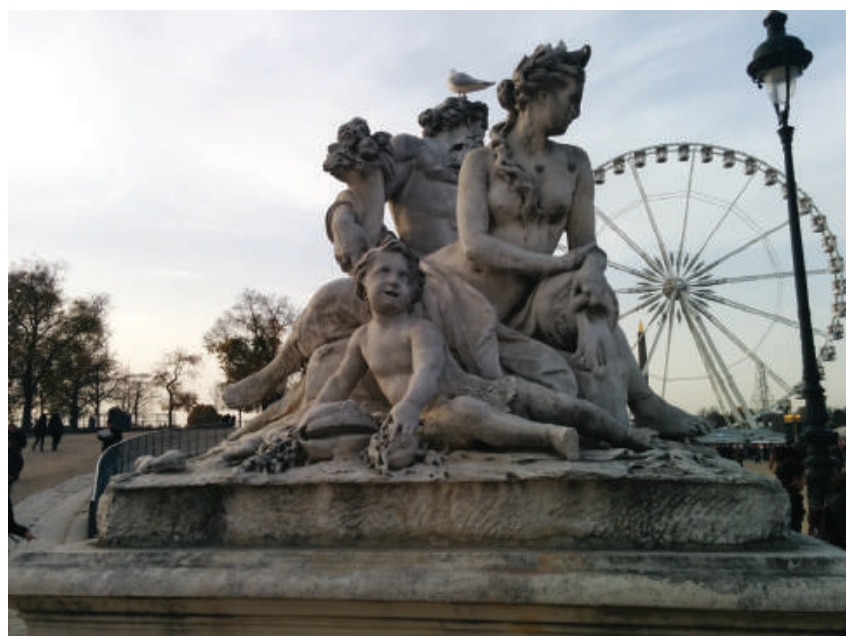

Fig.4.22. Corneille Van Cleve. Alegorias aos rios La Loire e Le Loiret. Jardin des Tuilleries, Paris.

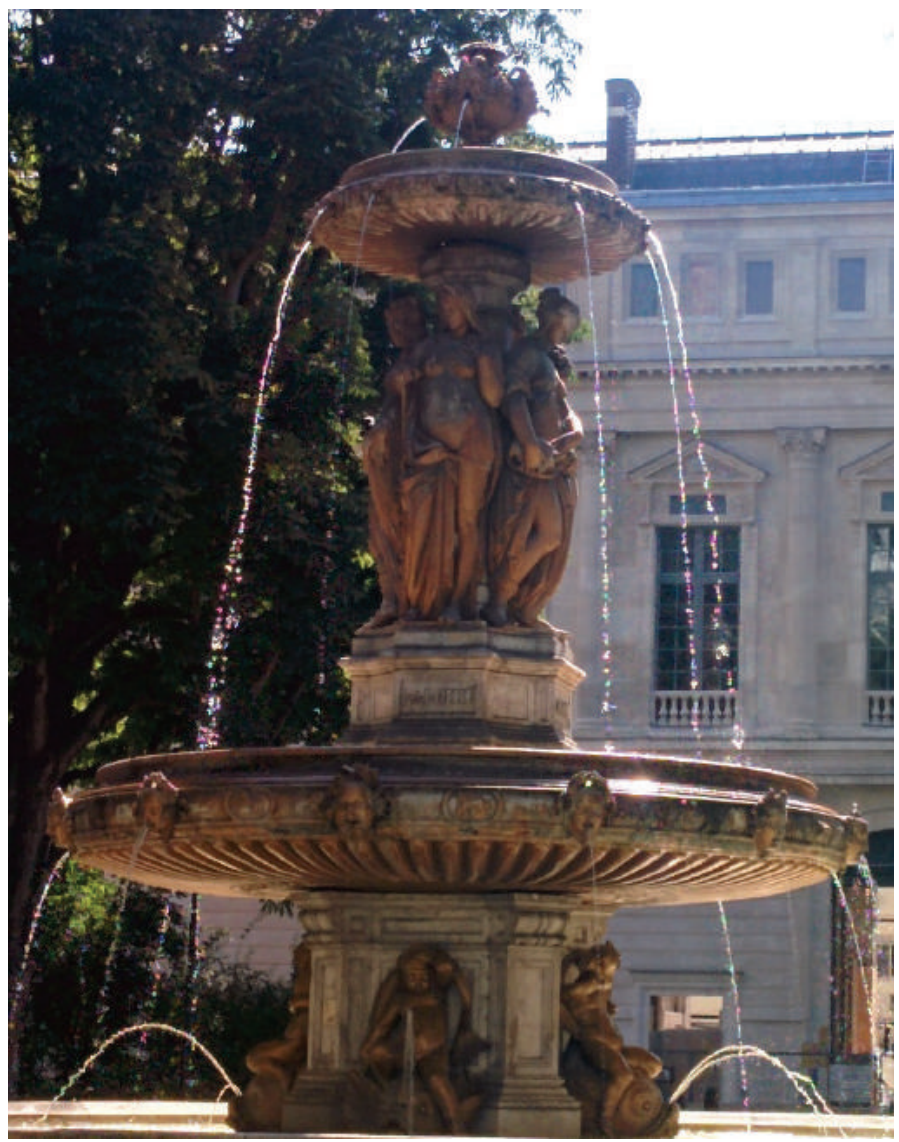

Fig.4.23. Fonte Louvois. 1844. Place Louvois, Paris. As quatro esculturas femininas representam os Rios

Seine, Garonne, Loire e Saône. Ao fundo, o prédio da antiga Biblioteca Imperial de França.
Fig.4.24. Pierre Lescot (arquitetura); Jean Goujon (escultura). Fontes das Ninfas (ou Fontes dos inocentes). 1549. Paris. 


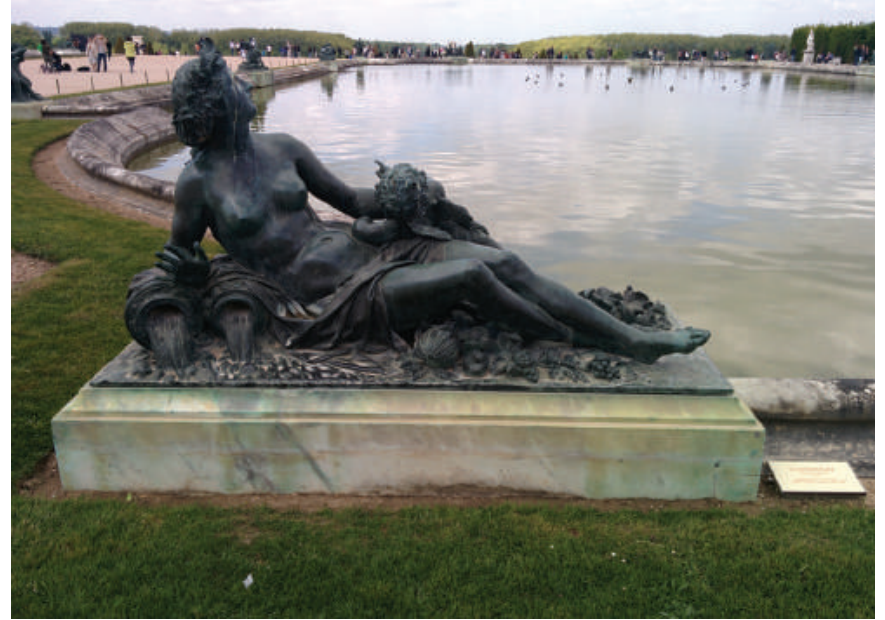

Fig.4.25. Balthasar Keller. La Dordogne (a partir de Antoine Coysevox.). Platéia de Água [Parterre d’eau]. Jardim do Palácio de Versailles.

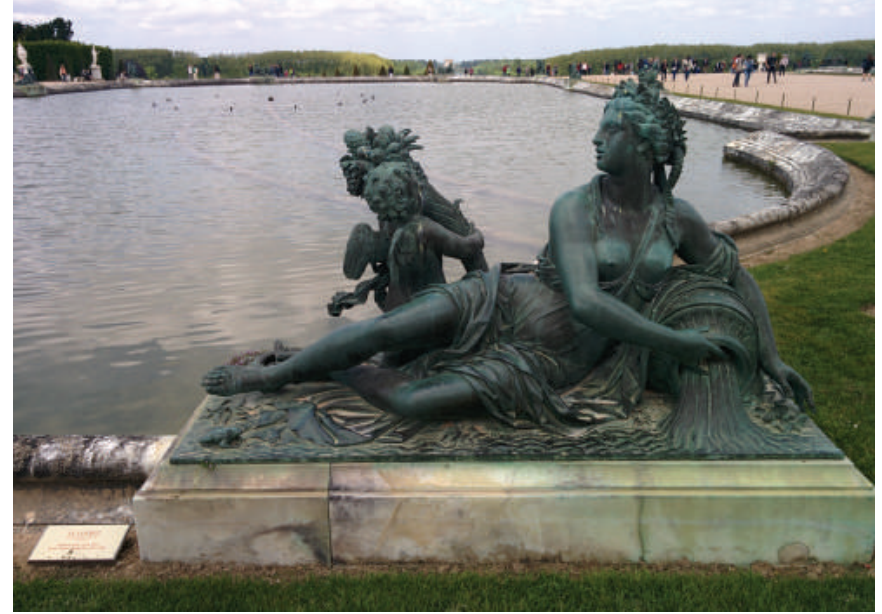

Fig.4.26. Balthasar Keller. Le Loiret (a partir de Thomas Regnaudin). Platéia de Água [Parterre d'eau]. Jardim do Palácio de Versailles.

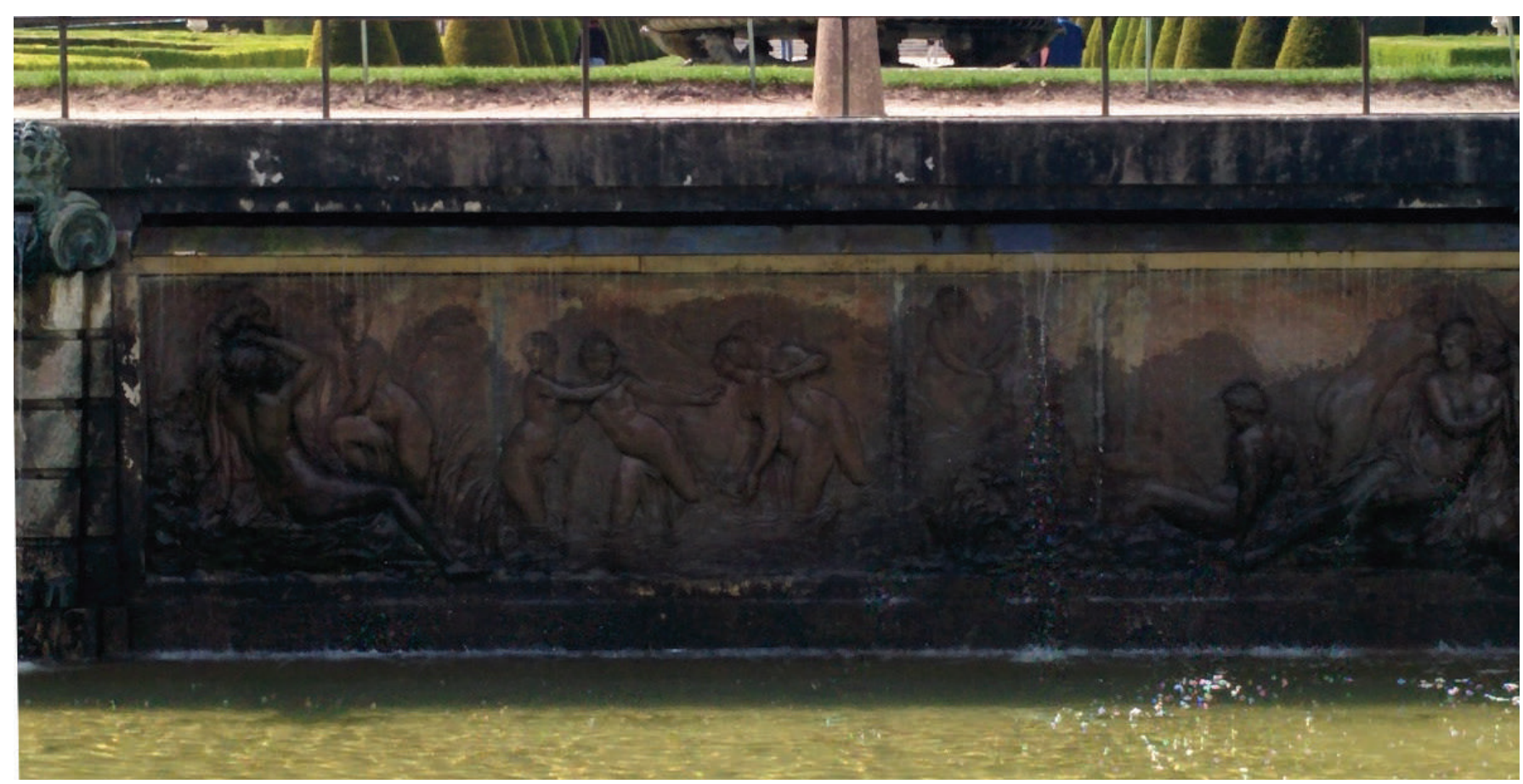

Fig.4.27. François Girardon. Banho das Ninfas. 1670-71. Jardim do Palácio de Versailles.

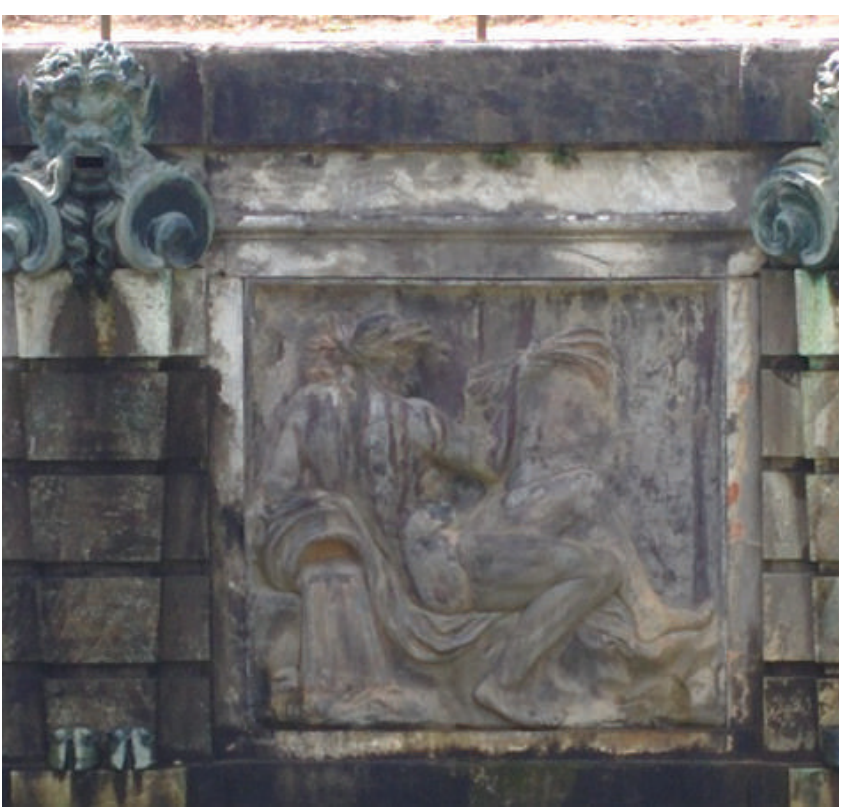

Fig.4.28. Le Hongre. conjunto do Banho das Ninfas. 1670-71. Jardim do Palácio de Versailles.

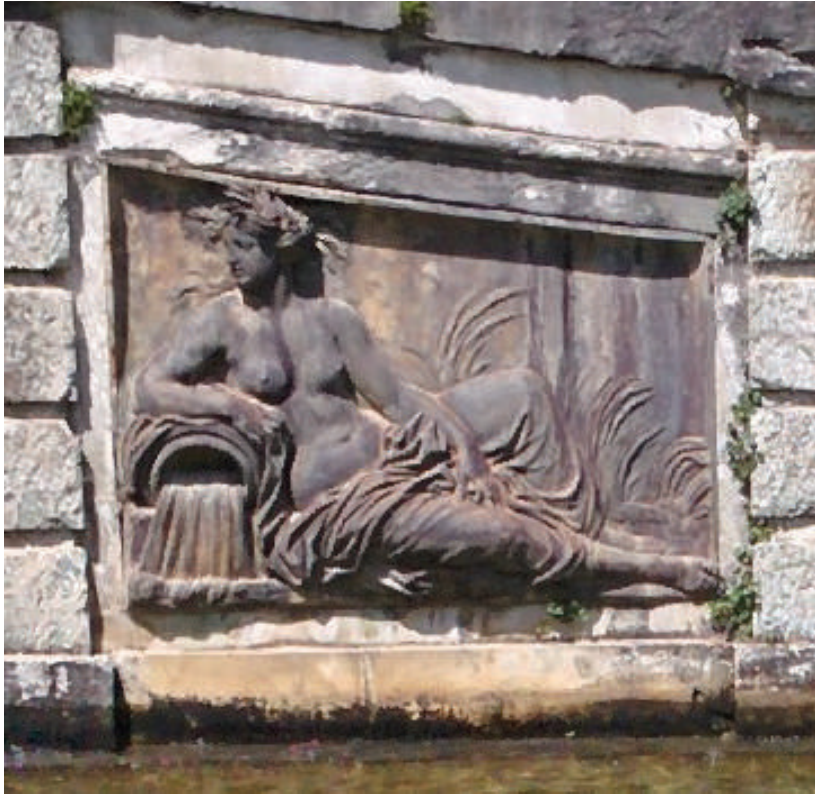

Fig.4.29. Alegoria fluvial. conjunto do Banho das

Ninfas. 1670-71. Jardim do Palácio de Versailles. 


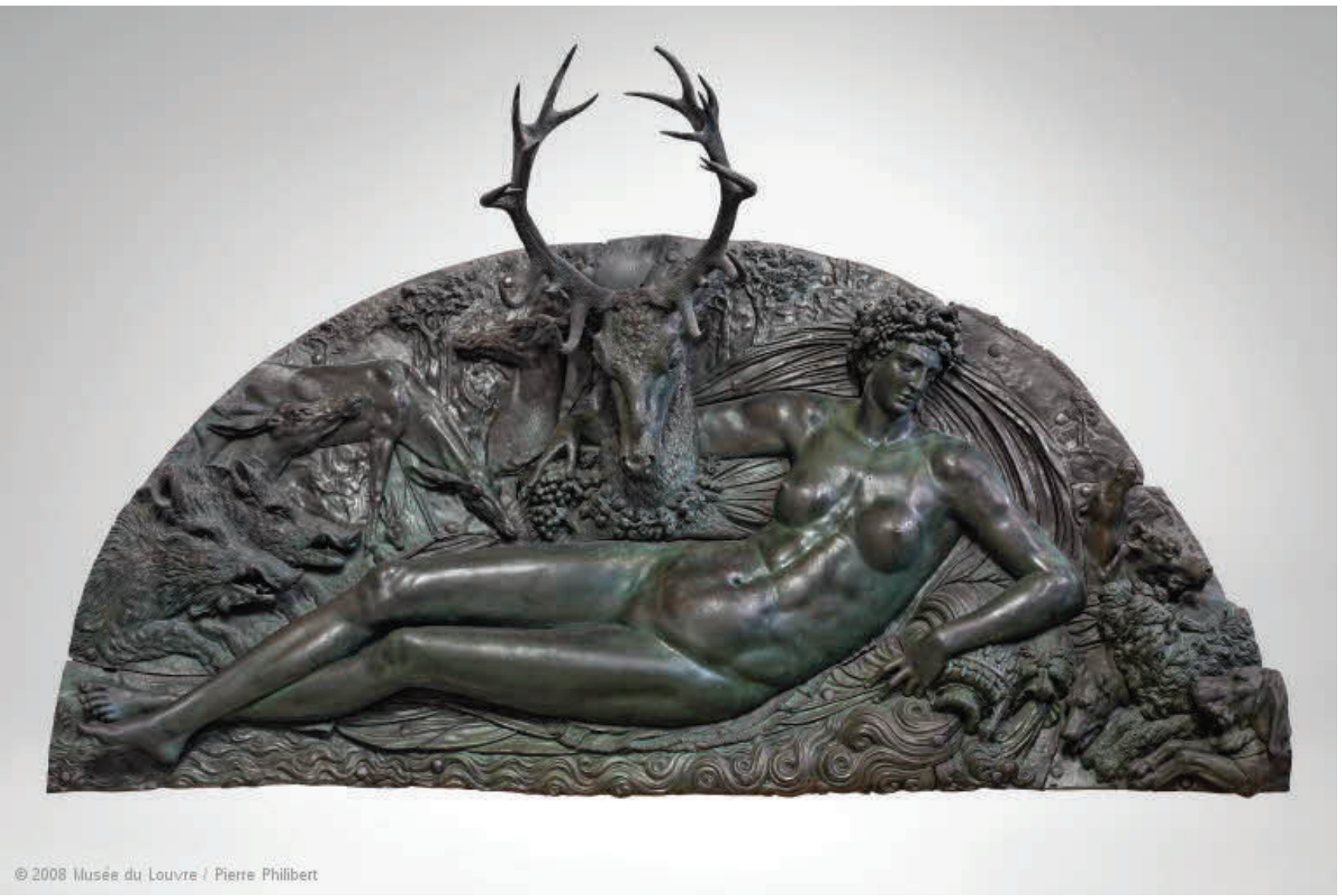

Fig.4.30. Benvenuto Cellini. La Nymphe de Fontainebleau, 1572, bronze. Museu do Louvre.

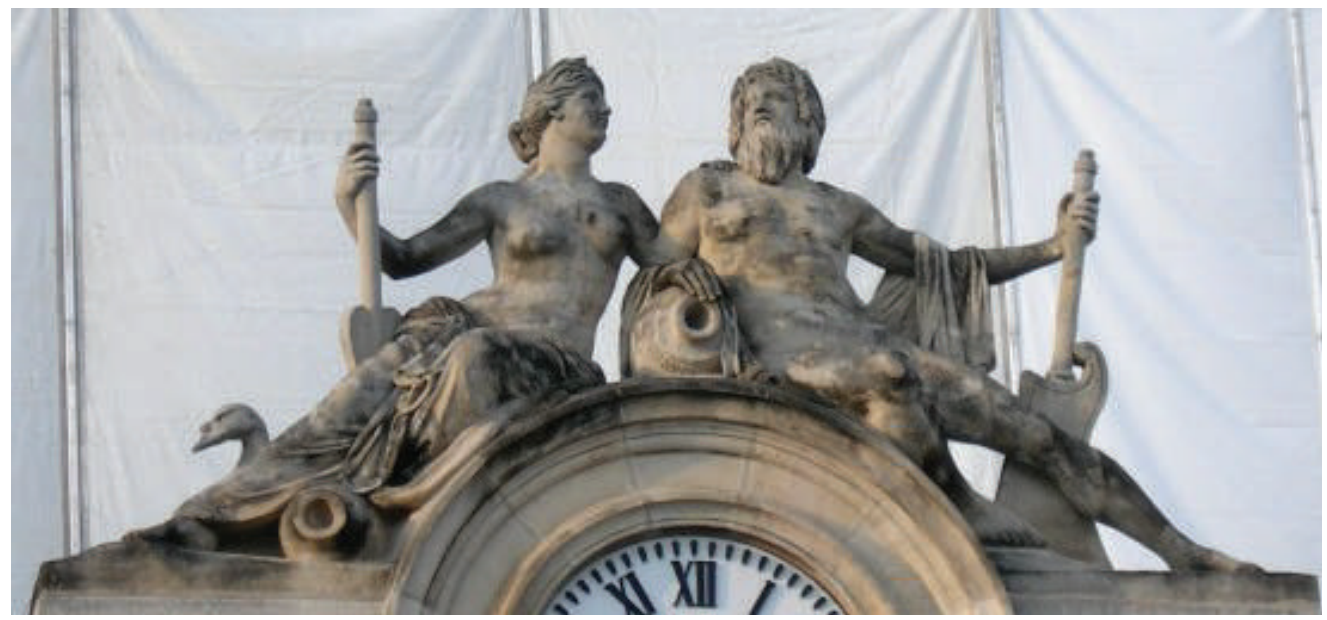

Fig.4.31. Jean Louis Brian. Alegorias aos rios Rhin e Seine. 1852. Gare de l'Est.

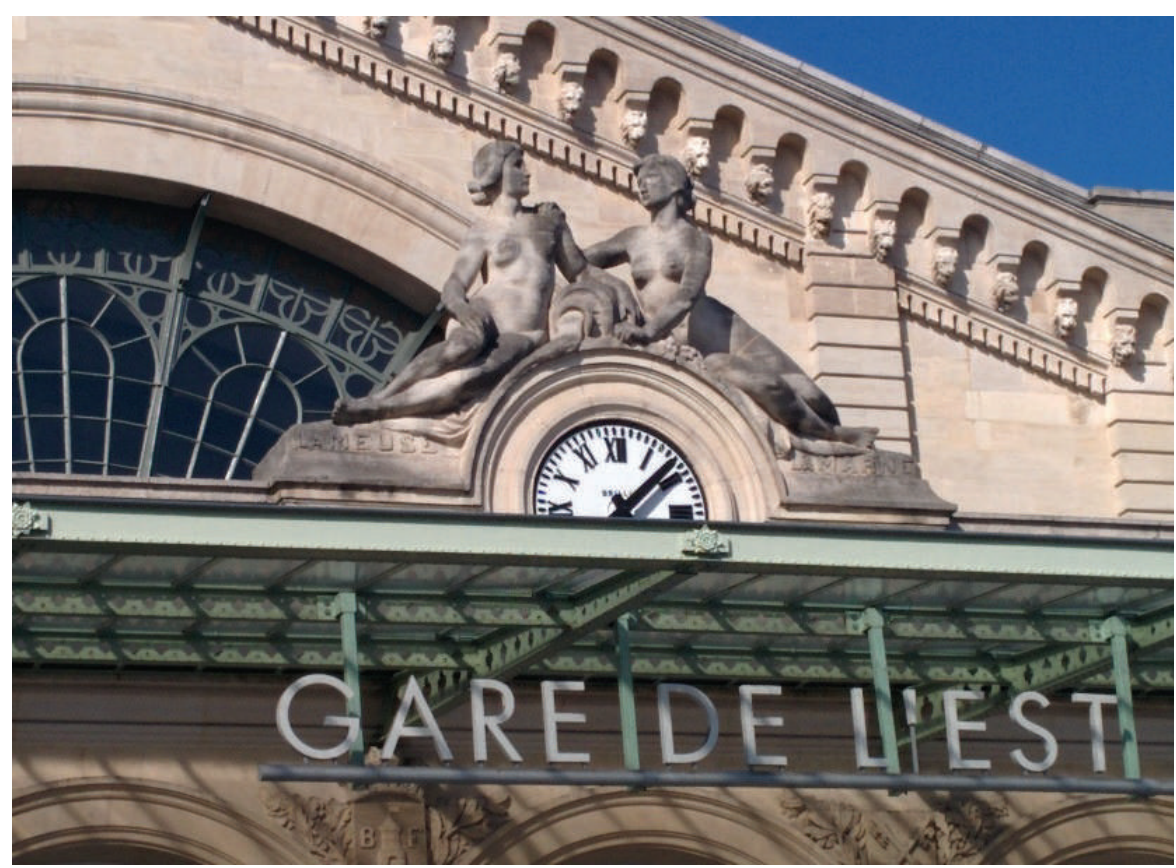

Fig.4.32. Jean Louis Brian. Alegorias aos rios Meuse e Marne. 1852. Gare de l'Est. 


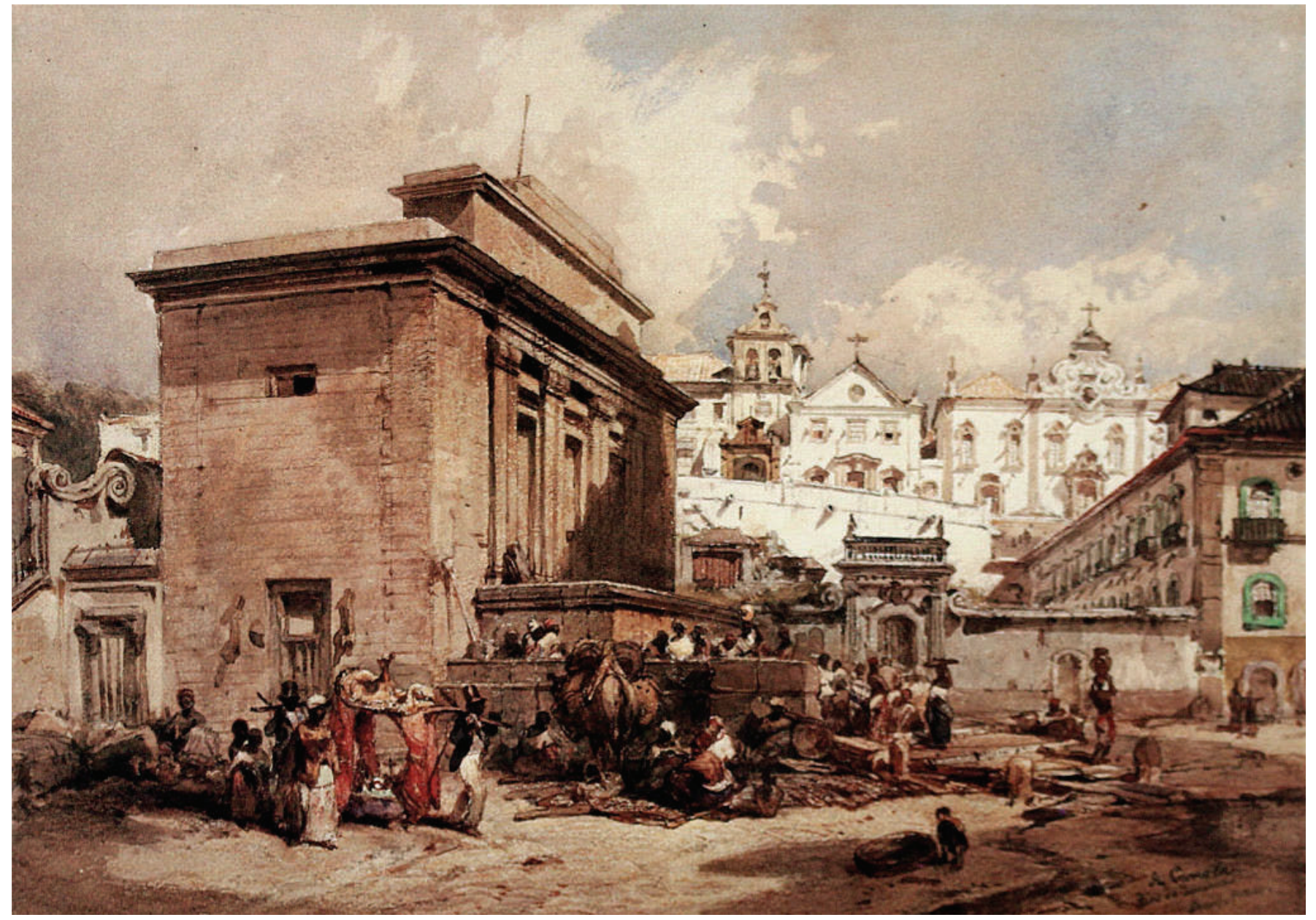

Fig.4.33. Edouard Hildebrandt. Largo da Carioca, com o Chafariz da Carioca. 1844. Aquarela sobre papel. Nationalgalerie, Berlim.

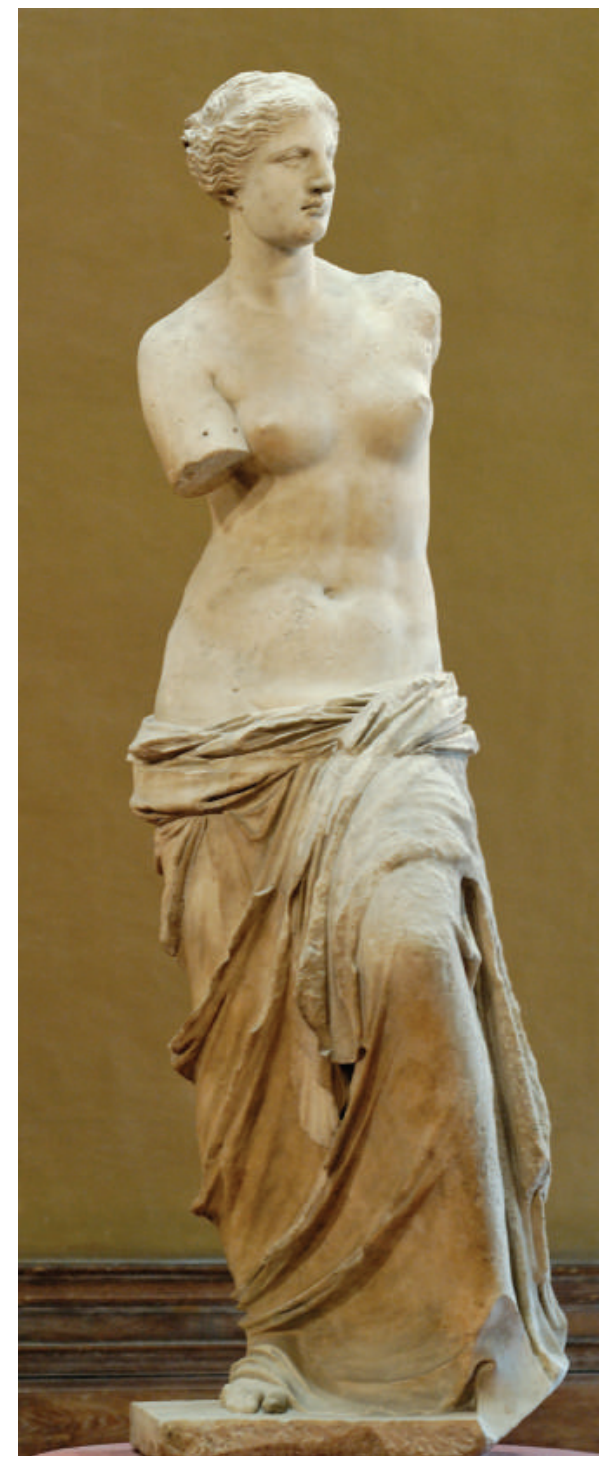

Fig.4.34. Afrodite, dita Vénus de Milo. ca. 100 A.C., mármore, Museu do Louvre.

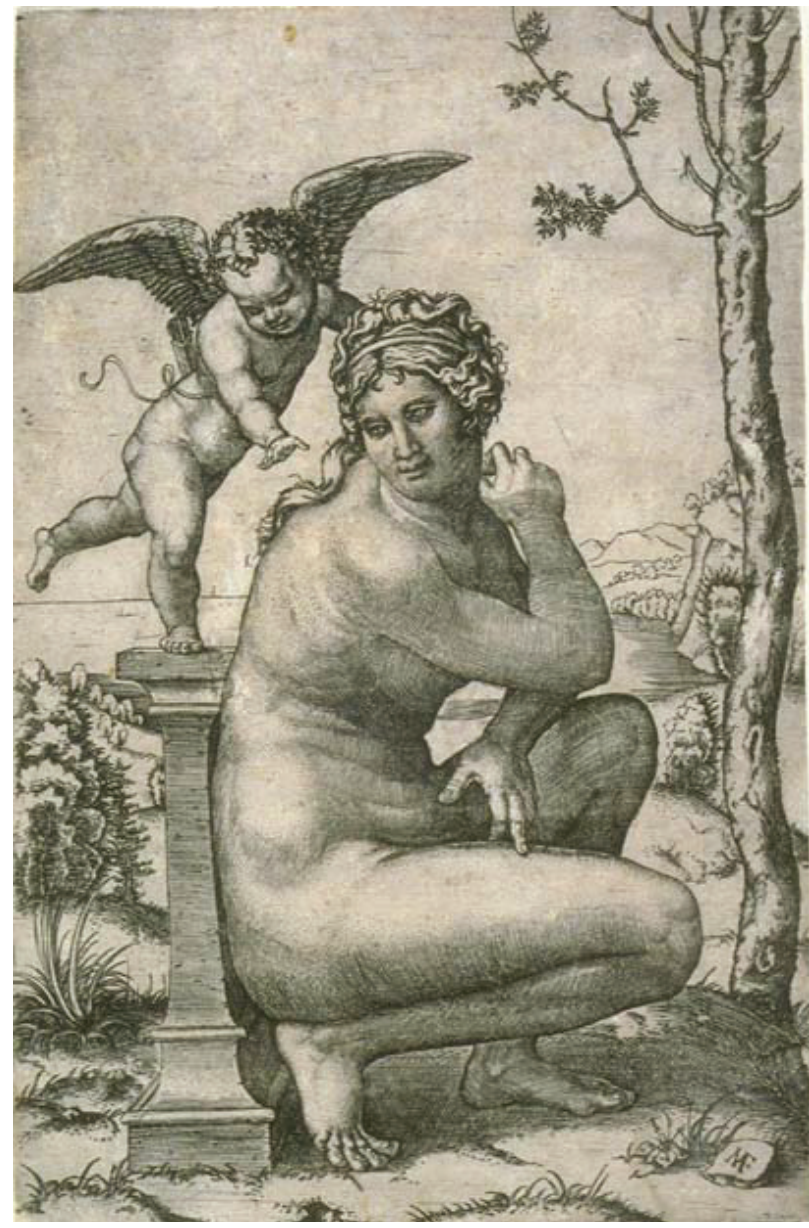

Fig.4.35. Marcantonio Raimondi. Venus agachada, ca.1505-1506, gravura sobre papel. Michigan Museum. 


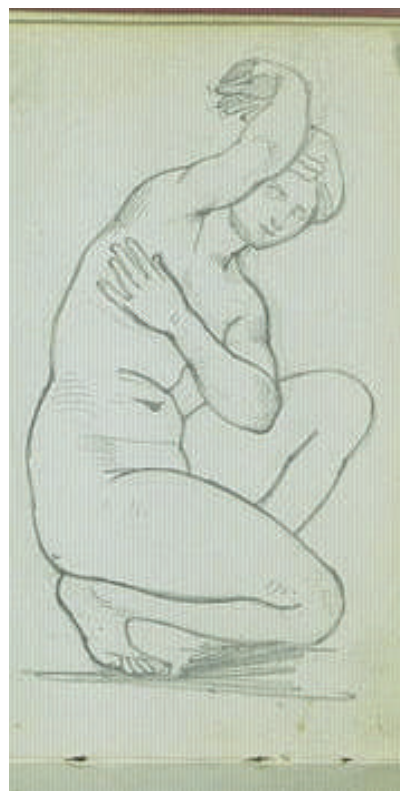

Fig.4.36. Eugène Delacroix. Estudo a partir da Vênus agachada do Louvre, desenho, primeiro quarto do século XIX. Museu do Louvre.

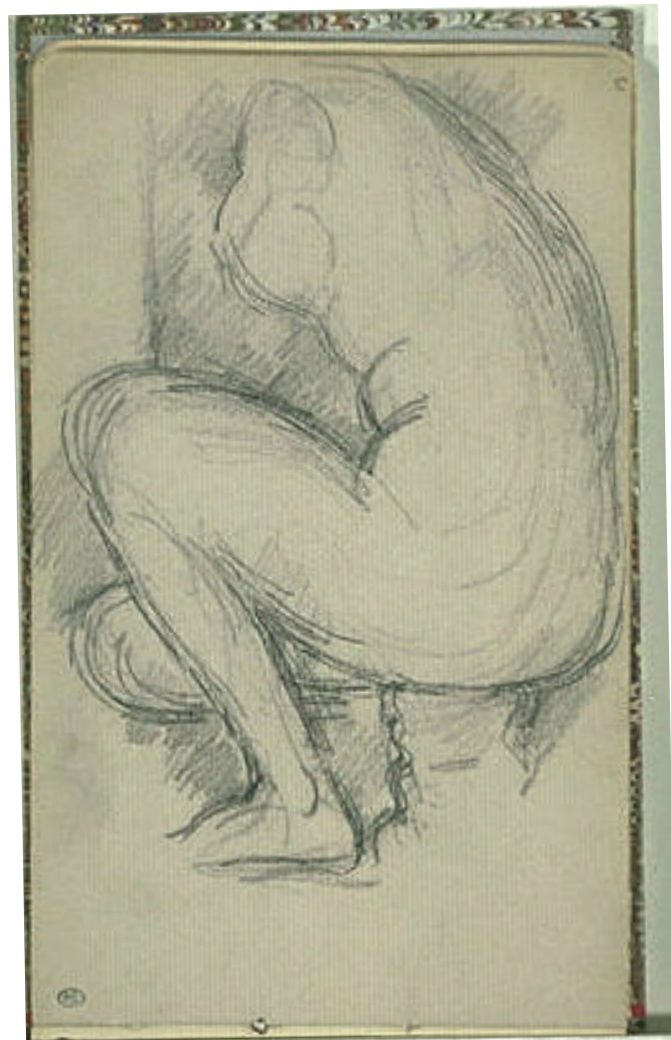

Fig.4.39. Paul Cezanne. Esboços de ninfa Agachada, Desenho, segunda metade do século XIX ao primeiro quadro do XX. Museu do Louvre.

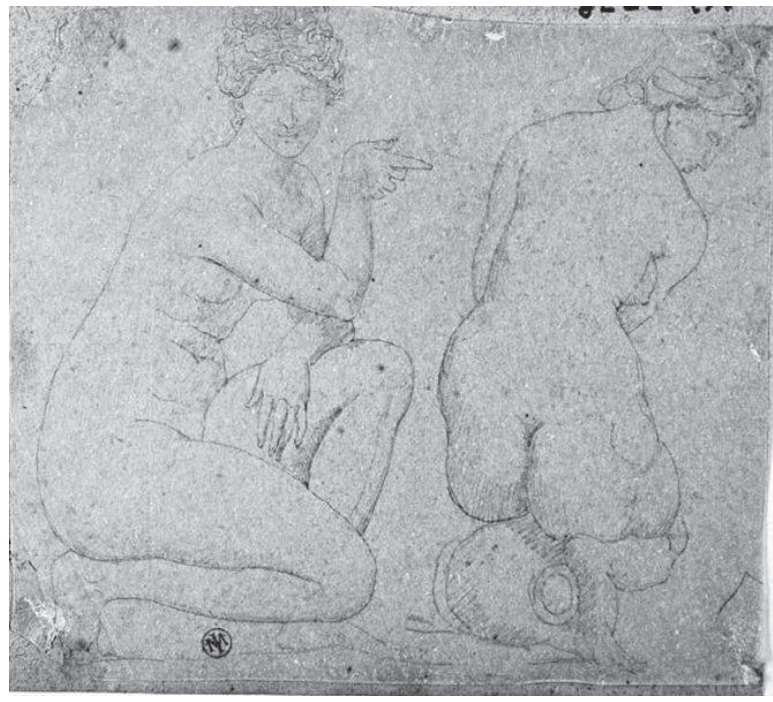

Fig.4.37. Jean Auguste Dominique Ingres.

Vênus agachada, desenho, pimeiro quarto do século XIX. Desenho. Museu Ingres, Montauban.

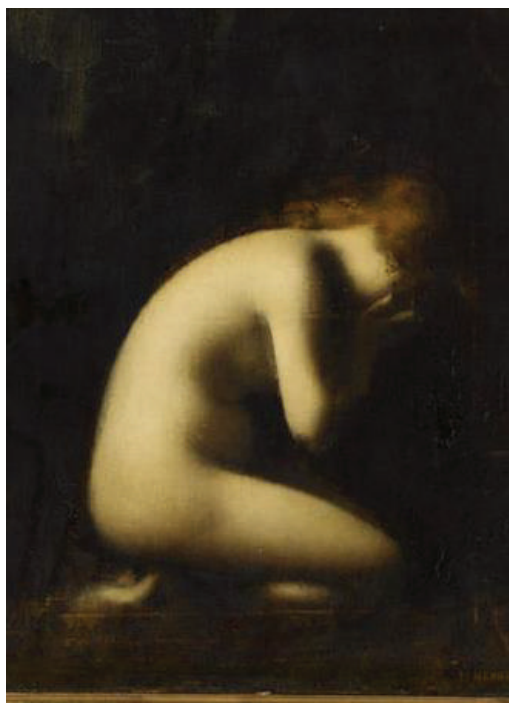

Fig.4.38. Jean-Jacques Henner. Nymphe qui pleure, óleo sobre, tela, 4e quart 19e siècle. Musée national Jean-Jacques Henner, Paris.

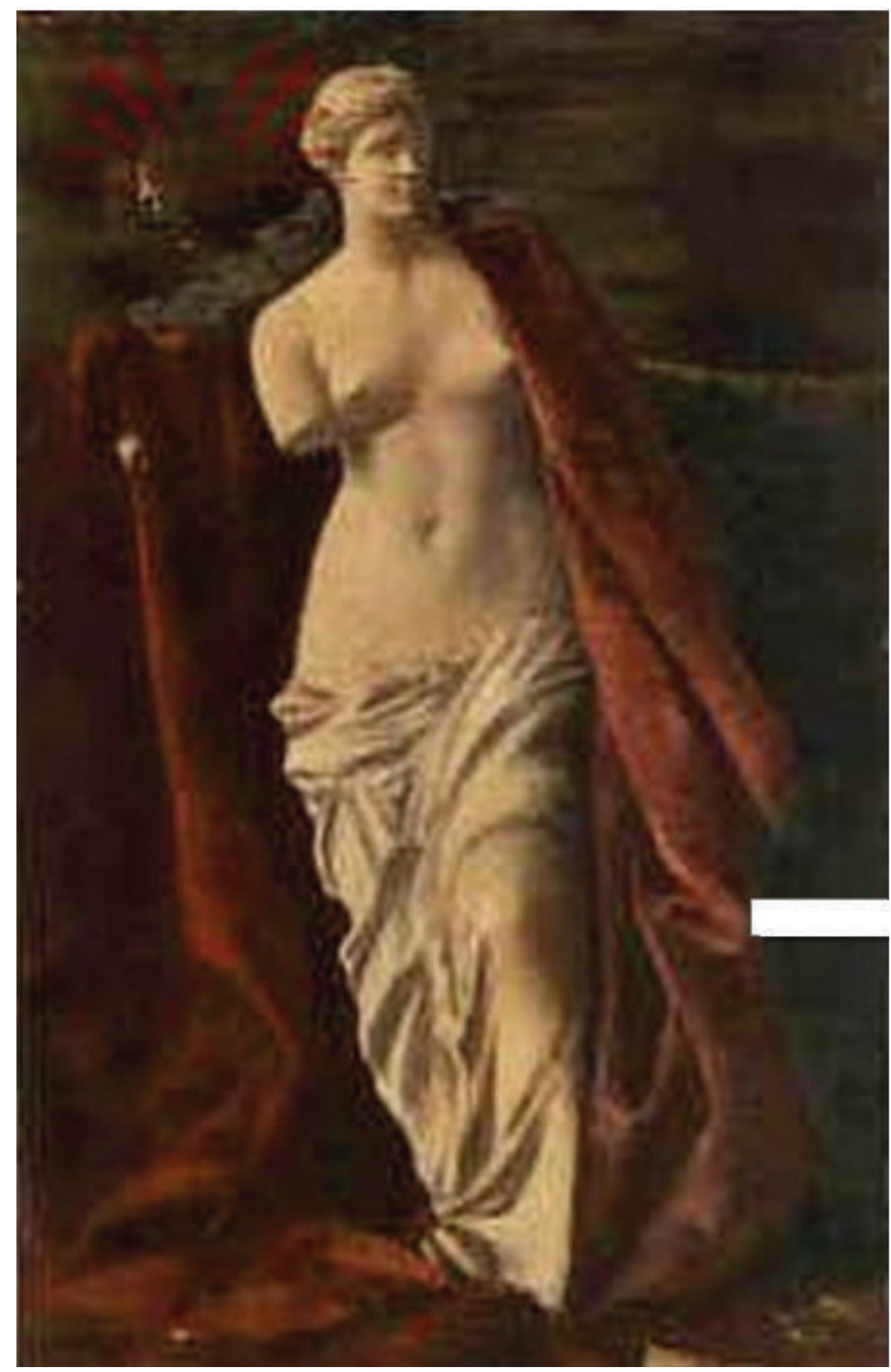

Fig.4.40. Pedro Américo. Cópia da Vênus de Milo. Loc. desconhecida (Leilão Pro arte, 11 de maio de 2009). 


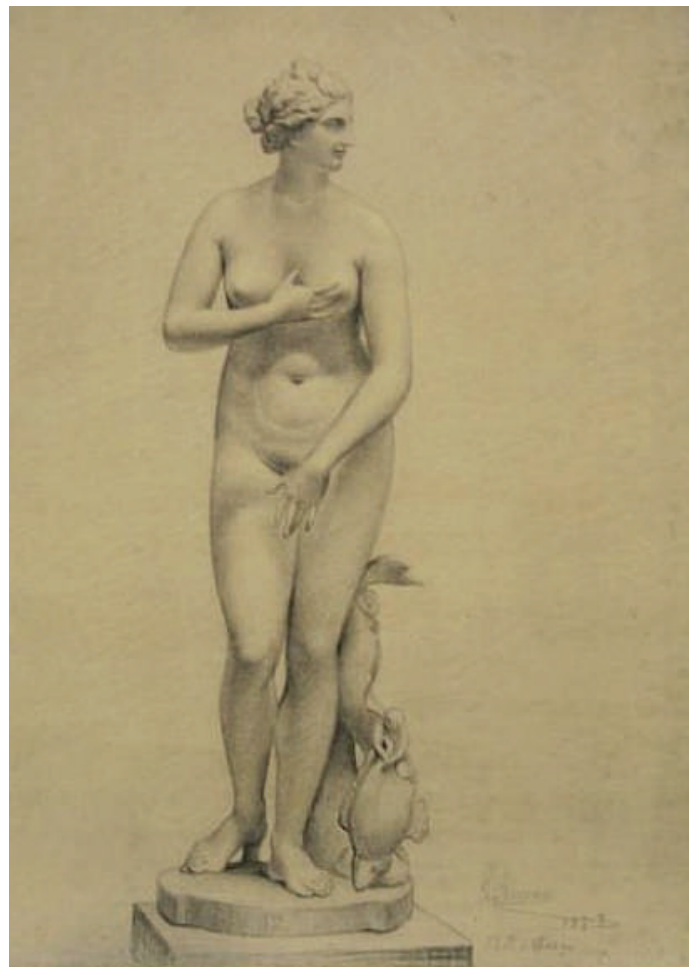

Fig.4.41. Pedro Américo. Vênus de Médicis, 1858 , carvão sobre papel, $63.6 \times 48 \mathrm{~cm}$. MNBA.

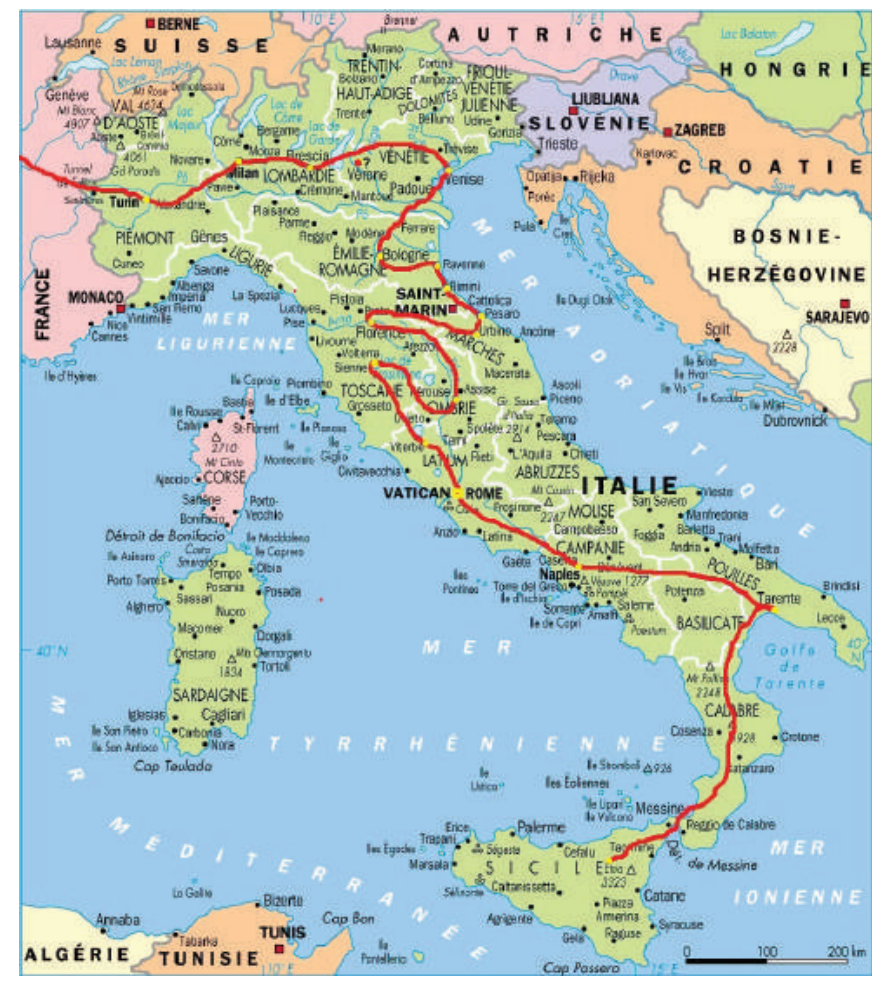

Fig.4.42. Possível percurso de cidades italianas feito por Américo em sua primeira estadia européia.

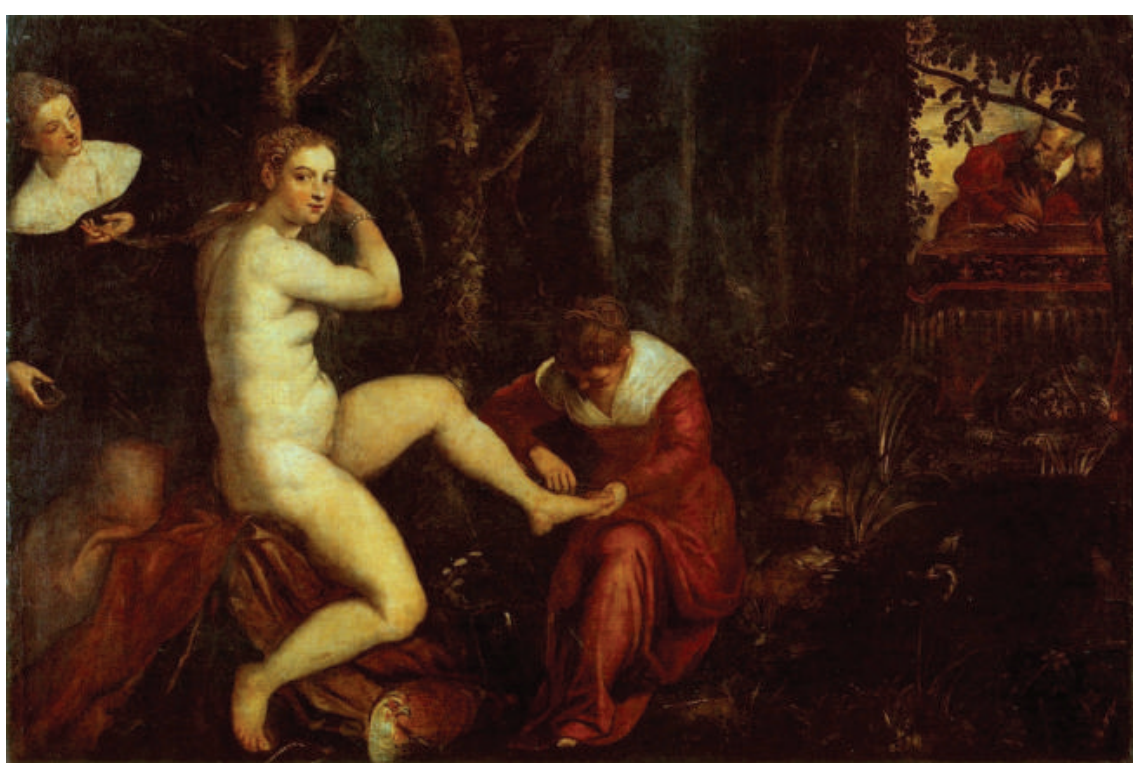

Fig.4.43. Jacopo Robusti, dito Tintoretto. Suzana ao banho, óleo sobre tela, 167 x $238 \mathrm{~cm}$. Museu do Louvre.

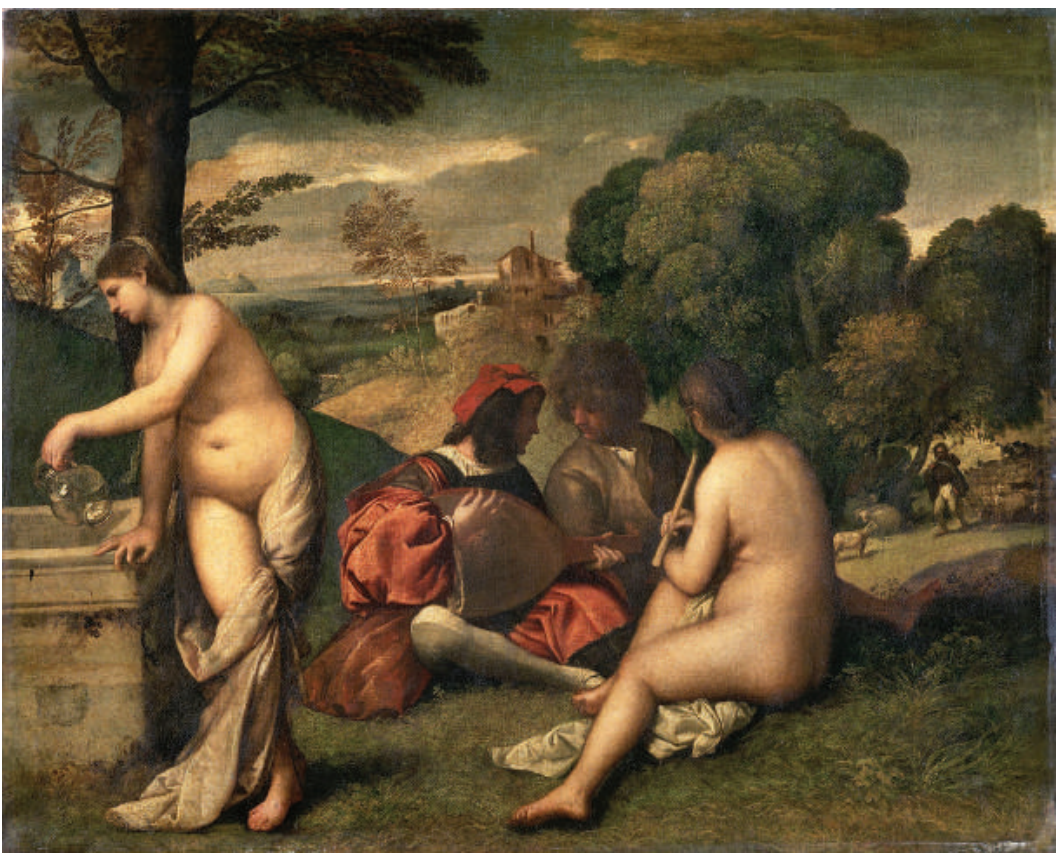

Fig.4.44. Ticiano Vecellio. O concerto campestre. ca. 1509, óleo sobre tela, $110 \mathrm{x}$ $138 \mathrm{~cm}$. Museu do Louvre. 


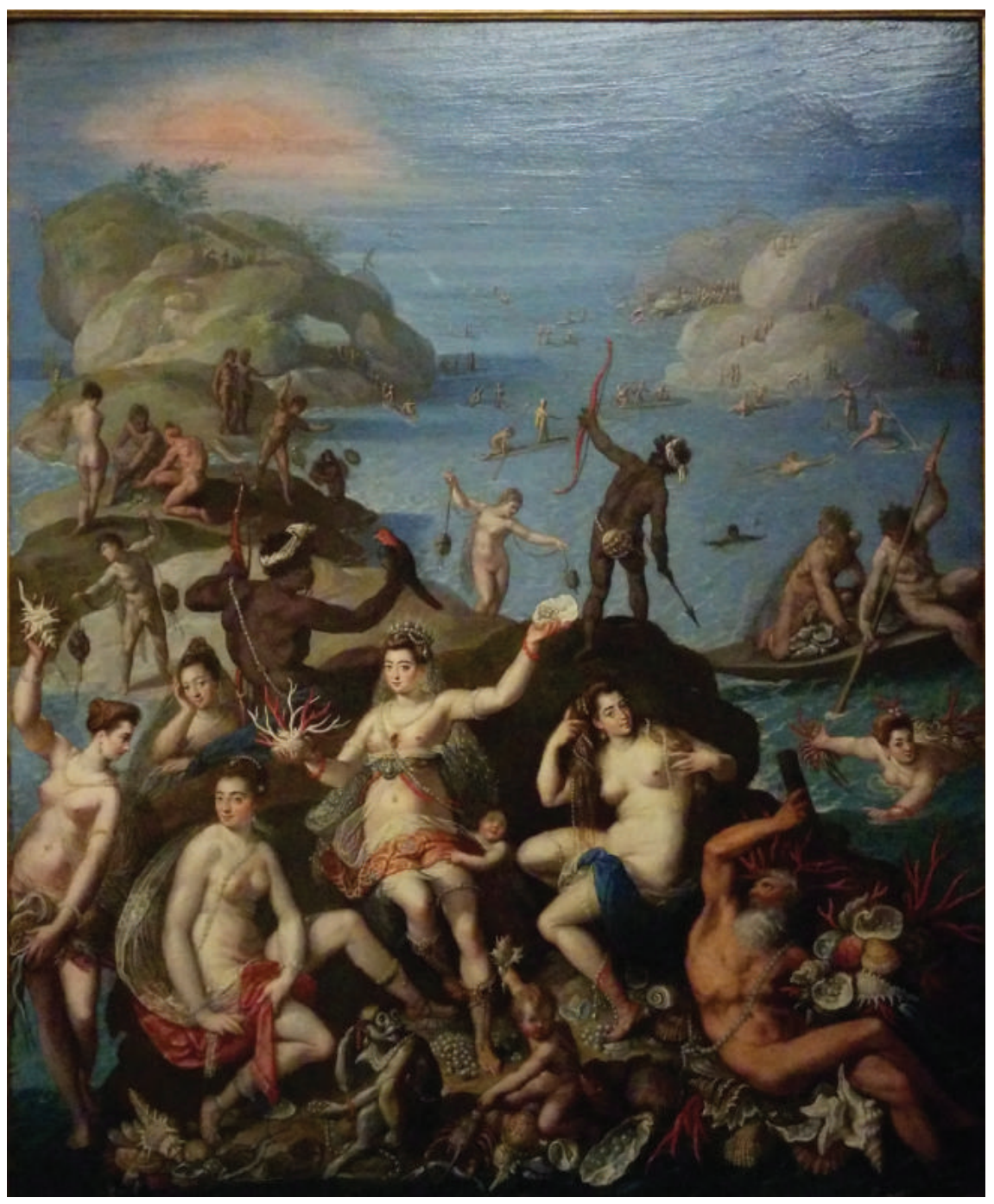

Fig.4.45. Jacopo Zucchi. Allegoria della discoperta dellAmerica, 1585, óleo sobre tela, 55 x $45 \mathrm{~cm}$ Galeria Borghèse.

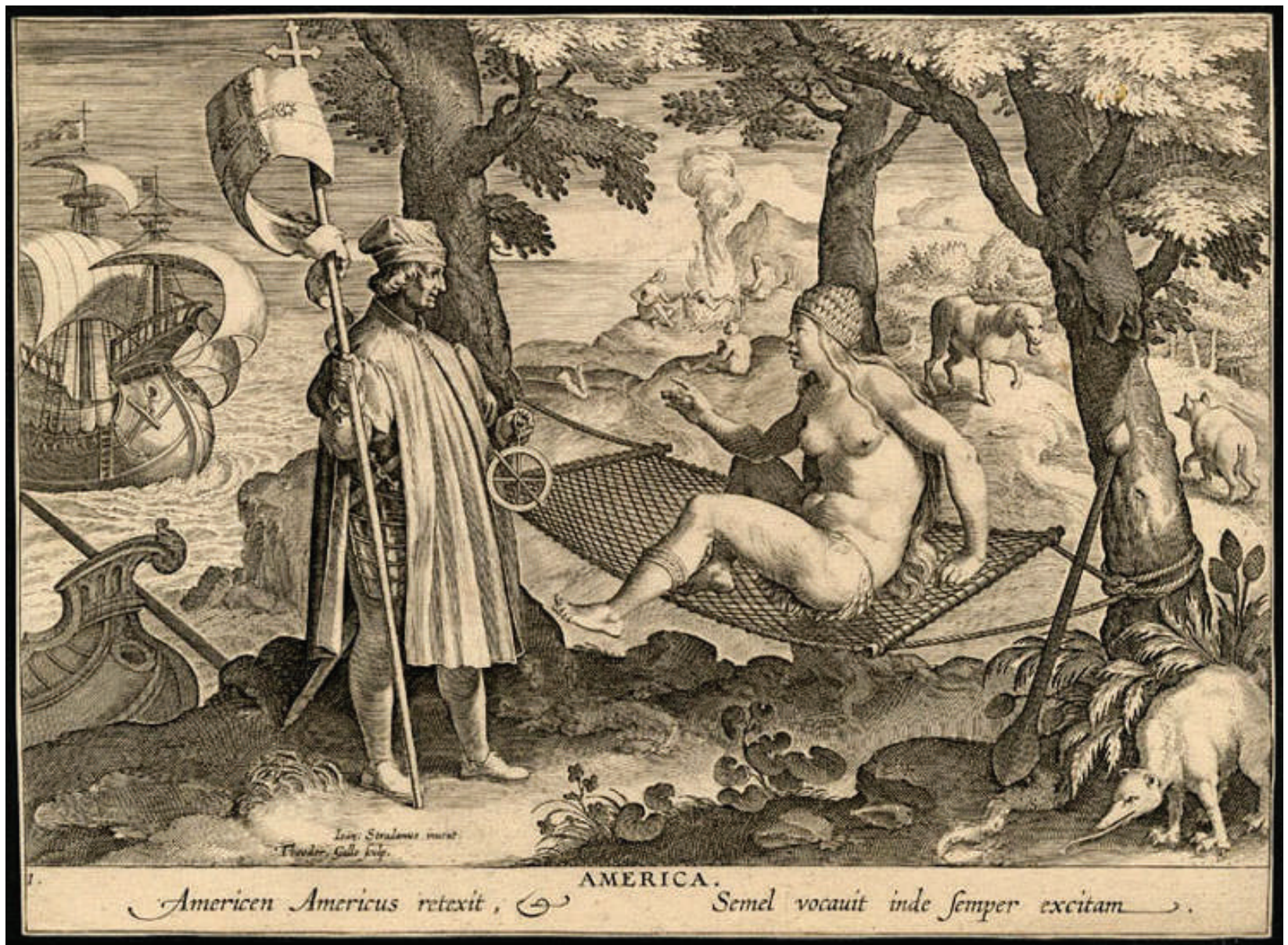

Fig.4.46. Jean-Théodore de Bry (a partir de Stradanus). Américo redescobre a América. Ele a chamou uma vez e desde então ela permanece acordada. 1575-80, gravura sobre papel, $19.8 \times 26.7 \mathrm{~cm}$. In: Americae decima pars (Oppenheim, c.1619) 


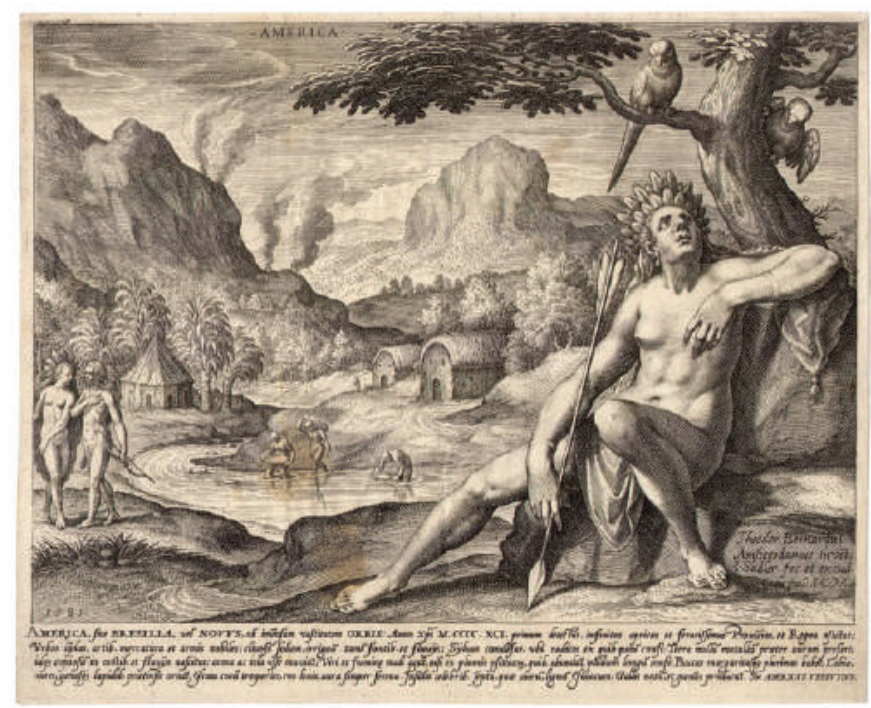

Fig.4.47. Jan Sadeler. America, 1581, gravura sobre papel, 16.1 x 22.1. RijksMuseum, Amsterdam.

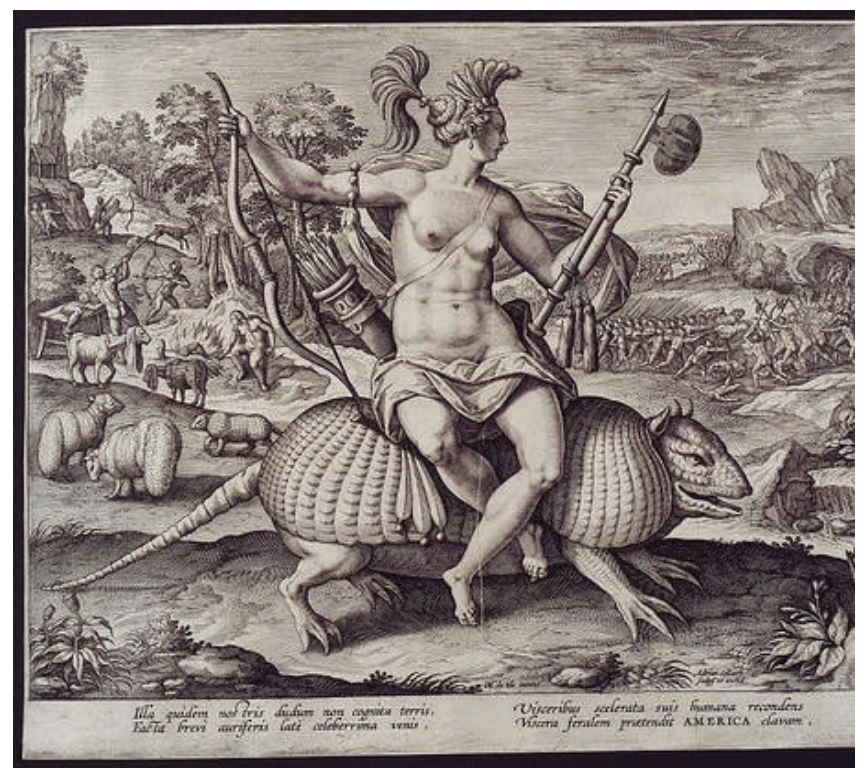

Fig.4.49. Adriaen Collaert (a partir de Marten de Vos). America. 1551-1600.Virtuelle Kupferstichkabinett.

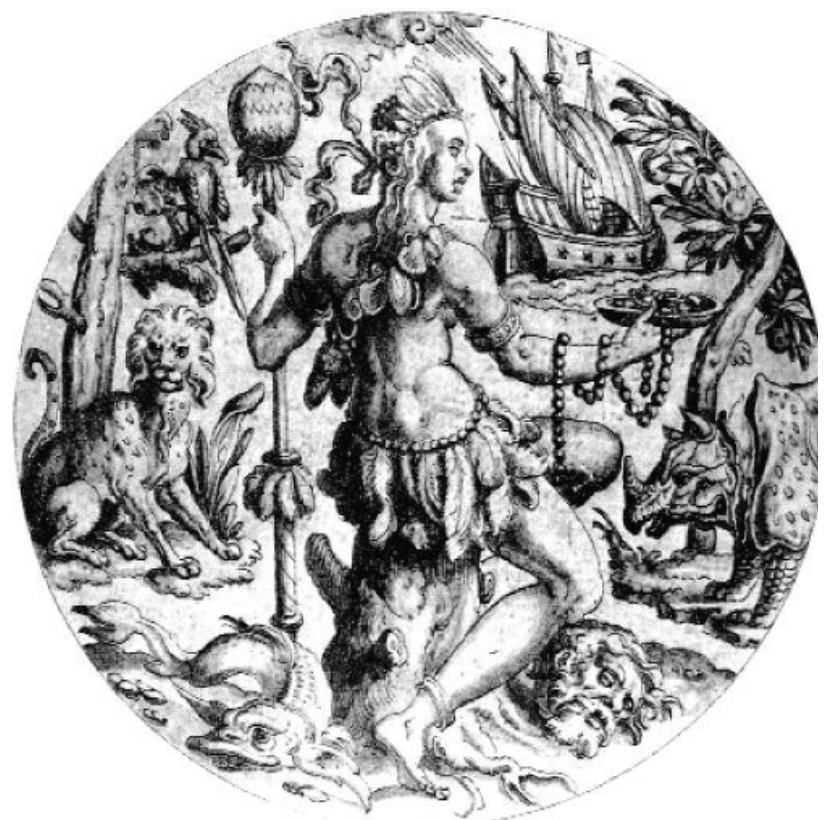

Fig.4.48. Marten de Vos. Alegoria da América. ca. 1600. Flandres.

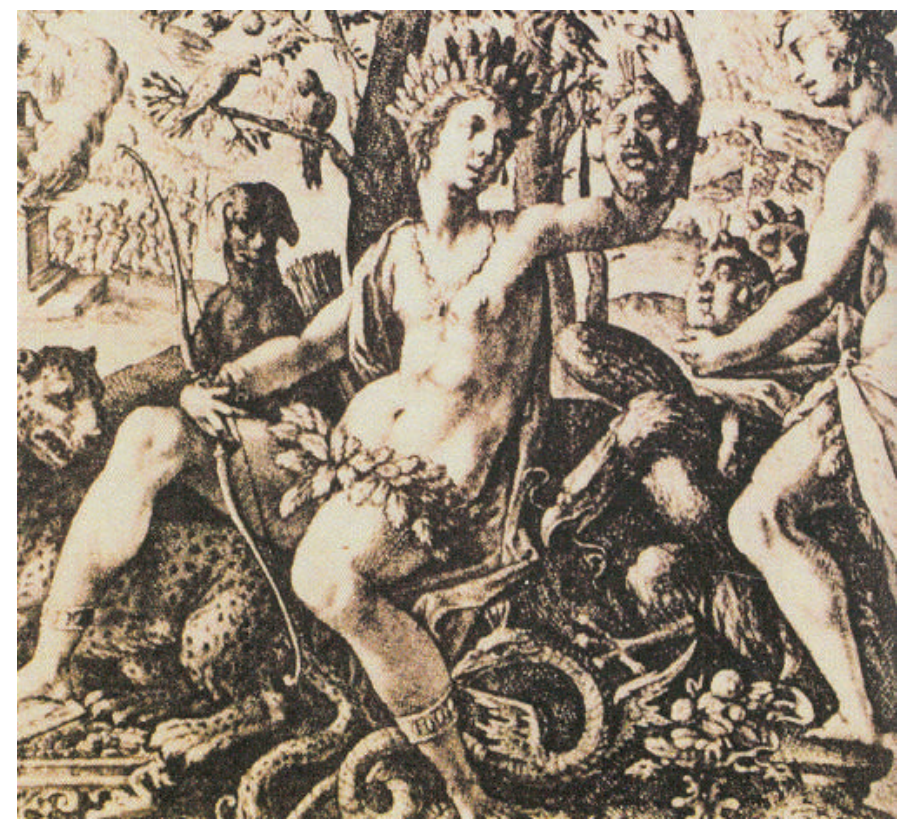

Fig.4.50. Crispin de Passe. Alegoria da América. 1639. Amsterdam.

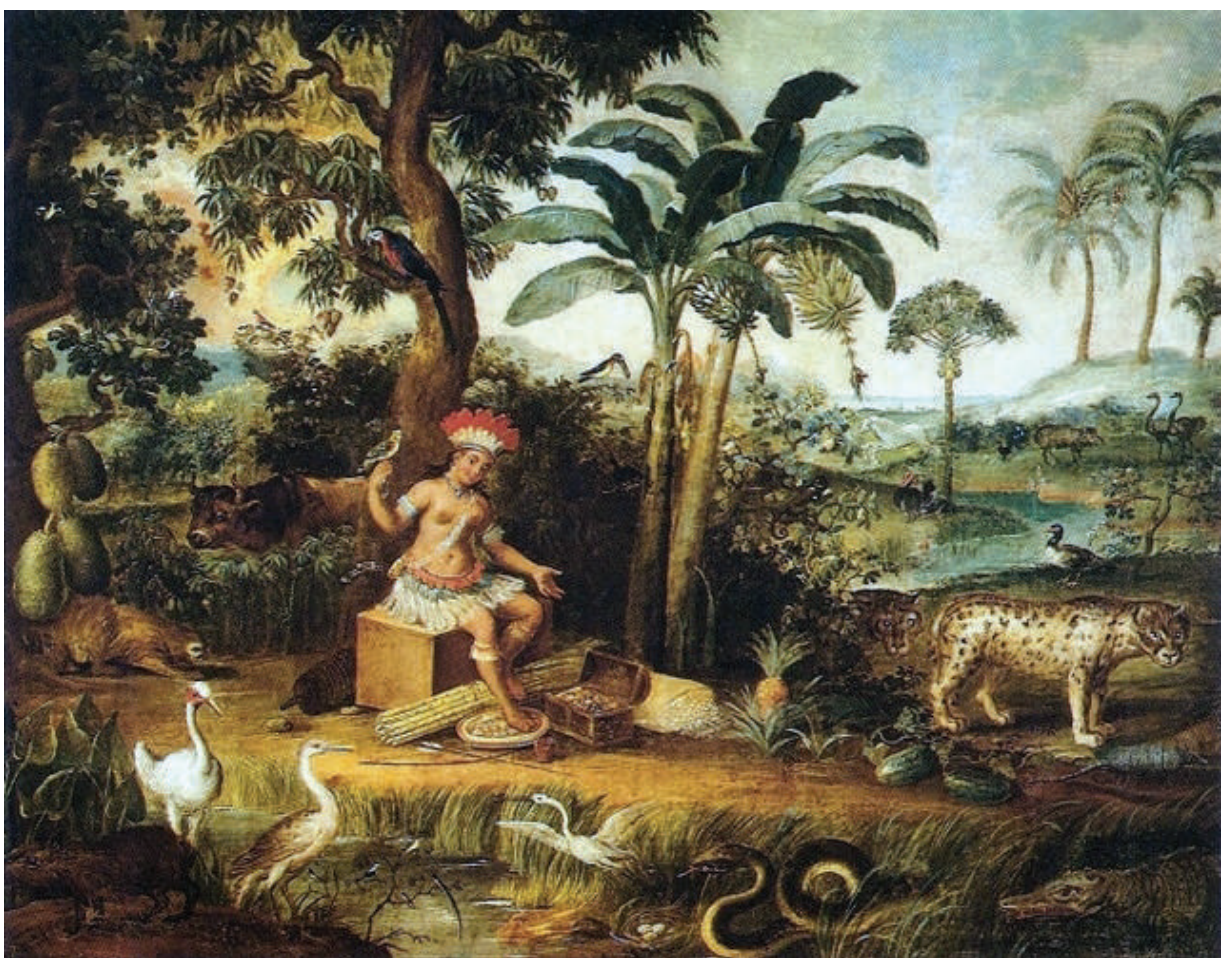

Fig.4.51. José Teófilo de Jesus, 1758-1847, América,s.d, óleo sobre tela, 65 x $82 \mathrm{~cm}$. Museu de Arte da Bahia. 


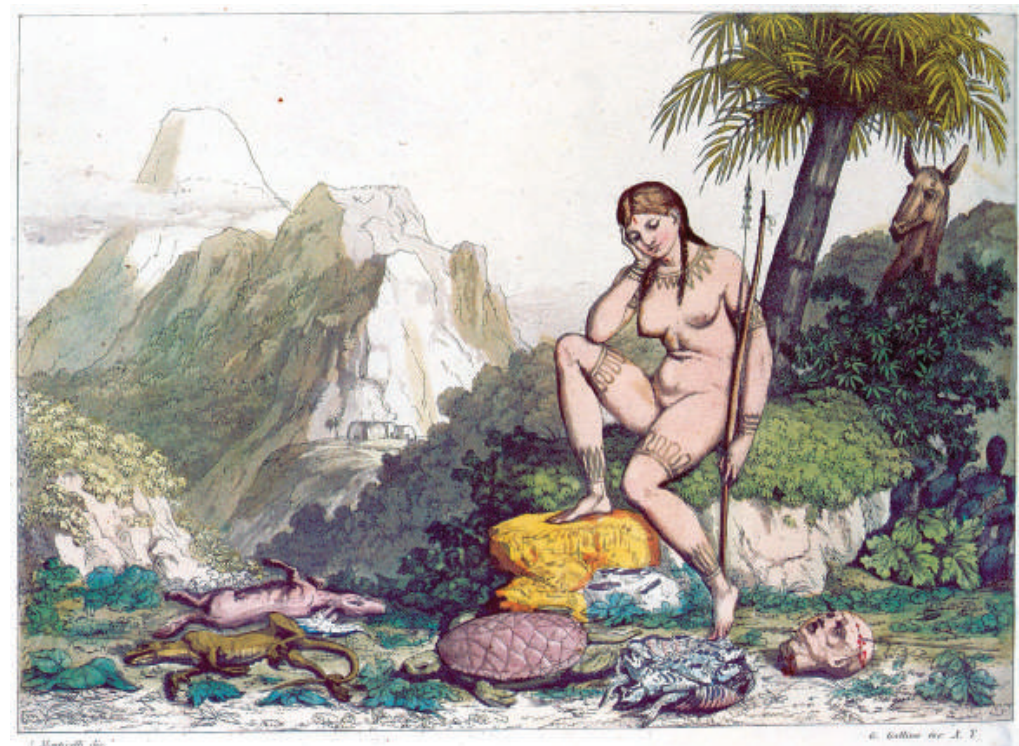

Fig.4.52. Alegoria da América. Impressa em Il costume antico e moderno, Milano, 1820-1821.

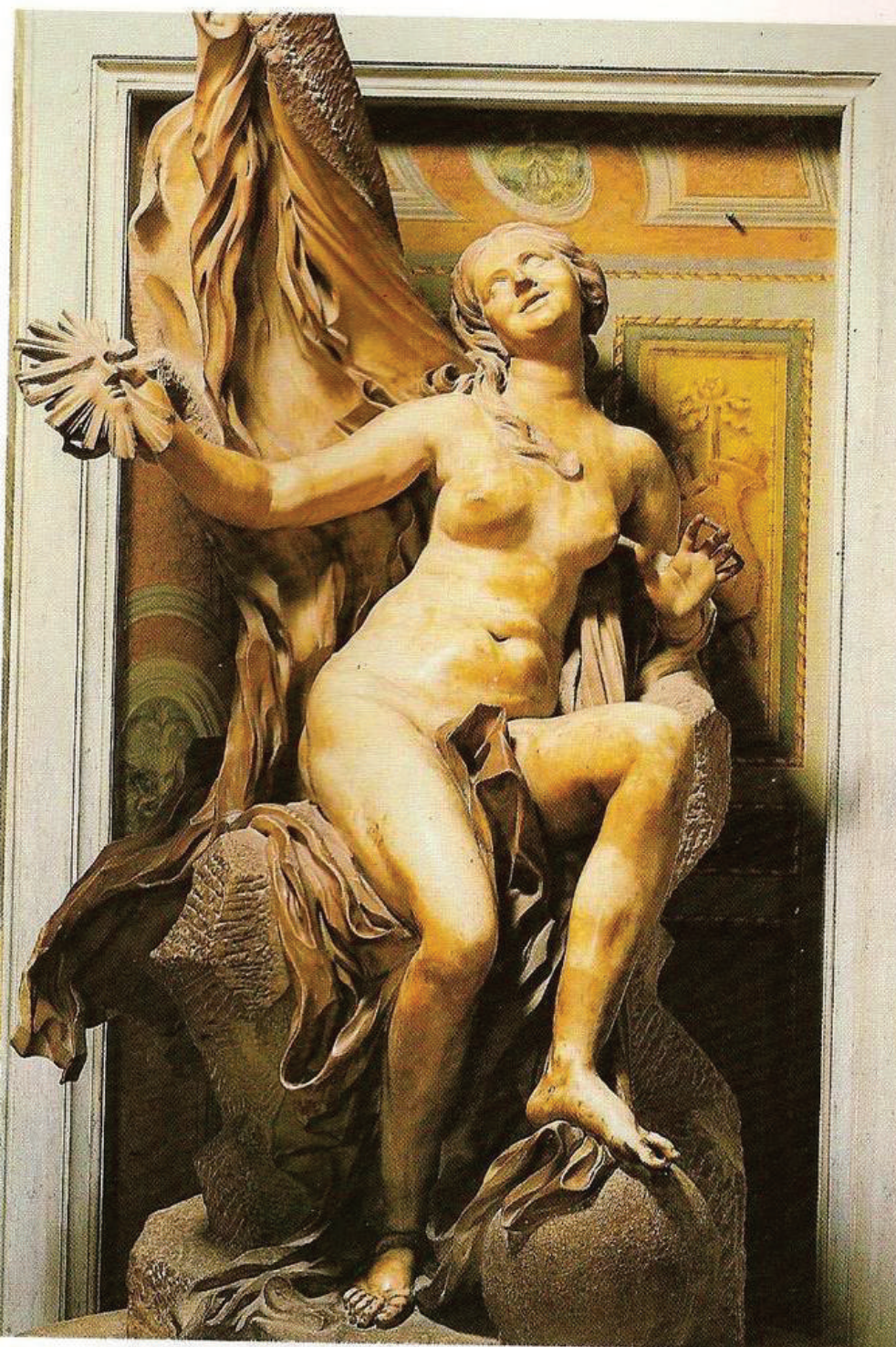

Fig.4.54. Bernini. A verdade Revelada, 1646-52, mármore, Galeria Borghèse.
ICONOLOGICA

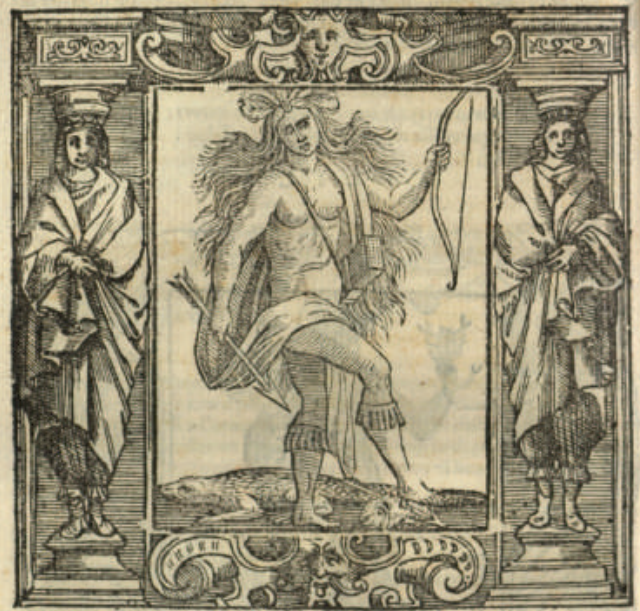

D ONNA ignuda, di carnagione fofca, di giallo color milto, di volto terD ribile, \& che vn velo rigato di pitù colori calandole da vna fpalla a tra.

uerfo al corpo, le copri le parti vergognofe.
Le chiome faranno fparfe, \& à torno al corpo fia vi vago, de artificiolo ornamento di penne di varij colori.

Tenga con la finiftra mano vn'arco, con la defl ra mano vna frezza, \& al fianco la faretra parimente piena difiezze, fotto vn piede vna teftuduamana paftata da yna ficzzza, \& per terra da vna parte fara vna lucertola, oueto vn li-

Per efler nouellamente foperta que fa parte del Mondo gli Antichi Scritcori non poffono hameine frritto cola alcuna, però mi è ftato mettieri veder lamo Gigli, Ferante Gonotici moderni ne hanno referto, cioe il Padre Gitoto prefiro miac fata ha to profitro mi ctata la viua voce del Signur Faufto Rughefe da Mentepu-

Fig.4.53. Alegoria da América. Impressa em Cesare Ripa. Iconologia. ed. 1683. p.68.

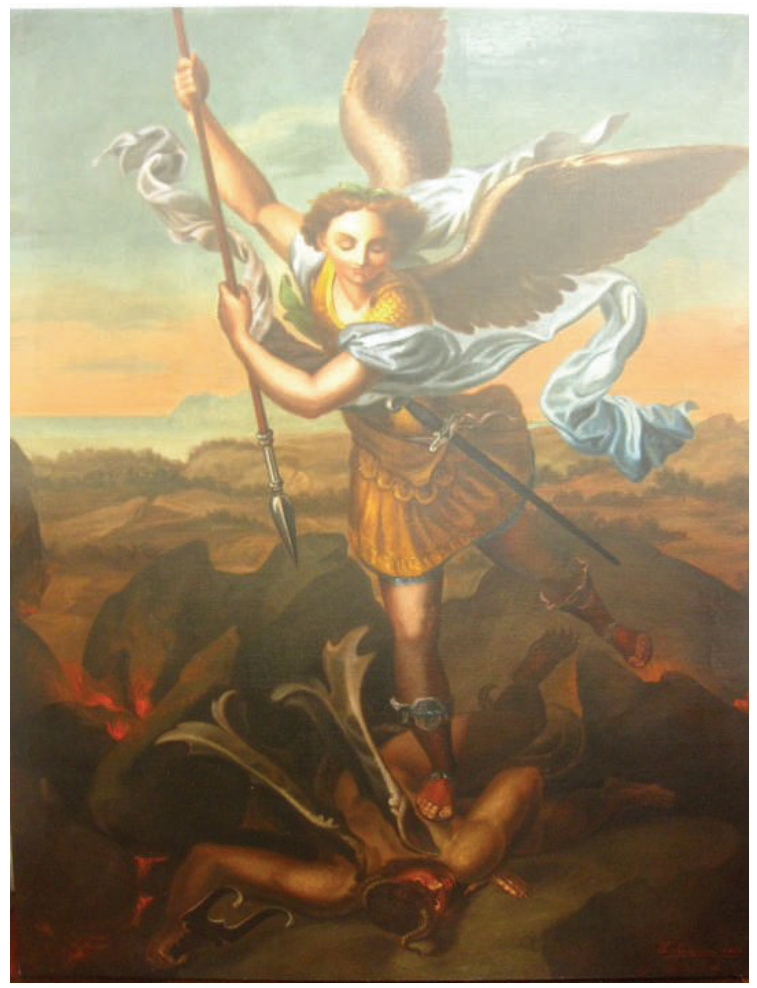

Fig.4.55. Pedro Américo. São Miguel Arcanjo e o Demônio (cópia de Rafael Sanzio), 1857 , óleo sobre tela, $136,5 \times 108,8 \mathrm{~cm}$ Mosteiro de São Bento - RJ. 


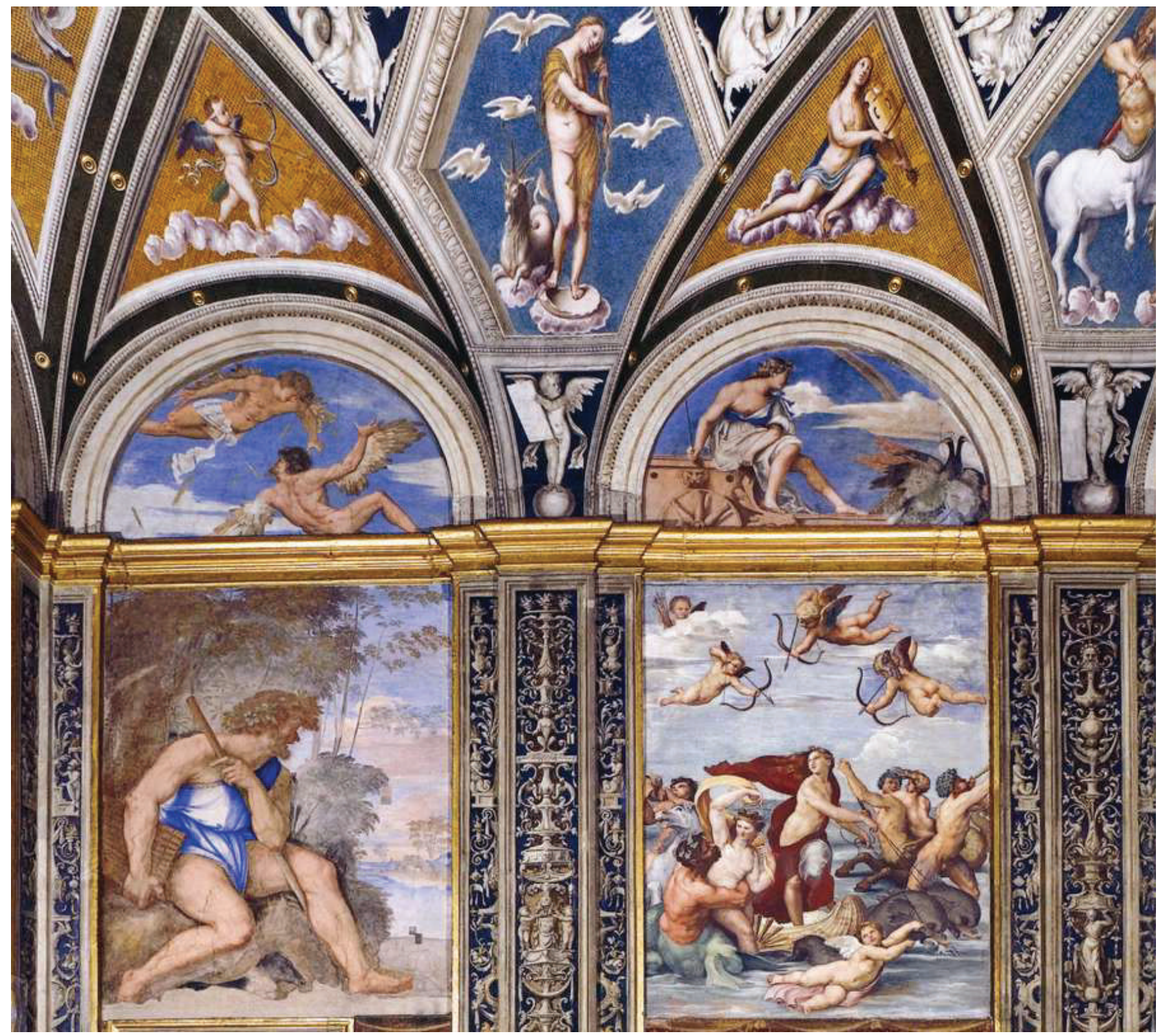

Fig.4.56. Rafael Sanzio. Visão fronta da Loggia di Galatea. 1517. Afresco. Villa Farnesina, Roma.

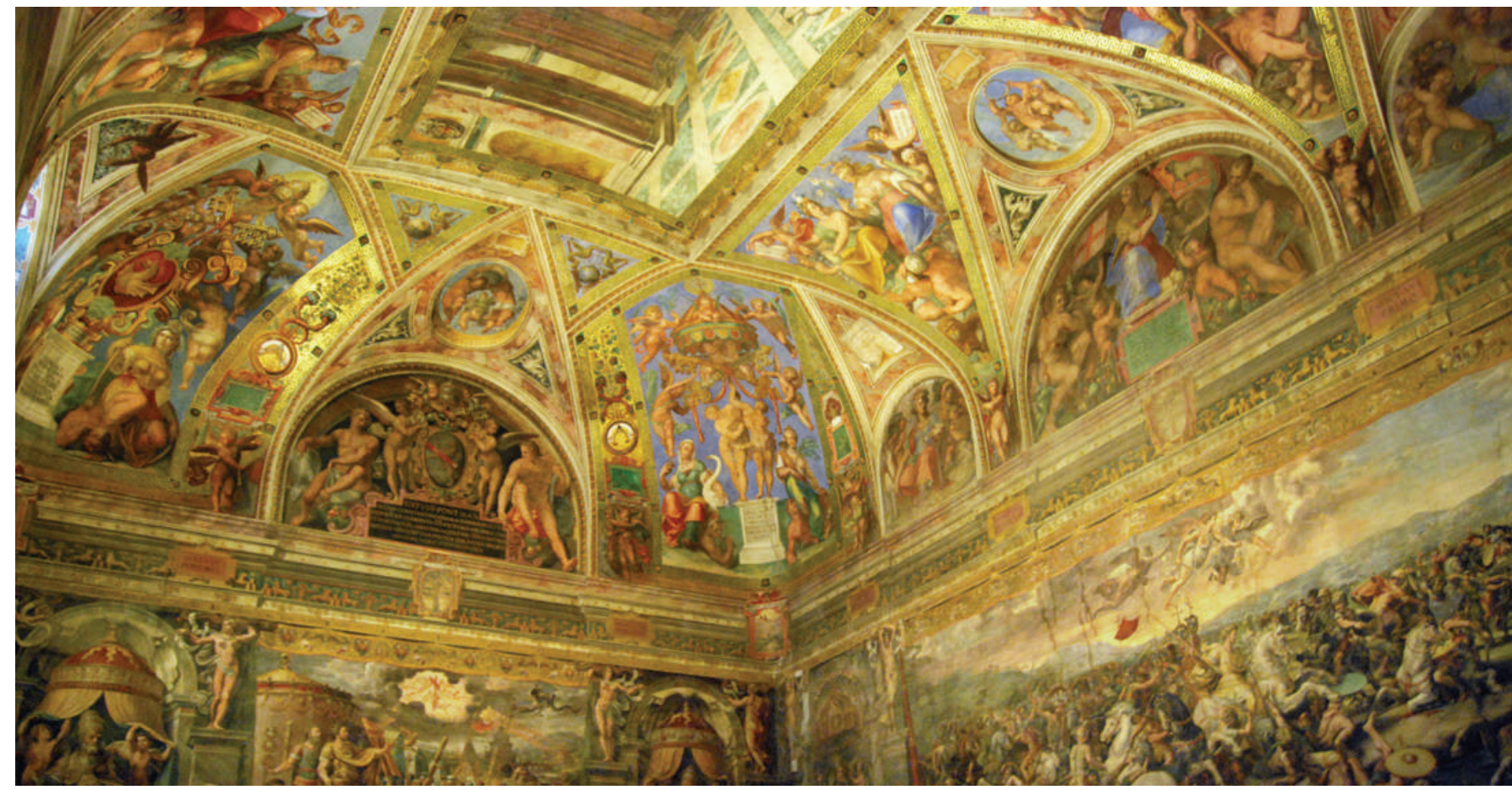

Fig.4.57. Rafael (desenho); Giulio Romano, Gianfrancesco Penni e Raffaellino del Colle (pintura). Sala de Constantino, 1517-25. Afresco. Vaticano. 


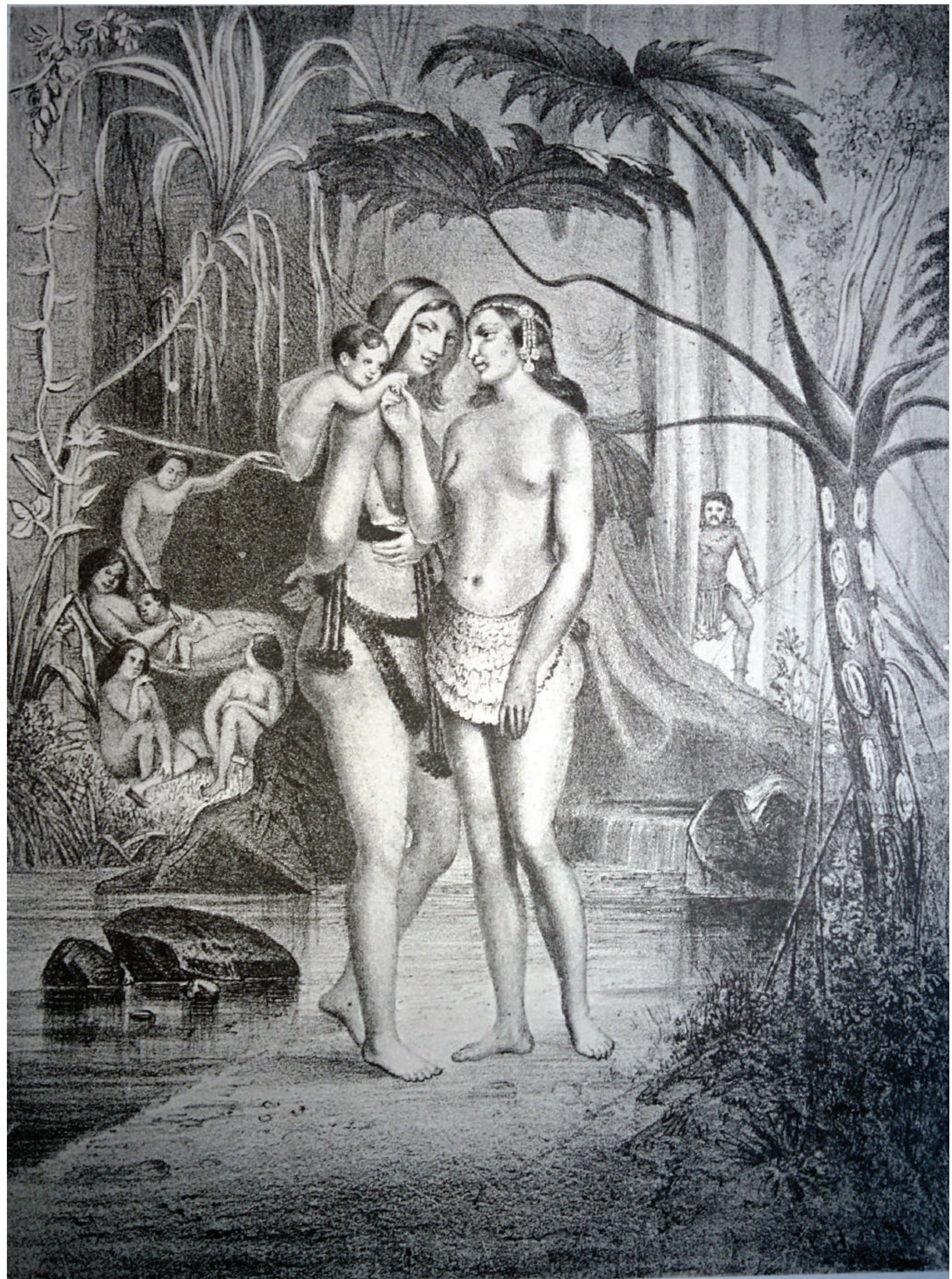

Fig.4.58. Claude-Joseph Barandier. Indígenas. Sem data, óleo sobre tela, Localização desconhecida. Litografado e impresso em: IMPERIAL INSTITUTO ARTÍSTICO. Recordações da Exposição Nacional de 1861. Rio de Janeiro: Imperial Instituto Artístico, 1862. 
Caderno de imagens Quinto Capítulo 



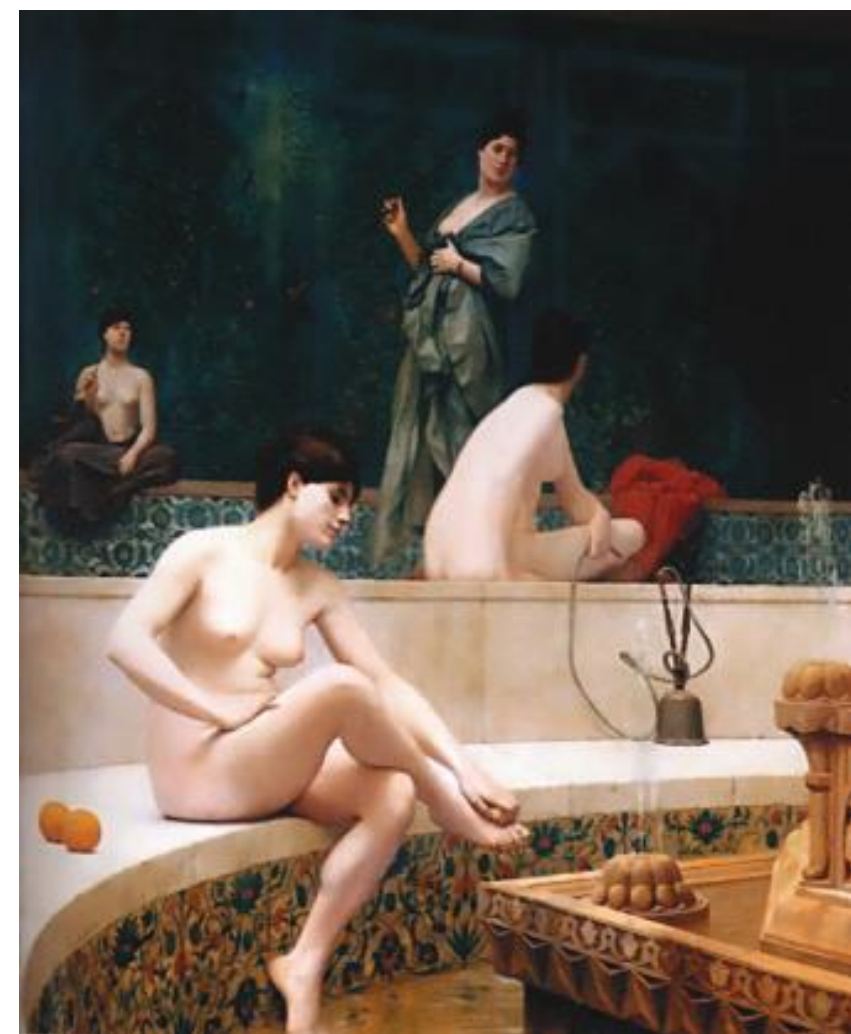

Fig.5.1. Jean-Léon Gérôme. As banhista do harém, 1901, óleo sobre tela, $99,7 \times 80,6 \mathrm{~cm}$. Collection privée.

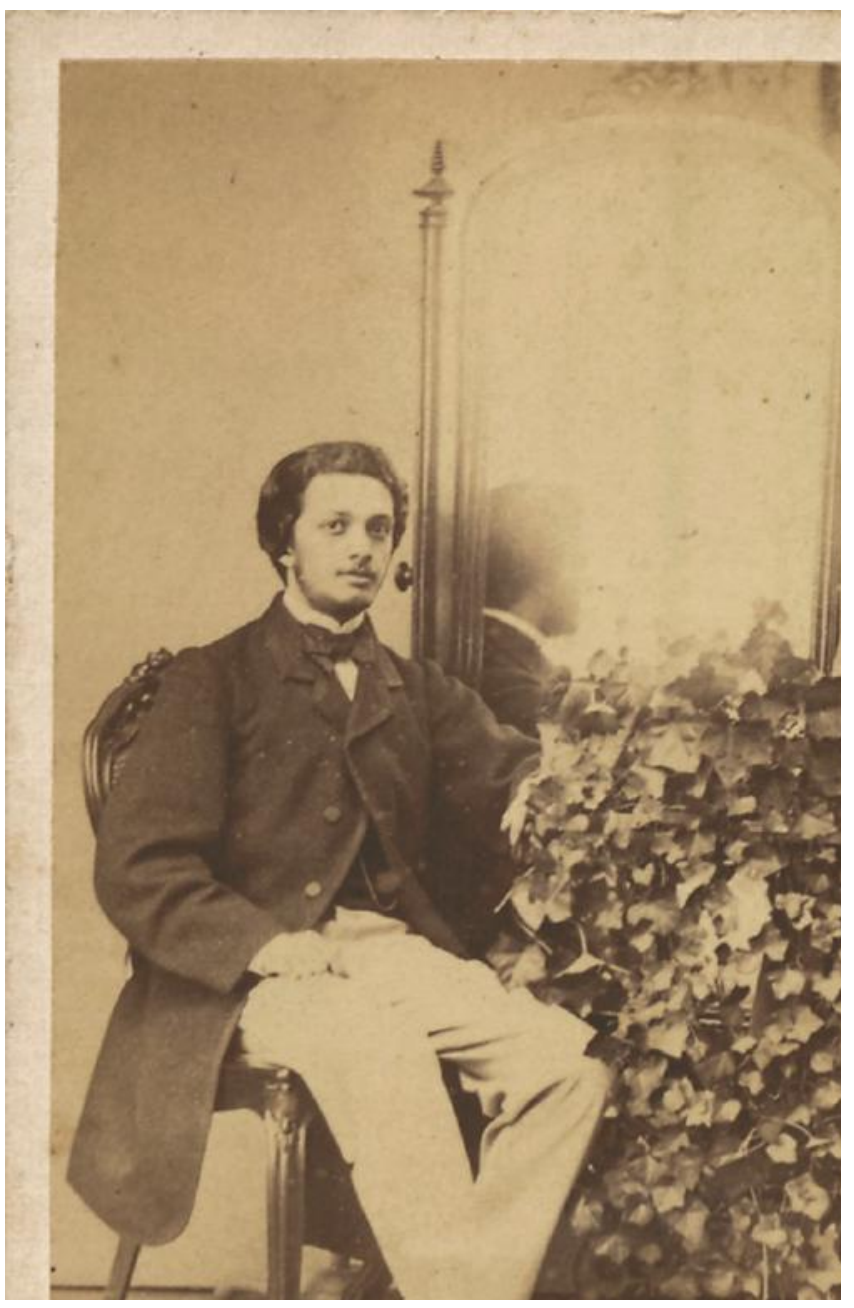

Fig.5.3. Egas Muniz Barreto de Aragão e Menezes (Barão Muniz de Aragão), 1871-1880, fotografia, $10 \times 6 \mathrm{~cm}$. Arquivo Nacional.

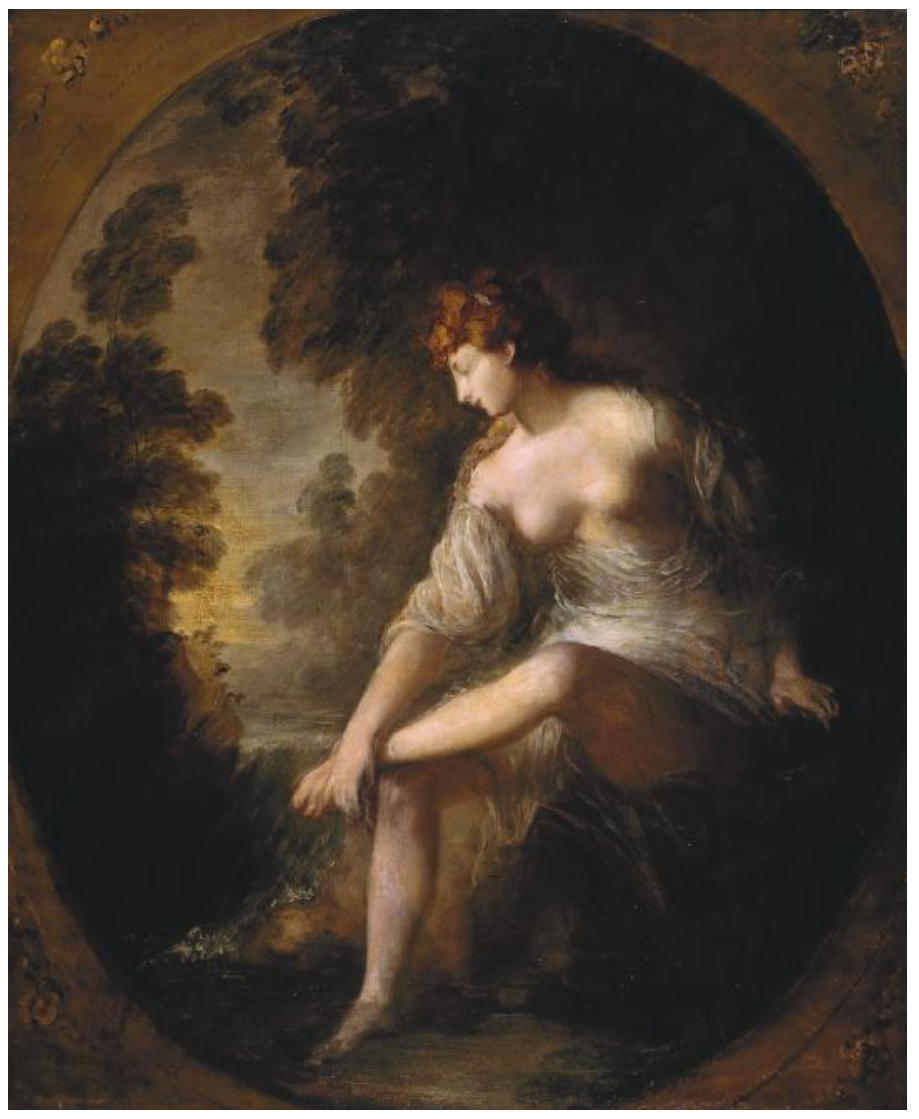

Fig.5.2. Thomas Gainsborough. Musidora. c.1780-8, óleo sobre tela, $188 \mathrm{~cm}$ x $153 \mathrm{~cm}$. Tate Gallery.

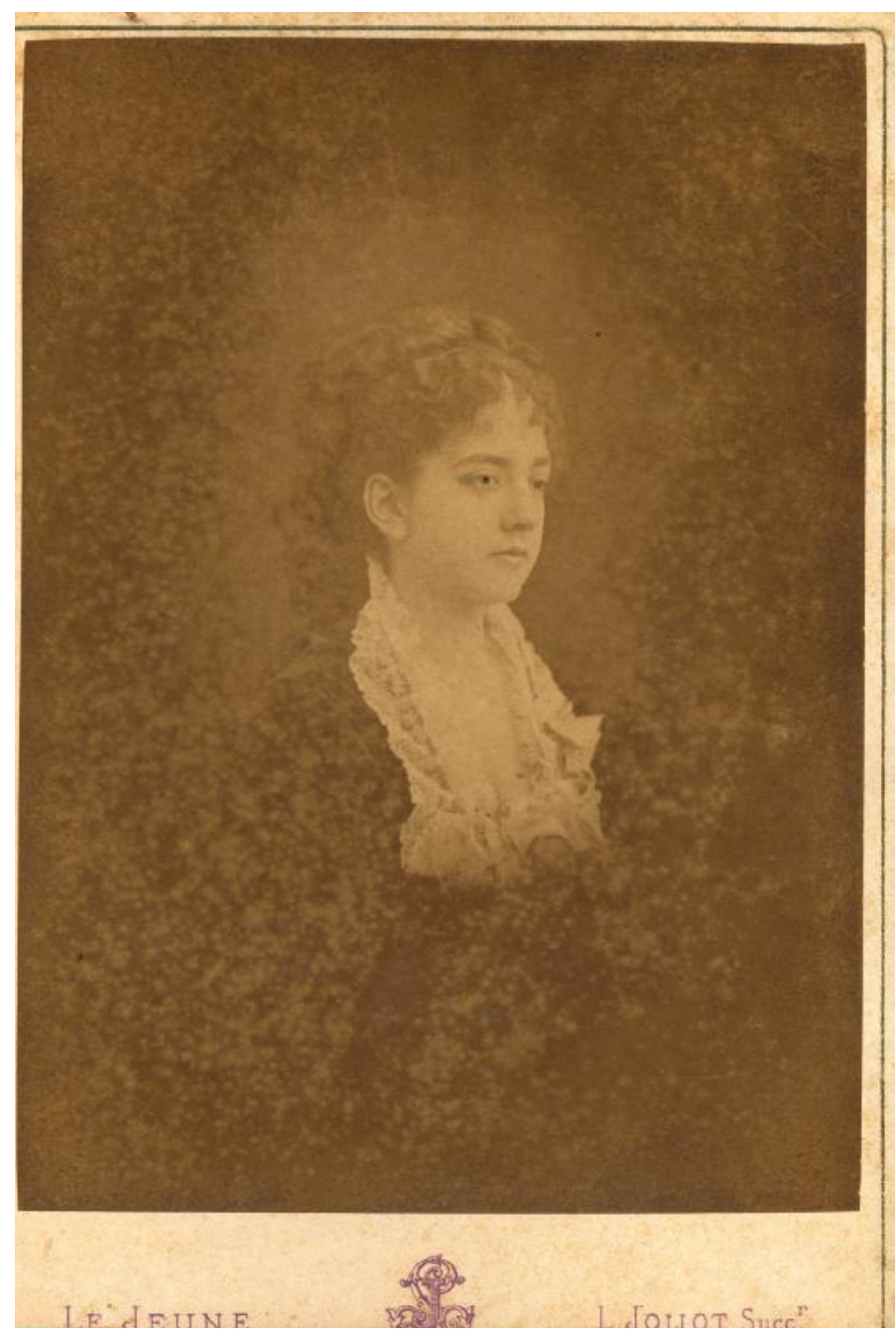

Fig.5.4. Senhora Egas Muniz Barreto de Aragão, nascida Nogueira da Gama. (Baronesa Muniz de Aragão), fotografia, cartão cabinet. Paris. 13,5 x $10 \mathrm{~cm}$. Arquivo Wanderley Pinho, IHGB. 

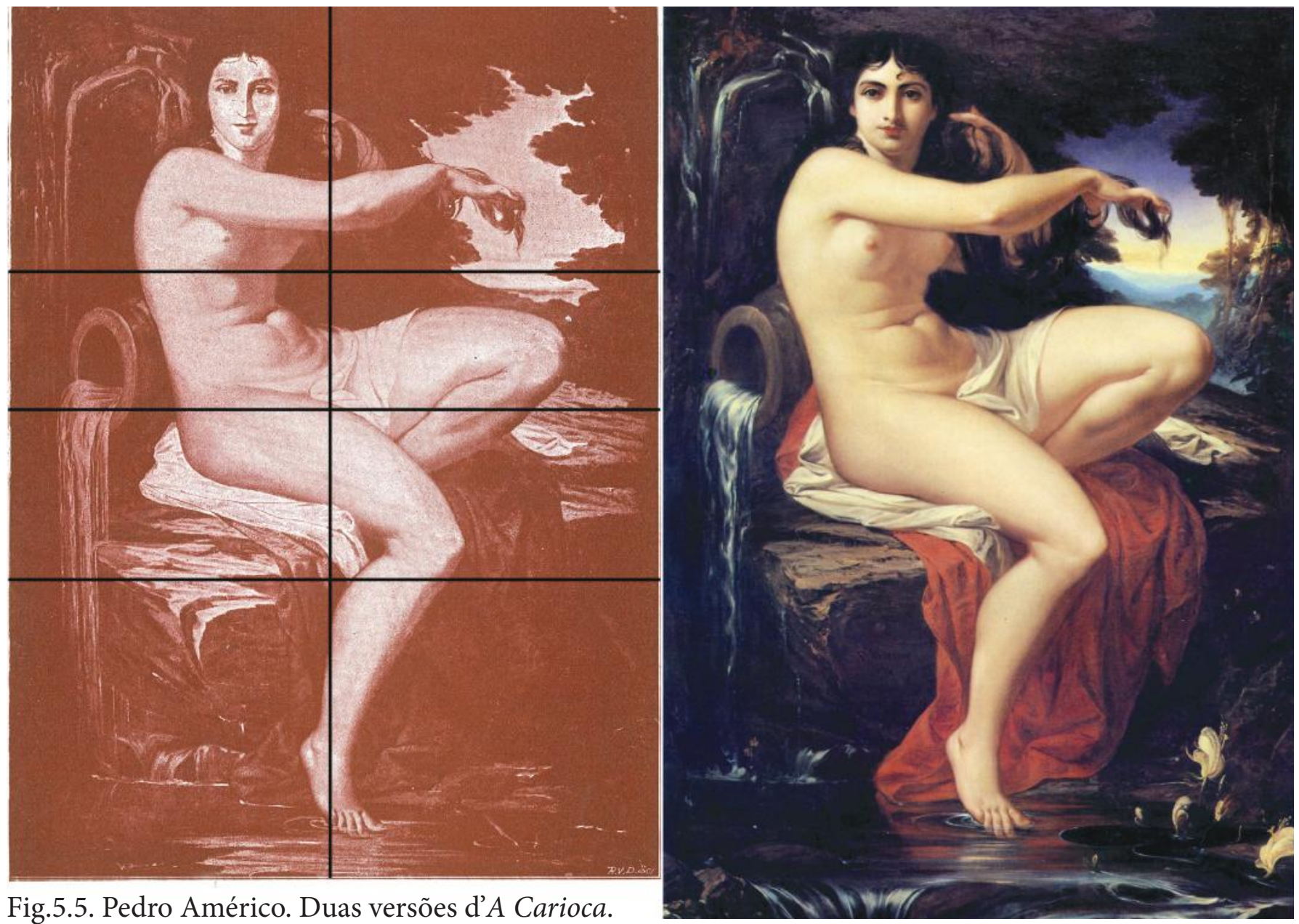

Fig.5.5. Pedro Américo. Duas versões d'A Carioca. 1864 e 1882. Indicação das linhas centrais, vertical e horizontal, e dos terços verticais.
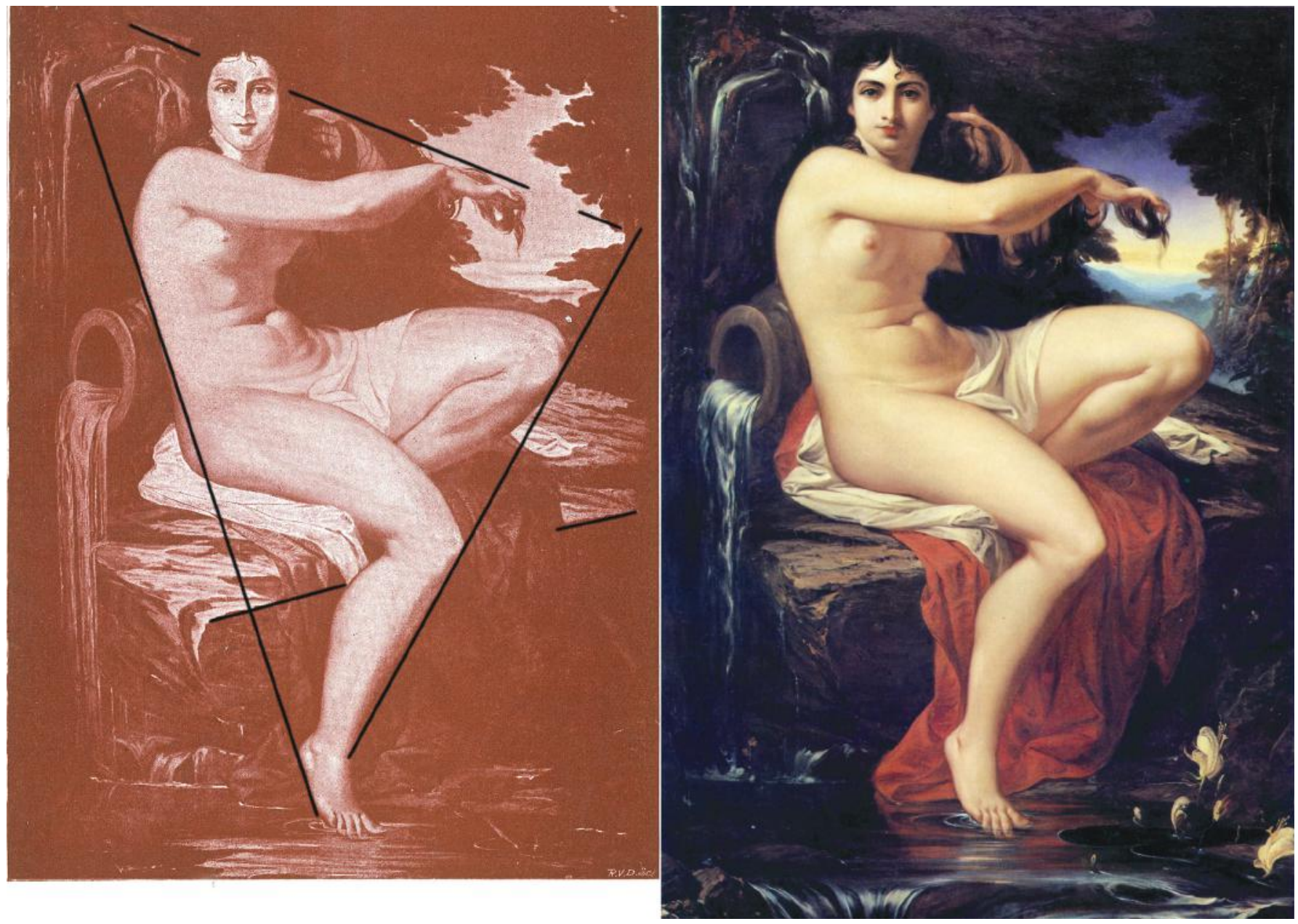

Fig.5.6. Pedro Américo. Duas versões d'A Carioca. 1864 e 1882. Indicação das linhas estéticas dominantes a partir da Filosofia aplicada às Belas Artes, de Sutter. 


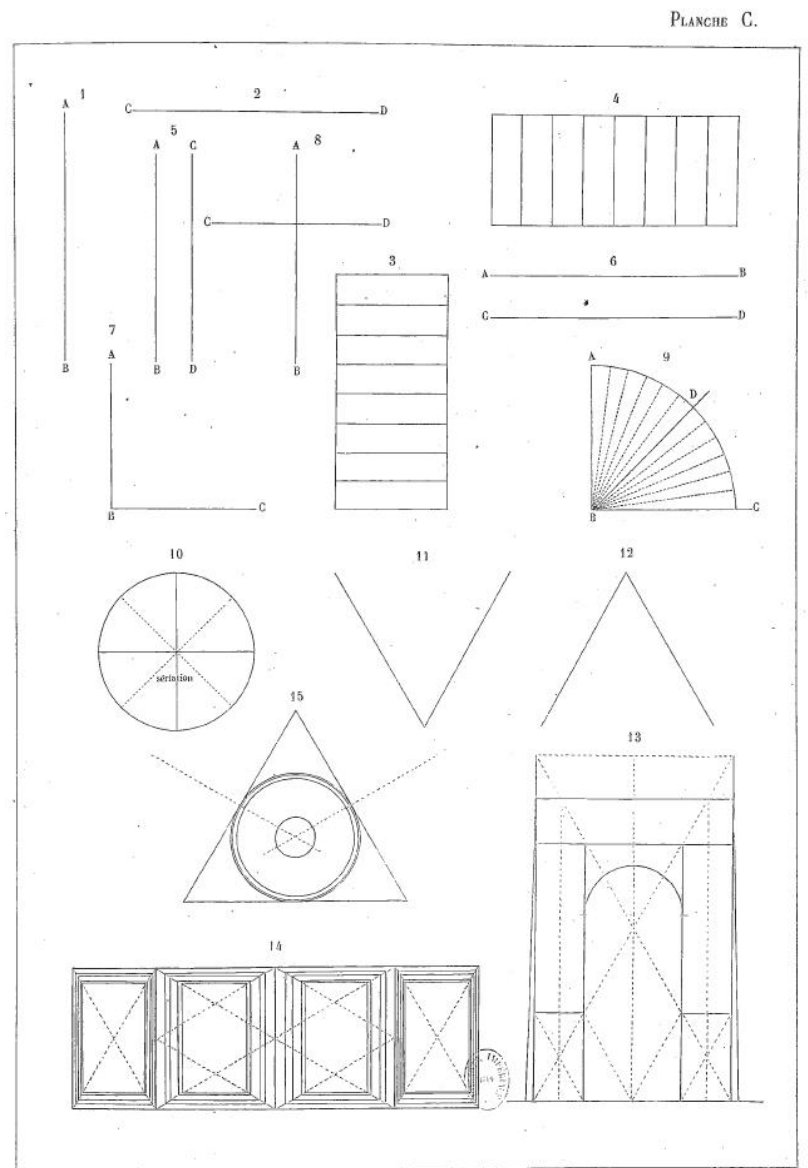

Fig.5.7. SUTTER, David. Esthétique générale et appliquée. Paris: Imprimerie impériale, 1865. Prancha C (ilustração 11).

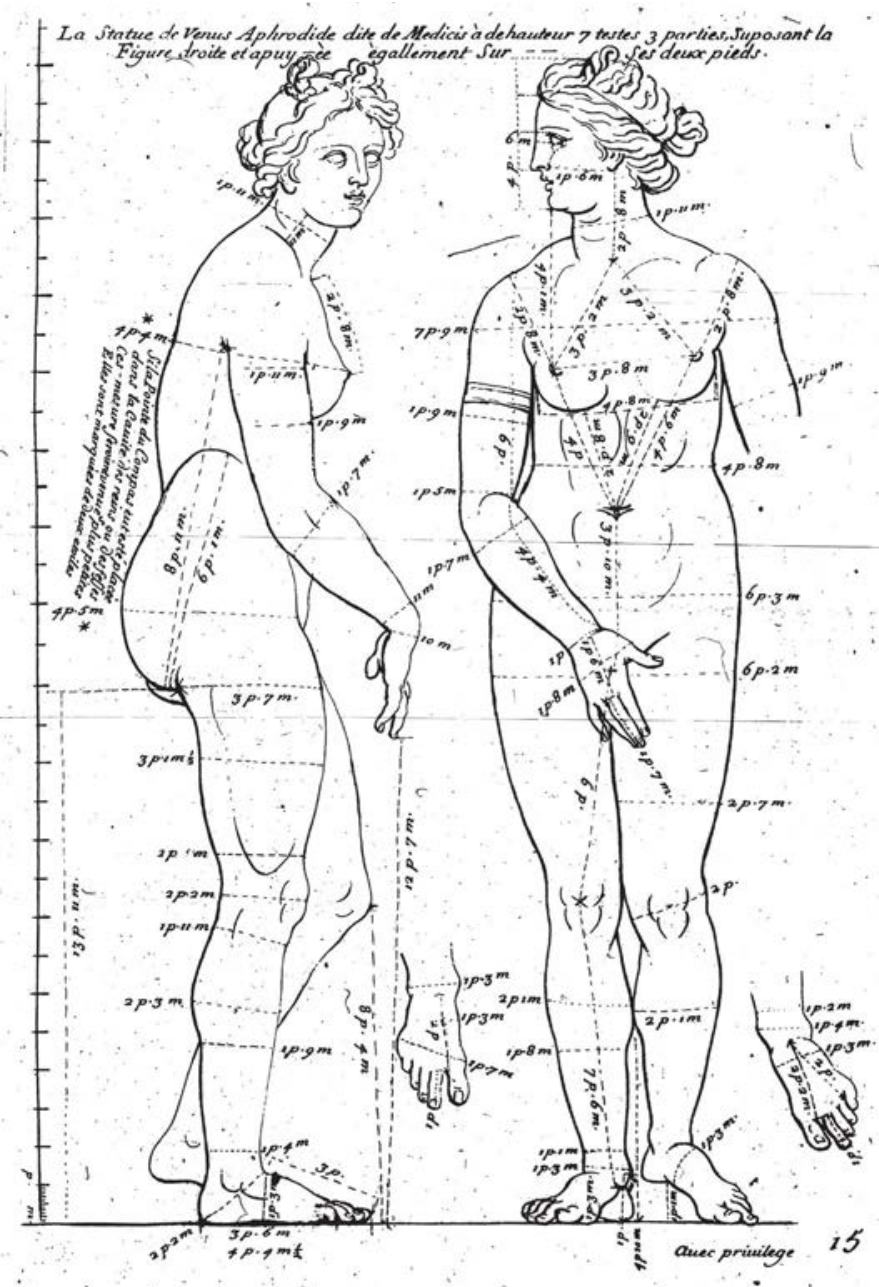

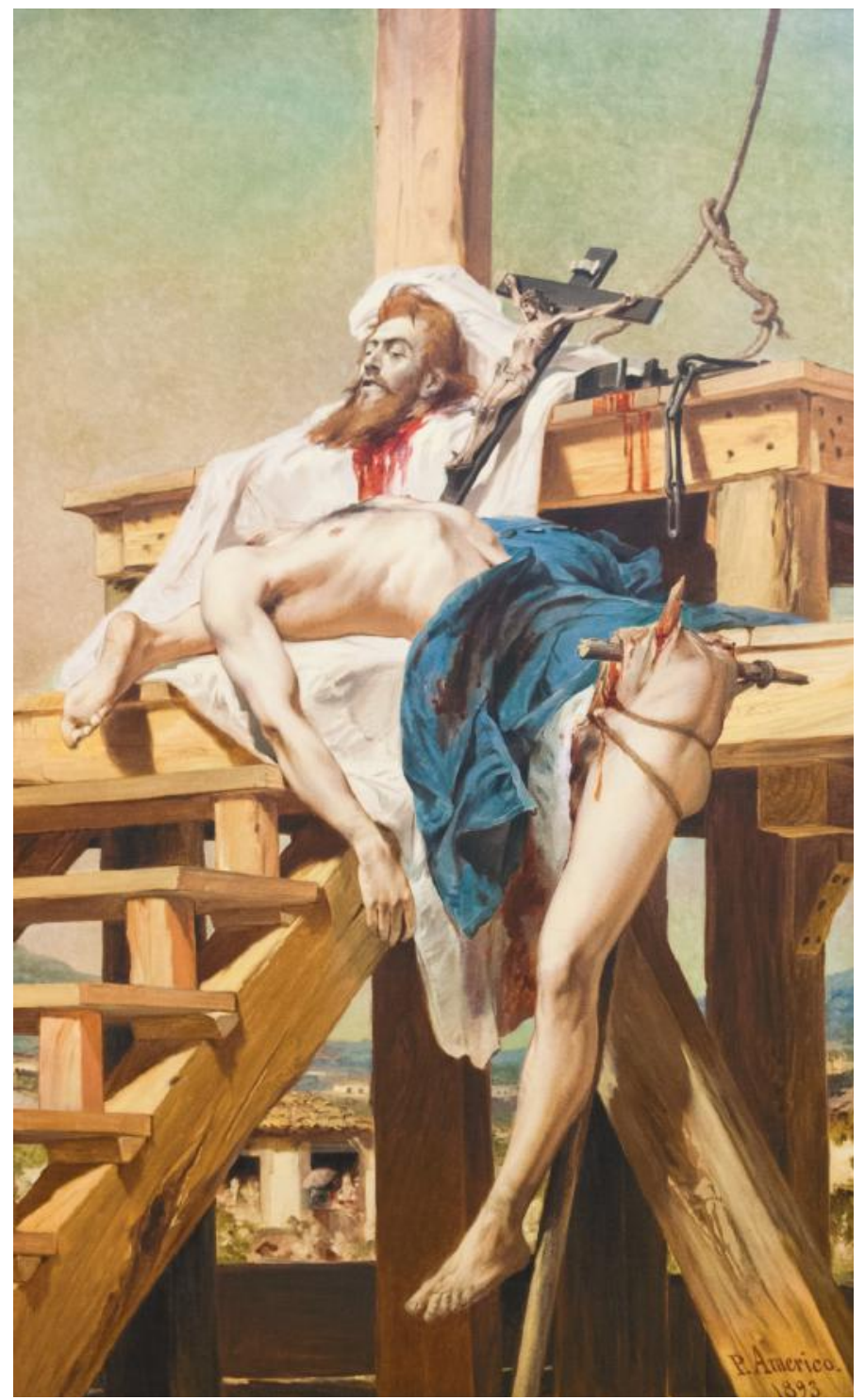

Fig.5.8. Pedro Américo. Tiradentes esquartejado, 1893, óleo sobre tela, $270 \times 165 \mathrm{~cm}$. Museu Mariano Procópio.

Fig.5.9. Vênus de Médicis. Medição das relações internas do corpo da estátua. In: AUDRAN, Gérard. Les proportions du corps humain mesurées sur les plus belles figure de l'antiquité. Paris: Bance Éditeur, 1855. Prancha 15. 
Les parties Juvisage J'vne Venus antique mesurèes de leurs mesmes grandeurs
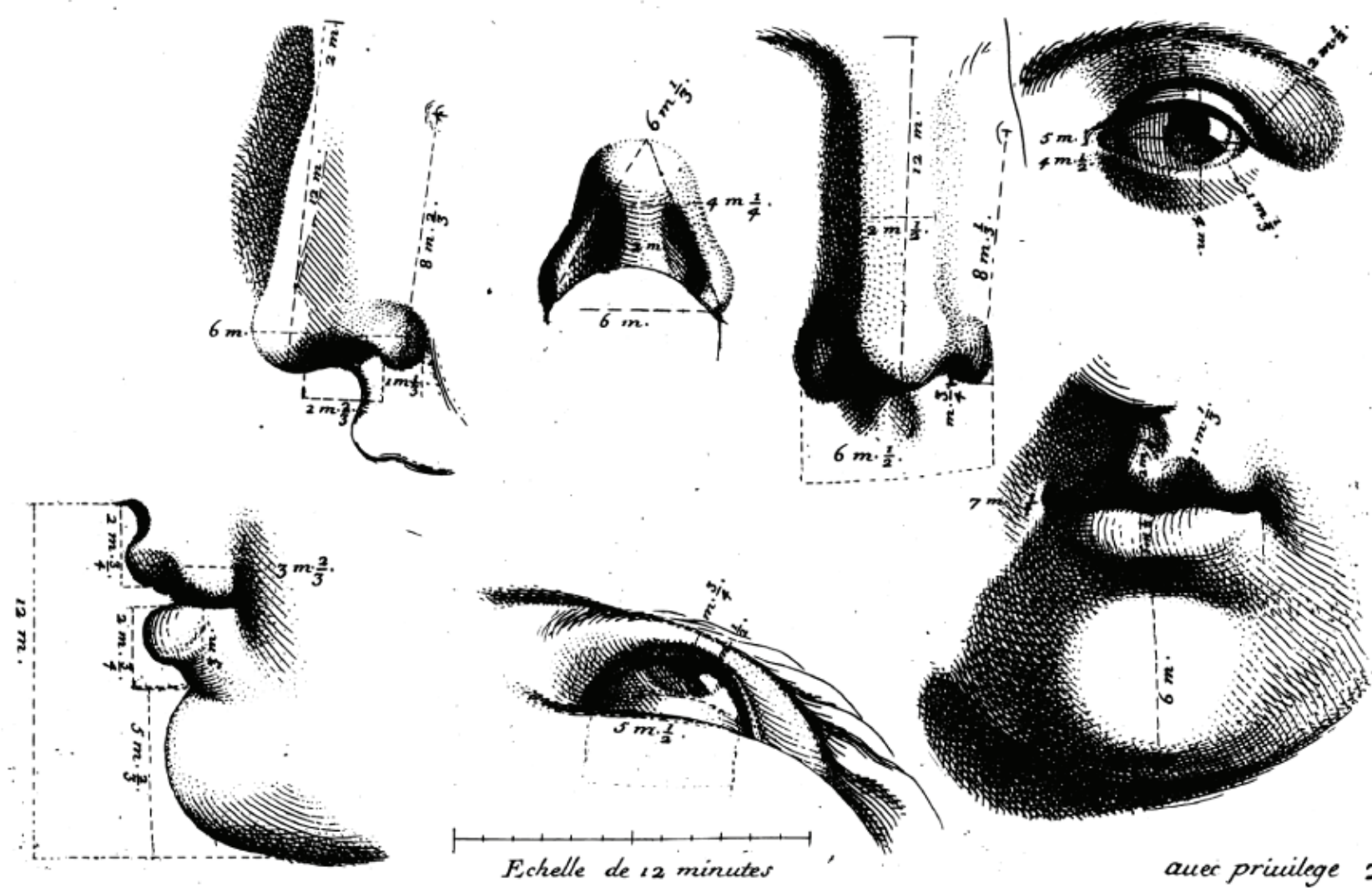

Fig.5.10. "As partes do rosto de uma Vênus antiga medidas de suas mesmas grandezas". In: AUDRAN, Gérard. Les proportions du corps humain mesurées sur les plus belles figure de l'antiquité. Prancha 28.

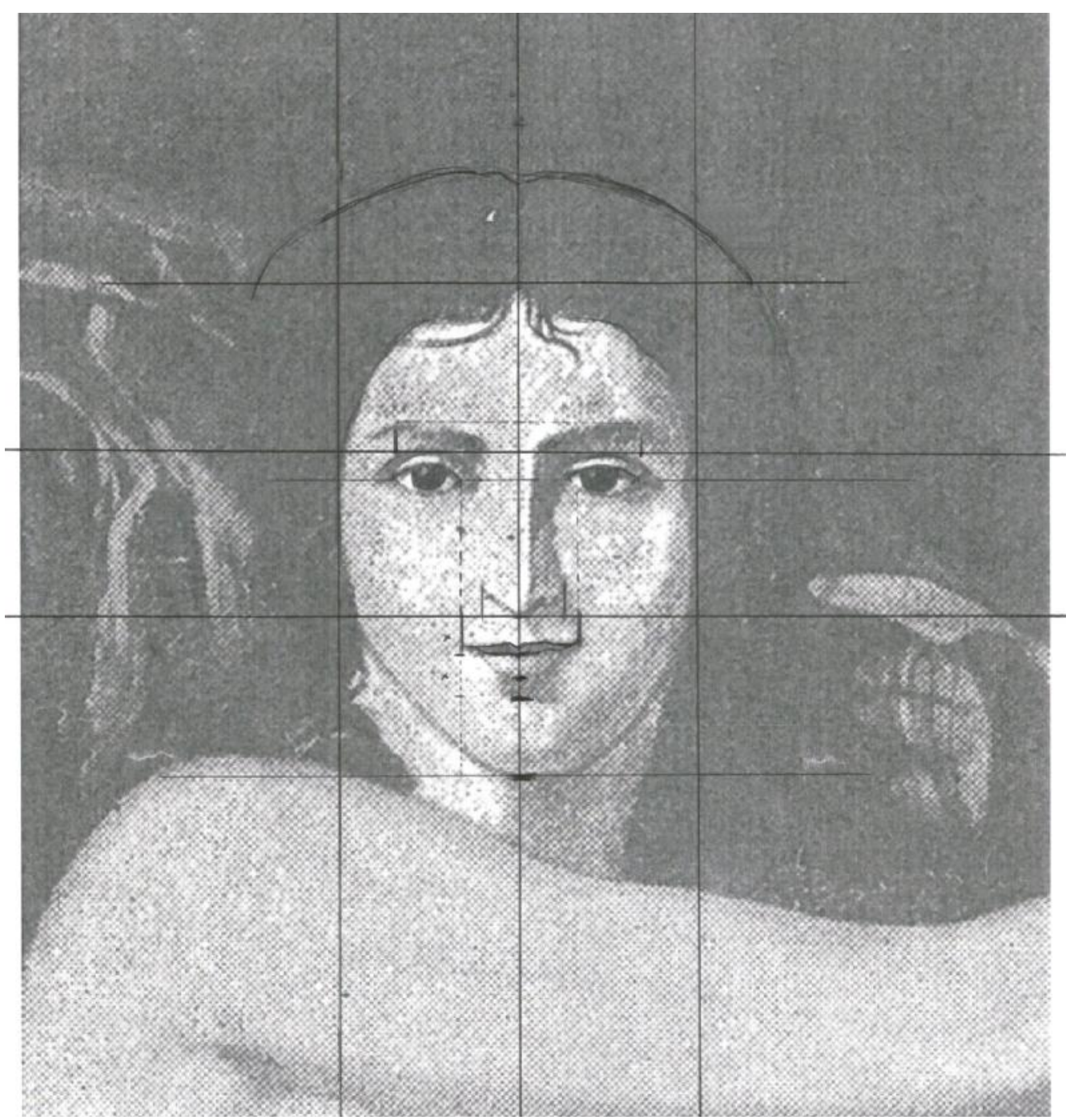

Fig.5.11. Pedro Américo. A Carioca, 1863-4. Estudo das proporções da face da figura. 


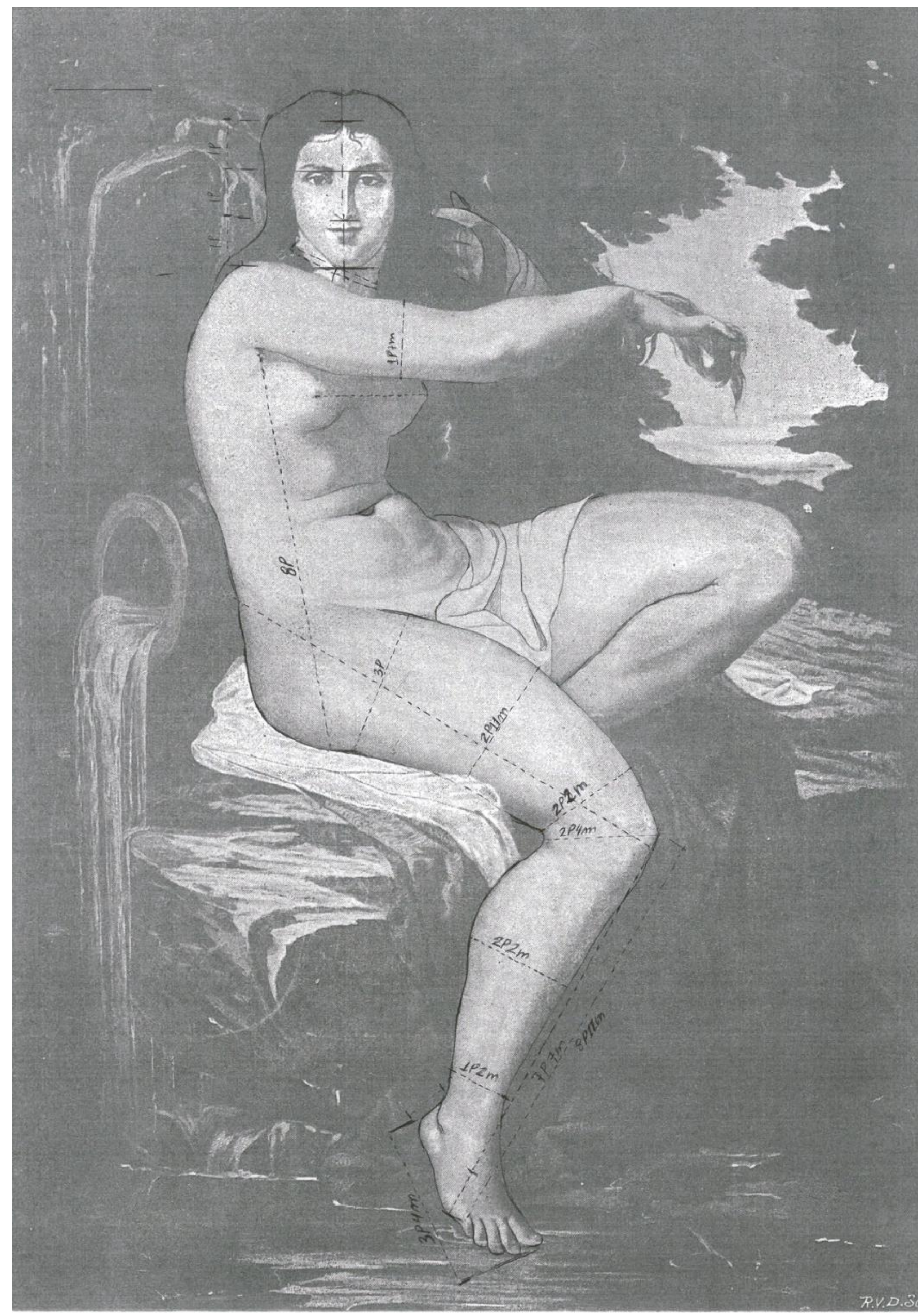

Fig.5.12. Pedro Américo. A Carioca, 1863-4. Estudo das proporções do corpo da figura. 


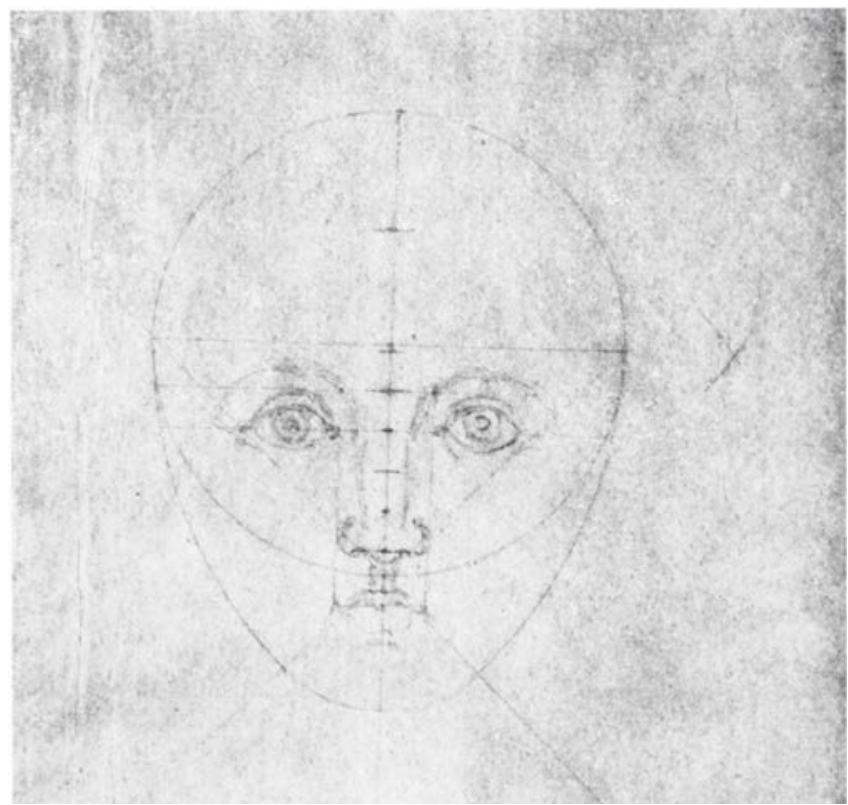

Fig.5.13. J. W. Goethe. Es-

tudo de proporção de rosto.

Nationale Forchungsund

Gedenkstätten der Klassischen

deutschen Literatur, Weimar.

Fig.5.14. J. J. Winckelmann. Estudo em proporção da cabeça humana e comentários. Società Columbaria, Firenze. IV, II, II, 52.
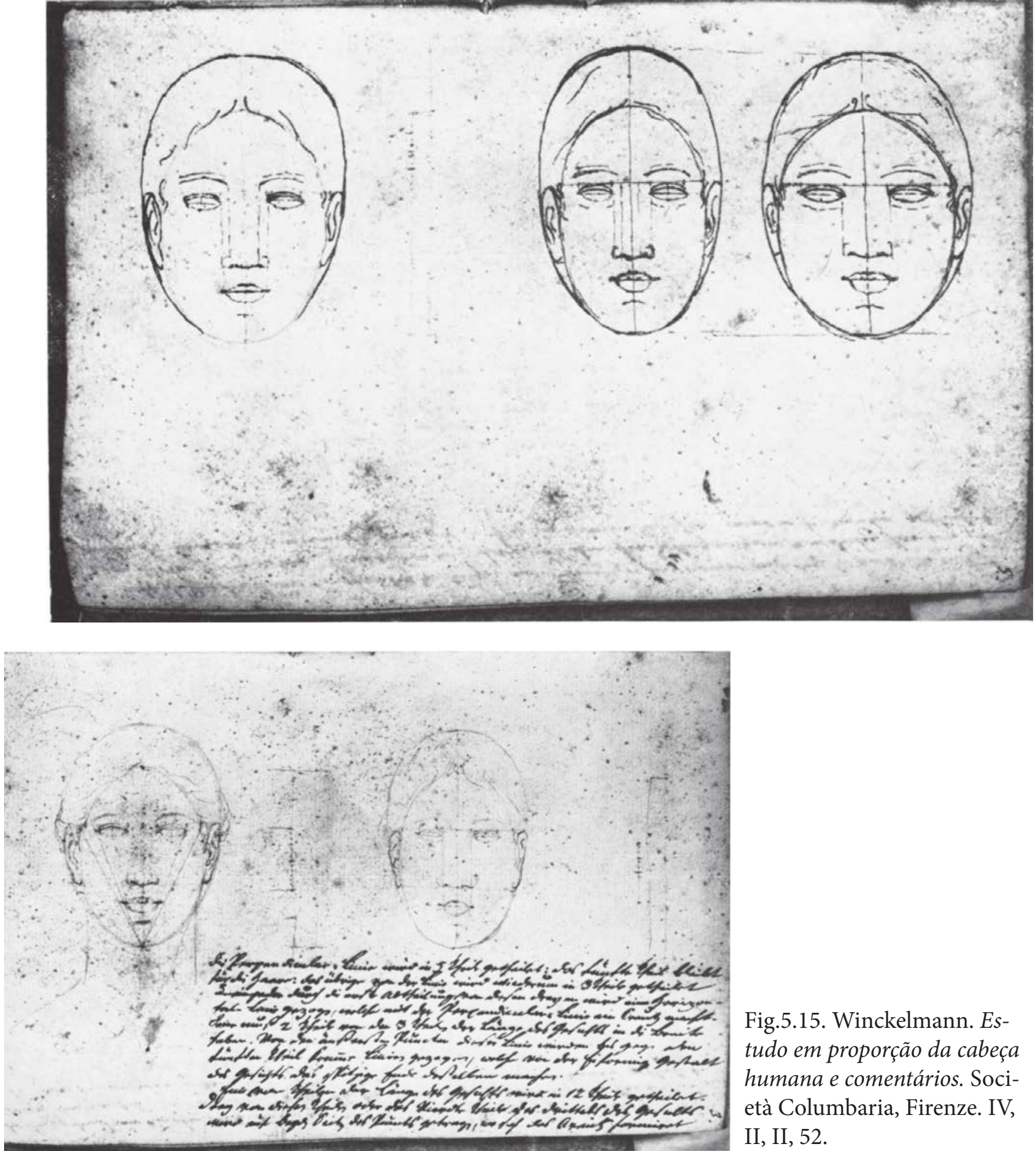

Fig.5.15. Winckelmann. Estudo em proporção da cabeça humana e comentários. Società Columbaria, Firenze. IV, II, II, 52. 

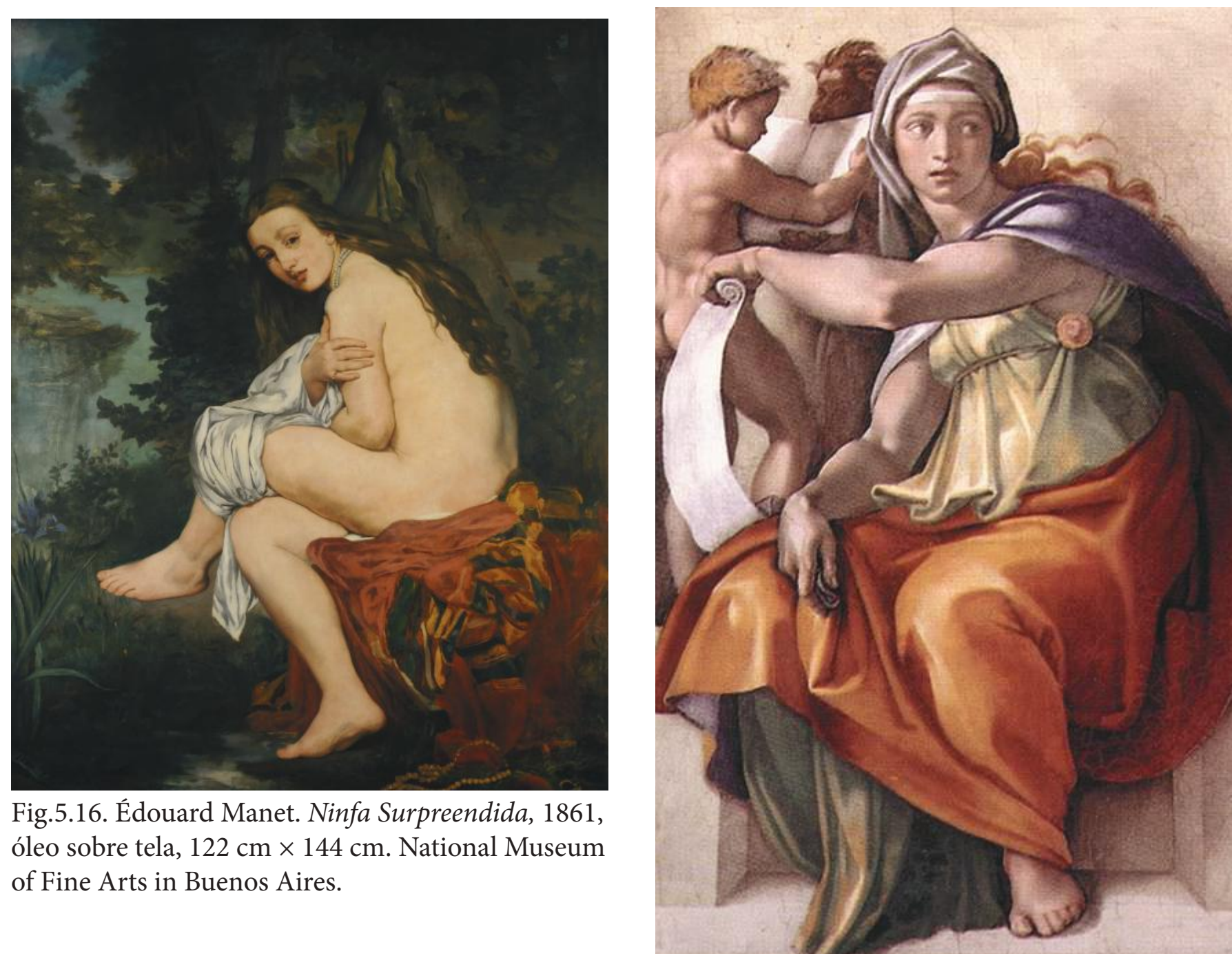

Fig.5.16. Édouard Manet. Ninfa Surpreendida, 1861, óleo sobre tela, $122 \mathrm{~cm} \times 144 \mathrm{~cm}$. National Museum of Fine Arts in Buenos Aires.
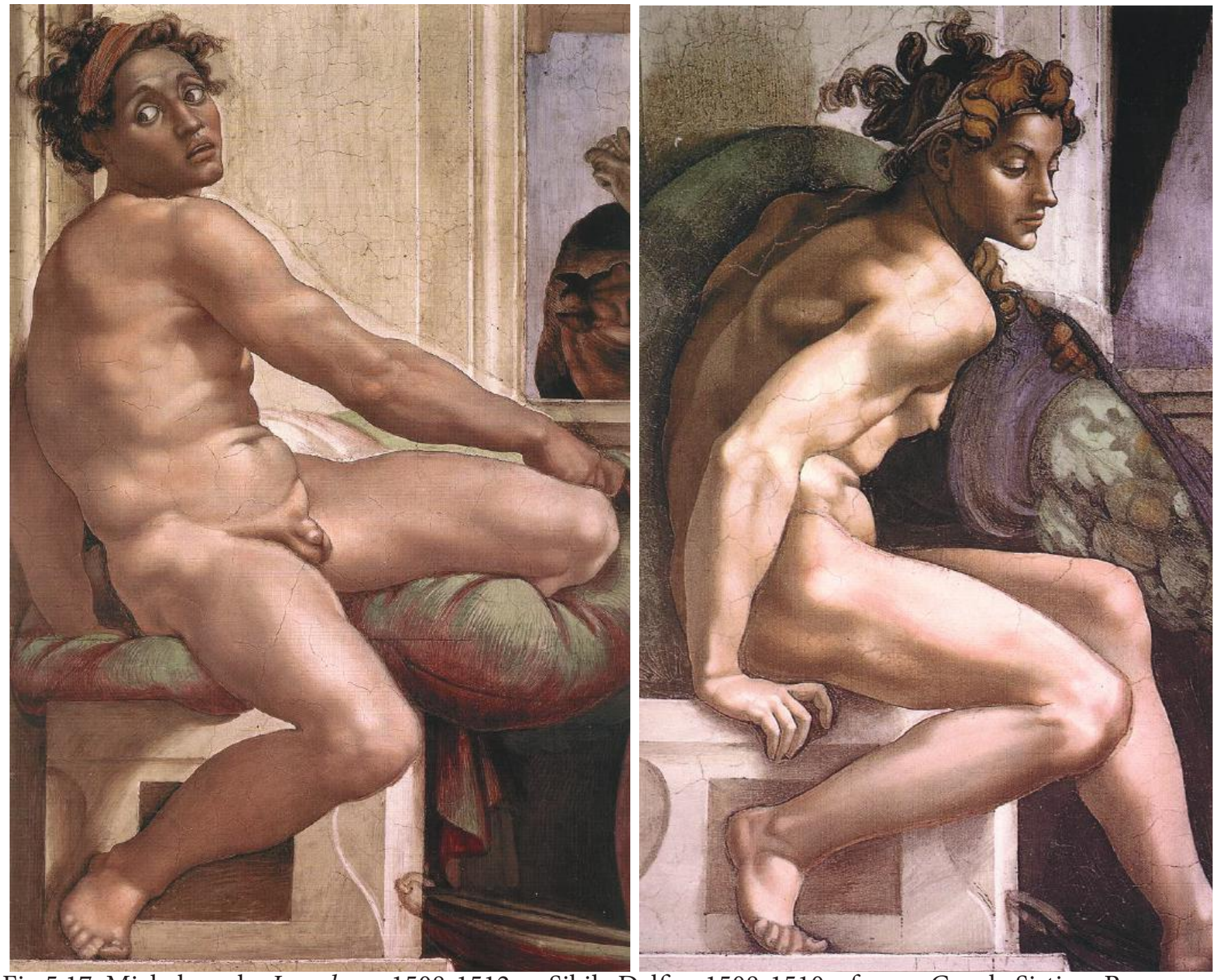

Fig.5.17. Michelangelo. Ignudos, c.1508-1512, e Sibila Delfica 1508-1510, afresco. Capela Sistina, Roma. 


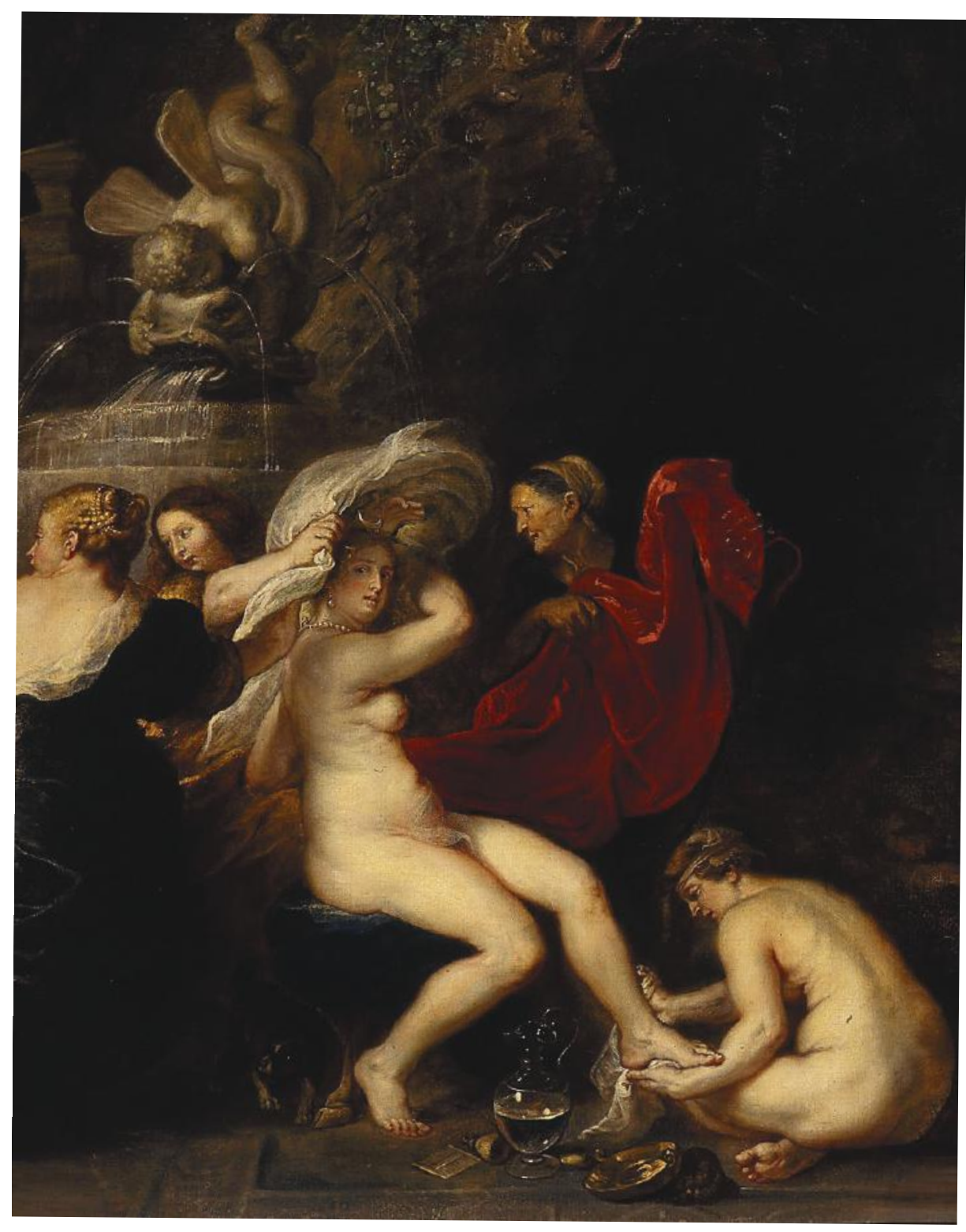

Fig.5.18. Peter Paul Rubens. O banho de Diana, 1635- 40, óleo sobre tela, $152.5 \times 120 \mathrm{~cm}$. Boijmans Collection.

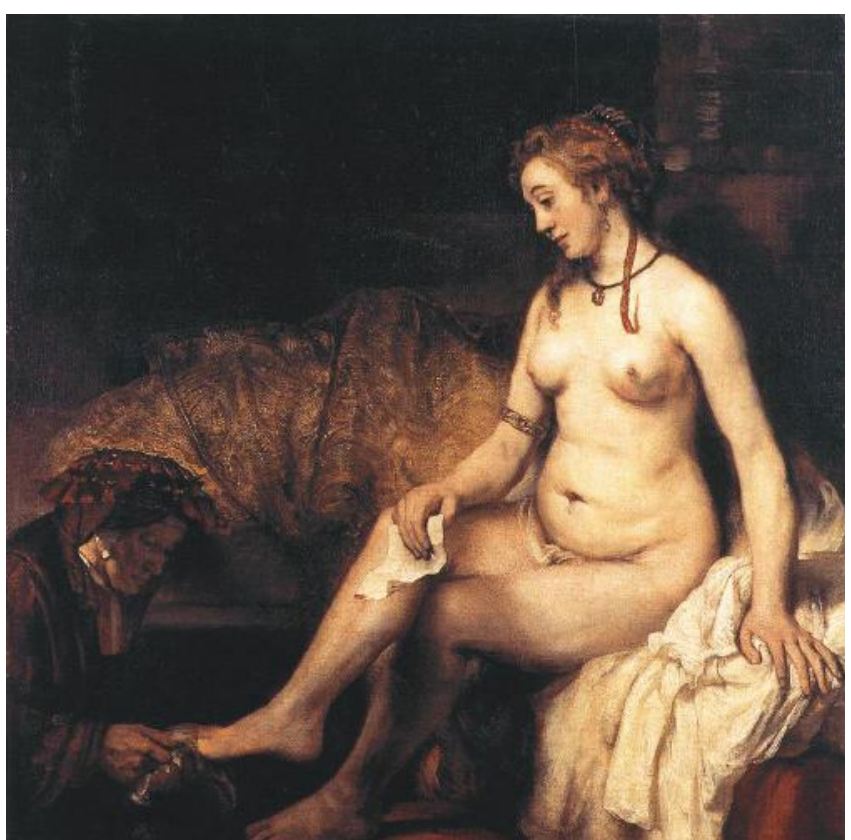

Fig.5.19. Rembrandt. Betsabéia se banhando, óleo sobre tela, 1654. 142 x 142. Museu do Louvre.

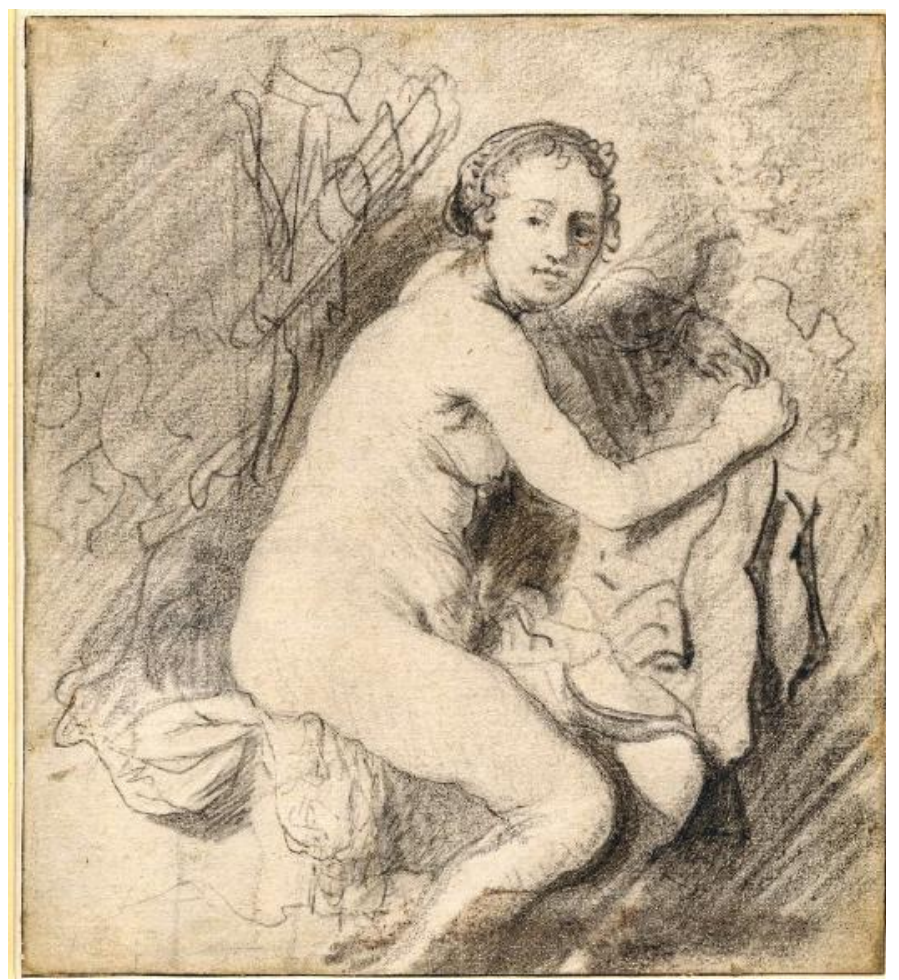

Fig.5.20. Rembrandt. Diana no Banho, ca.1629, Carvão sobre papel, 18.1 x $16.4 \mathrm{~cm}$. British Museum, London. 


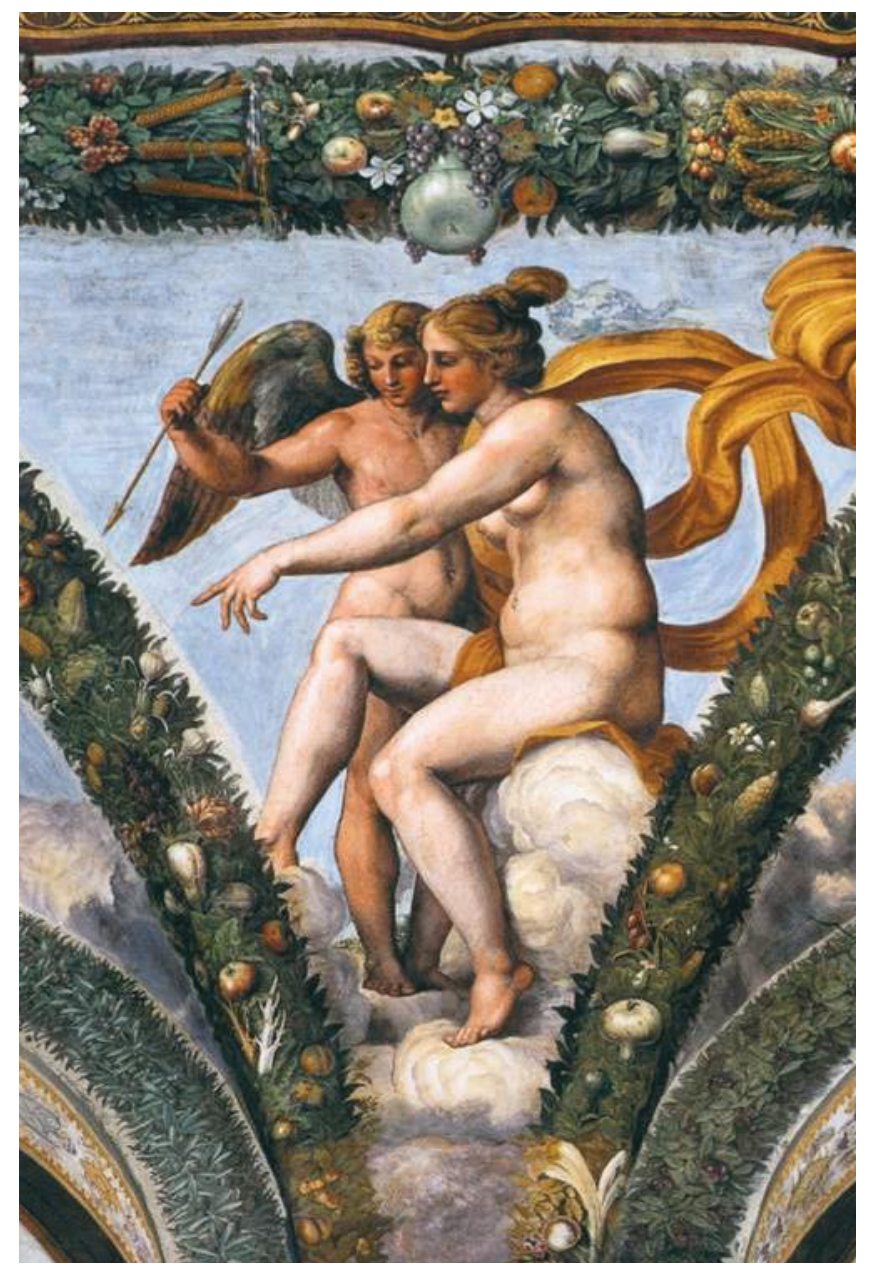

Fig.5.21. Rafael. Vênus e Cupido. 1517-18, afresco. Villa Farnesina, Roma.

Fig.5.22. Ticiano, Vênus e Adonis, 1554 , óleo sobre tela, $180 \times 207 \mathrm{~cm}$.

Museo del Prado, Madrid.

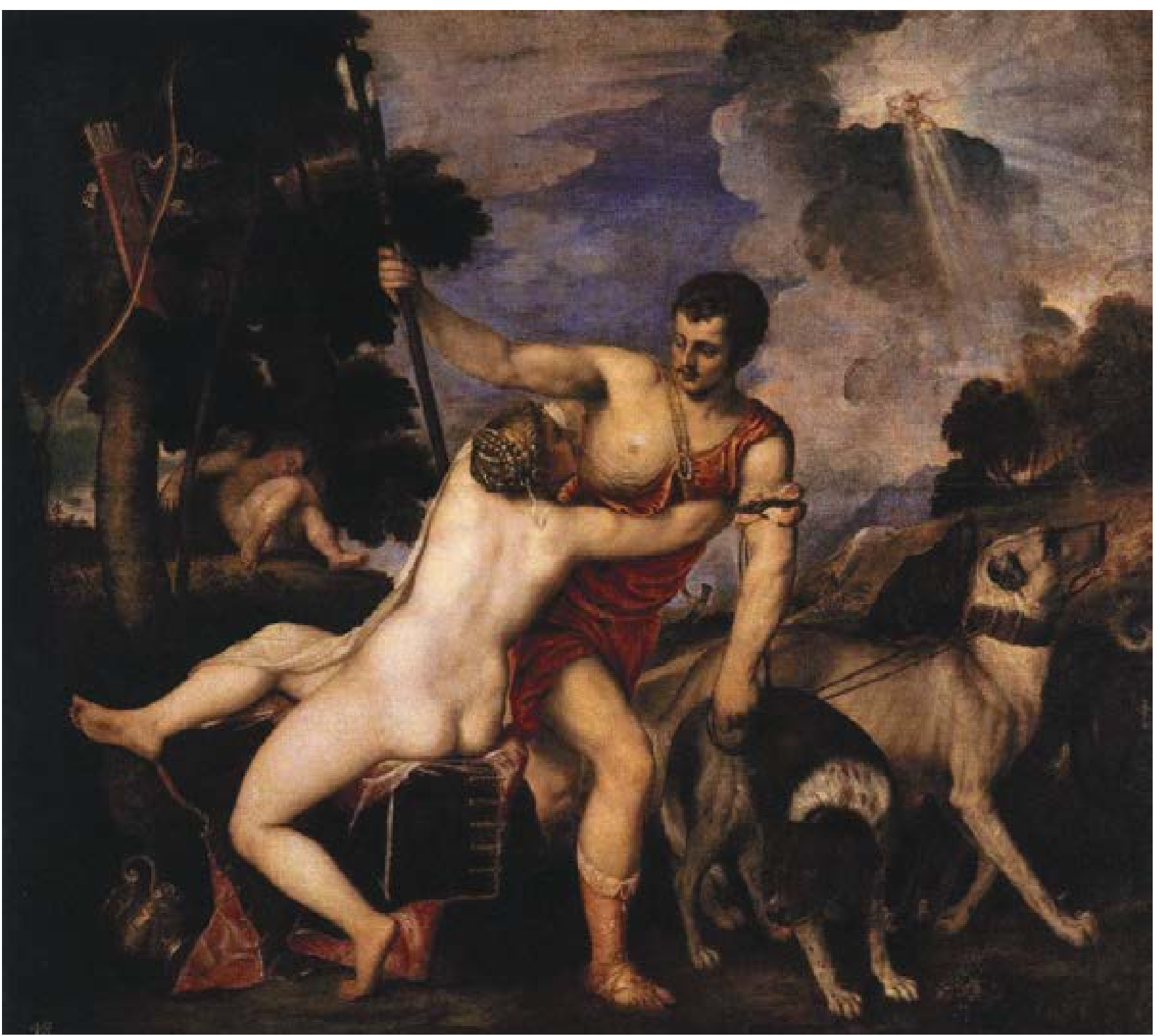




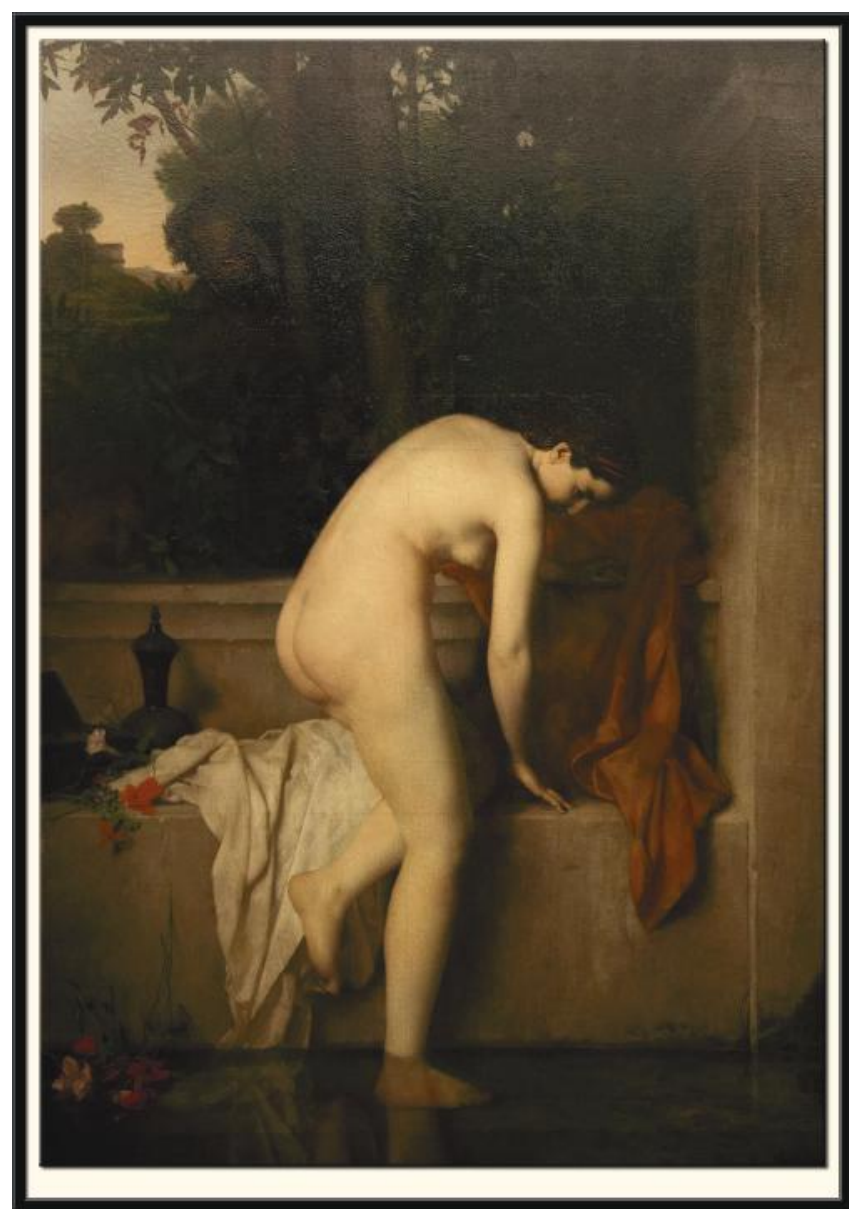

Fig.5.23. Jean-Jacques Henner.

A casta Suzana, 1864, óleo

sobre tela, $185 \times 130 \mathrm{~cm}$. Paris,

Musée d'Orsay.

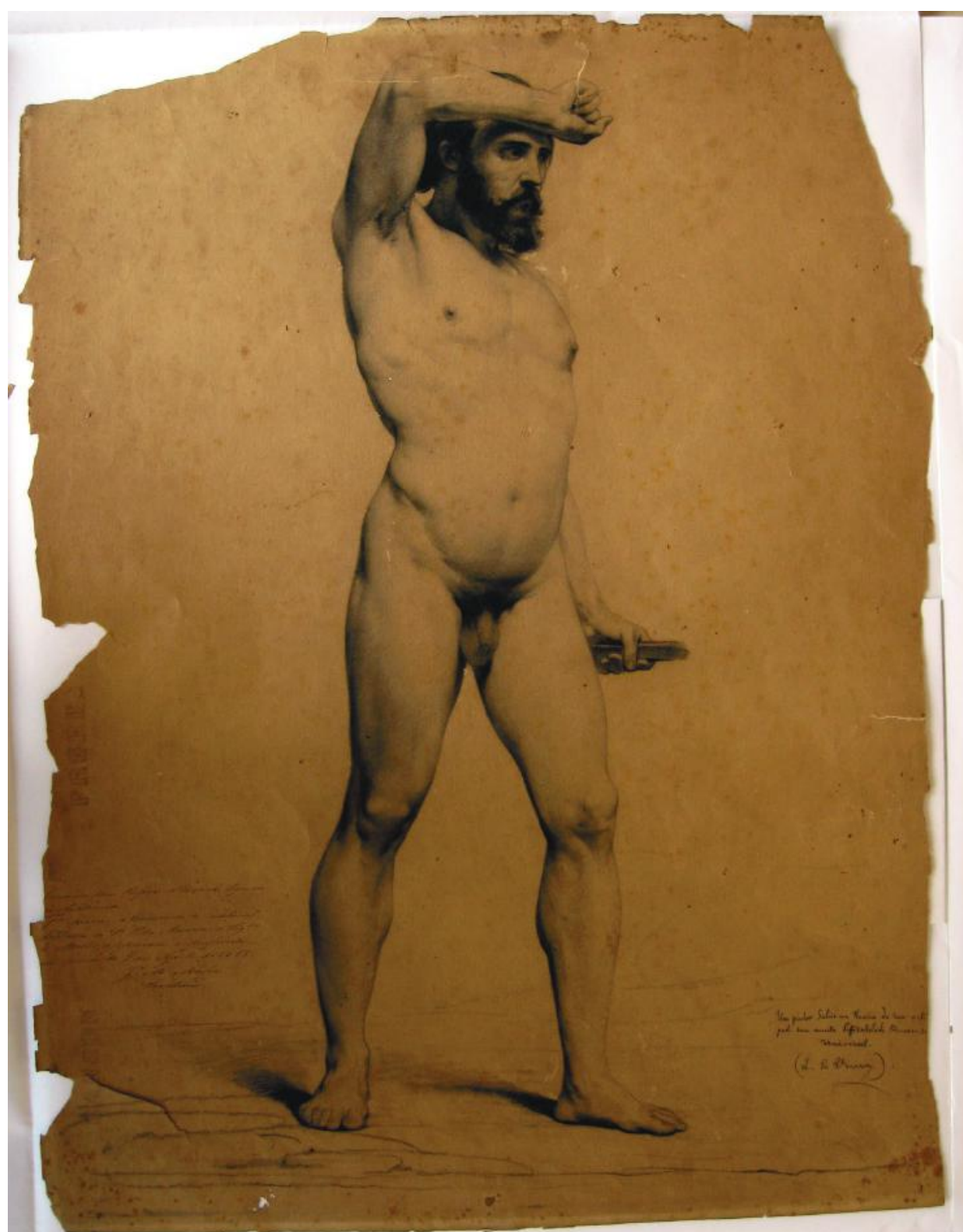

Fig.5.24. Pedro Américo. Academia Masculina. Prova para concurso da cadeira de Desenho Figurado da AIBA, 1865, carvão e Lápis sobre papel. Museu d. João VI. 


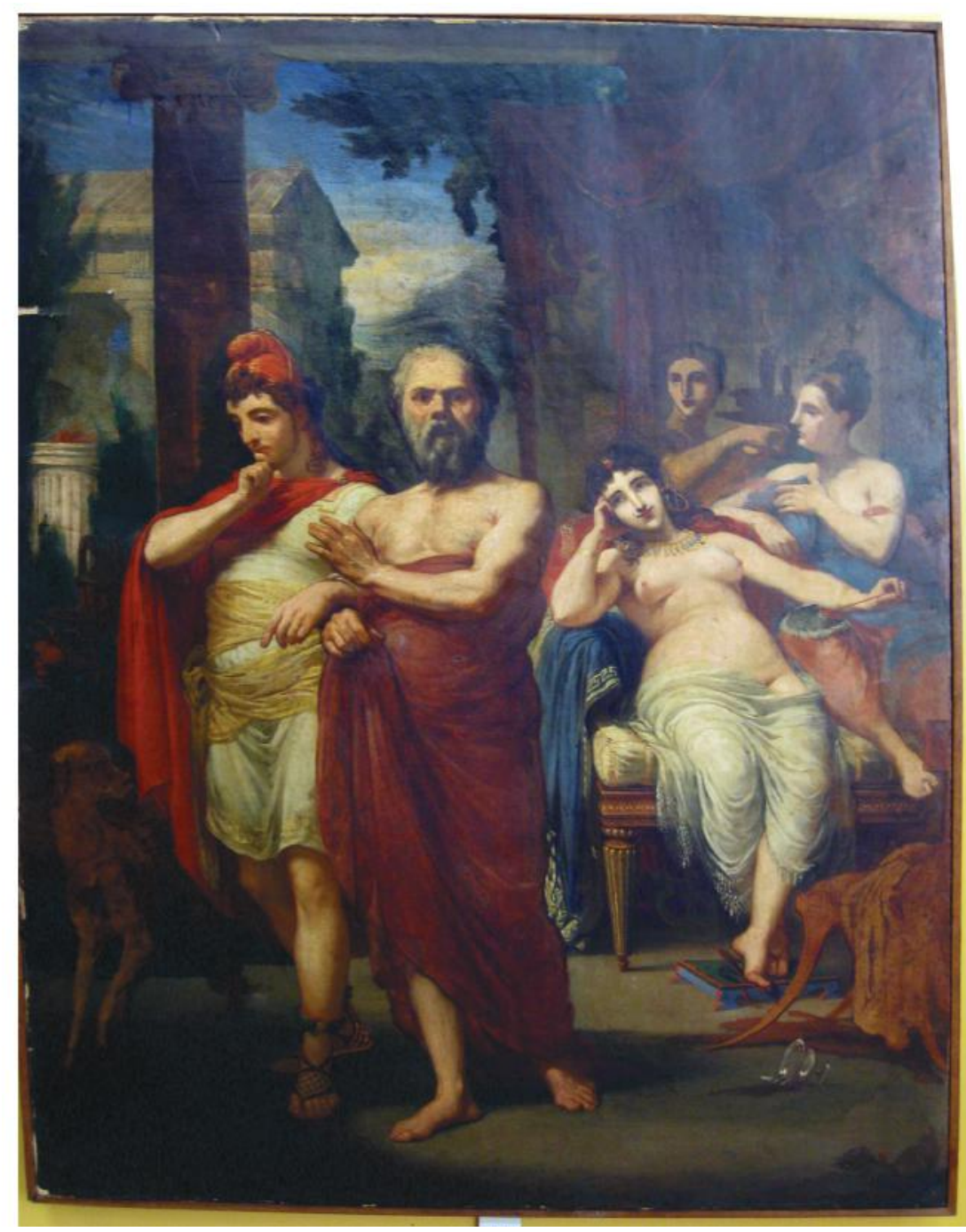

Fig.5.25. Pedro Américo. Sócrates afastando Alcebíades do vício, 1865, óleo sobre tela,130,5 x $97 \mathrm{~cm}$. Rio de Janeiro, Museu d. João VI - EBA/ UFRJ.

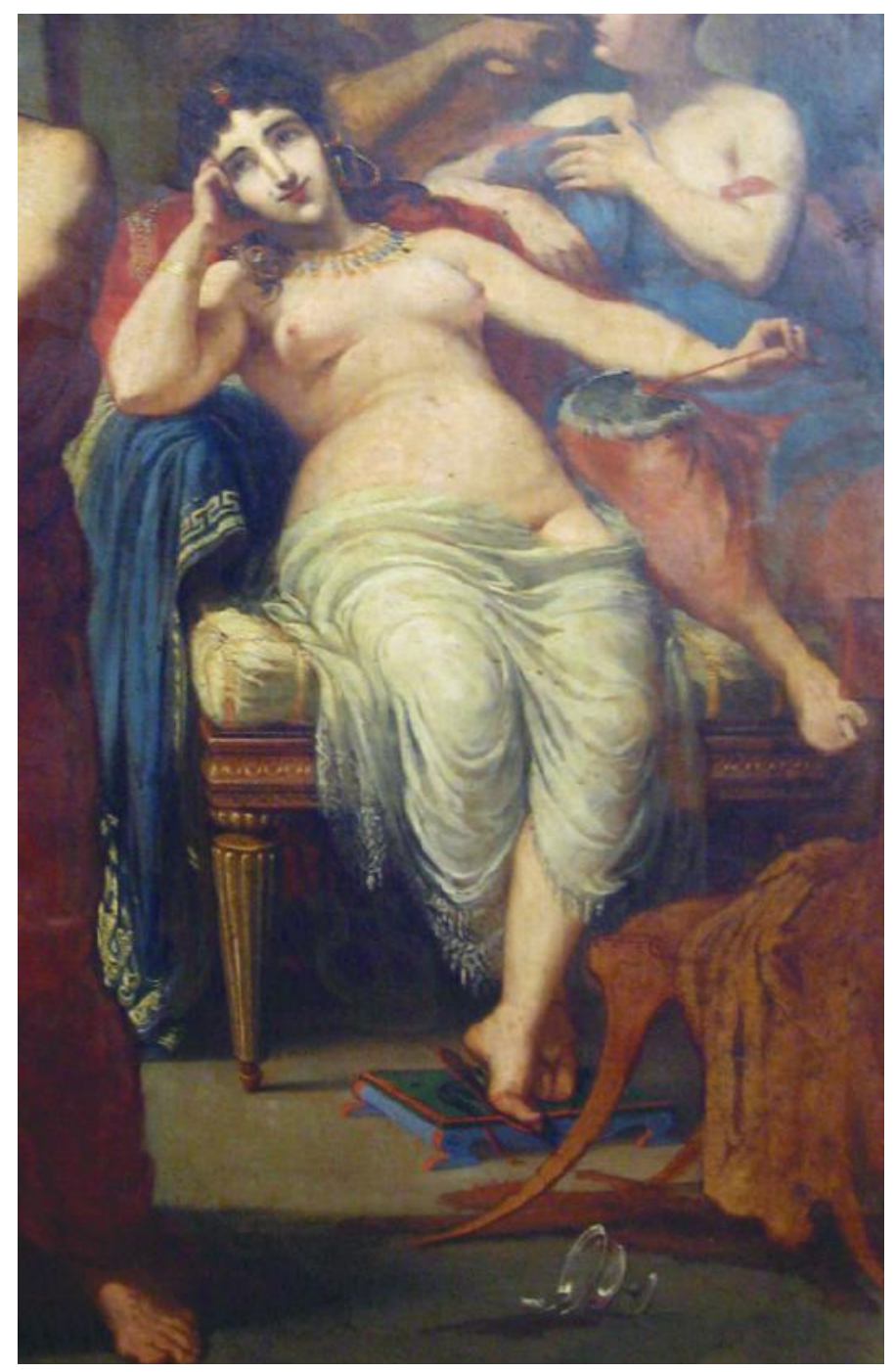

Fig.5.26. Pedro Américo. Recorte sobre Aspásia do quadro Sócrates afastando Alcebíades do vício, 1865. 


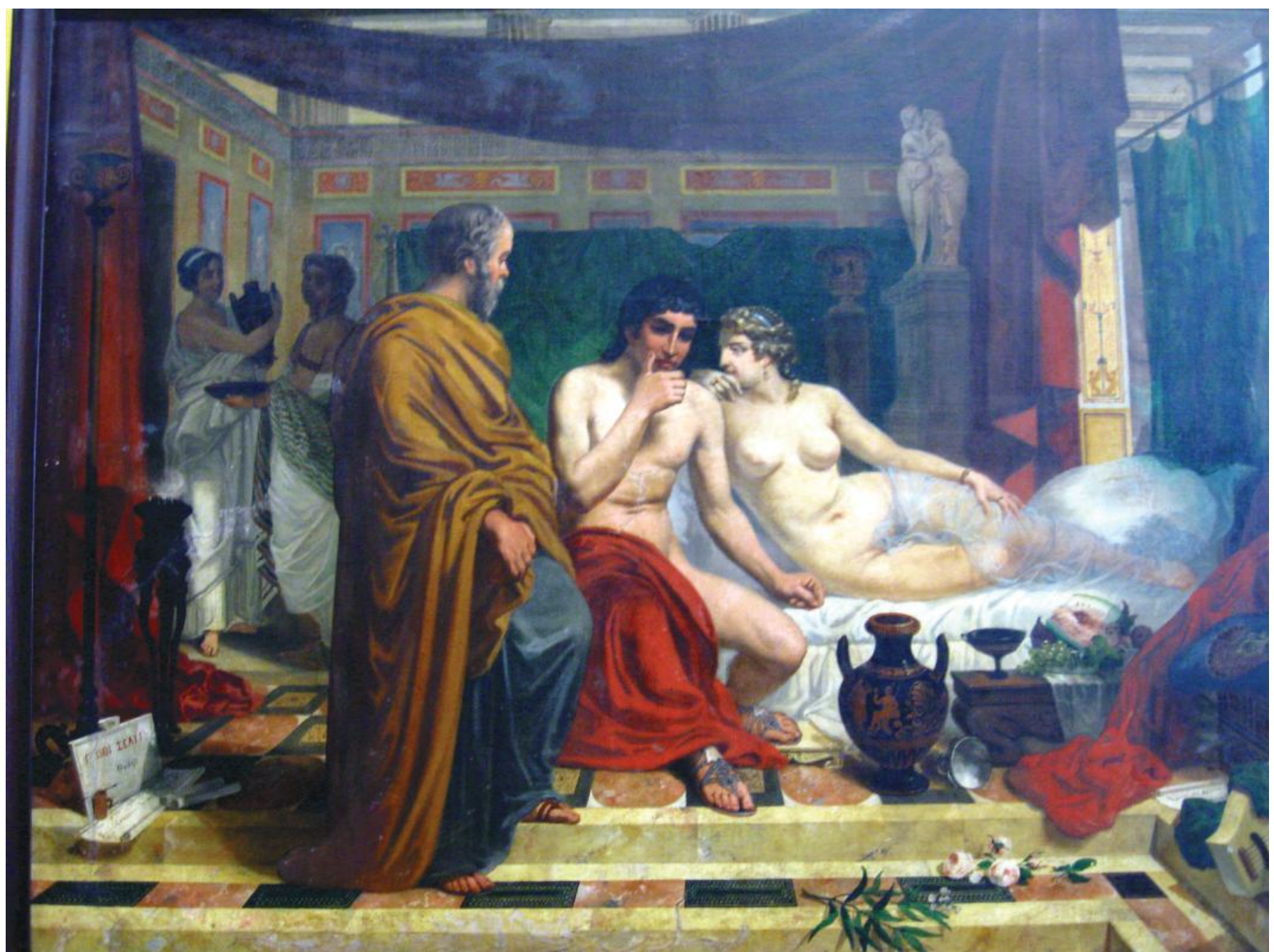

Fig.5.27. Jules Le Chevrel. Sócrates afastando Alcebíades do vício, 1865, óleo sobre tela, 97 x 130,5 cm. Rio de Janeiro, Museu d. João VI - EBA/UFRJ.

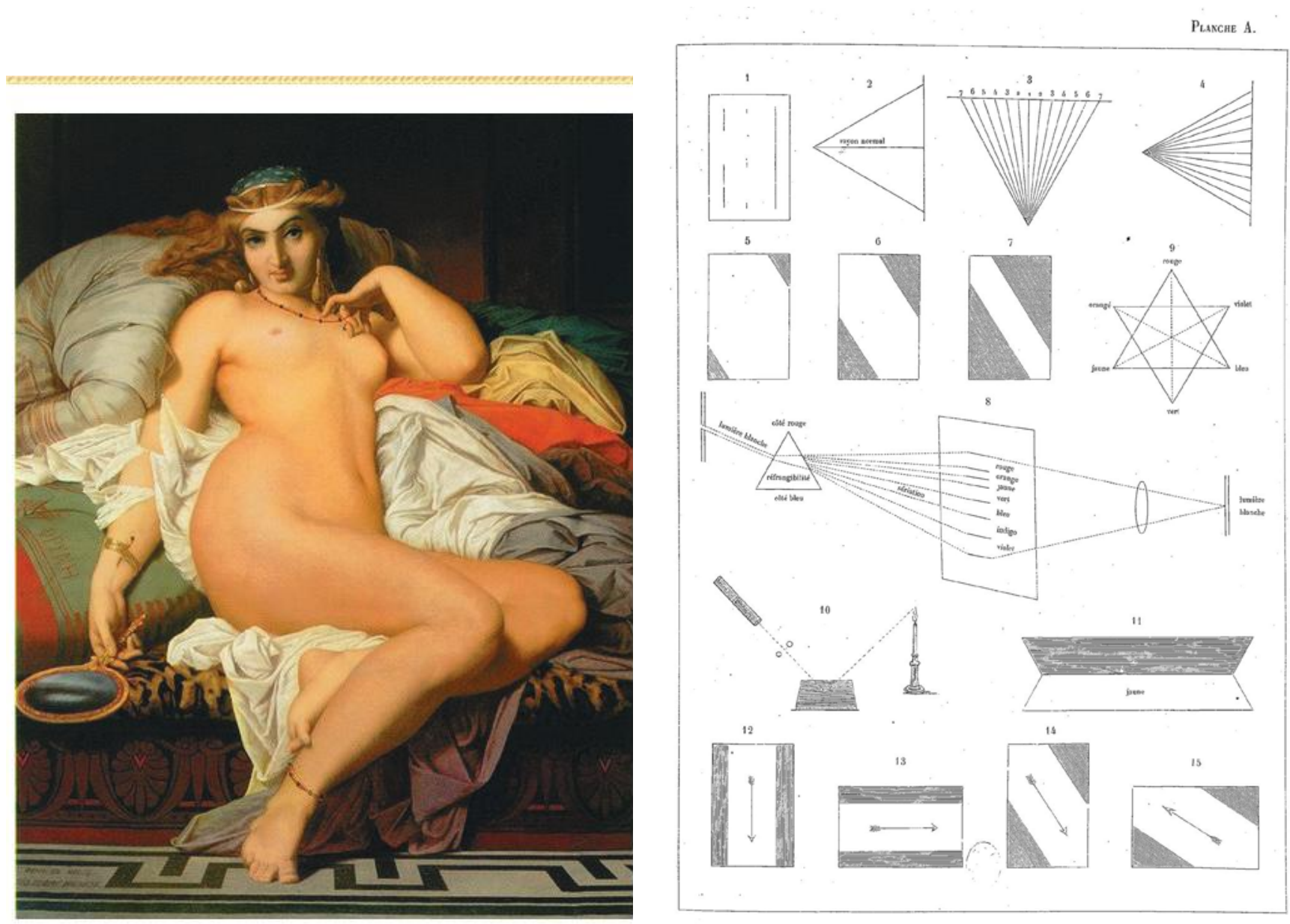

Fig.5.28. Gustave Boulanger. Frinéia, 1850, óleo sobre tela, 185 x $152 \mathrm{~cm}$. Museu Van Gogh, Amsterdam.
Fig.5.29. SUTTER, David. Esthétique générale et appliquée. Paris: Imprimerie impériale, 1865. Prancha A (ilustrações 5, 6 e 7). 


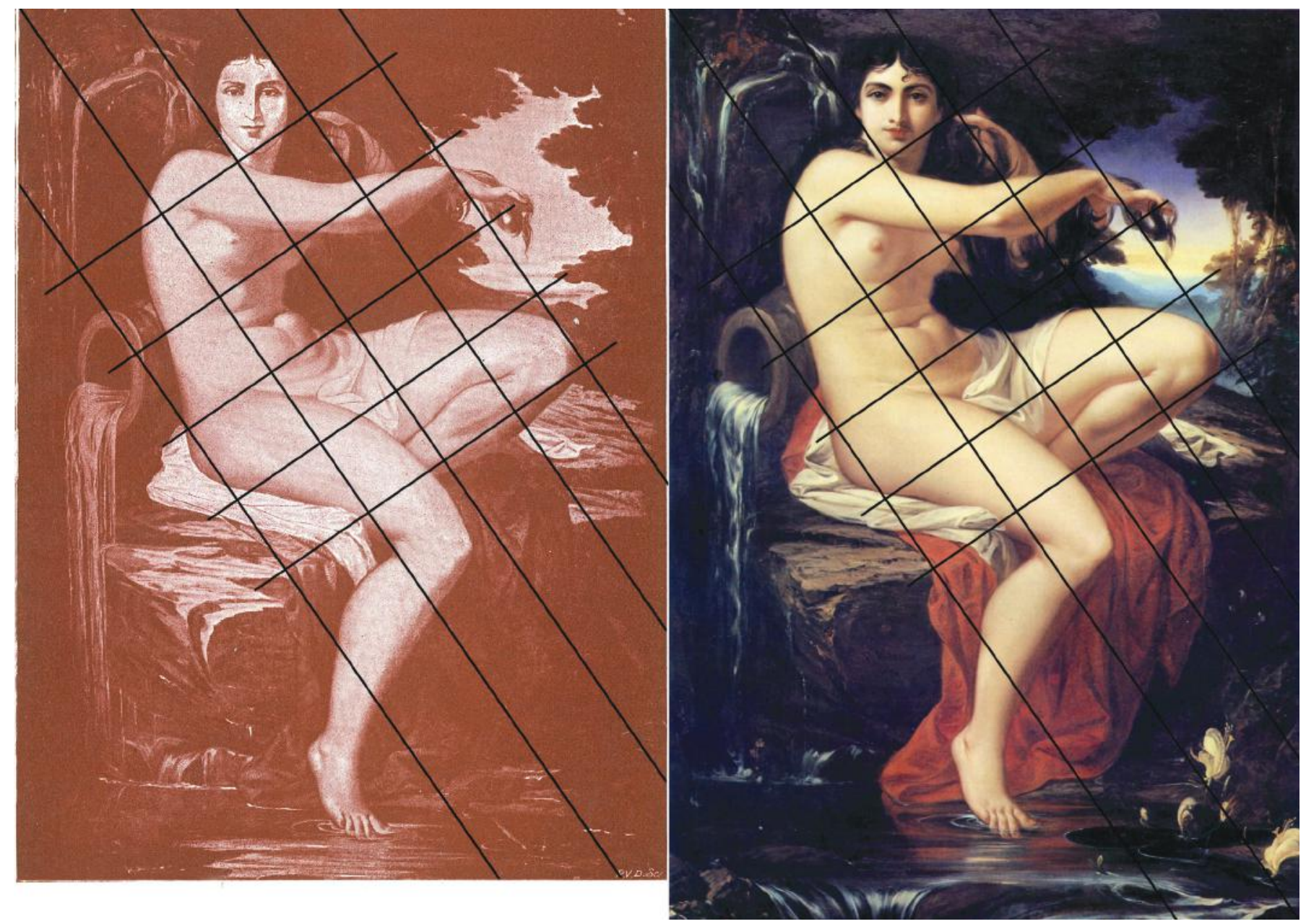

Fig.5.30. Duas versões dA Carioca. 1864 e 1882. Indicação das direções gerais das luzes e sombras.
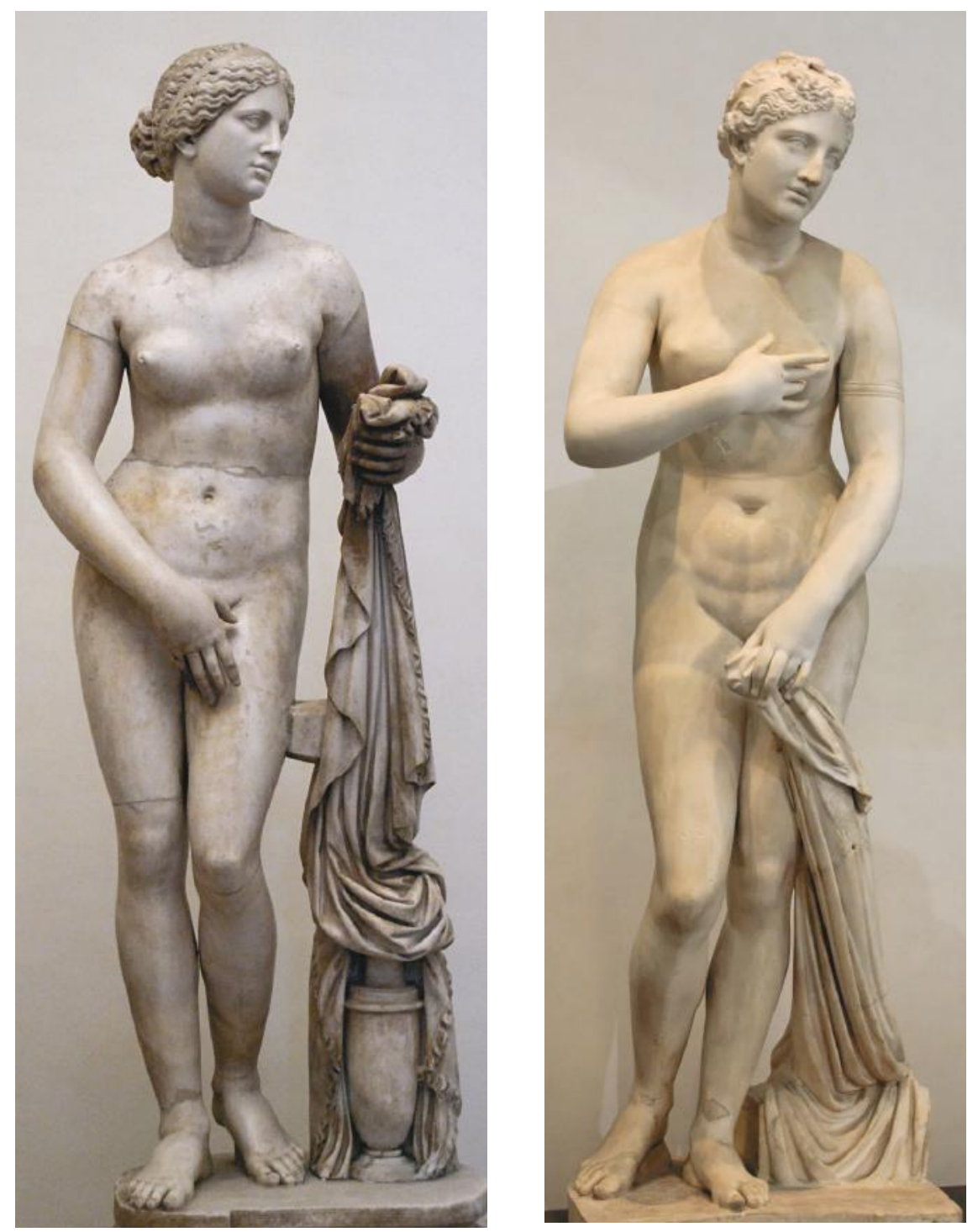

À extrema esquerda: Fig.5.31. Afrodite de Cnido. Cópia romana da Vênus de Cnido, de Praxíteles. Entre 360 e 330 A.C. Palazzo Altemps, Roma.

Fig.5.32. Menophantos. Afrodite de Menophantos. I século A.C. National Museum of Rome. Palazzo Massimo alle Terme. Cópia da Vênus Cnido. 

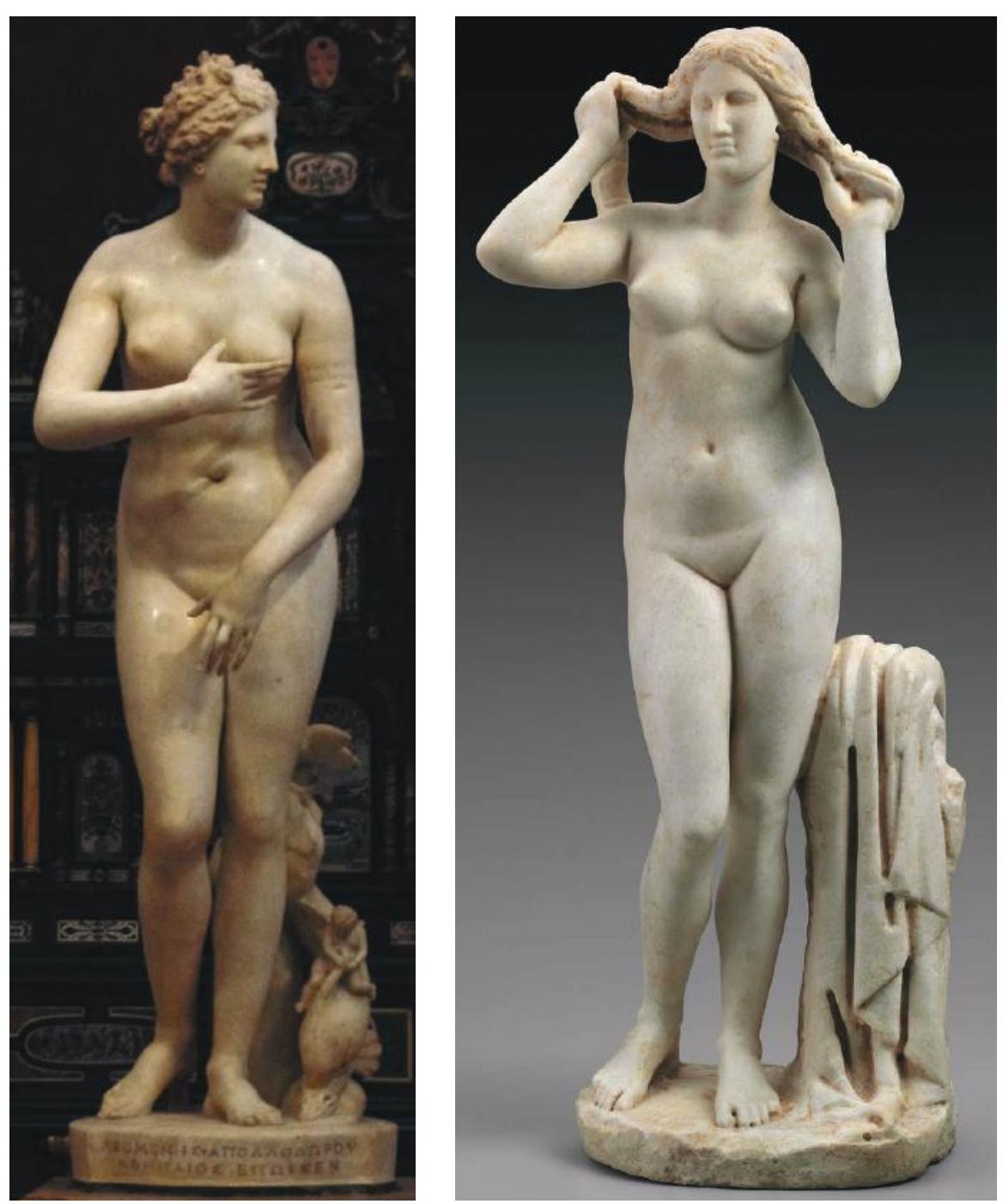

À esquerda: fig.5.33. Vênus de

Médicis. cópia do I século A.C. de uma estátua em bronze do tipo da Afrodite de Cnido, mármore. Galeria Uffizi, Florença.

Fig.5.34. Estatueta de Afrodite torcendo os cabelos. Período Helenístico ou Imperial. 100 A.C.-70 D.C., mármore. Museu de Belas Artes de Boston.

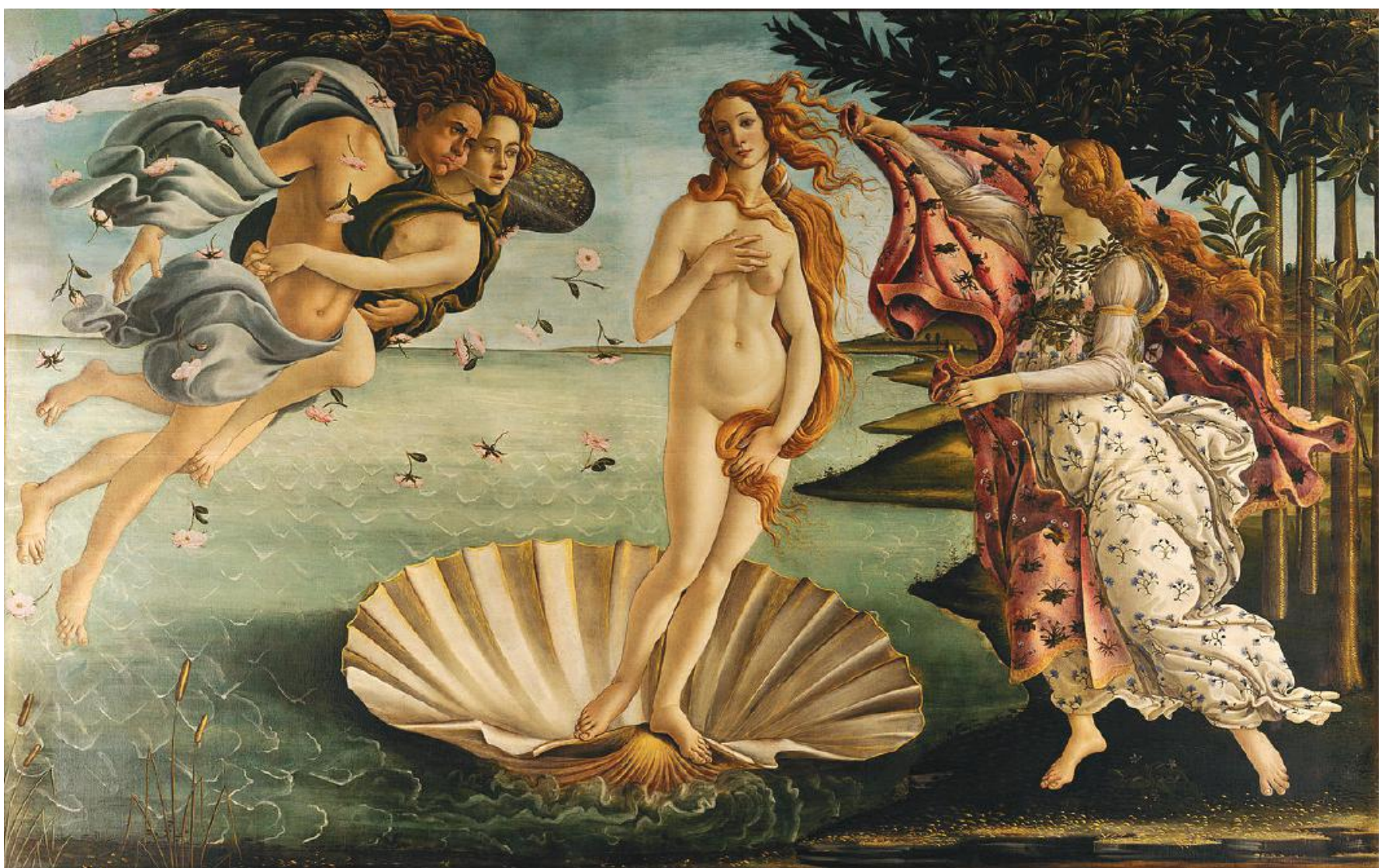

Fig.5.35. Sandro Botticelli. O nascimento de Vênus, ca. 1486., têmpera sobre tela, $172.5 \mathrm{~cm} \times 278.9$ $\mathrm{cm}$. Uffizi, Florença. 


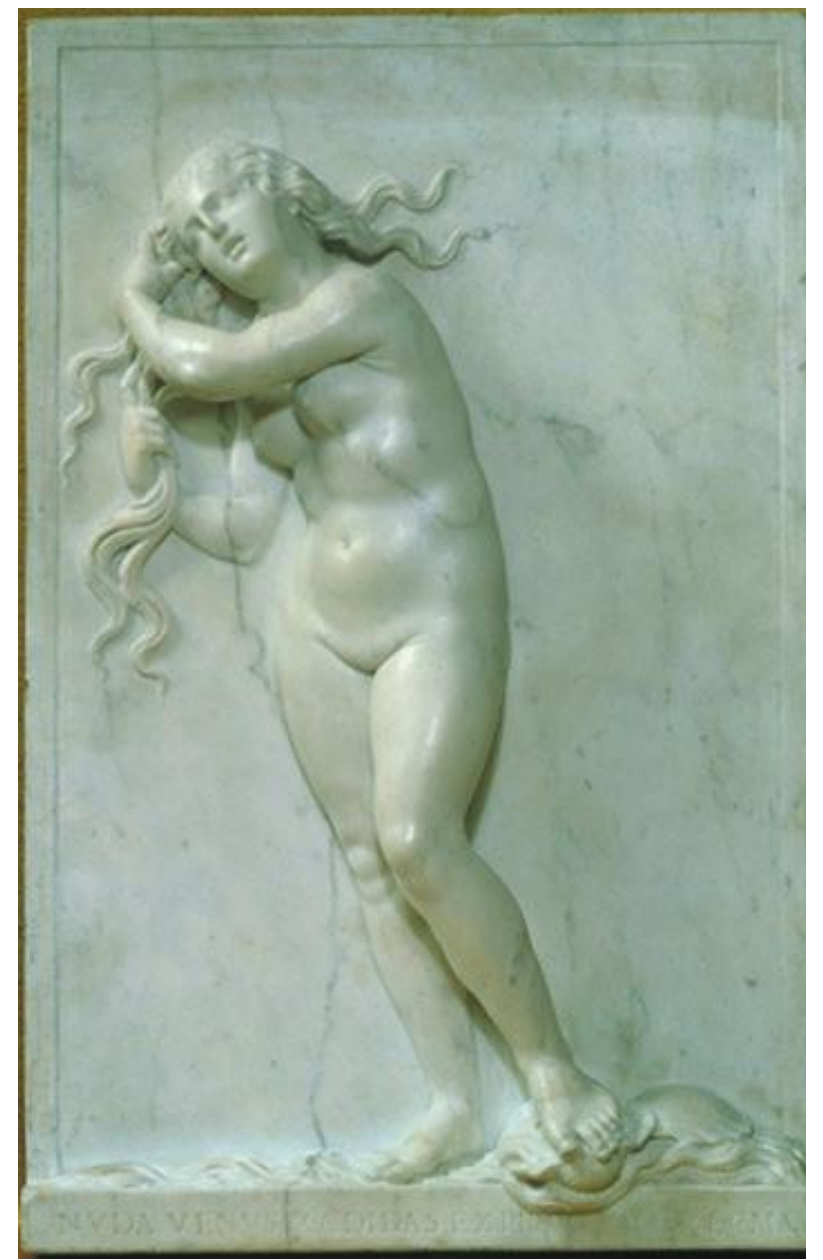

Fig.5.36. Antonio Lombardo. Vênus Anadiomêna, ca.1510-15, mármore. 41 x $23 \mathrm{~cm}$. Victoria and Albert Museum, Londres.

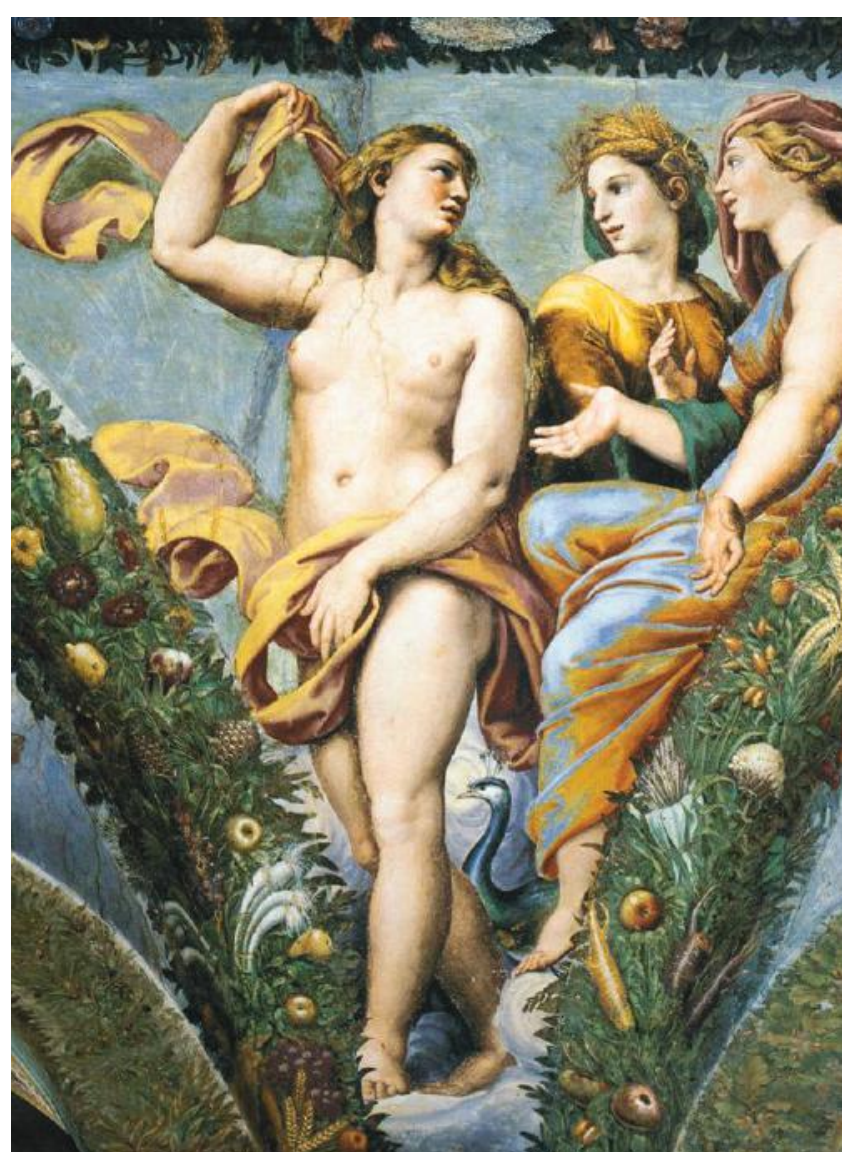

Fig.5.38. Rafael. Vênus, Ceres e Juno. 1517-18, Afresco. Villa Farnesina, Rome.

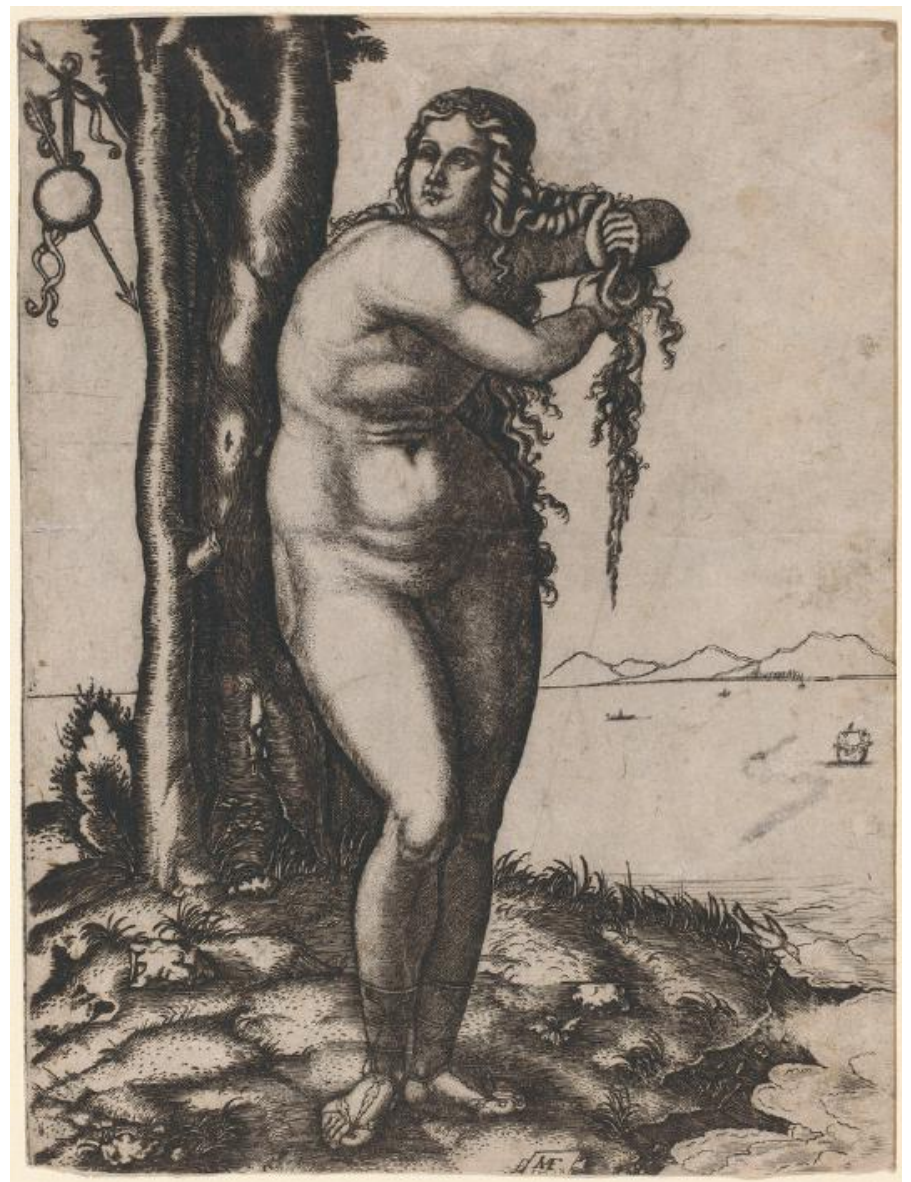

Fig.5.37. Marcantonio Raimondi. Nascimento de Vênus (ou Vênus saindo do mar). 1506, gravura, $21 \mathrm{x}$ $14.7 \mathrm{~cm}$. Museu de Arte de Boston.

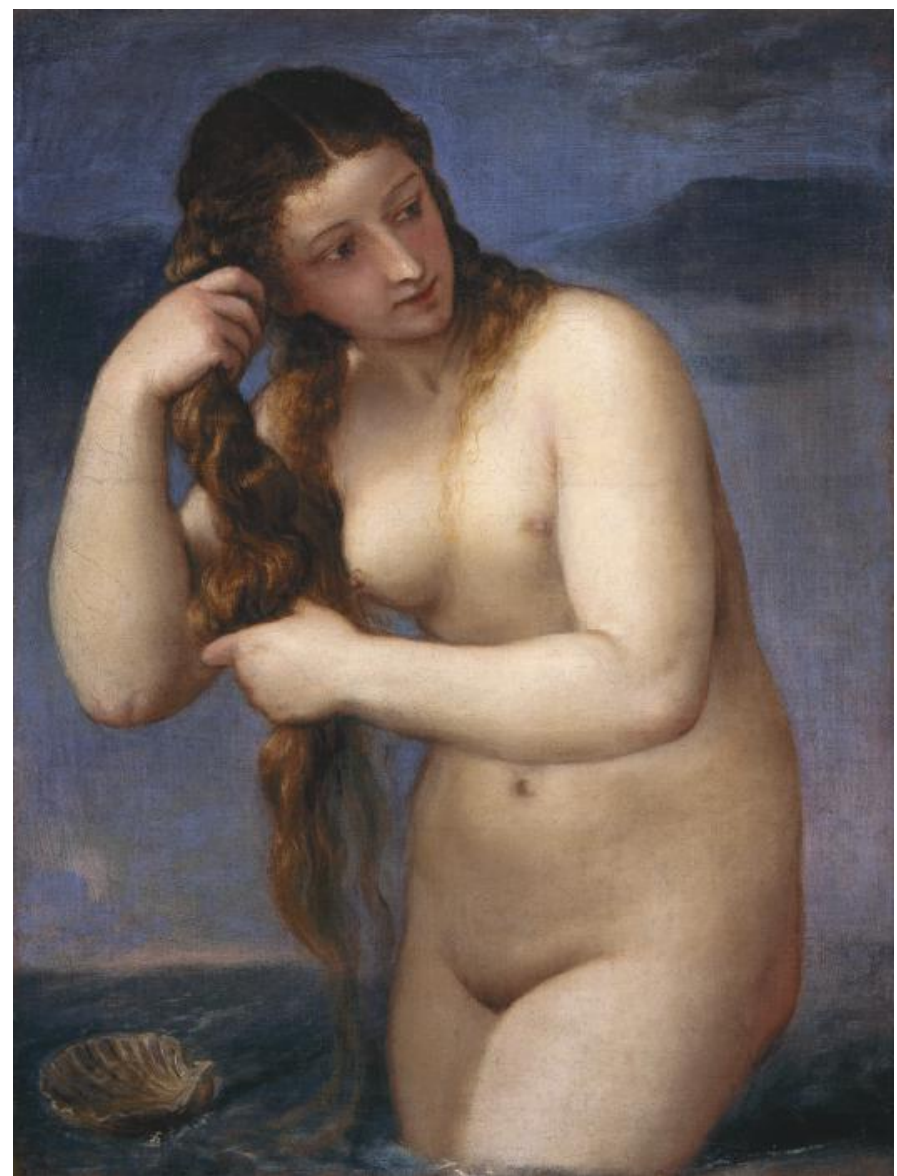

Fig.5.39. Ticiano. Vênus Anadiomêna, ca.1520, óleo sobre tela, $75.8 \times 57.6 \mathrm{~cm}$. National Galleries of Scotland. 


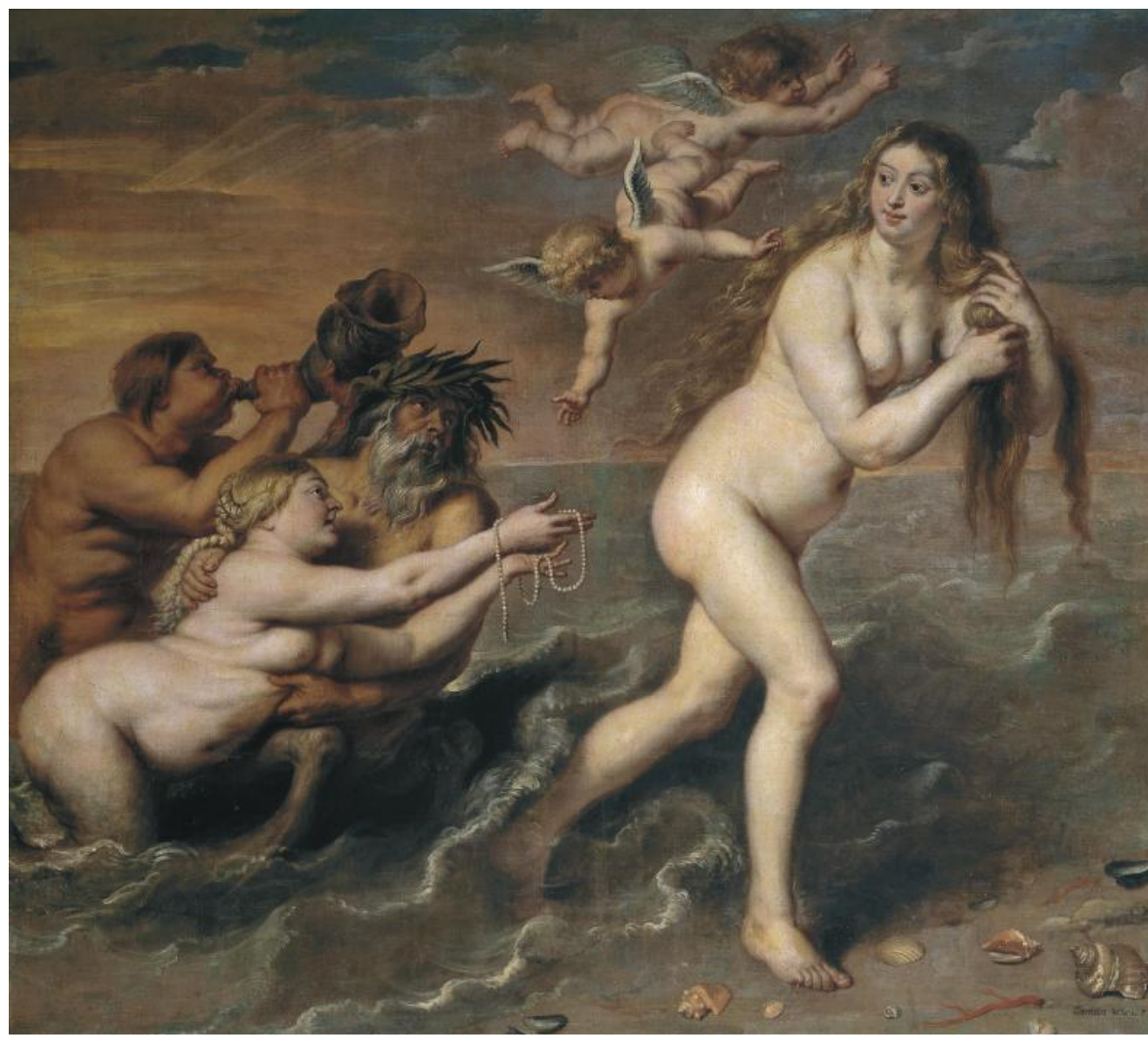

Fig.5.40. Cornelis de Vos.O nascimento de Vênus, 1636, óleo sobre tela, 187 $\mathrm{cm}$ x $208 \mathrm{~cm}$, Museu do Prado, Madri.

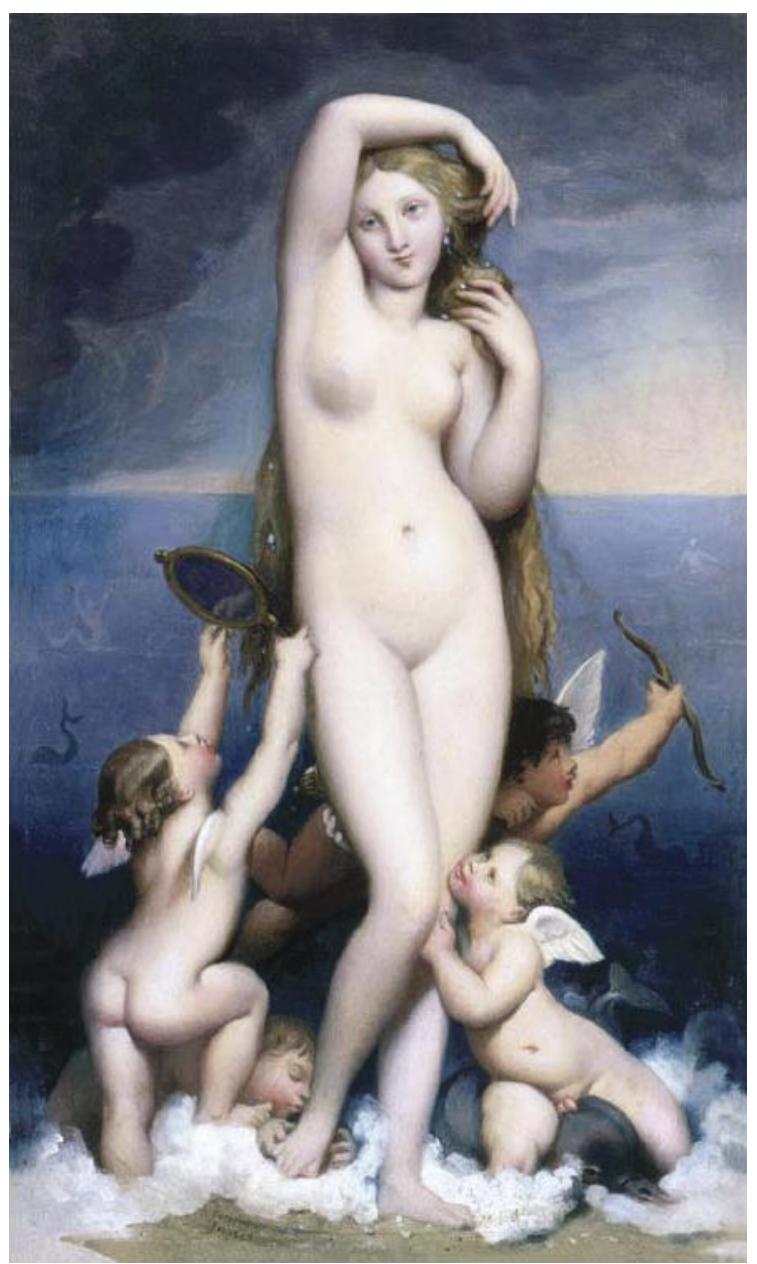

Fig.5.41. Jean-Auguste-Dominique Ingres, Vênus Anadiomêna, 1858, óleo sobre tela, 641.8 x 36 1.4. Musée Condé, Chantilly.

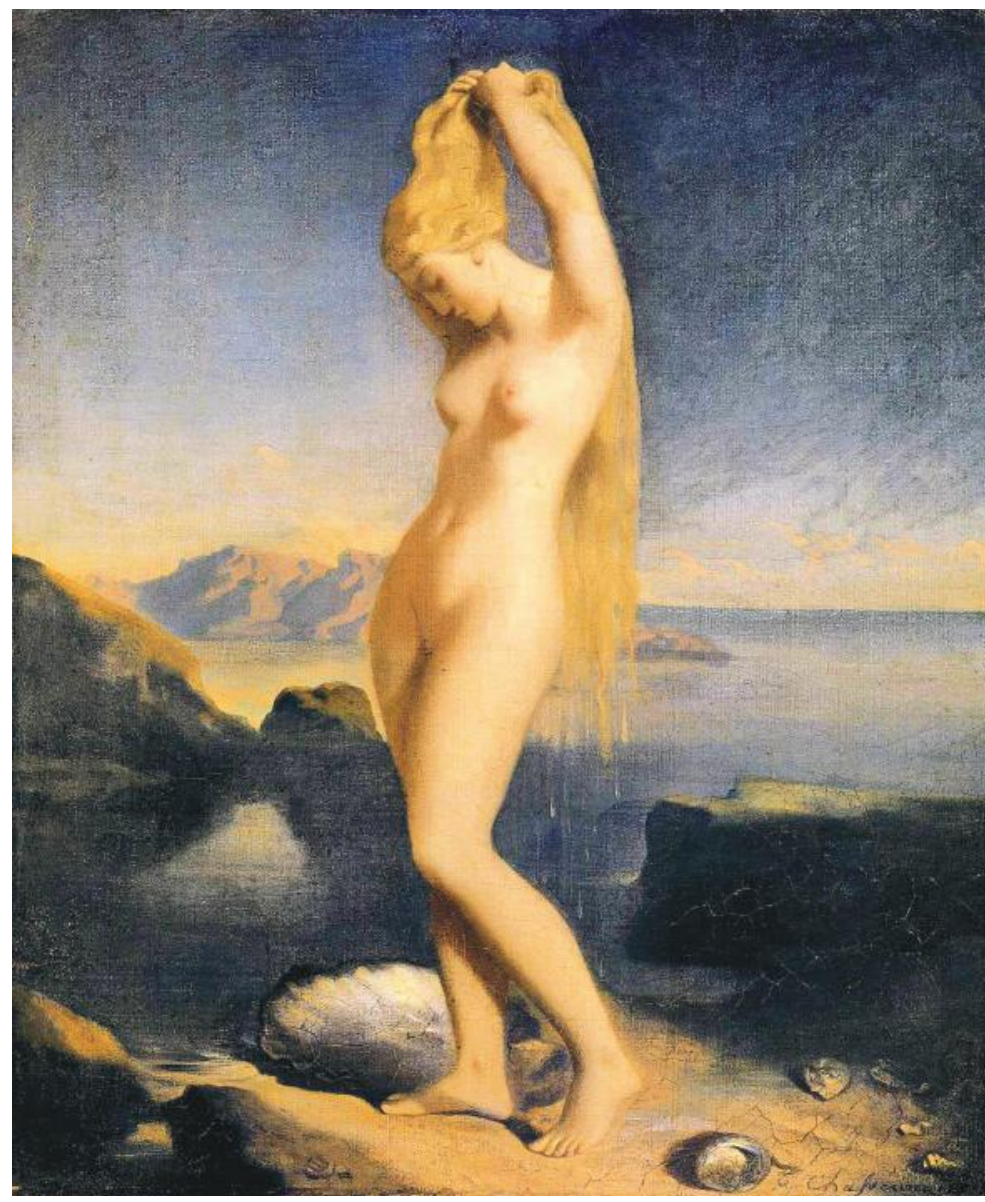

Fig.5.42. Theodore Chasseriau. Vênus marina dita Anadiomêna, 1838, óleo sobre tela, Museu do Louvre. 


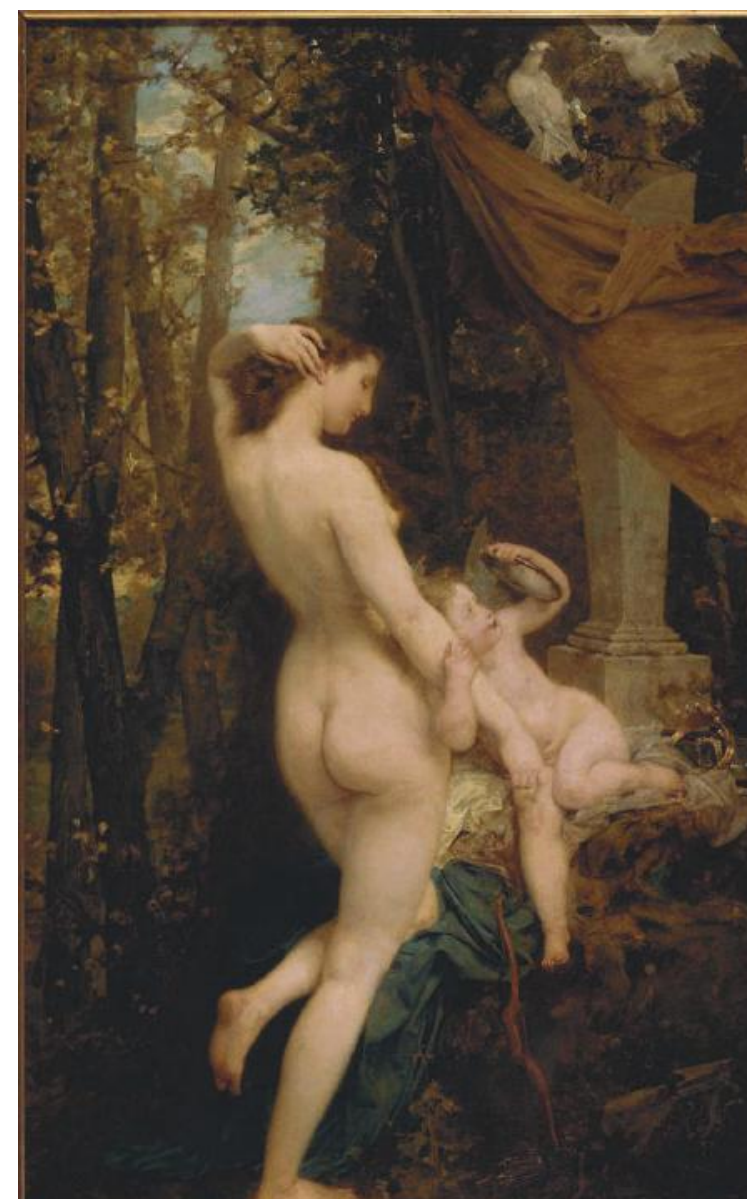

Fig.5.43. Paul Baudry. Toilette de Vênus, 1858, óleo sobre tela. Museu de bordeaux.

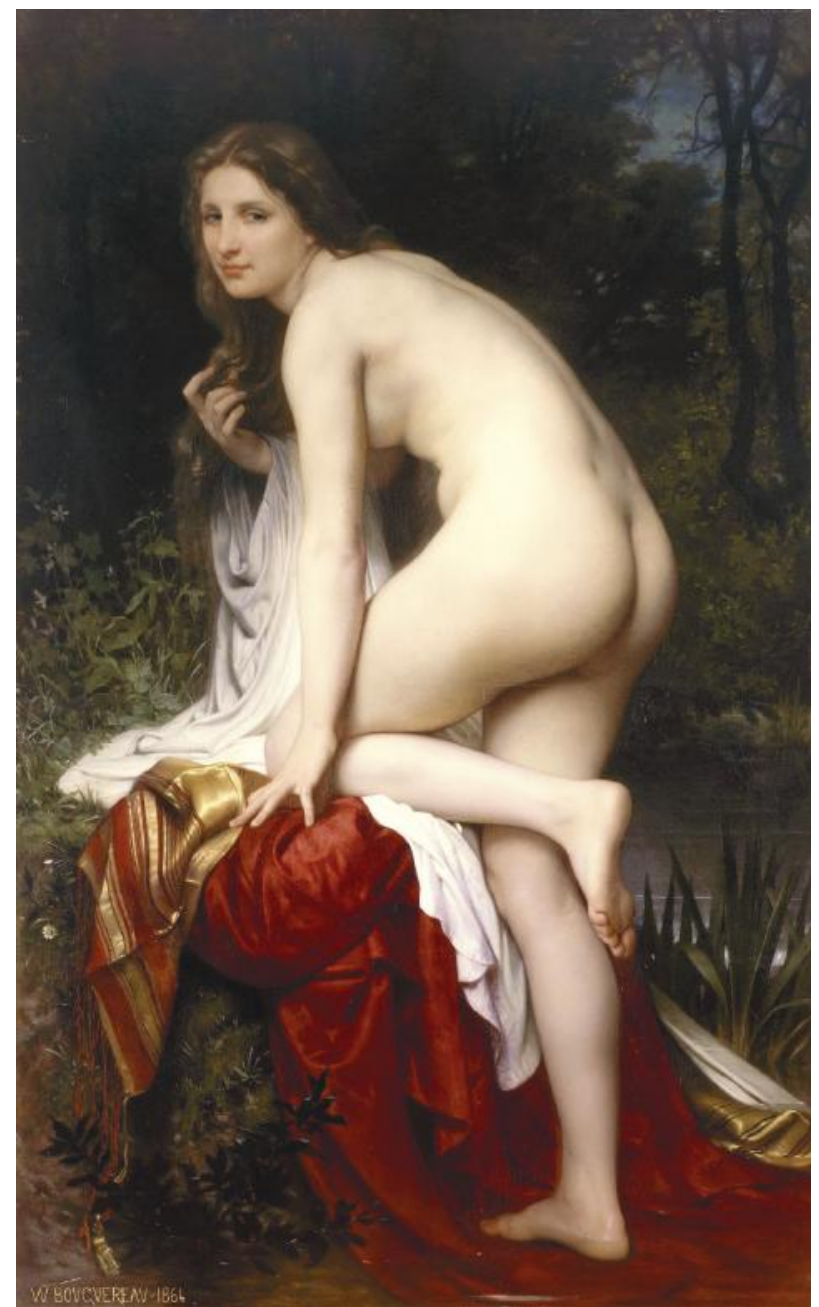

Fig.5.45. William-Adolphe Bouguereau. Banhista, 1864, óleo sobre tela. 166.5 x $103.5 \mathrm{~cm}$. Museum voor Schone Kunsten, Ghent.

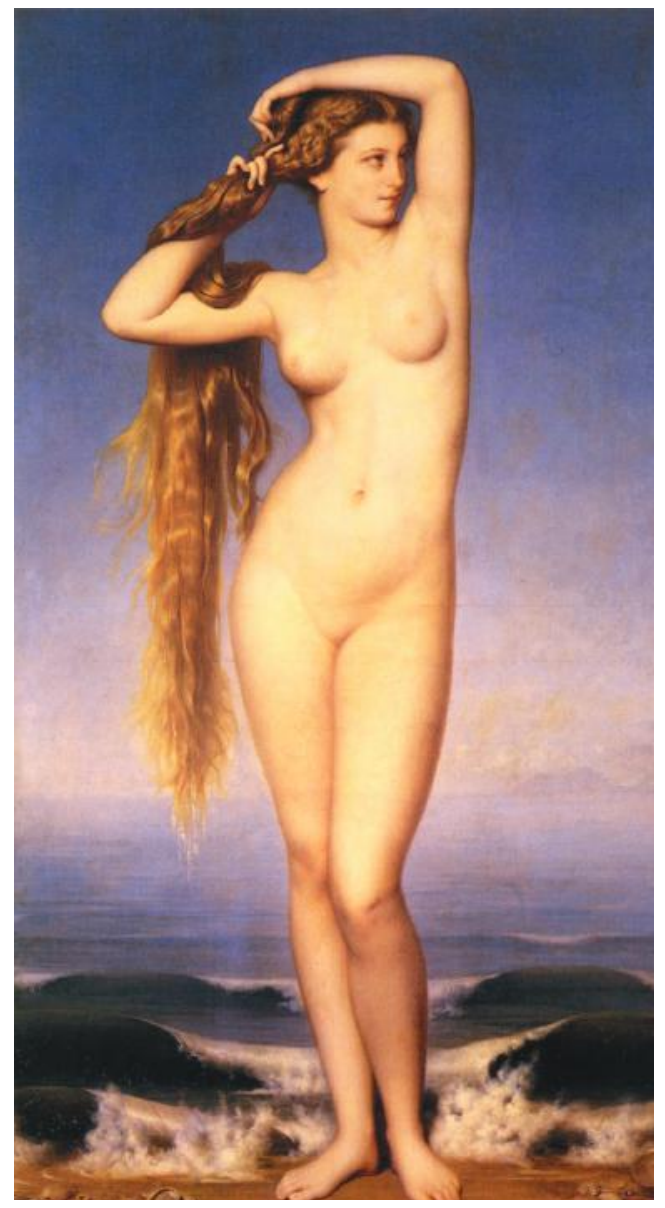

Fig.5.44. Amaury-Duval. O nascimento de Vênus, 1862, óleo sobre tela, $196.85 \times 108.90 \mathrm{~cm}$. Palais des beaux-arts de Lille.

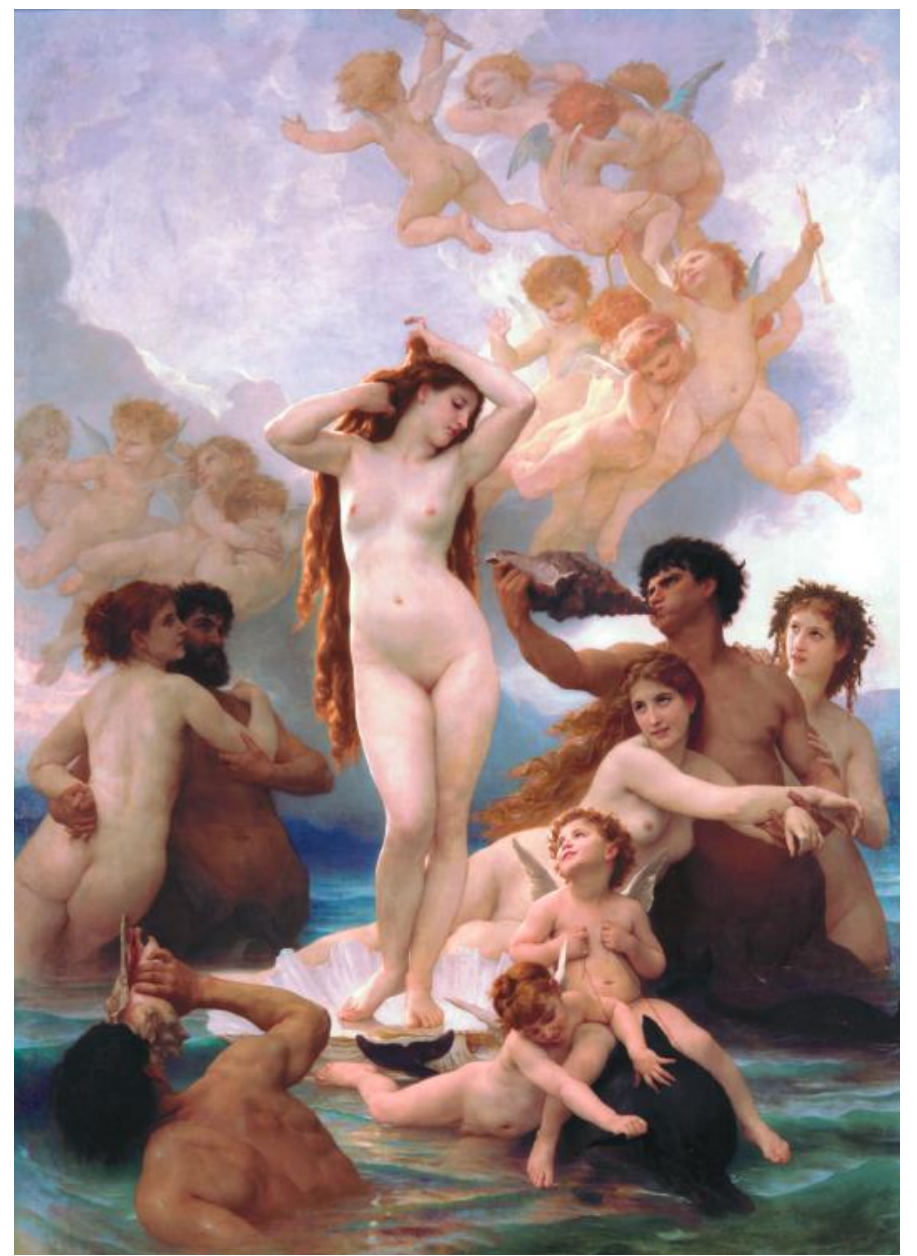

Fig.5.46. Bouguereau. O nascimento de Vênus, 1879, óleo sobre tela. 300 x $218 \mathrm{~cm}$. Musée d'Orsay, Paris. 


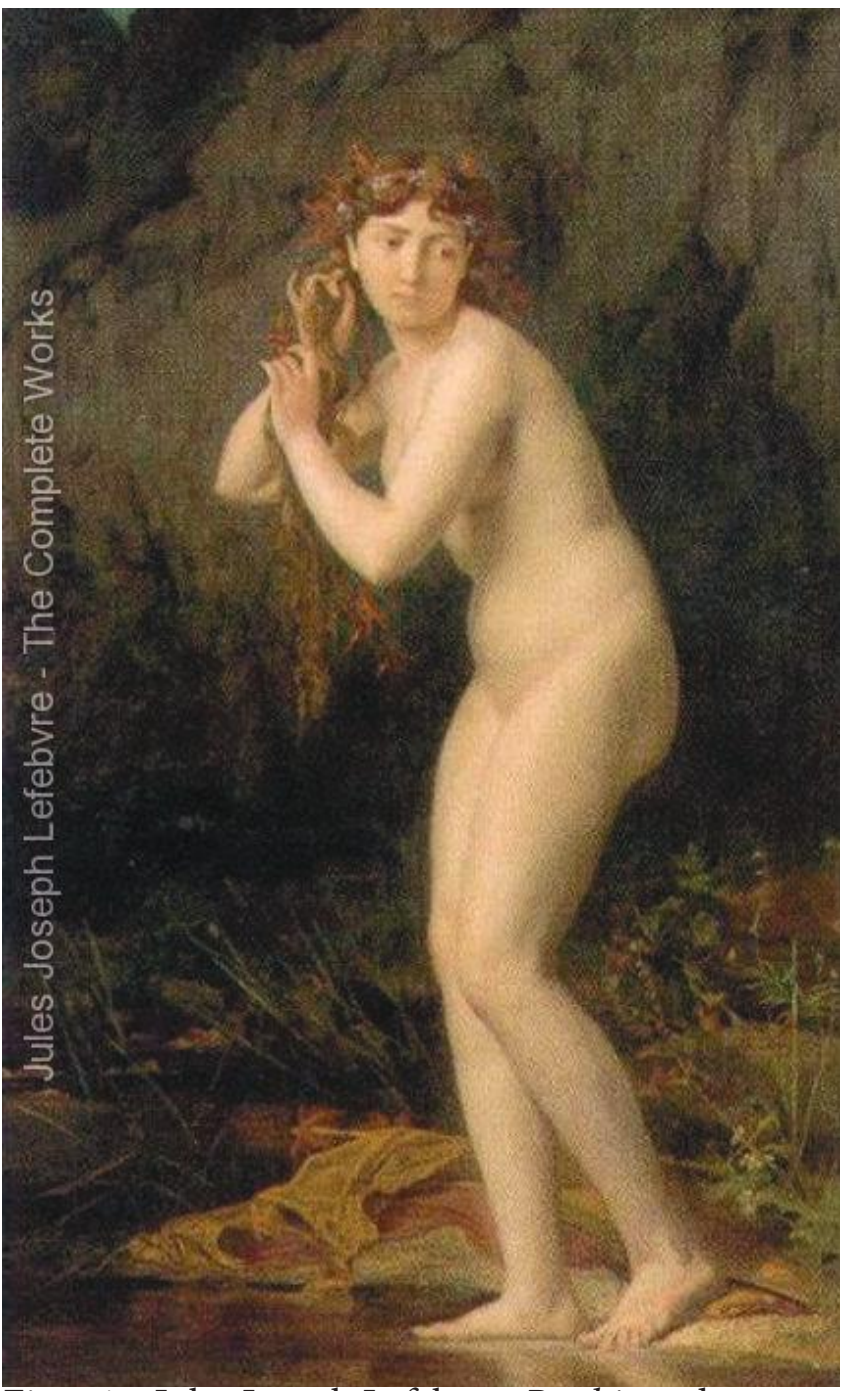

Fig.5.47. Jules Joseph Lefebvre. Banhista. data desconhecida, óleo sobre tela, 60 x $95 \mathrm{~cm}$. Localização não encontrada.

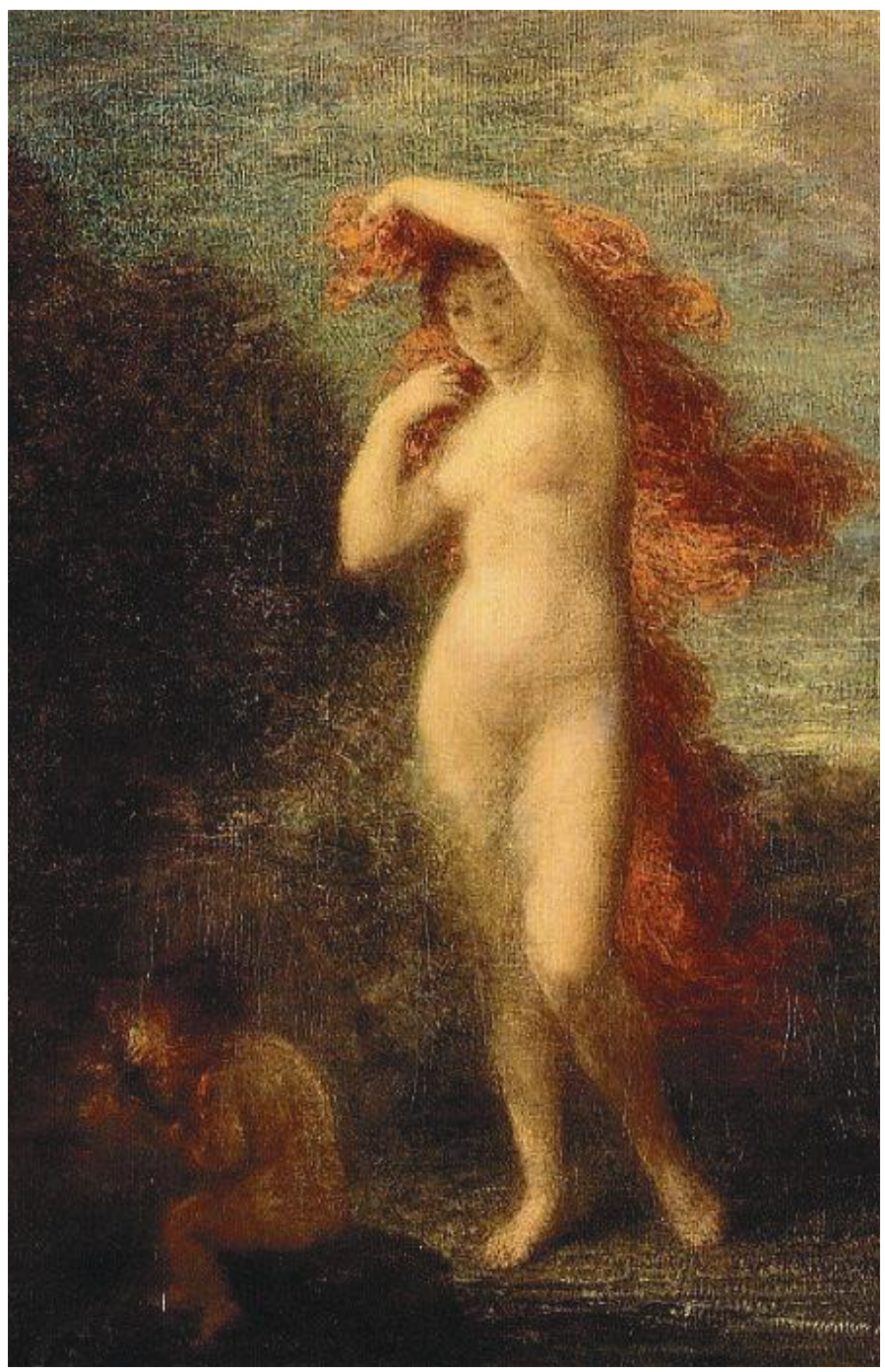

Fig.5.48. Henri Fantin-Latour. Vênus e cupido, 1902, óleo sobre tela. Coleção privada.

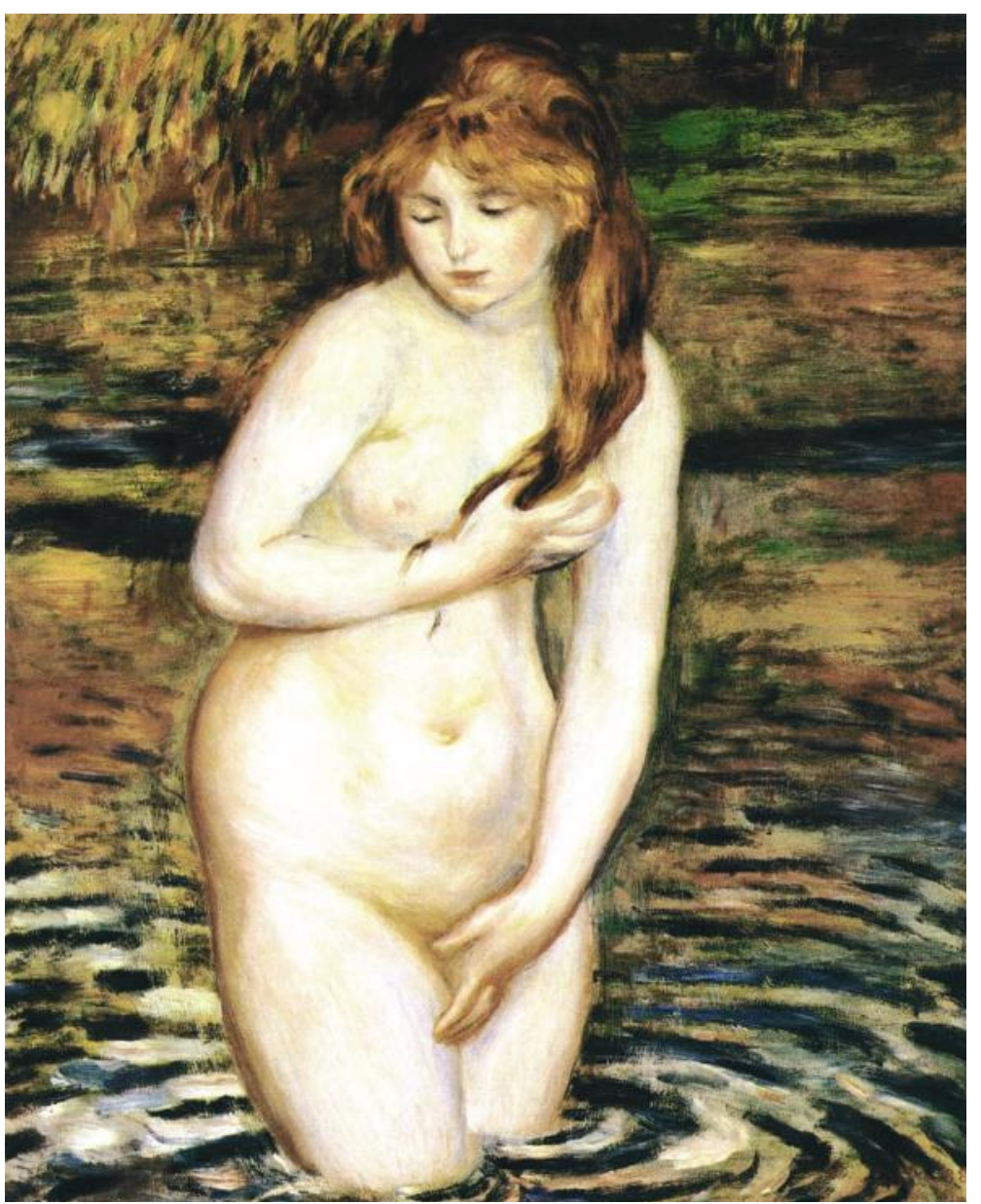

Fig.5.49. Pierre-Auguste Renoir. Banhista. 1888, óleo sobre tela, 81 x $66 \mathrm{~cm}$. Private collection. 


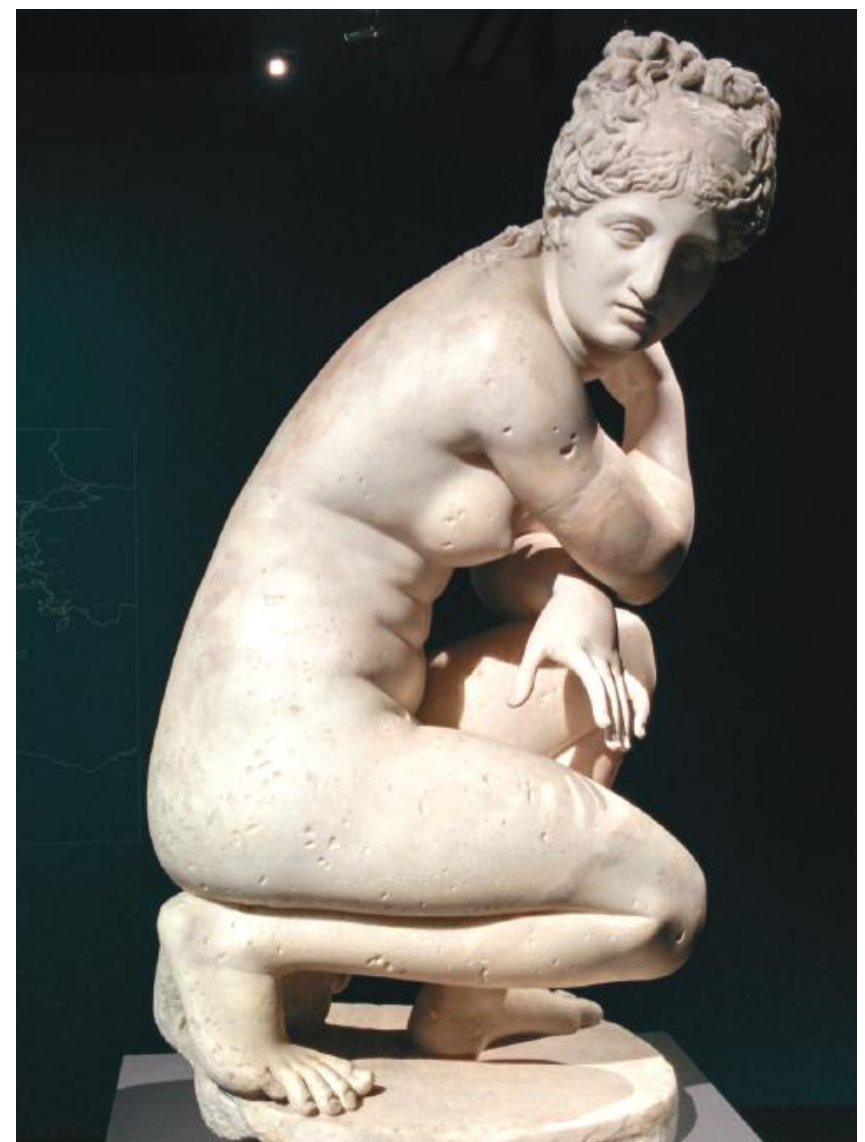

Fig.5.50. Afrodite Agachada. Cópia romana do II século D.C. a partir do original do século III ou II A.C de Doidalsas. Casa Real Inglesa, Londres.

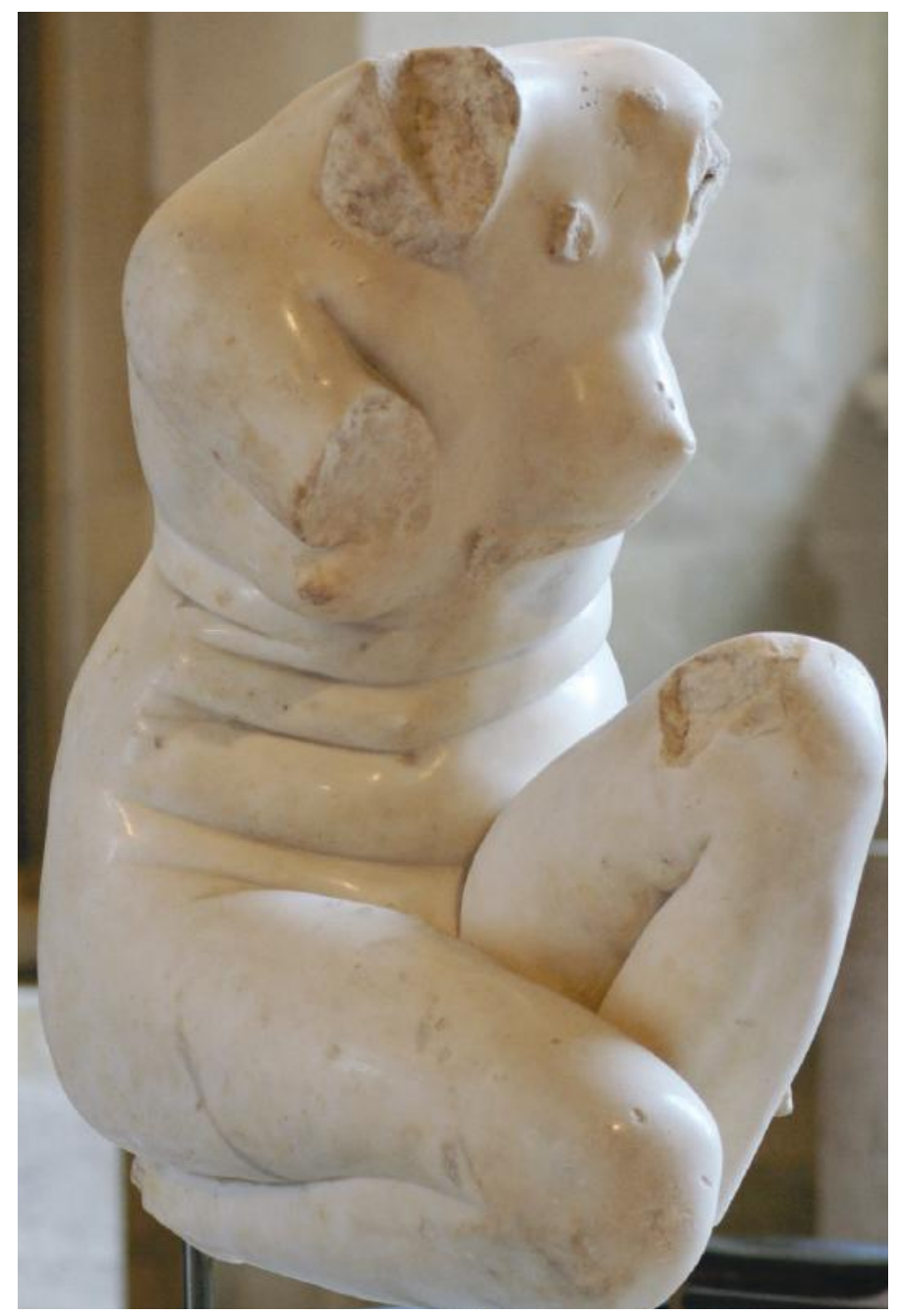

Fig.5.52. Afrodite agachada. Cópia romana do I ou II século D.C. Mármore. Museu do Louvre, Paris.

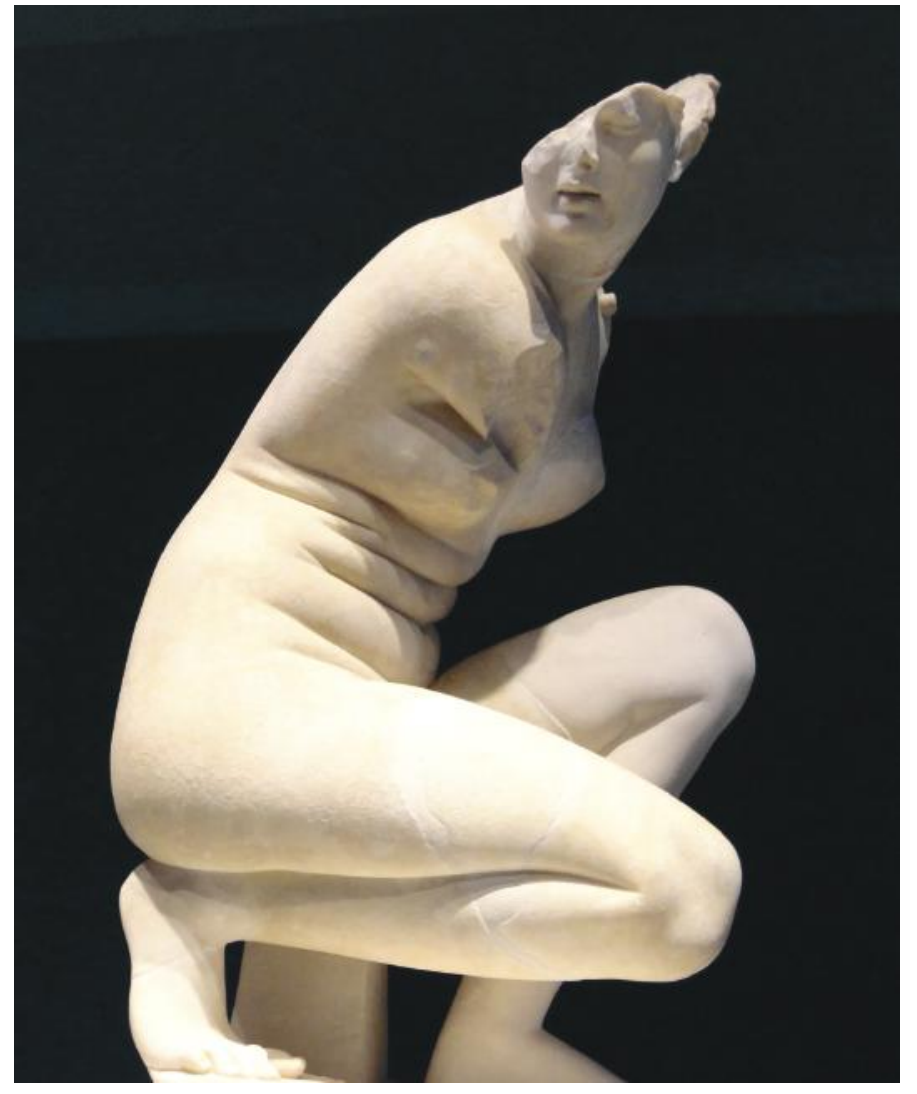

Fig.5.51. Aphrodite de Doidalsas. Cópia romana da Villa Hadriana. ROme, Museo Nazionale Romano. Palazzo Massimo alle Terme.

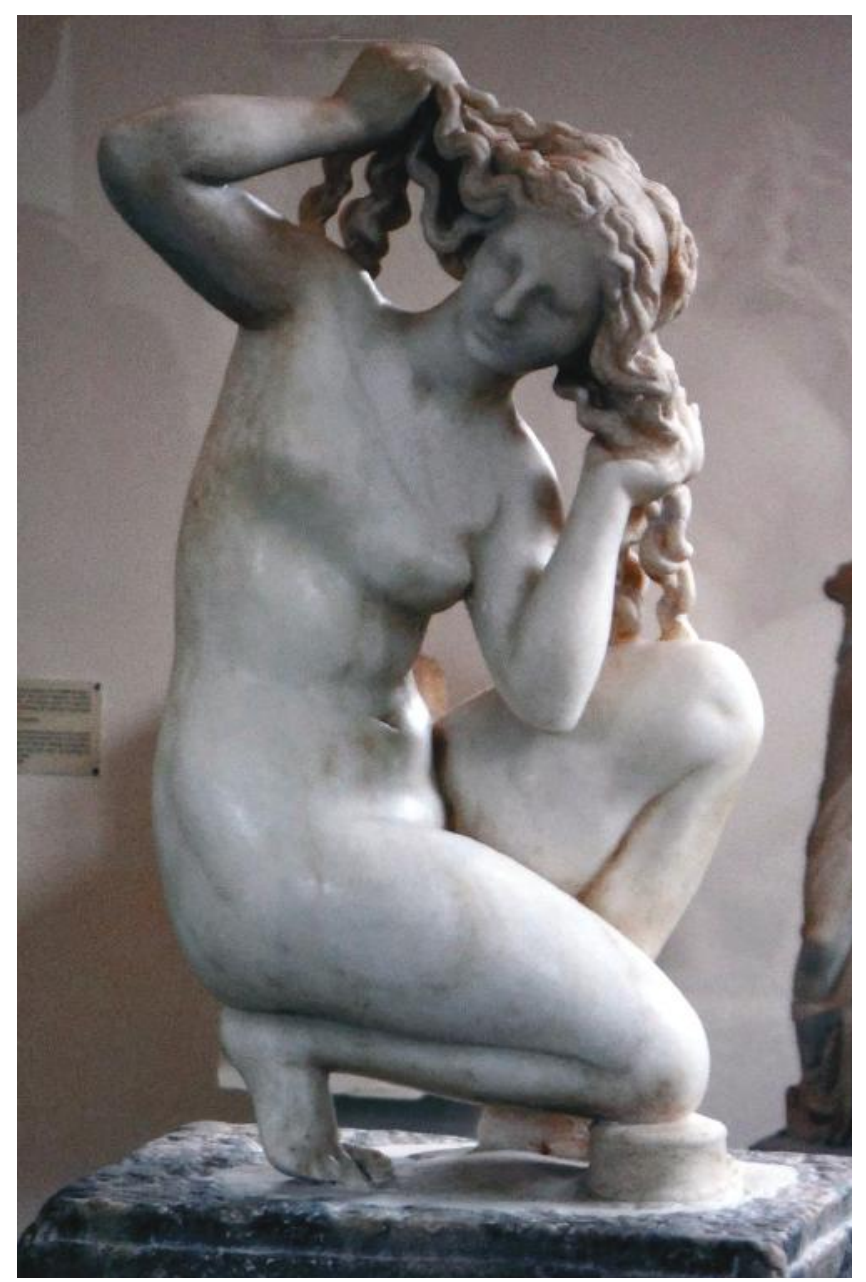

Fig.5.53. Autor desconhecido. Venus de Rhodes. I século A.C, mármore. Archaeological Museum of Rhodes. 


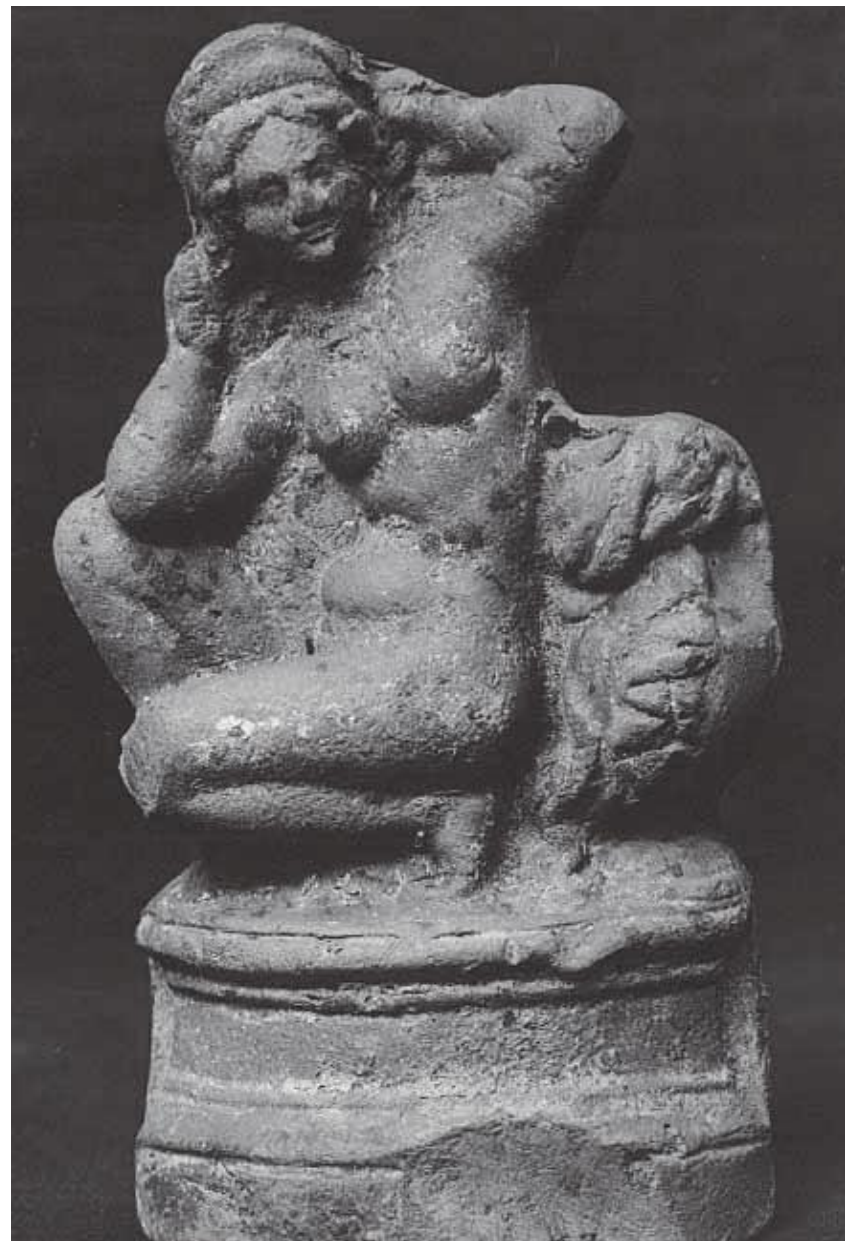

Fig.5.54. Afrodite agachada Anadiomêna. I século A.C., argila. Museu do Louvre.

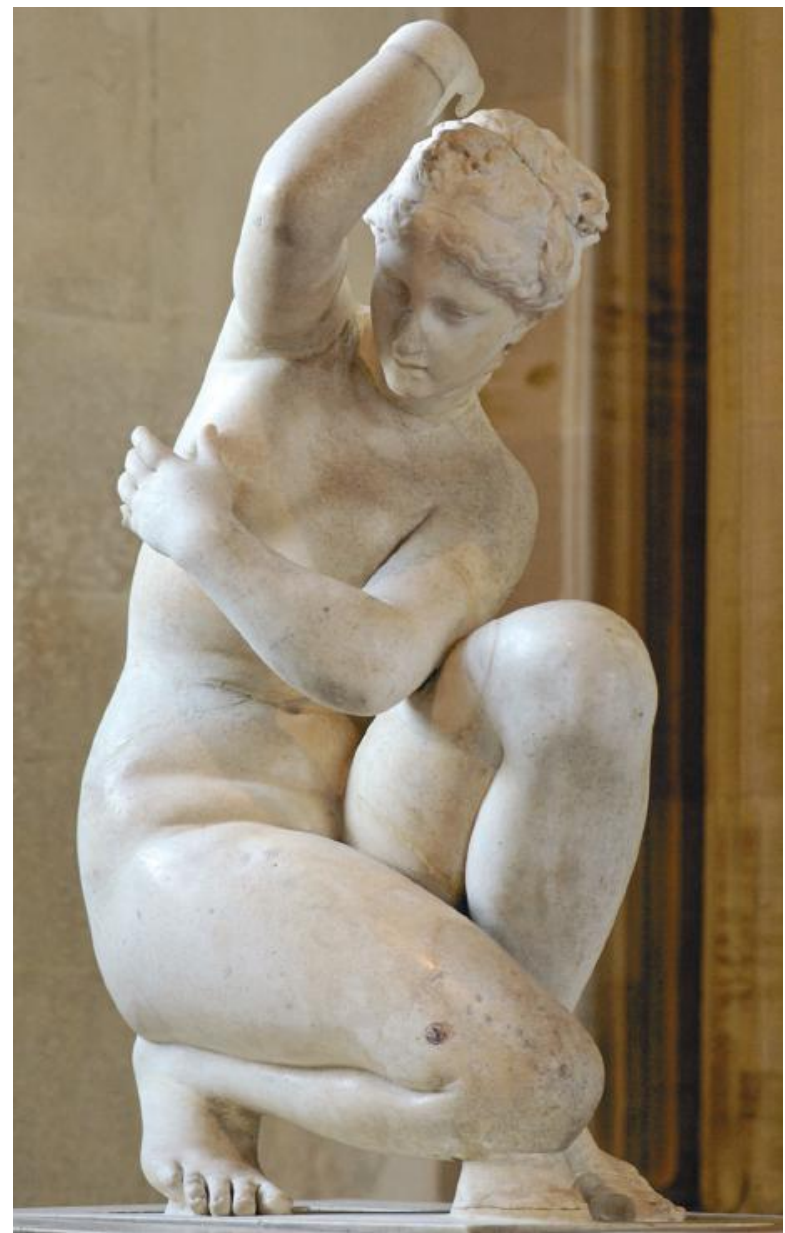

Fig.5.56. Afrodite agachada. Variante romana da época imperial a partir de um tema helenístico, màrmore. Museu do Louvre.

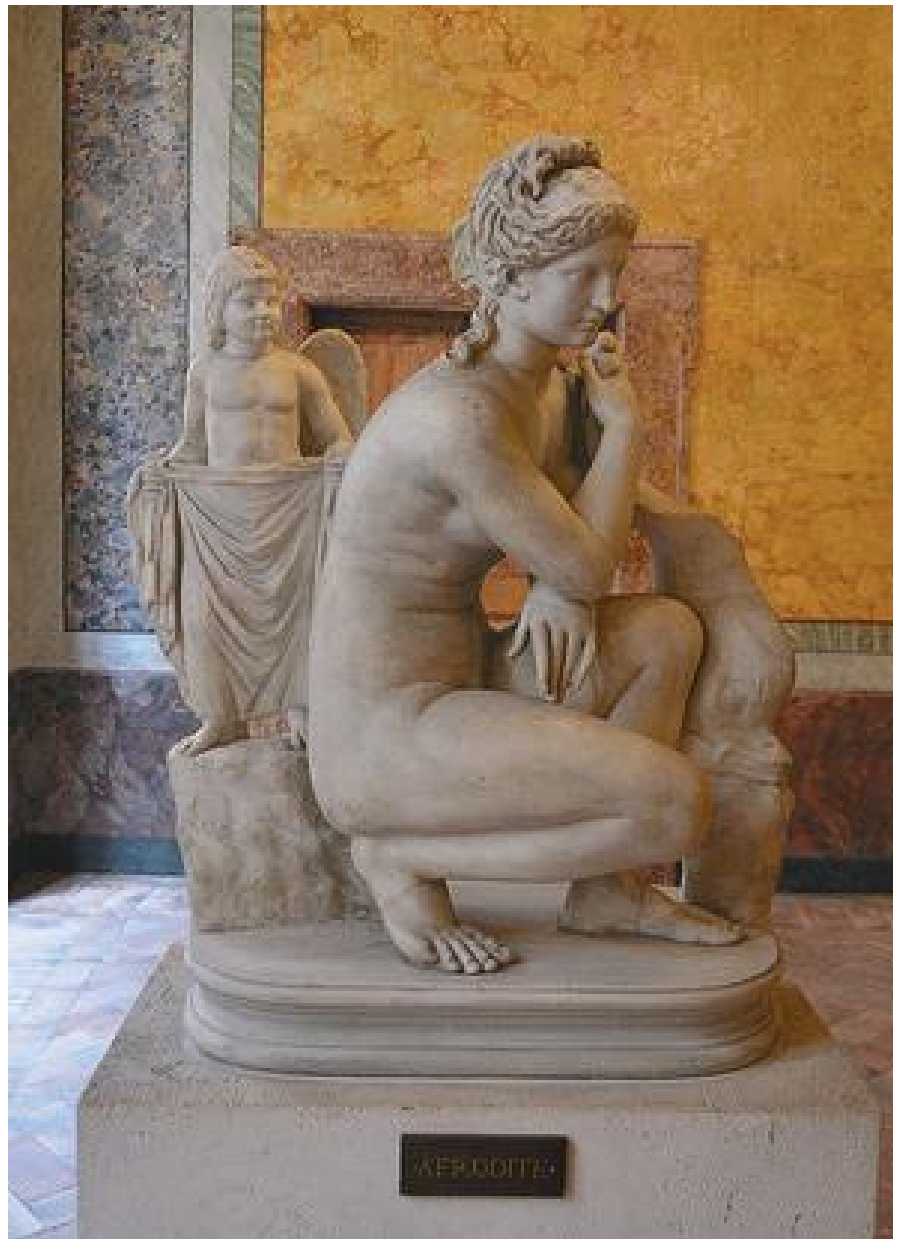

Fig.5.55. Afrodite ao banho. Variação romana do original grego atribuído a Doidalsas, mármore. Palacio Altemps, Roma.

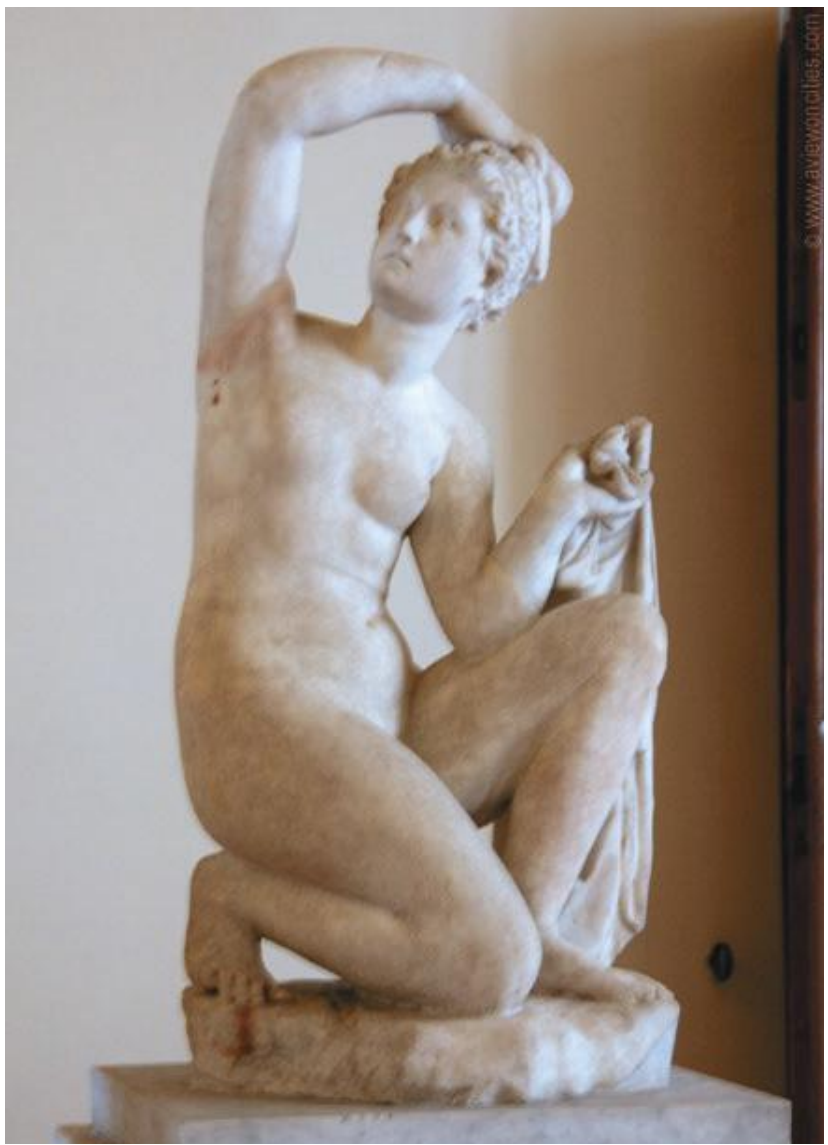

Fig.5.57. Afrodite em seu banho. Variação do original de helenístico de Doidalsas, mármore. Coleção Ludovisi. Coleção Cesi. Palácio Altemps, Roma. 

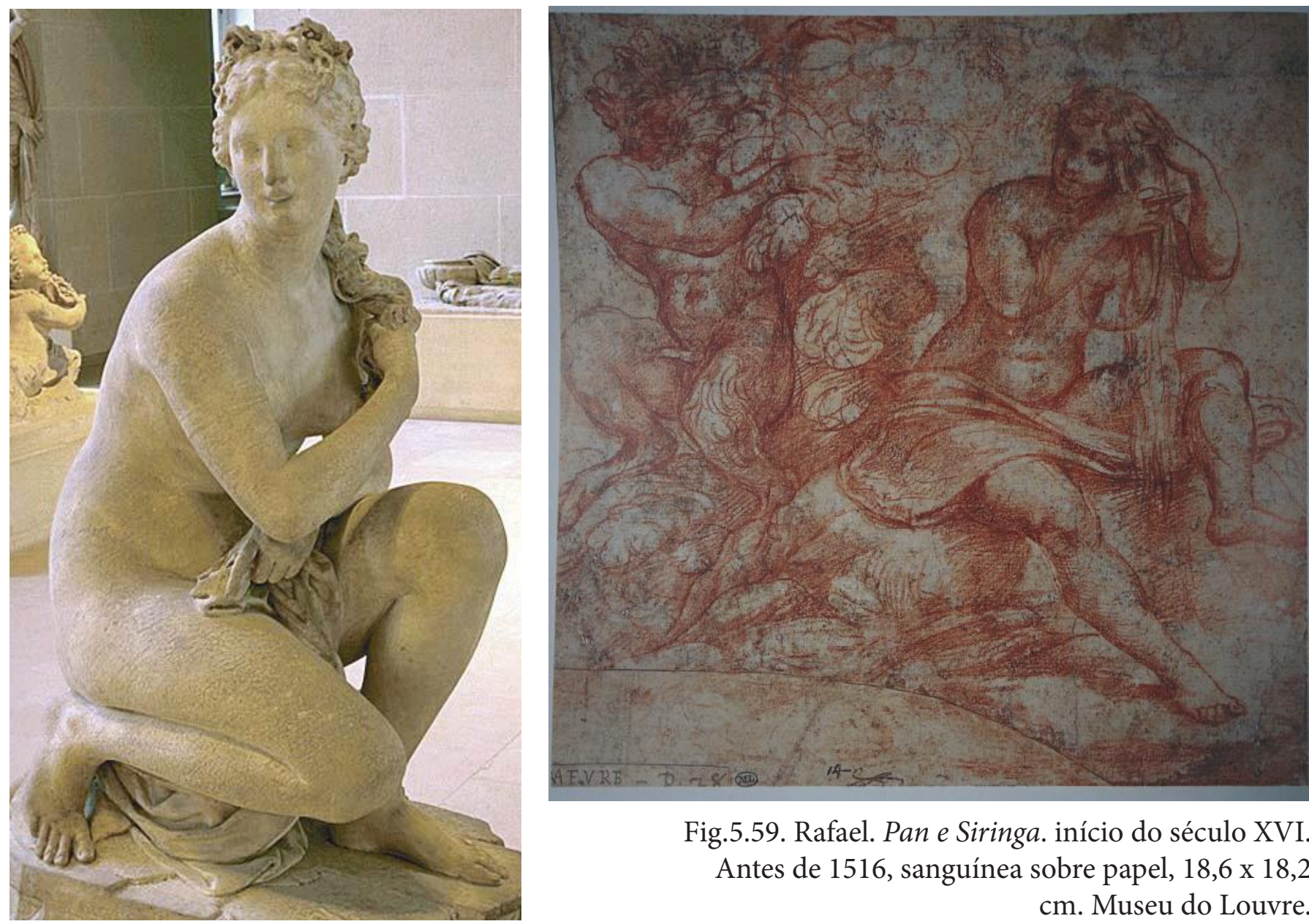

Fig.5.59. Rafael. Pan e Siringa. início do século XVI. Antes de 1516, sanguínea sobre papel, 18,6 x 18,2 $\mathrm{cm}$. Museu do Louvre.

Fig.5.58. Charles Antoine Coysevox.

Vénus agachada, mármore. 1686. Musée du Louvre. Na base da obra o artista havia inscrita a falta assinatura de Fídias.

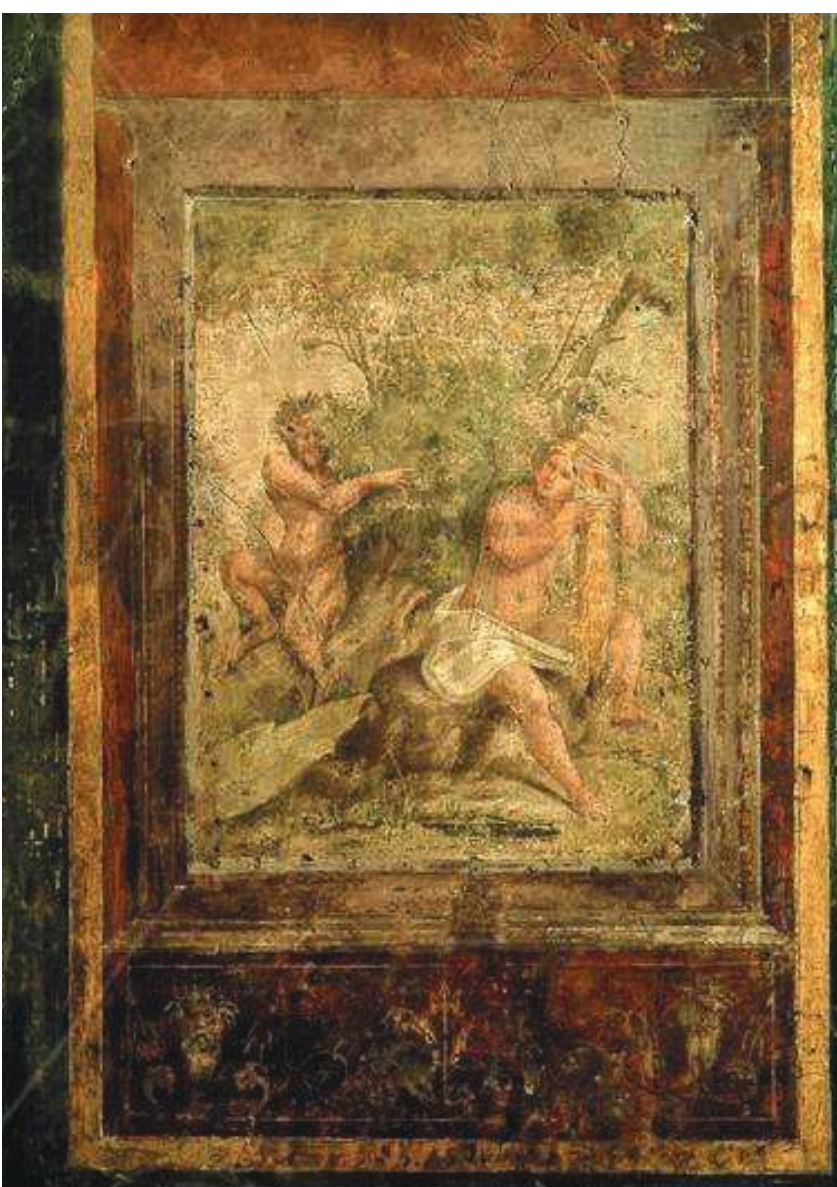

rig.5.60. Kätael. Pan e siringa. 1b16, atresco na parede oeste do banheiro do cardeal Bibbiena. Vaticano, Roma.

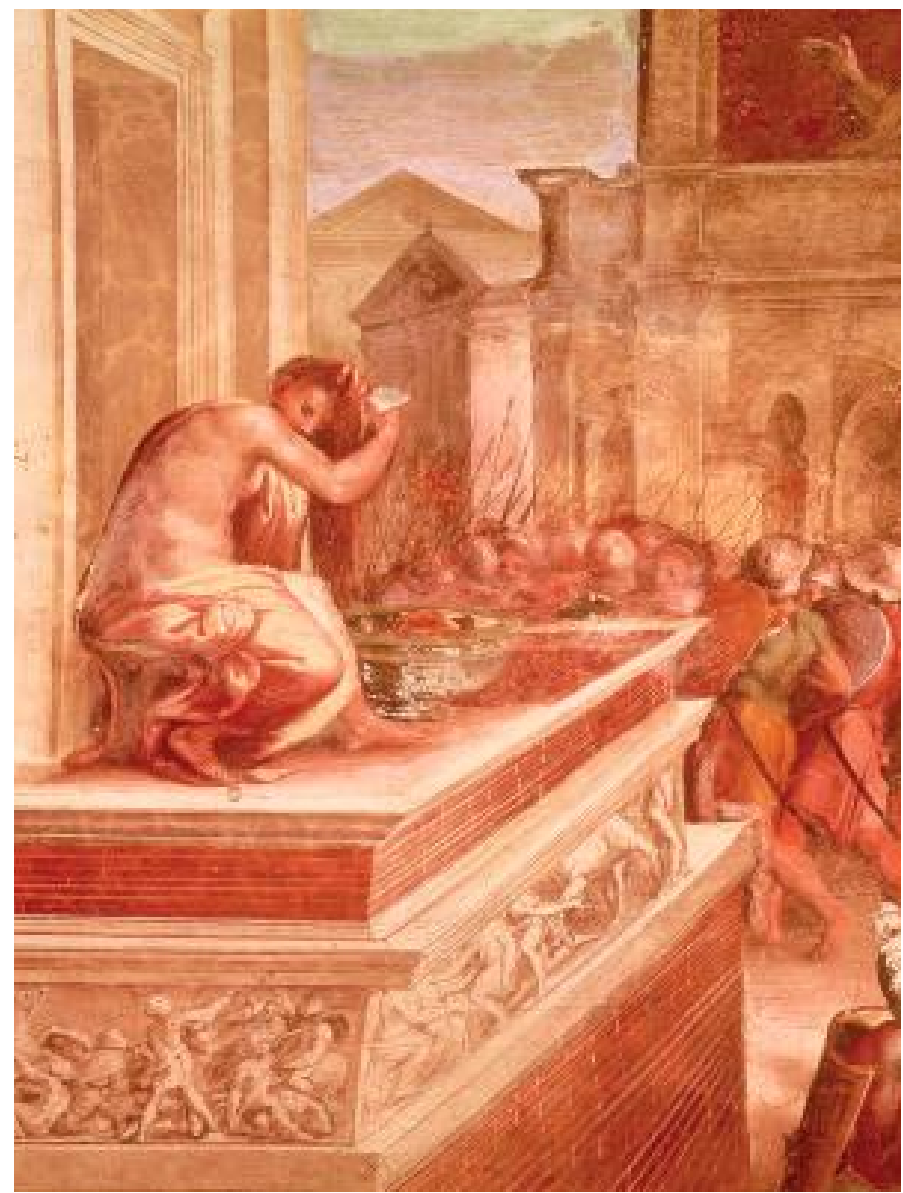

Fig.5.61. Rafael. Davi e Betsabéia. ca.1517, afresco. Roma, Vaticano. 


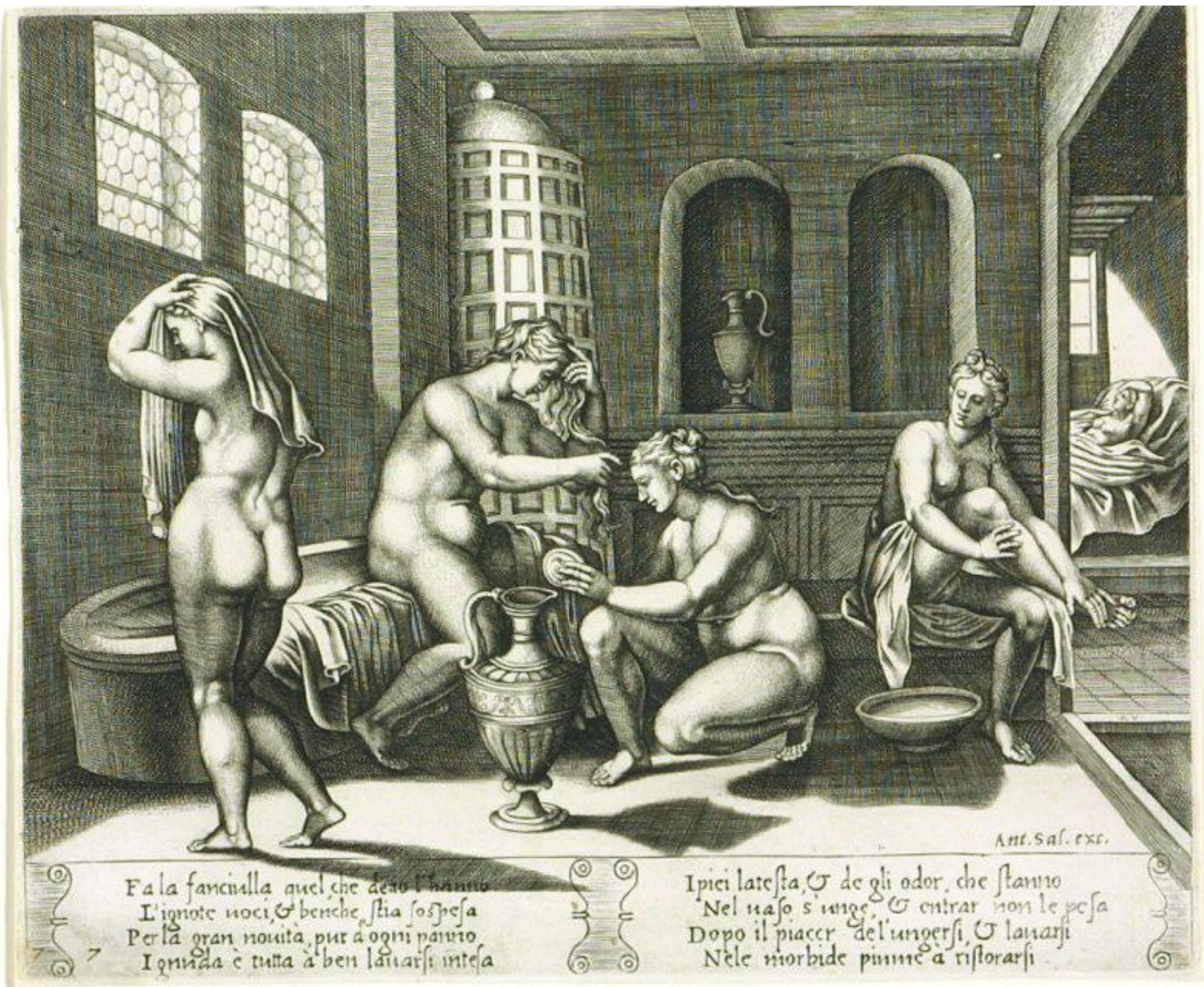

Fig.5.62. Agostino dei Musi (a partir de Rafa-

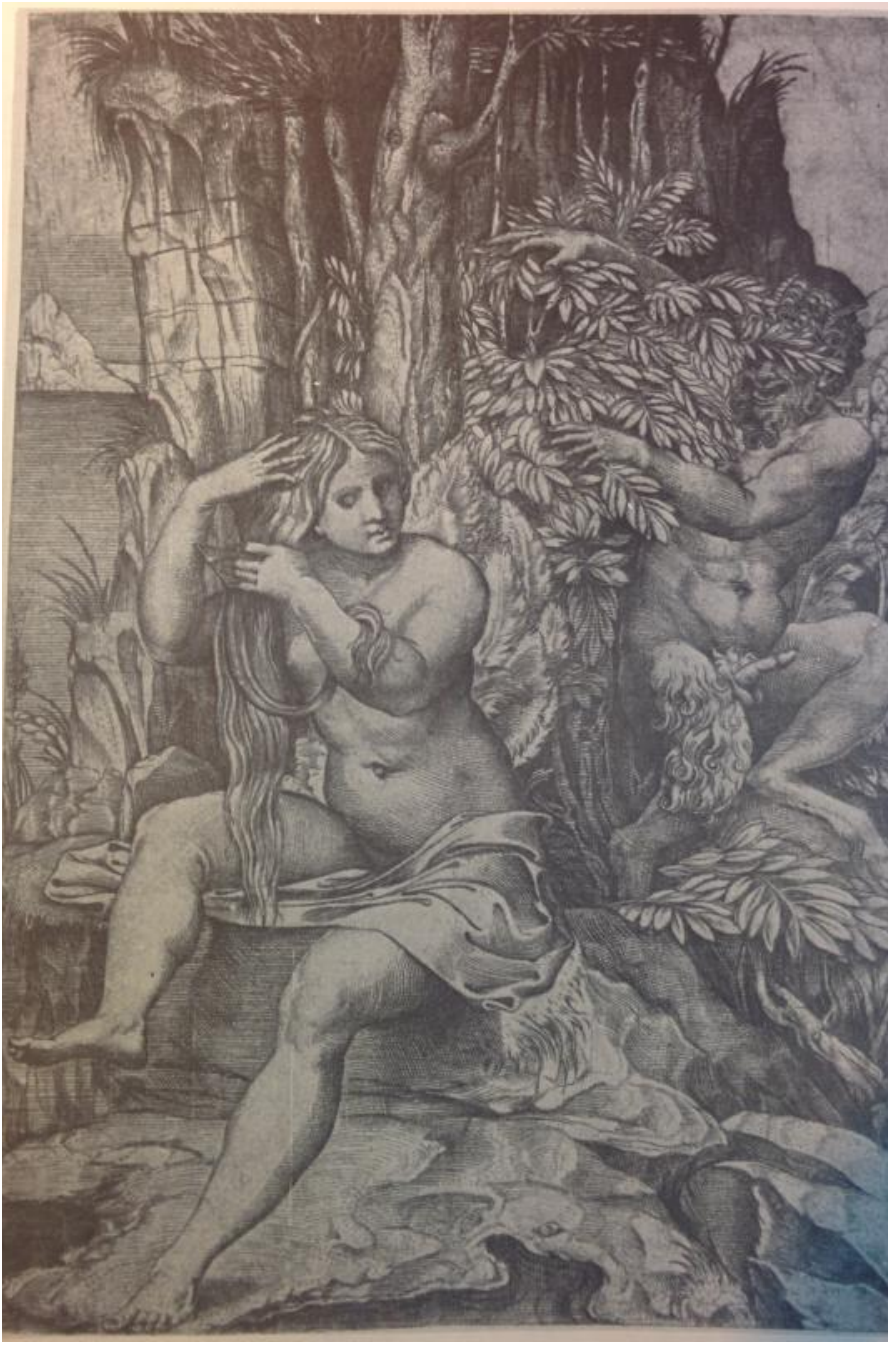

el). Vênus atendida em seu banho, gravura. 19.6 x $23.6 \mathrm{~cm}$. Publicado por Antonio Salamanca, 1530-60.

Fig.5.63. Marcantonio Raimondi (a partir de Rafael). Pan e Siringa, gravura, 24.7 x $17 \mathrm{~cm}$. Graphische Sammlung Albertina, Viena. 


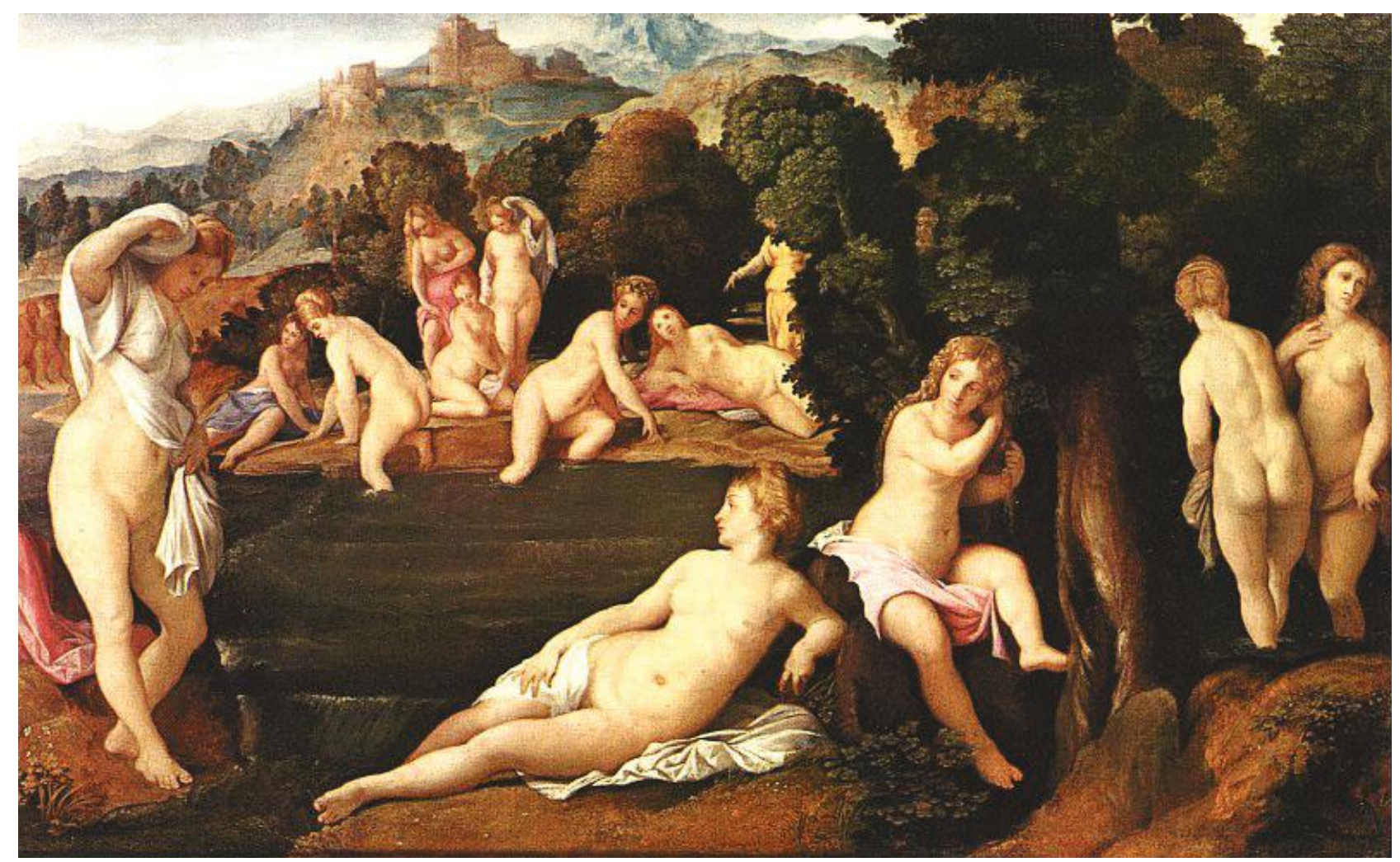

Fig.5.64. Palma Vecchio. Diana e Calisto. 1525/1528. Óleo sobre tela, 77.5 x 124 cm. Kunsthistoriches Museum, Viena.

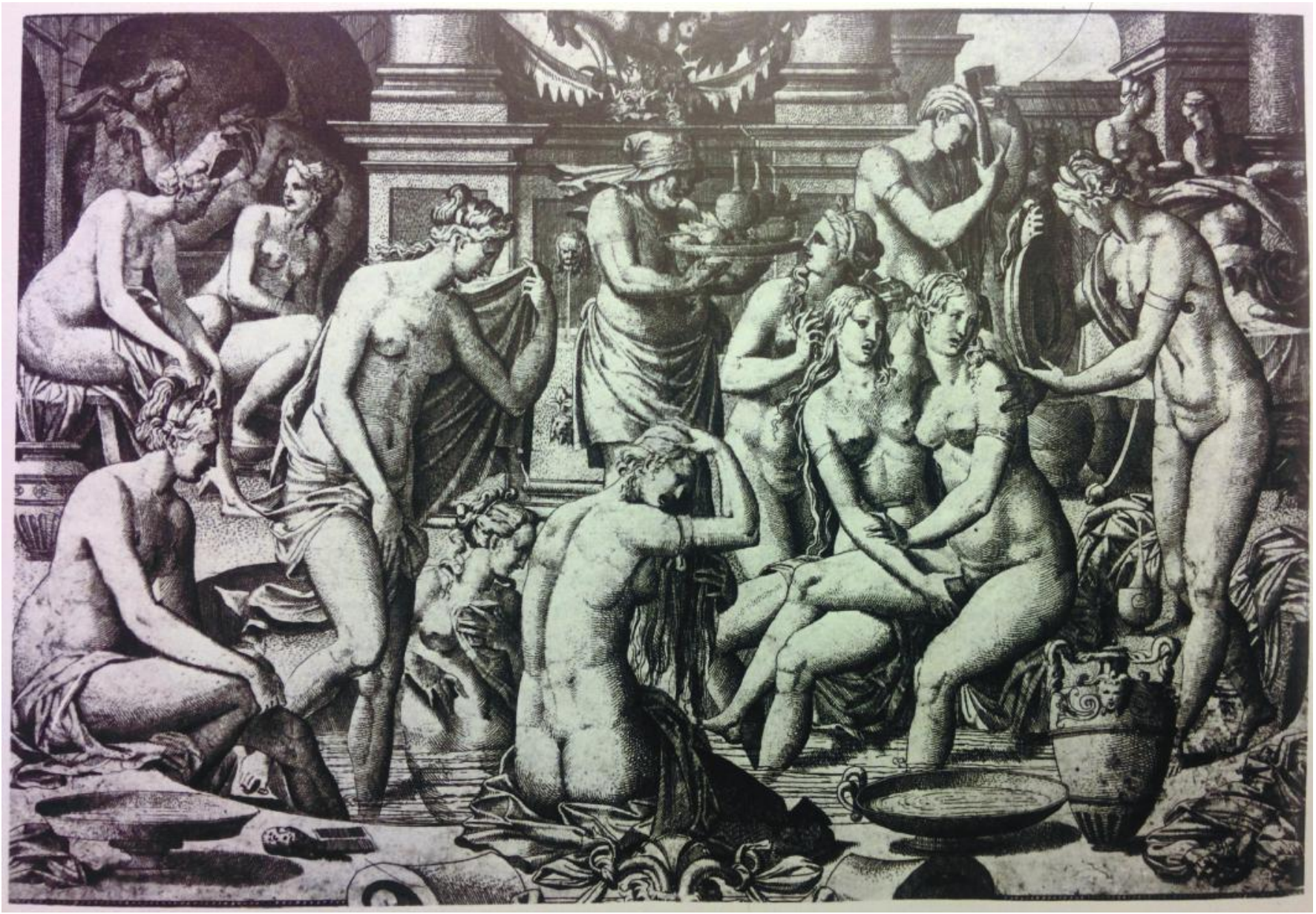

Fig.5.65. Jean Cousin. Mulheres no banho. Água forte a partir de Luca Penni. 1543-45. Coleção Particular, Paris. 


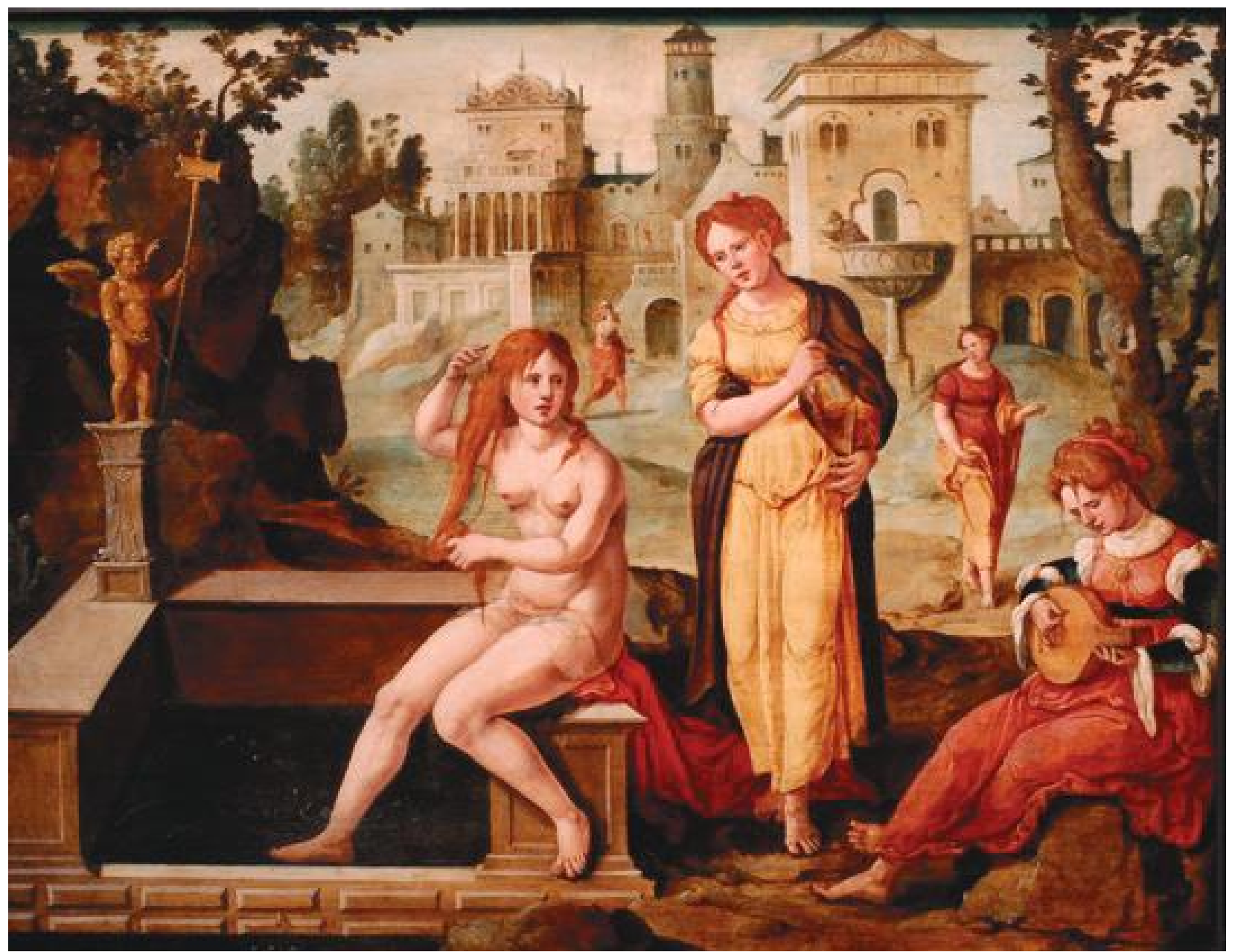

Fig.5.66. Jan Swart van Groningen. Betsabéia no banho, 1535-1540. Óleo sobre tela.

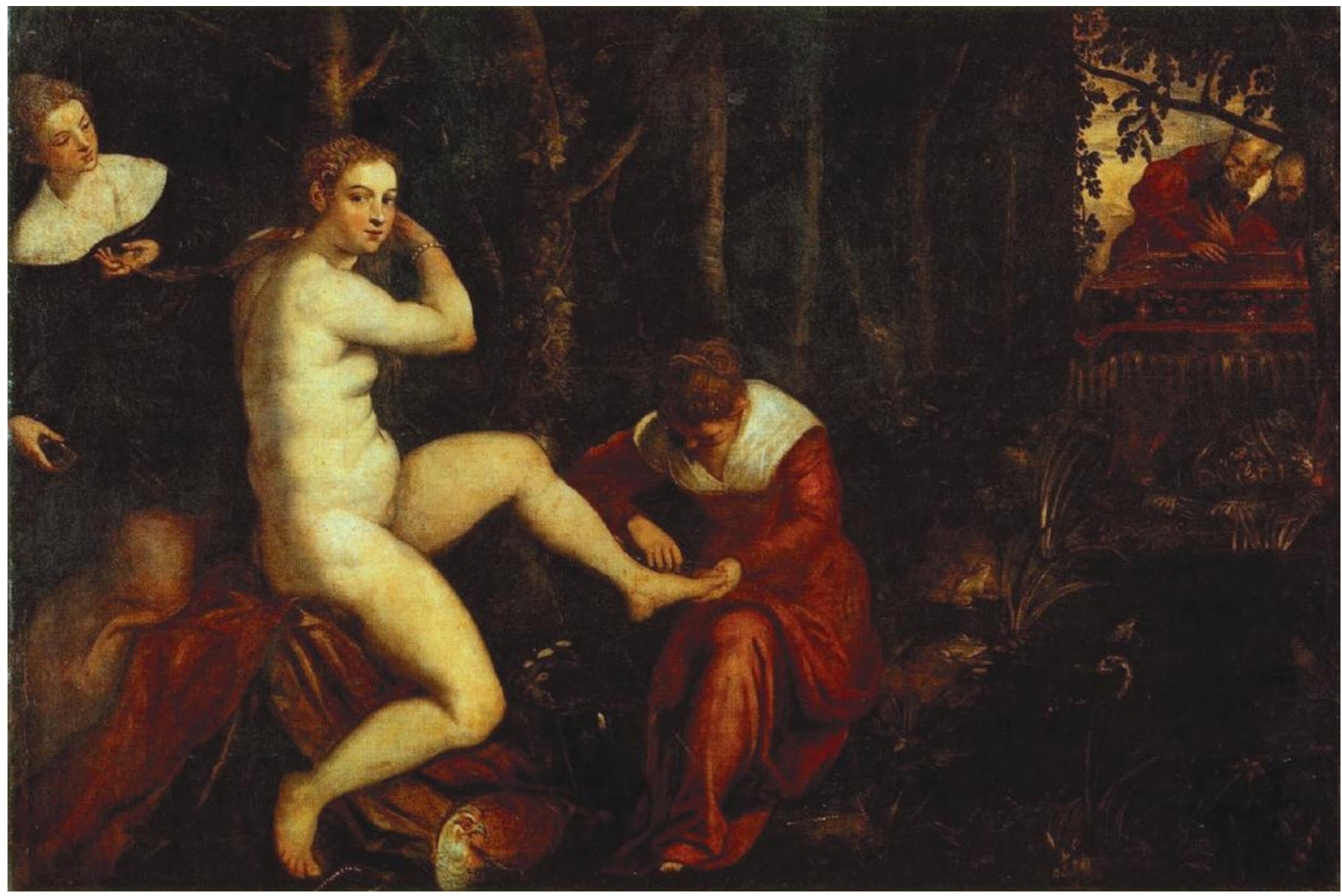

Fig.5.67. Jacopo Robsit, dito Tintoreto. Suzana no Banho, 1550, óleo sobre tela, 167 x $238 \mathrm{~cm}$. Museu do Louvre. 


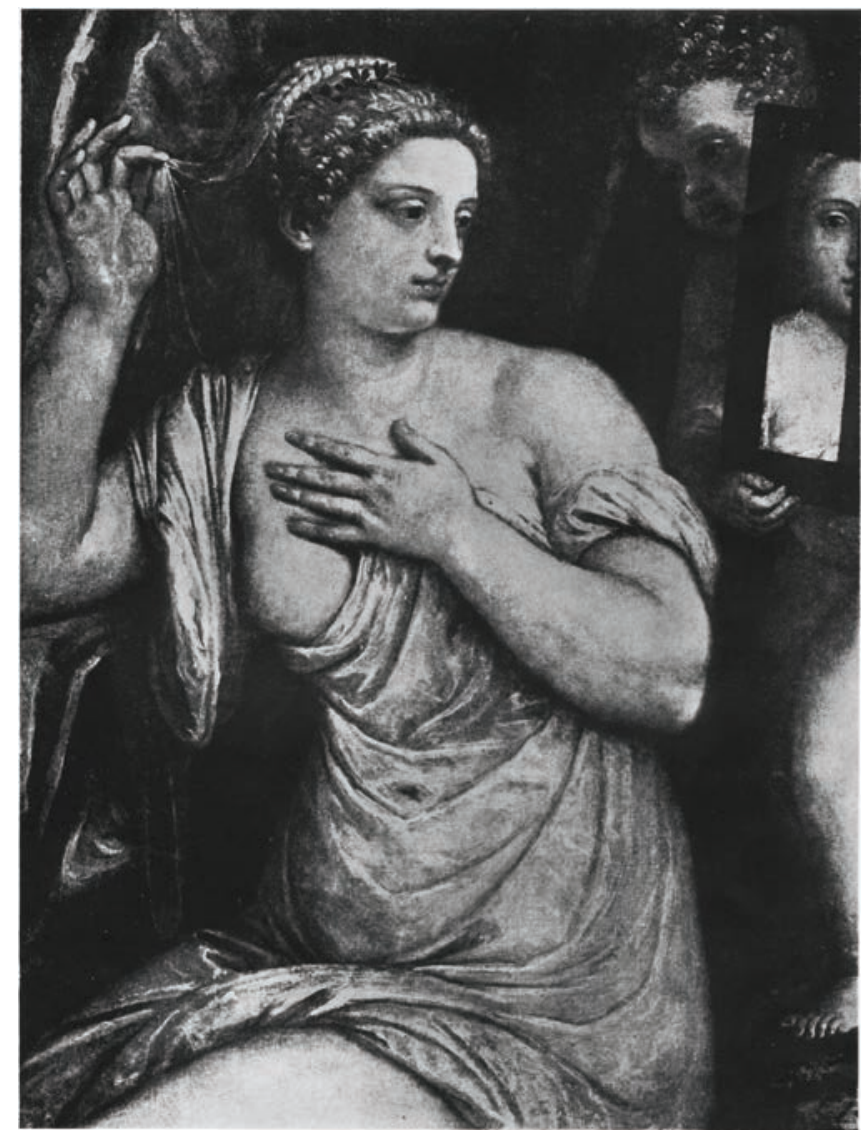

Fig.5.68. Paolo Veronese (atribuído). Vênus em seu toilette, ca.1570, óleo sobre tela, $87 \times 71 \mathrm{~cm}$. Localização desconhecida.

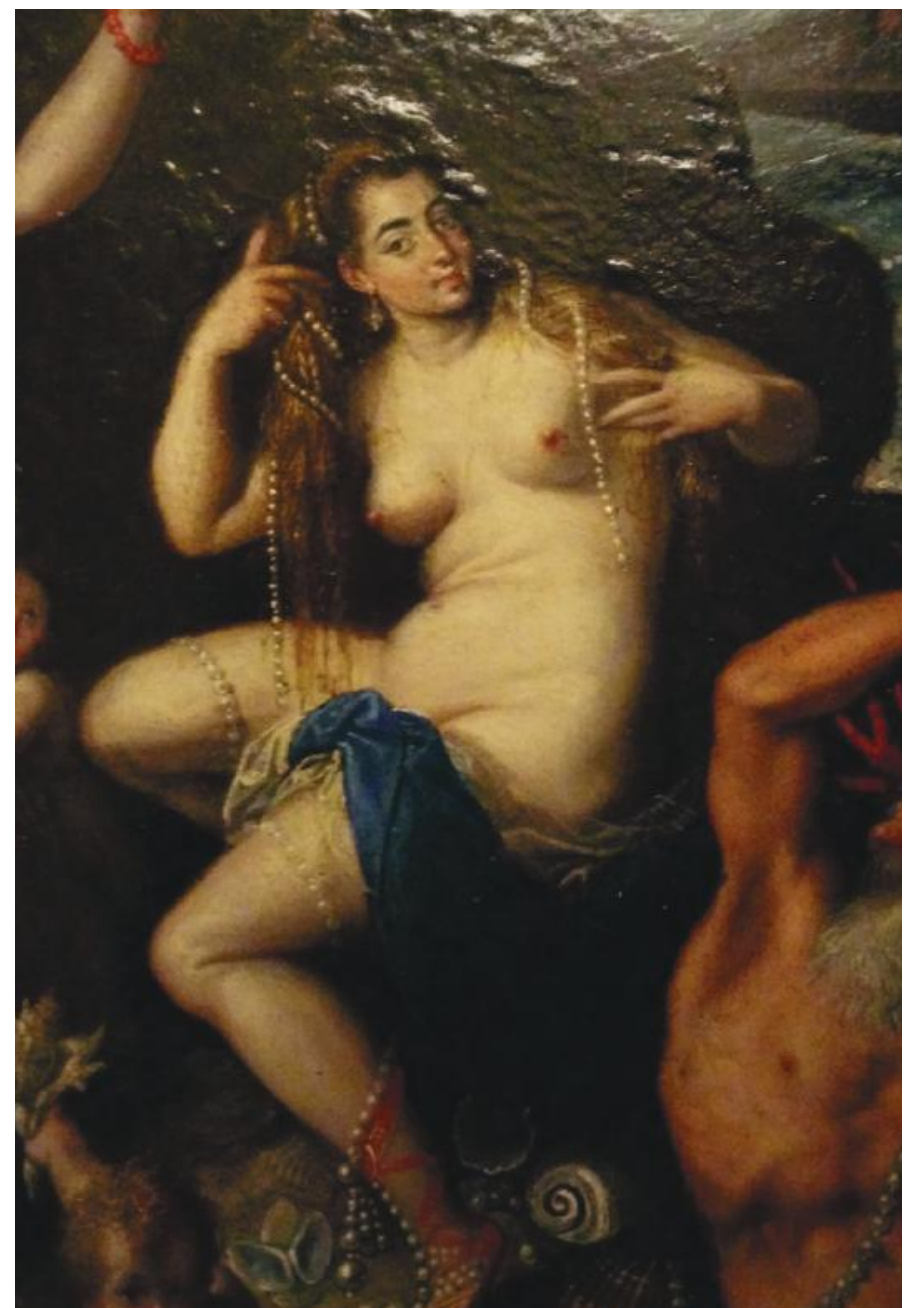

Fig.5.69. Jacopo Zucchi. Recorte da Allegoria della discoperta dellAmerica, 1585, óleo sobre tela. Galeria Borghèse.

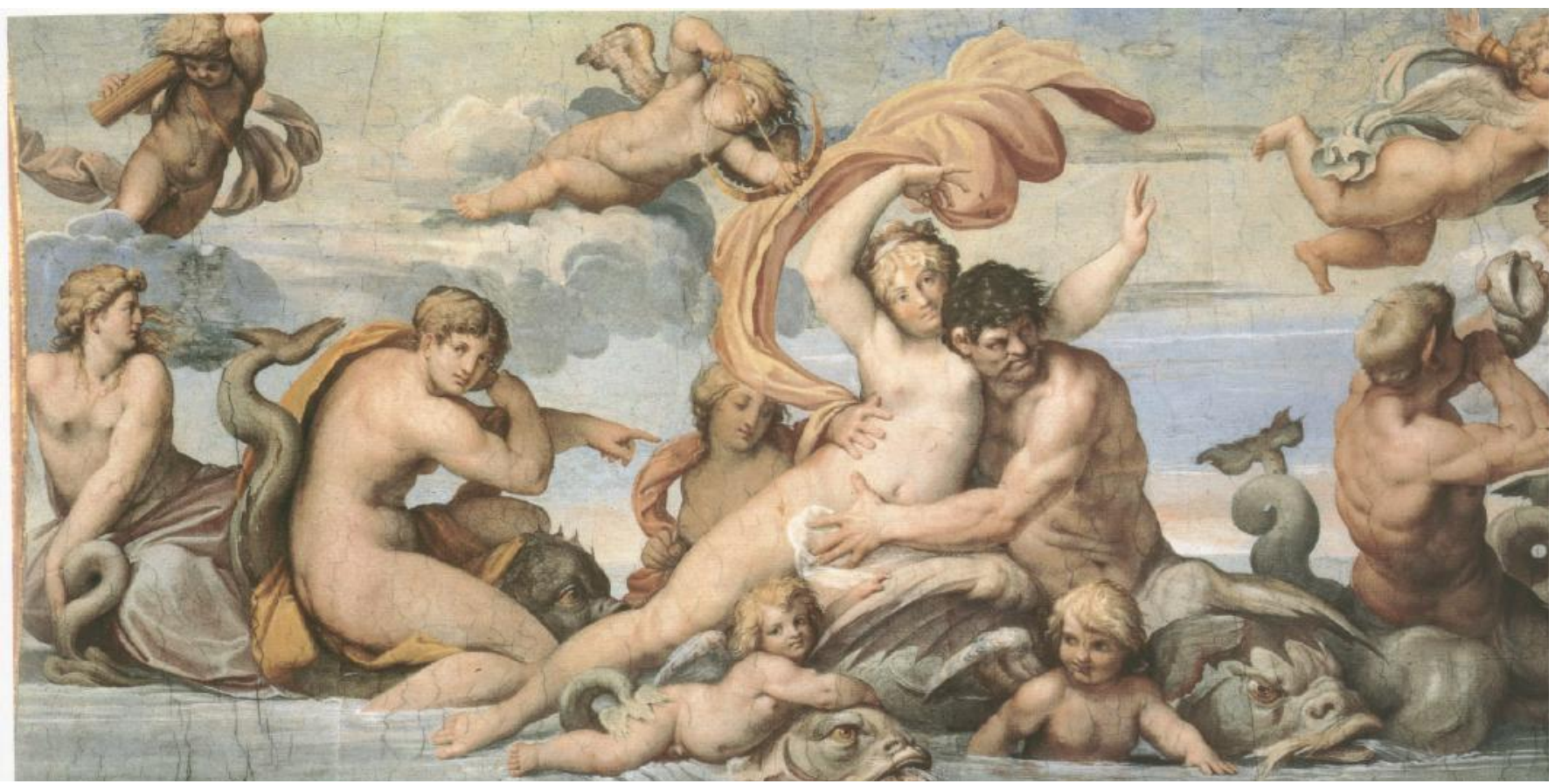

Fig.5.70. Agostino Carracci. Glauco e Scylla, 1597, afresco. Galeria Farnese, Roma. 


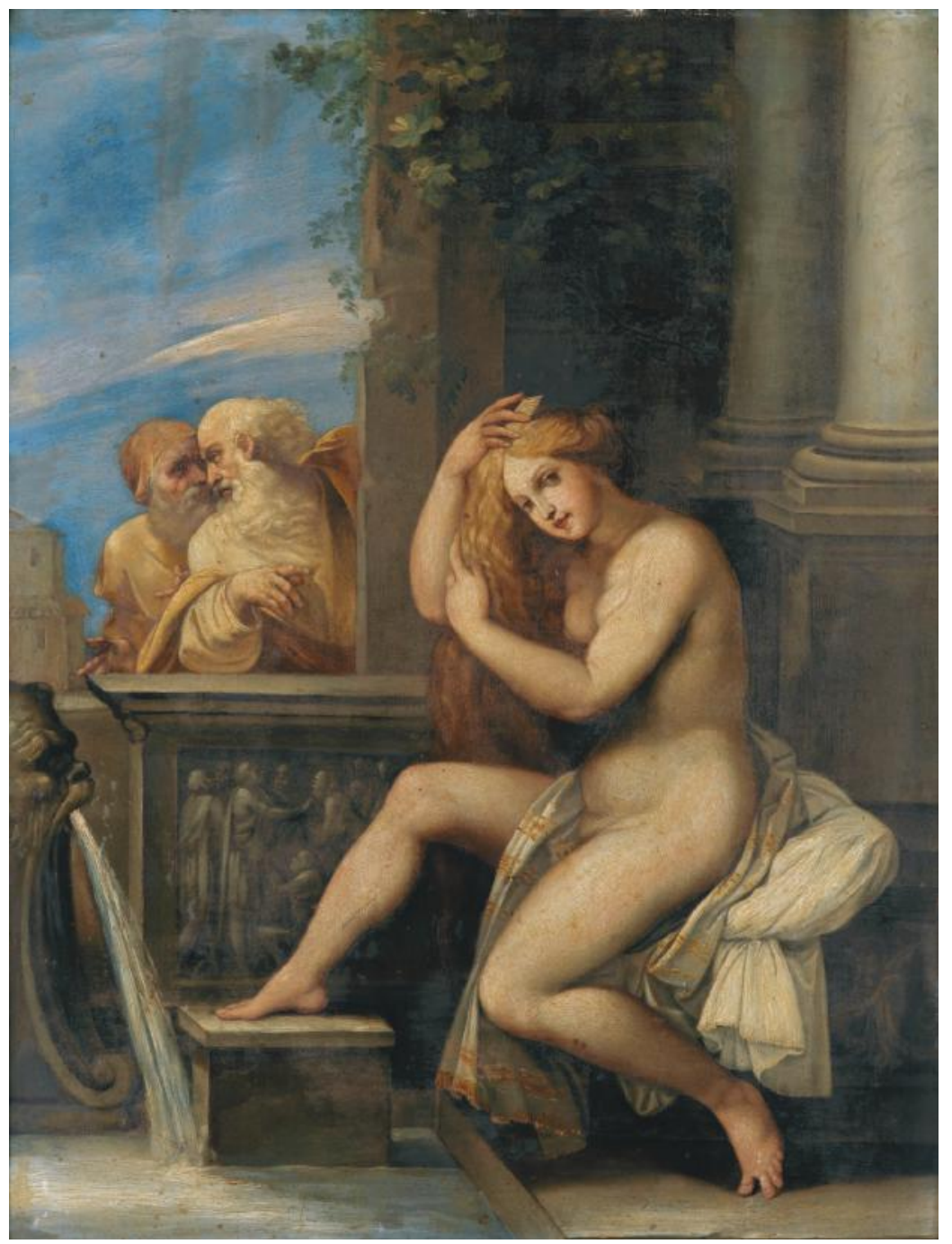

Fig.5.71. Giuseppe Cesari, dito Cavalier d’Arpino. Suzana e os velhos, ca.1606, óleo sobre madeira, $52,2 \times 38,5 \mathrm{~cm}$. Coleção particular.

Fig.5.72. Nicolas Poussin. Vênus e Marte, 1633-1634, óleo sobre tela, 157.5 x $189.8 \mathrm{~cm}$. Museu de arte de Toledo.
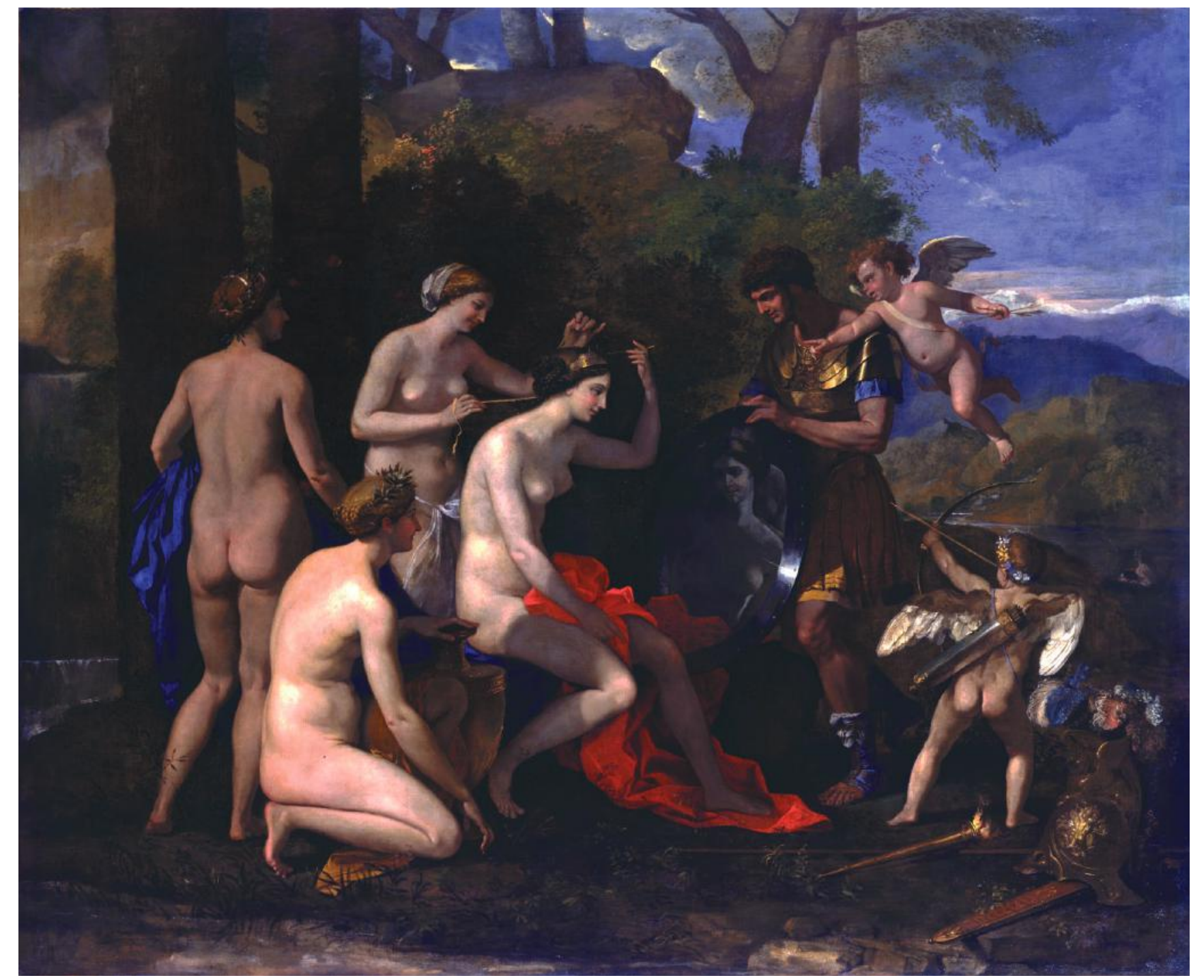


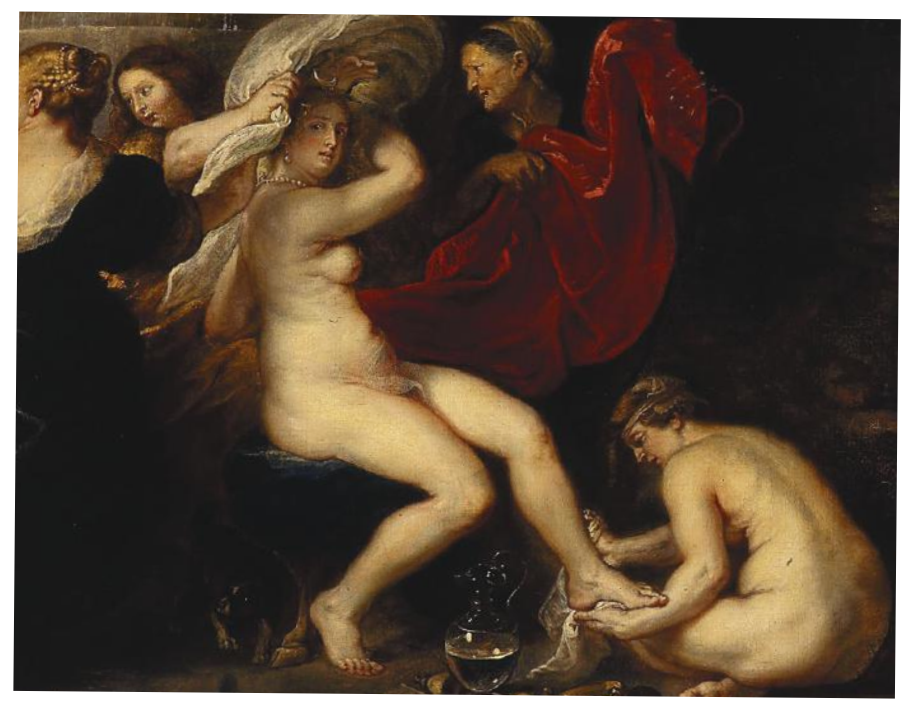

Fig.5.73. Peter Paul Rubens. O banho de Diana, 1635- 40, óleo sobre tela. 152.5 x $120 \mathrm{~cm}$.
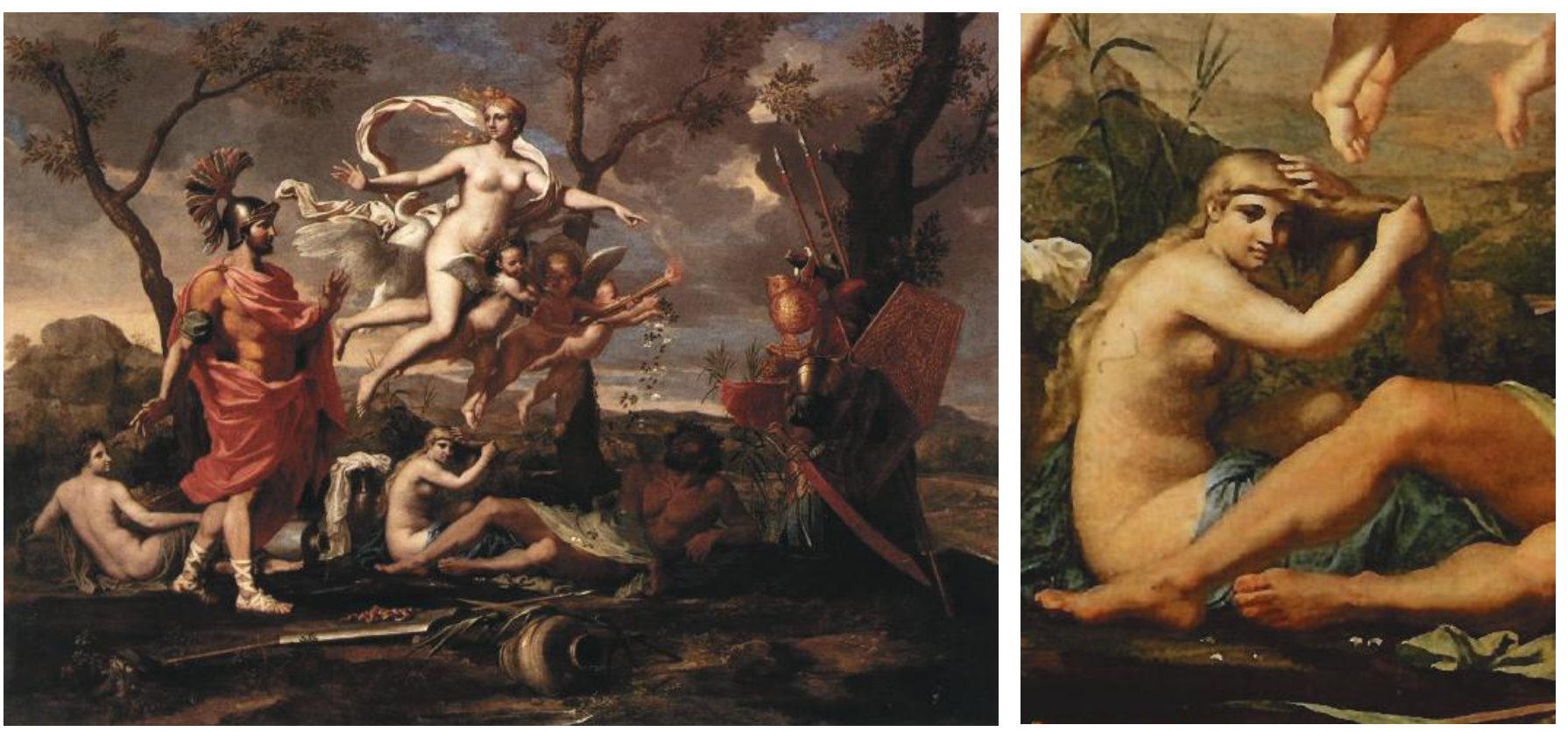

Fig.5.74. Nicolas Poussin. Vênus apresentando as armas a Eneias. 1639.105 x 142 cm. Musée des BeauxArts, Rouen, France

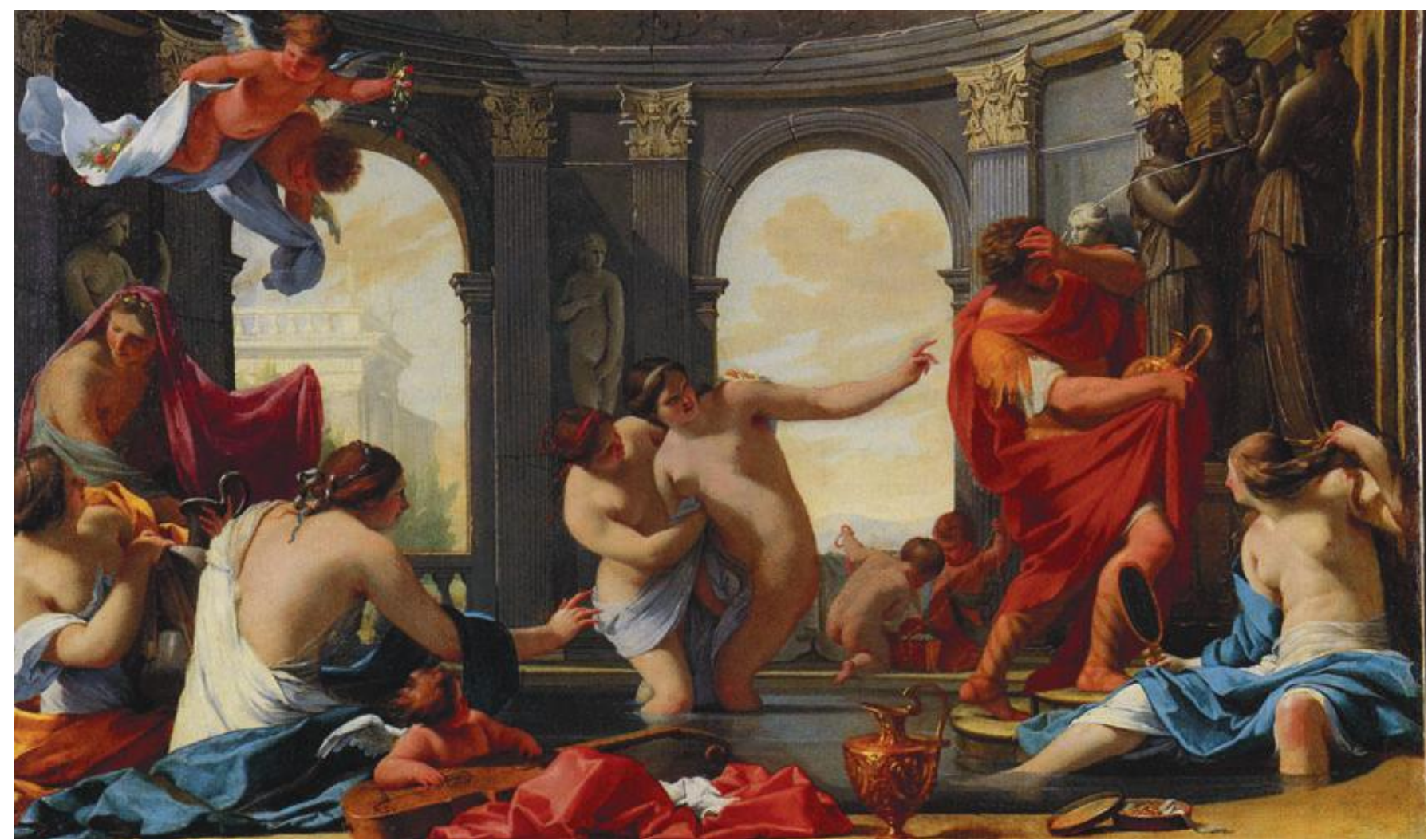

Fig.5.75. Eustache Le Sueur. Polífilo no banho das ninfas, 1637-38, óleo sobre tela, 94x156,4 cm. Museu Magnin, Dijon. 


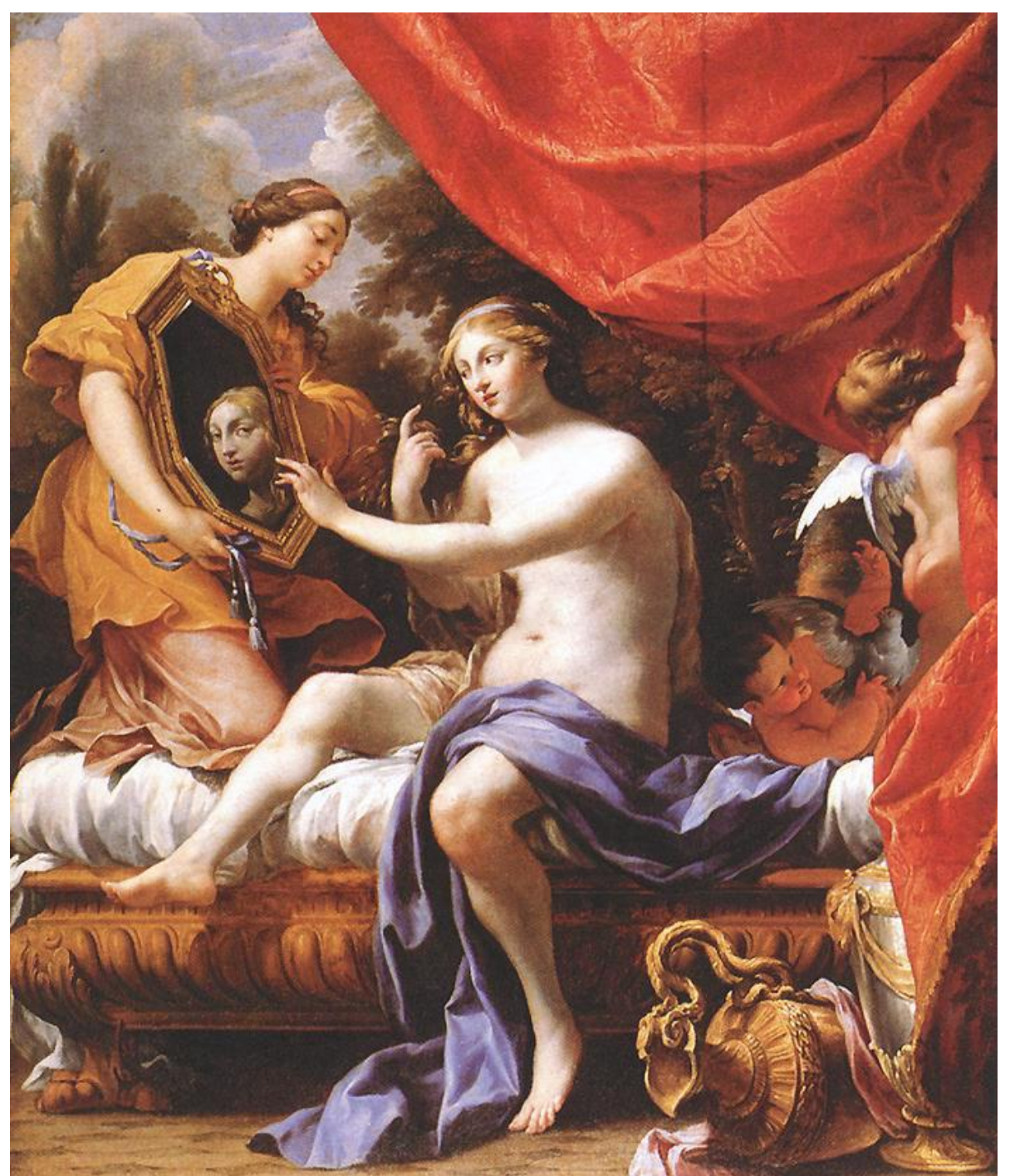

Fig.5.76. Simon Vouet. $O$ toilette de Vênus, 1629, óleo sobre la, 183.8 x $153 \mathrm{~cm}$. Cincinnati Art Museum.

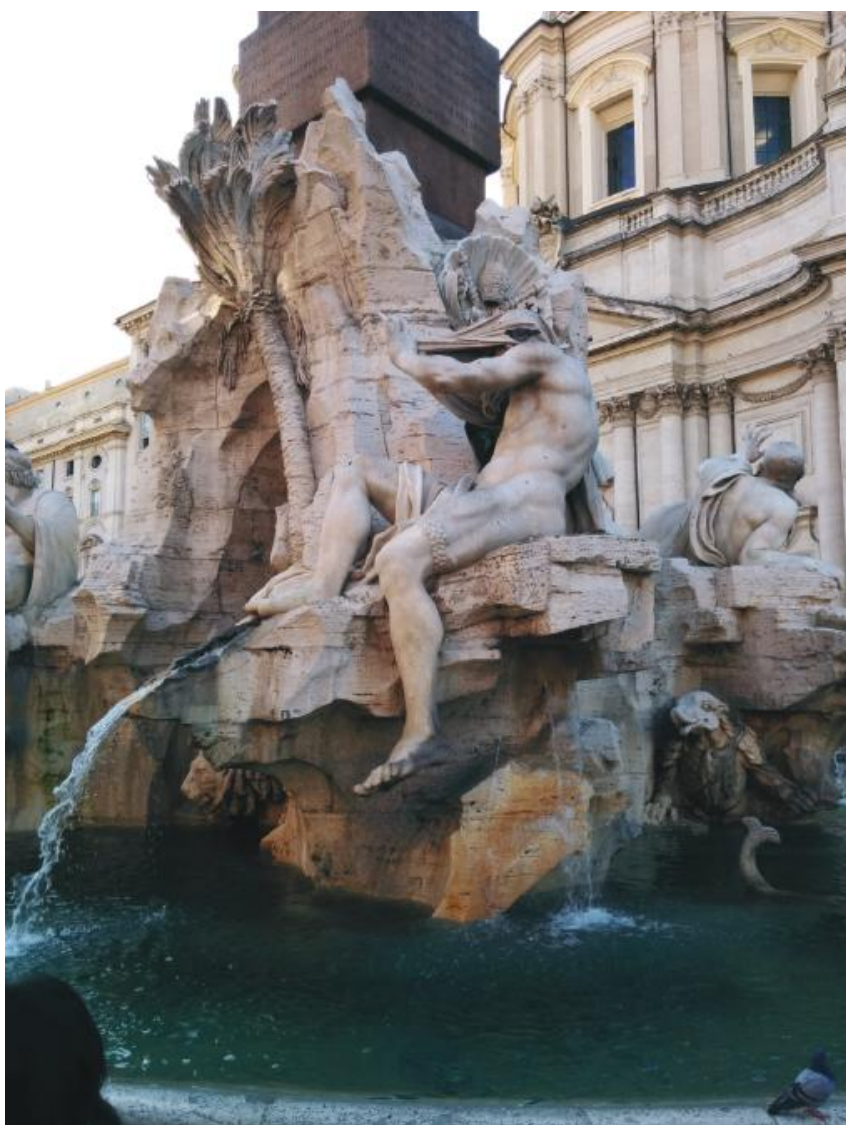

Fig.5.77. Gian Lorenzo Bernini. Fonte dos quatro rios. 1648-1651. Piazza Nanova, Roma.

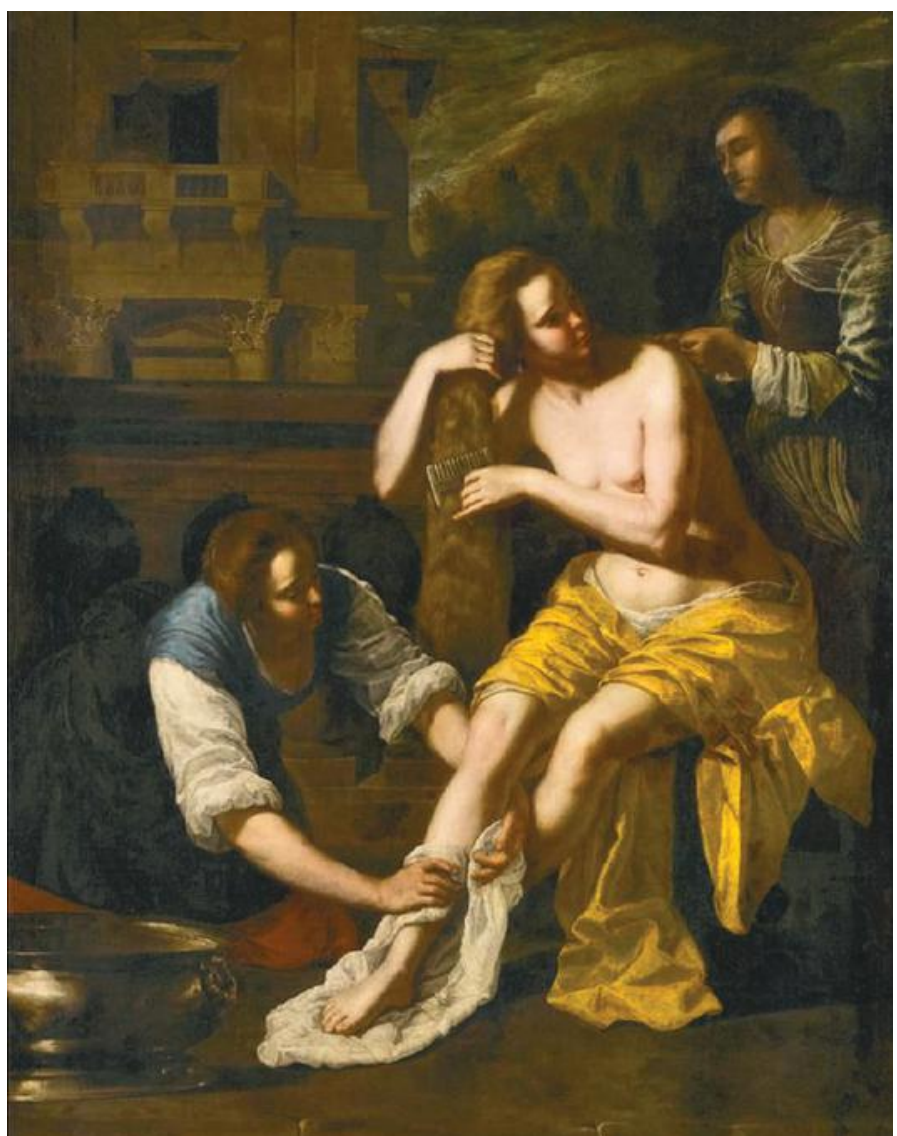

Fig.5.78. Artemisia Gentileschi. Betsabéia no banho, década de 1640, óleo sobre tela, 205 x $156 \mathrm{~cm}$. Private collection 


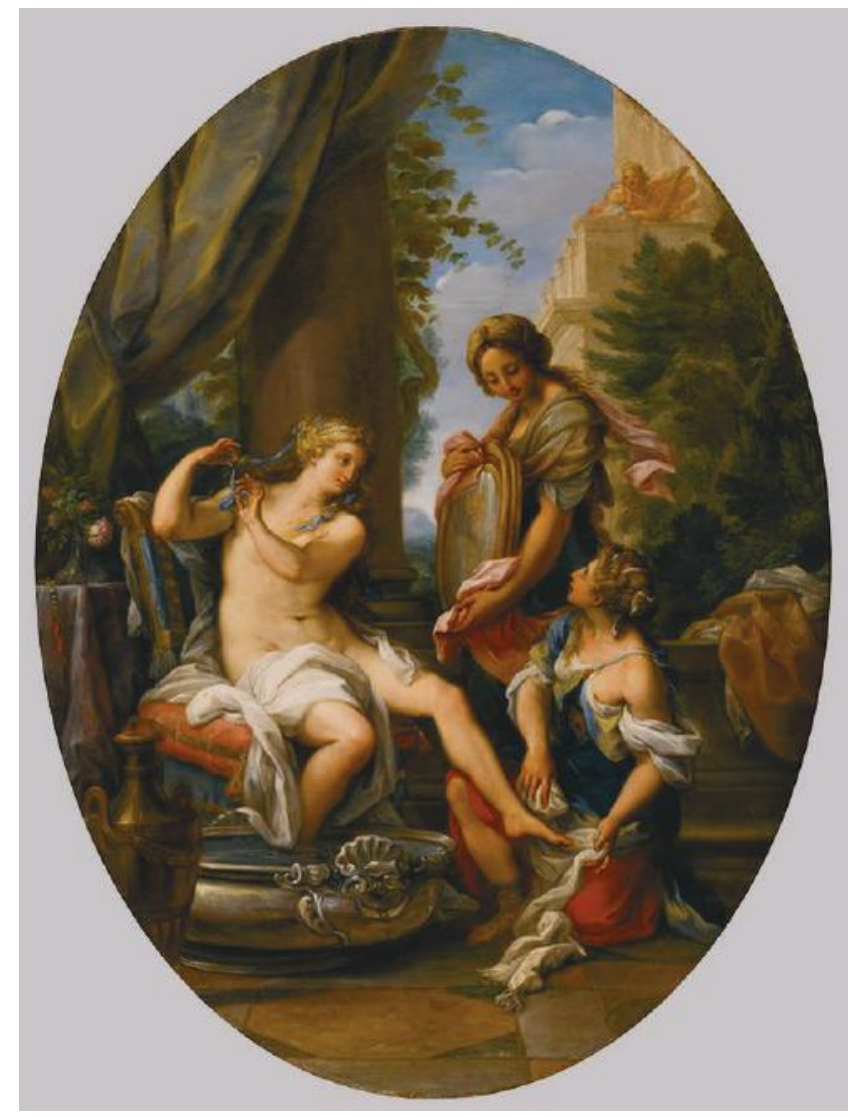

Fig.5.79. Giuseppe Bartolomeo Chiari. O toilette de Betsabéia. segunda metade do séc. XVII ou primeira do XVIII, óleo sobre tela, 138 x $98 \mathrm{~cm}$. Coleção particular.

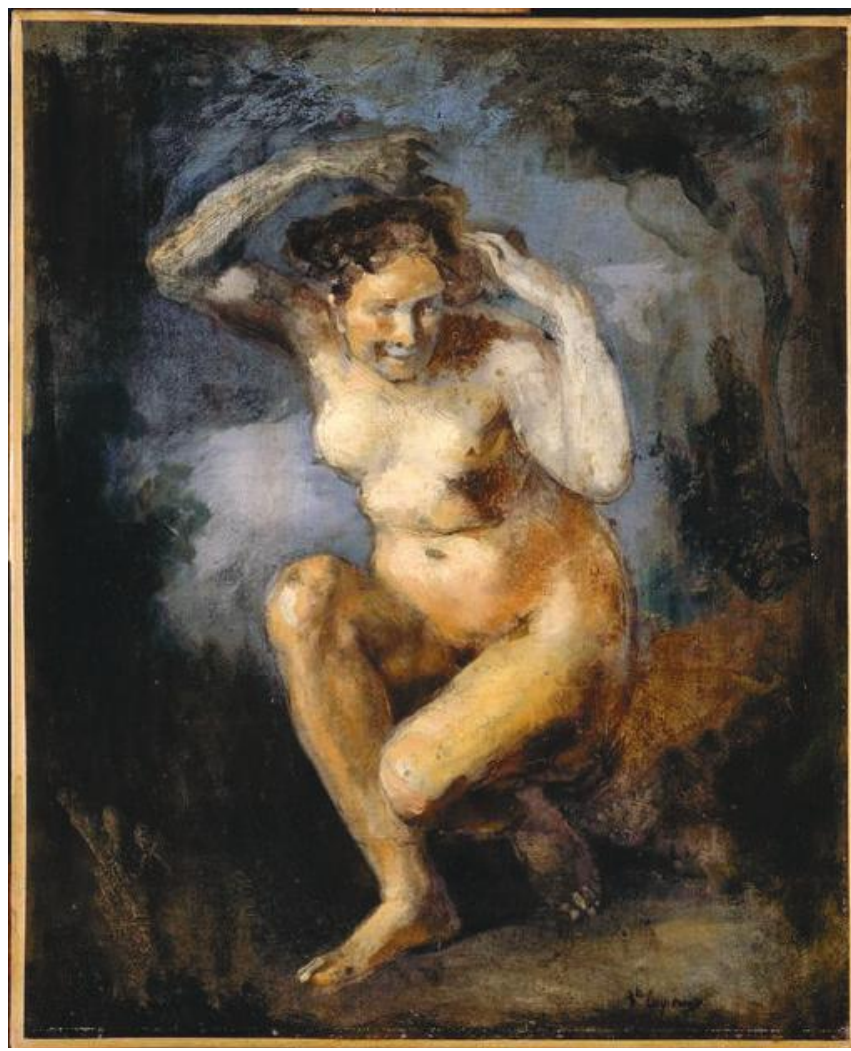

Fig.5.81. Jean-Baptiste Carpeaux. Flora agachada. Terceiro quarto do sec. XIX, óleo sobre tela, $\mathrm{Mu}-$ seu de Belas Artes de Valenciennes.

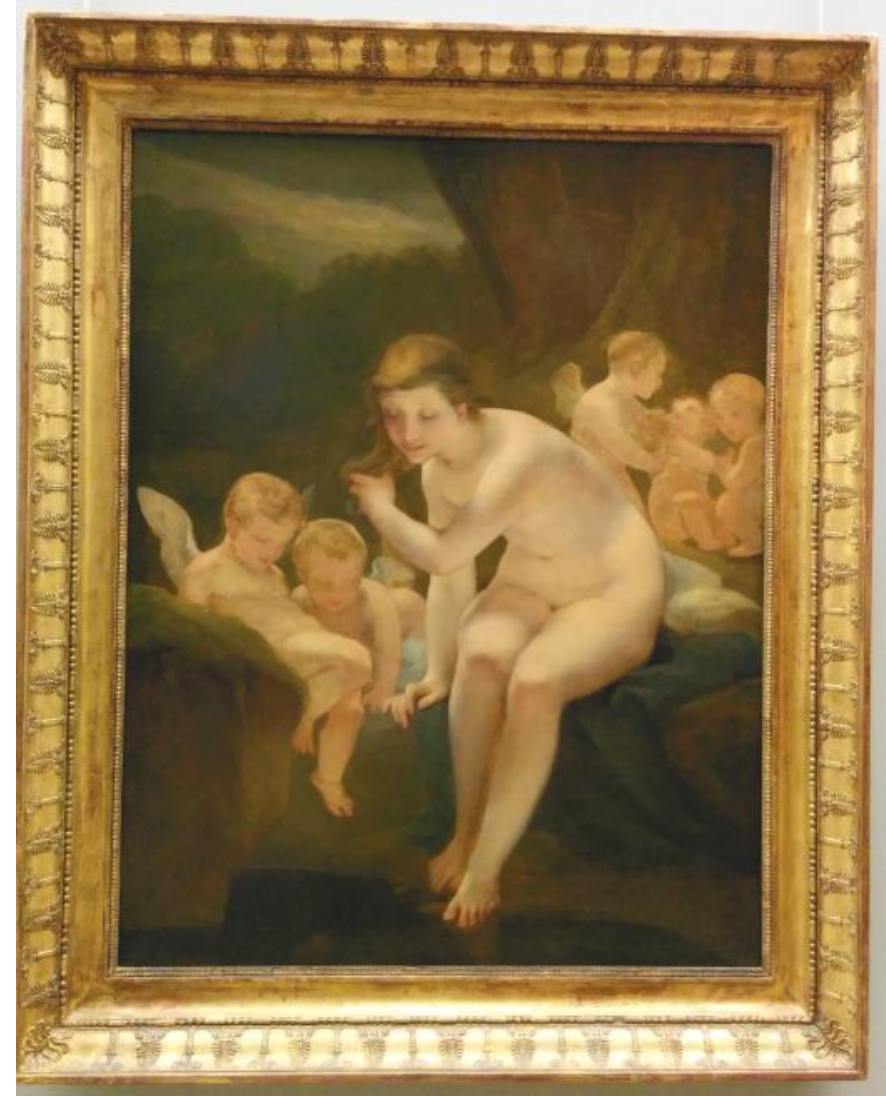

Fig.5.80. P.-.P. Prud'hon. Vênus no banho ou A inocência, 1810, óleo sobre tela. Museu do Louvre.

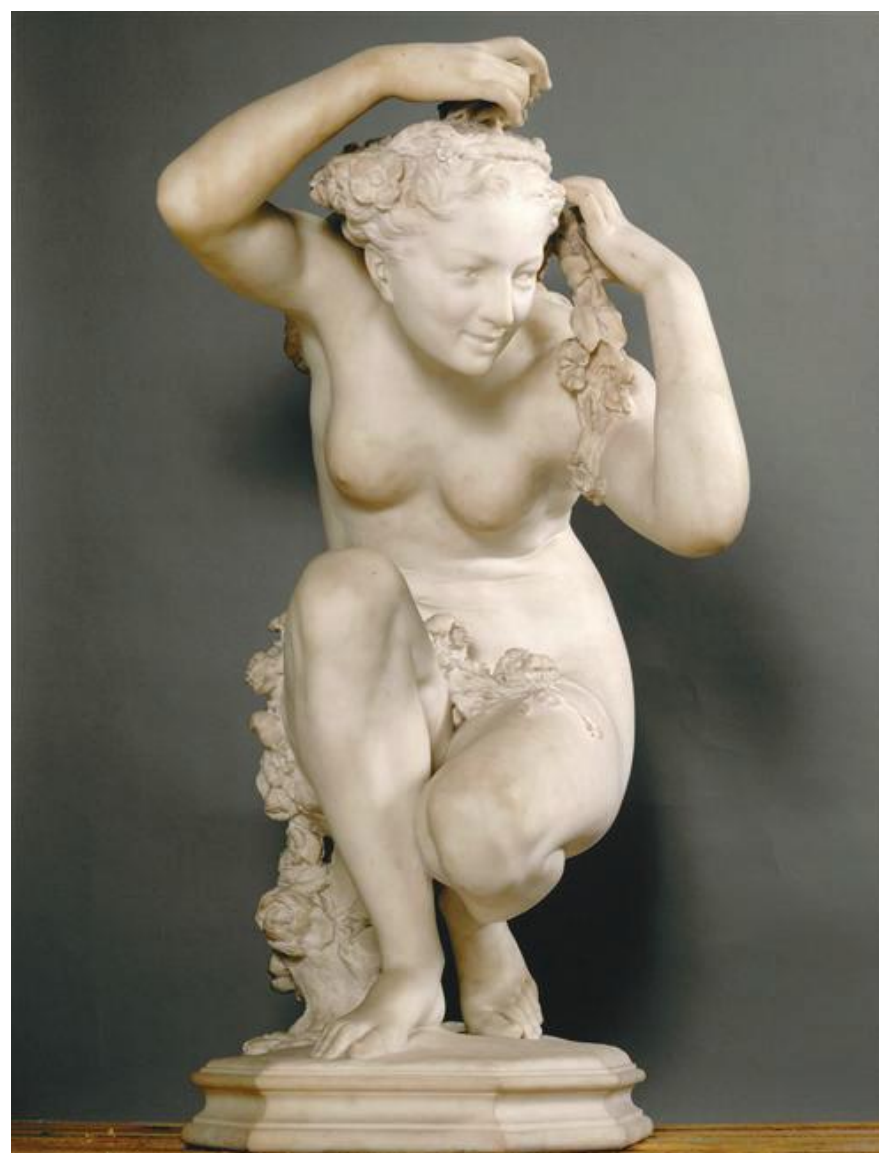

Fig.5.82. Jean-Baptiste Carpeaux. Primavera ou Flora agachada. Século XIX, mármore, Museu de Belas Artes de Valenciennes. 


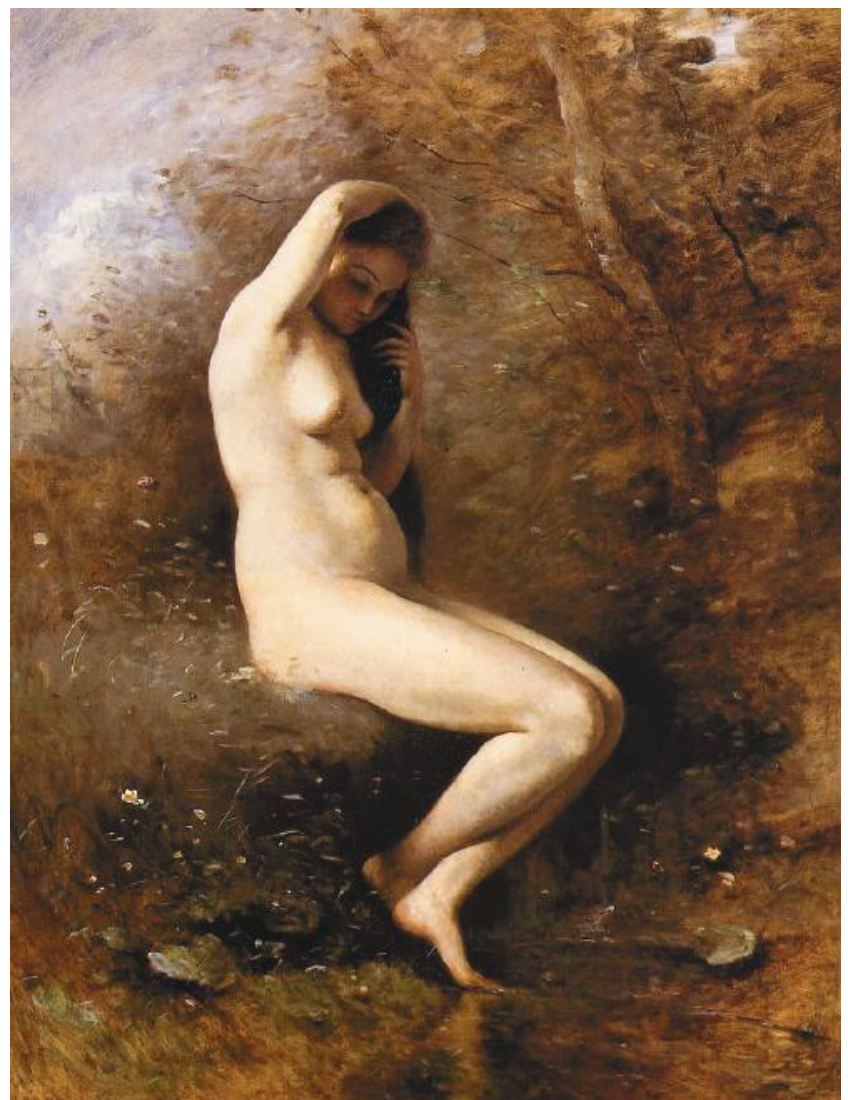

Fig.5.83. J.-B.-.Camille Corot. Vênus no banho. c.1873-74, óleo sobre tela, 90 x $116 \mathrm{~cm}$. Londres, Coleção Privada.

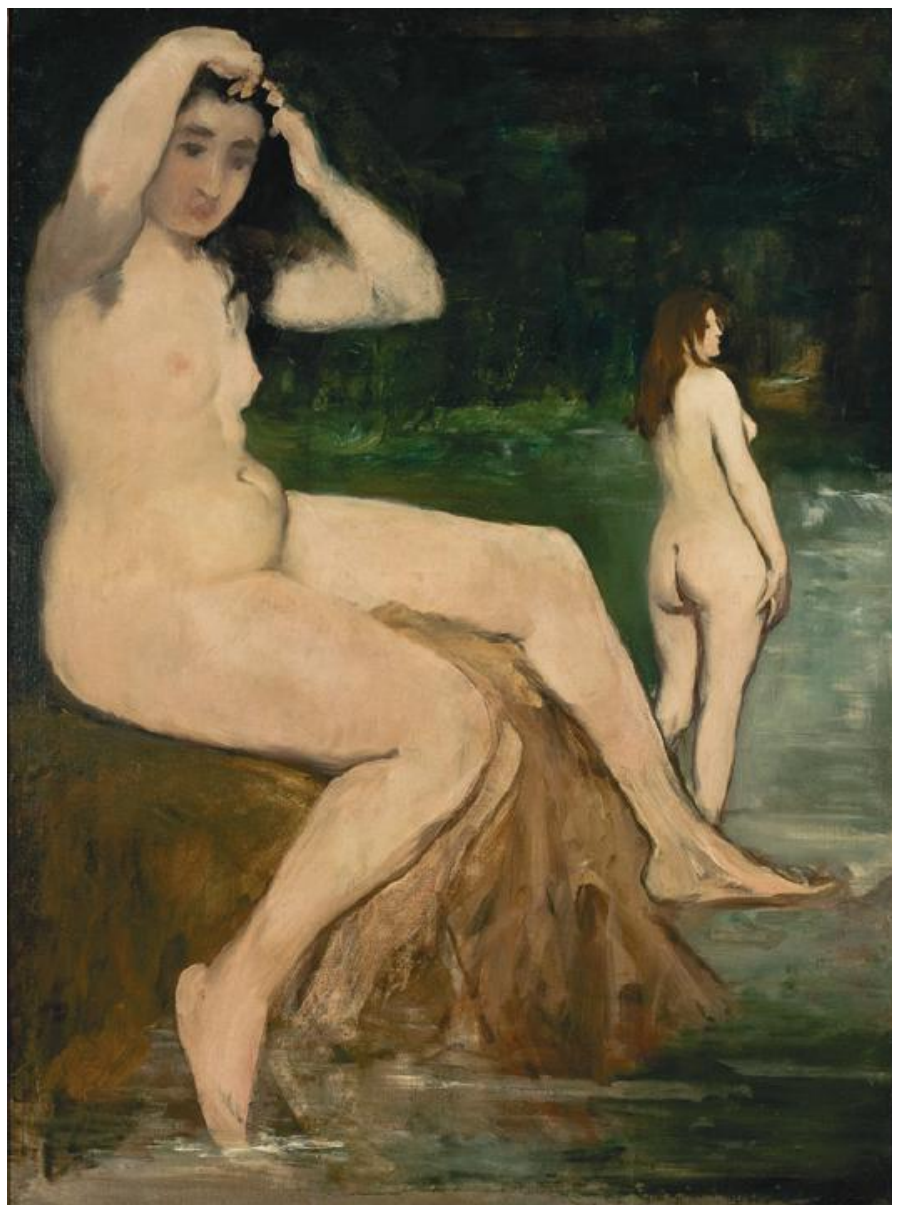

Fig.5.84. Édouard Manet. Banhistas no Sena. 18741876, óleo sobre tela, 132 x $98 \mathrm{~cm}$. Museu de Arte de São Paulo.

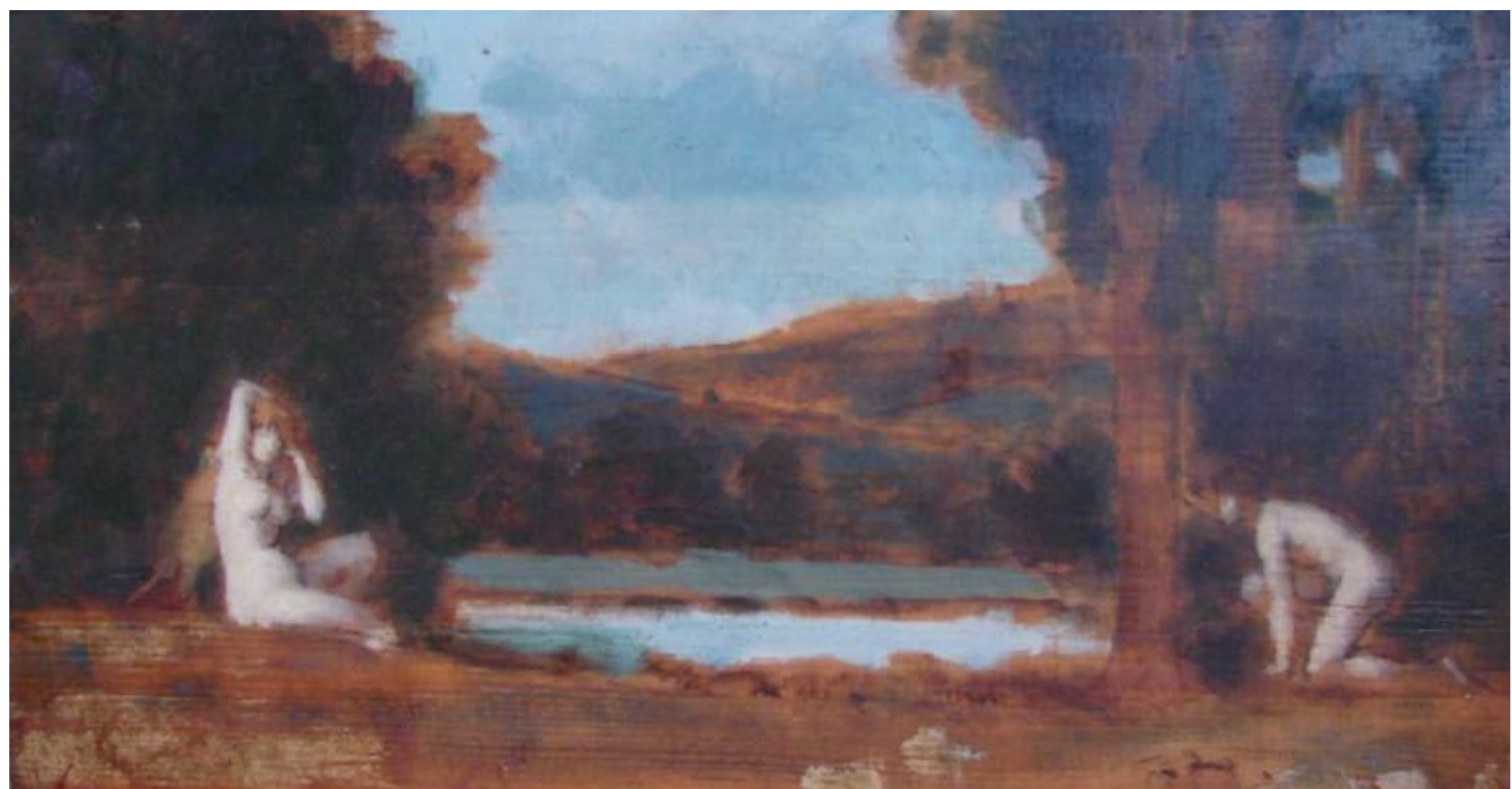

Fig.5.85. Jean-Jacques Henner. Ninfa surpreendida se penteando, último quarto do século XIX, óleo sobre tela, Musée National Jean-Jacques Henner, Paris. 


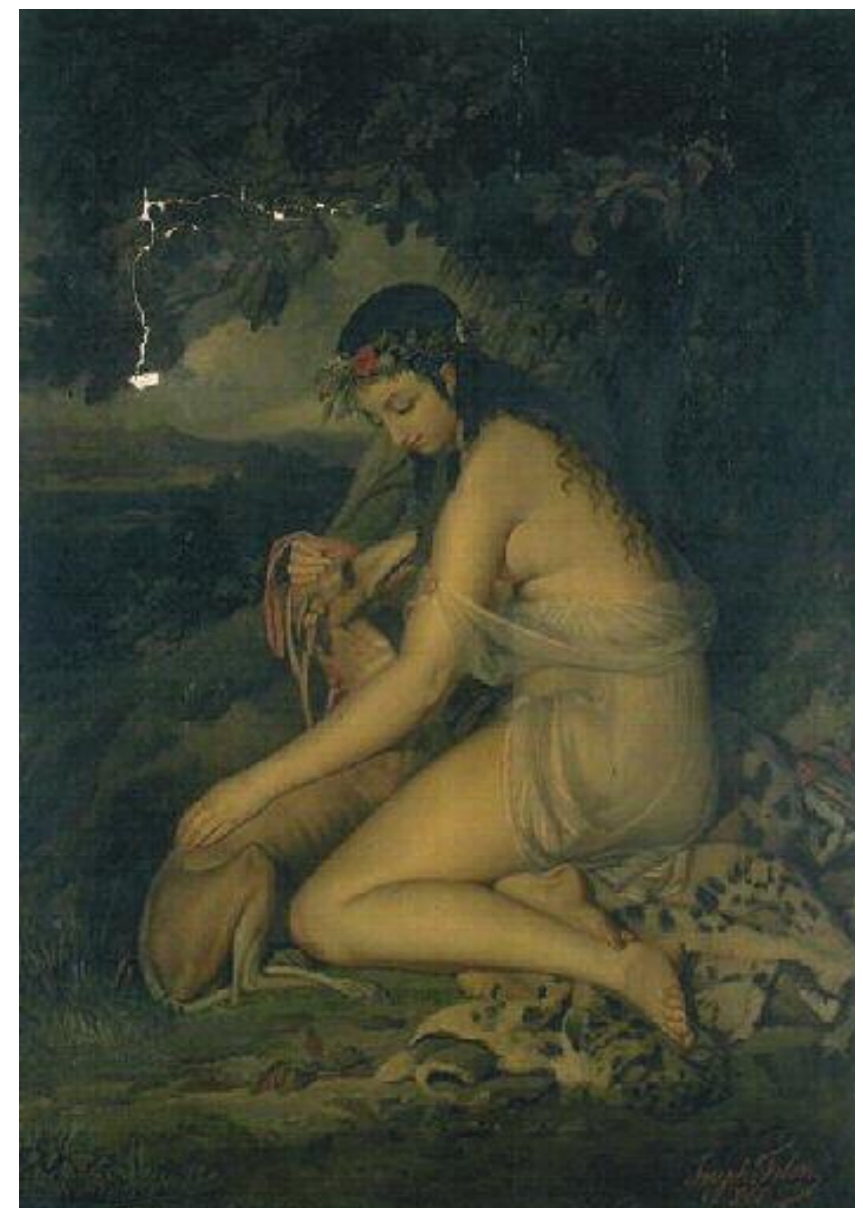

Fig.5.86. Joseph Félon. Ninfa caçadora, segundo quarto do séc. XIX, óleo sobre tela. Musée des beaux-arts Bordeaux.

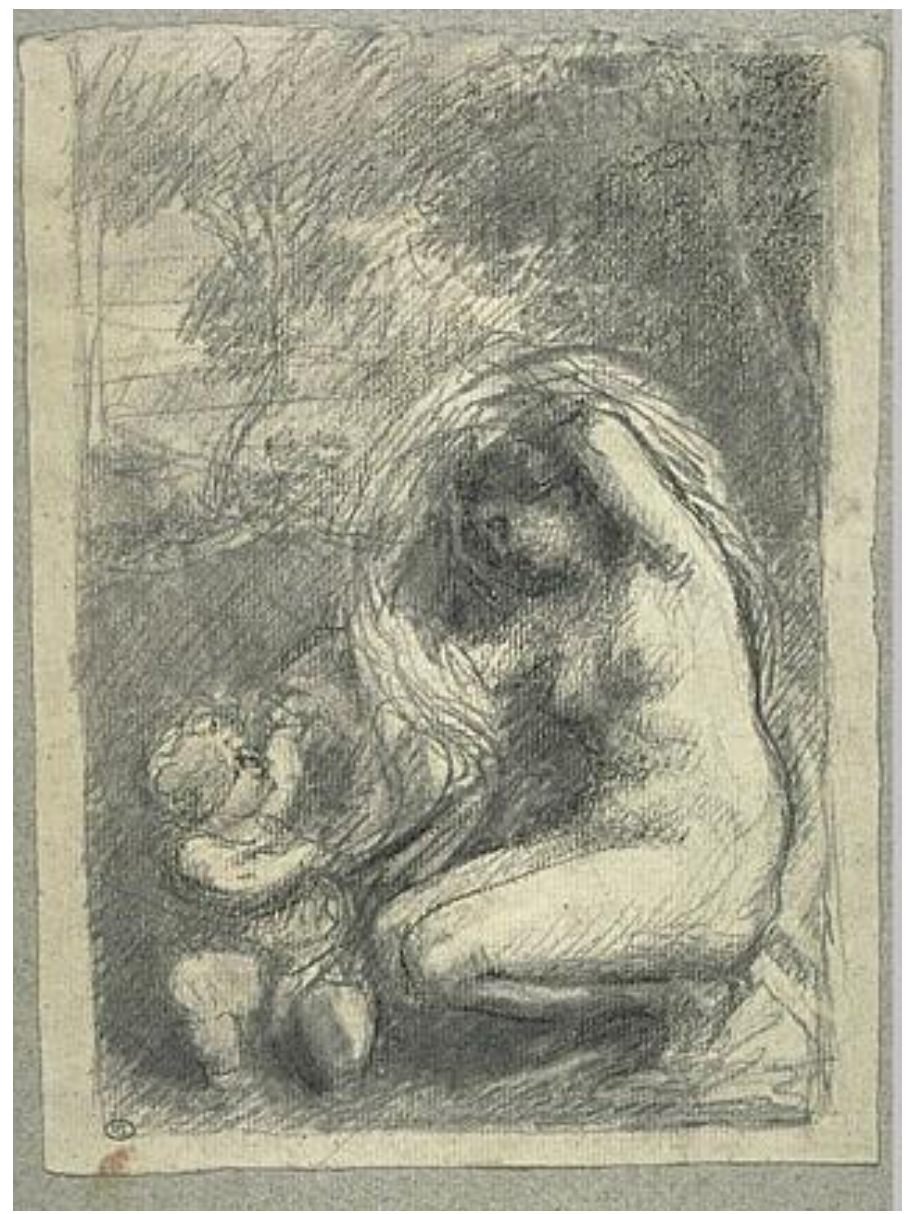

Fig.5.87. Henri Fantin-Latour. Ninfa da maneira, s.d., óleo sobre tela, $22.5 \times 12.25$. Niland Collection.

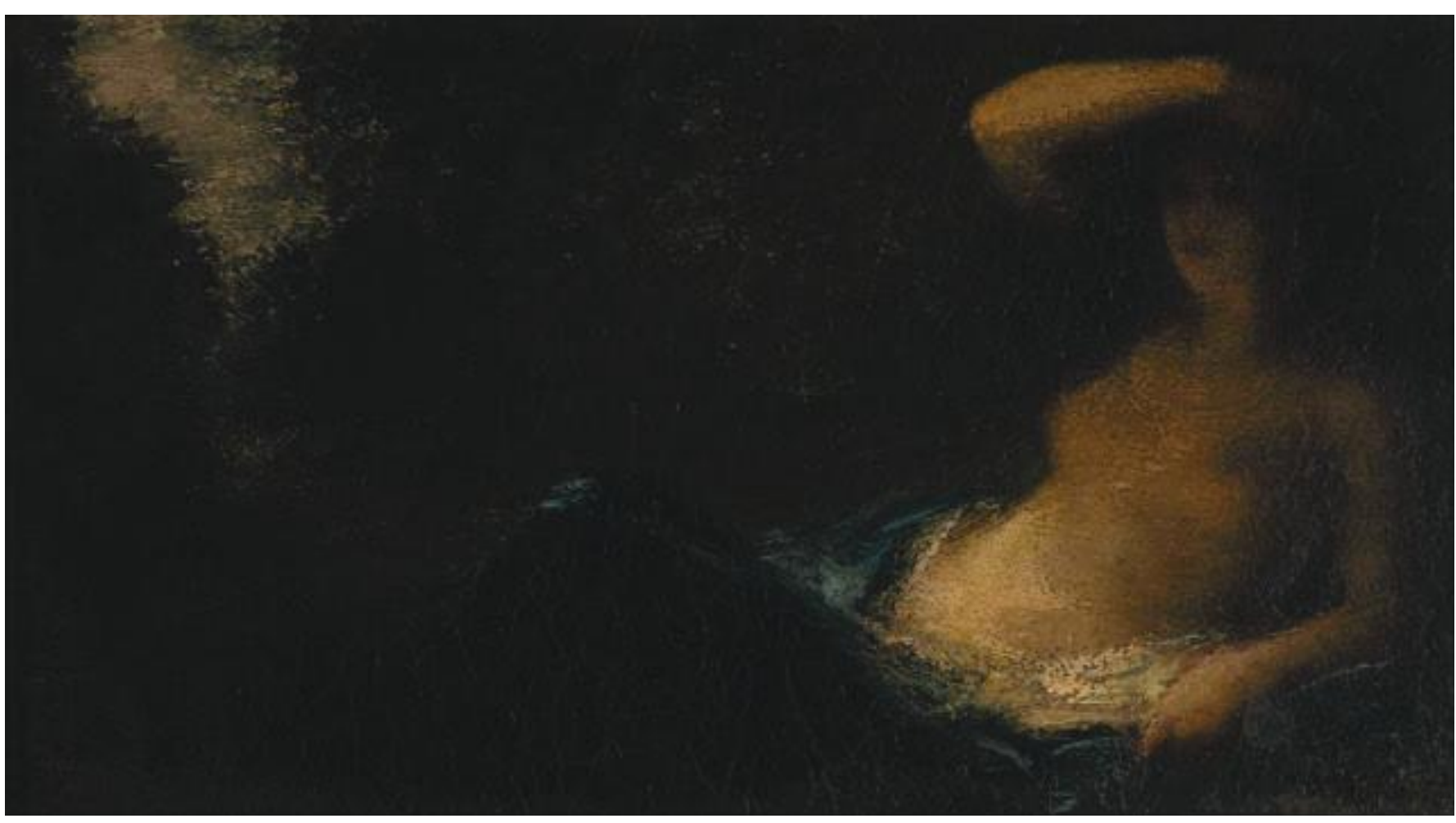

Fig.5.88. Fantin-Latour. Ninfa e Amor, segunda metade do século XIX, primeira metade do XX, óleo sobre tela. Musée du Louvre. 


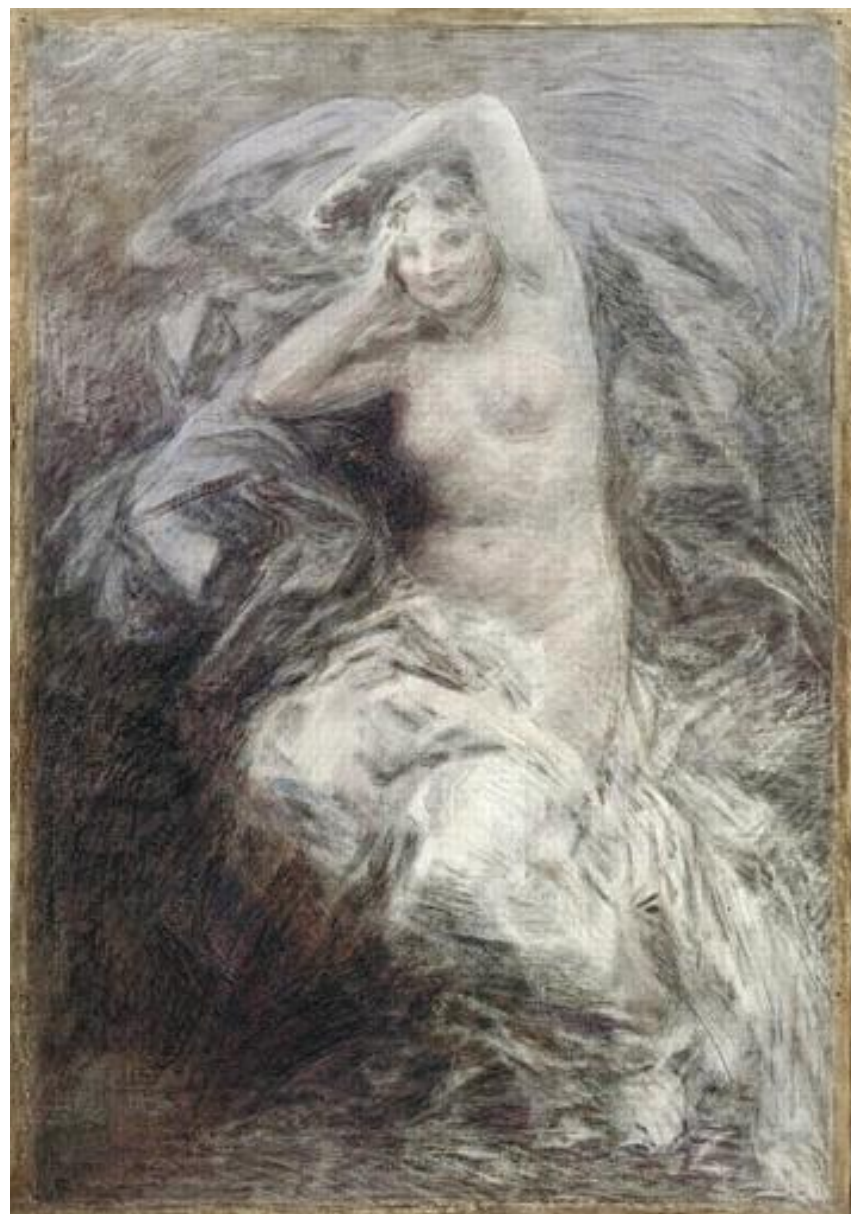

Fig.5.89. Fantin-Latour. Ninfa com véu azul, primeiro quarto do século XX, óleo sobre tela, Musée des beaux-arts Nantes.

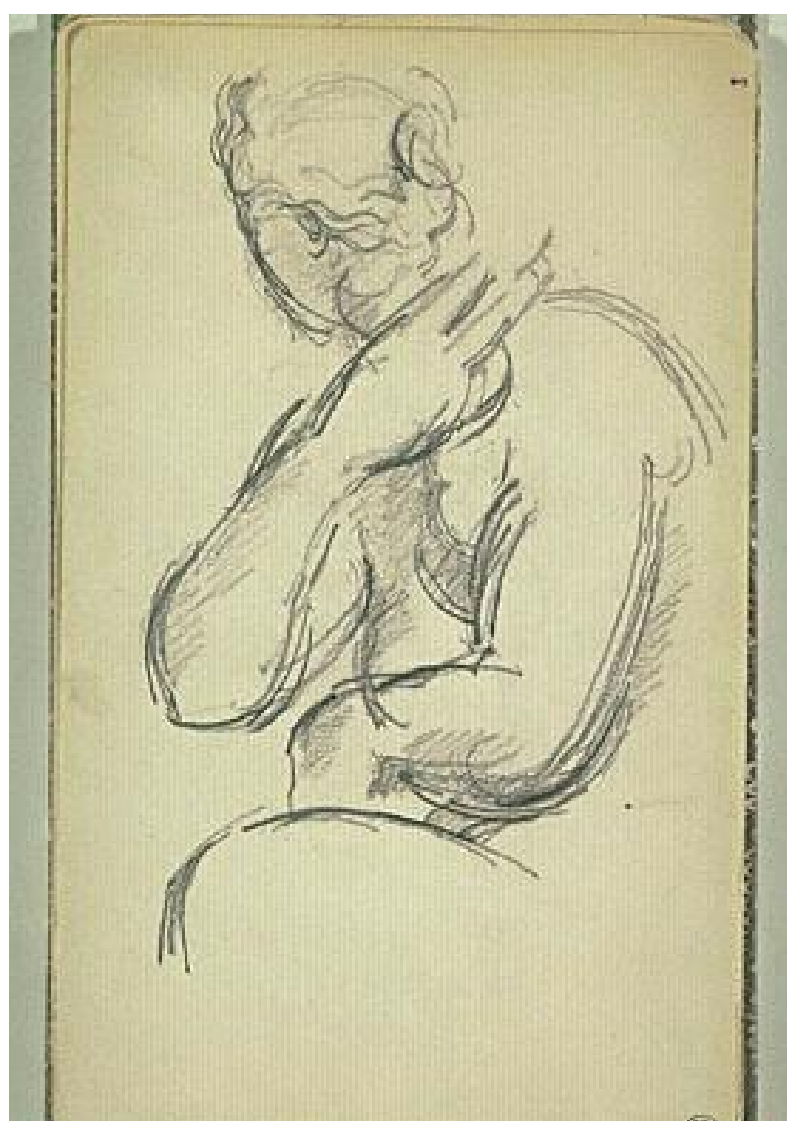

Fig.5.91. Paul Cezanne. Esboços de ninfa Agacha$d a$, segunda metade do século XIX ao primeiro quadro do XX, desenho. Museu do Louvre.

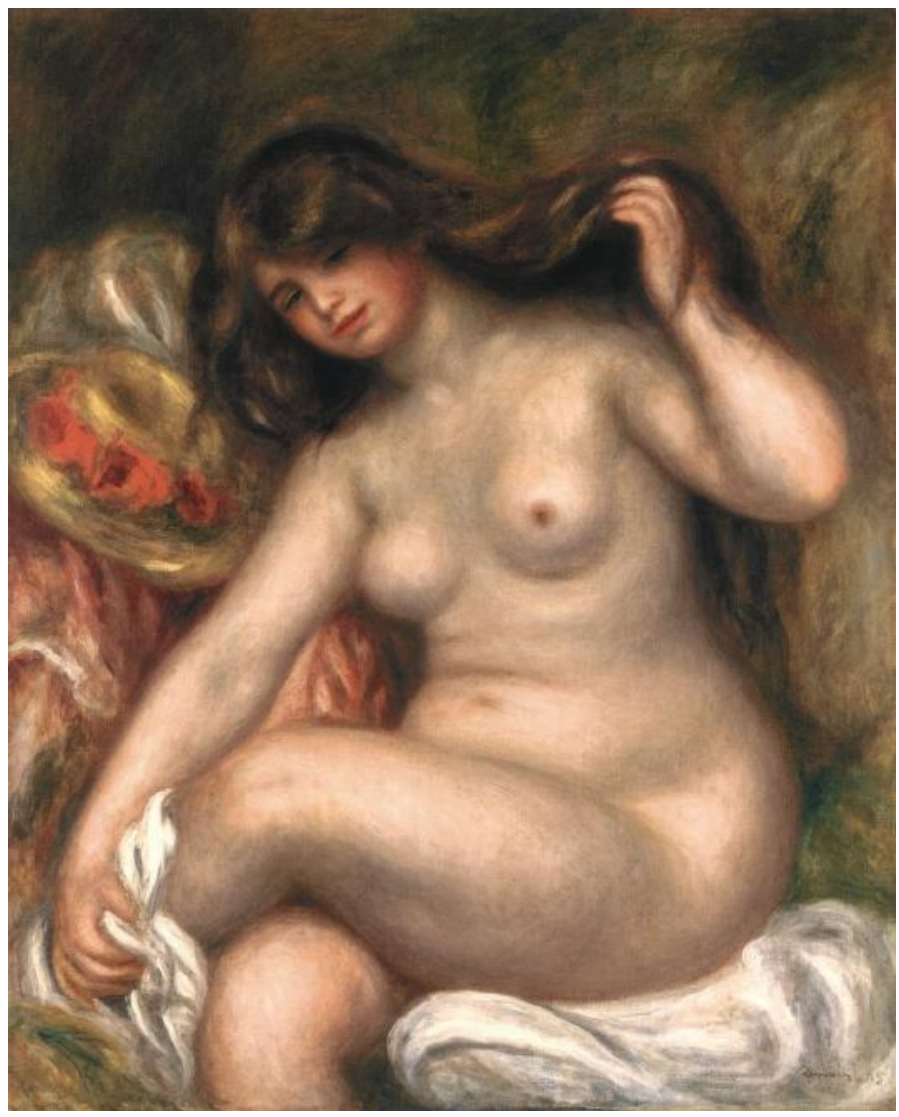

Fig.5.90. Pierre-Auguste Renoir. Grande Banhista. 1905, óleo sobre tela, 97 x $73 \mathrm{~cm}$. Museum of Art, Philadelphia.

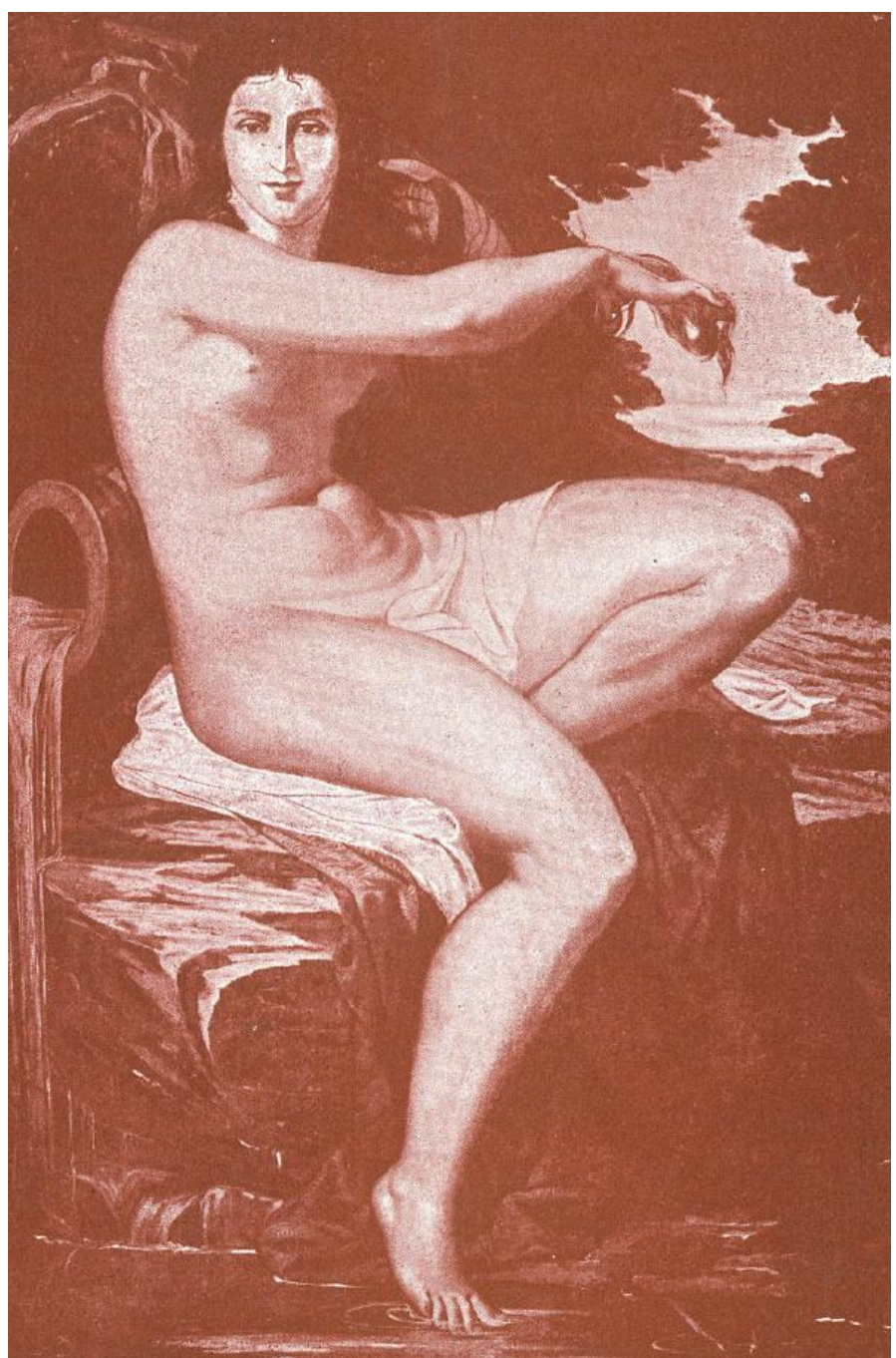

Fig.5.92. Pedro Américo. A Carioca, 1863-4, óleo sobre tela, 203 x $134 \mathrm{~cm}$. Localização atual e estado desconhecidos. 


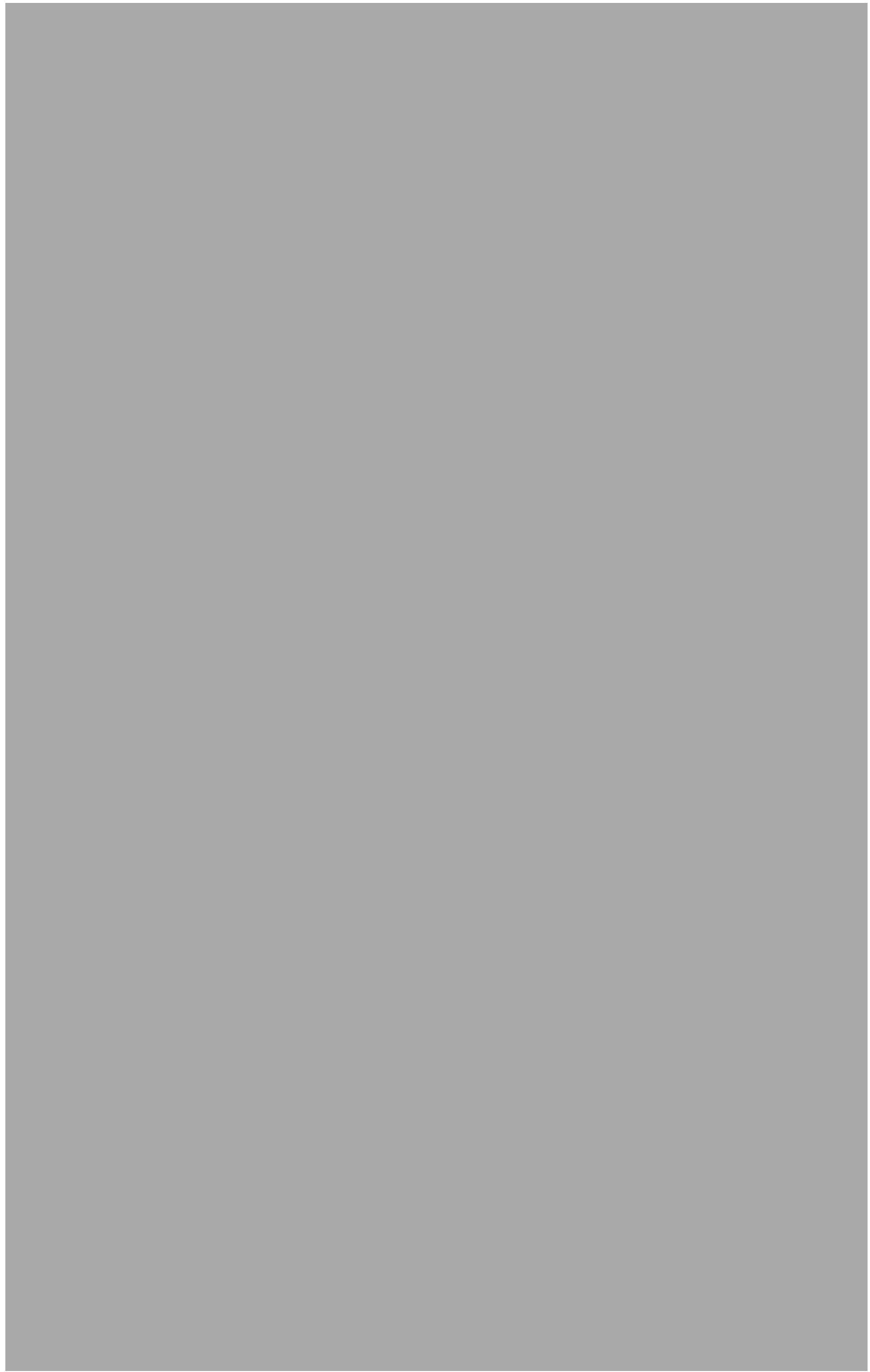



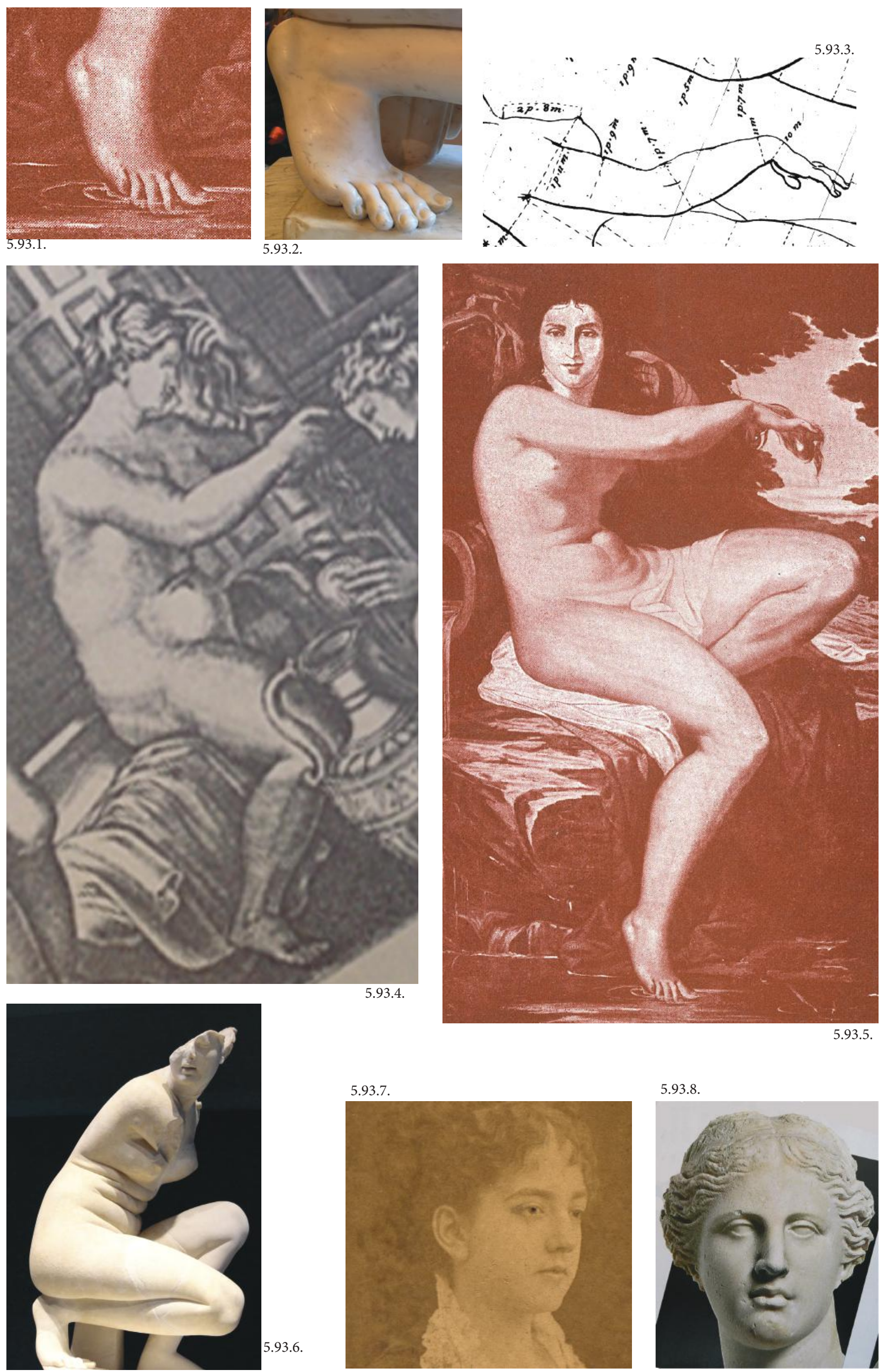

5.93.4.

5.93.5.

5.93.7.

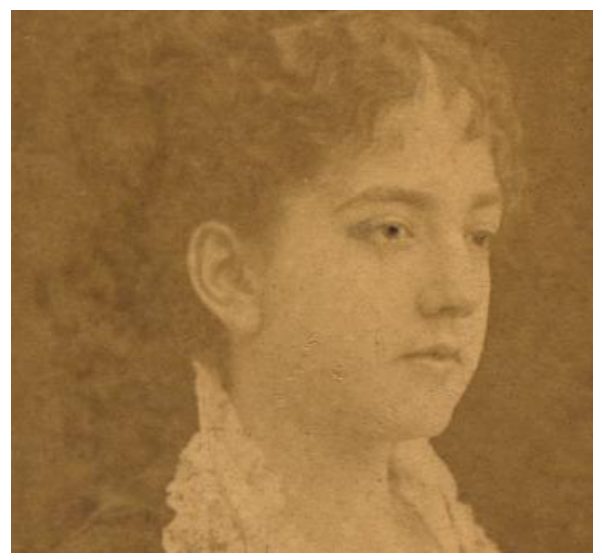

5.93.8.

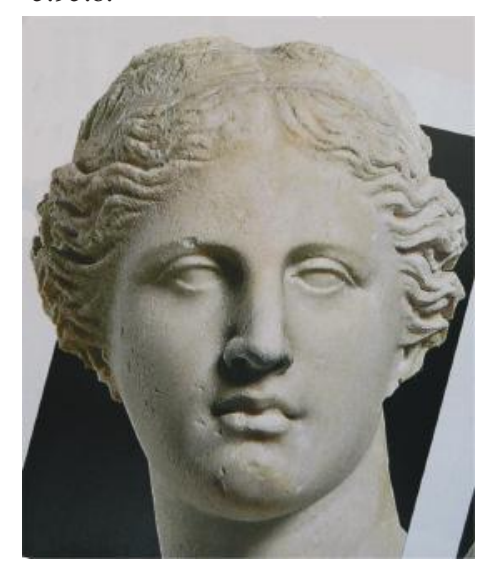



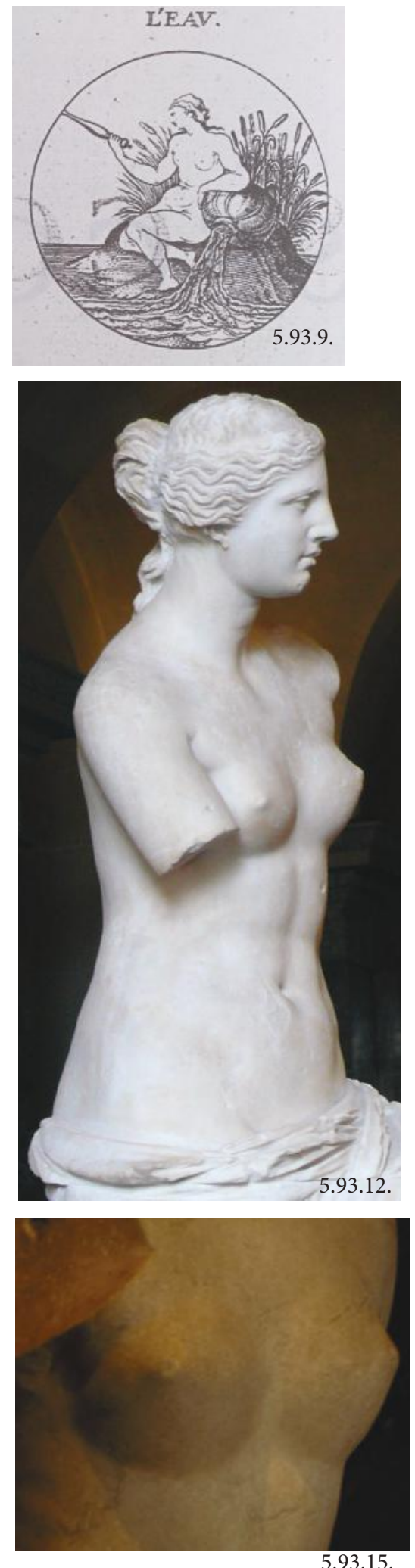

Fig.5.93. Ensaio visual sobre a síntese eclética nA Carioca.

5.93.1. Pé dA Carioca

5.93.2. Pé da Vênus agachada

5.93.3. Braço da Vênus de Médicis, horiz. 5.93.4. Pisqué no Banho. A p. de Rafael 5.93.5. A Carioca

5.93.6. Vênus Agachada.

5.93.7. Rosto da Senhora Moniz Aragão 5.93.8. Rosto da Vênus de Milo.

5.93.9. Alegoria à Água. Cesare Ripa. 5.93.10. Vênus Ferida. A partir de Rafael 5.93.11. Afrodite Agachada. P. Altemps. 5.93.12. Vênus de Milo.

5.93.13. Suzana e os velhos. Tintoretto. 5.93.14. Vênus e Adonis. Ticiano.

5.93.15. Busto da Vênus de Cnido.

5.93.16. Leda. Cópia de Michelangelo.
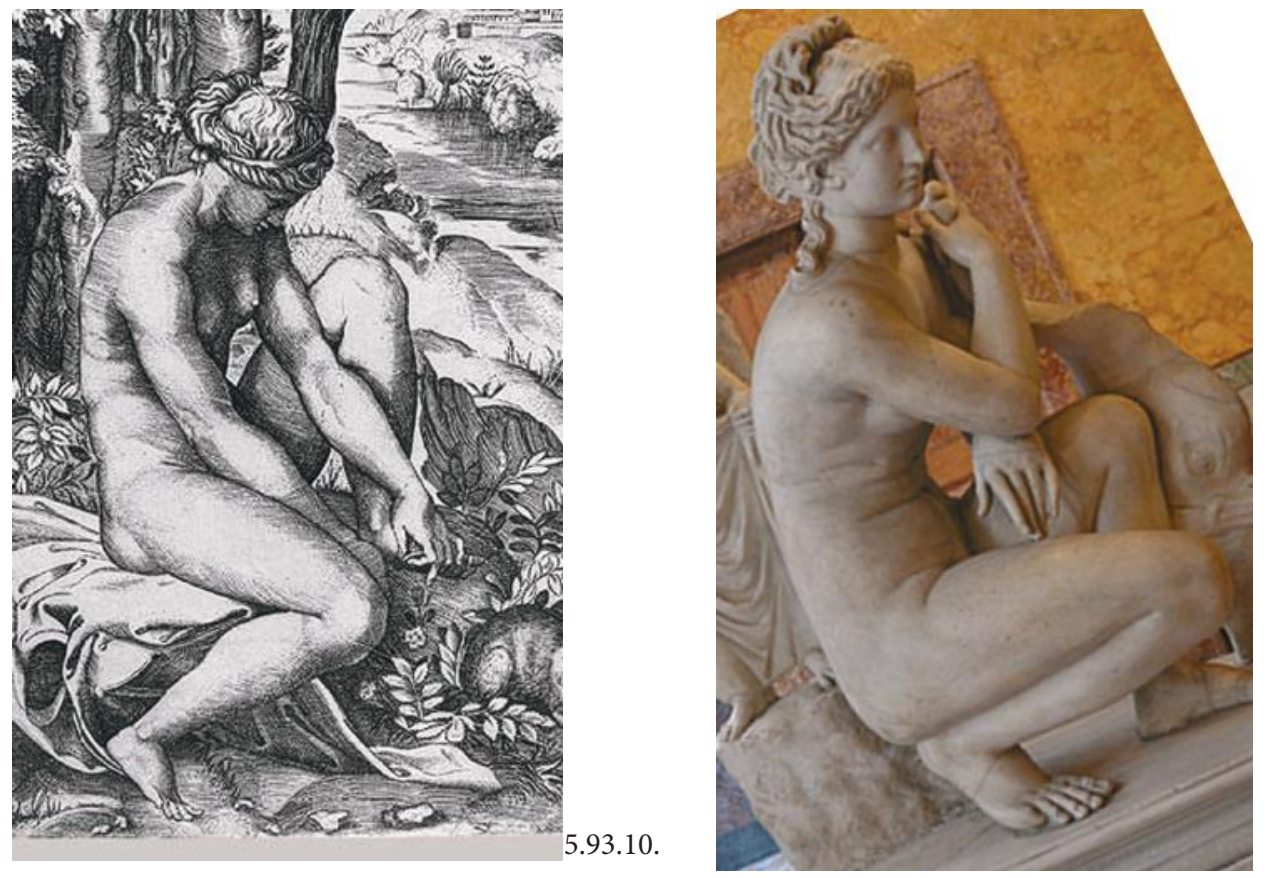

5.93 .10

5.93.11.
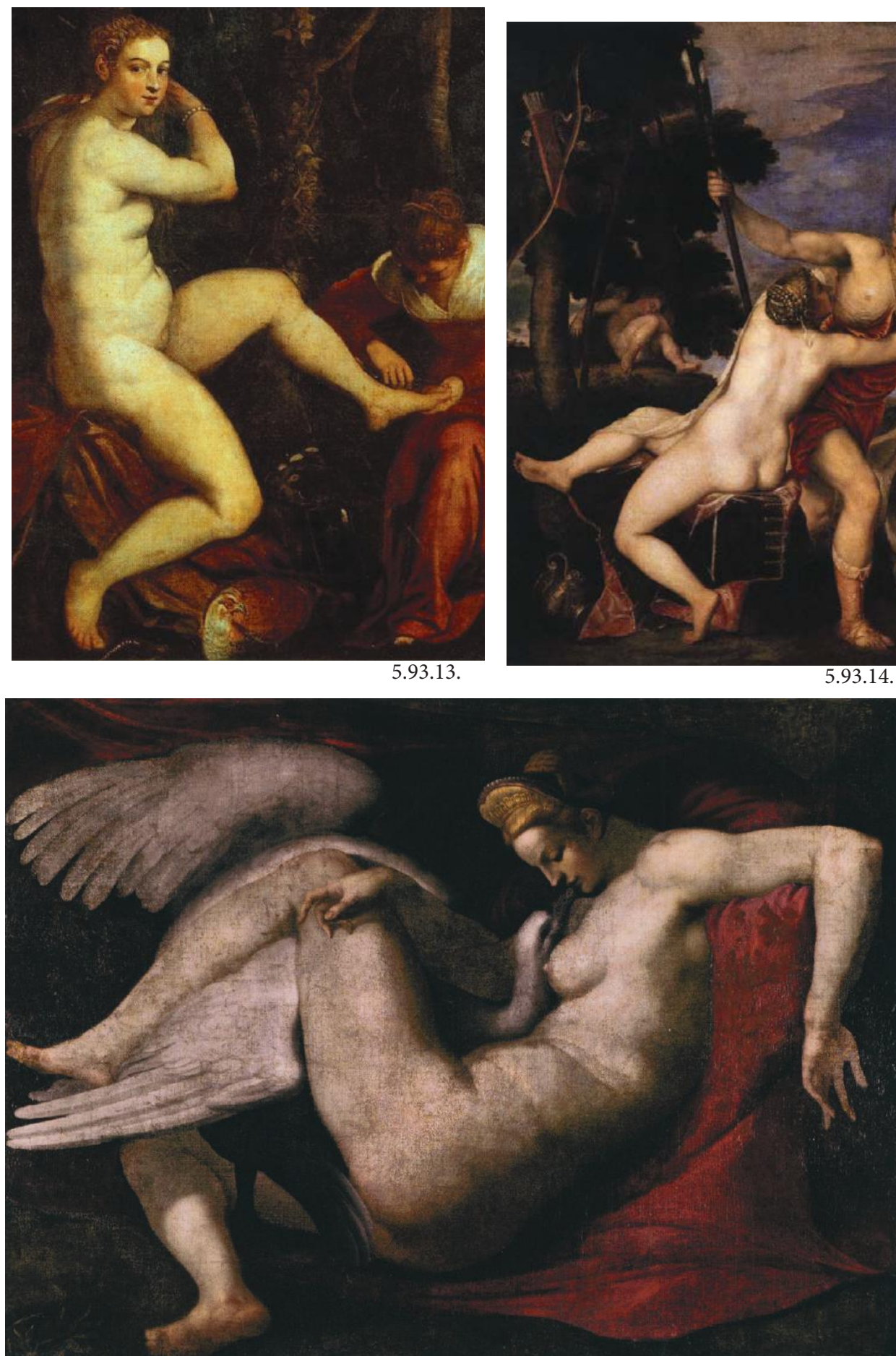


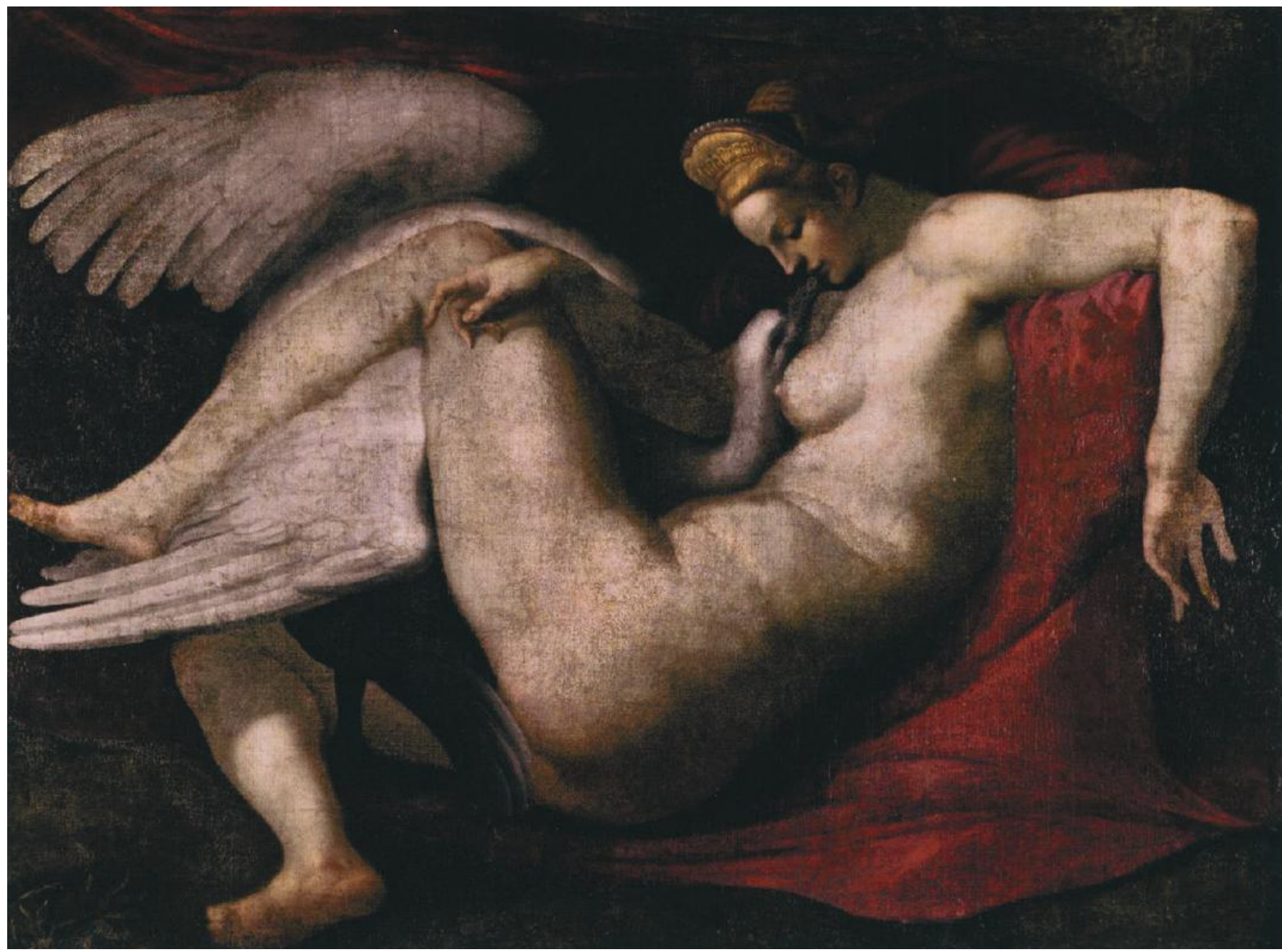

Fig.5.94. Copia de Michelangelo. Leda e o cisne, depois de 1530, óleo sobre tela, $105 \mathrm{~cm} \mathrm{x} 141 \mathrm{~cm}$. National Gallery.

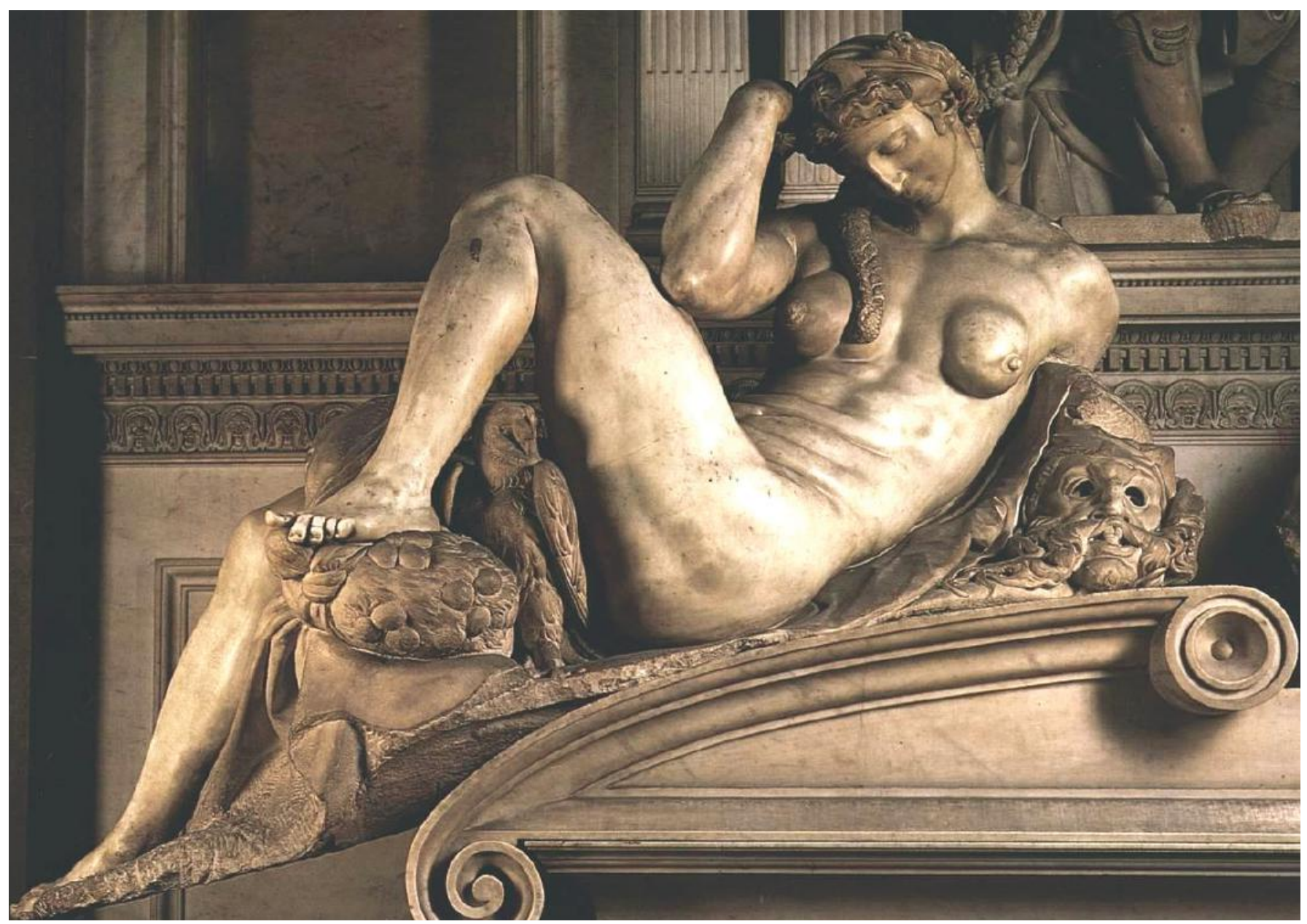

Fig.5.95. Michelangelo. A noite, 1524-27, mármore. Basílica San Lorenzo, Florença. 


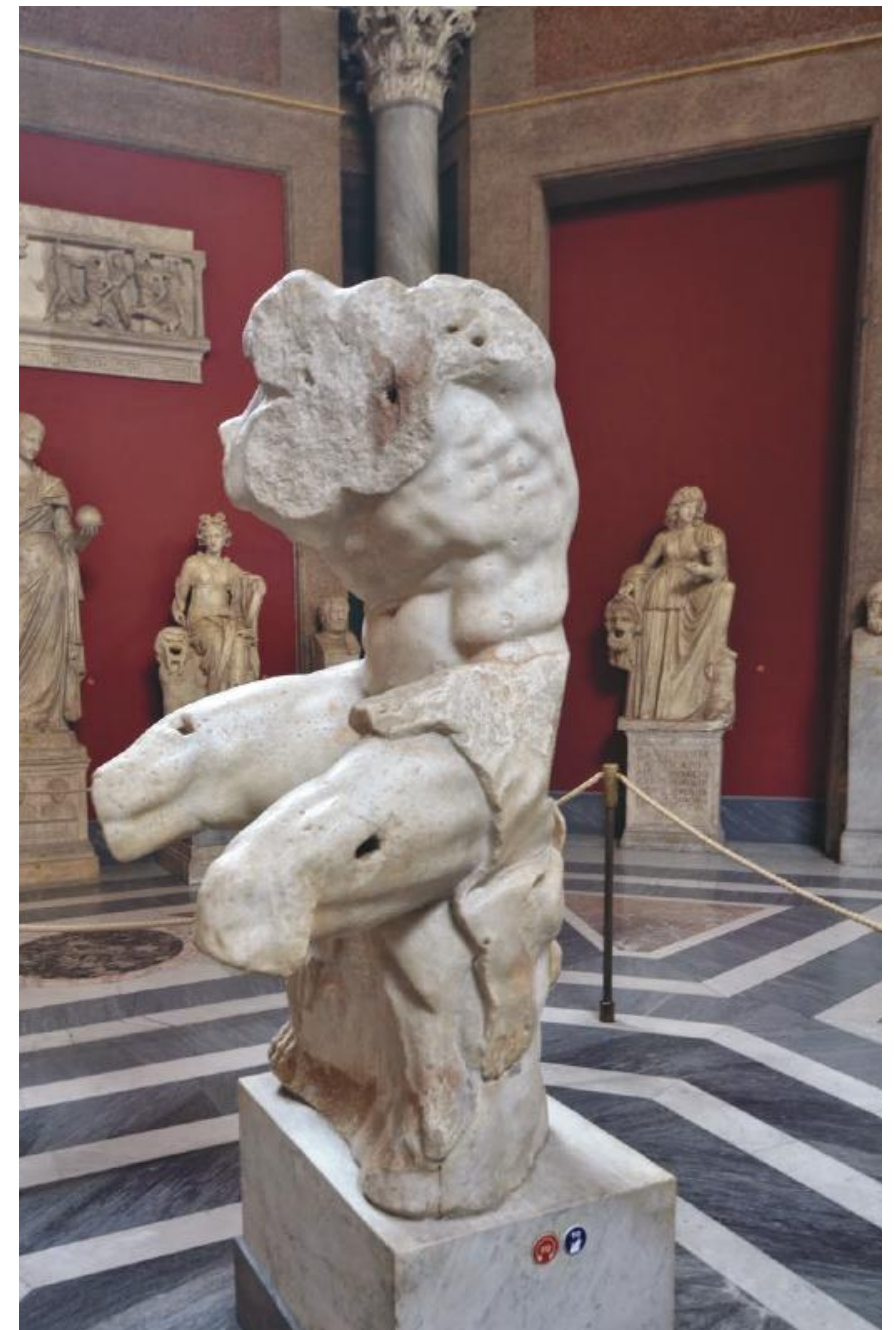

Fig.5.96. Apollonios. Torso de Belvedere, I século A.C. Mármore. Museu do Vaticano, Roma.

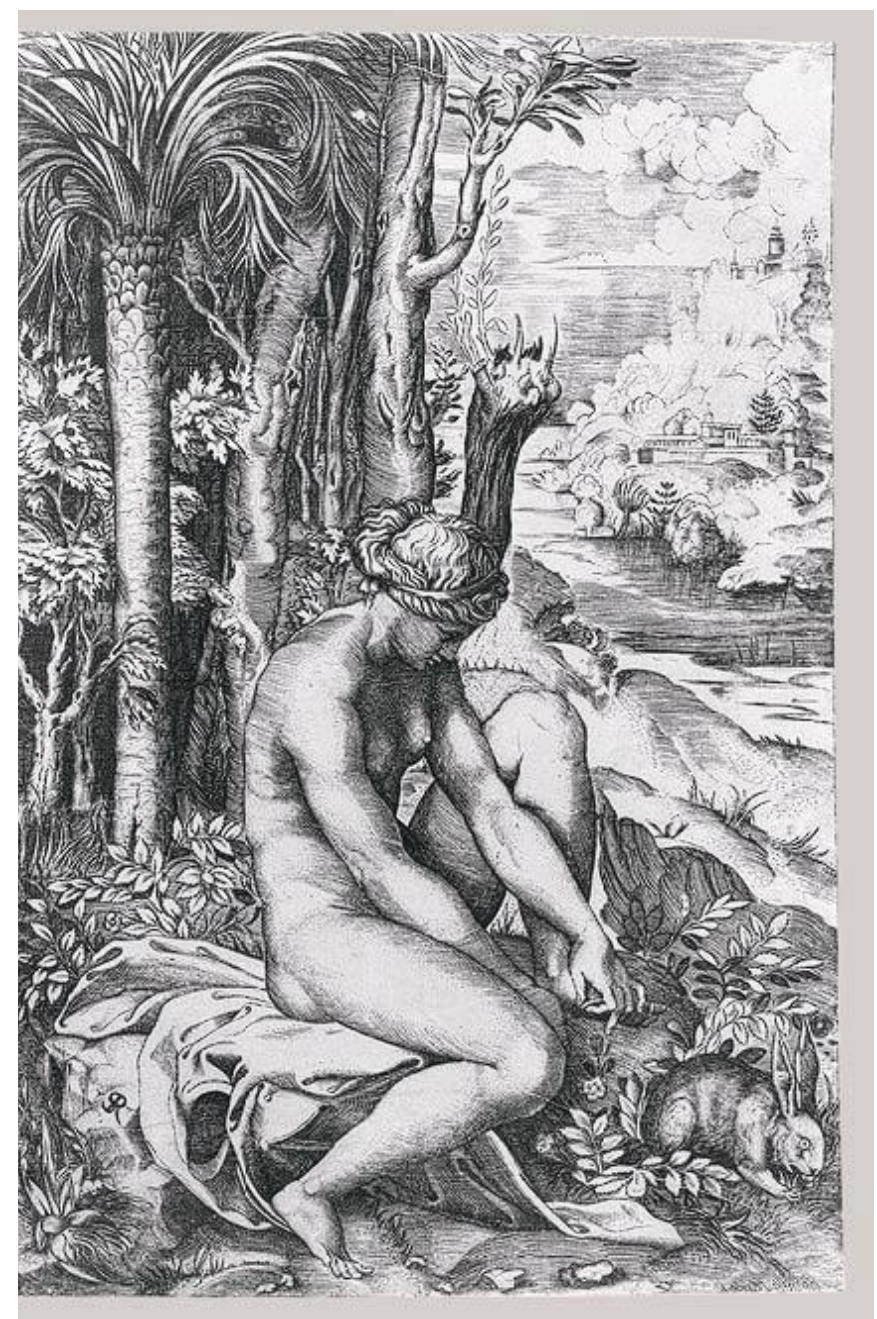

Fig.5.97. Marco Dente da Ravenna (a partir de Rafael). Vênus ferida, gravura. Metropolitam Museum of Art.

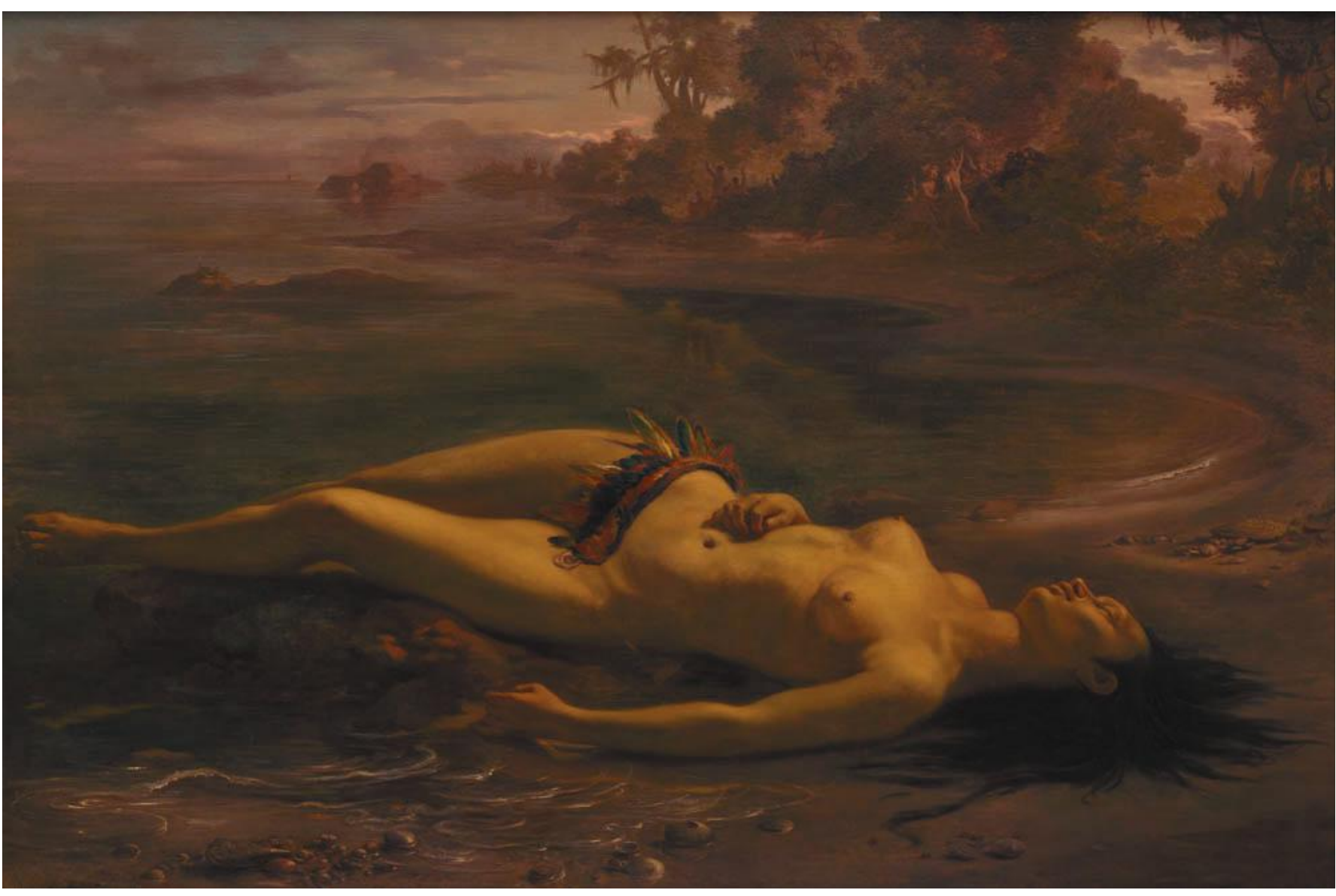




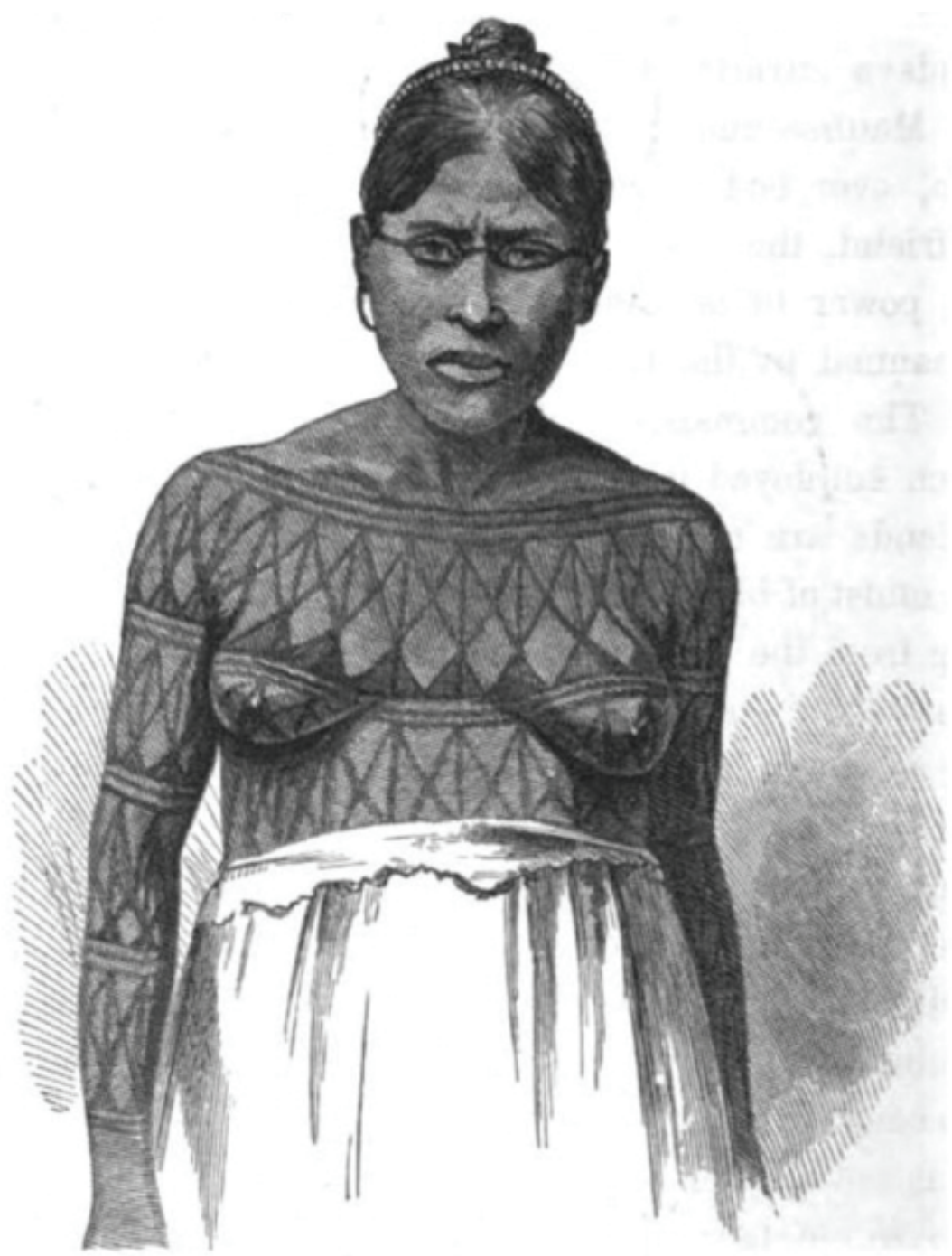

Fig.5.99. Indio Mundurucu; mulher, Gravura a partir de uma fotografia do Dr. Gustavo, de Manaus." IN: AGASSIZ, Louis; AGASSIZ, Elizabeth Cabot Cary. A journey in Brazil. Boston: Ticknor and Fields, 1869. p.313. 
Caderno de imagens Sexto Capítulo 



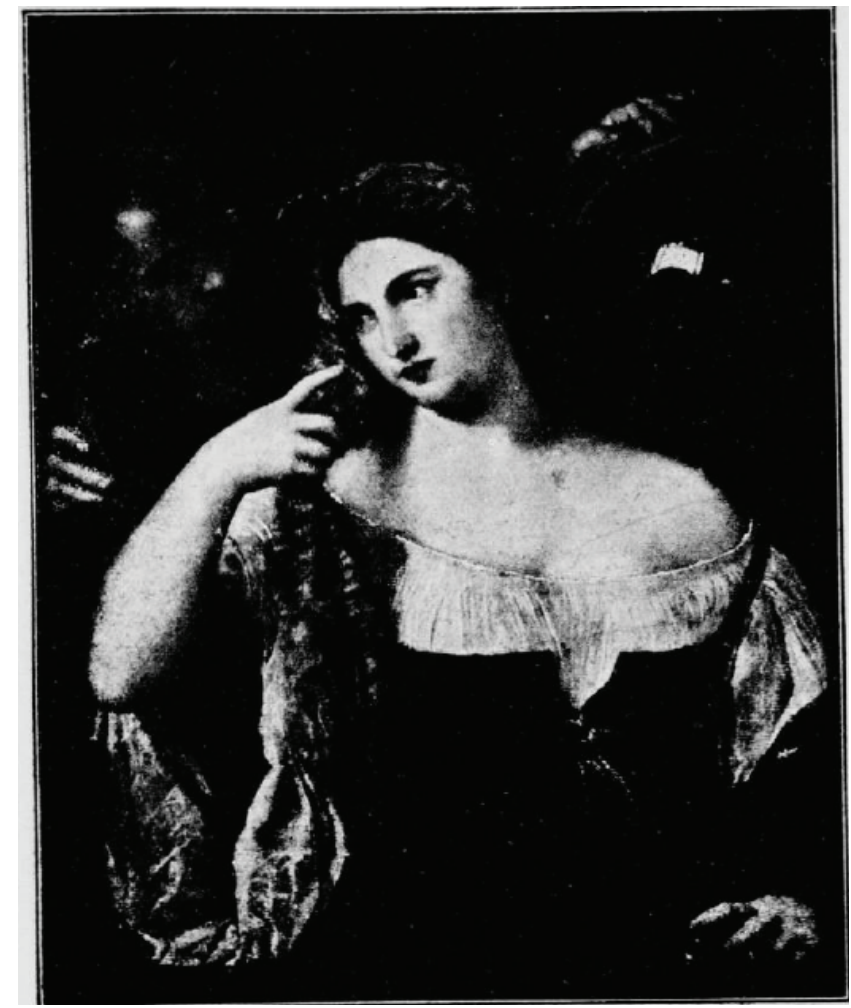

Fig.6.1. G. Bellenger, cópia do quadro Laura di Dianti, de Ticiano. Prancha II do livro: LECOQ DE BOISBAUDRAN, Horace. L'education de la mémoire pittoresque et la formation de l'artiste. Paris: H. Laurens, 1920.

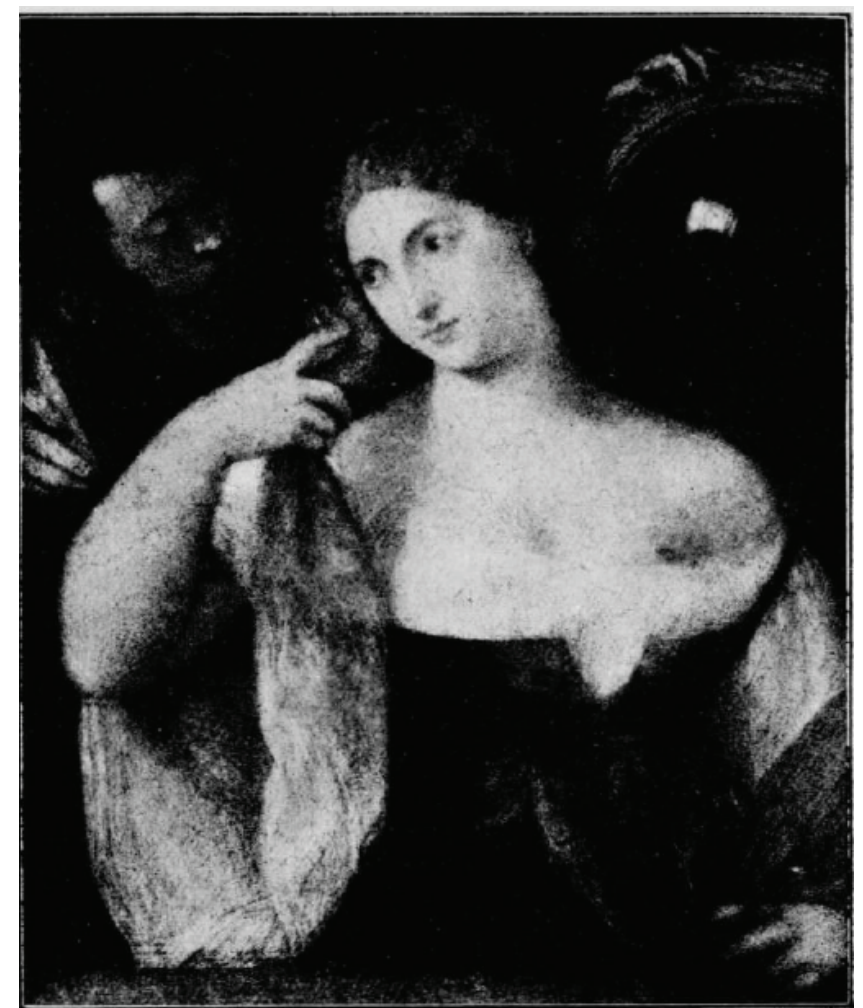

Fig.6.2. G. Bellegender. Desenho de memória feito depois de copiar o Laura di Dianti. Executado diante de comissão feita pela École des Beaux-Arts. Prancha III do mesmo livro.
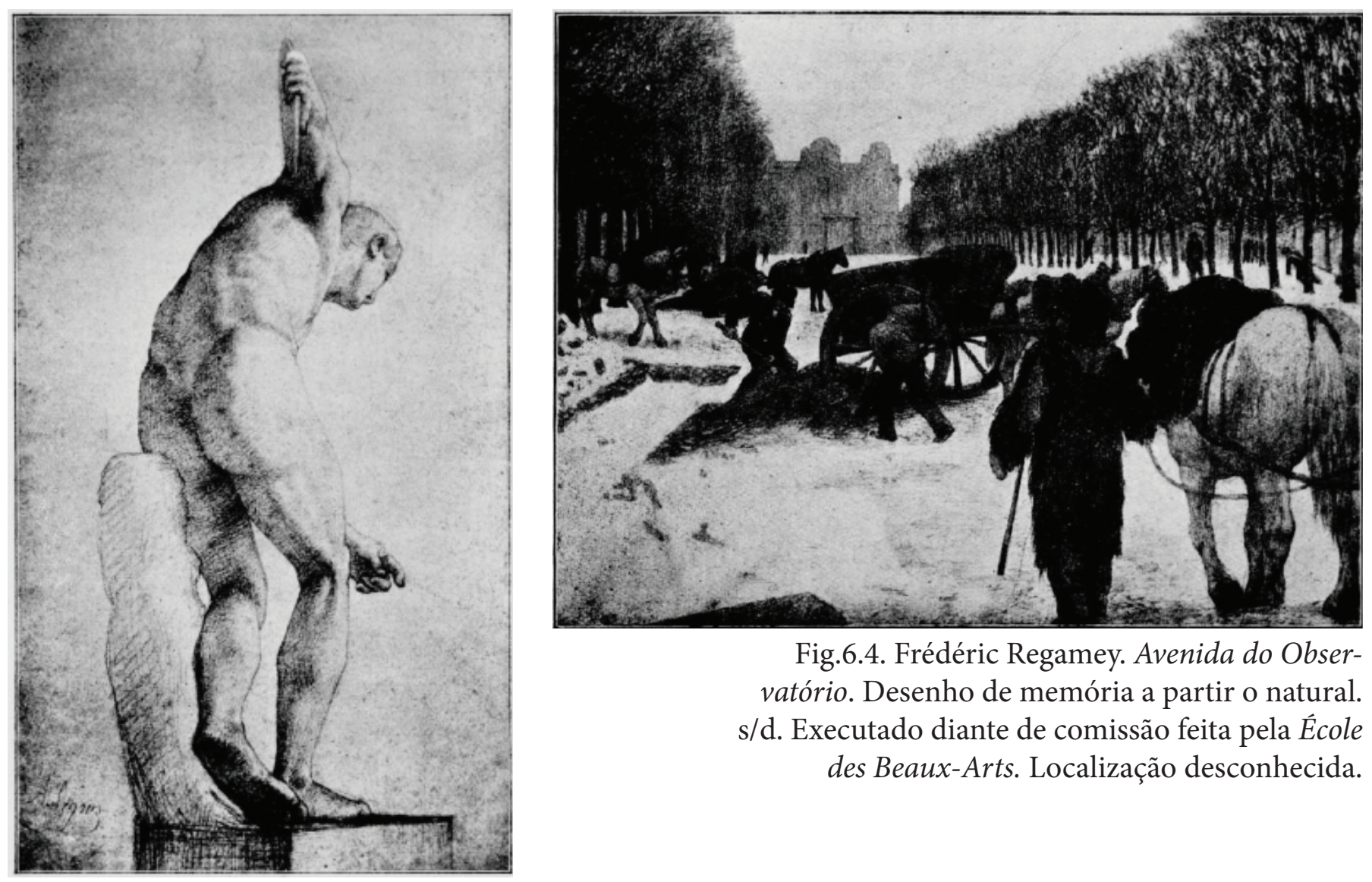

Fig.6.4. Frédéric Regamey. Avenida do Observatório. Desenho de memória a partir o natural. s/d. Executado diante de comissão feita pela École des Beaux-Arts. Localização desconhecida.

Fig.6.3. Alphonse Legros. Desenho de memória feito a partir de uma estátua antiga. S/d. Localização desconhecida. Prancha IX do mesmo livro. 

Caderno de imagens Sétimo Capítulo 



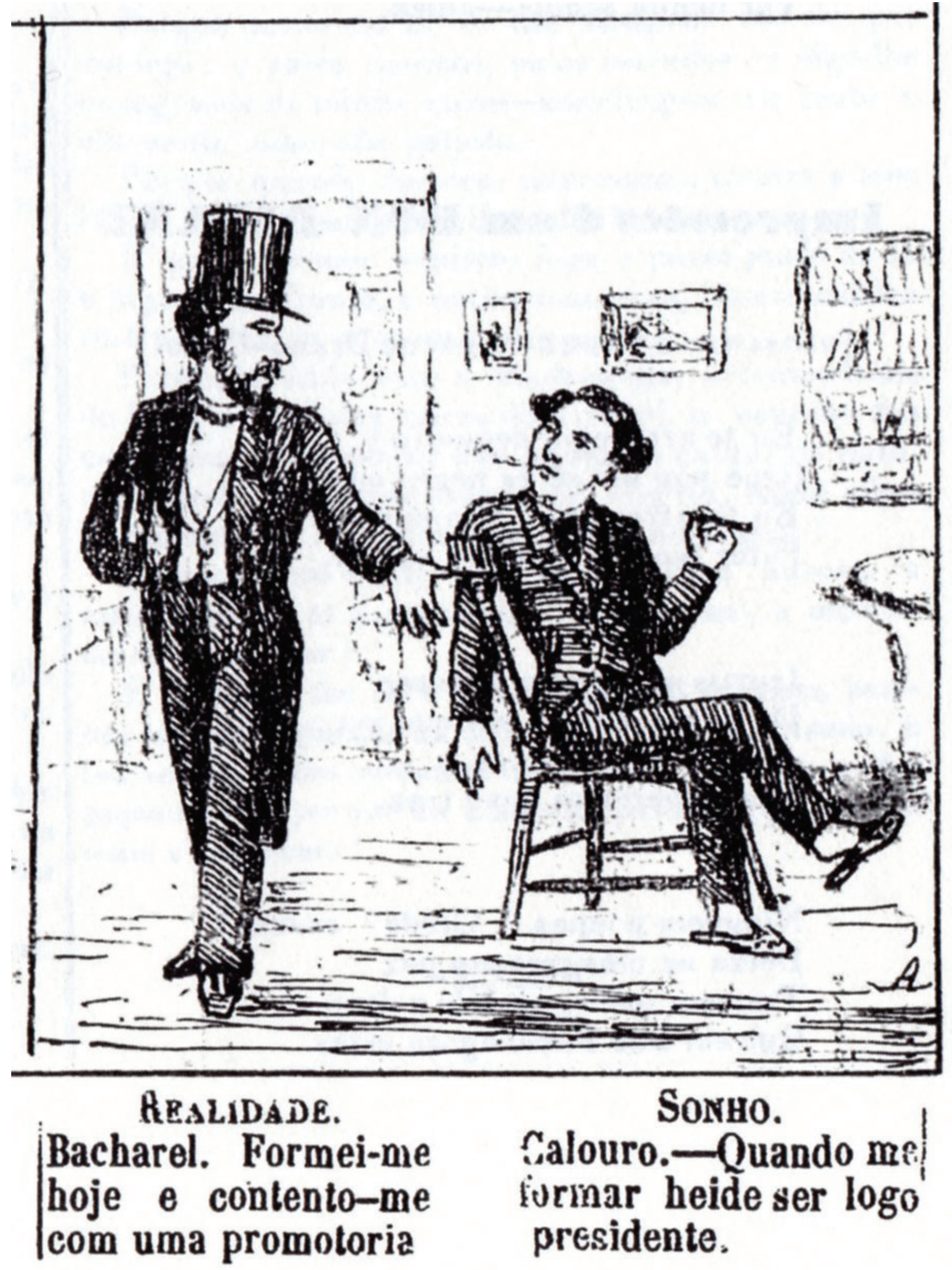

Fig.7.1. Angelo Agostini. Charge publicada na revista Diabo Coxo. Ano I, n.5. São Paulo, outubro de 1864. 


\section{Lista de Imagens}

\section{Folhas de rosto}

Pedro Américo. Autorretrato aos 11 anos, 1854, desenho sobre papel. Antiga Coleção Cardoso de Oliveira. Localização atual desconhecida. OLIVEIRA, J.M. Cardoso de. Pedro Américo sua vida e suas obras. Rio de Janeiro: Imprensa Nacional, 1943. p.31.

Pedro Américo, 1871, Fotografia. Coleção Biblioteca Nacional, Rio de Janeiro.

\section{Primeiro Capítulo}

Figura.1.1. Paul Delaroche. Hemiciclo do Palácio das Belas Artes, 1837-41. École des Beaux-Arts de Paris.

Fig.1.2. Plano do terreno da École des Beaux-Arts de Paris.

Fig.1.3. Jacques-Louis David. Retrato do Papa Pio VII. 1805, óleo sobre madeira, 86 x $71 \mathrm{~cm}$. Musée du Louvre.

Fig.1.4. Hyacinthe Rigaud. Portrait d'Honorat Joan Lafita, Clara Rigaud, Soeur de Hyacinthe Rigaud et de leur fille aînée Maria. Também intitulado: La famille Laffite. 16951696, óleo sobre tela. $83 \times 103 \mathrm{~cm}$. Paris, Musée du Louvre.

Fig.1.5.Guido Reni. Déjanire enlevée par le centaure Nessus. ca.1617-21. óleo sobre tela. 239 x $193 \mathrm{~cm}$. Musée du Louvre.

fig. 1.6.Théodore Géricault. Le Radeau de la Méduse. 1818-19, óleo sobre tela, $491 \mathrm{x}$ $716 \mathrm{~cm}$. Musée du Louvre.

Fig.1.3. Charles Giraud, Musée Napoléon III, sala de terracotas no Louvre, também conhecida como A Galeria Campana. 1866, óleo sobre tela. Museu do Louvre, Paris.

\section{Quarto Capítulo}

Fig. 4.1. Pedro Américo. A Carioca, 1863-4, óleo sobre tela, 203 x 134 cm. Localização atual e estado desconhecidos.

Fig. 4.2. Pedro Américo. A Carioca, 1882, óleo sobre tela, 205 x $135 \mathrm{~cm}$. Museu Nacional de Belas Artes, Rio de Janeiro.

Fig.4.3. Victor Meirelles. Amor sacro, cópia de Ticiano, óleo sobre tela, 107 x 88,5 cm. Museu Dom João VI. 
Fig. 4.4. Victor Meirelles. Bacante, 1857-58, óleo sobre tela, 77.9 x $87.5 \mathrm{~cm}$. MNBA.

Fig. 4.5 . Alexandre Cabanel. Naissance de Vénus. 1863, óleo sobre tela, 130 x $225 \mathrm{~cm}$. Musée d'Orsay.

Fig.4.6.Paul Baudry. La Perle et la vague, 1862, óleo sobre tela, $83.5 \mathrm{~cm} \times 178 \mathrm{c}$. Museo do Prado, Madri.

Fig.4.7. Amaury-Duval. La Naissance de Vénus. 1862, óleo sobre tela, $196.85 \times 108.90$ cm. Palais des Beaux-arts de Lille.

Fig.4.8. Édouard Manet. Déjeuneur sur l'herbe. 1862-3, óleo sobre tela, 208 x $264 \mathrm{~cm}$. Musée d'Orsay.

Fig.4.9. Édouard Manet. Olympia. 1863, óleo sobre tela, 130.5 x $190 \mathrm{~cm}$. Musée d'Orsay.

Fig.4.10. A. Cabanel. Ninfa abduzida por um fauno. 1861, óleo sobre tela, 130.5 x 190 cm. Musée d'Orsay.

Fig.4.11. Jean-Léon Gérôme. Socrates buscando Alcibiades na casa de Aspásia, 1861, óleo sobre tela, Terence Garnett Collection.

Fig.4.12. Jean-Léon Gérôme. Frineia diante do areópago, 1861, óleo sobre tela, 80,5 $\times$ $128 \mathrm{~cm}$, Hamburg Kunsthalle, Hamburgo, Allemanha.

Fig.4.14. Ingres. A Banhista de Valpincon, 1808, óleo sobre tela, Museu do Louvre.

Fig.4.13. Jean-Auguste-Dominique Ingres. La Source. 1820-1856, óleo sobre tela, 163 x $80 \mathrm{~cm}$.

Musée d'Orsay.

Fig.4.17. Jean-Auguste-Dominique Ingres, Venus Andyomène, 1858, óleo sobre tela, 64,18 x 36,14 cm. Musée Condé, Chantilly.

Fig.4.16. Gustave Courbet. La Source. 1868, óleo sobre tela, Musée d'Orsay.

Fig.4.15. Gustave Courbet. La Source. 1862, óleo sobre tela, 120 x $74.3 \mathrm{~cm}$. Metropolitan Museum of Art.

Fig.4.21. Nicolas Coustou, 1658-1733. La Seine et la Marne, 1704-1712. Jardin des Tuileries, Paris.

Fig.4.19. Louis Petitot. La Seine, 1846. Rive gauche, Ponte do Carrousel. Paris.

Fig.4.20. Alegoria a Rios franceses. 1861. Louvre, fachada da Ponte do Carrossel.

Fig.4.18. Pierre-Ambroise Richebourg (1810-1875). Salon des Beaux-Arts. Nef du Palais de l'Industrie. Paris VIIIe. 1861, fotografia, tiragem em papel albuminado, 38.5 x $27.5 \mathrm{~cm}$. BNF, Paris.

Fig.4.24. Pierre Lescot (arquitetura); Jean Goujon (escultura). Fontes das Ninfas (ou Fontes dos inocentes). 1549. Paris.

Fig.4.23. Fonte Louvois. 1844. Place Louvois, Paris. 
Fig.4.22. Corneille Van Cleve. Alegorias aos rios La Loire e Le Loiret. Jardin des Tuilleries, Paris.

Fig.4.25. Balthasar Keller. La Dordogne (a partir de Antoine Coysevox.). Platéia de Água [Parterre d'eau]. Jardim do Palácio de Versailles.

Fig.4.26. Balthasar Keller. Le Loiret (a partir de Thomas Regnaudin). Platéia de Água [Parterre d'eau]. Jardim do Palácio de Versailles.

Fig.4.27. François Girardon. Banho das Ninfas. 1670-71. Jardim do Palácio de Versailles.

Fig.4.28. Le Hongre. conjunto do Banho das Ninfas. 1670-71. Jardim do Palácio de Versailles.

Fig.4.29. Alegoria fluvial. conjunto do Banho das Ninfas. 1670-71. Jardim do Palácio de Versailles.

Fig.4.30. Benvenuto Cellini. La Nymphe de Fontainebleau, 1572, bronze. Museu do Louvre.

Fig.4.31. Jean Louis Brian. Alegorias aos rios Rhin e Seine. 1852. Gare de 1'Est. Paris.

Fig.4.32. Jean Louis Brian. Alegorias aos rios Meuse e Marne. 1852. Gare de l'Est. Paris.

Fig.4.33. Edouard Hildebrandt. Largo da Carioca, com o Chafariz da Carioca. 1844. Aquarela sobre papel. Nationalgalerie, Berlim.

Fig.4.34. Afrodite, dita Vénus de Milo. ca. 100 A.C., mármore, Museu do Louvre.

Fig.4.35. Marcantonio Raimondi. Venus agachada, ca.1505-1506, gravura sobre papel. Michigan Museum.

Fig.4.36. Eugène Delacroix. Estudo a partir da Vênus agachada do Louvre, desenho, primeiro quarto do século XIX. Museu do Louvre.

Fig.4.37. Jean Auguste Dominique Ingres. Vênus agachada, desenho, pimeiro quarto do século XIX. Desenho. Museu Ingres, Montauban.

Fig.4.38. Jean-Jacques Henner. Nymphe qui pleure, óleo sobre, tela, 4e quart 19e siècle. Musée national Jean-Jacques Henner, Paris.

Fig.4.39. Paul Cézanne. Esboços de ninfa Agachada, Desenho, segunda metade do século XIX ao primeiro quadro do XX. Museu do Louvre.

Fig.4.40. Pedro Américo. Cópia da Vênus de Milo. Loc. desconhecida.

Fig.4.41. Pedro Américo. Vênus de Médicis, 1858, carvão sobre papel, $63.6 \times 48 \mathrm{~cm}$. MNBA.

Fig.4.42. Possível percurso de cidades italianas feito por Américo em sua primeira estadia européia. 
Fig.4.43. Jacopo Robusti, dito Tintoretto. Suzana ao banho, óleo sobre tela, 167 x 238 $\mathrm{cm}$. Museu do Louvre.

Fig.4.44. Ticiano Vecellio. O concerto campestre. ca. 1509, óleo sobre tela, 110 x 138 cm. Museu do Louvre.

Fig.4.45. Jacopo Zucchi. Allegoria della discoperta dellAmerica, 1585,

óleo sobre tela, 55 x $45 \mathrm{~cm}$ Galeria Borghèse.

Fig.4.46. Jean-Théodore de Bry (a partir de Stradanus). Américo redescobre a América. Ele a chamou uma vez e desde então ela permanece acordada. 1575-80, gravura sobre papel, $19.8 \times 26.7 \mathrm{~cm}$. In: Americae decima pars (Oppenheim, c.1619).

Fig.4.47. Jan Sadeler. America, 1581, gravura sobre papel, 16.1 x 22.1. RijksMuseum, Amsterdam.

Fig.4.48. Marten de Vos. Alegoria da América. ca.1600. Flandres.

Fig.4.49. Adriaen Collaert (a partir de Marten de Vos). America. 1551-1600.Virtuelle Kupferstichkabinett.

Fig.4.50. Crispin de Passe. Alegoria da América. 1639. Amsterdam.

Fig.4.51. José Teófilo de Jesus, 1758-1847, América,s.d, óleo sobre tela, 65 x $82 \mathrm{~cm}$. Museu de Arte da Bahia.

Fig.4.52. Alegoria da América. Impressa em Il costume antico e moderno, Milano, 18201821.

Fig.4.53. Alegoria da América. Impressa em RIPA, Cesare. Iconologia. ed. 1683. p.68.

Fig.4.54. Bernini. A verdade Revelada, 1646-52, mármore, Galeria Borghèse.

Fig.4.55. Pedro Américo. São Miguel Arcanjo e o Demônio (cópia de Rafael Sanzio), 1857, óleo sobre tela, 136,5 x 108,8 cm Mosteiro de São Bento - RJ.

Fig.4.56. Rafael Sanzio. Visão fronta da Loggia di Galatea. 1517. Afresco. Villa Farnesina, Roma.

Fig.4.57. Rafael (desenho); Giulio Romano, Gianfrancesco Penni e Raffaellino del Colle (pintura). Sala de Constantino, 1517-25. Afresco. Vaticano.

Fig.4.58. Claude-Joseph Barandier. Indígenas. Sem data, óleo sobre tela, Localização desconhecida. Litografado e impresso em: IMPERIAL INSTITUTO ARTÍSTICO.

Recordações da Exposição Nacional de 1861. Rio de Janeiro: Imperial Instituto Artístico, 1862.

\section{Quinto Capítulo}


Fig.5.1. Jean-Léon Gérôme. As banhista do harém, 1901, óleo sobre tela, 99,7 × 80,6 cm. Coleção privada.

Fig.5.2. Thomas Gainsborough. Musidora. c.1780-8, óleo sobre tela, $188 \mathrm{~cm}$ x $153 \mathrm{~cm}$. Tate Gallery.

Fig.5.4. Senhora Egas Muniz Barreto de Aragão, nascida Nogueira da Gama. (Baronesa Muniz de Aragão), fotografia, cartão cabinet. Paris. 13,5 x $10 \mathrm{~cm}$. Arquivo Wanderley Pinho, IHGB.

Fig.5.3. Egas Muniz Barreto de Aragão e Menezes (Barão Muniz de Aragão), 18711880 , fotografia, $10 \times 6 \mathrm{~cm}$. Arquivo Nacional.

Fig.5.5. Pedro Américo. Duas versões d'A Carioca. 1864 e 1882. Indicação das linhas centrais, vertical e horizontal, e dos terços verticais.

Fig.5.6. Pedro Américo. Duas versões d'A Carioca. 1864 e 1882. Indicação das linhas estéticas dominantes a partir da Filosofia aplicada às Belas Artes, de Sutter.

Fig.5.7. SUTTER, David. Esthétique générale et appliquée. Paris: Imprimerie impériale, 1865. Prancha C (ilustração 11).

Fig.5.8. Pedro Américo. Tiradentes esquartejado, 1893, óleo sobre tela, $270 \times 165 \mathrm{~cm}$. Museu Mariano Procópio.

Fig.5.9. Vênus de Médicis. Medição das relações internas do corpo da estátua. In: AUDRAN, Gérard. Les proportions du corps humain mesurées sur les plus belles figure de l'antiquité. Paris: Bance Éditeur, 1855. Prancha 15.

Fig.5.10. "As partes do rosto de uma Vênus antiga medidas de suas mesmas grandezas". In: AUDRAN, Gérard. Les proportions du corps humain mesurées sur les plus belles figure de l'antiquité. Prancha 28.

Fig.5.11. Pedro Américo. A Carioca, 1863-4. Estudo das proporções da face da figura.

Fig.5.12. Pedro Américo. A Carioca, 1863-4. Estudo das proporções do corpo da figura.

Fig.5.13. J. W. Goethe. Estudo de proporção de rosto. Nationale Forchungsund Gedenkstätten der Klassischen deutschen Literatur, Weimar.

Fig.5.14. J. J. Winckelmann. Estudo em proporção da cabeça humana e comentários. Società Columbaria, Firenze. IV, II, II, 52.

Fig.5.15. Winckelmann. Estudo em proporção da cabeça humana e comentários. Società Columbaria, Firenze. IV, II, II, 52.

Fig.5.16. Édouard Manet. Ninfa Surpreendida, 1861, óleo sobre tela, $122 \mathrm{~cm} \times 144 \mathrm{~cm}$. Museu Nacional de Belas Artes de Buenos Aires.

Fig.5.17. Michelangelo. Ignudos, c.1508-1512, e Sibila Delfica 1508-1510, afresco. Capela Sistina, Roma. 
Fig.5.18. Peter Paul Rubens. O banho de Diana, 1635- 40, óleo sobre tela, 152.5 x 120 cm. Boijmans Collection.

Fig.5.19. Rembrandt. Betsabéia se banhando, óleo sobre tela, 1654. 142 x 142. Museu do

Louvre.

Fig.5.20. Rembrandt. Diana no Banho, ca.1629, Carvão sobre papel, 18.1 x $16.4 \mathrm{~cm}$. British Museum, London.

Fig.5.21. Rafael. Vênus e Cupido. 1517-18, afresco. Villa Farnesina, Roma.

Fig.5.22. Ticiano, Vênus e Adonis, 1554, óleo sobre tela, 180 x $207 \mathrm{~cm}$. Museo del Prado, Madrid.

Fig.5.23. Jean-Jacques Henner. A casta Suzana, 1864, óleo sobre tela, 185 x 130cm. Paris,

Musée d'Orsay.

Fig.5.24. Pedro Américo. Academia Masculina. Prova para concurso da cadeira de Desenho

Figurado da AIBA, 1865, carvão e Lápis sobre papel. Museu d. João VI.

Fig.5.26. Pedro Américo. Recorte sobre Aspásia do quadro Sócrates afastando Alcebiades do vício, 1865.

Fig.5.25. Pedro Américo. Sócrates afastando Alcebíades do vício, 1865, óleo sobre tela,130,5 x 97 cm. Rio de Janeiro, Museu d. João VI - EBA/ UFRJ.

Fig.5.28. Gustave Boulanger. Frinéia, 1850, óleo sobre tela, 185 x $152 \mathrm{~cm}$. Museu Van Gogh, Amsterdam.

Fig.5.27. Jules Le Chevrel. Sócrates afastando Alcebíades do vício, 1865, óleo sobre tela, 97 x 130,5 cm. Rio de Janeiro, Museu d. João VI - EBA/UFRJ.

Fig.5.29. SUTTER, David. Esthétique générale et appliquée. Paris: Imprimerie impériale, 1865. Prancha A (ilustrações 5, 6 e 7).

Fig.5.30. Duas versões dA Carioca. 1864 e 1882. Indicação das direções gerais das luzes e sombras.

Fig.5.31.Afrodite de Cnido. Cópia romana da Vênus de Cnido, de Praxíteles. Entre 360 e 330 A.C. Palazzo Altemps, Roma.

Fig.5.32. Menophantos. Afrodite de Menophantos. I século A.C. National Museum of Rome. Palazzo Massimo alle Terme. Cópia da Vênus Cnido.

Fig.5.33. Vênus de Médicis. cópia do I século A.C. de uma estátua em bronze do tipo da Afrodite de Cnido, mármore. Galeria Uffizi, Florença. 
Fig.5.34. Estatueta de Afrodite torcendo os cabelos. Período Helenístico ou Imperial. 100 A.C.-70 D.C., mármore. Museu de Belas Artes de Boston.

Fig.5.35. Sandro Botticelli. O nascimento de Vênus, ca. 1486., têmpera sobre tela, 172.5 $\mathrm{cm} \times 278.9 \mathrm{~cm}$. Uffizi, Florença.

Fig.5.36. Antonio Lombardo. Vênus Anadiomêna, ca.1510-15, mármore. 41 x $23 \mathrm{~cm}$. Victoria and Albert Museum, Londres.

Fig.5.37. Marcantonio Raimondi. Nascimento de Vênus (ou Vênus saindo do mar). 1506, gravura, 21 x $14.7 \mathrm{~cm}$. Museu de Arte de Boston.

Fig.5.38. Rafael. Vênus, Ceres e Juno. 1517-18, Afresco. Villa Farnesina, Rome.

Fig.5.39. Ticiano. Vênus Anadiomêna, ca.1520, óleo sobre tela, 75.8 x 57.6cm. National Galleries of Scotland.

Fig.5.41. Jean-Auguste-Dominique Ingres, Vênus Anadiomêna, 1858, óleo sobre tela, 64 1.8 x 36 1.4. Musée Condé, Chantilly.

Fig.5.42. Theodore Chasseriau. Vênus marina dita Anadiomêna, 1838, óleo sobre tela, Museu do Louvre.

Fig.5.40. Cornelis de Vos. O nascimento de Vênus, 1636, óleo sobre tela, $187 \mathrm{~cm}$ x 208 cm, Museu do Prado, Madri.

Fig.5.43. Paul Baudry. Toilette de Vênus, 1858, óleo sobre tela. Museu de Bordeaux.

Fig.5.44. Amaury-Duval. O nascimento de Vênus, 1862, óleo sobre tela, $196.85 \times 108.90$ $\mathrm{cm}$. Palais des Beaux-arts de Lille.

Fig.5.45. William-Adolphe Bouguereau. Banhista, 1864, óleo sobre tela. 166.5 x 103.5 $\mathrm{cm}$. Museum voor Schone Kunsten, Ghent.

Fig.5.46. Bouguereau. O nascimento de Vênus, 1879, óleo sobre tela. 300 x $218 \mathrm{~cm}$. Musée d'Orsay, Paris.

Fig.5.47. Jules Joseph Lefebvre. Banhista, data desconhecida, óleo sobre tela, 60 x 95 cm. Localização não encontrada.

Fig.5.48. Henri Fantin-Latour. Vênus e cupido, 1902, óleo sobre tela. Coleção privada.

Fig.5.49. Pierre-Auguste Renoir. Banhista. 1888, óleo sobre tela, 81 x 66 cm. Coleção privada.

Fig.5.50. Afrodite Agachada. Cópia romana do II século D.C. a partir do original do século III ou II A.C de Doidalsas. Casa Real Inglesa, Londres.

Fig.5.51. Aphrodite de Doidalsas. Cópia romana da Villa Hadriana. ROme, Museo Nazionale Romano. Palazzo Massimo alle Terme.

Fig.5.52. Afrodite agachada. Cópia romana do I ou II século D.C. Mármore. Museu do Louvre, Paris. 
Fig.5.53. Autor desconhecido. Venus de Rhodes. I século A.C, mármore. Archaeological Museum of Rhodes.

Fig.5.54. Afrodite agachada Anadiomêna. I século A.C., argila. Museu do Louvre.

Fig.5.55. Afrodite ao banho. Variação romana do original grego atribuído a Doidalsas, mármore. Palacio Altemps, Roma.

Fig.5.56. Afrodite agachada. Variante romana da época imperial a partir de um tema helenístico, màrmore. Museu do Louvre.

Fig.5.57. Afrodite em seu banho. Variação do original de helenístico de Doidalsas, mármore. Coleção Ludovisi. Coleção Cesi. Palácio Altemps, Roma.

Fig.5.58. Charles Antoine Coysevox. Vénus agachada, mármore. 1686. Musée du Louvre.

Fig.5.59. Rafael. Pan e Siringa. início do século XVI. Antes de 1516, sanguínea sobre papel, 18,6 x 18,2 cm. Museu do Louvre.

Fig.5.60. Rafael. Pan e Siringa. 1516, afresco na parede oeste do banheiro do cardeal Bibbiena, Vaticano, Roma.

Fig.5.61. Rafael. Davi e Betsabéia. ca.1517, afresco. Roma, Vaticano.

Fig.5.63. Marcantonio Raimondi (a partir de Rafael). Pan e Siringa, gravura, 24.7 x 17 cm. Graphische Sammlung Albertina, Viena.

Fig.5.62. Agostino dei Musi (a partir de Rafael). Vênus atendida em seu banho, gravura. 19.6 x $23.6 \mathrm{~cm}$. Publicado por Antonio Salamanca, 1530-60.

Fig.5.64. Palma Vecchio. Diana e Calisto. 1525/1528. Óleo sobre tela, 77.5 x $124 \mathrm{~cm}$. Kunsthistoriches Museum, Viena.

Fig.5.65. Jean Cousin. Mulheres no banho. Água forte a partir de Luca Penni. 1543-45. Coleção Particular, Paris.

Fig.5.66. Jan Swart van Groningen. Betsabéia no banho, 1535-1540. Óleo sobre tela.

Fig.5.67. Jacopo Robsit, dito Tintoreto. Suzana no Banho, 1550, óleo sobre tela, 167 x $238 \mathrm{~cm}$. Museu do Louvre.

Fig.5.68. Paolo Veronese (atribuído). Vênus em seu toilette, ca.1570, óleo sobre tela, 87 x $71 \mathrm{~cm}$. Localização desconhecida.

Fig.5.69. Jacopo Zucchi. Recorte da Allegoria della discoperta dellAmerica, 1585, óleo sobre tela. Galeria Borghèse.

Fig.5.70. Agostino Carracci. Glauco e Scylla, 1597, afresco. Galeria Farnese, Roma.

Fig.5.71. Giuseppe Cesari, dito Cavalier d'Arpino. Suzana e os velhos, ca.1606, óleo sobre madeira, 52,2 x $38,5 \mathrm{~cm}$. Coleção particular. 
Fig.5.72. Nicolas Poussin. Vênus e Marte, 1633-1634, óleo sobre tela, 157.5 x $189.8 \mathrm{~cm}$. Museu de arte de Toledo.

Fig.5.74. Nicolas Poussin. Vênus apresentando as armas a Eneias. 1639.105 x $142 \mathrm{~cm}$. Musée des Beaux-Arts, Rouen, France.

Fig.5.75. Eustache Le Sueur. Polifilo no banho das ninfas, 1637-38, óleo sobre tela, 94x156,4 cm. Museu Magnin, Dijon.

Fig.5.73. Peter Paul Rubens. O banho de Diana, 1635- 40, óleo sobre tela. 152.5 x 120 $\mathrm{cm}$.

Fig.5.76. Simon Vouet. $O$ toilette de Vênus, 1629, óleo sobre tela, 183.8 x $153 \mathrm{~cm}$. Cincinnati Art Museum.

Fig.5.77. Gian Lorenzo Bernini. Fonte dos quatro rios. 1648-1651. Piazza Nanova, Roma.

Fig.5.78. Artemisia Gentileschi. Betsabéia no banho, década de 1640, óleo sobre tela, 205 x $156 \mathrm{~cm}$. Coleção privada.

Fig.5.79. Giuseppe Bartolomeo Chiari. O toilette de Betsabéia. segunda metade do séc. XVII ou primeira do XVIII, óleo sobre tela, 138 x $98 \mathrm{~cm}$. Coleção particular.

Fig.5.80. P.-.P. Prud'hon. Vênus no banho ou A inocência, 1810, óleo sobre tela. Museu do Louvre.

Fig.5.81. Jean-Baptiste Carpeaux. Flora agachada. Terceiro quarto do sec. XIX, óleo sobre tela, Museu de Belas Artes de Valenciennes.

Fig.5.82. Jean-Baptiste Carpeaux. Primavera ou Flora agachada. Século XIX, mármore, Museu de Belas Artes de Valenciennes.

Fig.5.85. Jean-Jacques Henner. Ninfa surpreendida se penteando, último quarto do século XIX, óleo sobre tela, Musée National Jean-Jacques Henner, Paris.

Fig.5.83. J.-B.-.Camille Corot. Vênus no banho. c.1873-74, óleo sobre tela, 90 x $116 \mathrm{~cm}$. Londres, Coleção Privada. Fig.5.84. Édouard Manet. Banhistas no Sena. 1874-1876, óleo sobre tela, 132 x $98 \mathrm{~cm}$. Museu de Arte de São Paulo.

Fig.5.86. Joseph Félon. Ninfa caçadora, segundo quarto do séc. XIX, óleo sobre tela. Musée des beaux-arts de Bordeaux.

Fig.5.87. Henri Fantin-Latour. Ninfa da maneira, s.d., óleo sobre tela, 22.5 x 12.25. Niland Collection.

Fig.5.88. Fantin-Latour. Ninfa e Amor, segunda metade do século XIX, primeira metade do XX, óleo sobre tela. Musée du Louvre.

Fig.5.89. Fantin-Latour. Ninfa com véu azul, primeiro quarto do século XX, óleo sobre tela, Musée des beaux-arts Nantes. 
Fig.5.90. Pierre-Auguste Renoir. Grande Banhista, 1905, óleo sobre tela, 97 x $73 \mathrm{~cm}$. Museum of Art, Philadelphia.

Fig.5.91. Paul Cézanne. Esboços de ninfa Agachada, segunda metade do século XIX ao primeiro quadro do XX, desenho. Museu do Louvre.

Fig.5.92. Pedro Américo. A Carioca, 1863-4, óleo sobre tela, 203 x 134 cm. Localização atual e estado desconhecidos.

Fig.5.93. Ensaio visual sobre a síntese eclética nA Carioca.

Fig.5.94. Copia de Michelangelo. Leda e o cisne, depois de 1530, óleo sobre tela, $105 \mathrm{~cm}$ x $141 \mathrm{~cm}$. National Gallery.

Fig.5.95. Michelangelo. A noite, 1524-27, mármore. Basílica San Lorenzo, Florença.

Fig.5.96. Apollonios. Torso de Belvedere, I século A.C. Mármore. Museu do Vaticano, Roma.

Fig.5.97. Marco Dente da Ravenna (a partir de Rafael). Vênus ferida, gravura. Metropolitam Museum of Art.

Fig.5.98. Victor Meirelles. Moema, 1866, óleo sobre tela. 129 x 190 cm. MASP.

Fig.5.99. Índio Mundurucu; mulher, Gravura a partir de uma fotografia do Dr. Gustavo, de Manaus." IN: AGASSIZ, Louis; AGASSIZ, Elizabeth Cabot Cary. A journey in Brazil. Boston: Ticknor and Fields, 1869. p.313.

\section{Sexto Capítulo}

Fig.6.1. G. Bellenger, cópia do quadro Laura di Dianti, de Ticiano. Prancha II do livro: LECOQ DE BOISBAUDRAN, Horace. L'education de la mémoire pittoresque et la formation de l'artiste. Paris: H. Laurens, 1920.

Fig.6.3. Alphonse Legros. Desenho de memória feito a partir de uma estátua antiga. S/d. Localização desconhecida. Prancha IX do mesmo livro.

Fig.6.2. G. Bellegender. Desenho de memória feitodepois de copiar o Laura di Dianti. Executado diante de comissão feita pela École des Beaux-Arts. Prancha III do mesmo livro.

Fig.6.4. Frédéric Regamey. Avenida do Observatório. Desenho de memória a partir o natural. s/d. Executado diante de comissão feita pela École des Beaux-Arts. Localização desconhecida.

\section{Sétimo Capítulo}

Fig.7.1. Angelo Agostini. Charge publicada na revista Diabo Coxo. Ano I, n.5. São Paulo, outubro de 1864. 